US Army Corps of Engineers ${ }_{\circledast}$

Engineer Research and

Development Center

Historic Landscape Management Plan for the Fort Huachuca Historic District National Historic Landmark and Supplemental Areas

Megan W. Tooker and Adam D. Smith

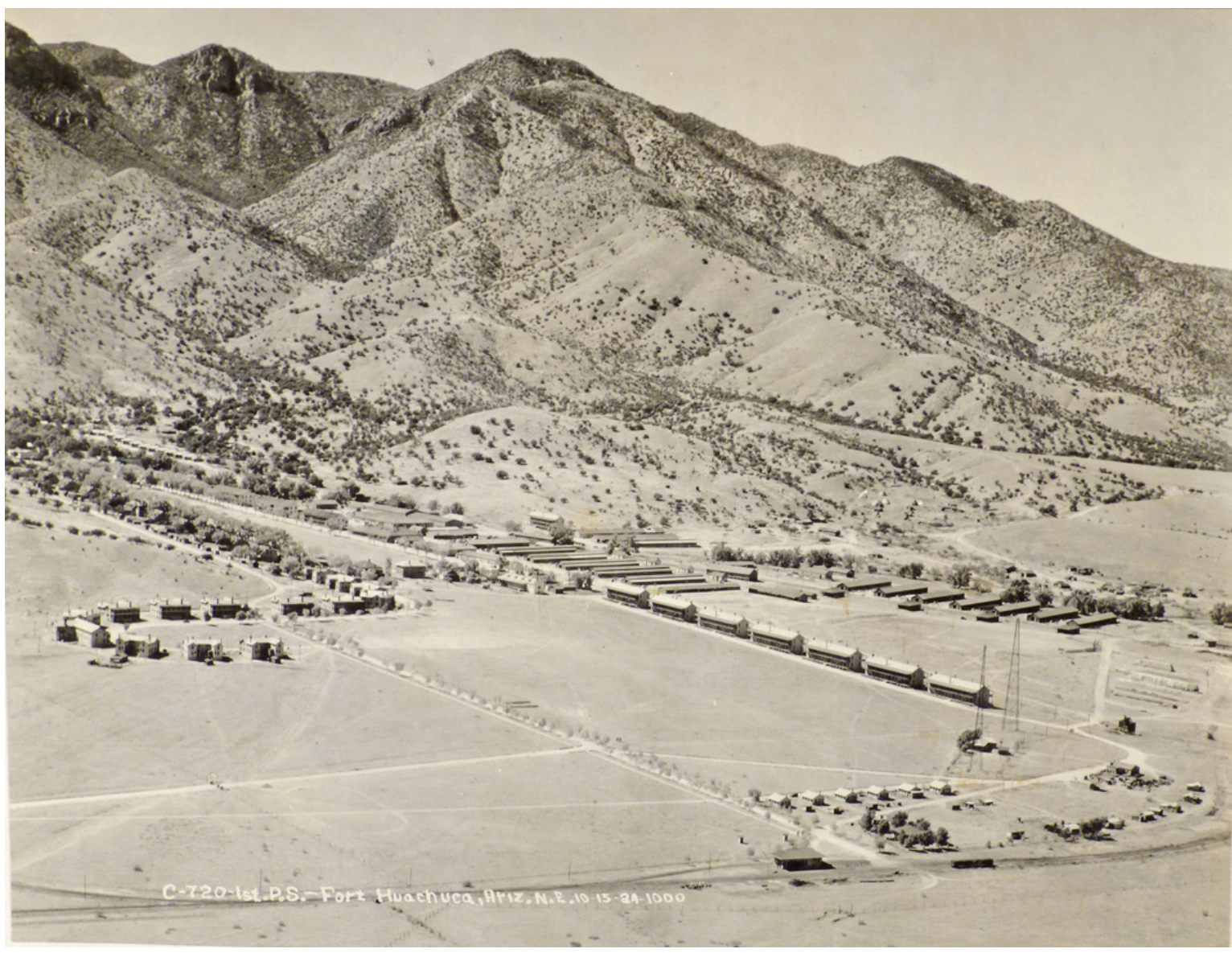


The U.S. Army Engineer Research and Development Center (ERDC) solves the nation's toughest engineering and environmental challenges. ERDC develops innovative solutions in civil and military engineering, geospatial sciences, water resources, and environmental sciences for the Army, the Department of Defense, civilian agencies, and our nation's public good. Find out more at www.erdc.usace.army.mil.

To search for other technical reports published by ERDC, visit the ERDC online library at https://erdclibrary.on.worldcat.org/discovery.

Cover Photo: Aerial of Fort Huachuca, 1924 (NARA College Park, RG165-FF). 


\section{Historic Landscape Management Plan for the Fort Huachuca Historic District National Historic Landmark and Supplemental Areas}

Megan W. Tooker and Adam D. Smith

Construction Engineering Research Laboratory U.S. Army Engineer Research and Development Center 2902 Newmark Drive

Champaign, IL 61822

Technical Report

Approved for public release; distribution is unlimited.

Prepared for Environmental and Natural Resources Division Directorate of Public Works

U.S. Army Garrison 3040 Butler Road, Building 22526

Fort Huachuca, AZ 85613

Under MIPR7ACE5355 


\section{Abstract}

The U.S. Congress codified the National Historic Preservation Act of 1966 (NHPA) to provide guidelines and requirements for preserving tangible elements of our nation's past. This preservation was done primarily through creation of the National Register of Historic Places (NRHP), which contains requirements for federal agencies to address, inventory, and evaluate their cultural resources, and to determine the effect of federal undertakings on properties deemed eligible or potentially eligible for the NRHP.

This work inventoried and evaluated the historic landscapes within the historic district at Fort Huachuca, California. A historic landscape context was developed; an inventory of all landscapes and landscape features within the historic district was completed; and these landscapes and features were evaluated using methods established in the Guidelines for Identifying and Evaluating Historic Military Landscapes (ERDC-CERL 2008), and their significance and integrity were determined. Photographic and historic documentation was completed for significant landscapes. Lastly, general management recommendations were provided to help preserve and/or protect these resources in the future.

DISCLAIMER: The contents of this report are not to be used for advertising, publication, or promotional purposes. Citation of trade names does not constitute an official endorsement or approval of the use of such commercial products. All product names and trademarks cited are the property of their respective owners. The findings of this report are not to be construed as an official Department of the Army position unless so designated by other authorized documents.

DESTROY THIS REPORT WHEN NO LONGER NEEDED. DO NOT RETURN IT TO THE ORIGINATOR. 


\section{Contents}

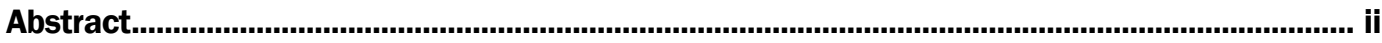

Figures and Tables ..................................................................................................................vii

Preface $\ldots \ldots \ldots \ldots \ldots \ldots \ldots$

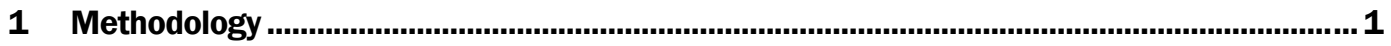

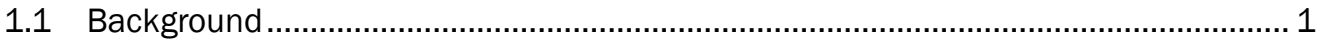

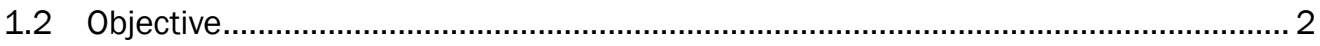

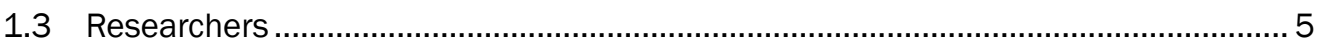

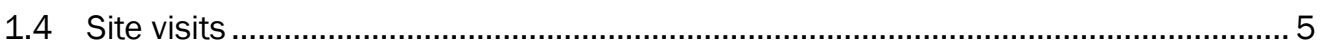

1.4.1 Fort Huachuca ...................................................................................................... 5

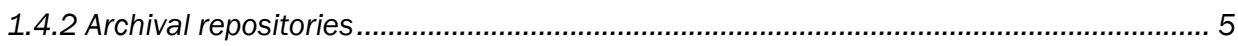

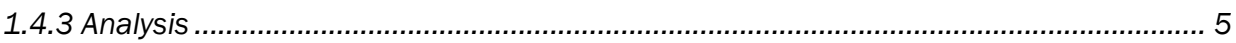

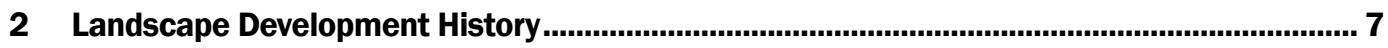

2.1 Frontier Era, 1880s .......................................................................................... 7

2.2 Expansion and World War I, 1910s............................................................... 14

2.3 Interwar Era, 1930s........................................................................................ 18

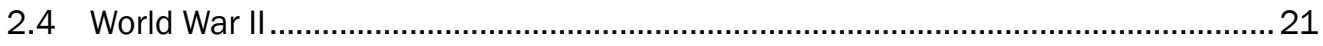

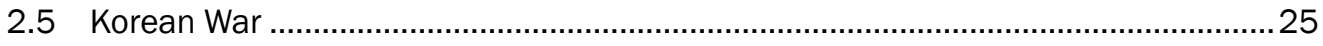

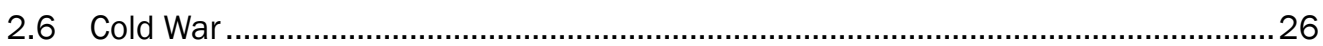

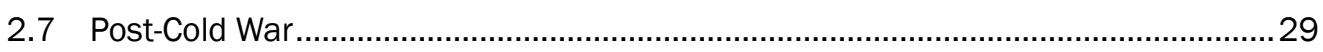

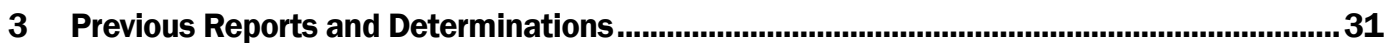

3.11974 National Register nomination................................................................... 31

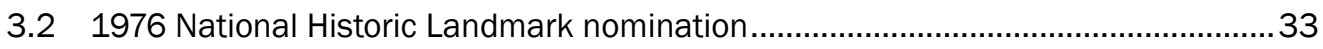

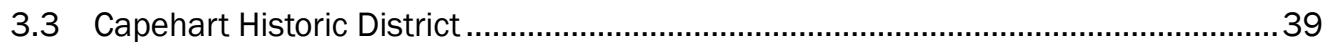

3.3.1 1999 report on Capehart housing and architect Richard Neutra ................................. 39

3.3.2 2001 programmatic agreement for the replacement of Army family housing.............. 39

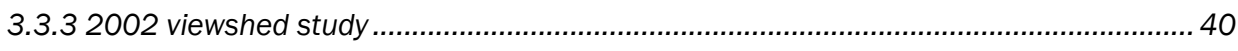

3.3.4 2008 programmatic agreement................................................................................. 42

3.3.5 2009 NRHP evaluation of 19 Capehart housing units, Cavalry Park 1......................... 42

3.4 WPA-era Historic District................................................................................. 43

3.4.1 1993 National Register nominations for Million Dollar Barracks and Stone

Quarters and Garage/Warrant Officers' Quarters.................................................. 43

3.4.2 2009 Legacy evaluation of CCC-WPA resources ......................................................... 44

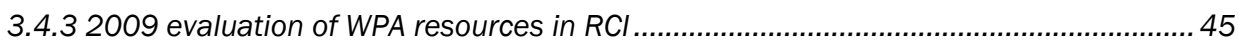

3.4.4 2013 architectural survey of 110 buildings and structures ......................................... 47

3.4.5 2014 evaluation of 30 buildings, 194 WPA features and identification of a

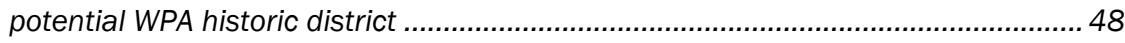

3.5 Other reports............................................................................................ 51

3.5.1 1988 Janus Associates, Inc. survey ...................................................................... 51

3.5.2 1989 Jackson Research Projects (JRP) evaluation .................................................... 51

3.5.3 1993 NRHP nomination for Fort Huachuca Historic District (never submitted)............52

3.5.4 2011 documentation and evaluation of 29 buildings and structures .......................... 55 


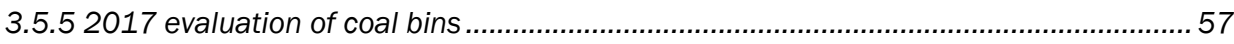

4 Landscape Inventory of the Fort Huachuca Historic District NHL.........................................58

4.1 Old Post Officers' Quarters.............................................................................60

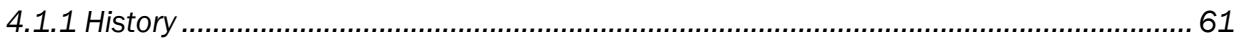

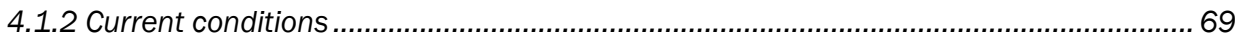

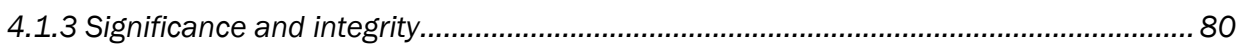

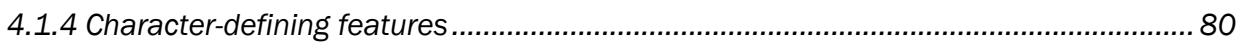

4.2 Old Post Barracks ................................................................................................... 80

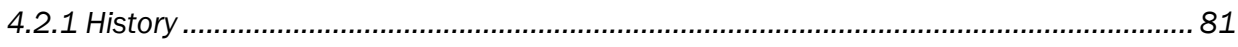

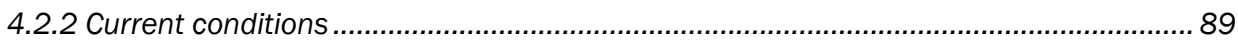

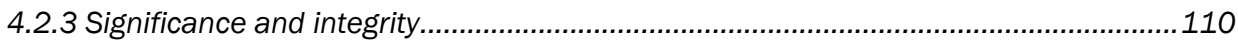

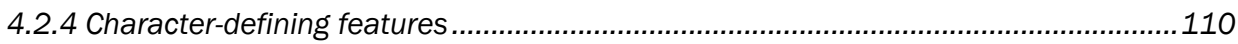

4.3 Old Post Administration ............................................................................. 111

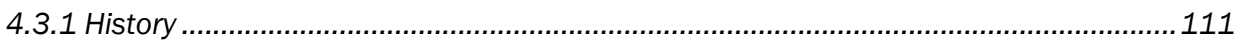

4.3.2 Current conditions ................................................................................................ 114

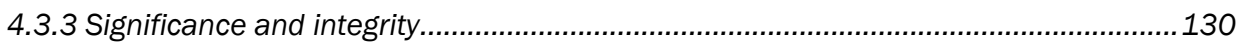

4.3.4 Character-defining features ............................................................................. 130

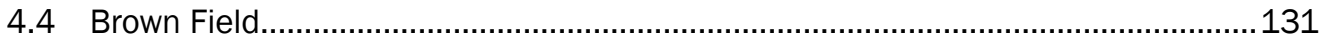

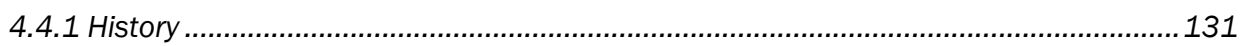

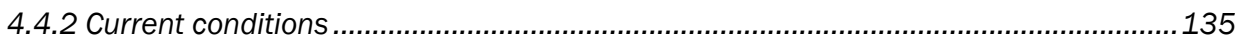

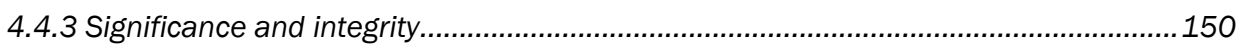

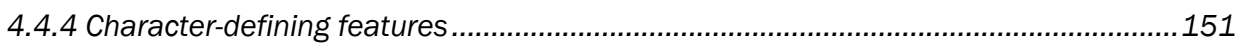

4.5 Old Post Recreation .............................................................................. 151

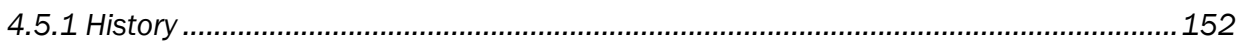

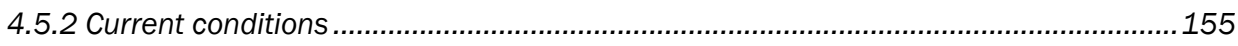

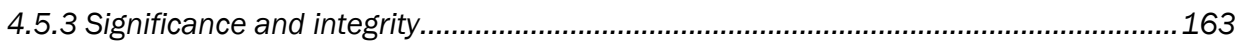

4.5.4 Character-defining features ............................................................................... 163

4.61914 Barracks ......................................................................................... 163

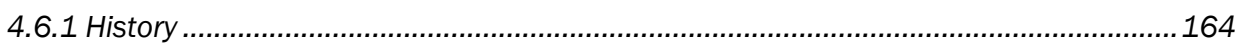

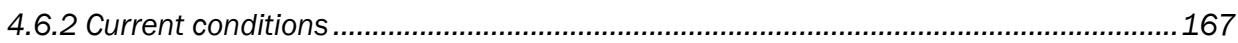

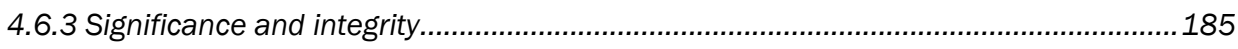

4.6.4 Character-defining features .................................................................................. 185

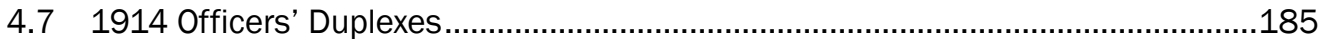

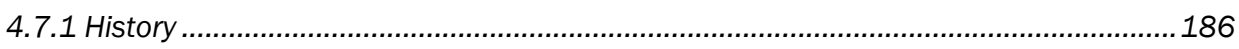

4.7.2 Current conditions ............................................................................................ 189

4.7.3 Significance and integrity................................................................................... 197

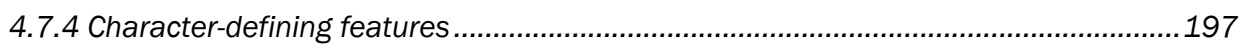

5 Character-Defining Features............................................................................................ 198

5.1 Site design and layout ................................................................................. 198

5.2 Topography and natural features..................................................................201

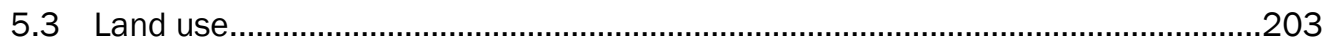

5.4 Transportation networks ....................................................................................203

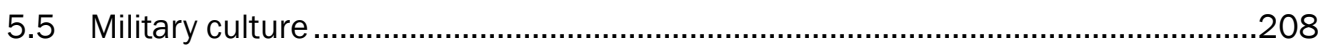

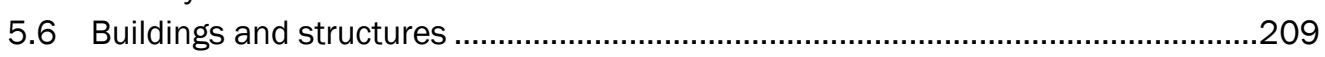

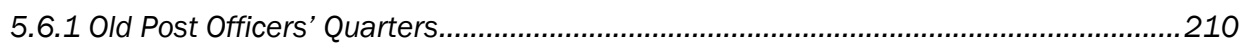




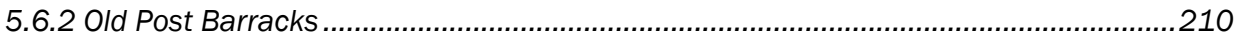

5.6.3 1914 Duplex Officers' Quarters........................................................................211

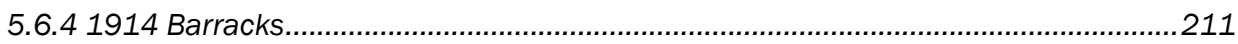

5.6.5 Old Post Administration and Recreation buildings .....................................................211

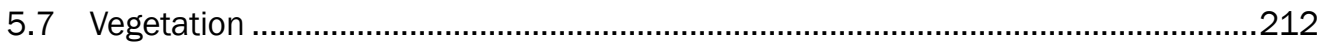

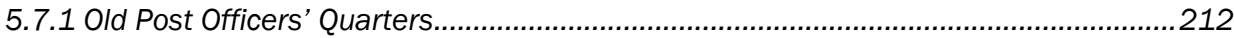

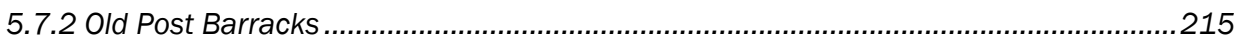

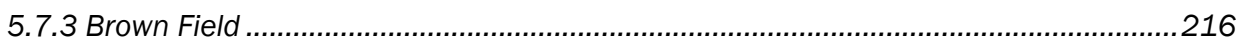

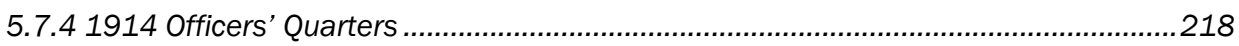

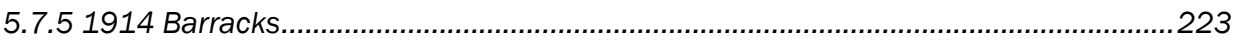

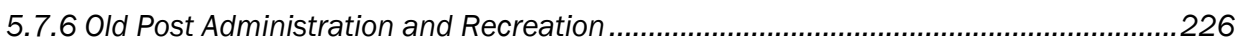

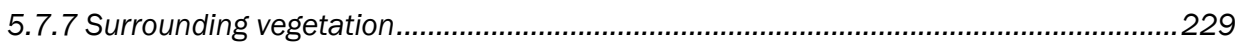

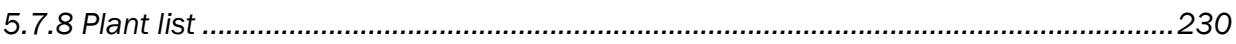

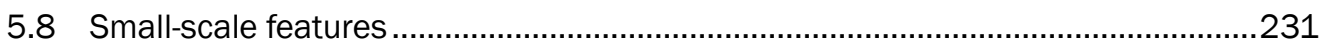

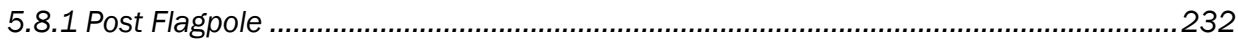

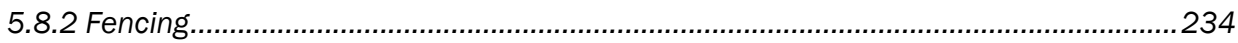

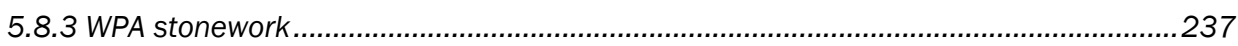

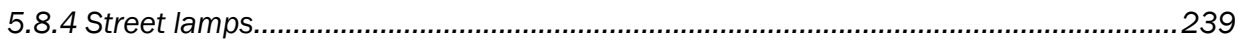

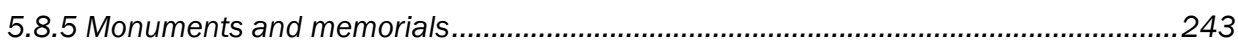

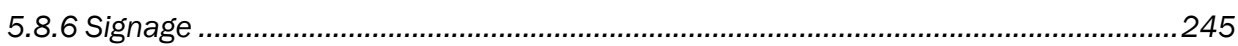

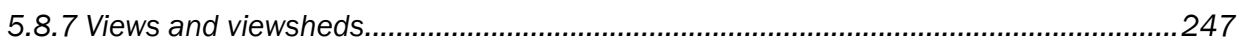

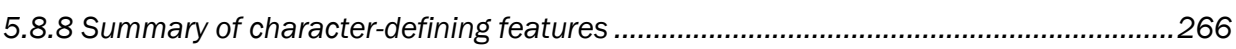

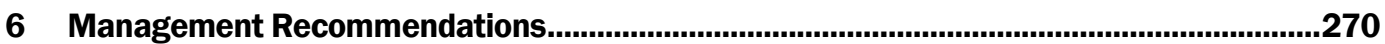

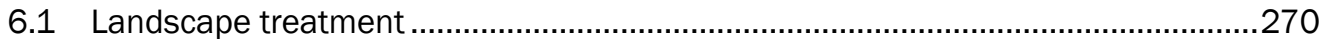

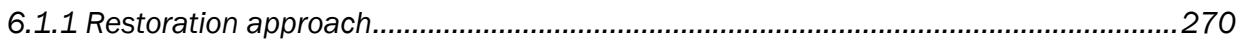

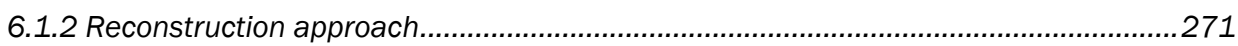

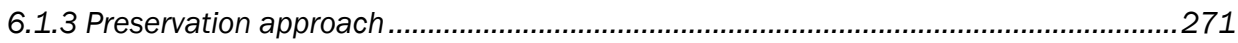

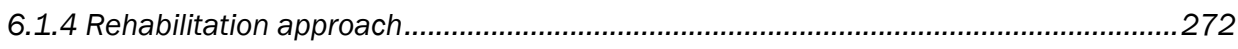

6.2 Overall management issues and recommendations ............................................22

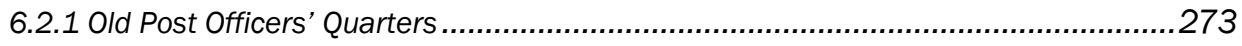

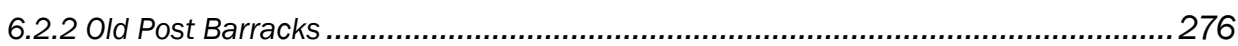

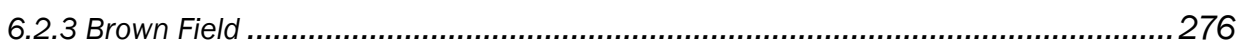

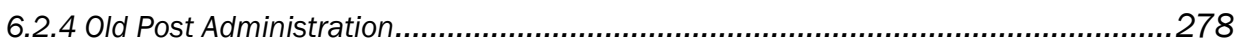

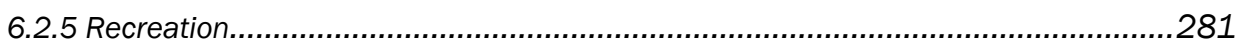

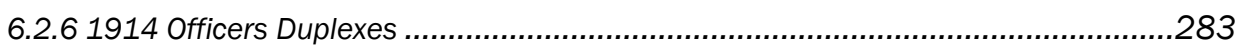

6.2.7 1914 Barracks ..............................................................................................285

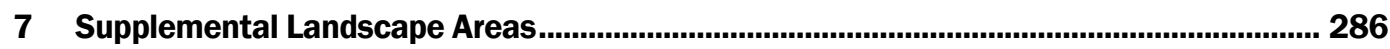

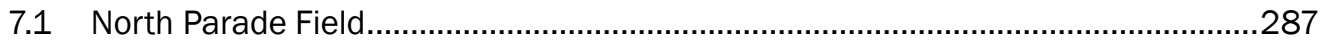

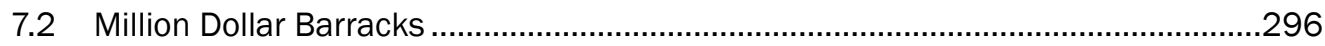

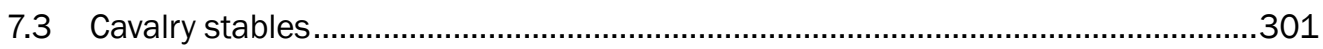

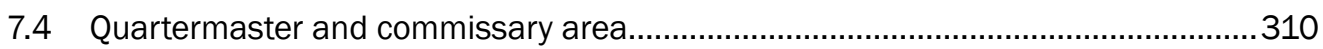

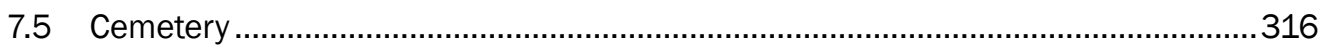

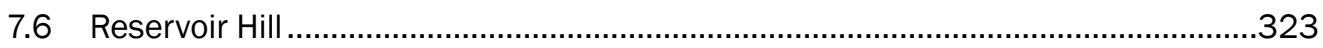

7.7 Cavalry Park 1 Housing Area ............................................................................326 


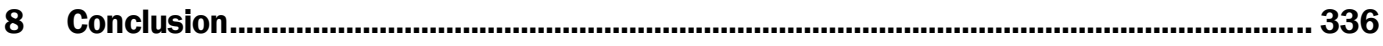

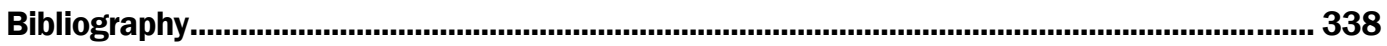

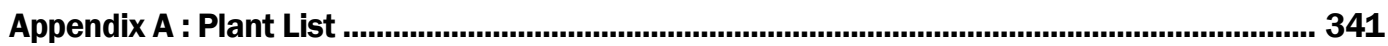

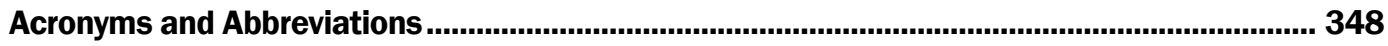

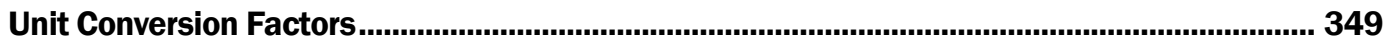

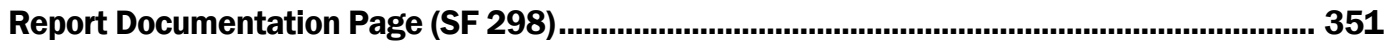




\section{Figures and Tables}

Figure

Figure 1. Location of Fort Huachuca in southeast Arizona.

Figure 2. Map showing the boundary of the Fort Huachuca Historic District NHL (red line) and contributing buildings (red) (ERDC-CERL).

Figure 3. Fort Huachuca map, 1893 (Fort Huachuca Museum).

Figure 4. View looking west of quartermaster subsistence storehouse [transformed into barracks c.1900] (now demolished) and barracks (22320, 22216, 22214, 22208 (R-L)), 1883 (NARA College Park, RG165-FF).

Figure 5. Front of the officers' quarters (R-L 22140, 22138, 22132, 22128, 22126, 22120, 22116, 22114, 22112) looking south, 1883 (NARA College Park, RG165-FF)............... 9

Figure 6. Map showing building locations prior to 1905 (NARA College Park, RG77).

Figure 7. Map detailing the layout of the Cantonment in circa 1911 (NARA College Park, RG92 Blueprint File).

Figure 8. View of an early plan for accommodating the 10th Calvary, c.1912 [Note this unrealized plan (in yellow) called for three circles of housing and the creation of a new large parade field and a different configuration of cavalry barracks and stables.] (NARA College Park, RG92 Blueprint File).

Figure 9. View of the construction for the 10th Calvary, circa 1913 (NARA College Park, RG92 Blueprint File).

Figure 10. View looking southeast at Stone Warrant Officers' Quarters (21103), 1939 (NARA College Park, RG 77-394 Box 9).

Figure 11. Million Dollar Barracks (31122, now Alchesay Barracks), 1940 (NARA College Park, RG 77-394 Box 9).

Figure 12. Looking west at WPA-constructed guard house (90020) at east end of Post, 1937 (NARA College Park RG 77-393 Box 95).

Figure 13. Map of the Old Post in 1945 (Fort Huachuca Directorate of Public Works [DPW])........23

Figure 14. Soldiers marching away from New Cantonment, 1942 (Fort Huachuca Museum).......24

Figure 15. Control tower at Libby Army Airfield, 1958 (Fort Huachuca Museum)............................25

Figure 16. Dedication of Greely Hall (61801), 1959 (Fort Huachuca Museum)............................27

Figure 17. Cavalry 1 Housing Area in 2016, looking southwest (ERDC-CERL 2016).......................27

Figure 18. 1993-era map showing location of former housing on North Field, (Fort Huachuca

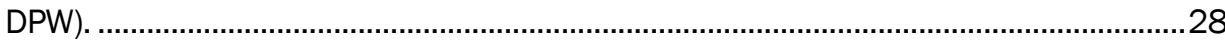

Figure 19. Map of the Old Post area in 2017 (Fort Huachuca DPW)............................................30

Figure 20. Historic buildings included in the 1974 NRHP nomination (Puzzi, 1973)......................33

Figure 21. Fort Huachuca "Old Post Area" NRHP district (in blue) was expanded to include NHL District boundary (in red) in 1976 (Adams, 1976)

Figure 22. Fort Huachuca NHL District boundary (in red) as revised in 1977 with 49 contributing buildings in black (1976 NHL nomination)

Figure 23. Viewshed boundary (in red) of the Fort Huachuca NHL District as identified by GADA (GADA, 2002).

Figure 24. Proposed Capehart Historic District, with boundary in orange, in the Cavalry I Housing Area (CP\&Y, 2009).

Figure 25. Map showing WPA features and buildings eligible to WPA-era Historic District 
Figure

(Tomes and Thomas, 2014). [Original map was cropped to show NHL District and immediate area for image readability.] .

Figure 26. Proposed contributing buildings, in black, in 1993 NRHP nomination (W\&Ms, 1993).

Figure 27. Fort Huachuca Historic District NHL boundary with defined landscape areas for

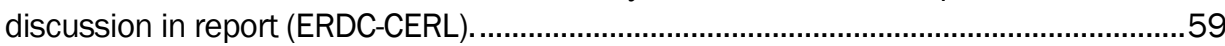

Figure 28. Officers' quarters landscape area map (ERDC-CERL)..................................................60

Figure 29. Looking north at front of the officers' quarters on the east side of the parade ground, 1883 (NARA College Park, RG165-FF).

Figure 30. Looking south at rear of the officers' quarters, 1883 (NARA College Park, RG165$\mathrm{FF}$.

Figure 31. View to the east of front of officers' quarters, 1898 (NARA College Park, RG111$\mathrm{SC})$.

Figure 32. View to the east of front of officers' quarters, 1899 (NARA College Park, RG111$\mathrm{SC})$.

Figure 33. View looking east at officers' quarters (22132 and 22128), c.1900 (NARA College Park, RG165-FF). .65

Figure 34. View looking south at officers' quarters (22126 and 22120), c.1900 (NARA College Park, RG165-FF).

Figure 35. View to the northeast of wood sidewalk and dirt street in front of officers' quarters, c.1900 (Fort Huachuca Museum).

Figure 36. View to the east of front facade of Building 22126 with an enclosed porch, 1936 (NARA College Park, RG 77-394 Box 9).

Figure 37. View looking northeast at officers' quarters (22112 and 22114) with screened porches, 1954 (NARA College Park, RG111_SC).

Figure 38. View looking northeast at officers' quarters (22114) with a screened porch, 1954 (NARA College Park, RG111-SC).

Figure 39. View to the northeast showing lush landscape plantings in front of quarters 22120 with screened porch, 1975 (Adams, 1975).

Figure 40. Looking northeast down Grierson Avenue at the row of officers' quarters (22112 in front) (ERDC-CERL, 2016).

Figure 41. View looking east of Officers' Quarters 22010 from across Brown Field (ERDCCERL, 2016).

Figure 42. View looking east of Officers' Quarters 22144 with enclosed porch from across Brown Field (ERDC-CERL, 2016).

Figure 43. View looking east of Officers' Quarters 22138 with enclosed porch from across parade field (ERDC-CERL, 2016).

Figure 44. View looking northeast of Officers' Quarters 22116, 22120, and 22126 with enclosed porches (ERDC-CERL, 2016).

Figure 45. View looking east at Officers' Quarters 22114 with enclosed porch (ERDC-CERL, 2016).

Figure 46. View looking east at Servant's Quarters 22113 with fence in front and fence behind (ERDC-CERL, 2016).

Figure 47. Looking east at Hazen House (22104) (ERDC-CERL, 2016)..........................................73

Figure 48. Looking east at Officers' Quarters 22108 (ERDC-CERL, 2016). .73 
Figure

Figure 49. Looking north down Grierson Avenue (ERDC-CERL, 2016)............................................74

Figure 50. Looking south along Grierson Avenue from Boyd Avenue (ERDC-CERL, 2016).............74

Figure 51. Looking south on Grierson Service Road behind the officers' quarters showing WPA ditch (ERDC-CERL, 2016).

Figure 52. Looking south on Grierson Service Road behind the officers' quarters showing WPA-era walls and drainage (ERDC-CERL, 2016).

Figure 53. Looking west at a WPA-era garage (22143) behind officers' quarters (22144) (ERDC-CERL, 2016).

Figure 54. Looking west at former servants' quarters (22142) behind officers' quarters (22140) (ERDC-CERL, 2016). 76

Figure 55. Looking southeast at Grierson Pool (22010) from entrance stairs (ERDC-CERL, 2016).

Figure 56. Looking southeast at Grierson Pool (22010) retaining wall along Grierson Service Road (ERDC-CERL, 2016).

Figure 57. Looking north at modern replacement stone-covered drainage ditch and garage (22007) along Grierson Service Road (ERDC-CERL, 2016)...

Figure 58. Looking south at modern stone-covered drainage ditch and carport (22013) along Grierson Service Road (ERDC-CERL, 2016).

Figure 59. Looking west at rear of family quarters (22104 and 22102) (ERDC-CERL, 2016).......79

Figure 60. View looking east of reservoir (22020) behind officers' quarters (42010) (ERDCCERL, 2016).

Figure 61. Old Post Barracks landscape area map (ERDC-CERL)

Figure 62. View looking northwest of the front of barracks (22208), c.1883 (NARA College Park, RG165-FF).

Figure 63. View looking west at the front of barracks (22208), c.1883 (NARA College Park, RG 165-FF).

Figure 64. View looking east at the rear of Building 22208 and the powder magazine (demolished) with Huachuca Creek in between, 1890 (NARA College Park, RG165-FF).

Figure 65. View looking northwest at barracks (22320), 1898 (Fort Huachuca Historical Museum).

Figure 66. View looking southeast at the rear of barracks (22208), c.1900 (NARA College Park, RG 92-F).

Figure 67. View looking east of the rear of barracks (22214 and 22215) with Huachuca Creek in the foreground, 1890 (NARA College Park, RG165-FF)

Figure 68. View looking southwest at Brown Field, the row of barracks $(22208,22214$, 22216, and 22320) and guard house (22328), 1899 (NARA College Park, RG165-FF)

Figure 69. View looking south at barracks (22320) and trees lining edge of Brown Field, 1898 (NARA College Park, RG111-SC).

Figure 70. View looking west at front of barracks (22214), c.1900 (NARA College Park, RG165-FF).

Figure 71. View looking west at front of barracks (22216), c.1900 (NARA College Park, RG165-FF)

Figure 72. View looking northwest at barracks (22320) and the former quartermaster 
Figure

subsistence storehouse turned into barracks (demolished), c.1900 (NARA College

Park, RG165-FF).

Figure 73. View looking west at the guard house (22328), c.1900 (NARA College Park, RG 92-F).

Figure 74. View looking northeast at the post bakery (22324) with the former quartermaster subsistence storehouse turned into barracks (demolished) behind, c.1900 (NARA College Park, RG 92-F).

Figure 75. View looking southwest at guard house (22328), c.1916 [Note the metal street lamp in front of building.] (Fort Huachuca Museum).

Figure 76. View looking east over Huachuca Creek towards the rear of the barracks, Brown Field, and Reservoir Hill, 1916 (NARA College Park, RG111-SC).

Figure 77. View looking northwest of barracks (22208) from Reservoir Hill (ERDC-CERL, 2016)

Figure 78. Looking west at barracks (22208) from across Brown Field (ERDC-CERL, 2016). .......90

Figure 79. Looking north at parking on Augur Avenue in front of barracks (22208) [Note missing trees along this edge of Brown Field.] (ERDC-CERL, 2016).

Figure 80. View to the west of landscaping between 22210 and 22214 (ERDC-CERL, 2016)......91

Figure 81. View towards the northeast of 22210 foreground and 22208 background from Christy and Adair Avenues intersection showing stone wall (ERDC-CERL, 2016)

Figure 82. View to the north of asphalt drainage ditch and stone wall on north side of 22208 (ERDC-CERL, 2016).

Figure 83. Looking east at stone drainage ditch on the west side of 22208 (ERDC-CERL, 2016).

Figure 84. View to the east of electrical equipment and wood screening on the rear of 22208 (ERDC-CERL, 2016).

Figure 85. Example of signage on west side of barracks (22208) along Hines Avenue (ERDCCERL, 2016).

Figure 86. Looking north along Hines Avenue with rear of barracks (22214) on right [Note example of modern street lamps.] (ERDC-CERL, 2016).

Figure 87. View to the east of an example of concrete sidewalk and steps with metal railings that connect the barracks area to the parking lot on the west side of Hines Avenue (ERDC-CERL, 2016)

Figure 88. View to the south of parking lot for buildings on the west side of Hines Avenue for former barracks now administration (ERDC-CERL, 2016).

Figure 89. View looking southwest across Brown Field at barracks $(22214,22216$, and 22320) (ERDC-CERL, 2016)

Figure 90. Looking south along Augur Avenue at parking in front of barracks (ERDC-CERL, 2016).

Figure 91. Looking north at the sidewalks and parking in front of barracks (22214) (ERDCCERL, 2016).

Figure 92. Looking west at front of barracks (22214) (ERDC-CERL, 2016). Note the lack of vegetation planted in front of barracks.

Figure 93. Looking west at front of barracks (22216). Note foundation plantings. (ERDCCERL, 2016).

Figure 94. Looking west between barracks (22216 and 22320) (ERDC-CERL, 2016). 
Figure

Figure 95. Looking west at barracks (22320) from Brown Field (ERDC-CERL, 2016).

Figure 96. Looking south at sidewalks and parking in front of 22332 along Augur Avenue (ERDC-CERL, 2016).

Figure 97. Shrub growth too close to building in front of 22320 (ERDC-CERL, 2016). .99

Figure 98. Concrete sidewalk and stone wall at entrance to barracks (22320). Note modern metal wildlife mesh under porch. (ERDC-CERL, 2016). 100

Figure 99. View looking north at shrubs between 22320 and 22324. Note curb along Augur

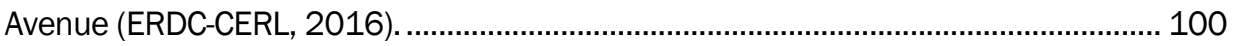

Figure 100. Looking south at drainage ditch and air conditioning at rear of 22320 (ERDCCERL, 2016) 101

Figure 101. Looking south at electrical units behind 22320 (ERDC-CERL, 2016)...................... 101

Figure 102. Looking east at concrete sidewalk and latrine (22322) (ERDC-CERL). ..................... 102

Figure 103. View looking north at sidewalk and tree behind 22320 (ERDC-CERL, 2016)........... 102

Figure 104. View looking south at seating and landscaping between 22316 and 22318 (ERDC-CERL, 2016). 103

Figure 105. View looking south at seating and barbecue behind 22320 (ERDC-CERL, 2016)... 103

Figure 106. View looking southeast at landscaping between 22216 and 22214 (ERDCCERL, 2016). 104

Figure 107. View looking northwest at landscaping in front of 22214 (ERDC-CERL, 2016)........ 104

Figure 108. View looking east at the front of Sam Kee Hall, former guard house (22328) (ERDC-CERL, 2016). 105

Figure 109. View looking west of the front of former school/post office (22326) (ERDC-CERL, 2016) 105

Figure 110. View of the east side of 22332 (ERDC-CERL, 2016) ............................................... 106

Figure 111. View looking north of detail of stairs on 22332 (ERDC-CERL, 2016)........................ 106

Figure 112. Looking west at landscaping between Boyd Avenue and 22332 and 22336 (ERDC-CERL, 2016). 107

Figure 113. Looking southeast at the northwest corner of 22336 and concrete sidewalk and metal handrails (ERDC-CERL, 2016). 107

Figure 114. View to the south of 22336 and concrete sidewalk and metal handrails (ERDCCERL, 2016). 108

Figure 115. View looking east at parking area behind 22328 with 22330 in right foreground (ERDC-CERL, 2016). 108

Figure 116. View looking east of the northwest oblique of 22330 and concrete sidewalk and concrete Americans with Disabilities Act (ADA) ramps (ERDC-CERL, 2016). ............... 109

Figure 117. View to the east of 22326 from Christy Avenue (ERDC-CERL, 2016)........................ 109

Figure 118. View to the southeast of 22326 and 22324 and power pole and electrical equipment (ERDC-CERL, 2016). 110

Figure 119. Old Post Administration landscape area map (ERDC-CERL). 111

Figure 120. View looking north at the Post Hospital (41408), c.1900 (NARA College Park, RG 92-F).

Figure 121. Looking north at Rodney Hall (41402), which was built in 1917 as the Post Headquarters, 1920 (Fort Huachuca Museum).

Figure 122. Looking northeast at the former Post Headquarters (41401), which also served 
Figure

as the Officers' Club from 1920 to 1941, now the Museum, 1920 (Fort Huachuca

Historical Museum). ............................................................................................. 113

Figure 123. View looking northwest of the former hospital (41408), c. 1953 (NARA College

Park, RG111-SCA).

Figure 124. View looking north at stone wall west of former hospital (41408), morgue in center (41409) [Note street lamp on Boyd Avenue and street lamp on Christy

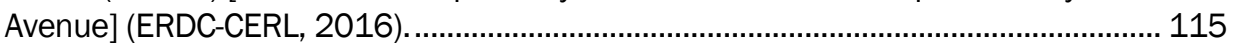

Figure 125. View looking north at former morgue building (41409) (ERDC-CERL)...................... 115

Figure 126. View looking north of bus stop shelter (41404) (ERDC-CERL, 2016)........................ 116

Figure 127. View looking northwest of 22334 and 41408 from Reservoir Hill (ERDC-CERL, 2016)................................................................................................................ 116

Figure 128. View looking north of 41408 showing concrete sidewalk and signs in front of building (ERDC-CERL, 2016). 117

Figure 129. View looking northwest at former hospital Building 41408 (ERDC-CERL, 2016)..... 117

Figure 130. View looking east of white picket fence concealing equipment in front of former hospital (41408) (ERDC-CERL, 2016).

Figure 131. View looking north at concrete ramp and metal handrails on east side of 41408 (ERDC-CERL, 2016).

Figure 132. View looking north at concrete sidewalk along east side of 41407 (ERDC-CERL, 2016)

Figure 133. View looking west at connections between 41408 and 41407 (ERDC-CERL, 2016).

Figure 134. View looking west at landscaping between 41408 and 41407 (ERDC-CERL, 2016) 120

Figure 135. View of concrete sidewalk, equipment, and concrete wall along northwest side of 41407 (ERDC-CERL, 2016).

Figure 136. View looking west at oblique of 41411 and Hungerford Avenue (ERDC-CERL, 2016)

Figure 137. View of northwest side of 41411 showing air conditioning equipment (ERDCCERL, 2016)

Figure 138. View of southwest side of 41411 (ERDC-CERL, 2016).

Figure 139. View looking east at air conditioning equipment on north side of 41408 (ERDCCERL, 2016) 122

Figure 140. View looking west at 41409 and 41410 and concrete retaining wall for 41411 (ERDC-CERL, 2016).

Figure 141. View looking north at Rodney Hall (41402), Garrison Headquarters (ERDC-CERL, 2016).

Figure 142. View looking north at concrete sidewalk alongside 41402 (ERDC-CERL, 2016)..... 124

Figure 143. View looking north at landscaping in front of 41402 (ERDC-CERL, 2016)................ 124

Figure 144. View looking south at space between 41402 and the parking lot for 41408 and 41407 (ERDC-CERL, 2016)...................................................................................... 125

Figure 145. View looking east at area behind 41401 (ERDC-CERL, 2016)................................. 125

Figure 146. View looking south at WPA-era former garage (41406) behind 41402 (ERDCCERL, 2016)....................................................................................................... 126

Figure 147. View looking west at 41403 behind 41402 (ERDC-CERL, 2016)............................. 126 
Figure

Figure 148. View looking north at area in between 41402 and 41401 (ERDC-CERL, 2016). .... 127

Figure 149. View looking northeast at trees in front of 41401 (ERDC-CERL, 2016).................... 127

Figure 150. View looking northwest at shrub on the side of 41401 (ERDC-CERL, 2016)............ 128

Figure 151. View looking southeast at rear of 41401 and second story fire escape (ERDCCERL, 2016)..................................................................................................... 128

Figure 152. Looking north at the Museum's wood sign with stone base at the northeast corner of Boyd and Grierson Avenues (ERDC-CERL, 2016)......................................... 129

Figure 153. View looking southwest from 41408 to Huachuca Mountain (ERDC-CERL, 2016) 129

Figure 154. View east down Boyd Avenue with 41402 on left and Brown Field on right (ERDC-CERL, 2016). 130

Figure 155. Brown Field landscape area map (ERDC-CERL)........................................................ 131

Figure 156. View south across Brown Field, c.1883 (NARA College Park, RG165-FF)................. 132

Figure 157. View south across Brown Field in the snow, 1898 (NARA College Park, RG111$\mathrm{SC})$ 133

Figure 158. View south over Brown Field, 1899 (NARA College Park, RG111-SC). 133

Figure 159. View looking northeast of the flagpole on Brown Field with officers' quarters behind, c.1900 (NARA College Park, RG165-FF).

Figure 160. View southeast at the officers' quarters, c.1900 (NARA College Park, RG165-FF).. 134

Figure 161. View south of the parade field showing the growth of trees, no date [Note gazebo (demolished) at lower left.] (NARA College Park, RG111-SC).

Figure 162. Fort Huachuca National Historic Landmark wood sign with stone base at northeast corner of Brown Field (ERDC-CERL, 2016). 136

Figure 163. View looking southeast at sign for Garrison Headquarters at the northern end of the parade field (ERDC-CERL, 2016).

Figure 164. View to the south of Brown Field and the officers' quarters (ERDC-CERL, 2016). ... 137

Figure 165. Looking north at Brown Field (ERDC-CERL, 2016). 137

Figure 166. Looking north at parking along Augur Avenue between barracks and Brown Field (ERDC-CERL, 2016).

Figure 167. View looking north at trees and bleachers on Brown Field (ERDC-CERL, 2016)...... 138

Figure 168. View looking north at rock planters and trees on the west side of the parade field (ERDC-CERL, 2016).

Figure 169. View looking northeast at concrete curb and rock retaining wall on west side of parade field (ERDC-CERL, 2016).

Figure 170. View looking north of fire hydrant, cast iron bollards, stone wall that hides a meter, and trees on west side of parade field (ERDC-CERL, 2016).

Figure 171. Looking north down Brown Field toward Garrison Headquarters (ERDC-CERL, 2016).

Figure 172. Looking south at Brown Field from Boyd Avenue (ERDC-CERL, 2016)...................... 141

Figure 173. Looking south of Brown Field (ERDC-CERL, 2016)................................................... 141

Figure 174. View looking north of trees along the east side of Brown Field (ERDC-CERL, 2016).

Figure 175. View looking north of backflow preventer on east side of Brown Field (ERDCCERL, 2016). 
Figure

Figure 176. Row of trees on south corner of Brown Field opposite 22138, 22140, and 22144 (ERDC-CERL, 2016).

Figure 177. View looking northeast at flagpole (22301) on Brown Field [erected in the 1950s] (ERDC-CERL, 2016).

Figure 178. View looking west at artillery piece at the base of the flagpole (22301) (ERDC-

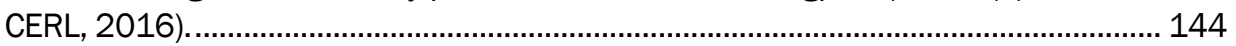

Figure 179. View looking west at the flagpole area (ERDC-CERL, 2016).................................... 144

Figure 180. View looking northwest at detail of the stone border and gravel bed by the flagpole (ERDC-CERL, 2016). 145

Figure 181. View looking north at stone wall and artillery piece at the flagpole area (ERDCCERL, 2016).

Figure 182. View looking east of stone memorial on the west side of the flagpole area with bronze plaque commemorating the designation as an NHL (ERDC-CERL, 2016)...... 146

Figure 183. View looking northeast at artillery pieces and evergreen tree at the base of the flagpole (ERDC-CERL, 2016).

Figure 184. View looking northeast towards gazebo (22303) on parade field (ERDC-CERL, 2016).

Figure 185. View east towards gazebo on south end of parade field (ERDC-CERL, 2016).......... 147

Figure 186. Looking southwest at the front of 22336 (ERDC-CERL, 2016)................................ 148

Figure 187. Looking southeast at the southwest side of 22336 (ERDC-CERL, 2016)................. 148

Figure 188. View looking east at the seating areas in front of 22336 along Boyd Avenue (ERDC-CERL, 2016). 149

Figure 189. View looking northeast at trees lining the parade field adjacent to parking lot for 22334 (ERDC-CERL, 2016).

Figure 190. View from northeastern end of parade field to the barracks (ERDC-CERL, 2016)... 150

Figure 191. View from eastern end of parade field to the officers' quarters (ERDC-CERL, 2016).. 150

Figure 192. Recreation landscape area map (ERDC-CERL). ...................................................... 151

Figure 193. View looking south of Brayton Hall (21115), 1918 (Fort Huachuca Museum)......... 153

Figure 194. View looking south of Brayton Hall (21115), 1941 (NARA College Park, RG 77, 393 Box 95). 153

Figure 195. View looking southeast of Brayton Hall (21115), 1954 (Puzzi, 1974). 154

Figure 196. View looking southwest at 21114, 1941 (NARA College Park, RG 77, 393 Box 95) 154

Figure 197. View looking northwest of enlisted men's pool located south of Brayton Hall (21115) (NARA College Park, RG 77, 393 Box 95). 155

Figure 198. Map showing the location of pool and tennis courts (center) in relation to 21115, 1944 (NARA College Park, RG 77, Folders 1-5). 155

Figure 199. View looking south at Brayton Hall (21115) from Brown Field (ERDC-CERL, 2016). 156

Figure 200. View looking south at Brayton Hall (21115) from of Adair Avenue showing shrubs and landscaping in front of building (ERDC-CERL, 2016). 157

Figure 201. Close-up of landscaping in front of Brayton Hall (21115) (ERDC-CERL, 2016)....... 157

Figure 202. View looking west of landscaping and stone wall in front of Brayton Hall (21115) 
Figure

(ERDC-CERL, 2016). 158

Figure 203. View looking south at area between Brayton Hall (21115) and 21114 (ERDCCERL, 2016). 158

Figure 204. View looking northeast at rear of Brayton Hall (21115) and its handicapped accessible parking lot (ERDC-CERL, 2016)... 159

Figure 205. View looking north of coal bin (no number on Real Property list) on the south side of Brayton Hall (21115) (ERDC-CERL, 2016). 159

Figure 206. View of concrete sidewalk on the east side of Brayton Hall (21115) (ERDC-CERL, 2016). 160

Figure 207. View looking north at trees in front of Brayton Hall (21115) along Adair Avenue (ERDC-CERL, 2016). 160

Figure 208. View of stone swale and stone drainage ditch to the southeast of Brayton Hall (21115) along Adair Avenue (ERDC-CERL, 2016).

Figure 209. View of metal street lamp southeast of Brayton Hall (21115) near intersection of Adair Avenue and Grierson Avenue (ERDC-CERL, 2016). 161

Figure 210. View to the south of 21114 with stone wall and concrete sidewalk [Note shrubs in front of building] (ERDC-CERL, 2016) 162

Figure 211. View looking north at parking lot right outside of the Fort Huachuca Historic District at the intersection of Adair and Christy Avenues (ERDC-CERL, 2016)............. 162

Figure 212. 1914 Barracks landscape area map (ERDC-CERL). 163

Figure 213. View southwest towards 41421 on the eastern end of the 1914 Parade Field, c.1917 (Fort Huachuca Museum). Note writing on the roof for aerial identification... 165

Figure 214. View south towards one of the 10th Calvary Barracks on the west side of the 1914 Parade Field, c.1917 [Note street lamp.] (Fort Huachuca Museum).

Figure 215. View looking west between 41418 and 41419 with 31122 in the background, c.1942 (Fort Huachuca Museum). 166

Figure 216. Aerial of Fort Huachuca looking southwest with the original fort on the left and the 1914 extension on the right, 1924 (NARA College Park, RG165-FF)..................... 166

Figure 217. View northwest of 1914 Barracks, 1954 (NARA College Park, RG111-SC).............. 167

Figure 218. View looking west towards the 1914 Barracks from North Parade Field (ERDCCERL, 2016) 167

Figure 219. East side of 41412 with parking lot (ERDC-CERL, 2016). 168

Figure 220. Looking northwest down the parking lot to the east of the 1914 Barracks (ERDCCERL, 2016). 168

Figure 221. View looking northwest of parking lot and WPA-era stone retaining wall off Hungerford Avenue with 1914 Barracks in the background (ERDC-CERL, 2016). ..... 169

Figure 222. Looking north down Rhea Avenue and the concrete sidewalk in front of the 1914 Barracks (ERDC-CERL, 2016).

Figure 223. View to the north of the area between 1914 Barracks and parking lot showing materials, signs, and ramps from parking lots (ERDC-CERL, 2016).

Figure 224. View southwest towards the 1914 Barracks (ERDC-CERL, 2016). 170

Figure 225. View to the west of former lavatory (41414) between 41412 and 41415 (ERDCCERL, 2016).

Figure 226. View to the west of 41415 (ERDC-CERL, 2016). 171

Figure 227. View looking west between 41415 and 41416 [Note additions on sides of 
Figure

barracks.] (ERDC-CERL, 2016).

Figure 228. View to the west of 41416 and parking lot (ERDC-CERL, 2016). 172

Figure 229. View to the west between 41418 and 41419 with 31122 in the background (ERDC-CERL, 2016).

Figure 230. View to the west between 41418 and 41419 with 31122 in the background (ERDC-CERL, 2016).

Figure 231. View to the north of bushes, concrete sidewalk, and stone gutter in front of 41418 (ERDC-CERL, 2016) 174

Figure 232. View to the north of bushes, concrete sidewalk, and ADA ramp on side of 41419 (ERDC-CERL, 2016).

Figure 233. View to the northeast of concrete ramp, metal handrails, and stone gutter in front of 41421 (ERDC-CERL, 2016).

Figure 234. Looking south down Rhea Avenue (ERDC-CERL, 2016). 175

Figure 235. WPA wall and cap at the north end of Rhea Avenue and just north of 41421 (ERDC-CERL, 2016).

Figure 236. View looking north of WPA-era drainage ditch at intersection of Christy Avenue and Smith Avenue (ERDC-CERL, 2016).

Figure 237. Looking south at 1914 Barracks and WPA ditch (ERDC-CERL, 2016)... 177

Figure 238. Blocked access to Rhea Avenue from Smith Avenue (ERDC-CERL, 2016)............... 177

Figure 239. Looking to the southeast at the rear of 41421 (ERDC-CERL, 2016)........................ 178

Figure 240. Looking west down Christy Avenue (ERDC-CERL, 2016).......................................... 178

Figure 241. Break in wall between Christy Avenue and the east side of 41421 (ERDC-CERL, 2016). 179

Figure 242. Landscaping on the west side of 41421 (ERDC-CERL, 2016). 179

Figure 243. View looking northwest toward wall and landscaping along Christy Avenue at entrance to parking lot behind Building 41419 (ERDC-CERL, 2016).

Figure 244. View north of WPA walls along Christy Avenue in rear of barracks (41418) (ERDC-CERL, 2016). 180

Figure 245. View looking northwest at WPA walls and brick walkway in rear of barracks (41416) (ERDC-CERL, 2016). 181

Figure 246. View looking north at rear of barracks (41412) and toward lavatory (41414) (ERDC-CERL, 2016).

Figure 247. View looking northwest at stone wall with concrete parge (covering over stone) and drainage ditch behind 41412 at the corner of Christy and Hungerford Avenues (ERDC-CERL, 2016).

Figure 248. Looking east down Hungerford Avenue at WPA-era walls and rear of former theater (41305) (ERDC-CERL, 2016).

Figure 249. View south at North Parade Field, parking lot and barracks (ERDC-CERL, 2016).... 183

Figure 250. Modern aluminum bench on 1914 North Parade Field (ERDC-CERL, 2016)........... 183

Figure 251. View towards the east of North Parade Field from 1914 Barracks towards the 1914 Officers' quarters on right (modern housing on left) (ERDC-CERL, 2016).

Figure 252. View to the northeast of the North Field from the 1914 Barracks (ERDC-CERL, 2016). 184

Figure 253. 1914 Officers' quarters landscape area map (ERDC-CERL). 185 
Figure

Figure 254. View south down Mizner Avenue showing trees and sidewalk, 1938 (NARA College Park, RG77).

Figure 255. View north down Mizner Avenue at Smith Avenue showing trees and sidewalk, 1938 (NARA College Park, RG77).

Figure 256. Aerial of Fort Huachuca with the original fort on the left and the 1914 extension on the right, with the officer's duplexes in center left, 1924 (NARA College Park, RG165-FF).

Figure 257. View looking southeast at 42014 and 42015, 1954 (NARA College Park). 189

Figure 258. View southeast of the 1914 Officers' Duplexes and associated open space (ERDC-CERL, 2016).

Figure 259. View east of 41015 from Hungerford Avenue (ERDC-CERL, 2016)......................... 190

Figure 260. View east of 41016 from 41305 (ERDC-CERL, 2016). 191

Figure 261. View south down Mizner Avenue showing street trees and sidewalk, 1938 (ERDC-CERL, 2016). 191

Figure 262. View north down Mizner Avenue at Smith Avenue showing street trees and sidewalk (ERDC-CERL, 2016).

Figure 263. Looking south down Grierson Service Road with garage 22021 on the left (ERDC-CERL, 2016).

Figure 264. View looking west at electrical boxes behind 41015 and 41016 (ERDC-CERL, 2016).

Figure 265. View looking northwest at shrubs and WPA stone wall behind 41014, 41015, 41016 (ERDC-CERL, 2016) 193

Figure 266. View looking southwest at garages 22023 and 22022 along Grierson Service Road (ERDC-CERL, 2016). 194

Figure 267. View looking west at stone drainage ditch southeast of 22023 (ERDC-CERL, 2016).. 194

Figure 268. View west of typical landscaping behind 42014 (ERDC-CERL, 2016). 195

Figure 269. Parking lot behind Allen Hall (42017), original Bachelor Officers' Quarters (ERDC-CERL, 2016). 195

Figure 270. View east at garage 42021 behind 42017 (ERDC-CERL, 2016). 196

Figure 271. View east of playground north east of Henry Circle associated with new Cavalry Park 5 housing area (ERDC-CERL, 2019).

Figure 272. Fort Huachuca map, c.1900 (NARA College Park, RG77 Blueprint File).................. 200

Figure 273. Fort Huachuca map, c.1914 (NARA College Park, RG77 Blueprint File).................. 201

Figure 274. Looking northeast over Fort Huachuca from the western part of Huachuca Canyon, c.1900 (NARA College Park, RG165-FF). 202

Figure 275. Looking northwest over Fort Huachuca from west of the reservoir, c. 1900 (NARA College Park, RG165-FF). 202

Figure 276. Looking east at an early view of roads and wood sidewalks in front of the officers' quarters, 1901 (Fort Huachuca Historical Museum). 204

Figure 277. Looking south at officers on the boardwalk in front of the quarters, c. 1900 (Fort Huachuca Historical Museum).

Figure 278. WAAC members arrive by train, 1942 (Fort Huachuca Historical Museum)............. 205

Figure 279. Former Southern Pacific railroad station at Fort Huachuca (located northeast of Old Post), 1943 (Fort Huachuca Historical Museum). 
Figure

Figure 280. Map showing rail line (green), rail station (magenta), the railroad trestle (green), and railroad worker housing (adjacent to railroad station), 1945 (Fort Huachuca).... 207

Figure 281. Looking north at remnants of railroad bed just east of stables (ERDC-CERL 2016). 208

Figure 282. View to the east of officers' quarters with vegetation and white picket fence, 1899 (NARA College Park, RG1111-SC). 213

Figure 283. View to the southeast of foundation plantings at 22114 (ERDC-CERL 2016).......... 213

Figure 284. View to the northeast of foundation plantings at 22120 (ERDC-CERL 2016)......... 214

Figure 285. View to the northeast of plantings at 22126 (ERDC-CERL 2016)............................. 214

Figure 286. Landscaping in front of 22215 (ERDC-CERL, 2016) ........................................... 215

Figure 287. Old Post area barracks (22208) with a lack of foundation plantings (ERDC-CERL, 2016). 216

Figure 288. View to the northwest of foundation plantings in front of Old Post Barracks $(22208,22214,22216), 1946$. [Note also row of shade trees along edge of Brown Field] (Fort Huachuca Museum).

Figure 289. Same view in 2016 showing that few trees remain along edge of Brown Field

(ERDC-CERL 2016)......................................................................................... 217

Figure 290. Officers' duplex (42011), 1941 (NARA College Park, RG111-SCA). .......................... 218

Figure 291. Officers' duplex (former Quarters 116), 1941 (NARA College Park, RG111-SCA).... 219

Figure 292. Officers' duplex (former Quarters 120), 1941 (NARA College Park, RG111-SCA).... 219

Figure 293. Plantings in front of 42017, Henry Circle (ERDC-CERL 2016).................................. 220

Figure 294. Officers' duplex (42018), Henry Circle (ERDC-CERL 2016)...................................... 220

Figure 295. Officers' duplex (41021), Henry Circle (ERDC-CERL 2016)...................................... 221

Figure 296. Aerial of Henry Circle showing orchard, 1929 (NARA College Park, RG165-FF)....... 221

Figure 297. View looking southeast at mature trees at corner of park, Henry Circle (ERDCCERL 2016). 222

Figure 298. Newly planted trees in Henry Circle along Mizner Avenue to screen modern neighborhood (ERDC-CERL 2016).

Figure 299. 10th Cavalry review, 1921 [Based on topography, it is likely this is the North Parade Field. Note the heavily planted trees along the edge of the field in front of barracks.] (Fort Huachuca Historical Museum).

Figure 300. View looking west at barracks (41414), no date [Note lack of plantings.] (NARA College Park, RG77 Entry 393 Box 95).

Figure 301. View looking west at barracks (41415), 1941 (NARA College Park, RG77 Entry 393 Box 95)

Figure 302. View looking west at barracks (41415) with some foundation plantings (ERDCCERL 2016).

Figure 303. View looking northwest at barracks (Building 41412) with no foundation plantings remaining (ERDC-CERL 2016).

Figure 304. View looking east of North Parade Field showing open space with no trees (ERDC-CERL 2016). 226

Figure 305. View to the north of former Post Headquarters, now Museum, 1943 [Note the evergreen foundation plantings.] (Fort Huachuca Historical Museum).

Figure 306. View to the north of the Museum, which no longer has foundation plantings, but 
Figure

several trees remain (ERDC-CERL 2016).

Figure 307. View to the west of plantings in front of former theater, 1936 (Fort Huachuca Historical Museum).

Figure 308. View to the west of the front of former theater (now the Museum Annex) with no landscaping (ERDC-CERL 2016).

Figure 309. Planting in front of former PX (Building 21115) (ERDC-CERL, 2016). 229

Figure 310. View looking south of vegetation along Huachuca Creek along Hines Road (ERDC-CERL 2016). 230

Figure 311. View to the southeast of the flagpole and officers' quarters, 1898 (Fort Huachuca Historical Museum). 233

Figure 312. View to the northeast of the flagpole and Quarters 22126, the Commanding General's residence from Star Hill (ERDC-CERL, 2016). 233

Figure 313. View to the south of the flagpole and surrounding vegetation and features (ERDC-CERL, 2016).

Figure 314. View to the south of picket fencing between Old Post Barracks, 1918 (Fort Huachuca Historical Museum). 235

Figure 315. View to the south showing only some of the officers' quarters have fencing by 1900 (Fort Huachuca Historical Museum).

Figure 316. View to the east showing fencing used today to separate the front from the rear yards of the officers' housing (ERDC-CERL 2016). 236

Figure 317. White vinyl fencing used to screen backflow preventor by former hospital (ERDCCERL 2016). 236

Figure 318. Looking east at stone wall and gate to yard behind Pershing House (22126) (ERDC-CERL 2016).

Figure 319. Looking north at WPA stone culvert adjacent to Building 41421 along Rhea Avenue (ERDC-CERL 2016). 238

Figure 320. Recent stonework concealing utilities on Brown Field (ERDC-CERL 2016). 238

Figure 321. Modern stone retaining wall along Boyd Avenue and stone planter at base of 6th Cavalry Memorial sign just south of the Fort Huachuca Museum (ERDC-CERL 2016).

Figure 322. Example of street lamp on Brown Field, c.1900 (NARA College Park)...................... 240

Figure 323. Street lamp style from Henry Circle, 1941 (NARA College Park). ............................... 240

Figure 324. Replica metal street lamp near 21114 (ERDC-CERL, 2016)..................................... 241

Figure 325. Typical lamp post in Fort Huachuca Historic District with Museum Annex (41305) in background (ERDC-CERL, 2016) ................................................................. 241

Figure 326. Manufacturer of replica street lamps (ERDC-CERL, 2016)...................................... 242

Figure 327. Street lamp located near Henry Circle (ERDC-CERL 2016)........................................ 242

Figure 328. Looking east at historical marker for NHL near flagpole on Brown Field (ERDCCERL 2016).

Figure 329. Looking northeast at monuments near flagpole on Brown Field (ERDC-CERL 2016).

Figure 330. Looking west at sculpture and monument of an Apache Scout in front of Museum Annex (ERDC-CERL 2016). 244

Figure 331. Looking north at Buffalo Soldiers Memorial located near the Credit Union (ERDCCERL 2016). 
Figure

Figure 332. Signage on Brown Field in front of Fort Huachuca Museum (ERDC-CERL 2016). ... 246

Figure 333. Signage at the Museum (ERDC-CERL 2016)........................................................... 246

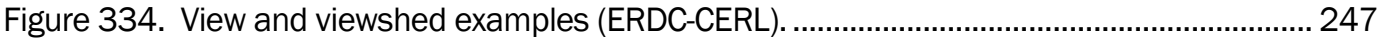

Figure 335. Looking east over Fort Huachuca from Star Hill, 1890 (NARA College Park, RG165-FF). 249

Figure 336. Post card of close-up view from Star Hill, date unknown (ERDC-CERL Collection)... 249

Figure 337. View south over Fort Huachuca from Star Hill (ERDC-CERL, 2016).......................... 250

Figure 338. Looking west over Fort Huachuca from west of the reservoir, c.1900 (NARA College Park, RG165-FF). 251

Figure 339. View north over Fort Huachuca from Reservoir Hill, 1954 (NARA College Park, RG111-SC). 252

Figure 340. Historic postcard of view from Reservoir Hill, date unknown (ERDC-CERL Collection). 252

Figure 341. Postcard of view from Reservoir Hill, c.1956 (ERDC-CERL Collection). ..................... 253

Figure 342. View north over Fort Huachuca from Reservoir Hill (ERDC-CERL, 2016). ................. 253

Figure 343. View southwest over Fort Huachuca, c.1883 (NARA College Park, RG165-FF)........ 254

Figure 344. View southwest over Fort Huachuca, 1893 (Fort Huachuca Museum).................... 254

Figure 345. View south from behind officers' quarters down Grierson Service Road (ERDC-

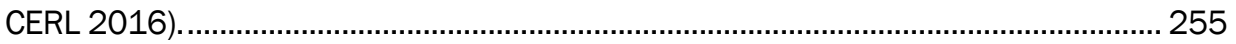

Figure 346. Aerial view of historic Cantonment, 1929 (NARA College Park, RG165-FF).............. 256

Figure 347. Aerial view of historic Cantonment, c.1980 (Fort Huachuca)................................... 256

Figure 348. View southeast of Pershing House and flagpole, 1898 (NARA College Park,

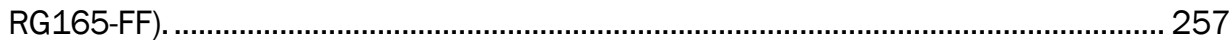

Figure 349. View east of the flagpole and Pershing House (ERDC-CERL 2016)......................... 258

Figure 350. View south of quarters along Grierson Avenue, c.1900 (Fort Huachuca Museum). 259

Figure 351. View north looking north along Grierson Avenue (ERDC-CERL 2016). ..................... 259

Figure 352. View south looking south along Grierson Avenue (ERD-CERL 2016)........................ 260

Figure 353. View north of barracks (22214, 22216, and 22320) along Augur Avenue, 1918 (Fort Huachuca Museum). 261

Figure 354. View southwest of 1880s Barracks looking southwest across Brown Field (ERDC-CERL 2016). 261

Figure 355. View south across Brown Field from hospital/Headquarters/Officers' Club, 1899 (NARA College Park, RG111-SC). 262

Figure 356. View south across Brown Field from hospital and Garrison Headquarters (ERDC-

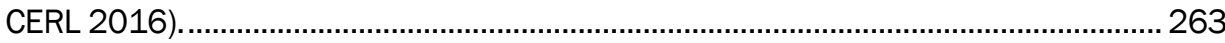

Figure 357. View north across Brown Field, 1900 (NARA College Park, RG165-FF)...................... 264

Figure 358. View north across Brown Field (ERDC-CERL 2016)............................................... 264

Figure 359. View south of 1914 Barracks looking up Rhea Avenue, 1918 (Fort Huachuca Historical Museum). ............................................................................................... 265

Figure 360. View south of 1914 Barracks looking up Rhea Avenue (ERDC-CERL 2016)............ 265

Figure 361. View east toward Henry Circle, the park and the quarters (ERDC-CERL 2016)........ 266

Figure 362. Planting plan for officers' quarters with shade and flowering trees behind and to 
Figure

sides of quarters (ERDC-CERL).

Figure 363. Planting plan for officers' quarters showing a variety of foundation plantings (ERDC-CERL).

Figure 364. Planting plan for officers' quarters using plants from proposed list in Appendix A

(ERDC-CERL).

Figure 365. View of proposed low plantings in from of barracks (ERDC-CERL). 276

Figure 366. Planting suggestions for trees along the perimeter of Brown Field (ERDC-CERL) .... 277

Figure 367. Planting suggestions for base of flagpole on Brown Field (ERDC-CERL). 278

Figure 368. Planting plan for Headquarters using plants from proposed list in Appendix A (ERDC-CERL). 279

Figure 369. Planting plan for Museum using plants from proposed list in Appendix A (ERDCCERL). 280

Figure 370. Planting plan for Bowling Alley (21114) using plants from proposed list in Appendix A (ERDC-CERL). .282

Figure 371. Planting plan for officers' duplexes showing shade trees in rear and flowering trees inside yards (ERDC-CERL).

Figure 372. Planting plan for officers' duplexes using plant list in Appendix A (ERDC-CERL). ..... 284

Figure 373. Supplemental landscape areas as identified by ERDC-CERL (2020)....................... 286

Figure 374. Map of North Parade Field landscape area (ERDC-CERL)....................................... 287

Figure 375. Aerial of North Parade Field with radio station at bottom center, 1923 (Fort Huachuca Historical Museum). 289

Figure 376. Looking northwest at the 25th Infantry Band on North Parade Field, 1933 (Fort Huachuca Museum)

Figure 377. Aerial of North Parade Field prior to construction of housing area, 1954 (Fort Huachuca Historical Museum).

Figure 378. Aerial showing the new housing area on the North Parade Field, 1961 (Fort Huachuca Historical Museum).

Figure 379. Looking east at the former theater (Building 41305) now the Museum Annex, with Apache Scout statue in foreground (ERDC-CERL 2016).

Figure 380. View south of heritage trail on the 1914 Parade Field (ERDC-CERL, 2016).

Figure 381. View west on the 1914 Parade Field with heritage trail sidewalk and historical interpretive sign (ERDC-CERL, 2016).

Figure 382. Example of historical interpretive signage along heritage trail sidewalk (ERDCCERL, 2016)

Figure 383. View east on the 1914 Parade Field with heritage trail sidewalk and historical interpretive signs (ERDC-CERL, 2016).

Figure 384. View of the parking lot at the eastern end of the 1914 Parade Field with 41331 credit union in center and Buffalo Soldier Statue Plaza at right (ERDC-CERL, 2016).

Figure 385. View towards 41330 at the north end of the North Field (ERDC-CERL, 2016)

Figure 386. View towards 41331 credit union on the north end of the North Parade Field (ERDC-CERL, 2016).

Figure 387. View west of the Buffalo Solder Legacy Plaza at the northeastern end of the 1914 Parade Field, with 41330 in the left background (ERDC-CERL, 2016).

Figure 388. View south toward the 1914 Officers' Quarters from the North Parade Field with 
Figure

2003 housing in front (ERDC-CERL, 2016).

Figure 389. Map of Million Dollar Barracks landscape area (ERDC-CERL). 296

Figure 390. View looking north of Million Dollar Barracks (now Alchesay Barracks), 1941

(NARA College Park, RG 77, 393 Box 94). 298

Figure 391. View east of Alchesay Barracks (31122) and parking lot (ERDC-CERL 2016)......... 298

Figure 392. View looking north of Enlisted Men's Grandstand, originally Building 109

(31124), 1941 (NARA College Park). 299

Figure 393. View looking north of Enlisted Men's Grandstand (31124) (ERDC-CERL 2016)..... 299

Figure 394. View looking north of Officers' Grandstand (31123) (ERDC-CERL 2016)................. 300

Figure 395. View east from Enlisted Men's Grandstand (31124) to Alchesay Barracks (31122) across baseball field (ERDC-CERL 2016). 300

Figure 396. Map of cavalry stables landscape area (ERDC-CERL). 301

Figure 397. Former stable buildings located west of Old Post Barracks, 1898 (Fort Huachuca Museum) 303

Figure 398. Photograph looking south of stables and stable guard and shops buildings to the east, 1918 (Library of Congress, Historic American Buildings Survey [HABS] AZ-210-11). 303

Figure 399. Map showing cavalry stables and associated buildings, 1923 (NARA College Park, RG 393, AZ-1). 304

Figure 400. Aerial looking south of Fort Huachuca, showing the original stables in the center and the current stables to the right, 1924 (NARA College Park, RG165-FF). 304

Figure 401. View looking west at stable building (30023), 1941 (NARA College Park, RG 77, 393 Box 95). 305

Figure 402. View looking west at stable building (30025), demolished, 1941 (NARA College Park, RG 77, 393 Box 95). 305

Figure 403. View northeast of stables on left, with Building 30023 in foreground and railroad bed with trees on right (ERDC-CERL, 2016). 307

Figure 404. View looking northeast at the stables 30023 and 30024 (ERDC-CERL, 2016)....... 307

Figure 405. View south of stone steps going up railroad bed to stable guardhouse location, looking towards 41420 (ERDC-CERL, 2016). 308

Figure 406. View south of stone steps from 30031 to parking lot (ERDC-CERL, 2016).............. 308

Figure 407. Looking southwest on railroad bed with stables on the right (ERDC-CERL, 2016). . 309

Figure 408. Looking at remnants of stone steps on right and railroad culvert on left (ERDC-

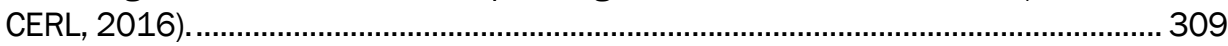

Figure 409. Map of quartermaster and commissary area (ERDC-CERL).................................... 310

Figure 410. Photograph looking south of area, 1918 (Library of Congress, HABS AZ-210-12)... 311

Figure 411. Looking northwest at Building 22526, former quartermaster stable (ERDCCERL).

Figure 412. Looking west at former Quartermaster Barracks, Building 22422, and eligible WPA retaining wall (ERDC-CERL 2016).

Figure 413. Looking southwest at Building 22530 (ERDC-CERL 2016).................................... 313

Figure 414. Looking north at warehouse building (31008) (ERDC-CERL 2016).......................... 314

Figure 415. View looking south of Building 22408, a quartermaster storehouse built in 1887

(ERDC-CERL 2016). 
Figure

Figure 416. View looking south at Building 22414, quartermaster warehouse built in 1920 (ERDC-CERL 2016).

Figure 417. View looking south at commissary storehouse and bakery (22420) (ERDC-CERL 2016).

Figure 418. View north from pedestrian bridge, adjacent to 22422, toward Butler Road Bridge over Huachuca Creek (ERDC-CERL 2016)..................................................... 316

Figure 419. Map of the Fort Huachuca Post Cemetery (ERDC-CERL).......................................... 317

Figure 420. Layout of Post Cemetery from 1893 map (Fort Huachuca Museum)....................... 318

Figure 421. View looking west at entrance to Fort Huachuca Cemetery (ERDC-CERL 2016)..... 319

Figure 422. View looking north at different stone wall types (ERDC-CERL 2016)........................ 319

Figure 423. View looking west of cemetery markers in the modern cremation section and iron fence along rear of cemetery (ERDC-CERL 2016). 320

Figure 424. View looking north of mature shade trees scattered throughout cemetery (ERDCCERL 2016). 320

Figure 425. View looking north at maintenance sheds (20034) (ERDC-CERL 2016). ................ 321

Figure 426. View looking north at restrooms (20036) (ERDC-CERL 2016). 321

Figure 427. View looking north at information kiosk (20032) and stonework (ERDC-CERL 2016).

Figure 428. View looking north at cemetery pavilion (20035) and seating (20035)................... 322

Figure 429. View looking west at entrance loop to Post Cemetery (ERDC-CERL 2016)............... 323

Figure 430. Map of Reservoir Hill landscape area (ERDC-CERL). 323

Figure 431. View looking south of chlorinator building (22004) and stairs and retaining walls, 1941 (NARA College Park). 325

Figure 432. View on Reservoir Hill looking north at WPA wall, Building 22003 in front, 22001 in center, and 22002 at rear on Reservoir Hill (ERDC-CERL 2016)............................ 325

Figure 433. View south toward parking area along Reservoir Hill Road (ERDC-CERL 2016)....... 326

Figure 434. Current map of Cavalry Park 1 Housing Area (ERDC-CERL) 327

Figure 435. View looking east at the front of the Stone Warrant Officers Quarters (21103) (ERDC-CERL 2016). 330

Figure 436. View looking north at the rear of the Stone Warrant Officers Quarters (21103) and associated garage (21104) (ERDC-CERL 2016).

Figure 437. View looking west of lone garage (20310) west of Hines Road (ERDC-CERL 2016)

Figure 438. View south of Capehart housing along Grierson Service Road (ERDC-CERL 2016)

Figure 439. View west of vegetation in front of 21206 in Cavalry Park 1 Housing Area (ERDCCERL 2016). 332

Figure 440. View west of vegetation in front of 21204 in Cavalry Park 1 Housing Area (ERDCCERL 2016). 332

Figure 441. View west of vegetation in front of 21102 in Cavalry Park 1 Housing Area (ERDCCERL 2016) 333

Figure 442. View south of 21101 in Cavalry Park 1 Housing Area and surrounding hills (ERDC-CERL 2016). 333

Figure 443. View looking west of Cavalry Park 1 housing area from Reservoir Hill (ERDC- 
Figure

Page

CERL 2016).

Figure 444. View looking south at front of former school (21112), now ACES administration (ERDC-CERL 2016).

Figure 445. View looking east at school (21112) and annex building (21110) (ERDC-CERL 2016). 
Table

Table 1. Twenty-seven historic buildings identified in the 1974 NRHP nomination (with updated table from 1975 additions) (Puzzi, 1973).

Table 2. Forty-nine contributing buildings to the 1976 Fort Huachuca National Historic Landmark Historic District (Adams, 1976).

Table 3. Table of WPA contributing buildings and resources at Fort Huachuca (Hart and Blackwell, 2009).

Table 4. Table of WPA contributing buildings and resources within the RCI footprint (CP\&Y, 2009).

Table 5. Buildings modified or constructed by WPA and their eligibility to WPA-Era Historic District (Tomes and Thomas, 2014).

Table 6. List of 16 buildings recommended as contributing (in addition to the 48 already listed as contributing in the Fort Huachuca Historic District) in the 1993 NR nomination (Wee and Mikesell, 1993).

Table 7. The 13 buildings adjacent to the Fort Huachuca NHL Historic District and their determinations (Valenzuela, 2011) ...............................................................................56

Table 8. List of buildings within the Old Post Officers' Quarters landscape area. ...........................60

Table 9. List of buildings within the Old Post Barracks landscape area. .........................................81

Table 10. List of buildings located within the Old Post Administration landscape area. .............. 111

Table 11. List of buildings within the Brown Field landscape area................................................ 131

Table 12. List of buildings within the Old Post Recreation landscape area. ................................. 152

Table 13. List of buildings within the 1914 Barracks landscape area. ........................................ 163

Table 14. List of buildings within the 1914 Officers' Quarters landscape area........................... 186

Table 15. List of trees and shrubs for Fort Huachuca from WWII completion report (NARA College Park, RG77 Completion Report). 230

Table 16. Character-defining features of the component landscapes in the NHL Historic District. 230

Table 17. Buildings associated with North Parade Field landscape area. .................................... 288

Table 18. Buildings associated with Million Dollar Barracks landscape area............................... 296

Table 19. List of buildings in the Cavalry landscape area.......................................................... 302

Table 20. Buildings in the quartermaster and commissary area. ............................................... 310

Table 21. Buildings associated with the Cemetery landscape area. ............................................ 317

Table 22. Buildings on Reservoir Hill...................................................................................... 324

Table 23. Table of buildings in Cavalry Park 1 landscape area....................................................... 328

Table A-1. Fort Huachuca Approved Plant List (IDG, 2008)........................................................ 342

Table A-2. Suggested trees that may be suitable for the historic district. ..................................... 344

Table A-3. Suggested shrubs that may be suitable for the historic district. ................................... 345

Table A-4. Suggested perennials and ground covers that may be suitable for the historic

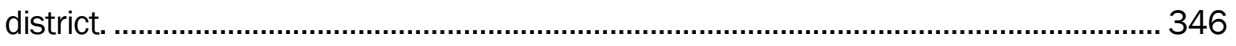

Table A-5. Common invasive species for the Southwest region ..................................................... 346 


\section{Preface}

This study was conducted for the Cultural Resources Manager in the Environmental and Natural Resources Division, Directorate of Public Works at Fort Huachuca, Arizona under MIPR7ACE5355 under Project Number 462097, "Historic Landscape Mgmt Plan - Ft. Huachuca." The technical monitor was Mr. Martyn Tagg, Cultural Resources Manager at the time of the contract.

The work was performed by the Land and Heritage Conservation Branch, of the Installations Division, of the Engineer Research and Development Center, Construction Engineering Research Laboratory (ERDC-CERL). At the time of publication, Ms. Ellen Hartman was Chief, Land and Heritage Conservation Branch; Mr. Charles Schroeder was Acting Chief, Installations Division; and Dr. Andrew Nelson was the Technical Director for Environmental Quality and Installations. Ms. Michelle Hanson was the Acting Deputy Director and Dr. Kumar Topudurti was the Acting Director of ERDC-CERL.

COL Teresa A. Schlosser was Commander of ERDC, and Dr. David W. Pittman was the Director. 
THIS PAGE INTENTIONALLY LEFT BLANK 


\section{Methodology}

\subsection{Background}

The U.S. Congress codified the National Historic Preservation Act of 1966 (NHPA), the nation's most effective cultural resources legislation to date, to provide guidelines and requirements for preserving tangible elements of our nation's past. This preservation was done primarily through creation of the National Register of Historic Places (NRHP). Contained within this piece of legislation are requirements for federal agencies to address their cultural resources, defined as any prehistoric or historic district, site, building, structure, or object (NHPA Sections 110 and 106). Section 110 requires federal agencies to inventory and evaluate their cultural resources. Section 106 requires the determination of effect of federal undertakings on properties deemed eligible or potentially eligible for the NRHP.

Fort Huachuca is located in Cochise County in southeastern Arizona, approximately 75 miles southeast of Tucson and 15 miles north of the border of Mexico (Figure 1). The installation encompasses 73,272 acres in the middle of San Pedro Valley at the base of the Huachuca Mountains. Fort Huachuca was established in 1877 as a frontier post during the Indian Wars. From 1913-1931, it served as home for the $10^{\text {th }}$ Cavalry "Buffalo Soldiers". Today, Fort Huachuca is home to the U.S. Army Intelligence Center of Excellence and the U.S. Army Network Enterprise Technology Command (NETCOM). 
Figure 1. Location of Fort Huachuca in southeast Arizona.

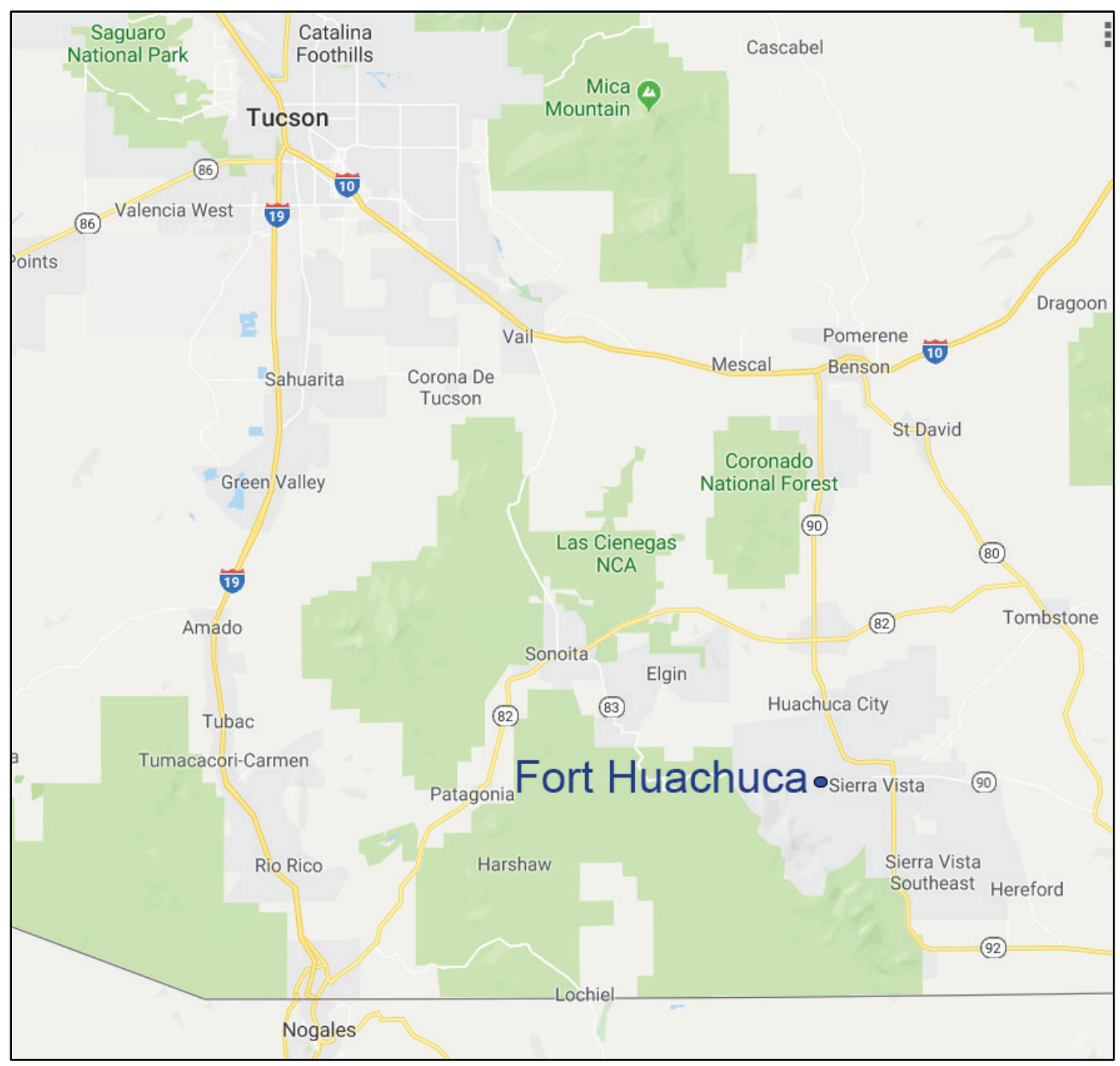

Source: www.google.com, accessed March 2019.

\subsection{Objective}

The original objective of this project was to inventory and evaluate the historic landscapes within the Fort Huachuca Historic District which is a National Historic Landmark (Figure 2). Since there are currently three NRHP historic districts (one is listed and two are eligible) and one National Historic Landmark (NHL) historic district at Fort Huachuca, the boundaries of this project were extended outside of the NHL historic district to include all potential historic resources tied to the periods of significance and management of the NHL historic district. In this report, a brief landscape development history is included to identify significant periods in the history of Fort Huachuca. Second, a list of all relevant Fort Huachuca reports reviewed for this project has been included. Third, an inventory of all landscapes and landscape features within the Old Post area (everything south of Smith Avenue/Winrow Road) was completed. These 
landscapes and features were evaluated according to the methods established in Guidelines for Identifying and Evaluating Historic Military Landscapes (ERDC-CERL, 2008) and their significance, integrity, and character-defining features described including photographic and historic documentation. Fourth, character-defining features of the overall NHL historic district are defined. Fifth, general management recommendations were provided to help preserve and/or protect these resources in the future. The management recommendations include planting plans intended to help installations preserve the landscape character in historically significant areas, as well as provide a list of appropriate and/or sustainable regional plant material while working with the "Fort Huachuca Plant List" in the Installation Design Guide (2008). While previous work included historic landscape posters created by CERL in 1997, they lack the building-to-building detail this report provides. Lastly, supplemental landscapes associated with the overall periods of significance and the Fort Huachuca Historic District NHL as outlined in Chapter 2 are described. 
Figure 2. Map showing the boundary of the Fort Huachuca Historic District NHL (red line) and contributing buildings (red) (ERDC-CERL).

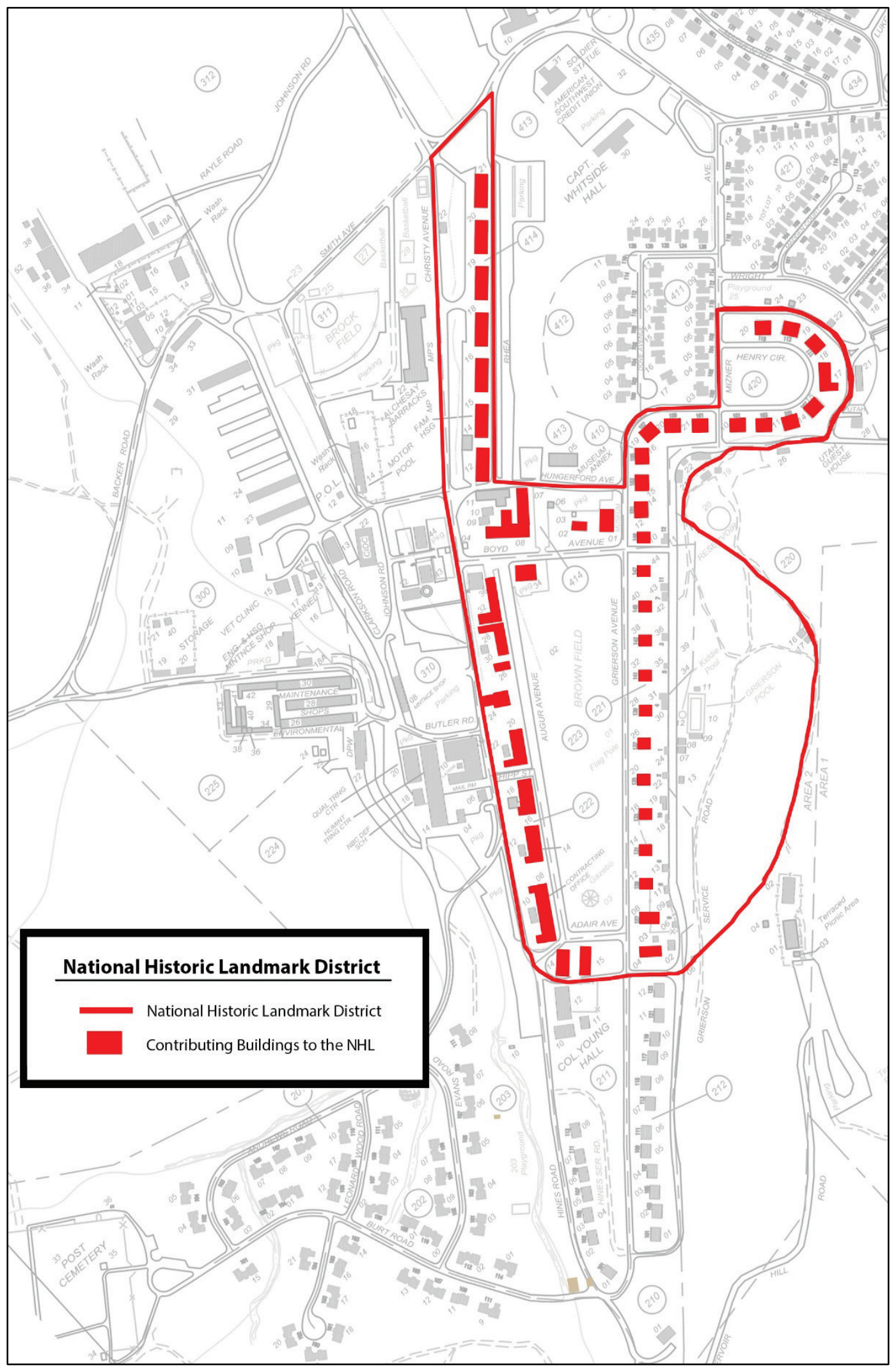




\subsection{Researchers}

This project was conducted by the U.S. Army Corps of Engineers, Engineering Research Development Center, Construction and Engineering Research Laboratory (ERDC-CERL), based in Champaign, IL. The research team included Adam D. Smith, Master of Architecture, with 22 years of experience in military architectural history, and Megan Tooker, Master of Landscape Architecture, as landscape historian with 22 years of experience.

\subsection{Site visits}

\subsubsection{Fort Huachuca}

ERDC-CERL personnel made one trip to Fort Huachuca in December 2016 to inventory the landscape and viewsheds and evaluate the existing Historic District. During that week, members of the team inventoried and photographed the landscape features, viewsheds and contributing buildings to the Historic District.

\subsubsection{Archival repositories}

ERDC-CERL researchers conducted a review of books, archival repositories, and online resources related to Fort Huachuca. The following places were contacted and/or searched:

- NRHP listings and nomination forms (online at https://www.nps.gov/Nr/publications/index.htm);

- Historic drawings, maps, photographs, and information were provided by the Cultural Resources Manager at Fort Huachuca;

- National Archives and Records Administration (NARA), College Park, Maryland (NARA);

- Fort Huachuca Museum.

\subsubsection{Analysis}

After initial research was completed, the team analyzed the gathered information. Archival information and field information were integrated throughout the course of the project. The information available was contained in text documents, photographs, and historic maps. Using archival sources, the research team extracted relevant historical 
information. The material was then combined to tell the story in both text and images.

Using information from the historic context, the overarching historic integrity was evaluated per the NRHP's definition. A cultural resource can retain or lose its historic integrity, meaning it either does or does not convey its historic significance. From this evaluation process, a recommendation of eligibility to the NRHP was made. The evaluation followed guidelines published by the National Park Service (NPS) in National Register Bulletin \#15, How to Apply the National Register Criteria for Evaluation; ${ }^{1}$ National Register Bulletin \#16A, How to Complete the National Register Registration Form ; 2 the National Register Bulletin, How to Prepare National Historic Landmark Nominations; 3 and The Secretary of the Interior's Standards for the Treatment of Historic Properties with Guidelines for the Treatment of Cultural Landscapes. 4

\footnotetext{
1 NPS. 1997. National Register Bulletin \#15: How to Apply the National Register Criteria for Evaluation. Washington, DC: U.S. Department of the Interior, National Park Service.

2 NPS. 1997. National Register Bulletin \#16A: How to Complete the National Register Registration Form. Washington, DC: U.S. Department of the Interior, National Park Service.

3 NPS. 1999. National Register Bulletin: How to Prepare National Historic Landmark Nominations. Washington, DC: U.S. Department of the Interior, National Park Service.

4 Kay D. Weeks and Anne E. Grimmer. 1995. Secretary of the Interior's Standards for the Treatment of Historic Properties with Guidelines for the Treatment of Cultural Landscapes. Washington, DC: U.S. Department of the Interior, National Park Service.
} 


\section{Landscape Development History}

This chapter outlines the history of Fort Huachuca's landscape development by identifying important periods of time influential in the growth of the installation.

\subsection{Frontier Era, 1880s}

Fort Huachuca was established as a camp in March 1877 to counter the Apache threat and secure the border with Mexico during the Apache Wars. It was one of 15 military posts constructed in Arizona south of the Gila River between 1856 and 1878 . Only two of these posts would survive after the end of the Apache threat in 1894. The mouth of Huachuca Canyon was selected as the site of the camp due to the shelter of the hills on three sides, it was on elevated ground, it had plenty of grass for grazing, and Huachuca Creek provided water. Old cottonwoods and sycamores lining the creek provided shade during the hot summer months, and the mountains contained forests of pine to provide lumber for building. 5

From the fort's founding in 1877 to Geronimo's final surrender in 1886, Fort Huachuca's primary mission was to subdue the Apaches. Temporary adobe and canvas buildings were constructed between 1877 and 1880. But these structures proved to be inadequate in thunderstorms. In 1879, a sawmill was erected near the mouth of the canyon, and the soldiers were paid extra to haul logs or use their skills for construction work. The first permanent structure was constructed in 1879 (Building 22108). Built of adobe, the building served as the first Post Hospital. Over the years it has served a hospital, school, officers' mess, and officers' quarters. While initially Fort Huachuca was a temporary camp, it was designated a fort in 1882.

The Quartermaster's Department began to prepare estimates and plans for permanent buildings at Camp Huachuca in September 1881. The first map and plan were completed in October 1881 under the direction of Colonel J.C. Kelton, assistant adjutant general of the Military Division of the Pacific at the Presidio. The plan was for a typical unfortified frontier fort arranged in a formal pattern around a broad, rectangular parade ground

${ }^{5}$ Rand F. Herbert et al. 1990. Fort Huachuca, Arizona: A Century of Development and Changing Missions 1877-1977. Davis, CA: Jackson Research Projects, p 18. 
(Figure 3). The central open space was surrounded with clusters of functionally related structures: hospital facilities and medical corps housing at the north end; officers' quarters along the eastern flank; commissaries and storehouses on the south at the entrance of the canyon; troop barracks, kitchen, bakery, and administration buildings along the western flank. ${ }^{6}$

Figure 3. Fort Huachuca map, 1893 (Fort Huachuca Museum).

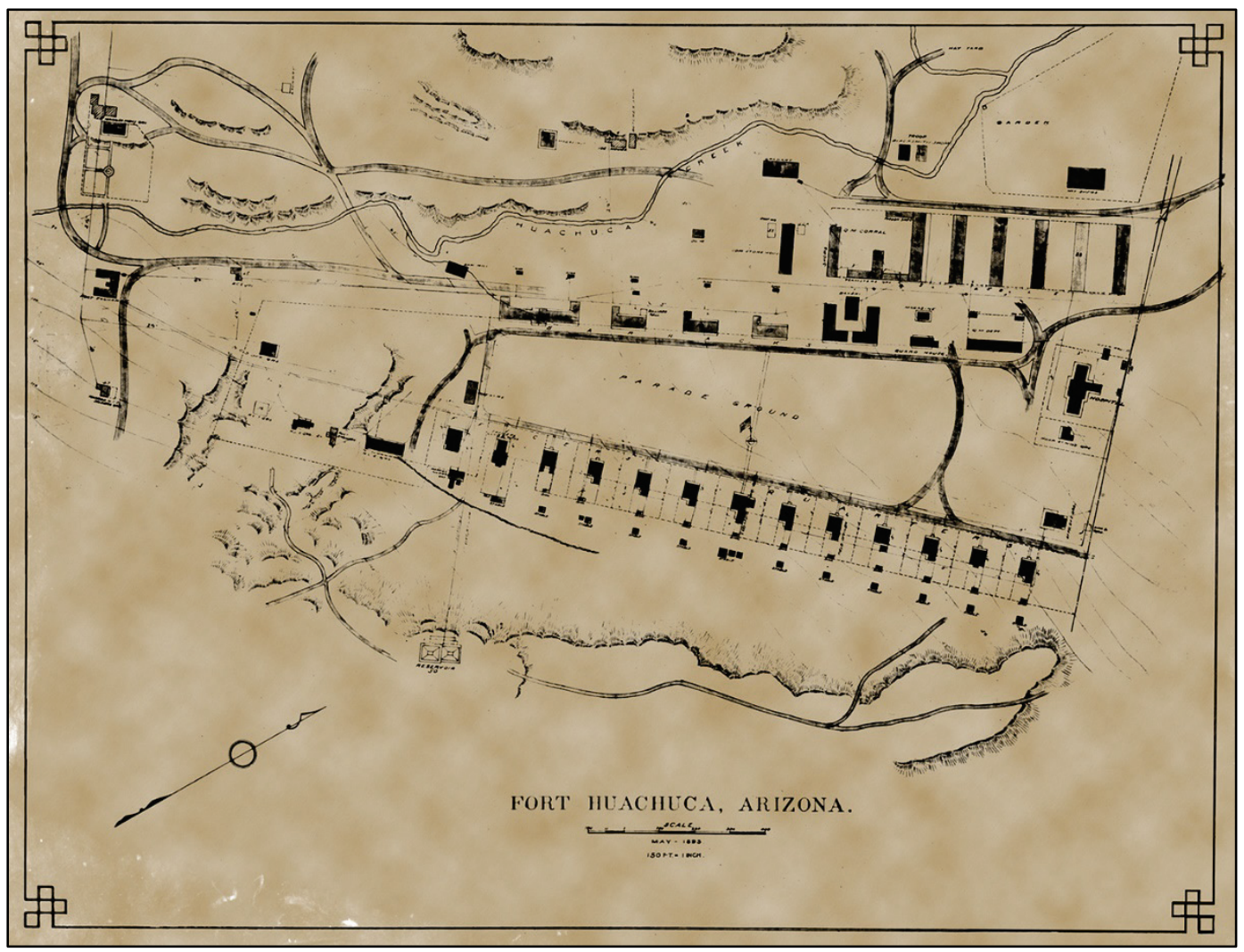

Due to increased unrest with the Apache, the number of troops at Fort Huachuca doubled from two companies to four in 1881. Appropriations followed, and Fort Huachuca began its new building program in the summer of 1882. Civilian construction workers were hired, and using locally available materials, the first of three 65-man two-story wooded barracks was completed that year (Building 22214).

In 1883 , three more barracks were constructed. Located along the west side of the parade field, one was a 130-man, double troop barrack building (22208); the other two were 65-man, single troop barrack buildings (22216 and 22220). All three were two-story frame structures with wide 
porches on both floors (Figure 4). Behind each company barrack was a communal water closet thanks to the reservoir in the hills above the post (22001) and water mains to distribute water around the post. By the end of 1884,11 adobe officers' quarters $(22108,22112,22114,22116,22120$, 22126, 22128, 22132, 22138, 22140, and 22144) were constructed along the east side of the parade ground (Figure 5). The residences had indoor plumbing and bathtubs with stables and water closets in the rear.

Figure 4. View looking west of quartermaster subsistence storehouse [transformed into barracks c.1900] (now demolished) and barracks (22320, 22216, 22214, 22208 (R-L)), 1883 (NARA College Park, RG165-FF).

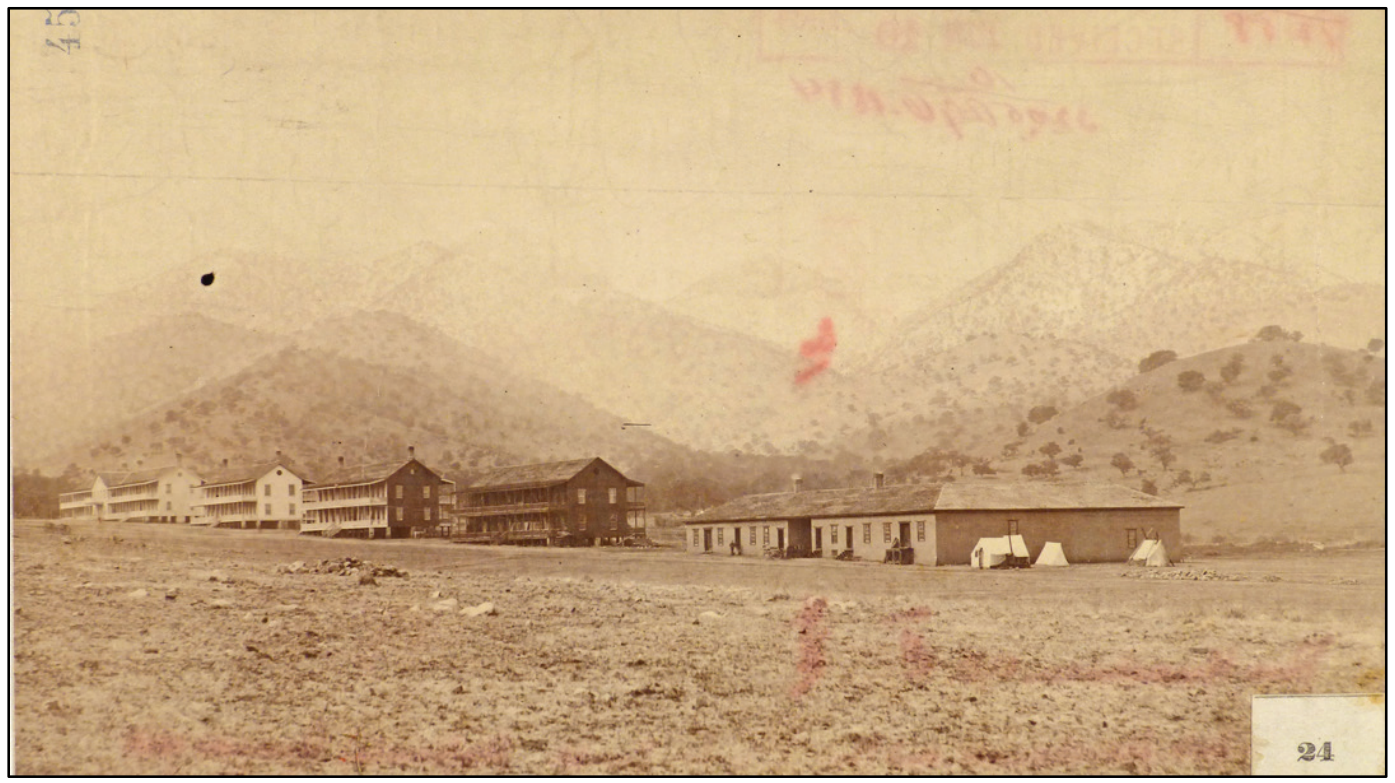

Figure 5. Front of the officers' quarters (R-L 22140, 22138, 22132, 22128, 22126, 22120, 22116, 22114, 22112) looking south, 1883 (NARA College Park, RG165-FF).

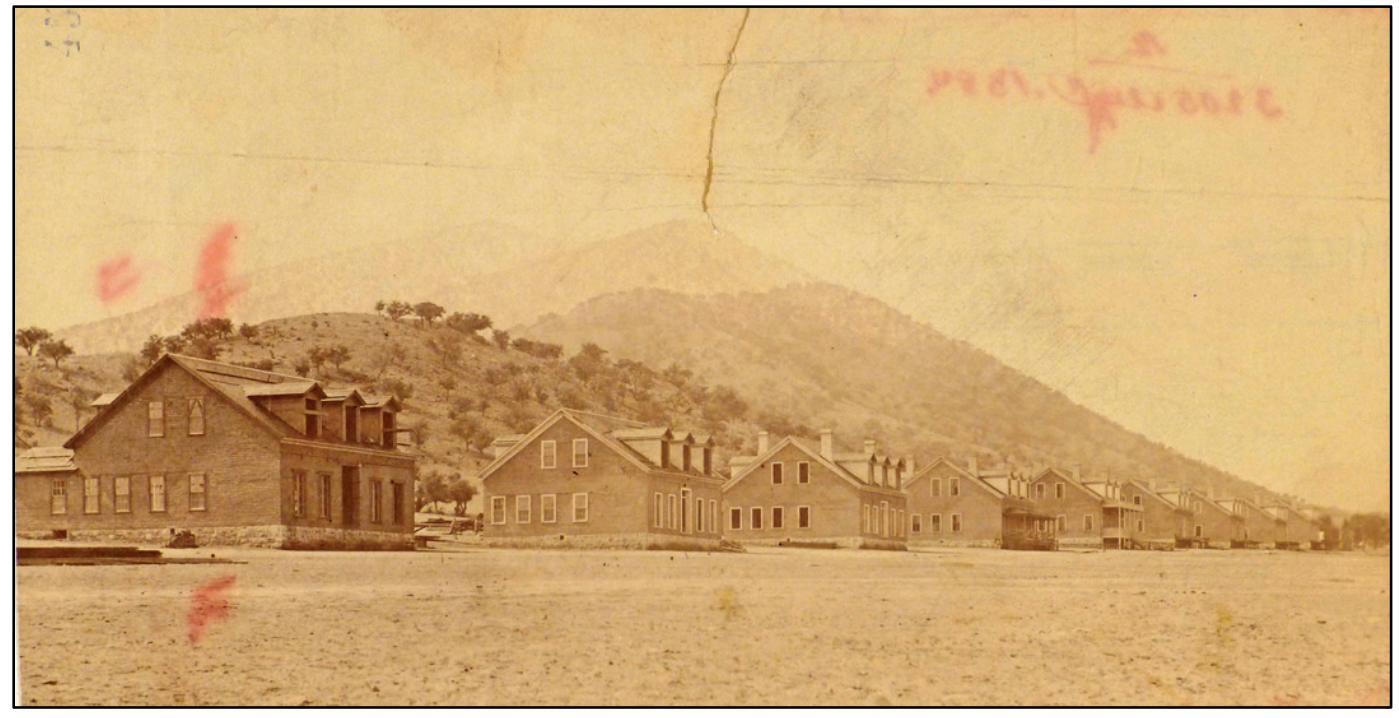


In 1884, a new Post Hospital was built to replace the existing eight-bed hospital (22108). A 24-bed adobe hospital (41408) was completed in 1885 . The building was surrounded by a $12 \mathrm{ft}$ wide porch and was constructed in conformance to the General Plan for Hospitals issued by the Surgeon General's Office in 1867 and 1870. In addition, a small two room adobe morgue (41409) was constructed adjacent to the hospital. A hospital officer's quarters (22104) was constructed at the south end of officer's row and was known as "Hazen House".

Fort Huachuca had other auxiliary buildings built at this time that survive today. The buildings include a guardhouse (22328), ordnance magazine (22330), a quartermaster storehouse (22332), a commissary storehouse (22408), and a post bakery (22324). The buildings were of good, solid adobe construction and clustered on or near the parade ground, north of the barracks. Early buildings that did not survive include an adobe married enlisted man's quarters, a one-story wood-framed amusement hall, a small one-story adobe residence for the commissary sergeant, and a troop barracks building built in 1886 . This building was "U-shaped" and located on the parade ground surrounding the post bakery. The barracks were demolished in 1955. Also built at this time were six troop stables, one teamsters' quarters and/or storeroom, and quartermaster shops, all located behind the Old Post Barracks near Huachuca Creek. Today, the troop stables are gone, but the quartermaster shop (22526) and the quartermaster stable (22530) remain.

After the surrender of Geronimo in 1886, the role of Fort Huachuca shifted to international-border defense. While only the 4th Cavalry remained, the number of troops stationed at Fort Huachuca did not decrease significantly. In 1888, the 4th Cavalry was again joined by the 9th Infantry. The Army constructed several new buildings to relieve overcrowding among the officers. The first was a two-story double officers' quarters (22104) built in 1891 at the south end of officers' row. In 1892, the quartermaster erected another two-story adobe double Bachelor Officers' Quarters (41401) opposite the northeast corner of the parade ground.

West of the central parade ground was the quartermaster section of the post. This area was also expanded during the 1890 s with the construction of a second ordnance magazine, an ice house, a butcher shop and two troop blacksmith shops. In addition, a small root house, an L-shaped storehouse adjacent to the commissary storehouse (22408), a granary, 
wagon shed, and hay shed were built on the west bank of Huachuca Creek. Only the storehouse has survived.

After 1889, the Army abandoned Forts McDowell, Mojave, Verde, Apache, and Lowell in Arizona Territory, as well as Fort Bowie in 1894 and Fort Grant in 1905. Fort Huachuca remained as the sole permanent military installation in southern Arizona. In 1901, Fort Huachuca was recommended as a permanent post for Headquarters and four troops of cavalry. This led to significant efforts to modernize the post in the early years of the 2oth century. These efforts included replacement of old water closets behind the enlisted barracks (22212 and 22322), a new ice plant, laundry facilities, and a tailor shop (demolished) (Figure 6).

At the south end of the parade ground, the Army carved out a new area to serve as a recreational center. Adjacent to the old amusement hall/chapel, the Army erected Brayton Hall (21115), an elegant two-story adobe building that served primarily as a gymnasium, theater, and library. In 1908, a bowling alley (21114) was constructed adjacent to Brayton Hall. Behind Brayton Hall and the amusement hall, the post's first swimming pool was built in 1908 (no longer present) (Figure 7). 
Figure 6. Map showing building locations prior to 1905 (NARA College Park, RG77).

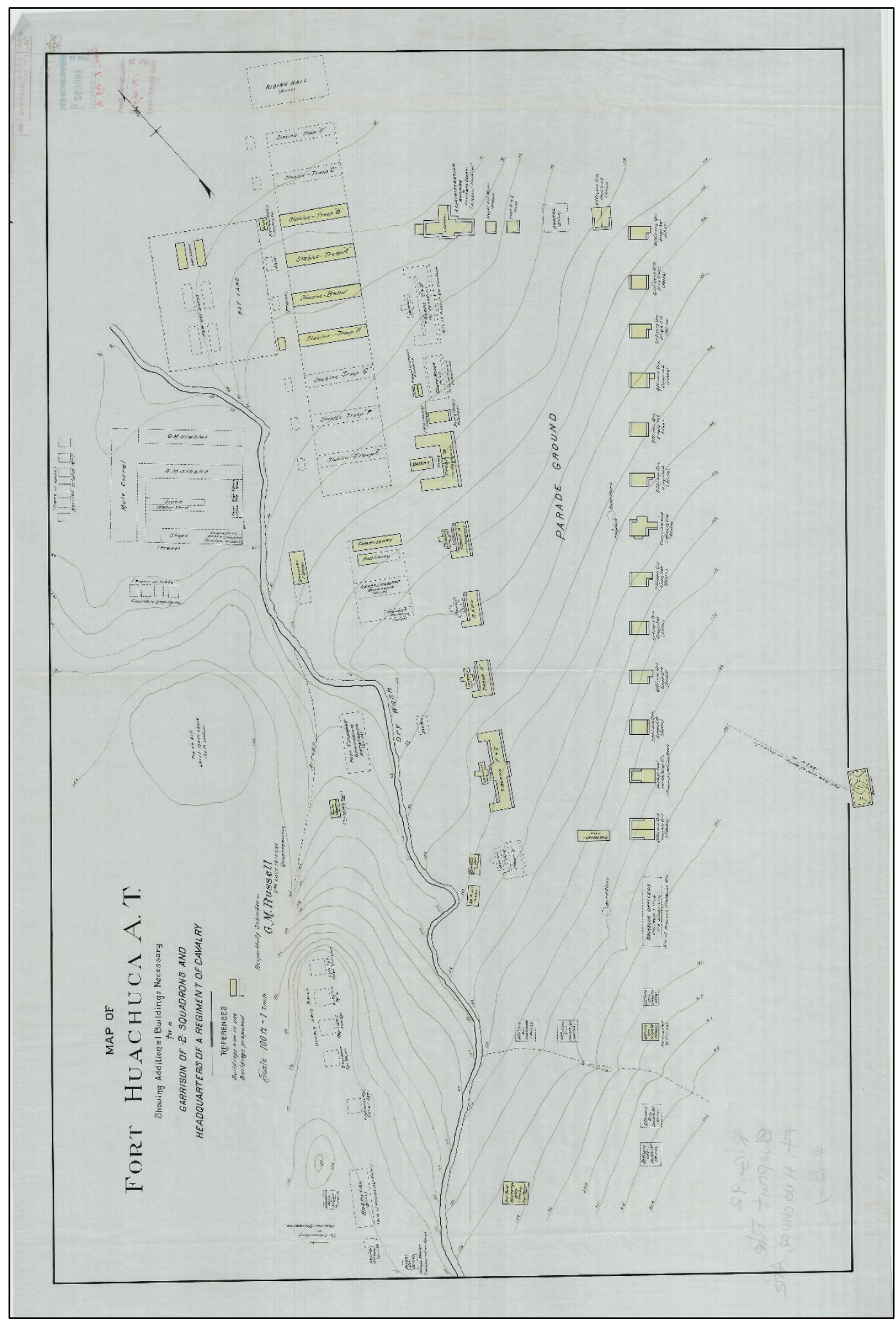


Figure 7. Map detailing the layout of the Cantonment in circa 1911 (NARA College Park, RG92 Blueprint File).

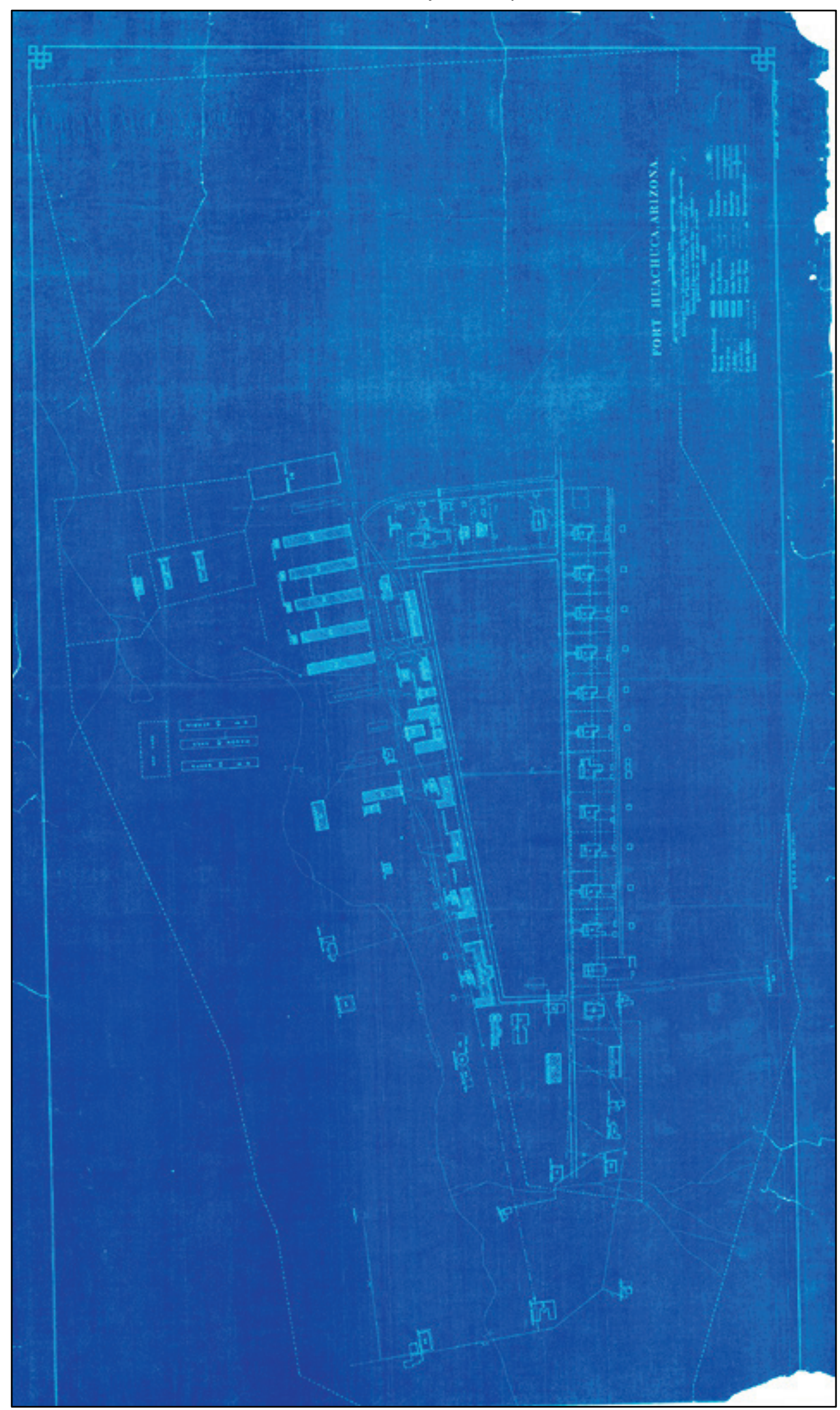




\subsection{Expansion and World War I, 1910s}

As the first decade of the new century drew to a close, soldiers at Fort Huachuca found themselves responding to recurrent incidents along the Mexican border. Alarmed that the Mexican revolution would spill across the border, President Taft ordered more troops to the southwest to strengthen border patrols. Between January and June 1911, the number of troops stationed at Fort Huachuca increased from 150 to 901 men when the entire 6th Cavalry Regiment was transferred to Fort Huachuca. To accommodate the new forces, the post quartermaster received an appropriation of \$110,000 to build troop barracks, cavalry stables, and officers' housing. However, the expansion plans were delayed due to events in Mexico.

A full-scale civil war broke out in Mexico in 1913. Troops from Fort Huachuca responded once again. Following an inspection of Fort Huachuca by the Secretary of War, the War Department decided to station the "Buffalo Soldiers" of the all-black 1oth Cavalry at Fort Huachuca. Indians of the Great Plains referred to the soldiers of the 10th Cavalry as "Buffalo Soldiers." Ultimately, the name "Buffalo Soldiers" was applied to all black soldiers in the Indian Wars. In 1913, the 10th Cavalry (the original Buffalo Soldiers) was moved to Fort Huachuca and was the only Army unit stationed at Fort Huachuca until 1927. This transfer began a long and distinguished period of service by that black cavalry regiment at Fort Huachuca.

By December 1913, all but one company of the 1oth Cavalry had arrived at Fort Huachuca, and the number of cavalry mounts increased dramatically. The arrival of more troops and mounts required the construction of many new buildings at the fort, with construction lasting until 1917. The new construction mainly took place to the north of the 188 os buildings, continuing the pattern of officers' quarters to the east, barracks to the west. The post quartermaster began to make plans and cost estimates for increasing the post permanently from regiment to brigade-size (Figure 8). The main focus of new construction was along Rhea Avenue, a northern extension of the existing line of barracks; in the quartermaster sector on the west side of the parade ground; and on Henry Circle, a horseshoe-shaped park-like boulevard north of Officers Row. 
Figure 8. View of an early plan for accommodating the $10^{\text {th }}$ Calvary, c.1912 [Note this unrealized plan (in yellow) called for three circles of housing and the creation of a new large parade field and a different configuration of cavalry barracks and stables.] (NARA College Park, RG92 Blueprint File).

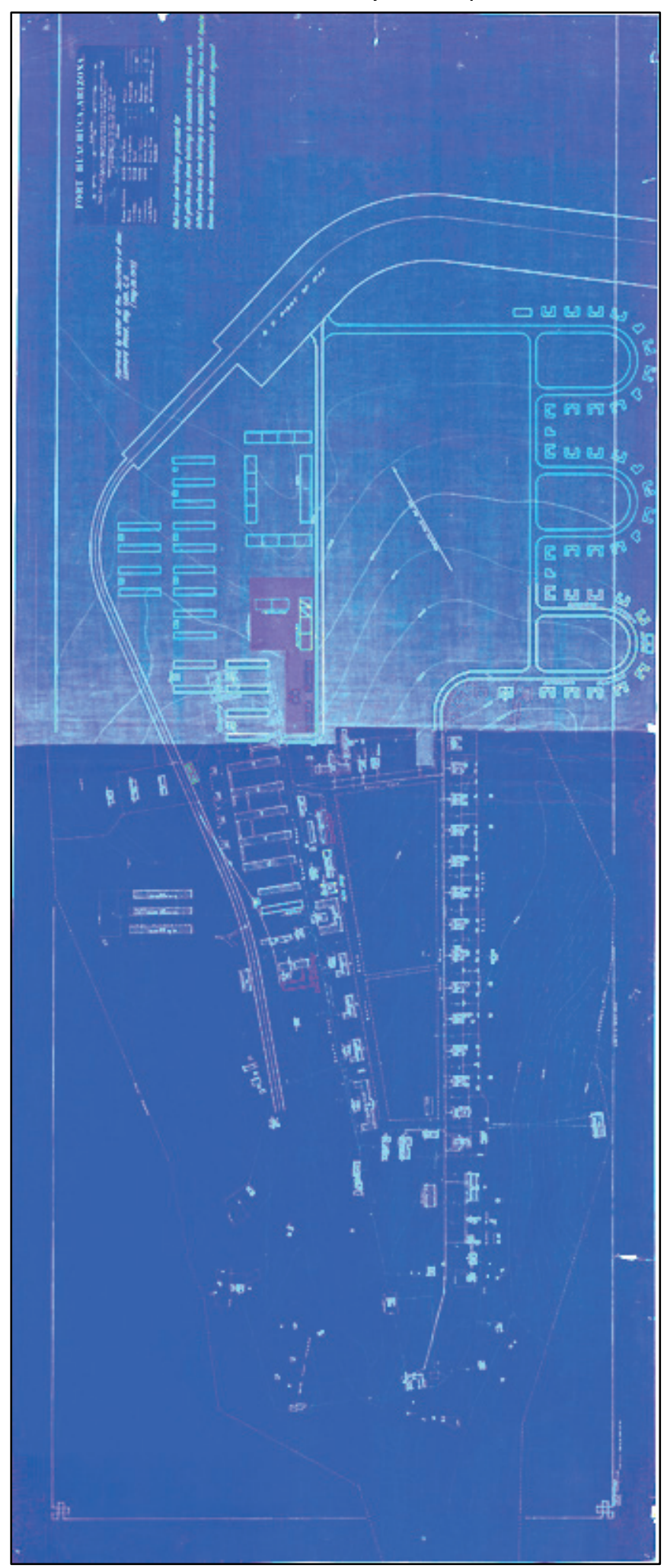


In 1912, the post quartermaster experimented by building one standardized two-story wood-frame officers' duplex (41014) on the north end of Grierson Avenue. The model proved successful for adaptation to Arizona, and two years later, eight sets of the same duplex (41015, 41016, 41019, 41020, 41021, 42010, 42011 and 42014) were built on the northern extension of Grierson Avenue and on the south side of Henry Circle. In 1915, two additional officers' duplexes of the same type (42015 and 42018), and a Bachelor Officers' Quarters (42017) were completed at the head of Henry Circle. Finally, in 1917, the Henry Circle loop was filled in with the completion of the final two officers' duplexes (42019 and 42020) (Figure 9).

Figure 9. View of the construction for the $10^{\text {th }}$ Calvary, circa 1913 (NARA College Park, RG92 Blueprint File).

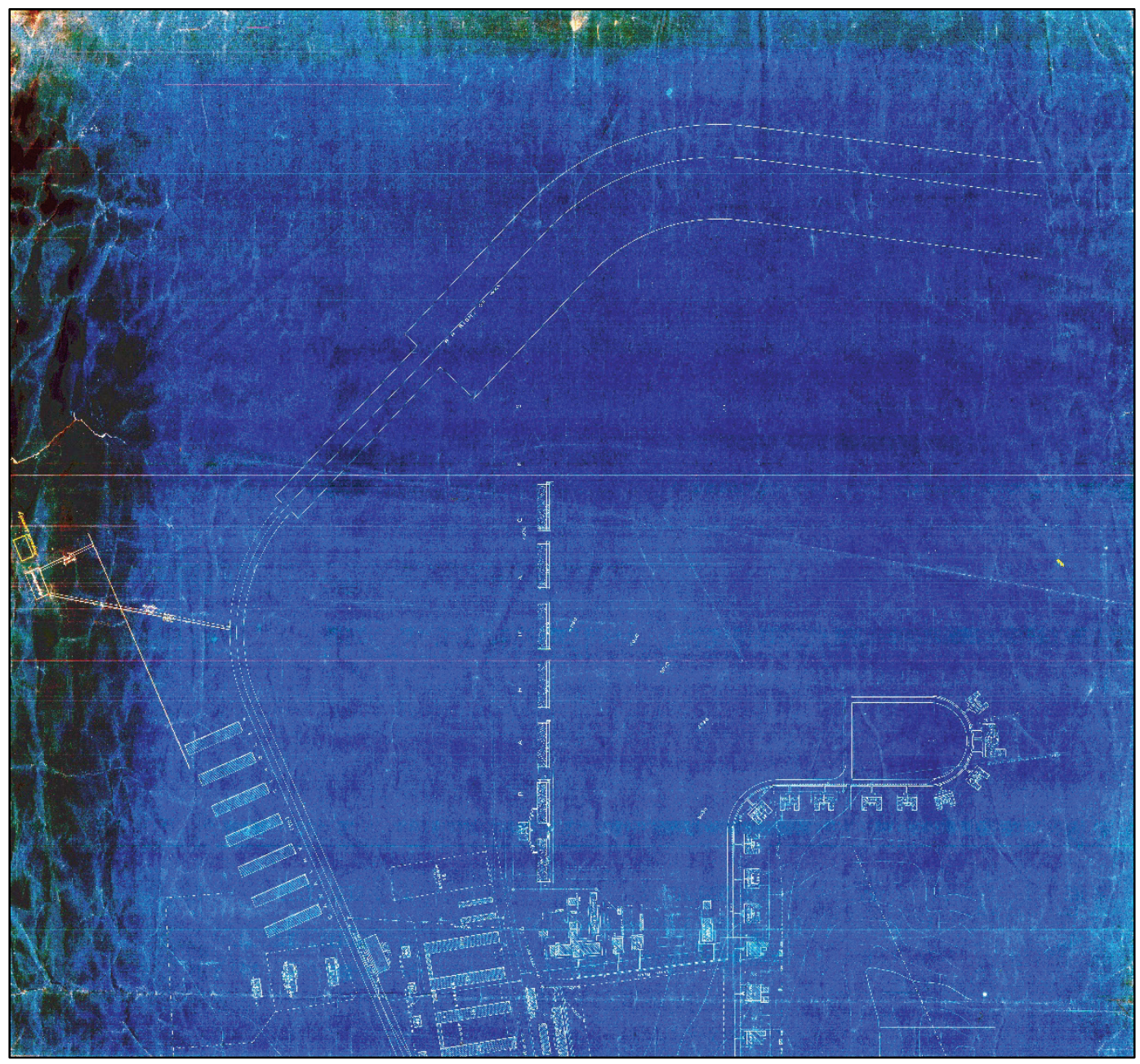

Seven new barracks with a capacity to house nearly 600 men were built on Rhea Avenue between 1914 and 1916. Two two-story, stucco on frame company barracks (4141 2 and 41415), designed similar to the earlier wooden 
barracks on the exterior elevations, were erected first just north of Hungerford Avenue. An accompanying lavatory (41414) was placed between the two structures at the rear of the barracks. Five additional barracks of the same type (41416, 41418, 41419, 41420, and 41421), but slightly longer, were added to the Rhea Avenue row at its north end in 1916. Lavatories for the barracks were placed in the basement. The barracks were located along the northwest edge of a drill field, North Field.

To serve the expanded cavalry post, a new quartermaster complex was constructed west of the barracks. Six temporary stables were first constructed to house the increased number of cavalry horses, and shops were built between the stables, which were probably used for blacksmithing and tack repair. These buildings no longer exist. Further west, bordering Huachuca Creek, the Army constructed a row of seven cavalry stables (only 30028, 30031 and 30033 remain today). Each of the wood-frame structures contained 39 double stalls, a forage and grain room, and a saddle room.

Many of the 19th century buildings underwent modifications during the build-up after 1913. Each of the single troop wooden barracks was extended to the north, and two modern lavatories (22210 and 22218) were built to serve some of these barracks. A new Post Headquarters Building (41402), Rodney Hall, was constructed in 1917. It is a two-story clay tile building located on the north end of the parade ground. The Post Headquarters was the communication and command center for the post. In the basement were a large workroom, store rooms, a printing press, and a photograph development lab. On the main floor, it contained a post office and message center, the commanding officer's room, and offices for the post adjutant, the officer's assembly room, and Headquarters for the intelligence office. The second floor housed administrative clerks, the post courthouse, clerks, the personnel sergeant, and the switchboard.

In 1920, as non-commissioned officers (NCO) returned from World War I (WWI) and settled into routine garrison life, the Army constructed two rows of wood-frame NCO residences at the southern end of the old post along Grierson and old Carter Roads. In addition, the Army erected a Ushaped vocational school as the Post Public School (Colored) south of Brayton Hall. Completed in June 1920, this wood-frame schoolhouse for black children contained eight school rooms and a library. Both the 39 NCO residences and the vocational school were dismantled and salvaged in 1956-1957 to make room for a new housing project. 
From 1918-1941, the mission at Fort Huachuca was primarily one of training and continued patrol duty along the Mexican border. During that time, two black regiments served on the post. The 1oth Cavalry, which was stationed at Fort Huachuca in 1913, would remain there until 1931. A second regiment, the 25th Infantry, another group of black troops, arrived on post in 1928. Both regiments were used for various duties at Fort Huachuca during that time, such as telegraph and radio operators, clerks, and other needed services; the Post Quartermaster also used the troops for building roads throughout the post. In 1931, Fort Huachuca ceased to operate as a cavalry post.

\subsection{Interwar Era, 1930s}

In 1933, as part of President Franklin Roosevelt's New Deal program, public-works projects, such as the Public Works Administration, the Civilian Conservation Corps (CCC), the Civil Works Administration (CWA), and the Works Progress Administration (WPA), provided work for many unemployed Americans and were instrumental in the construction of a large number of buildings and structures across the U.S. At Fort Huachuca, these organizations set about updating the post's facilities by renovating or replacing existing buildings and constructing roads, wells, bridges, and other infrastructure. The majority of buildings constructed at Fort Huachuca during this time were WPA projects. The WPA was active on post from 1934 to 1941, and projects included modifications on or construction of over 60 buildings and constructing a system of retaining walls, culverts, ditches, and rock walls.

In addition to various rehabilitation and new construction projects, the WPA built two grandstands (31124 and 31125) at the baseball field, laid out a ditch system, and rebuilt a fence around the perimeter of the post. The increased importance of motor vehicles to U.S. Army activities resulted in the construction of several buildings used to facilitate automobile-storage and -maintenance functions. In addition to numerous garages built throughout the post, two filling stations (30110 and 30012) were constructed in 1934 and 1939, respectively. A motor-transport pool (30114) was built in 1934, and an adjacent shop building (30115) was built in 1939. 
The Stone Warrant Officers' Quarters (21103) and its associated garage (21104) were built in 1938-1939 (Figure 10). ${ }^{7}$ Located to the southwest of the parade ground, the stone duplex was built to house two warrant officers and their families. The Stone House and garage were originally surrounded by frame $\mathrm{NCO}$ quarters.

Figure 10. View looking southeast at Stone Warrant Officers' Quarters (21103), 1939 (NARA College Park, RG 77-394 Box 9).

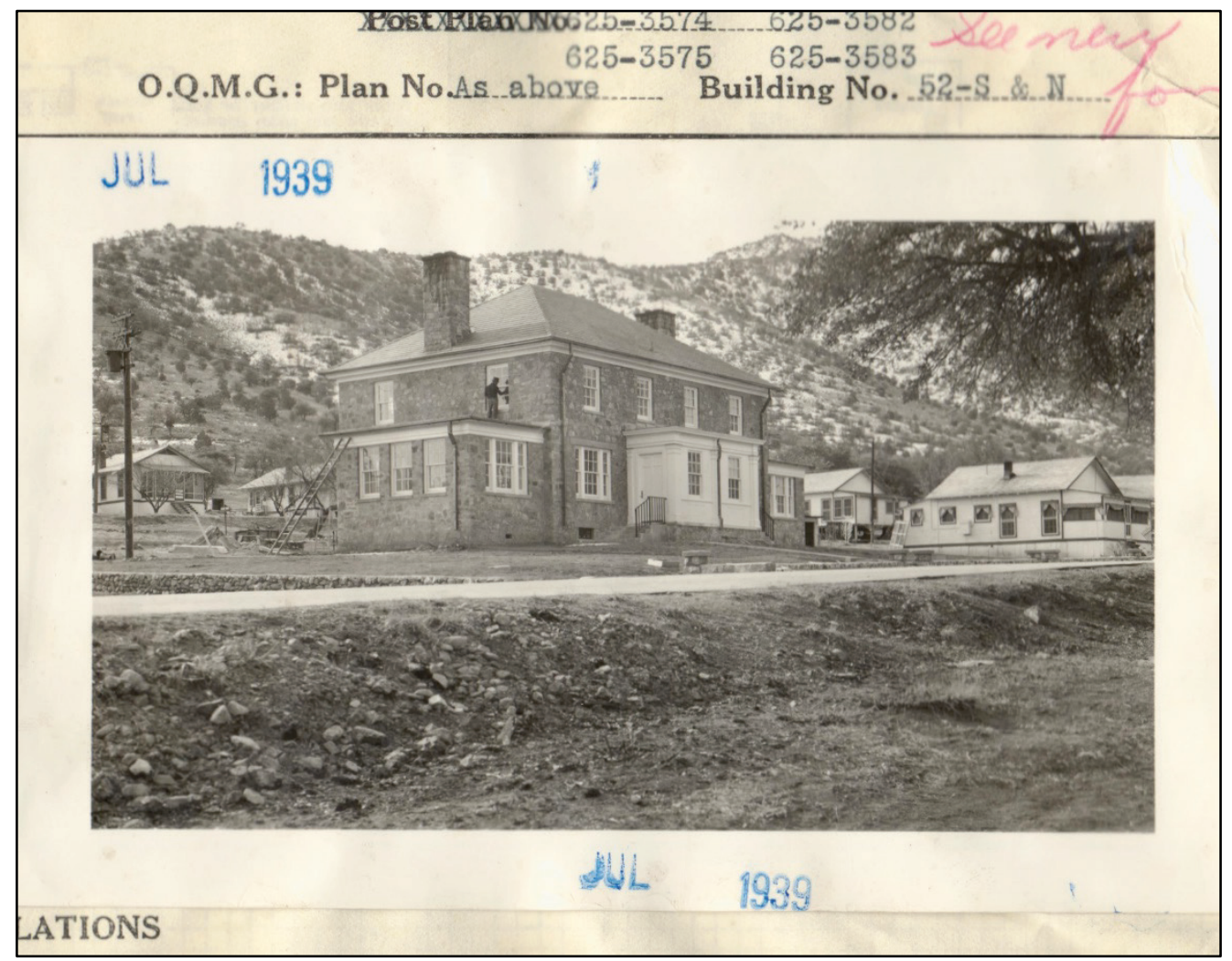

Among the last of the WPA projects was the construction of the "Million Dollar Barracks" (31122, now named Alchesay Barracks after an Apache Scout) to house the troops of the 25th Infantry (Figure 11). The barracks was so named because of the cost of construction; at the time, it was the most expensive building on post. ${ }^{8}$ The three-story, poured concrete Spanish Colonial Revival structure was completed in 1939. Most of the WPA projects completed prior to 1940 consisted primarily of infrastructural upgrades and the rehabilitation of buildings not directly related to pre-war-

\footnotetext{
7 Rand F. Herbert and Stephen D. Mikesell, 1993. National Register Nomination for Stone Quarters and Garage/Warrant Officers' Quarters, Fort Huachuca.

8 Rand F. Herbert and Stephen D. Mikesell, 1993. National Register Nomination for Stone Quarters and Garage/Warrant Officers' Quarters, Fort Huachuca.
} 
personnel increase and mobilization. The construction of the "Million Dollar Barracks" marked the beginning of a shift toward projects that addressed the expansion of both the post and its mission.

Figure 11. Million Dollar Barracks (31122, now Alchesay Barracks), 1940 (NARA College Park, RG 77-394 Box 9).

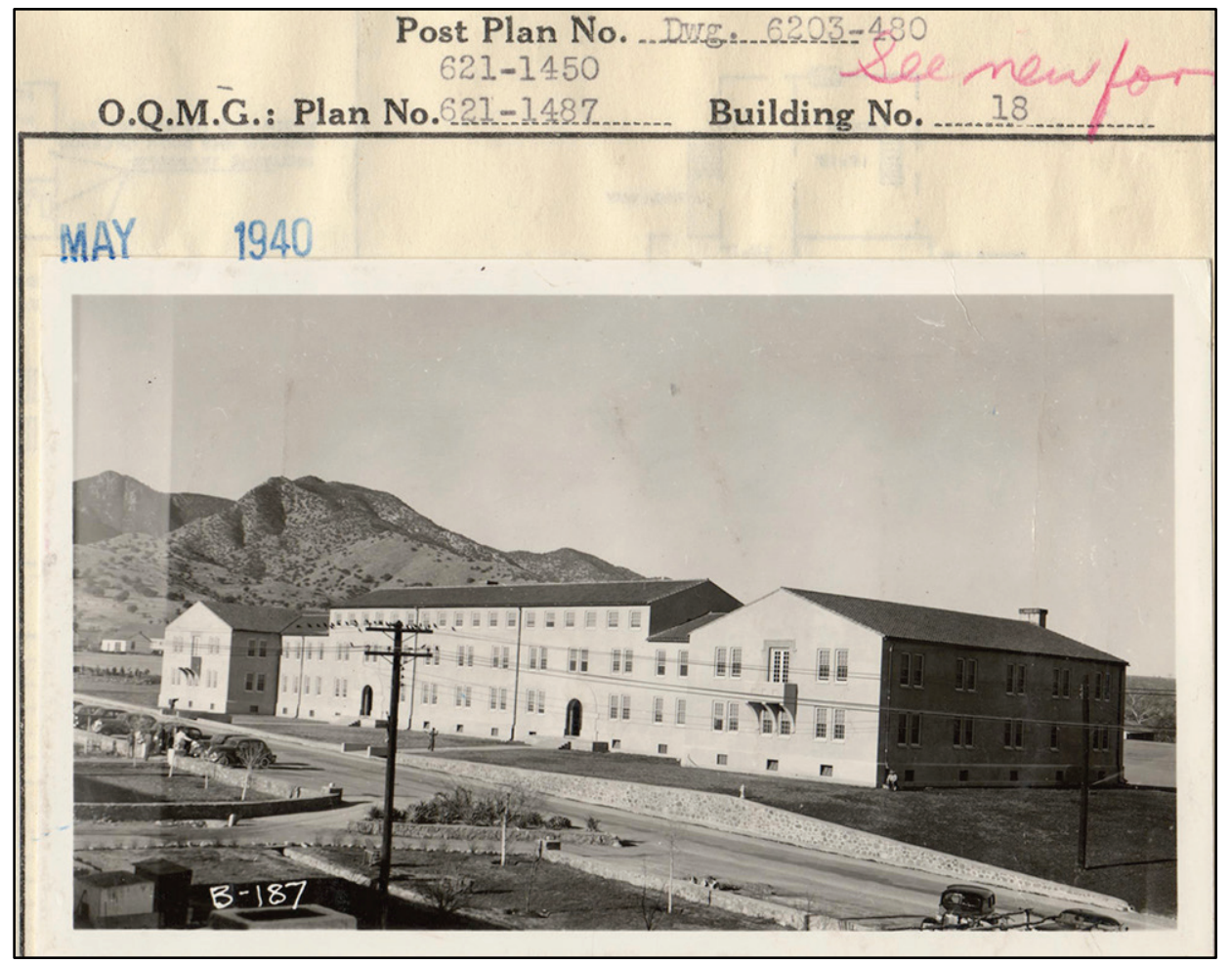

Several of the WPA and/or CCC-era projects at Fort Huachuca involved construction to establish a regular source and storage of water for the post. Resources associated with WPA water source and retention projects include Reservoir No. 2 (22002) and the Chlorine Building (22004) on Reservoir Hill to the south of Brown Field. From the founding of Fort Huachuca, the securing of a reliable water source has been paramount to the viability of the post. Therefore, it is no surprise that a considerable amount of the WPA funding and labor expended at Huachuca related to sourcing and storing water. Collectively, these two structures are similar in their utilitarian design, with the reservoir constructed of poured concrete structural walls and the Chlorine Building reflecting the fieldstone construction typical of many WPA and CCC projects. In addition, a guard house (90020) was constructed in 1936 at the east entrance to the installation (Figure 12). 
Many improvements were made to the rear of the Old Post Officers' Quarters along Grierson Service Road. These included: stone garages for officers' automobiles (20310, 22006, 22021, 22022, 22023, 22109, 22113, 22119, 22131, 22135, 22143, 41010, 42021, 42022, 42023, and 42024), servants' quarters (22111, 22118, 22122, 22124, 22130, 22134, 22142, and 41011), retaining walls, and drainage ditches. Drainage ditches were also added to the front and rear of the row of the four double barracks fronting the north side of the parade ground. By 1942, WPA funding was largely reallocated toward facilitation of the United States' entry into WWII.

Figure 12. Looking west at WPA-constructed guard house (90020) at east end of Post, 1937 (NARA College Park RG 77-393 Box 95).

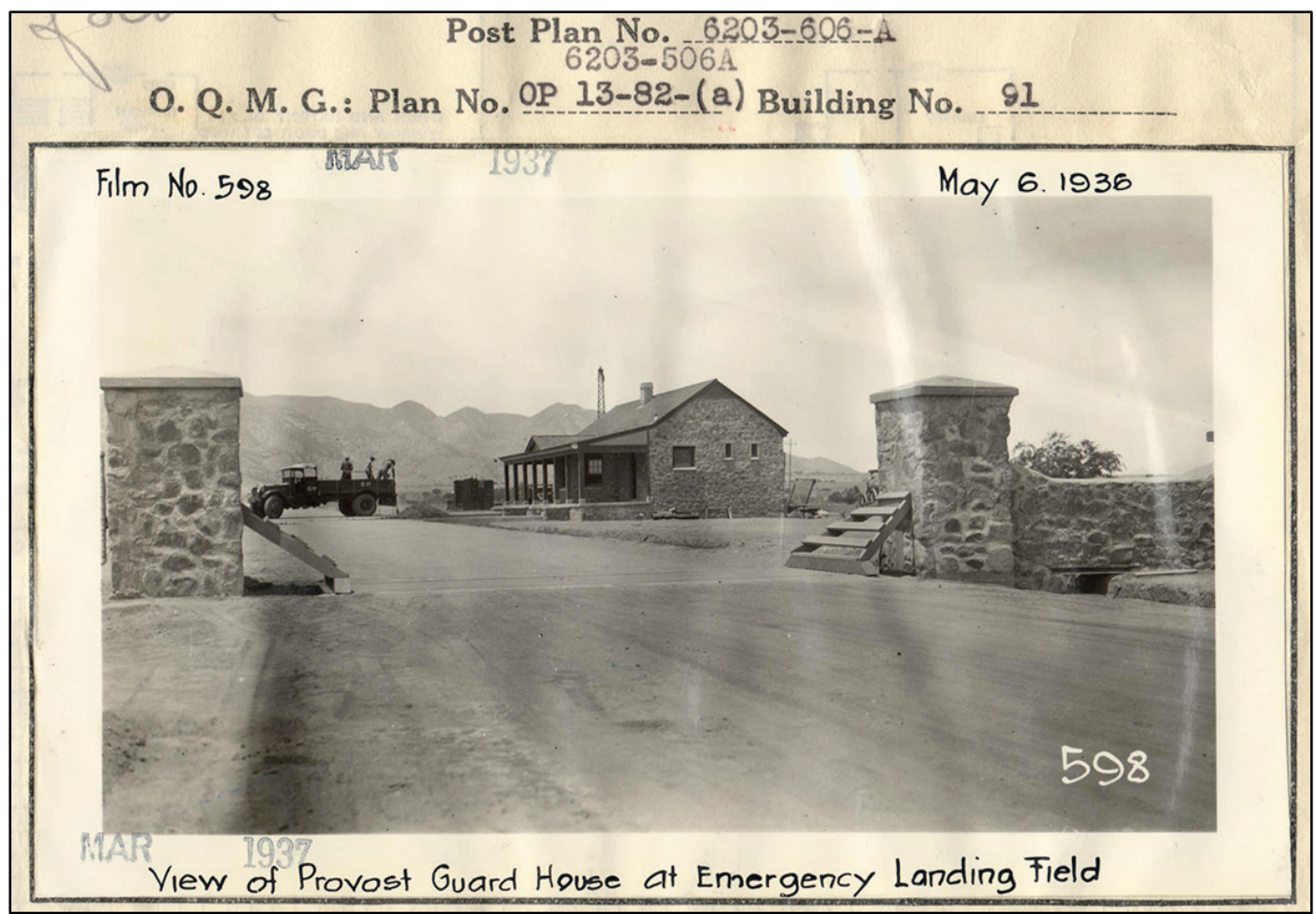

\subsection{World War II}

During World War II (WWII), Fort Huachuca became a major training center for black troops. During this new era of mobilization, the incoming trainees would significantly raise the post's soldier population. The 93rd Infantry Division was reactivated at Fort Huachuca in 1942. In November 1942, 6 months after the reactivation of the 93rd Infantry Division, the 32nd and 33rd Women's Army Auxiliary Corps (WAACS) arrived at Fort Huachuca. The women took over roles, such as cooking, bookkeeping, truck driving etc., to allow more men to serve in combat duties. To accommodate the expanding personnel population on post, new facilities were 
built at a rapid pace. For the WAACS, six barracks, two mess halls, and a large administration building that housed a library, game rooms, a post exchange, and a beauty parlor were constructed.

In addition to the WAACS facilities, barracks, hospitals, maintenance shops, offices, warehouses, and recreational facilities were built, including duplicates because of segregation. Between January and June 1942, 226 buildings were constructed and became known as the New Cantonment. In addition to these buildings, a new water system to accommodate the increased population, had to be constructed including the addition of two wells. 9 The New Cantonment was located east of the Old Post, on the sloping piedmont north of Soldier Creek. The area was midway between the Old Post and the new well fields near the eastern boundary of the military reservation. With the exception of WWII temporary buildings constructed just north of the rail line, few changes were made to the Old Post area during this time (Figure 13).

9 Herbert et al. 1999. Fort Huachuca, 1877-1977, pp. 113-115. 
Figure 13. Map of the Old Post in 1945 (Fort Huachuca Directorate of Public Works [DPW]).

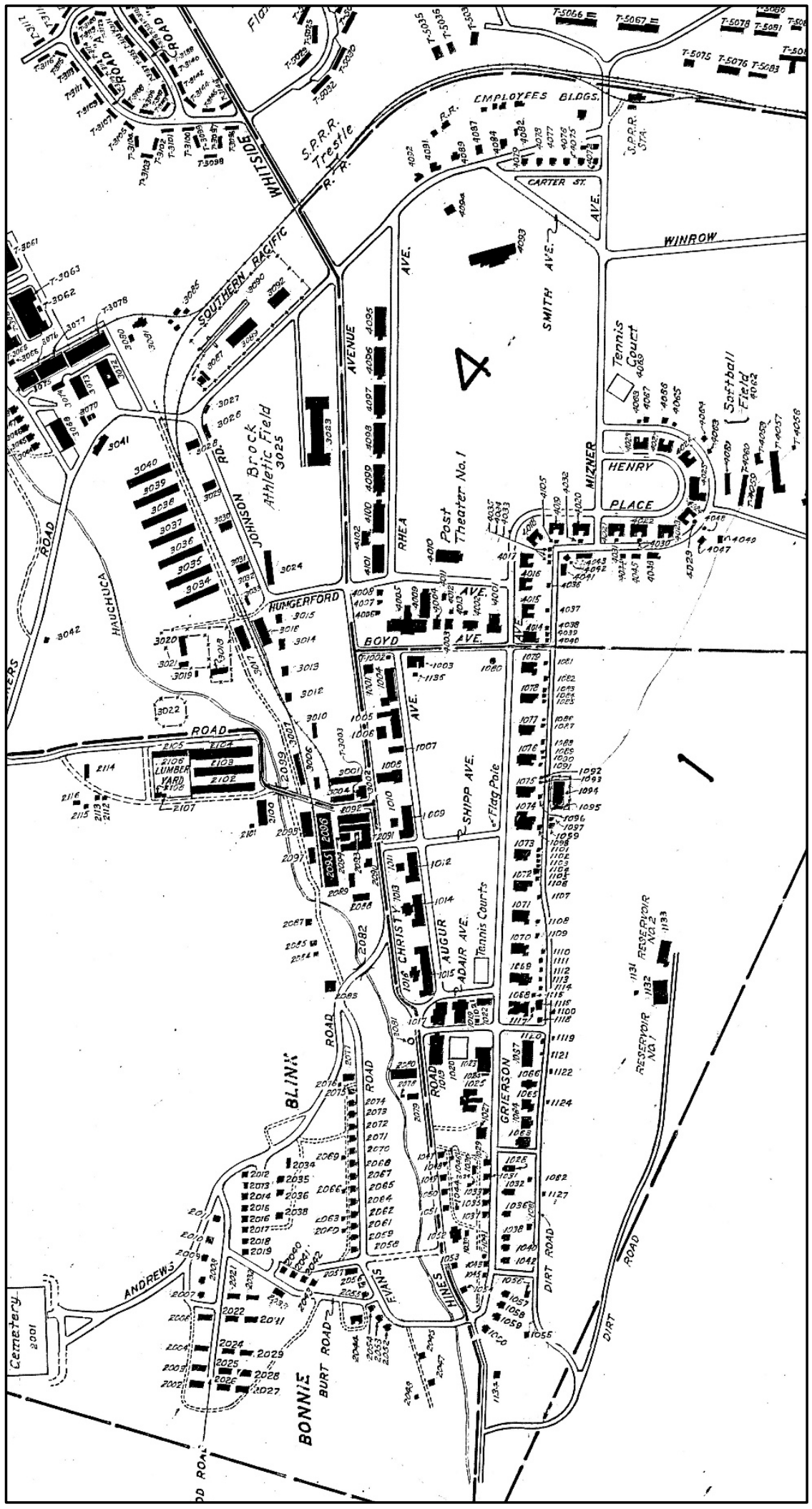


On 13 April 1943, the 92nd Infantry Division was formed at Fort Huachuca. As a result, Fort Huachuca became home to the largest number of black soldiers in the country; each of the two divisions totaled approximately 15,000 men. Although veterans of these divisions would be sometimes called "Buffalo Soldiers," the term was given by Native Americans to black soldiers who fought during the Indian Wars half a century earlier. ${ }^{10}$

Training activities at Fort Huachuca during the new wartime mission included long marches wearing full packs, tactical exercises, demolition training, and various drills (Figure 14). During that time, the post functioned as the supply distribution center, including equipment, rations, and laundry, for all of Arizona's military units and for many military units in New Mexico and southern California. After the 92nd and 93rd Infantry Divisions were deployed overseas in 1944, the remaining population at Fort Huachuca was composed of soldiers who stayed behind to receive additional training or who did not meet the military's requirements for combat soldiers.

Figure 14. Soldiers marching away from New Cantonment, 1942 (Fort Huachuca Museum).

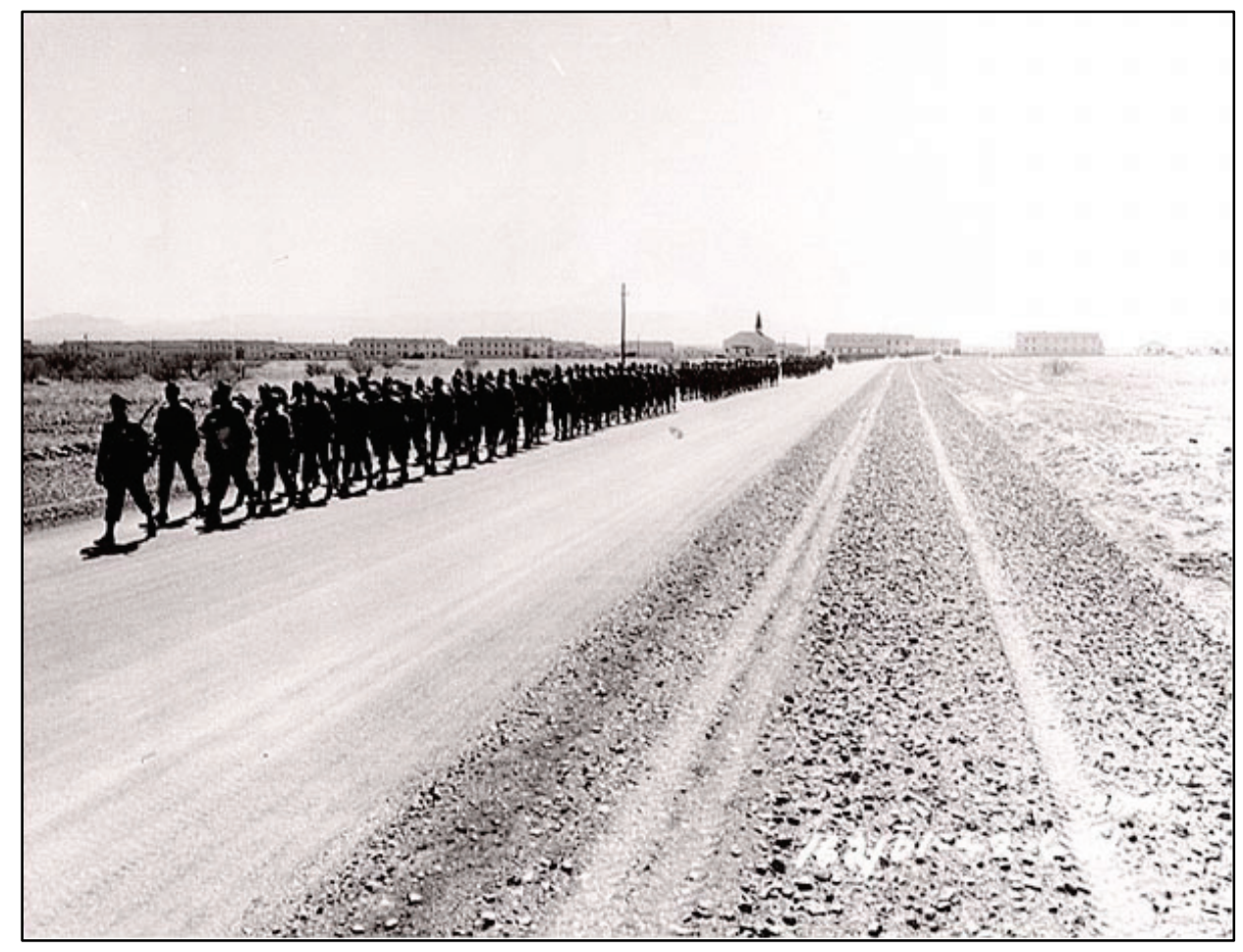

After the war, the War Assets Administration declared the post surplus in 1947 and began to dismantle and sell the temporary structures. The post

10 Angel Tomes. 2013. Architectural Survey of 110 Buildings, p. 11. 
was deactivated on September 15, 1947, and turned over to the Arizona Fish and Game Department for use as a game preserve and the Army National Guard. Game grazed on the land until the mid-1950s.

\subsection{Korean War}

On February 1, 1951, the U.S. Air Force took official possession of the fort, which served the 417th and 419th Aviation Brigades and the 45th, 304th, 923rd and 934th Engineer Aviation Groups. In support of the Korean War effort, the post trained aviation engineers in airfield construction. As part of the training, one of the first tasks of the aviation engineers and engineer aviation groups was the on-post construction of Libby Airfield. The built infrastructure of the field included a control tower, a fire station, a hangar building, and an airstrip. Libby Army Airfield was constructed north of the Old Post (Figure 15).

Figure 15. Control tower at Libby Army Airfield, 1958 (Fort Huachuca Museum).

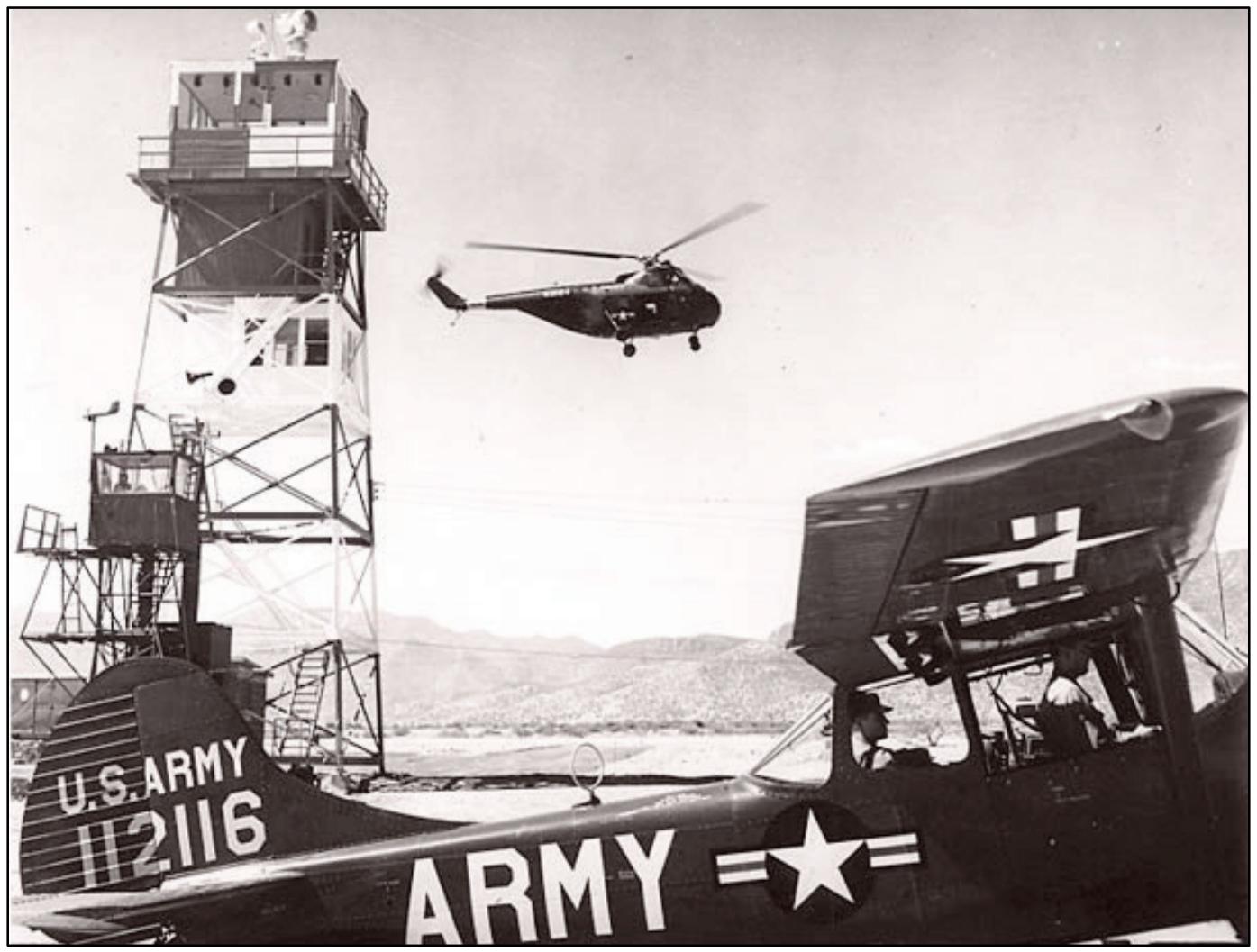

After the end of the war in 1953, Fort Huachuca was again placed on inactive status. While a caretaker detachment was left on post for the next several months, the post was put under the control of the U.S. Army's Chief Signal Officer on February 1, 1954. 


\subsection{Cold War}

In 1954, Fort Huachuca was returned to permanent status as the site of the U.S. Army Electronic Proving Ground (EPG). The EPG's mission was to conduct engineer and user tests of electronic communications equipment and systems and to prepare and develop command-control systems. The EPG Headquarters was at Greely Hall (61801), a large concrete facility, which is currently the Network Enterprise Command (NETCOM) Headquarters (Figure 16). The EPG's area of operation included facilities and field test sites throughout southern Arizona; however, the majority of its testing was accomplished at Fort Huachuca. As a result, there was another growth spurt at the post during the 1950 os and early 1960 s to support its new mission of military research and development for electronic warfare.

While most of the growth and construction efforts were concentrated north of the Old Post area, several family housing areas were built in and around the Old Post area. The Cavalry 1 Housing Area was built directly south of the Old Post area and nestled in the rolling landscape of the canyon. Another housing area (Figure 17), Bonnie Blink, was constructed southwest of the Old Post area in the Cemetery Canyon near the cemetery. A third was constructed in a semicircular form on North Field southeast of the barracks constructed between 1914 and 1916 (Figure 18). All of these were International Style Capehart units and built between 1957 and 1958. 
Figure 16. Dedication of Greely Hall (61801), 1959 (Fort Huachuca Museum).

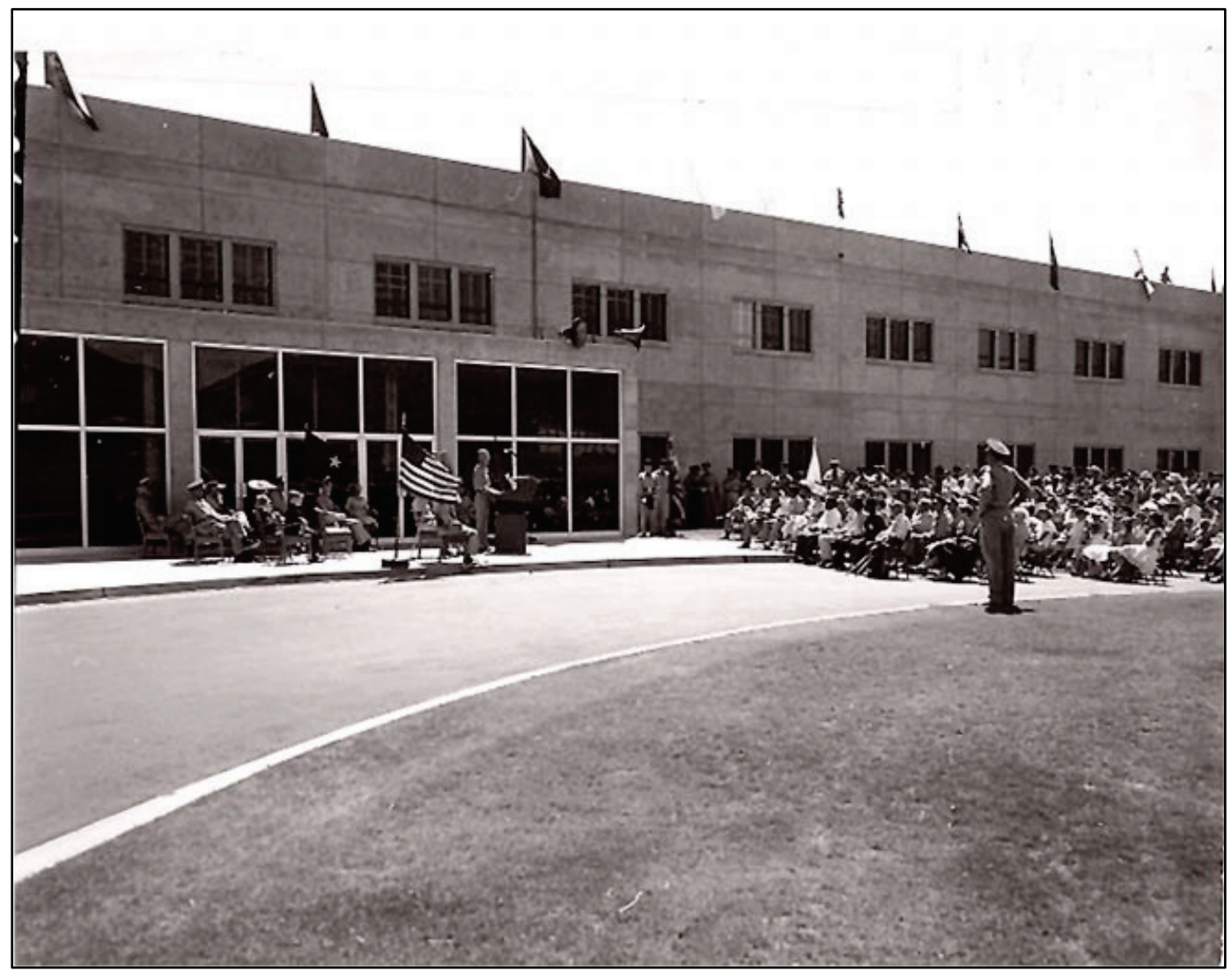

Figure 17. Cavalry 1 Housing Area in 2016, looking southwest (ERDC-CERL 2016).

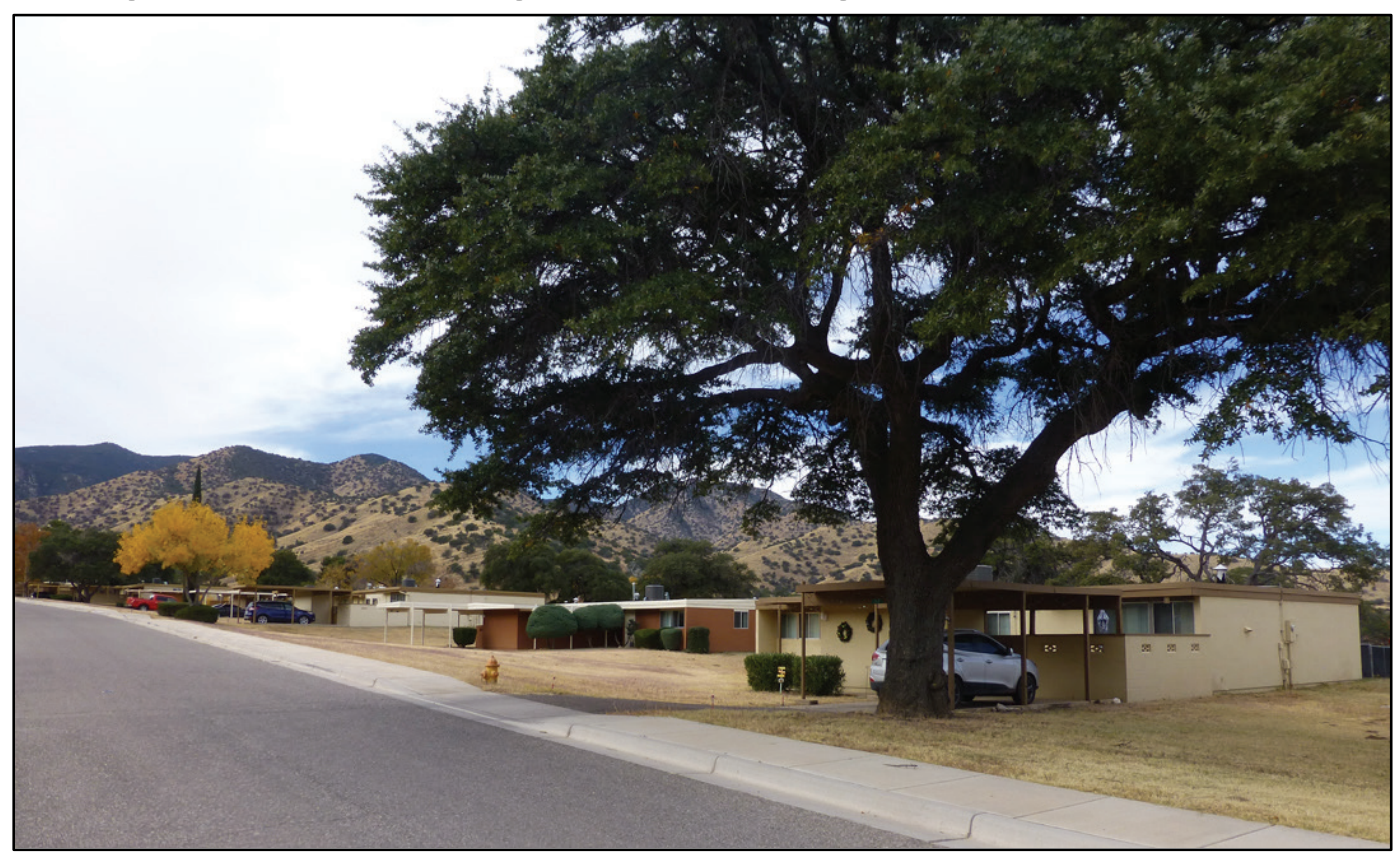


Figure 18. 1993-era map showing location of former housing on North Field, (Fort Huachuca DPW).

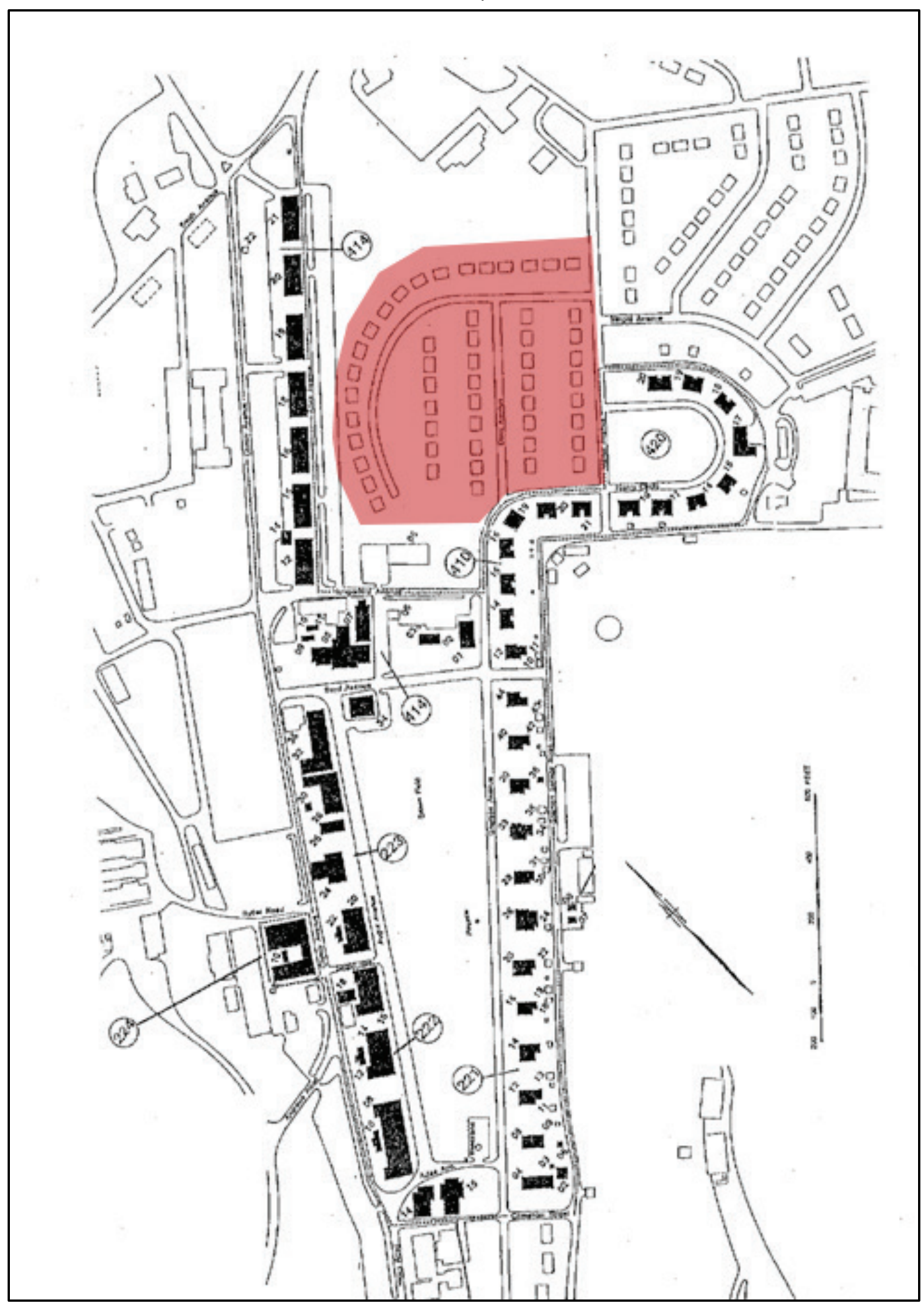

In addition to the EPG, the U.S. Army Strategic Communications (STRATCOM) command was located at Fort Huachuca in 1967 and the 
U.S. Army Intelligence Center and School (USAICS) in 1971. Subsequent years saw the activation or transference of several communication and electronic-related divisions to Fort Huachuca, while continuing to operate as a U.S. Army Training and Doctrine Command (TRADOC) installation. These major commands operate at the fort and are the main focus of activity today. ${ }^{11}$

\subsection{Post-Cold War}

Recent construction efforts in and around the Old Post area were the demolition and construction of new family housing areas. The 1950s housing in the Cavalry 5 Housing Area, located on North Field, was demolished and replaced with new housing built in the 2000s. At the same time, new housing replaced the 195 os housing in the Bonnie Blink Housing Area, between the Old Post and the cemetery. In addition, three of the original stables (30025, 30026, and 30027) west of the 1914 Barracks were demolished to create a corral, which was never constructed (Figure 19).

Today, Fort Huachuca's mission continues to be one of military intelligence training and technological research and testing. The installation is also used for the training of U.S. Army Reserve and National Guard units. Most training activities, many of which are related to electronic warfare and information systems, occur inside secure buildings, although limited maneuvers take place in the landscape. Fort Huachuca remains a prominent military installation in the southwest U.S. and is the headquarters for the NETCOM and U.S. Army Intelligence Center of Excellence.

11 Angel Tomes. 2013. Architectural Survey, Tucson, AZ: SRI, Inc., p. 13. 
Figure 19. Map of the Old Post area in 2017 (Fort Huachuca DPW).

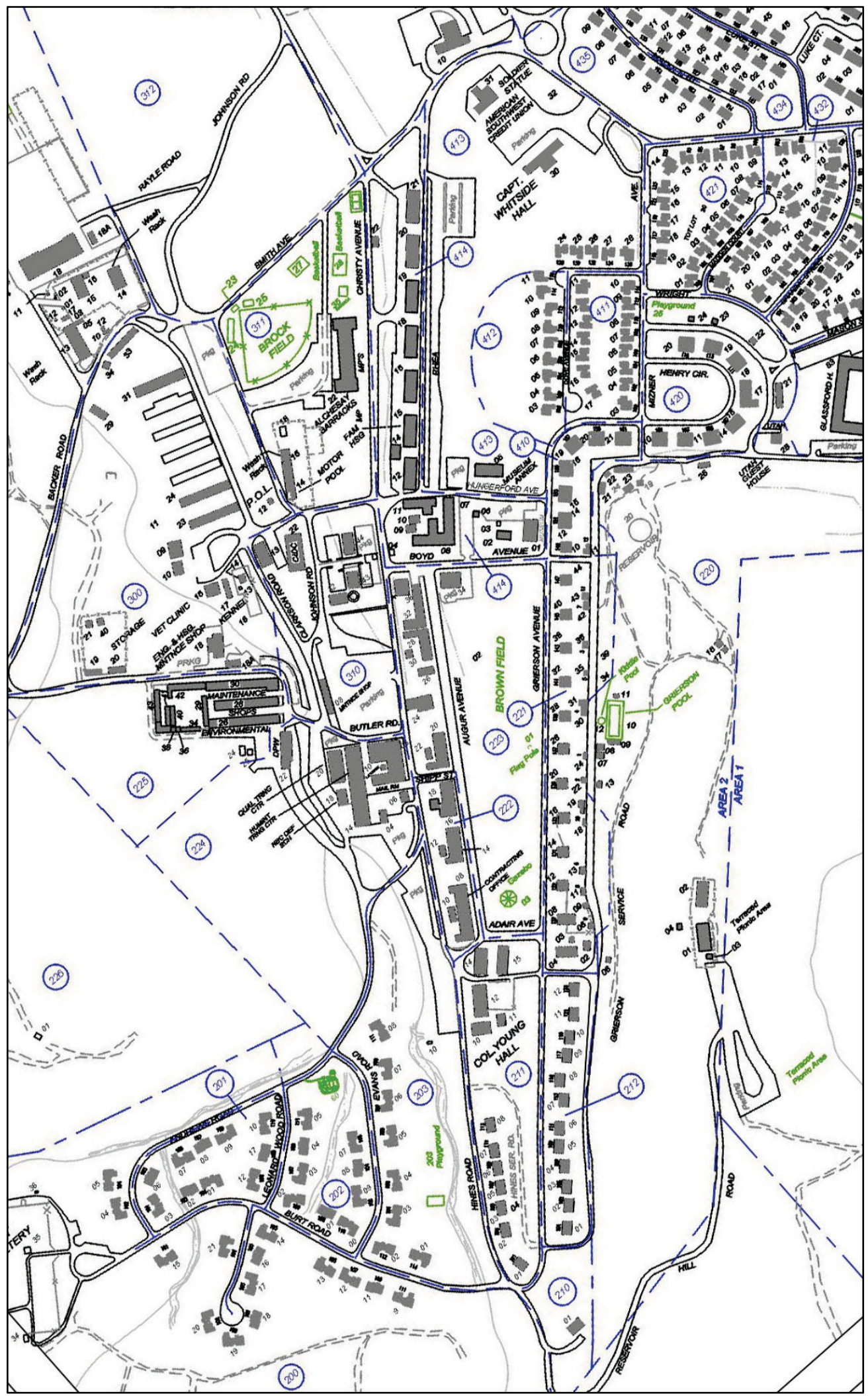




\section{Previous Reports and Determinations}

The following reports were the ones primarily used in determining characteristics of the landscapes in the Fort Huachuca Historic District NHL and surrounding landscape areas.

\subsection{National Register nomination}

The "Old Post Area" or "Old Fort Huachuca" at Fort Huachuca was listed as a historic district on the NRHP on 20 November $1974 .{ }^{12}$ The historic district was determined significant as the site of Camp Huachuca, since it was established in 1877 as an outpost to protect early settlers from Indian attacks. The buildings and structures listed in the nomination as contributing to the historic district included 25 buildings surrounding Brown Field, the original parade field: 12 family quarters (1891-1884), three barracks (1883), the bowling alley (1908), recreation hall (1905), Post Hospital (1880), second Post Hospital (1855), post bakery (1886), post office and school (1896), guard house (1885), quartermaster storehouse (1881), Post Exchange (PX) restaurant (1920), and Headquarters building (1917).

In 1975, an updated table was sent to the National Register to be included with the original nomination. This new table added officers' quarters (41012) and Enlisted Men's Barracks (22216) to the list of contributing buildings for a total of 27 buildings (Table 1). No period of significance (POS) was listed in initial nomination, but it is assumed it ended in 1920, which was the date of construction of the newest building (PX Restaurant, Building 22334).

A boundary for the 27 buildings in the historic district includes the area between Carnahan Street, Grierson Service Road, Hungerford Avenue, and Hines Road/Christy Avenue (Figure 20).

\footnotetext{
12 Herman V. Puzzi. 1973. Old Post Area, Old Fort Huachuca: National Register of Historic Places Inventory-Nomination Form. Washington, DC: U.S. Department of the Interior, National Park Service. Entered National Register, 20 November 1974 (74000443). The nomination listed "Old Fort Huachuca" as the historic name and "Old Post Area" as the common name. Both names have been used over the years.
} 
Table 1. Twenty-seven historic buildings identified in the 1974 NRHP nomination (with updated table from 1975 additions) (Puzzi, 1973).

\begin{tabular}{|c|c|c|c|}
\hline Building No. & Name & Function & Year built \\
\hline 21114 & 105A Hines 14 & Bowling Alley Annex & 1908 \\
\hline 21115 & Brayton Hall & Library/Gymnasium & 1905 \\
\hline 22104 & Hazen House & Captains' Duplex & 1891 \\
\hline 22108 & Carleton House & $\begin{array}{l}\text { Post Hospital/Officer's } \\
\text { Quarters }\end{array}$ & 1880 \\
\hline 22112 & Cruse House & Officer's Quarters & 1884 \\
\hline 22114 & Carr House & Officer's Quarters & 1884 \\
\hline 22116 & Bernard House & Officer's Quarters & 1884 \\
\hline 22120 & Crook House & Officer's Quarters & 1884 \\
\hline 22126 & Pershing House & Officer's Quarters & 1884 \\
\hline 22128 & Miles House & Officer's Quarters & 1884 \\
\hline 22132 & Wilder House & Officer's Quarters & 1884 \\
\hline 22138 & Winans House & Officer's Quarters & 1884 \\
\hline 22140 & Macomb House & Officer's Quarters & 1884 \\
\hline 22144 & Sanford House & Officer's Quarters & 1884 \\
\hline 22208 & 6th Cavalry Hall & Double Barracks & 1883 \\
\hline 22214 & 4th Cavalry Hall & Calvary Hall & 1882 \\
\hline 22216 & 10th Cavalry Hall & Cavalry Hall & 1883 \\
\hline 22320 & 5th Cavalry Hall & Barrack/Administration & 1883 \\
\hline 22324 & DeRosey Cabell Hall & Bakery & 1886 \\
\hline 22326 & DeRussy Hall & School/Post Office & 1899 \\
\hline 22328 & Sam Kee Hall & Guard House & 1881 \\
\hline 22332 & Gresham Hall & $\begin{array}{l}\text { Quartermaster's } \\
\text { Storehouse }\end{array}$ & 1883 \\
\hline 22334 & Mar Kim Hall & $\begin{array}{l}\text { Post Exchange } \\
\text { Restaurant }\end{array}$ & 1920 \\
\hline 41012 & Morrow House & Officer's Quarters & 1884 \\
\hline 41401 & $\begin{array}{l}\text { Ft Huachuca } \\
\text { Historical Museum }\end{array}$ & $\begin{array}{l}\text { Post } \\
\text { Chapel/BOQ/Officers' } \\
\text { Club }\end{array}$ & 1892 \\
\hline 41402 & Rodney Hall & Post Headquarters & 1917 \\
\hline 41408 & Leonard Wood Hall & Hospital & 1885 \\
\hline
\end{tabular}


Figure 20. Historic buildings included in the 1974 NRHP nomination (Puzzi, 1973).

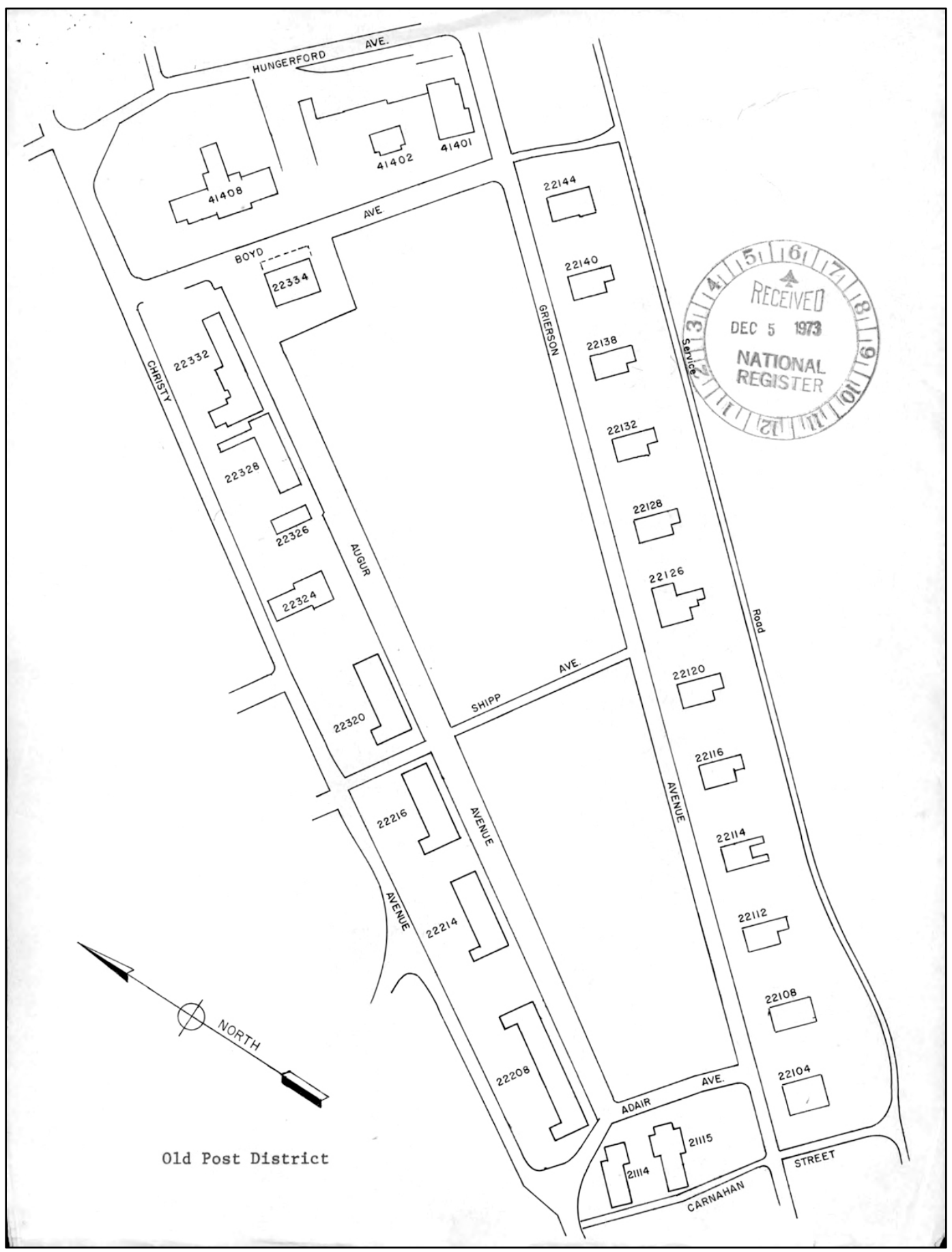

\subsection{National Historic Landmark nomination}

In 1976, the Old Post Area Historic District became the Fort Huachuca National Historic Landmark (NHL) District (also referred to as the Fort Huachuca Historic District) with an expanded boundary and the addition 
of 21 buildings to the district. 13 The new NHL nomination recognized the historic development of the fort through 1931 and its fourfold national significance. First, Fort Huachuca played a prominent role in the pursuit and capture of Geronimo, leading to the collapse of the last significant American Indian group. Second, Fort Huachuca served as the station for the Army's experimental heliograph network during the Apache threat in the $188 \mathrm{os}$. Third, for its contributions to patrolling the U.S.-Mexican border from the late 1800 s to 1920 . And fourth, for the significance of Fort Huachuca as one of the country's foremost centers of African American military service. Fort Huachuca was home to the famed $10^{\text {th }}$ Cavalry, which was responsible for garrisoning the post from 1913 to 1916 and was headquartered at Fort Huachuca until 1931. Other contributing African American units at Fort Huachuca included the $24^{\text {th }}$ Infantry, the $9^{\text {th }}$ Cavalry and the $25^{\text {th }}$ Infantry.

The NHL increased the boundary of the Fort Huachuca Historic District to include the officer's duplexes along Henry Circle (41014, 41015, 41016, 41019, 41020, 41021, 42010, 42011, 42014, 42015, 42018, 42019, 42020), the Bachelor Officers' Quarters (BOQ) (42017), and the Enlisted Men's Barracks built between 1913 and 1916 (41412, 41415, 41416, 41418, 41419, $41420,41421)$ for a total of 48 contributing buildings. However, the total was increased to 49 buildings when it was discovered that the description of the Post Hospital (41408) includes (although not called out by number) what was called, in the nomination, the Post Hospital "wing" (41407). The NHL nomination treats the two buildings as one hospital, but in terms of real property, they are separate buildings with individual numbers. The table below shows the corrected number of 49 contributing buildings (Table 2). While not called out in the nomination, all other buildings within the NHL boundary are non-contributing.

\footnotetext{
13 George R. Adams. 1976. Fort Huachuca National Register of Historic Places Inventory - Nomination Form. [National Historic Landmark]. Washington, DC: U.S. Department of the Interior, National Park Service, January. The NHL nomination was submitted in January 1976. According to the National Park Service, it was accepted on 11 May 1976. According to the Fort Huachuca Museum website and the commemorative plaque on Brown Field, Fort Huachuca became an NHL during its centennial year, 1977. The NHL nomination was given the same number as the previous nomination by the NPS NHL staff (74000443).
} 
Table 2. Forty-nine contributing buildings to the 1976 Fort Huachuca National Historic Landmark Historic District (Adams, 1976).

\begin{tabular}{|c|c|c|c|}
\hline Building No. & Name & Function & Year built \\
\hline 21114 & 105A Hines 14 & Bowling Alley Annex & 1908 \\
\hline 21115 & Brayton Hall & Library/Gymnasium & 1905 \\
\hline 22104 & Hazen House & Captains' Duplex & 1891 \\
\hline 22108 & Carleton House & Post Hospital/Officer's Quarters & 1880 \\
\hline 22112 & Cruse House & Officer's Quarters & 1884 \\
\hline 22114 & Carr House & Officer's Quarters & 1884 \\
\hline 22116 & Bernard House & Officer's Quarters & 1884 \\
\hline 22120 & Crook House & Officer's Quarters & 1884 \\
\hline 22126 & Pershing House & Officer's Quarters & 1884 \\
\hline 22128 & Miles House & Officer's Quarters & 1884 \\
\hline 22132 & Wilder House & Officer's Quarters & 1884 \\
\hline 22138 & Winans House & Officer's Quarters & 1884 \\
\hline 22140 & Macomb House & Officer's Quarters & 1884 \\
\hline 22144 & Sanford House & Officer's Quarters & 1884 \\
\hline 22208 & 6th Cavalry Hall & Double Barracks & 1883 \\
\hline 22214 & 4th Cavalry Hall & Calvary Hall & 1882 \\
\hline 22216 & 10th Cavalry Hall & Cavalry Hall & 1883 \\
\hline 22320 & 5th Cavalry Hall & Barrack/Administration & 1883 \\
\hline 22324 & DeRosey Cabell Hall & Bakery & 1886 \\
\hline 22326 & DeRussy Hall & School/Post Office & 1899 \\
\hline 22328 & Sam Kee Hall & Guard House & 1881 \\
\hline 22332 & Gresham Hall & Quartermaster's Storehouse & 1883 \\
\hline 22334 & Mar Kim Hall & Post Exchange Restaurant & 1920 \\
\hline 41012 & Morrow House & & 1884 \\
\hline 41014 & Nowlan House & Officers' Duplex & 1914 \\
\hline 41015 & Holbrook House & Officers' Duplex & 1914 \\
\hline 41016 & Schuyler House & Officers' Duplex & 1914 \\
\hline 41019 & Galbraith House & Officers' Duplex & 1914 \\
\hline 41020 & Cornell House & Officers' Duplex & 1914 \\
\hline 41021 & Sherburne House & Officers' Duplex & 1914 \\
\hline 41401 & Ft Huachuca Historical Museum & Post Chapel/BOQ/Officers' Club & 1892 \\
\hline 41402 & Rodney Hall & Post Headquarters & 1917 \\
\hline
\end{tabular}




\begin{tabular}{|l|l|l|l|}
\hline Building No. & Name & Function & Year built \\
\hline 41407 & Hospital & Office & 1914 \\
\hline 41408 & Leonard Wood Hall & Hospital & 1885 \\
\hline 41412 & & Barracks & 1914 \\
\hline 41415 & & Barracks & 1914 \\
\hline 41416 & & Barracks & 1916 \\
\hline 41418 & & Barracks & 1916 \\
\hline 41419 & & Barracks & 1916 \\
\hline 41420 & & Barracks & 1916 \\
\hline 41421 & & Barracks & 1915 \\
\hline 42010 & Michie House & Officers' Duplex & 1914 \\
\hline 42011 & Forsyth House & Officers' Duplex & 1914 \\
\hline 42014 & Baldwin House & Officers' Duplex & 1914 \\
\hline 42015 & Byram House & Officers' Duplex & 1915 \\
\hline 42017 & Allen House & Bachelor Officers' Quarters & 1915 \\
\hline 42018 & Dixon House & Officers' Duplex & 1915 \\
\hline 42019 & Gale House & Officers' Duplex & 1917 \\
\hline 42020 & Bascom House & Officers' Duplex & 1917 \\
\hline & & & \\
\hline 4 & & & 14 \\
\hline 4 & & & 19 \\
\hline 4
\end{tabular}

The boundary for the NHL historic district was increased to meet the new POS from 1877-1931. The 1974 NRHP boundary (Old Post Area/Old Fort Huachuca Historic District) was increased to form the new much larger Fort Huachuca NHL Historic District. The boundary increase included the officers' duplexes, BOQ, and barracks built between 1913 and 1916. In addition, the boundary was increased to include a portion of a ridge southeast of the officers' quarters that was reputed to be the site of the longdemolished post heliography station (Figure 21). This area was designated essential to both the scenic and historical integrity of the area. The Fort Huachuca Historic District was accepted as a national historic landmark on 11 May 1976. 
Figure 21. Fort Huachuca "Old Post Area" NRHP district (in blue) was expanded to include NHL District boundary (in red) in 1976 (Adams, 1976).

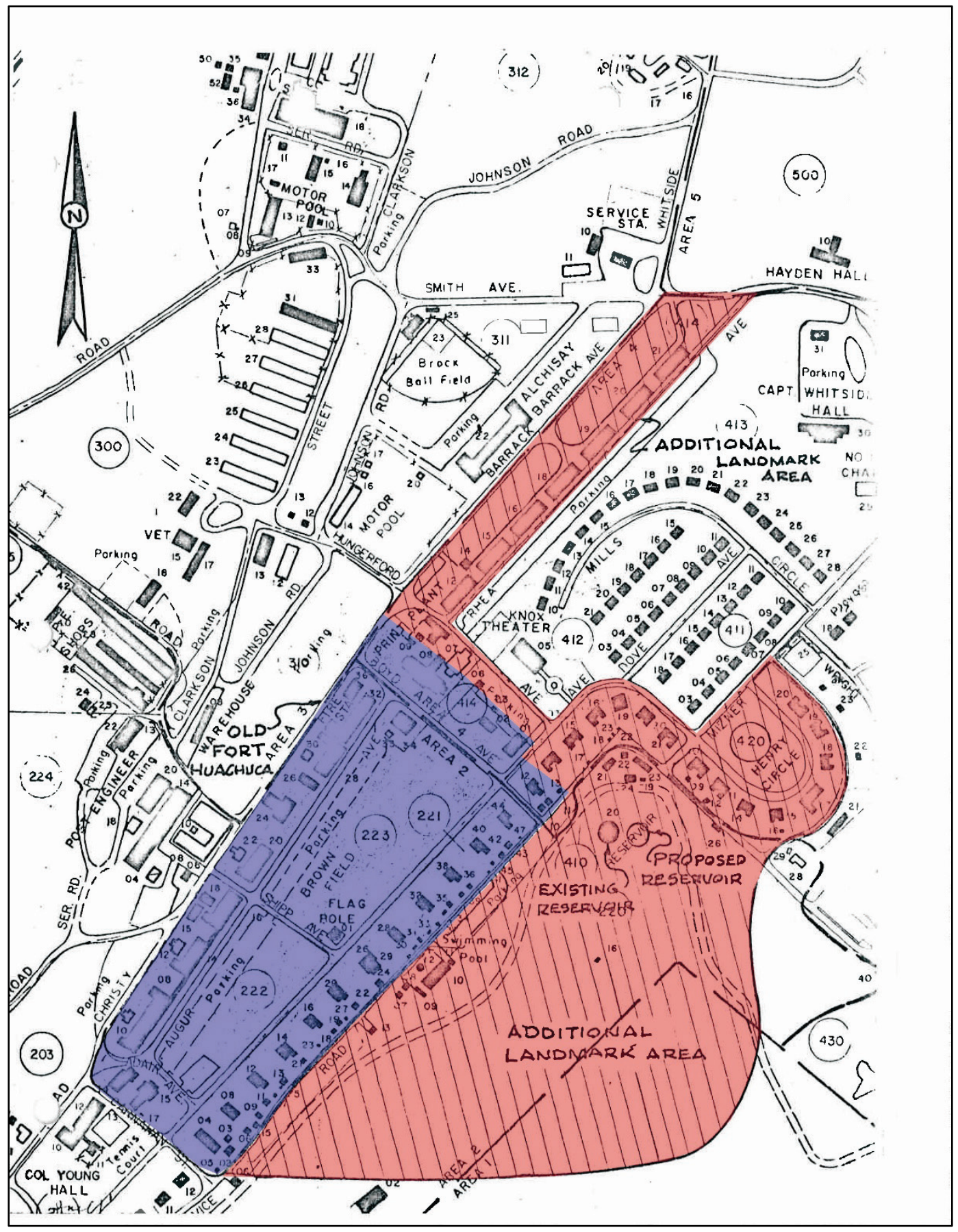

After the NHL was submitted, the Army requested the boundary be adjusted to allow for the construction of a new, much-needed, second water reservoir. Neither the NHL program staff nor the Arizona State Historic Preservation Office (SHPO) believed the boundary adjustment was an adverse effect (Figure 22). Since the boundary of the NHL historic district 
encompasses the entire Old Post National Register Historic District and the contributing buildings, the 1974 and 1976 have been treated as one entity by the NHL, Fort Huachuca, and Arizona SHPO.

Figure 22. Fort Huachuca NHL District boundary (in red) as revised in 1977 with 49 contributing buildings in black (1976 NHL nomination).

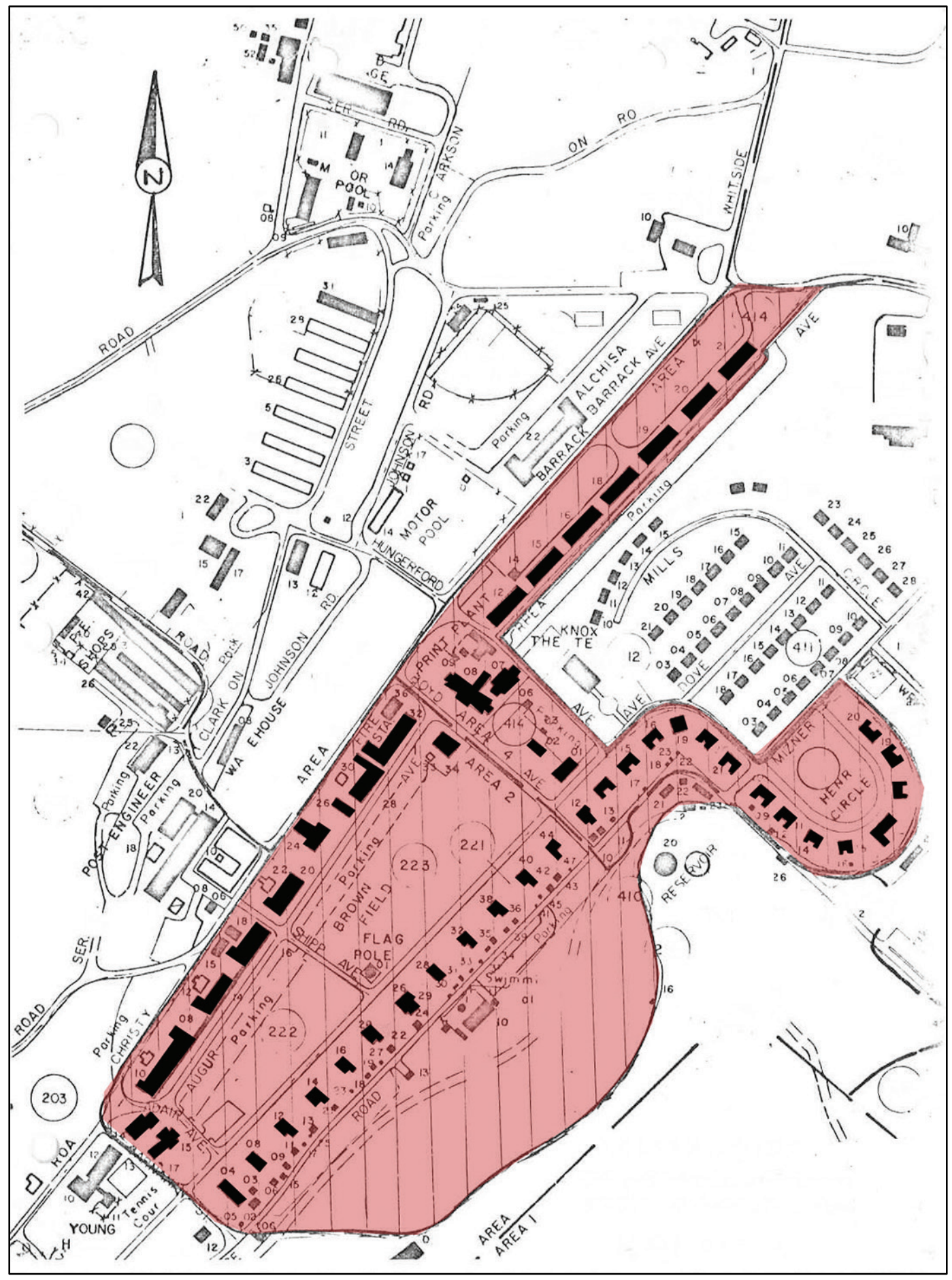




\subsection{Capehart Historic District}

\subsubsection{9 report on Capehart housing and architect Richard Neutra}

When Fort Huachuca proposed to demolish 1,561 Army housing units at Fort Huachuca and build 1,165 new units between 2001 and 2013, it was determined the demolition may have an adverse effect on the Fort Huachuca NHL district. The Arizona SHPO requested the historical significance of the housing units be determined prior to demolition. The 1999 report by the U.S. Army Corps of Engineers (USACE) Center for Expertise for Preservation of Historic Structures and Buildings found the Capehart housing at Fort Huachuca did not meet the criteria for eligibility to the National Register for association with the architect Richard Neutra. ${ }^{14}$ The research failed to find any written evidence to support the association as suggested by the Arizona SHPO. The only names associated with the housing units were Blanton and Cole Architects and Engineers of Tucson, AZ. The Capehart housing was built between 1949 and 1962 under the direction of the Los Angeles District Corps of Engineers. In addition, the report determined that while the housing did not meet the national level of significance, an evaluation of local or state level significance may be conducted on a case-by-case basis once they reach 50 years of age.

\subsubsection{1 programmatic agreement for the replacement of Army family housing}

A programmatic agreement among Fort Huachuca, The Arizona SHPO, NPS, and the Advisory Council on Historic Preservation (ACHP) was signed in 2001 regarding the replacement of Capehart Army Family Housing as proposed above. 15 The programmatic agreement (PA) states that while Fort Huachuca may demolish and replace any or all of the housing units listed in the PA, it will retain the Cavalry Park I Housing Area. Included in Cavalry Park I are 19 Capehart International Style units located just outside the Fort Huachuca NHL District on the southwest end of Grierson and Hines Roads. These units are to be used for their original purpose as single-family housing, and their integrity will be preserved. In

\footnotetext{
14 Center of Expertise for Preservation of Historic Structures and Buildings, Seattle District Corps of Engineers, 1999. Capehart Housing at Fort Huachuca, Arizona: Determination of Eligibility for the National Register Due to Association with Richard Neutra, Architect. Prepared for Directorate of Installation Support, U.S. Army Intelligence Center and Fort Huachuca, Fort Huachuca, AZ 85613. Seattle, WA: Seattle District Corps of Engineers.

15 Programmatic Agreement Among Fort Huachuca, the Arizona State Historic Preservation Office (SHPO), and the Advisory Council on Historic Preservation (ACHP) Regarding the Replacement of Army Family Housing, 2001.
} 
addition, the mature landscaping around these buildings contributes to the setting of Fort Huachuca NHL and will be maintained and protected. Stipulations were made for the new construction to protect the cemetery and the viewshed of the Fort Huachuca NHL District. New construction at the Cavalry Park 5 Housing Area is to have a landscaped transition zone between the NHL district and the housing area.

\subsubsection{2 viewshed study}

As part of the PA for the replacement of the Capehart Army Family Housing project, it was stipulated that Fort Huachuca determine the viewshed of the NHL Historic District. A 2002 report, determined the viewshed boundary of the district (Figure 23) and provided photographic documentation of the viewshed. ${ }^{16}$ Views documented in the report include southwest along officers' row, southwest towards barracks along the parade field, north towards the Museum, Headquarters, and hospital, and views into the NHL from Reservoir Hill and Star Hill.

16 Fort Huachuca, 2002. Viewshed Study, Fort Huachuca National Historic Landmark, Fort Huachuca, Arizona. [FH-02-68]. Fort Huachuca, AZ: Environmental and Natural Resources Division, U.S. Army Garrison, Fort Huachuca. 
Figure 23. Viewshed boundary (in red) of the Fort Huachuca NHL District as identified by GADA (GADA, 2002).

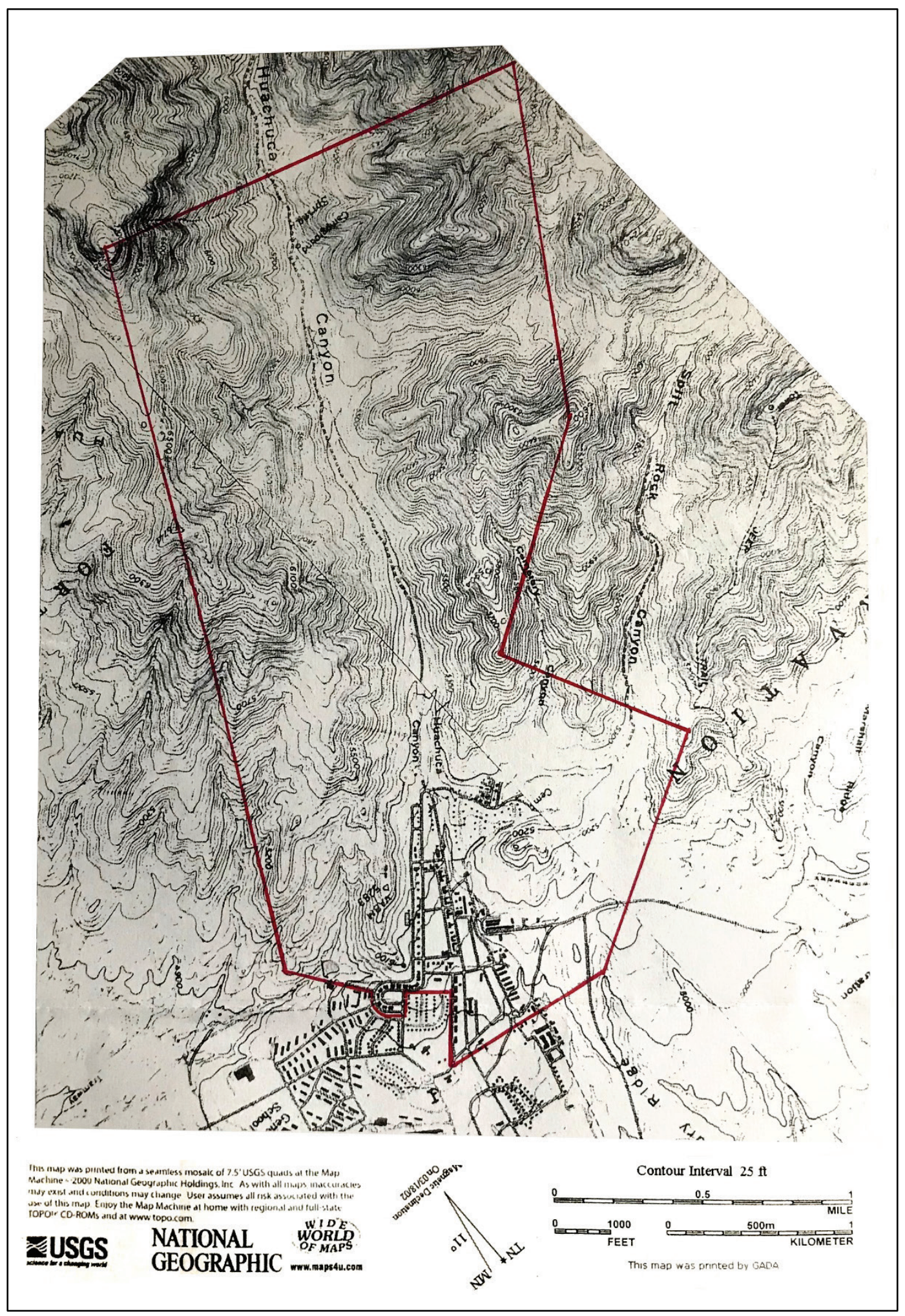




\subsubsection{8 programmatic agreement}

When Fort Huachuca elected to privatize family housing through the Residential Communities Initiative (RCI) program, a PA was signed between Fort Huachuca, the Arizona SHPO, NPS and the ACHP. ${ }^{17}$ Creation of the RCI resulted in the transfer of long-term interest of housing and other ancillary facilities at Fort Huachuca to Michaels Military Housing, LLC. The PA stipulated the evaluation or re-evaluation of 45 buildings and structures at Fort Huachuca to include the Capehart housing units in the Cavalry Park I neighborhood and the buildings and structures constructed by the WPA in the 1930 in order to resolve the question of eligibility.

\subsubsection{NRHP evaluation of 19 Capehart housing units, Cavalry Park 1}

As stipulated in the $2008 \mathrm{PA}$ above for the privatization of family housing at Fort Huachuca, a 2009 report by CP\&Y evaluated the 19 Capehart housing units in the Cavalry Park I Housing Area for inclusion on the NRHP. ${ }^{18}$ The housing area was found eligible and a Capehart Historic District proposed (Figure 24).

\footnotetext{
17 Programmatic Agreement Among the US Army Intelligence Center and Fort Huachuca, the Arizona State Historic Preservation Office (SHPO), and the Advisory Council on Historic Preservation (ACHP) for the Privatization of Family Housing at Fort Huachuca, Arizona, 2008.

18 CP\&Y, Inc., 2009. National Register of Historic Places Evaluation of Cavalry 1 Housing Area. Fort Huachuca, Arizona. CPY Project \#MMH09023.00. CP\&Y Inc., Austin, Texas. [FH-09-6].
} 
Figure 24. Proposed Capehart Historic District, with boundary in orange, in the Cavalry I Housing Area (CP\&Y, 2009).

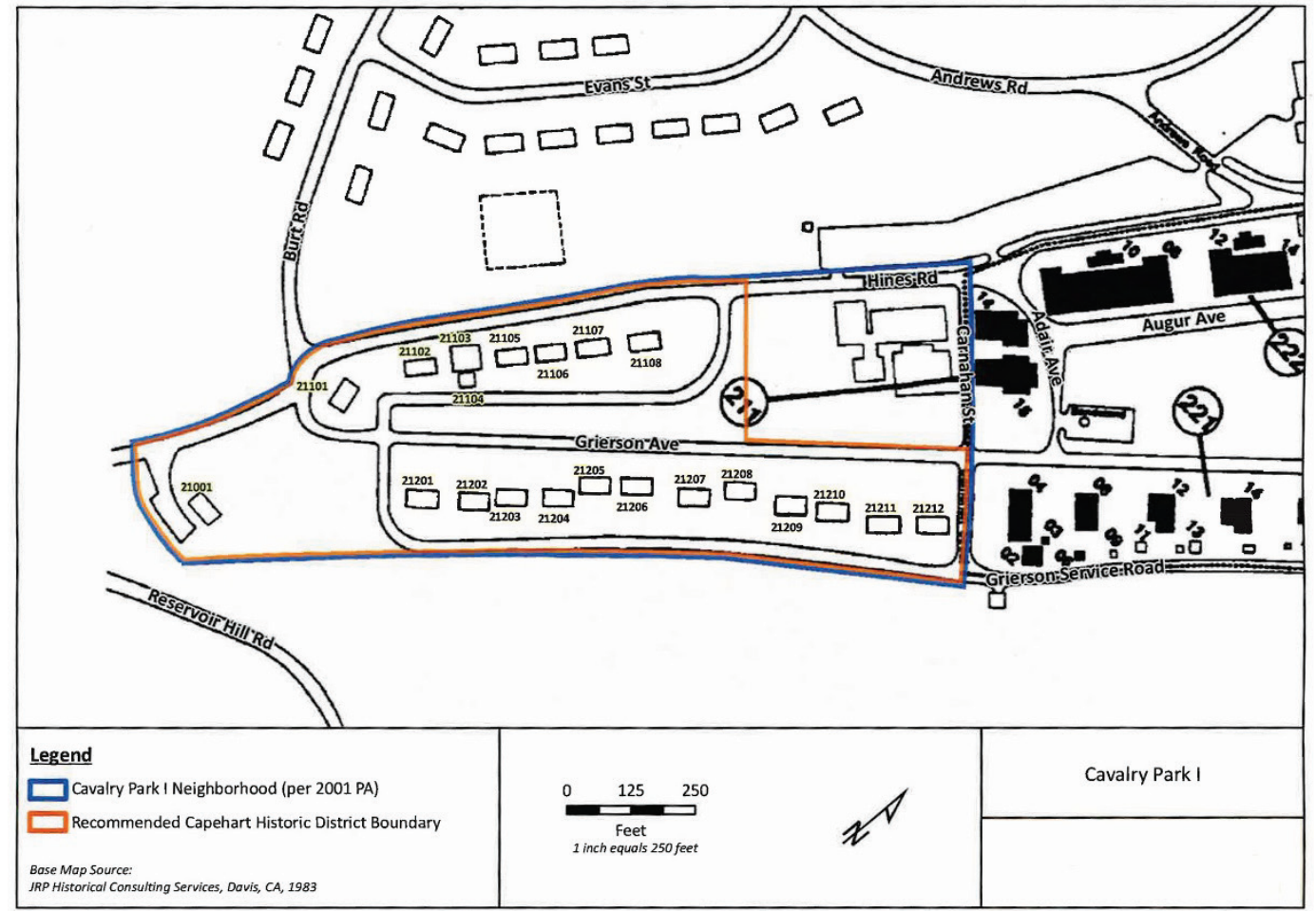

\subsection{WPA-era Historic District}

\subsubsection{National Register nominations for Million Dollar Barracks and Stone Quarters and Garage/Warrant Officers' Quarters}

In 1993, JPR Historical Consulting Services wrote a National Register nomination for the Million Dollar Barracks (31122), for the Stone Quarters (21103), and the associated garage (21104). The Million Dollar Barracks were constructed in 1939 by the Army Quartermaster Corps. The nomination determined the building individually eligible for listing in the National Register at the local level of significance under eligibility Criterion $\mathrm{C}$ in the area of architecture as an important example of the design and construction work of the Quartermaster Corps, U.S. Army, as well as a major example of the workmanship of New Deal-era relief workers. The building is the largest at Fort Huachuca that was either designed by the Quartermaster Corps or built by relief workers. The POS was determined to be from 1939, when it was built, to 1943,50 -years from the completion of the nomination.

The Stone Quarters and garage, located in the Capehart Historic District along Hines Road, were also determined individually eligible under A as a 
combination of WPA and Public Works Administration (PWA) construction and as a local example of the larger, national trend of New Deal programs. Under C, it was an example of New Deal architecture and an example of the construction techniques associated with WPA projects throughout Fort Huachuca. Although both nominations were completed, they were never submitted to Arizona SHPO.

\subsubsection{Legacy evaluation of CCC-WPA resources}

In 2009, Hart and Blackwell completed a survey of CCC-WPA-era resources at Fort Huachuca. ${ }^{19}$ The survey was part of a larger nationwide context on WPA and CCC resources on U.S. Department of Defense (DoD) installations. The interwar period facilities documented during this study consisted of WPA-constructed sources built between ca. 1934 and ca. 1940. During this period in history, Fort Huachuca still served as a staging area for troops patrolling the Mexican border. By this time, the post had successfully made the transition from a cavalry fort to an infantry fort during the economic downturn. Federal work programs initiated during this time, such as the CCC and WPA, resulted in the appearance of standardized plans and a new architectural aesthetic on Fort Huachuca's landscape. In general, the WPA supported Fort Huachuca through improvement projects on post that included building repairs, road repairs, water-source development and retention, new building construction, and construction of infrastructure resources associated with drainage conveyance, landscape improvements, and transportation.

No resources associated with the CCC training camp were determined extant at Huachuca, and little documentation was found associating the CCC camp with extant resources. However, several WPA-era resources built between 1936 and 1939 were found to be eligible, including the West Gate Guardhouse (11510), the bridge over Huachuca Creek, Enlisted Men's Grandstand (31124), Reservoir 2 (22002), the Chlorinator Building (22004), and the drainage ditches and walls along Grierson Street. The resources determined not eligible in this survey include the officer's grandstand, the double latrine at target range (15331), the stone embankment at

19 Daniel Hart and Chad Blackwell, 2009. CCC-WPA Resources Legacy Grant Case Study: Fort Huachuca, Arizona. Appendix D in Nationwide Context, Inventory, and Heritage Assessment of Works Progress Administration and Civilian Conservation Corps Resources on Department of Defense Installations. Legacy Project No. 07-357. Engineering-Environmental Management, Denver, Colorado. [FH-08-8] 
Southern Pacific Railroad (SPRR) Crossing, the garage behind Allen house (42021), and WPA renovations to the utilities warehouse. A list of these resources is in Table 3.

Table 3. Table of WPA contributing buildings and resources at Fort Huachuca (Hart and Blackwell, 2009).

\begin{tabular}{|l|l|l|l|l|l|}
\hline Historic Name & $\begin{array}{l}\text { Building } \\
\text { No. }\end{array}$ & $\begin{array}{l}\text { Construction } \\
\text { Date }\end{array}$ & Original Use & Current Use & $\begin{array}{l}\text { NRHP Eligibility } \\
\text { Recommendation }\end{array}$ \\
\hline $\begin{array}{l}\text { West (Canelo) Gate } \\
\text { Guardhouse }\end{array}$ & 11510 & c1938 & Guard house & Guard house & NRHP eligible \\
\hline $\begin{array}{l}\text { Double Latrine at Target } \\
\text { Range }\end{array}$ & 15331 & 1938 & Latrine & Vacant & Not NRHP eligible \\
\hline $\begin{array}{l}\text { Bridge over Huachuca } \\
\text { Creek }\end{array}$ & 31123 & 1937 & Transportation & Transportation & NRHP eligible \\
\hline $\begin{array}{l}\text { Officers' Grandstand } \\
\text { Grandstand }\end{array}$ & 31124 & 1937 & Recreation & Recreation & $\begin{array}{l}\text { NRHP eligible-surveyed in 2000, } \\
\text { no change to evaluation }\end{array}$ \\
\hline $\begin{array}{l}\text { Stone Embankment at } \\
\text { SPRR Crossing }\end{array}$ & $1936-7$ & Transportation & Transportation & Not NRHP eligible \\
\hline $\begin{array}{l}\text { Garage behind Allen } \\
\text { House }\end{array}$ & 42021 & 1936 & Garage & Garage & Not NRHP eligible \\
\hline $\begin{array}{l}\text { Drainage Ditches and } \\
\text { Walls along Grierson } \\
\text { Street }\end{array}$ & Recreation & Not NRHP eligible \\
\hline Reservoir No. 2 & 22002 & 1939 & Water storage & Water storage & NRHP eligible \\
\hline $\begin{array}{l}\text { Water Treatment Plant } \\
\text { Water }\end{array}$ & 22004 & 1938 & $\begin{array}{l}\text { Water } \\
\text { treatment }\end{array}$ & NRHP eligible \\
\hline
\end{tabular}

\subsubsection{9 evaluation of WPA resources in RCI}

In 2009, the WPA resources in the RCI footprint at Fort Huachuca were evaluated for the NRHP by CP\&Y, Inc. of Austin, TX. ${ }^{20}$ The WPA resources at Fort Huachuca are a physical link to the New Deal in Arizona. The pervasiveness of WPA features at Fort Huachuca, not just within the RCI footprint, evokes the hundreds of WPA relief workers stationed there and the many hours they spent laboring to improve its resources. The resources determined eligible in this report include the Stone Warrant Officers' Quarters (21103) and its garage (21104); servants' quarters (22111, 22118, 22122, 22124, 22130, 22134, 22142, and 41011); garages (20310, 22006, 22021, 22022, 22023, 22109, 22113, 22119, 22131, 22135, 22143, 41010, 42021, 42022, 42023, and 42024); various improvements to the Officers' Row housing; retaining walls; and box culverts. It was determined the

$20 \mathrm{CP} \& Y$, Inc. 2009. National Register of Historic Places Evaluation of WPA Resources within the Residential Communities Initiative Footprint. Fort Huachuca, Arizona. CPY Project \#MMH09023.00. CP\&Y Inc., Austin, Texas. [FH-09-5] 
stacked stone ditches along the Grierson Service Road lack integrity, and more research was needed on the coal bins (Table 4).

Table 4. Table of WPA contributing buildings and resources within the RCl footprint (CP\&Y, 2009).

\begin{tabular}{|c|c|c|c|c|c|}
\hline Historic Name & $\begin{array}{l}\text { Building } \\
\text { No. }\end{array}$ & $\begin{array}{c}\text { Construction } \\
\text { Date }\end{array}$ & $\begin{array}{l}\text { Original } \\
\text { Use }\end{array}$ & $\begin{array}{l}\text { Current } \\
\text { Use }\end{array}$ & $\begin{array}{l}\text { NRHP Eligibility } \\
\text { Recommendation }\end{array}$ \\
\hline Warrant Officers' Quarters & 22103 & 1939 & Quarters & Quarters & NRHP eligible \\
\hline Warrant Officers' garage & 22104 & 1939 & Garage & Garage & NRHP eligible \\
\hline Servant's Quarters & 22008 & 1936 & $\begin{array}{l}\text { Servant's } \\
\text { Quarters }\end{array}$ & Storage & NRHP eligible \\
\hline Servant's Quarters & 22106 & 1936 & $\begin{array}{l}\text { Servant's } \\
\text { Quarters }\end{array}$ & Storage & NRHP eligible \\
\hline Servant's Quarters & 22111 & 1936 & $\begin{array}{l}\text { Servant's } \\
\text { Quarters }\end{array}$ & Storage & NRHP eligible \\
\hline Servant's Quarters & 22118 & 1936 & $\begin{array}{l}\text { Servant's } \\
\text { Quarters }\end{array}$ & Storage & NRHP eligible \\
\hline Servant's Quarters & 22122 & 1936 & $\begin{array}{l}\text { Servant's } \\
\text { Quarters }\end{array}$ & Storage & NRHP eligible \\
\hline Servant's Quarters & 22124 & 1936 & $\begin{array}{l}\text { Servant's } \\
\text { Quarters }\end{array}$ & Storage & NRHP eligible \\
\hline Servant's Quarters & 22130 & 1936 & $\begin{array}{l}\text { Servant's } \\
\text { Quarters }\end{array}$ & Storage & NRHP eligible \\
\hline Servant's Quarters & 22134 & 1936 & $\begin{array}{l}\text { Servant's } \\
\text { Quarters }\end{array}$ & Storage & NRHP eligible \\
\hline Servant's Quarters & 22136 & 1936 & $\begin{array}{l}\text { Servant's } \\
\text { Quarters }\end{array}$ & Storage & NRHP eligible \\
\hline Servant's Quarters & 22142 & 1936 & $\begin{array}{l}\text { Servant's } \\
\text { Quarters }\end{array}$ & Storage & NRHP eligible \\
\hline Servant's Quarters & 41011 & 1936 & $\begin{array}{l}\text { Servant's } \\
\text { Quarters }\end{array}$ & Storage & NRHP eligible \\
\hline Garage & 20310 & 1936 & Garage & Garage & NRHP eligible \\
\hline Garage & 22006 & 1936 & Garage & Garage & NRHP eligible \\
\hline Garage & 22007 & 1936 & Garage & Garage & NRHP eligible \\
\hline Garage & 22021 & 1936 & Garage & Garage & NRHP eligible \\
\hline Garage & 22022 & 1936 & Garage & Garage & NRHP eligible \\
\hline Garage & 22023 & 1936 & Garage & Garage & NRHP eligible \\
\hline Garage & 22109 & 1936 & Garage & Garage & NRHP eligible \\
\hline Garage & 22113 & 1936 & Garage & Garage & NRHP eligible \\
\hline Garage & 22119 & 1936 & Garage & Garage & NRHP eligible \\
\hline Garage & 22131 & 1936 & Garage & Garage & NRHP eligible \\
\hline Garage & 22135 & 1936 & Garage & Garage & NRHP eligible \\
\hline Garage & 22143 & 1936 & Garage & Garage & NRHP eligible \\
\hline Garage & 41010 & 1936 & Garage & Garage & NRHP eligible \\
\hline Garage & 42021 & 1936 & Garage & Garage & NRHP eligible \\
\hline Garage & 42022 & 1936 & Garage & Garage & NRHP eligible \\
\hline Garage & 42023 & 1936 & Garage & Garage & NRHP eligible \\
\hline Garage & 42024 & 1936 & Garage & Garage & NRHP eligible \\
\hline
\end{tabular}




\begin{tabular}{|l|c|c|c|c|l|}
\hline Historic Name & $\begin{array}{c}\text { Building } \\
\text { No. }\end{array}$ & $\begin{array}{c}\text { Construction } \\
\text { Date }\end{array}$ & $\begin{array}{c}\text { Original } \\
\text { Use }\end{array}$ & $\begin{array}{c}\text { Current } \\
\text { Use }\end{array}$ & $\begin{array}{l}\text { NRHP Eligibility } \\
\text { Recommendation }\end{array}$ \\
\hline $\begin{array}{l}\text { Improvements to historic housing (porch } \\
\text { aprons, stair side walls, decorative walls, } \\
\text { steps, planting beds) }\end{array}$ & (WPA-027) & $1935-1940$ & & & NRHP eligible \\
\hline $\begin{array}{l}\text { Box culverts along Grierson Service } \\
\text { Road }\end{array}$ & (WPA-028) & 1936 & & & NRHP eligible \\
\hline $\begin{array}{l}\text { Stacked Stone Ditches along Grierson } \\
\text { Service Road and rear yards }\end{array}$ & (WPA-029) & 1936 & & & $\begin{array}{l}\text { Lacks integrity, not } \\
\text { eligible }\end{array}$ \\
\hline $\begin{array}{l}\text { Retaining walls along Grierson Service } \\
\text { Road and rear yards }\end{array}$ & (WPA-030) & $1935-1940$ & & NRHP eligible \\
\hline $\begin{array}{l}\text { Concrete bins along Grierson Service } \\
\text { Road and rear yards }\end{array}$ & (WPA-031) & 1920 & Coal bins & Coal bins & $\begin{array}{l}\text { Inconclusive origin; not } \\
\text { eligible }\end{array}$ \\
\hline
\end{tabular}

\subsubsection{3 architectural survey of $\mathbf{1 1 0}$ buildings and structures}

In a 2013 survey of 110 previously unevaluated buildings constructed between 1916 and 1961, SRI identified 17 facilities that were recommended eligible for NRHP listing. ${ }^{21}$ Of the 17, eight were recommended individually eligible for their association with the development of critical water-related infrastructure (90013, 90014, 90015, 90016, 90017, 90018, 90431, and 90672). Two facilities (30012 and 30114) were recommended individually eligible for their representation of architectural styles (Colonial Revival and Art Deco). Most of the buildings evaluated were not located in or near the NHL Historic District. However, seven of the facilities (15331, 22026, 22538, 31125, 41403, 41406, 90020), as well as one individually eligible (90018), were considered contributors to a potential WPA Historic District that builds upon the WPA/CCC Historic District proposed by Valenzuela in 2011 (See 3.4.5).

Of the seven remaining potentially eligible buildings, five are located in or near the NHL Historic District (Buildings 22026, 22538, 31125, 41403, and 41406). Building 22026, a 4-car family housing garage previously not evaluated, was found to have stonemasonry features contributing to the WPA. The Quartermaster Storage Building (22538) constructed in 1940 retains many of its original construction details: stone walls and the iron entrance gates connected to stone sidewalls. The Officers' Grandstand (31125) was evaluated in 2009 by Hart and Blackwell and found not eligible since it was missing the canopy and stadium-style folding chairs, but it is re-evaluated in this report. The extant materials and workmanship were found to make it contributing to a WPA Historic District. Building 41403,

\footnotetext{
21 Angel Tomes, 2013. Architectural Survey, Documentation, and Evaluation of 110 Buildings and Structures at Fort Huachuca, Arizona. Fort Huachuca Cultural Resources Report FH-12-6. Statistical Research, Tucson.
} 
Heat Building, was constructed in 1936 as a vault. It also housed the furnace for Rodney Hall (41402). Building 41406 was originally built as a 2car garage (now storage) in 1936. These two buildings tie physically and aesthetically to similar buildings on post that are representative of WPA design and workmanship.

In this report, 22 buildings near the NHL Historic District were found not eligible (21110, 21111, 21112, 22013, 22336, 22406, 22524, 22525, 30018, 30033, 30113, 30115, 30115, 30118, 30134, 30136, 30138, 30152, 31013, 31114, 41331, and 41411).

\subsubsection{4 evaluation of 30 buildings, 194 WPA features and identification of a potential WPA historic district}

In this report, SRI inventoried, documented and evaluated 194 aboveground elements of infrastructure (including drainage ditches, culverts, retaining walls, stairs, a bridge, and a stone embankment at a former Southern Pacific Railroad crossing) constructed by the WPA during the period of 1934-1940. ${ }^{22}$ This report also assessed 30 buildings for NRHP eligibility. None of these buildings were found eligible.

Of the 194 WPA features, 172 were recommended as eligible to a WPA historic district. These features include 86 culvert openings, 33 stairs, 17 drainage ditches, 16 retaining walls, 17 walls, one stone embankment, one dam and one bridge (Figure 25). This report also identified 49 previously recorded buildings modified or constructed by the WPA that also contribute to the historic district (Table 5). Eighteen coal bins were identified in the report but not evaluated.

\footnotetext{
22 Angel Tomes and Scott Thomas, 2014. Inventory, Documentation, and Evaluation of 30 Buildings and Structures, 192 Works Progress Administration (WPA) Features, and Identification of a Potential WPA Historic District at Fort Huachuca, Arizona. Fort Huachuca Cultural Resources Report FH-12-21. Statistical Research, Tucson.
} 
Figure 25. Map showing WPA features and buildings eligible to WPA-era Historic District (Tomes and Thomas, 2014). [Original map was cropped to show NHL District and immediate area for image readability.]

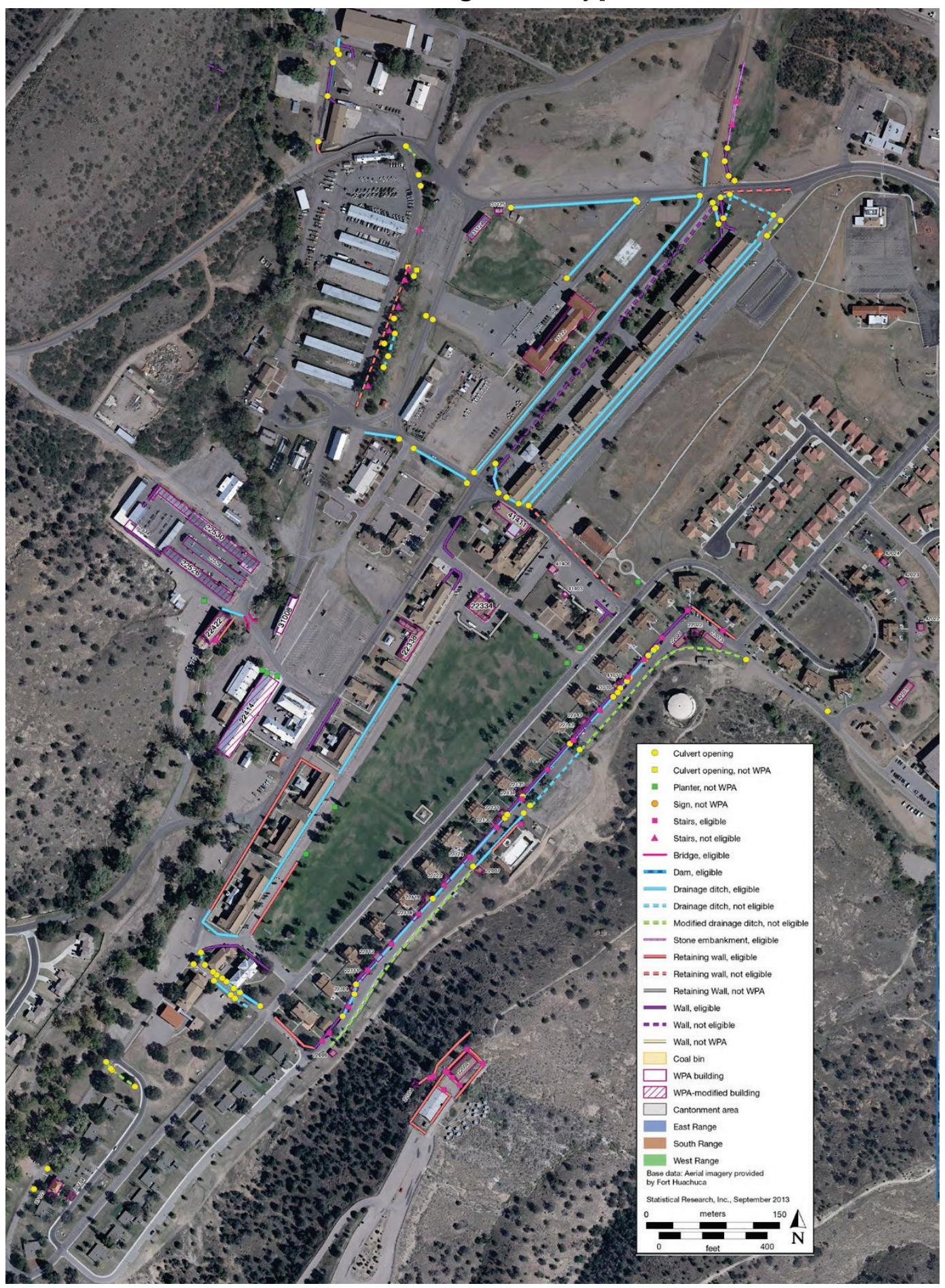


Table 5. Buildings modified or constructed by WPA and their eligibility to WPA-era Historic District (Tomes and Thomas, 2014).

\begin{tabular}{|c|c|c|c|}
\hline Facility Number & $\begin{array}{l}\text { Historic (Current) Facility Use / } \\
\text { Name }\end{array}$ & Year Completed & $\begin{array}{c}\text { Eligibility } \\
\text { Recommendation }\end{array}$ \\
\hline 11510 & Sentry Station (West Gate) & 1936 & Eligible; WPA \\
\hline 15331 & Latrine & 1938 & Eligible; WPA \\
\hline 15476 & Club House (Golf Course) & 1916 & Not eligible \\
\hline 20310 & Garage & 1936 & Eligible; WPA \\
\hline 21103 & Warrant Officers' Quarters & 1939 & Eligible; WPA \\
\hline 21104 & Garage & 1939 & Eligible; WPA \\
\hline 22001 & Reservoir & 1884 & Eligible; NHL* \\
\hline 22002 & Reservoir & 1938 & Eligible; WPA \\
\hline 22004 & Chlorine Building & 1938 & Eligible; WPA \\
\hline 22006 & Garage & 1936 & Eligible; WPA \\
\hline 22021 & Garage & 1936 & Eligible; WPA \\
\hline 22022 & Garage & 1936 & Eligible; WPA \\
\hline 22023 & Garage & 1936 & Eligible; WPA \\
\hline 22026 & Garage & 1936 & Eligible; WPA \\
\hline 22109 & Garage & 1936 & Eligible; WPA \\
\hline 22111 & Servant's Quarters & 1936 & Eligible; WPA \\
\hline 22113 & Garage & 1936 & Eligible; WPA \\
\hline 22118 & Servant's Quarters & 1936 & Eligible; WPA \\
\hline 22119 & Garage & 1936 & Eligible; WPA \\
\hline 22122 & Servant's Quarters & 1936 & Eligible; WPA \\
\hline 22124 & Servant's Quarters & 1936 & Eligible; WPA \\
\hline 22130 & Servant's Quarters & 1936 & Eligible; WPA \\
\hline 22131 & Garage & 1936 & Eligible; WPA \\
\hline 22134 & Servant's Quarters & 1936 & Eligible; WPA \\
\hline 22135 & Garage & 1936 & Eligible; WPA \\
\hline 22142 & Servant's Quarters & 1936 & Eligible; WPA \\
\hline 22143 & Servant's Quarters & 1936 & Eligible; WPA \\
\hline 22414 & Quartermaster Warehouse & 1920 & Eligible; WPA \\
\hline 22422 & Quartermaster Barracks & 1917 & Eligible; WPA \\
\hline 22526 & Quartermaster Shop & 1903 & Eligible; NHL* \\
\hline 22528 & Quartermaster Storage & 1940 & Eligible; WPA \\
\hline 22530 & Quartermaster Stable & 1903 & Eligible; $\mathrm{NHL}^{*}$ \\
\hline 22538 & Warehouse & 1940 & Eligible; WPA \\
\hline 31008 & Warehouse & 1942 & Eligible; WPA \\
\hline 31122 & Barracks & 1939 & Eligible; WPA \\
\hline 31124 & Enlisted Grandstand & 1937 & Eligible; NHL* \\
\hline 31125 & Officer's Grandstand & 1936 & Eligible; WPA \\
\hline 41010 & Garage & 1936 & Eligible; WPA \\
\hline 41011 & Servant's Quarters & 1936 & Eligible; WPA \\
\hline 41403 & Furnace Vault & 1936 & Eligible; WPA \\
\hline 41406 & Garage & 1936 & Eligible; WPA \\
\hline
\end{tabular}




\begin{tabular}{|c|l|c|l|}
\hline Facility Number & \multicolumn{1}{|c|}{$\begin{array}{c}\text { Historic (Current) Facility Use / } \\
\text { Name }\end{array}$} & Year Completed & \multicolumn{1}{|c|}{$\begin{array}{c}\text { Eligibility } \\
\text { Recommendation }\end{array}$} \\
\hline 41411 & Garage & 1936 & Eligible; NHL* \\
\hline 42021 & Garage & 1936 & Eligible; WPA \\
\hline 42022 & Garage & 1936 & Eligible; WPA \\
\hline 42023 & Garage & 1936 & Eligible; WPA \\
\hline 42024 & Garage & 1936 & Eligible; WPA \\
\hline 90017 & Well House & 1939 & Not eligible \\
\hline 90018 & Pump House & 1937 & Eligible; WPA \\
\hline $\begin{array}{l}\text { 90020 } \\
\text { Provost Station House }\end{array}$ & 1936 & Eligible; WPA \\
\hline $\begin{array}{l}\text { * While these buildings were determined eligible to NHL district in the 1993 nomination (Wee and Mikesell), the } \\
\text { nomination was never sent to SHPO; buildings are not currently contributing to NHL District. This report noted some of } \\
\text { the buildings may have been built or modified by WPA. The report table does not list them as contributing to WPA-era } \\
\text { Historic District, and they may be since they are not contributing to NHL district. }\end{array}$ \\
\hline
\end{tabular}

\subsection{Other reports}

\subsubsection{Janus Associates, Inc. survey}

A 1988 architectural and historical resources survey that documented the appearance and significance of the remaining 63 buildings within the Fort Huachuca Historic District NHL. The recommendation of this report was to expand the 1977 NHL boundary to include an additional 31 buildings and structures with similar period and area of significance. ${ }^{23}$ It also recommended expanding the POS to include buildings and structures constructed by Depression-era federal relief program personnel from 19291939 to include an additional 23 buildings.

\subsubsection{Jackson Research Projects (JRP) evaluation}

This 1989 evaluation was conducted to field check the inventory and integrity of the historic-age resources evaluated by Janus and comment on the recommendations provided in the 1988 report. Jackson Research Projects (JRP) conducted an evaluation of 115 pre-1940 buildings and structures within the cantonment area of Fort Huachuca. They concluded that although these buildings date to the POS for the NHL historic district, none retain sufficient integrity to be considered individually eligible resources, nor would they contribute to the existing NHL historic district. In addition, the team evaluated 31 pre-1940 buildings outside the current boundaries of the NHL historic district, and those buildings were also

\footnotetext{
23 Janus Associates, Inc., 1988. Draft Technical Synthesis Report: Fort Huachuca Architectural/Historical Resources Survey. Phoenix, Arizona: Janus Associates, Inc. [FH-88-2]
} 
recommended as not individually eligible to the NRHP due to loss of integrity and their construction dates being after the POS of the NHL historic district. 24

\subsubsection{NRHP nomination for Fort Huachuca Historic District (never submitted)}

In 1993, a new NRHP nomination was written by JRP Historical Consulting Services of Davis, CA. ${ }^{25}$ The intent was to clearly identify which buildings contributed and which did not contribute to the historic district. This nomination increased the POS from 1880 to 1931. In addition, it listed 65 buildings as contributing as well as two sites, Brown Field and Henry Circle. The nomination found 21 buildings were non-contributing and two objects, the flagpole and the band stand, were non-contributing, as both were added outside of the POS.

The new historic district nomination recommended 16 buildings as contributing in addition to the 49 that were already contributing to the NHL historic district (Table 6). These 16 buildings included the morgue (41409), lavatories (22210, 22212, 22218, 22322, 22410, and 41414) associated with the barracks, servants' quarters and stables along Grierson Service Road from the 1880 os (22007, 22008, 22102, 22106, 22136), dental office (41410), storehouse (22408), and ordnance warehouse (22330). The 21 non-contributing buildings located within the district were built in or after 1934 and were mainly the garages and servants' quarters.

This nomination boundary contracted the 1977 NHL boundary on the east side. It was felt the contour line on the east was not a useable boundary, and since the heliograph station site was unknown and unrecognizable on the ground, the boundary was shifted to Grierson Service Road. The boundary was expanded slightly on the west side to include Buildings 22408 and 22410. This boundary did not include the stables and most of the quartermaster corps warehouse area, explaining the areas lacked integrity (Figure 26).

\footnotetext{
24 Jackson Research, 1989. Fort Huachuca: An Evaluation of Architectural/Historical Resources. Davis, California: Jackson Research. [FH-89-6]

25 Stephen R. Wee and Stephen D. Mikesell, 1993. National Register of Historic Places Registration Form for Fort Huachuca Historic District, National Register. Unpublished document, U.S. Department of the Interior, National Park Service. [FH-93-9]
} 
Table 6. List of 16 buildings recommended as contributing (in addition to the 48 already listed as contributing in the Fort Huachuca Historic District) in the 1993 NR nomination (Wee and Mikesell, 1993).

\begin{tabular}{|c|l|l|c|}
\hline Building No. & Name & Original Function & Year Built \\
\hline 22007 & Stable & Stable & 1887 \\
\hline 22008 & Servants Quarters & & 1890 \\
\hline 22102 & Hazen House Annex & Hospital Officer's Quarters & 1887 \\
\hline 22103 & Water Valve Building & & 1920 \\
\hline 22106 & Servants Quarters & & 1895 \\
\hline 22136 & Servants Quarters & & 1895 \\
\hline 22210 & Sep Toilet/Shower & Lavatory & 1916 \\
\hline 22212 & Sep Toilet/Shower & Lavatory Old Barracks: 4th & 1903 \\
\hline 22218 & & Lavatory Old Barracks: 5th & 1916 \\
\hline 22322 & & Lavatory & 1903 \\
\hline 22330 & Salvador Sepulveda Historical Interpretation & Ordnance Warehouse (Guardhouse?) & 1882 \\
\hline 22408 & & & 1887 \\
\hline 22410 & Sep Toilet/Shower & Storehouse, Quartermaster Office & 1915 \\
\hline 41409 & & Lavatory/Latrine (Quartermaster & 1887 \\
\hline 41410 & Skelton Hall & Engineer Office?) & 1920 \\
\hline 41414 & & Morgue & 1914 \\
\hline
\end{tabular}


Figure 26. Proposed contributing buildings, in black, in 1993 NRHP nomination (W\&Ms, 1993).

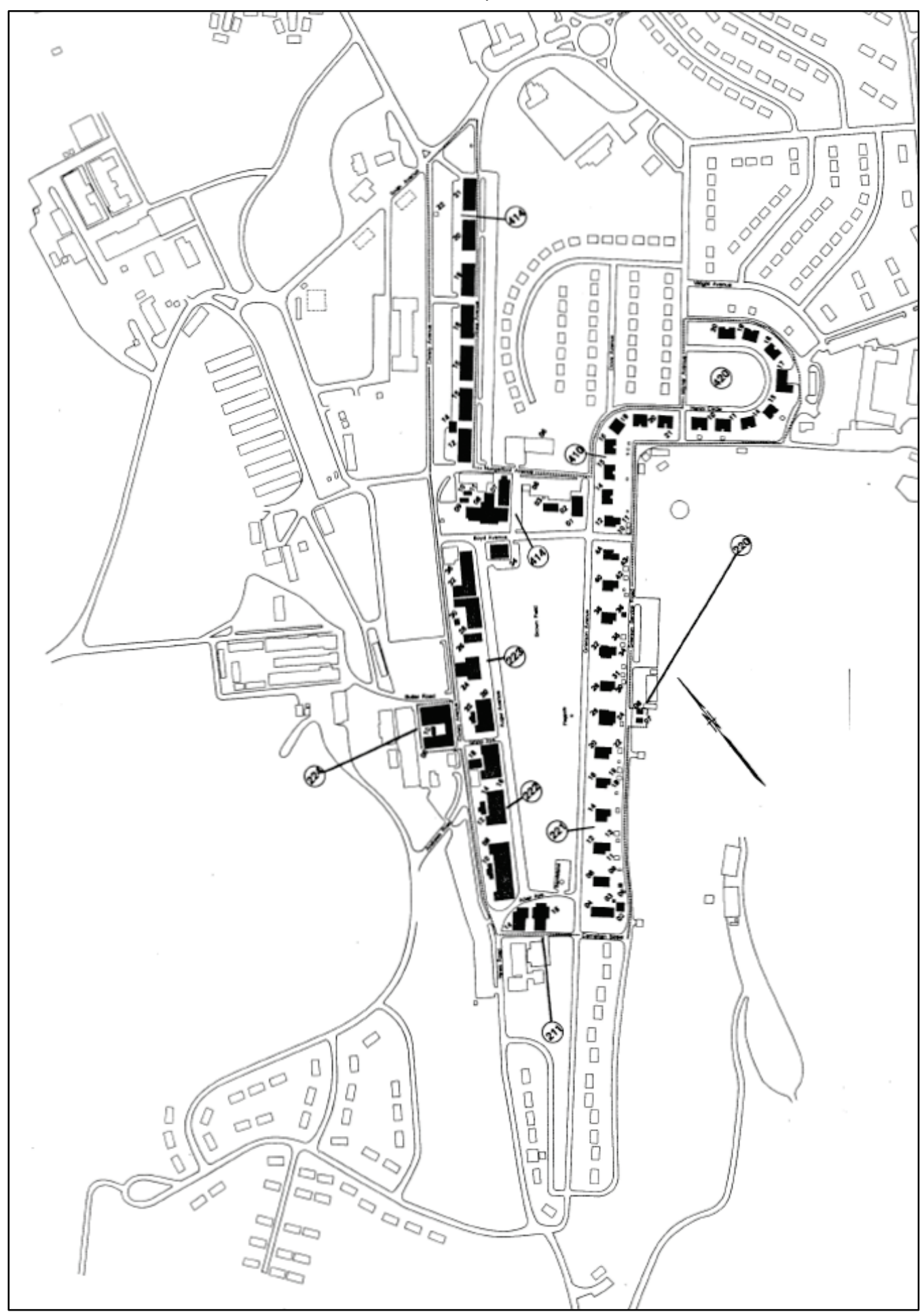




\subsubsection{1 documentation and evaluation of 29 buildings and structures}

This report was an architectural survey and NRHP evaluation of 16 buildings and 13 structures on Fort Huachuca. ${ }^{26}$ These resources were either unevaluated or had been previously evaluated with conflicting recommendations. Of the 29 resources surveyed, 13 were located adjacent to the Fort Huachuca Historic District NHL. Their determinations and associated themes are listed in Table 6. Only one building, Quartermaster Corps (QMC) Warehouse (22414), was found eligible under the Early History (Fort Huachuca NHL District, 1877-1931) theme. ${ }^{27}$ Under the same theme, two buildings, the QMC and Supply Troop Barracks (22422) and the Masonic Lodge (Building 22418), were determined not eligible, although it is noted these two facilities should be re-examined for their association with the $10^{\text {th }}$ Cavalry Regiment. ${ }^{28}$

Six buildings were found eligible under the theme Interwar Years and Government Sponsored Work Programs of the New Deal Era (19331942): Water Reservoir No. 2 (22002), NCO Quarters (22028), QMC Warehouse (22420), QM Storage (22528), Post Engineer Storage (31008), and Whitside (School) Hall (41330). Based on a Nationwide Context, it was noted there are a large number of buildings and structures at Fort Huachuca related to this theme and period of construction that could form a cohesive district whose resources retain sufficient integrity according to NRHP requirements. ${ }^{29}$

\footnotetext{
26 Elizabeth S. Valenzuela, 2011. FY 12 SRM Facilities and Demolition Projects: Documentation and National Register Evaluation of 29 Buildings on Fort Huachuca, Arizona. Fort Huachuca Cultural Resources Report FH-11-8. Valenzuela Preservation Studios, Austin, Texas, and Venadero Group, Phoenix.

27 Period of Significance (1877-1931) for “Early History" theme was determined in 1993 Draft Nomination, never submitted to SHPO. Period of Significance for Fort Huachuca Historic District NHL is 1877-1920.

28 See also Draft NRHP Nomination Form for Facility 22418, the 10th Cavalry Mason Lodge, (Fort Huachuca Cultural Resources Intern, 2015), not submitted to SHPO.

29 Dr. Susan Goodfellow, Marjorie Norwick, Chad Blackwell, Dan Hart and Kathryn Plimpton, 2009. Nationwide Context, Inventory, and Heritage Assessment of Works Progress Administration and Civilian Conservation Corps Resources on Department of Defense Installations. Legacy Report No. 07-357. Department of Defense, Office of the Deputy Under Secretary of Defense for Installations \& Environment, Legacy Resource Management Program, Crystal City, Virginia.
} 
Table 7. The 13 buildings adjacent to the Fort Huachuca NHL Historic District and their determinations (Valenzuela, 2011).

\begin{tabular}{|c|c|c|c|c|}
\hline Facility & $\begin{array}{l}\text { Historic (Current) Facility } \\
\text { Use / Name }\end{array}$ & $\begin{array}{c}\text { NRHP Eligibility } \\
\text { Recommendation }\end{array}$ & $\begin{array}{l}\text { NRHP } \\
\text { Criteria }\end{array}$ & Historic Context Theme \\
\hline 22002 & Reservoir No. 2 (Water Supply) & Eligible & A & $\begin{array}{l}\text { Interwar Years and Government } \\
\text { Sponsored Work } \\
\text { Programs of the New Deal Era } \\
(1933-1942)\end{array}$ \\
\hline 22028 & $\begin{array}{l}\text { NCO Quarters (Army Lodging) / Utah } \\
\text { House }\end{array}$ & Eligible & A & $\begin{array}{l}\text { Interwar Years and Government } \\
\text { Sponsored Work } \\
\text { Programs of the New Deal Era } \\
(1933-1942)\end{array}$ \\
\hline 22040 & $\begin{array}{l}\text { Storage (Organization } \\
\text { Storage Building) }\end{array}$ & Not Eligible & None & $\begin{array}{l}\text { Cold War Era - Reactivation of Fort } \\
\text { Huachuca and } \\
\text { the Growth of Specialized Military } \\
\text { Training (1951- } \\
\text { 1991) }\end{array}$ \\
\hline 22414 & $\begin{array}{l}\text { QMC Warehouse (General Instruction } \\
\text { Building, Storage General Purpose, } \\
\text { Organization Storage Building, Drug/ } \\
\text { Alcohol Abuse Facility [ASAP]) }\end{array}$ & Eligible & A & $\begin{array}{l}\text { Early History (Fort Huachuca NHL } \\
\text { District, 1877- } \\
\text { 1931); Interwar Years and } \\
\text { Government Sponsored } \\
\text { Work Programs of the New Deal Era } \\
(1933-1942)\end{array}$ \\
\hline 22418 & $\begin{array}{l}\text { Masonic Lodge (General Instruction } \\
\text { Building, Organization Storage Building } \\
\text { / Fire Department and Arizona } \\
\text { Ambulance) }\end{array}$ & Not Eligible & None & $\begin{array}{l}\text { Early History (Fort Huachuca NHL } \\
\text { District, 1877- } \\
\text { 1931); Interwar Years and } \\
\text { Government Sponsored } \\
\text { Work Programs of the New Deal Era } \\
(1933-1942)\end{array}$ \\
\hline 22420 & $\begin{array}{l}\text { QMC Warehouse (General Instruction } \\
\text { Building / Educational Services) }\end{array}$ & Eligible & A & $\begin{array}{l}\text { Interwar Years and Government } \\
\text { Sponsored Work } \\
\text { Programs of the New Deal Era } \\
(1933-1942)\end{array}$ \\
\hline 22422 & $\begin{array}{l}\text { QMC and Supply Troop Barracks } \\
\text { (Administrative General Purpose / Main } \\
\text { Directorate of Public Works Building) }\end{array}$ & Not Eligible & None & $\begin{array}{l}\text { Early History (Fort Huachuca NHL } \\
\text { District, 1877- } \\
\text { 1931); Interwar Years and } \\
\text { Government Sponsored } \\
\text { Work Programs of the New Deal Era } \\
(1933-1942)\end{array}$ \\
\hline 22528 & $\begin{array}{l}\text { QM Storage (Storage } \\
\text { General Purpose) }\end{array}$ & Eligible & $A$ and $C$ & $\begin{array}{l}\text { Interwar Years and Government } \\
\text { Sponsored Work } \\
\text { Programs of the New Deal Era } \\
(1933-1942)\end{array}$ \\
\hline 22542 & $\begin{array}{l}\text { Engineer Warehouse } \\
\text { (Storage General Purpose) }\end{array}$ & Not Eligible & None & $\begin{array}{l}\text { Cold War Era - Reactivation of Fort } \\
\text { Huachuca and } \\
\text { the Growth of Specialized Military } \\
\text { Training (1951- } \\
\text { 1991) }\end{array}$ \\
\hline 30116 & Battery Shop (Vacant) & Not Eligible & None & $\begin{array}{l}\text { Cold War Era - Reactivation of Fort } \\
\text { Huachuca and } \\
\text { the Growth of Specialized Military } \\
\text { Training (1951- } \\
\text { 1991) }\end{array}$ \\
\hline
\end{tabular}




\begin{tabular}{|c|c|c|c|c|}
\hline Facility & $\begin{array}{l}\text { Historic (Current) Facility } \\
\text { Use / Name }\end{array}$ & $\begin{array}{c}\text { NRHP Eligibility } \\
\text { Recommendation }\end{array}$ & $\begin{array}{l}\text { NRHP } \\
\text { Criteria }\end{array}$ & Historic Context Theme \\
\hline 30117 & $\begin{array}{l}\text { Paint Spray Shop (Vehicle Maintenance } \\
\text { Shop, Vacant) }\end{array}$ & Not Eligible & None & $\begin{array}{l}\text { Cold War Era - Reactivation of Fort } \\
\text { Huachuca and } \\
\text { the Growth of Specialized Military } \\
\text { Training (1951- } \\
\text { 1991) }\end{array}$ \\
\hline 31008 & $\begin{array}{l}\text { Post Engineer Storage, Exchange } \\
\text { Warehouse / Hangman's Warehouse }\end{array}$ & Eligible & $A$ and $C$ & $\begin{array}{l}\text { Interwar Years and Government } \\
\text { Sponsored Work } \\
\text { Programs of the New Deal Era } \\
(1933-1942)\end{array}$ \\
\hline 41330 & $\begin{array}{l}\text { Capt. Whitside School (Administrative } \\
\text { General Purpose) / Whitside Hall }\end{array}$ & Eligible & $A$ and $C$ & $\begin{array}{l}\text { Interwar Years and Government } \\
\text { Sponsored Work } \\
\text { Programs of the New Deal Era } \\
(1933-1942)\end{array}$ \\
\hline
\end{tabular}

\subsubsection{7 evaluation of coal bins}

In 2017, a draft report was compiled documenting that the coal bins likely date to 1920 and are associated with early use of the officers' quarters. $3^{\circ}$ These coal bins, located along the service roads behind the quarters and duplexes, contribute to the historic feel of the district along with the servant's quarters, stables and later the garages. The report recommends the 18 coal bins be eligible to the Fort Huachuca NHL Historic District, since the new date of construction of 1920 falls within the POS for the district. This report has not been submitted to the SHPO.

30 Anna E. Schneider, 2017. Historic District Coal Bins: Cultural Resources Evaluation, Fort Huachuca, Arizona, [Draft]. Cultural Resources Report FH-17-17, Fort Huachuca, AZ. 


\section{Landscape Inventory of the Fort Huachuca Historic District NHL}

The current condition for the landscape discussions in this chapter are related to the 49 buildings contributing to the Fort Huachuca Historic District NHL. The historic district has been broken down into seven component landscapes: Old Post Officers' Quarters, Old Post Barracks, Old Post Administration, Brown Field, Old Post Recreation, 1914 Barracks, and 1914 Officers' Duplexes (Figure 27). The following descriptions of these include a list of buildings. The other buildings and structures found within this NHL boundary were found to be non-contributing to the NHL; however, additional reports may have found the remaining buildings and structures within the historic district to be either eligible or not eligible under different contexts.

Other significant landscape areas located outside of the NHL boundary will be discussed in Chapter 8. These supplemental landscape areas include the North Parade Field (the historic field associated with the 1914 Barracks and the $10^{\text {th }}$ Cavalry), the cavalry stables, the Quartermaster and Commissary Area, the Post Cemetery, Reservoir Hill, and the Cavalry 1 Housing Area. 
Figure 27. Fort Huachuca Historic District NHL boundary with defined landscape areas for discussion in report (ERDC-CERL).

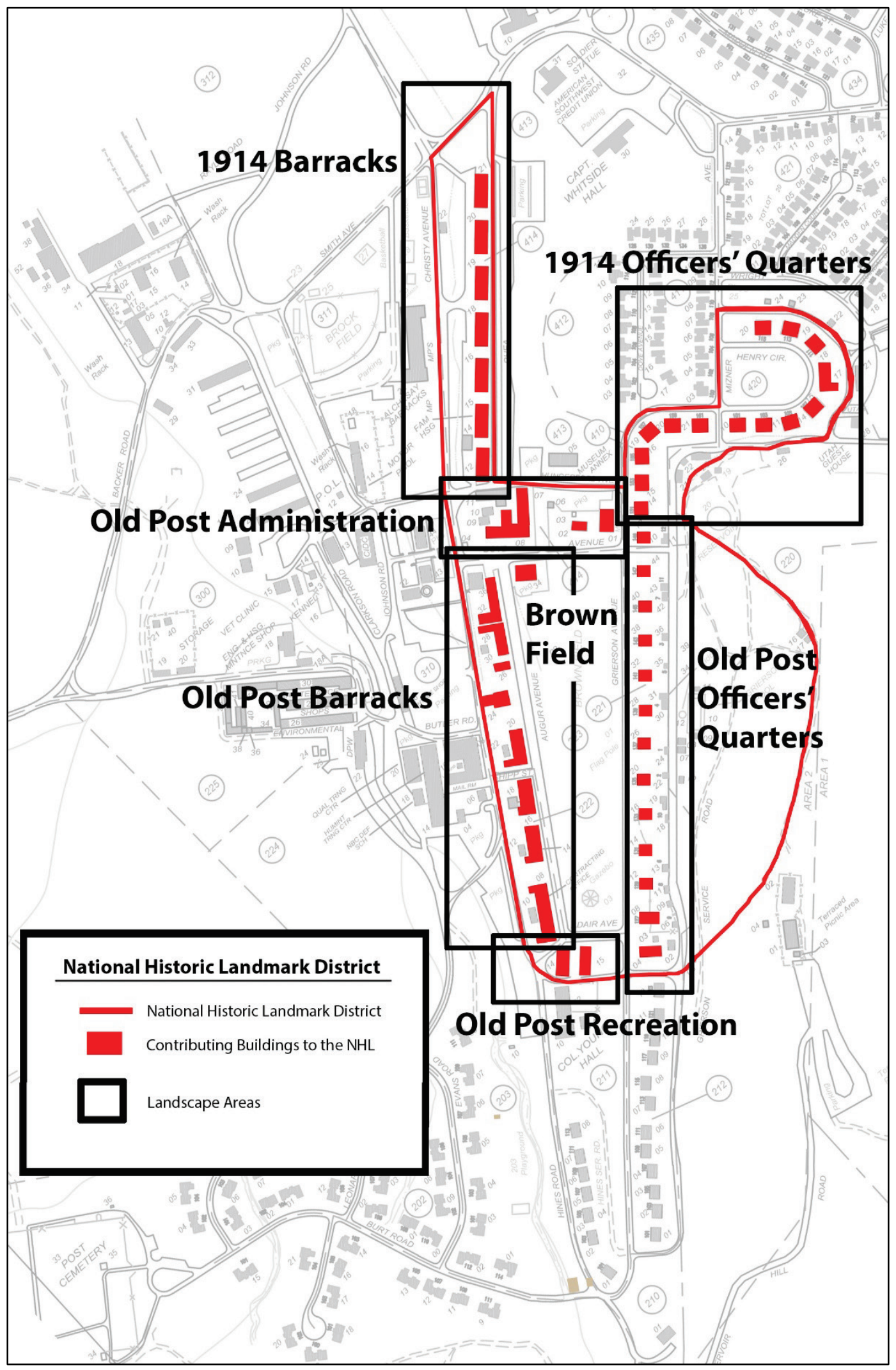




\subsection{Old Post Officers' Quarters}

The Old Post Officers' Quarters (Buildings 22112, 22114, 22116, 22120, 22126, 22128, 22132, 22138, 22140, and 22144, and 41012) are located on the southeast side of Brown Field on Grierson Avenue and consists of 11 officers' quarters, three family quarters, seven associated garages, 10 servants' quarters, and nine coal bins. ${ }^{31}$ On the southeast side of Grierson Service Road are a garage (22007), a servant's quarters (22008), Grierson Pool (22010 and 22012) and a carport (22013) (Figure 28, Table 8).

Figure 28. Officers' quarters landscape area map (ERDC-CERL).

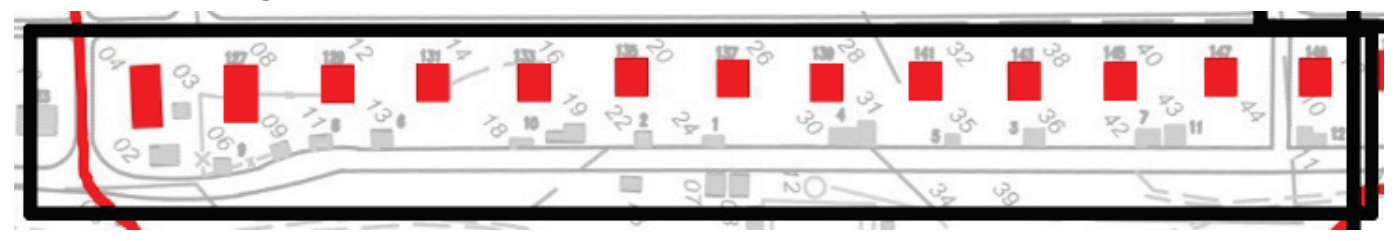

Table 8. List of buildings within the Old Post Officers' Quarters landscape area ${ }^{32}$.

\begin{tabular}{|c|c|c|c|c|}
\hline Building Number & Year Built & Original Use & Current Use & Historic Status \\
\hline 41010 & 1936 & Garage & Garage & NREC \\
\hline 41011 & 1936 & Servant's Quarters & Storage & NREC \\
\hline 41012 & 1884 & Housing & Family Quarters & NHLC \\
\hline 22007 & 1936 & Garage & Garage & NEV \\
\hline 22008 & 1884 & Servant's Quarters & Storage & NEV \\
\hline 22010 & 1935 & Grierson Pool & & DNE \\
\hline 22012 & 1954 & Wading Pool & & DNE \\
\hline 22013 & 1957 & Carport & Carport & DNE \\
\hline 22102 & 1887 & Housing & Family Quarters & NHLC \\
\hline 22103 & 1920 & Water Meter & Water Meter & NEV \\
\hline 22104 & 1891 & Housing & Family Quarters & NHLC \\
\hline 22105 & 1920 & Coal Bin & Coal Bin & NEV \\
\hline 22106 & 1895 & Servant's Quarters & Storage & DNE \\
\hline 22108 & 1880 & Housing & Family Quarters & NHLC \\
\hline 22109 & 1936 & Garage & Garage & NREC \\
\hline 22111 & 1916 & Servant's Quarters & Storage & DNE \\
\hline 22112 & 1884 & Housing & Family Quarters & NHLC \\
\hline 22113 & 1938 & Garage & Garage & NREC \\
\hline 22114 & 1884 & Housing & Family Quarters & NHLC \\
\hline 22115 & 1920 & Coal Bin & Coal Bin & NEV \\
\hline
\end{tabular}

${ }^{31}$ Coal bin numbers are from Schneider, Anna E, Historic Coal Bins Cultural Resources Evaluation, DRAFT, FH-17-17 (Fort Huachuca, AZ, 2017). Since this report has not been sent to AZ SHPO, they are listed as NEV.

32 NREC (National Register Eligible Contributing); NHLC (National Historic Landmark Contributing); NEV (Not Evaluated); DNE (Determined Not Eligible). 


\begin{tabular}{|c|c|c|c|c|}
\hline Building Number & Year Built & Original Use & Current Use & Historic Status \\
\hline 22116 & 1884 & Housing & Family Quarters & NHLC \\
\hline 22117 & 1920 & Coal Bin & Coal Bin & NEV \\
\hline 22118 & 1936 & Servant's Quarters & Storage & NREC \\
\hline 22119 & 1936 & Garage & Garage & NREC \\
\hline 22120 & 1884 & Housing & Family Quarters & NHLC \\
\hline 22121 & 1920 & Coal Bin & Coal Bin & NEV \\
\hline 22122 & 1920 & Servant's Quarters & Storage & NREC \\
\hline 22123 & 1920 & Coal Bin & Coal Bin & NEV \\
\hline 22124 & 1936 & Servant's Quarters & Storage & NREC \\
\hline 22126 & 1884 & Housing & Family Quarters & NHLC \\
\hline 22127 & 1920 & Coal Bin & Coal Bin & NEV \\
\hline 22128 & 1884 & Housing & Family Quarters & NHLC \\
\hline 22130 & 1936 & Servant's Quarters & Servant's Quarters & NREC \\
\hline 22131 & 1936 & Garage & Garage & NREC \\
\hline 22132 & 1884 & Housing & Family Quarters & NHLC \\
\hline 22134 & 1936 & Servant's Quarters & Storage & NREC \\
\hline 22135 & 1936 & Garage & Garage & NREC \\
\hline 22136 & 1895 & Servant's Quarters & Storage & DNE \\
\hline 22138 & 1884 & Housing & Family Quarters & NHLC \\
\hline 22139 & 1920 & Coal Bin & Coal Bin & NEV \\
\hline 22140 & 1884 & Housing & Family Quarters & NHLC \\
\hline 22142 & 1936 & Servant's Quarters & Storage & NREC \\
\hline 22143 & 1936 & Garage & Garage & NREC \\
\hline 22144 & 1884 & Housing & Family Quarters & NHLC \\
\hline 22145 & 1920 & Coal Bin & Coal Bin & DNE \\
\hline 22147 & 1920 & Coal Bin & Coal Bin & DNE \\
\hline
\end{tabular}

\subsubsection{History}

The Old Post Officers' Quarters were constructed in 1884. The officers' quarters prominently line the east side of Brown Field, the post parade field. These 11, 1-1/2-story, gable-roofed, stuccoed, adobe dwellings complete officers' row. 33 The 11 quarters vary some in design, but all have about 5,000 sq ft of floor space in a southwest-northeast oriented main block and one or two small, one-story, gable-roofed rear ells. Most of the buildings have three gabled roof dormers on both the front and rear slopes of the main block roof, but a few of the dwellings have a single, large gabled wall dormer on each slope. All the quarters have a one-story, hip roofed enclosed porch (originally open) across the front facade and one to

33 Note that Quarters 41012 was left off the list of contributing buildings on the 1974 nomination, most likely due to the numbering and its location north of Boyd Avenue. However, it was erected with the other nine in 1884. It was added to the nomination in 1975. 
three small outbuildings in the rear. Six-over-six sash windows predominate in each residence, and all the dwellings are served by two or more stuccoed interior chimneys. Two additional quarters (Building 22108 and 22104) are of a different plan.

When the post was first built in the 1880 s, each adobe officer's quarters had two adobe-walled outbuildings: a water closet and a stable. The water closet was located west of the Grierson Service Road, near the house, while the stable was located east of the road. By 1906, a third building, a servant's quarters, had been added to the rear of most but not all of the quarters, next to the water closet. By the 1920s, all but one of the stables had been removed. The remaining stable (Building 22007) is located behind Pershing House. This building has been used as a garage since the 1920 .

During the mid-1930s, all the water closets were removed, and automobile garages were built in locations that did not correspond with the old stables, their functional predecessors. Most of the servants' quarters, or at least the original location of the earlier adobe servants' quarters, were rebuilt of wood-frame or hollow clay tile on the old stone foundation. All garages except Building 22007 (the converted stable) were built in the mid-1930s. In summary, eight garages, one carport and 11 servants' quarters comprise the 20 service buildings associated with the officers' quarters. Historically these quarters were numbered 1 through 13 , with Quarters 1, located in the center, belonging to the commanding officer (Figures 29-39). 
Figure 29. Looking north at front of the officers' quarters on the east side of the parade ground, 1883 (NARA College Park, RG165-FF).

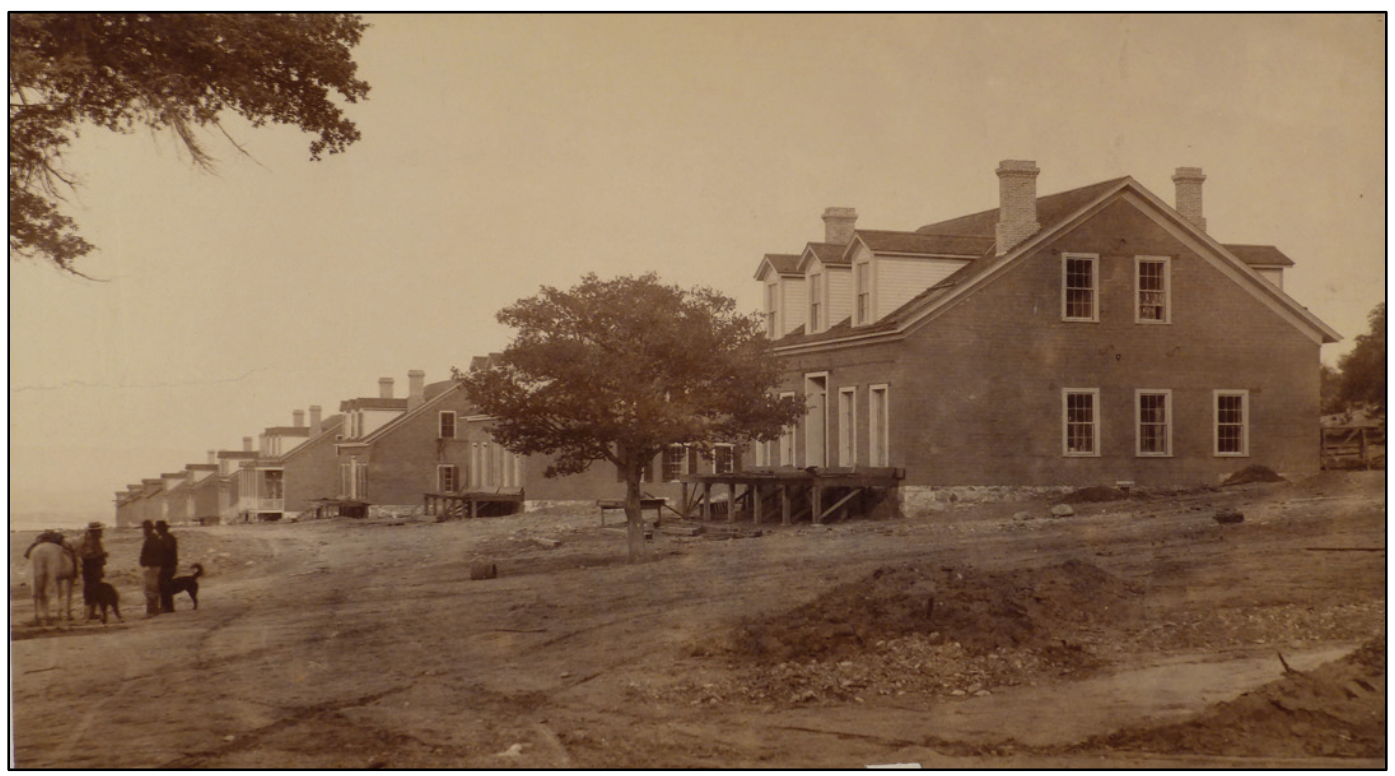

Figure 30. Looking south at rear of the officers' quarters, 1883 (NARA College Park, RG165FF).

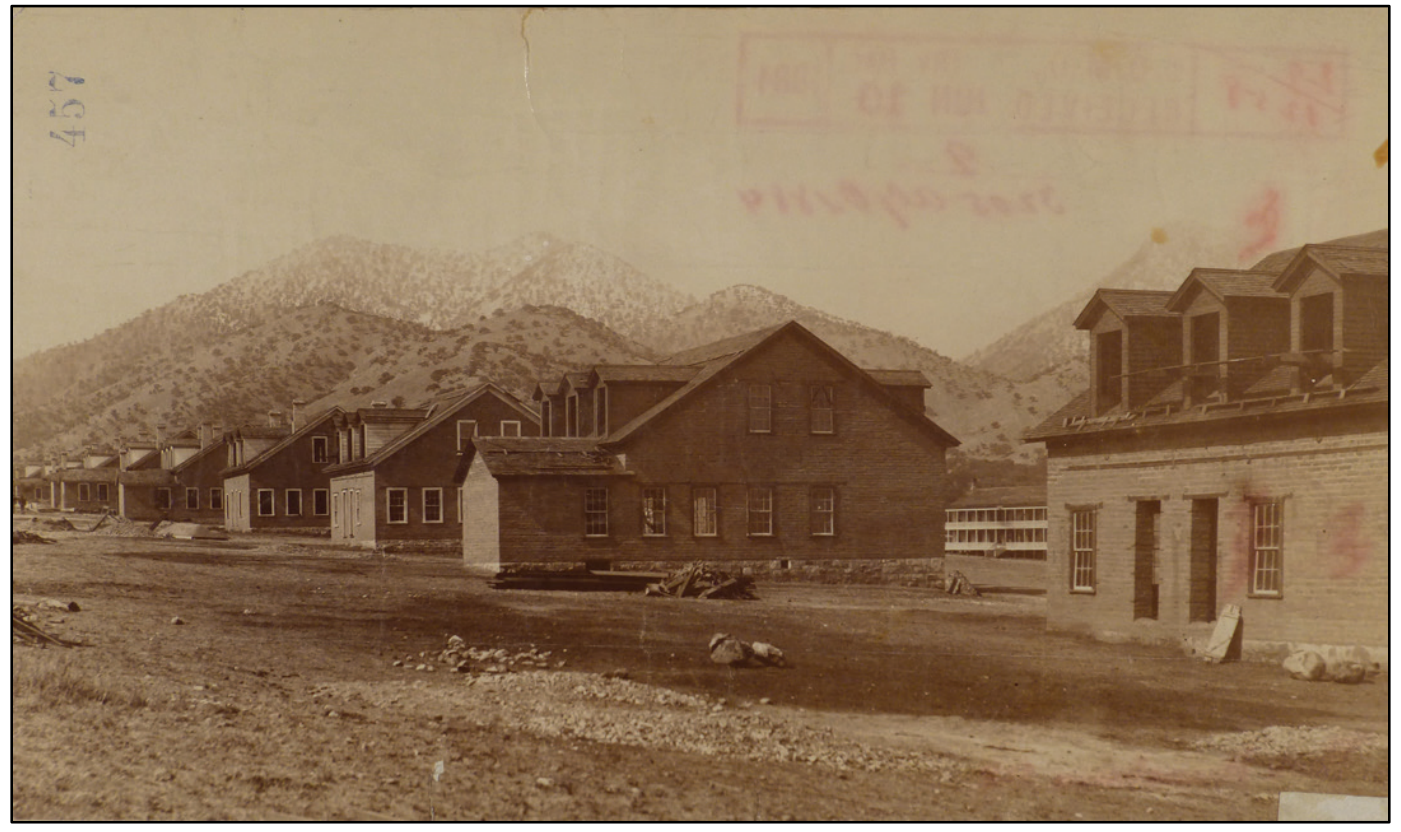


Figure 31. View to the east of front of officers' quarters, 1898 (NARA College Park, RG111$\mathrm{SC}$ ).

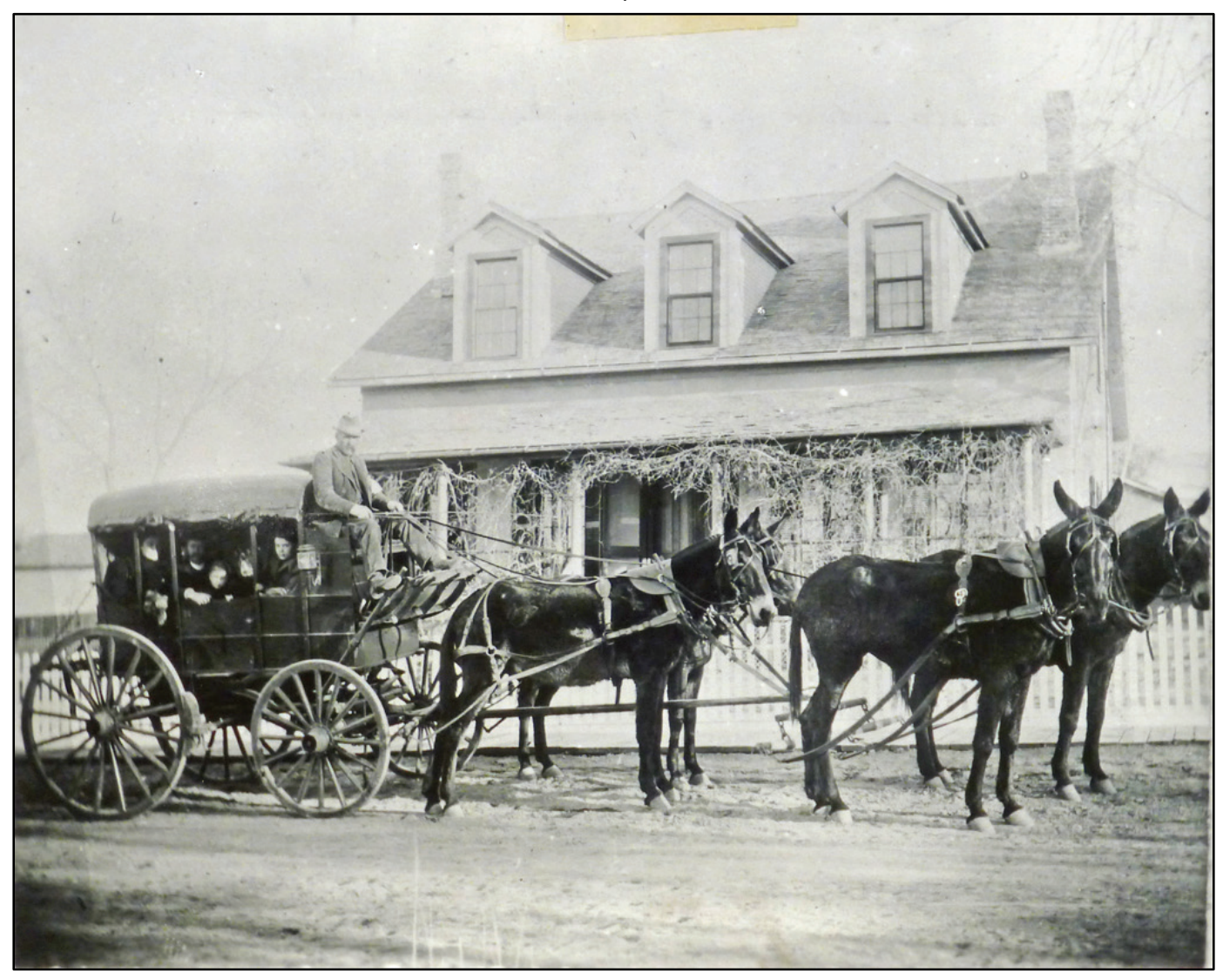


Figure 32. View to the east of front of officers' quarters, 1899 (NARA College Park, RG111$\mathrm{SC}$ ).

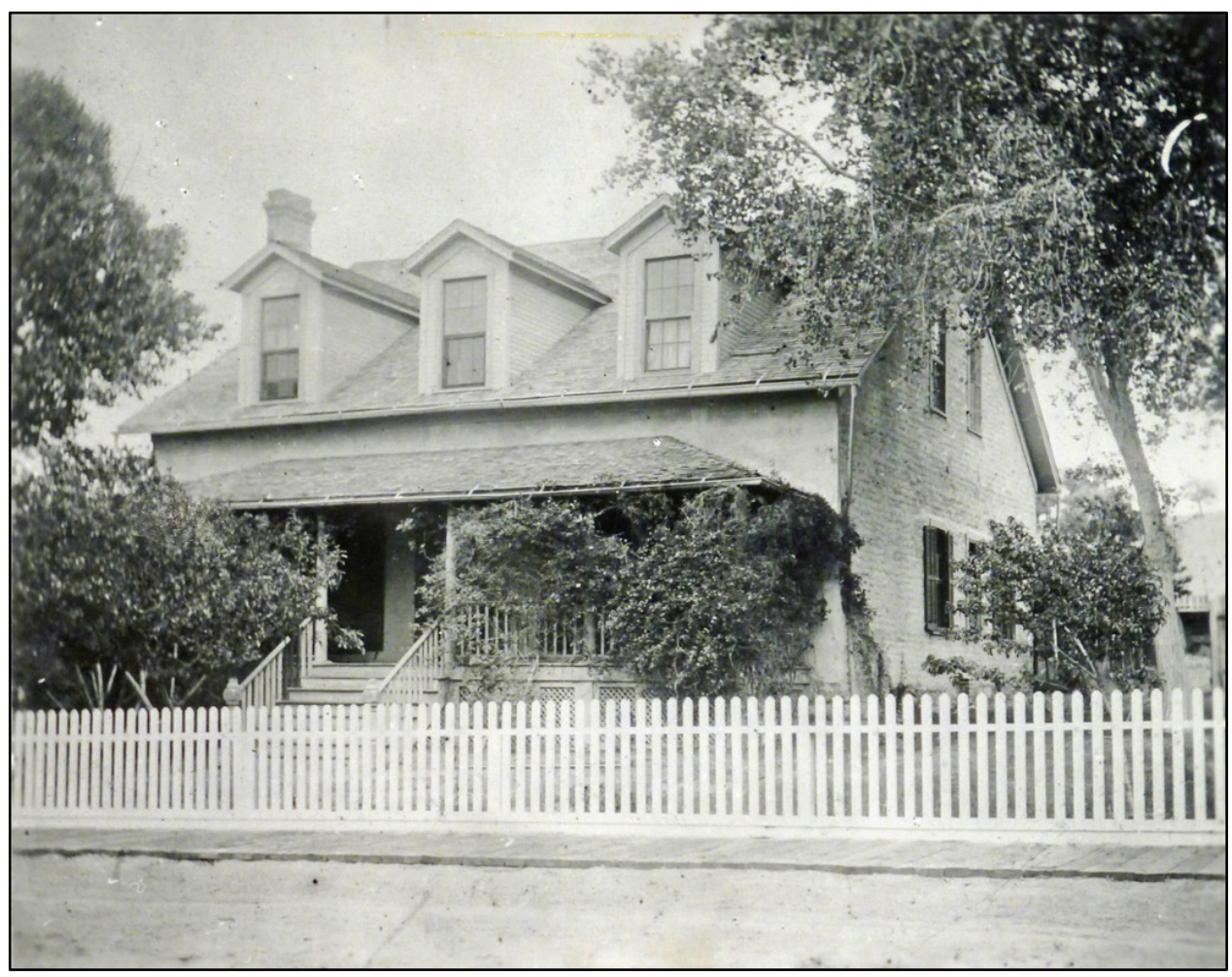

Figure 33. View looking east at officers' quarters (22132 and 22128), c.1900 (NARA College Park, RG165-FF).

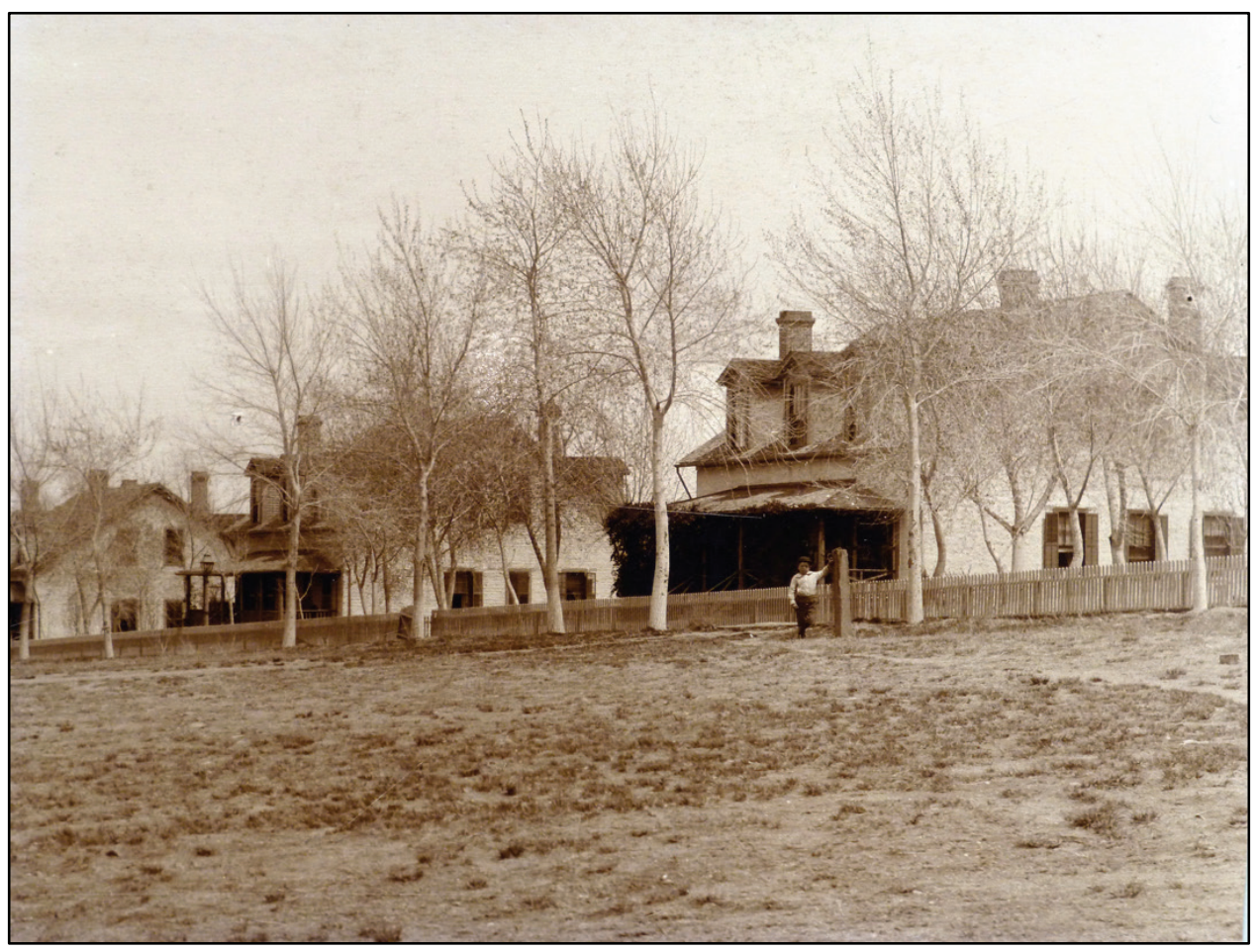


Figure 34. View looking south at officers' quarters (22126 and 22120), c.1900 (NARA College Park, RG165-FF).

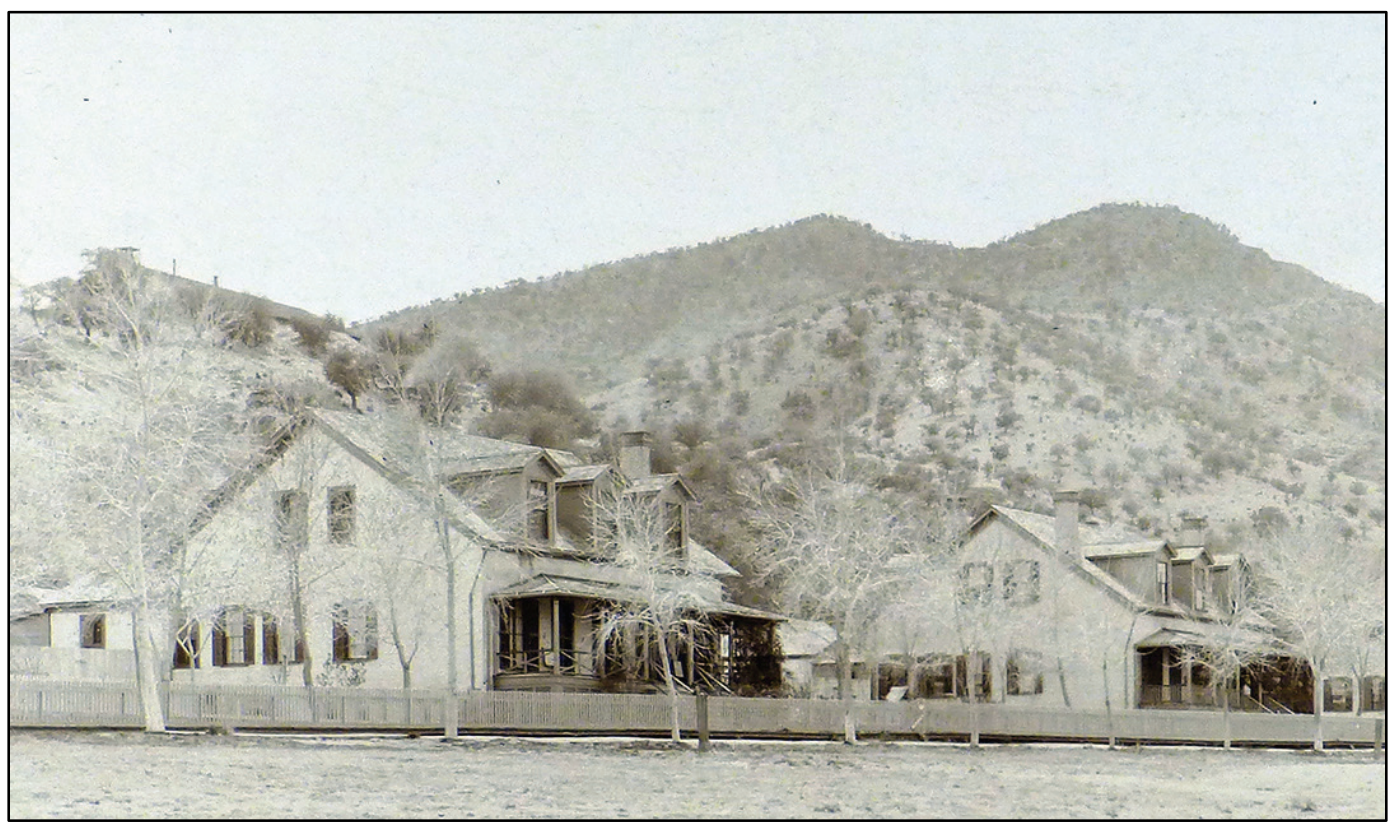

Figure 35. View to the northeast of wood sidewalk and dirt street in front of officers' quarters, c.1900 (Fort Huachuca Museum).

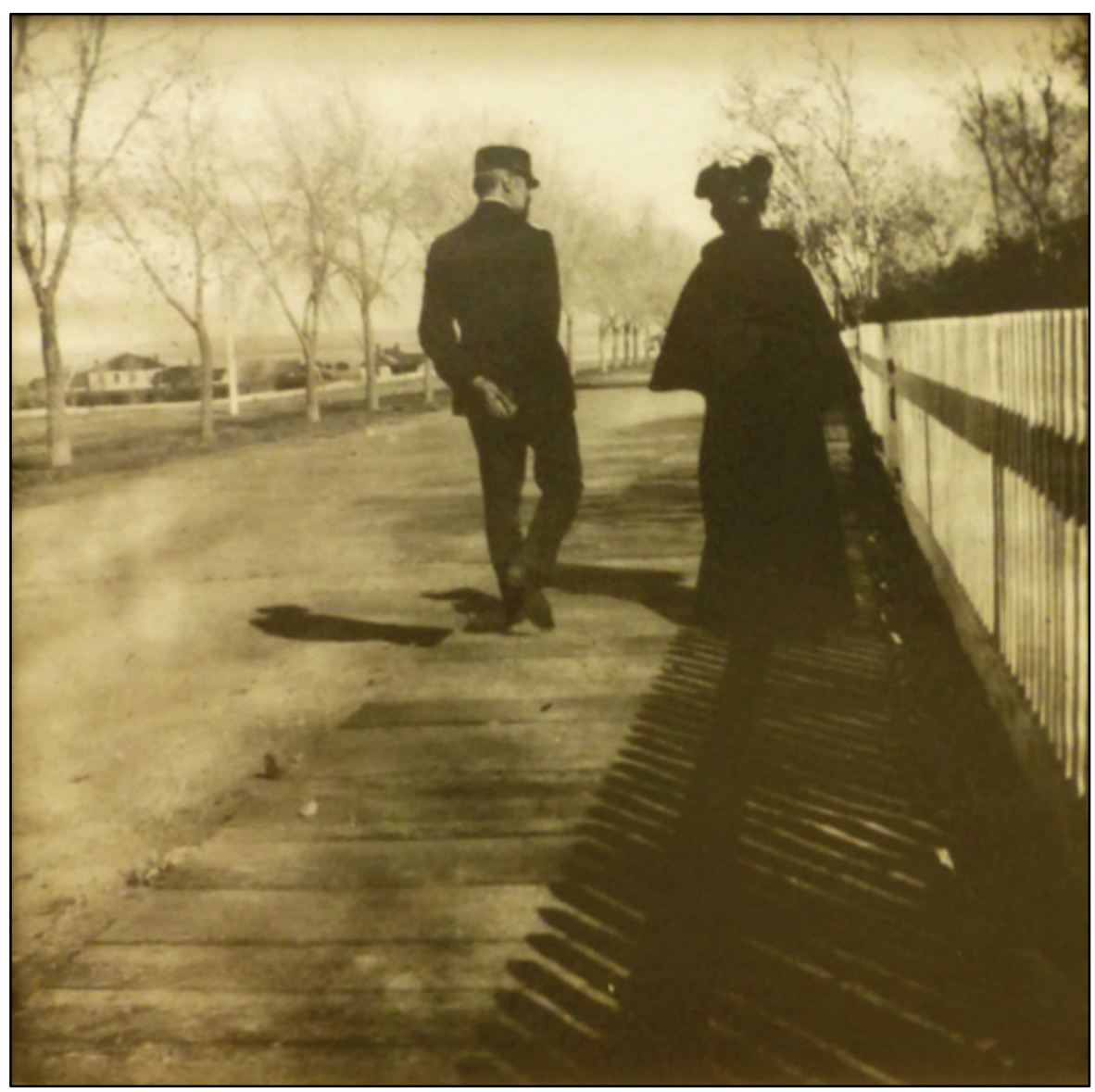


Figure 36. View to the east of front facade of Building 22126 with an enclosed porch, 1936 (NARA College Park, RG 77-394 Box 9).

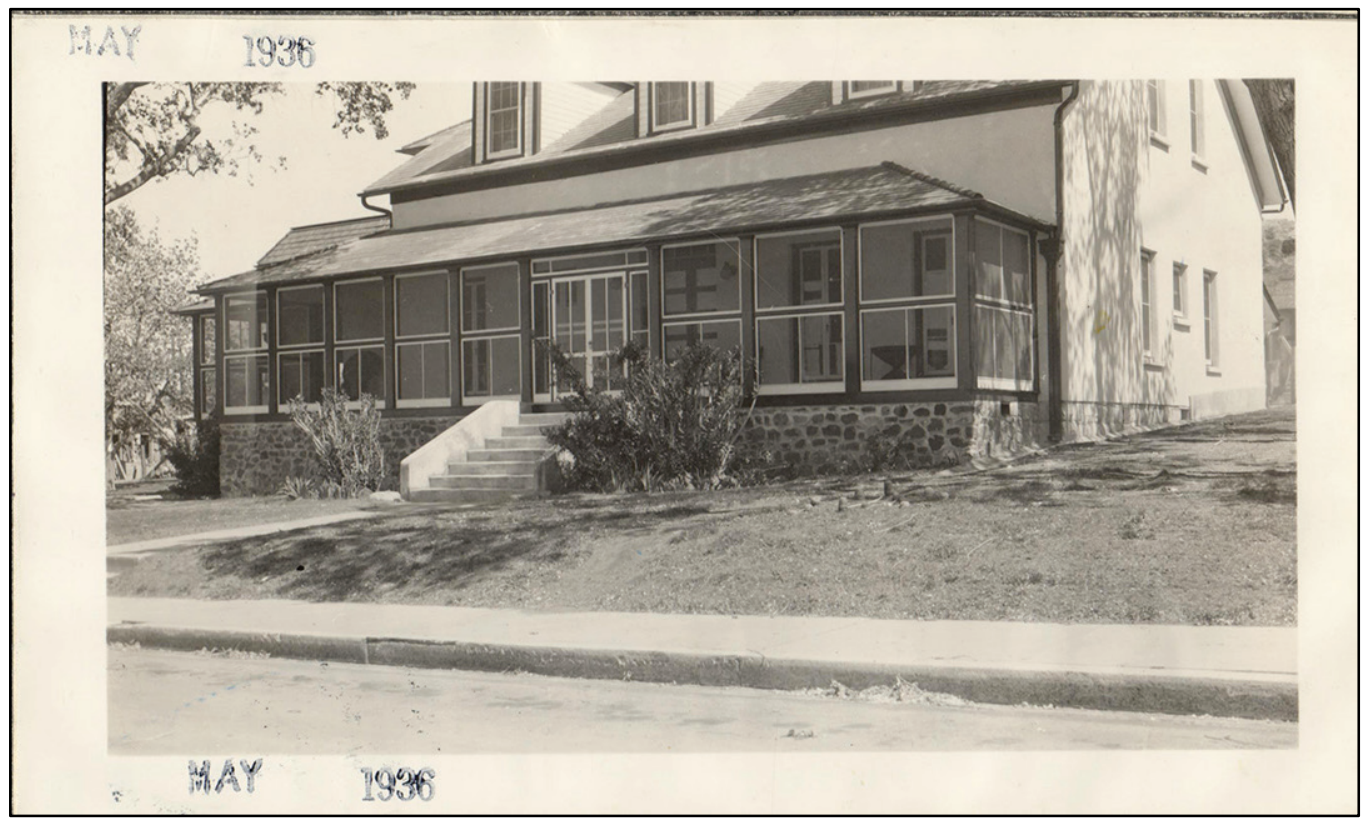

Figure 37. View looking northeast at officers' quarters (22112 and 22114) with screened porches, 1954 (NARA College Park, RG111_SC).

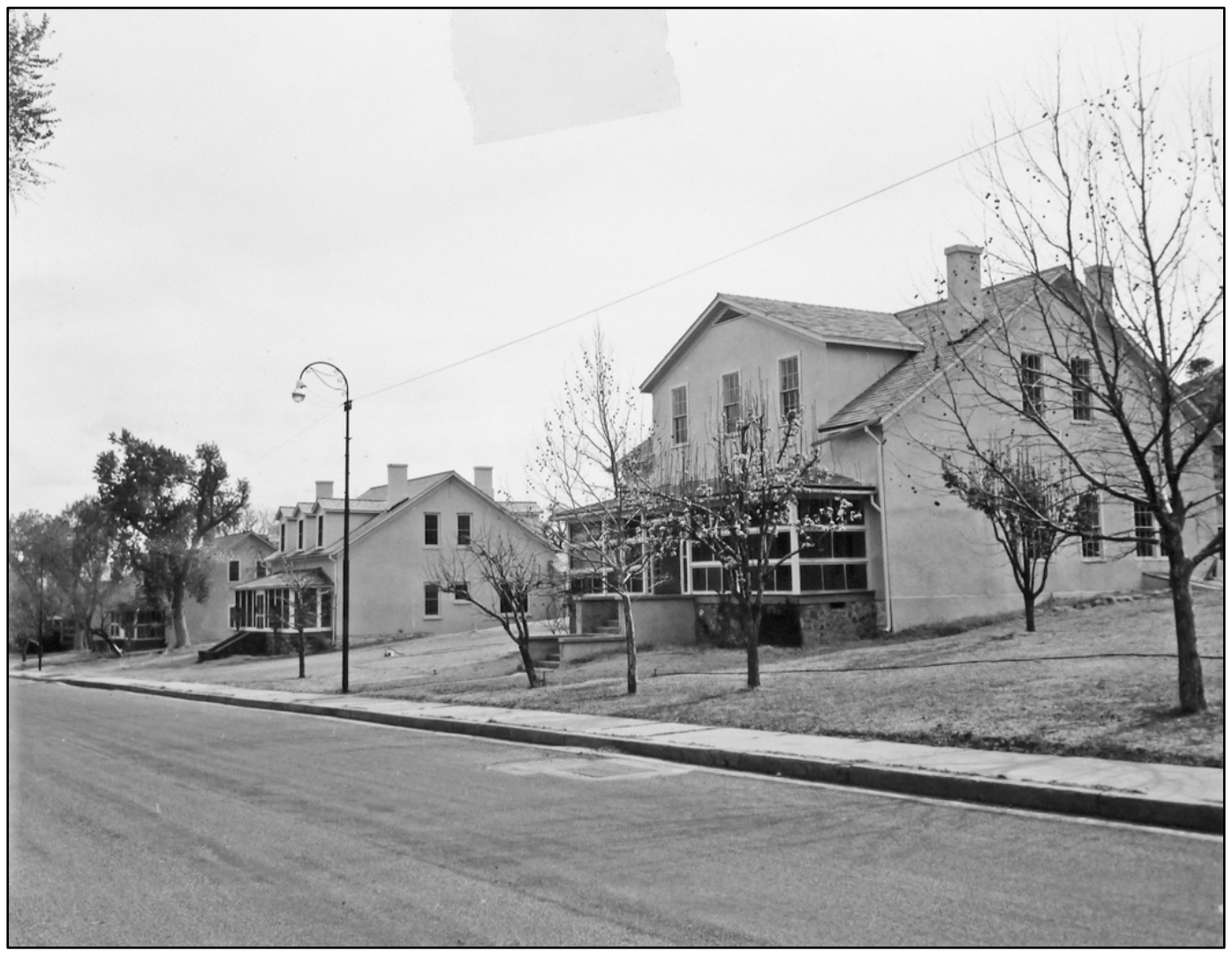


Figure 38. View looking northeast at officers' quarters (22114) with a screened porch, 1954 (NARA College Park, RG111-SC).

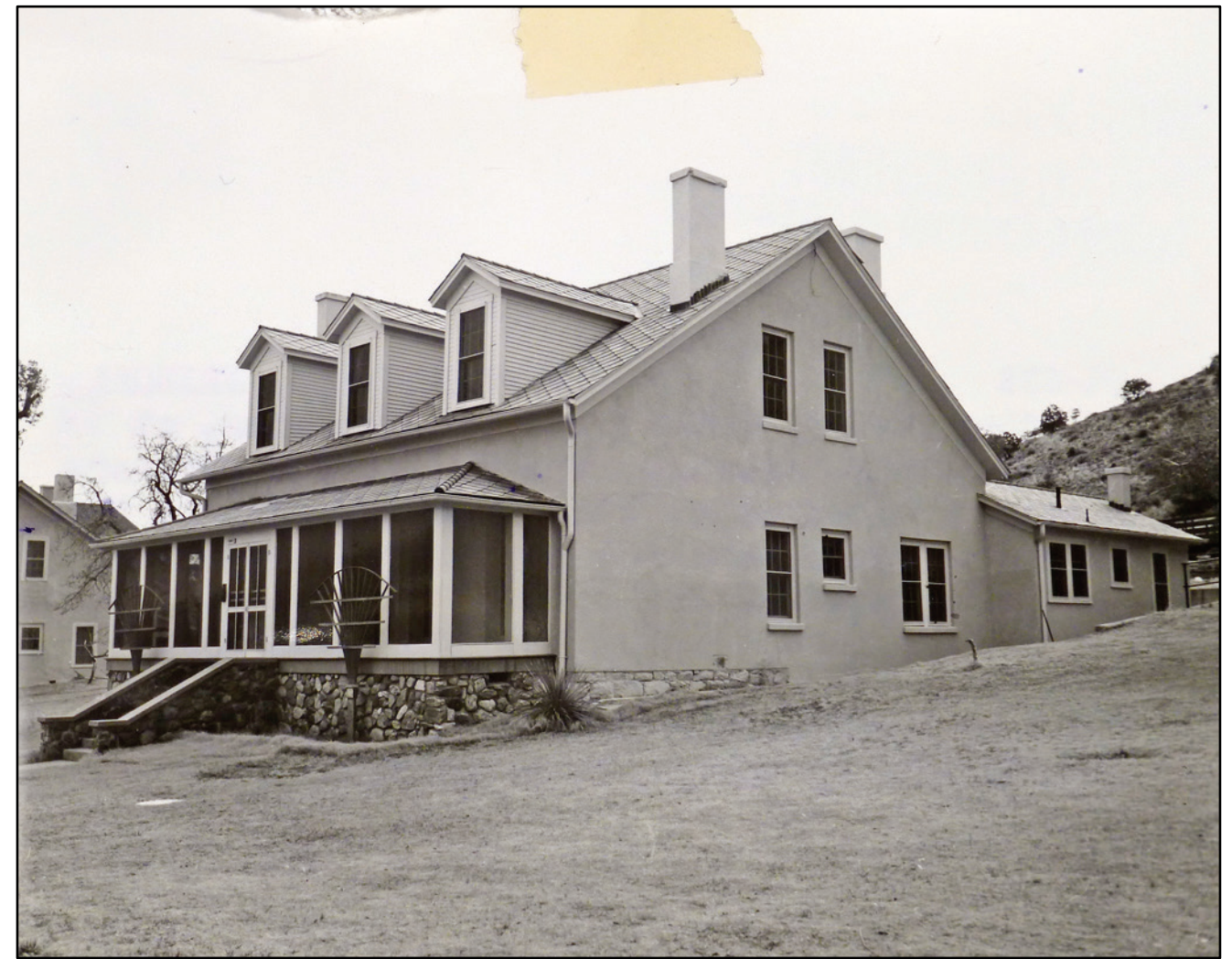

Figure 39. View to the northeast showing lush landscape plantings in front of Quarters 22120 with screened porch, 1975 (Adams, 1975).

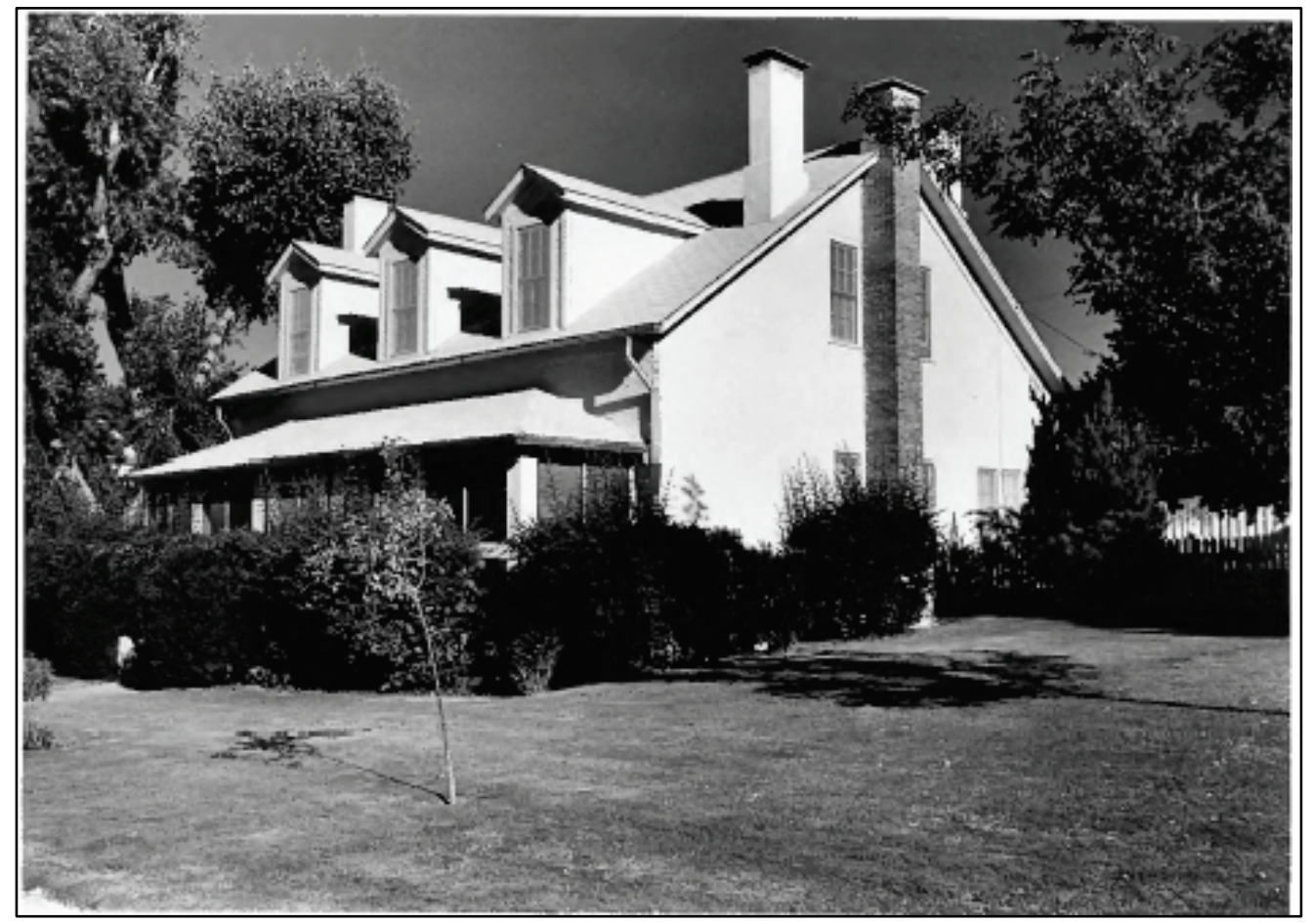




\subsubsection{Current conditions}

The Old Post Officers' Quarters retain a remarkably high degree of integrity to their appearance in the mid-1880s. The dormers in some of the buildings were extensively modified in the mid-1930s, the rear kitchens have been modified and enlarged, and the wood front steps were replaced with concrete during the mid-1930s. The 1880 s wood picket fences are gone, but some are still present on the rear yards. The front foundation plantings vary from quarters to quarters, some just have a few evergreens, and others have ornamental trees flanking the sides of the residences.

Behind the quarters are several other resources including 1930s garages, 1930's servant quarters (on the Old Post-era footprints), and 1920s coal bins that are part of the historic landscape. In addition, there is the officers' pool (22010) and wading pool (22012) located east of Grierson Service Road in the hillside. These resources remain today (Figures 40-60).

Figure 40. Looking northeast down Grierson Avenue at the row of officers' quarters (22112 in front) (ERDC-CERL, 2016).

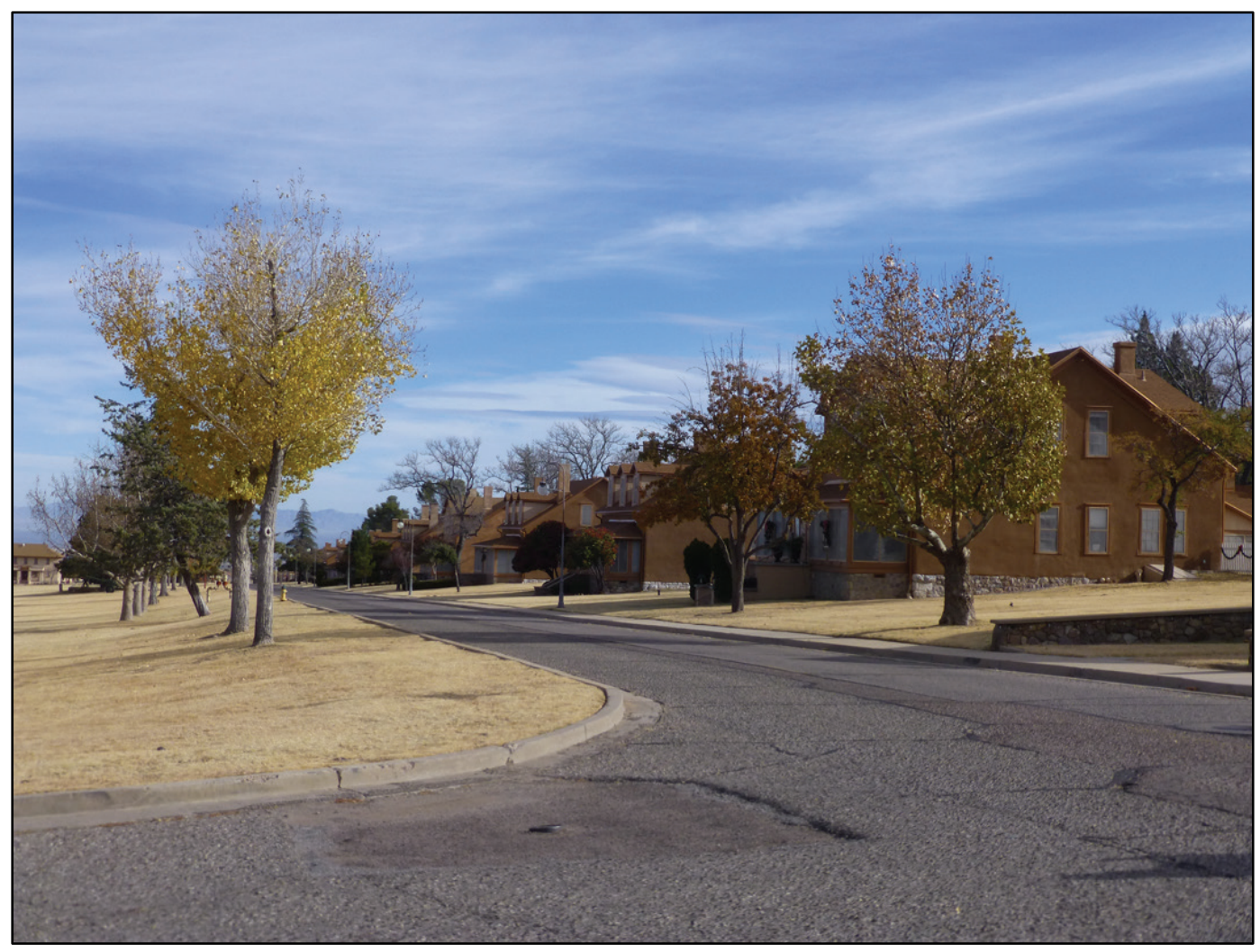


Figure 41. View looking east of Officers' Quarters 22010 from across Brown Field (ERDCCERL, 2016).

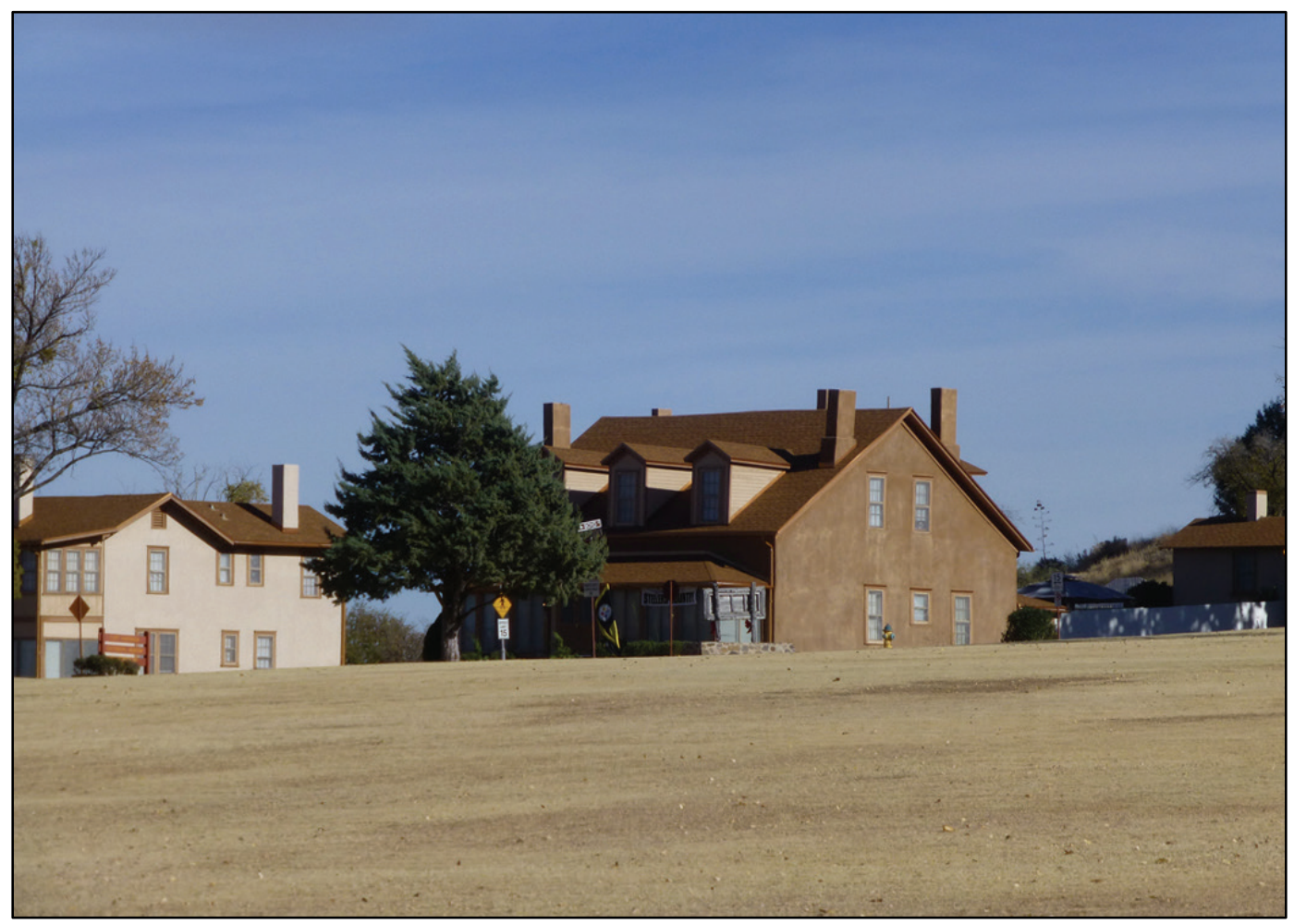

Figure 42. View looking east of Officers' Quarters 22144 with enclosed porch from across Brown Field (ERDC-CERL, 2016).

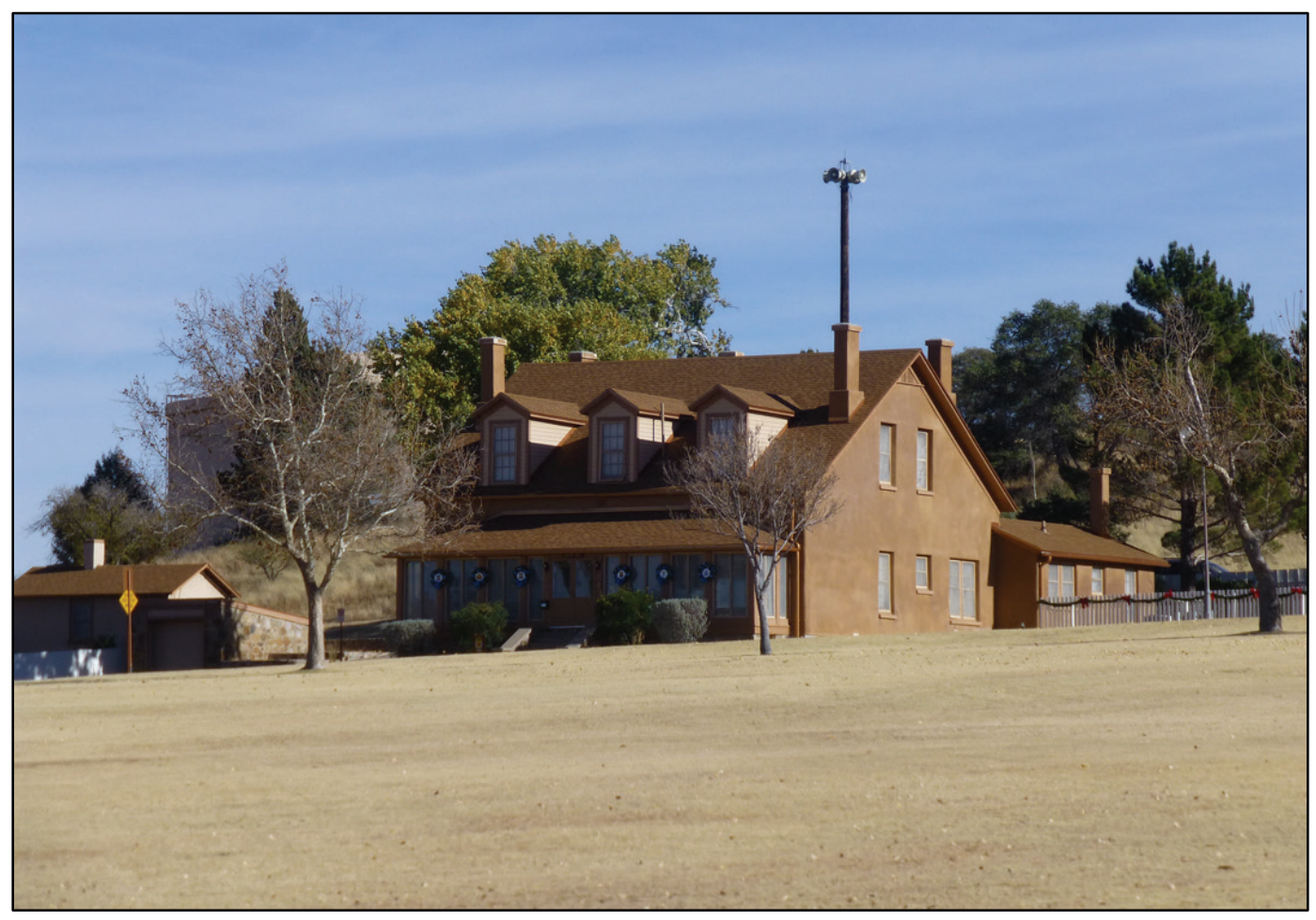


Figure 43. View looking east of Officers' Quarters 22138 with enclosed porch from across parade field (ERDC-CERL, 2016).

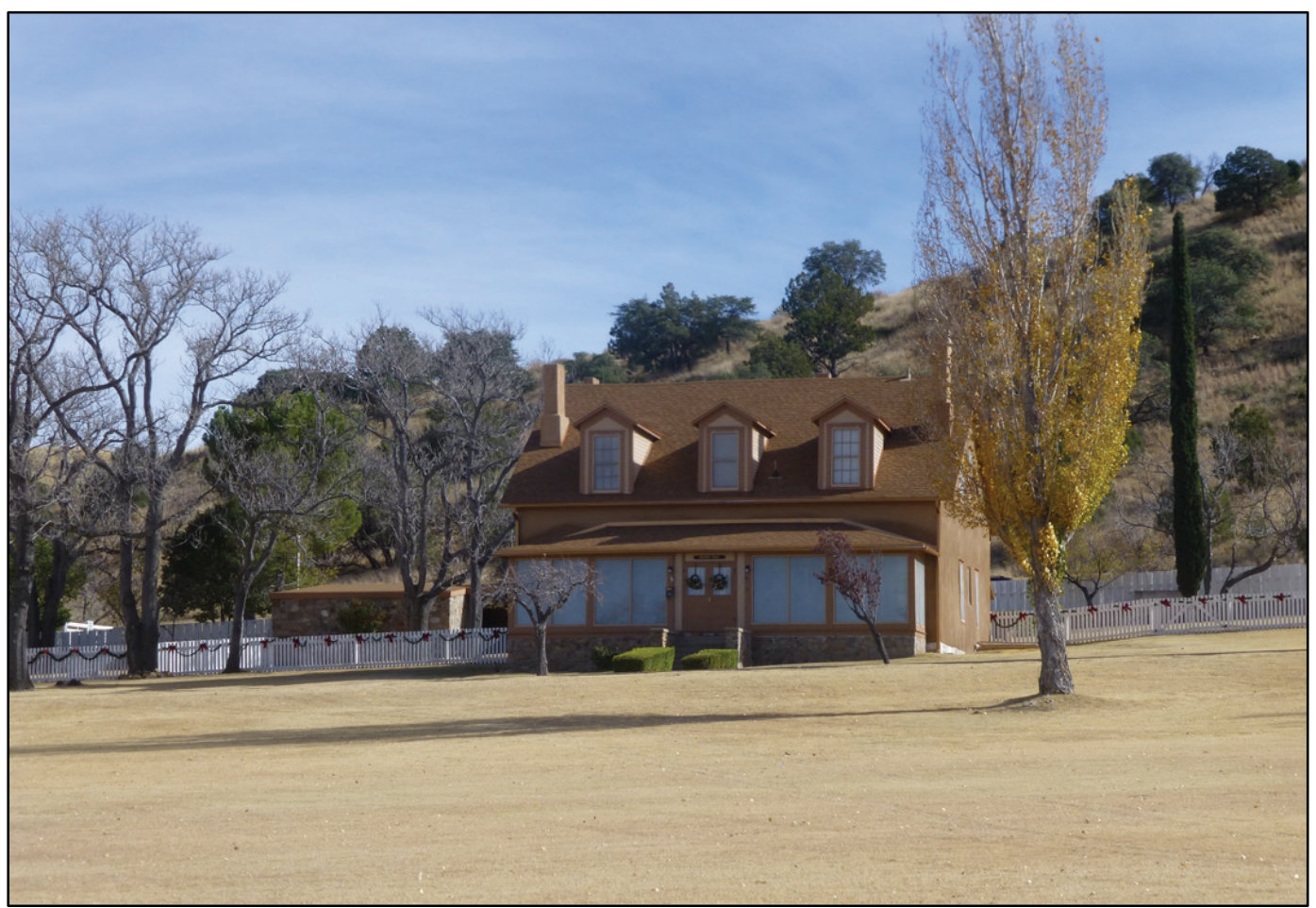

Figure 44. View looking northeast of Officers' Quarters 22116, 22120, and 22126 with enclosed porches (ERDC-CERL, 2016).

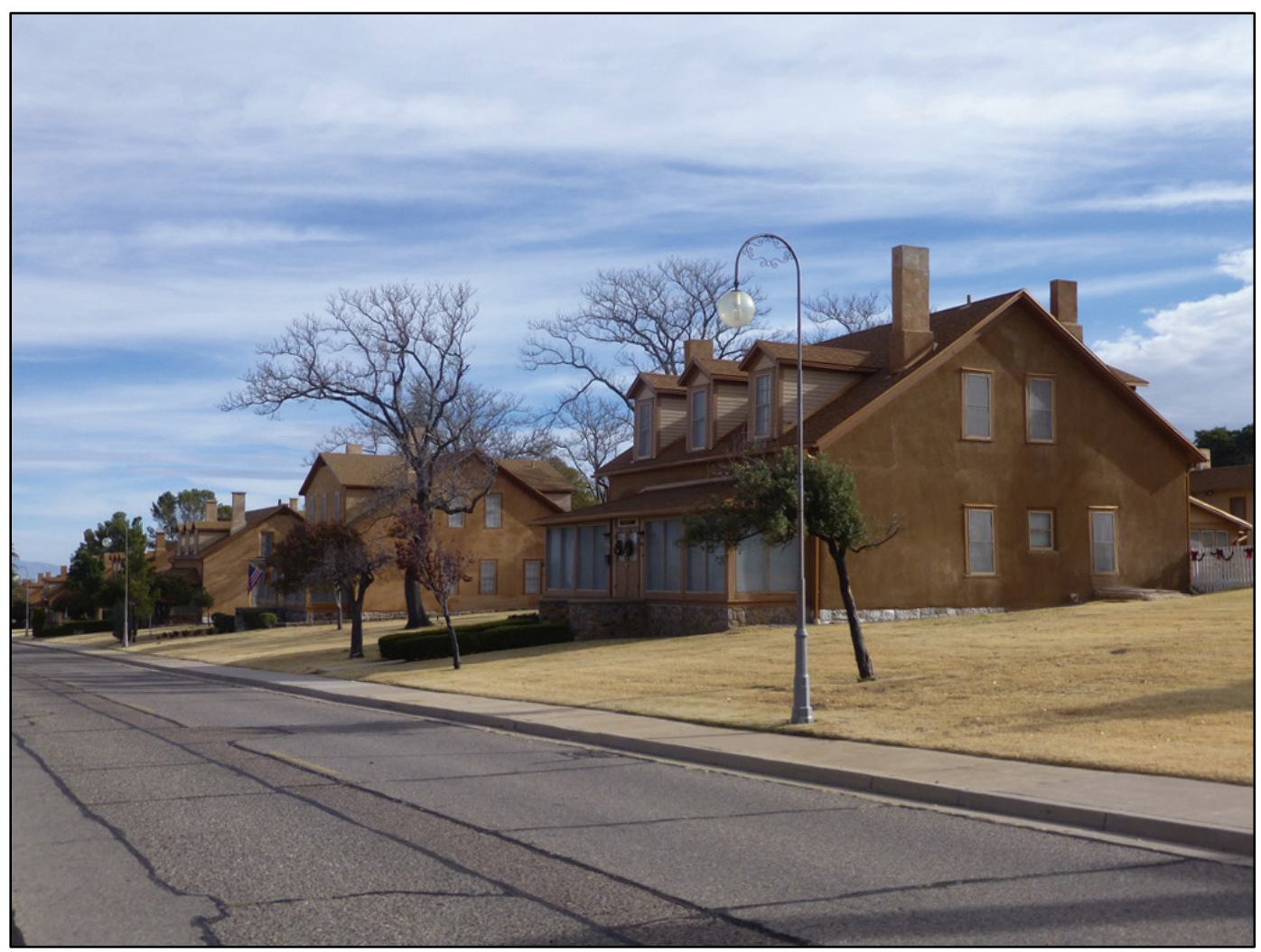


Figure 45. View looking east at Officers' Quarters 22114 with enclosed porch (ERDC-CERL, 2016).

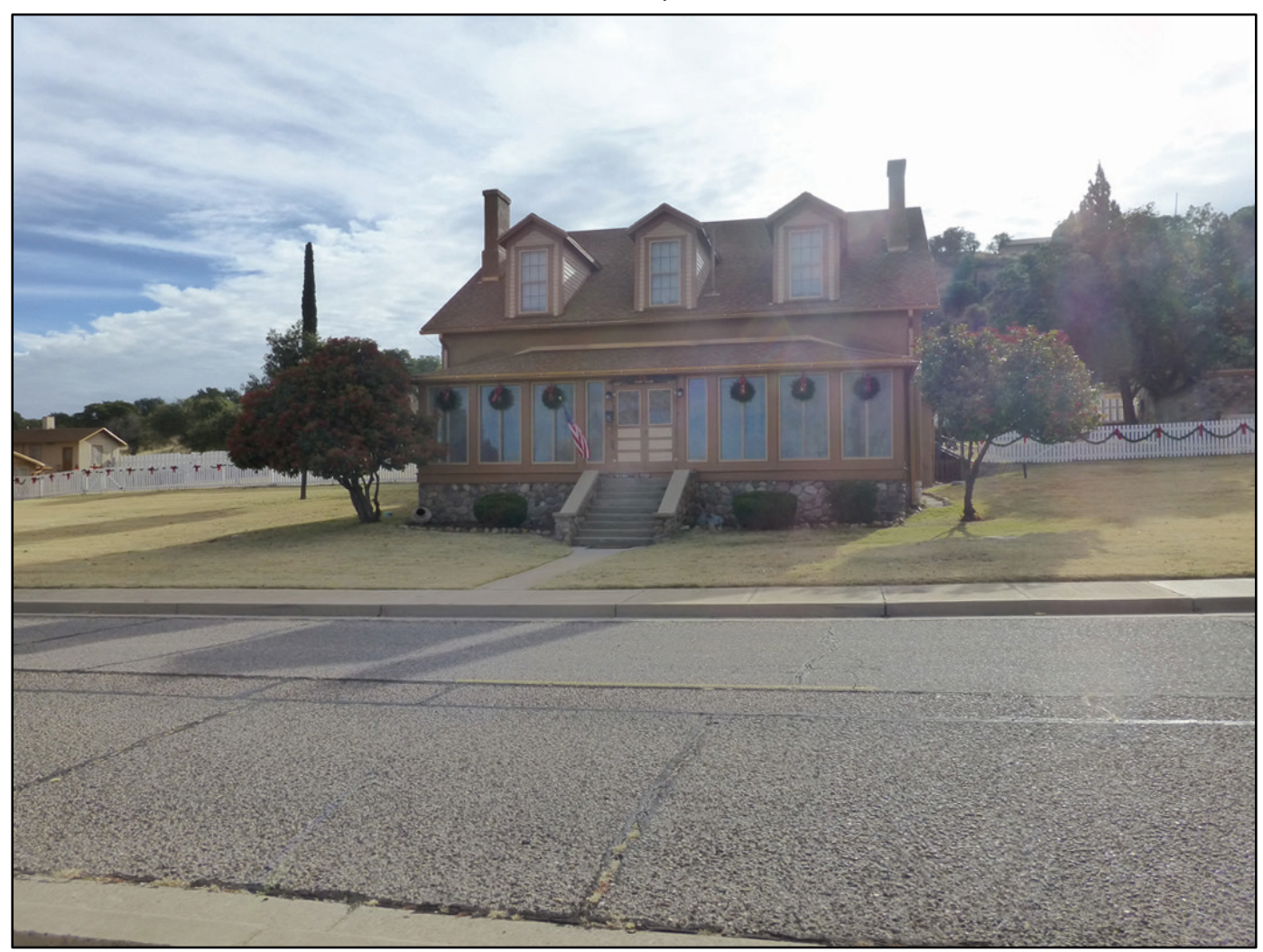

Figure 46. View looking east at Servant's Quarters 22113 with fence in front and fence behind (ERDC-CERL, 2016).

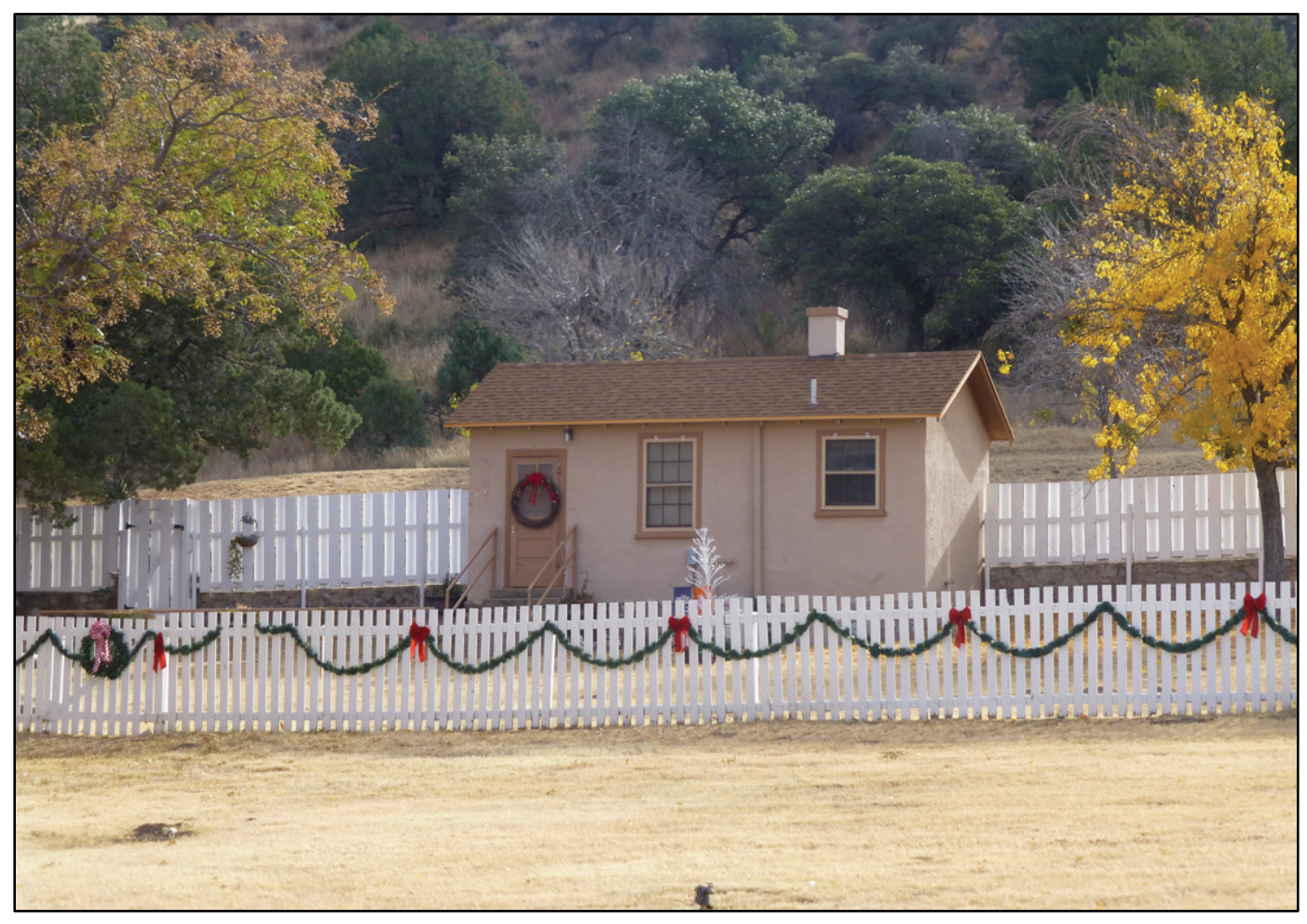


Figure 47. Looking east at Hazen House (22104) (ERDC-CERL, 2016).

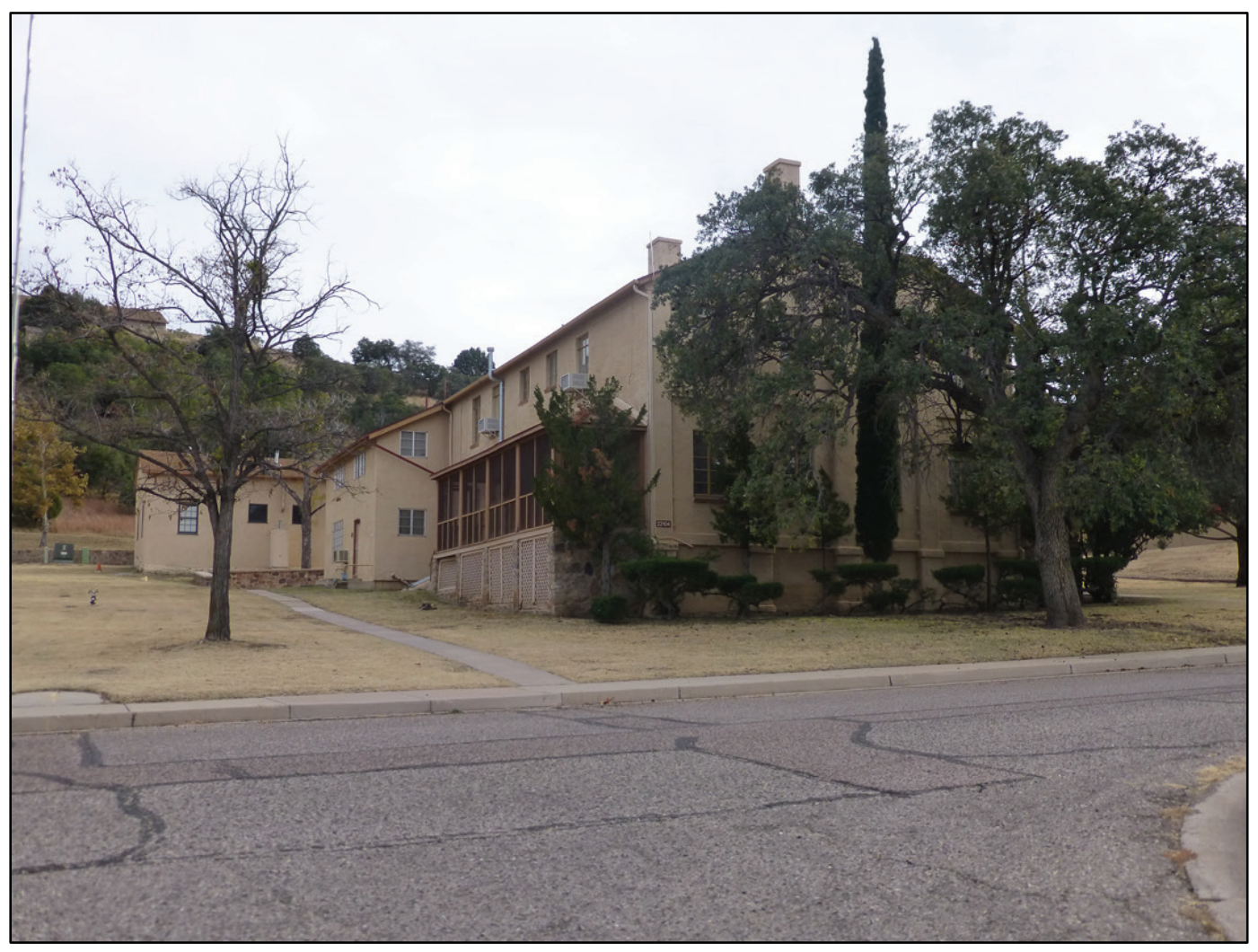

Figure 48. Looking east at Officers' Quarters 22108 (ERDC-CERL, 2016).

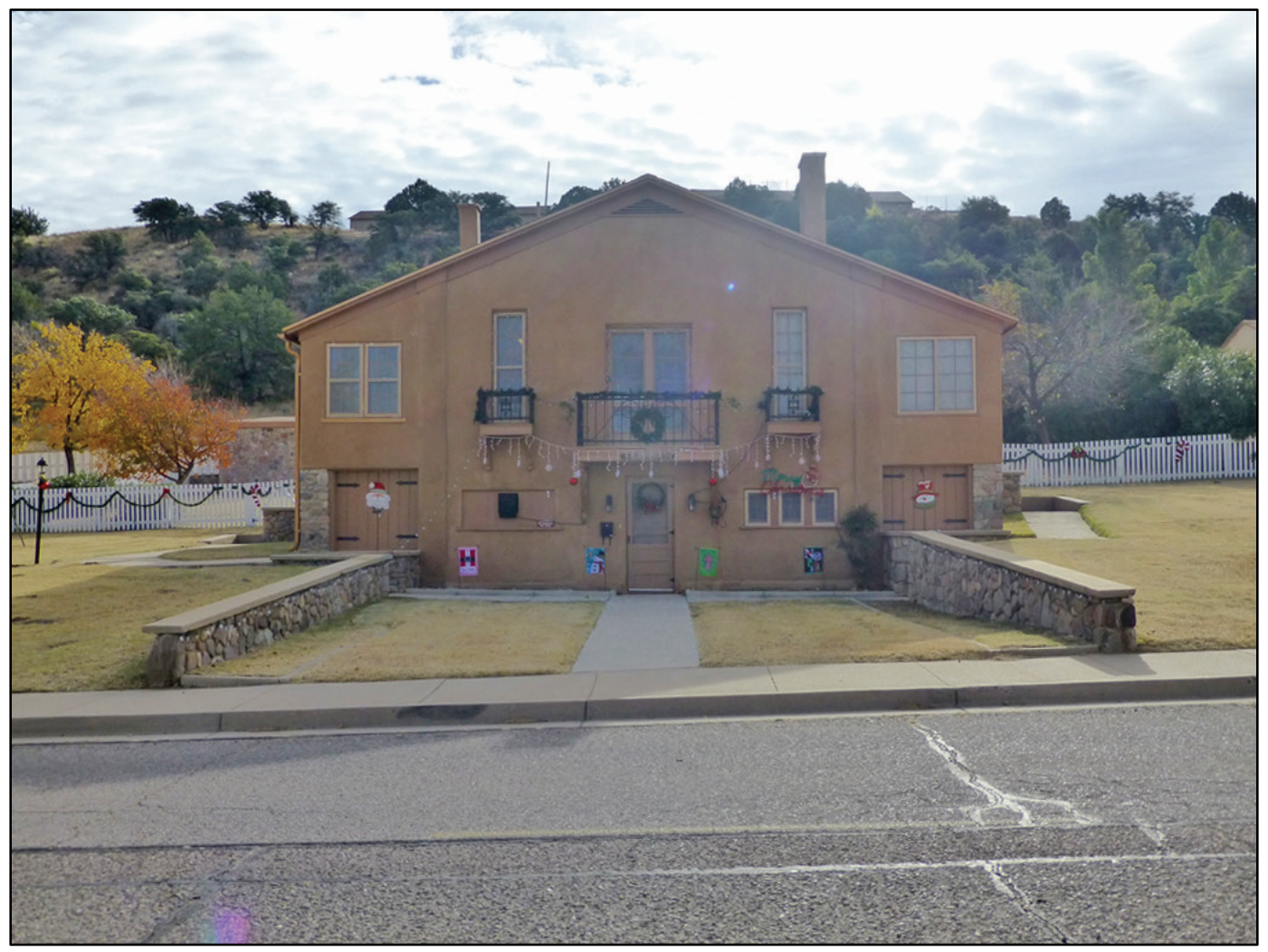


Figure 49. Looking north down Grierson Avenue (ERDC-CERL, 2016).

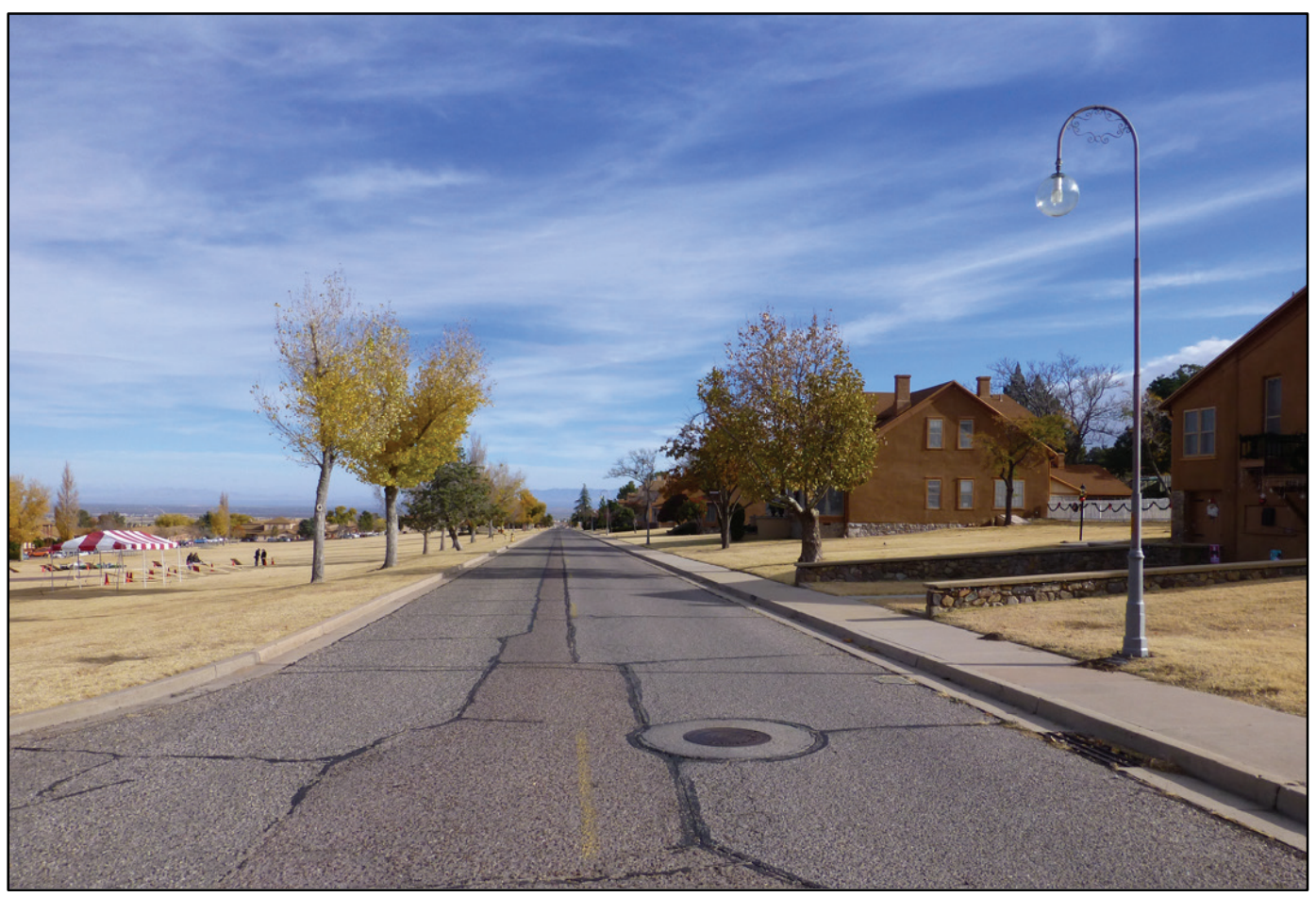

Figure 50. Looking south along Grierson Avenue from Boyd Avenue (ERDC-CERL, 2016).

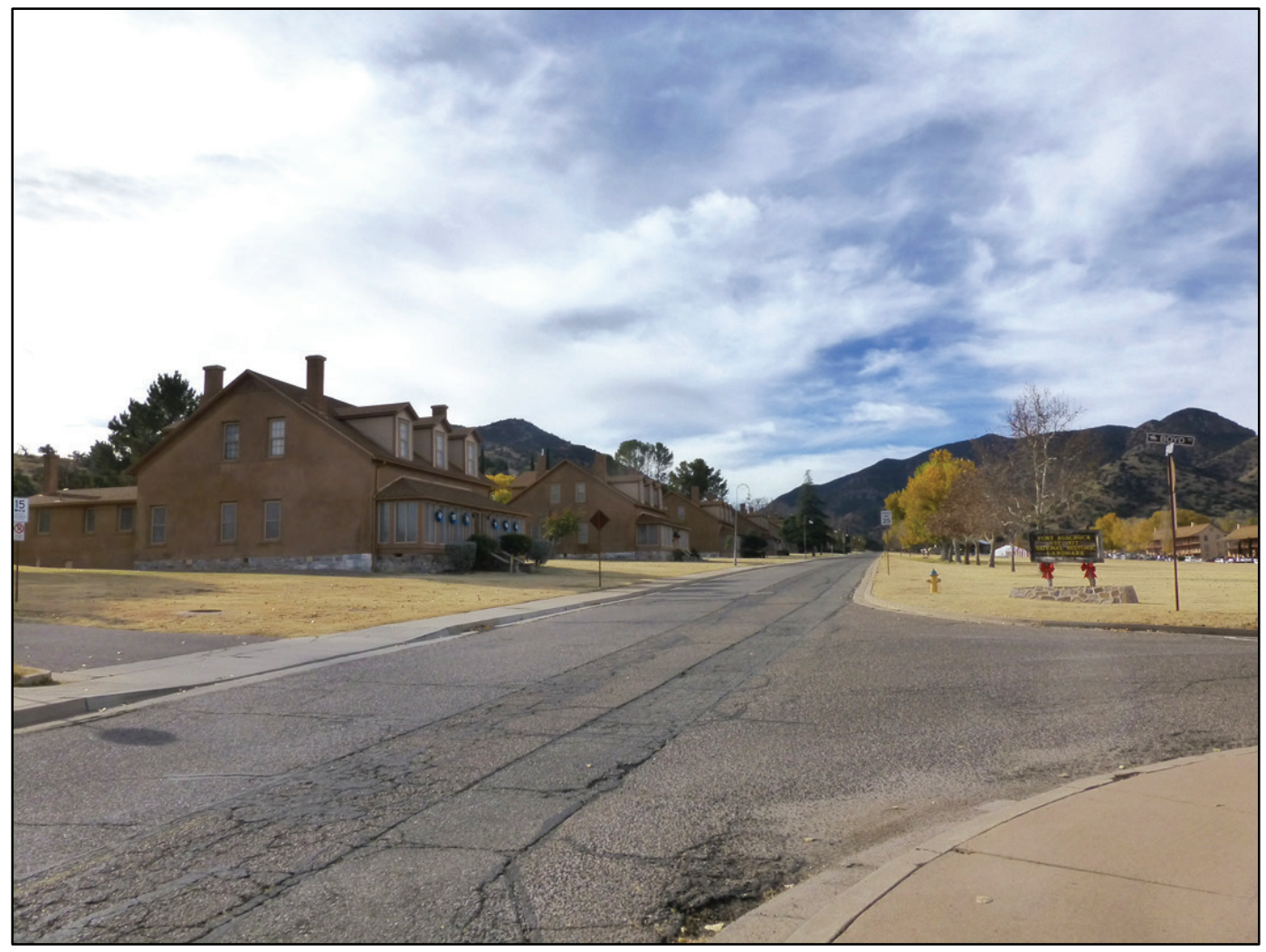


Figure 51. Looking south on Grierson Service Road behind the officers' quarters showing WPA ditch (ERDC-CERL, 2016).

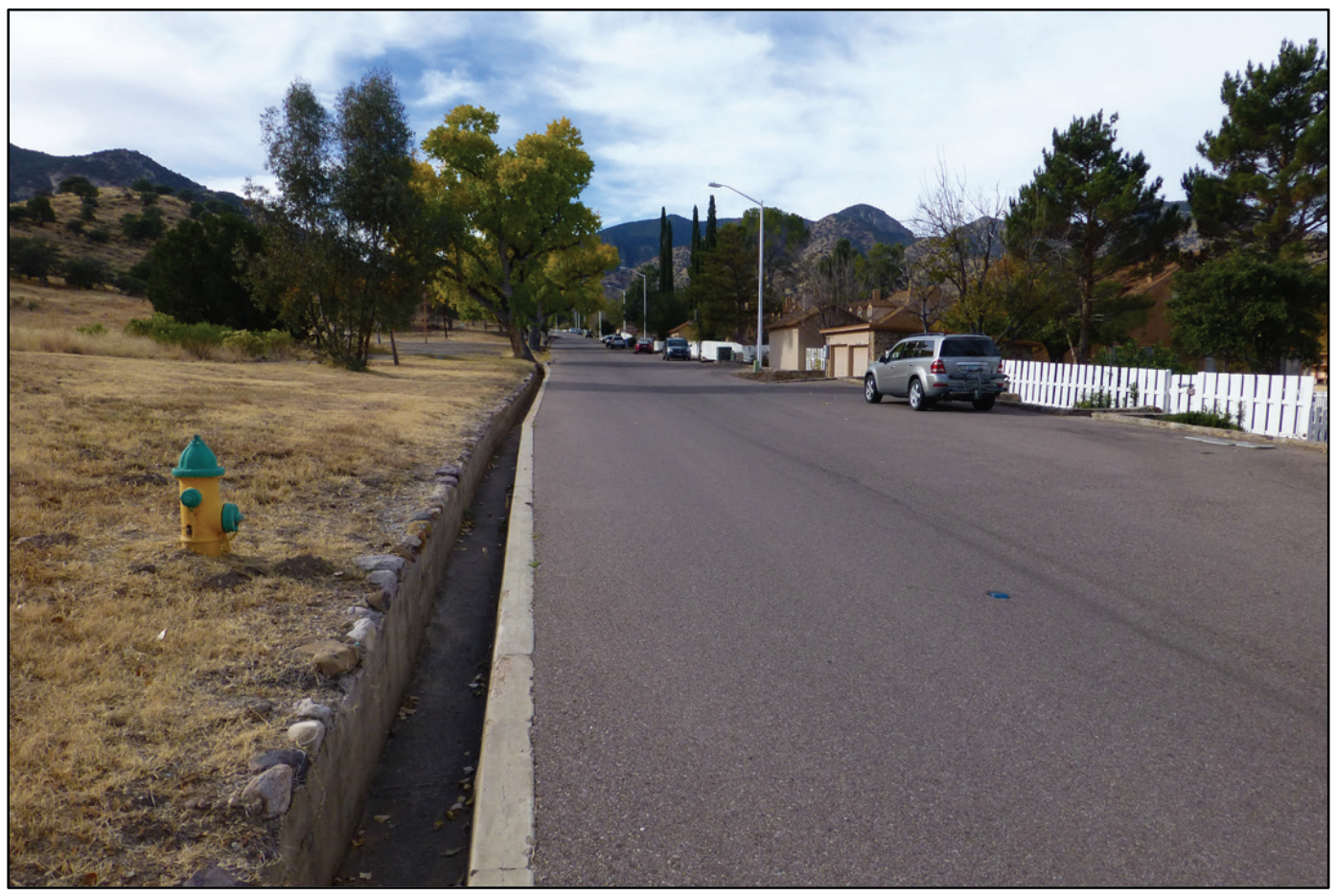

Figure 52. Looking south on Grierson Service Road behind the officers' quarters showing WPA-era walls and drainage (ERDC-CERL, 2016).

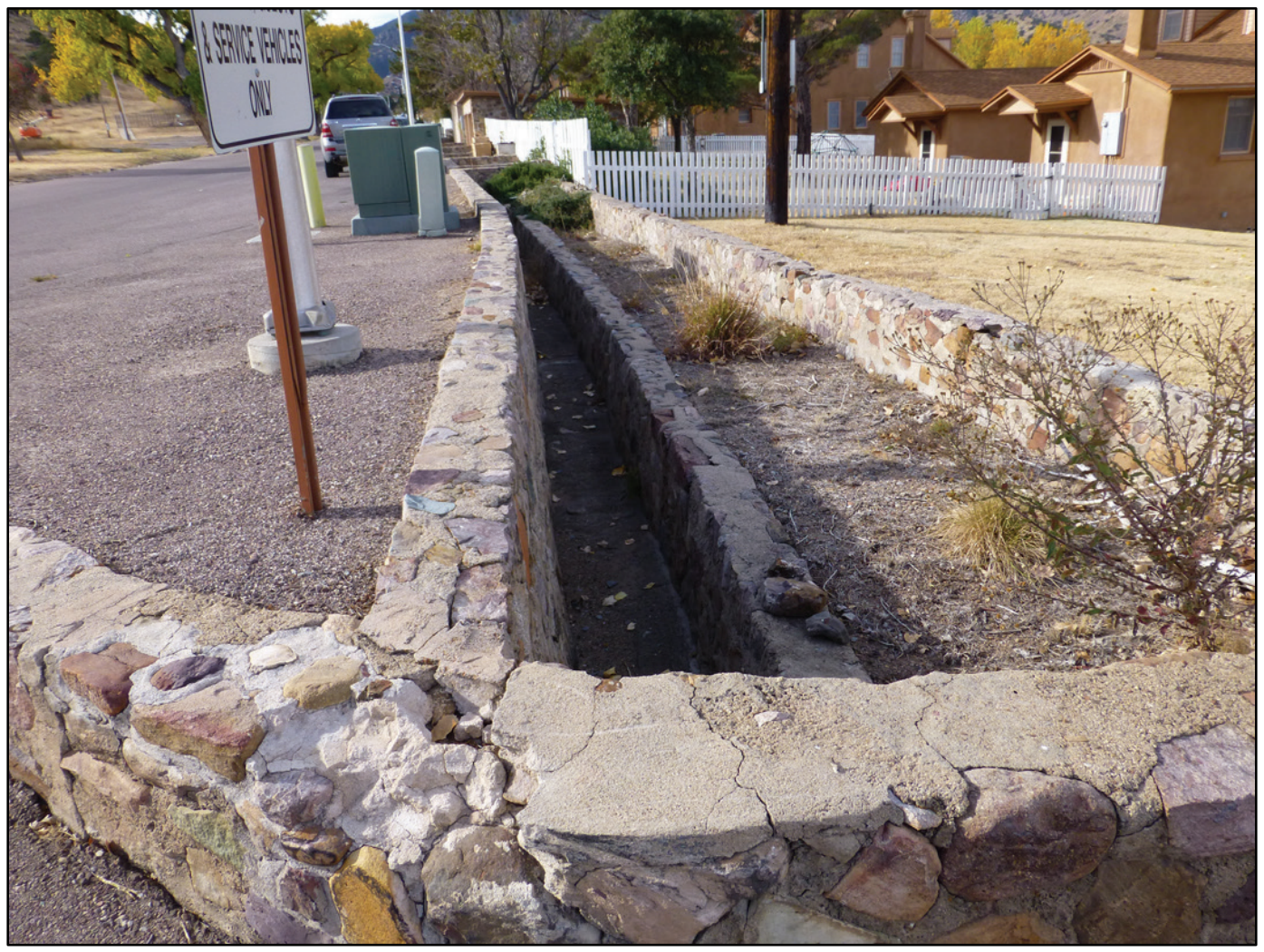


Figure 53. Looking west at a WPA-era garage (22143) behind officers' quarters (22144)

(ERDC-CERL, 2016).

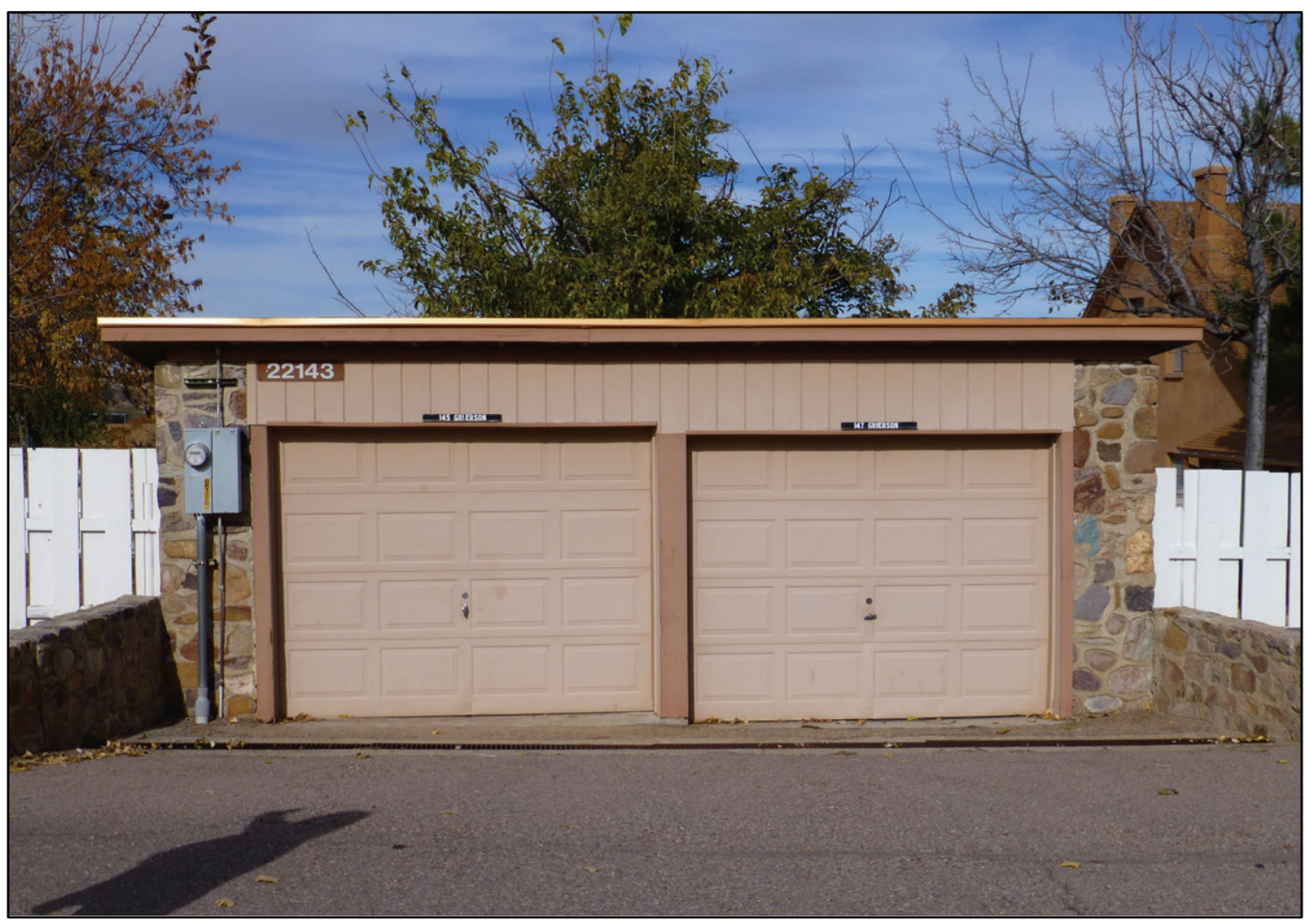

Figure 54. Looking west at former servants' quarters (22142) behind officers' quarters (22140) (ERDC-CERL, 2016).

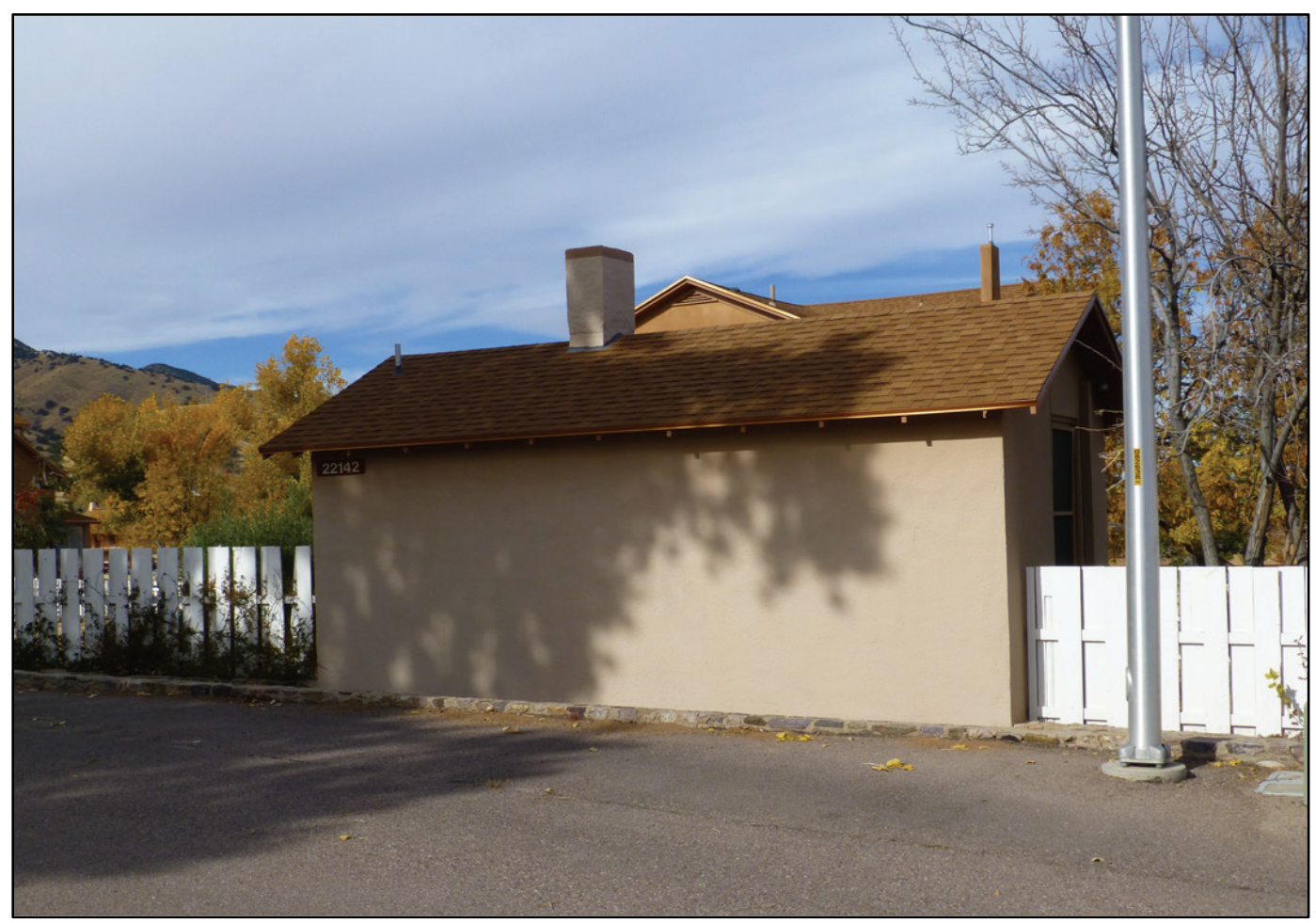


Figure 55. Looking southeast at Grierson Pool (22010) from entrance stairs (ERDC-CERL, 2016).

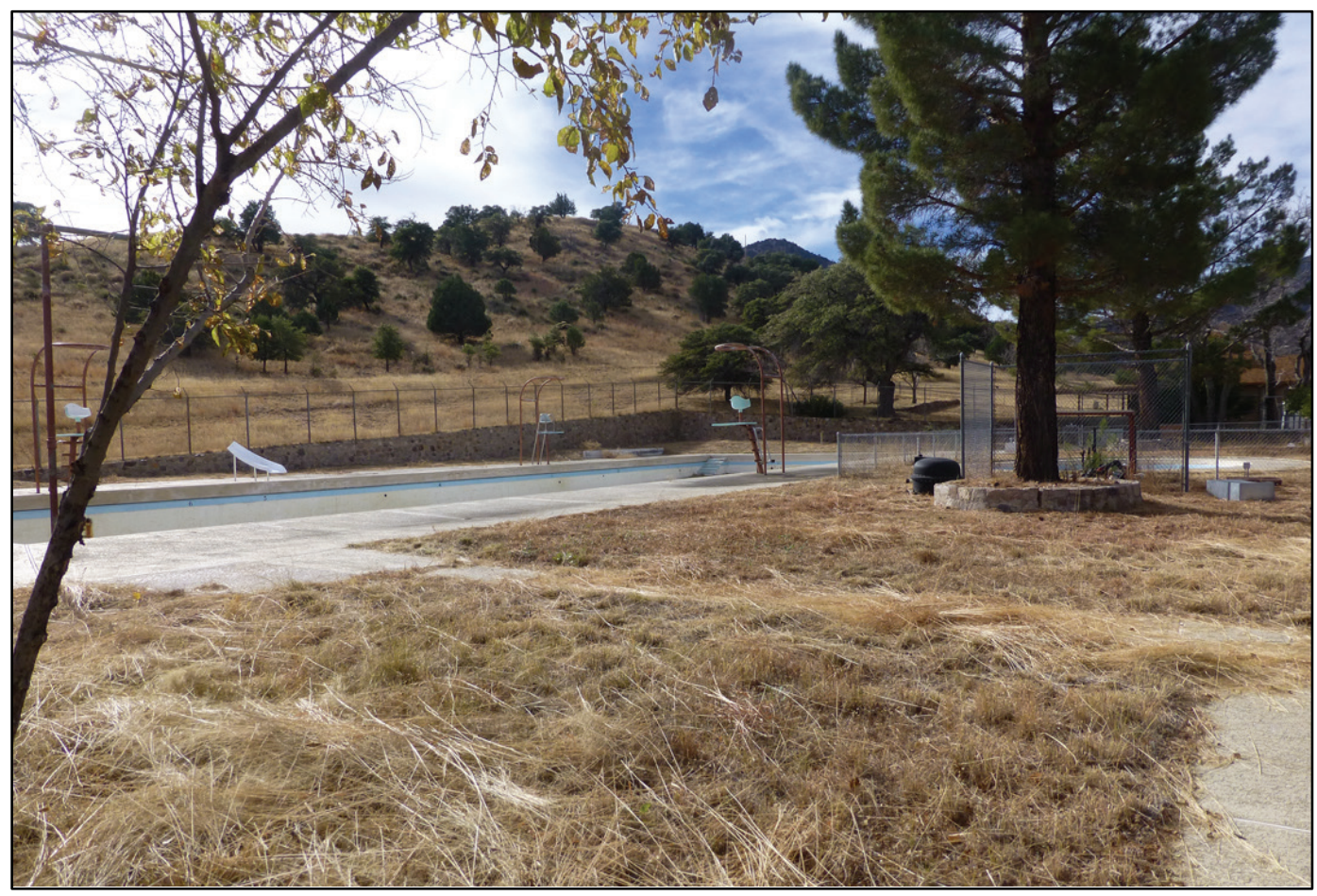

Figure 56. Looking southeast at Grierson Pool (22010) retaining wall along Grierson Service Road (ERDC-CERL, 2016).

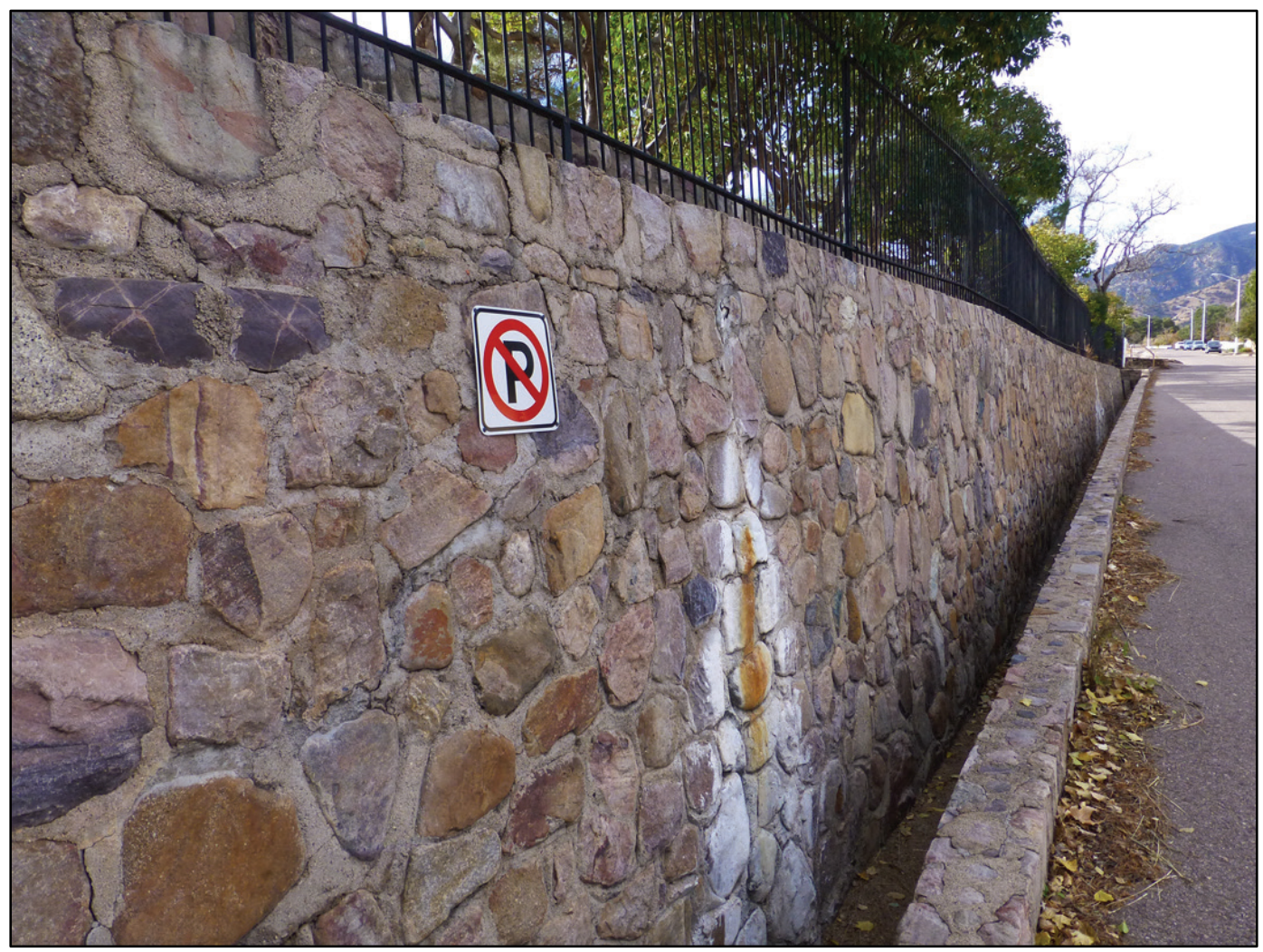


Figure 57. Looking north at modern replacement stone-covered drainage ditch and garage (22007) along Grierson Service Road (ERDC-CERL, 2016).

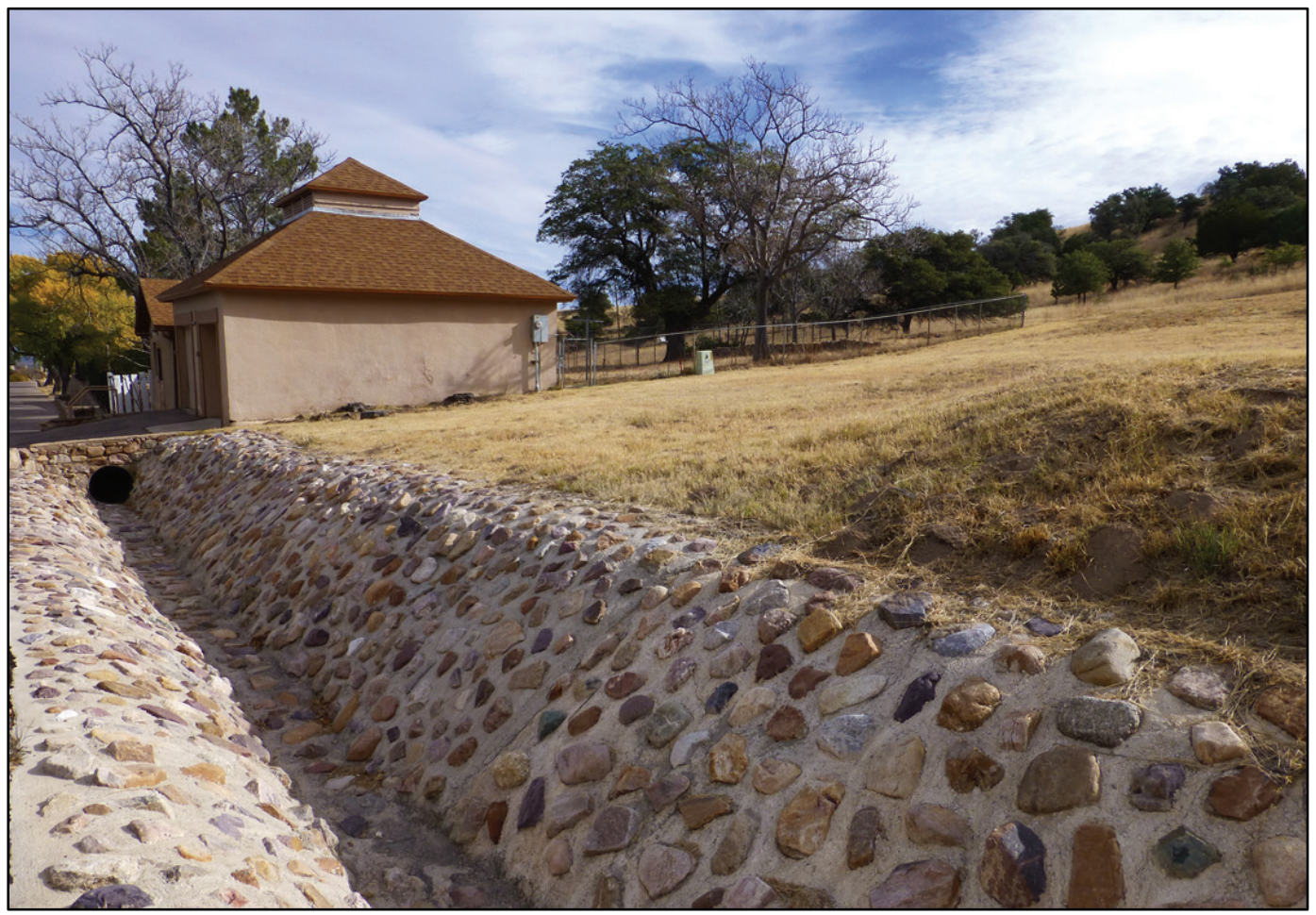

Figure 58. Looking south at modern stone-covered drainage ditch and carport (22013) along Grierson Service Road (ERDC-CERL, 2016).

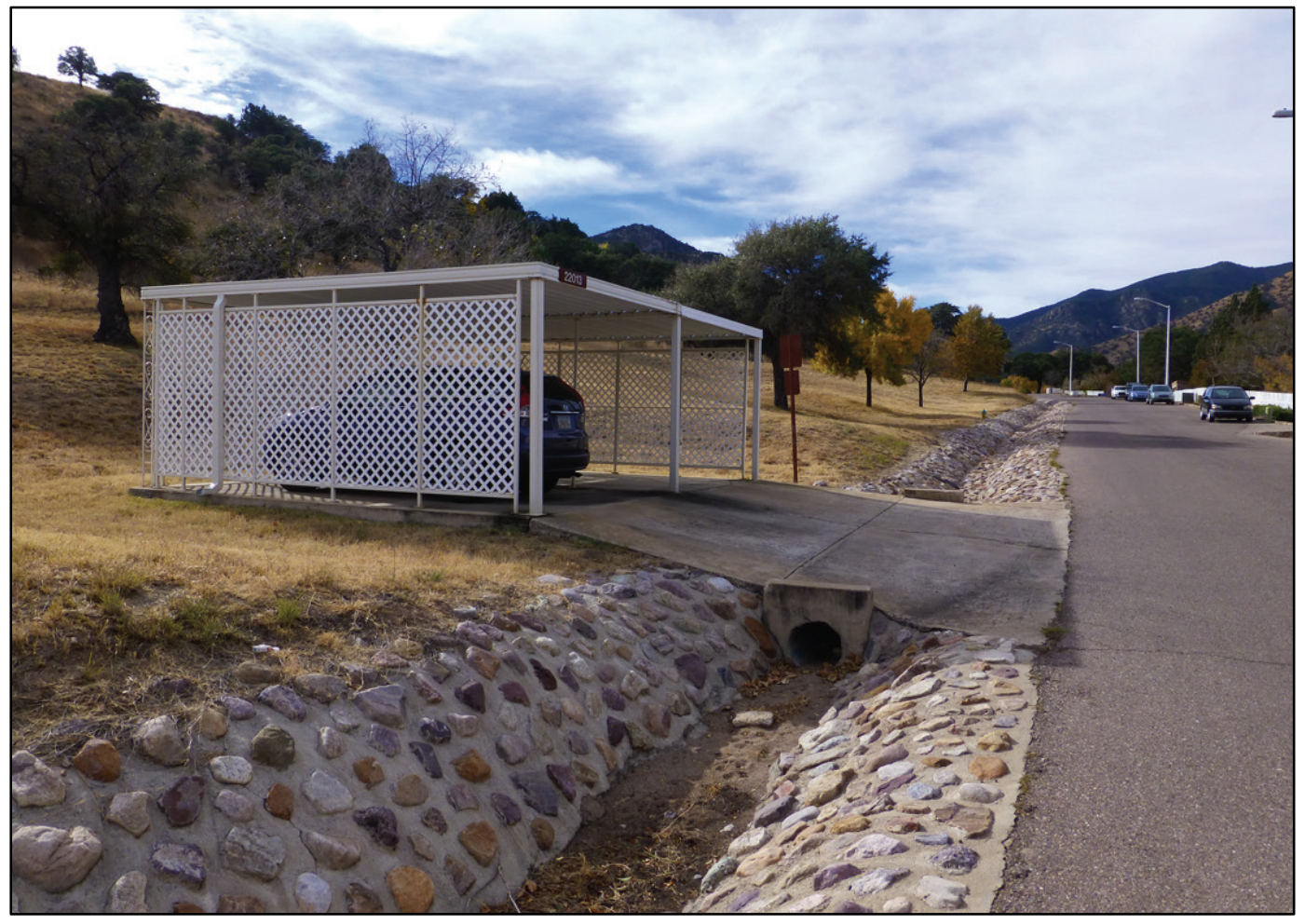


Figure 59. Looking west at rear of family quarters (22104 and 22102) (ERDC-CERL, 2016).

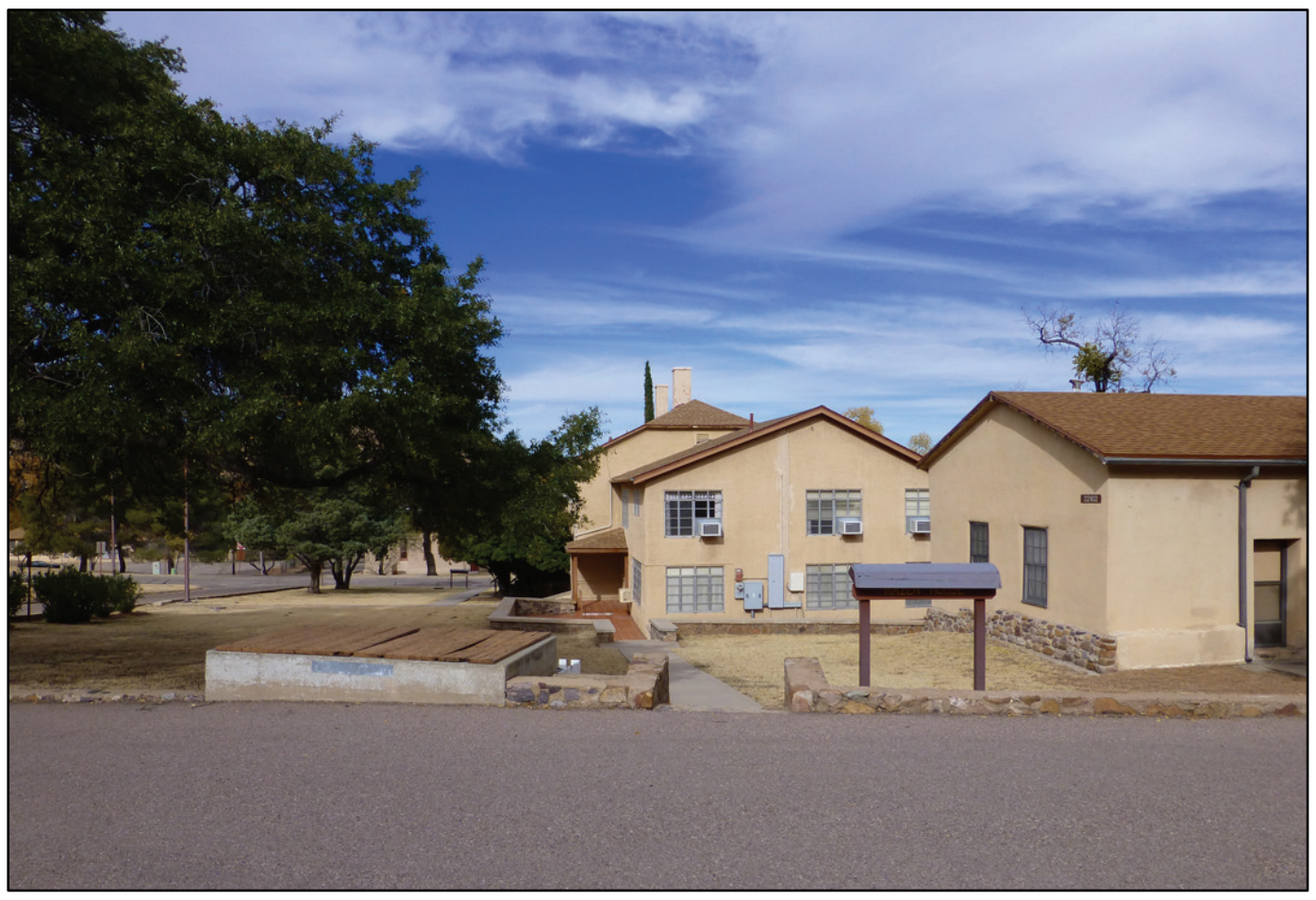

Figure 60. View looking east of reservoir (22020) behind officers' quarters (42010) (ERDCCERL, 2016).

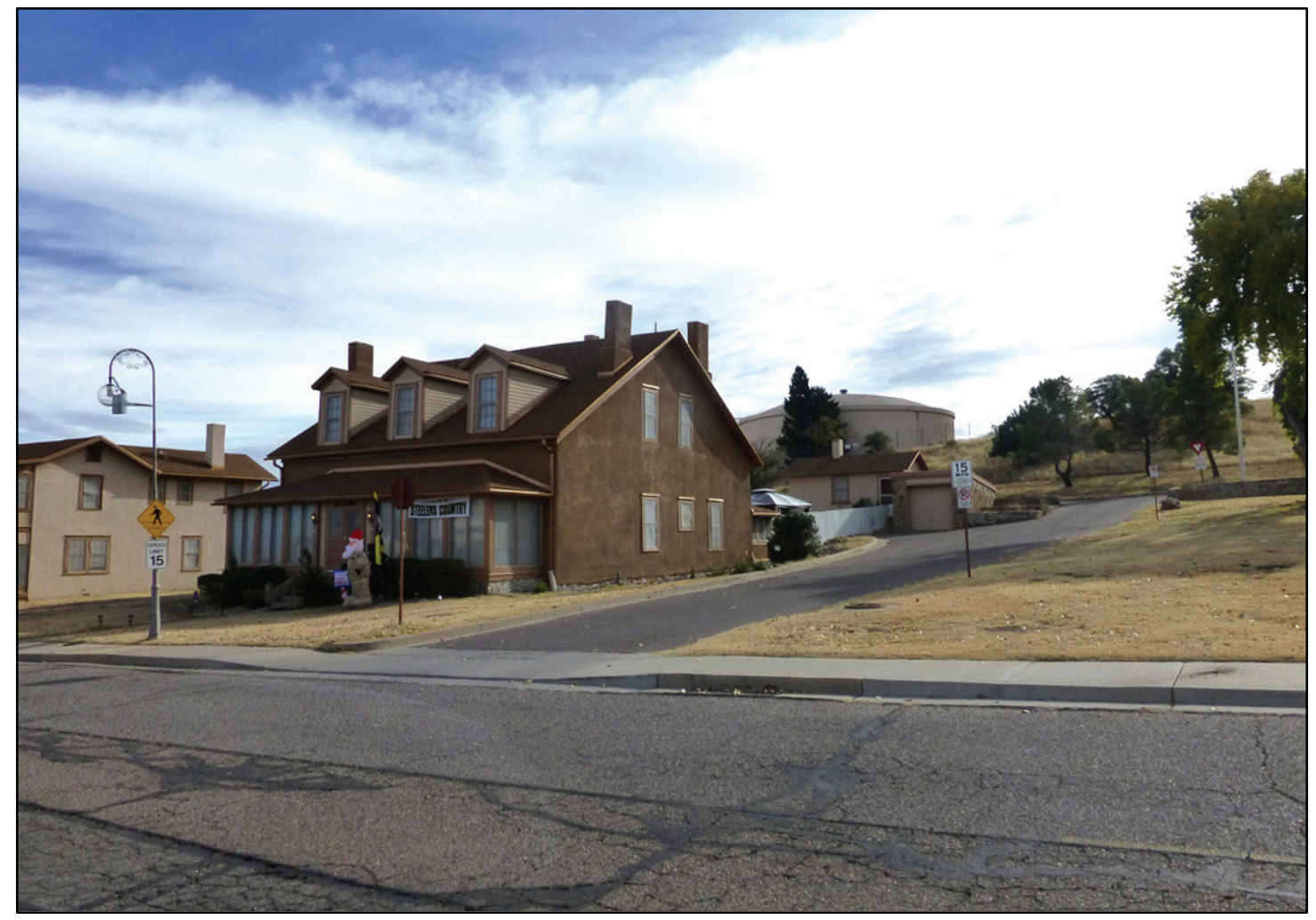




\subsubsection{Significance and integrity}

These quarters and their associated support buildings located along Brown Field have high significance as some of the first permanent buildings built as part of the original frontier post. While there have been a few architectural modifications to the dormers and while the front porches were enclosed in the mid-1930s, these changes do not significantly impact the integrity of the quarters. They retain location, association, setting, design, feeling, materials and workmanship.

\subsubsection{Character-defining features}

Character-defining features include:

- Layout and location along the southeast side of Brown Field

- Consistent architecture and setbacks

- Associated garages and servants' quarters

- Associated coal bins

- Foundation plantings around quarters and specimen trees in yard

- WPA-era ditches, culverts and retaining walls

- Views along Grierson Avenue

\subsection{Old Post Barracks}

The Old Post Barracks (Buildings 22208, 22214, 22216, and 22320) are located across Brown Field from Officers' Row (Figure 61). Four latrines (22210, 22212, 22218, and 22322) are located northwest of the barracks. Also in this row of buildings along the northwest side of Brown Field are the post bakery (22324), the post office/school (22326), guardhouse (22328), ordnance warehouse (22332), quartermaster storehouse (22330) and fire house (22336) (Table 9). 
Figure 61. Old Post Barracks landscape area map (ERDC-CERL).

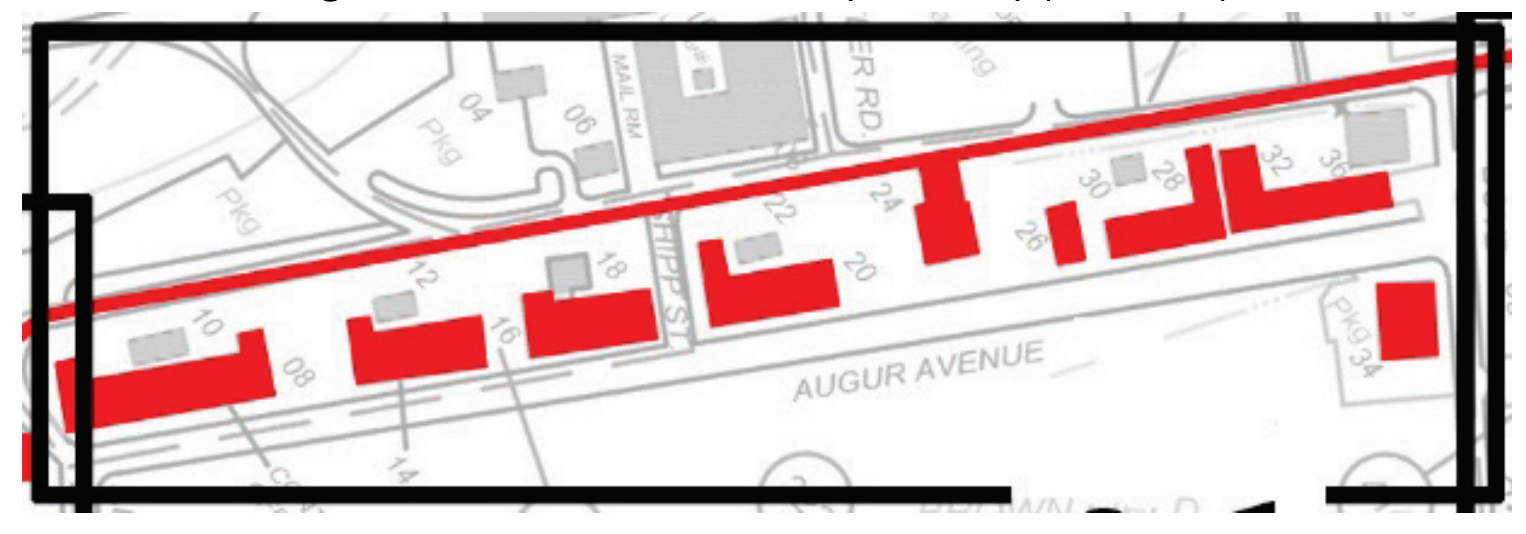

Table 9. List of buildings within the Old Post Barracks landscape area.

\begin{tabular}{|c|c|l|l|c|}
\hline Building Number & Year Built & \multicolumn{1}{|c|}{ Original Use } & \multicolumn{1}{|c|}{ Current Use } & Historic Status \\
\hline 22208 & 1882 & Barracks & Administration & NHLC \\
\hline 22210 & 1916 & Latrine & Lavatory & NEV \\
\hline 22212 & 1903 & Latrine & Lavatory & NEV \\
\hline 22214 & 1882 & Barracks & Administration & NHLC \\
\hline 22216 & 1882 & Barracks & Administration & NHLC \\
\hline 22218 & 1916 & Latrine & Lavatory & NEV \\
\hline 22320 & 1883 & Barracks & Administration & NHLC \\
\hline 22322 & 1903 & Latrine & Lavatory & NEV \\
\hline 22324 & 1886 & Bakery & Communication Center & NHLC \\
\hline 22326 & 1899 & School/Post Office & Administrative & NHLC \\
\hline 22328 & 1882 & Guard House & Administrative & NHLC \\
\hline 22330 & 1889 & Ordnance Warehouse & Storage & NEV \\
\hline 22332 & 1882 & Quartermaster's Storehouse & Administrative & NHLC \\
\hline 22336 & 1934 & Fire Station & Police/Military Police Station & DNE \\
\hline
\end{tabular}

\subsubsection{History}

The two-story, gable-roofed, frame barracks were built in 1882- 83. They rest on stone foundations and generally are typical of all Army barracks of that era. All have two-tiered, shed-roofed, square post- supported, ironrailed galleries front and rear. All are two bays wide, but Building 22208 is much longer than the other three. It contains approximately $32,000 \mathrm{sq} f t$ of floor space, while each of the others has about 15,00o. Each barrack has a full basement, displays six-over-six sash windows, has a series of interior chimneys along the roof crest, and is connected to the adjacent barrack by a covered walk. Latrines were added behind the barracks between 1903 and 1916. Other post-era service-type buildings include a bakery (22324), 
a school/post office (22326), a guard house (22328), an ordnance warehouse (22330), and a quartermaster storehouse (22332). A fire station was added to the landscape in the 1930s (22336) (Figures 62-76).

Figure 62. View looking northwest of the front of barracks (22208), c.1883 (NARA College Park, RG165-FF).

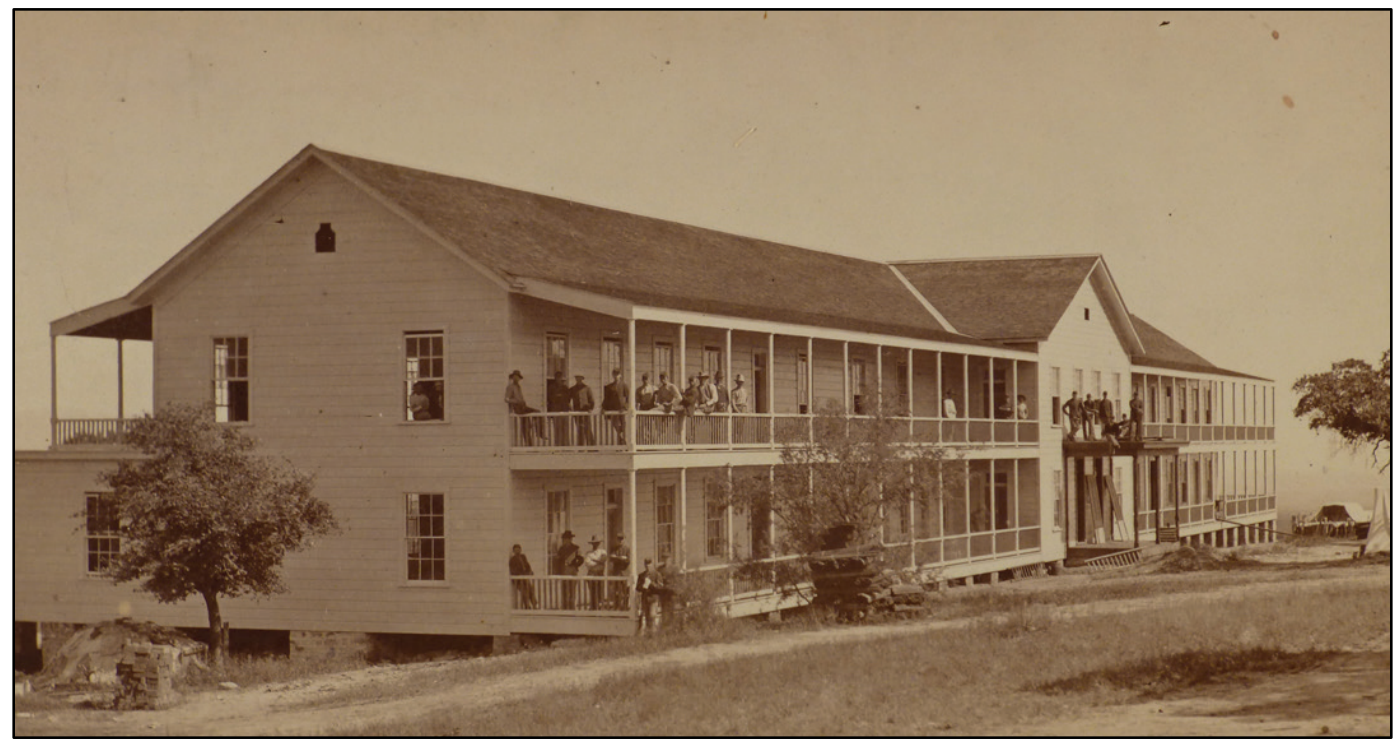

Figure 63. View looking west at the front of barracks (22208), c.1883 (NARA College Park, RG 165-FF).

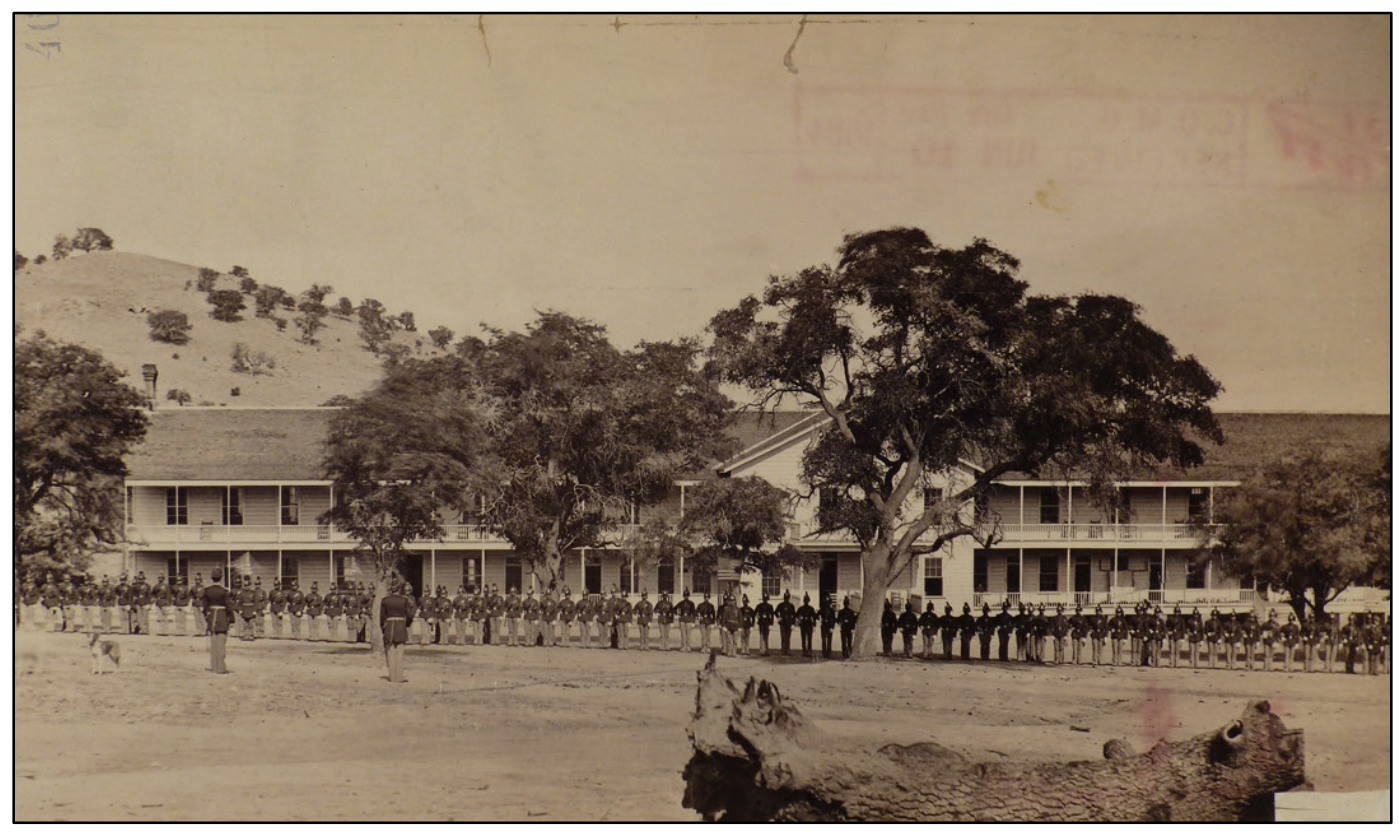


Figure 64. View looking east at the rear of Building 22208 and the powder magazine (demolished) with Huachuca Creek in between, 1890 (NARA College Park, RG165-FF).

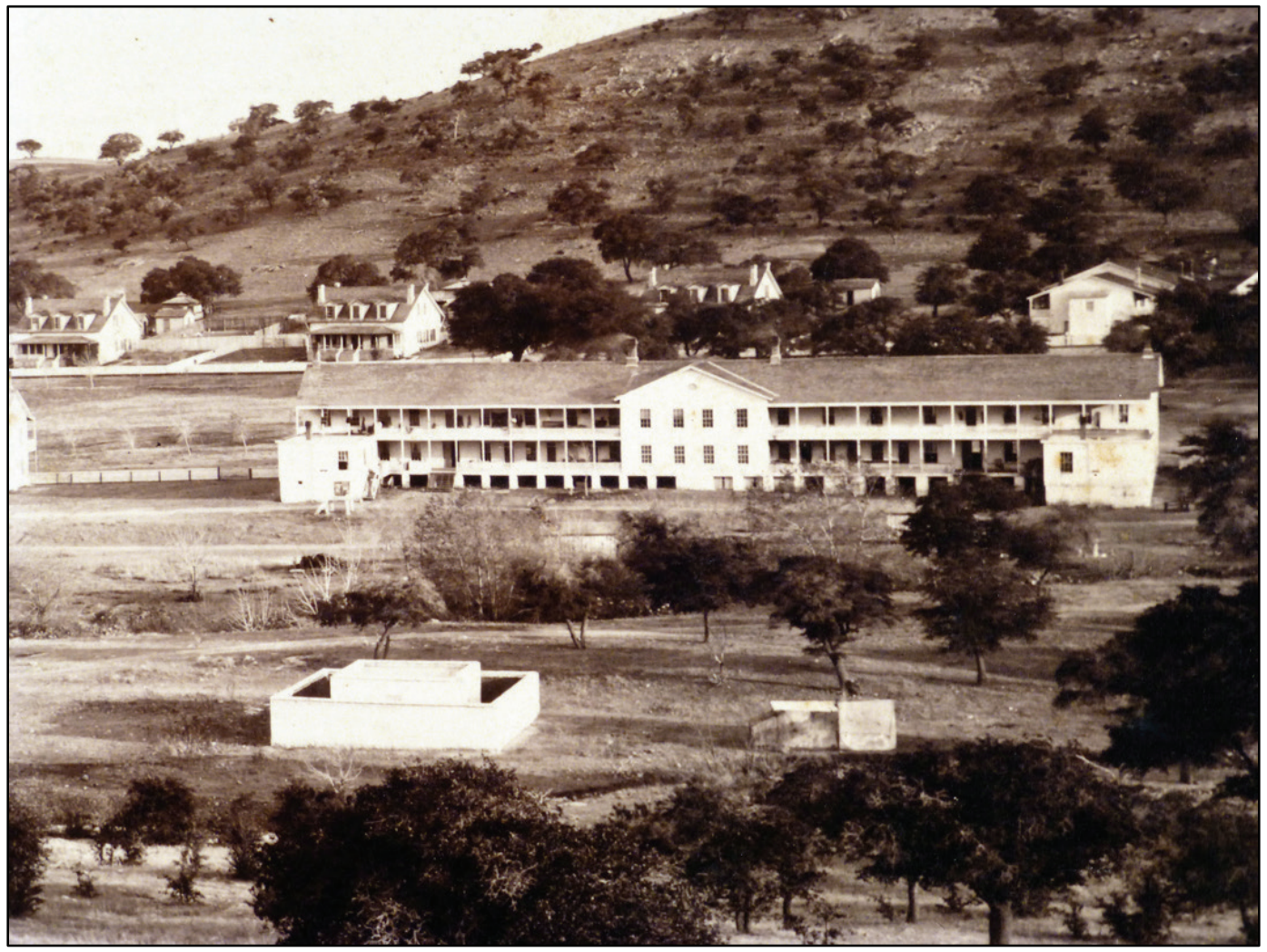

Figure 65. View looking northwest at barracks (22320), 1898 (Fort Huachuca Historical Museum).

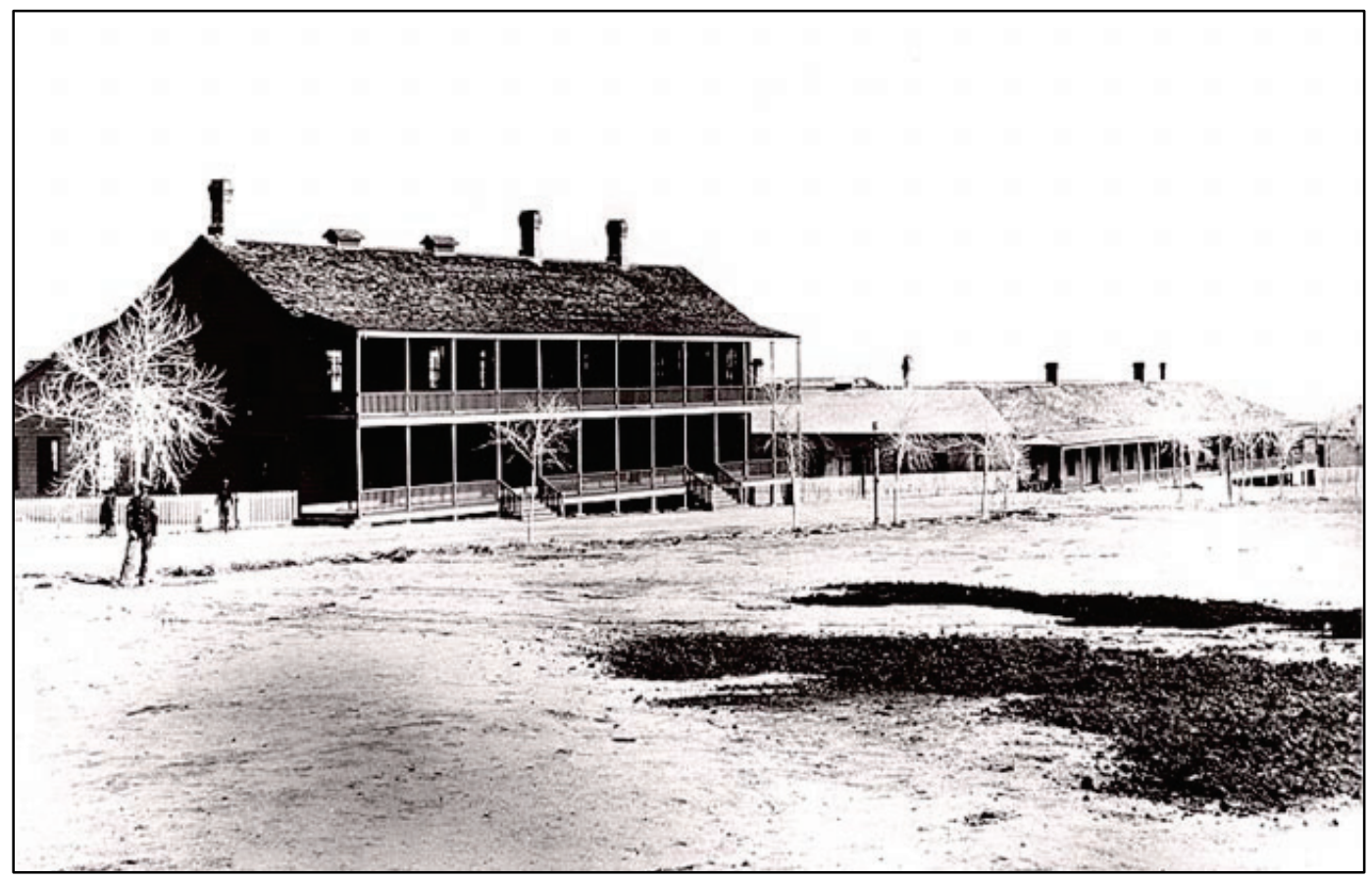


Figure 66. View looking southeast at the rear of barracks (22208), c.1900 (NARA College Park, RG 92-F).

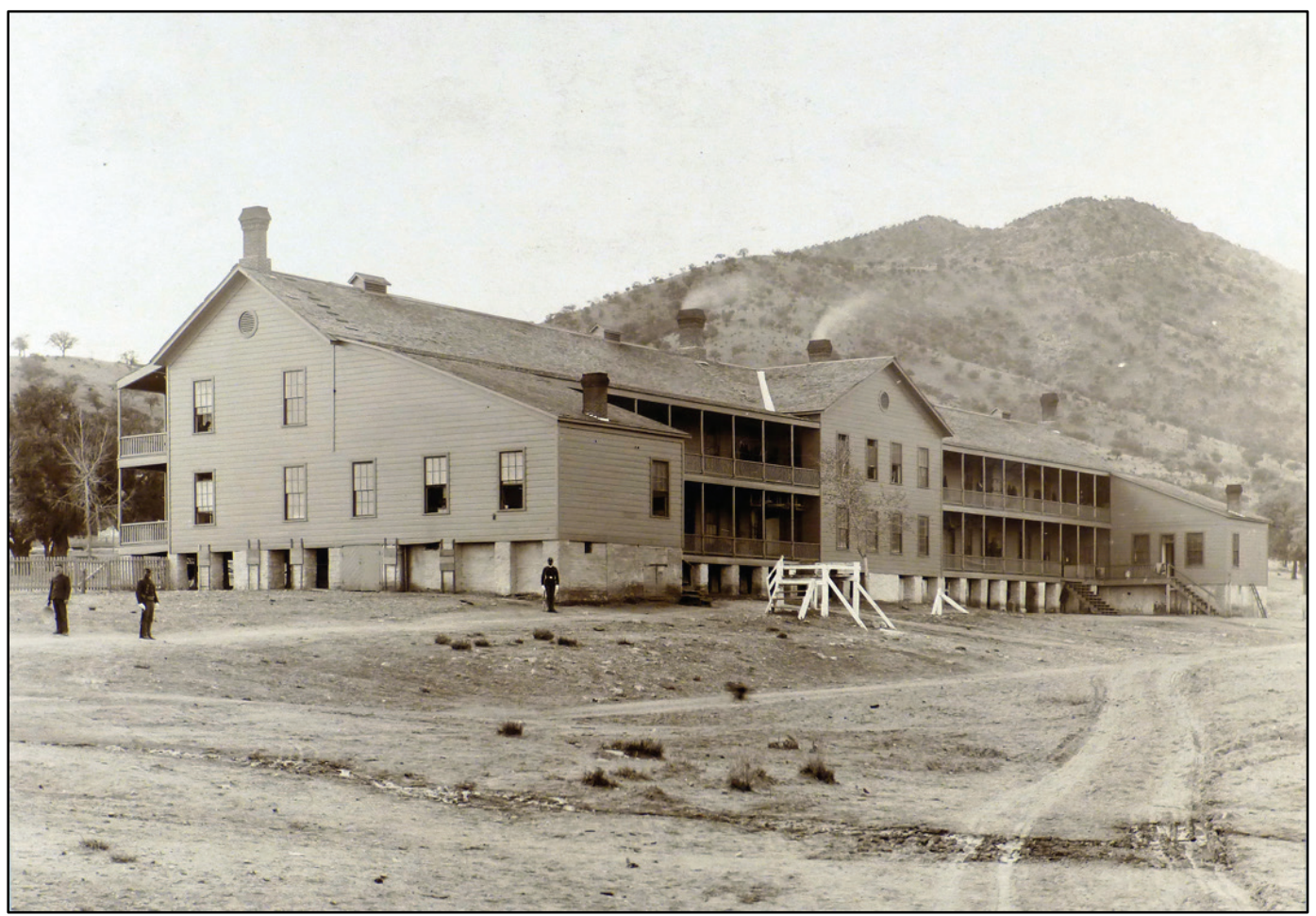

Figure 67. View looking east of the rear of barracks (22214 and 22215) with Huachuca Creek in the foreground, 1890 (NARA College Park, RG165-FF).

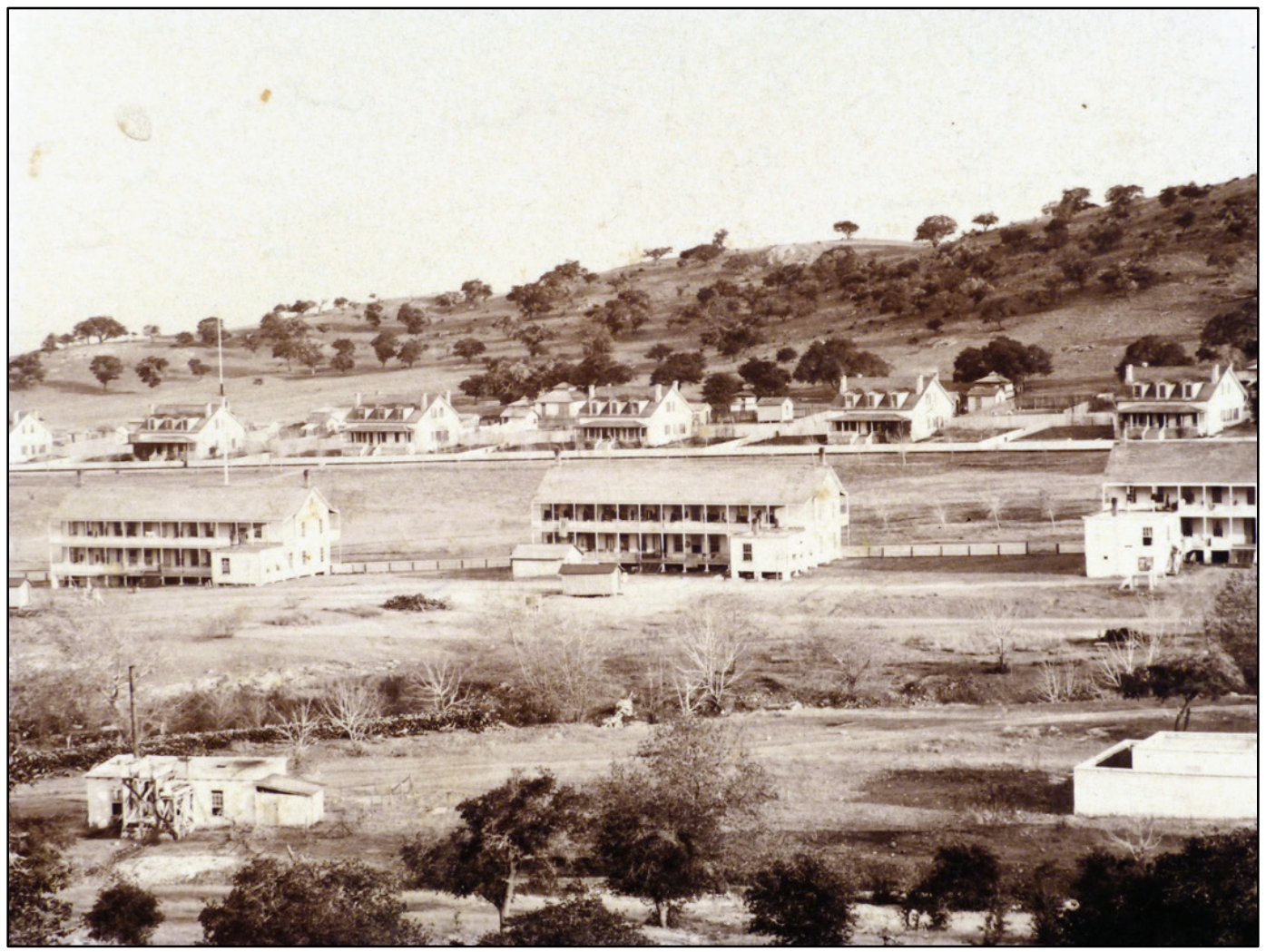


Figure 68. View looking southwest at Brown Field, the row of barracks $(22208,22214$, 22216, and 22320) and guard house (22328), 1899 (NARA College Park, RG165-FF).

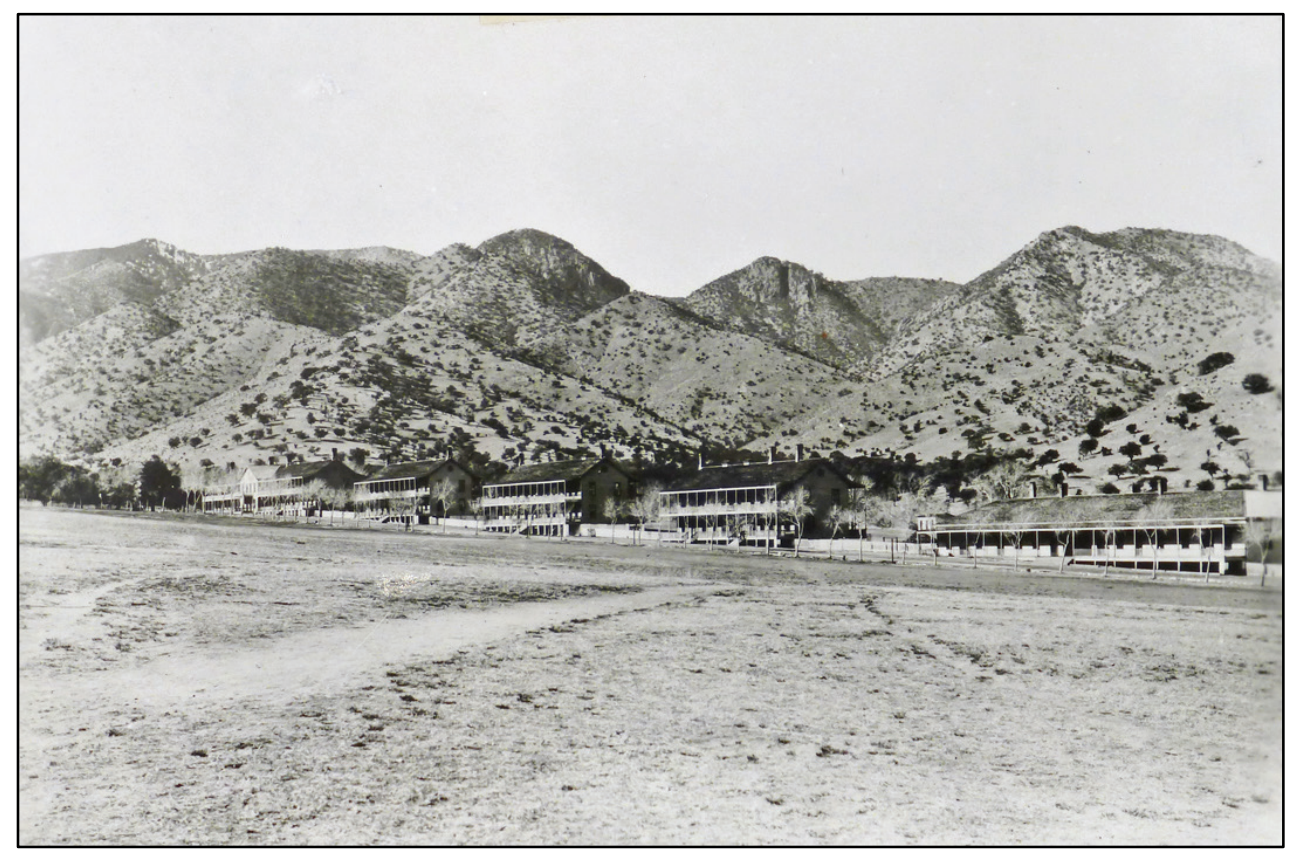

Figure 69. View looking south at barracks (22320) and trees lining edge of Brown Field, 1898 (NARA College Park, RG111-SC).

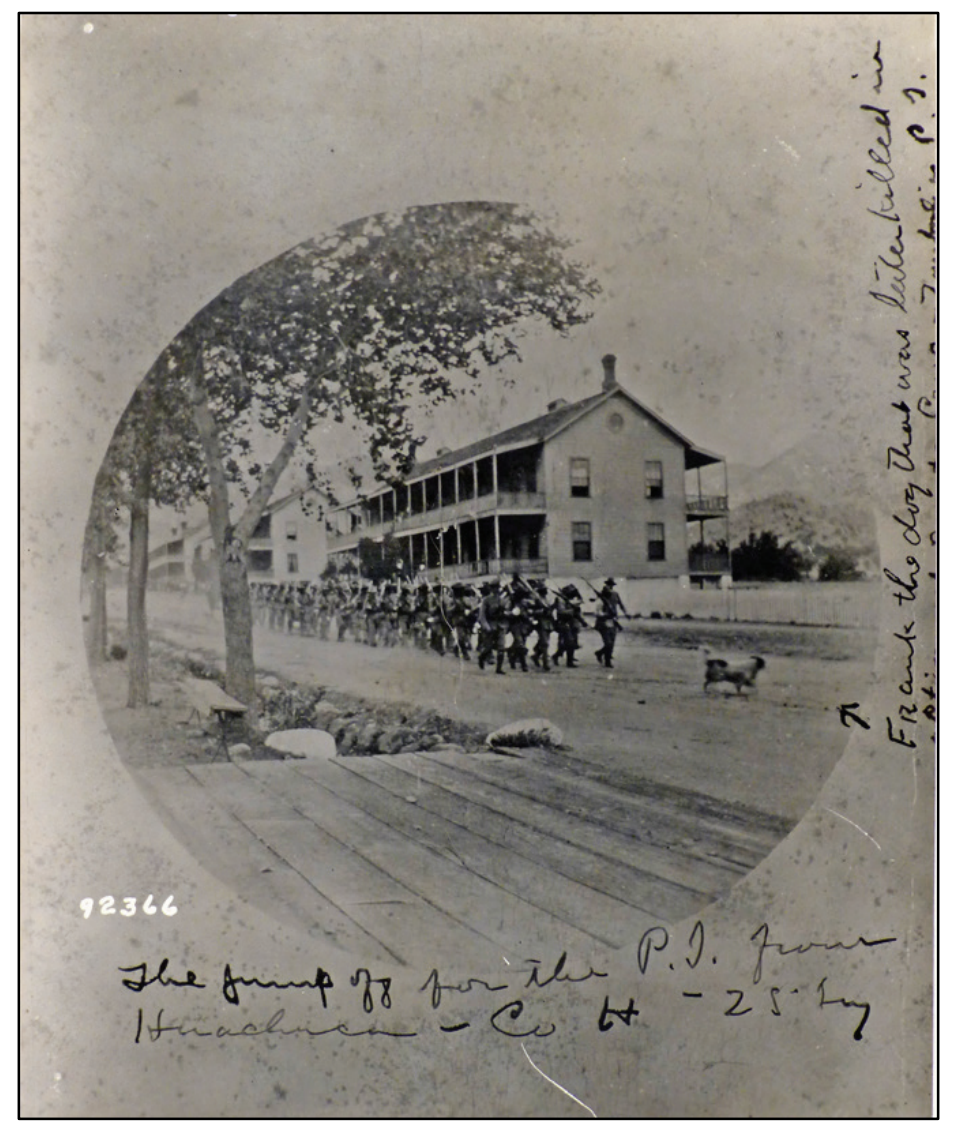


Figure 70. View looking west at front of barracks (22214), c.1900 (NARA College Park, RG165-FF).

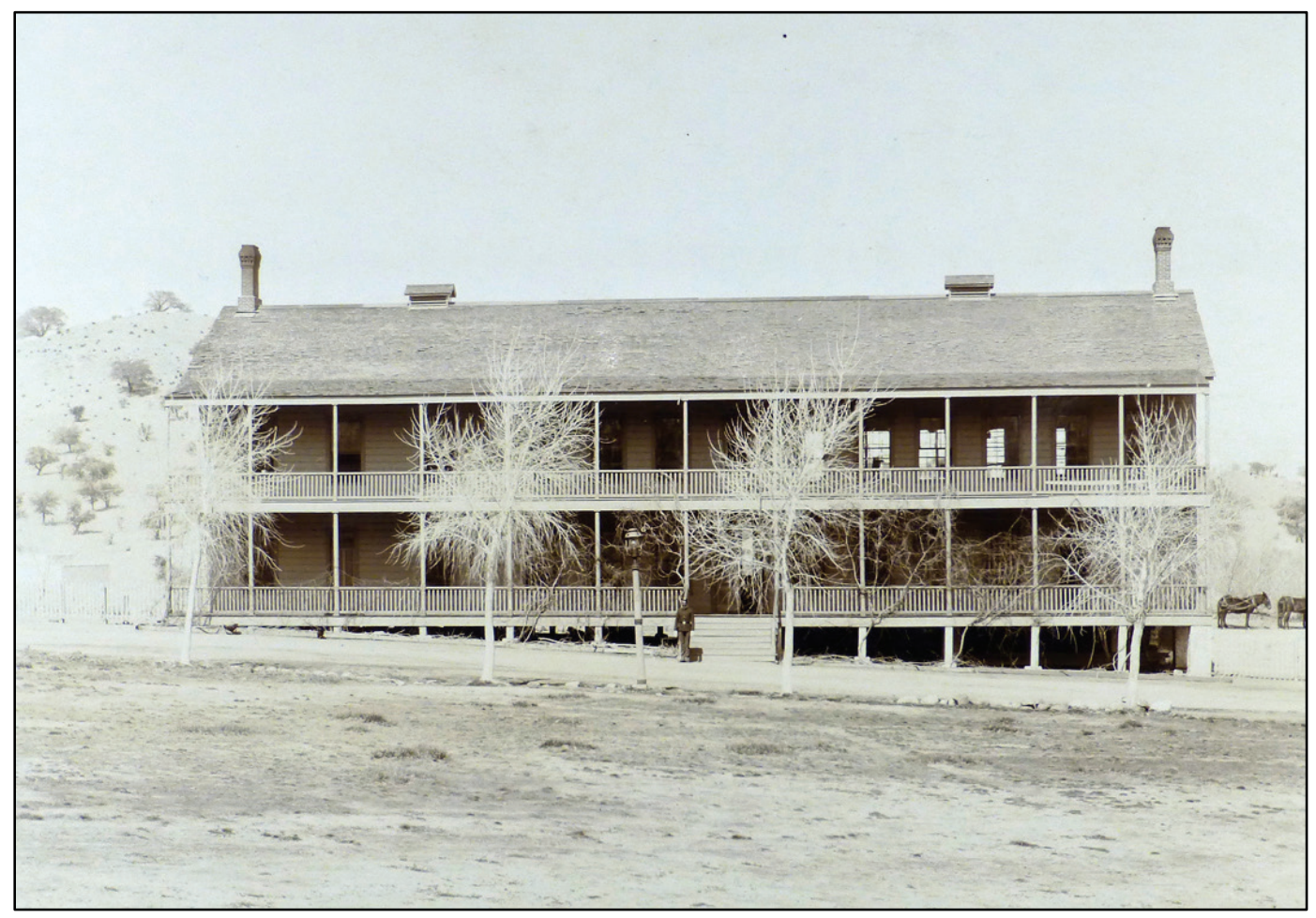

Figure 71. View looking west at front of barracks (22216), c.1900 (NARA College Park, RG165-FF).

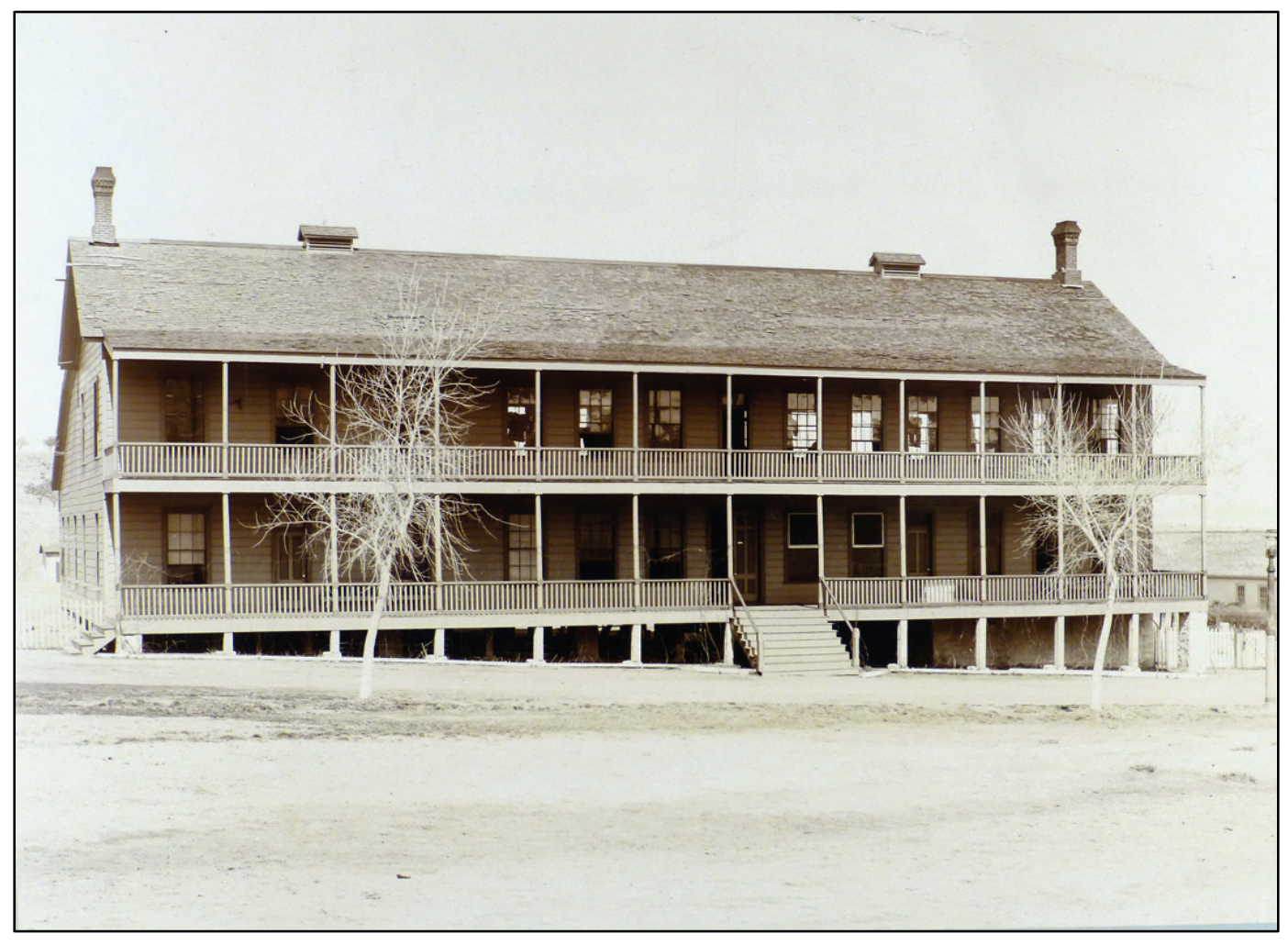


Figure 72. View looking northwest at barracks (22320) and the former quartermaster subsistence storehouse turned into barracks (demolished), c.1900 (NARA College Park, RG165-FF).

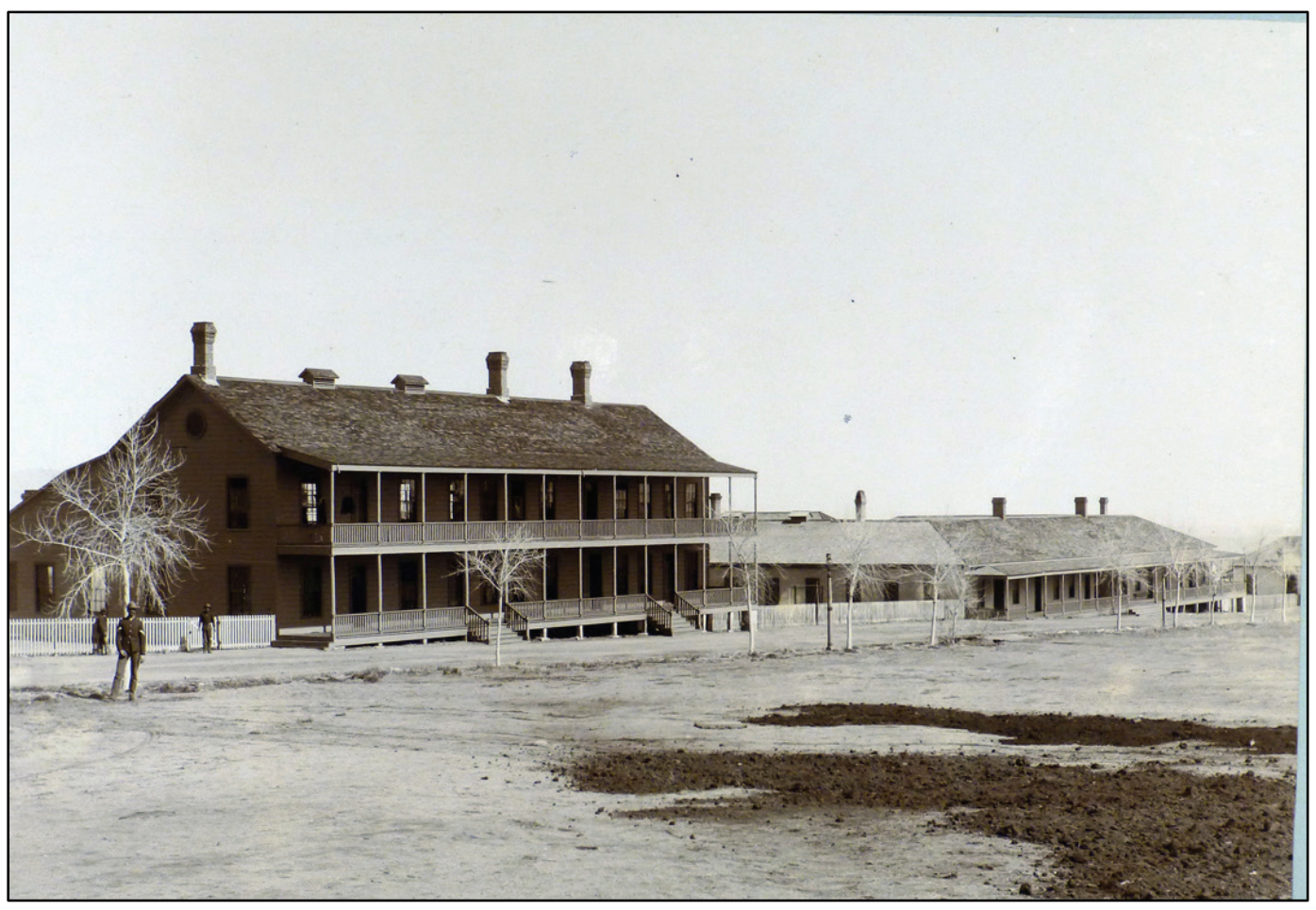

Figure 73. View looking west at the guard house (22328), c.1900 (NARA College Park, RG 92-F).

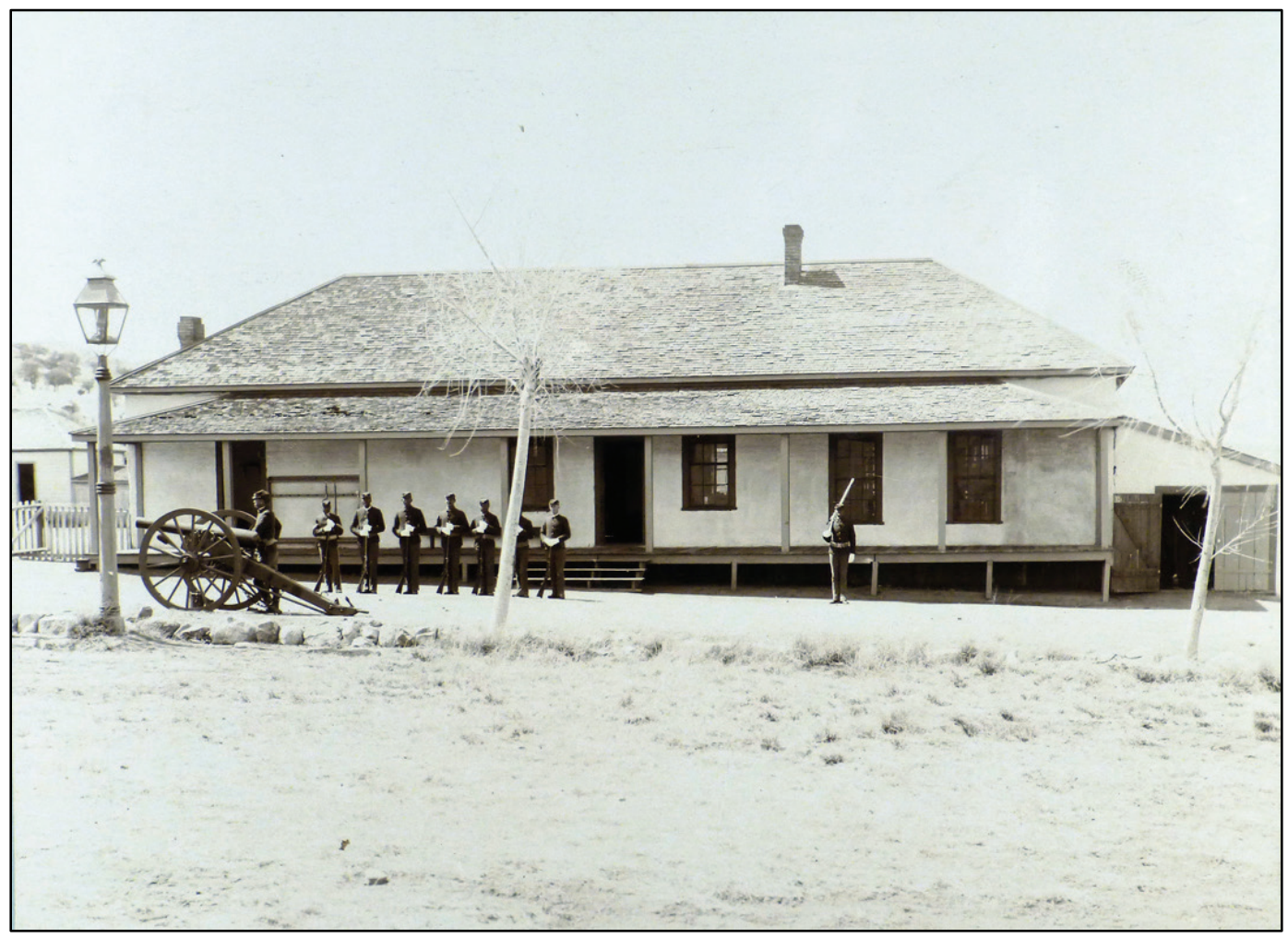


Figure 74. View looking northeast at the post bakery (22324) with the former quartermaster subsistence storehouse turned into barracks (demolished) behind, c.1900 (NARA College Park, RG 92-F).

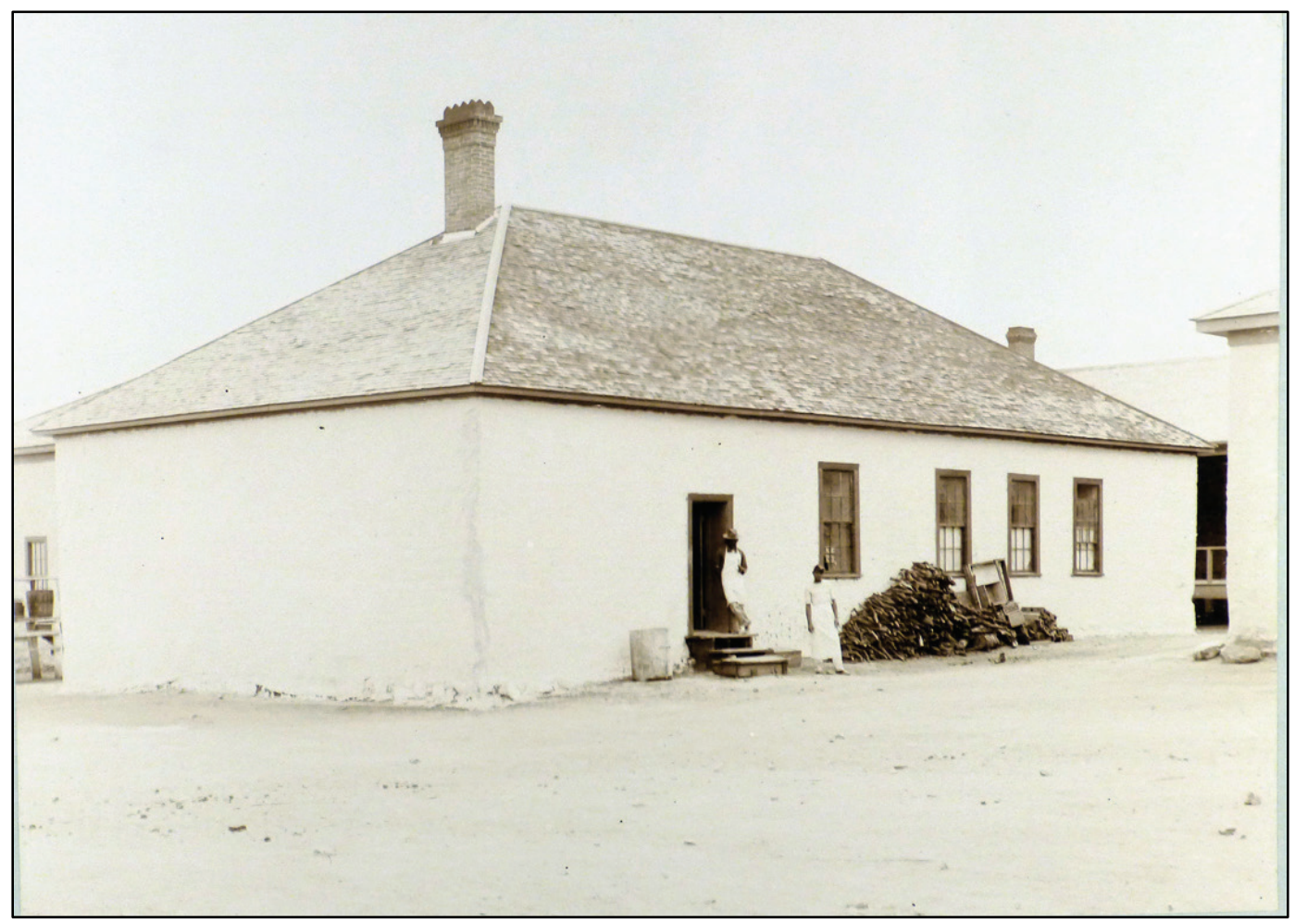

Figure 75. View looking southwest at guard house (22328), c.1916 [Note the metal street lamp in front of building.] (Fort Huachuca Museum).

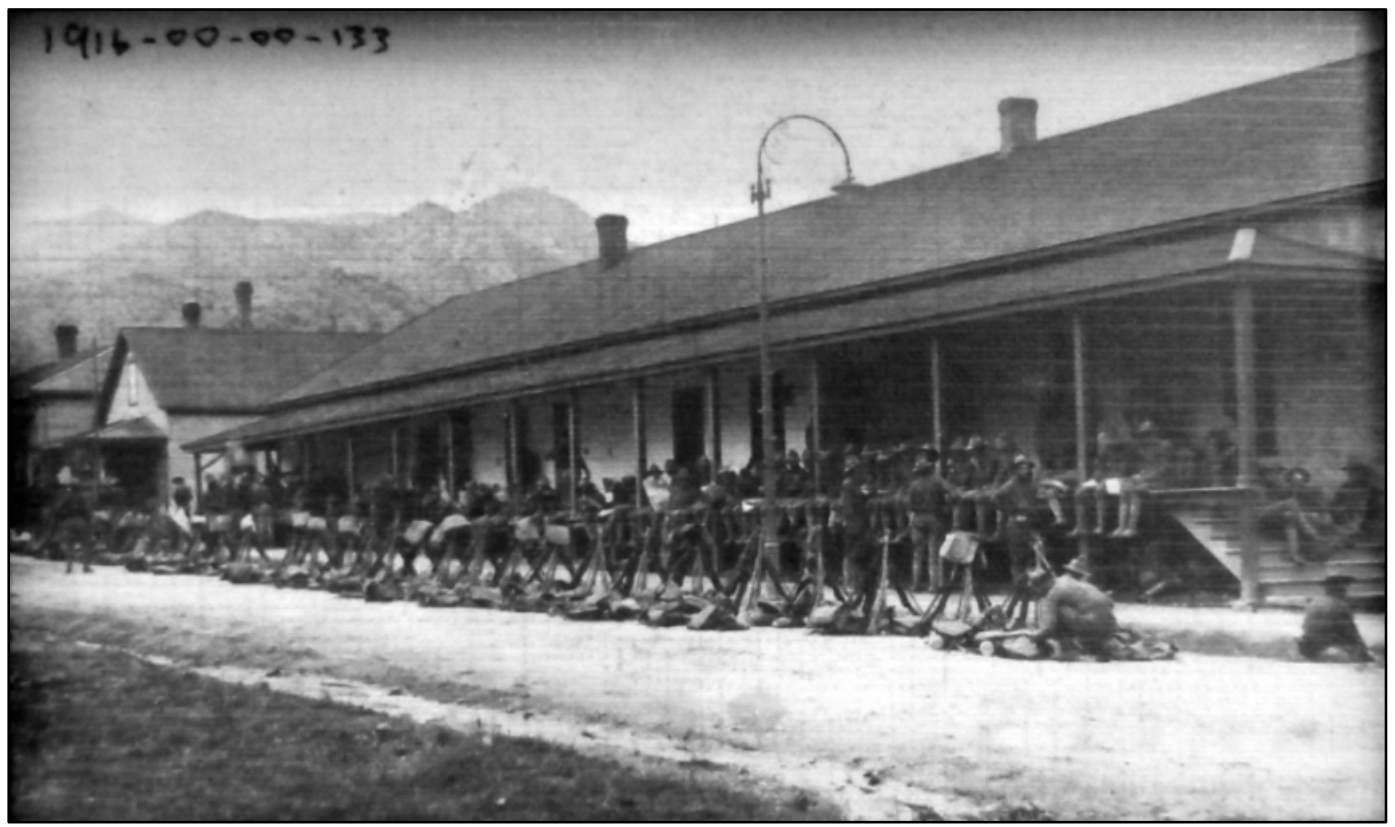


Figure 76. View looking east over Huachuca Creek towards the rear of the barracks, Brown Field, and Reservoir Hill, 1916 (NARA College Park, RG111-SC).

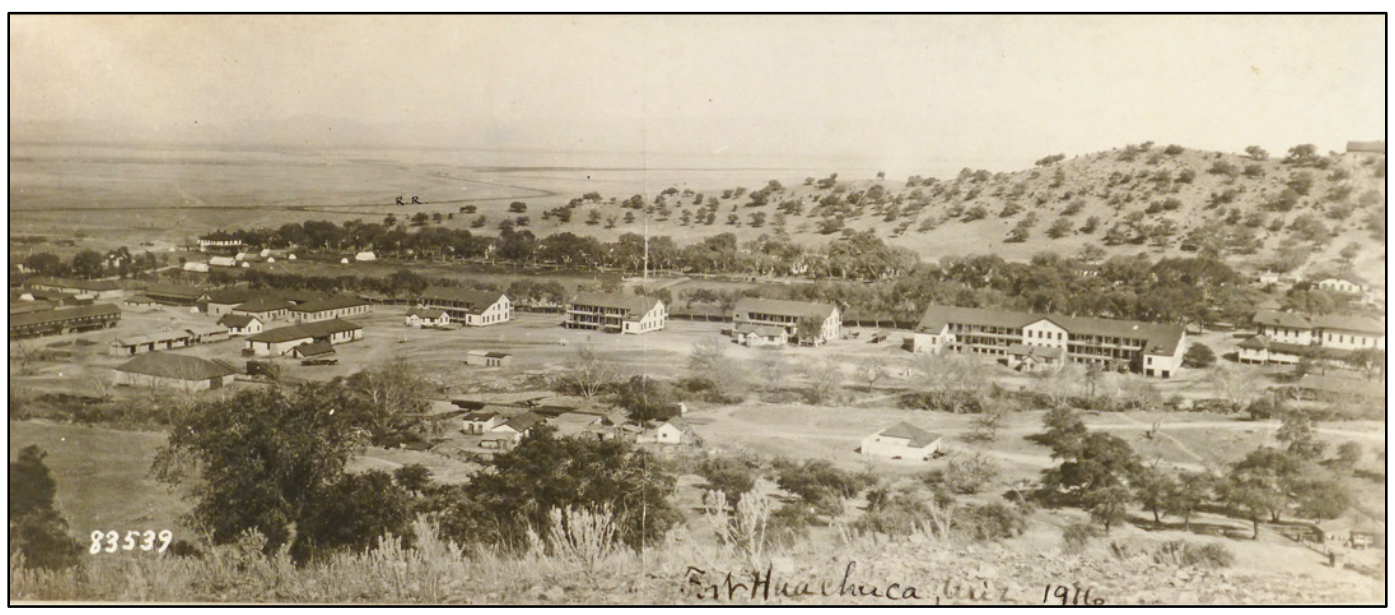

\subsubsection{Current conditions}

The barracks today are used for administration, and they have undergone internal alterations to provide modern heating and cooling, floor coverings, drop ceilings, fluorescent lighting, and new partitioning. The exteriors are little changed since the post's cavalry days. While some landscaping remains, most barracks have none. Parking is now in front of barracks along Augur Avenue (Figures 77-118).

Figure 77. View looking northwest of barracks (22208) from Reservoir Hill (ERDC-CERL, 2016).

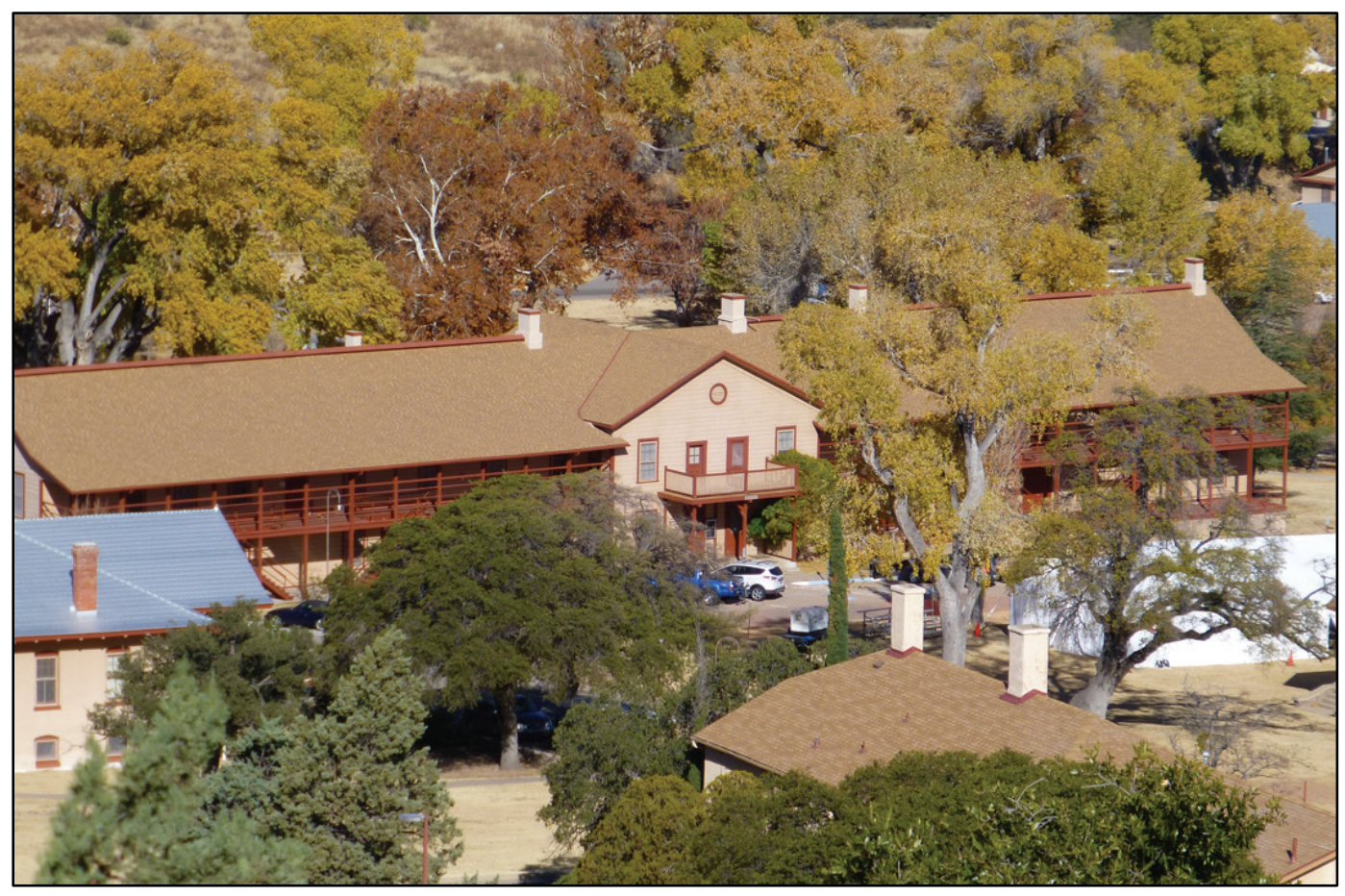


Figure 78. Looking west at barracks (22208) from across Brown Field (ERDC-CERL, 2016).

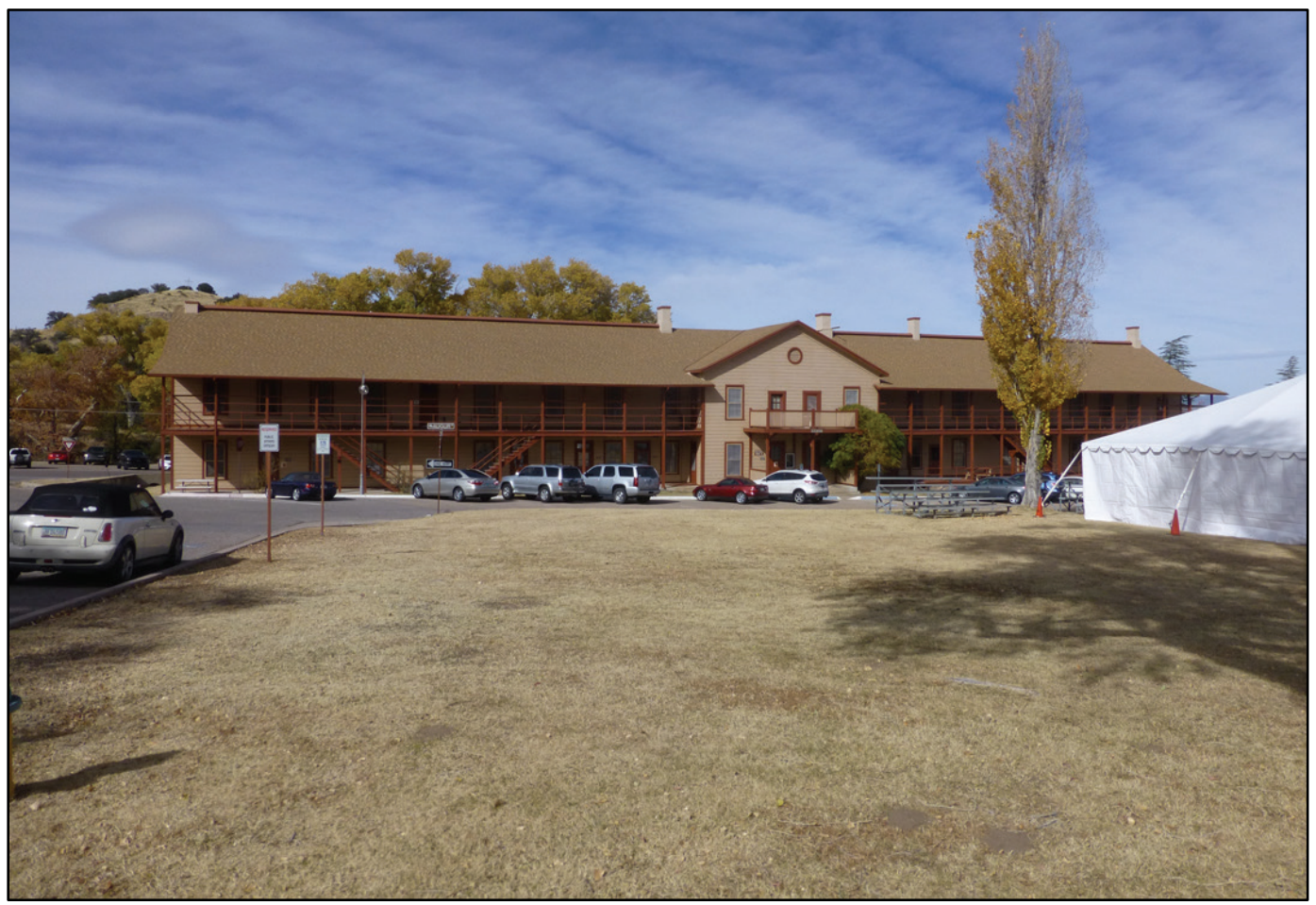

Figure 79. Looking north at parking on Augur Avenue in front of barracks (22208) [Note missing trees along this edge of Brown Field.] (ERDC-CERL, 2016).

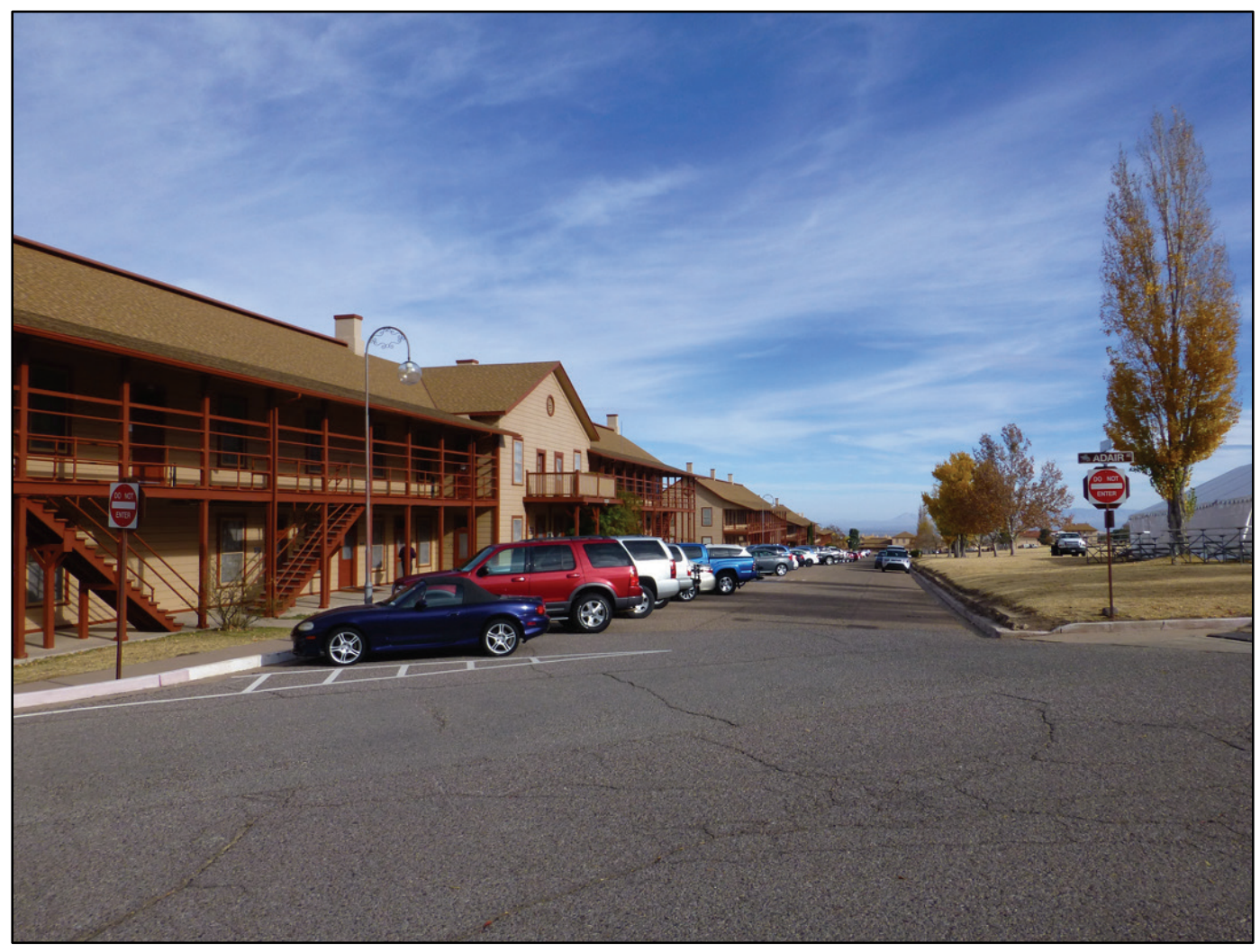


Figure 80. View to the west of landscaping between 22210 and 22214 (ERDC-CERL, 2016).

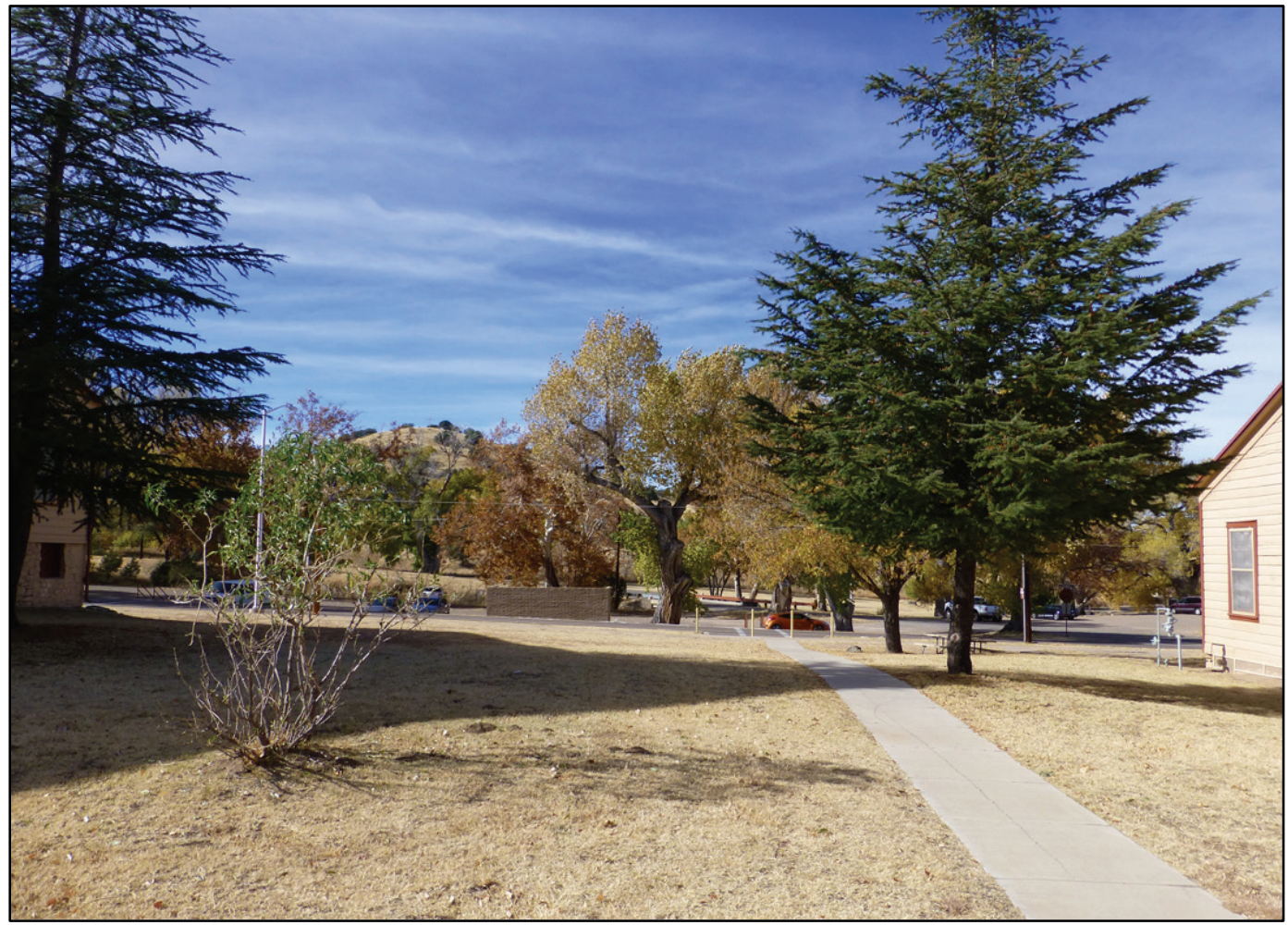

Figure 81. View towards the northeast of 22210 foreground and 22208 background from Christy and Adair Avenues intersection showing stone wall (ERDC-CERL, 2016).

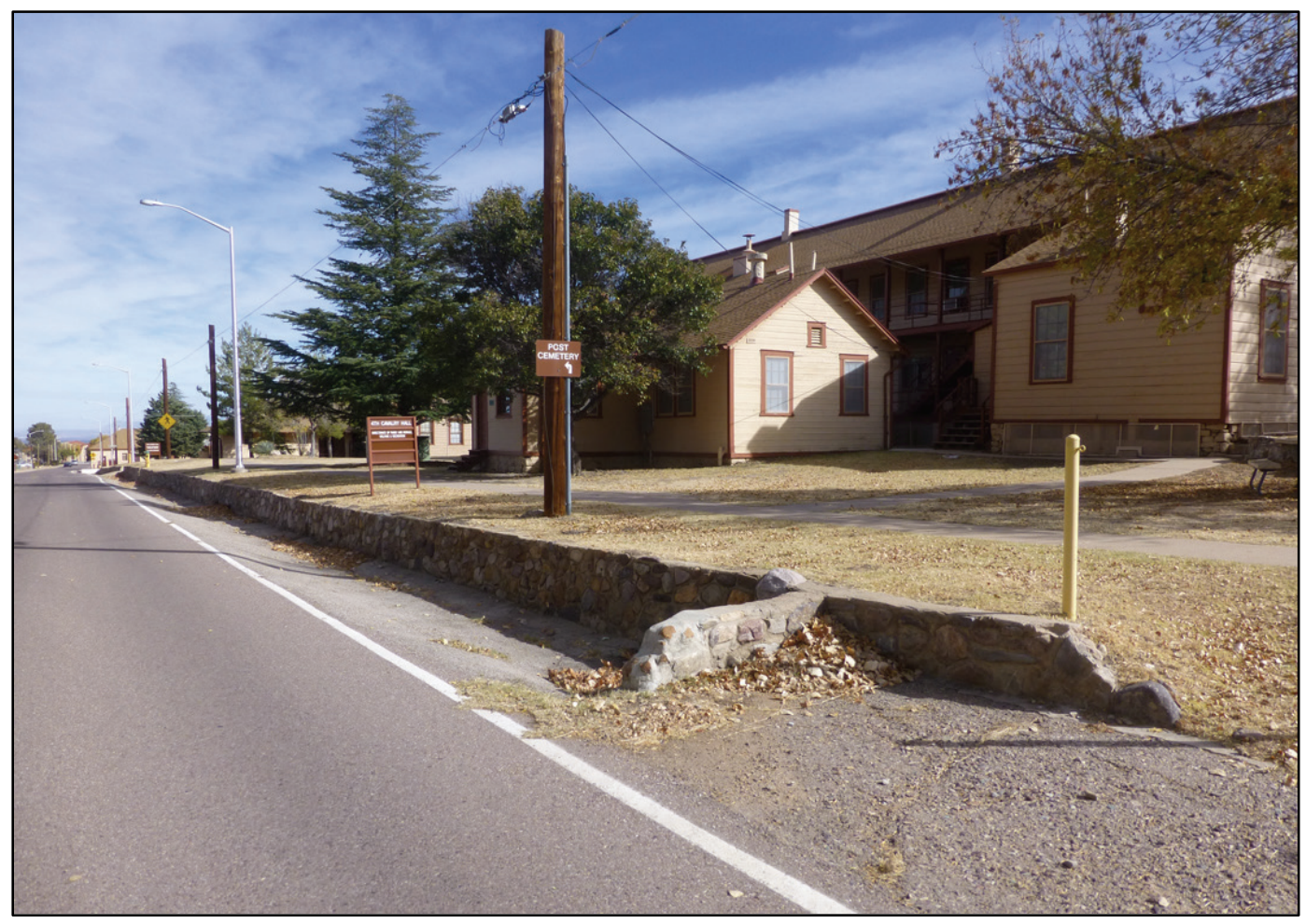


Figure 82. View to the north of asphalt drainage ditch and stone wall on north side of 22208 (ERDC-CERL, 2016).

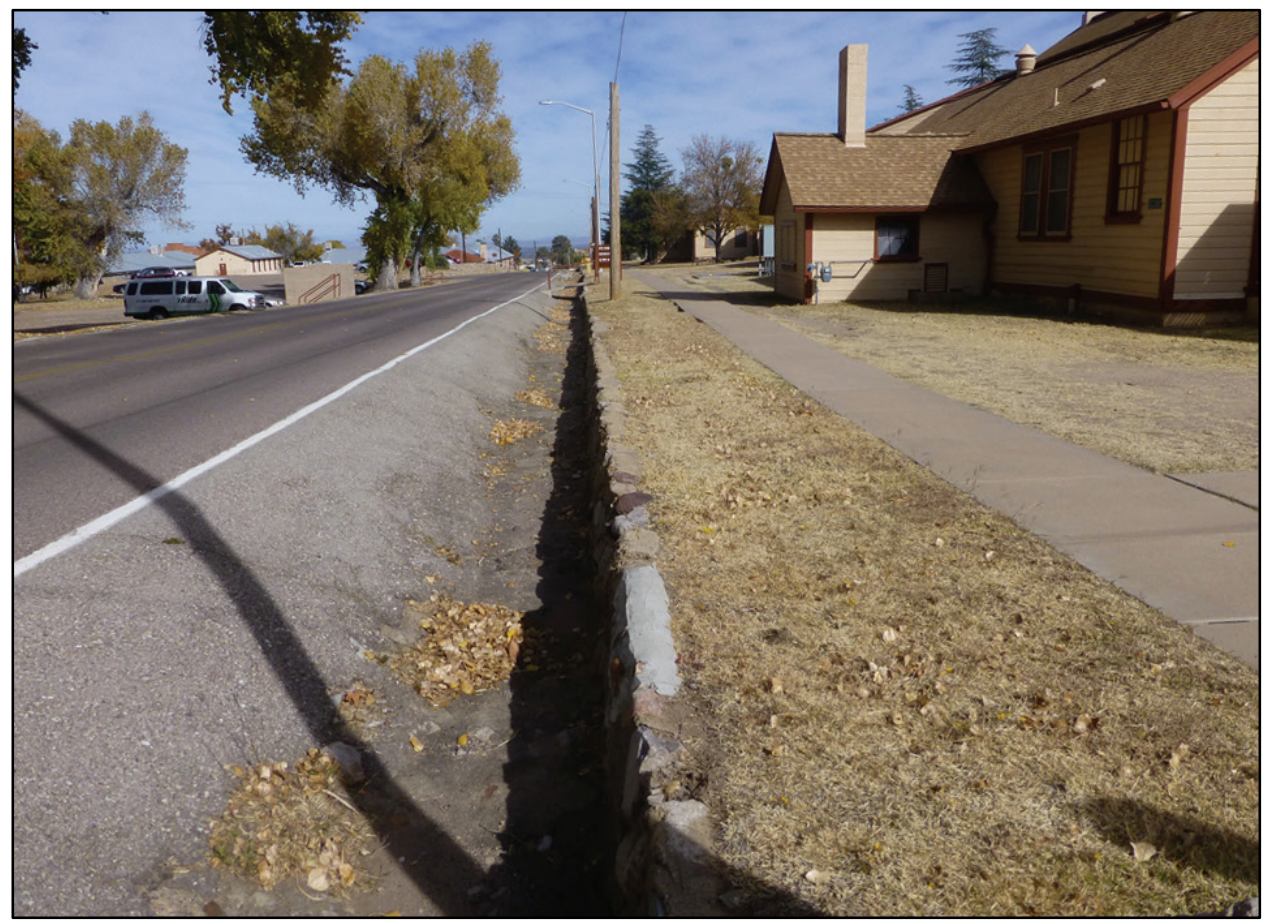

Figure 83. Looking east at stone drainage ditch on the west side of 22208 (ERDC-CERL, 2016).

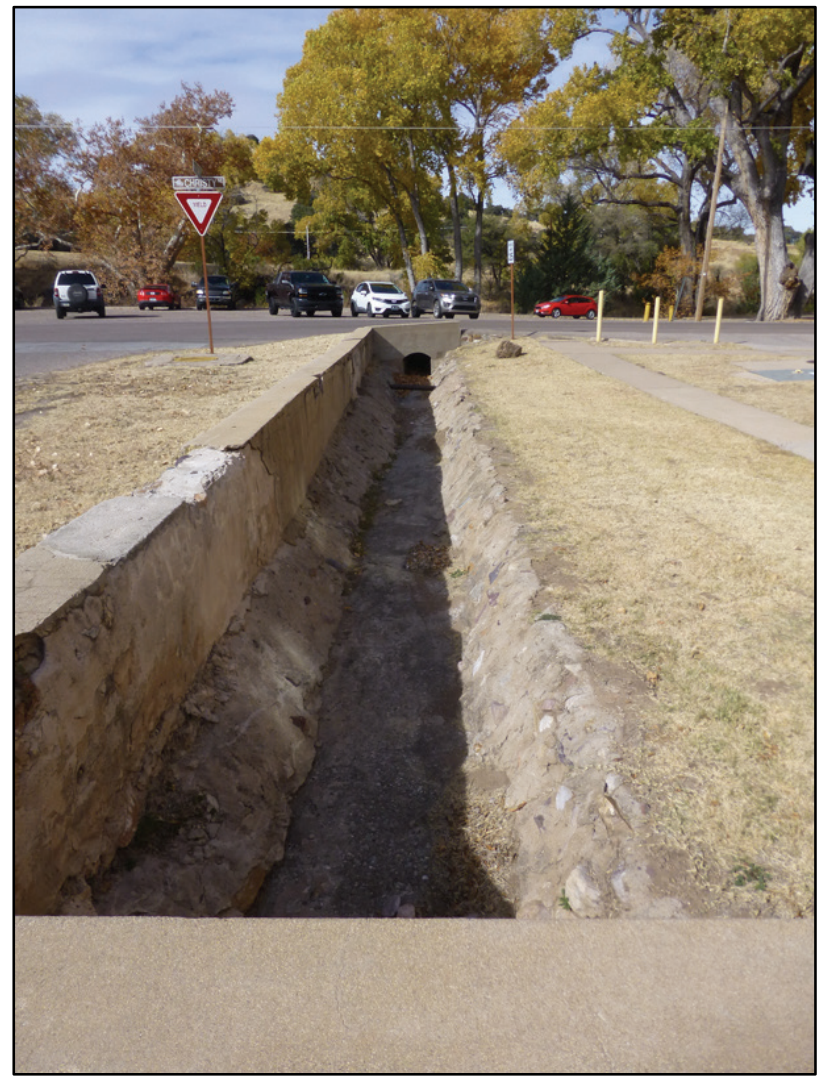


Figure 84. View to the east of electrical equipment and wood screening on the rear of 22208 (ERDC-CERL, 2016).

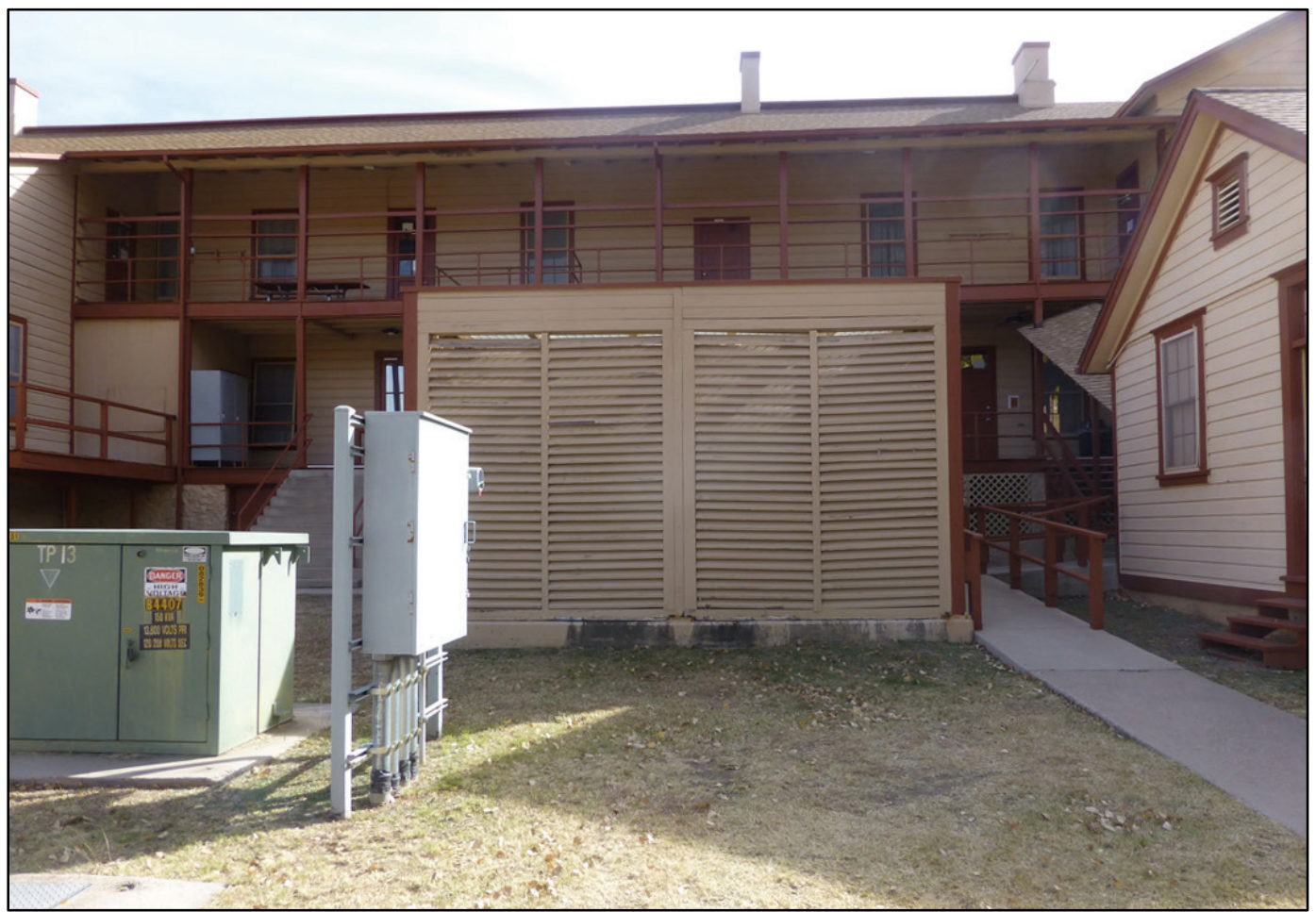

Figure 85. Example of signage on west side of barracks (22208) along Hines Avenue (ERDCCERL, 2016).

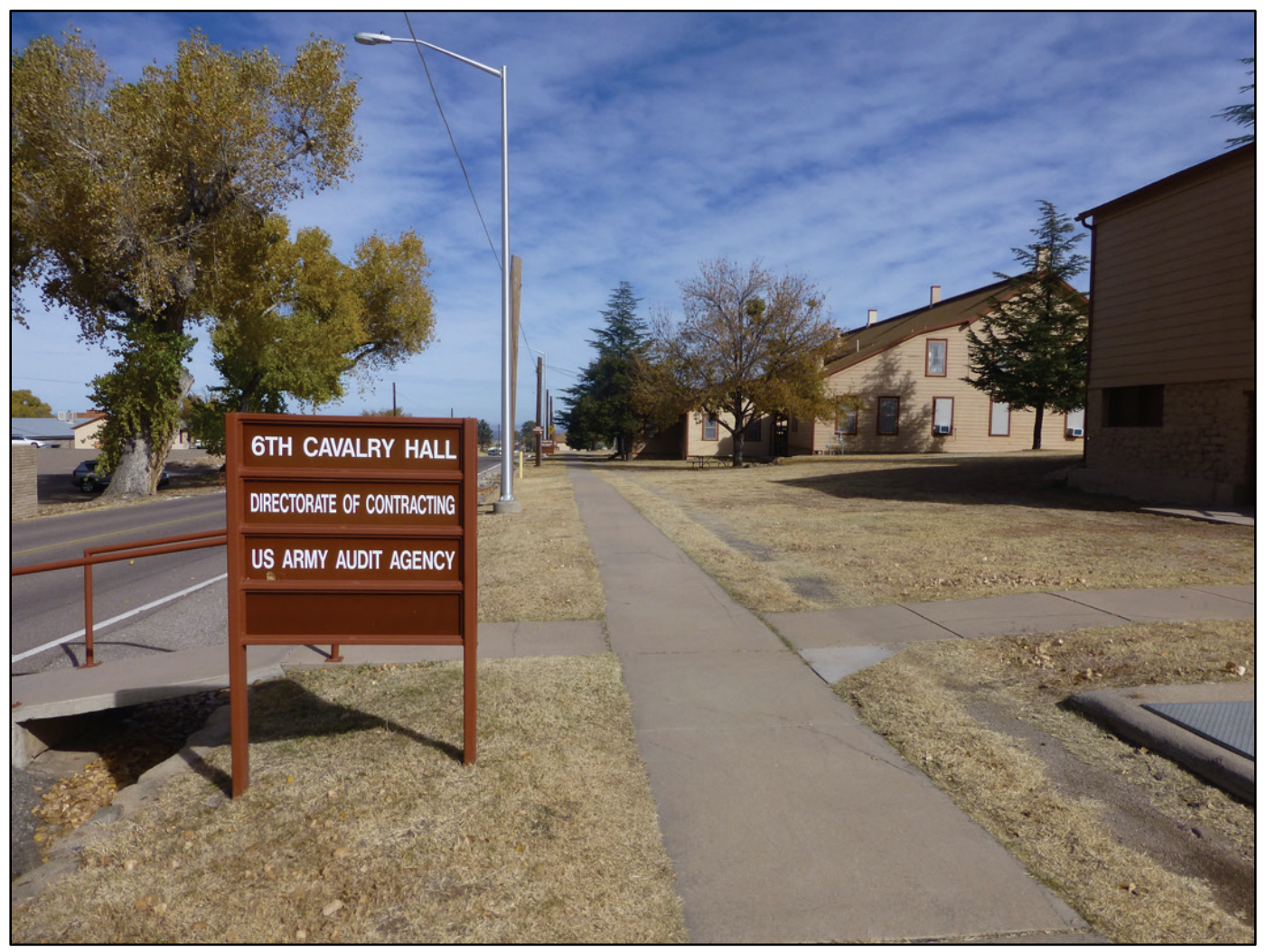


Figure 86. Looking north along Hines Avenue with rear of barracks (22214) on right [Note example of modern street lamps.] (ERDC-CERL, 2016).

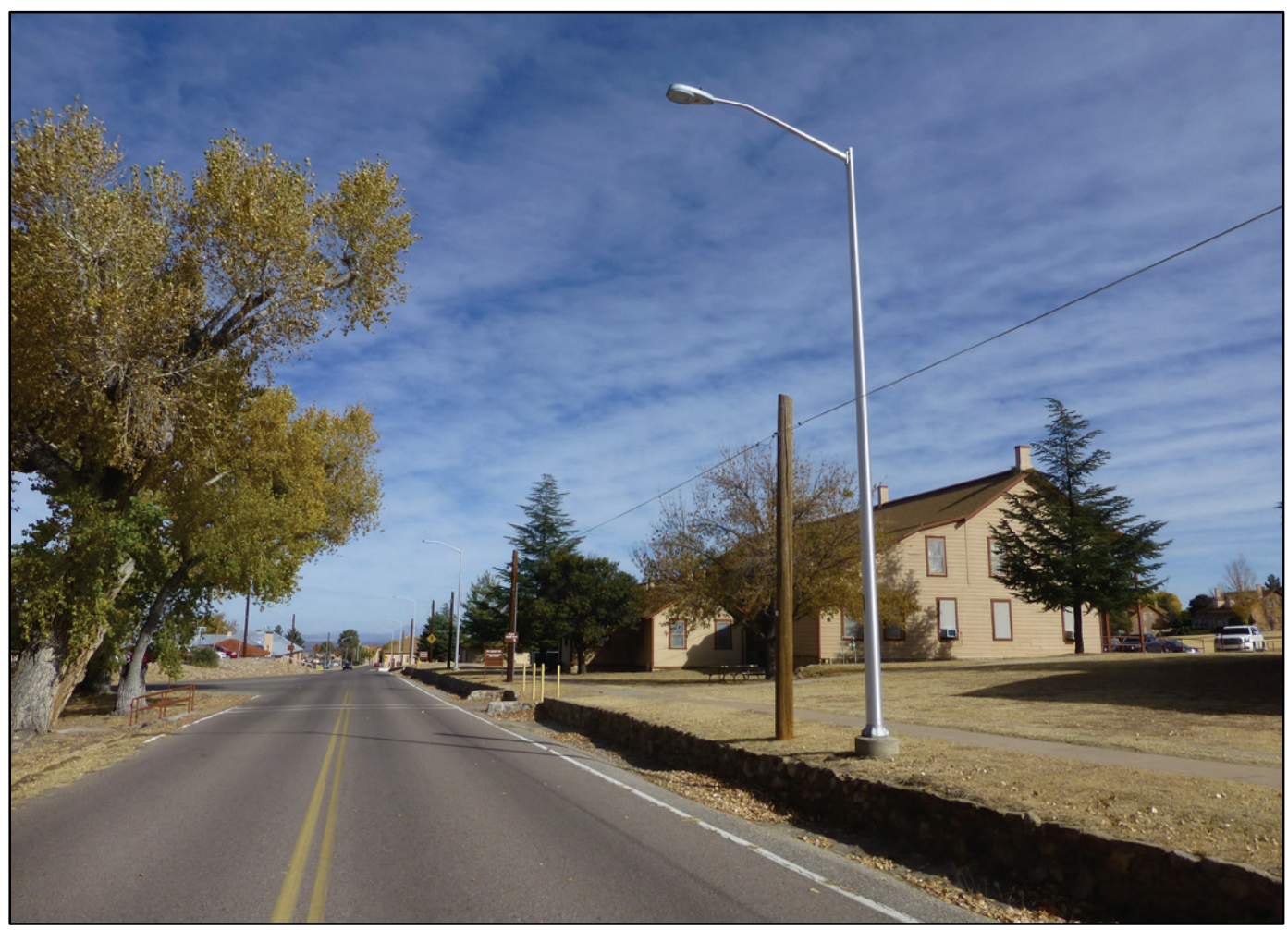

Figure 87. View to the east of an example of concrete sidewalk and steps with metal railings that connect the barracks area to the parking lot on the west side of Hines Avenue (ERDCCERL, 2016).

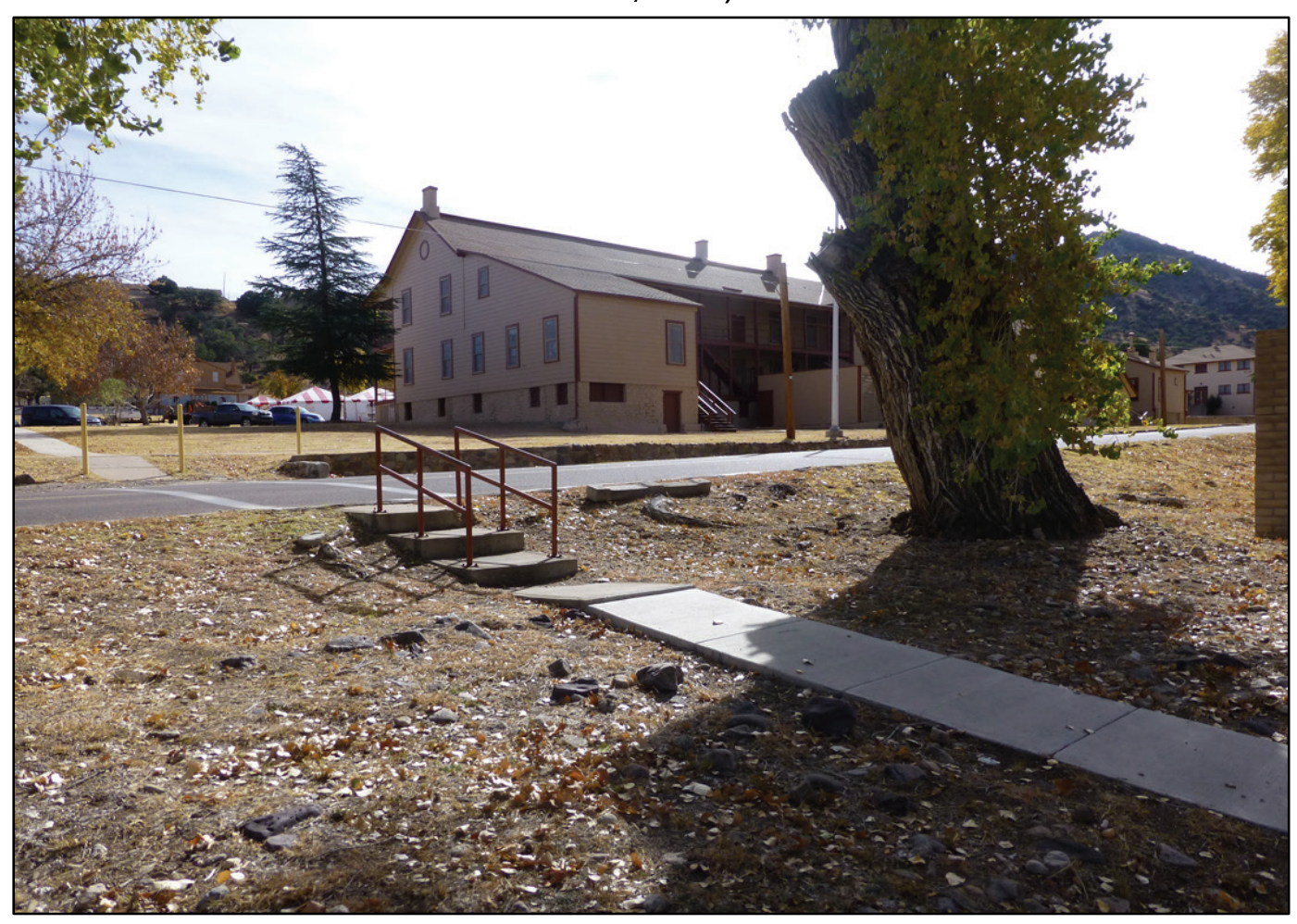


Figure 88. View to the south of parking lot for buildings on the west side of Hines Avenue for former barracks now administration (ERDC-CERL, 2016).

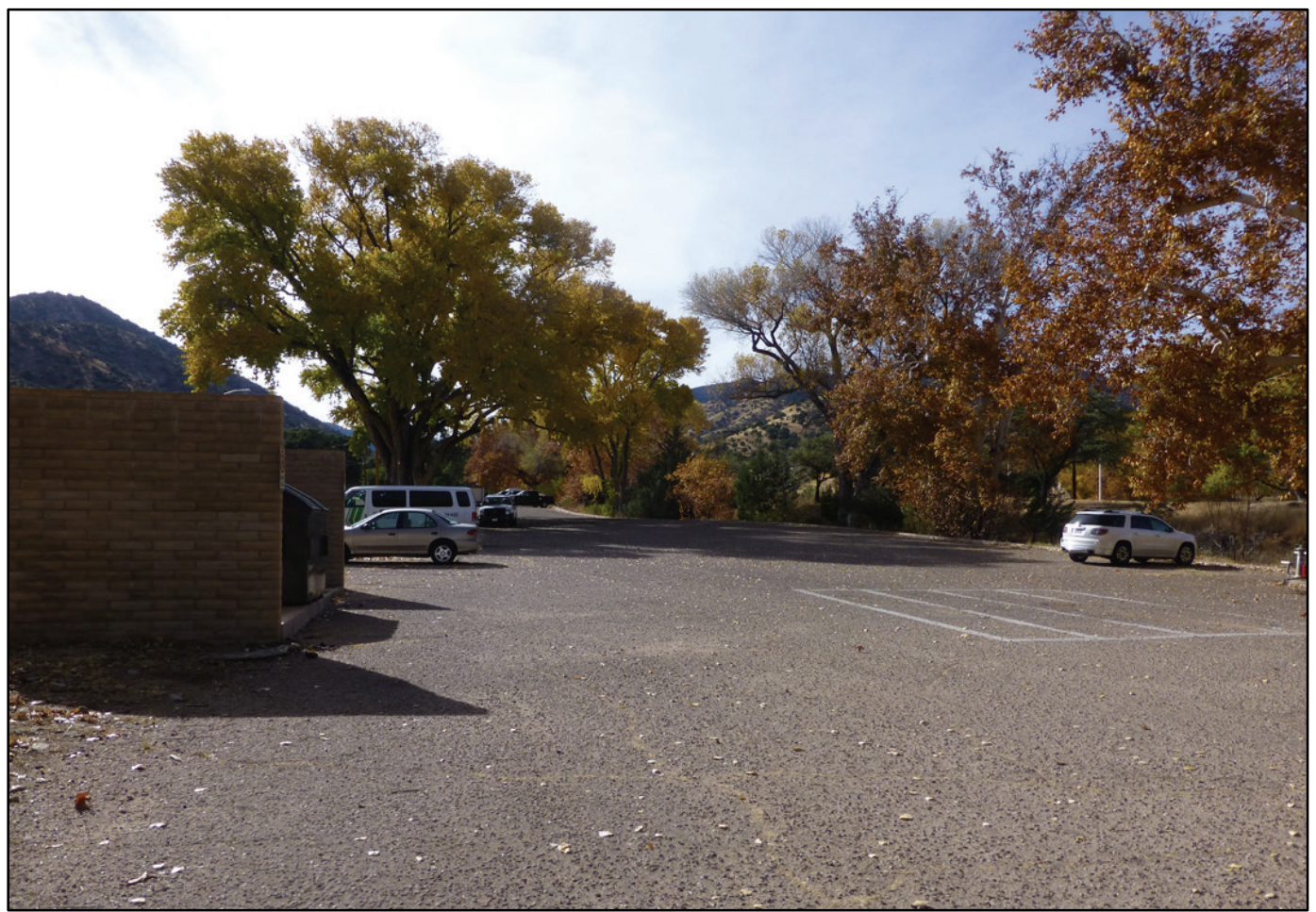

Figure 89. View looking southwest across Brown Field at barracks $(22214,22216$, and 22320) (ERDC-CERL, 2016).

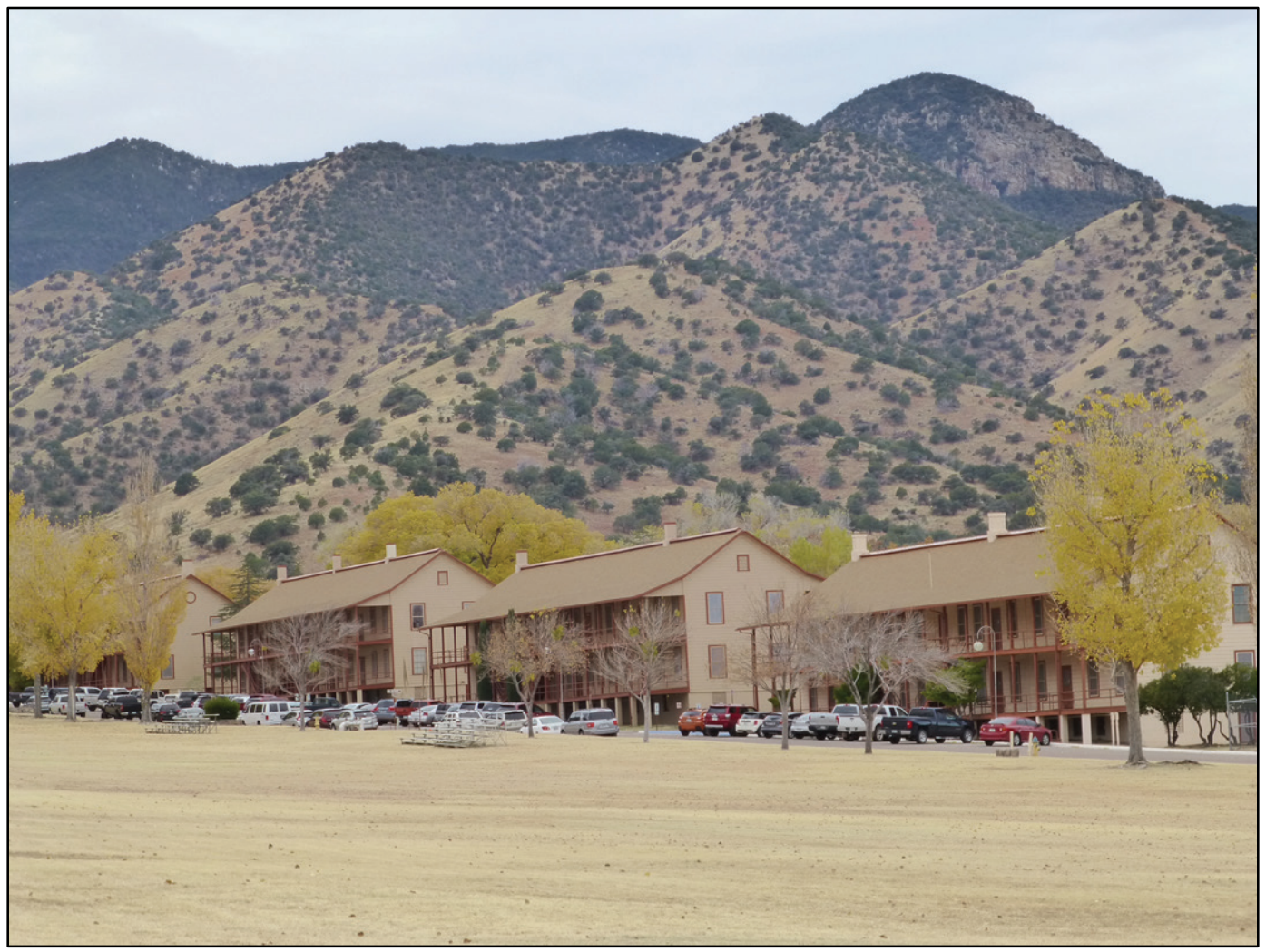


Figure 90. Looking south along Augur Avenue at parking in front of barracks (ERDC-CERL, 2016).

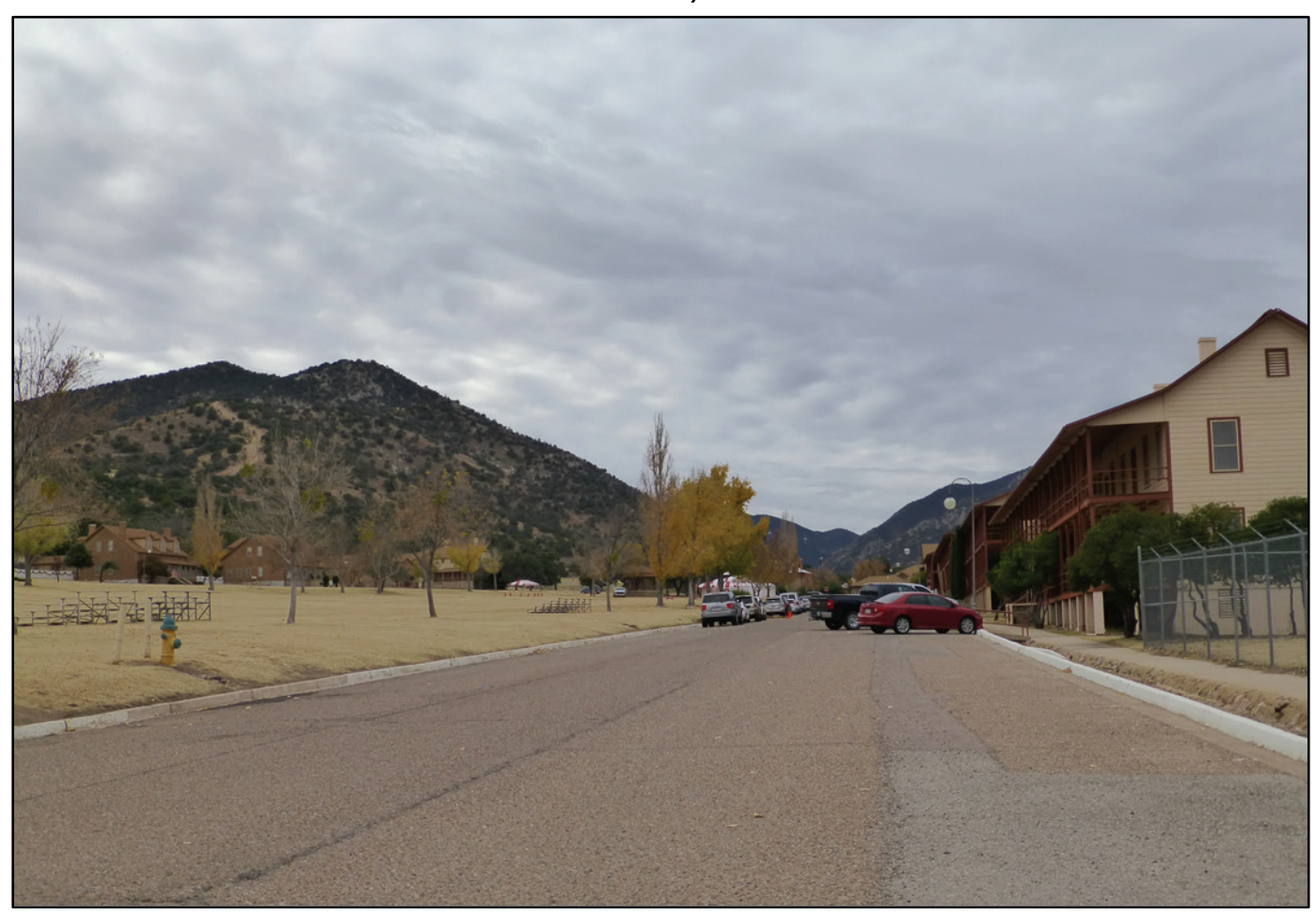

Figure 91. Looking north at the sidewalks and parking in front of barracks (22214) (ERDCCERL, 2016).

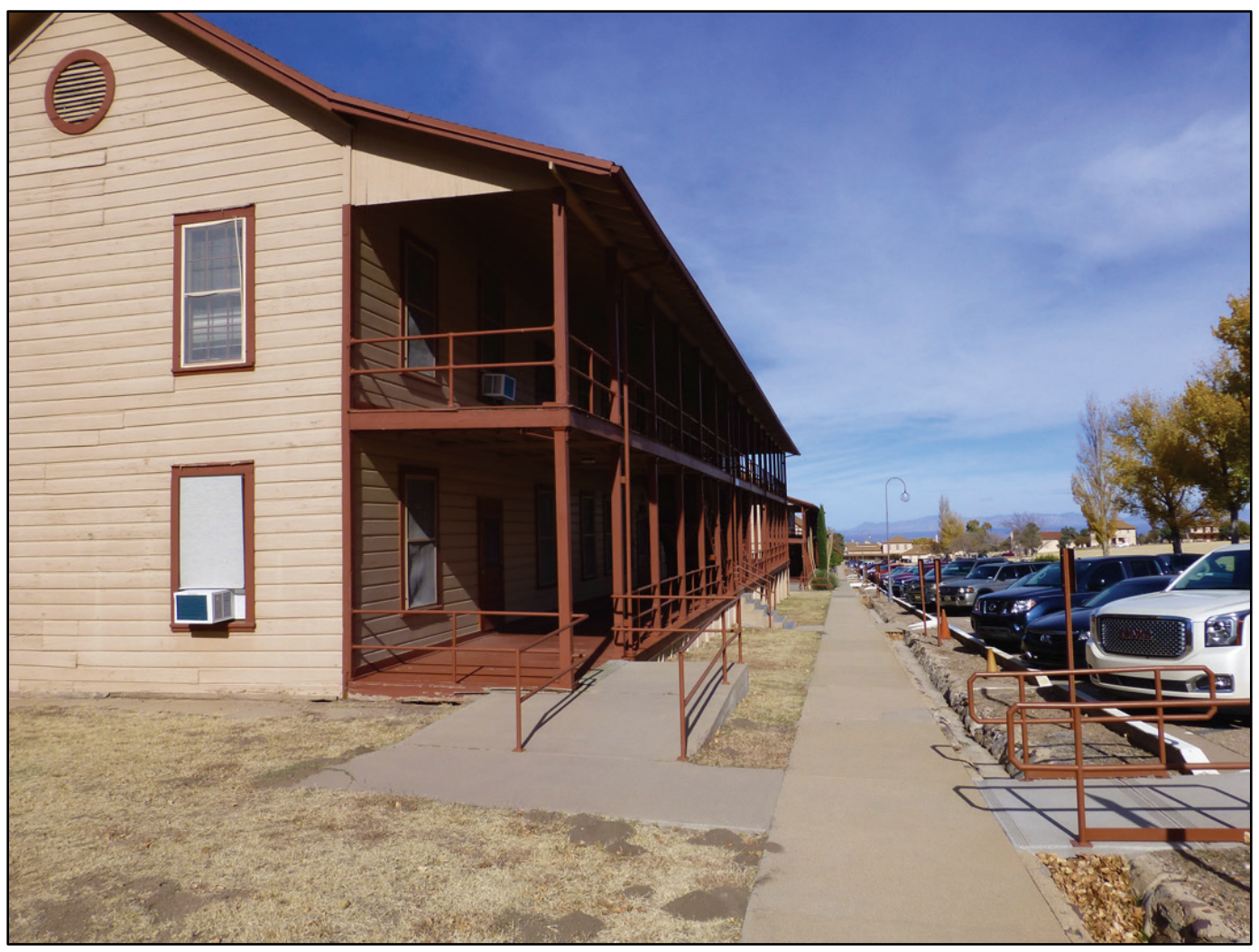


Figure 92. Looking west at front of barracks (22214) (ERDC-CERL, 2016). Note the lack of vegetation planted in front of barracks.

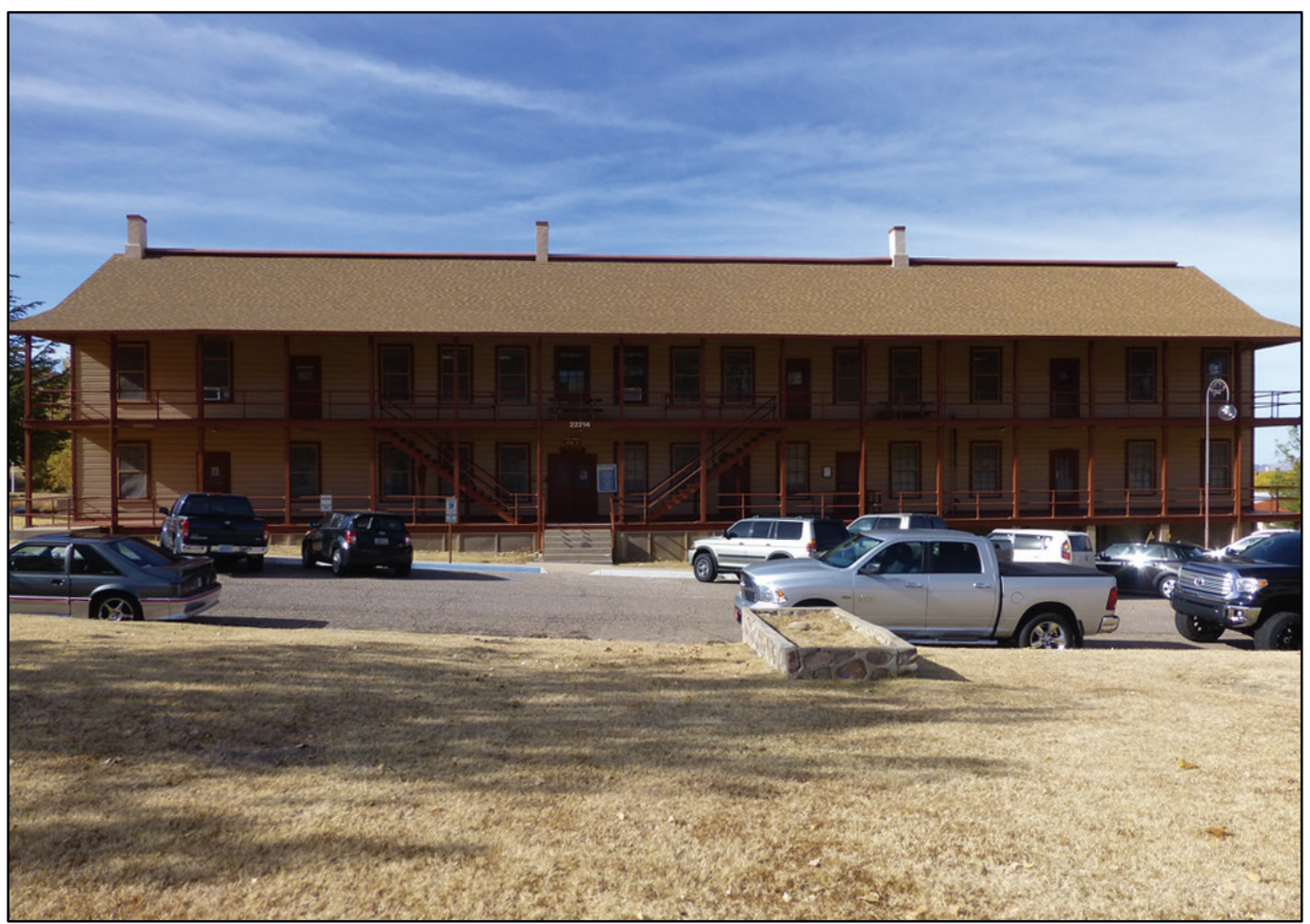

Figure 93. Looking west at front of barracks (22216). Note foundation plantings. (ERDCCERL, 2016).

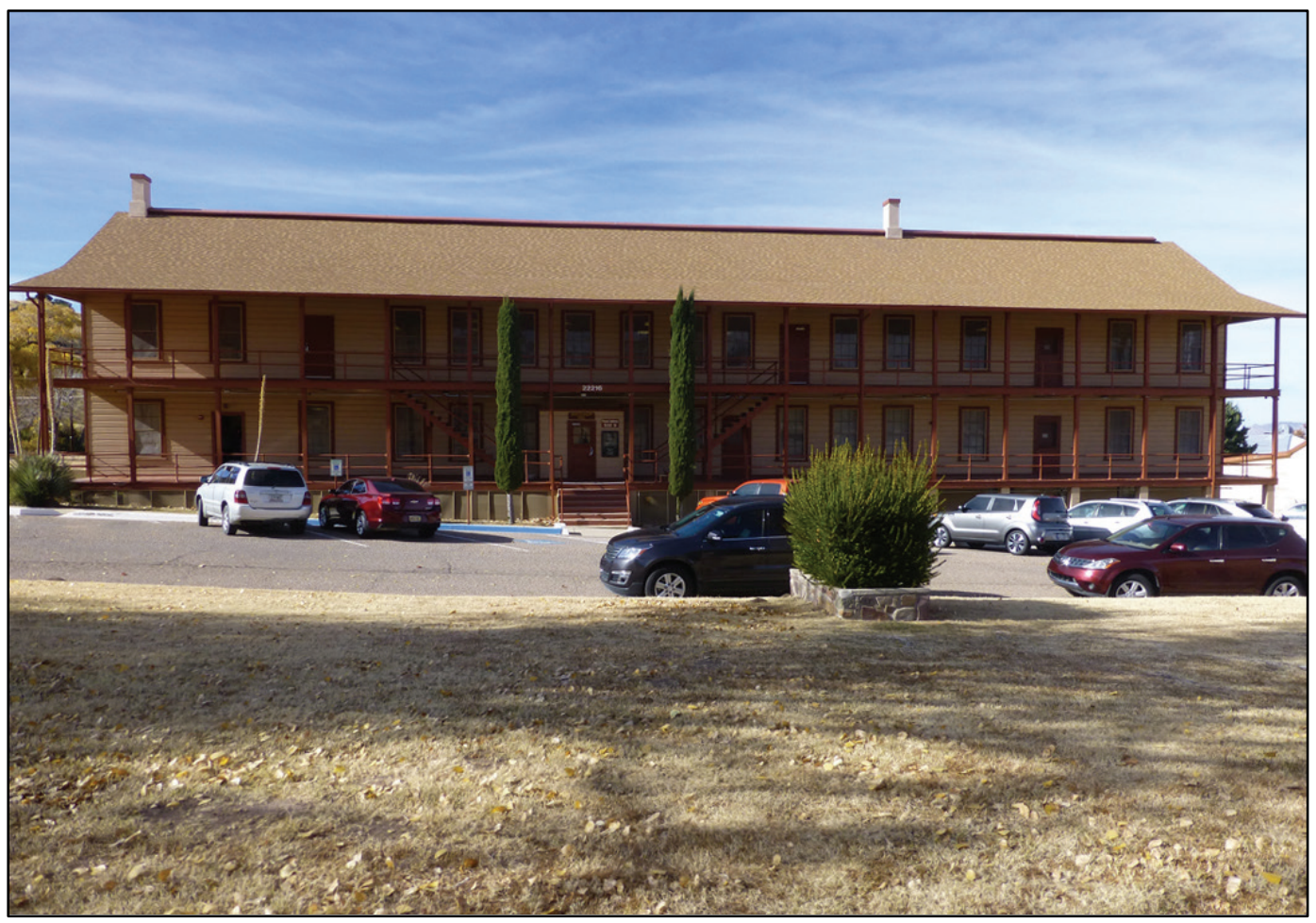


Figure 94. Looking west between barracks (22216 and 22320) (ERDC-CERL, 2016).

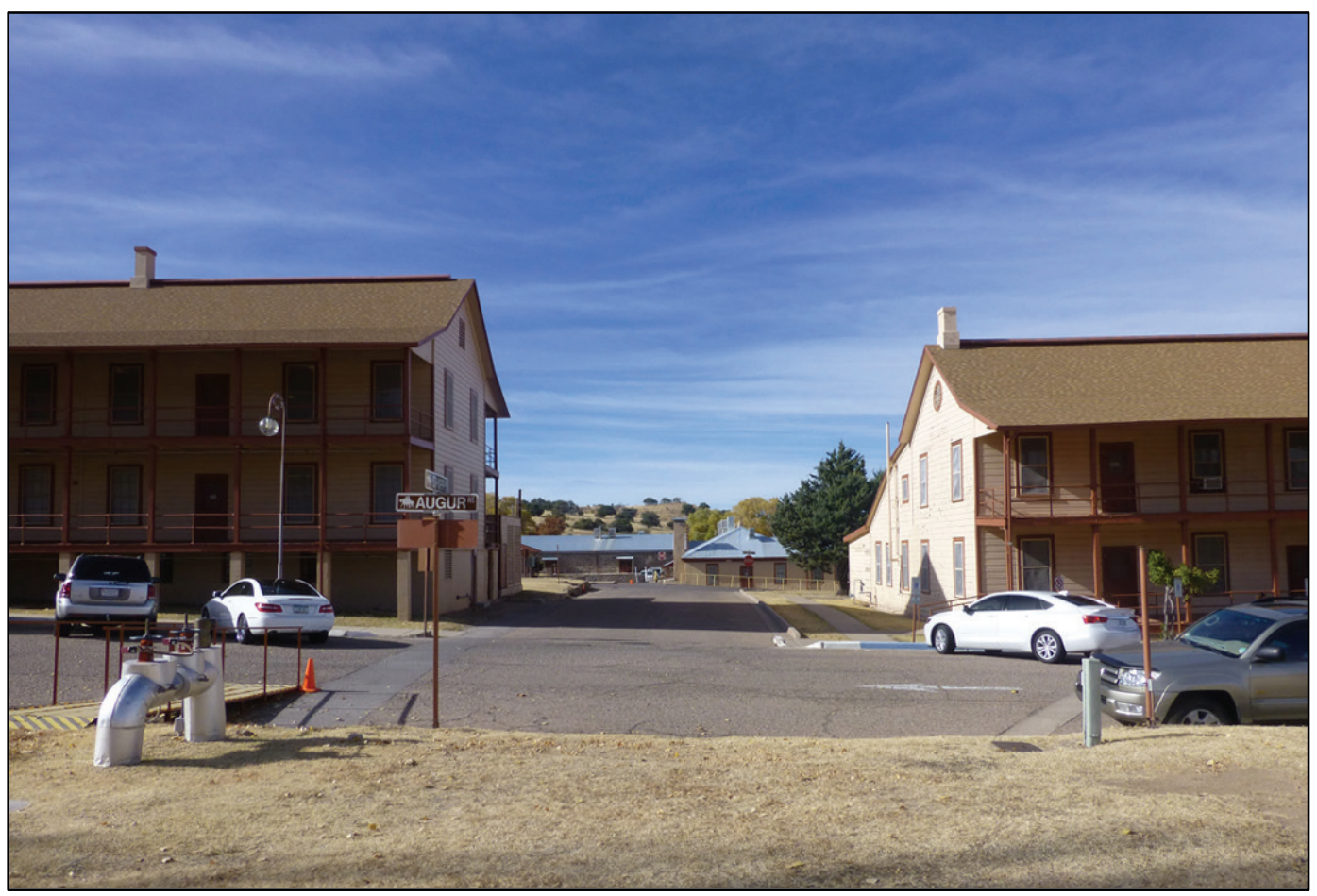

Figure 95. Looking west at barracks (22320) from Brown Field (ERDC-CERL, 2016).

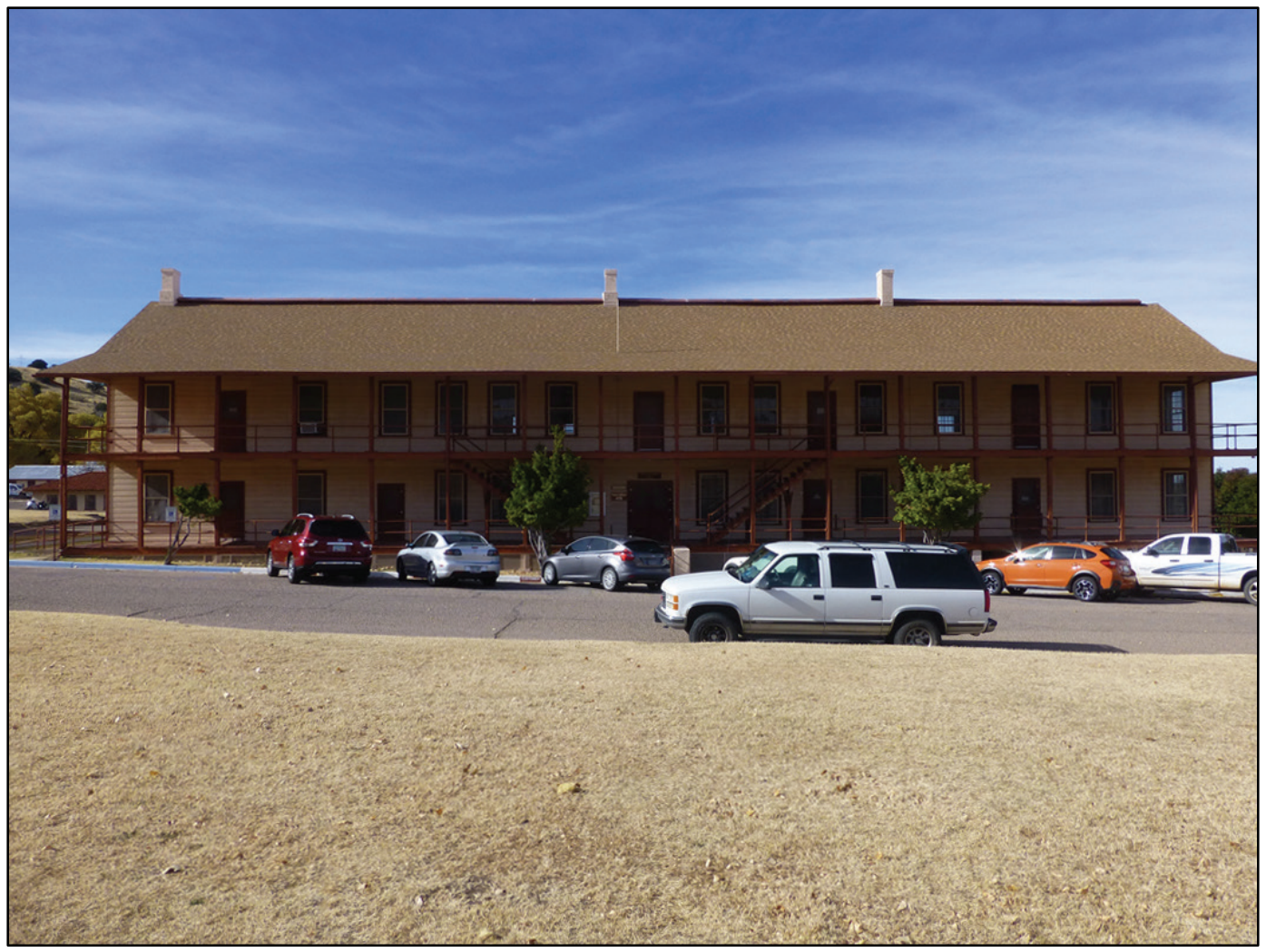


Figure 96. Looking south at sidewalks and parking in front of 22332 along Augur Avenue (ERDC-CERL, 2016).

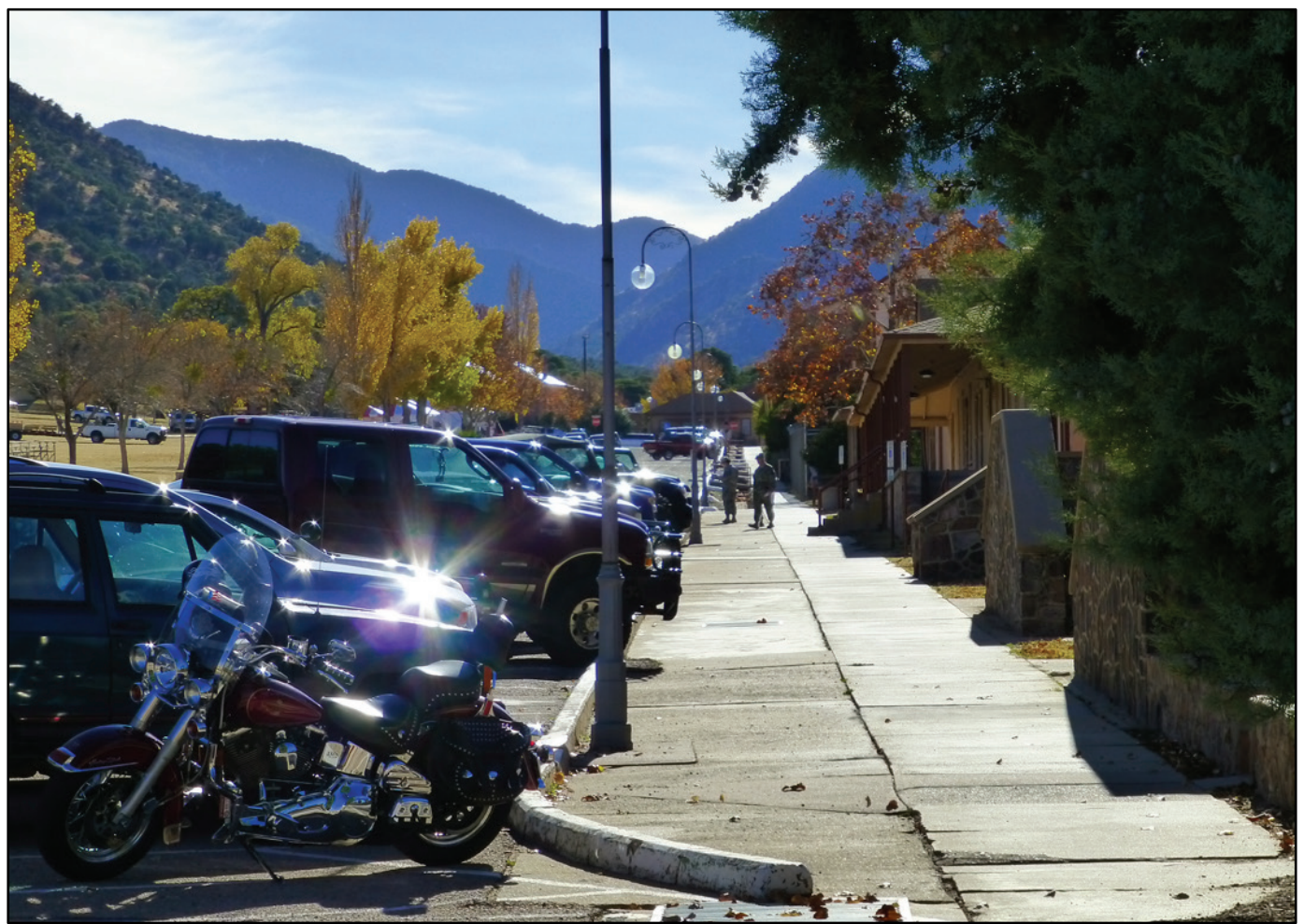

Figure 97. Shrub growth too close to building in front of 22320 (ERDC-CERL, 2016).

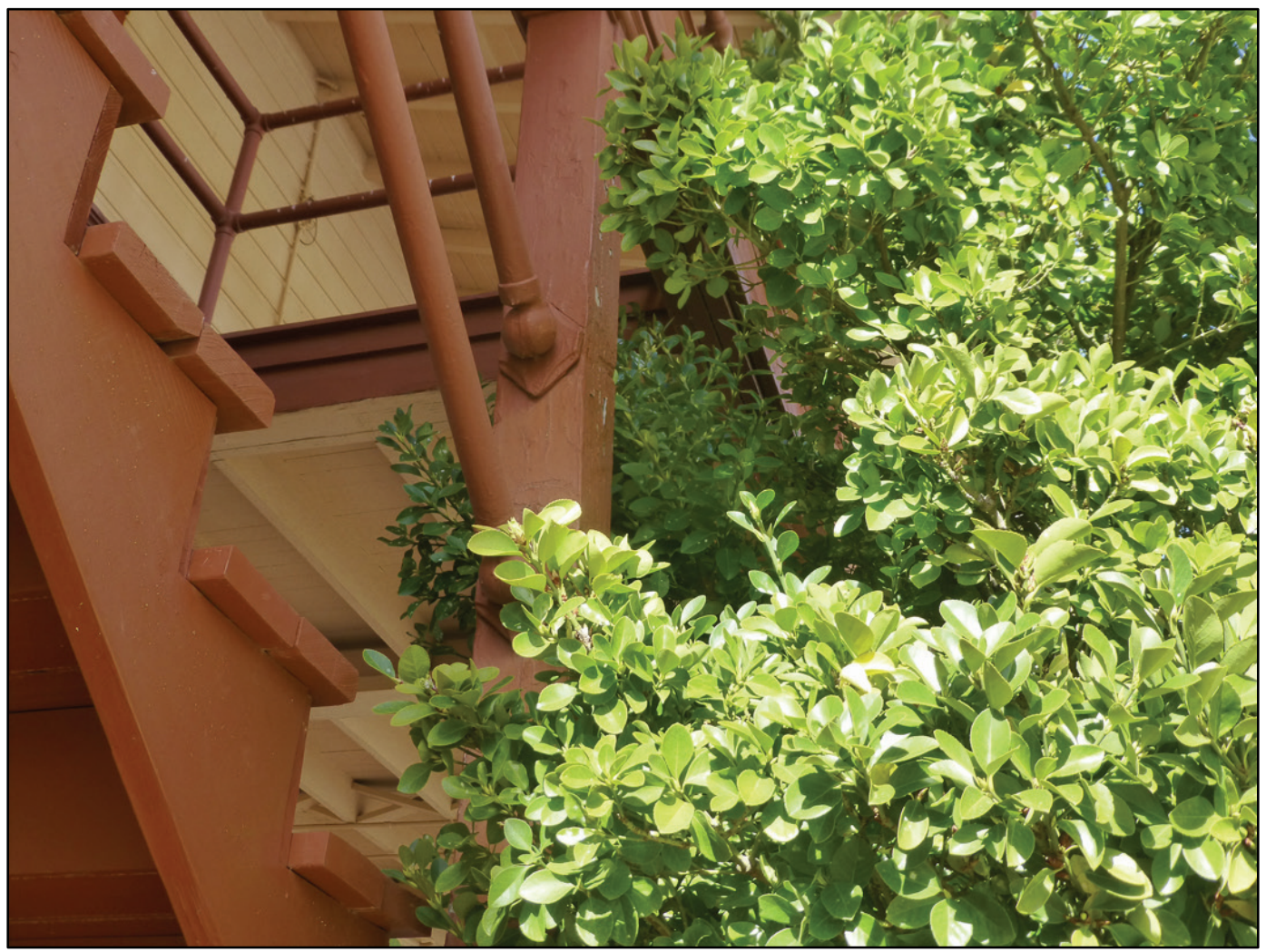


Figure 98. Concrete sidewalk and stone wall at entrance to barracks (22320). Note modern metal wildlife mesh under porch. (ERDC-CERL, 2016).

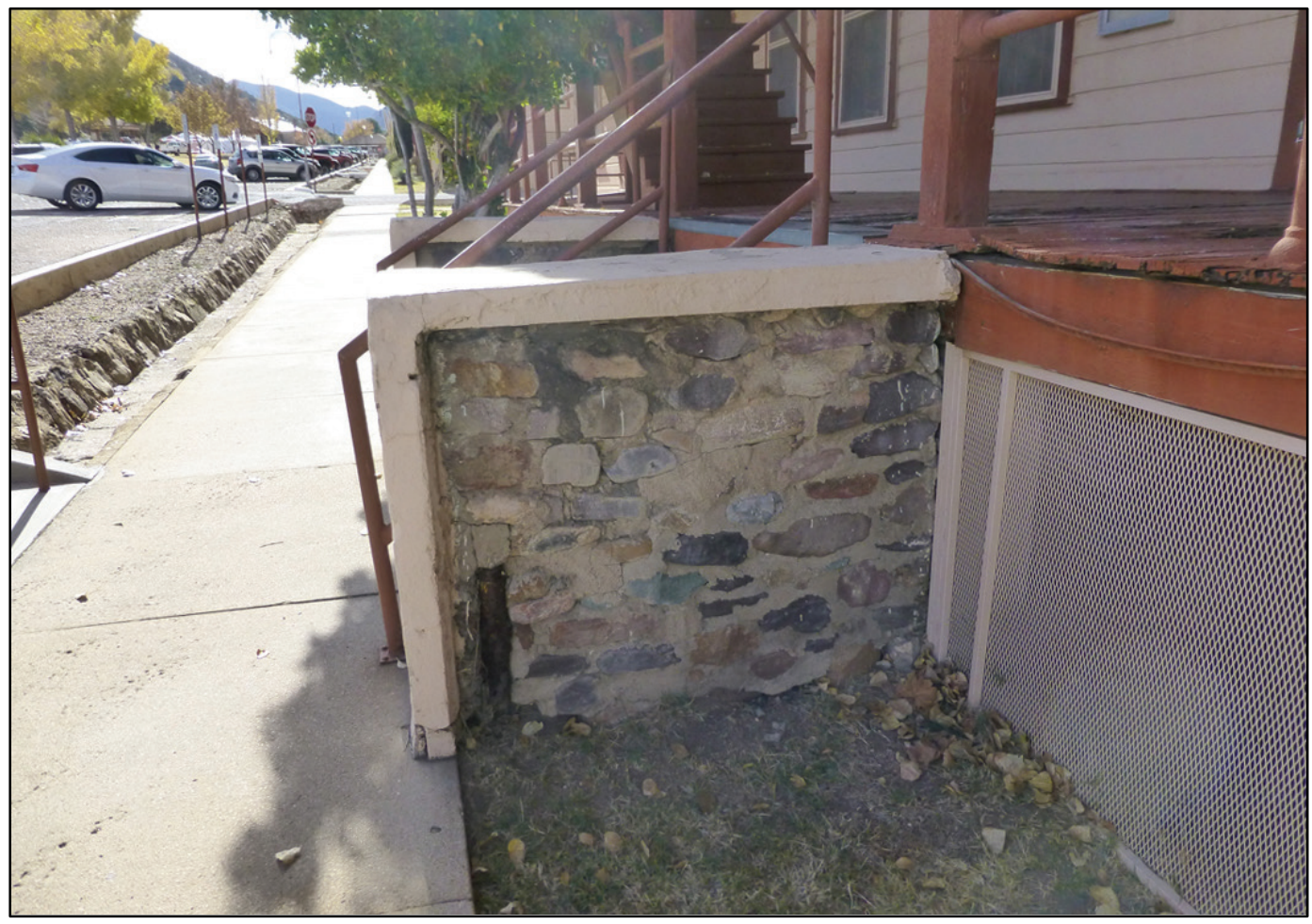

Figure 99. View looking north at shrubs between 22320 and 22324. Note curb along Augur Avenue (ERDC-CERL, 2016).

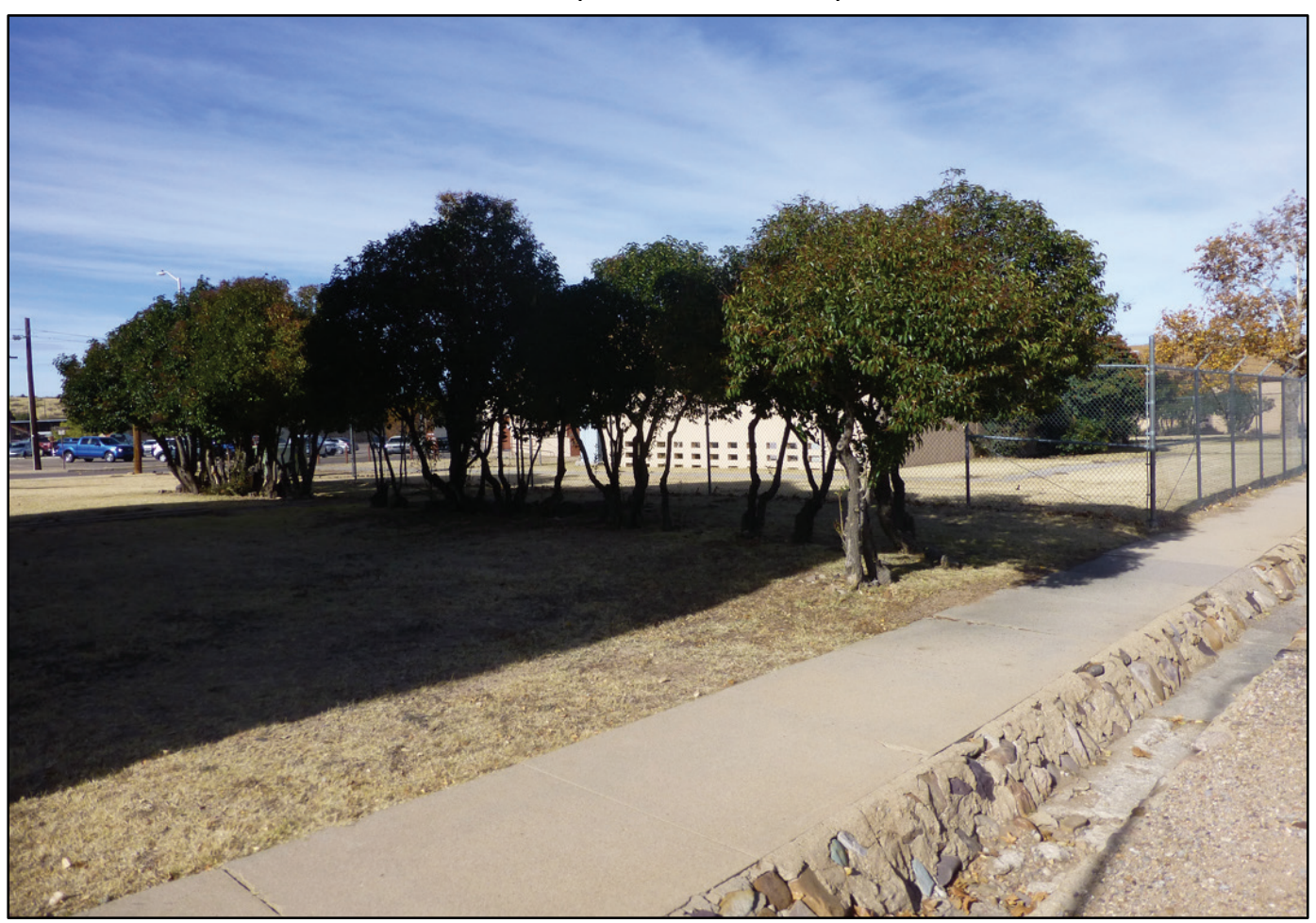


Figure 100. Looking south at drainage ditch and air conditioning at rear of 22320 (ERDCCERL, 2016).

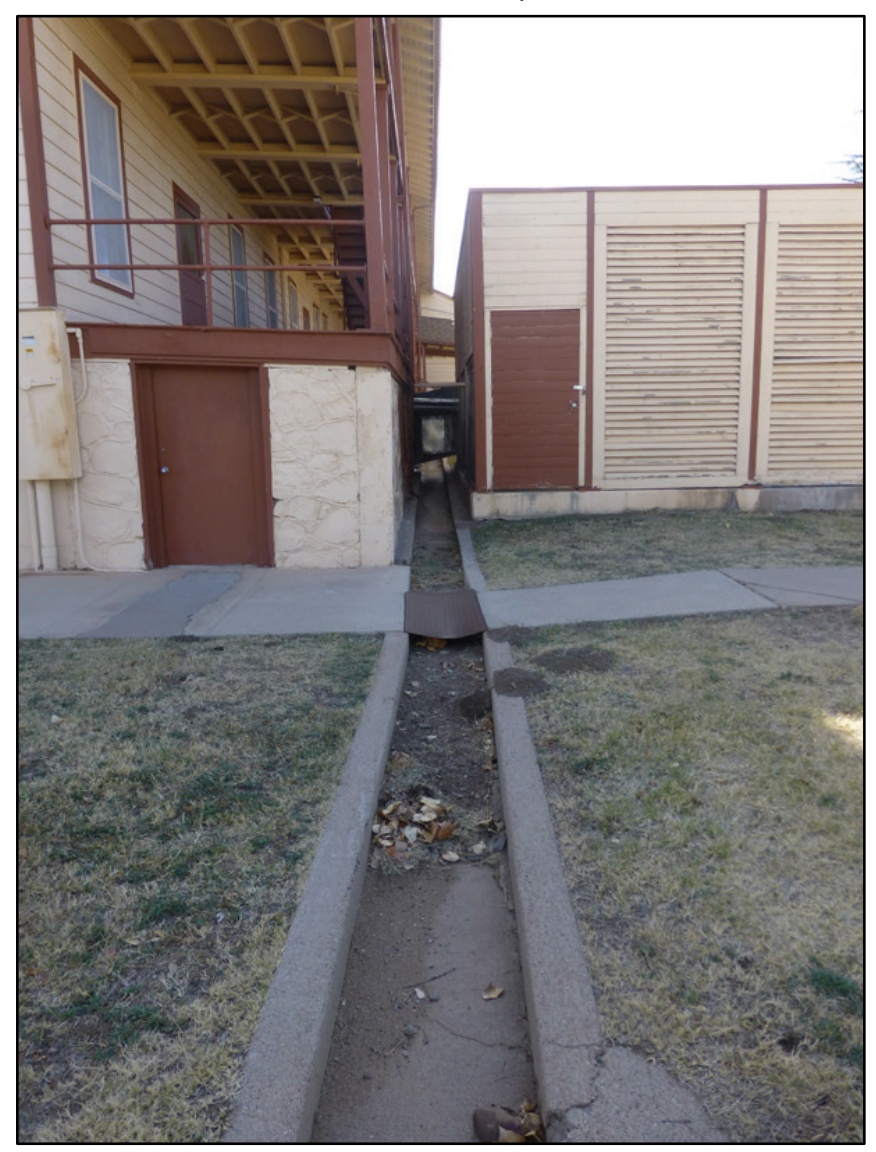

Figure 101. Looking south at electrical units behind 22320 (ERDC-CERL, 2016).

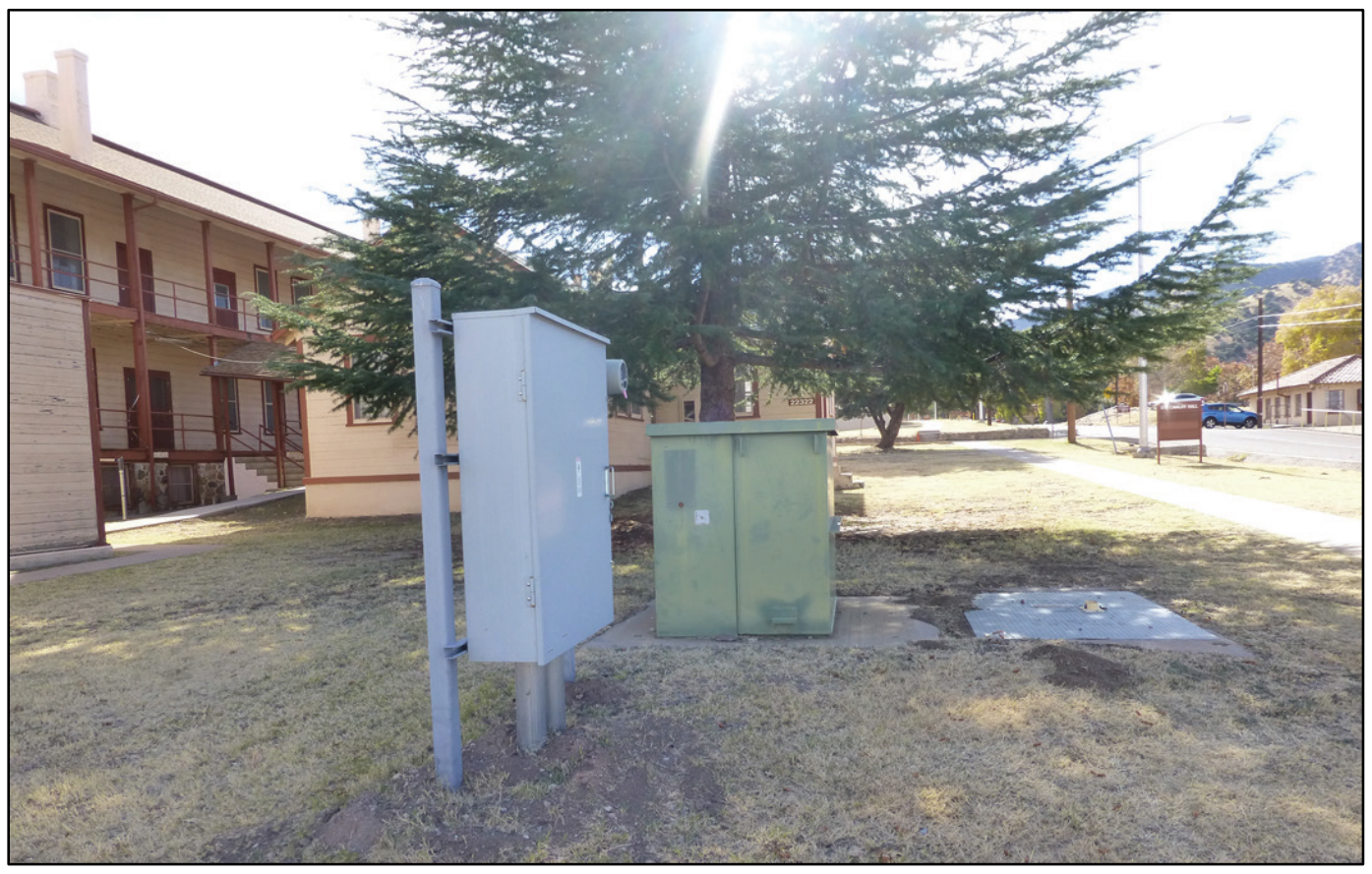


Figure 102. Looking east at concrete sidewalk and latrine (22322) (ERDC-CERL).

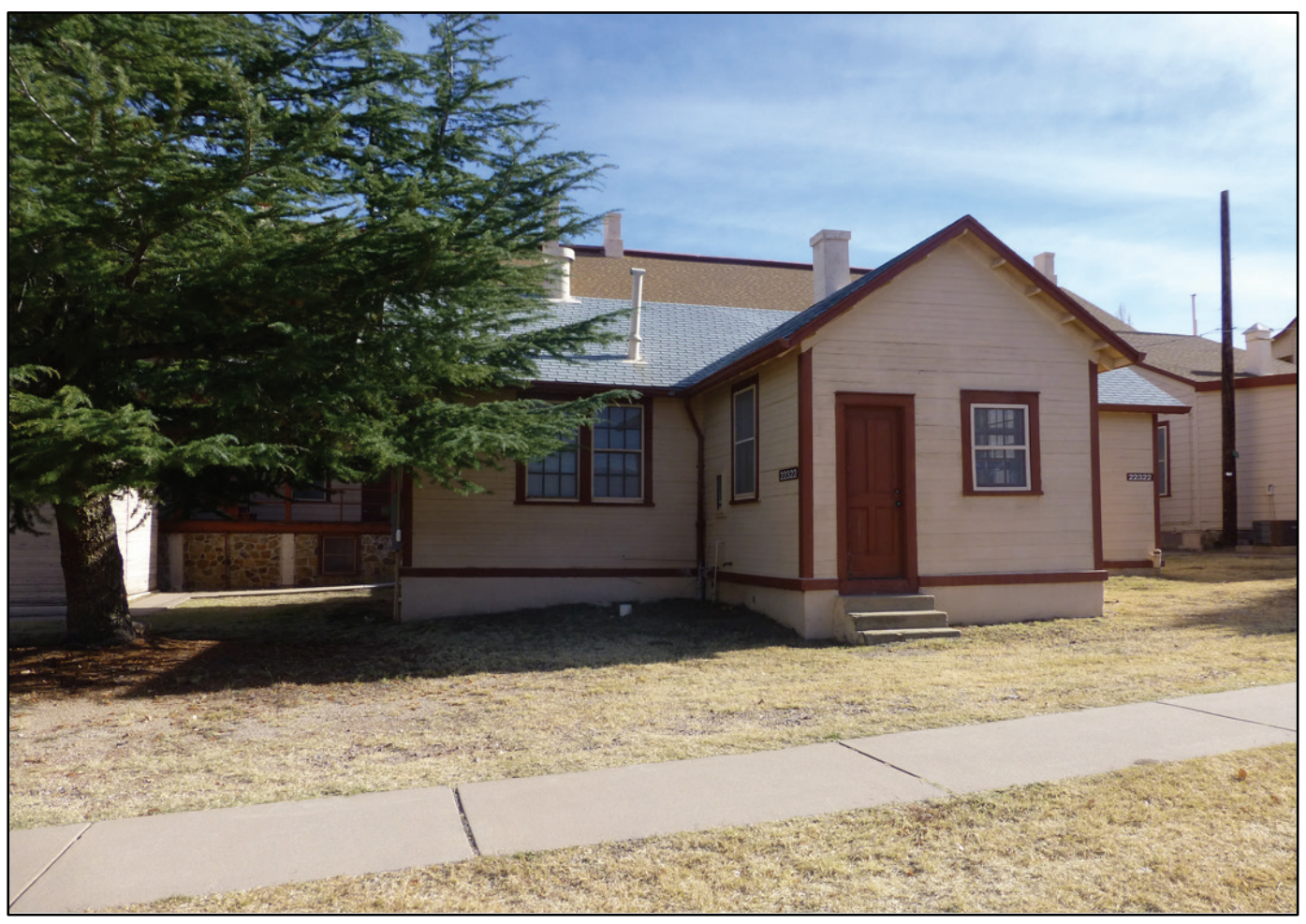

Figure 103. View looking north at sidewalk and tree behind 22320 (ERDC-CERL, 2016).

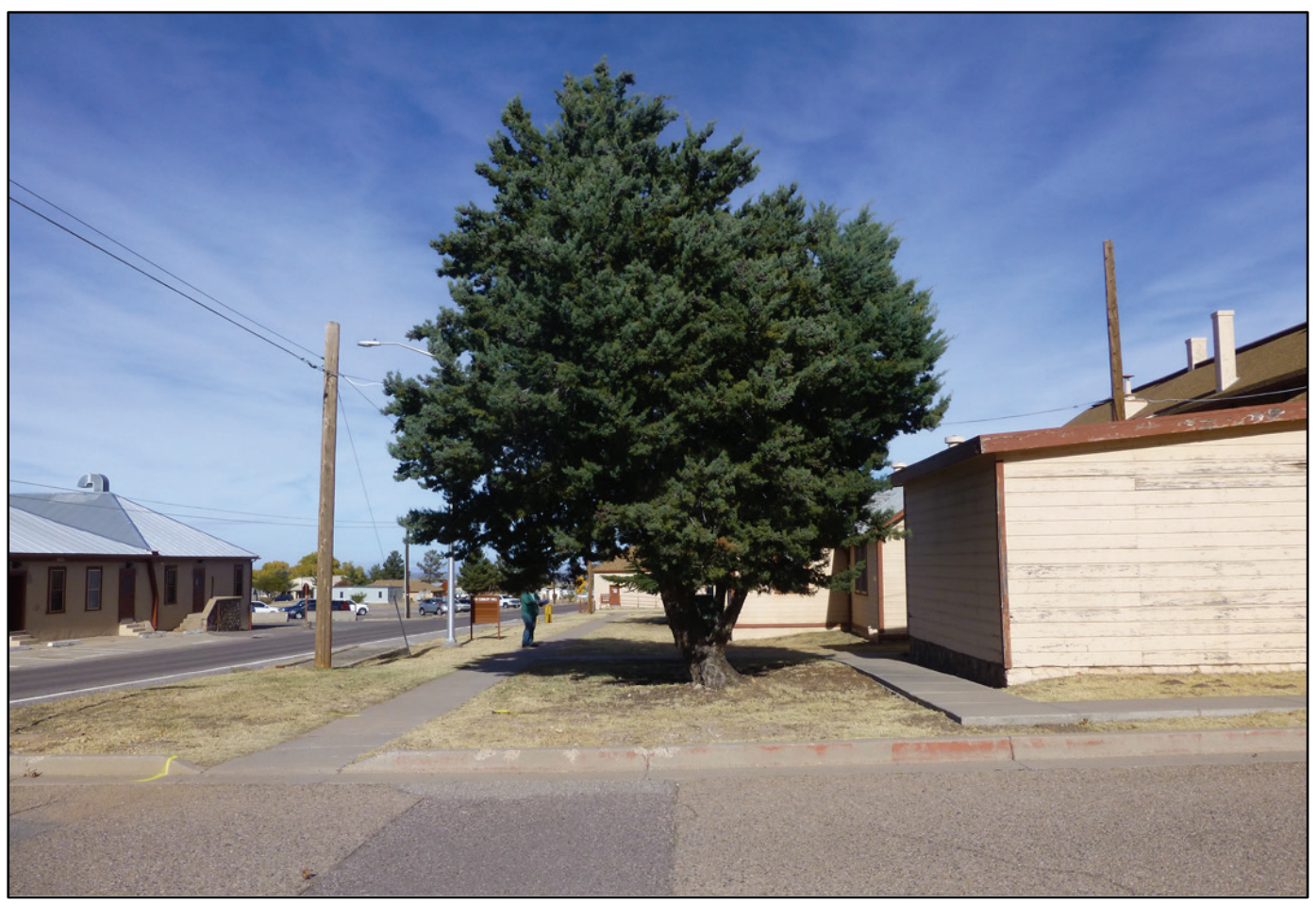


Figure 104. View looking south at seating and landscaping between 22316 and 22318 (ERDC-CERL, 2016).

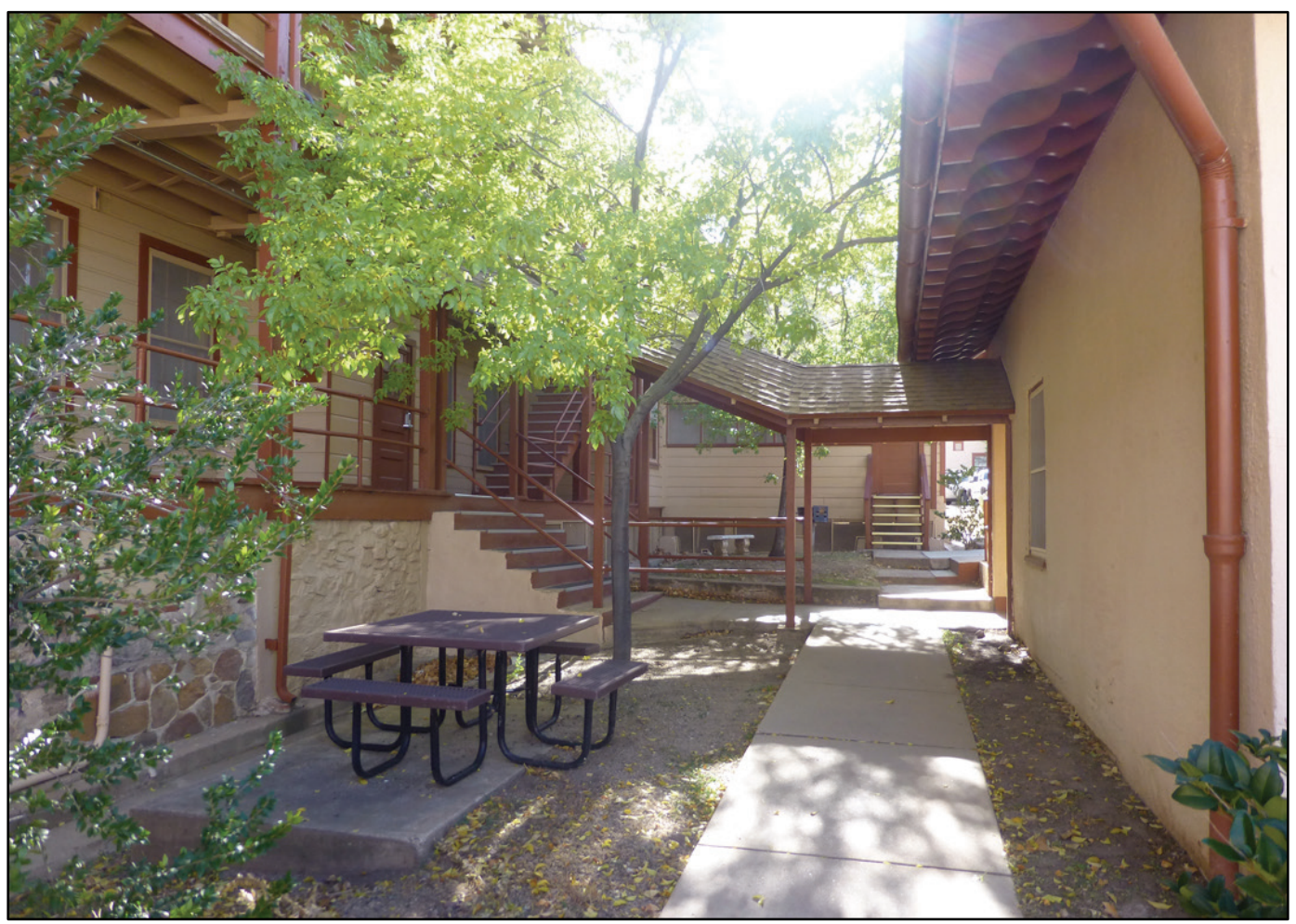

Figure 105. View looking south at seating and barbecue behind 22320 (ERDC-CERL, 2016).

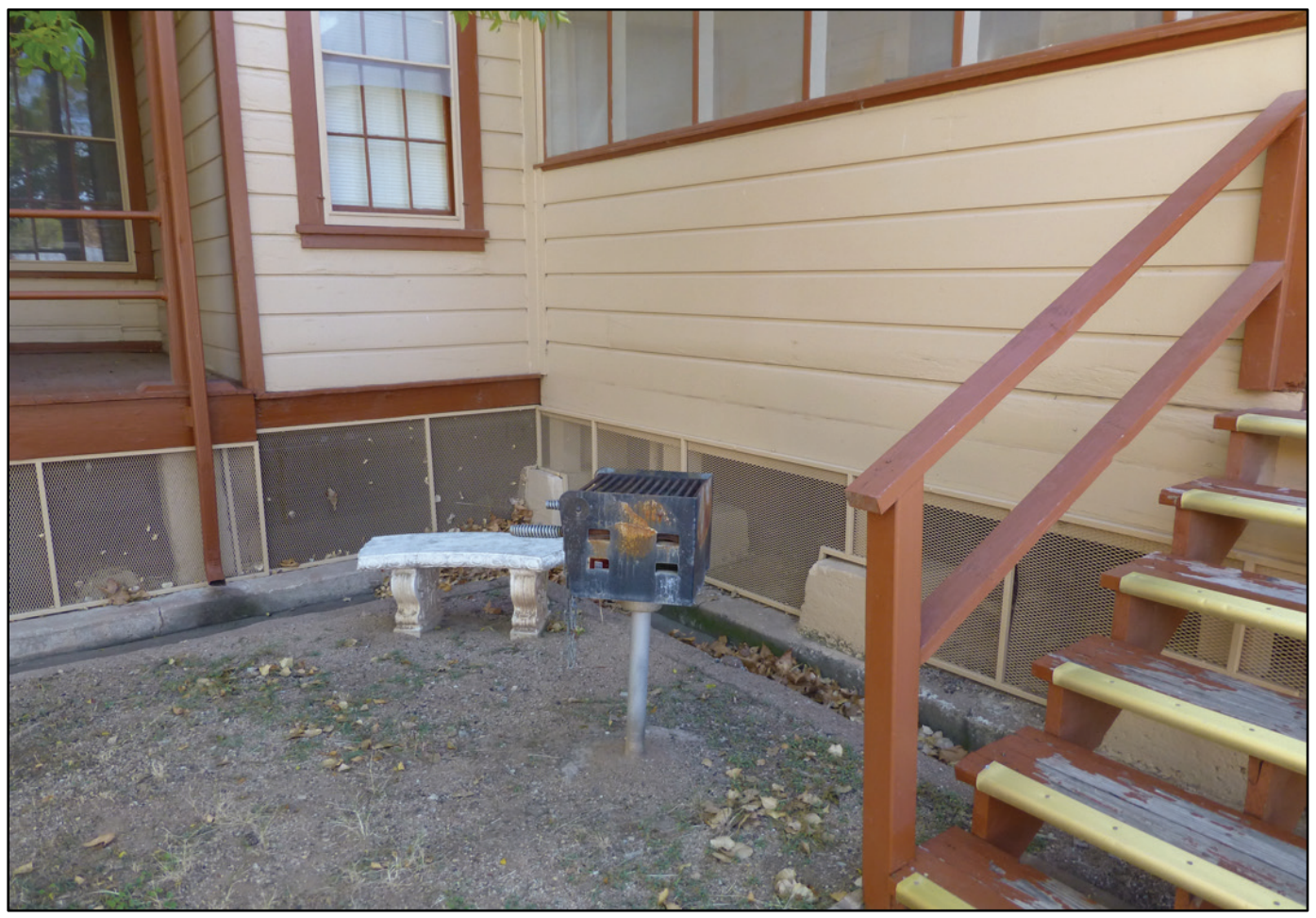


Figure 106. View looking southeast at landscaping between 22216 and 22214 (ERDC-CERL, 2016).

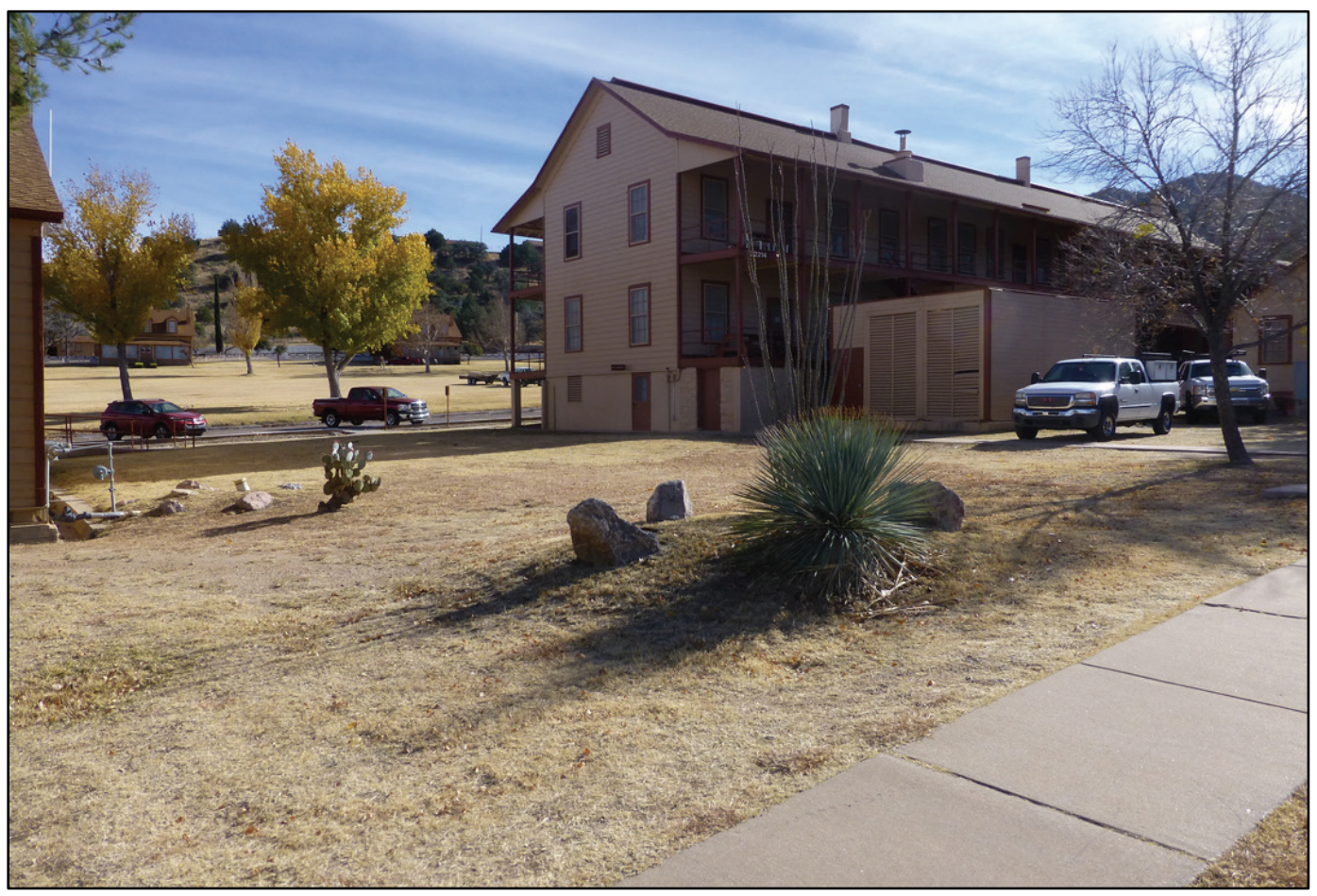

Figure 107. View looking northwest at landscaping in front of 22214 (ERDC-CERL, 2016).

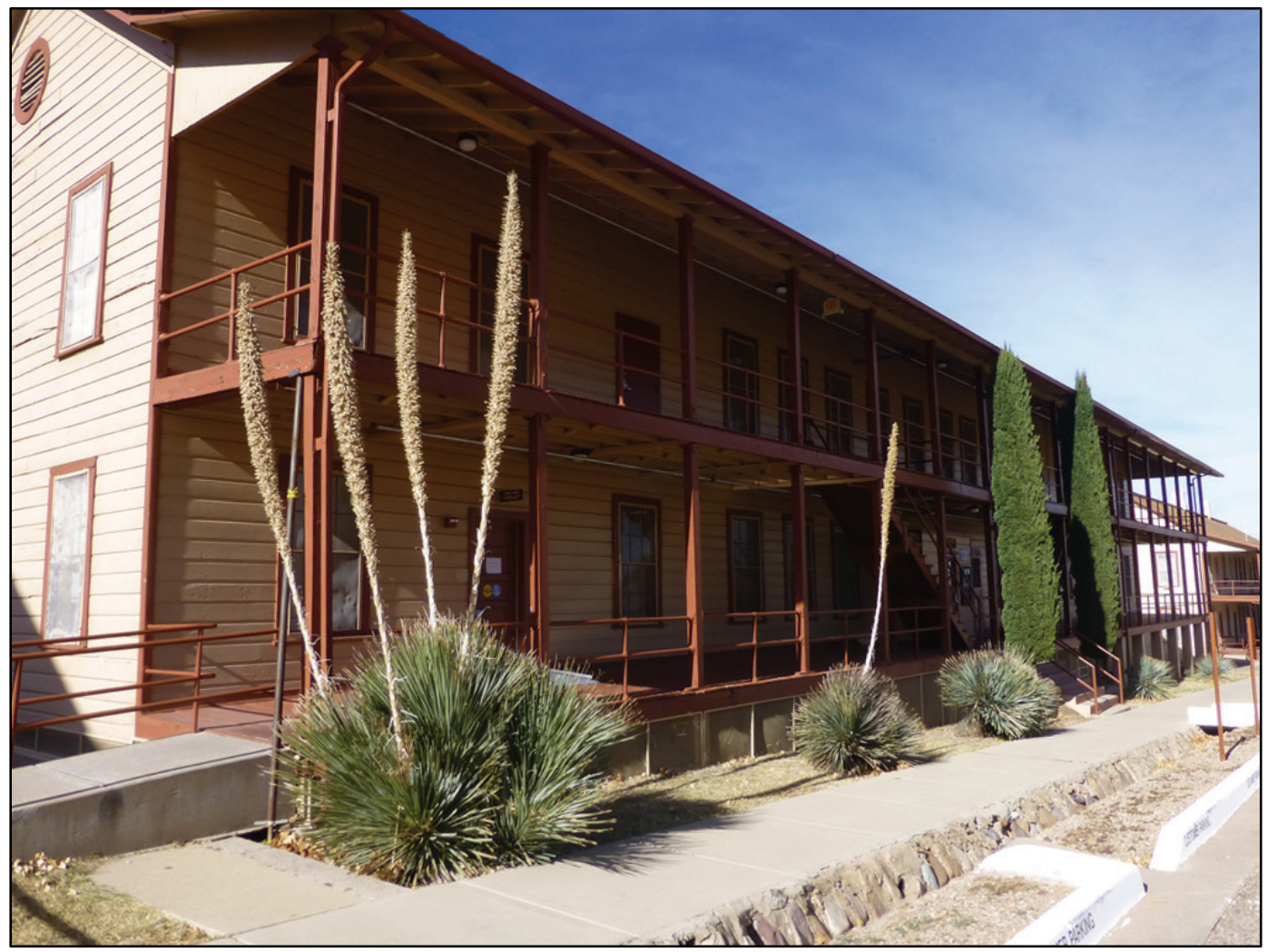


Figure 108. View looking east at the front of Sam Kee Hall, former guard house (22328) (ERDC-CERL, 2016).

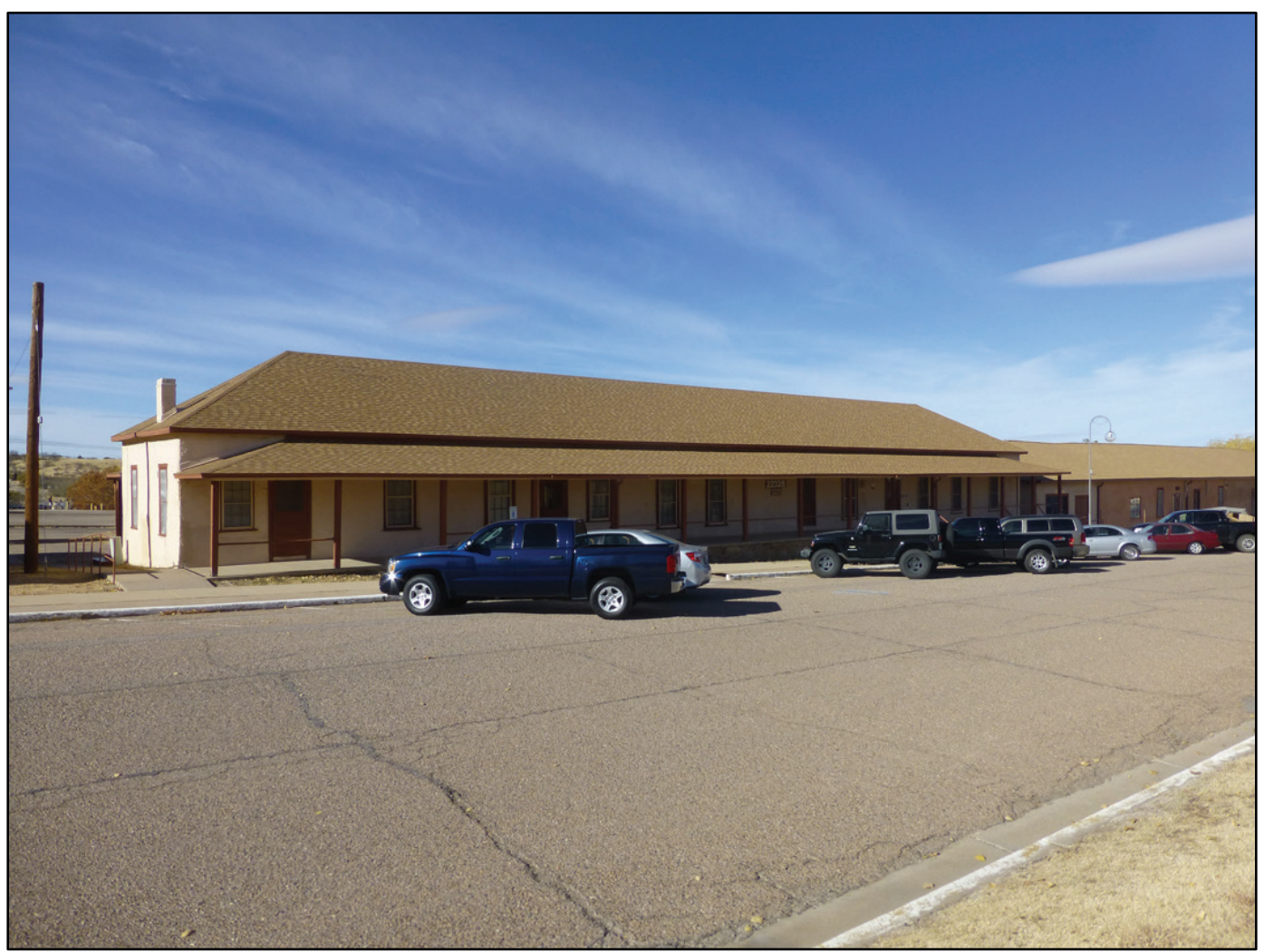

Figure 109. View looking west of the front of former school/post office (22326) (ERDC-CERL, 2016).

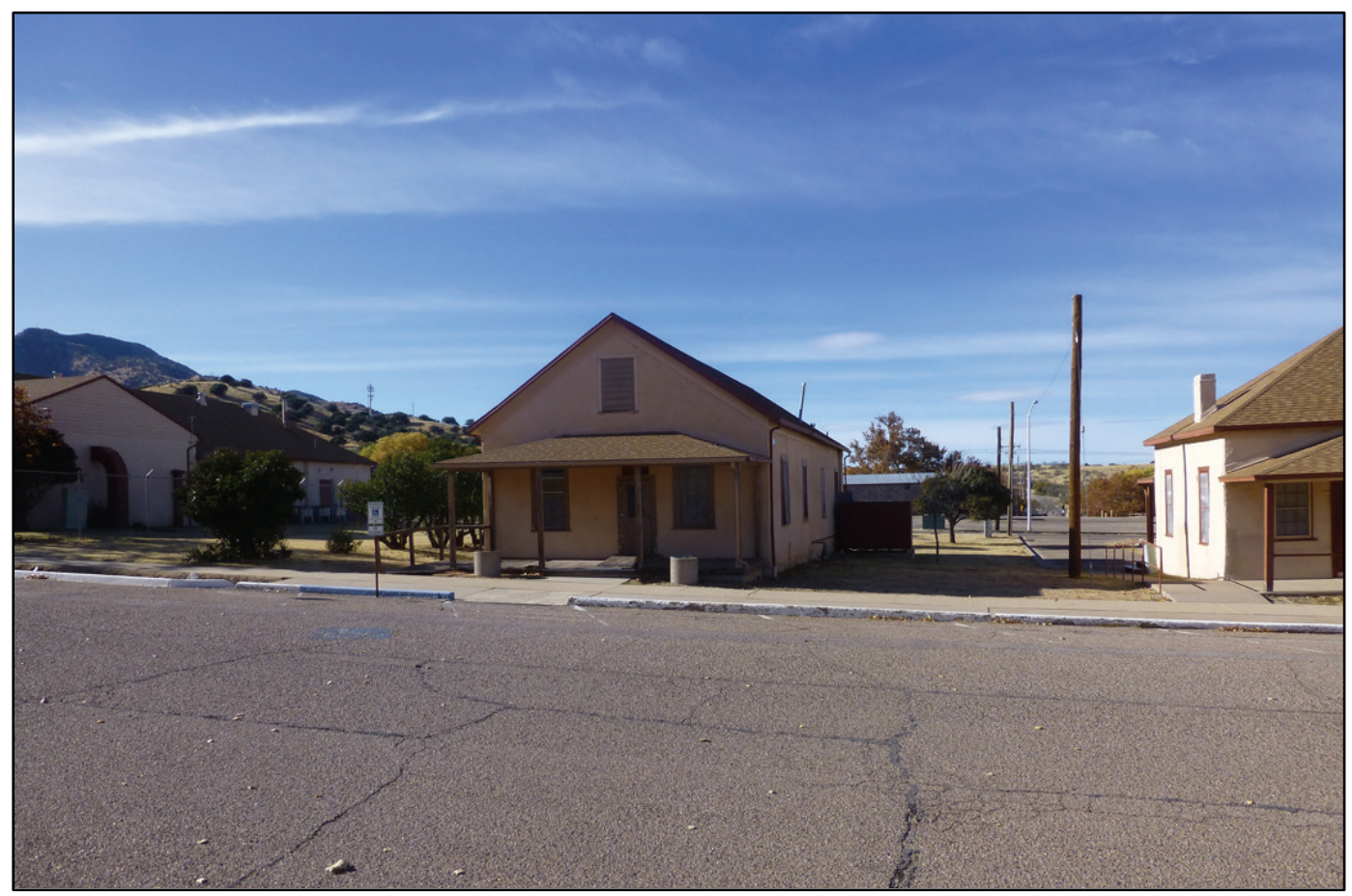


Figure 110. View of the east side of 22332 (ERDC-CERL, 2016).

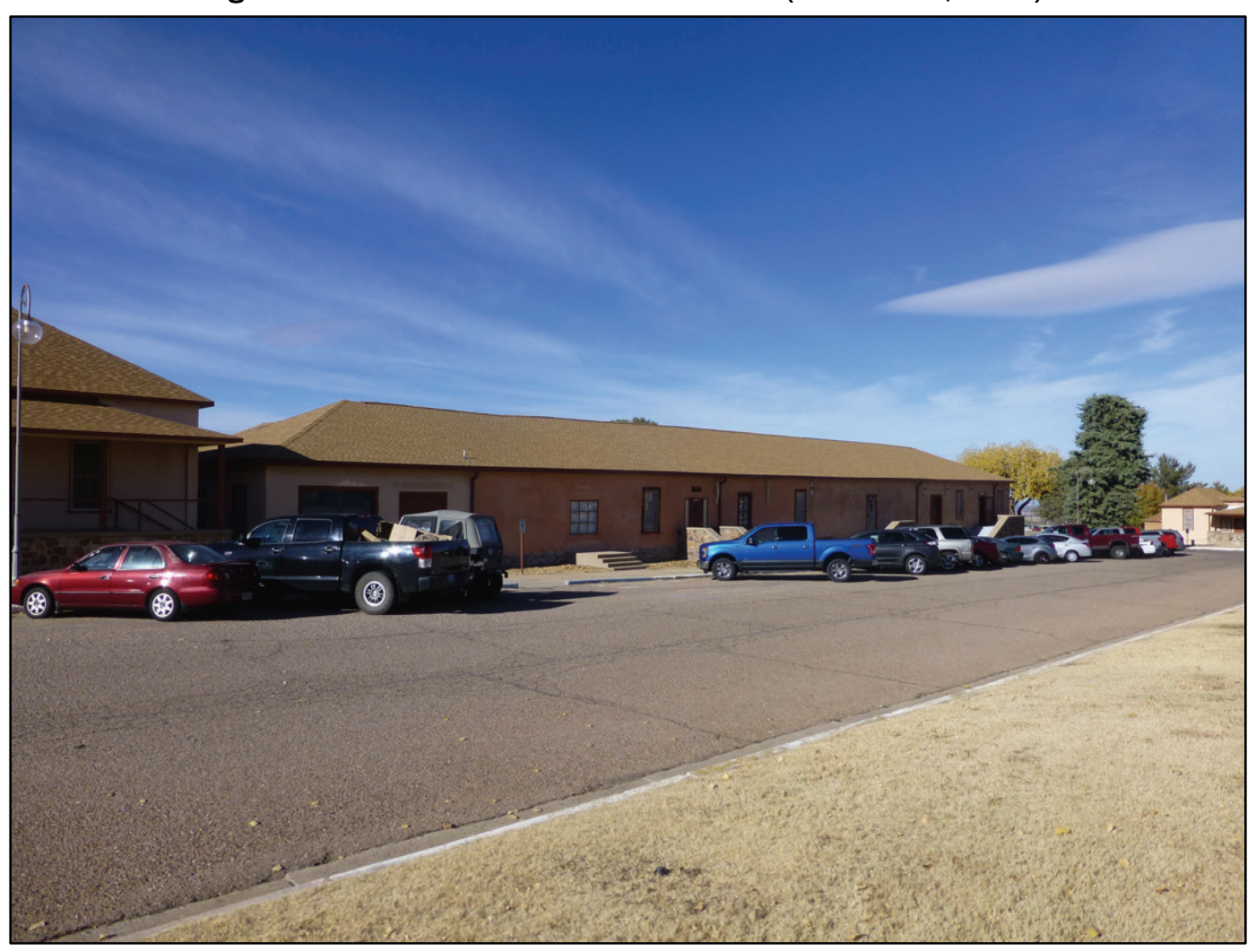

Figure 111. View looking north of detail of stairs on 22332 (ERDC-CERL, 2016).

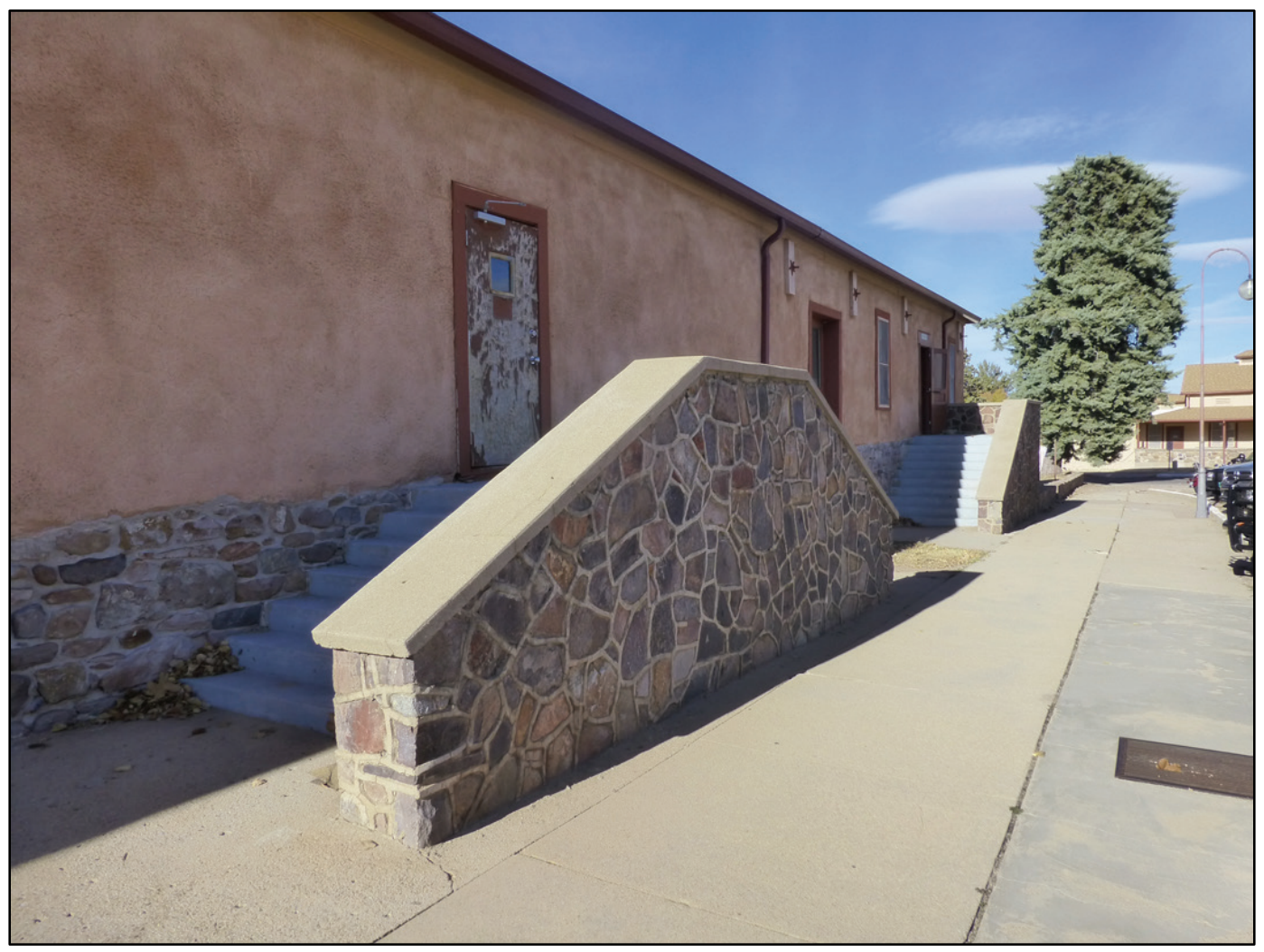


Figure 112. Looking west at landscaping between Boyd Avenue and 22332 and 22336 (ERDC-CERL, 2016).

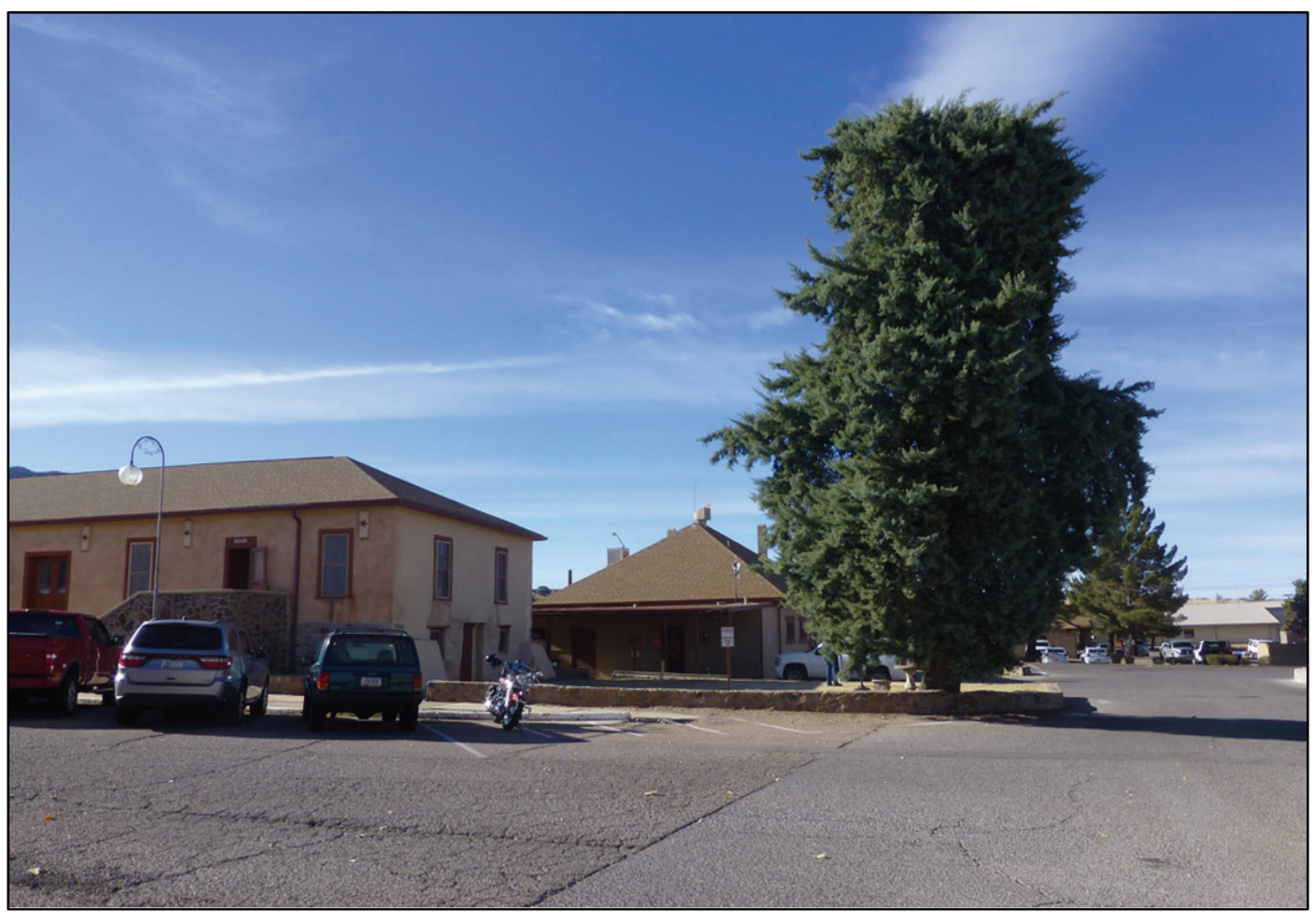

Figure 113. Looking southeast at the northwest corner of 22336 and concrete sidewalk and metal handrails (ERDC-CERL, 2016).

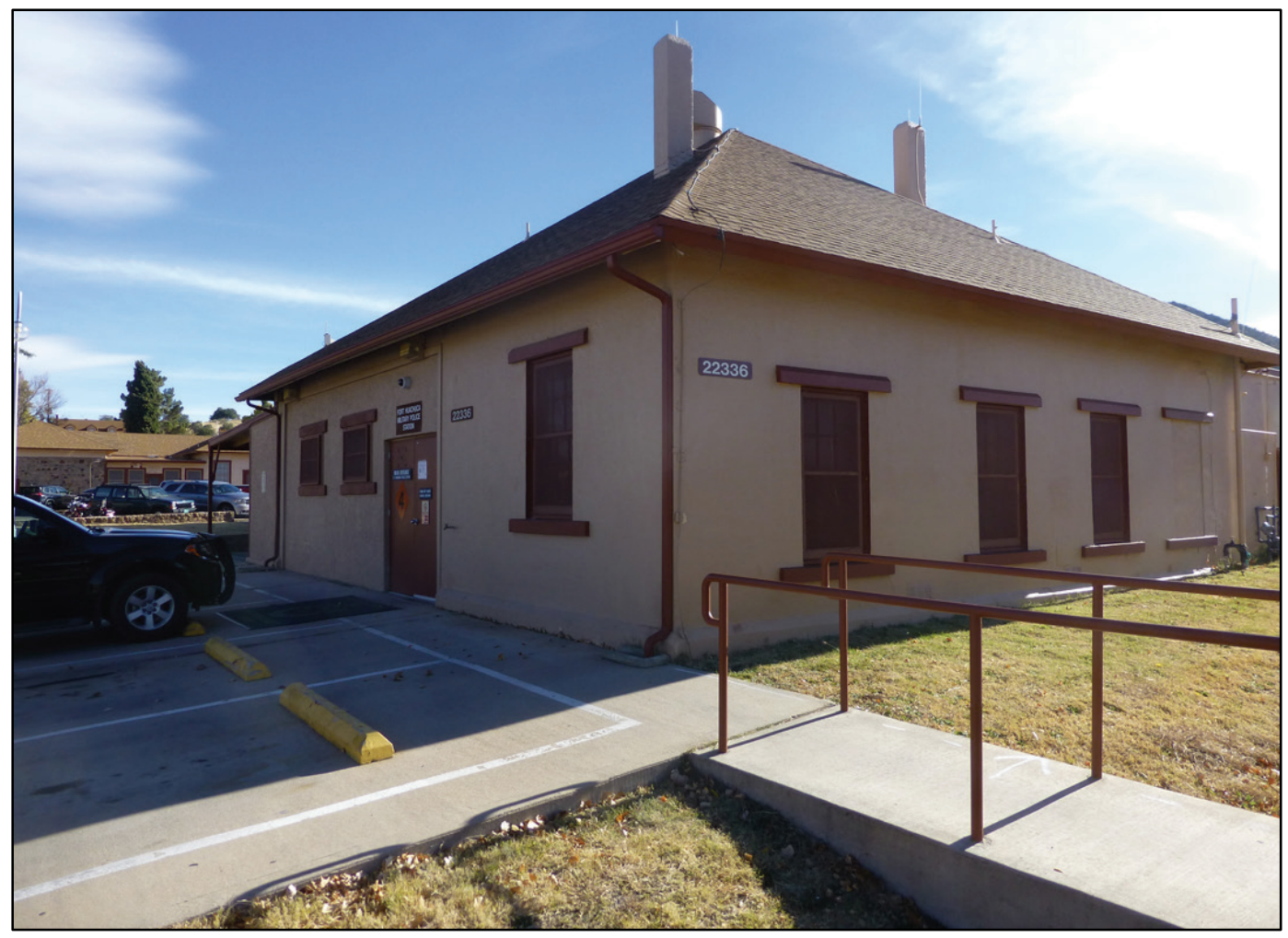


Figure 114. View to the south of 22336 and concrete sidewalk and metal handrails (ERDCCERL, 2016).

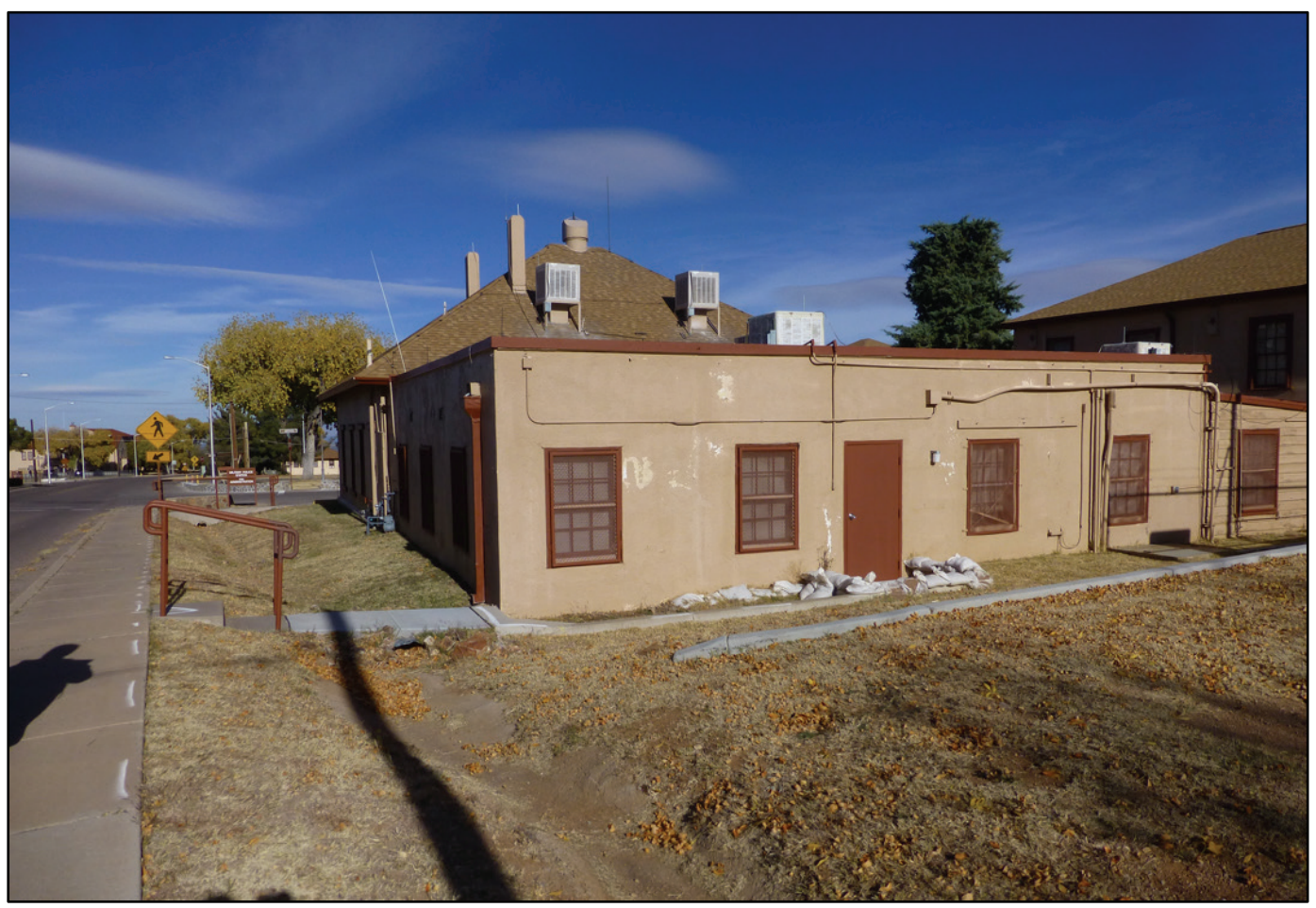

Figure 115. View looking east at parking area behind 22328 with 22330 in right foreground (ERDC-CERL, 2016).

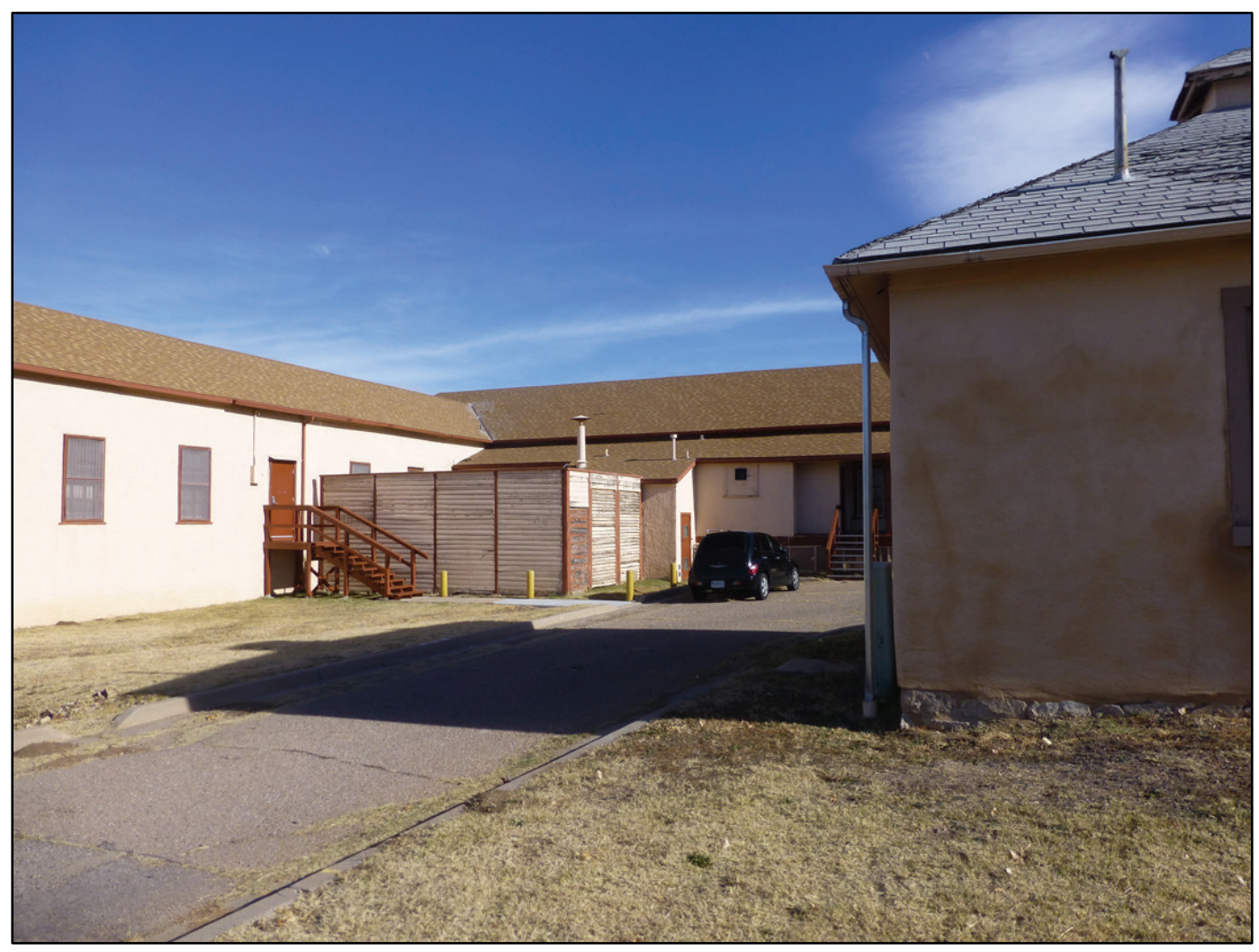


Figure 116. View looking east of the northwest oblique of 22330 and concrete sidewalk and concrete Americans with Disabilities Act (ADA) ramps (ERDC-CERL, 2016).

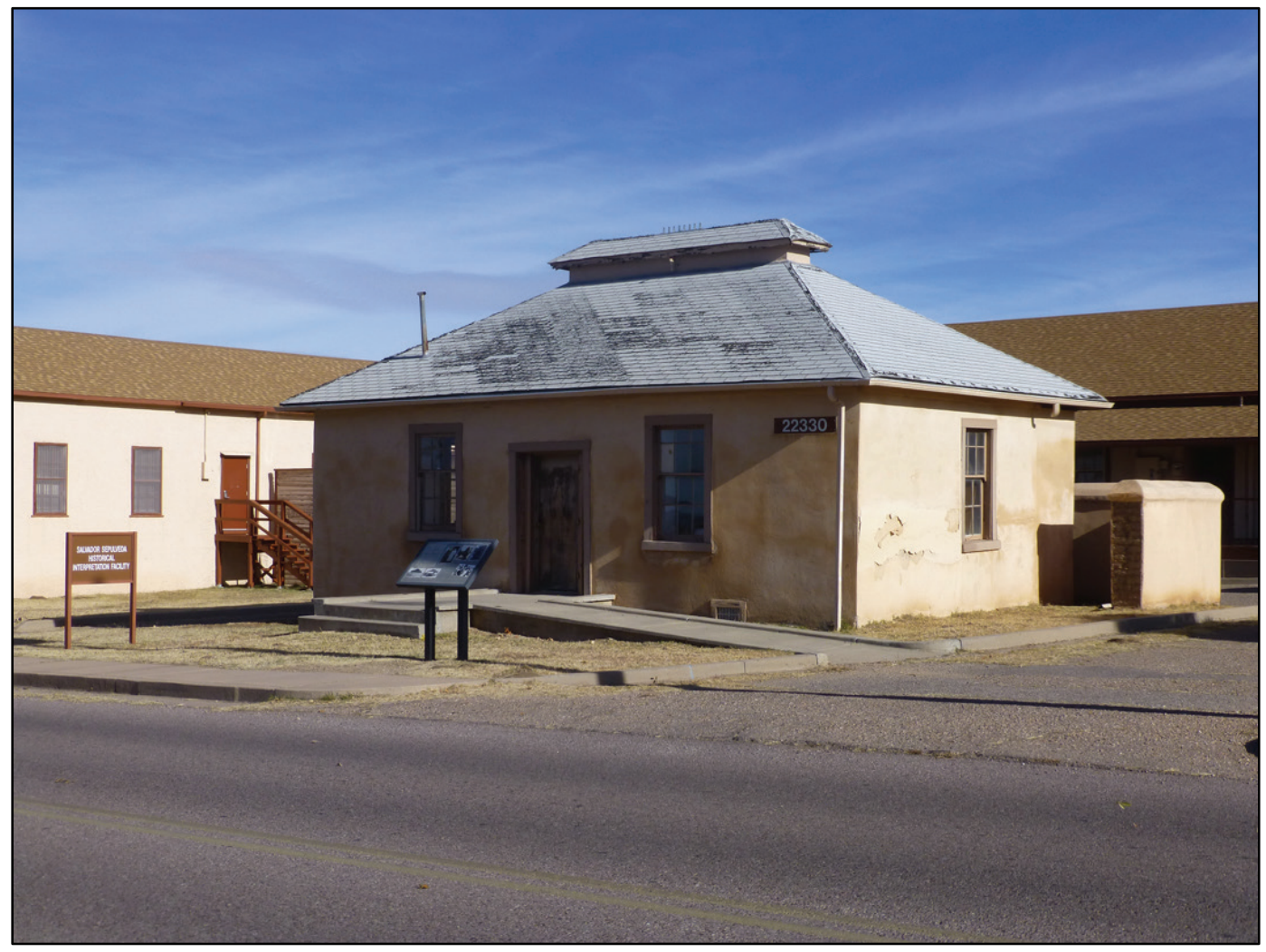

Figure 117. View to the east of 22326 from Christy Avenue (ERDC-CERL, 2016).

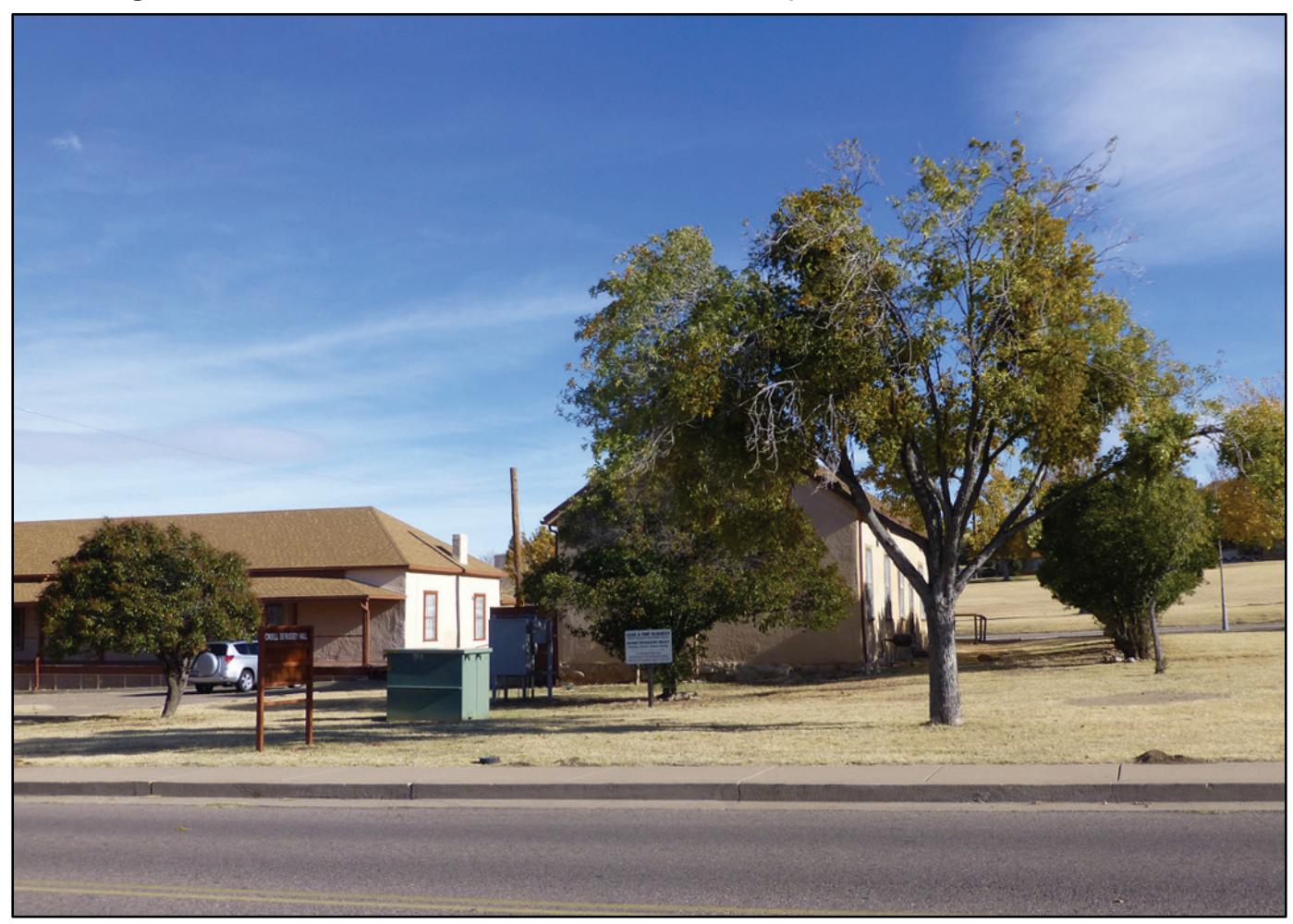


Figure 118. View to the southeast of 22326 and 22324 and power pole and electrical equipment (ERDC-CERL, 2016).

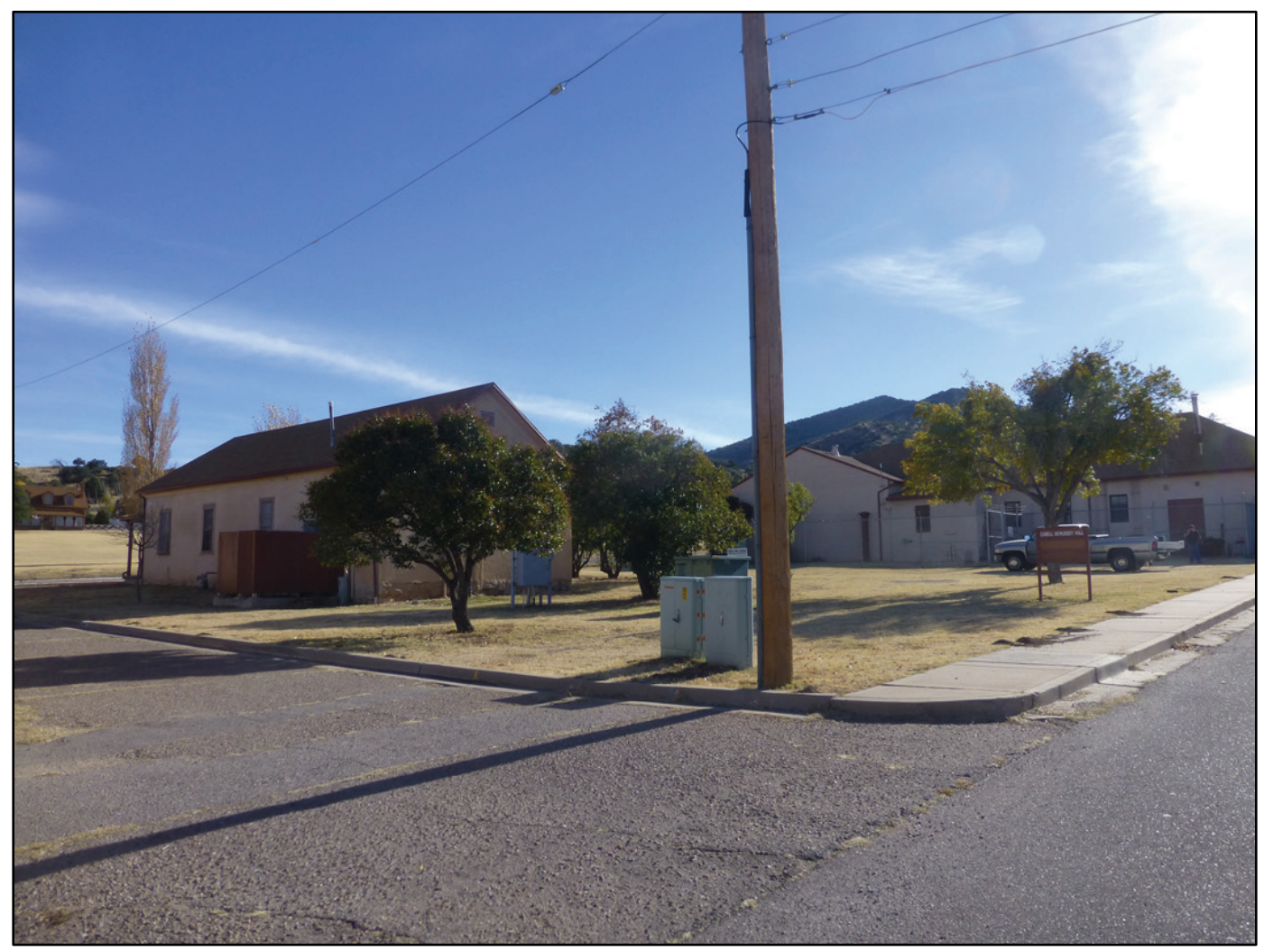

\subsubsection{Significance and integrity}

The barracks and other buildings in this landscape area have high significance as they were part of the original frontier post and the architecture, materials, and workmanship. In addition, their locations and settings adjacent to the parade field and the other original post building are still the same. However, the introduction of parking in front of the barracks between the barracks and the parade field somewhat detracts from this relationship. There is a large lack of foundation plantings and shade trees, which is not in keeping with the historic character.

\subsubsection{Character-defining features}

Character-defining features include:

- Layout and location along the southwest side of Brown Field

- Consistent architecture and setbacks

- Associated latrines

- Remaining foundation plantings and specimen trees on side and rear of buildings 
- WPA-era ditches, culverts and retaining walls

- Views along Augur Avenue.

\subsection{Old Post Administration}

During the initial construction of the post, the first administration buildings were built along the north edge of Brown Field (Figure 119). These buildings today are administration in use and consist of two hospital buildings, the vault, the morgue, two garages, the Headquarters, the former Headquarters/current Museum, and an office building (Table 10).

Figure 119. Old Post Administration landscape area map (ERDC-CERL).

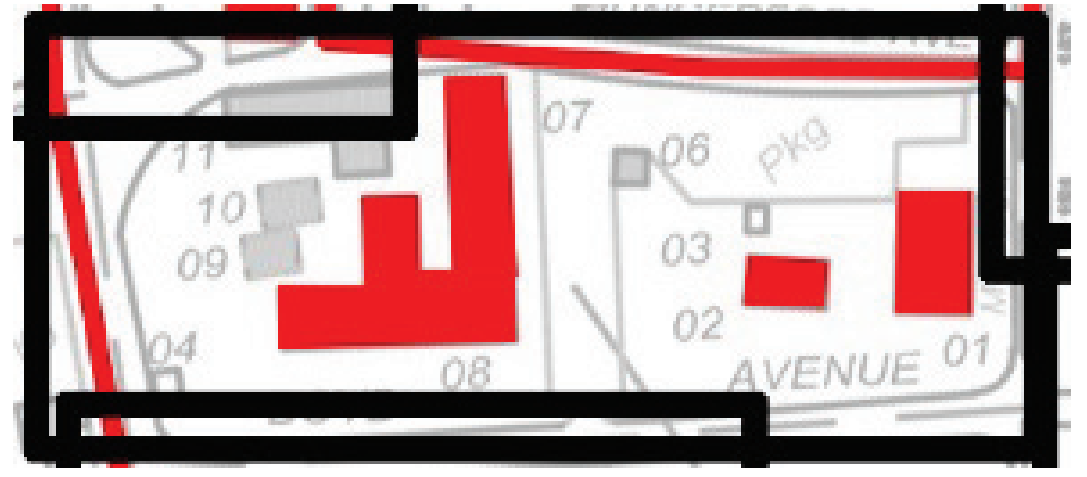

Table 10. List of buildings located within the Old Post Administration landscape area.

\begin{tabular}{|c|c|l|l|c|}
\hline Building Number & Year Built & Original Use & Current Use & Historic Status \\
\hline 41401 & 1892 & Post Headquarters & Museum & NHLC \\
\hline 41402 & 1917 & Office & Administrative & NHLC \\
\hline 41403 & 1936 & Vault & Heating Plant Building & NREC \\
\hline 41404 & 1972 & Bus Stop & Bus Stop & NEV \\
\hline 41406 & 1936 & Garage & Storage & NREC \\
\hline 41407 & 1914 & Hospital & Administrative & NHLC \\
\hline 41408 & 1885 & Hospital & Administrative & NHLC \\
\hline 41409 & 1887 & Morgue & Storage & NEV \\
\hline 41410 & 1920 & Dental Office & Storage & NEV \\
\hline 41411 & 1936 & Garage & Warehouse & NREC \\
\hline
\end{tabular}

\subsubsection{History}

The eight original administration buildings included the Post Headquarters, the post office, guard house, and numerous buildings associated with the Post Hospital. The Headquarters building (41401) was built in 1892 of adobe walls (Figure 121). It included a one-story porch, 5 -ft wide, which extended across the façade, half of each side's elevation, and was originally built as a duplex. Building 41401 (now the Fort Huachuca Museum) also 
had many other uses over the years: post chapel, home of the post chaplain, a BOQ, remodeled in 1920 as the Officers' Club and used as that until 1941, then Post Headquarters until 1969, then the Museum. An office building, now the Headquarters building (41402), called Rodney Hall, was constructed in 1917.

The Post Hospital (41408) was constructed in 1885. A morgue (41409) was built as part of the hospital complex in 1887. A new hospital building (41407) was built in 1914 to support the addition of the $10^{\text {th }}$ cavalry to Fort Huachuca. An office building was built in 1920 (41410) adjacent to the hospital (Figures 120-123).

Figure 120. View looking north at the Post Hospital (41408), c.1900 (NARA College Park, RG 92-F).

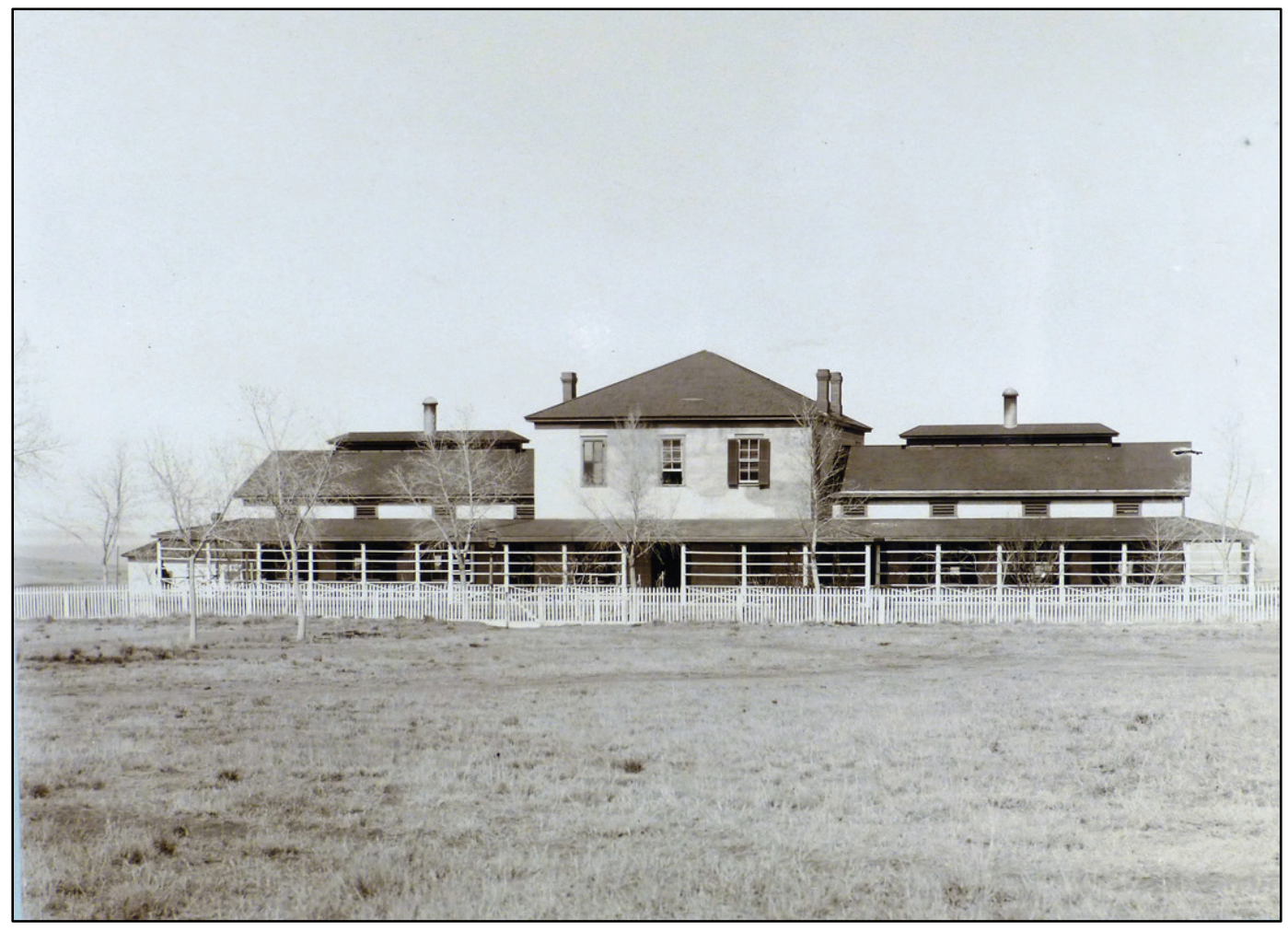


Figure 121. Looking north at Rodney Hall (41402), which was built in 1917 as the Post Headquarters, 1920 (Fort Huachuca Museum).

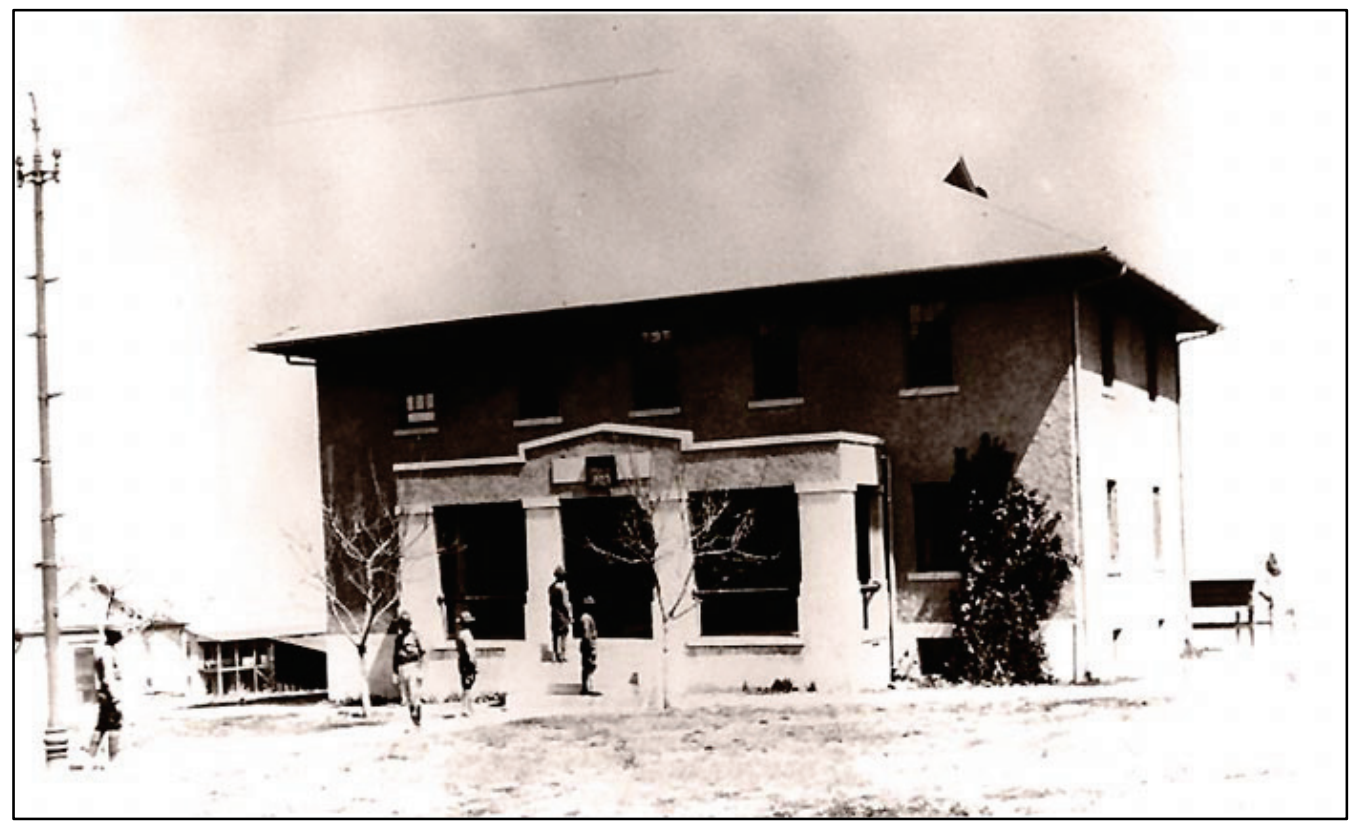

Figure 122. Looking northeast at the former Post Headquarters (41401), which also served as the Officers' Club from 1920 to 1941, now the Museum, 1920 (Fort Huachuca Historical Museum).

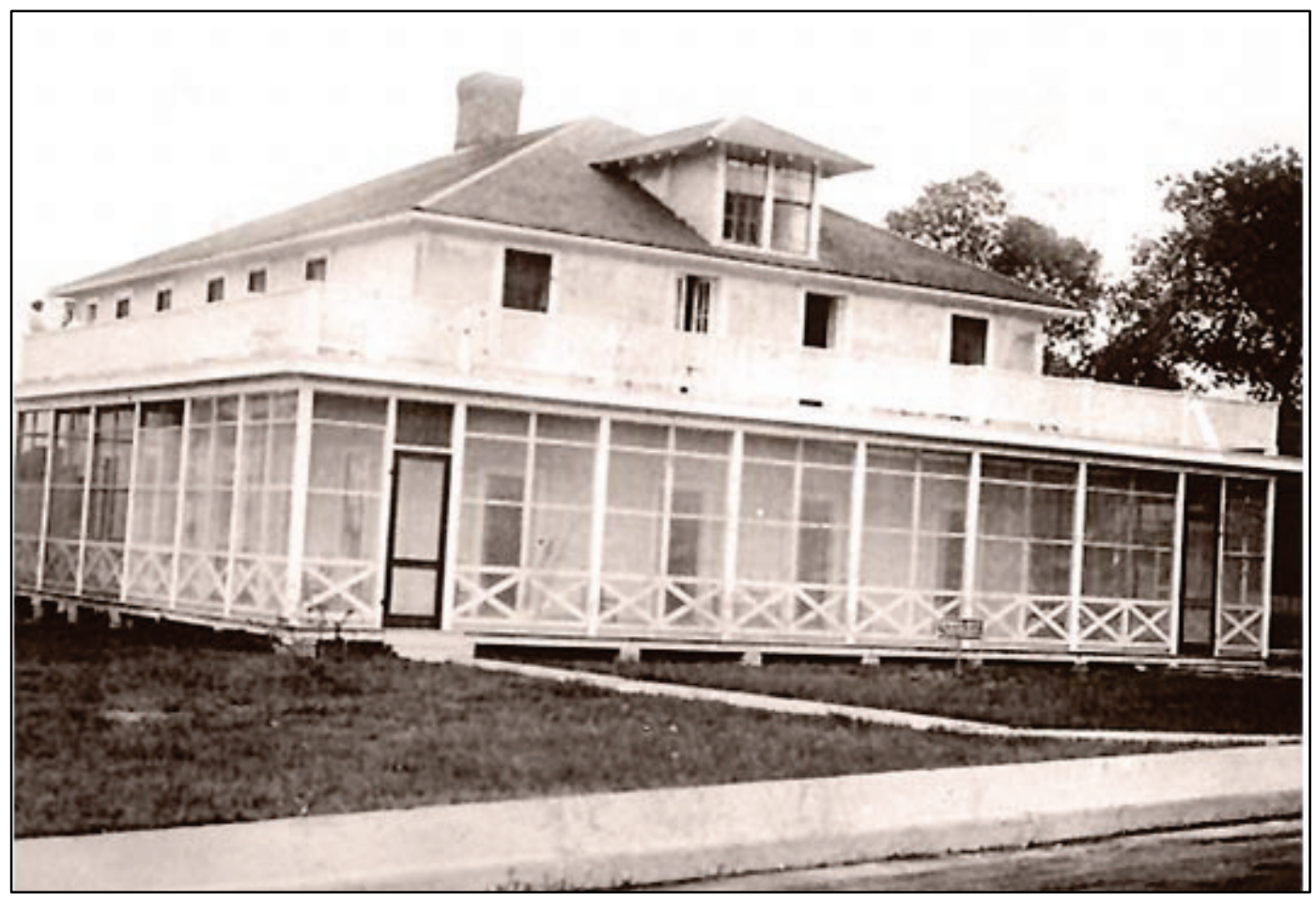


Figure 123. View looking northwest of the former hospital (41408), c. 1953 (NARA College Park, RG111-SCA).

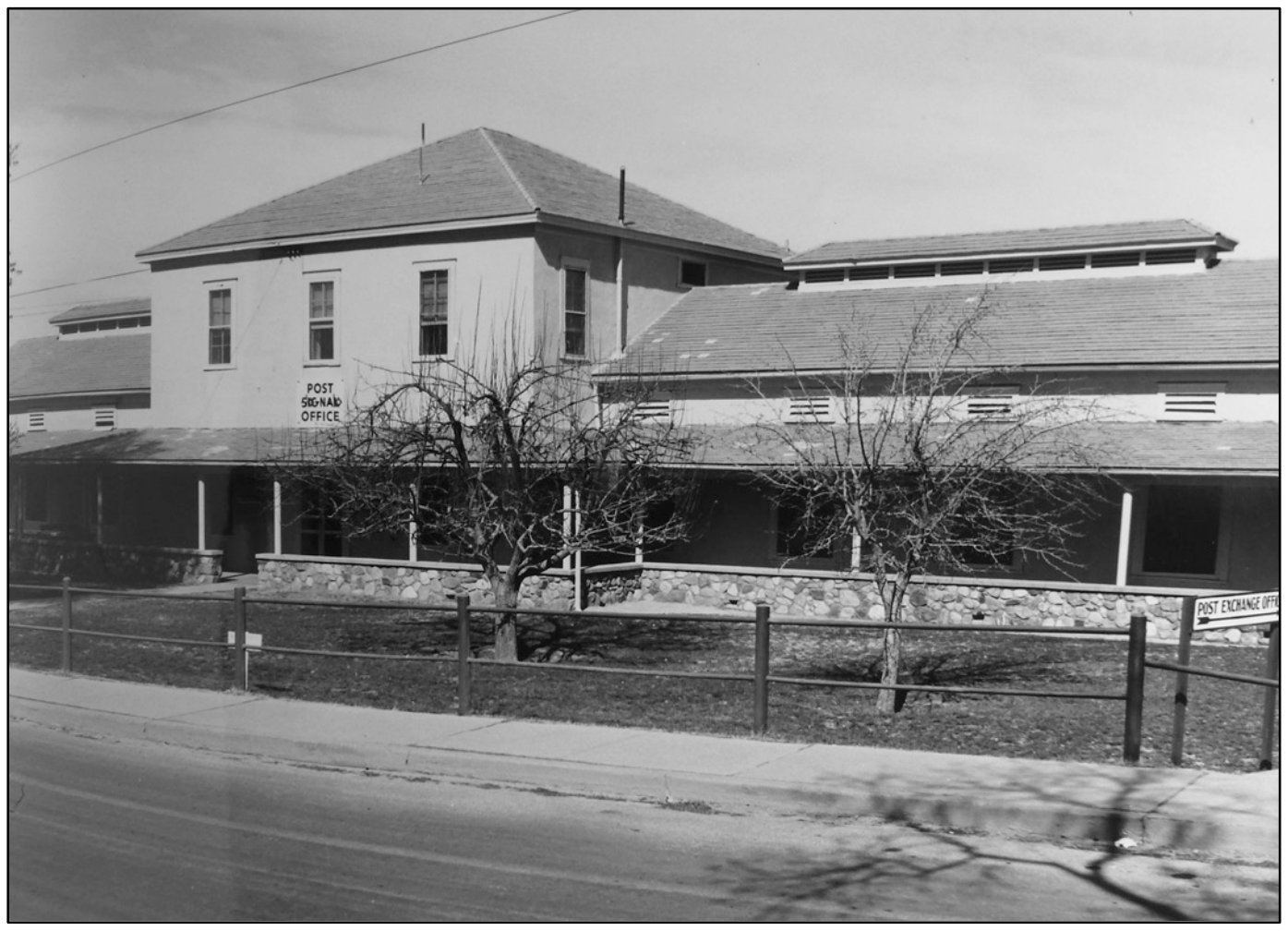

\subsubsection{Current conditions}

While the uses of the administration buildings have changed over the years, they still occupy a prominent location along the northern edge of Brown Field and retain their architectural character. Building 41402 still serves as the Headquarters. In 1960, Building 41401 was re-dedicated as the Post Museum, at which time the porch was returned to approximately its original appearance. The other hospital buildings serve as administration or storage (Figures 124-154). 
Figure 124. View looking north at stone wall west of former hospital (41408), morgue in center (41409) [Note street lamp on Boyd Avenue and street lamp on Christy Avenue] (ERDCCERL, 2016).

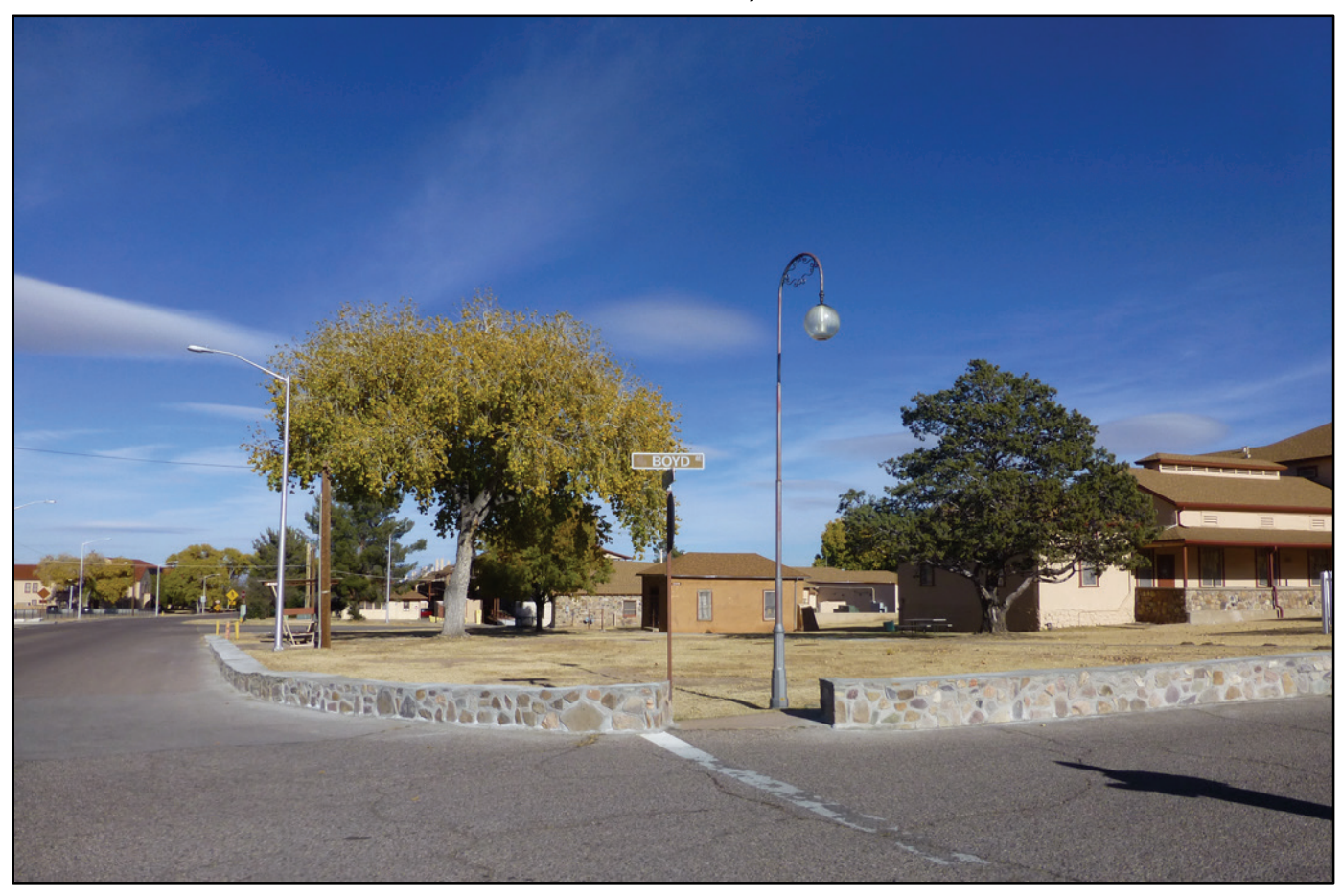

Figure 125. View looking north at former morgue building (41409) (ERDC-CERL).

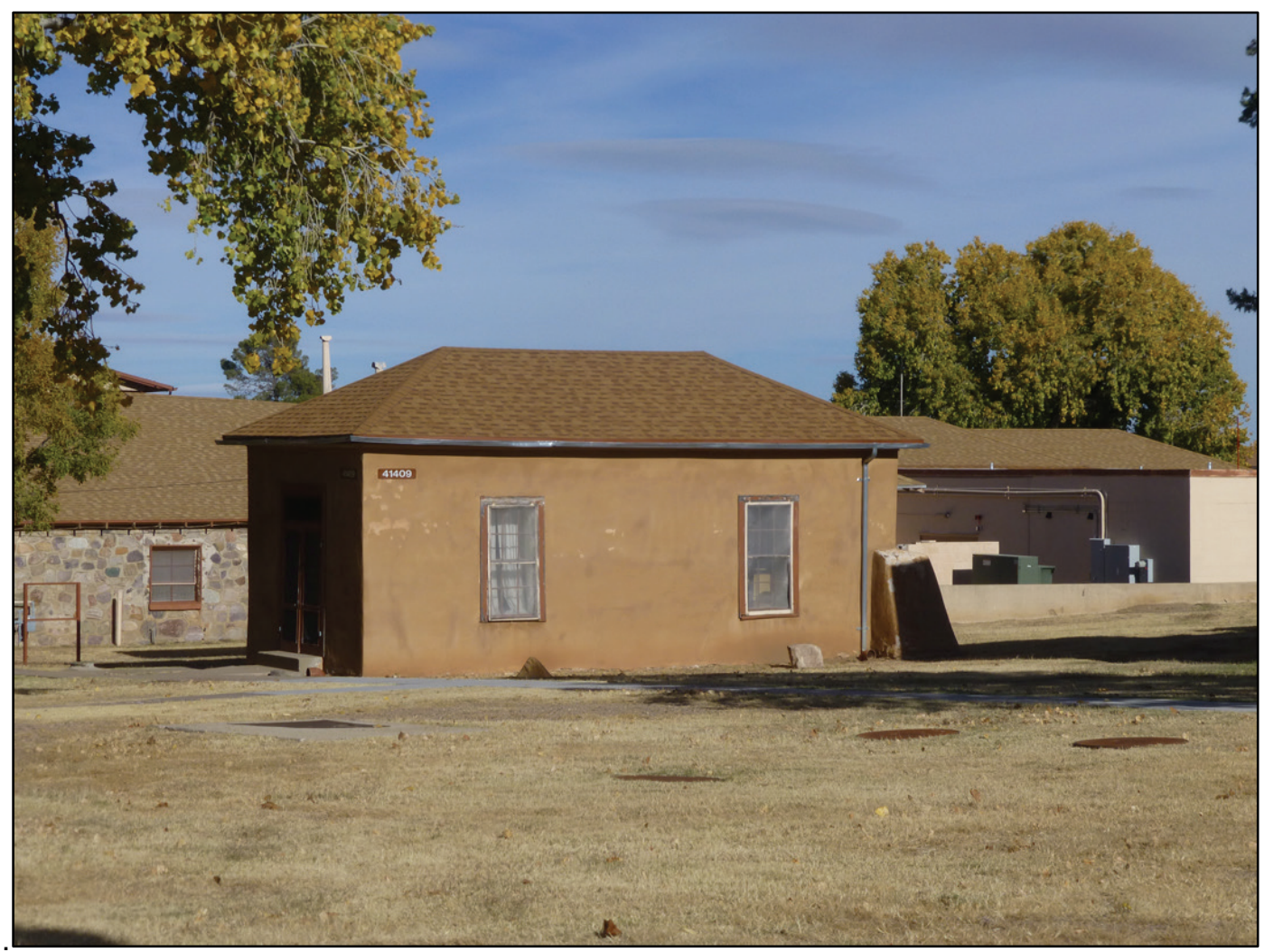


Figure 126. View looking north of bus stop shelter (41404) (ERDC-CERL, 2016).

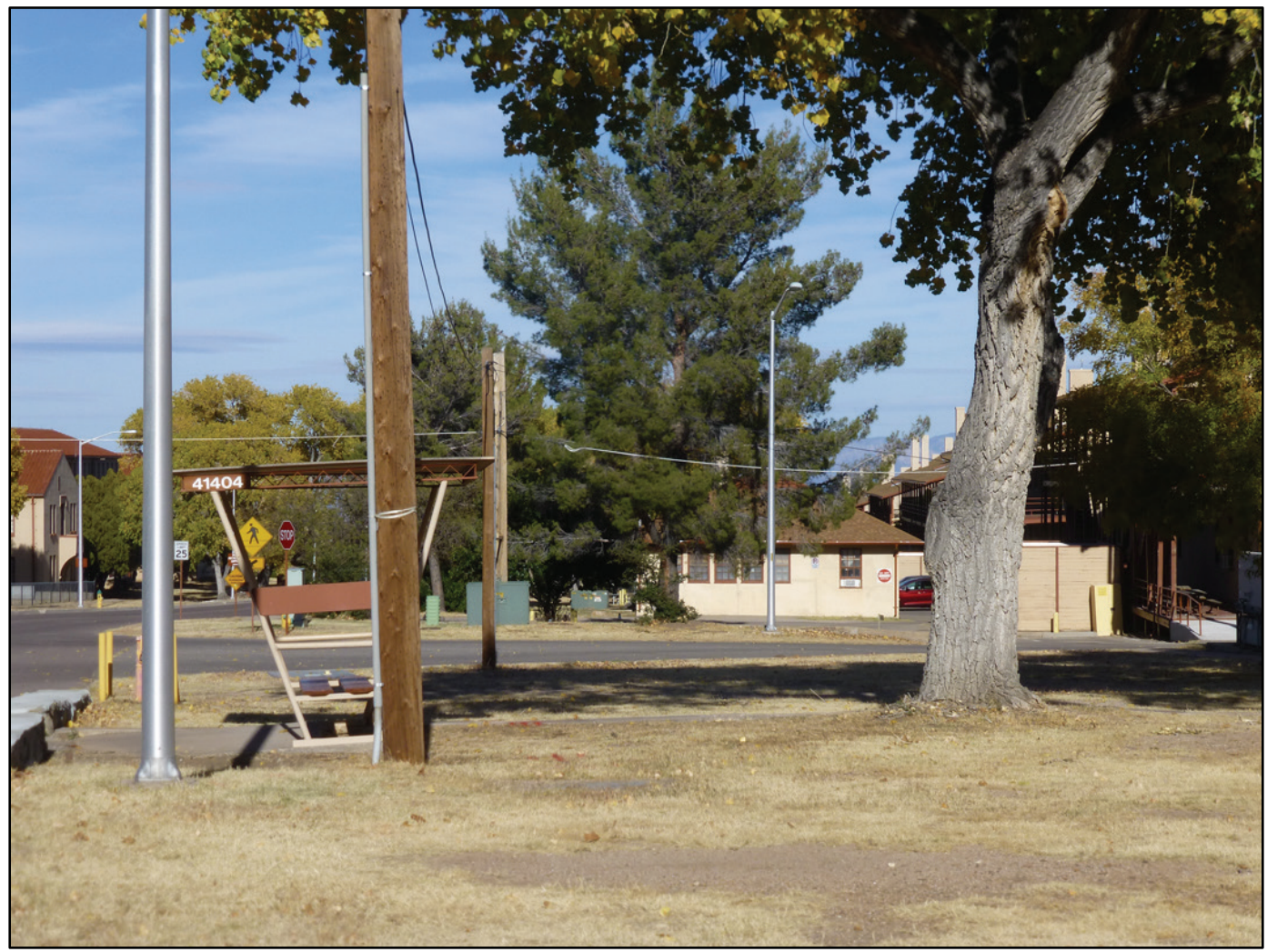

Figure 127. View looking northwest of 22334 and 41408 from Reservoir Hill (ERDC-CERL, 2016).

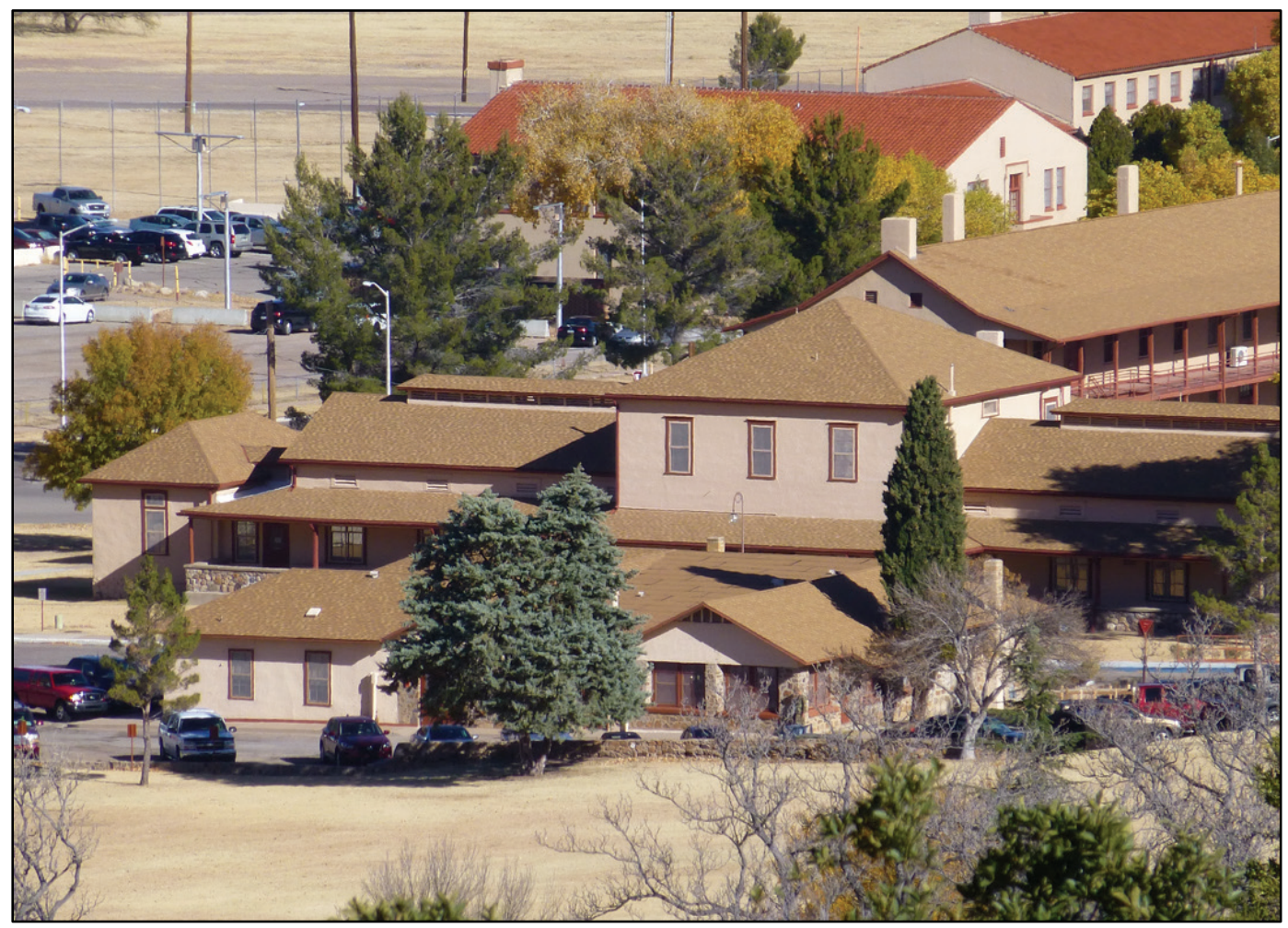


Figure 128. View looking north of 41408 showing concrete sidewalk and signs in front of building (ERDC-CERL, 2016).

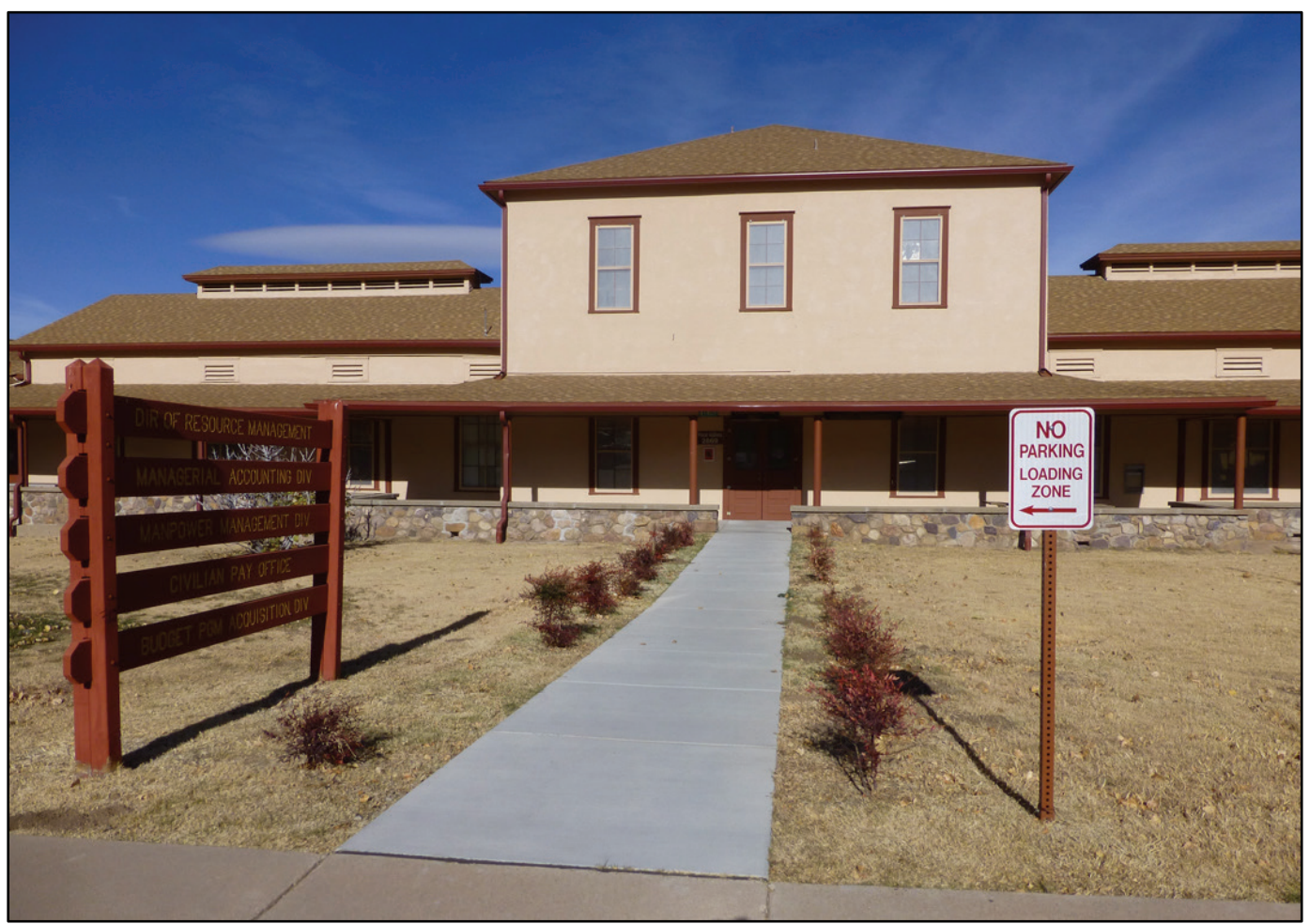

Figure 129. View looking northwest at former hospital Building 41408 (ERDC-CERL, 2016).

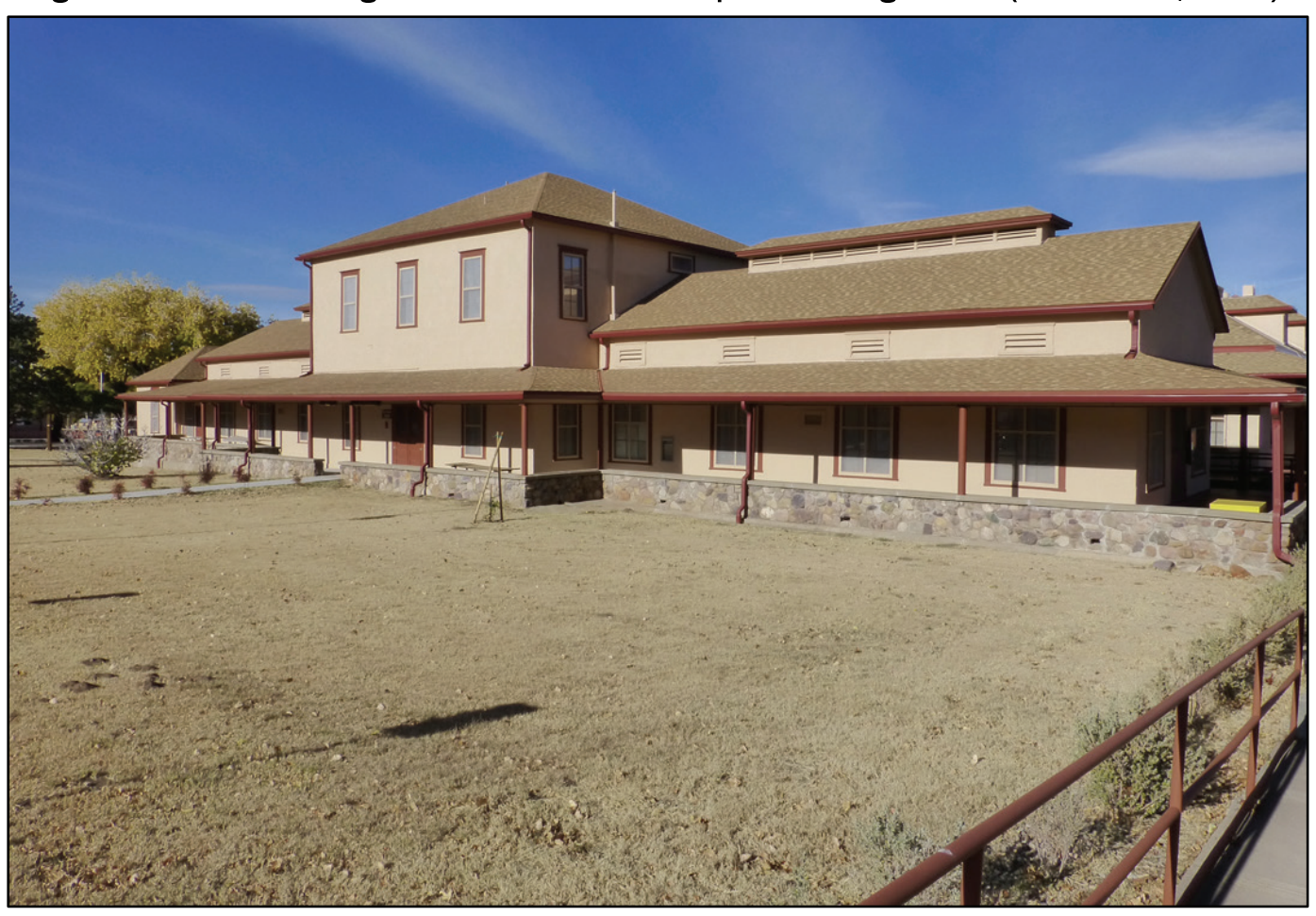


Figure 130. View looking east of white picket fence concealing equipment in front of former hospital (41408) (ERDC-CERL, 2016).

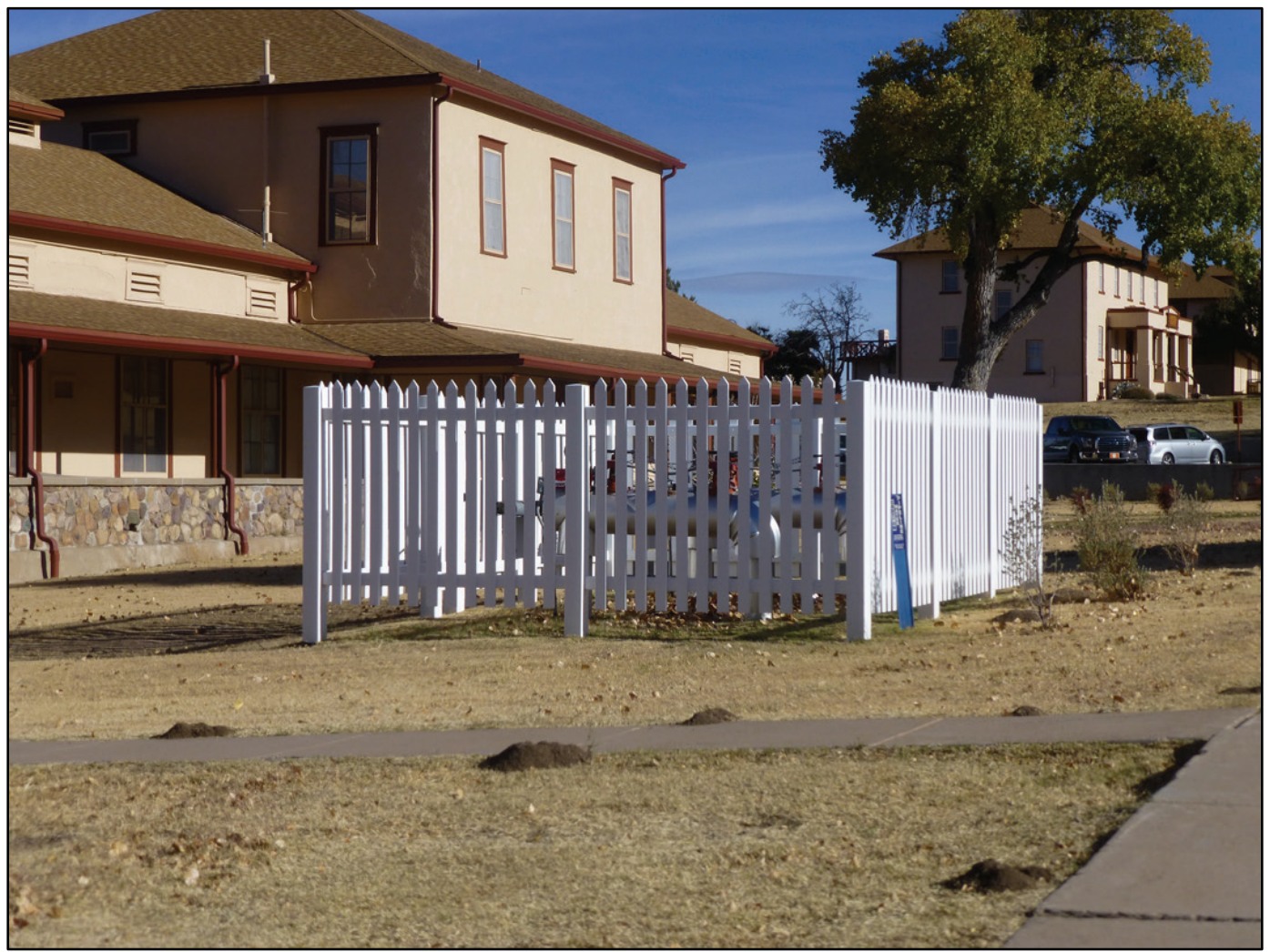

Figure 131. View looking north at concrete ramp and metal handrails on east side of 41408 (ERDC-CERL, 2016).

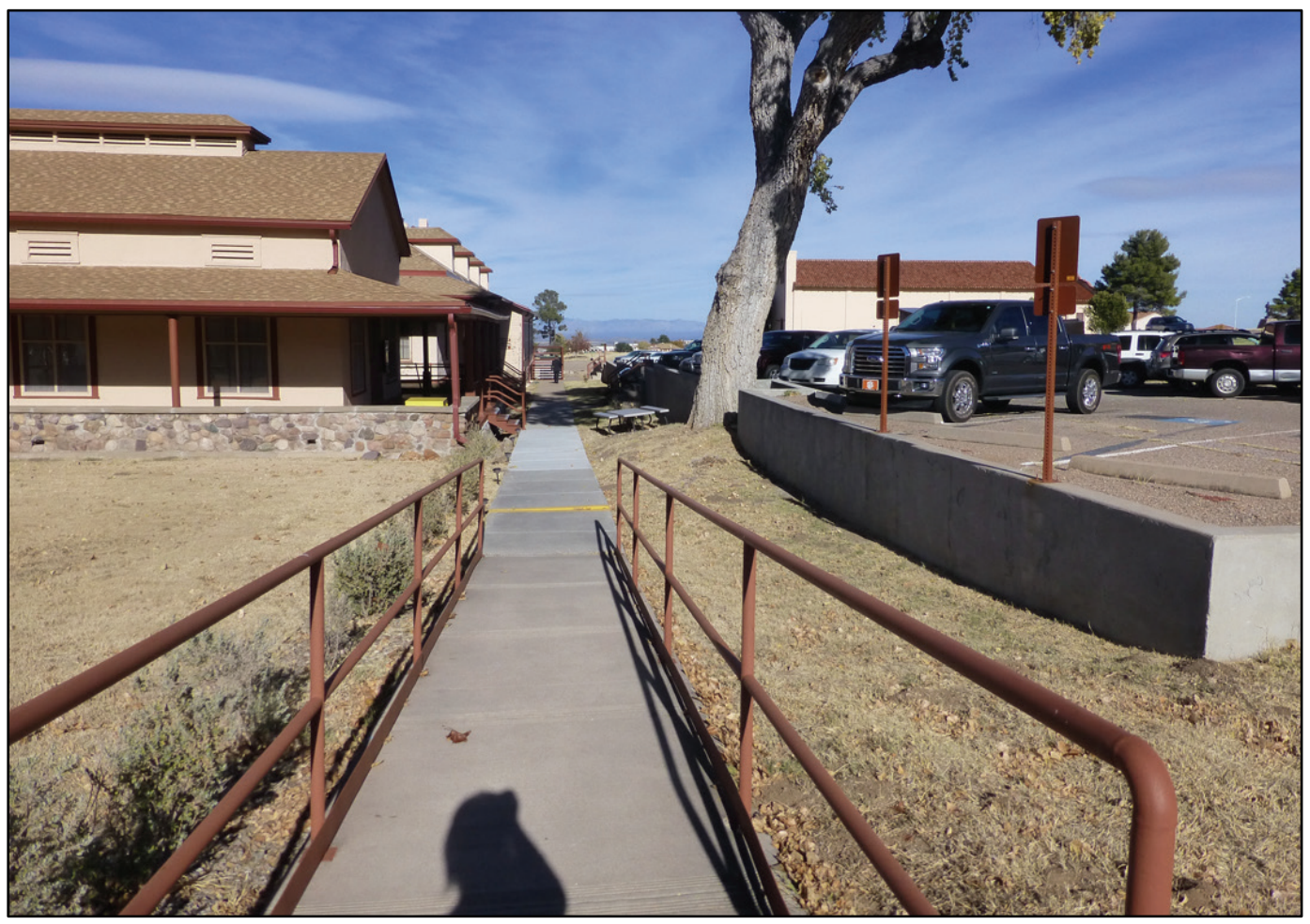


Figure 132. View looking north at concrete sidewalk along east side of 41407 (ERDC-CERL, 2016).

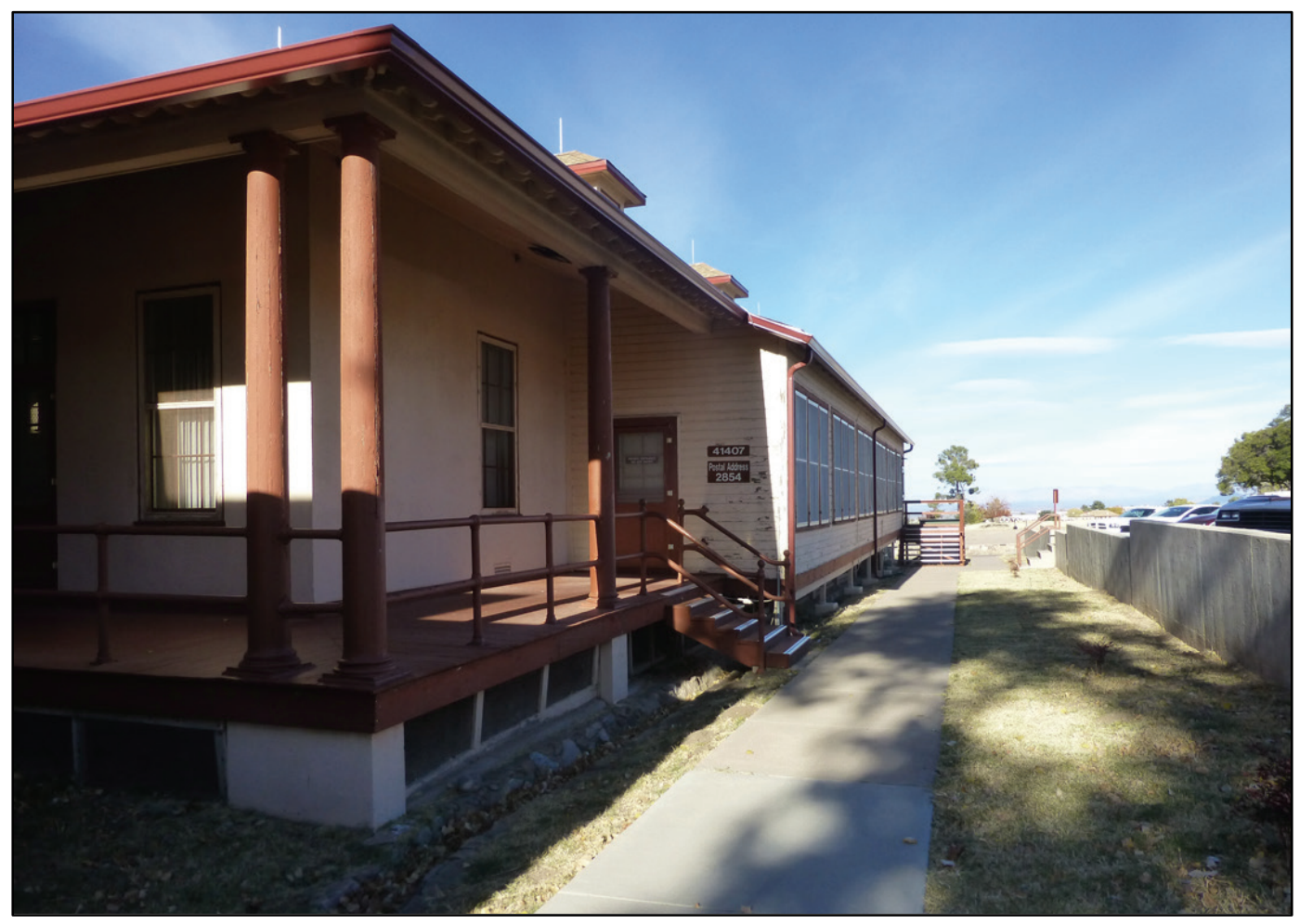

Figure 133. View looking west at connections between 41408 and 41407 (ERDC-CERL, 2016).

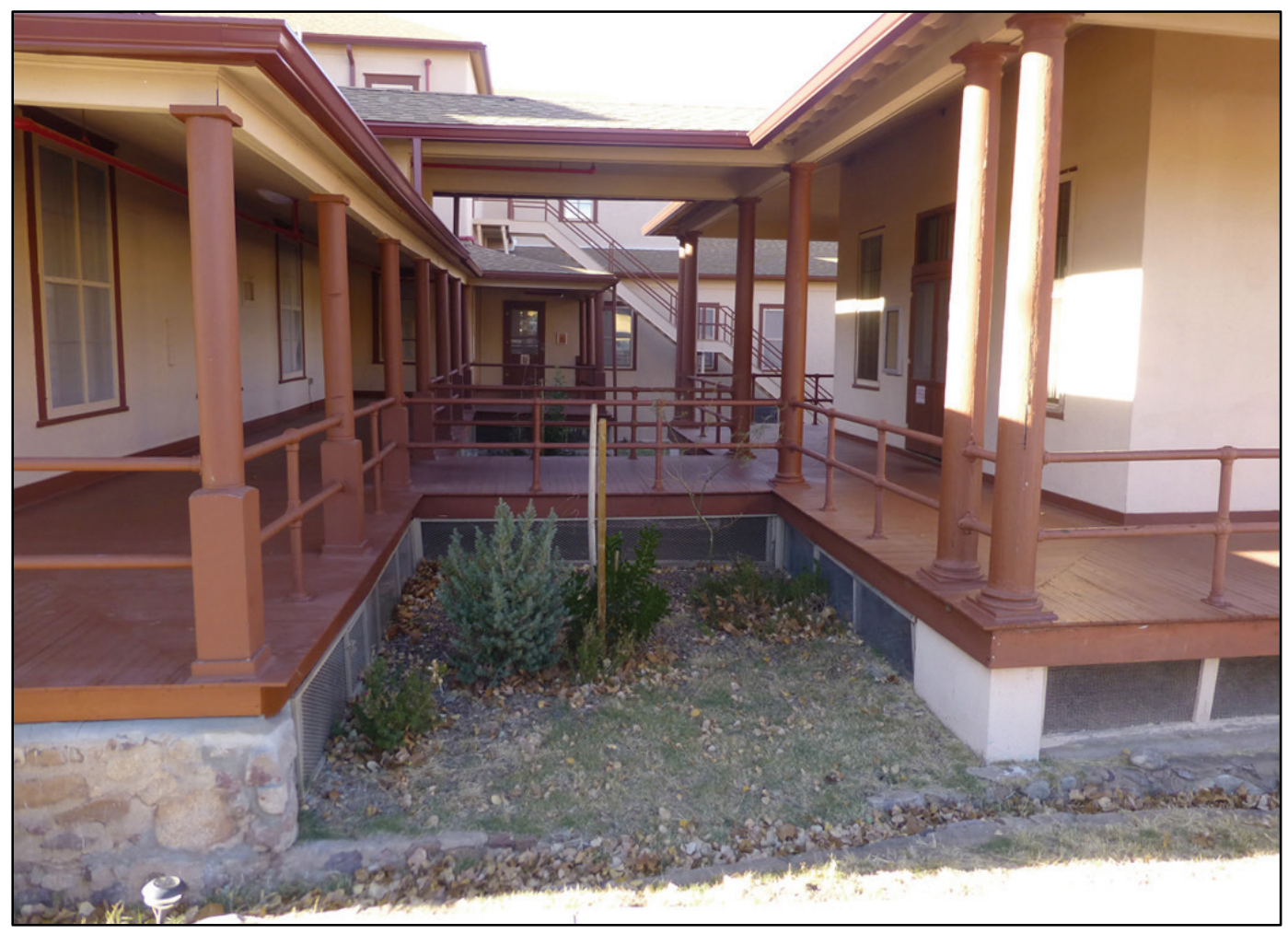


Figure 134. View looking west at landscaping between 41408 and 41407 (ERDC-CERL, 2016).

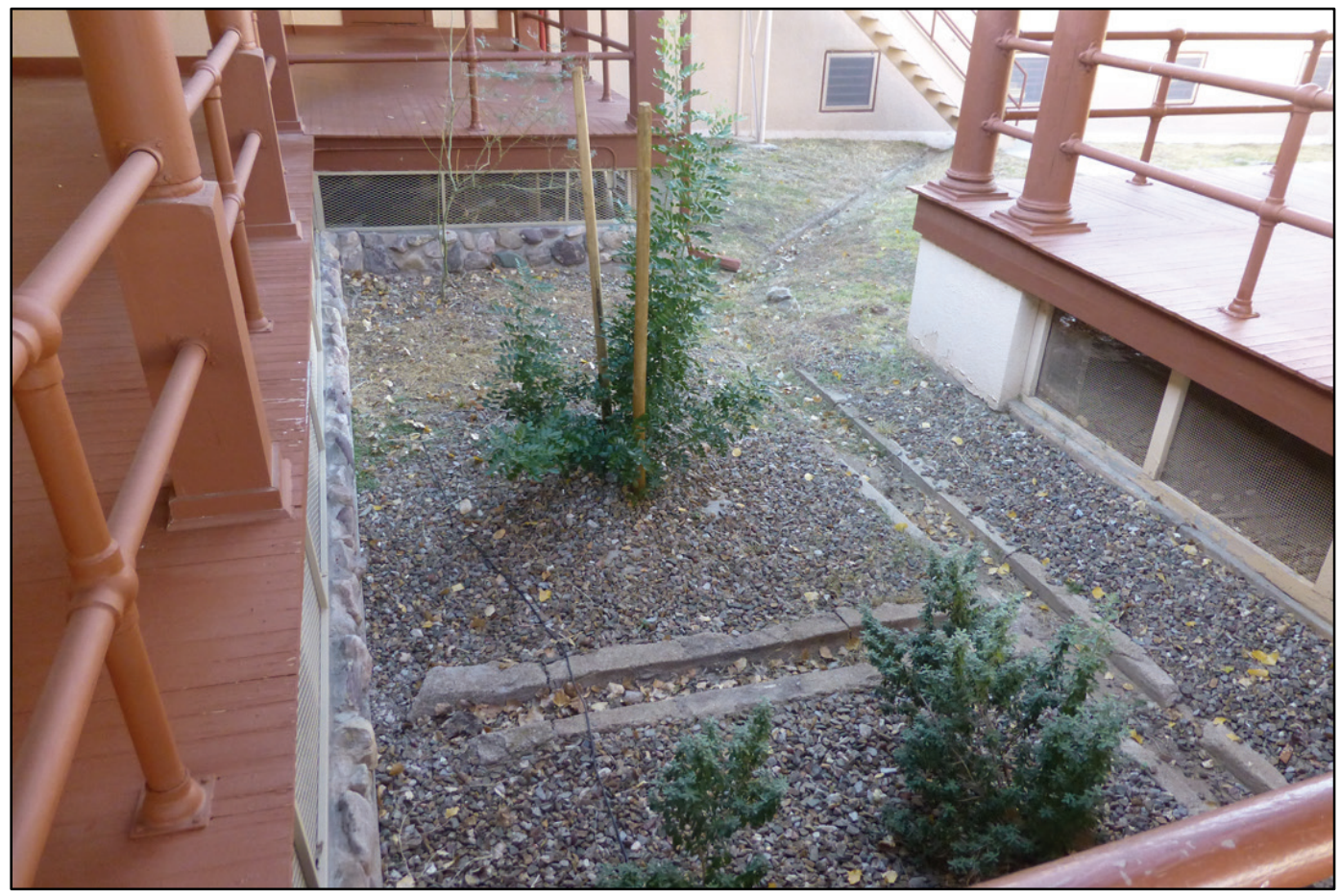

Figure 135. View of concrete sidewalk, equipment, and concrete wall along northwest side of 41407 (ERDC-CERL, 2016).

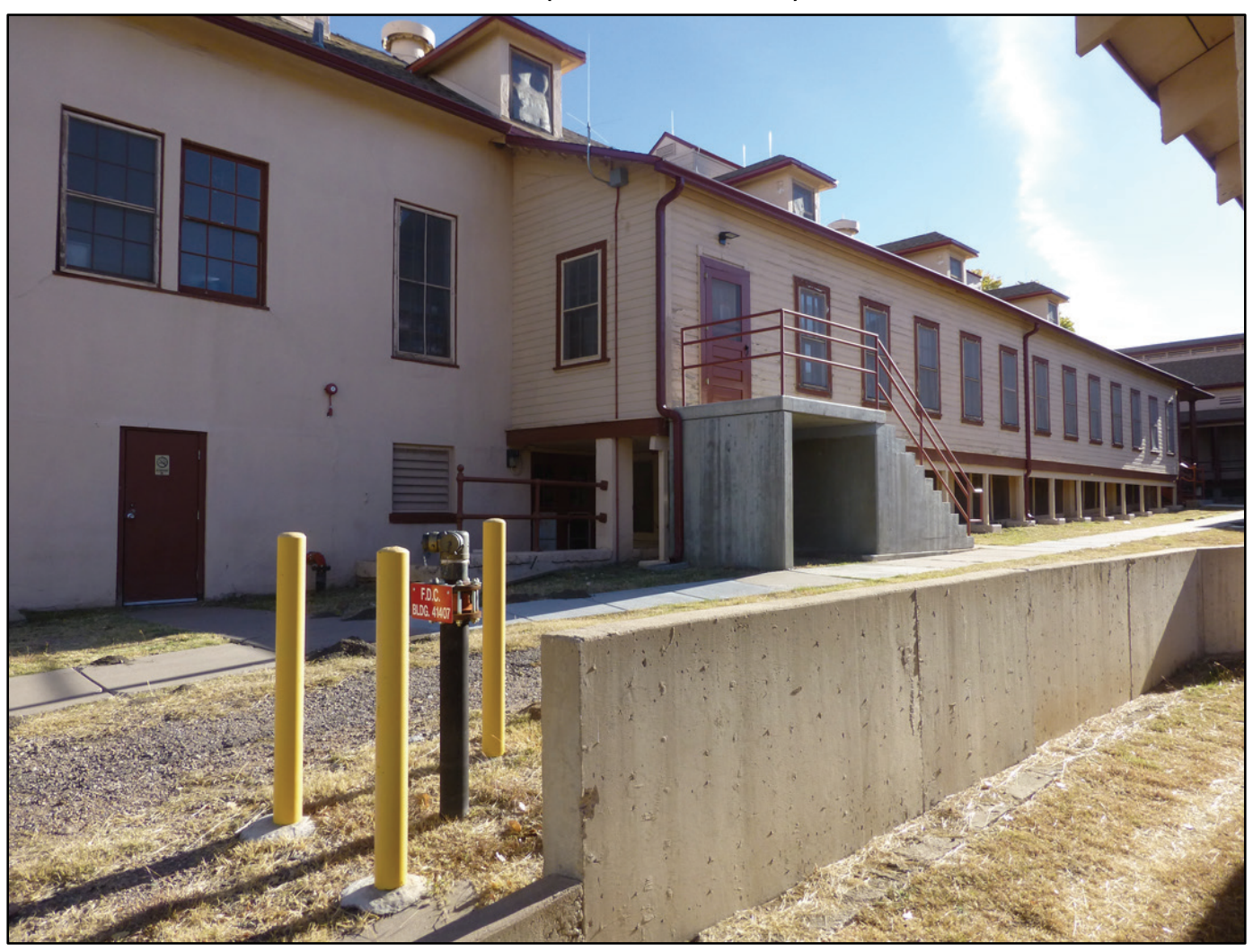


Figure 136. View looking west at oblique of 41411 and Hungerford Avenue (ERDC-CERL, 2016).

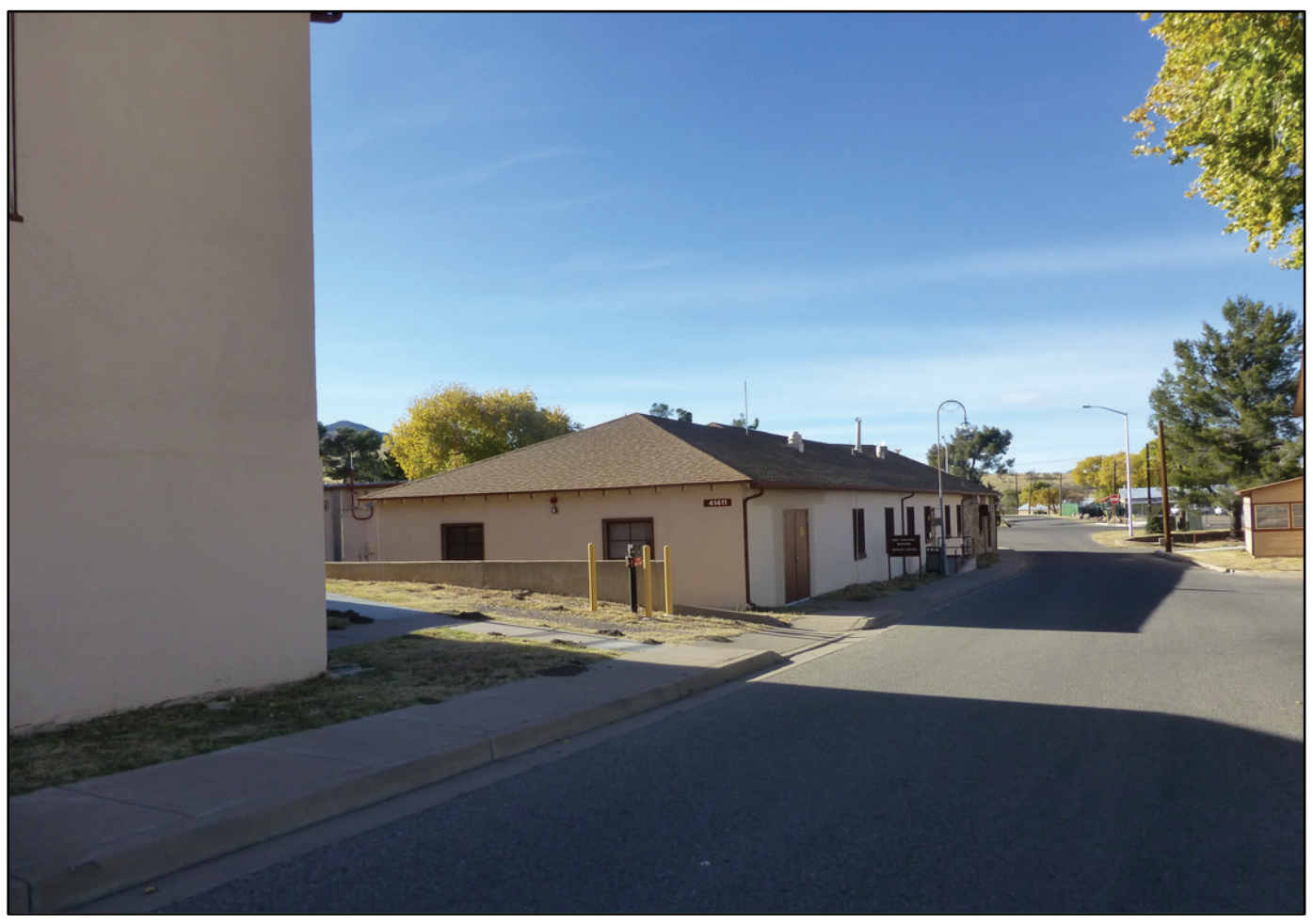

Figure 137. View of northwest side of 41411 showing air conditioning equipment (ERDCCERL, 2016).

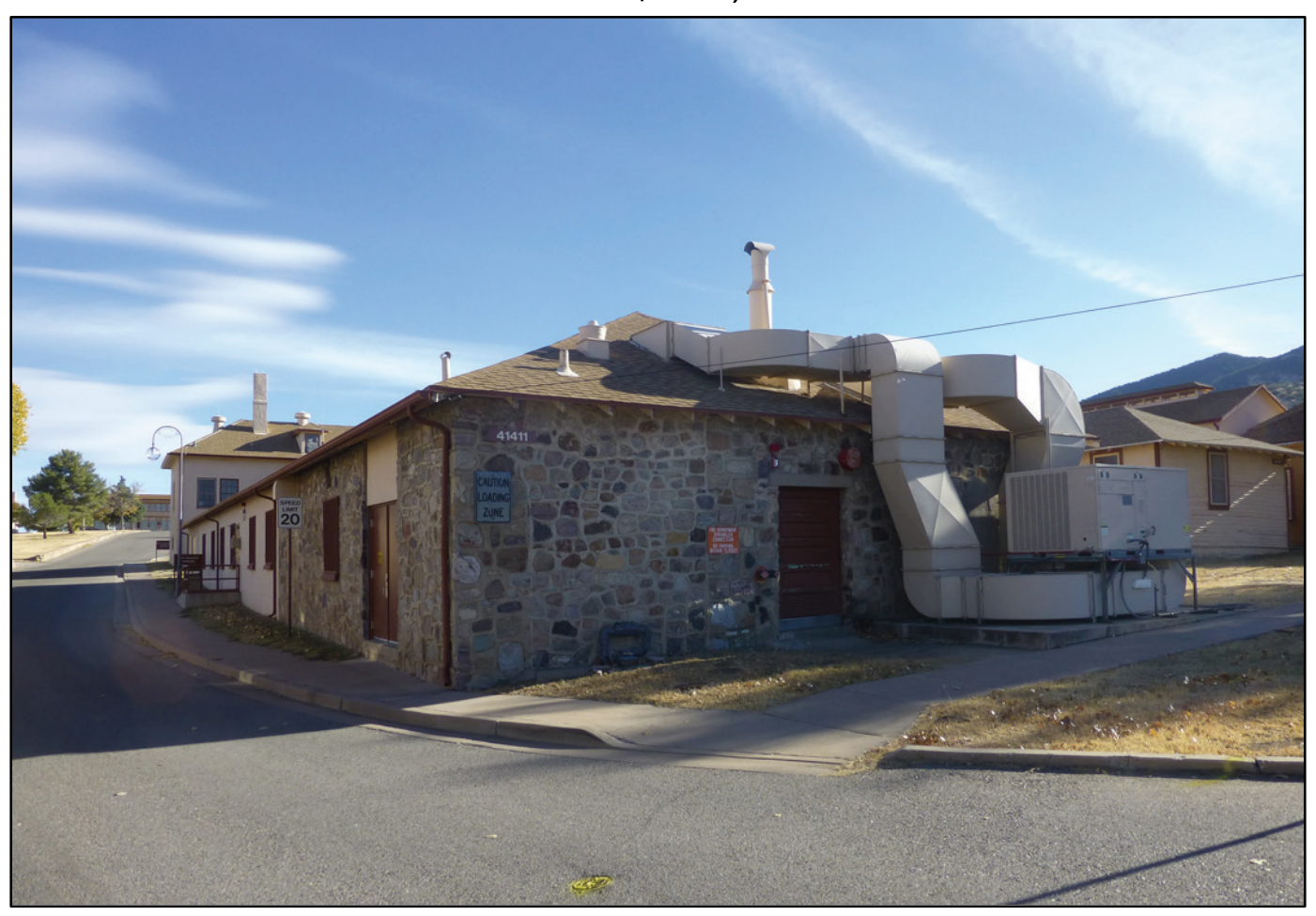


Figure 138. View of southwest side of 41411 (ERDC-CERL, 2016).

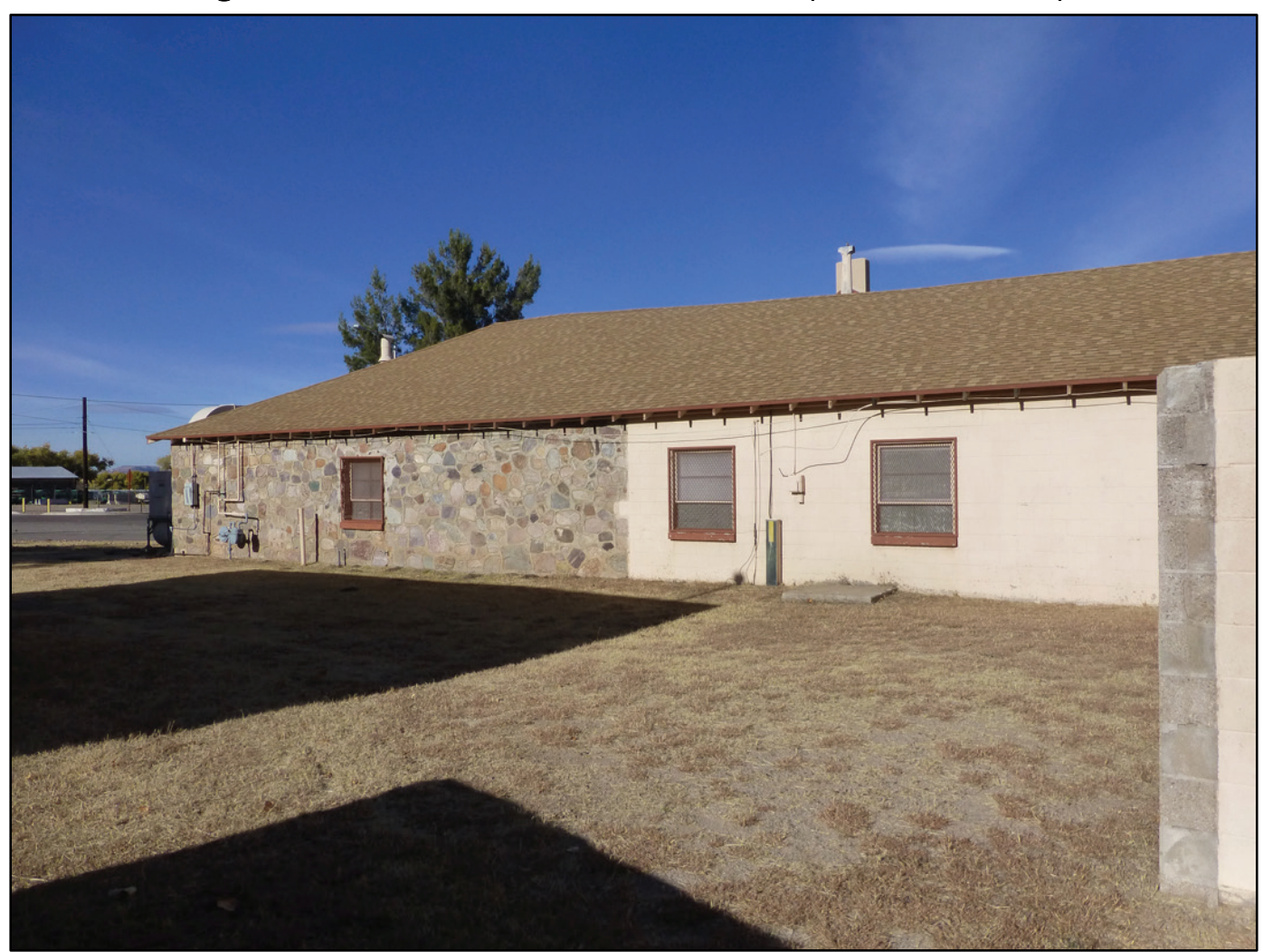

Figure 139. View looking east at air conditioning equipment on north side of 41408 (ERDCCERL, 2016).

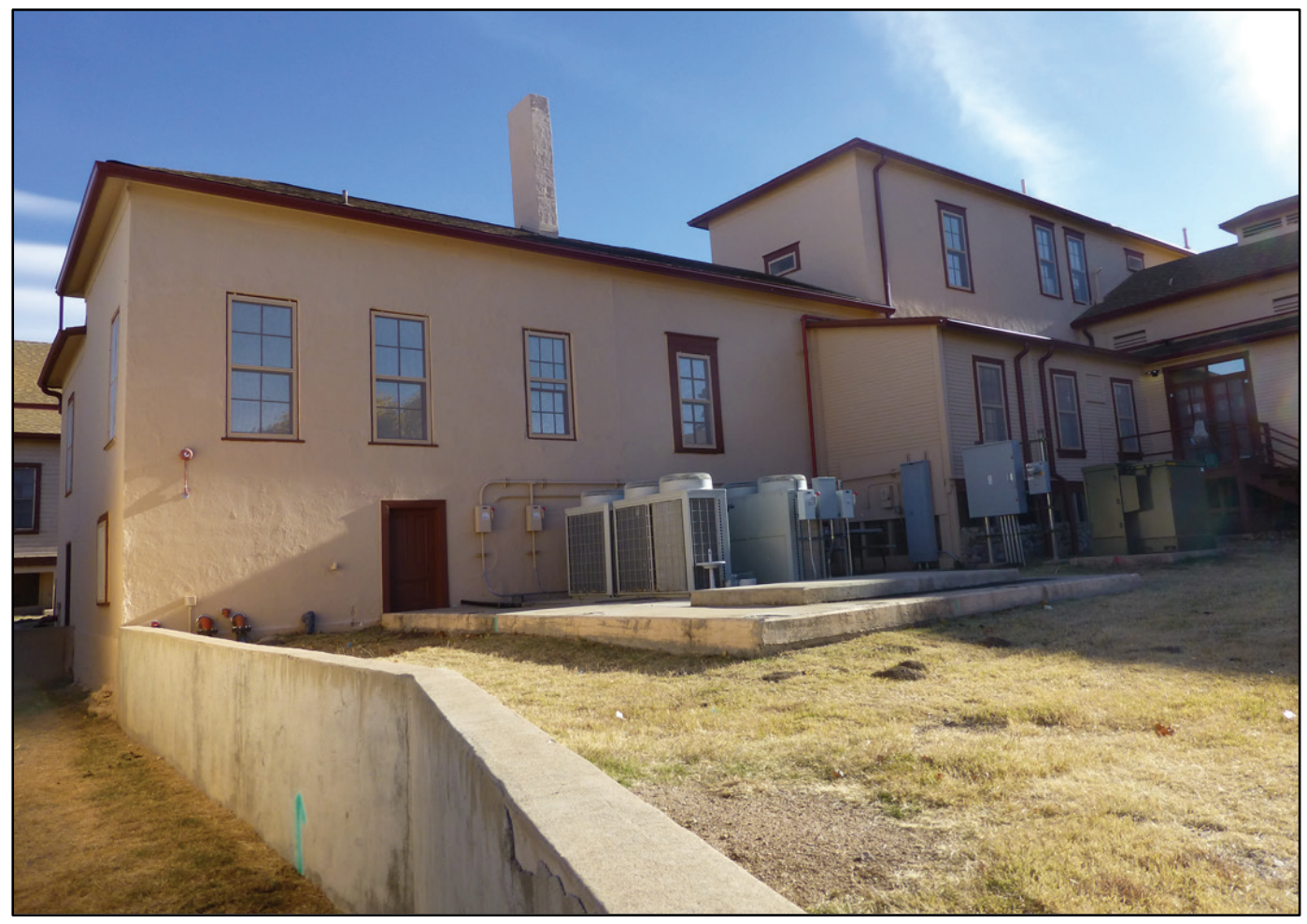


Figure 140. View looking west at 41409 and 41410 and concrete retaining wall for 41411 (ERDC-CERL, 2016).

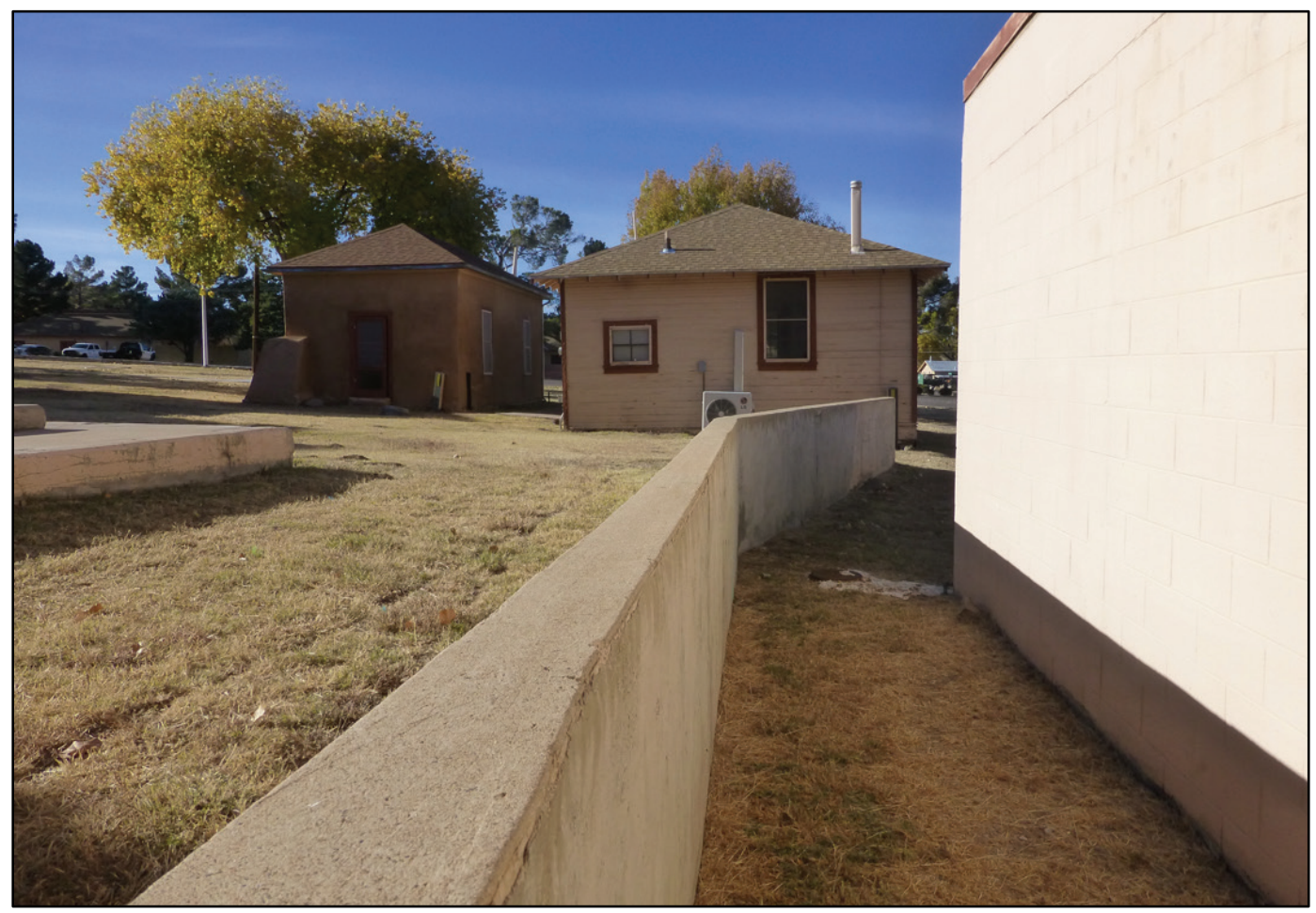

Figure 141. View looking north at Rodney Hall (41402), Garrison Headquarters (ERDC-CERL, 2016).

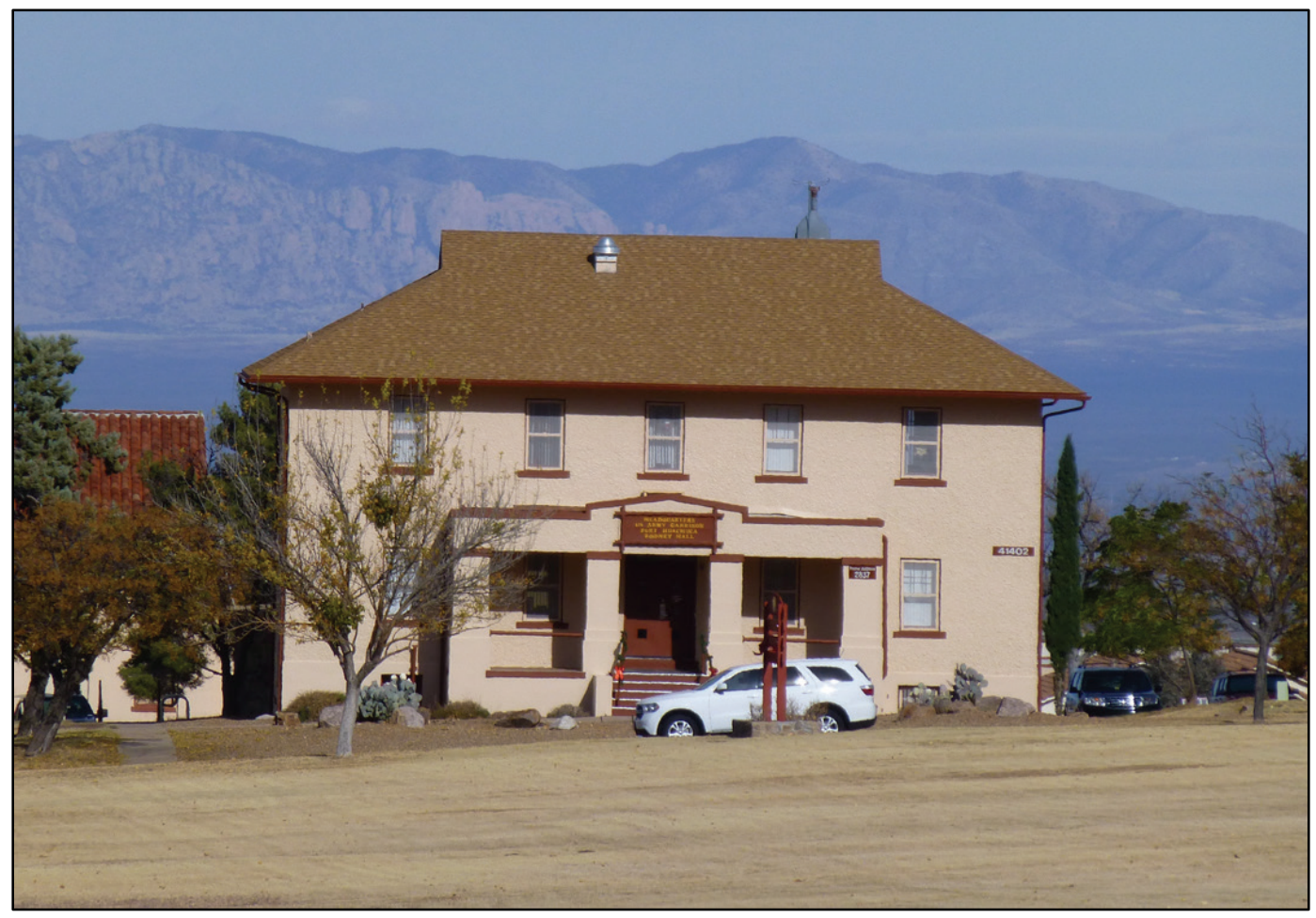


Figure 142. View looking north at concrete sidewalk alongside 41402 (ERDC-CERL, 2016).

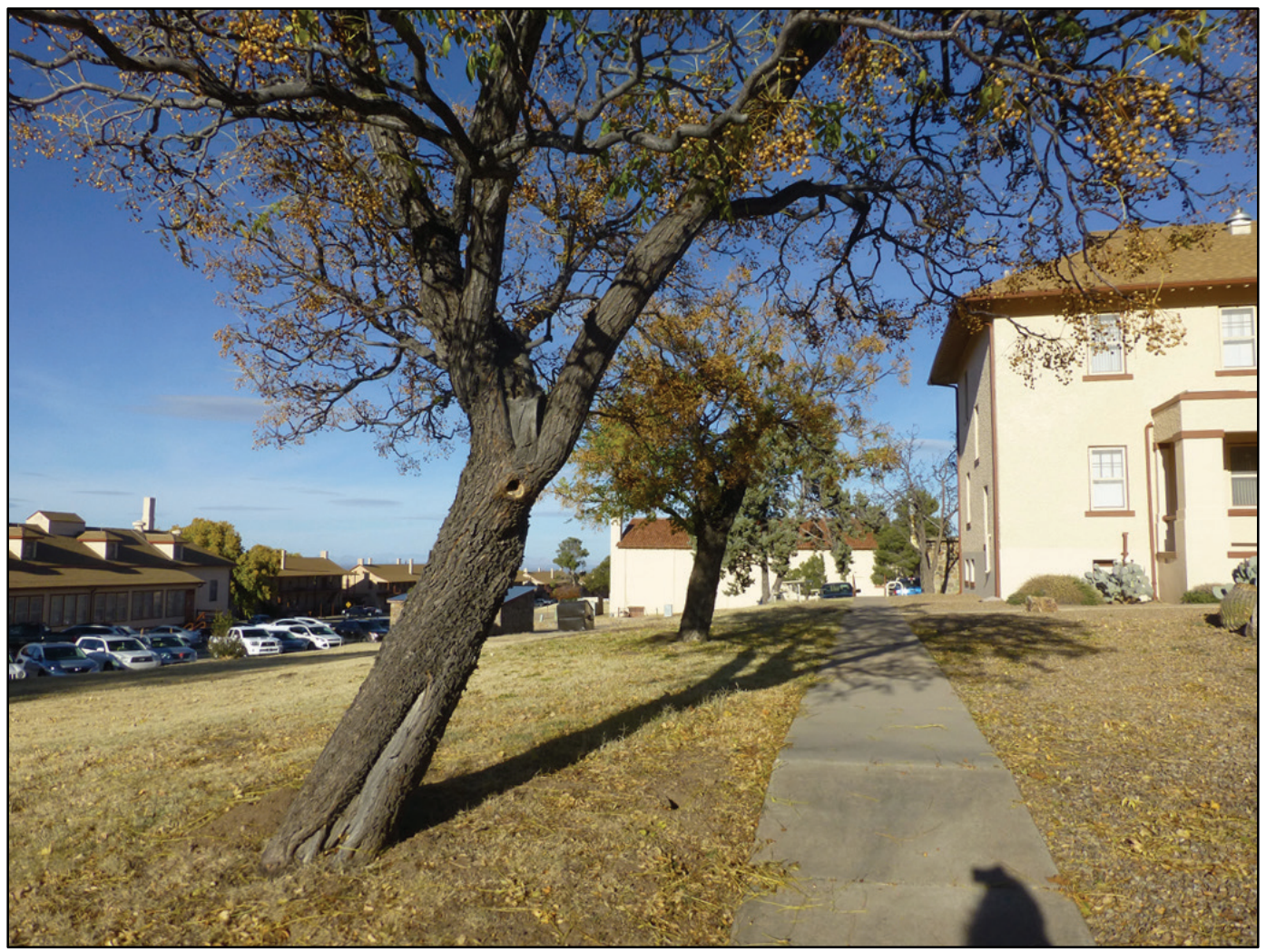

Figure 143. View looking north at landscaping in front of 41402 (ERDC-CERL, 2016).

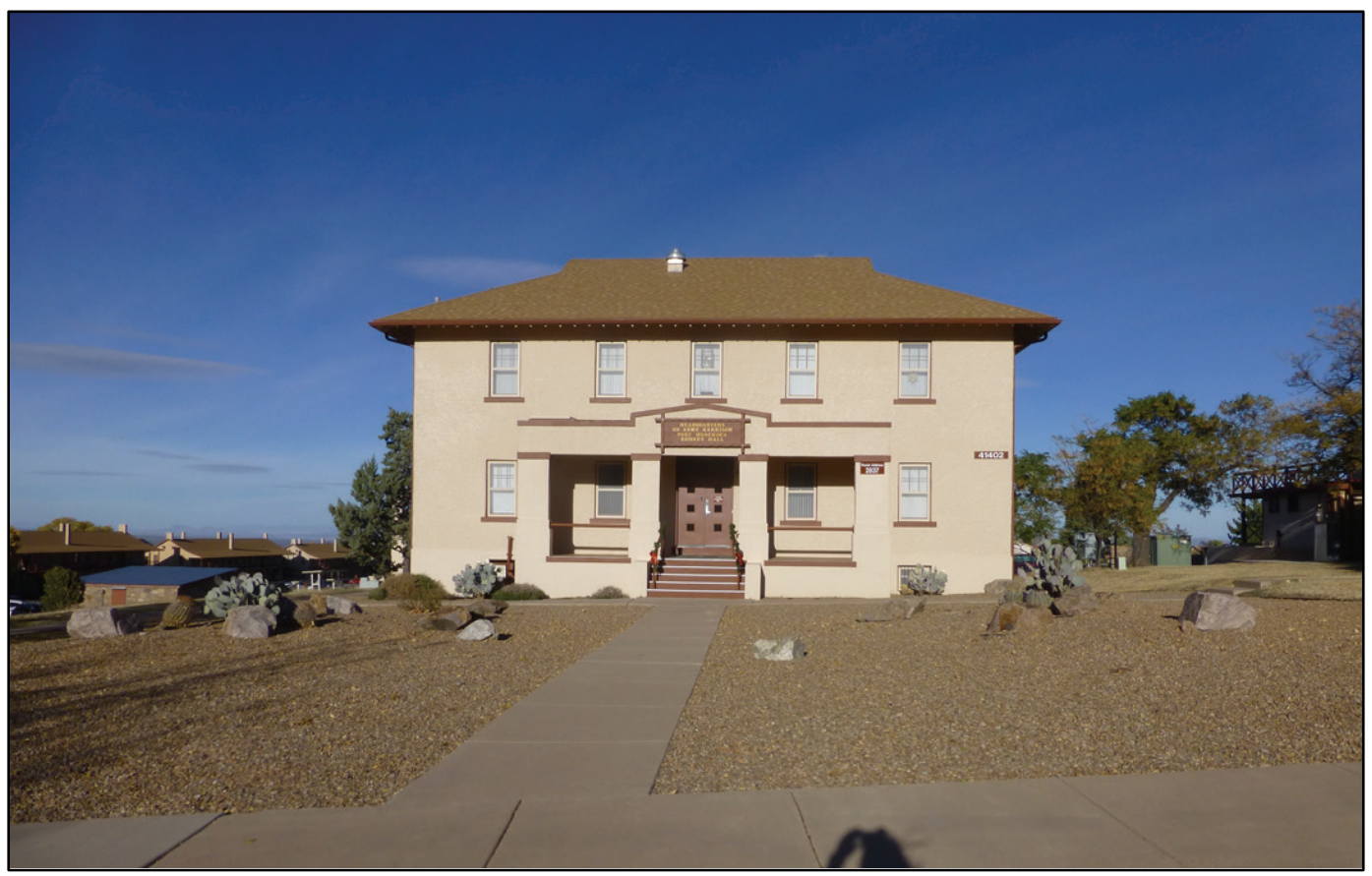


Figure 144. View looking south at space between 41402 and the parking lot for 41408 and 41407 (ERDC-CERL, 2016).

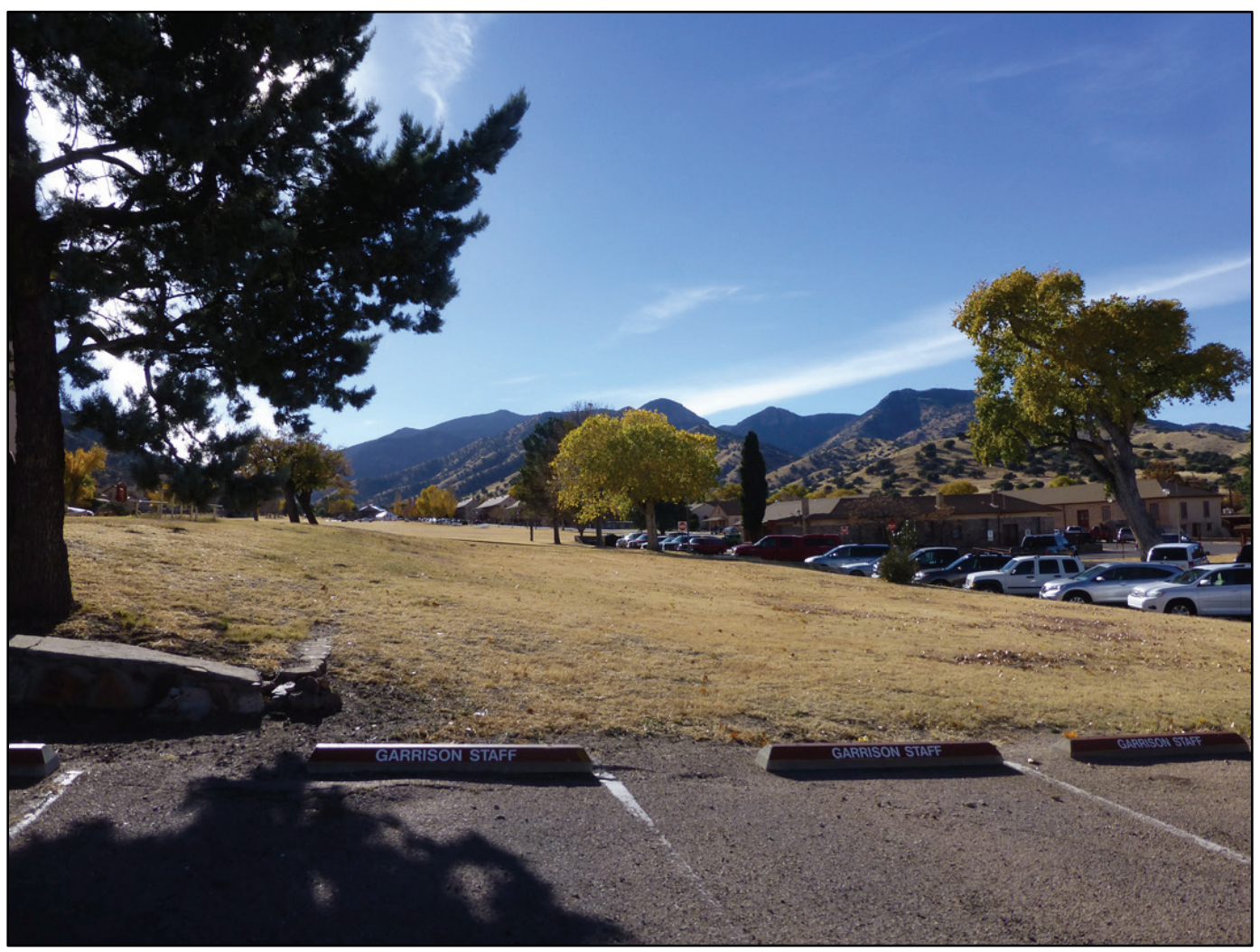

Figure 145. View looking east at area behind 41401 (ERDC-CERL, 2016).

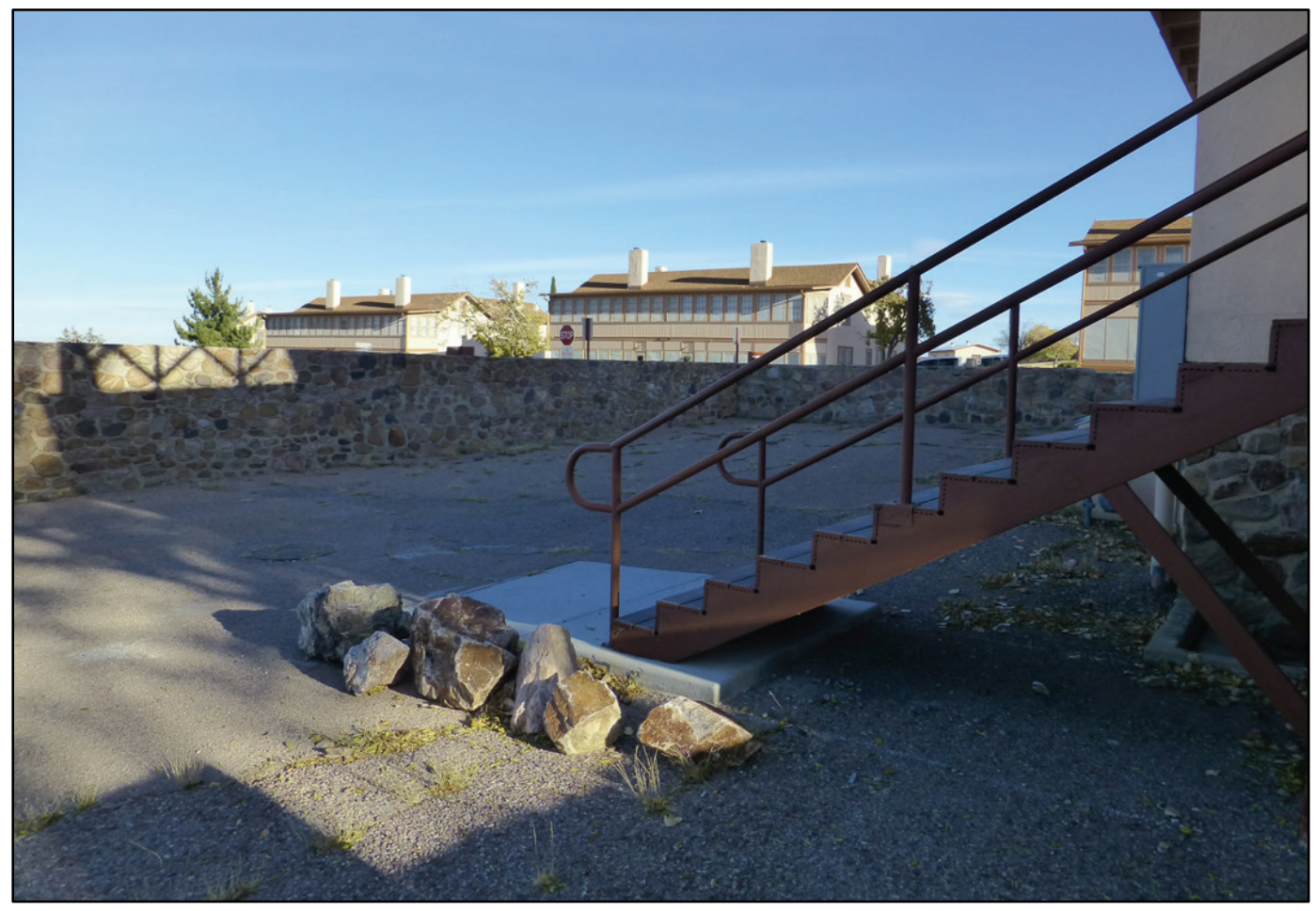


Figure 146. View looking south at WPA-era former garage (41406) behind 41402 (ERDCCERL, 2016).

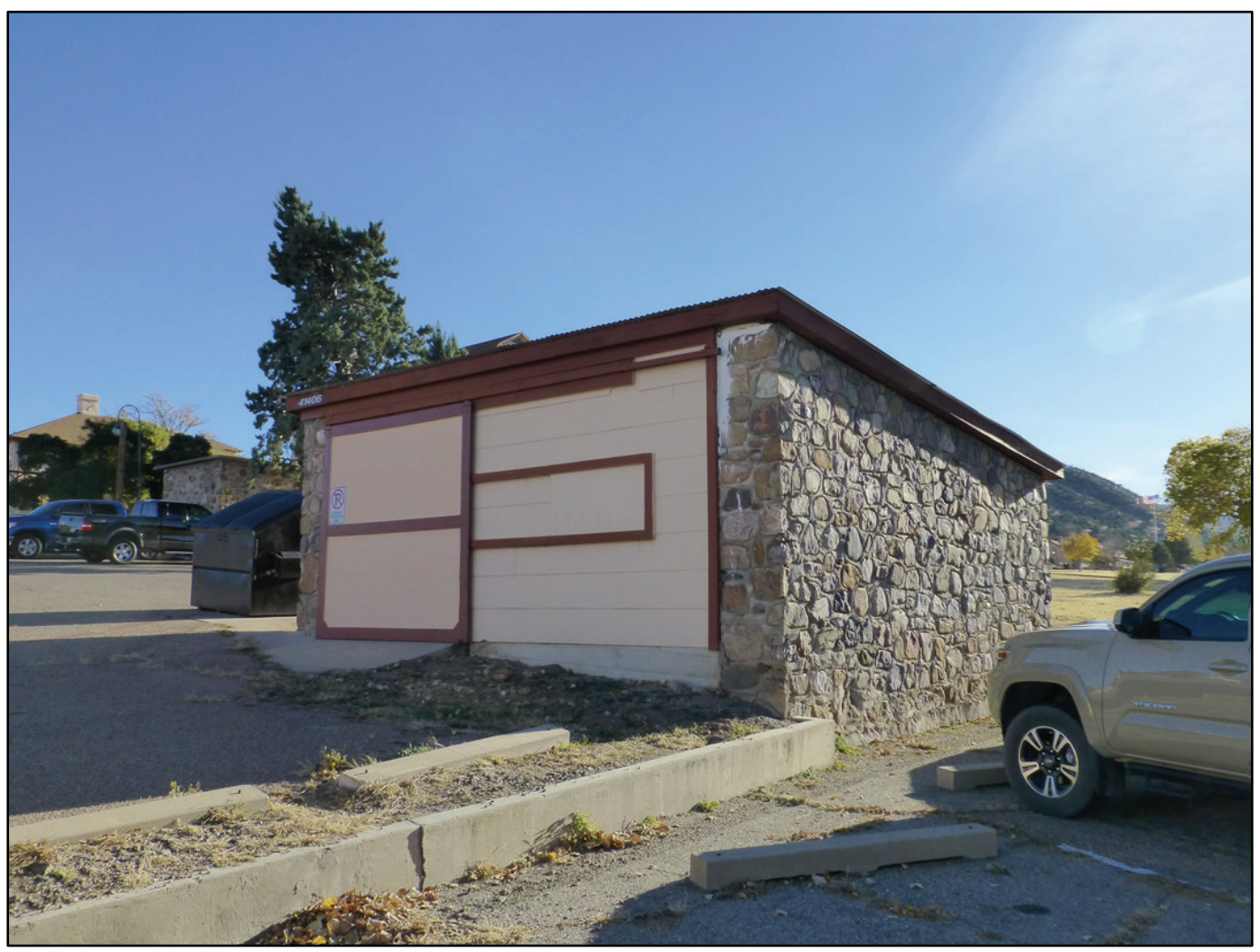

Figure 147. View looking west at 41403 behind 41402 (ERDC-CERL, 2016).

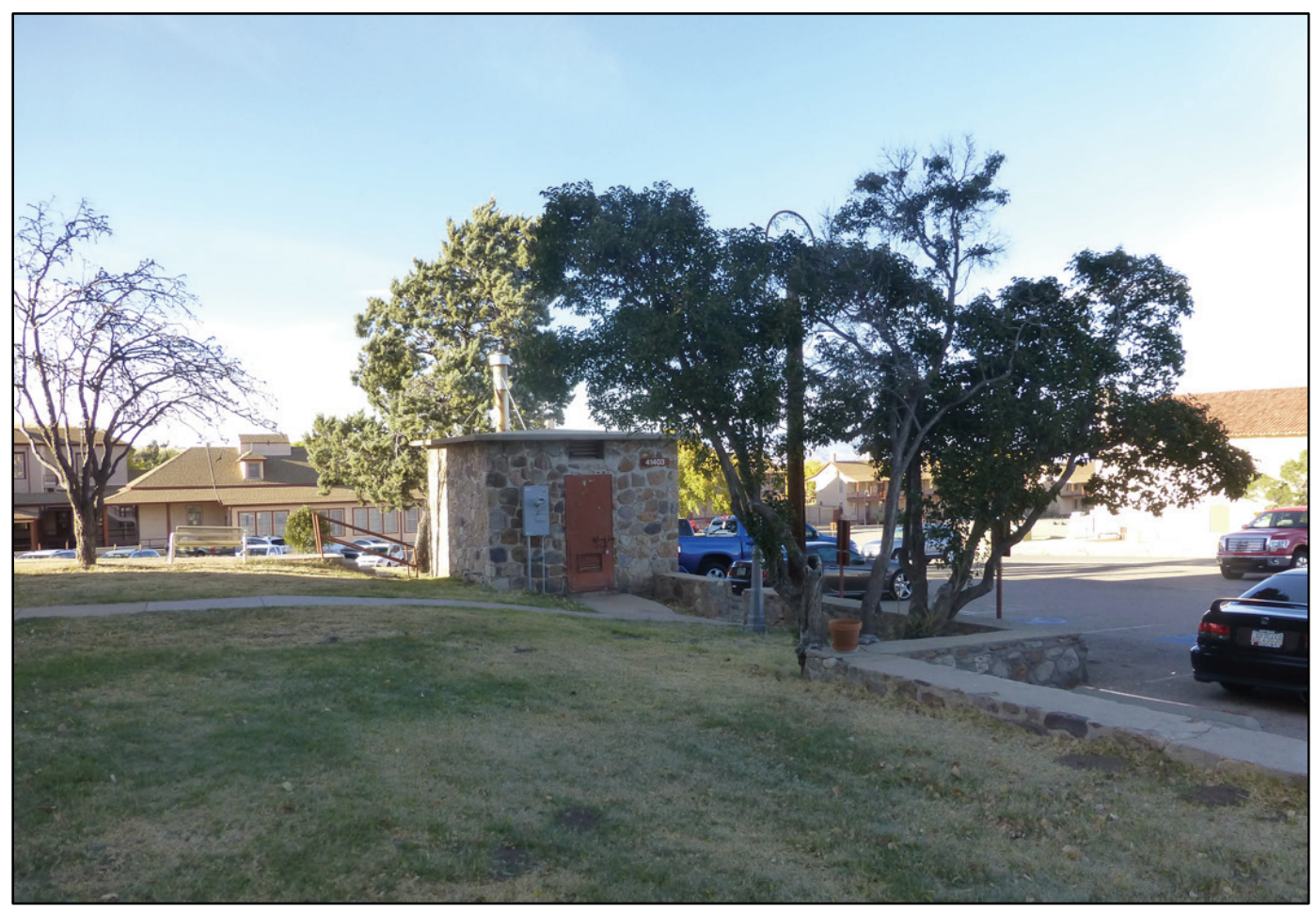


Figure 148. View looking north at area in between 41402 and 41401 (ERDC-CERL, 2016).

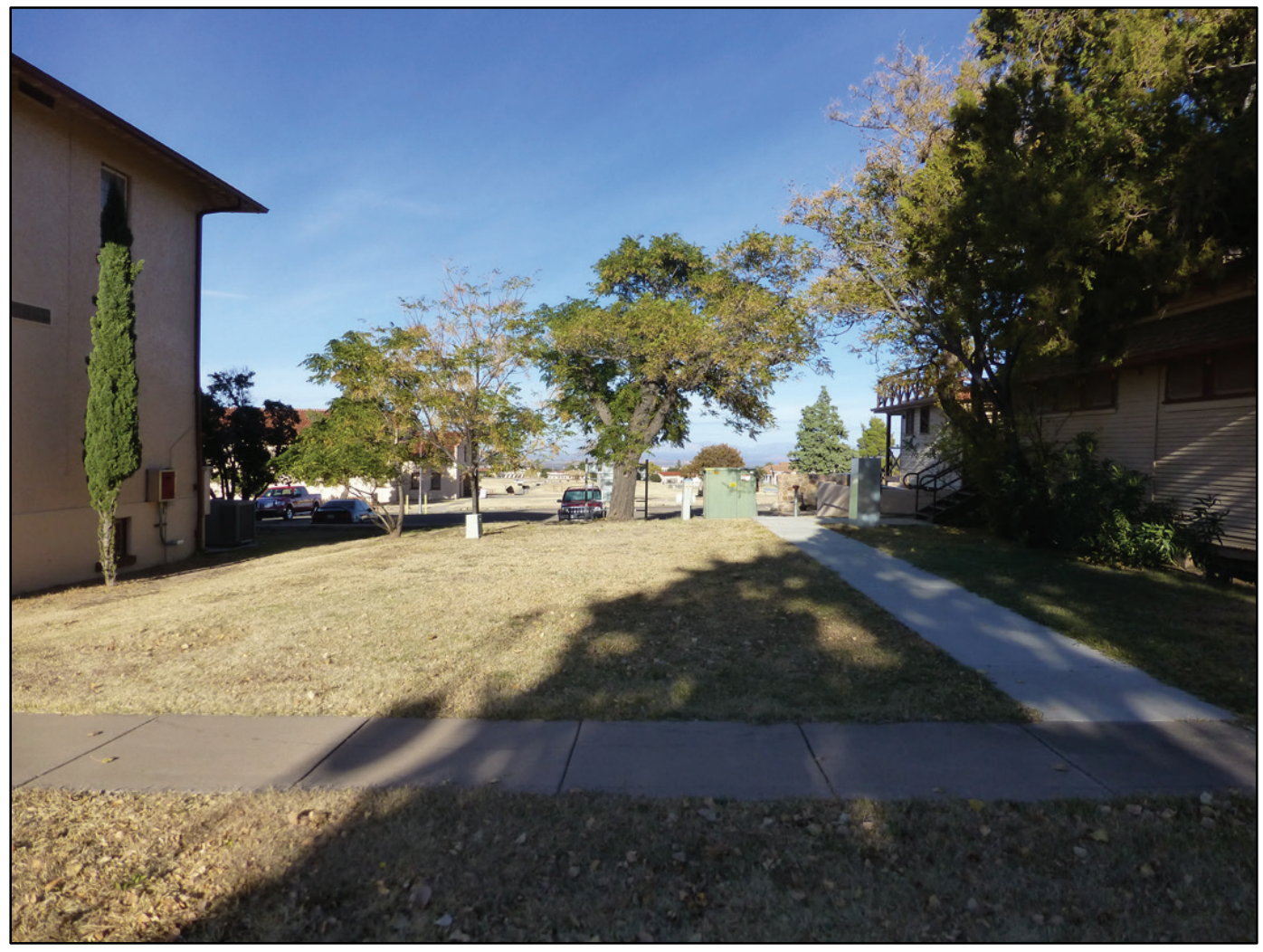

Figure 149. View looking northeast at trees in front of 41401 (ERDC-CERL, 2016).

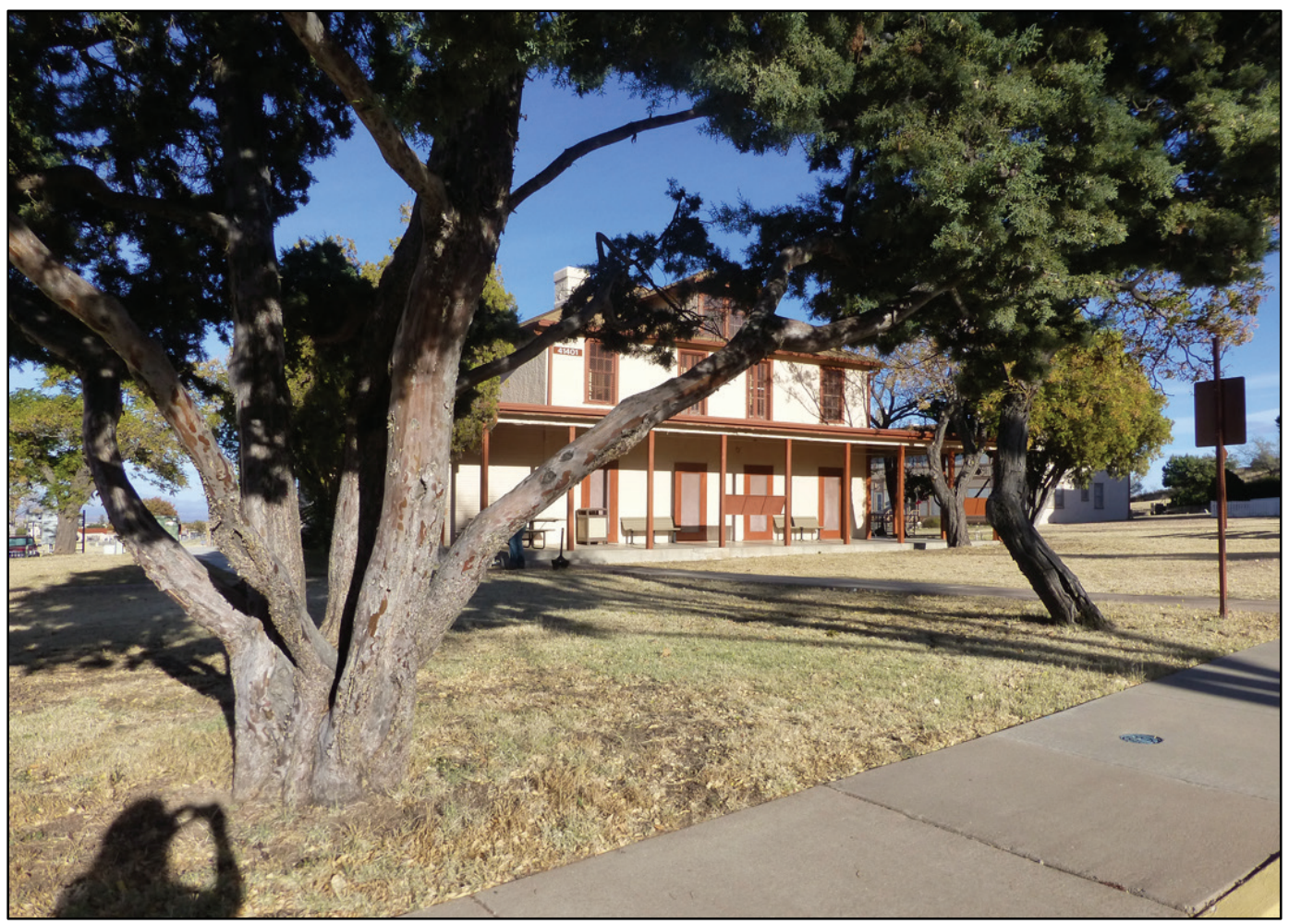


Figure 150. View looking northwest at shrub on the side of 41401 (ERDC-CERL, 2016).

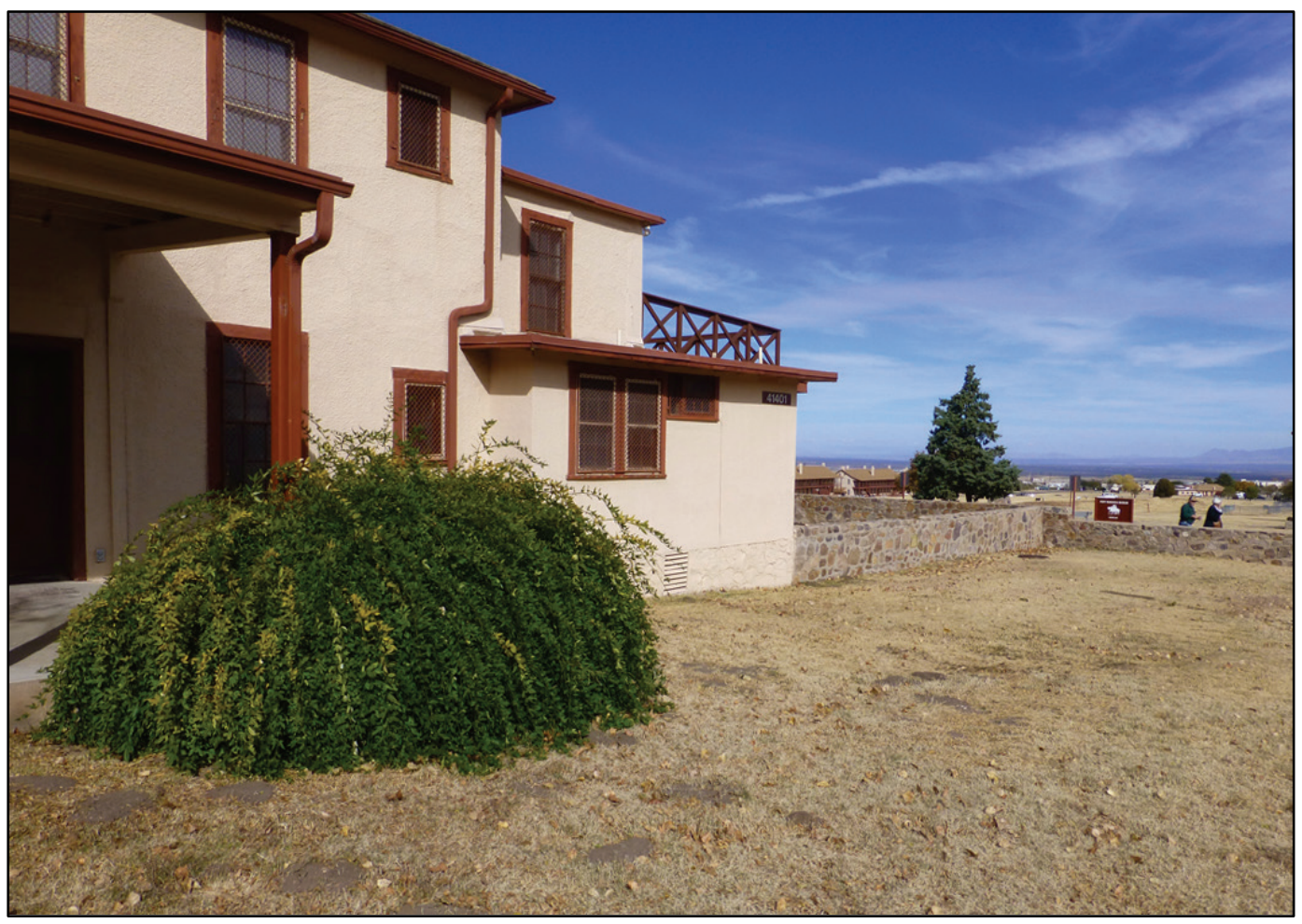

Figure 151. View looking southeast at rear of 41401 and second story fire escape (ERDCCERL, 2016).

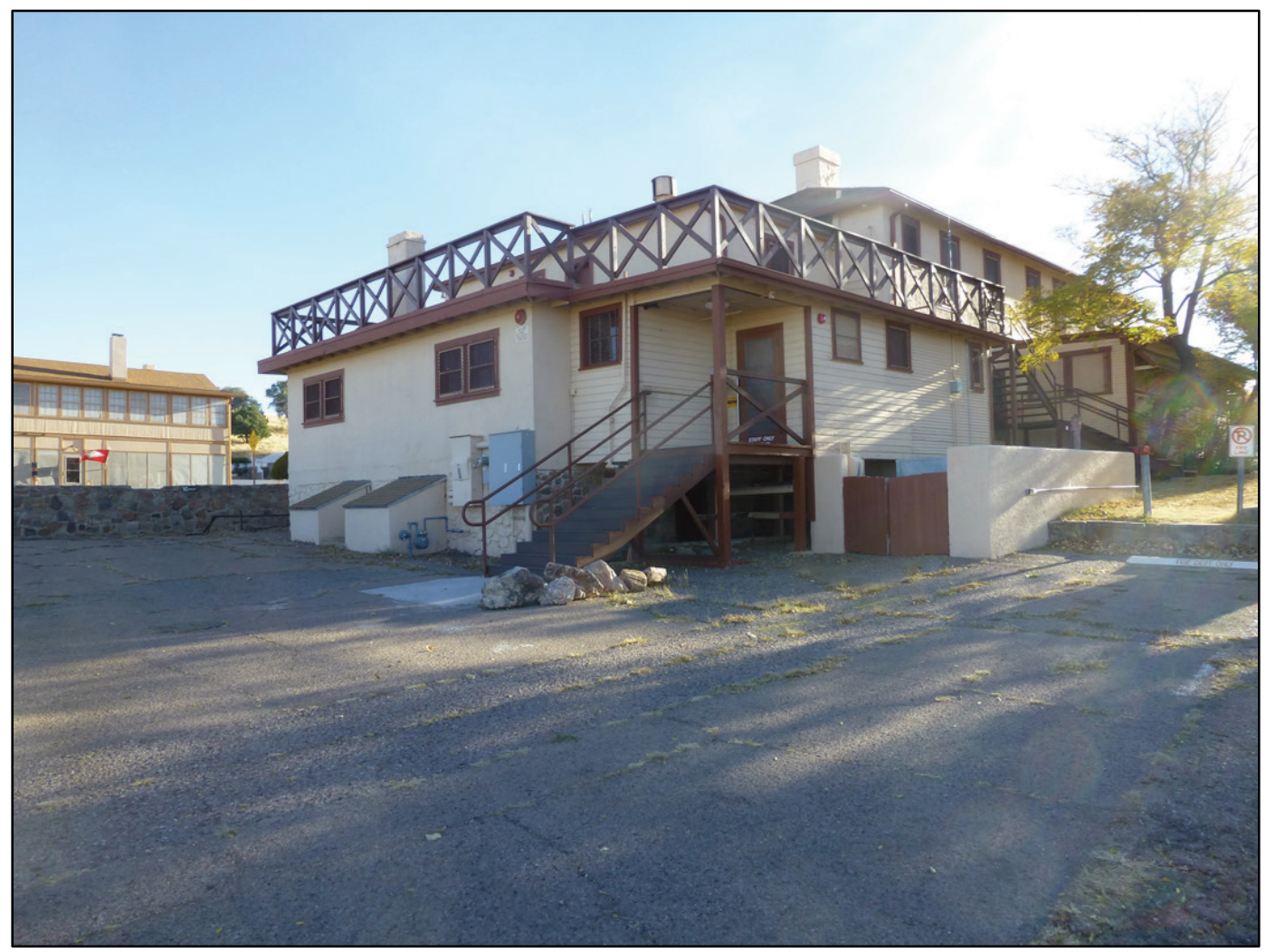


Figure 152. Looking north at the Museum's wood sign with stone base at the northeast corner of Boyd and Grierson Avenues (ERDC-CERL, 2016).

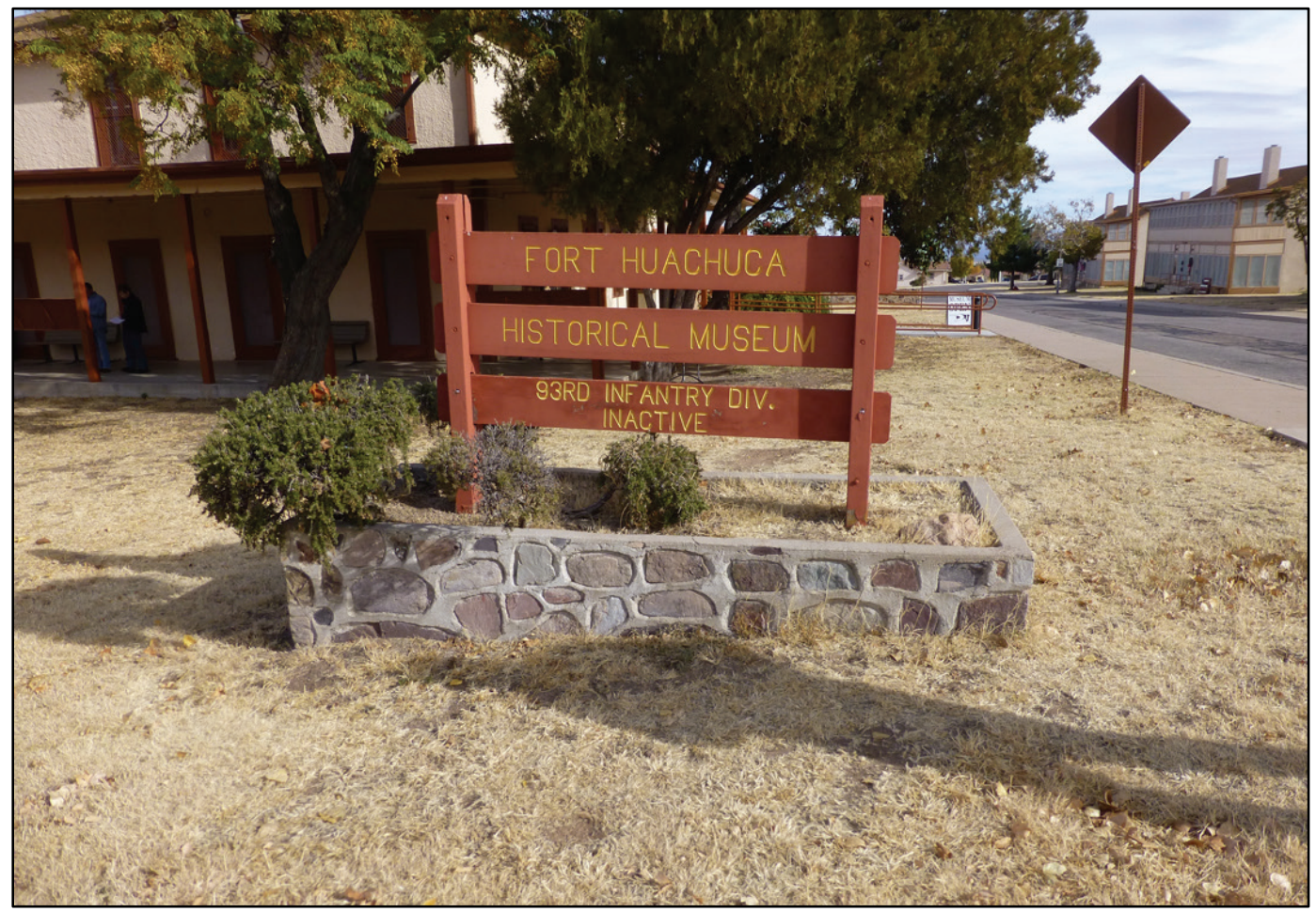

Figure 153. View looking southwest from 41408 to Huachuca Mountain (ERDC-CERL, 2016).

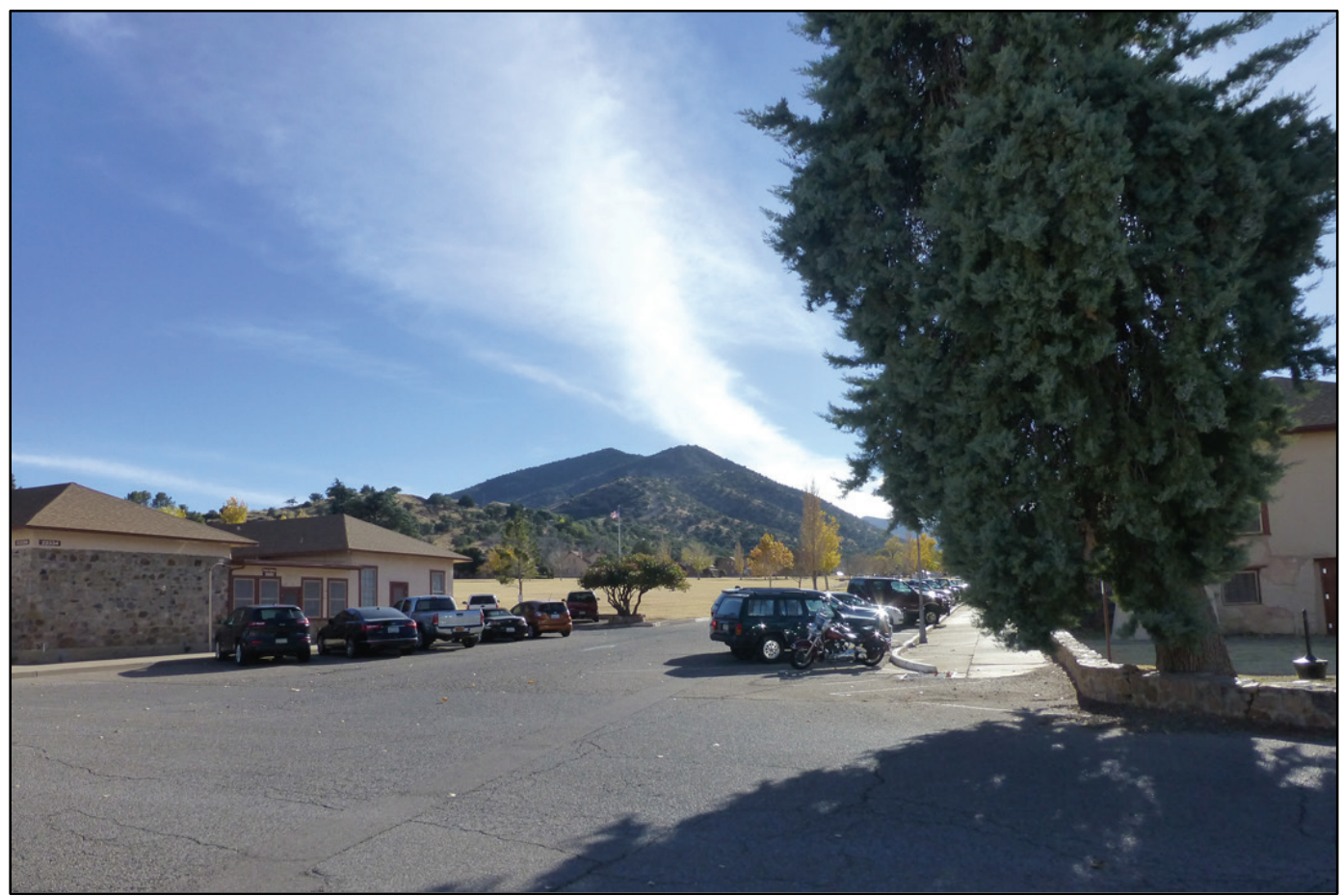


Figure 154. View east down Boyd Avenue with 41402 on left and Brown Field on right (ERDCCERL, 2016).

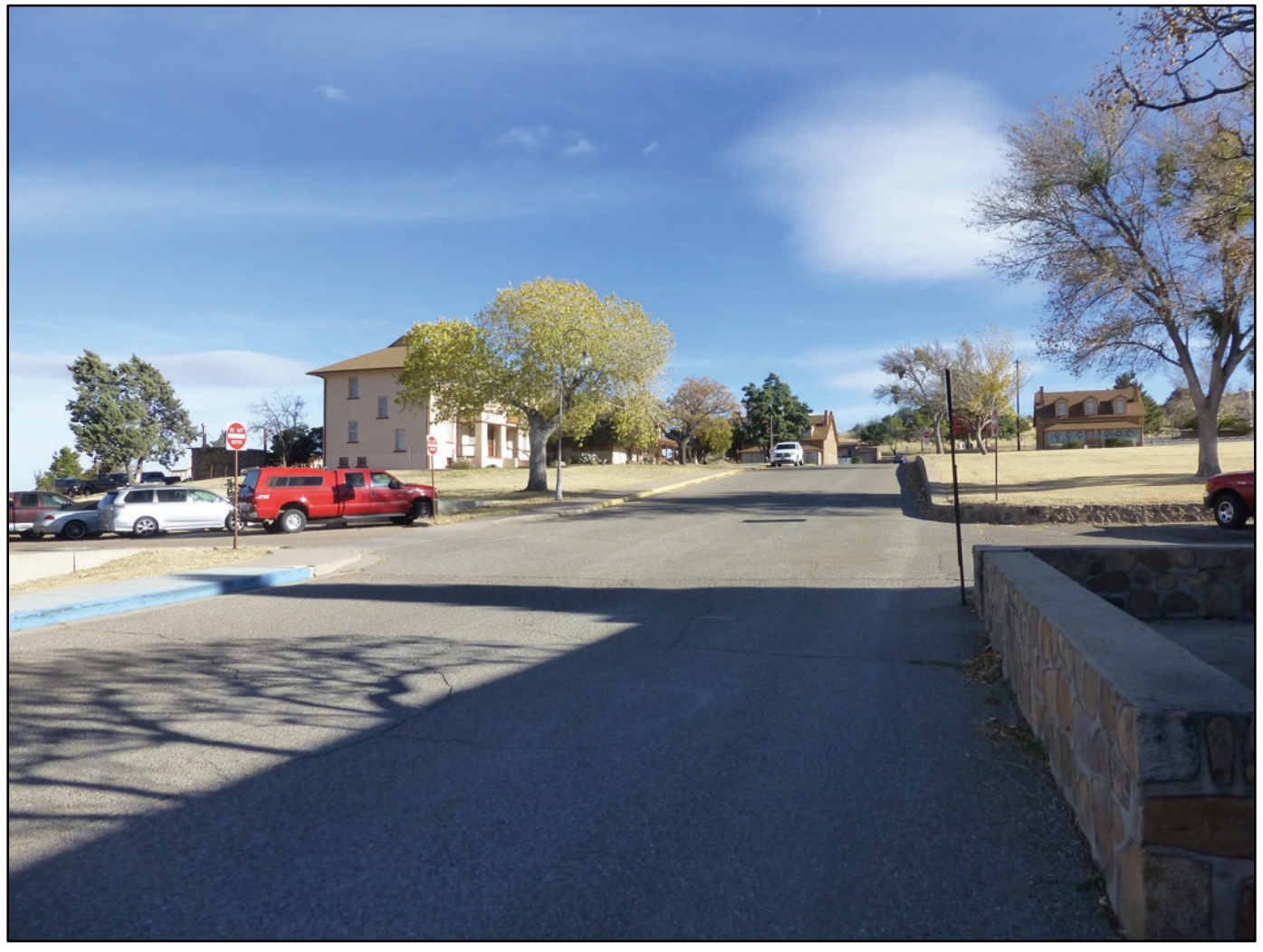

\subsubsection{Significance and integrity}

The administration buildings are clustered along the north side and northwest corner of the parade ground. While each building is unique at Huachuca, some may have been from standardized Quartermaster Corps plans. The administrative and hospital buildings vary widely in size, architectural detail, and degree of modification. Many have undergone changes in use over the years, but all contribute to the historic district. In general, most of these buildings retain a high degree of integrity.

\subsubsection{Character-defining features}

Character-defining features include:

- Unique but compatible architecture

- Prominent location at north end of parade field

- Consistent land use as administration

- Views to and from parade field. 


\subsection{Brown Field}

Brown Field is the centrally-located parade field at the heart of the Old Post (Figure 155). Resources included in this landscape include the flagpole, gazebo and the Post Exchange Restaurant building (22334) (Table 11).

Figure 155. Brown Field landscape area map (ERDC-CERL).

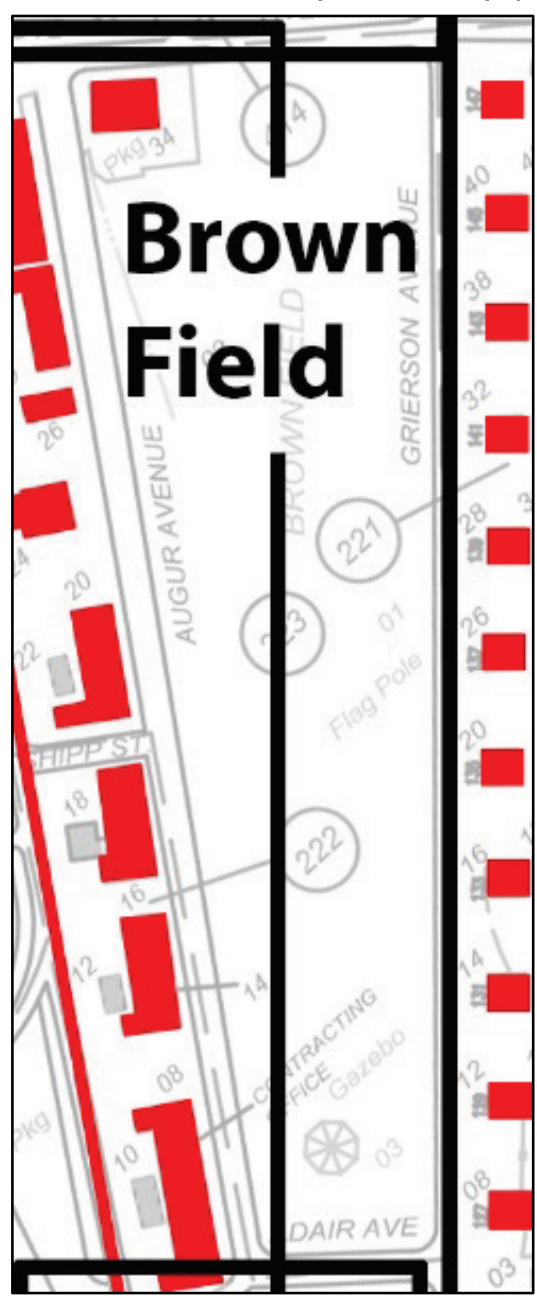

Table 11. List of buildings within the Brown Field landscape area.

\begin{tabular}{|c|c|l|l|c|}
\hline Building Number & Year Built & \multicolumn{1}{|c|}{ Original Use } & \multicolumn{1}{c|}{ Current Use } & Historic Status \\
\hline 22301 & 1951 & Flagpole & Flagpole & NEV \\
\hline 22302 & 1880 & Brown Field & Brown Field & NHLC \\
\hline 22303 & 1982 & Recreation Shelter (Gazebo) & Recreation Shelter (Gazebo) & NEV \\
\hline 22334 & 1920 & Post Exchange Restaurant & Administrative & NHLC \\
\hline
\end{tabular}

\subsubsection{History}

Brown Field, the heart of the post, was part of the original post design and spatial layout since the 1880 s. The tree-lined open space served as drill 
space for the cavalry as well as ceremonial space for the post. A bandstand was located in the northeast corner of the parade field as early as 1920. The flagpole was located in front of historic Quarters 1, the installation commander's house known as Pershing House (Building 22126). The edge of the parade field was heavily planted with street or shade trees.

A 1911 map shows a gazebo (or bandstand) adjacent to the flagpole in front of Pershing House. A later photograph shows the bandstand in the northeast corner of Brown Field (Figure 161). A PX Restaurant (22334) was constructed in the northwest corner of the parade field in 1920 across from the 1915 hospital. The building replaced the Braydon Hall basement as the PX restaurant (Figures 156-161).

Figure 156. View south across Brown Field, c.1883 (NARA College Park, RG165-FF).

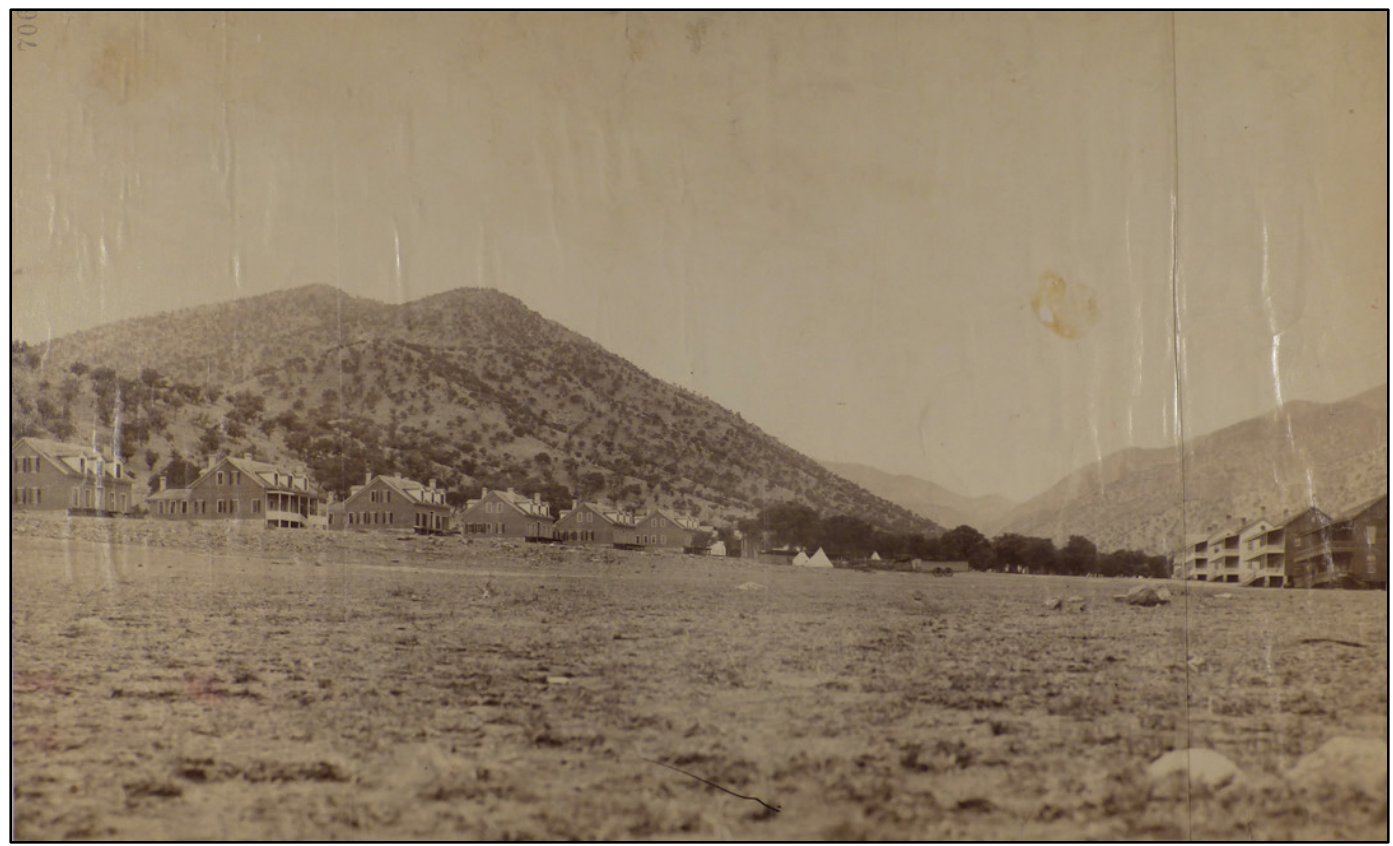


Figure 157. View south across Brown Field in the snow, 1898 (NARA College Park, RG111$\mathrm{SC})$.

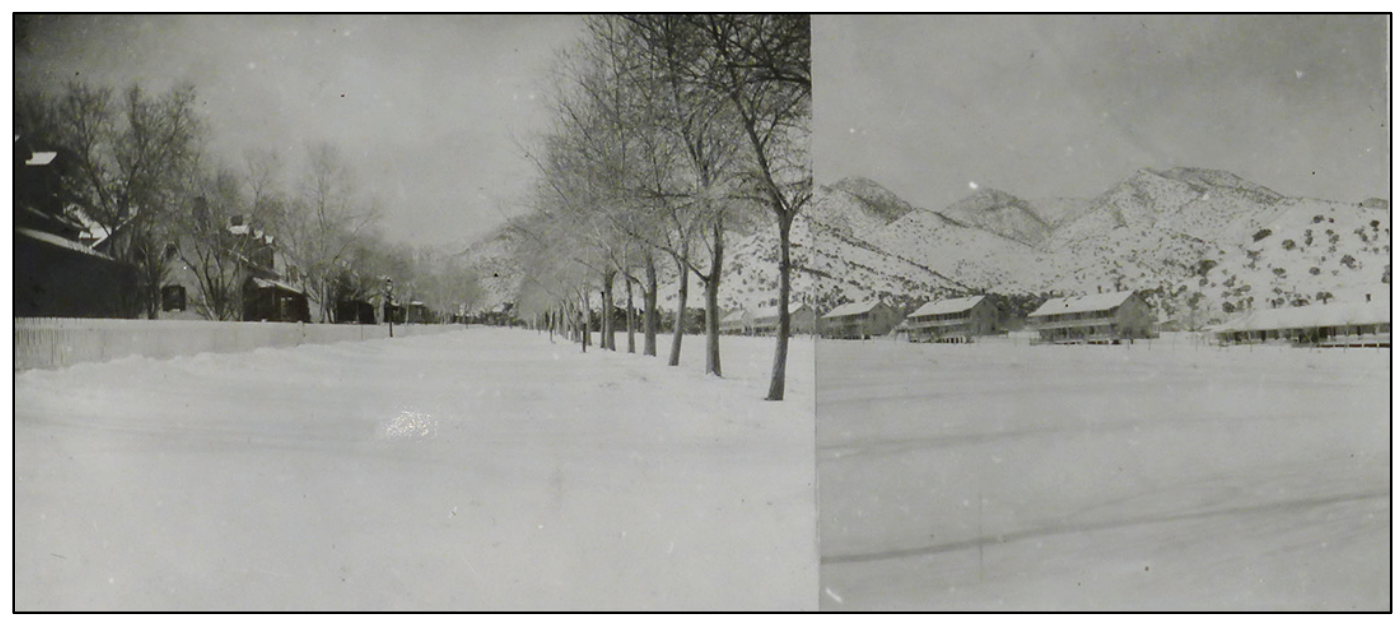

Figure 158. View south over Brown Field, 1899 (NARA College Park, RG111-SC).

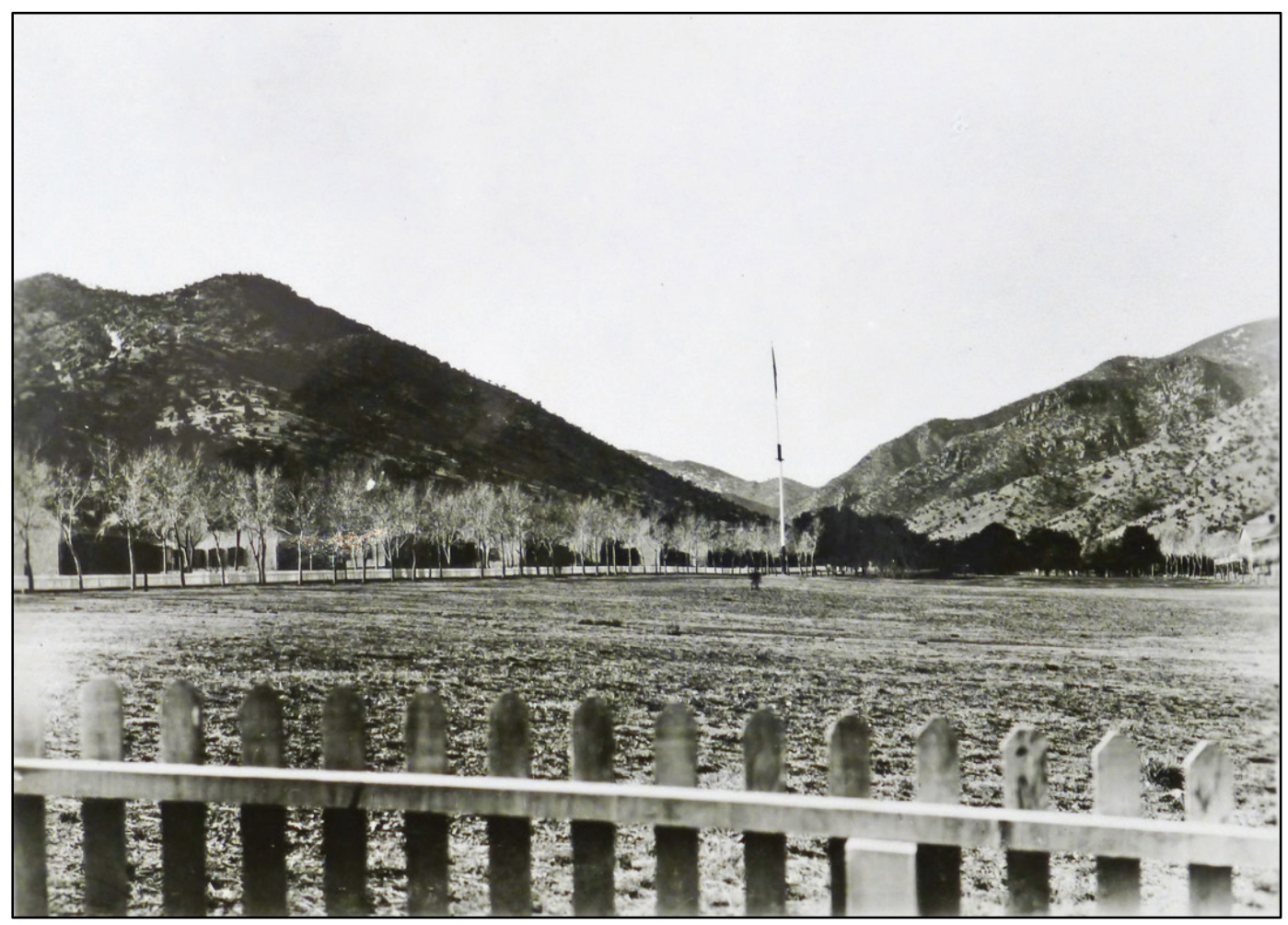


Figure 159. View looking northeast of the flagpole on Brown Field with officers' quarters behind, c.1900 (NARA College Park, RG165-FF).

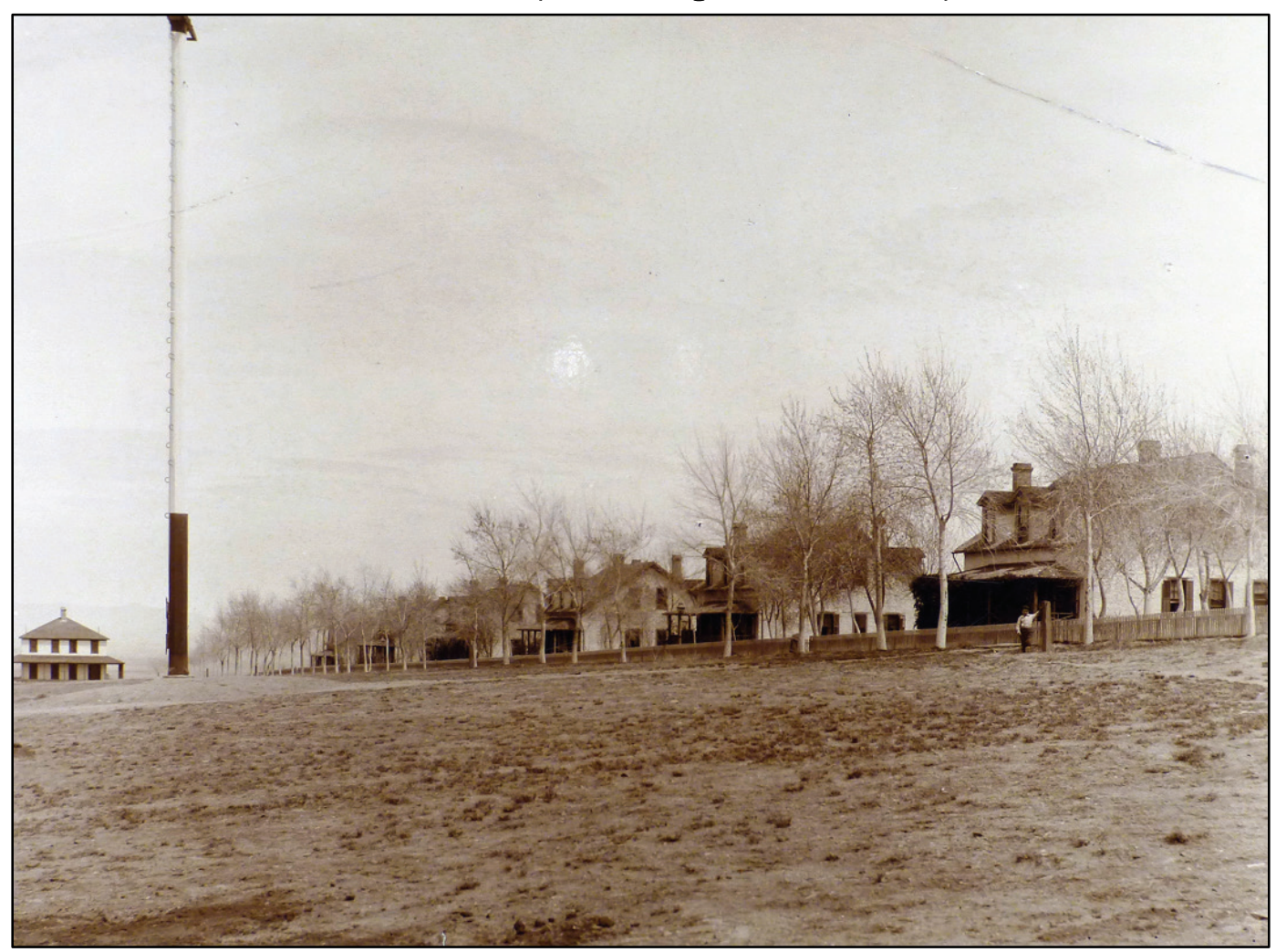

Figure 160. View southeast at the officers' quarters, c.1900 (NARA College Park, RG165-FF).

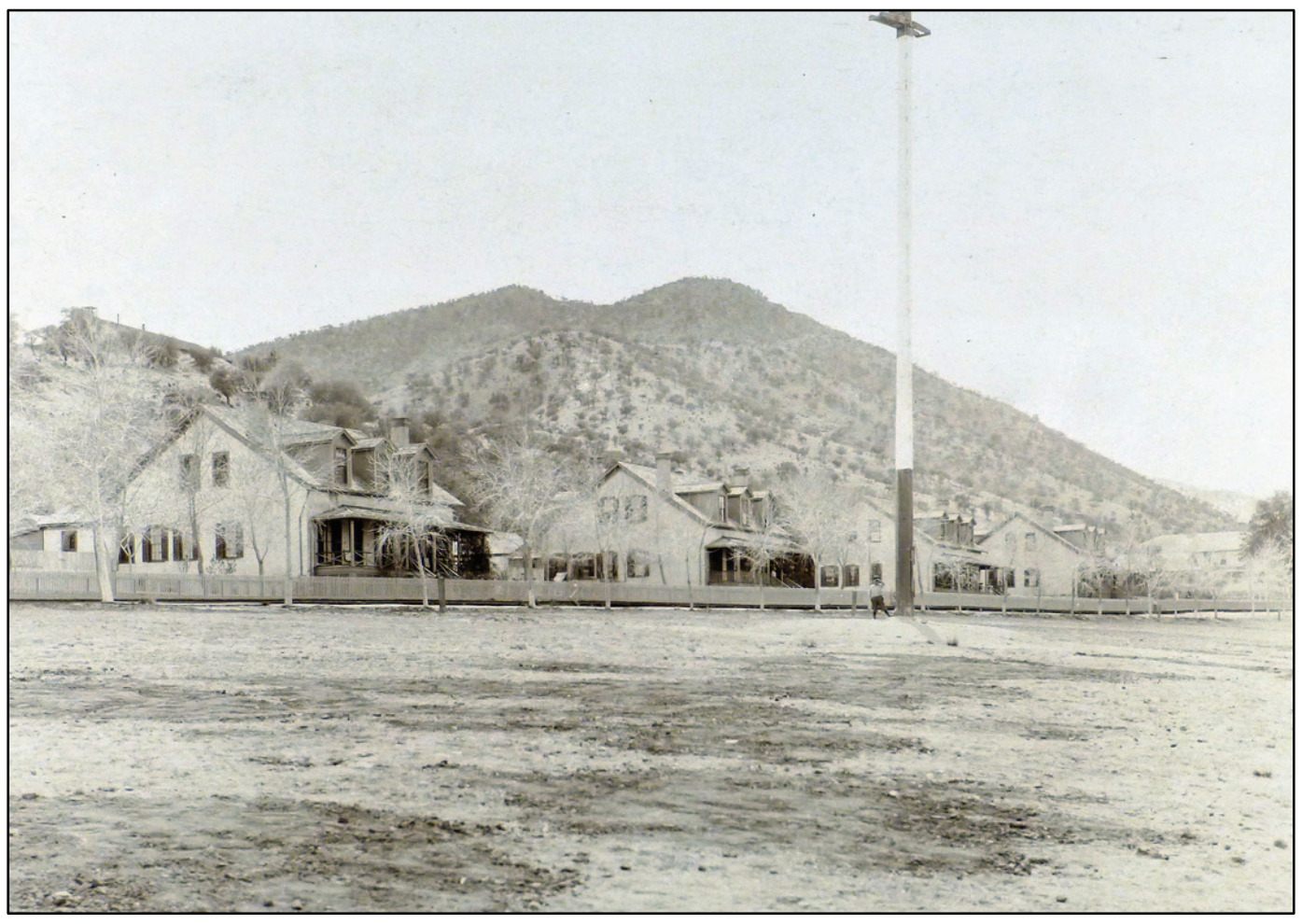


Figure 161. View south of the parade field showing the growth of trees, no date [Note gazebo (demolished) at lower left.] (NARA College Park, RG111-SC).

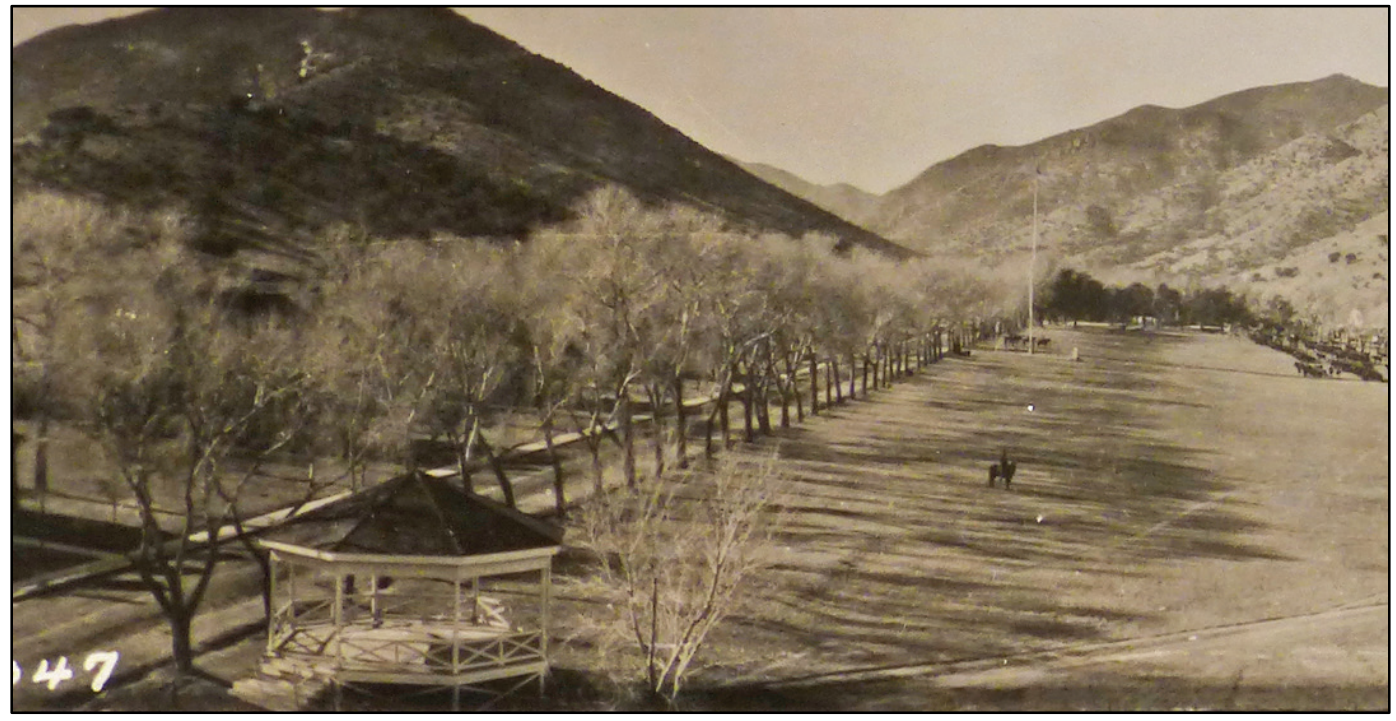

\subsubsection{Current conditions}

Brown Field continues to be a distinct open space in the center of the Old Post area. A wood Fort Huachuca sign is located in the northeast corner of the parade field. It was rebuilt recently, but likely, the original dated to 1977. It is unknown if it replaced an older sign in this location.

On the west side of Brown Field, parking has been added in front of the barracks and other buildings along Augur Avenue. Also along the west side of Brown Field are some street trees, which historically lined the parade field but not as many as seen in historic photographs. Interspersed with the trees are some stone planters and sections of remaining stone curb or retaining wall along Augur Avenue.

The east side of the field is also lined with trees, although a few are missing. The flagpole (22301), located in front of Pershing House (22126), was replaced in 1951. There is currently a stone retaining wall around the flagpole. It is unknown when exactly this wall was added. Two artillery pieces are located in the northwest and southwest corners, and two flower beds are in northeast and southeast corners. A stone with the NHL plaque is in front of the retaining wall on the west side. In addition, two evergreen trees flank the west side corners. 
The gazebo (22303) is now located at the southeast corner of the parade field in front of Building 22114. The PX Restaurant (22334) has been utilized as offices since the Korean War, although a seating area behind a stone wall is still located in the front of the building along Augur Avenue. There are still many sweeping views across Brown Field (Figures 162-191).

Figure 162. Fort Huachuca National Historic Landmark wood sign with stone base at northeast corner of Brown Field (ERDC-CERL, 2016).

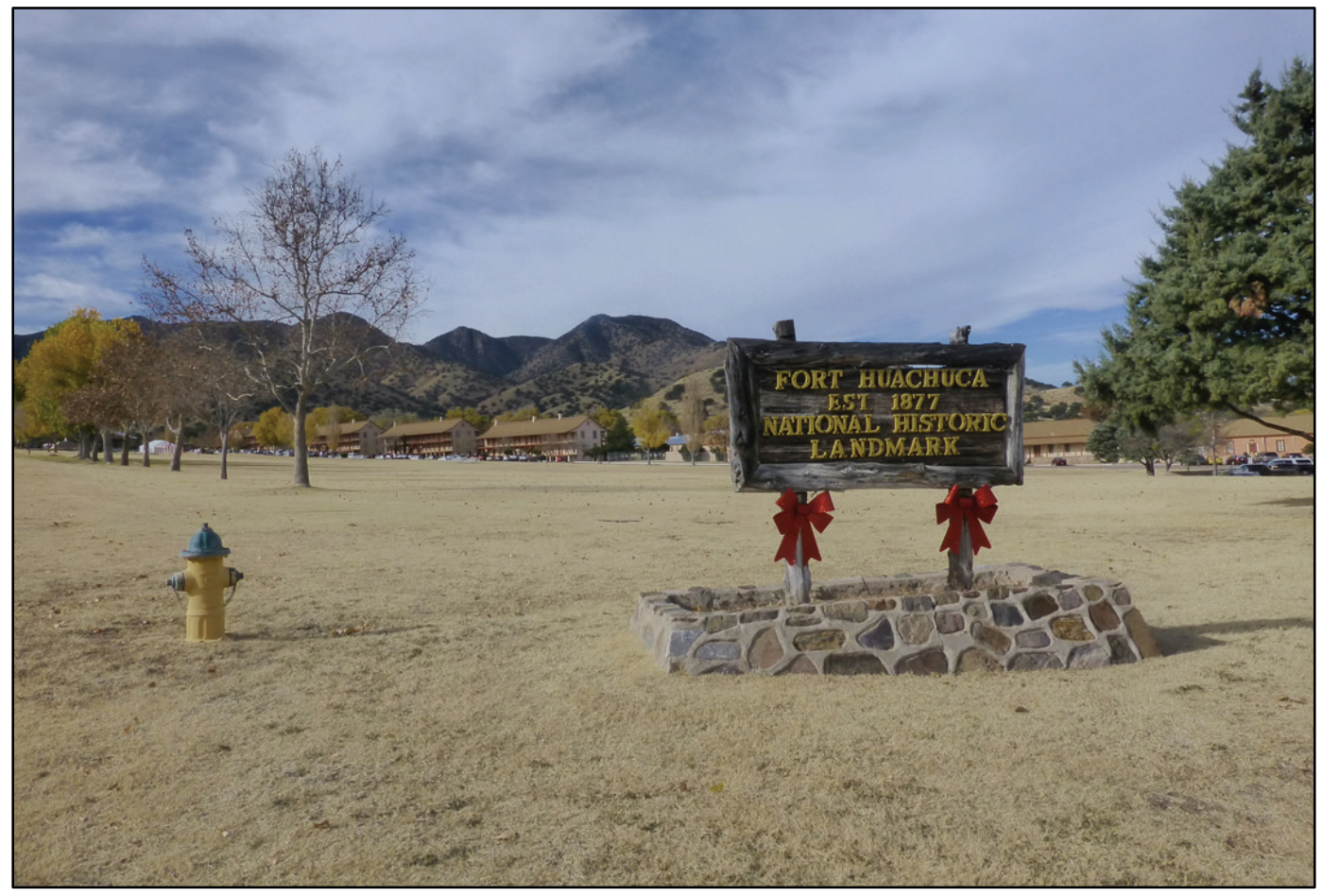


Figure 163. View looking southeast at sign for Garrison Headquarters at the northern end of the parade field (ERDC-CERL, 2016).

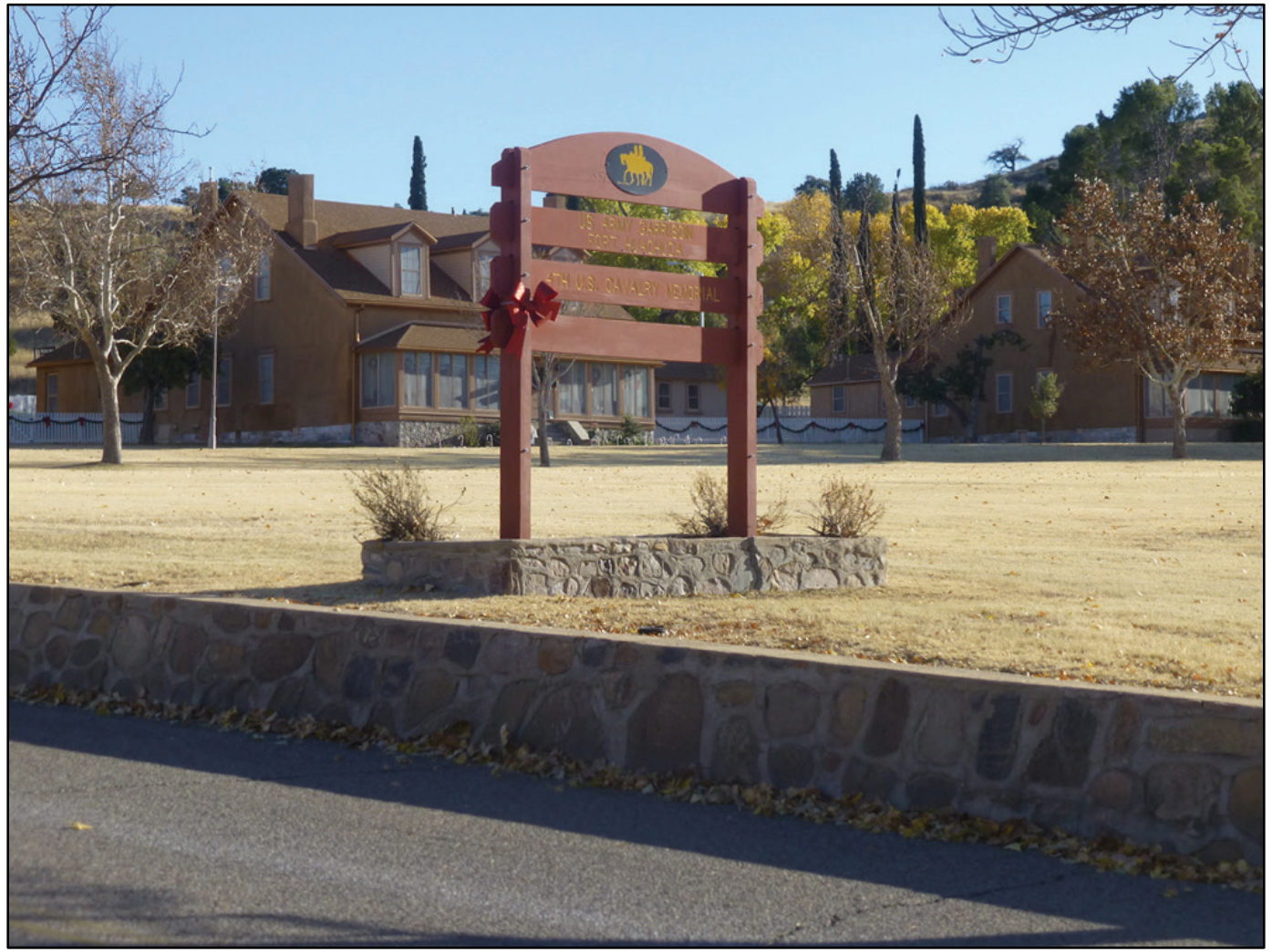

Figure 164. View to the south of Brown Field and the officers' quarters (ERDC-CERL, 2016).

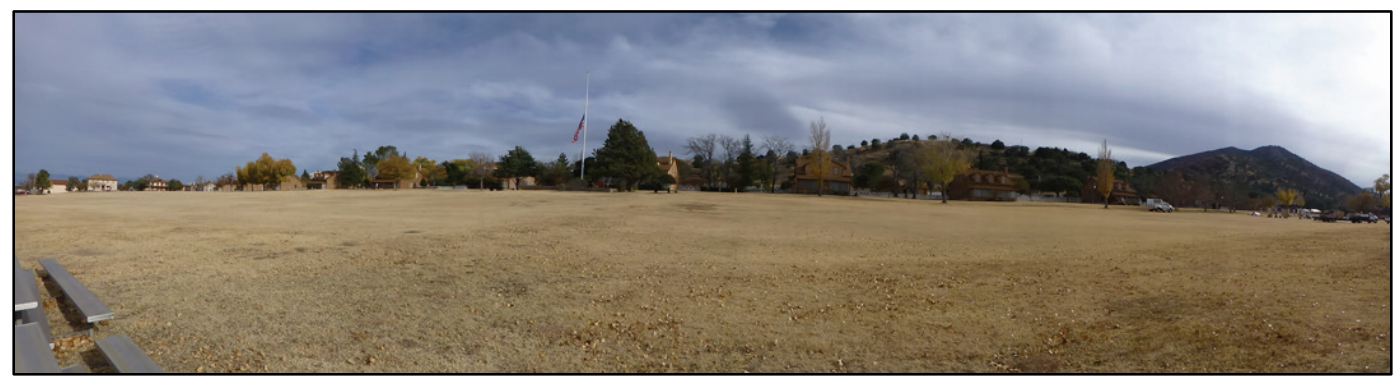

Figure 165. Looking north at Brown Field (ERDC-CERL, 2016).

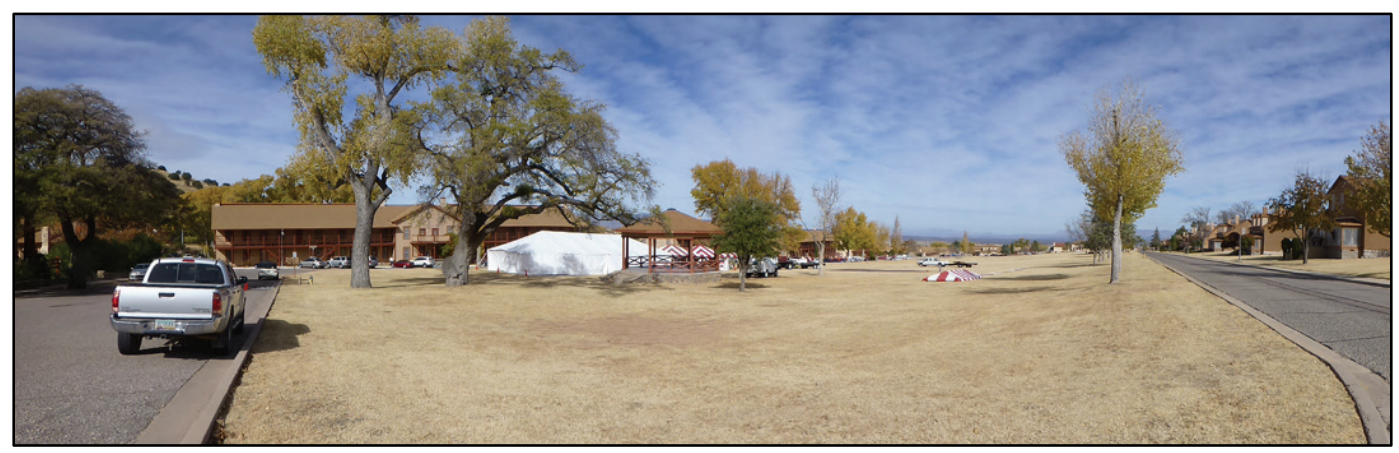


Figure 166. Looking north at parking along Augur Avenue between barracks and Brown Field (ERDC-CERL, 2016).

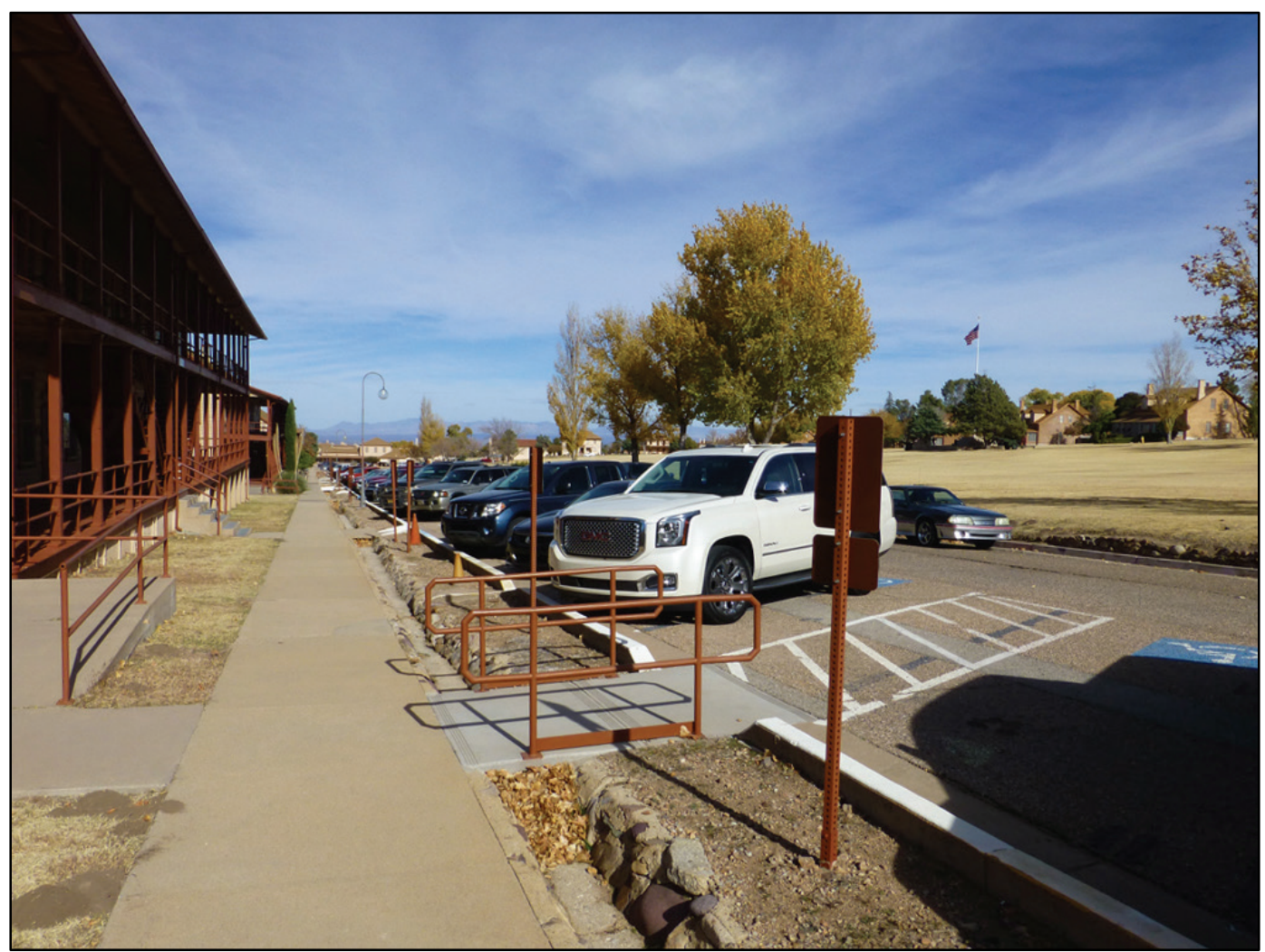

Figure 167. View looking north at trees and bleachers on Brown Field (ERDC-CERL, 2016).

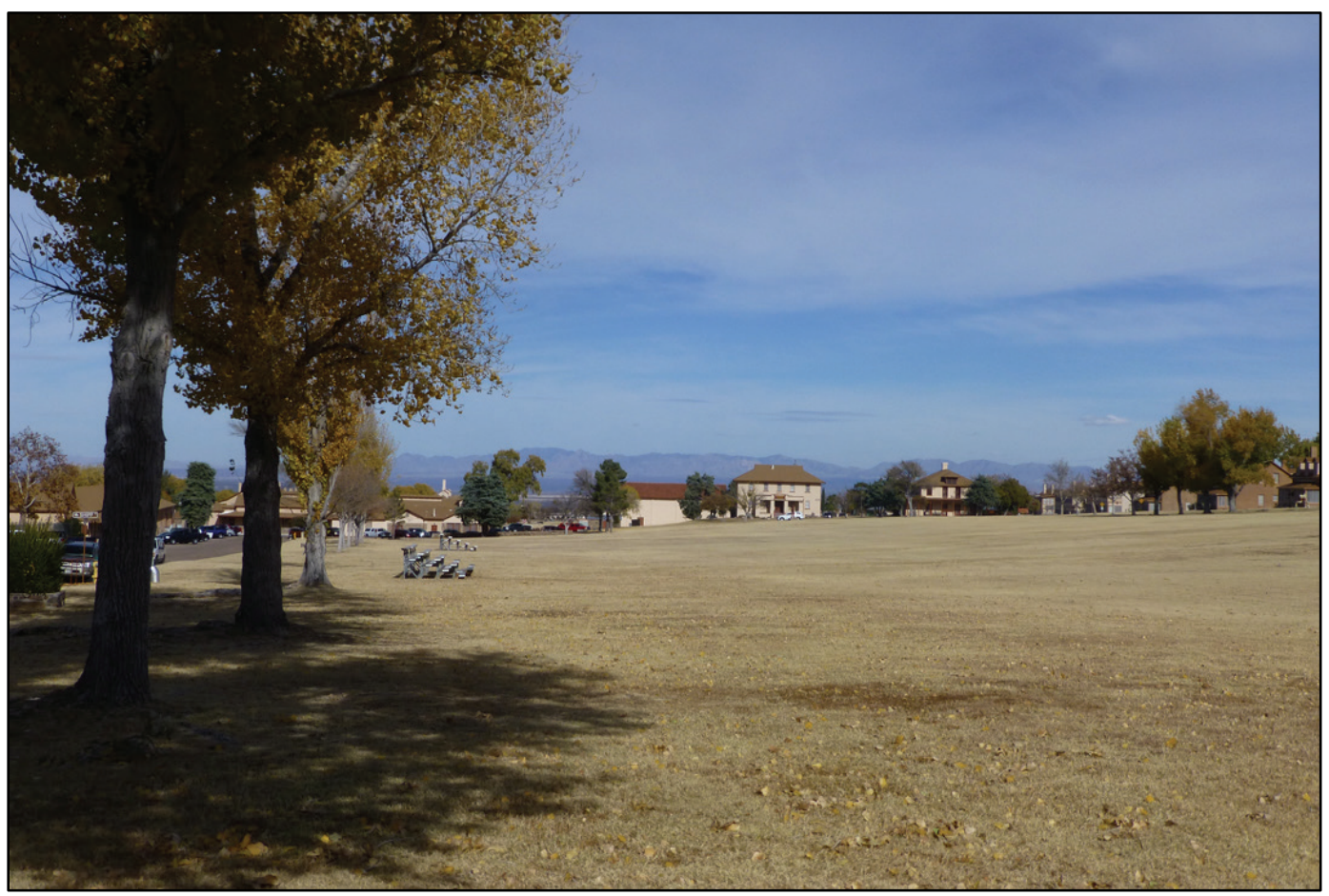


Figure 168. View looking north at rock planters and trees on the west side of the parade field (ERDC-CERL, 2016).

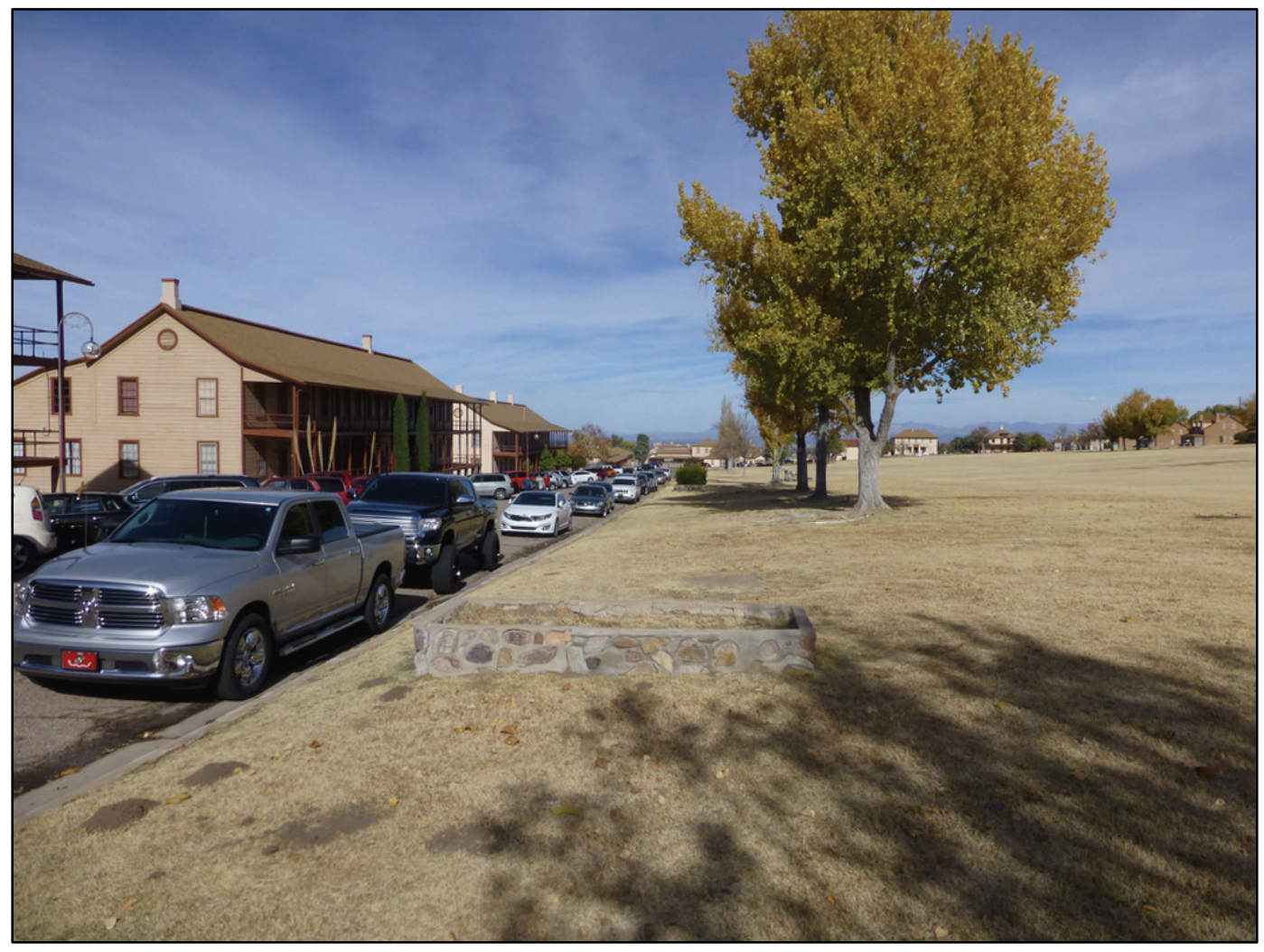

Figure 169. View looking northeast at concrete curb and rock retaining wall on west side of parade field (ERDC-CERL, 2016).

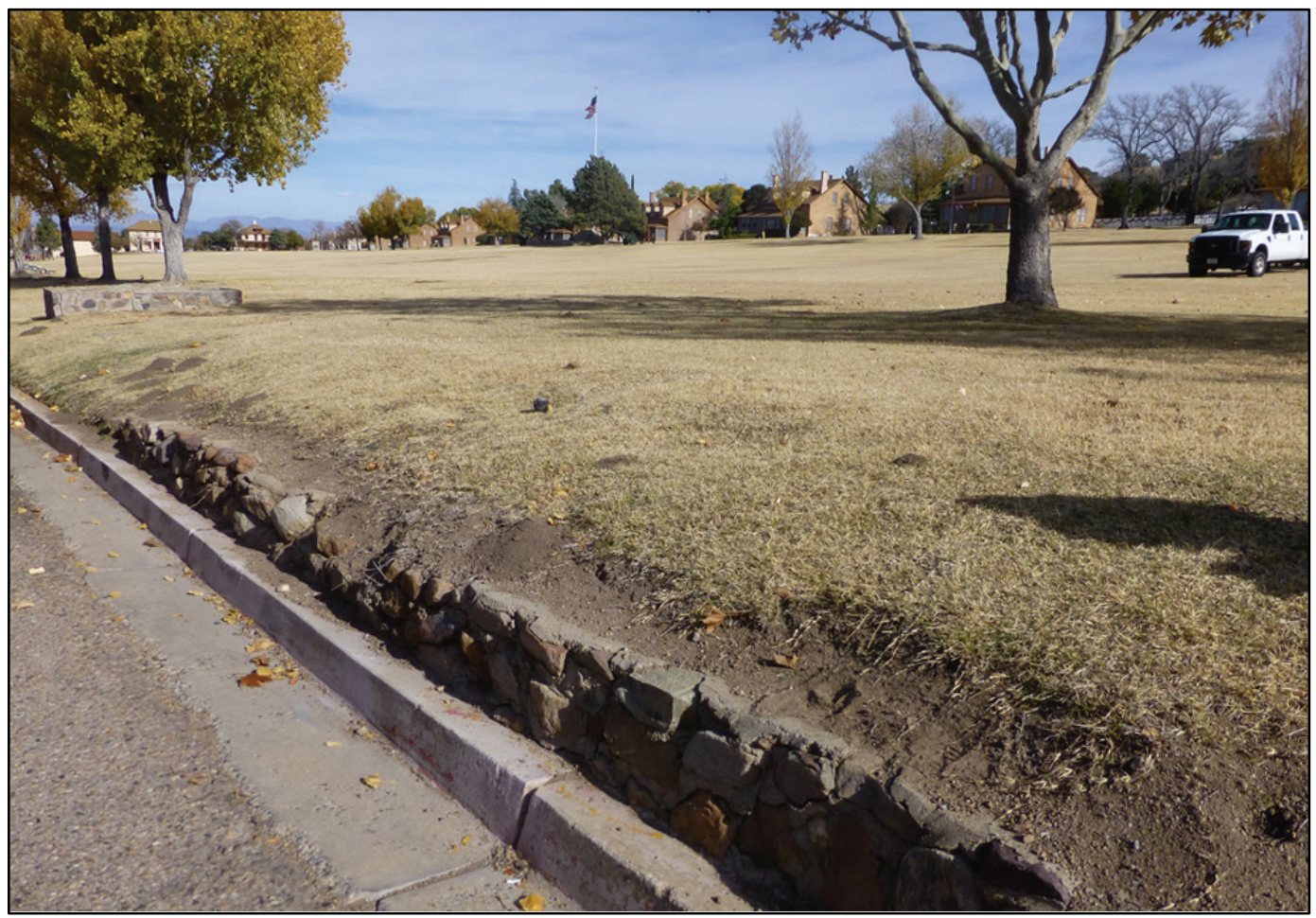


Figure 170. View looking north of fire hydrant, cast iron bollards, stone wall that hides a meter, and trees on west side of parade field (ERDC-CERL, 2016).

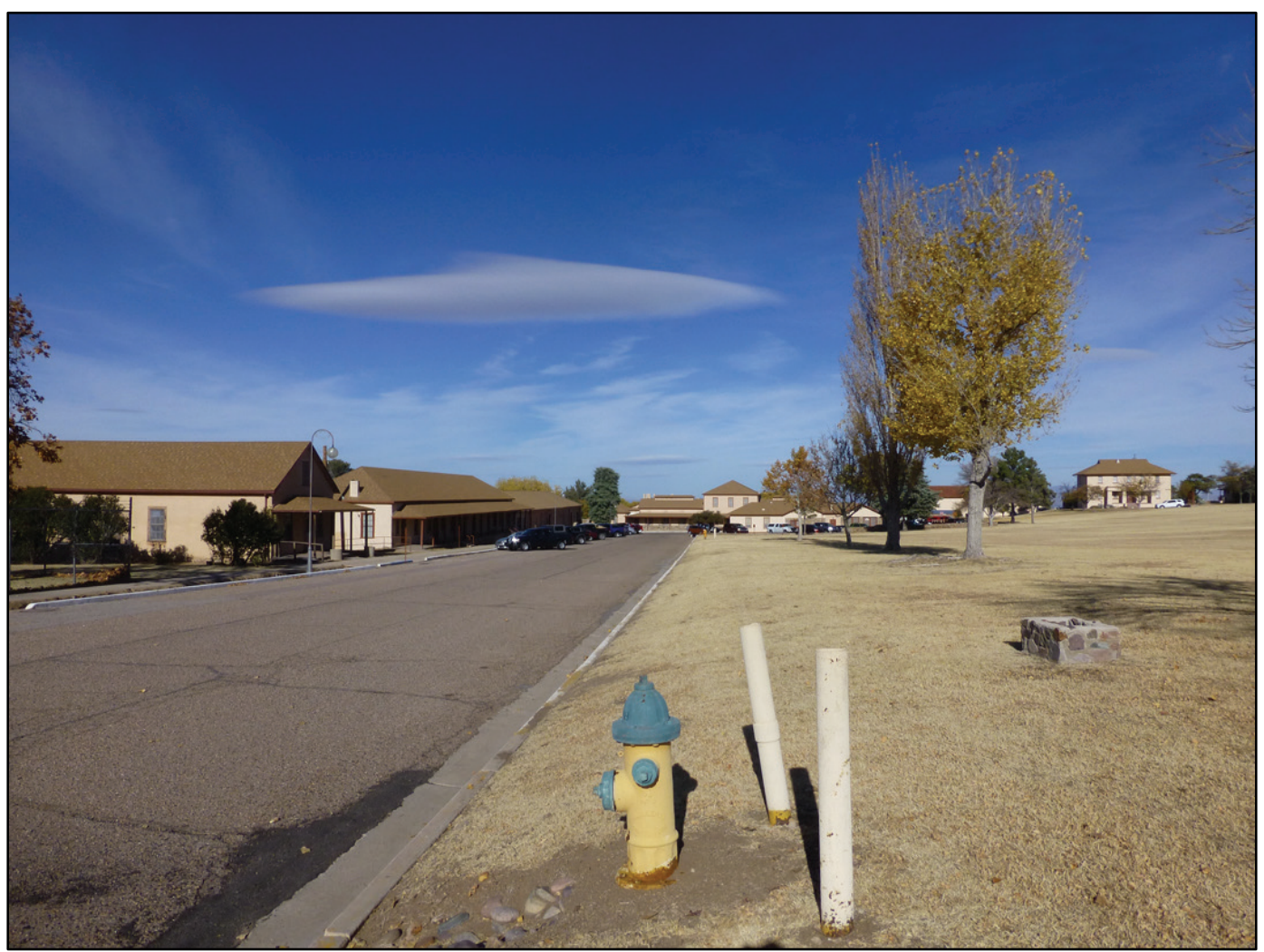

Figure 171. Looking north down Brown Field toward Garrison Headquarters (ERDC-CERL, 2016).

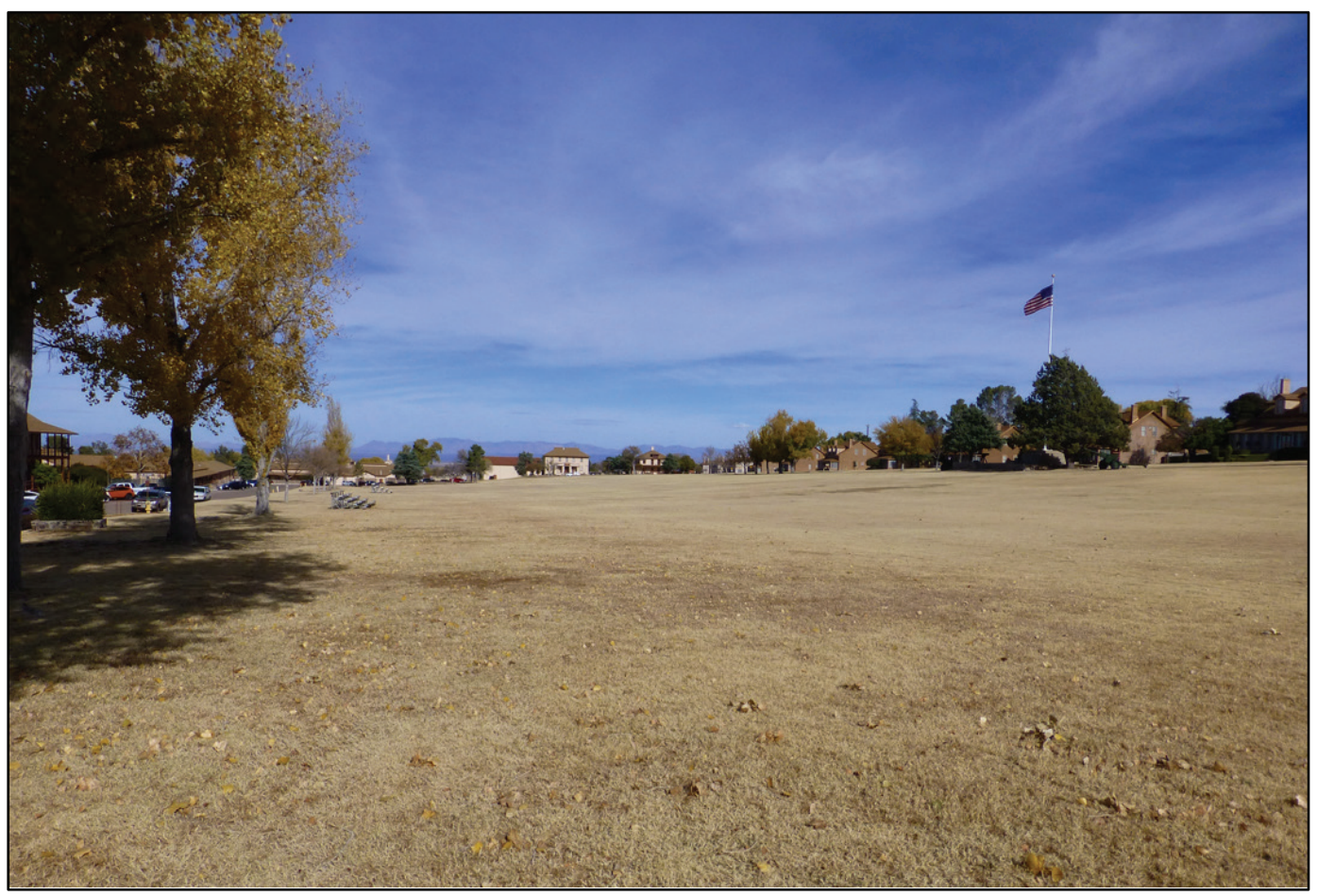


Figure 172. Looking south at Brown Field from Boyd Avenue (ERDC-CERL, 2016).

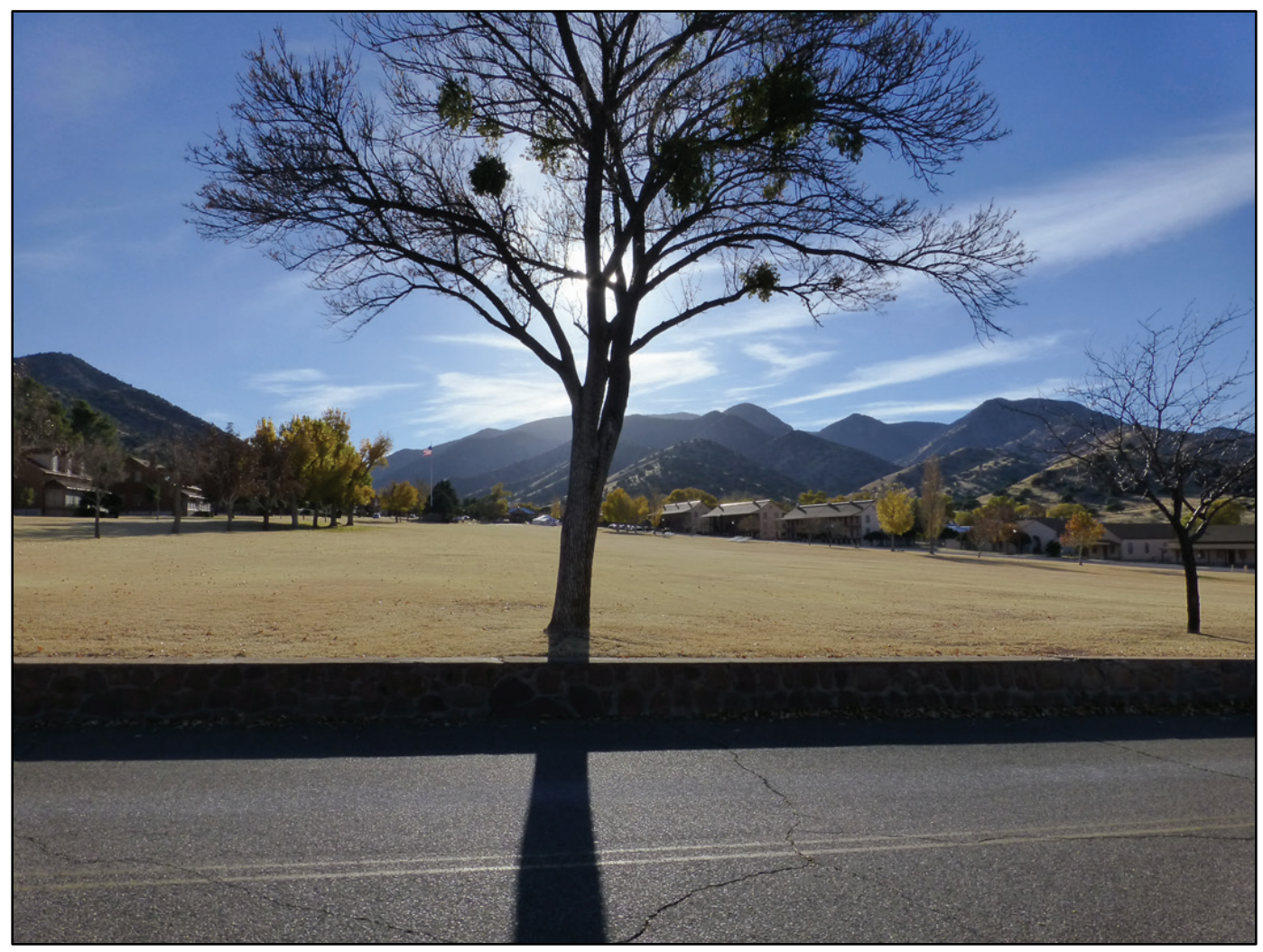

Figure 173. Looking south of Brown Field (ERDC-CERL, 2016).

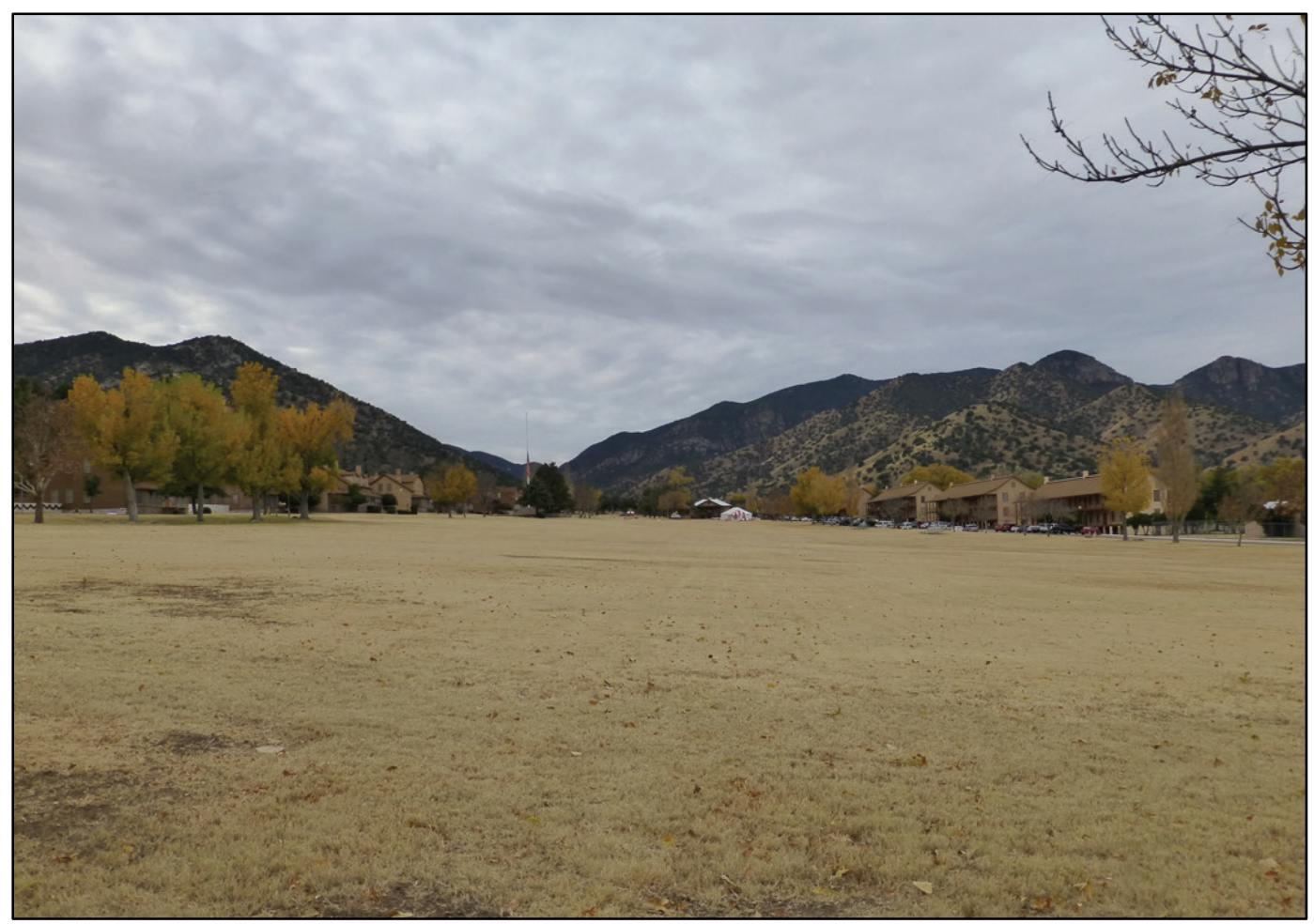


Figure 174. View looking north of trees along the east side of Brown Field (ERDC-CERL, 2016).

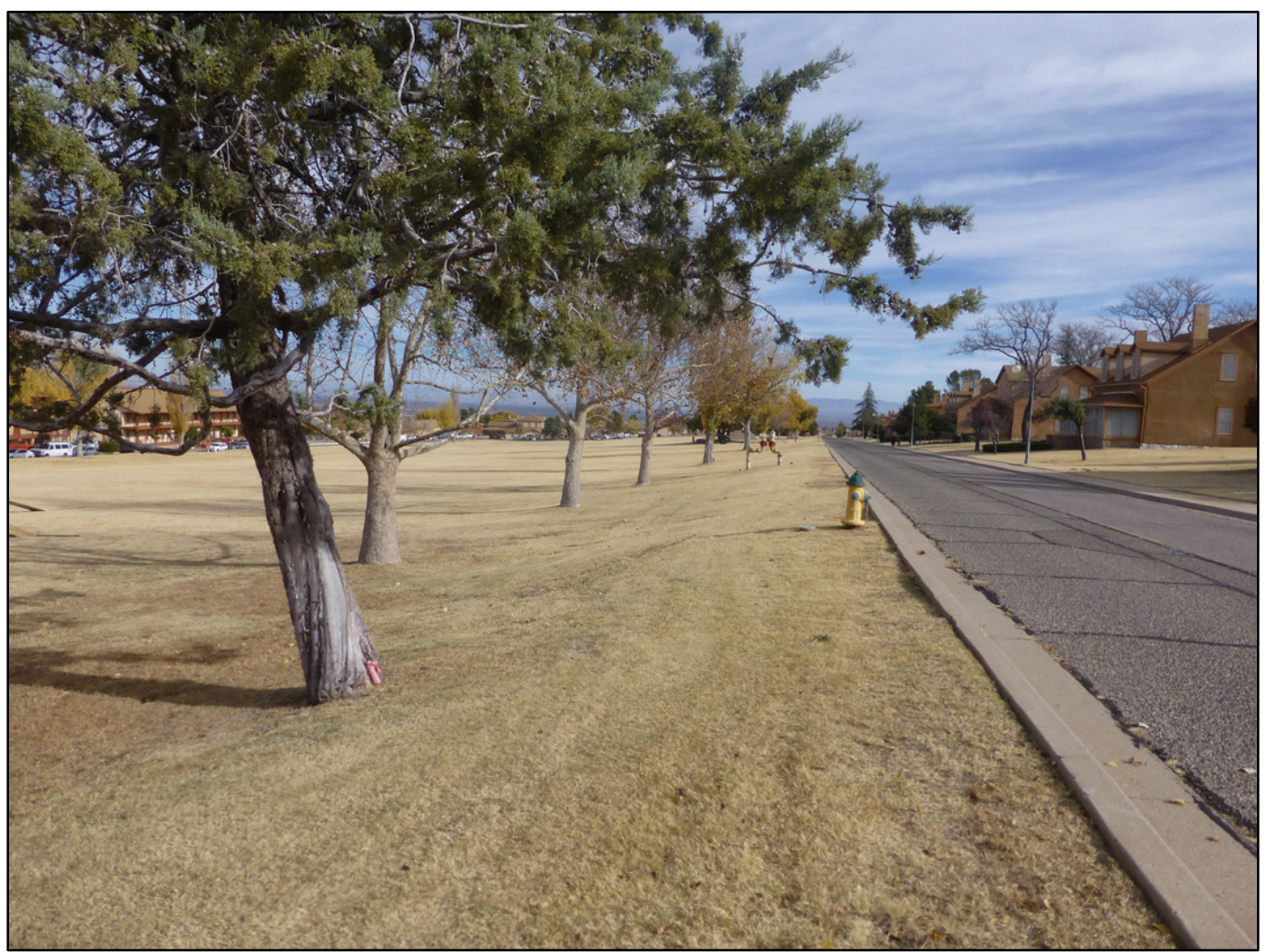

Figure 175. View looking north of backflow preventer on east side of Brown Field (ERDCCERL, 2016).

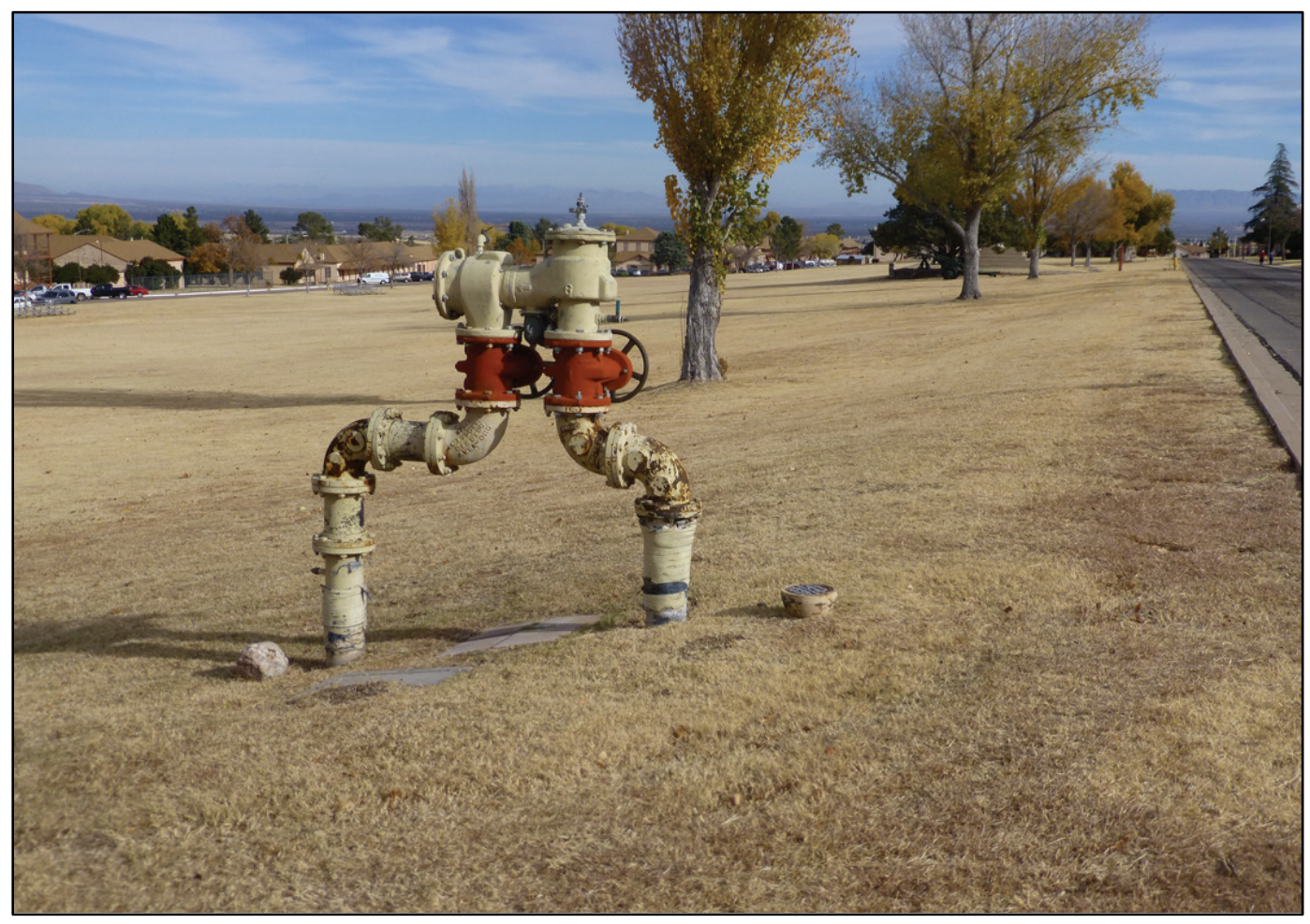


Figure 176. Row of trees on south corner of Brown Field opposite 22138, 22140, and 22144 (ERDC-CERL, 2016).

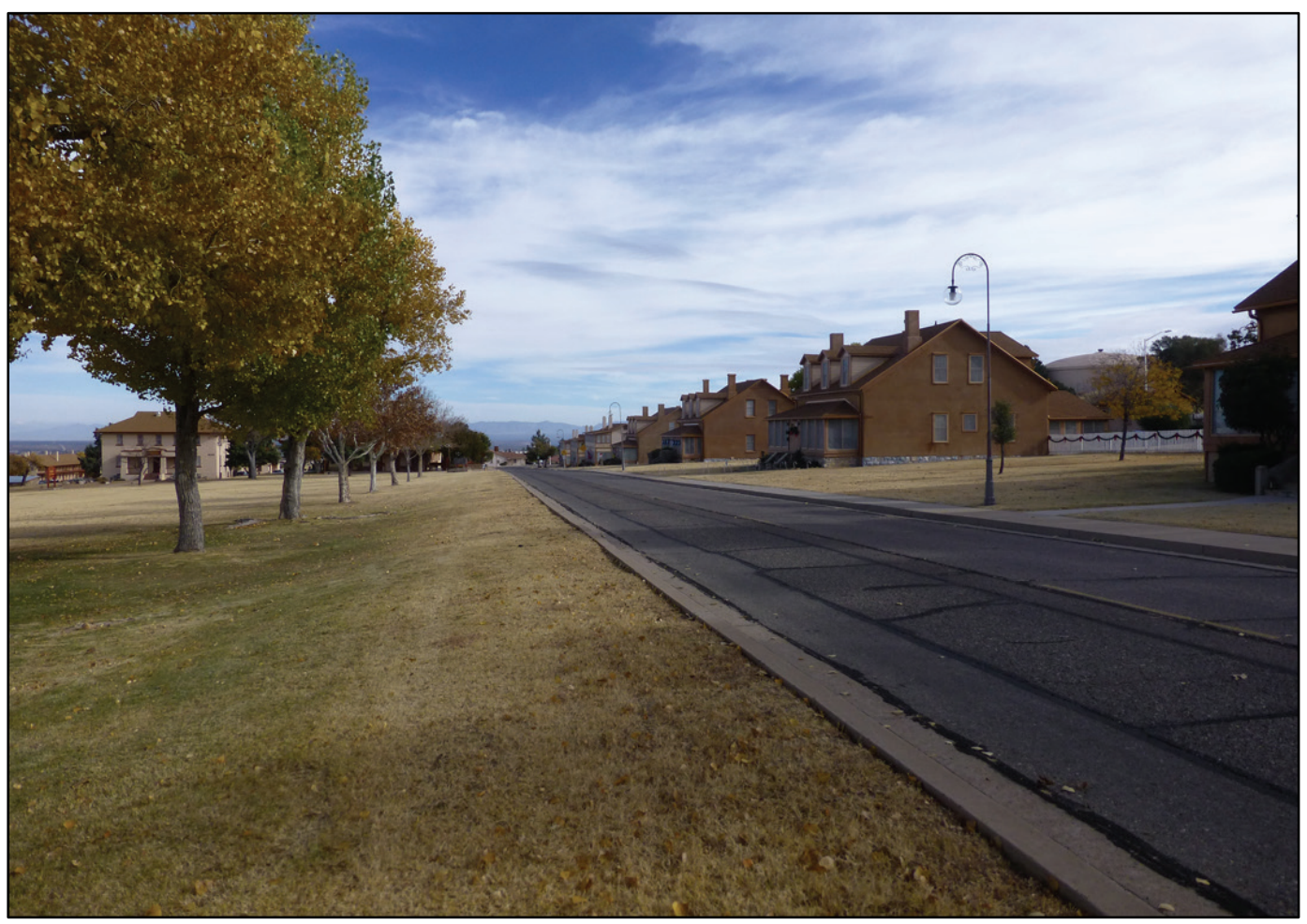

Figure 177. View looking northeast at flagpole (22301) on Brown Field [erected in the 1950s] (ERDC-CERL, 2016).

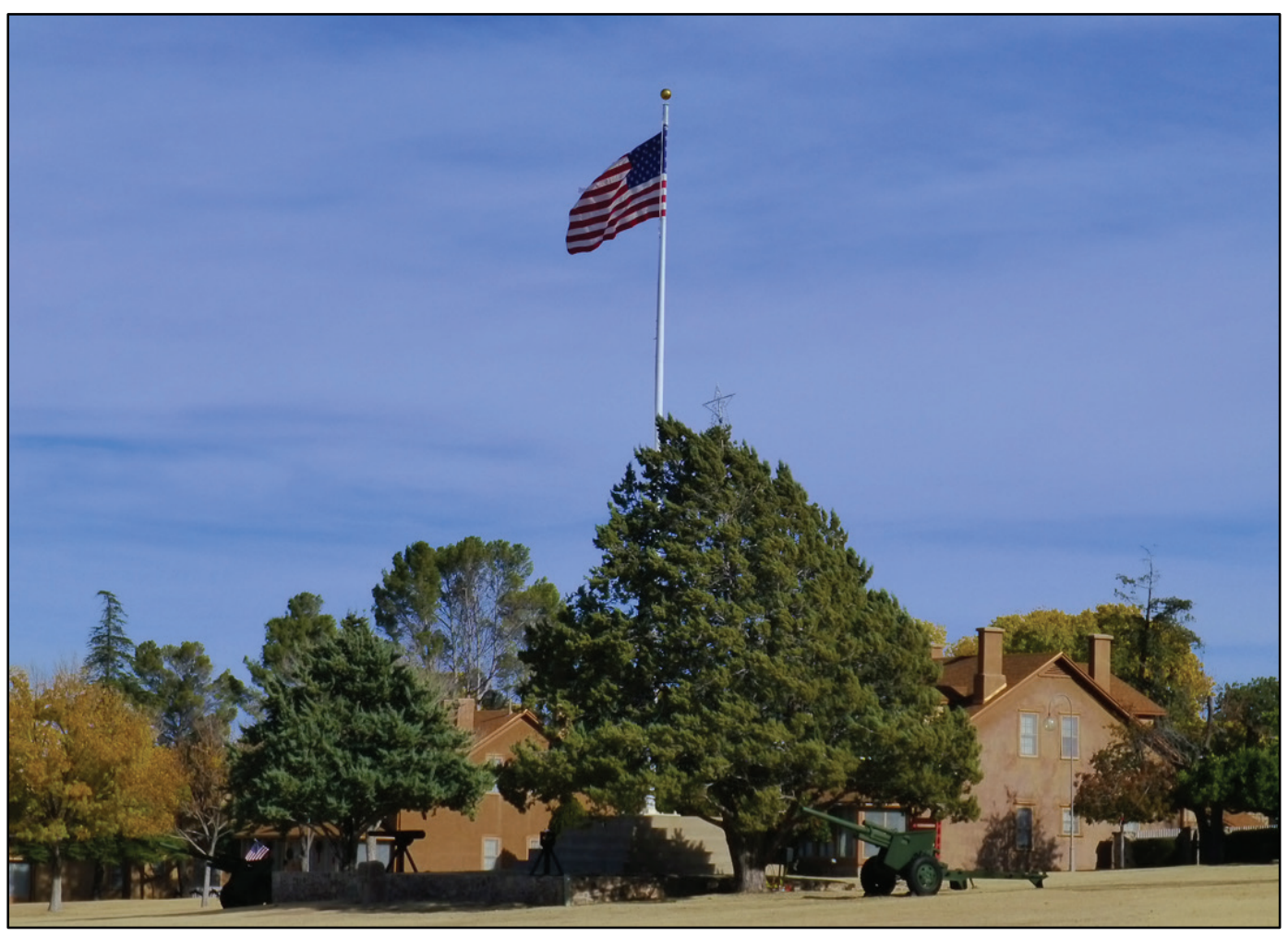


Figure 178. View looking west at artillery piece at the base of the flagpole (22301) (ERDCCERL, 2016).

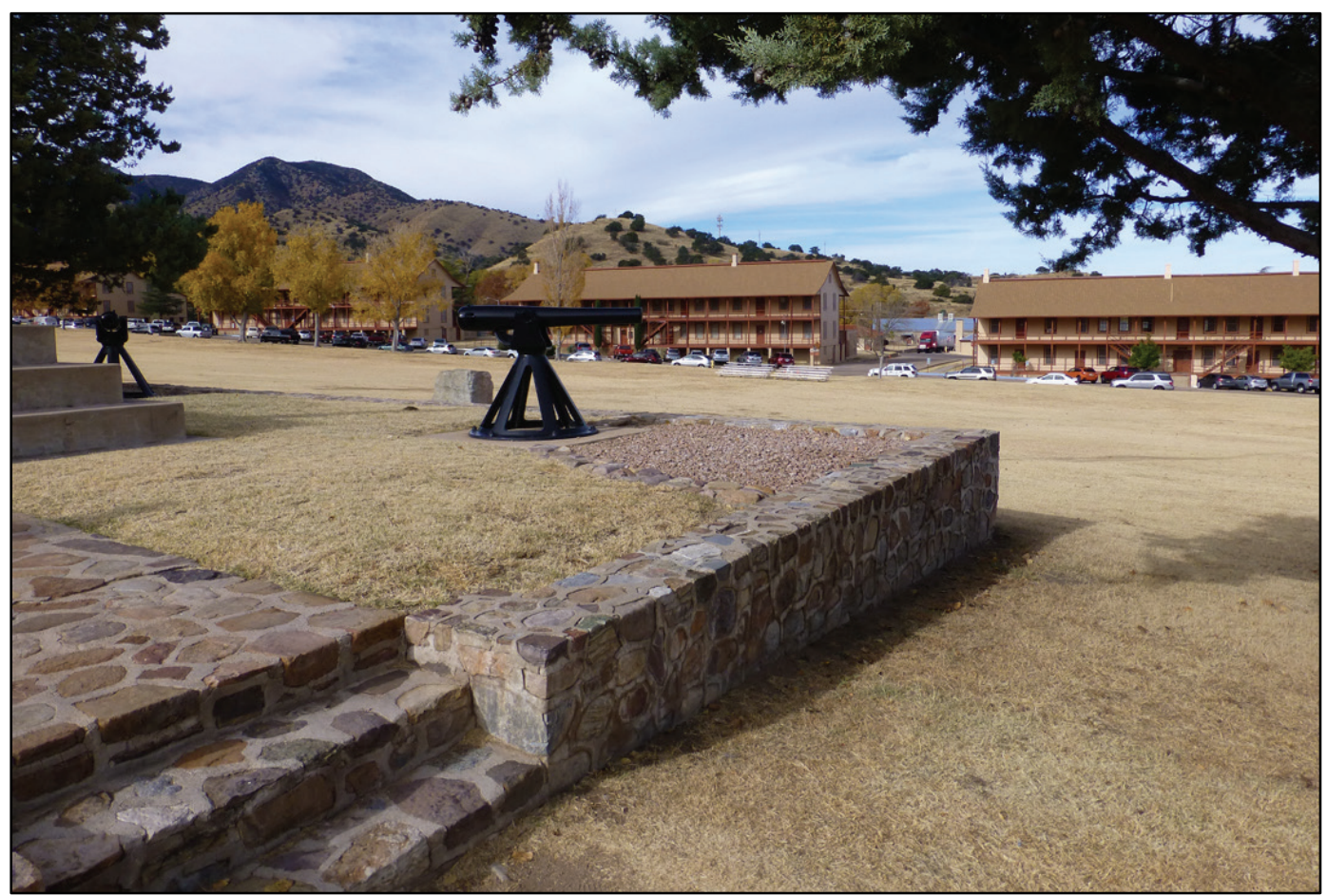

Figure 179. View looking west at the flagpole area (ERDC-CERL, 2016).

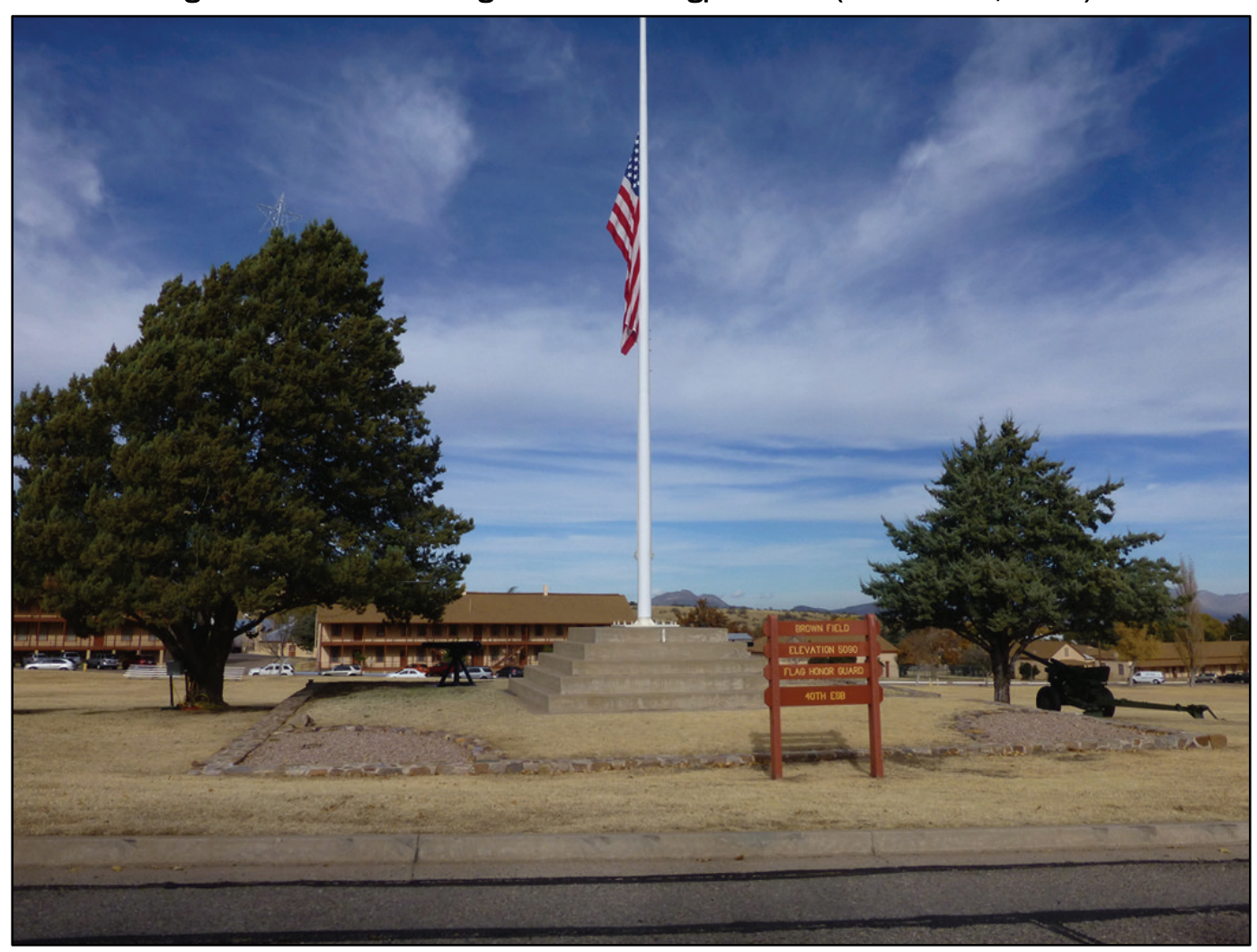


Figure 180. View looking northwest at detail of the stone border and gravel bed by the flagpole (ERDC-CERL, 2016).

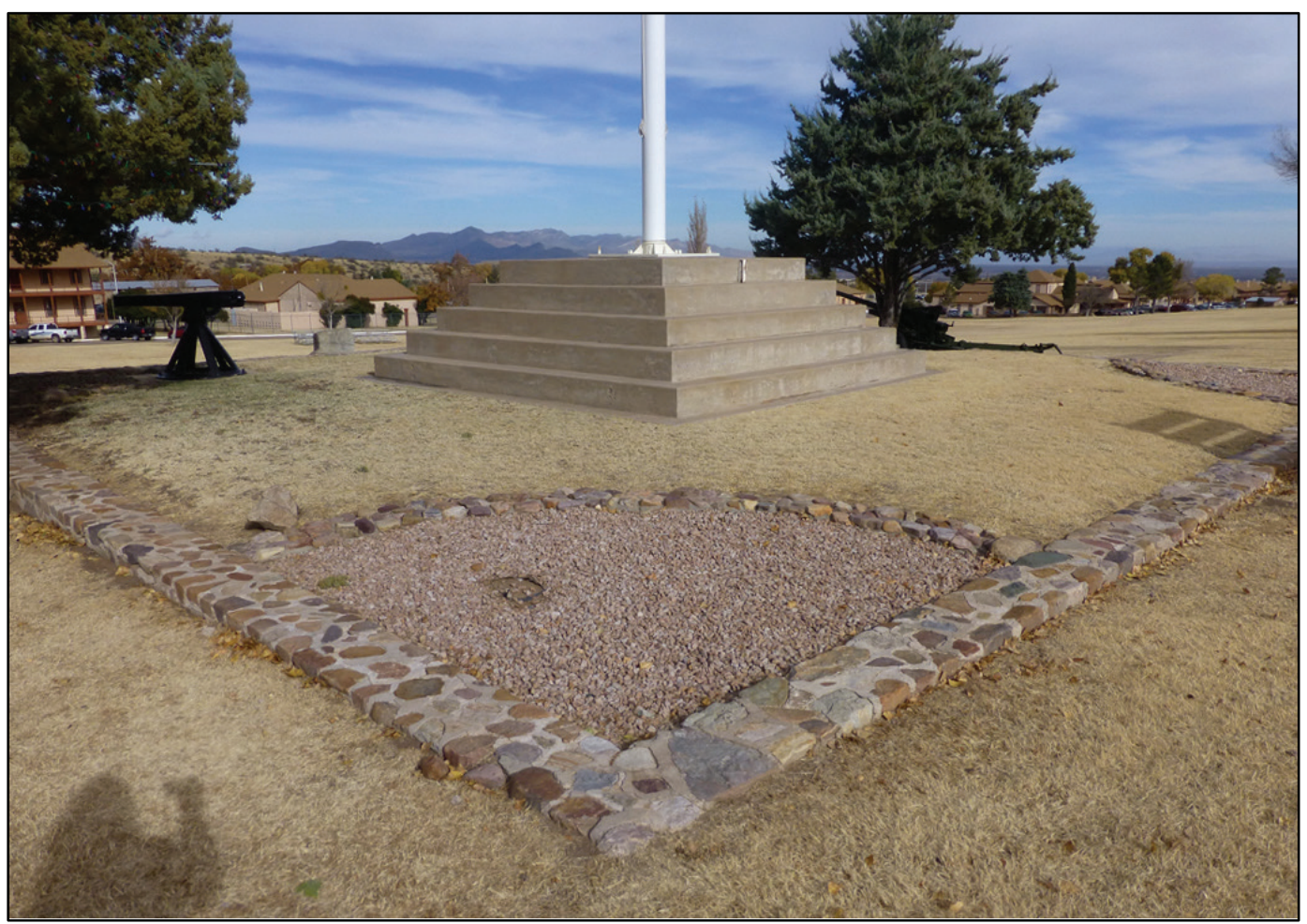

Figure 181. View looking north at stone wall and artillery piece at the flagpole area (ERDCCERL, 2016).

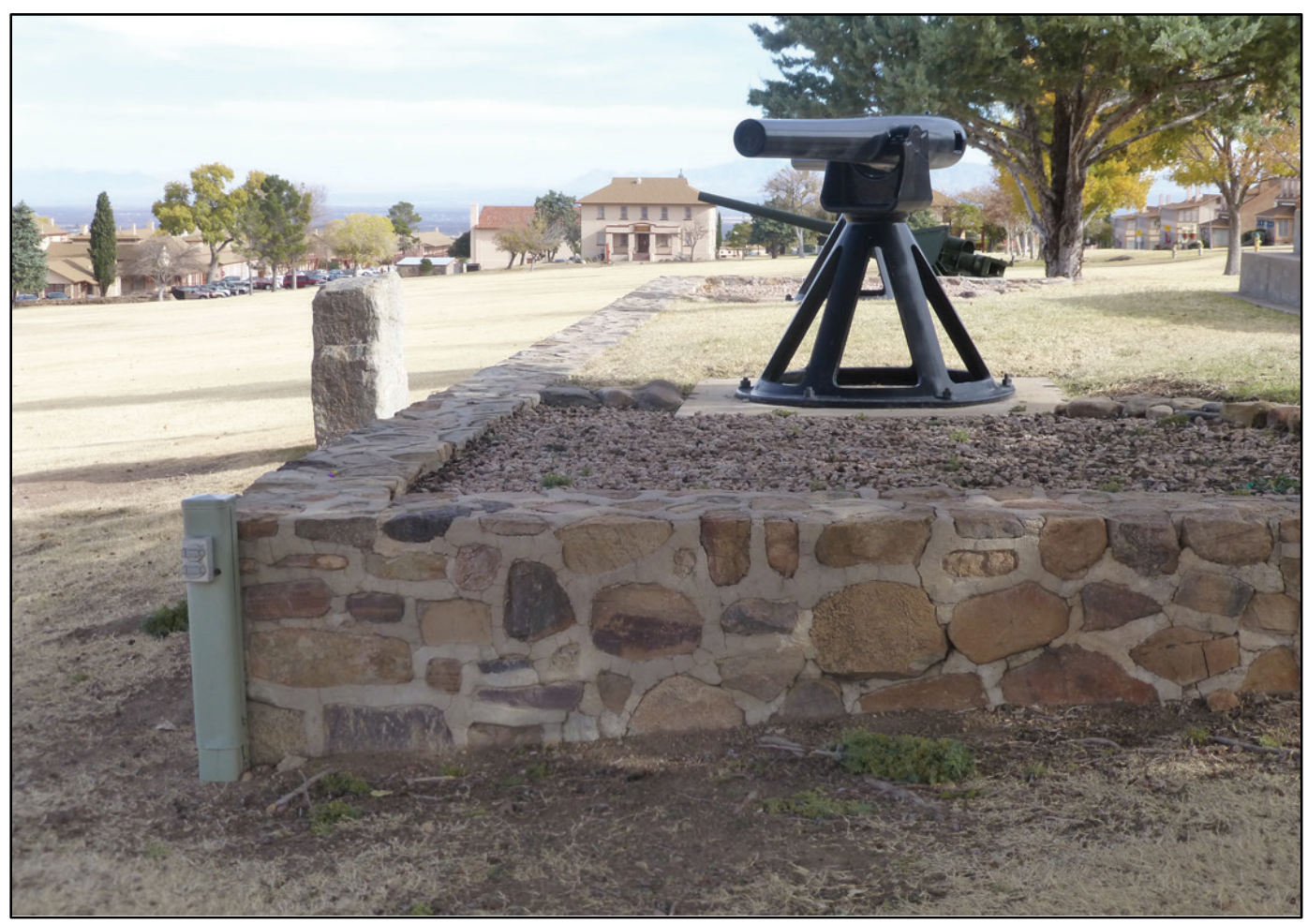


Figure 182. View looking east of stone memorial on the west side of the flagpole area with bronze plaque commemorating the designation as an NHL (ERDC-CERL, 2016).

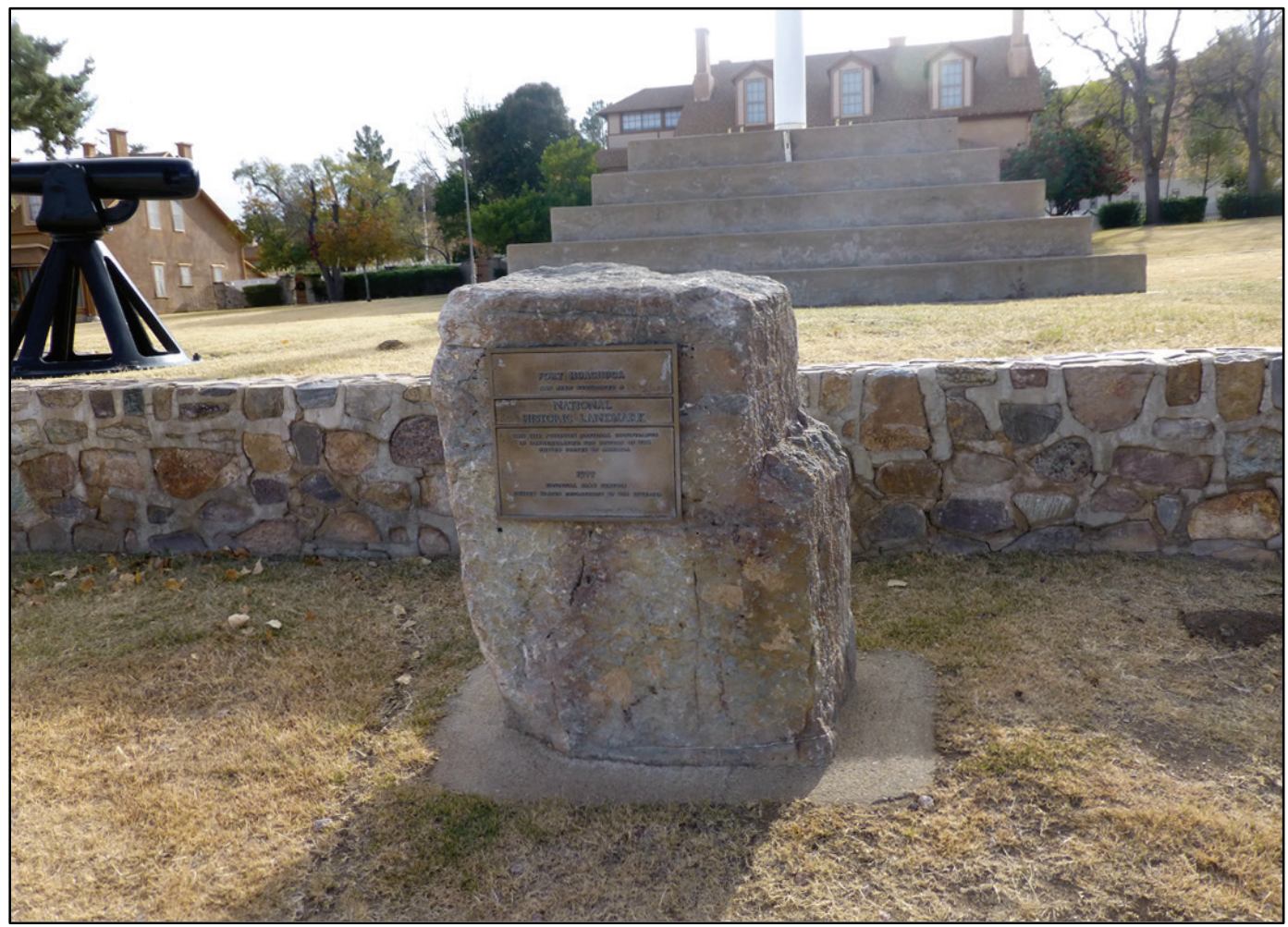

Figure 183. View looking northeast at artillery pieces and evergreen tree at the base of the flagpole (ERDC-CERL, 2016).

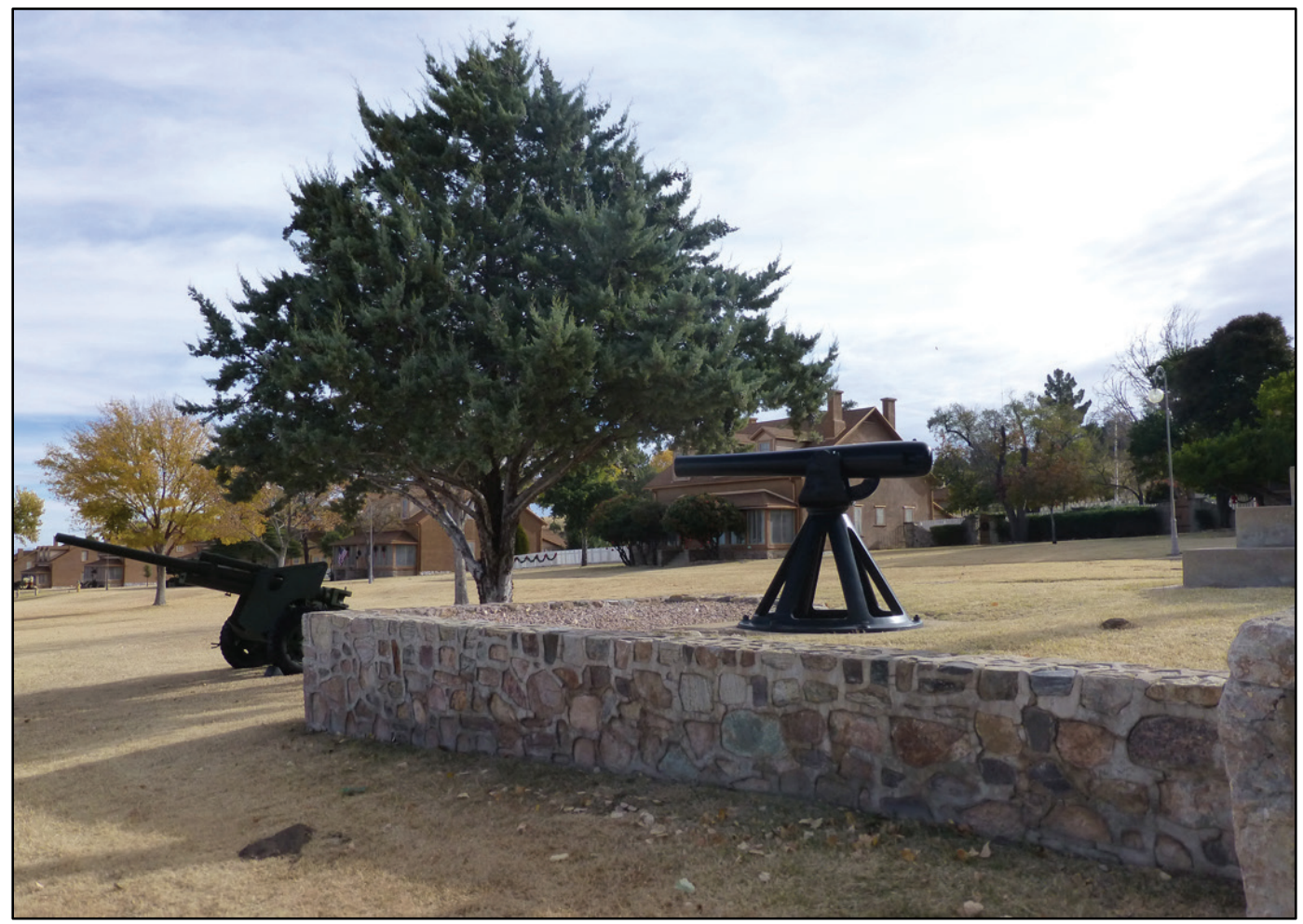


Figure 184. View looking northeast towards gazebo (22303) on parade field (ERDC-CERL, 2016).

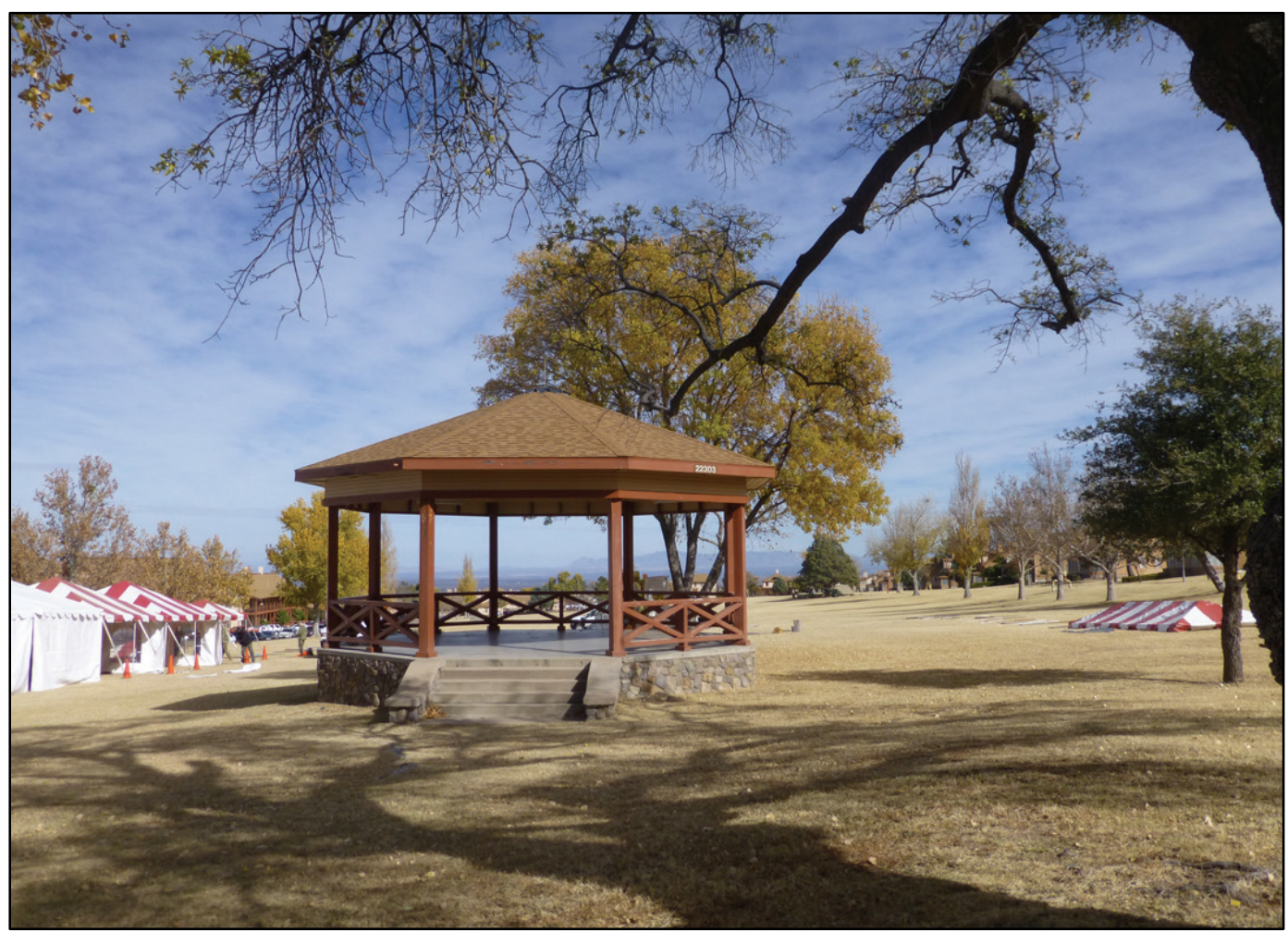

Figure 185. View east towards gazebo on south end of parade field (ERDC-CERL, 2016).

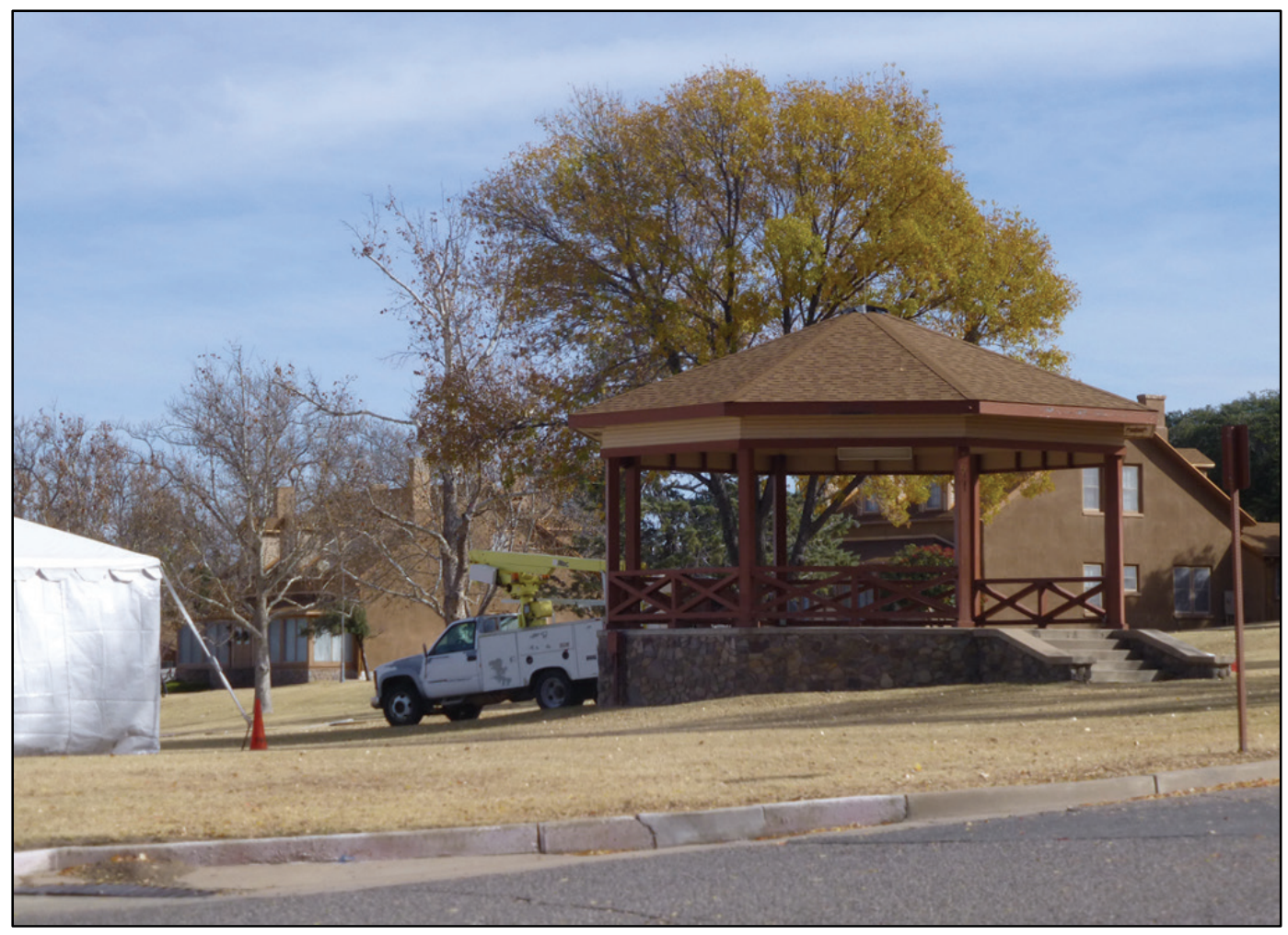


Figure 186. Looking southwest at the front of 22336 (ERDC-CERL, 2016).

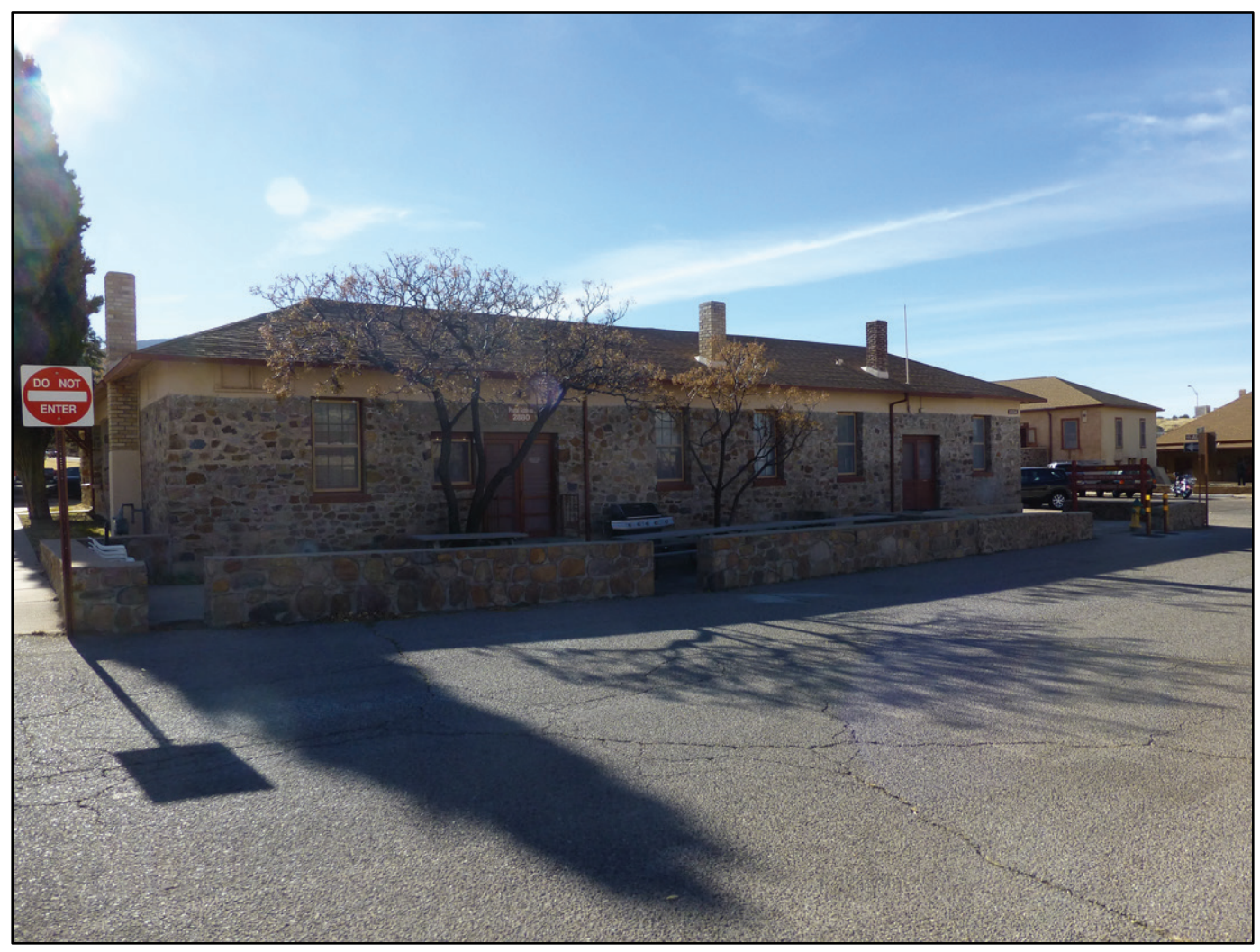

Figure 187. Looking southeast at the southwest side of 22336 (ERDC-CERL, 2016).

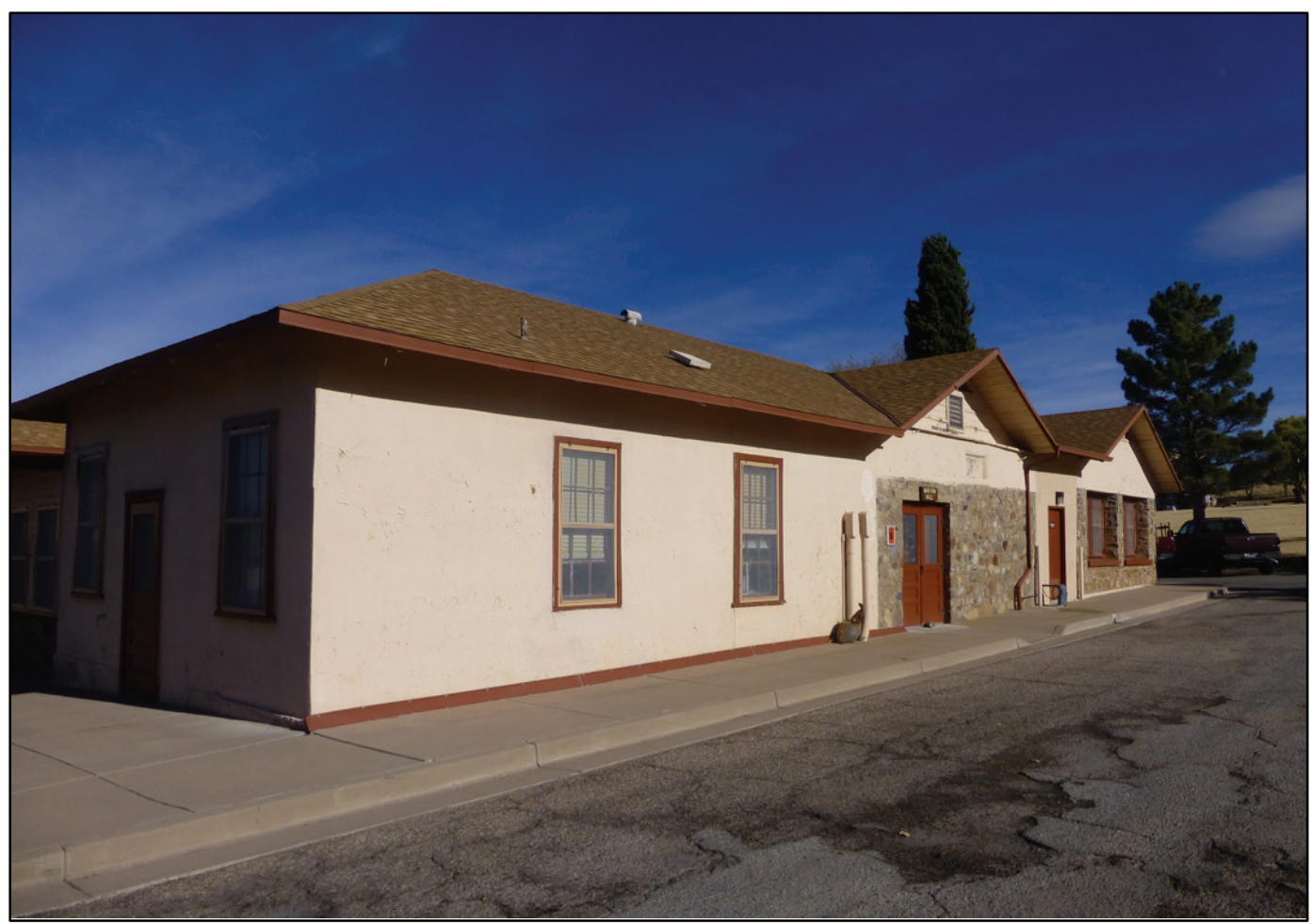


Figure 188. View looking east at the seating areas in front of 22336 along Boyd Avenue (ERDC-CERL, 2016).

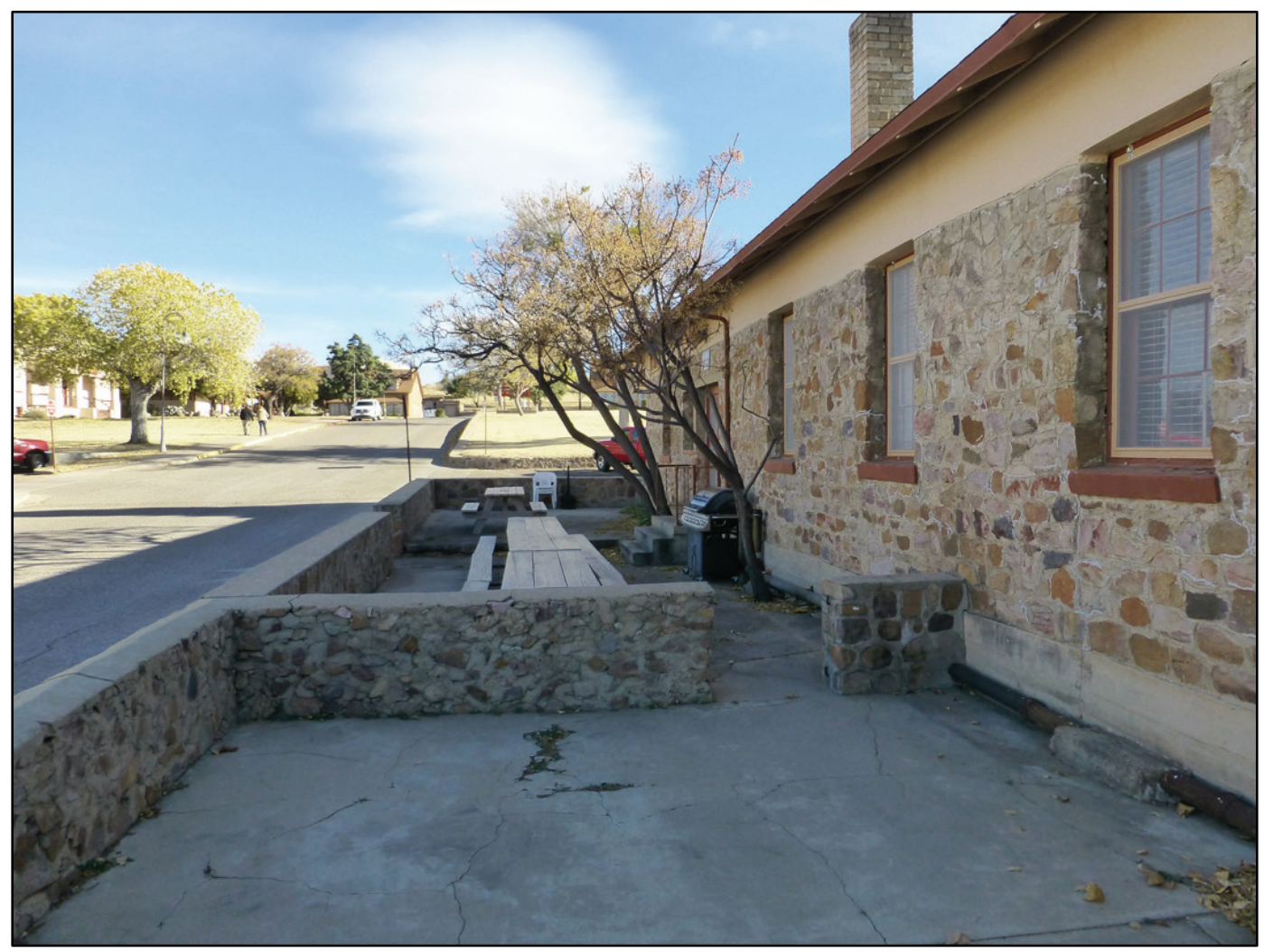

Figure 189. View looking northeast at trees lining the parade field adjacent to parking lot for 22334 (ERDC-CERL, 2016).

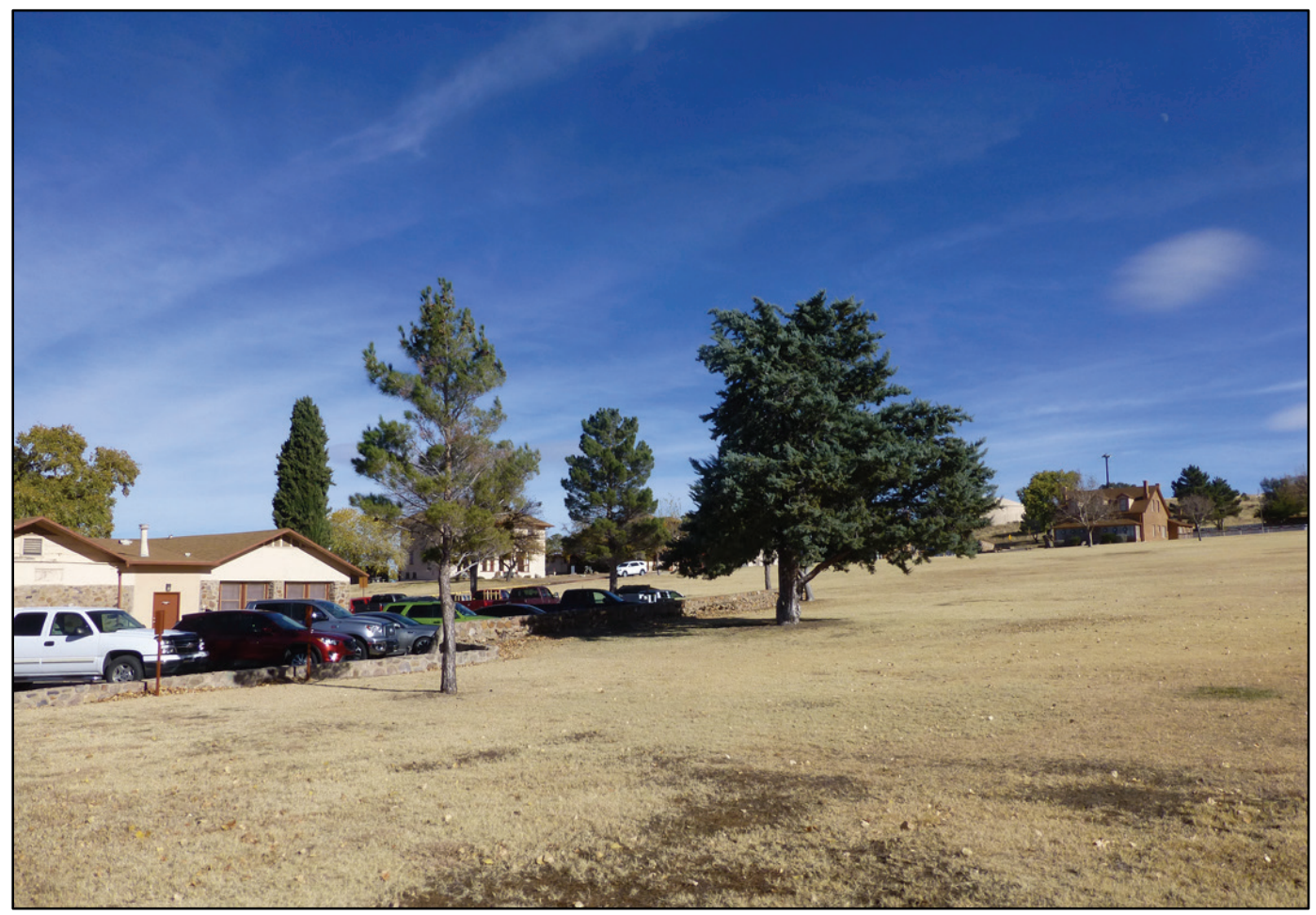


Figure 190. View from northeastern end of parade field to the barracks (ERDC-CERL, 2016).

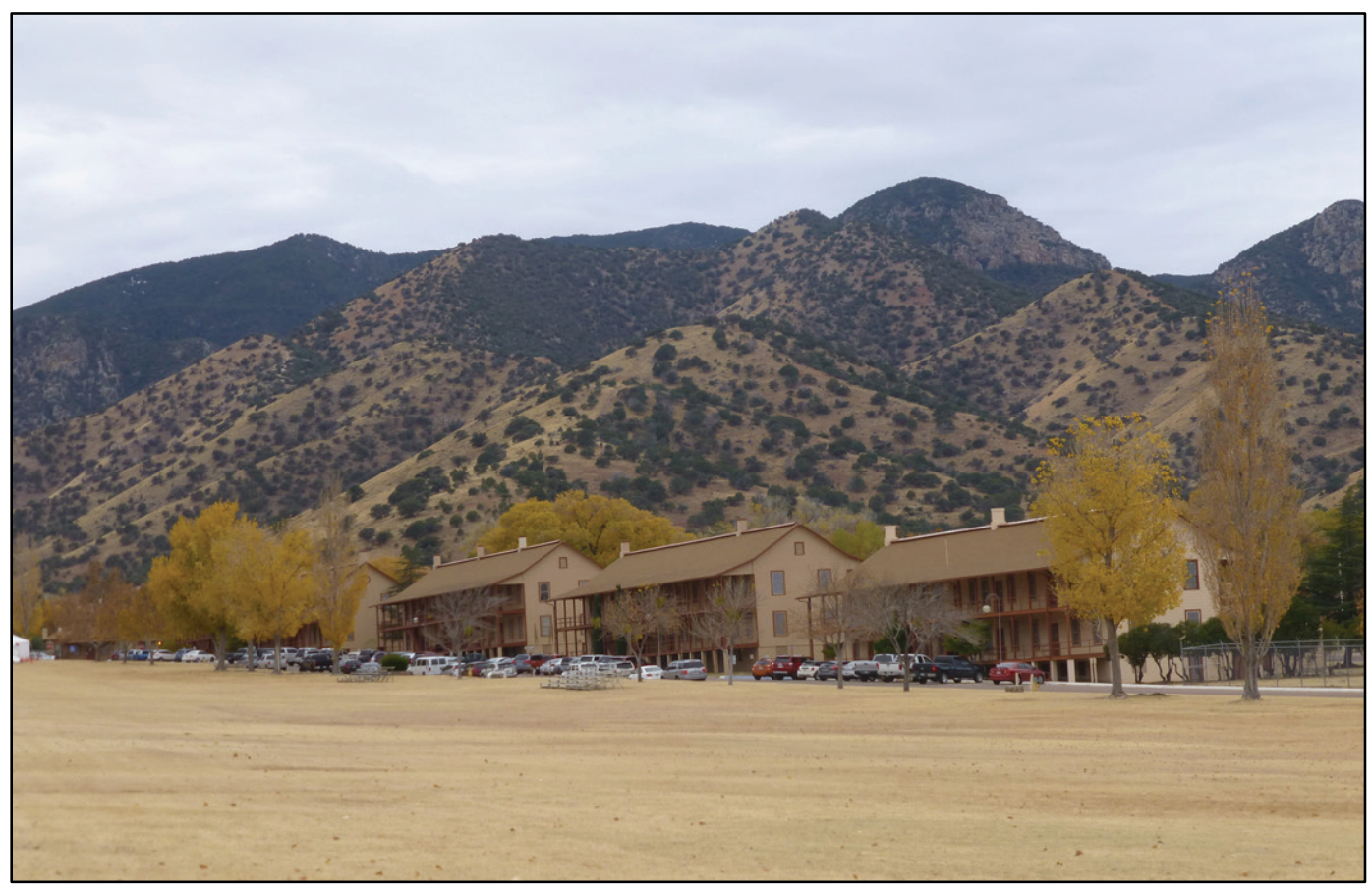

Figure 191. View from eastern end of parade field to the officers' quarters (ERDC-CERL, 2016).

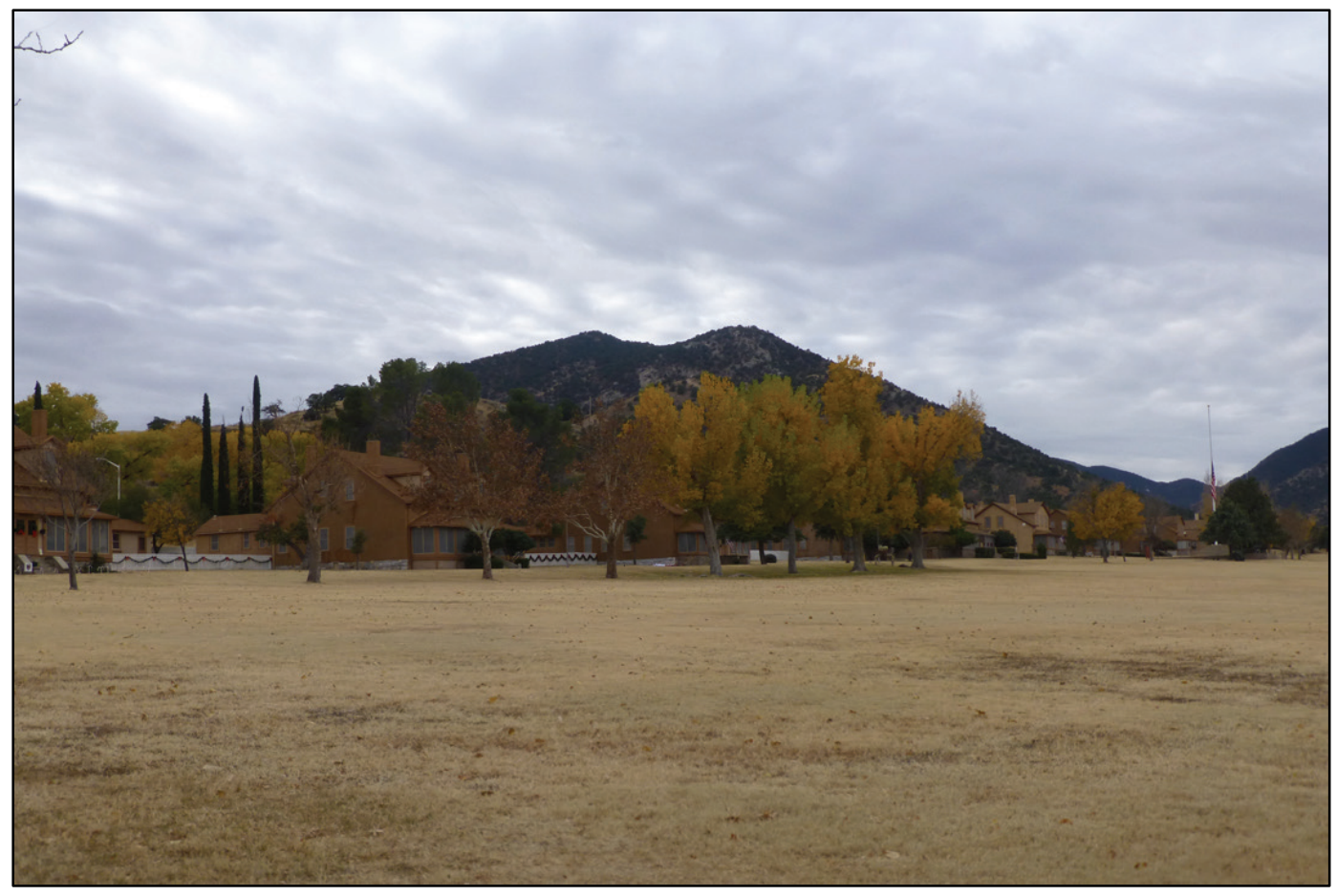

\subsubsection{Significance and integrity}

By far the most significant and visually dominant landscape element in the Old Post is Brown Field, the approximately 15-acre parade ground. Part of 
the original 1880 s plan, Brown Field retains a high degree of integrity. The parade field influenced the layout and spatial organization of the post which remains in place today. However, it has lost many of the shade trees that lined the edges and are seen in historic photographs from the early 1900s. Significant views remain of Brown Field and the historic architecture lining the parade field.

\subsubsection{Character-defining features}

Character-defining features include:

- Central focus of Old Post area

- Open space for drills and ceremonial use

- Lined with Old Post-era buildings

- Views across the parade field to historic buildings.

\subsection{Old Post Recreation}

At the turn of the century, two recreation buildings were added at the southern end of the parade field: a bowling alley (21114) and a PX/gymnasium (21115) (Figure 192). In 1920, a coal bin (21117) was added to the southeast corner of 21115 (Table 12).34

Figure 192. Recreation landscape area map (ERDC-CERL).

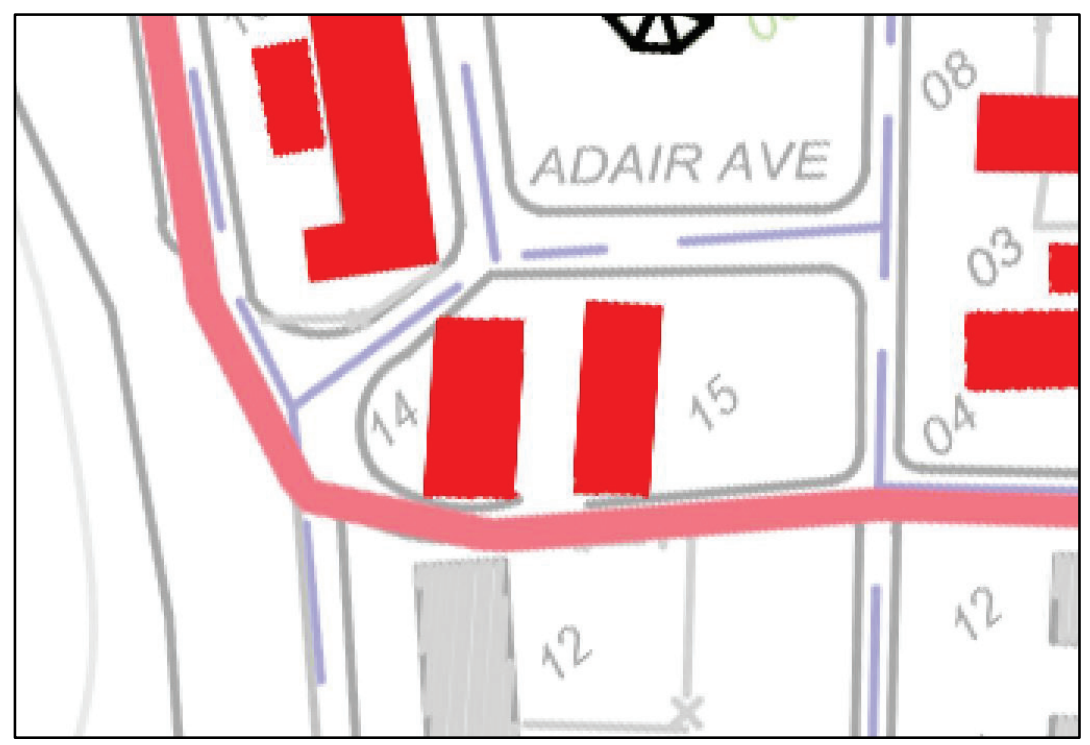

\footnotetext{
34 RP number for coal bin may not be correct. See note in Anna E. Schneider, 2017. "Historic District Coal Bins: Cultural Resources Evaluation, Fort Huachuca, Arizona," [Draft] Cultural Resources Report FH-1717, Fort Huachuca, AZ.
} 
Table 12. List of buildings within the Old Post Recreation landscape area.

\begin{tabular}{|c|c|l|l|c|}
\hline Building Number & Year Built & \multicolumn{1}{|c|}{ Original Use } & \multicolumn{1}{c|}{ Current Use } & Historic Status \\
\hline & & & $\begin{array}{l}\text { Army Continuing } \\
\text { Administration } \\
\text { System (ACES) }\end{array}$ & NHLC \\
\hline 21114 & 1908 & Bowling Alley & Administrative & NHLC \\
\hline 21115 & 1905 & Post Exchange/Gymnasium & Coal bin & NEV \\
\hline 21117 & 1920 & Coal bin & &
\end{tabular}

\subsubsection{History}

The Fort Huachuca historic district includes two buildings constructed for recreational opportunities to the enlisted men and officers stationed at this remote installation. These recreational buildings were located at the south end of the parade ground, easily accessible to both the enlisted personnel to the west and officers to the east. Brayton Hall (Building 21115) was constructed in 1915 as a PX and gymnasium (Figures 193, 194, and 195). Its neo-classical portico and fanlight entry on the facade make it one of the most prominent buildings on the parade ground. In the basement, there was the first Officers' Club, as well as the enlisted mens' canteen, where soldiers gathered to socialize and drink beer. The building also contained a Chinese restaurant operated by Sam Kee, where gourmet dinners of stuffed or pressed duck, venison, steak, and Chinese delicacies were served.

The bowling alley (21114) was constructed in 1908 (Figure 196). Originally T-shaped, it had a lobby in the front and a long and narrow bowling lane to the rear. In 1908, the post's first swimming pool was built behind Brayton Hall (Figure 197). In addition to the pool, there were tennis courts both in front of Brayton Hall on the southeast corner of Brown Field and northwest of pool directly behind Brayton Hall by WWII (Figure 198). 
Figure 193. View looking south of Brayton Hall (21115), 1918 (Fort Huachuca Museum).

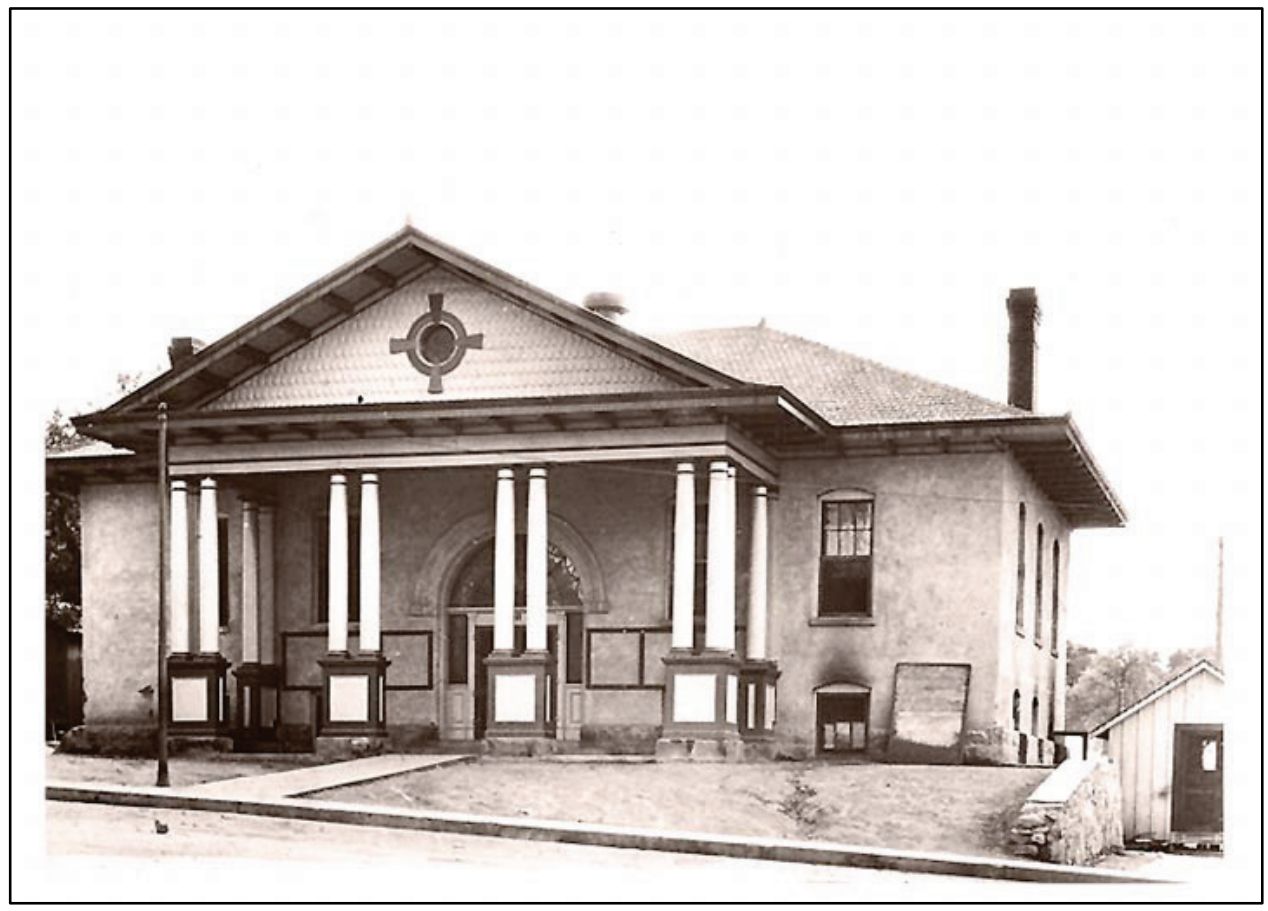

Figure 194. View looking south of Brayton Hall (21115), 1941 (NARA College Park, RG 77, 393 Box 95).

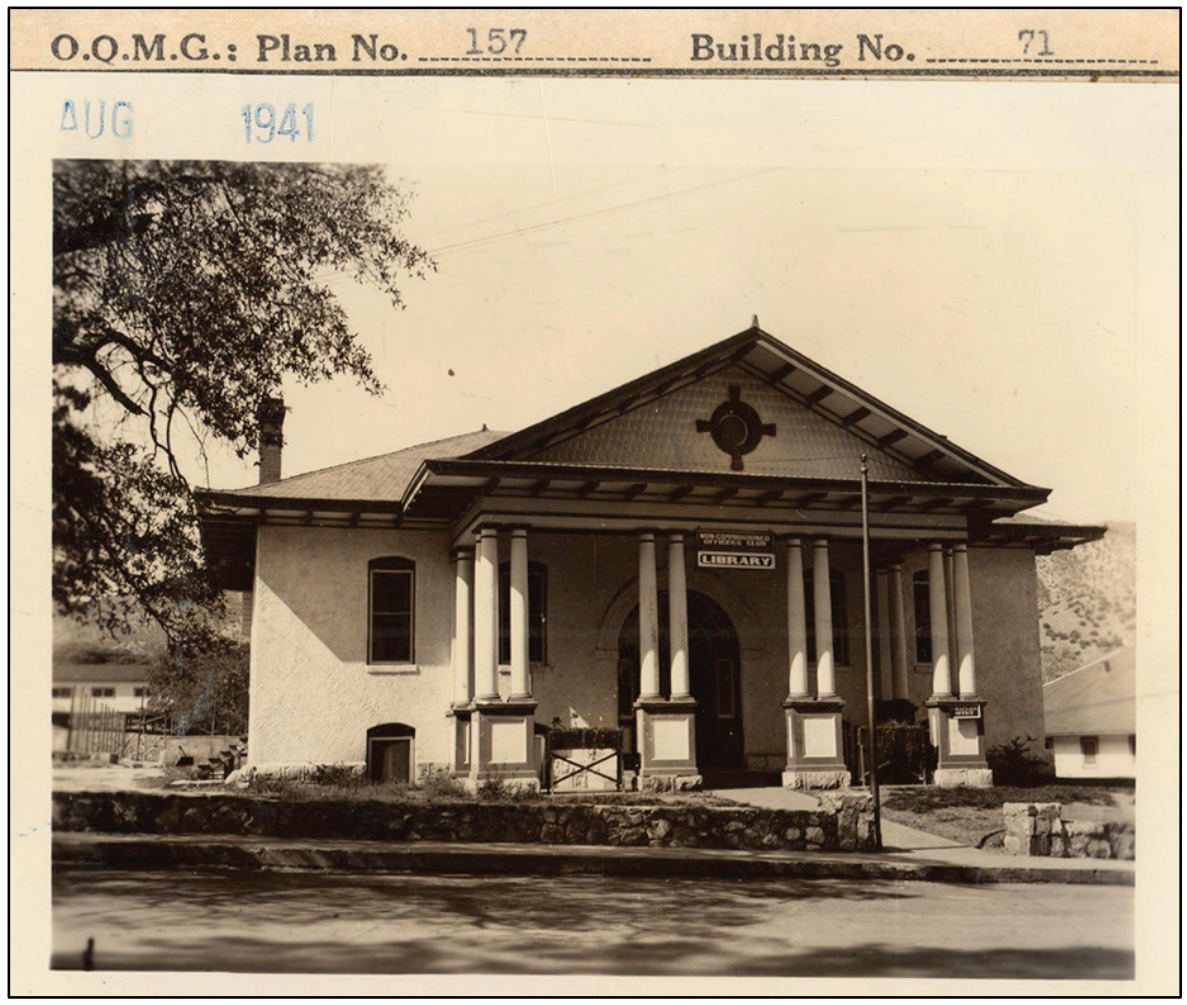


Figure 195. View looking southeast of Brayton Hall (21115), 1954 (Puzzi, 1974).

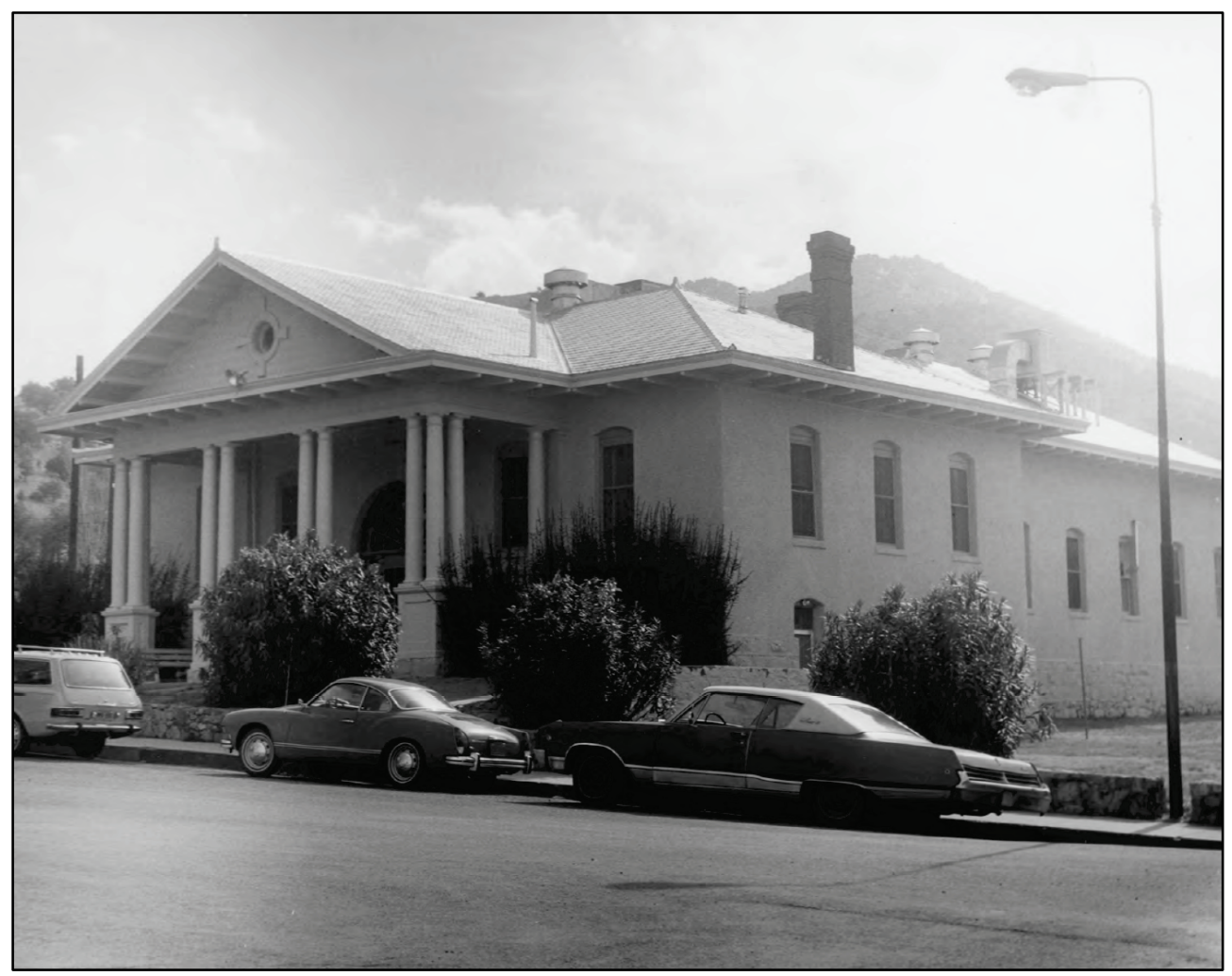

Figure 196. View looking southwest at 21114, 1941 (NARA College Park, RG 77, 393 Box 95).

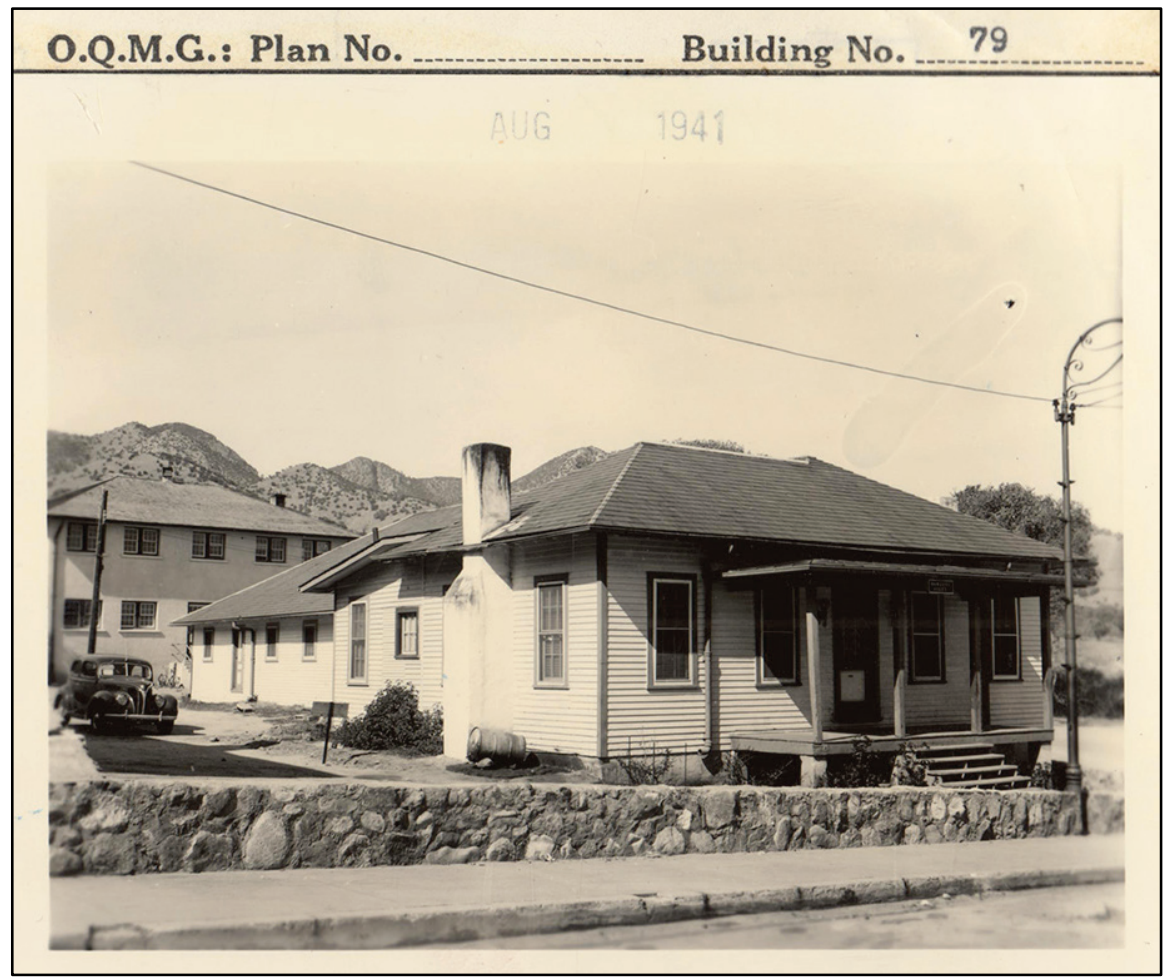


Figure 197. View looking northwest of enlisted men's pool located south of Brayton Hall (21115) (NARA College Park, RG 77, 393 Box 95).

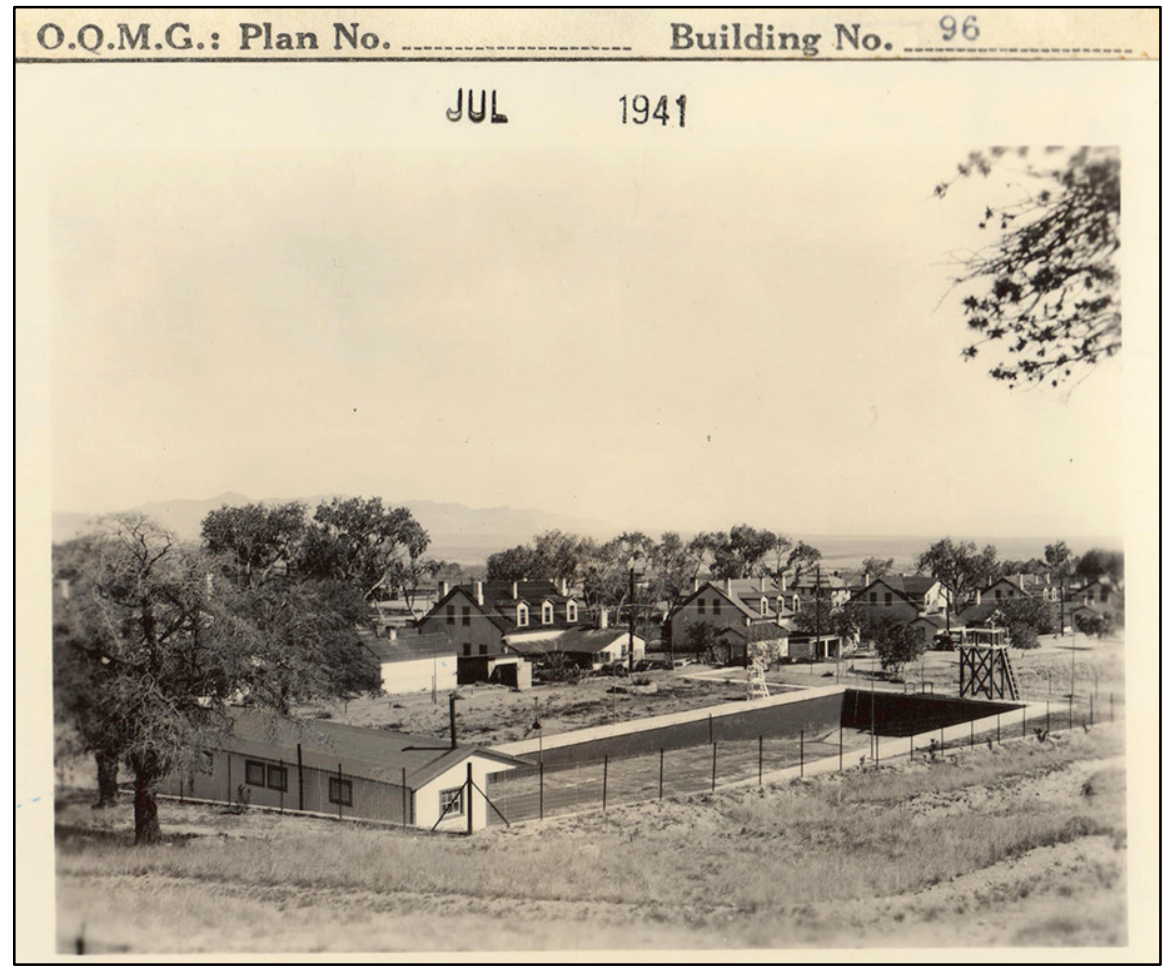

Figure 198. Map showing the location of pool and tennis courts (center) in relation to 21115, 1944 (NARA College Park, RG 77, Folders 1-5).

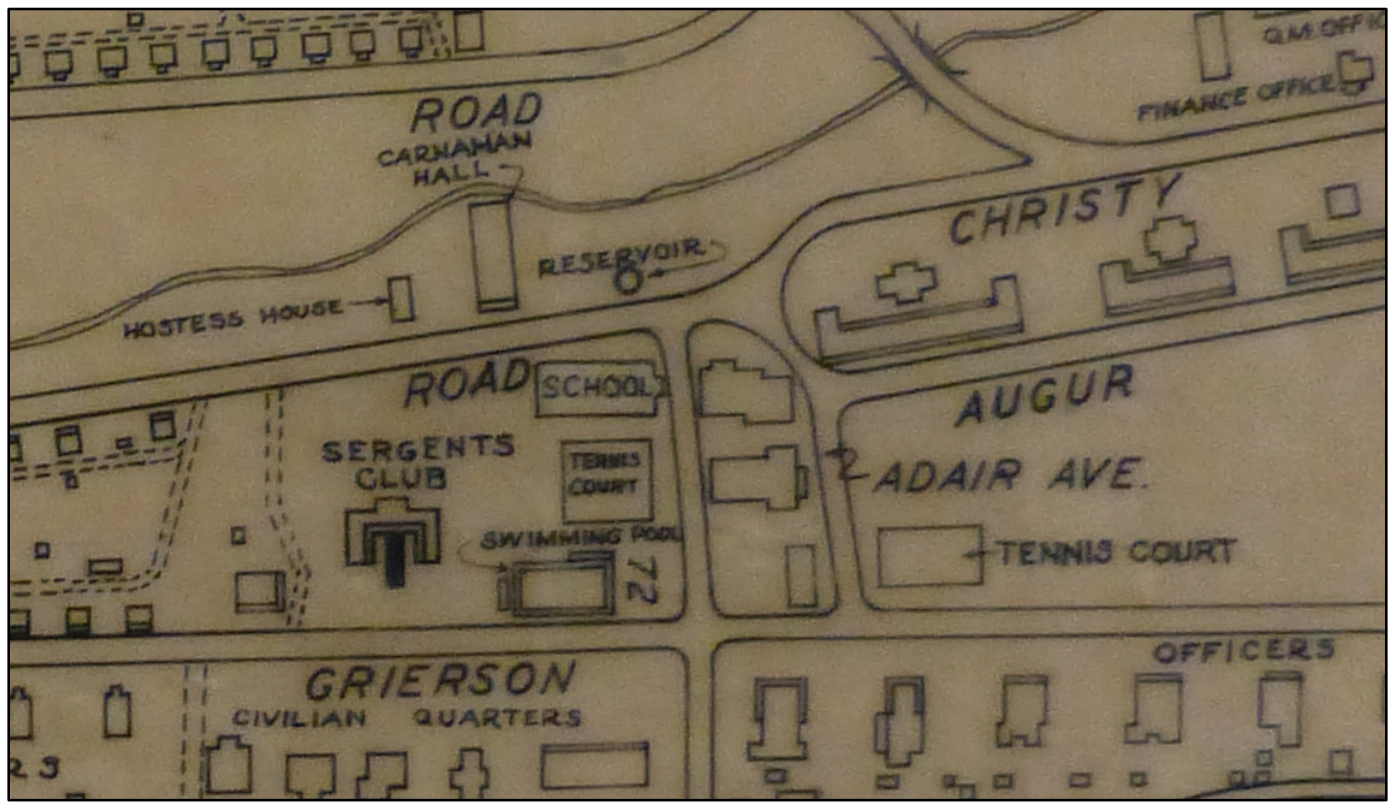

\subsubsection{Current conditions}

The PX and gymnasium (21115) has had many uses over the years. In the 1940s, it was a library and NCO Club. It is now offices for Judge Advocate 
General (JAG) and Public Affairs. The bowling alley (21114) was enlarged in 1915 to include a kitchen and living space for the proprietor. In 1937, the building was expanded in the rear. The new construction continued the stone masonry of the original, although the differences in the quality of masonry clearly distinguish between the generations of construction. It is now part of the ACES facilities (Figures 199-211).

Figure 199. View looking south at Brayton Hall (21115) from Brown Field (ERDC-CERL, 2016).

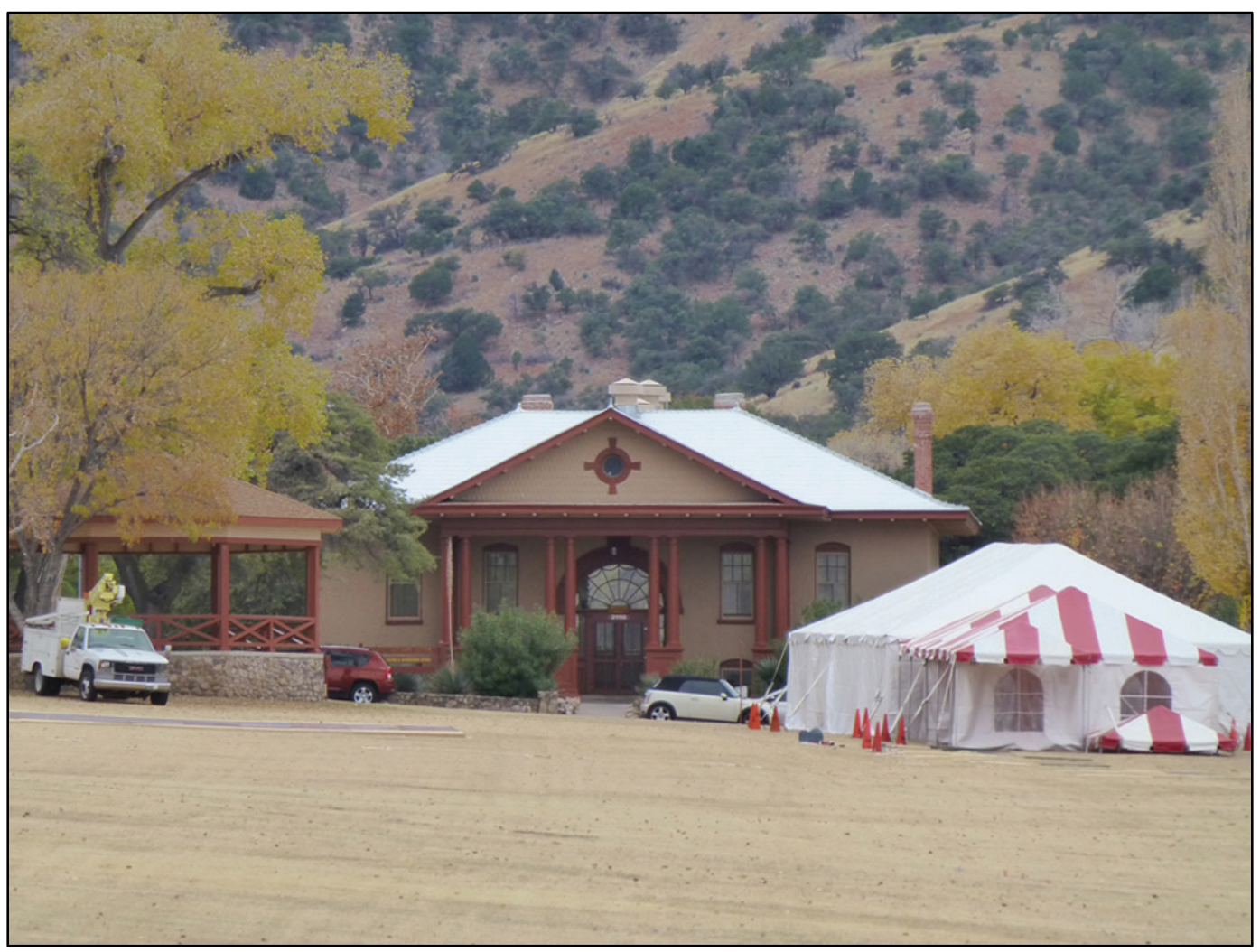


Figure 200. View looking south at Brayton Hall (21115) from of Adair Avenue showing shrubs and landscaping in front of building (ERDC-CERL, 2016).

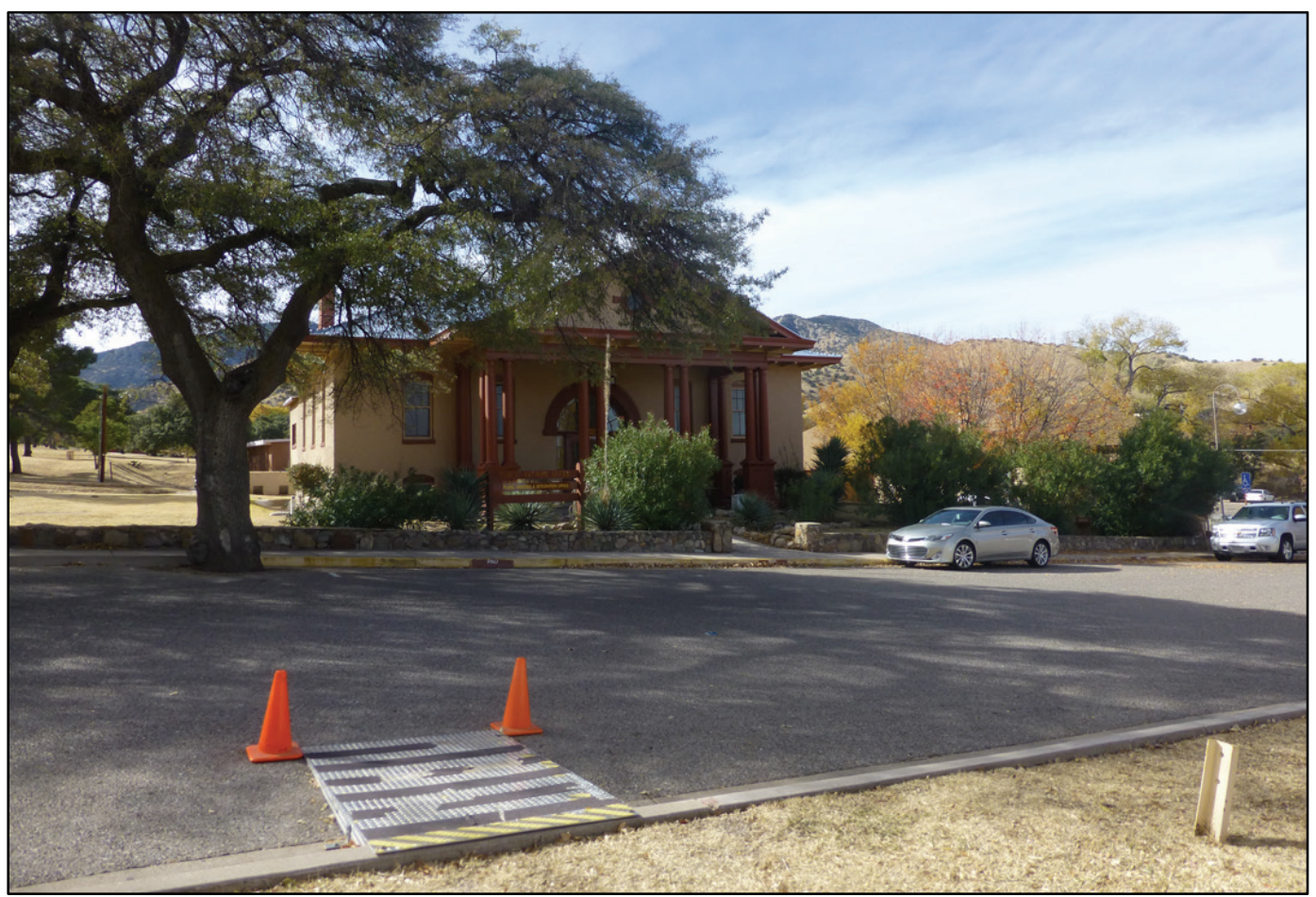

Figure 201. Close-up of landscaping in front of Brayton Hall (21115) (ERDC-CERL, 2016).

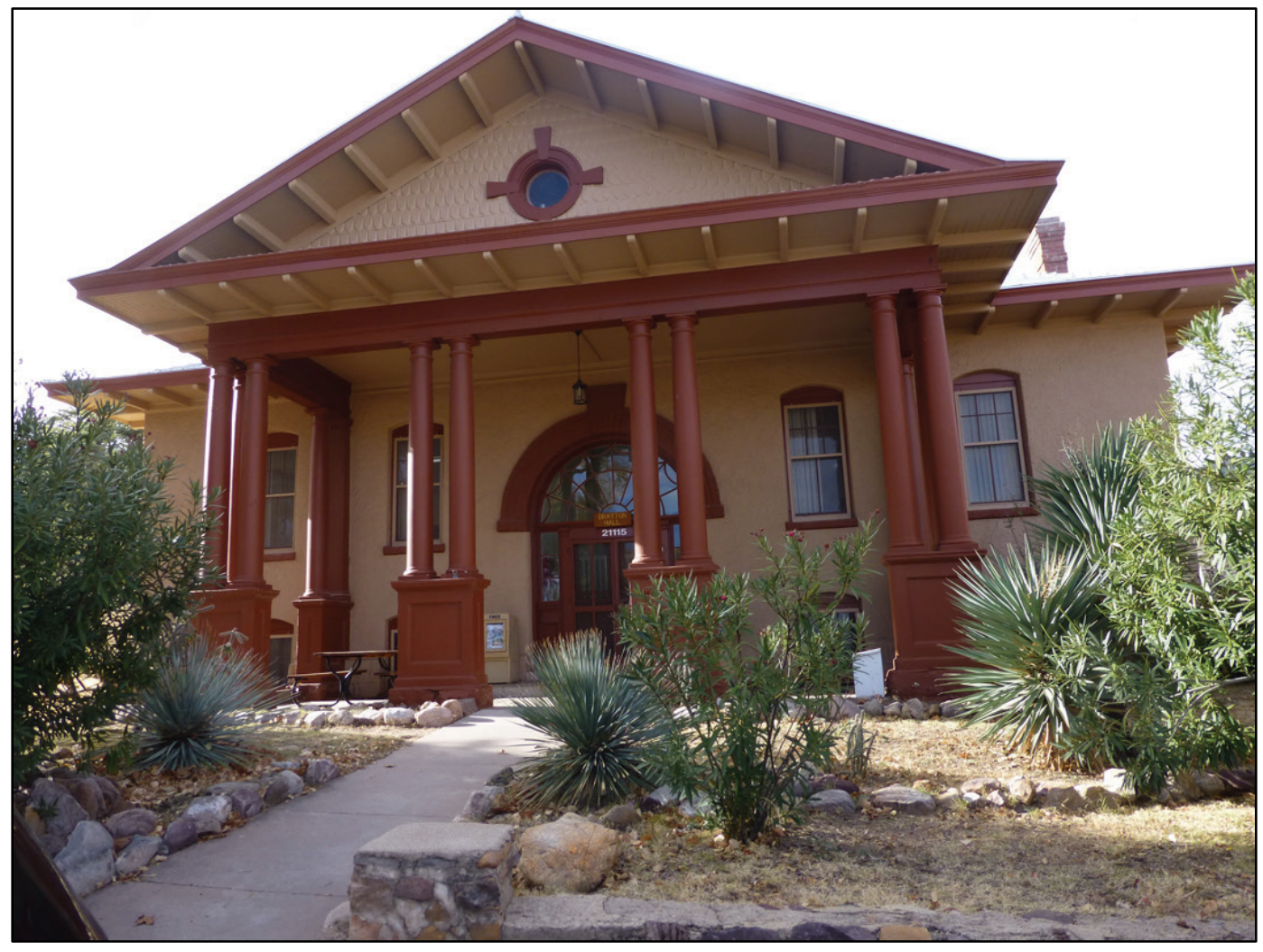


Figure 202. View looking west of landscaping and stone wall in front of Brayton Hall (21115)

(ERDC-CERL, 2016).

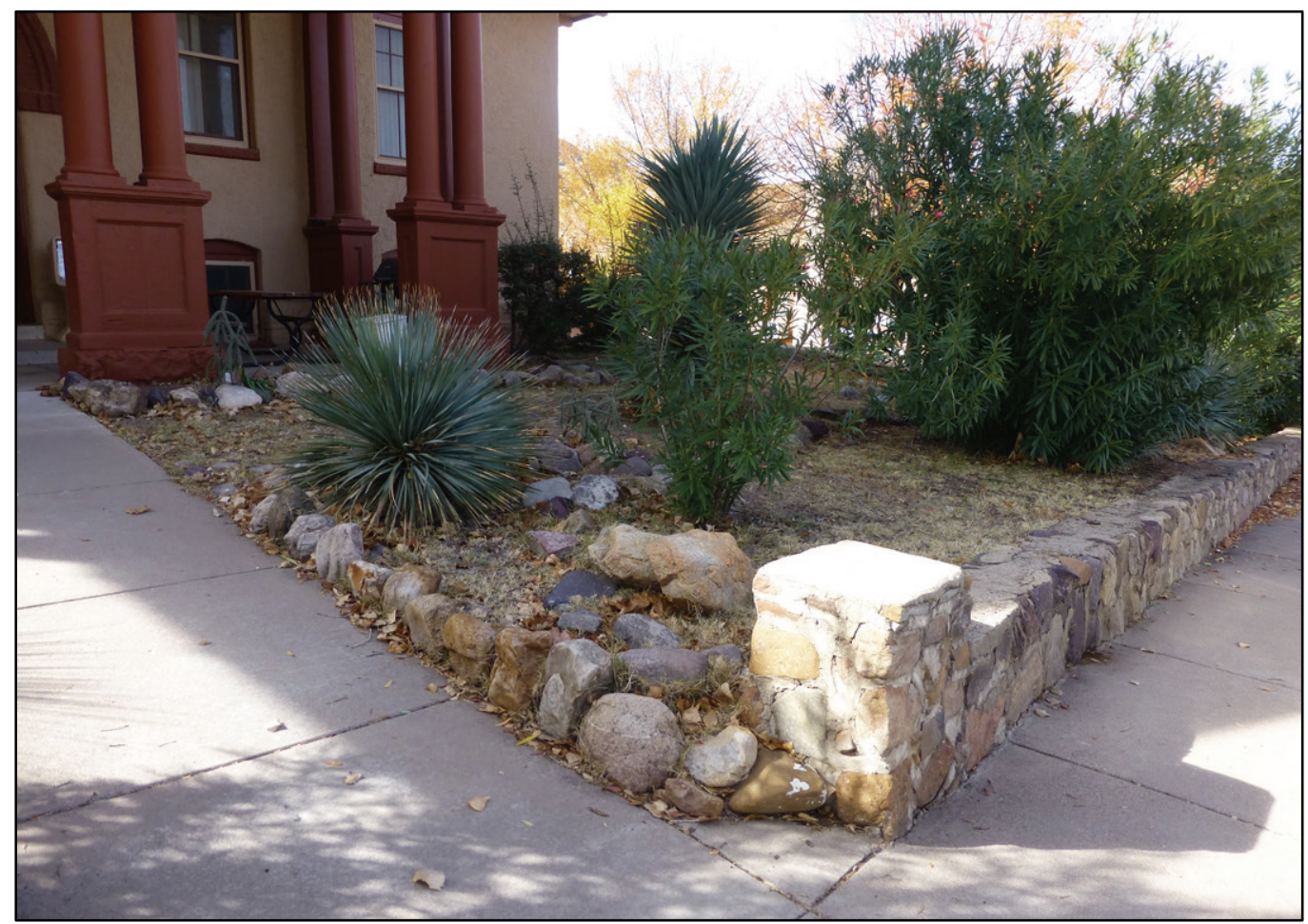

Figure 203. View looking south at area between Brayton Hall (21115) and 21114 (ERDCCERL, 2016).

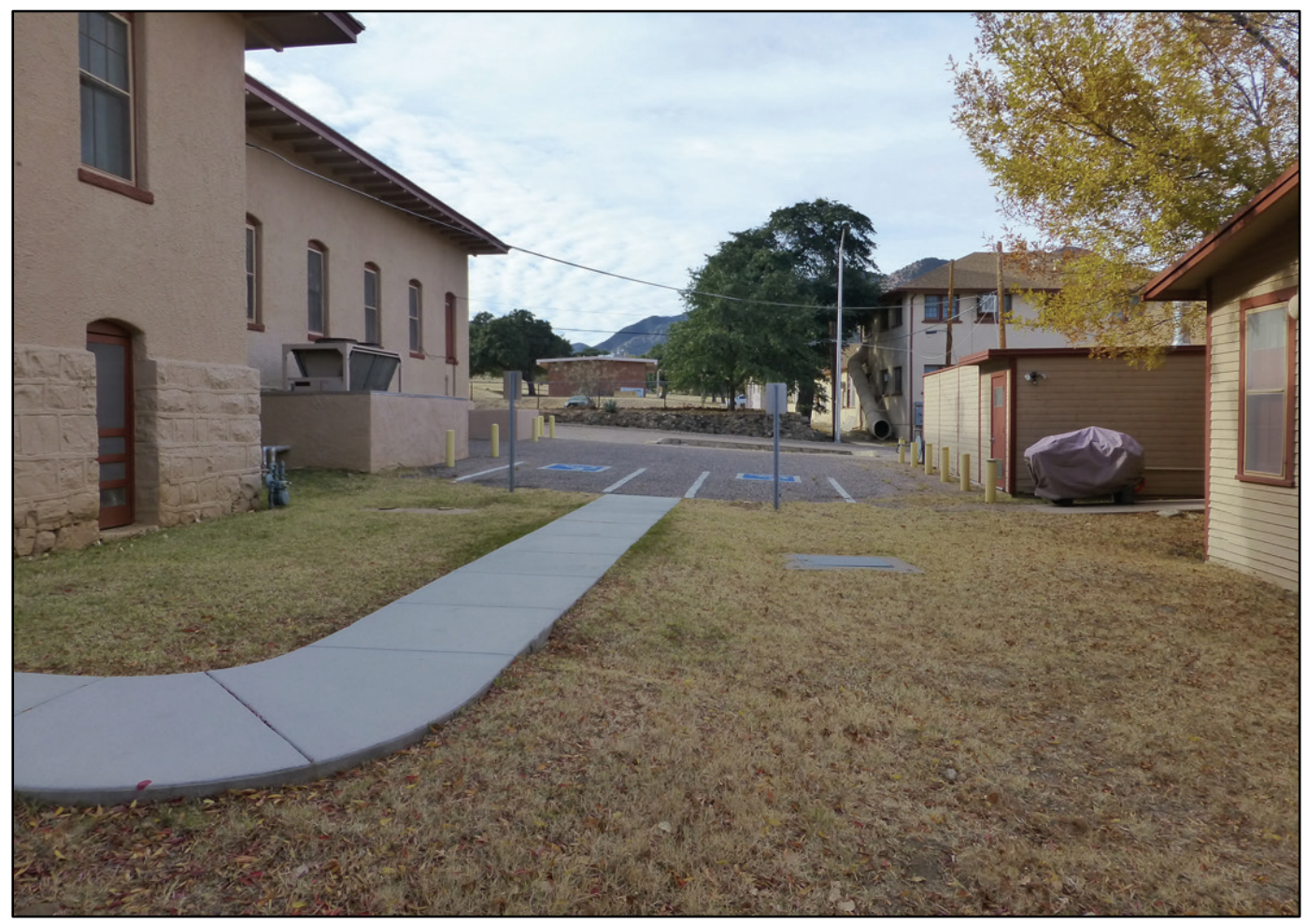


Figure 204. View looking northeast at rear of Brayton Hall (21115) and its handicapped accessible parking lot (ERDC-CERL, 2016).

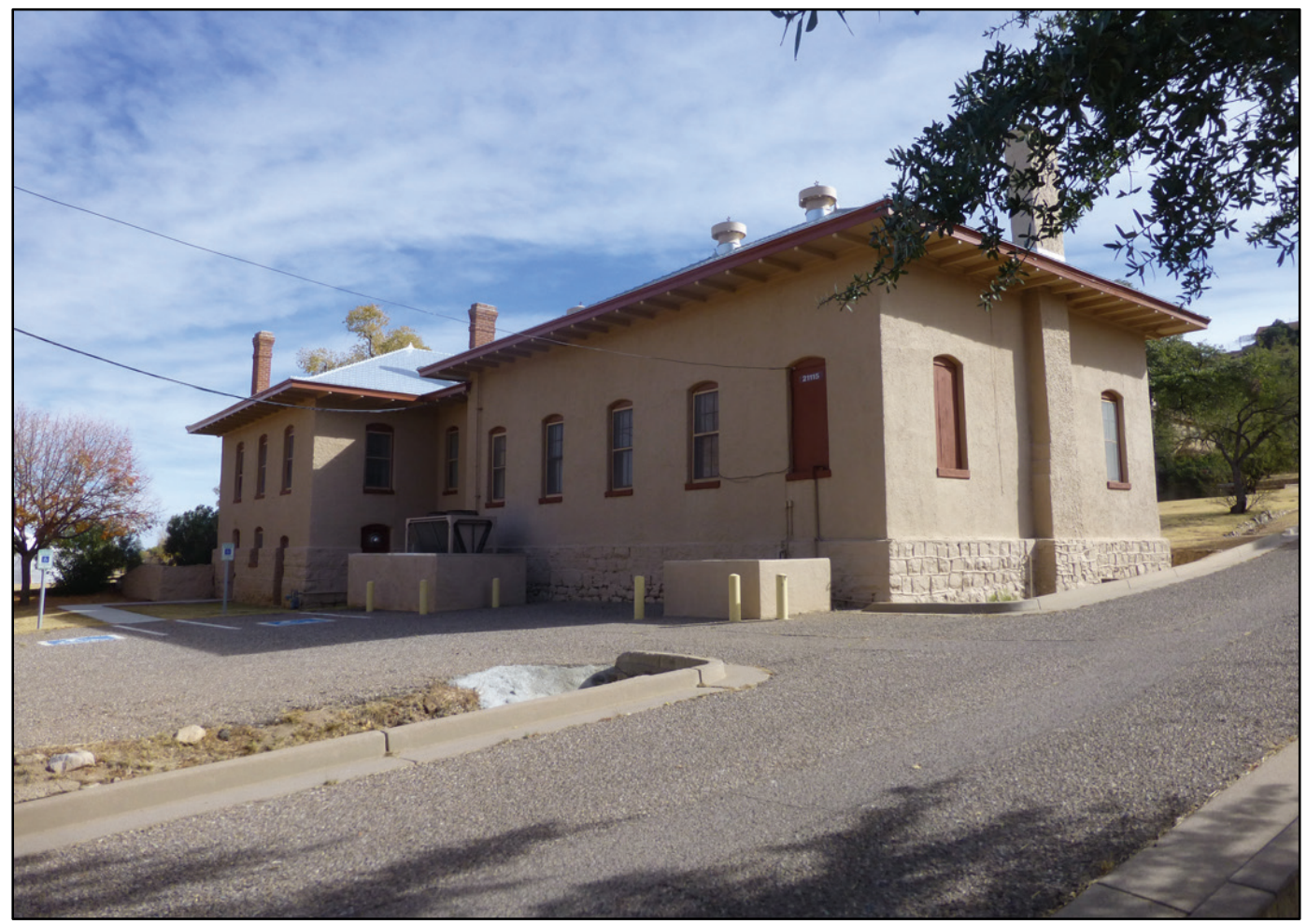

Figure 205. View looking north of coal bin (no number on Real Property list) on the south side of Brayton Hall (21115) (ERDC-CERL, 2016).

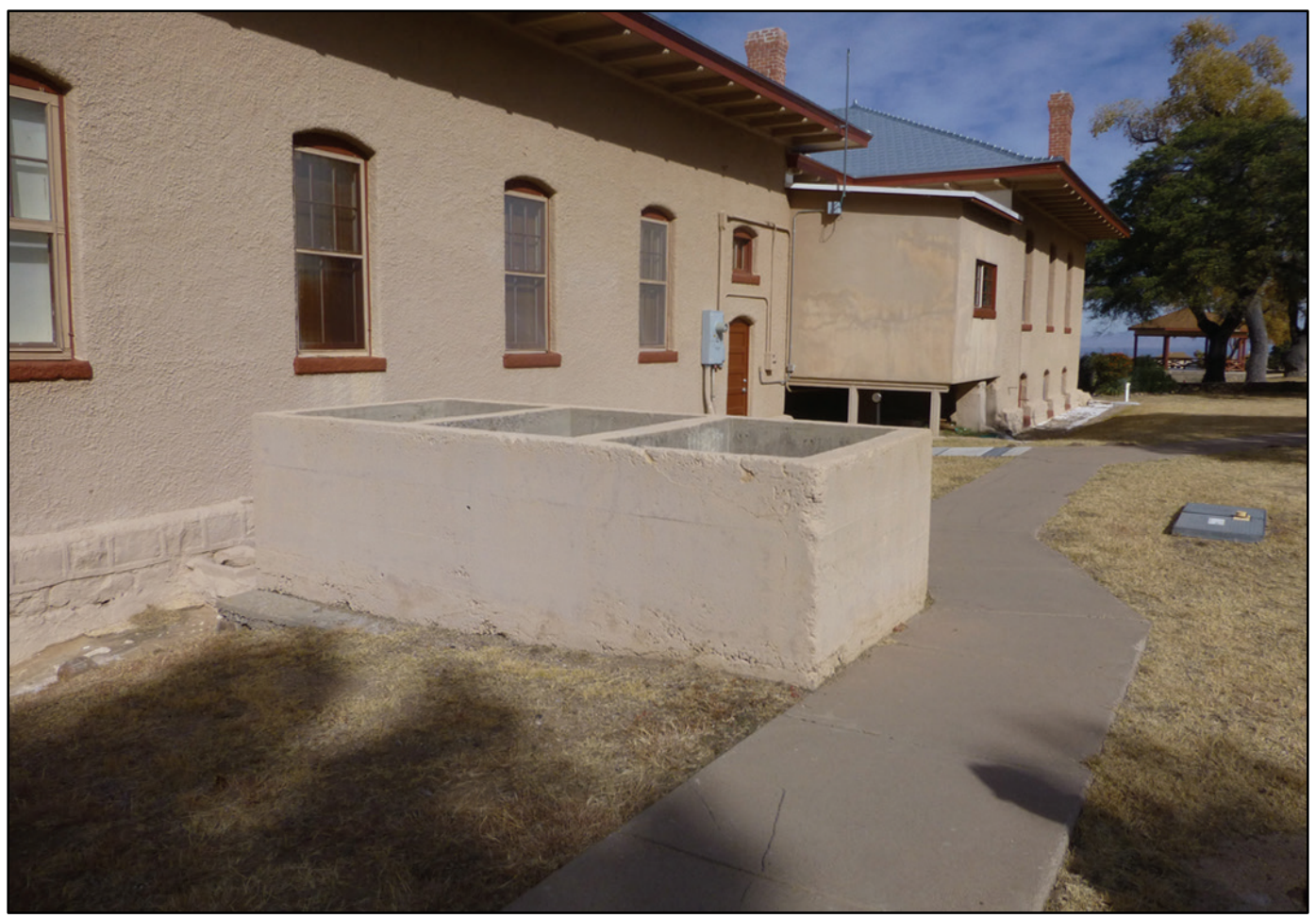


Figure 206. View of concrete sidewalk on the east side of Brayton Hall (21115) (ERDC-CERL, 2016).

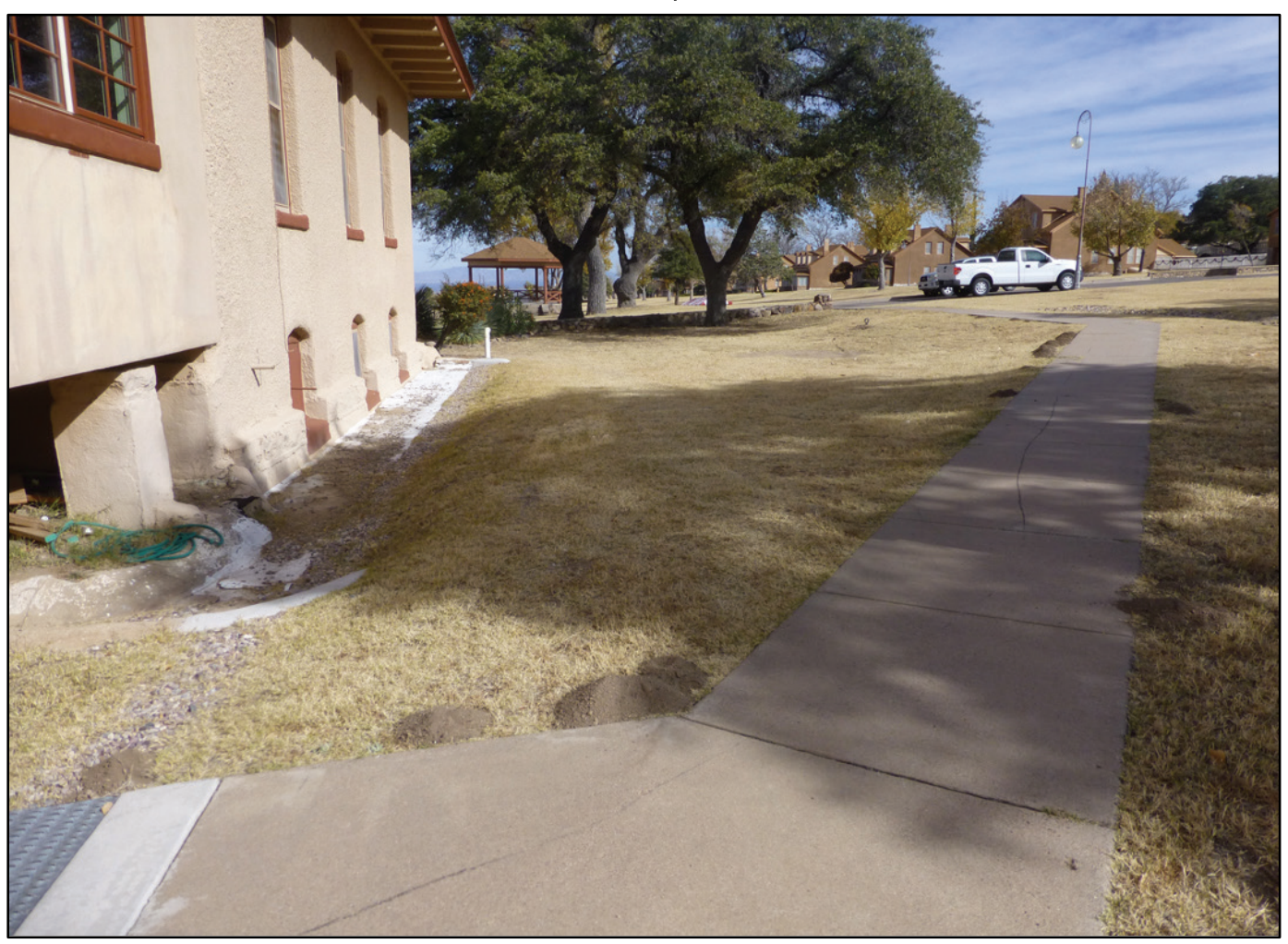

Figure 207. View looking north at trees in front of Brayton Hall (21115) along Adair Avenue (ERDC-CERL, 2016).

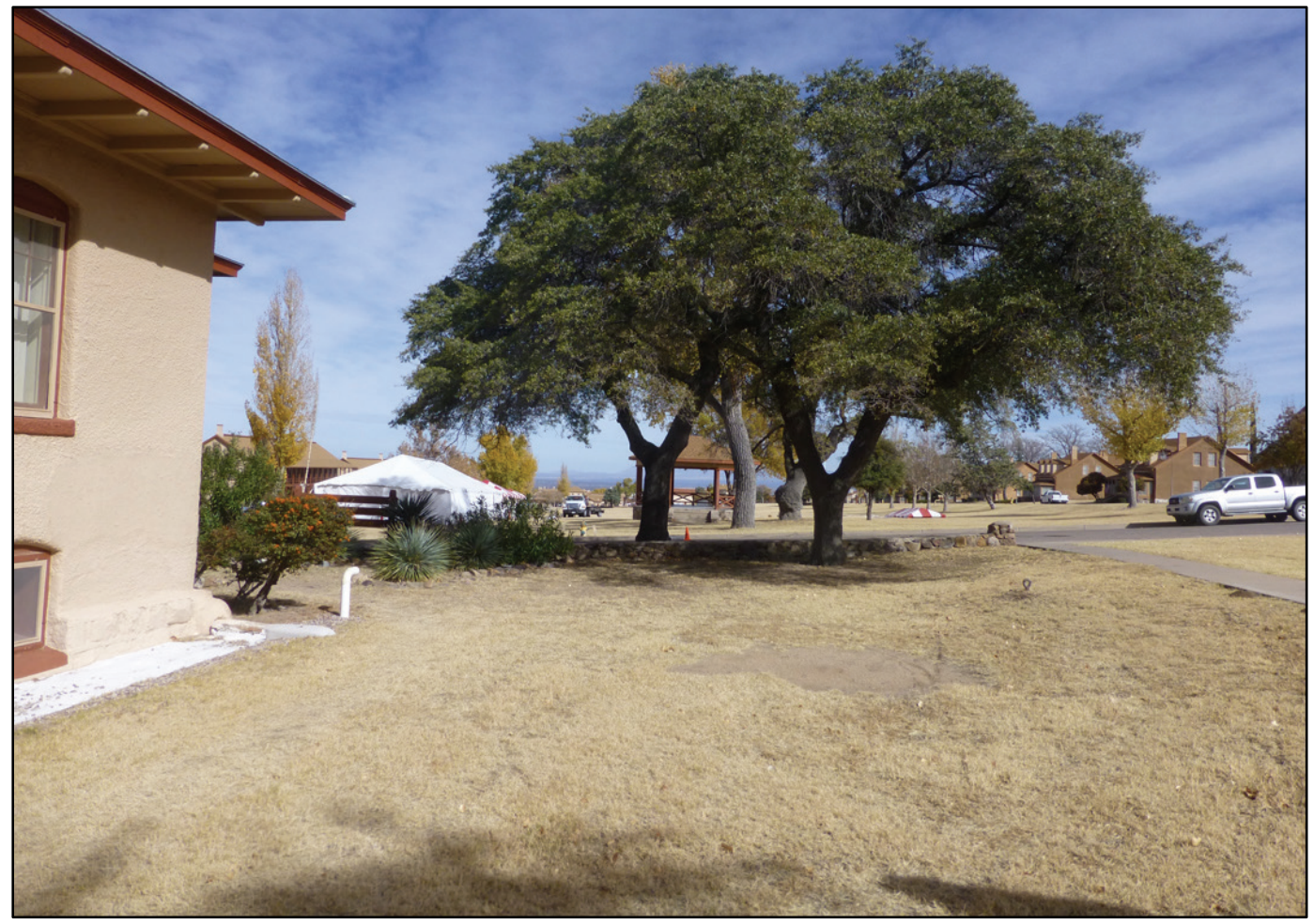


Figure 208. View of stone swale and stone drainage ditch to the southeast of Brayton Hall (21115) along Adair Avenue (ERDC-CERL, 2016).

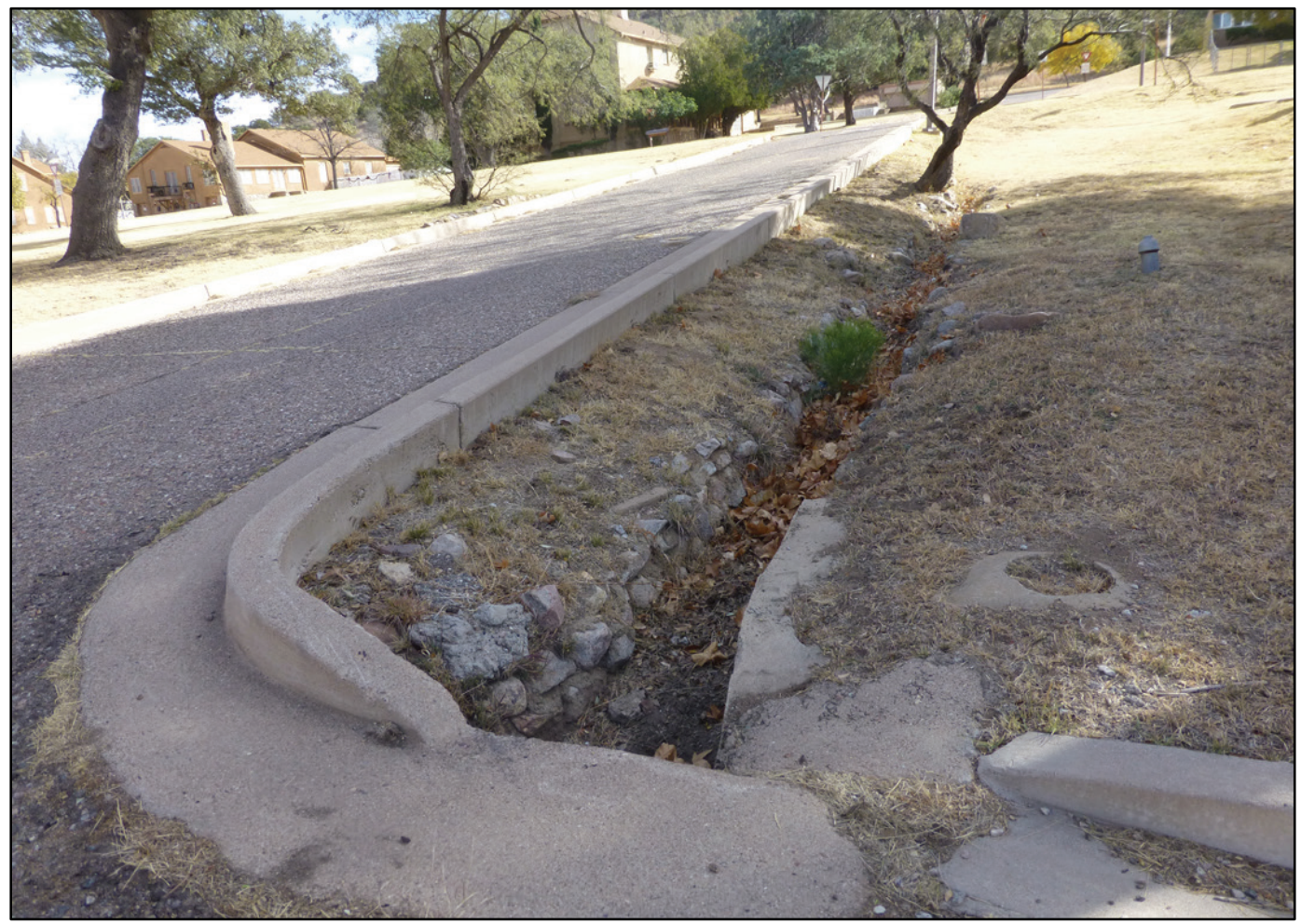

Figure 209. View of metal street lamp southeast of Brayton Hall (21115) near intersection of Adair Avenue and Grierson Avenue (ERDC-CERL, 2016).

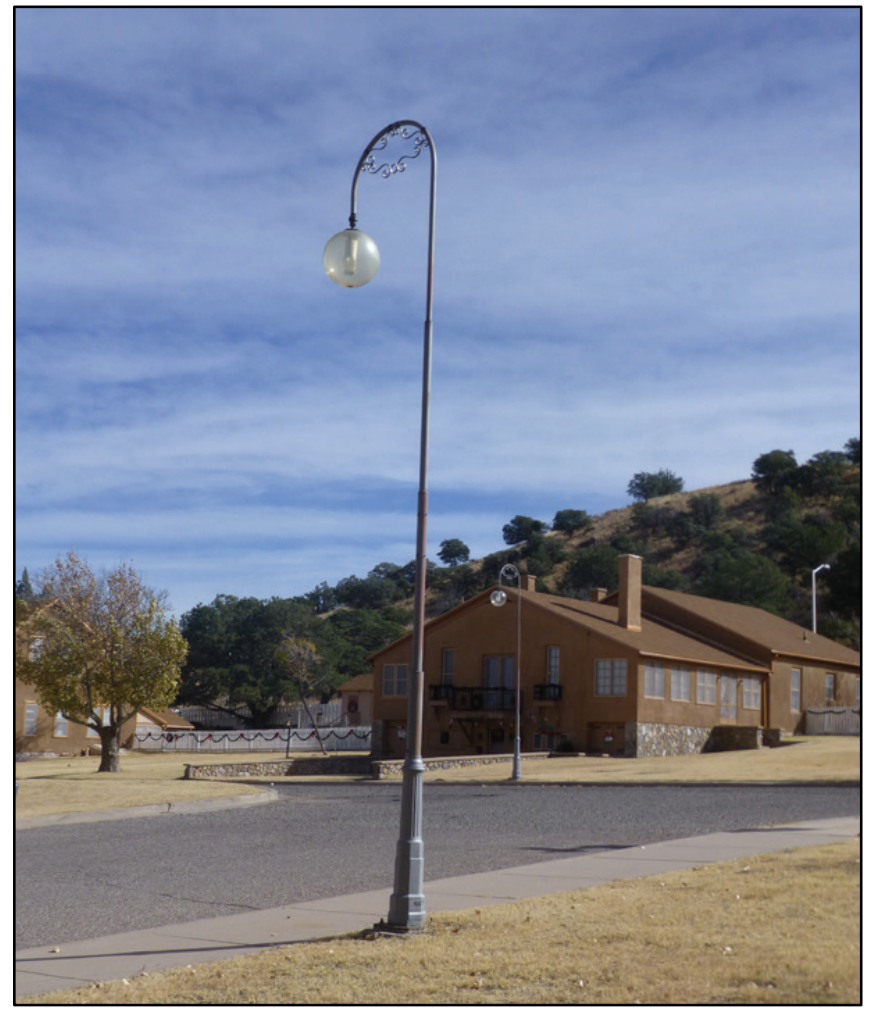


Figure 210. View to the south of 21114 with stone wall and concrete sidewalk [Note shrubs in front of building] (ERDC-CERL, 2016).

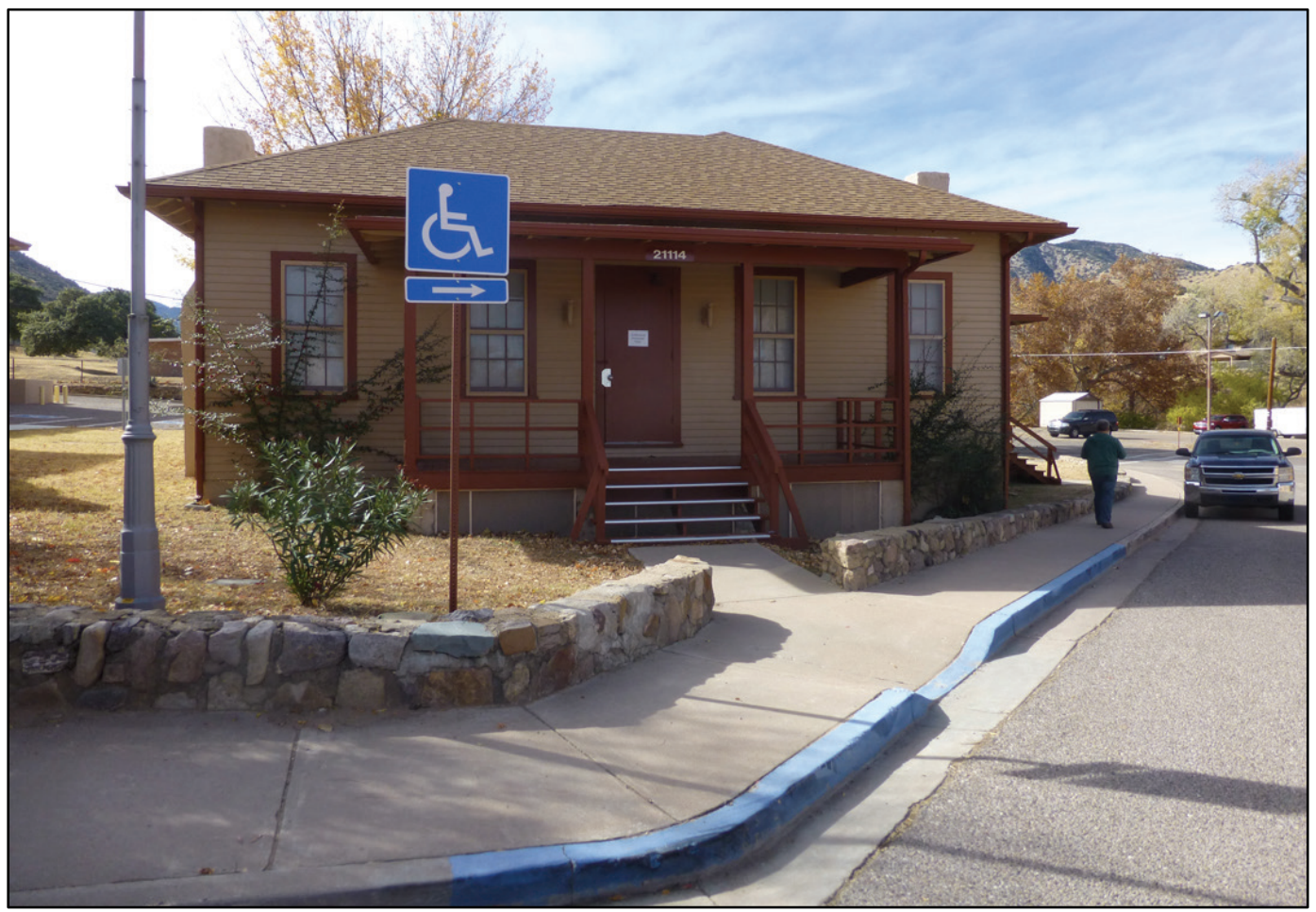

Figure 211. View looking north at parking lot right outside of the Fort Huachuca Historic District at the intersection of Adair and Christy Avenues (ERDC-CERL, 2016).

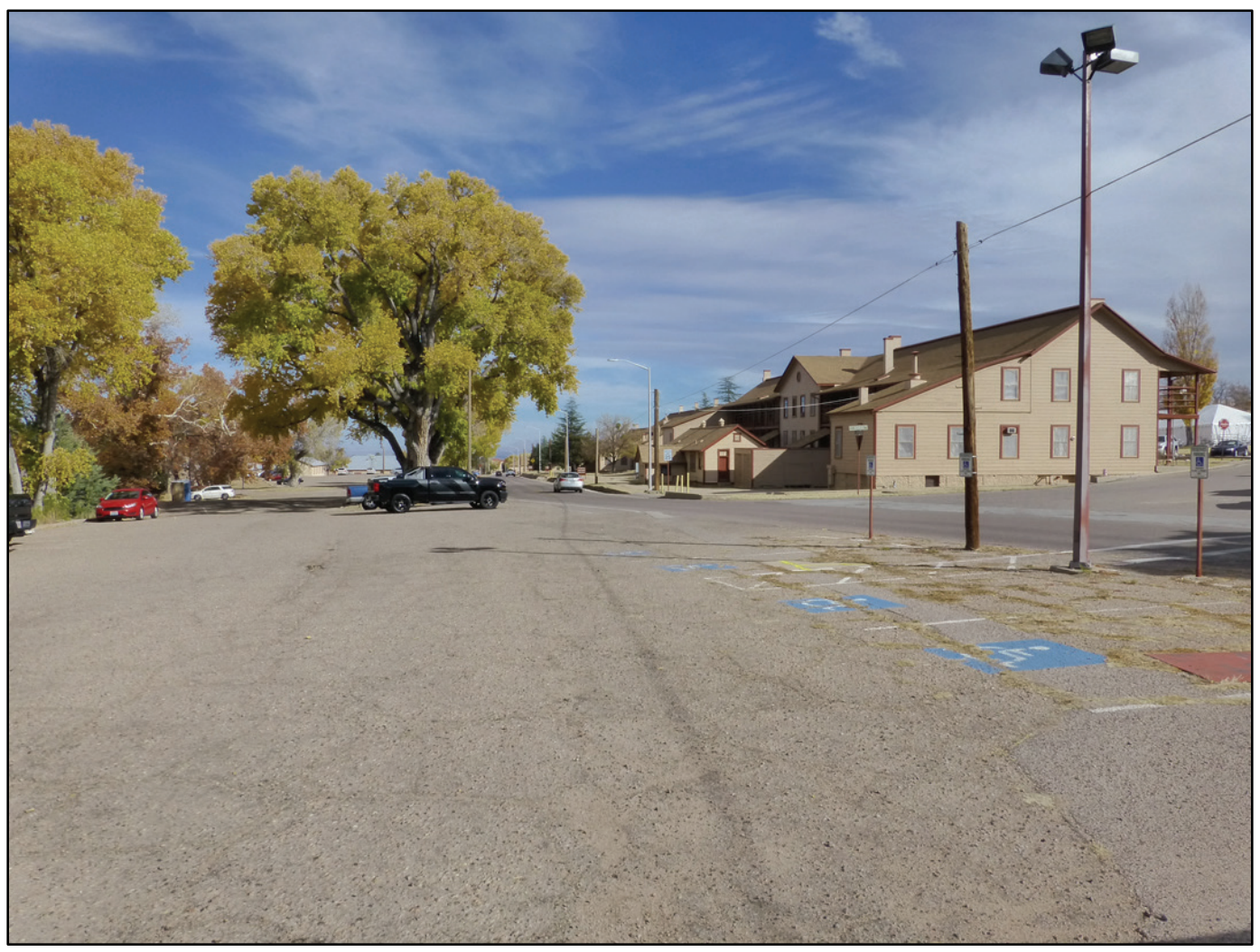




\subsubsection{Significance and integrity}

Although it is heavily modified, the former bowling alley (21114) retains sufficient character to qualify as a contributing element of this historic district. Brayton Hall (21115), now offices, has also retained its integrity. The associated coal bin (not on Real Property list) is still extant.

\subsubsection{Character-defining features}

Character-defining features include:

- Prominent location along south end of parade field

- Unique but compatible architecture

- Views to and from parade field

- Consistent land use.

\subsection{Barracks}

The seven barracks (41412, 41415, 41416, 41418, 41419, 41420, and 41421) are located along Rhea Avenue, north of the initial Old Post buildings (Figure 212). The buildings line the west side of an open space that is known as North Parade field (also seen as Lower Parade Field). This area also includes a lavatory (41414) and a bus stop (Table 13).

Figure 212. 1914 Barracks landscape area map (ERDC-CERL).

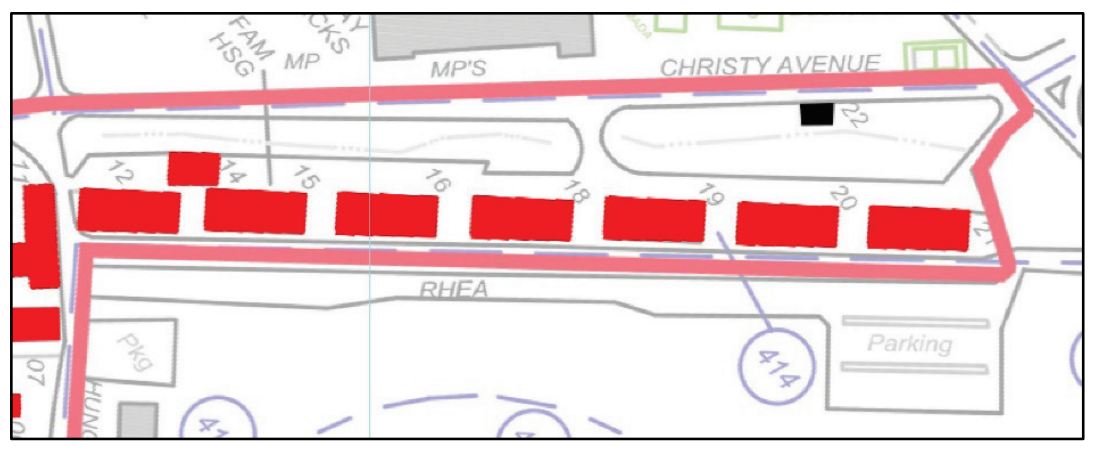

Table 13. List of buildings within the 1914 Barracks landscape area.

\begin{tabular}{|c|c|l|l|c|}
\hline Building Number & Year Built & Original Use & Current Use & Historic Status \\
\hline 41412 & 1914 & Barracks & Administrative & NHLC \\
\hline 41414 & 1914 & Lavatory & Administrative & NEV \\
\hline 41415 & 1914 & Barracks & Administrative & NHLC \\
\hline 41416 & 1916 & Barracks & Administrative & NHLC \\
\hline 41418 & 1916 & Barracks & Administrative & NHLC \\
\hline 41419 & 1916 & Barracks & Administrative & NHLC \\
\hline
\end{tabular}




\begin{tabular}{|c|c|l|l|c|}
\hline Building Number & Year Built & Original Use & Current Use & Historic Status \\
\hline 41420 & 1913 & Barracks & Administrative & NHLC \\
\hline 41421 & 1915 & Barracks & Administrative & NHLC \\
\hline 41422 & 1972 & Bus Stop Shelter & Bus Stop Shelter & NEV \\
\hline
\end{tabular}

\subsubsection{History}

During the period 1914-17, the facilities at Fort Huachuca were expanded dramatically to accommodate an enhanced border patrol mission for the cavalry. Seven barracks were built along Rhea Avenue tripling the troop capacity of the post. These barracks were patterned after the Old Post Barracks but were not identical to them. They were constructed using Quartermaster Plan No. 299, with slight variations to the designs of the buildings over the 2 years of construction. The 1914 Barracks (41412 and 41415), designed for a 76-man company, included an internal kitchen located at the left end of the first story. The 1916 Barracks were designed for 87-man companies. These buildings also included internal latrines, as opposed to the freestanding latrine behind the 1914 buildings (41414).

The 1914-16 Barracks were sided in stucco and are so today. Like the 1880 s Barracks, these included two-story verandas at the front and rear with exterior stairs with metal pipe railings, a porch design that was repeated on the 1880 s Barracks when their wood rails were replaced with metal pipe rails 1917. Other similar features included $6 / 6$ double-hung wooden sash windows and five-panel wooden doors (Figures 213-217). 
Figure 213. View southwest towards 41421 on the eastern end of the 1914 Parade Field, c.1917 (Fort Huachuca Museum). Note writing on the roof for aerial identification.

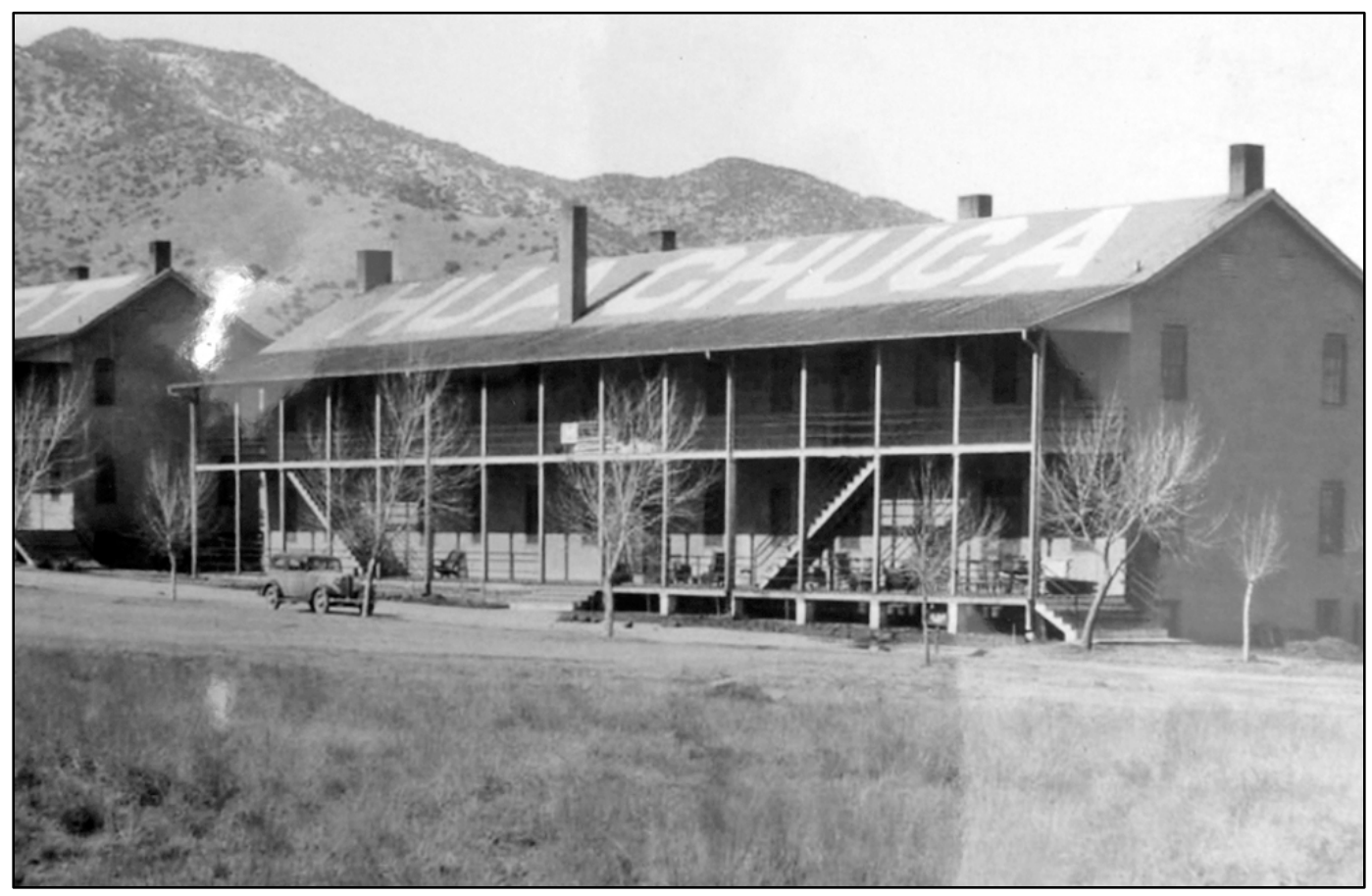

Figure 214. View south towards one of the $10^{\text {th }}$ Calvary Barracks on the west side of the 1914 Parade Field, c.1917 [Note street lamp.] (Fort Huachuca Museum).

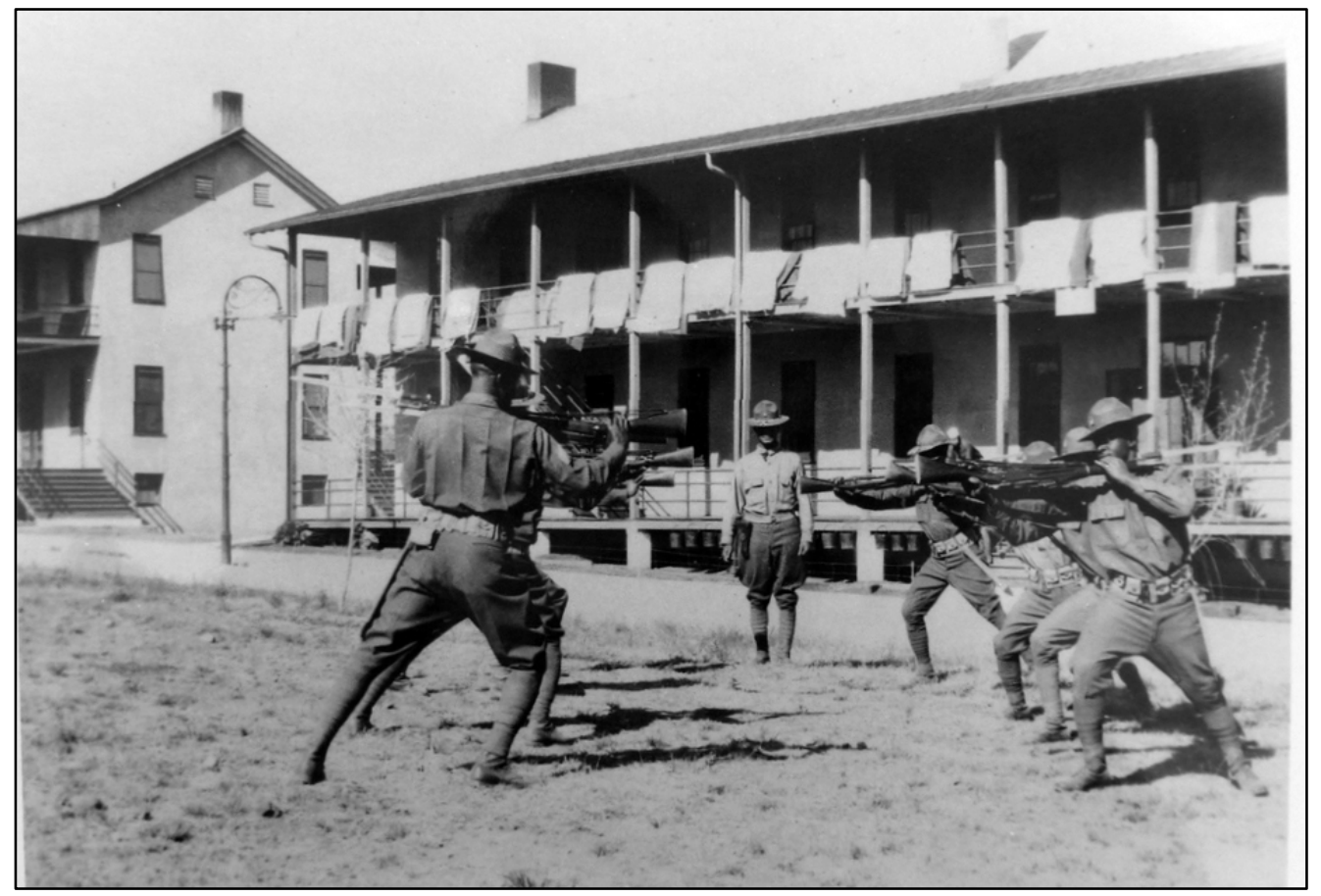


Figure 215. View looking west between 41418 and 41419 with 31122 in the background, c.1942 (Fort Huachuca Museum).

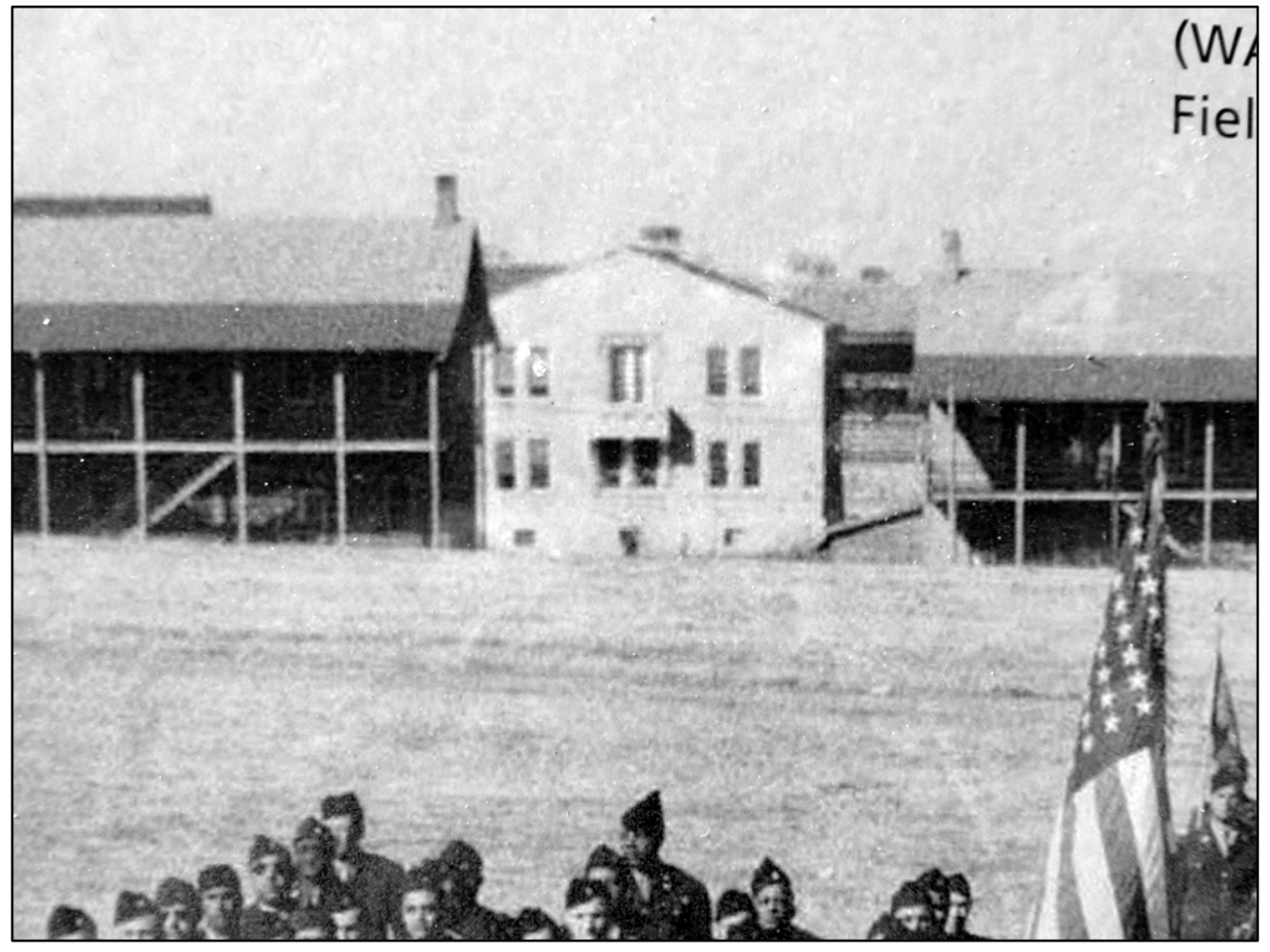

Figure 216. Aerial of Fort Huachuca looking southwest with the original fort on the left and the 1914 extension on the right, 1924 (NARA College Park, RG165-FF).

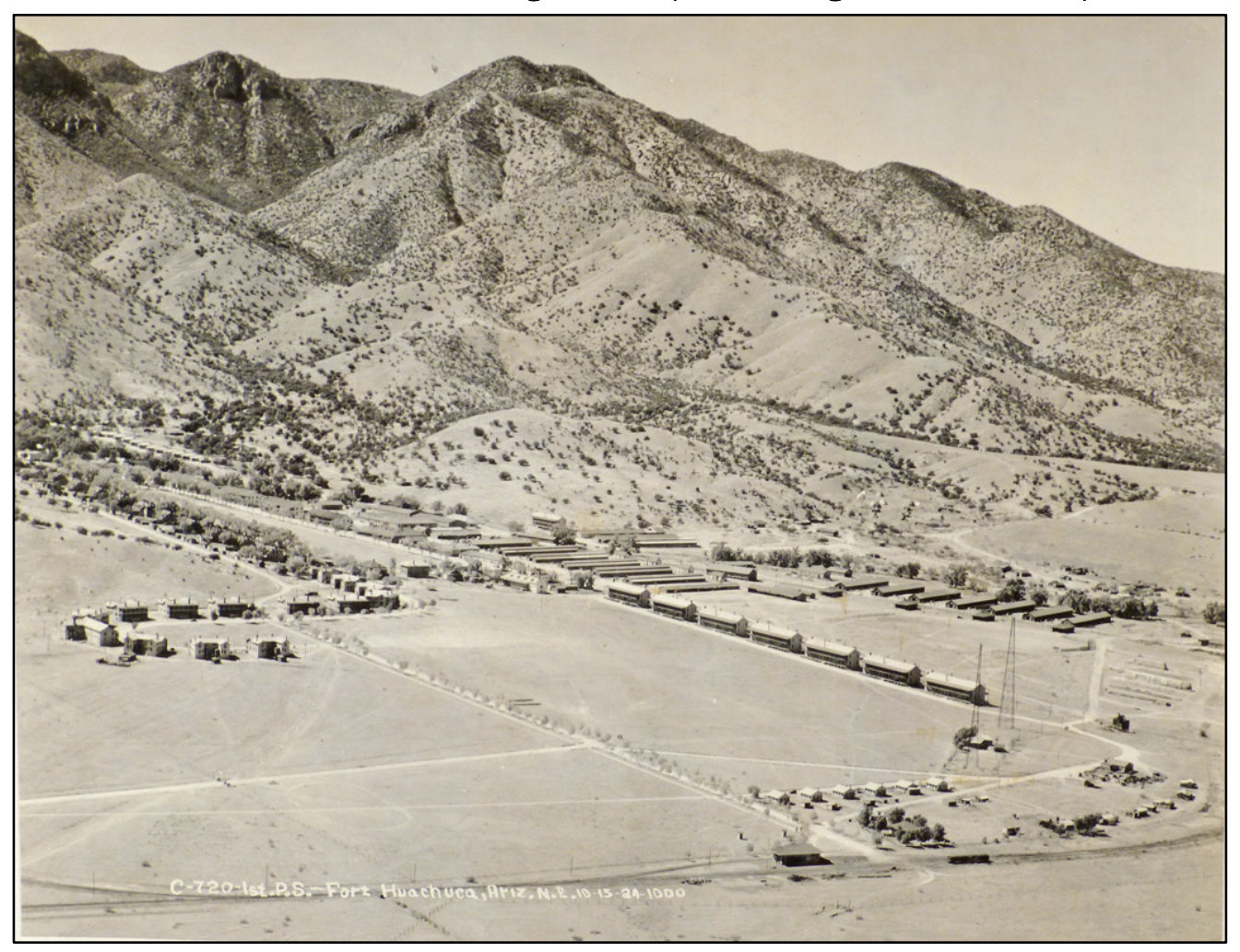


Figure 217. View northwest of 1914 Barracks, 1954 (NARA College Park, RG111-SC).

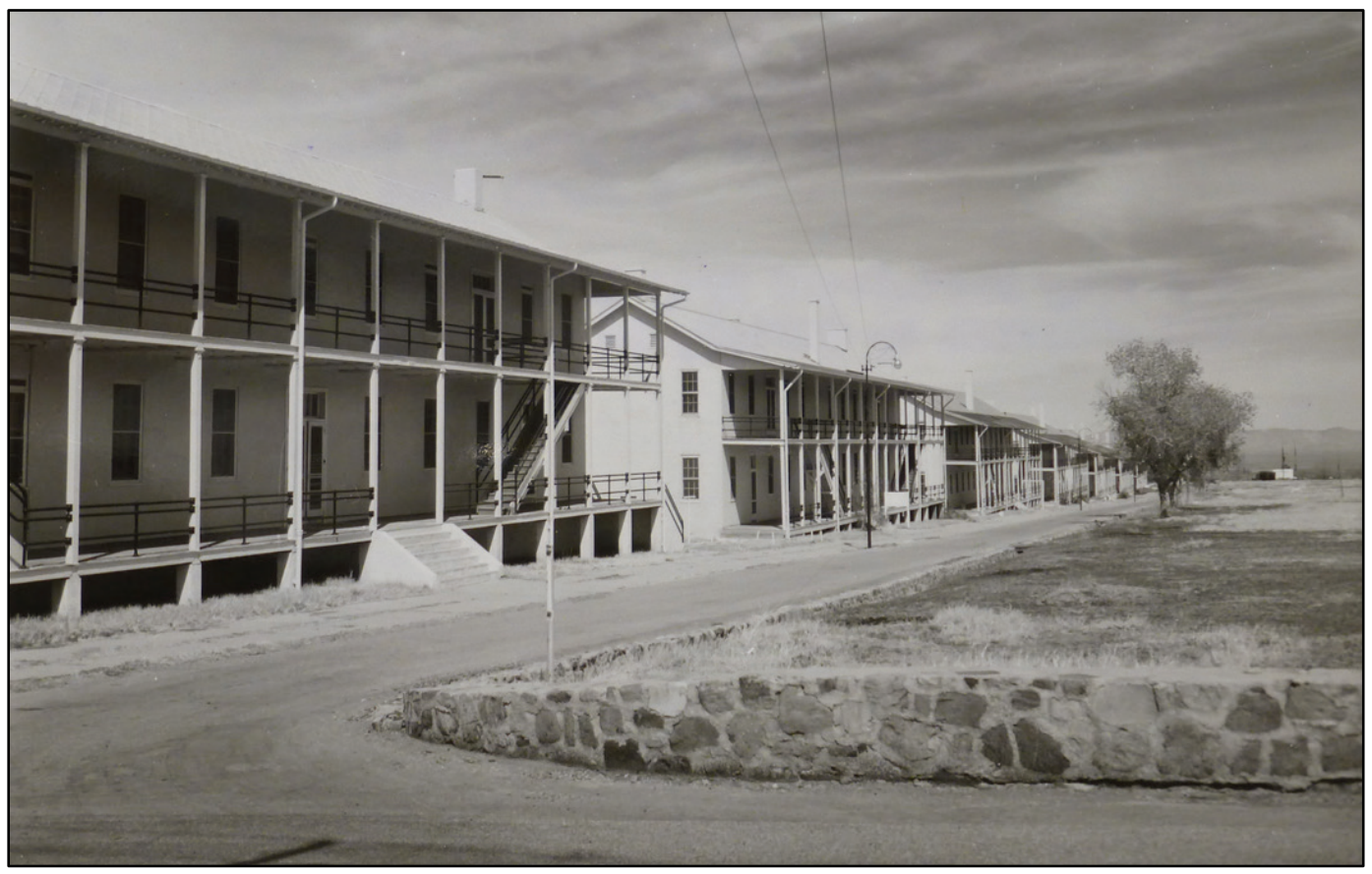

\subsubsection{Current conditions}

By the 1940s, each building also included a small screen porch extension at the left, first story, adjoining the kitchen. Each of these screen porches, which were not part of original construction, still exist but have been heavily modified since their construction, probably in the early 1940s (Figures 218-252).

Figure 218. View looking west towards the 1914 Barracks from North Parade Field (ERDCCERL, 2016).

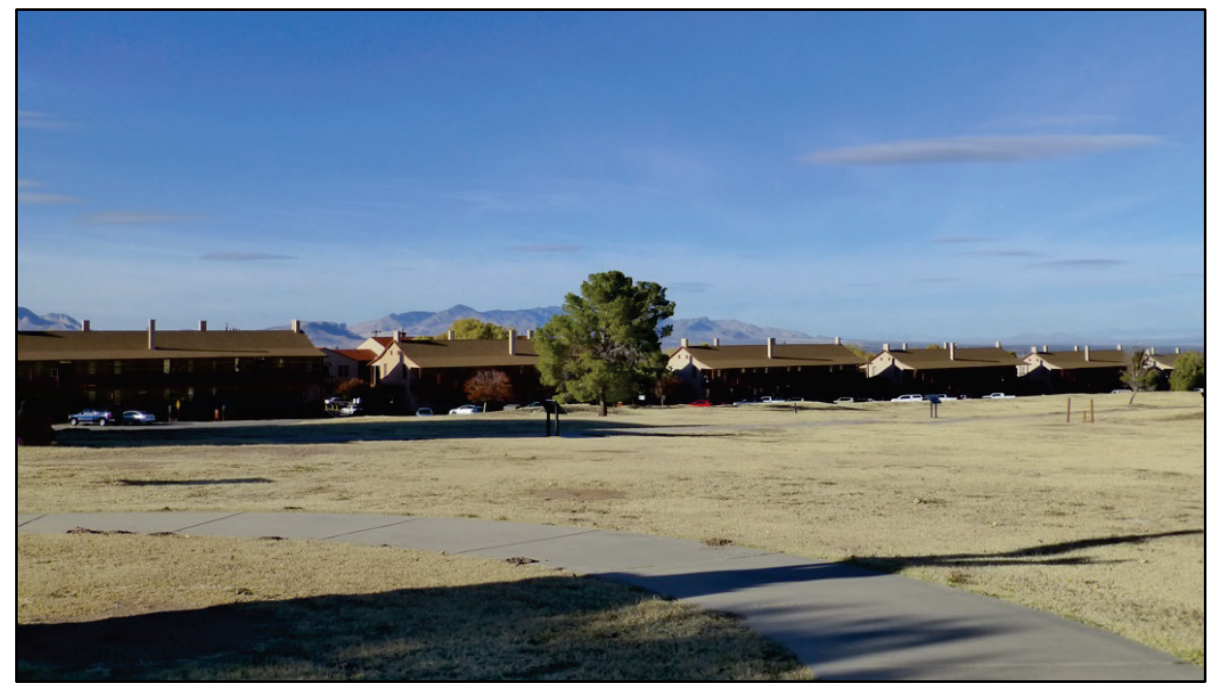


Figure 219. East side of 41412 with parking lot (ERDC-CERL, 2016).

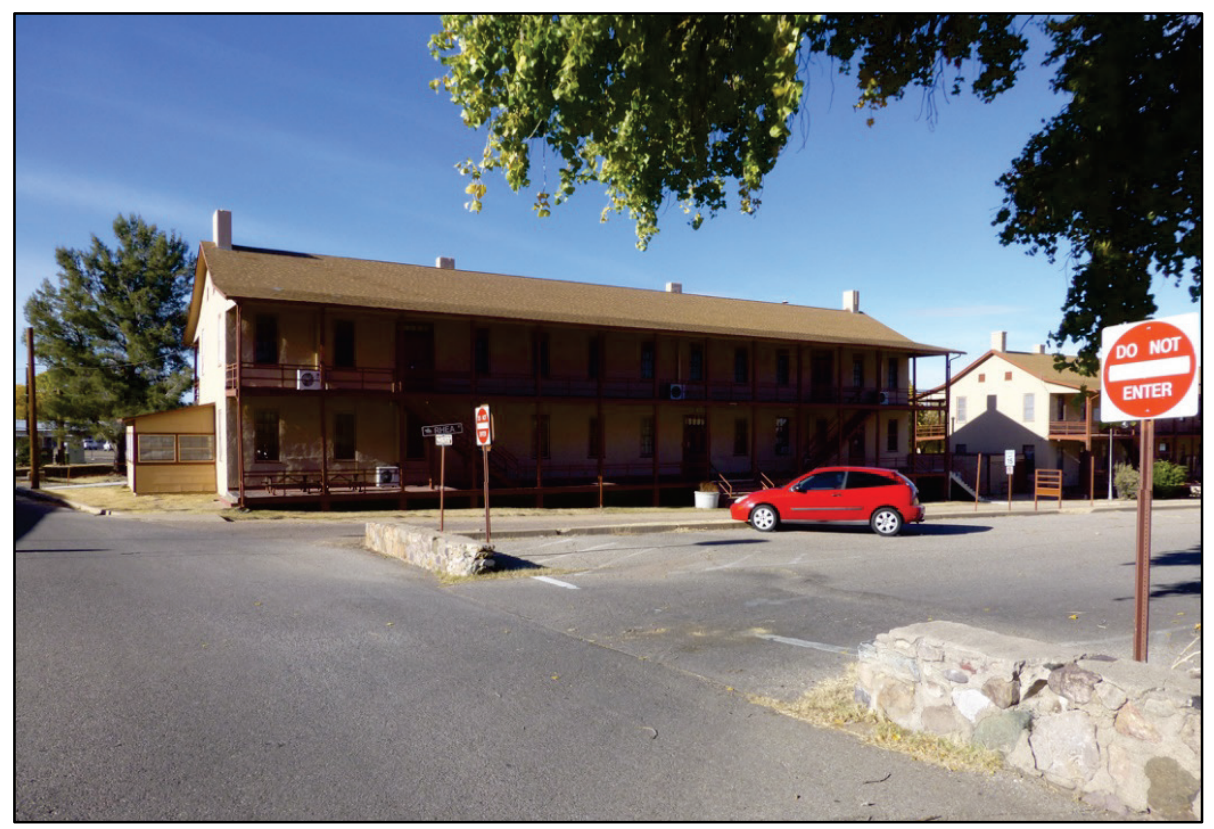

Figure 220. Looking northwest down the parking lot to the east of the 1914 Barracks (ERDCCERL, 2016).

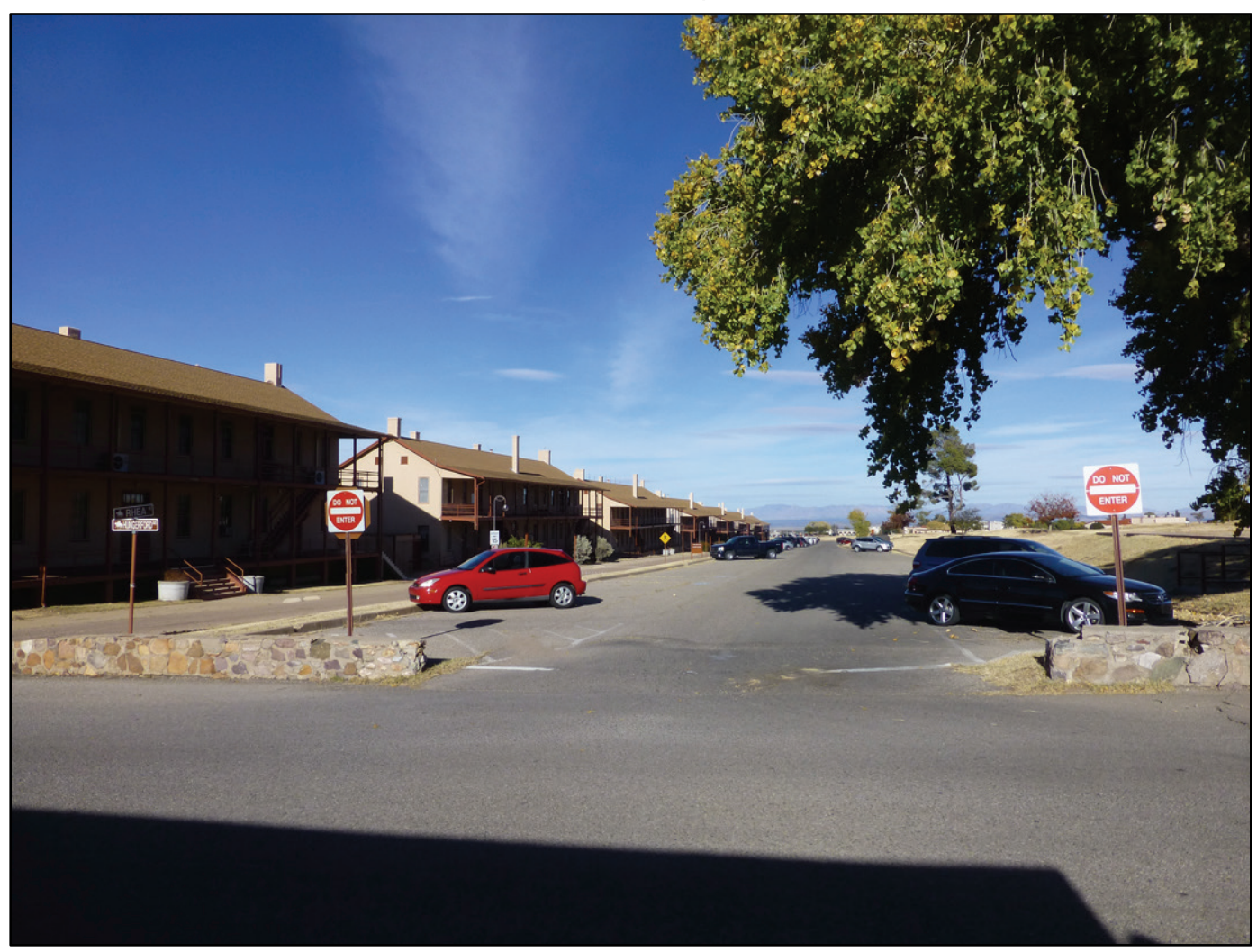


Figure 221. View looking northwest of parking lot and WPA-era stone retaining wall off Hungerford Avenue with 1914 Barracks in the background (ERDC-CERL, 2016).

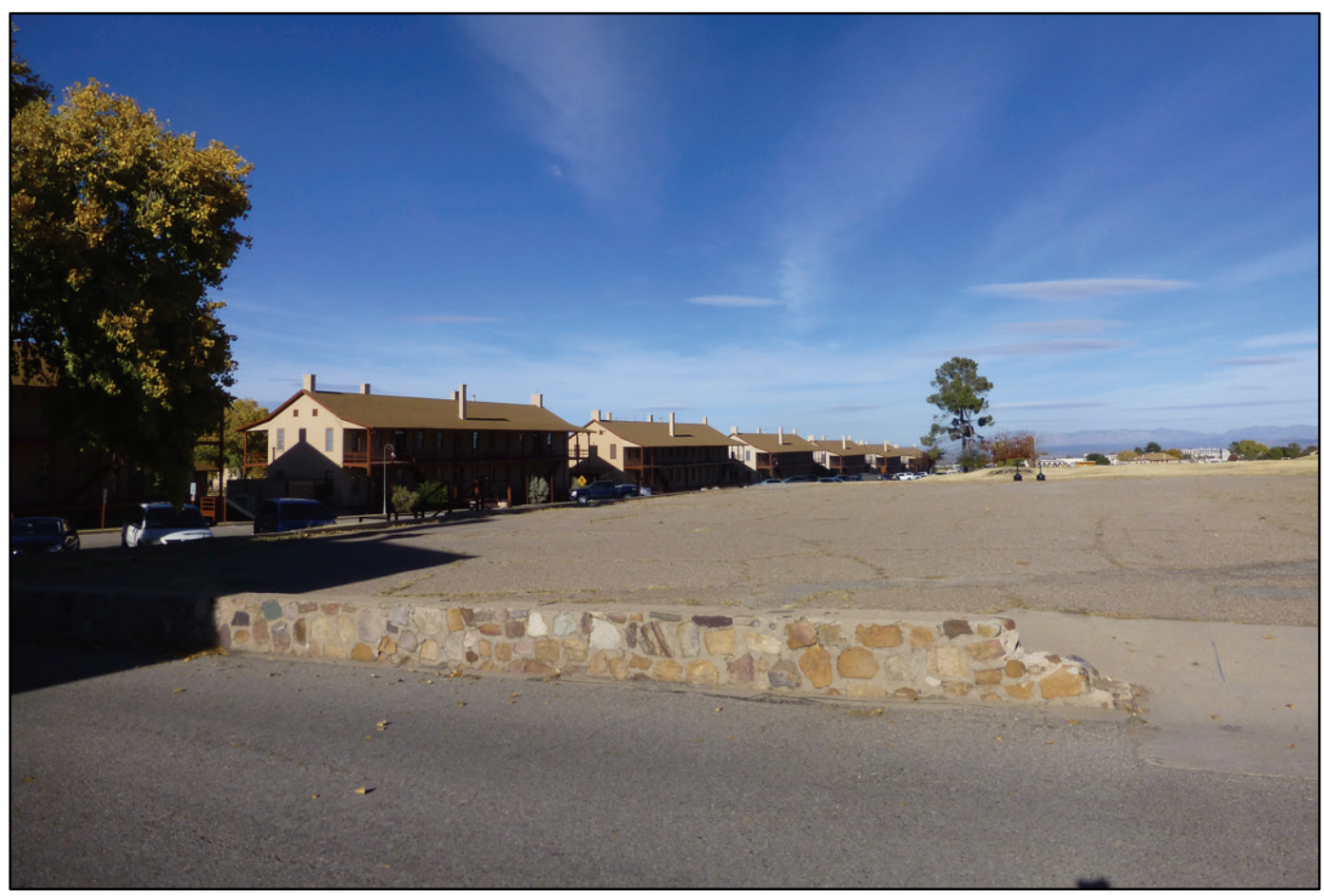

Figure 222. Looking north down Rhea Avenue and the concrete sidewalk in front of the 1914 Barracks (ERDC-CERL, 2016).

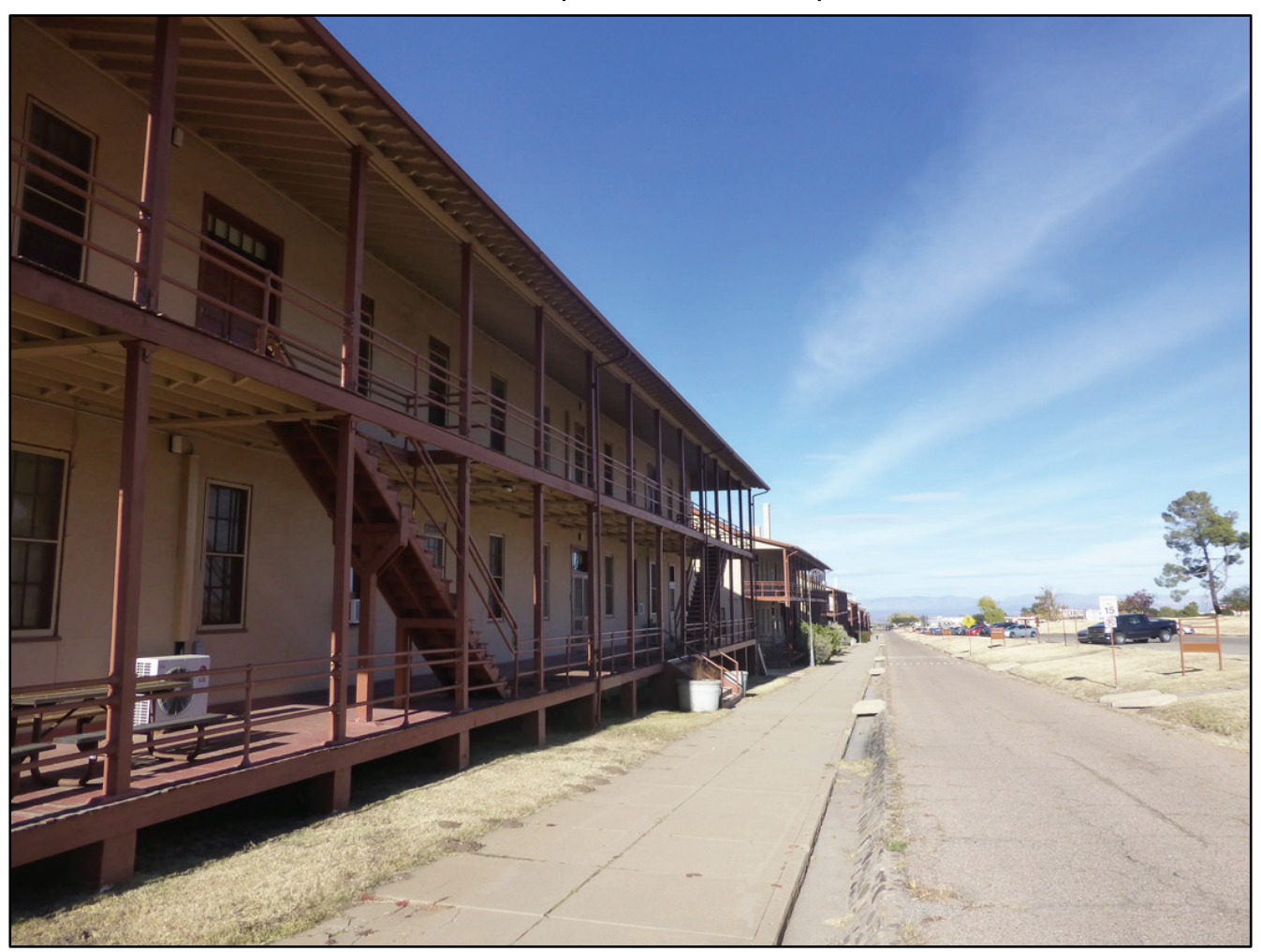


Figure 223. View to the north of the area between 1914 Barracks and parking lot showing materials, signs, and ramps from parking lots (ERDC-CERL, 2016).

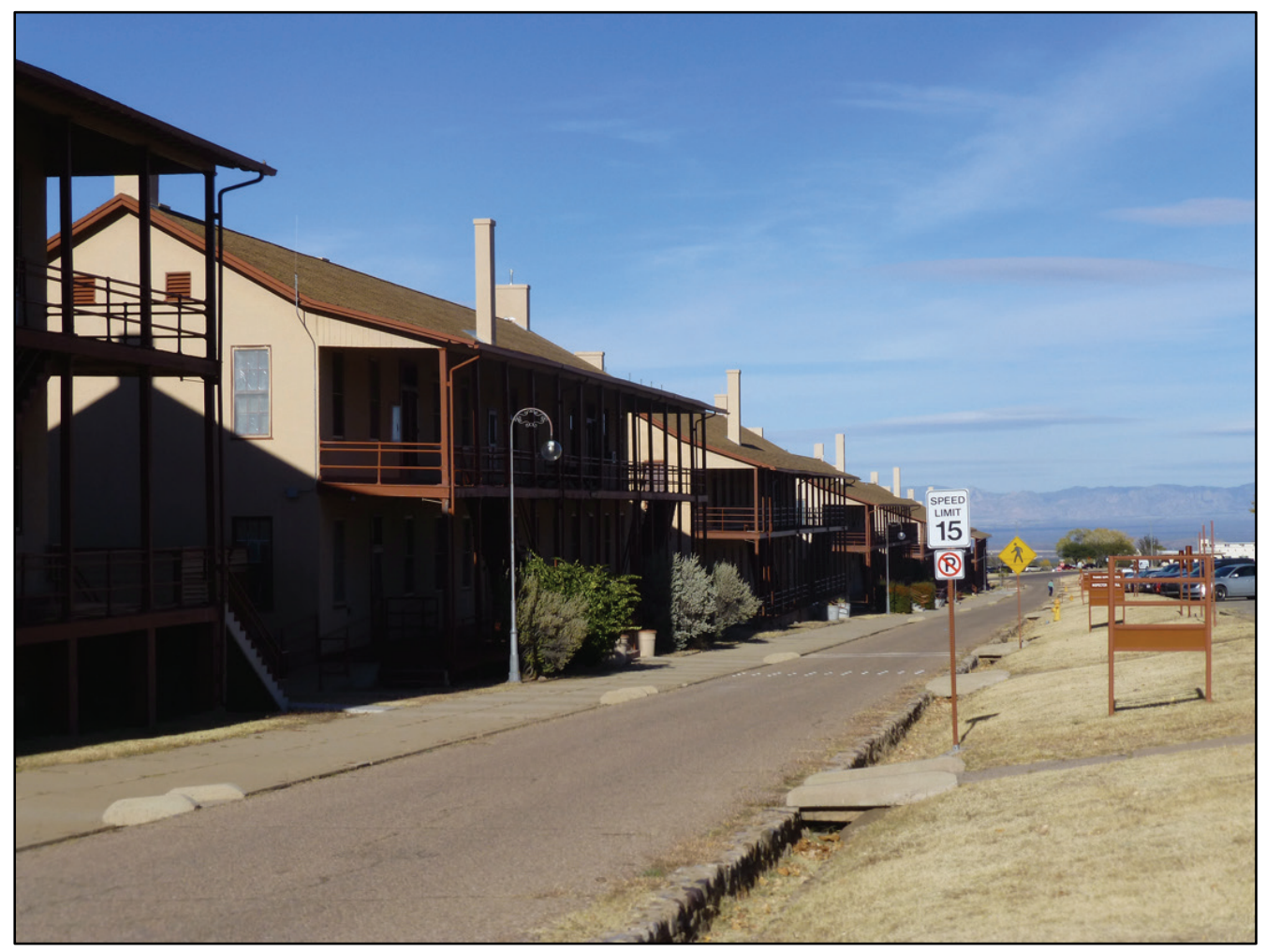

Figure 224. View southwest towards the 1914 Barracks (ERDC-CERL, 2016).

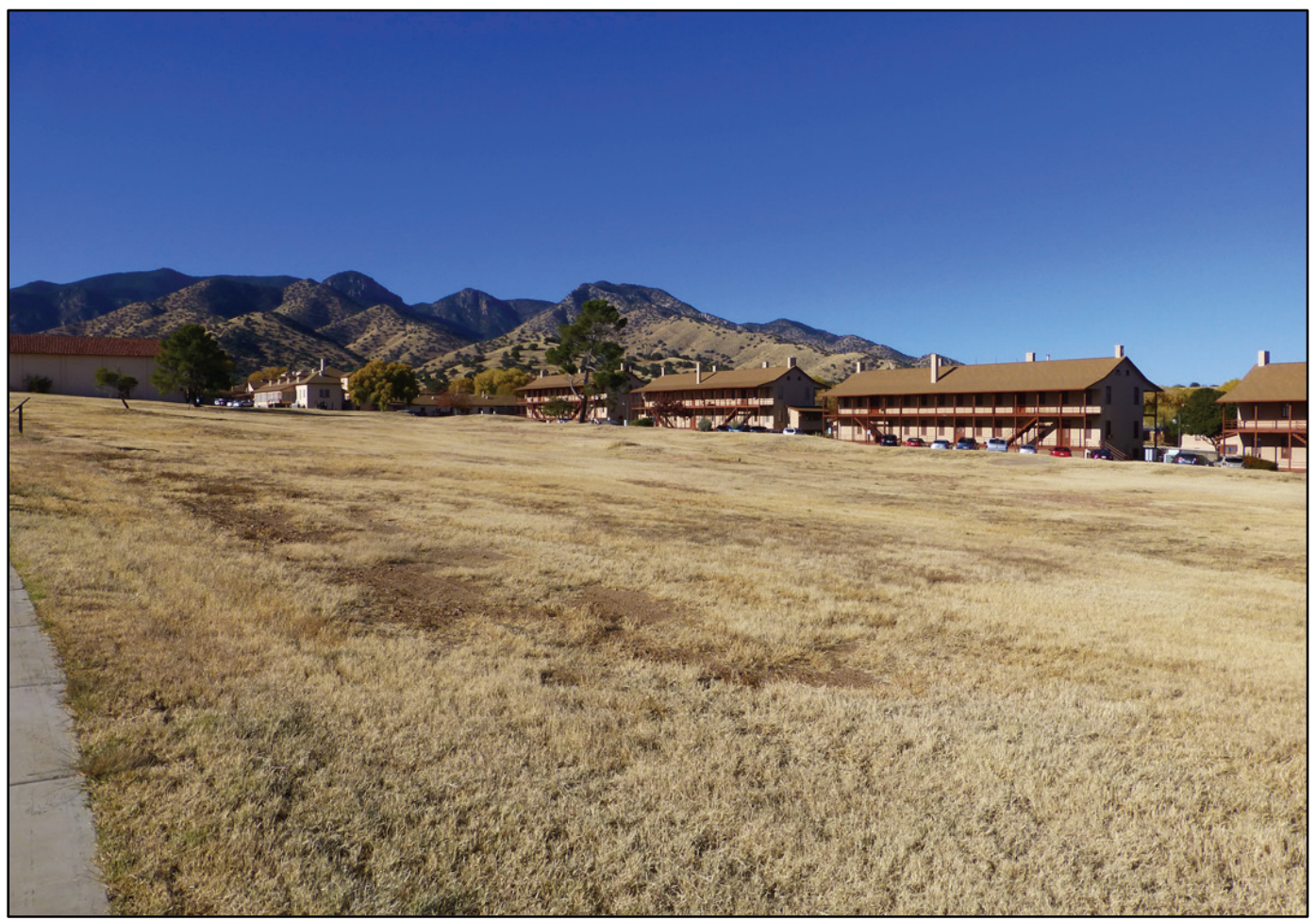


Figure 225. View to the west of former lavatory (41414) between 41412 and 41415 (ERDCCERL, 2016).

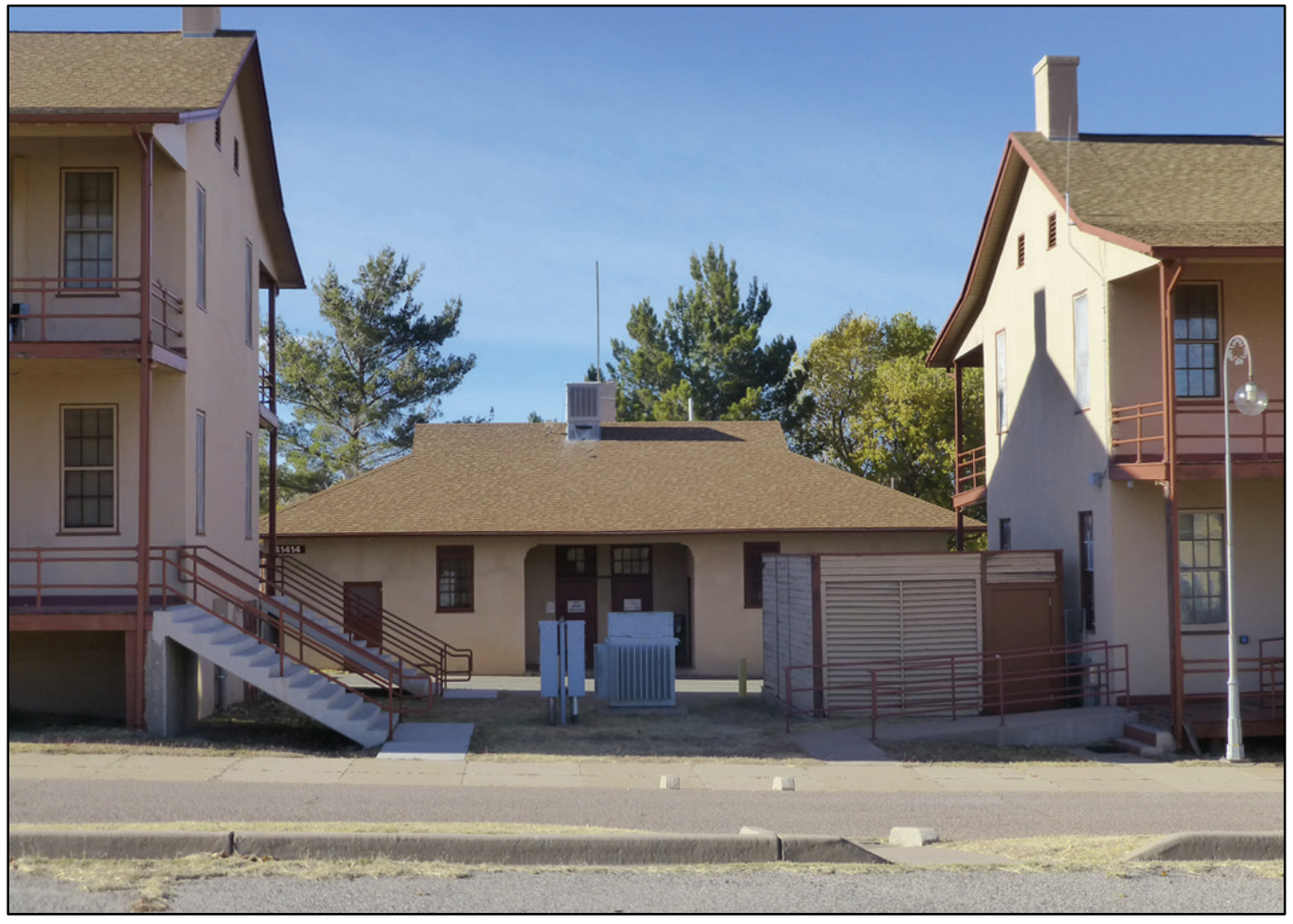

Figure 226. View to the west of 41415 (ERDC-CERL, 2016).

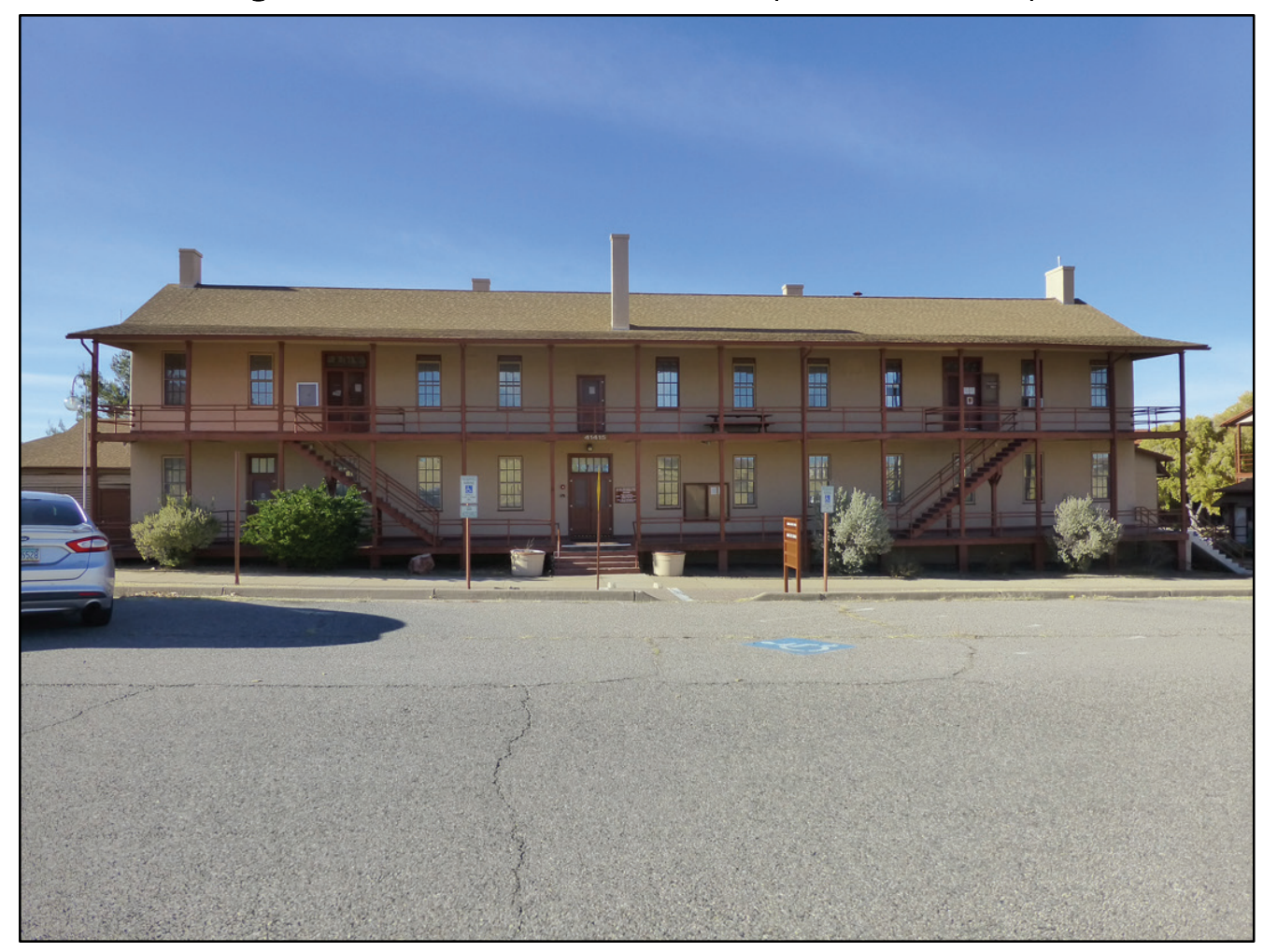


Figure 227. View looking west between 41415 and 41416 [Note additions on sides of barracks.] (ERDC-CERL, 2016).

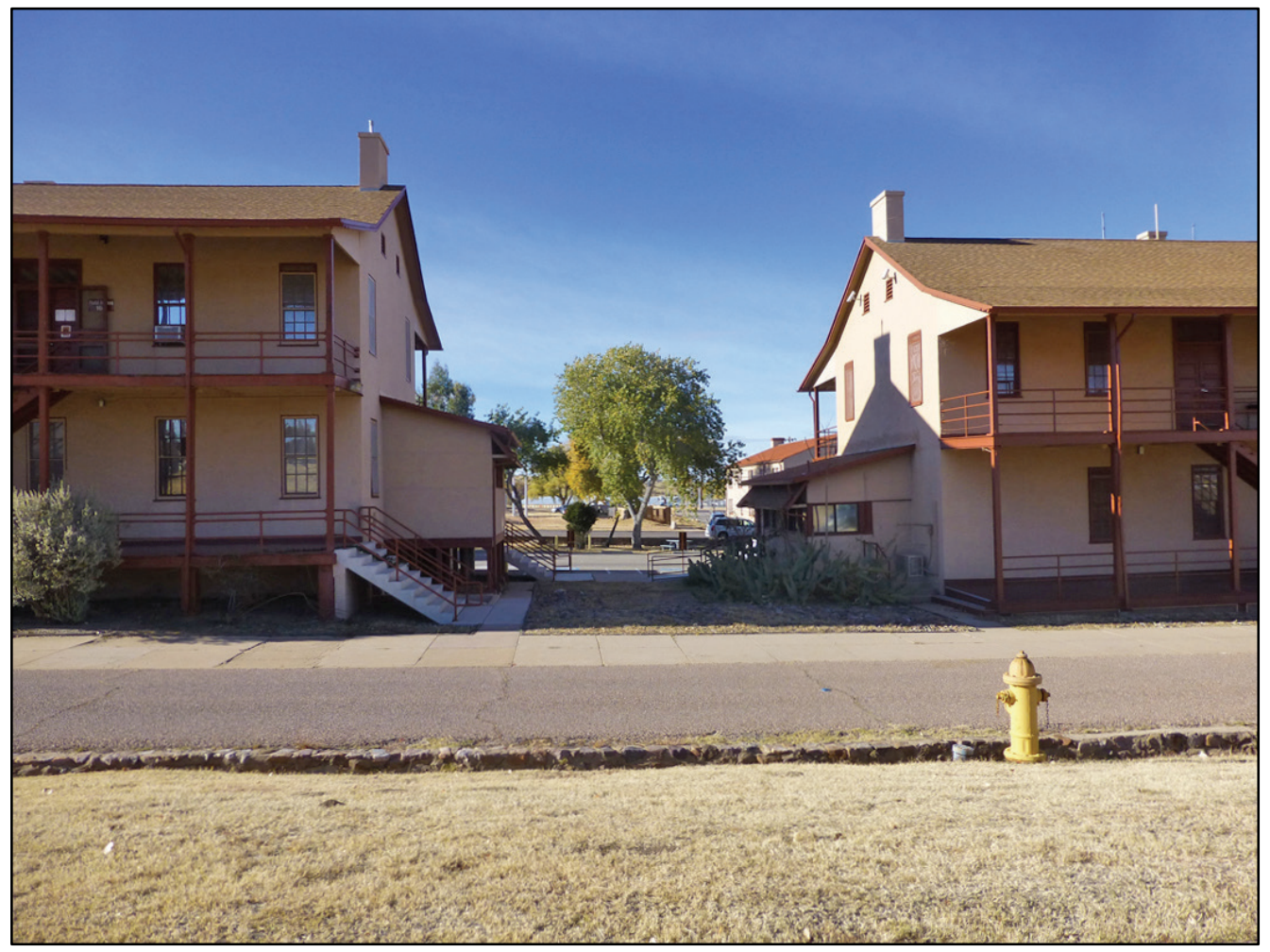

Figure 228. View to the west of 41416 and parking lot (ERDC-CERL, 2016).

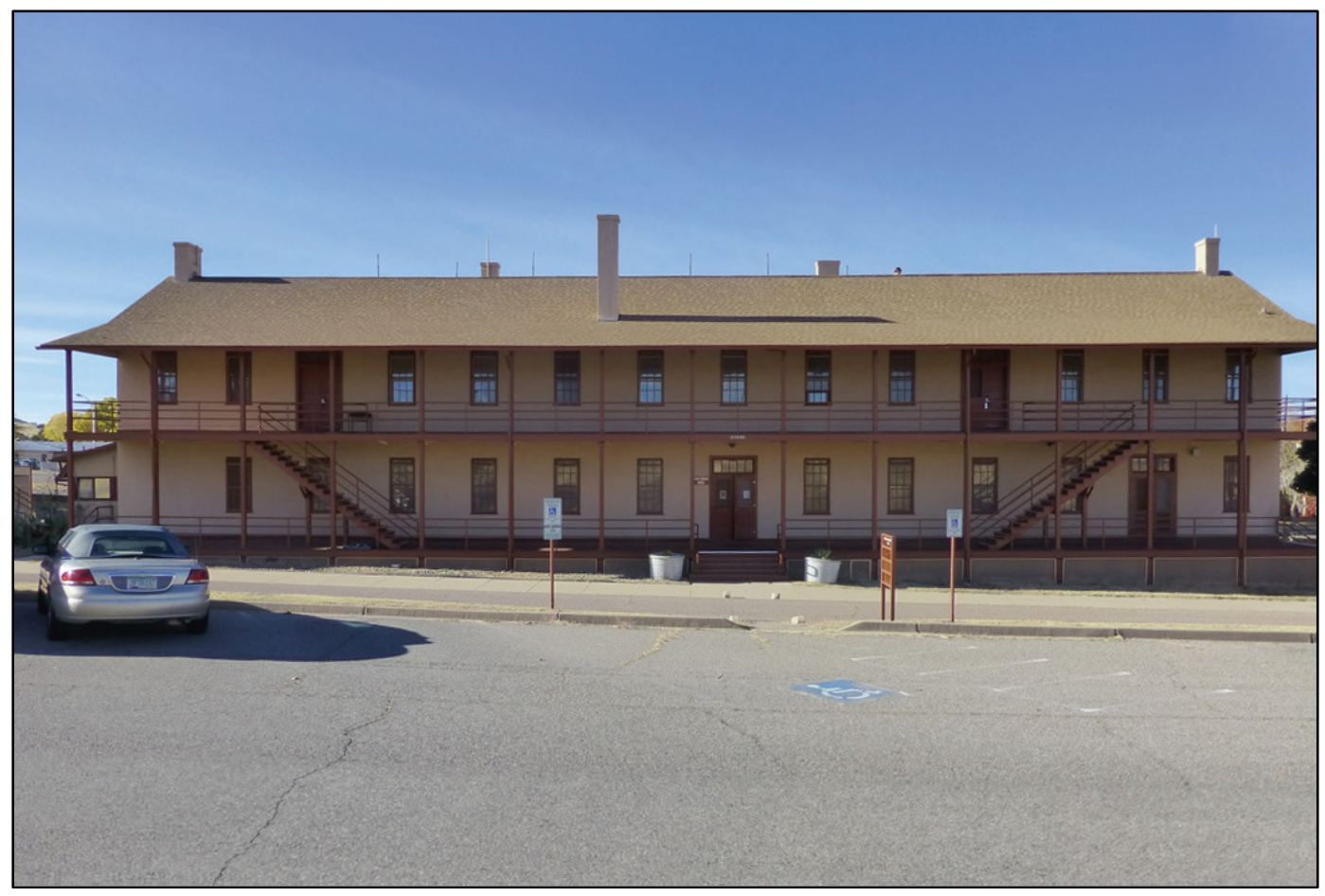


Figure 229. View to the west between 41418 and 41419 with 31122 in the background (ERDC-CERL, 2016).

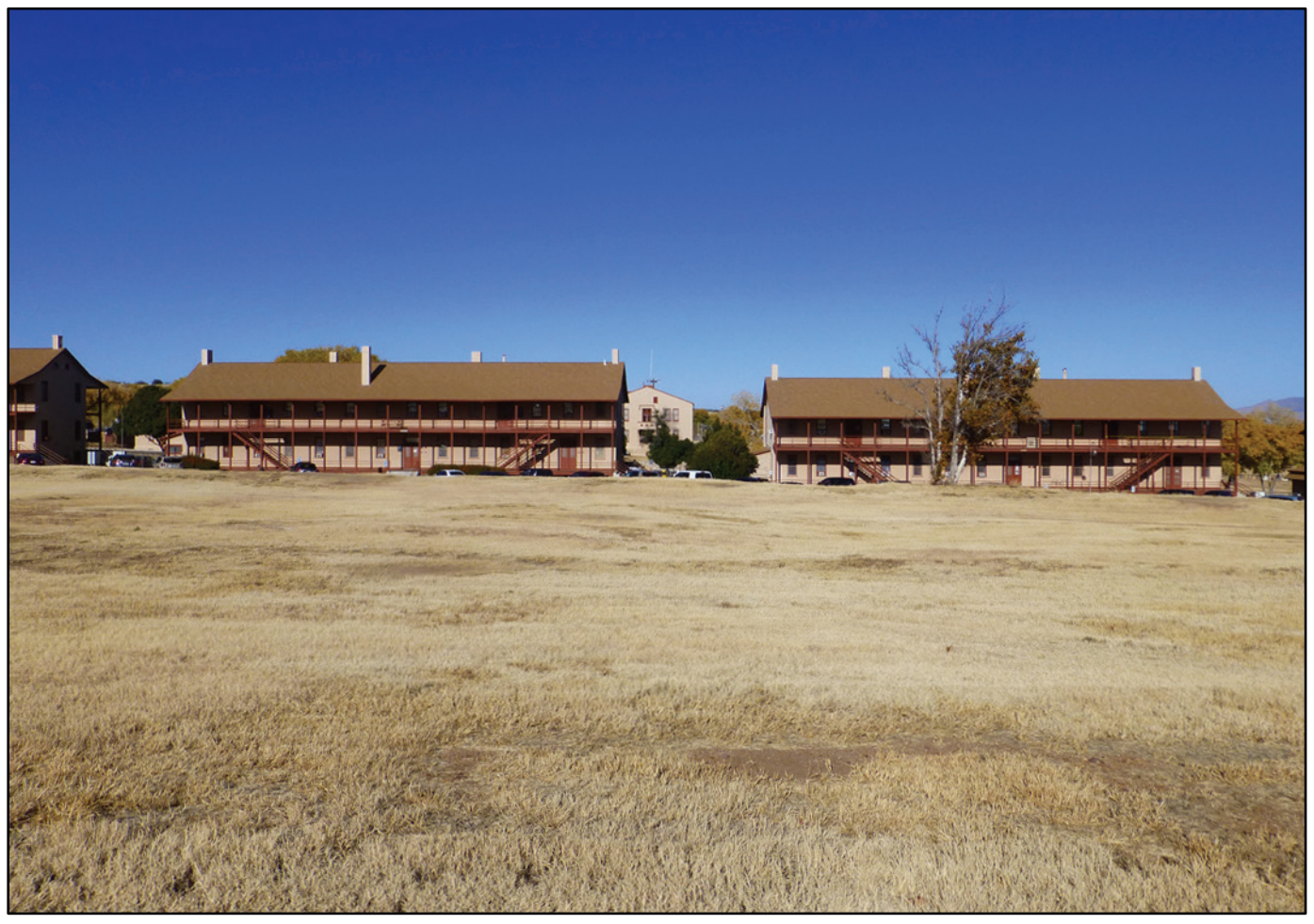

Figure 230. View to the west between 41418 and 41419 with 31122 in the background (ERDC-CERL, 2016).

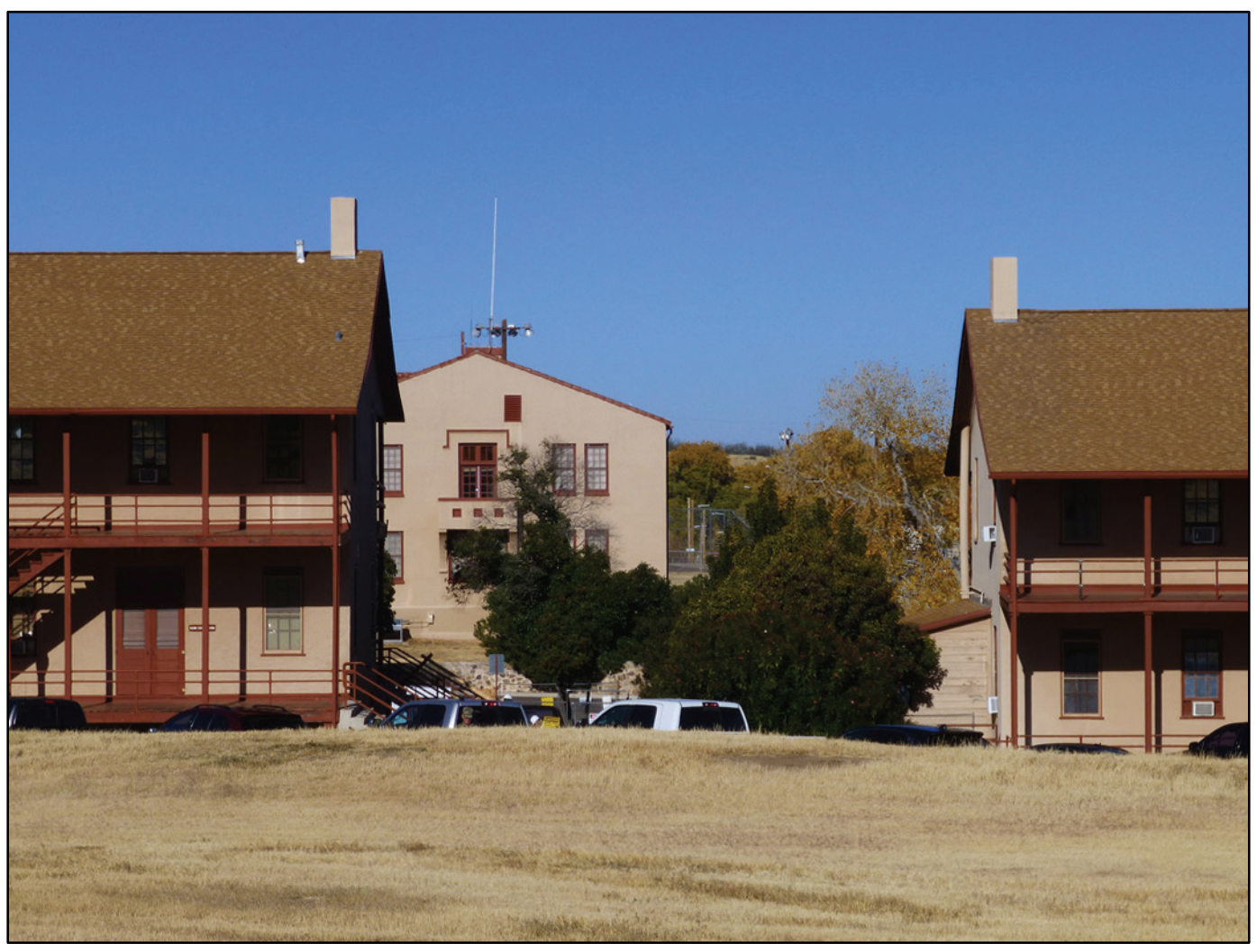


Figure 231. View to the north of bushes, concrete sidewalk, and stone gutter in front of 41418 (ERDC-CERL, 2016).

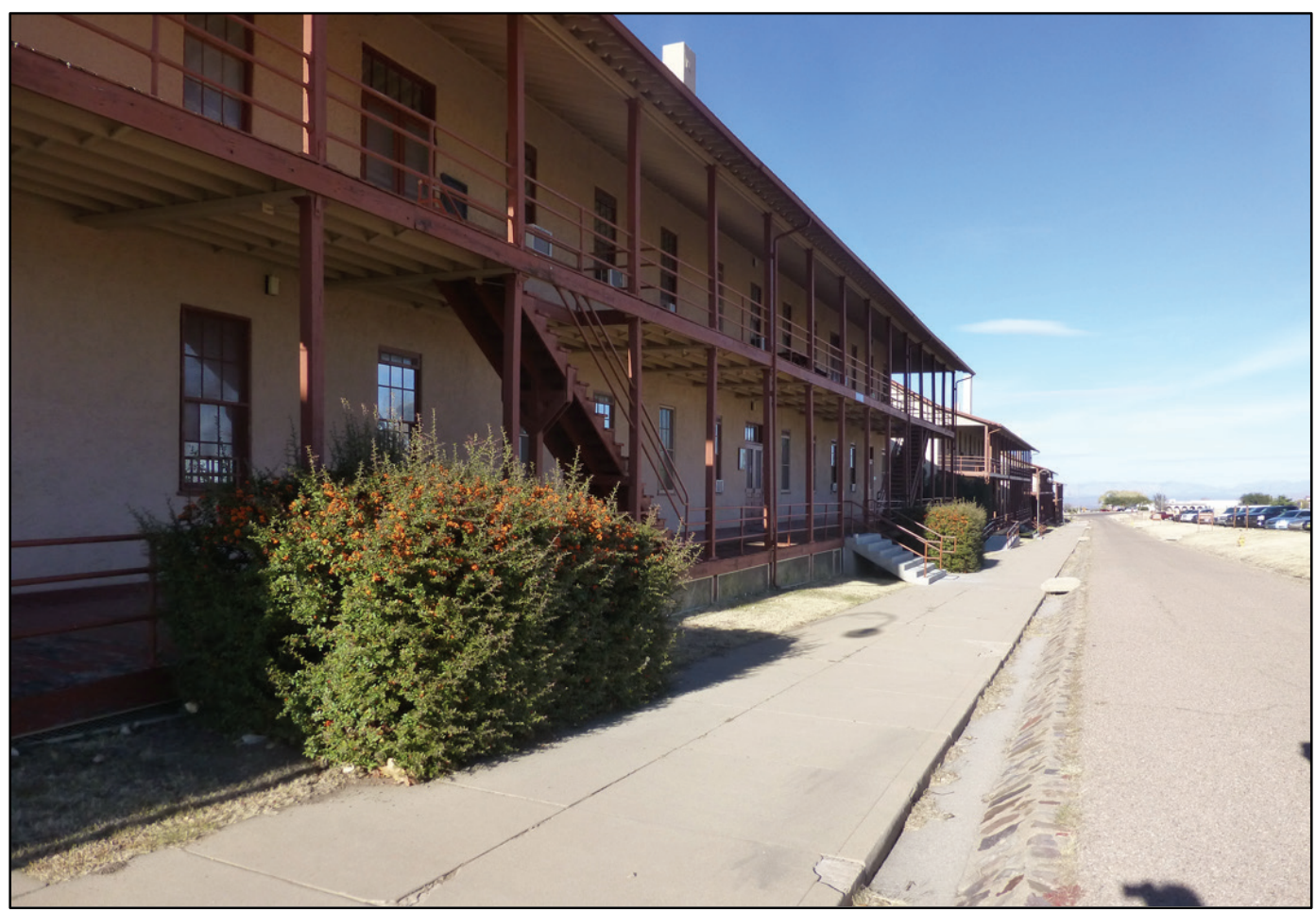

Figure 232. View to the north of bushes, concrete sidewalk, and ADA ramp on side of 41419 (ERDC-CERL, 2016).

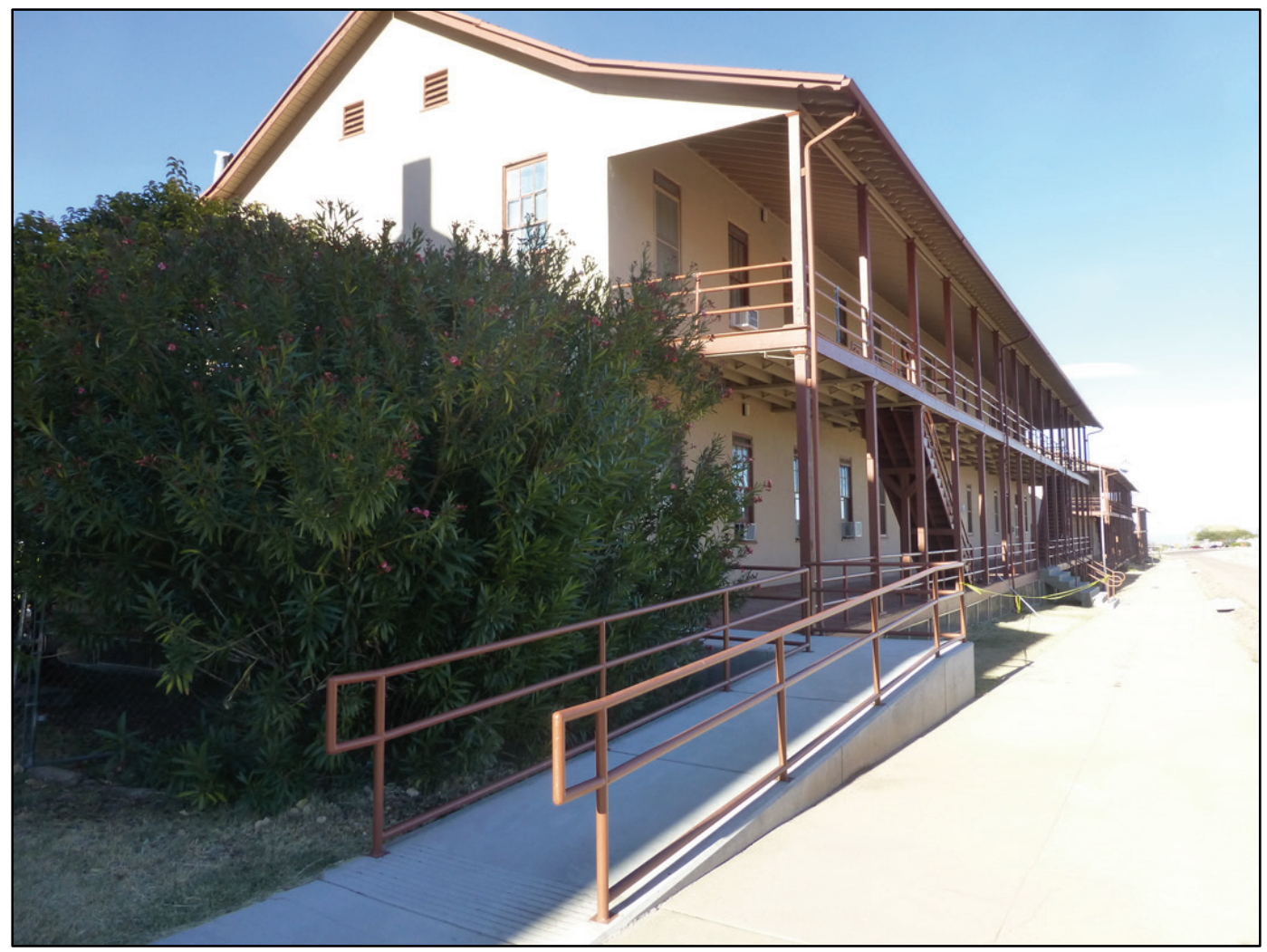


Figure 233. View to the northeast of concrete ramp, metal handrails, and stone gutter in front of 41421 (ERDC-CERL, 2016).

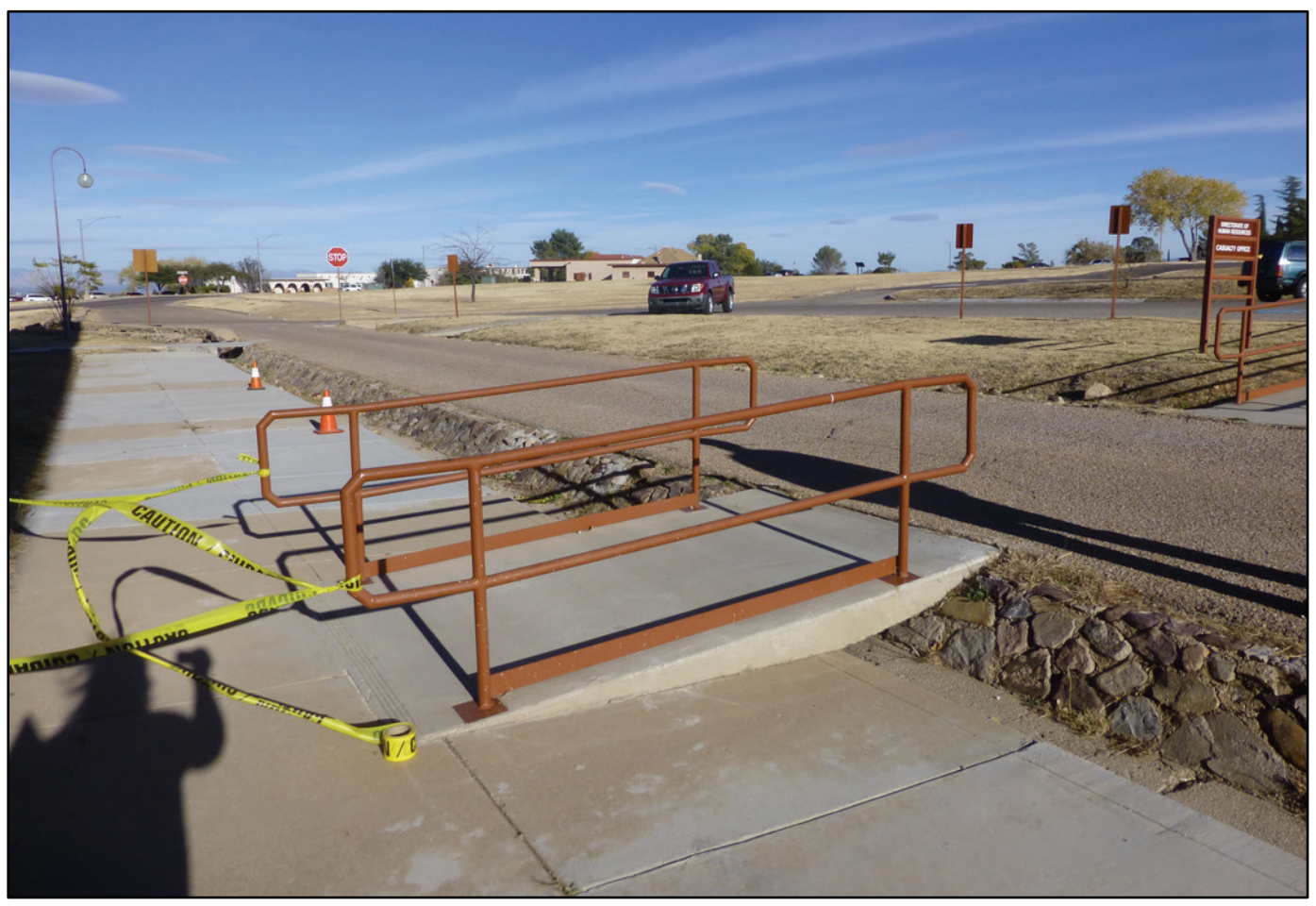

Figure 234. Looking south down Rhea Avenue (ERDC-CERL, 2016).

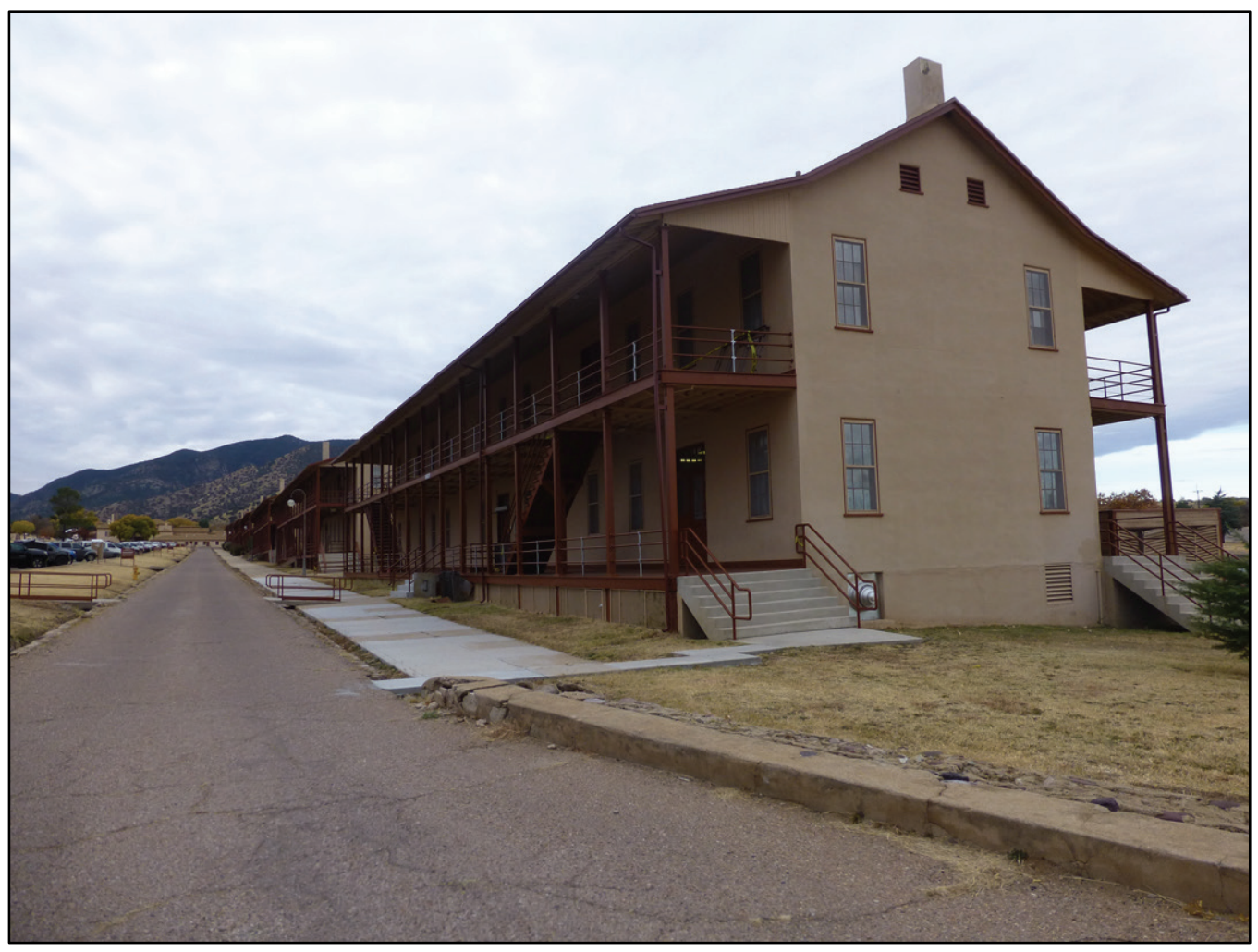


Figure 235. WPA wall and cap at the north end of Rhea Avenue and just north of 41421 (ERDC-CERL, 2016).

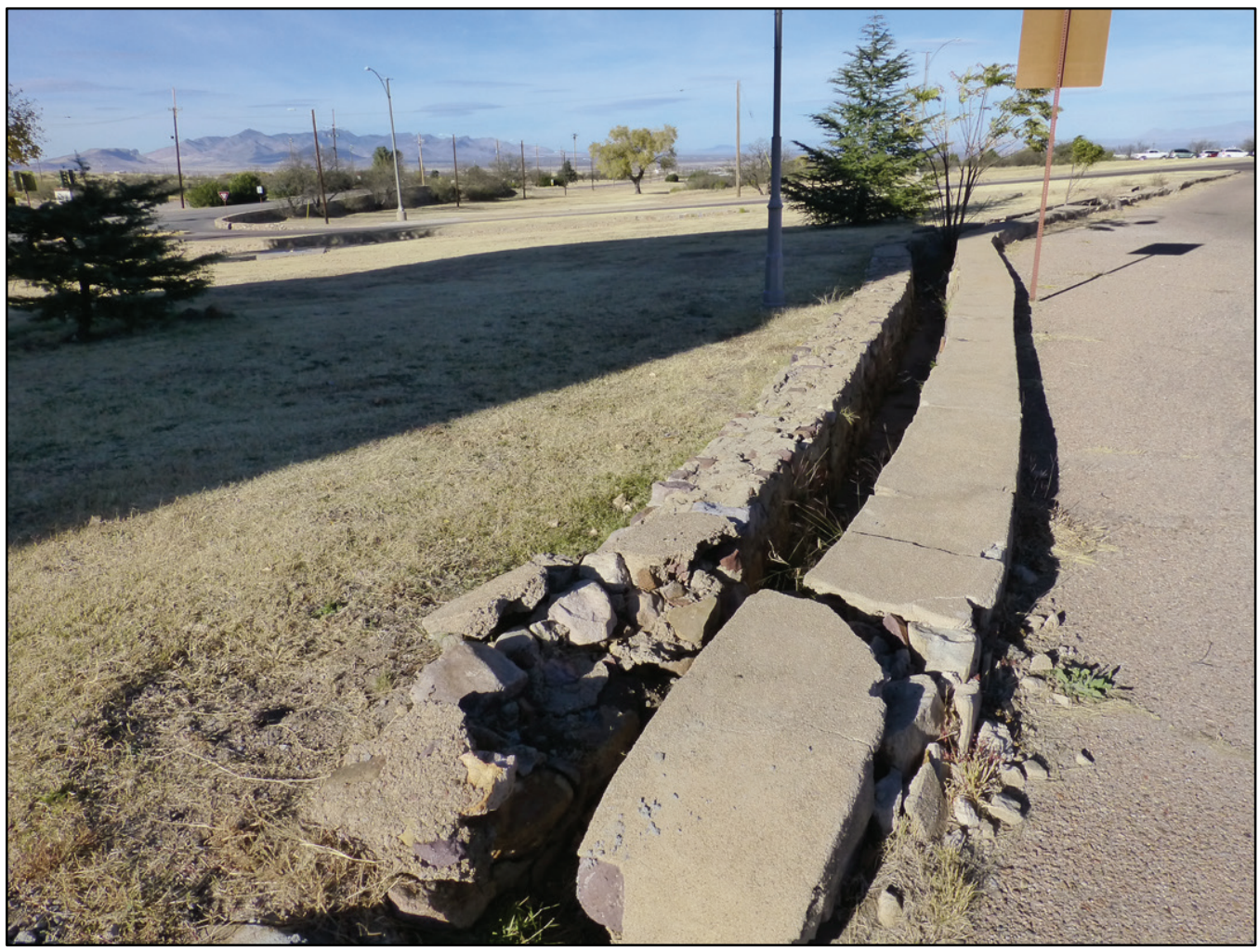

Figure 236. View looking north of WPA-era drainage ditch at intersection of Christy Avenue and Smith Avenue (ERDC-CERL, 2016).

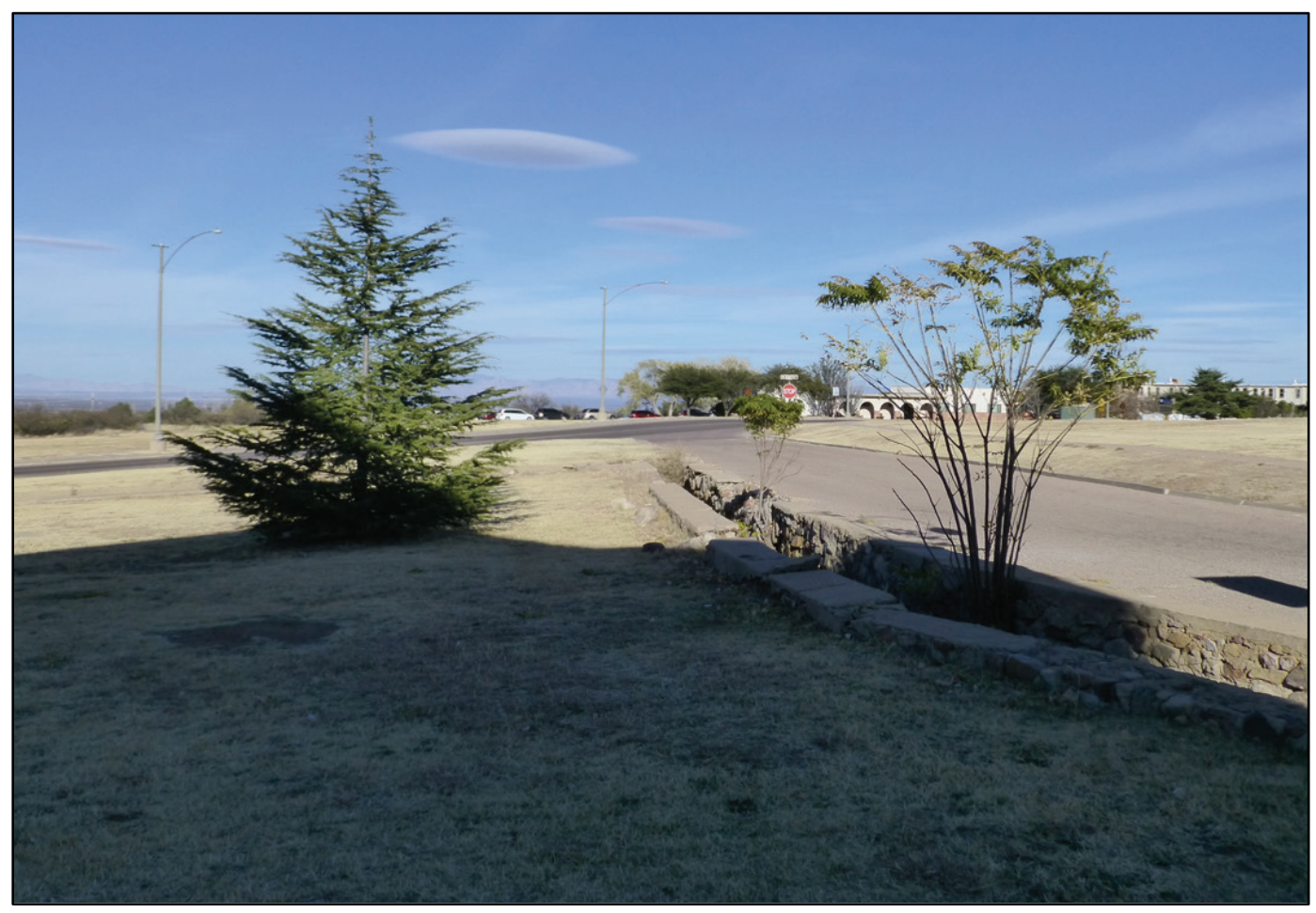


Figure 237. Looking south at 1914 Barracks and WPA ditch (ERDC-CERL, 2016).

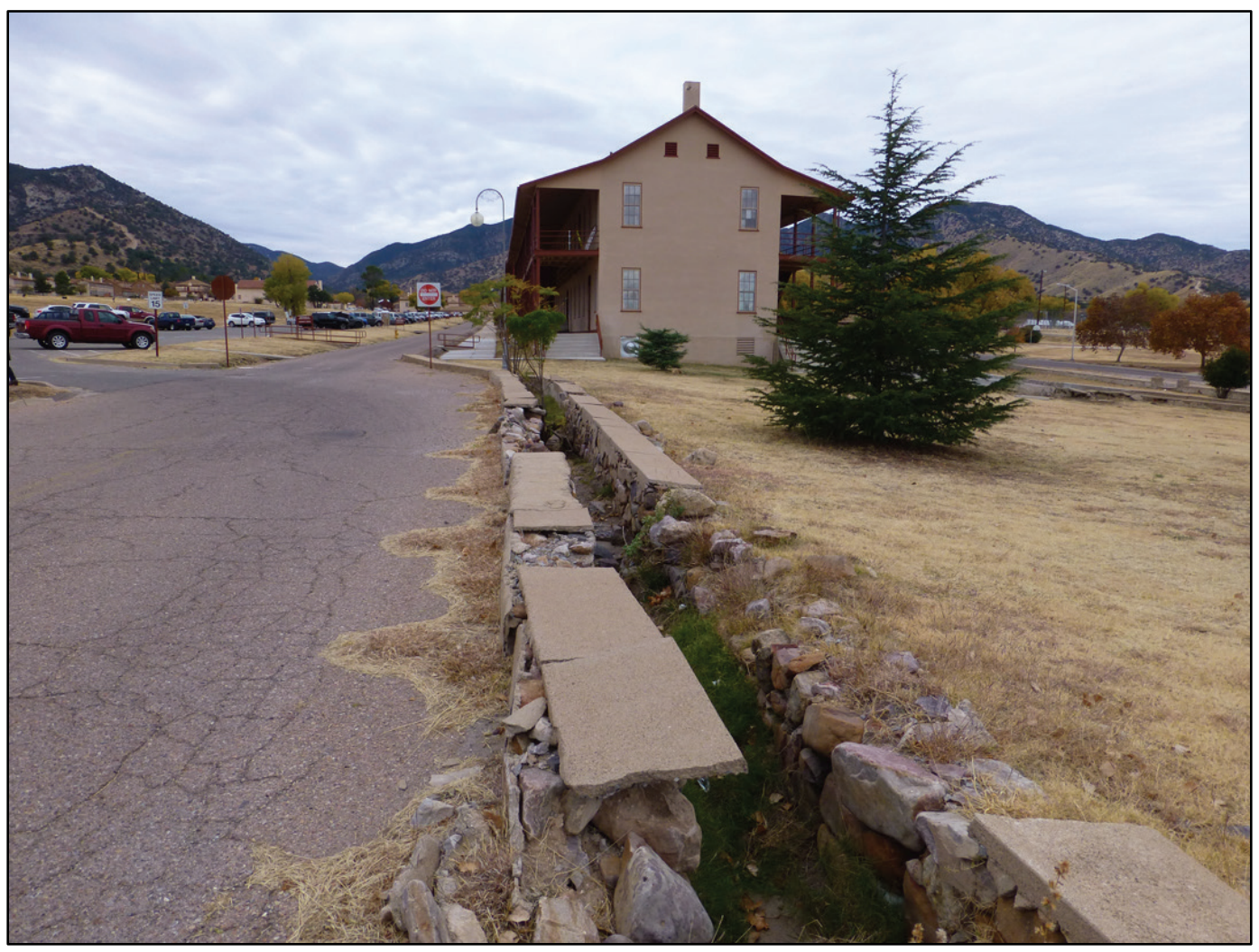

Figure 238. Blocked access to Rhea Avenue from Smith Avenue (ERDC-CERL, 2016).

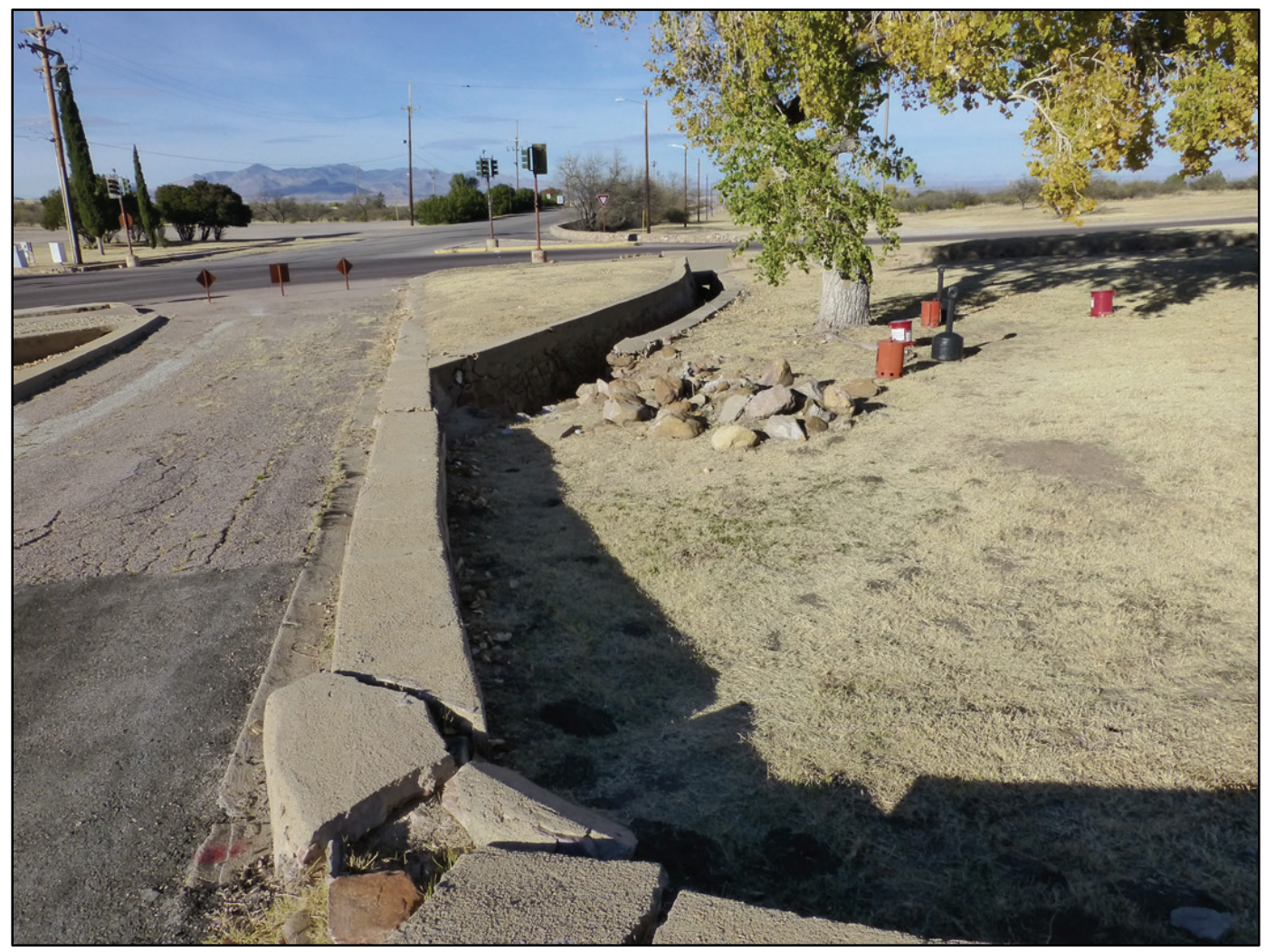


Figure 239. Looking to the southeast at the rear of 41421 (ERDC-CERL, 2016).

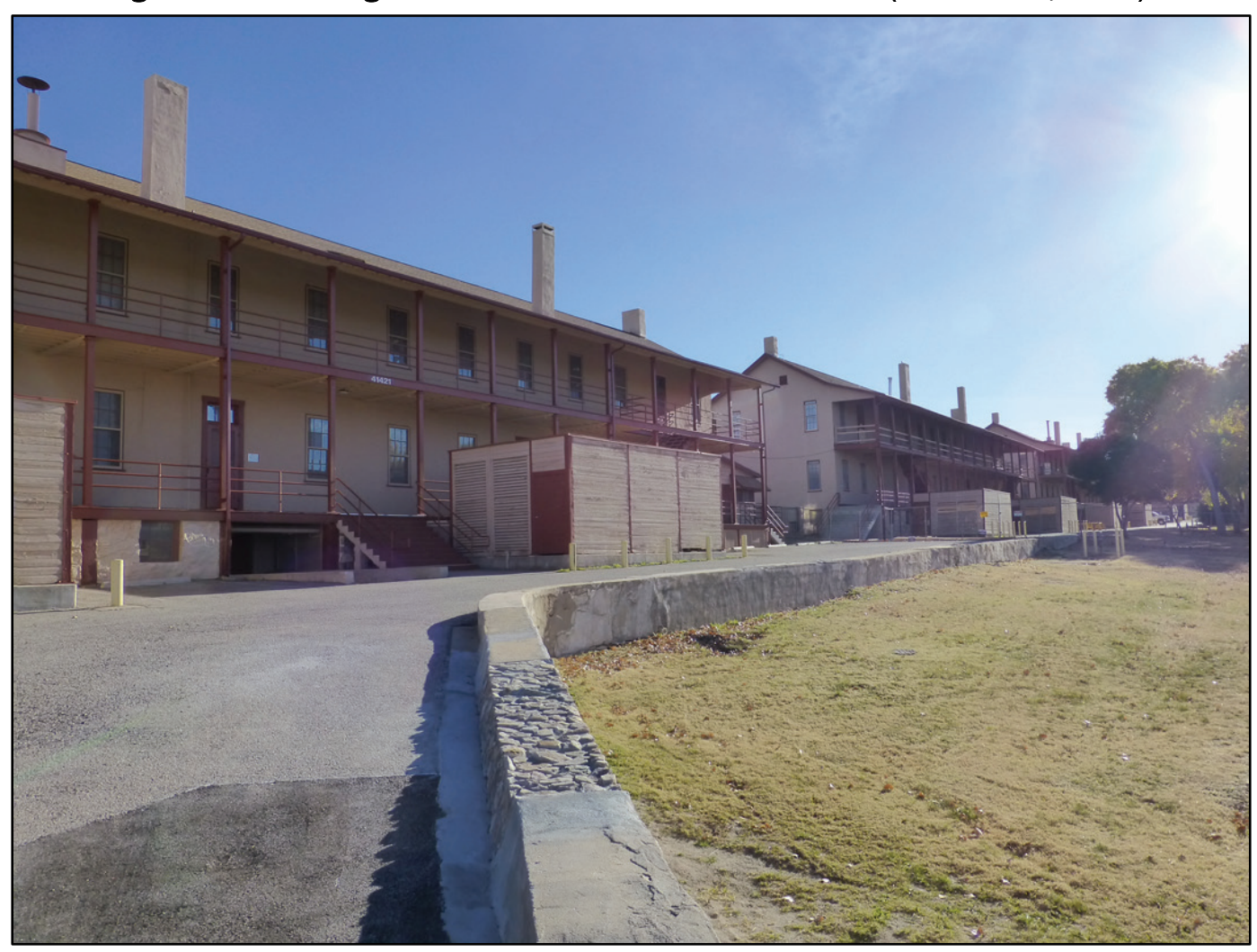

Figure 240. Looking west down Christy Avenue (ERDC-CERL, 2016).

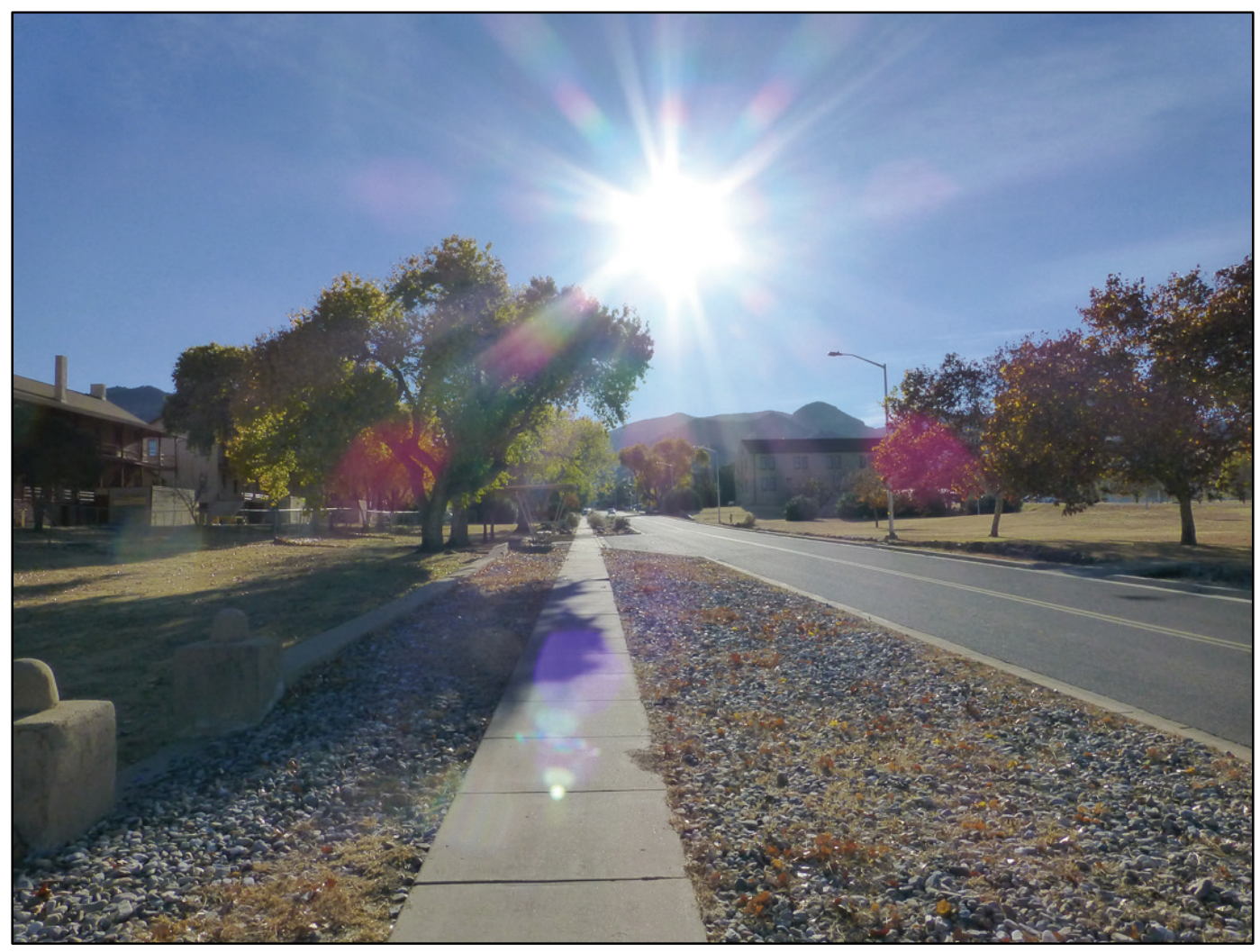


Figure 241. Break in wall between Christy Avenue and the east side of 41421 (ERDC-CERL, 2016).

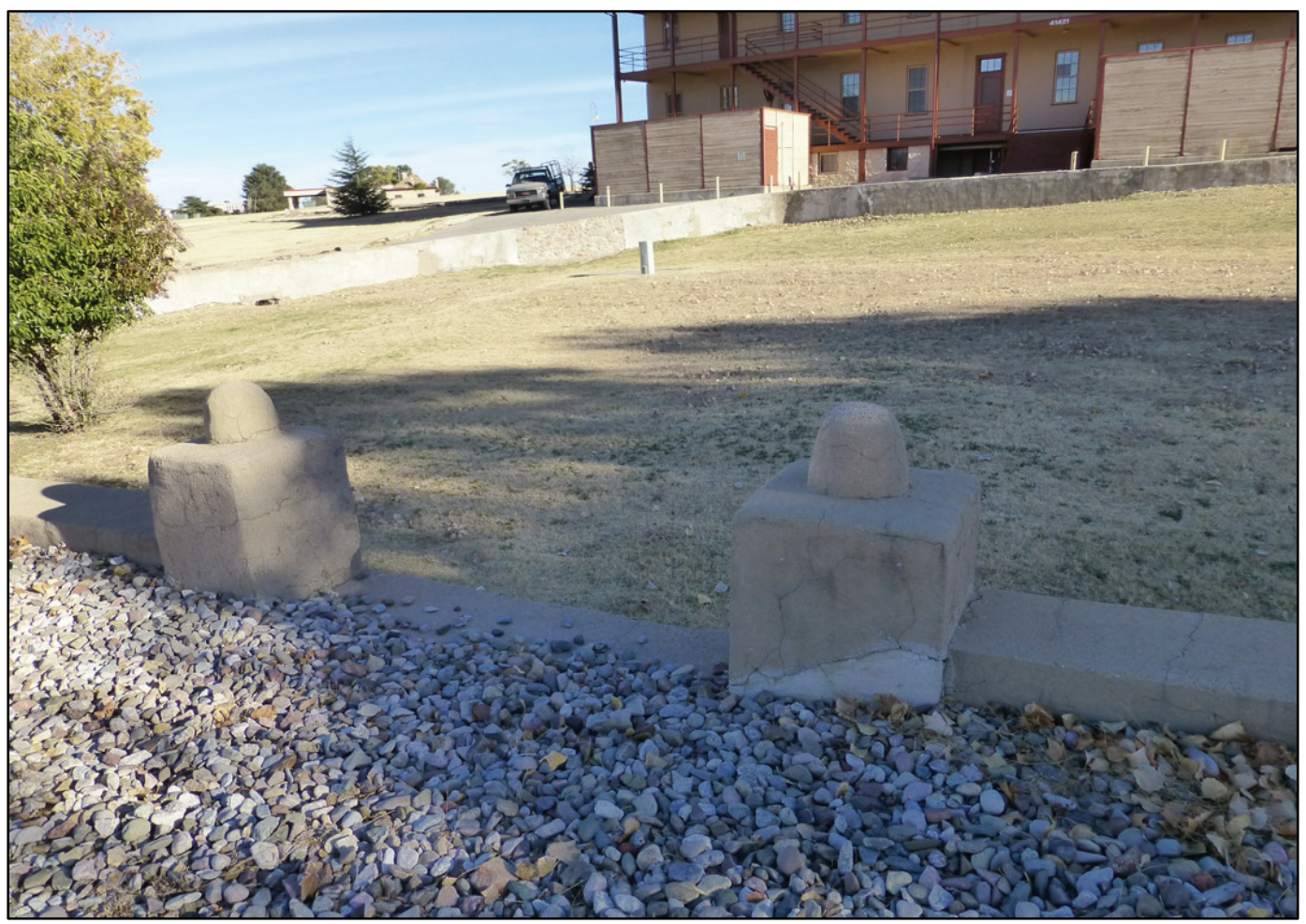

Figure 242. Landscaping on the west side of 41421 (ERDC-CERL, 2016).

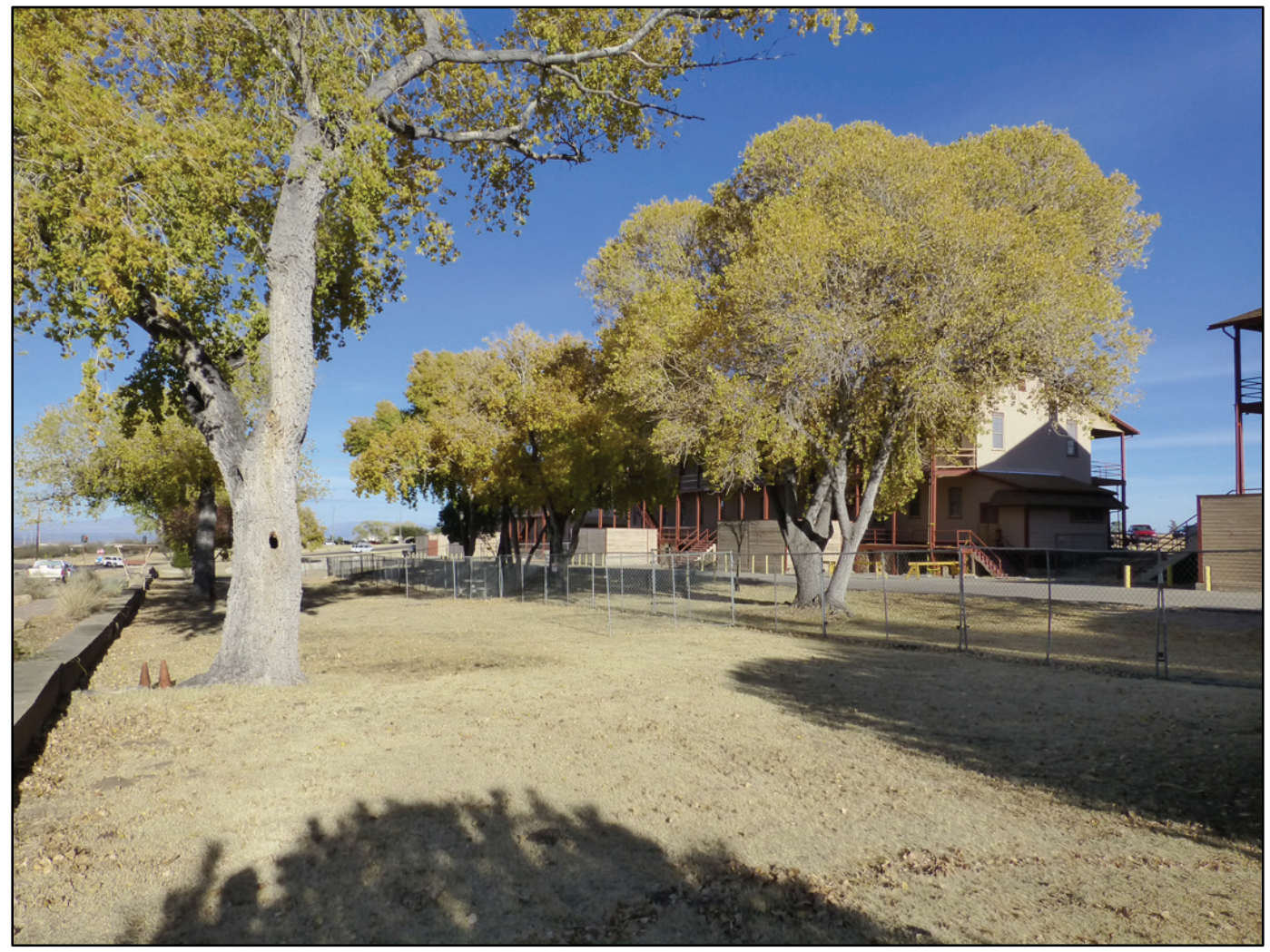


Figure 243. View looking northwest toward wall and landscaping along Christy Avenue at entrance to parking lot behind Building 41419 (ERDC-CERL, 2016).

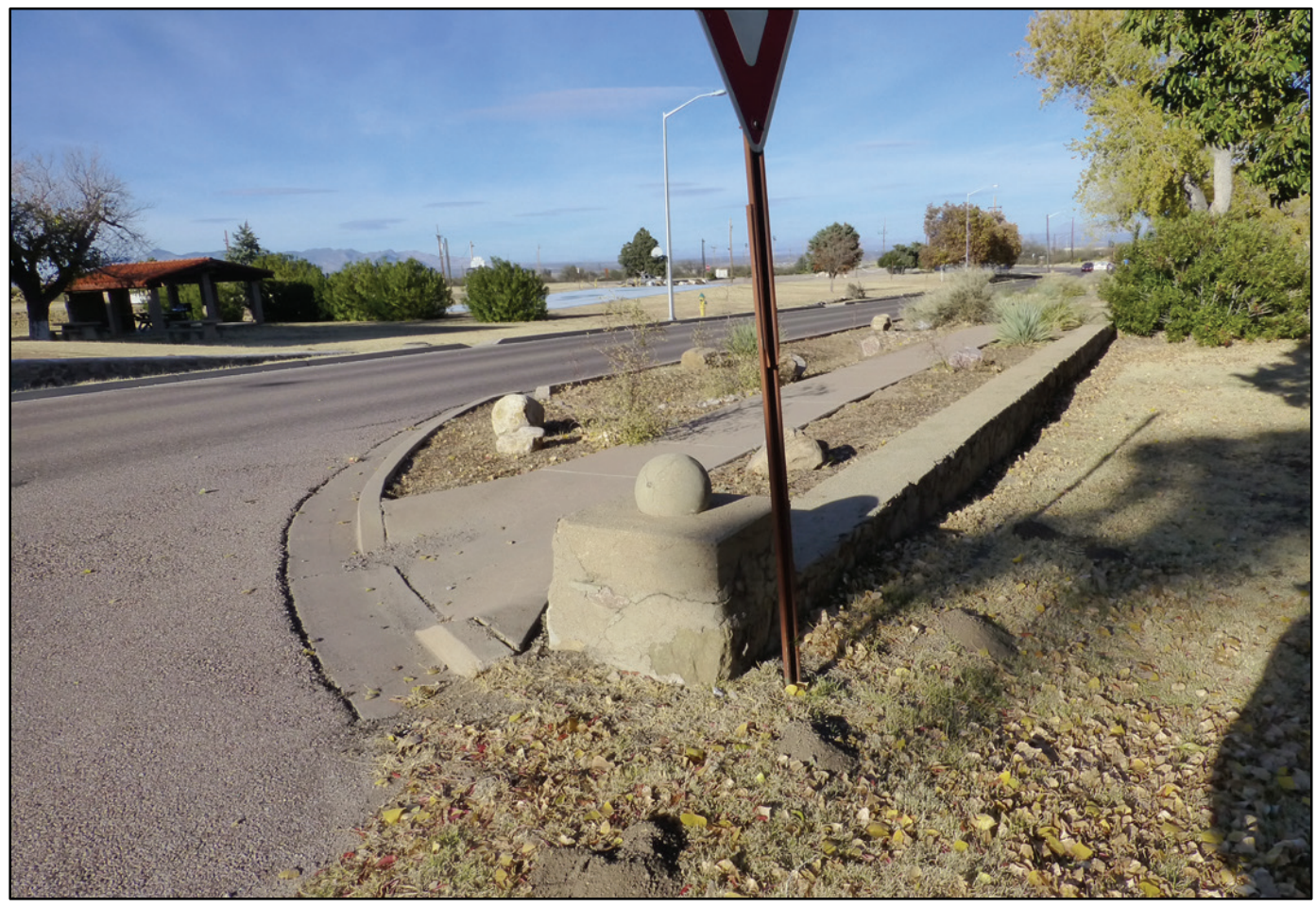

Figure 244. View north of WPA walls along Christy Avenue in rear of barracks (41418) (ERDCCERL, 2016).

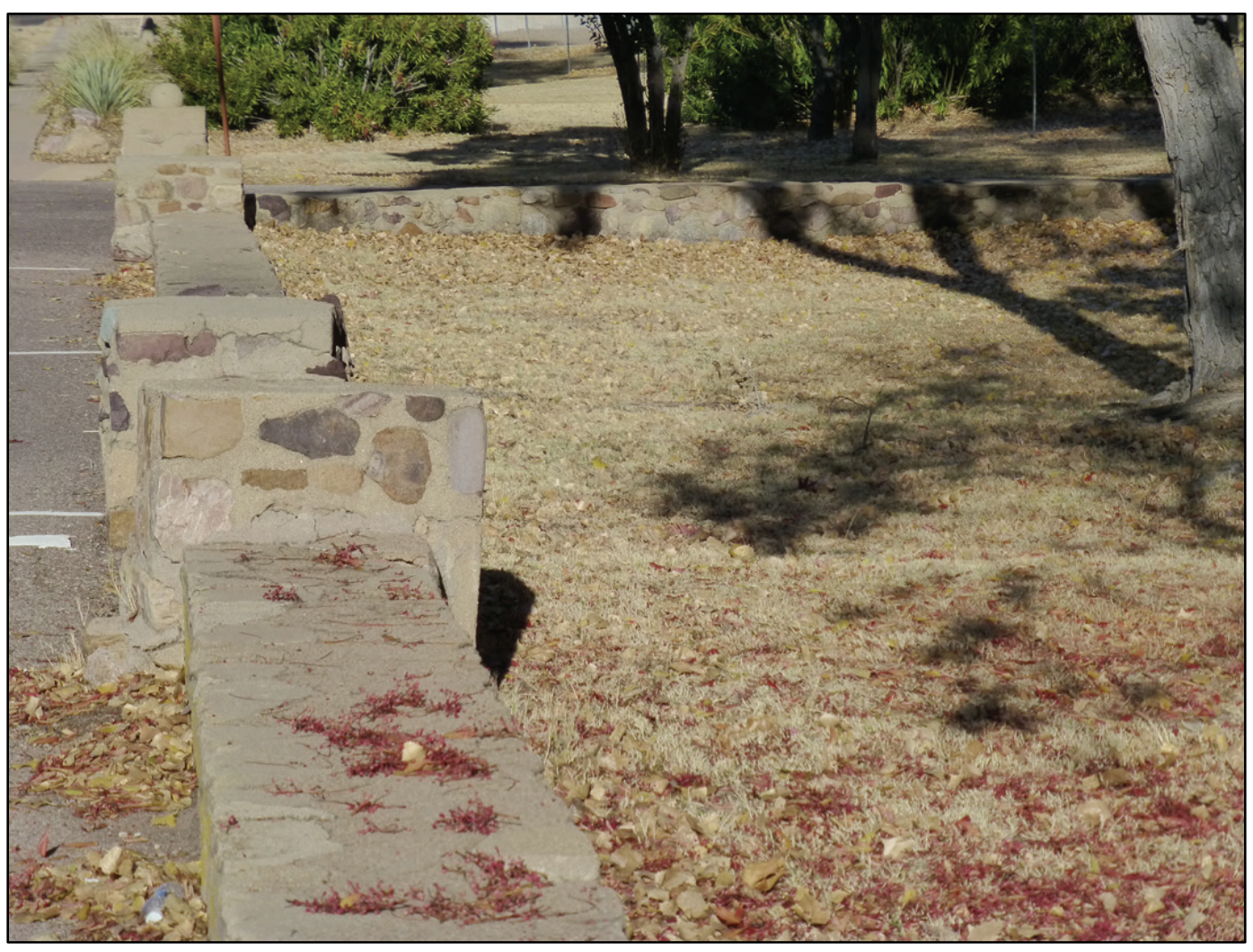


Figure 245. View looking northwest at WPA walls and brick walkway in rear of barracks

(41416) (ERDC-CERL, 2016).

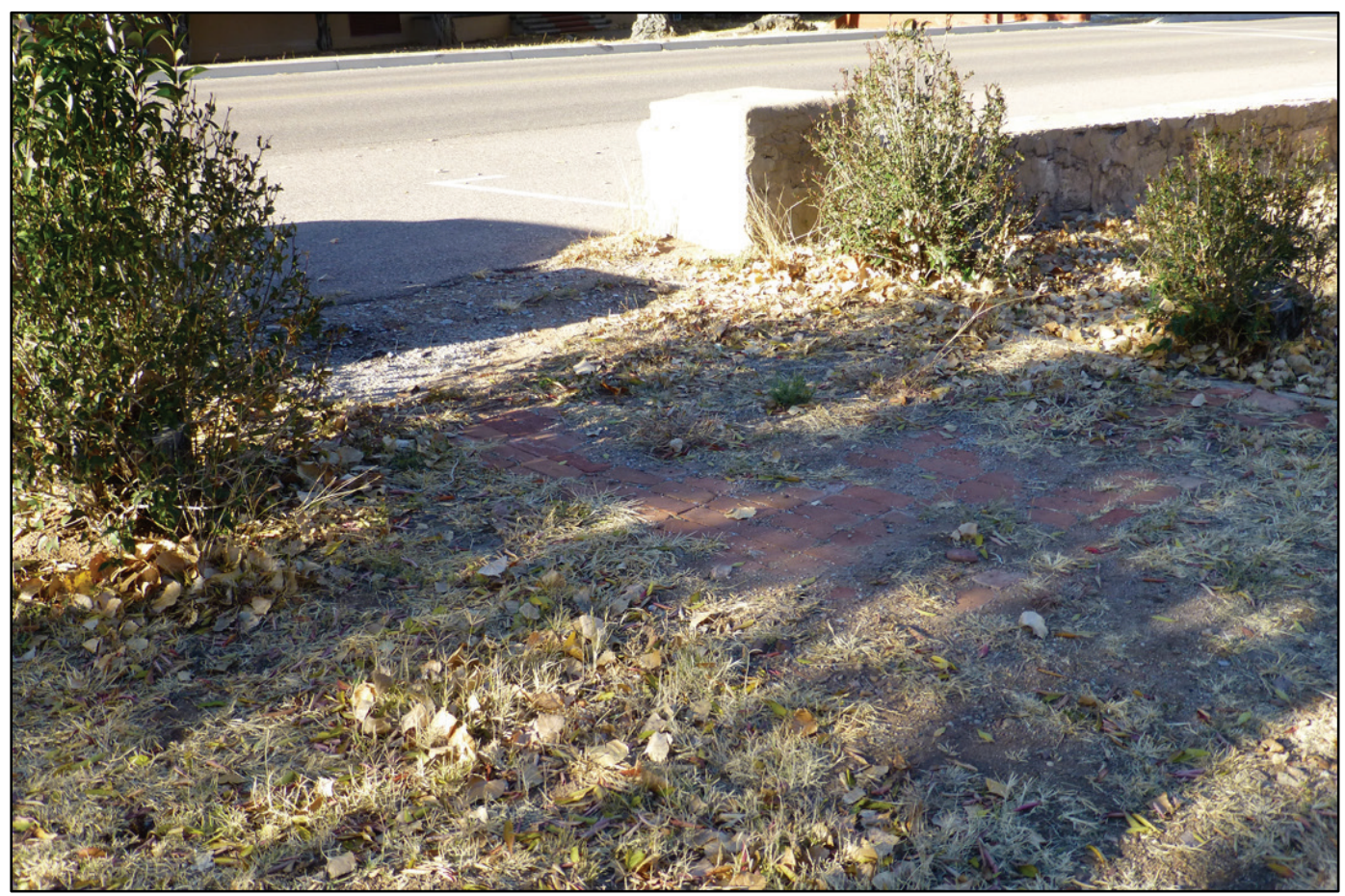

Figure 246. View looking north at rear of barracks (41412) and toward lavatory (41414) (ERDC-CERL, 2016).

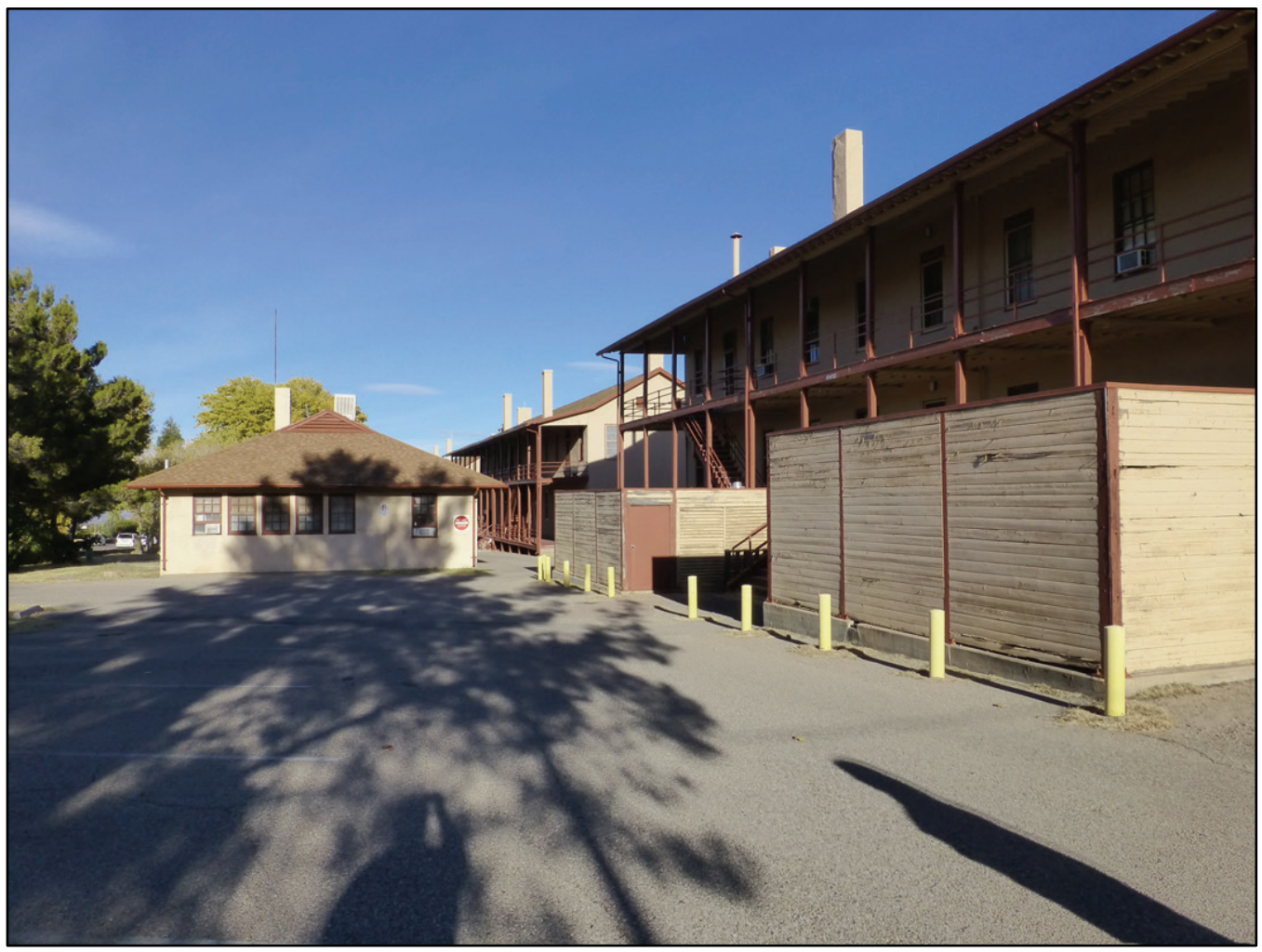


Figure 247. View looking northwest at stone wall with concrete parge (covering over stone) and drainage ditch behind $\mathbf{4 1 4 1 2}$ at the corner of Christy and Hungerford Avenues (ERDCCERL, 2016).

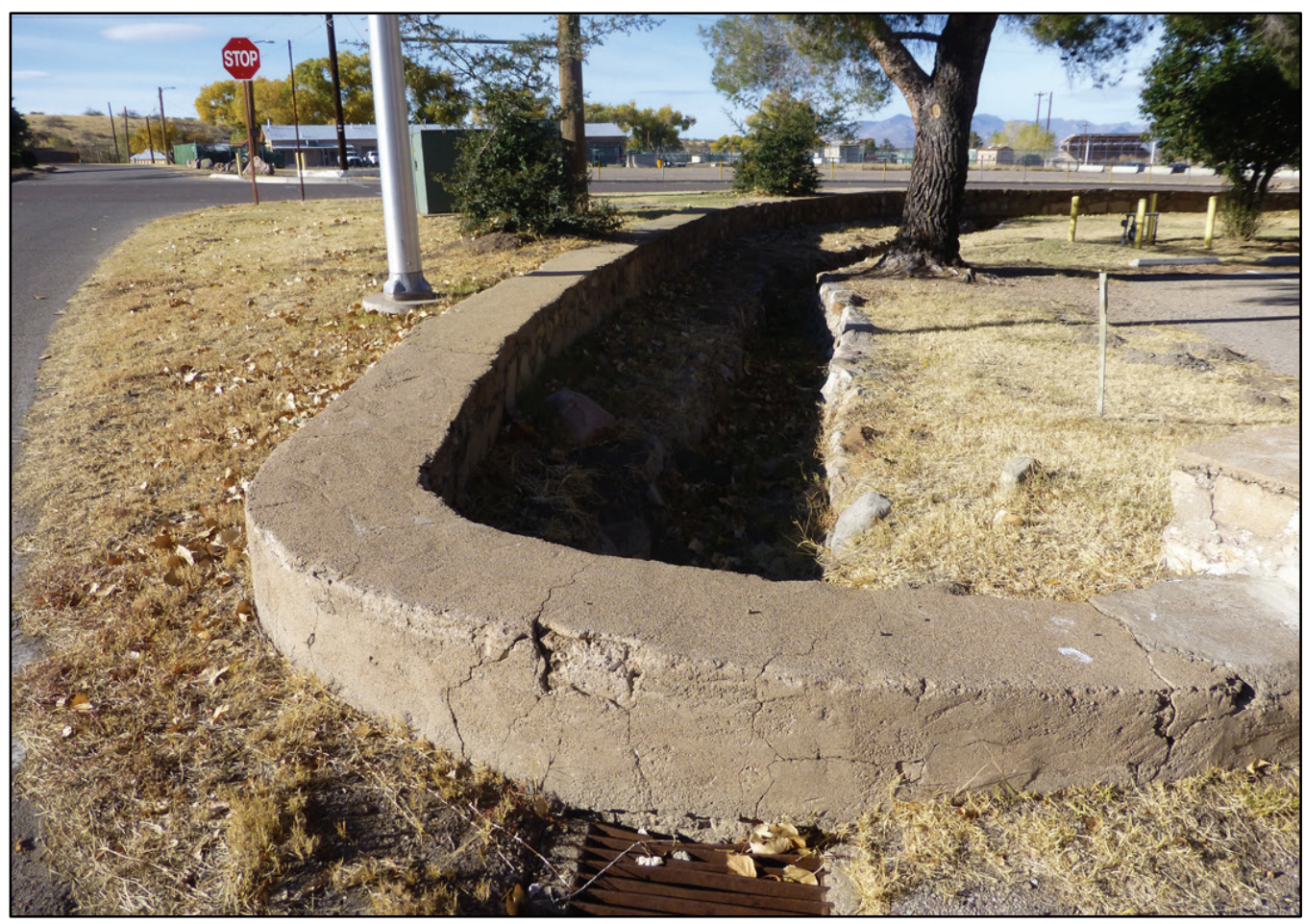

Figure 248. Looking east down Hungerford Avenue at WPA-era walls and rear of former theater (41305) (ERDC-CERL, 2016).

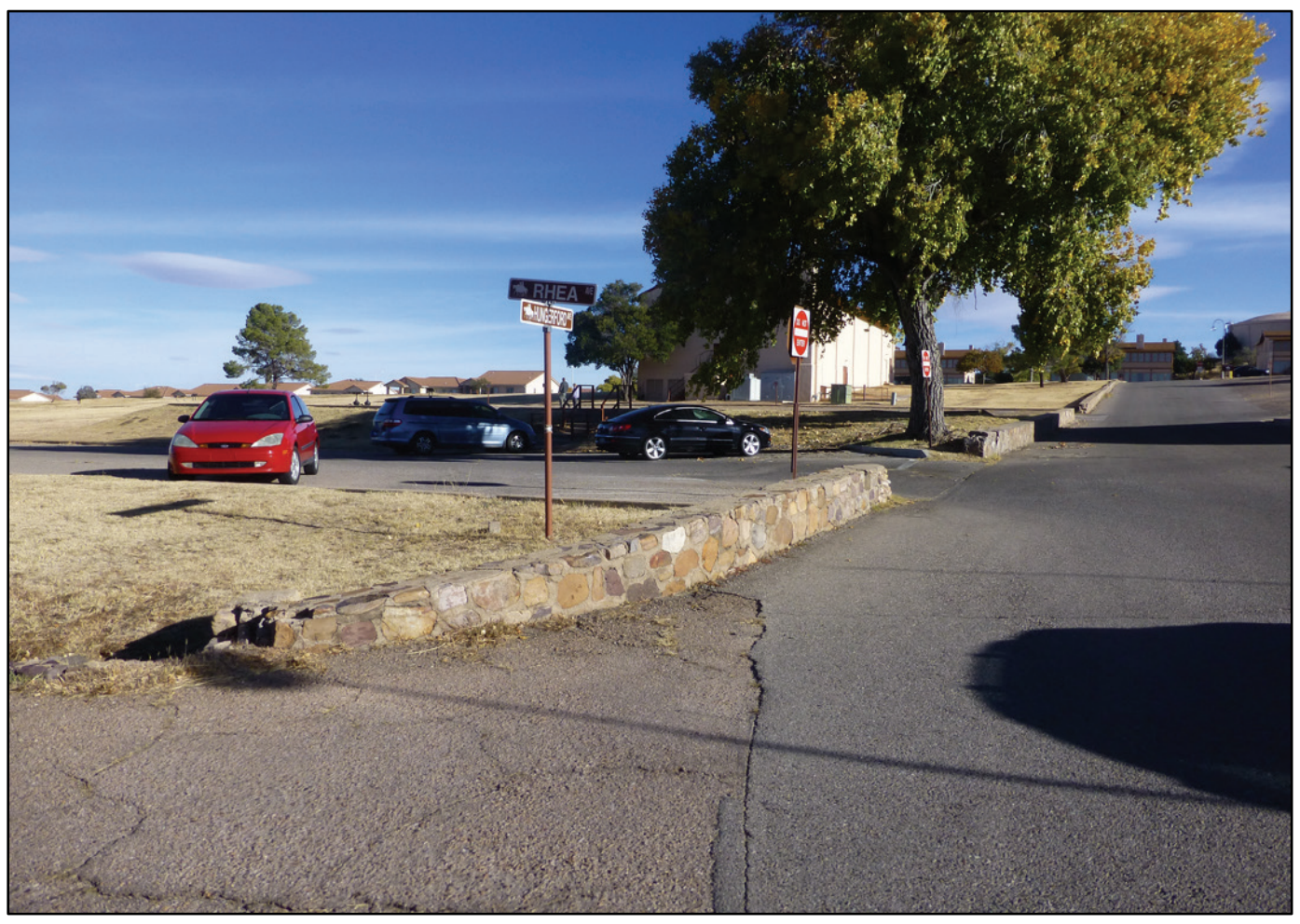


Figure 249. View south at North Parade Field, parking lot and barracks (ERDC-CERL, 2016).

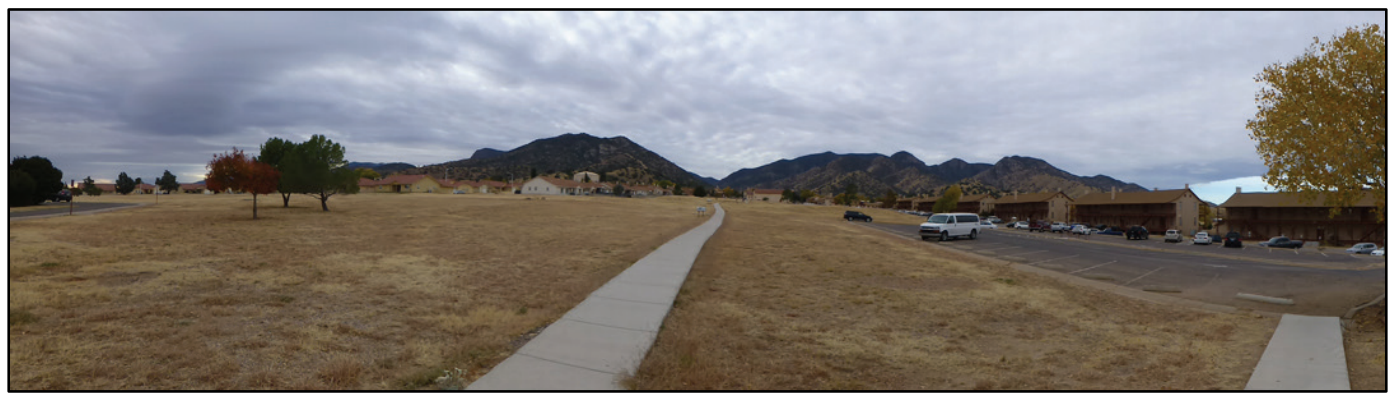

Figure 250. Modern aluminum bench on 1914 North Parade Field (ERDC-CERL, 2016).

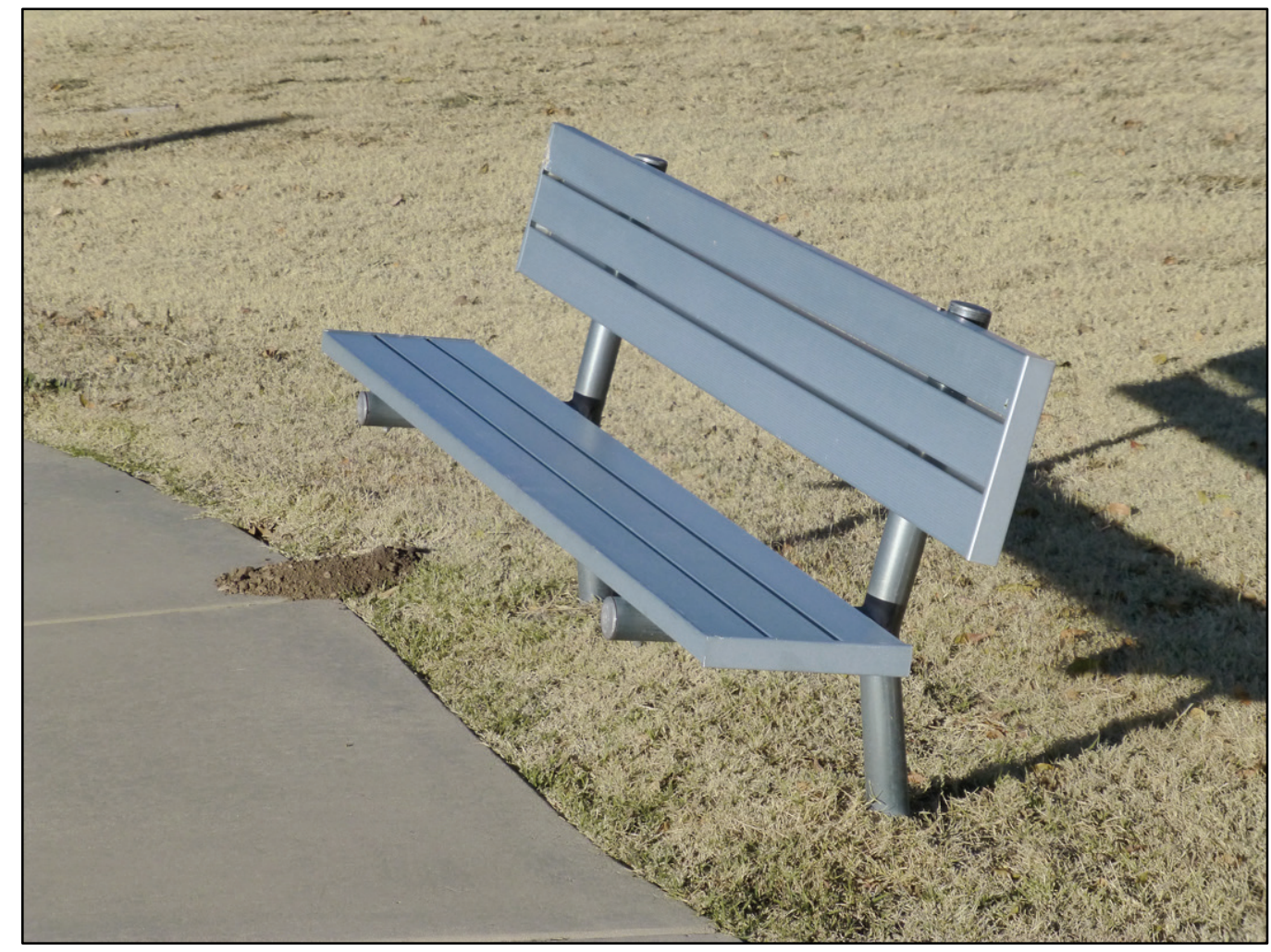


Figure 251. View towards the east of North Parade Field from 1914 Barracks towards the 1914 Officers' Quarters on right (modern housing on left) (ERDC-CERL, 2016).

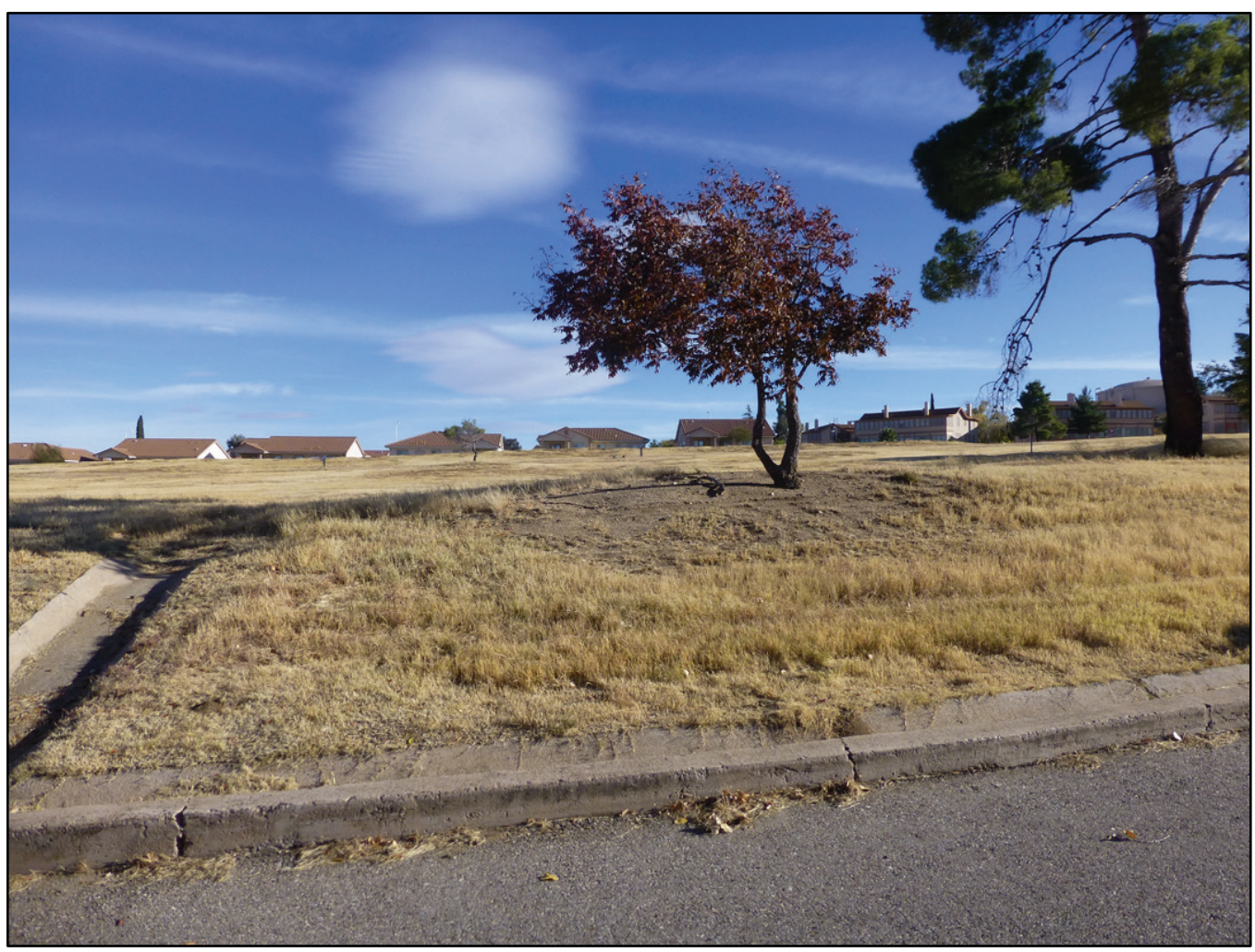

Figure 252. View to the northeast of the North Field from the 1914 Barracks (ERDC-CERL, 2016).

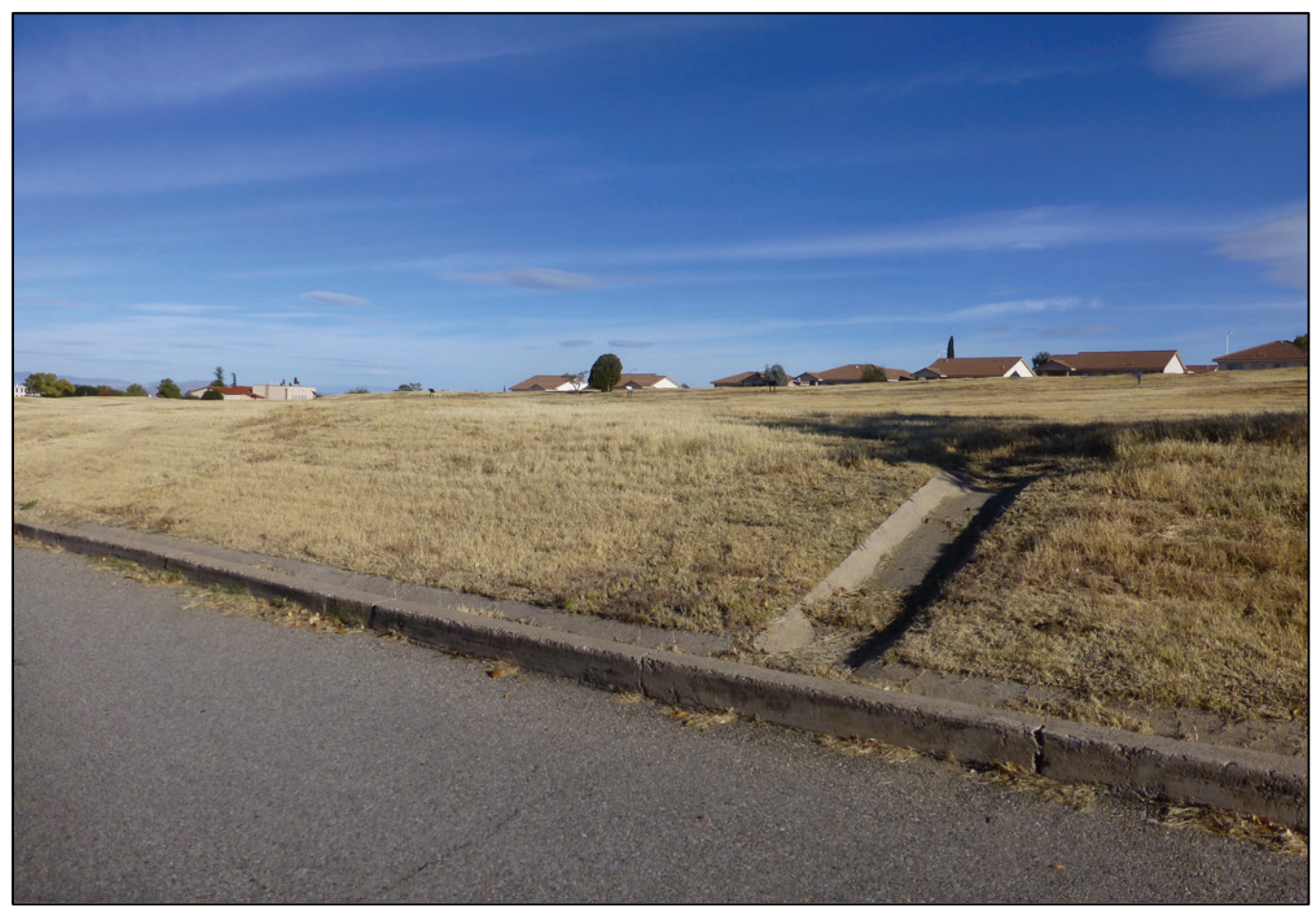




\subsubsection{Significance and integrity}

These barracks are significant since they were constructed as part of the 1910s expansion of the Old Post to accommodate arrival of the 1oth Cavalry. Moderate integrity due to addition of parking lot and construction of housing and history trail on historic drill field (North Field). Very little foundation plantings or vegetation around buildings remain.

\subsubsection{Character-defining features}

Character-defining features include:

- Long rectangular barracks fronting a large open drill field (North Field)

- Consistent architecture and setbacks as Old Post Barracks.

\subsection{Officers' Duplexes}

Officers' Duplexes (Buildings 41014, 41015, 41016, 41019, 41020, 41021, 42010, 42011, 42014, 42015, 42018, 42019, and 42020) are located along Grierson Avenue and around Henry Circle (Figure 253). Situated in a semicircular line beginning at the northeast end of the Old Post area officers' row and continuing around Henry Circle. The associated garages are on the building list below but fall outside of the NHL boundary (except for 22021, 22022, and 22023). The associated coal bins are listed in the list below (Table 14).

Figure 253. 1914 Officers' Quarters landscape area map (ERDC-CERL).

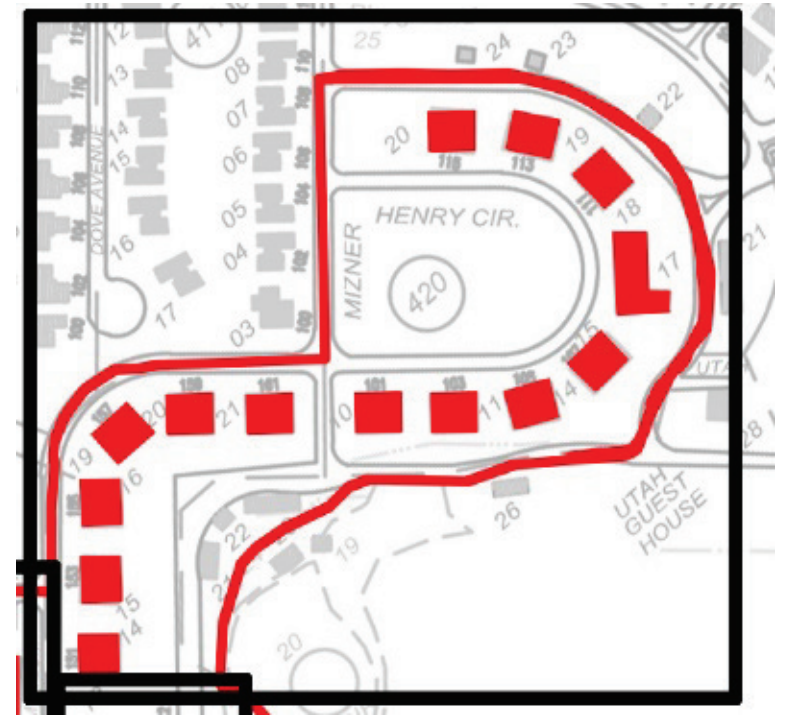


Table 14. List of buildings within the 1914 Officers' Quarters landscape area.

\begin{tabular}{|c|c|c|c|c|}
\hline Building Number & Year Built & Original Use & Current Use & Historic Status \\
\hline 22019 & 1970 & $\begin{array}{l}\text { Water Support/Treatment Building } \\
\text { (presumed) }\end{array}$ & $\begin{array}{l}\text { Water Support/Treatment } \\
\text { Building }\end{array}$ & NEV \\
\hline 22021 & 1936 & Garage & Garage & NREC \\
\hline 22022 & 1936 & Garage & Garage & NREC \\
\hline 22023 & 1936 & Garage & Garage & NREC \\
\hline 22024 & 1962 & Pump House & $\begin{array}{l}\text { Water Support/Treatment } \\
\text { Building }\end{array}$ & NEV \\
\hline 22026 & 1936 & Garage & Garage & NREC \\
\hline 41014 & 1912 & Officers' Duplex & Family Quarters & NHLC \\
\hline 41015 & 1914 & Officers' Duplex & Family Quarters & NHLC \\
\hline 41016 & 1914 & Officers' Duplex & Family Quarters & NHLC \\
\hline 41017 & 1920 & Coal Bin & Coal Bin & NEV \\
\hline 41018 & 1920 & Coal Bin & Coal Bin & NEV \\
\hline 41019 & 1914 & Officers' Duplex & Family Quarters & NHLC \\
\hline 41020 & 1914 & Officers' Duplex & Family Quarters & NHLC \\
\hline 41021 & 1914 & Officers' Duplex & Family Quarters & NHLC \\
\hline 41022 & 1920 & Coal Bin & Coal Bin & NEV \\
\hline 41023 & 1920 & Coal Bin & Coal Bin & NEV \\
\hline 41024 & 1920 & Coal Bin & Coal Bin & NEV \\
\hline 42009 & 1920 & Coal Bin & Coal Bin & NEV \\
\hline 42010 & 1914 & Officers' Duplex & Family Quarters & NHLC \\
\hline 42011 & 1914 & Officers' Duplex & Family Quarters & NHLC \\
\hline 42014 & 1914 & Officers' Duplex & Family Quarters & NHLC \\
\hline 42015 & 1915 & Officers' Duplex & Family Quarters & NHLC \\
\hline 42017 & 1915 & Officers' Duplex & $\begin{array}{l}\text { Army Lodging (Allen } \\
\text { House) }\end{array}$ & NHLC \\
\hline 42018 & 1915 & Officers' Duplex & Family Quarters & NHLC \\
\hline 42019 & 1917 & Officers' Duplex & Family Quarters & NHLC \\
\hline 42020 & 1917 & Officers' Duplex & Family Quarters & NHLC \\
\hline 42021 & 1936 & Garage & Garage & NREC \\
\hline 42022 & 1936 & Garage & Garage & NREC \\
\hline 42023 & 1936 & Garage & Garage & NREC \\
\hline 42024 & 1936 & Garage & Garage & NREC \\
\hline
\end{tabular}

\subsubsection{History}

These multiple-family quarters were erected between 1912 and 1917. They vary in size from about 4,000 to about 6,000 sq ft, but they are similar in design. With one exception, all are two-story, U-shaped, gable-roofed, beige-painted, stucco-covered, frame buildings that consist of a rectangular-shared main block and two two-story rear ells. A two-tiered, shedroofed gallery extends fully across each front facade. The lower tier is screened. Each building has four stuccoed chimneys - two in the front and 
two in the rear. The exception is 42017, which is approximately twice the size of the surrounding duplexes and served as a Bachelor Officers Quarters. The quarters were built surrounding a horseshoe-shaped park (Figures 254-257).

The associated garages, located just outside the NHL historic district boundary, were built in 1936 and were evaluated as contributing to the WPA-era Historic District. In addition, there are stone ditches and culverts behind the quarters that were constructed by the WPA as well.

According to a 1945 map, tennis courts were located northeast of Henry Place where Wright Street is today. A softball field was located southeast of the tennis courts behind 42018 .

Figure 254. View south down Mizner Avenue showing trees and sidewalk, 1938 (NARA College Park, RG77).

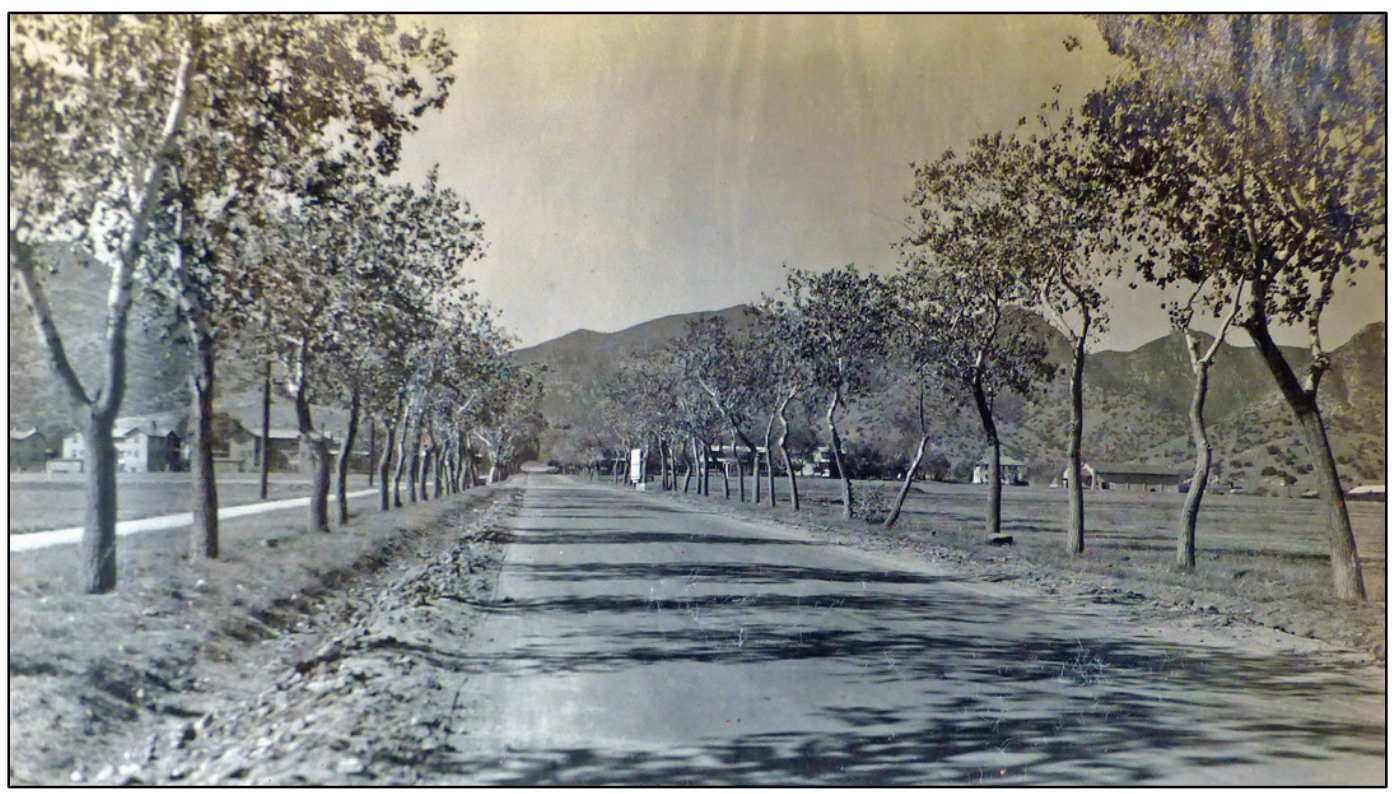


Figure 255. View north down Mizner Avenue at Smith Avenue showing trees and sidewalk, 1938 (NARA College Park, RG77).

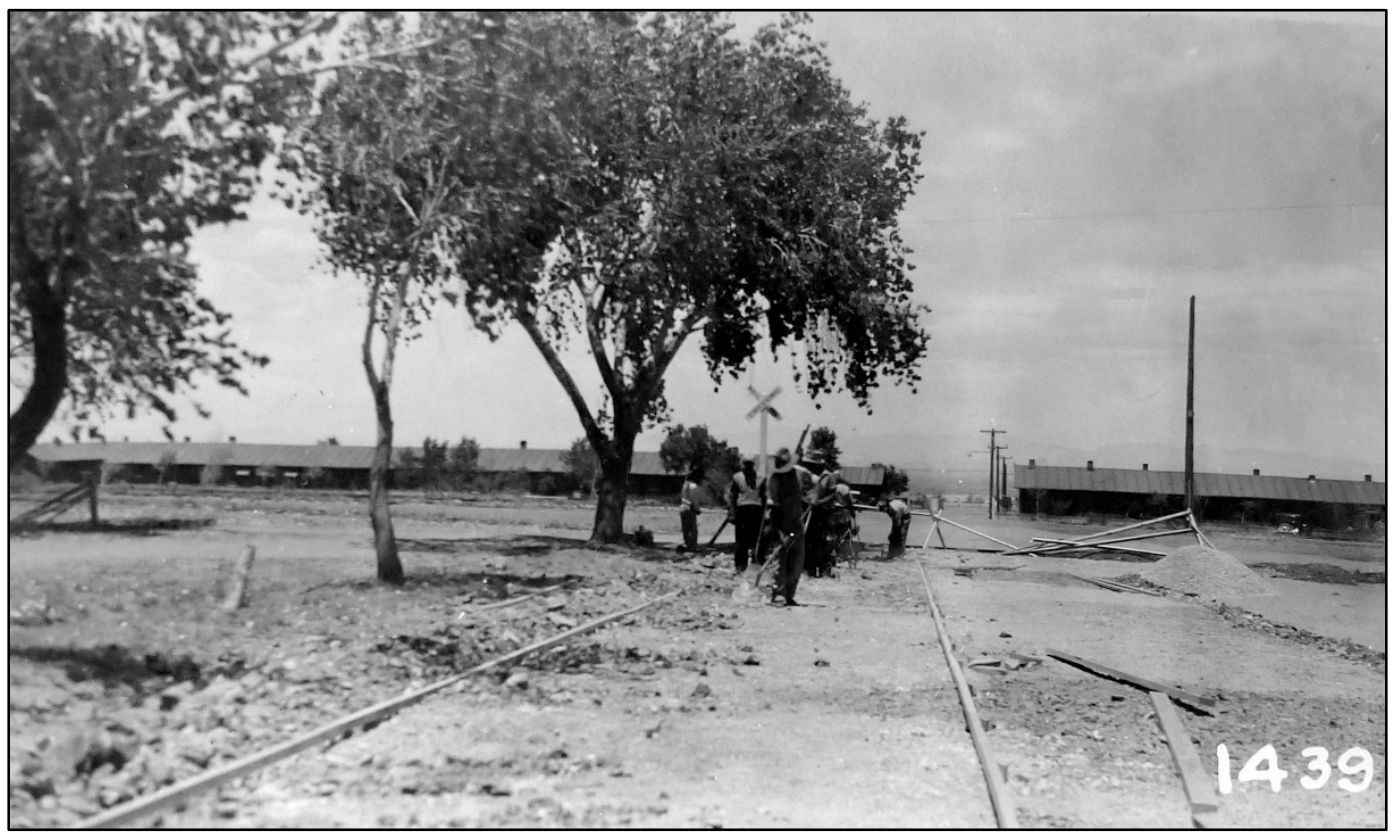

Figure 256. Aerial of Fort Huachuca with the original fort on the left and the 1914 extension on the right, with the officer's duplexes in center left, 1924 (NARA College Park, RG165-FF).

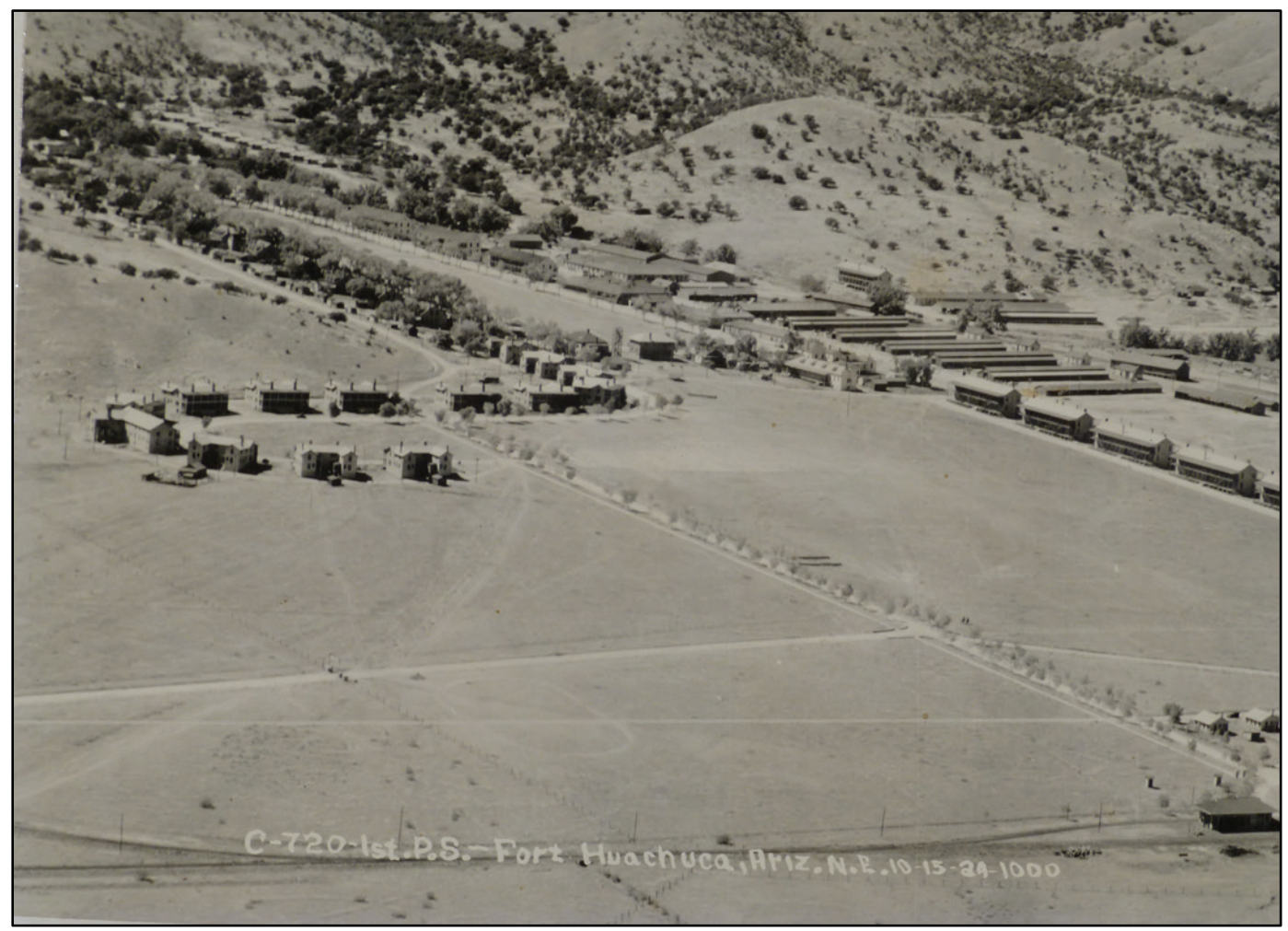


Figure 257. View looking southeast at 42014 and 42015, 1954 (NARA College Park).

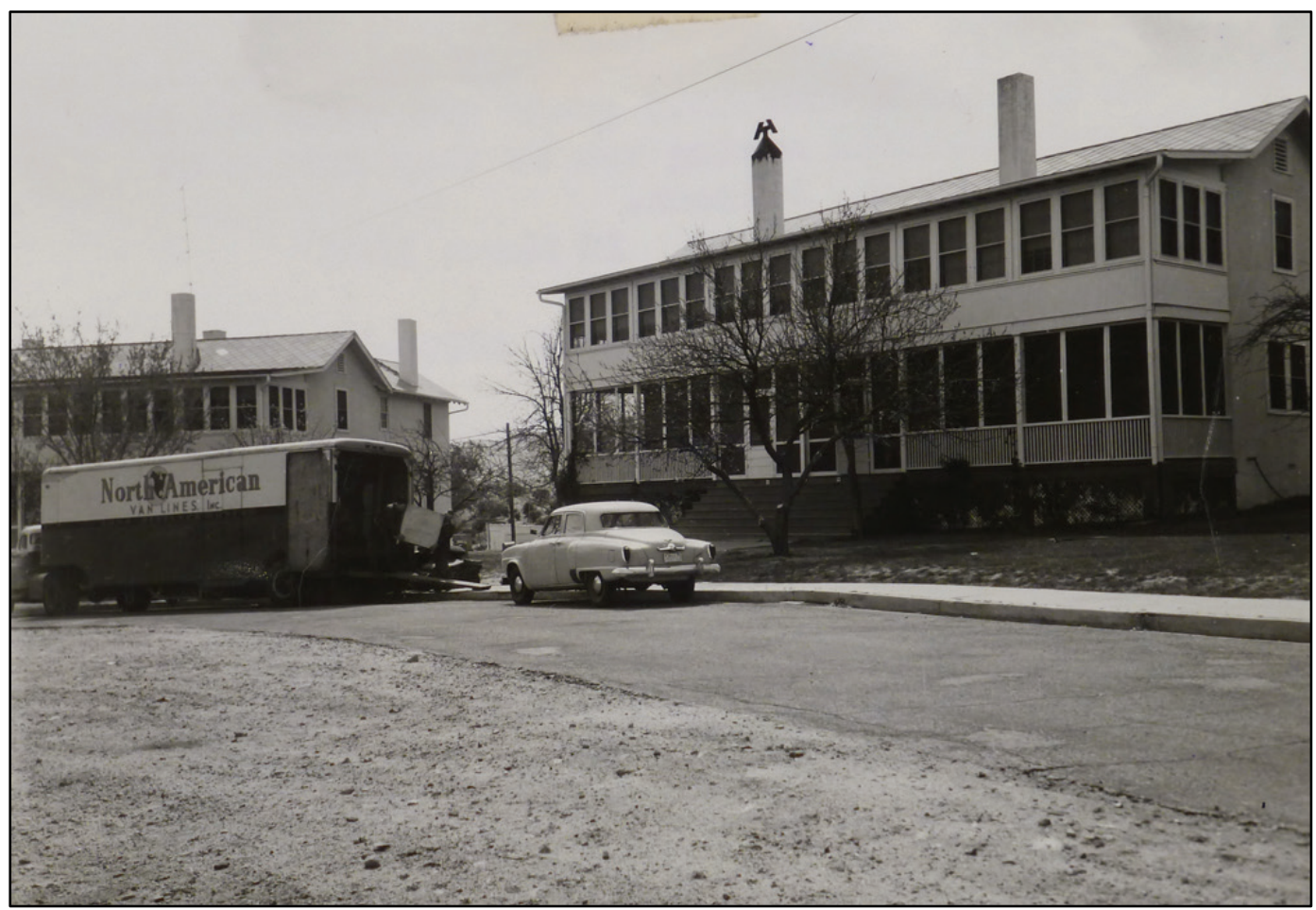

\subsubsection{Current conditions}

The buildings have changed only a little since their construction. First the porches were enclosed with screens around 1918 and later with sashes and windows. In the 1930s, the rear of each of the six buildings were enlarged by filling in the center portion. These enlargements occurred during the POS. The buildings continue to serve their original function. The garages are still present as are some coal bins. Historic photos exist of additional coal bins attached to the WPA-era garages, but they are gone today.

The circle is still open space, although two rows of trees were planted to screen a new housing area across the street. A new playground, added between 2003 and 2007, is northeast of Henry Circle. While this playground replaced an older playground, present on 1970s maps, in the same spot, the playground was associated with the housing area across the street (Figures 258-271). 
Figure 258. View southeast of the 1914 Officers' Duplexes and associated open space (ERDC-CERL, 2016).

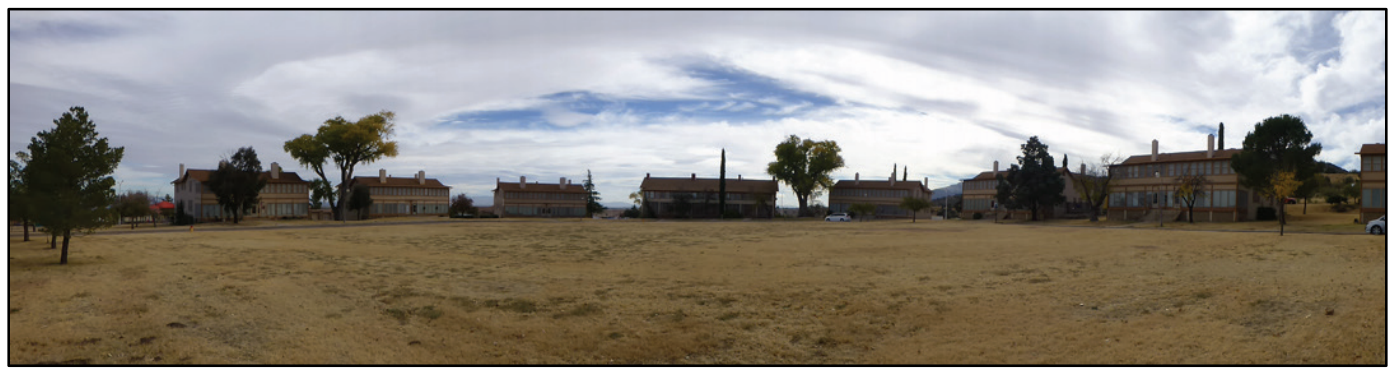

Figure 259. View east of 41015 from Hungerford Avenue (ERDC-CERL, 2016).

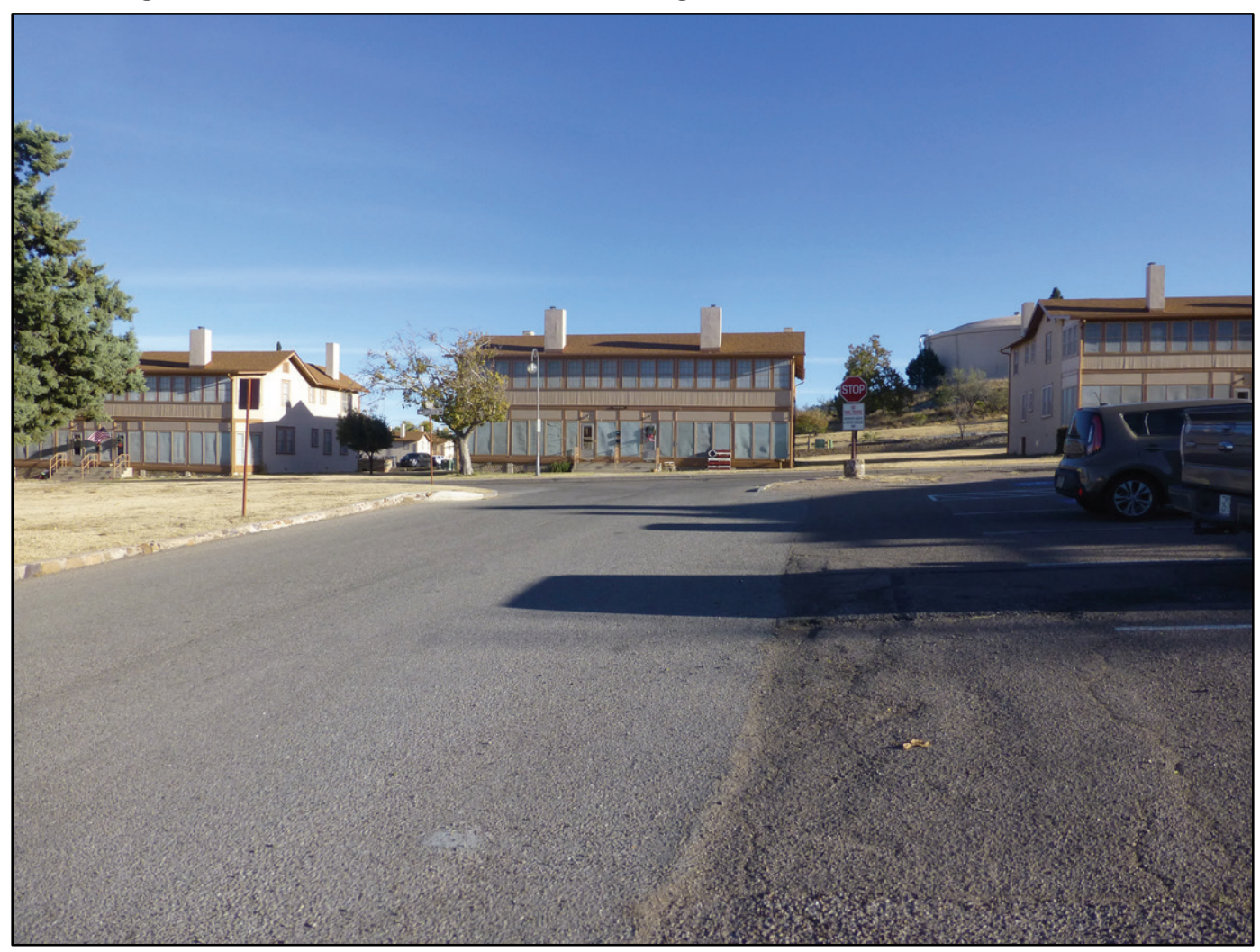


Figure 260. View east of 41016 from 41305 (ERDC-CERL, 2016).

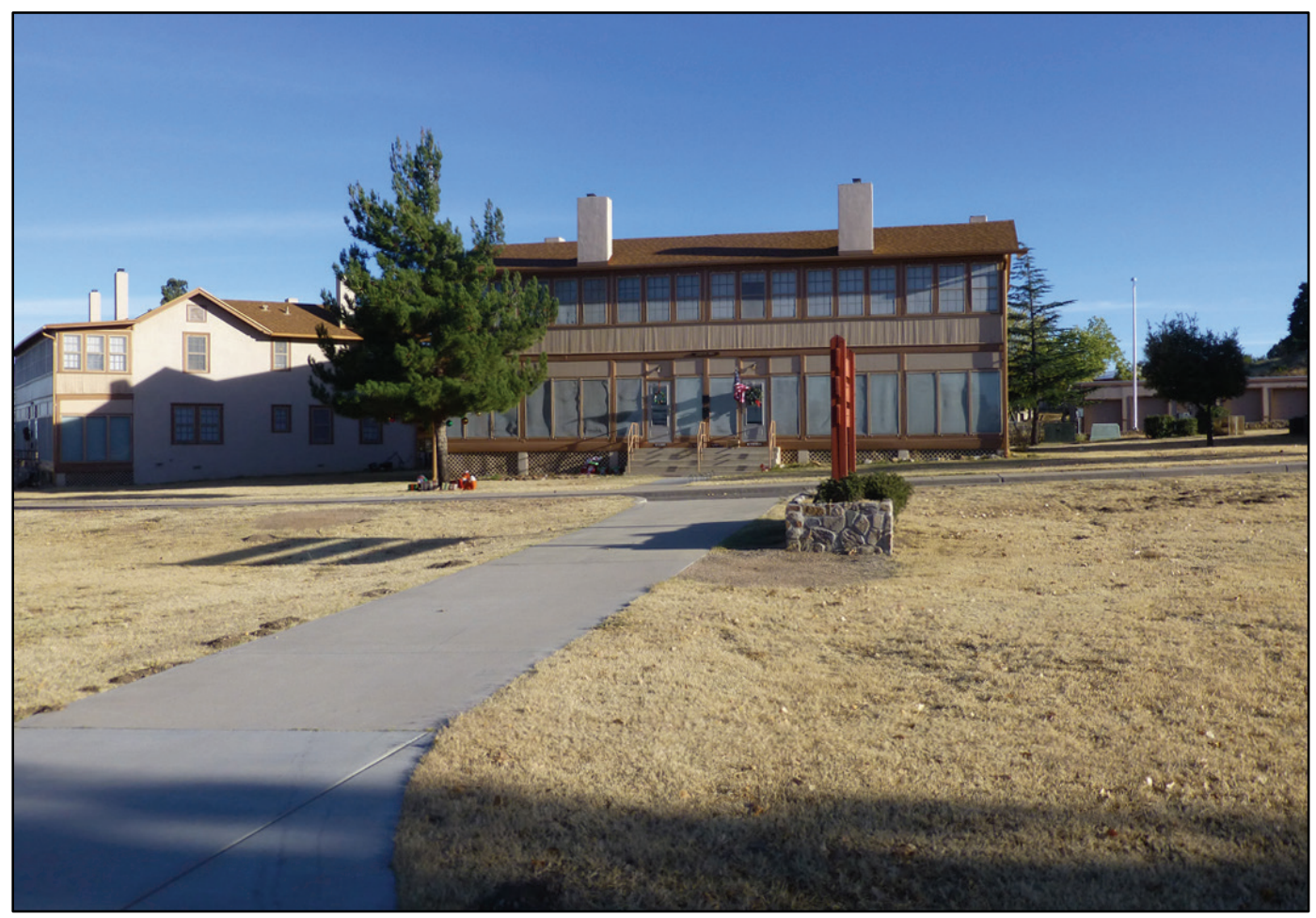

Figure 261. View south down Mizner Avenue showing street trees and sidewalk, 1938 (ERDCCERL, 2016).

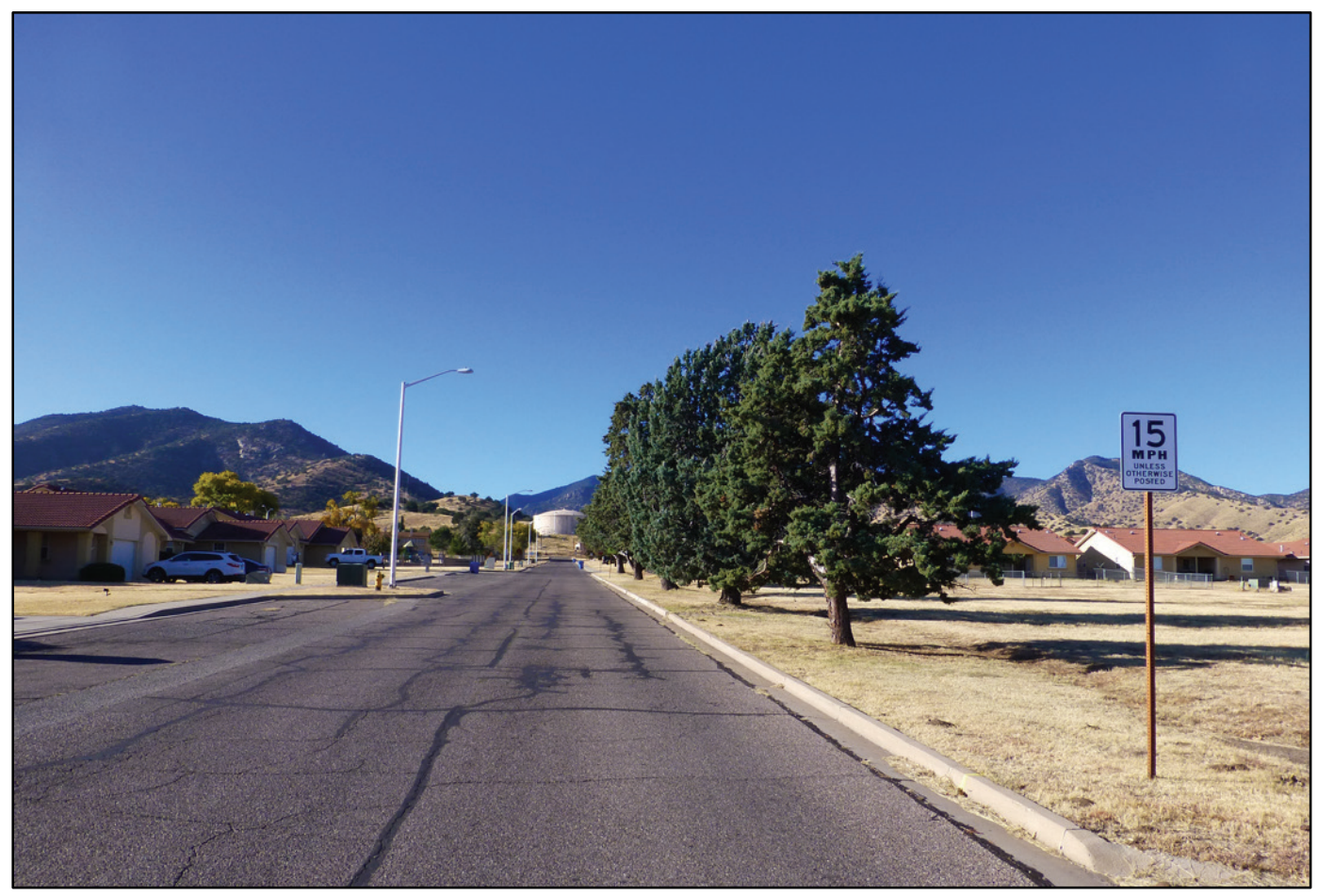


Figure 262. View north down Mizner Avenue at Smith Avenue showing street trees and sidewalk (ERDC-CERL, 2016).

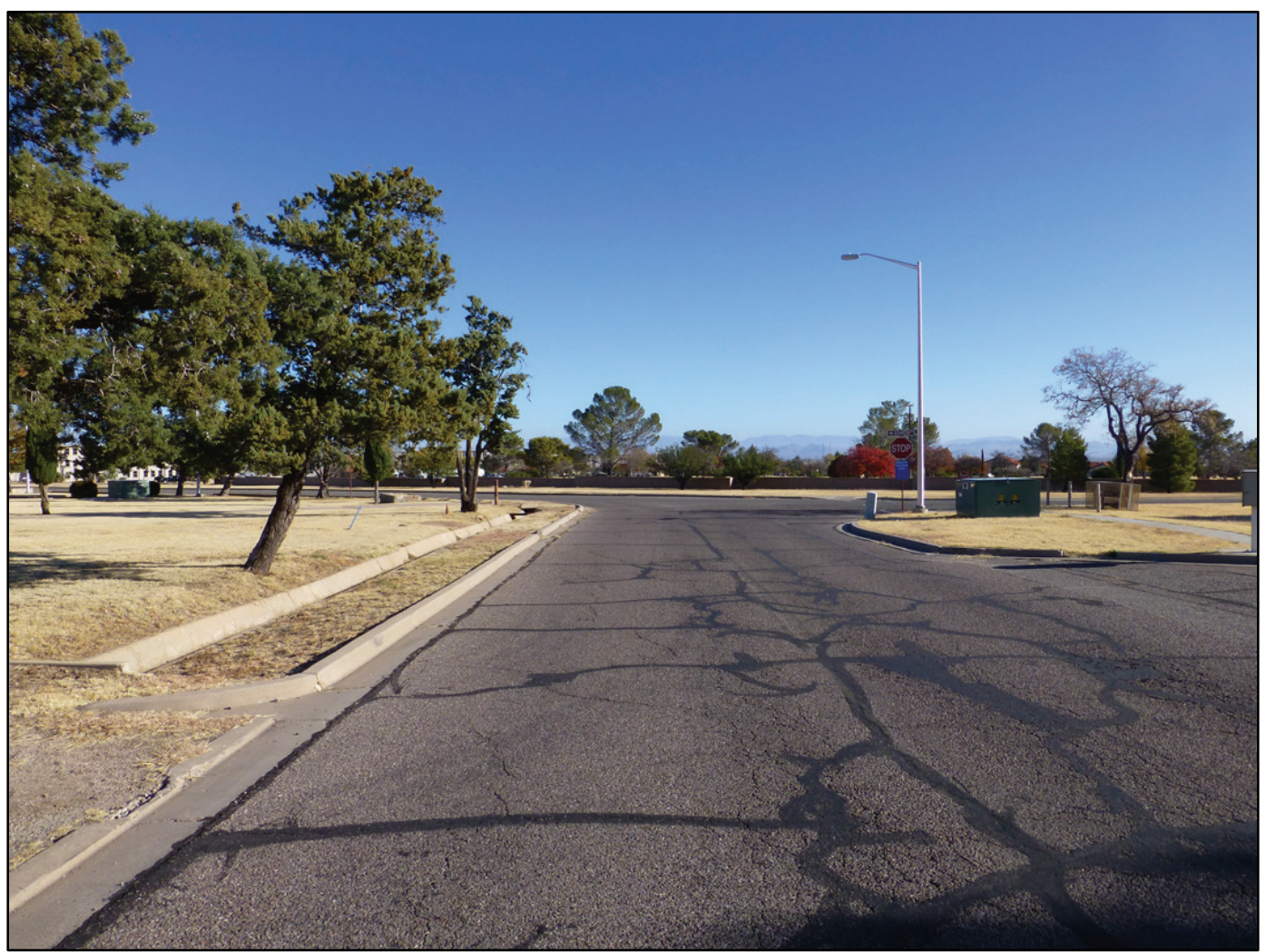

Figure 263. Looking south down Grierson Service Road with garage 22021 on the left (ERDCCERL, 2016).

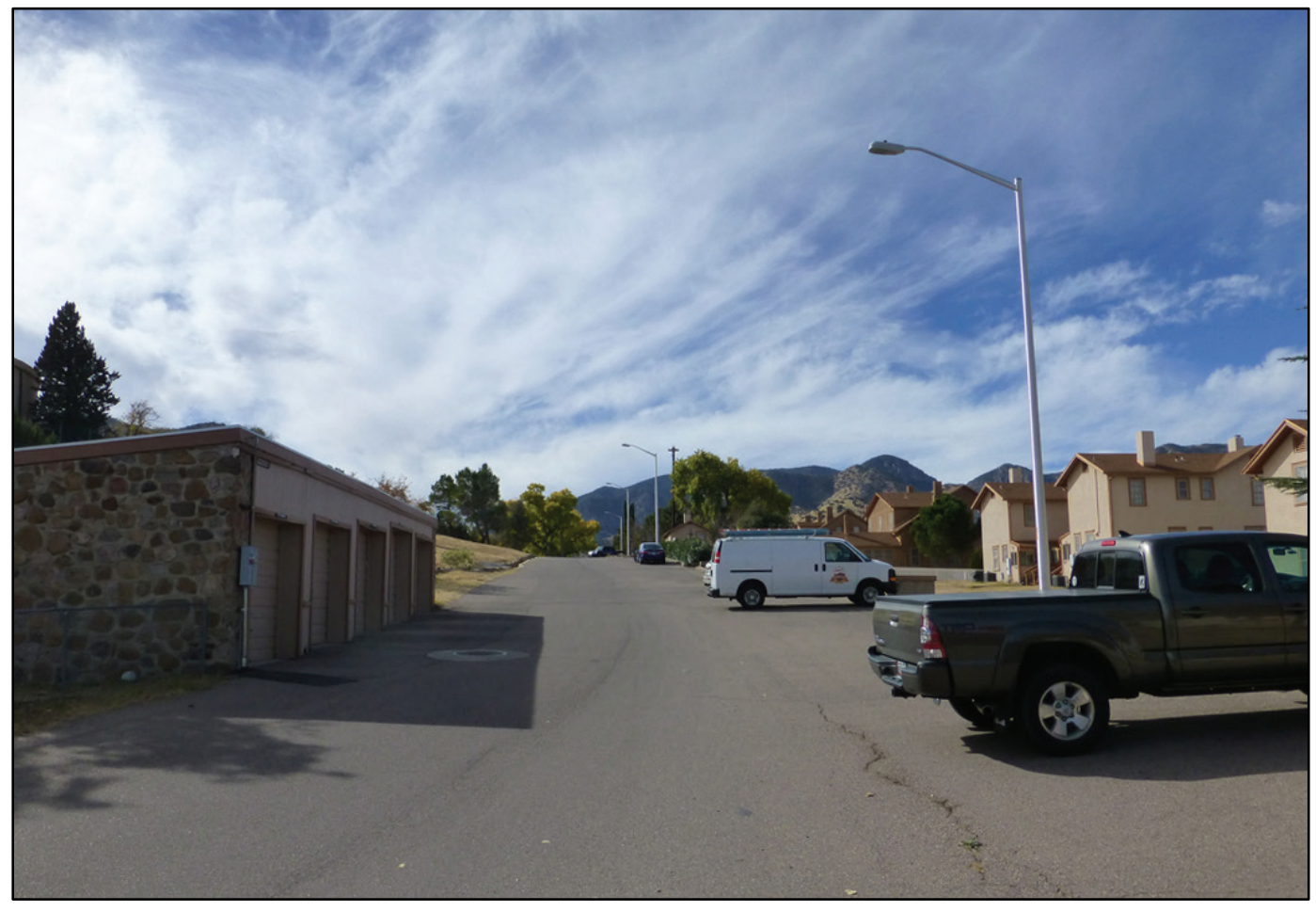


Figure 264. View looking west at electrical boxes behind 41015 and 41016 (ERDC-CERL, 2016).

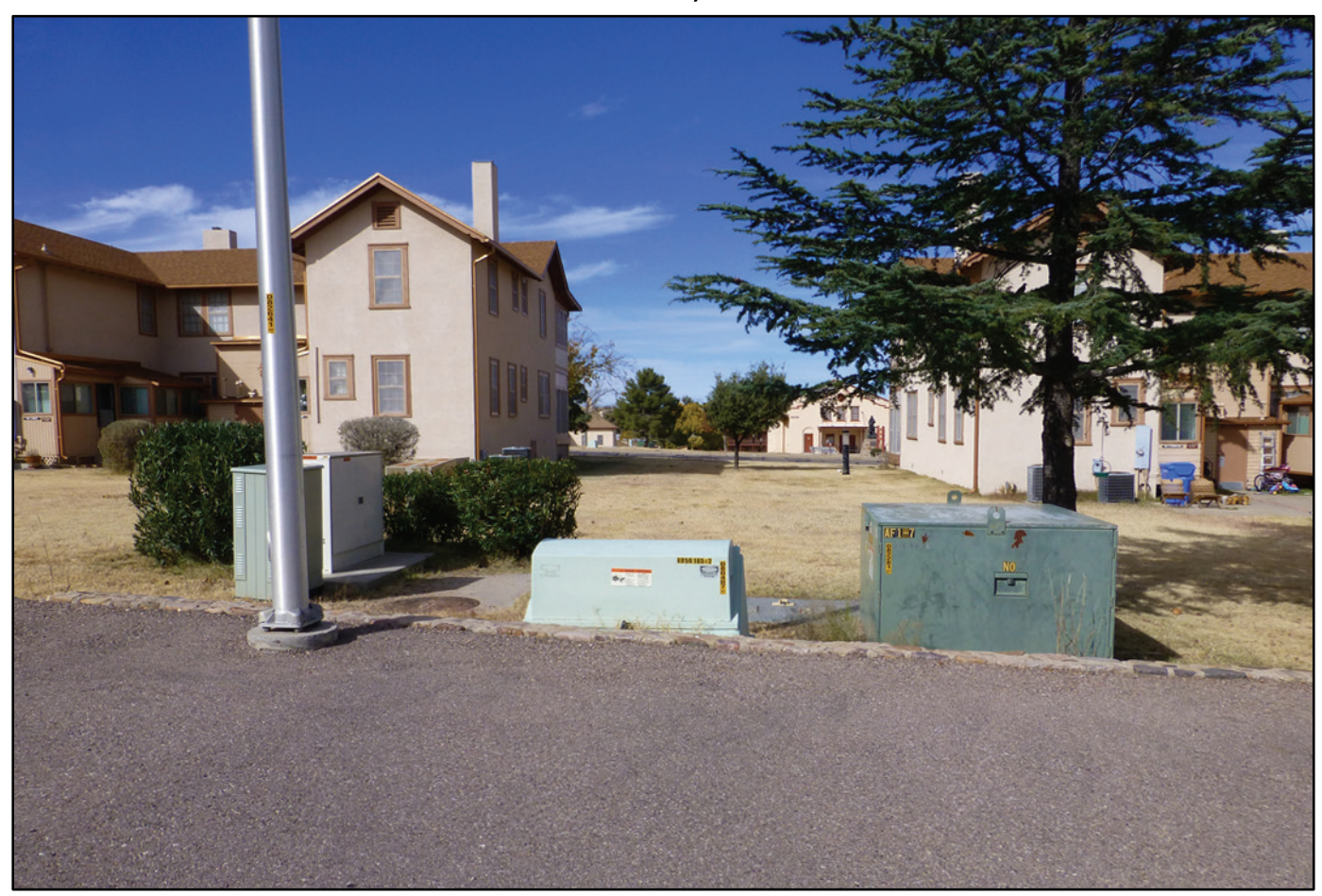

Figure 265. View looking northwest at shrubs and WPA stone wall behind 41014, 41015, 41016 (ERDC-CERL, 2016).

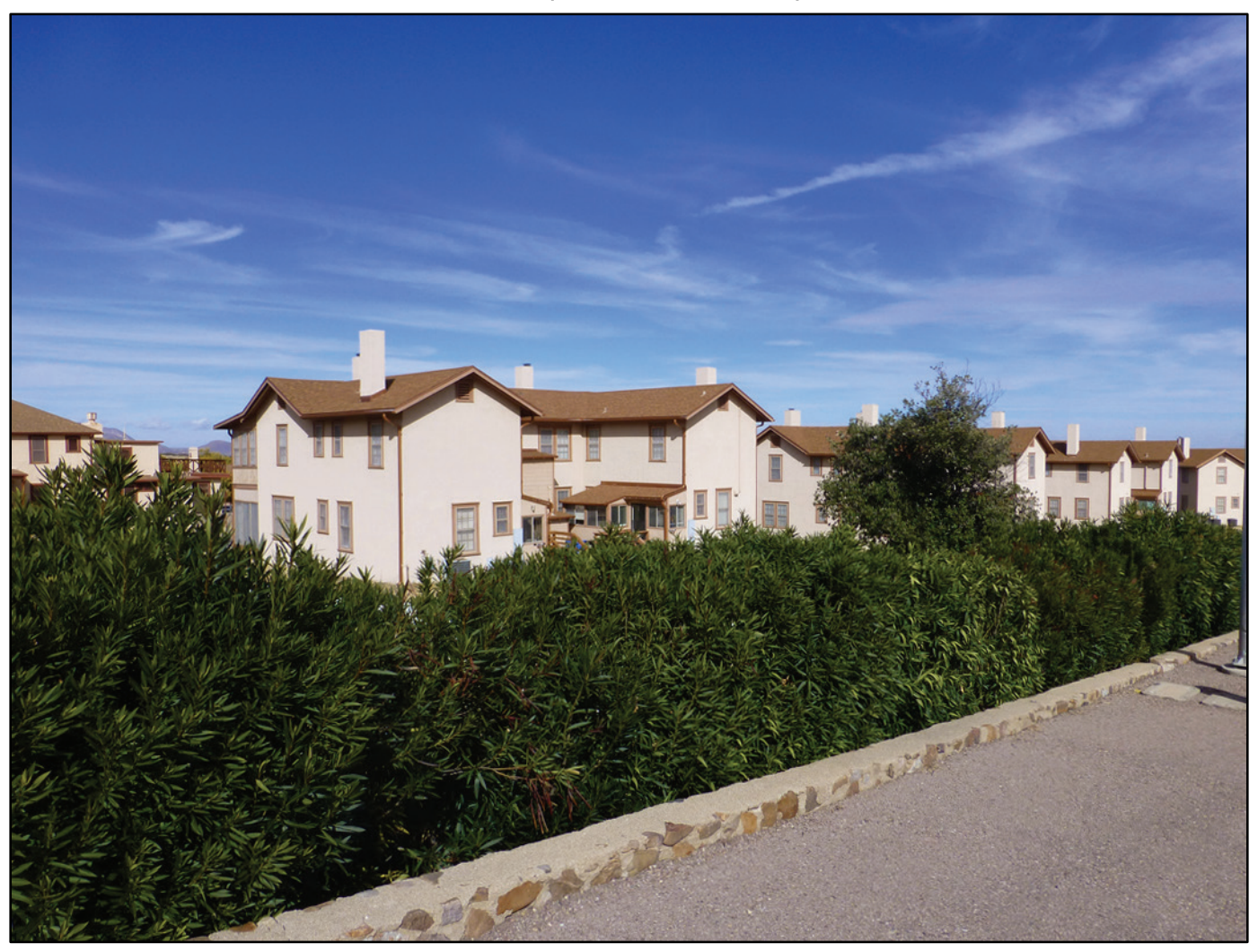


Figure 266. View looking southwest at garages 22023 and 22022 along Grierson Service Road (ERDC-CERL, 2016).

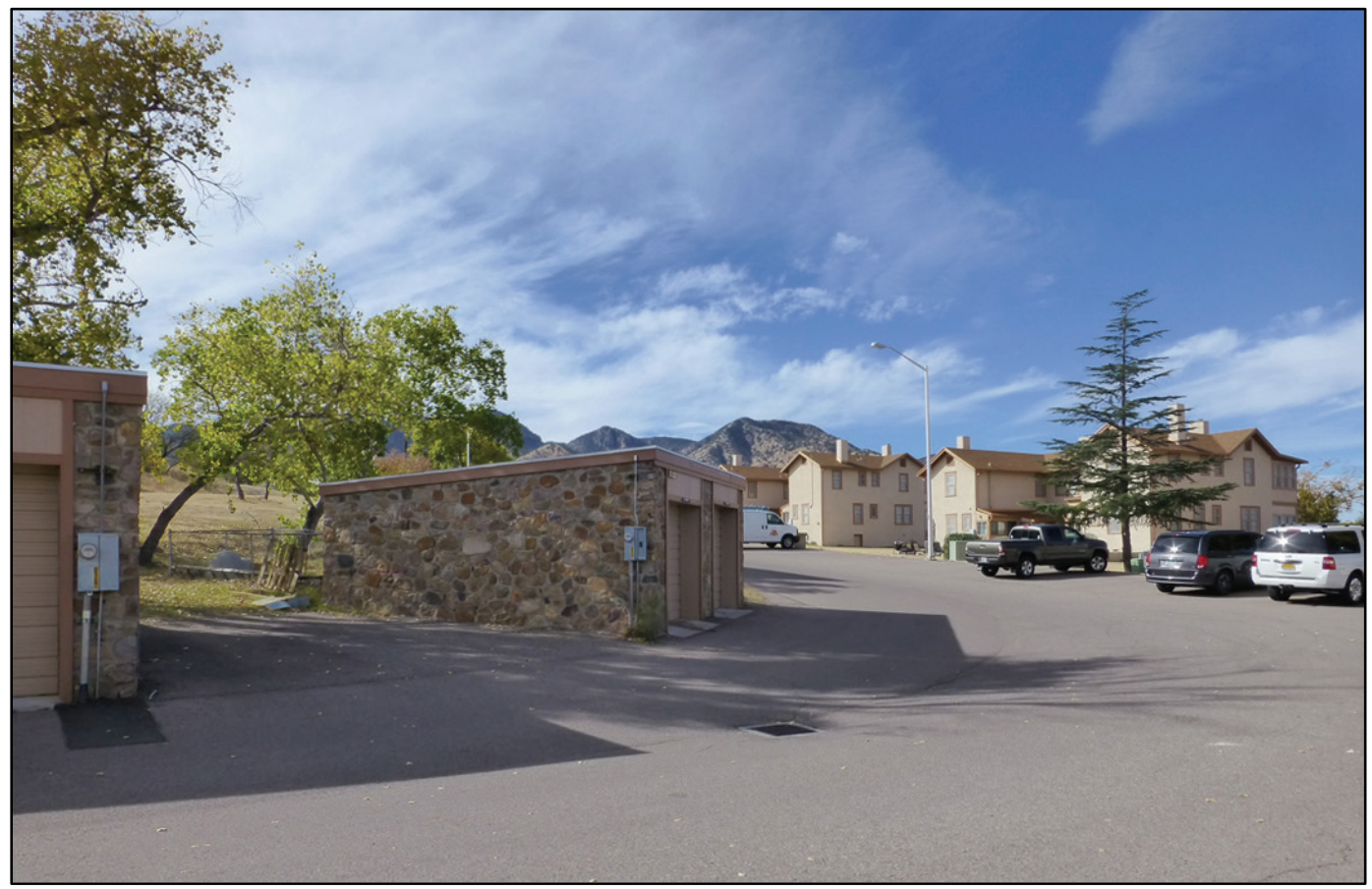

Figure 267. View looking west at stone drainage ditch southeast of 22023 (ERDC-CERL, 2016).

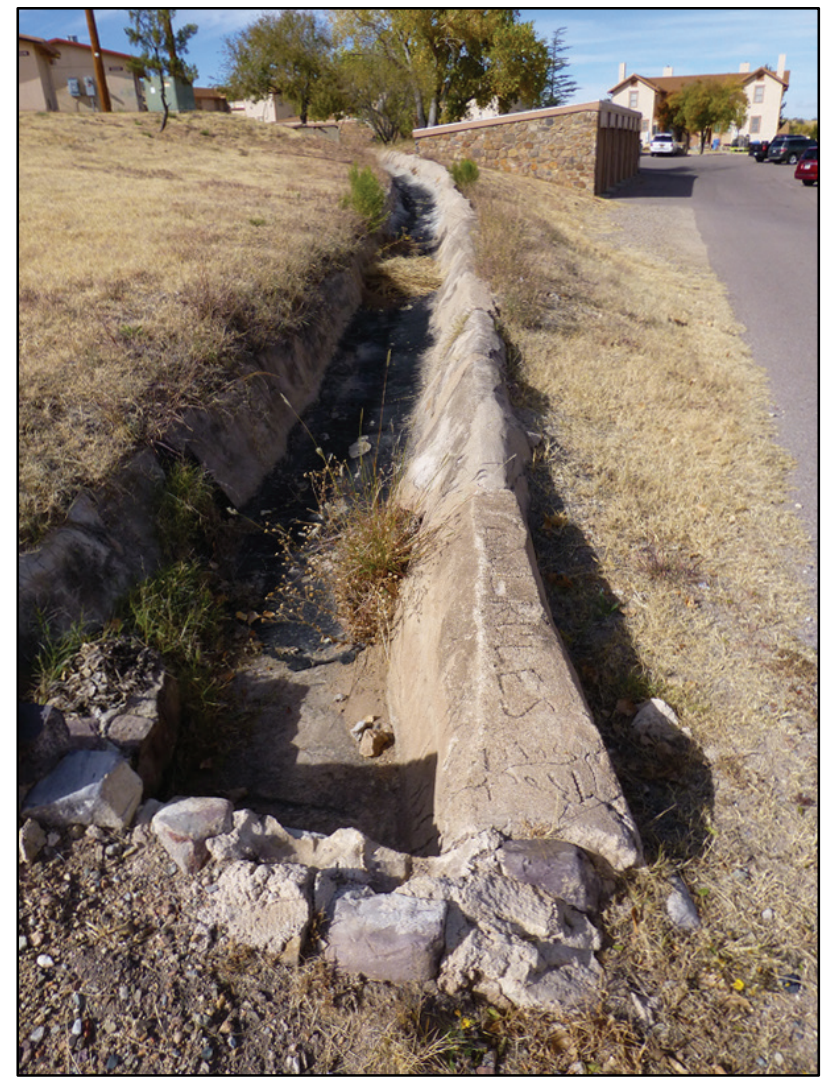


Figure 268. View west of typical landscaping behind 42014 (ERDC-CERL, 2016).

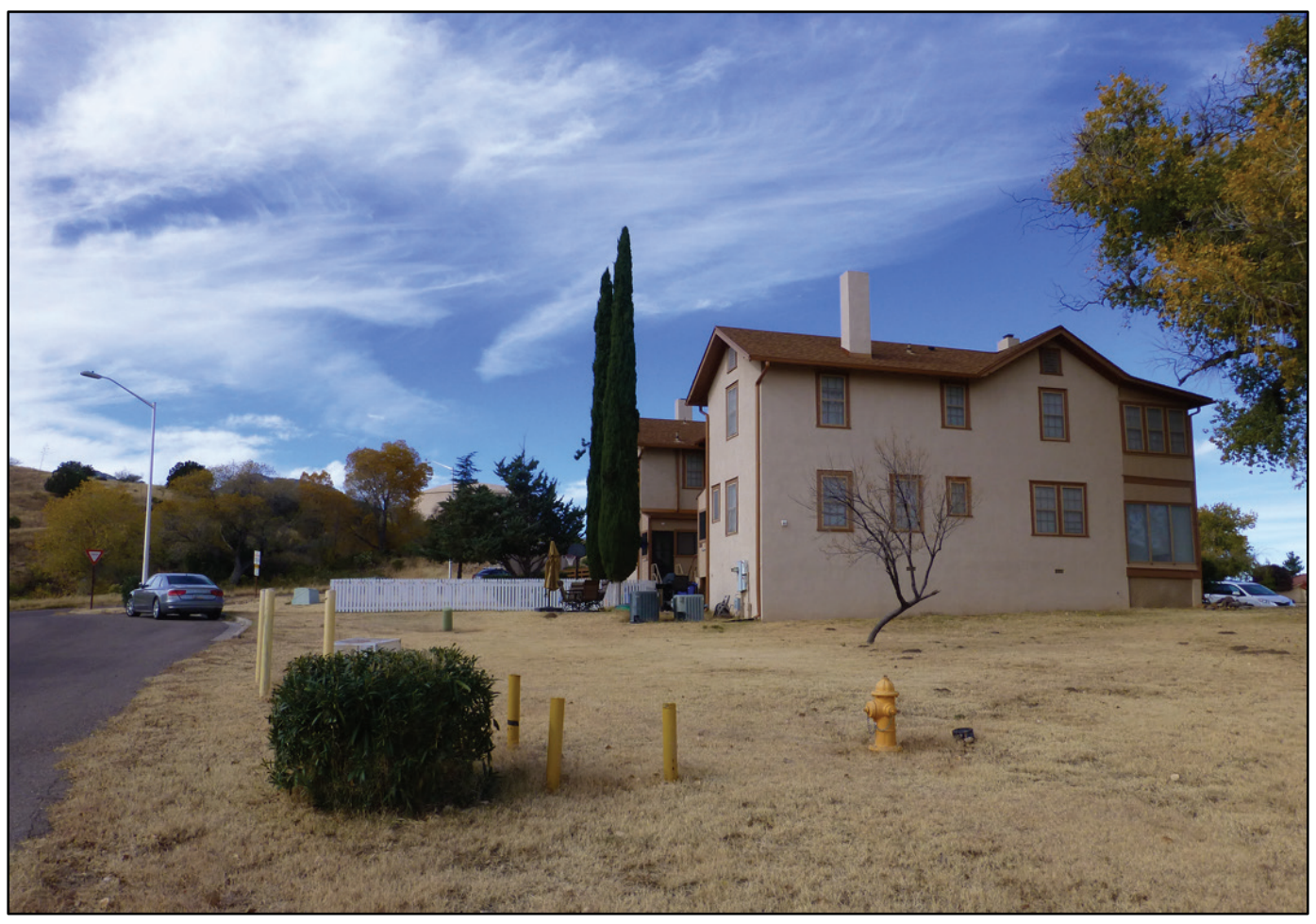

Figure 269. Parking lot behind Allen Hall (42017), original Bachelor Officers' Quarters (ERDCCERL, 2016).

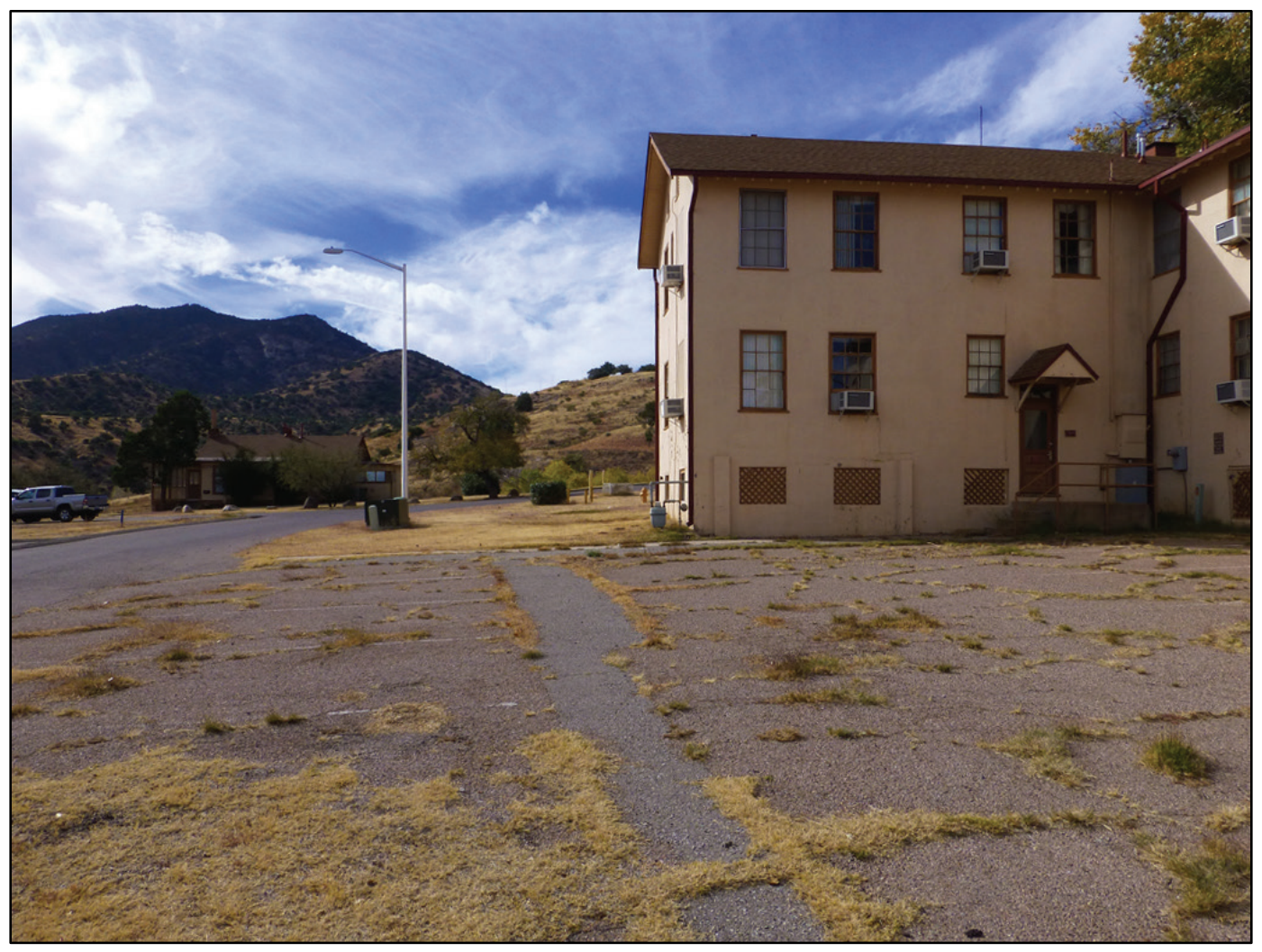


Figure 270. View east at garage 42021 behind 42017 (ERDC-CERL, 2016).

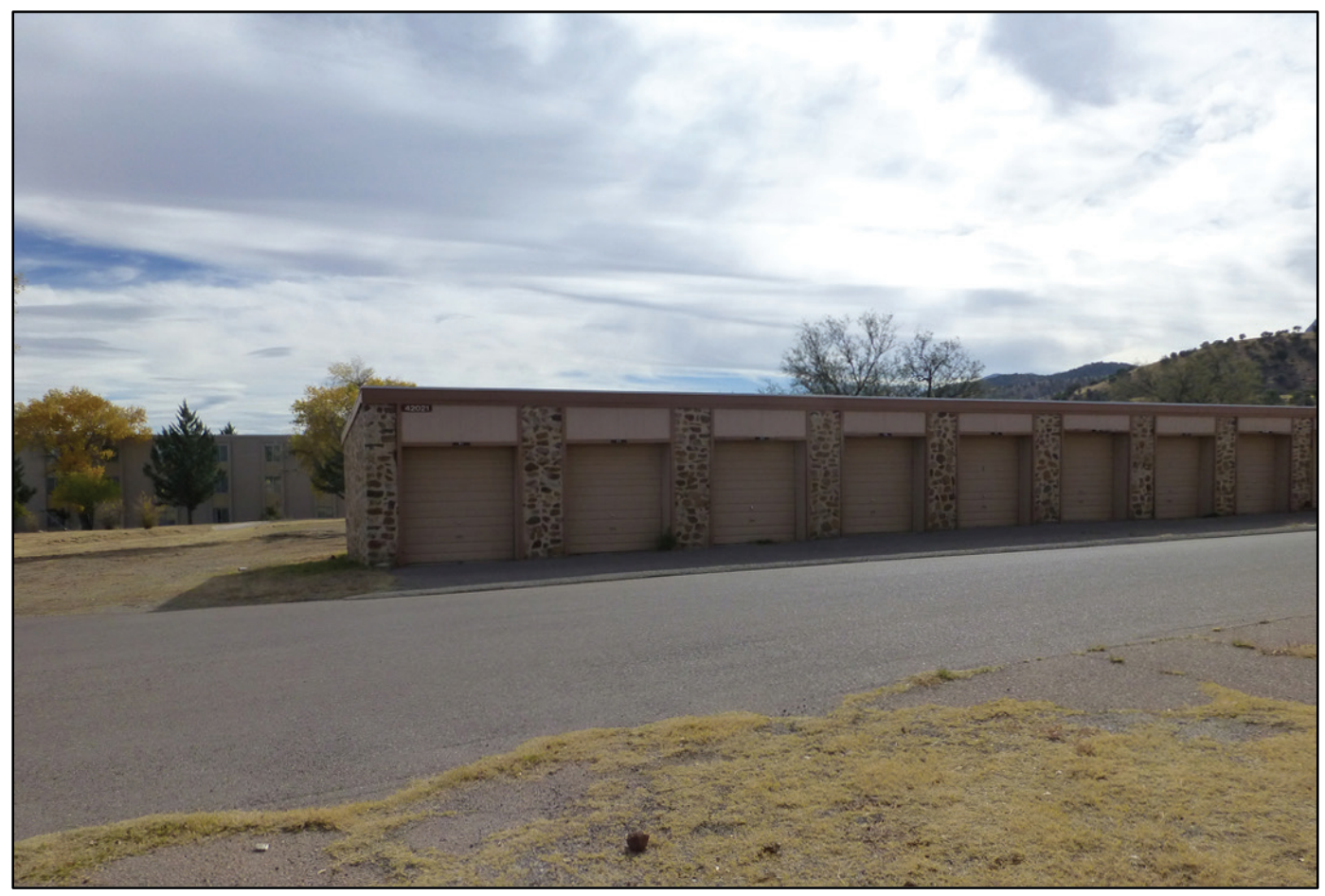

Figure 271. View east of playground north east of Henry Circle associated with new Cavalry Park 5 housing area (ERDC-CERL, 2019).

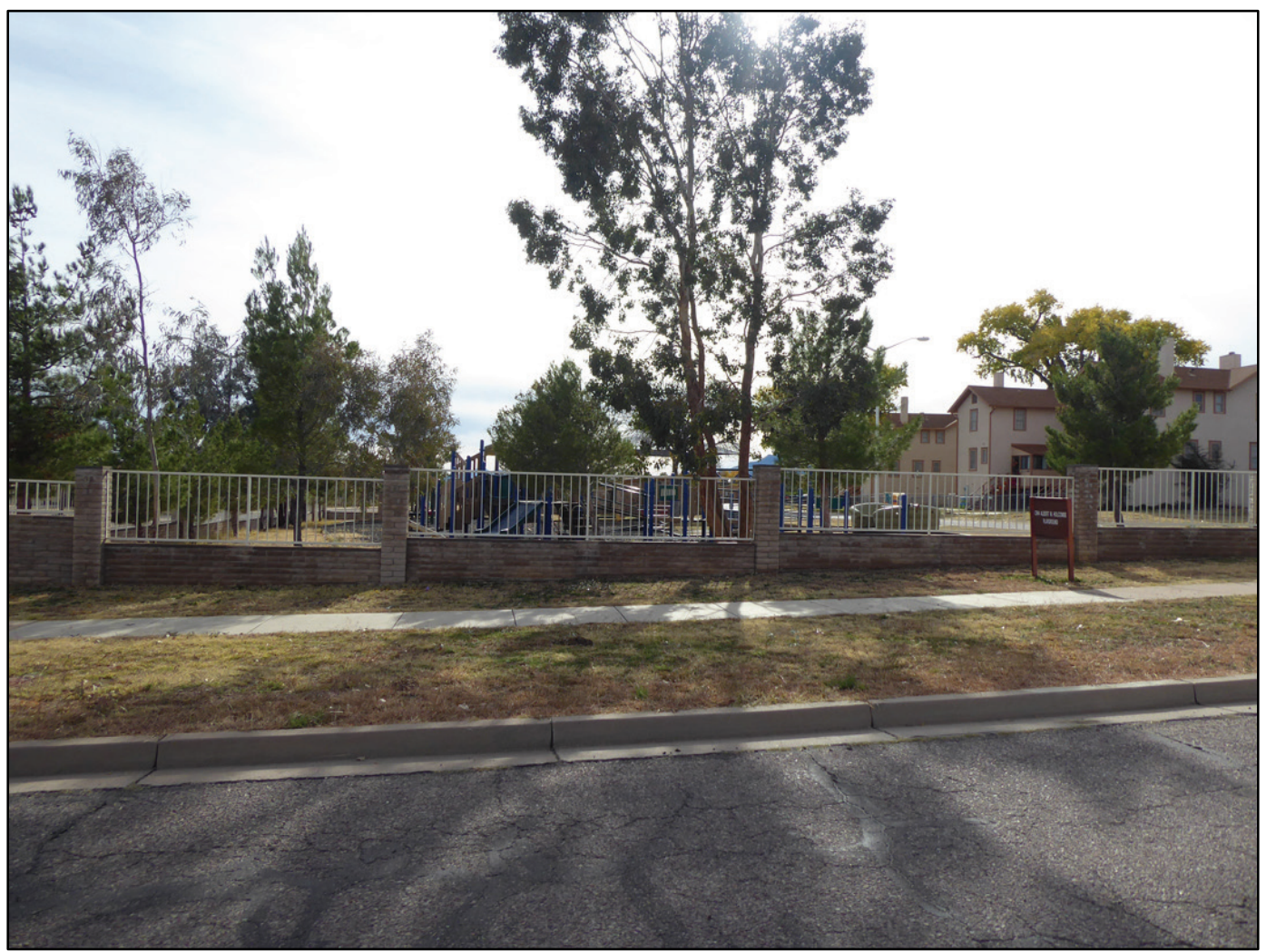




\subsubsection{Significance and integrity}

The quarters are a significant resource in the NHL Historic District for their contribution to the 1914 expansion to accommodate the $10^{\text {th }}$ cavalry. While the original design has been compromised through enclosures of the porches, the enclosures occurred during the POS and are not considered a modification. The rear in-fill occurred after the POS, but it affects only the rear elevation and is not present on all buildings. In general, the frame duplexes retain a high degree of integrity and are all contributing elements of this historic district.

The semicircular park in the center of Henry Circle remains open space today. Historically, this space was an orchard. Recent tree plantings are along Mizner Avenue to screen the new housing area across the street, and an older tree remains at the northwest corner of the park.

Three garages (22021, 22022, and 22023) are included in the 1977 NHL district boundary. They are non-contributing since they are not on the list of contributing buildings. The rest of the associated garages are outside the NHL historic district but are included, with the other three, in the discontiguous WPA-era Historic District. Coal bins are located behind many of the quarters. Some quarters have chain-link fencing, others have wood picket fencing. The new playground to the northeast is adjacent but not associated with the housing area.

Little remains of the park and foundation plantings. Several large shade trees remain between the quarters.

\subsubsection{Character-defining features}

Character-defining features include:

- Semicircular layout around Henry Circle and central park

- Consistent architecture and setbacks

- Layout and location along the east side of North Parade Field

- Associated WPA garages

- Specimen trees and foundation plantings where remain

- WPA-era ditches, culverts and retaining walls

- Views along Henry Circle. 


\section{Character-Defining Features}

The NPS defines historic character-defining features of a landscape as "prominent or distinctive aspects, qualities, or characteristics of a cultural landscape that contribute significantly to its physical character." 35 Through the study of landscapes, the built environment is explained by the physical remains of the natural and cultural shaping forces. The historic landscapes of Fort Huachuca are significant because they illustrate the adaptation of the built environment to the cultural values and the educational and military mission of the installation. This chapter identifies the historically significant features and characteristics of the Fort Huachuca landscape which are used to evaluate the built environment.

To identify the prominent or distinctive characteristics that make a landscape historic, the physical features of the site are divided into nine areas: site and layout, land use, topography, expressions of military cultural values, transportation networks, views and viewsheds, buildings and structures, vegetation, and small-scale features. These landscape characteristics combine to form the built environment that is the primary image of Fort Huachuca and the NHL Historic District.

\subsection{Site design and layout}

In historic landscape studies, the term "landscape characteristic" has a specific meaning. Landscape characteristics are defined as the "tangible evidence of the activities and habits of the people, who occupied, developed, used, and shaped the land to serve human needs; they may reflect the beliefs, attitudes, traditions and values of these people." ${ }^{6}$ Identifying the characteristics of the military landscape requires an understanding of the natural and cultural forces that have shaped it. This section will describe these processes and the resulting landscape features that together comprise the military landscape.

\footnotetext{
35 Charles A. Birnbaum, National Park Service Preservation Brief \#36 - Protecting Cultural Landscapes: Planning, Treatment and Management of Historic Landscapes, (Washington, DC: National Park Service 1996), 4.

36 National Park Service, National Register Bulletin \#30 - Guidelines for Evaluating and Documenting Rural Historic Landscapes, (Washington, DC: US Department of the Interior, National Park Service, 1999), 3.
} 
Sites for military installations are selected because a location meets the physical requirements of the mission. The landscape is then spatially organized to accommodate the land use needs of the inhabiting military forces. The design of a military installation's built environment incorporates relationships between environmental features with the necessities of the specific military mission. 37 The layout of any military installation is based on the relationships among the pre-existing landscape's predominant landforms, topography, climate, water bodies, and vegetation, as well as the military's lands use requirements. 38

The site plan for Army posts, particularly on the Western frontier, was straightforward and practical, not based on complex geometric forms, as would be the case in later generations of post design. Fort Huachuca was laid out in a rectangular plan with a large parade field flanked by buildings divided according to function. The post was nestled at the foot of the Huachuca Mountains at an elevation of more than $5000 \mathrm{ft}$, providing both a defensible position against the Huachuca Mountains and views of troop movements across the broad plain of the San Pedro River.

As originally conceived, the post was a rectangle of buildings around the parade ground. The four sides of the rectangle were divided into functional units (Figure 272). Officers' quarters were located along the long side to the east. On the long west side were two functional units -- enlisted personnel barracks at the south, utilitarian buildings at the north. The short north end of the parade ground was occupied by the large hospital building as well as a duplex for officers (became the Headquarters then the Officers' Club). The land south of the parade ground was occupied by recreational buildings, specifically, a PX/gymnasium and, in 1908, a bowling alley. Various buildings were scattered outside the rectangles, including the stables, which were to the west. The plan, then, was simple and utilitarian in its design, emphasizing sectors of buildings by function with the great parade ground serving as a common area.

\footnotetext{
37 Suzanne Keith Loechl, Susan I. Enscore, Megan W, Tooker, and Samuel A. Batzli. 2009, Guidelines for Identifying and Evaluating Historic Military Landscapes. (Champaign, IL: Construction Engineering Research Laboratory), p. 67.

38 Ibid.
} 
Figure 272. Fort Huachuca map, c.1900 (NARA College Park, RG77 Blueprint File).

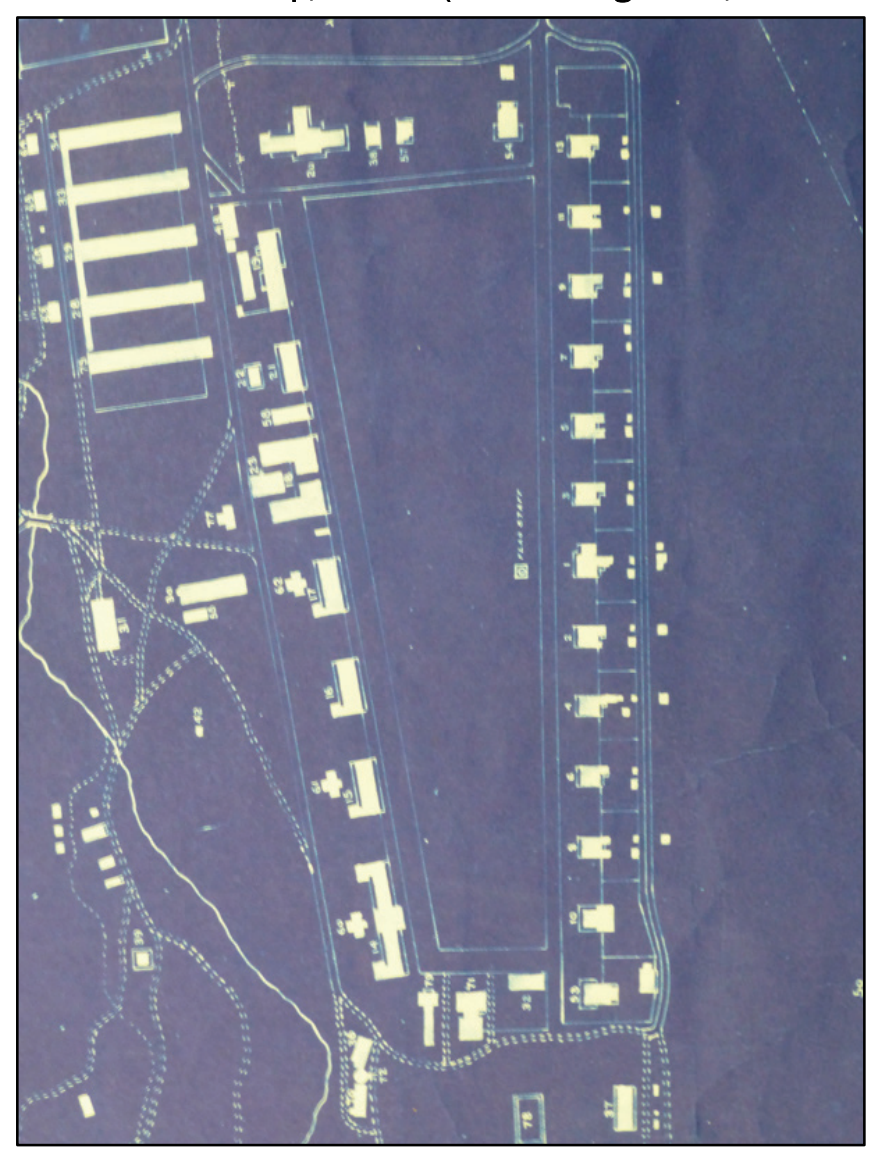

The most dramatic change in the Old Post was during the years 1914-17, when Fort Huachuca was expanded for border patrol duties. Some new buildings were constructed within the old rectangle, but the majority of new construction was to the north (Figure 273). New officers' quarters were built to the north of the existing quarters, maintaining the pattern on the east side of the parade ground, and new barracks were built to the north of the existing barracks, maintaining that pattern as well. The Quartermaster Corps built its own new buildings to the west of its former location, behind the troop barracks and south of the stables. 
Figure 273. Fort Huachuca map, c.1914 (NARA College Park, RG77 Blueprint File).

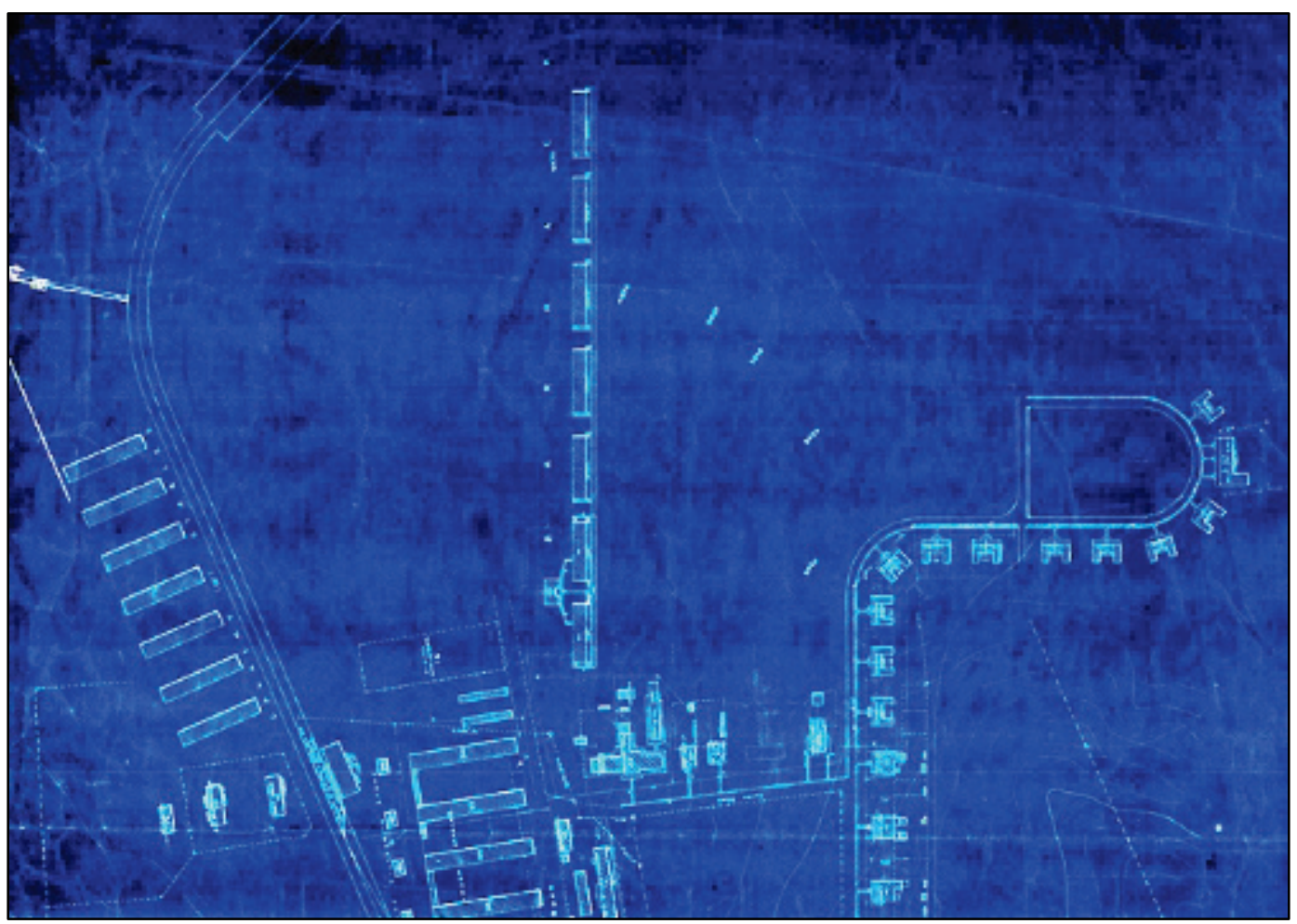

After 1931 and especially after 1939, the old pattern of the post began to disappear. When cavalry units were dispersed in 1931, the function of the post began to reflect is new role. Minor construction went forward during the 1930s, most of it by Federal relief forces, both within and outside the historic core of the post. The build-up before and during World War II resulted in massive new construction, nearly all of it well beyond the boundaries of this historic district.

\subsection{Topography and natural features}

The decision to situate the permanent post at the base of the Huachuca Mountains in the early 188 os was influenced by certain natural landscape features. The elevation of the site provided necessary panoramic views over the valley, and the three-sided enclosure at the mouth of the canyon provided natural protection (Figures 274 and 275). There were ample indigenous grasses for livestock grazing, and mature trees that provided some degree of shade from the oppressive desert sun. In addition, Huachuca Creek provided plenty of water to the site. 
Figure 274. Looking northeast over Fort Huachuca from the western part of Huachuca Canyon, c.1900 (NARA College Park, RG165-FF).

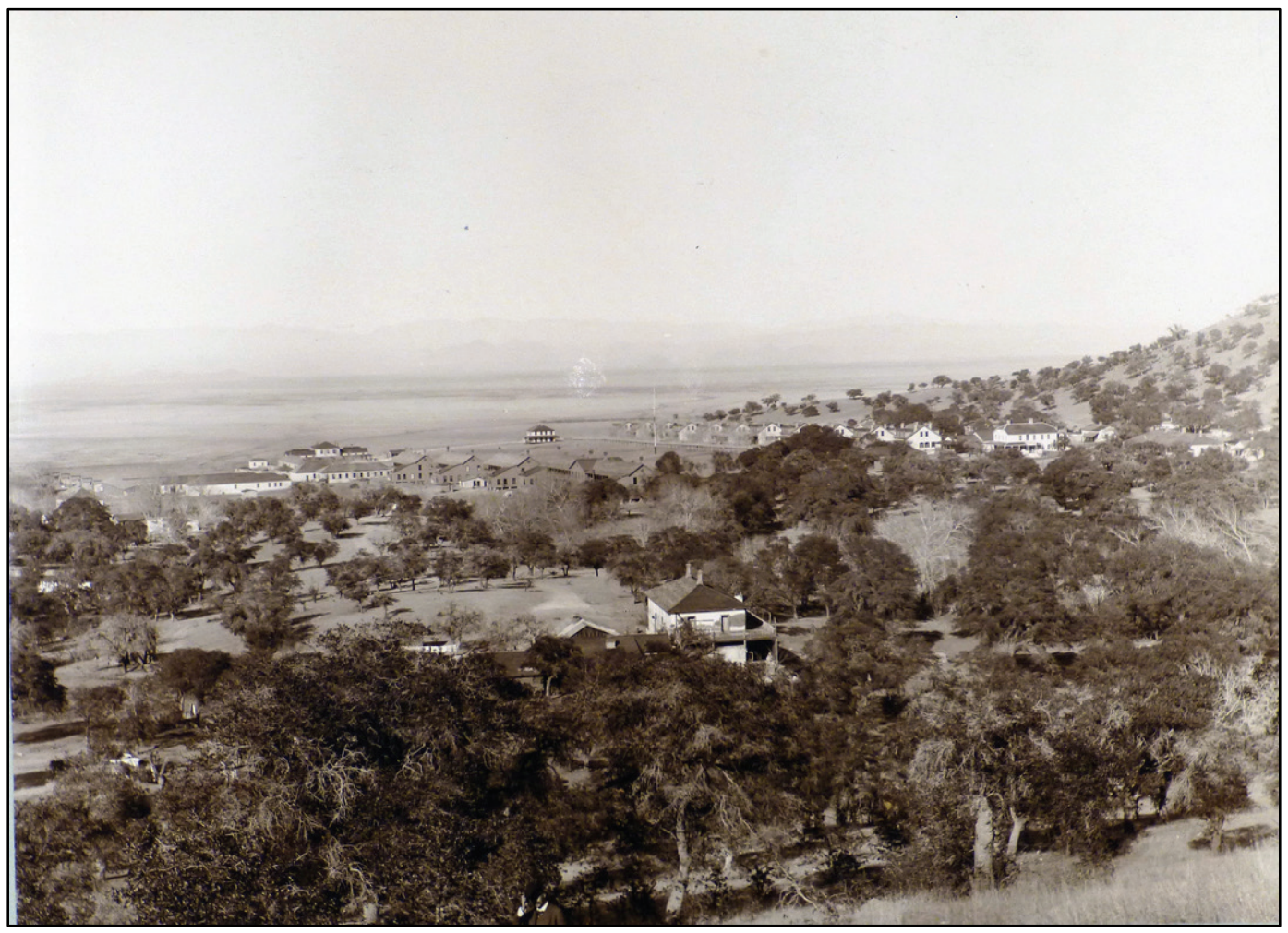

Figure 275. Looking northwest over Fort Huachuca from west of the reservoir, c. 1900 (NARA College Park, RG165-FF).

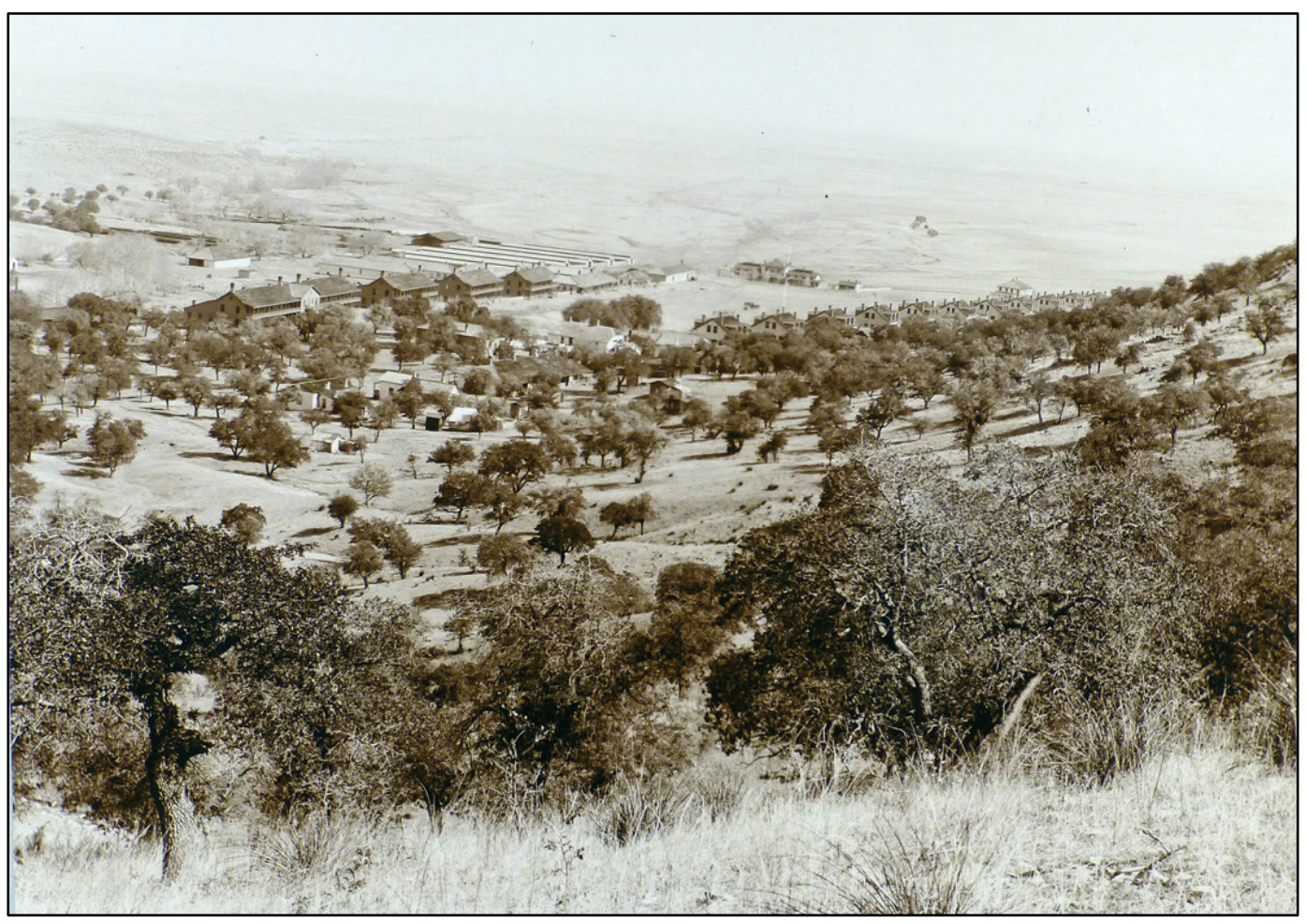




\subsection{Land use}

The military mission directs how the military uses the land. Because military installations are planned and organized to efficiently accommodate the military mission, the landscape is often utilitarian where function is prioritized over aesthetics. Most landscape changes on a military installation are related to military mission; some mission-related land use changes occur directly while others occur indirectly. 39 Land use areas that are directly related to the mission at Fort Huachuca include the cavalry areas, ranges and EPG areas. Areas that support the military mission include the housing areas, administrative areas, recreation, retail and/or commercial, and education.

The Old Post was clearly laid out around the central parade field according to land use. Barracks along one side, the officers' quarters on the other with the administration and recreation at either end. The 1910s expansion retained that pattern with the barracks along the west side along a drill field and the quarters to the east. These clear land use areas remain today.

\subsection{Transportation networks}

Transportation networks on military installations are an important characteristic of military landscapes because the movement of troops and equipment is vital to the military mission. Most military transportation systems have a distinct hierarchy to facilitate efficient mobilization of troops and distribution of supplies. $4^{\circ}$ In general, Army installations were planned to connect with regional systems of trails, primary and secondary roads, railroads, or navigable waterways.

The original layout of the roads of the Old Post remain today. Expansions to the north in 1910 s and south in 1920 s for NCO housing enlarged the rectangular pattern. The first roads of the Old Post were dirt. Historic photographs show a wood boardwalks or sidewalks to protect pedestrians from the dust and mud (Figures 276-277).

The discovery of silver in the Tombstone area brought the Southern Pacific Railroad to the area. The line to Tucson in March 1880, with a spur to Tombstone and the San Pedro Valley, was completed by the mid-1880s.

39 Loechl et al. 2009, p. 70.

40 Ibid, p. 77. 
The potential of the railroad contributed to the selection of the site for a new fort. The railroad curved around the north end of the Cantonment terminating in the quartermaster area to the west (Figure 278). A railroad station was located at the end of Mizner Ave just outside of the NHL historic district (Figures 279 and 280). The station is no longer extant. The railroad bed is visible just east of the stables as raised bed, and a railroad trestle still exists to the east almost to the Buffalo Soldiers gate (Figure 281). However, the construction of current roads, for example Smith Ave, have removed any other evidence of the rail line in the project area.

Figure 276. Looking east at an early view of roads and wood sidewalks in front of the officers' quarters, 1901 (Fort Huachuca Historical Museum).

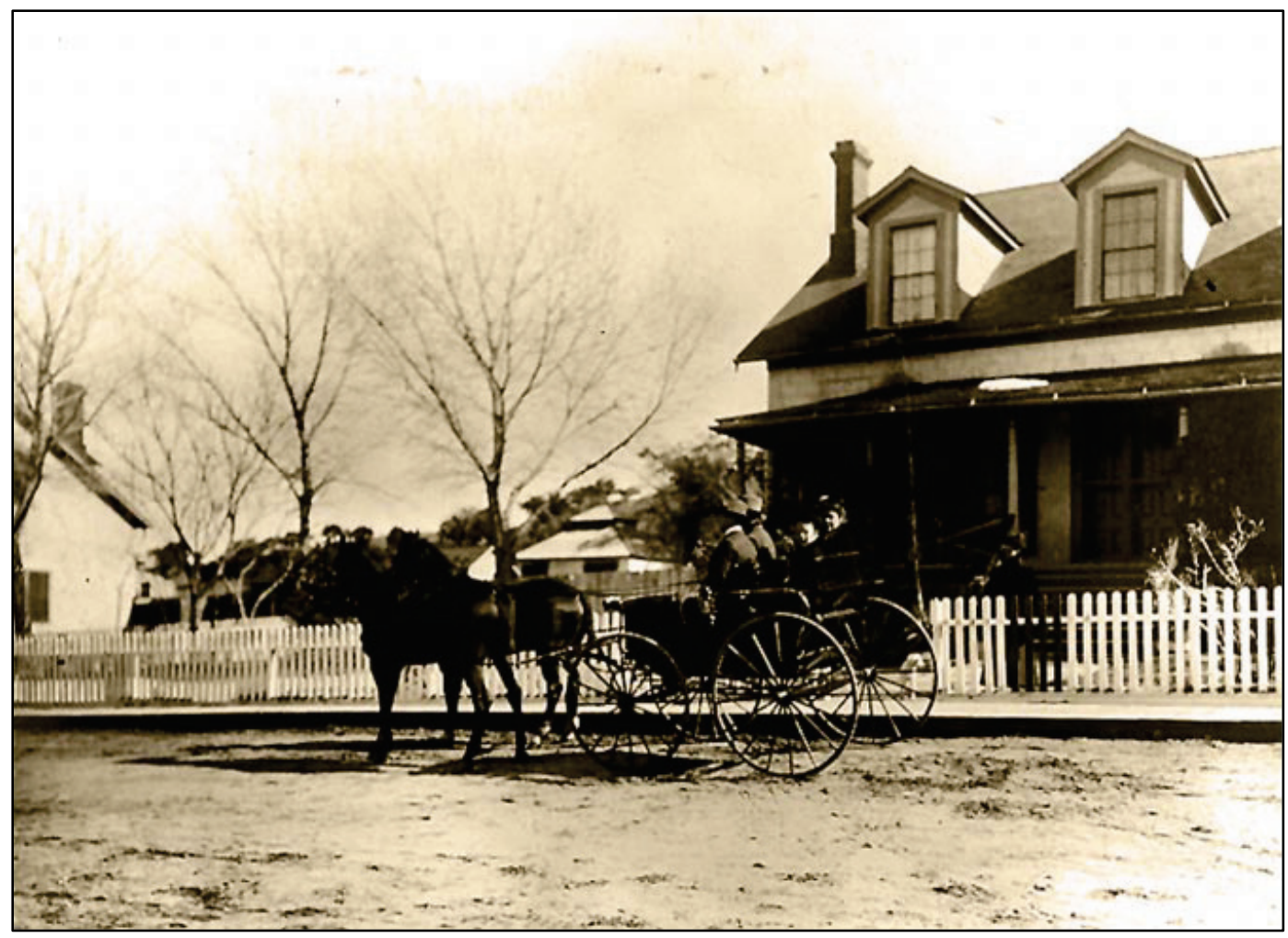


Figure 277. Looking south at officers on the boardwalk in front of the quarters, c. 1900 (Fort Huachuca Historical Museum).

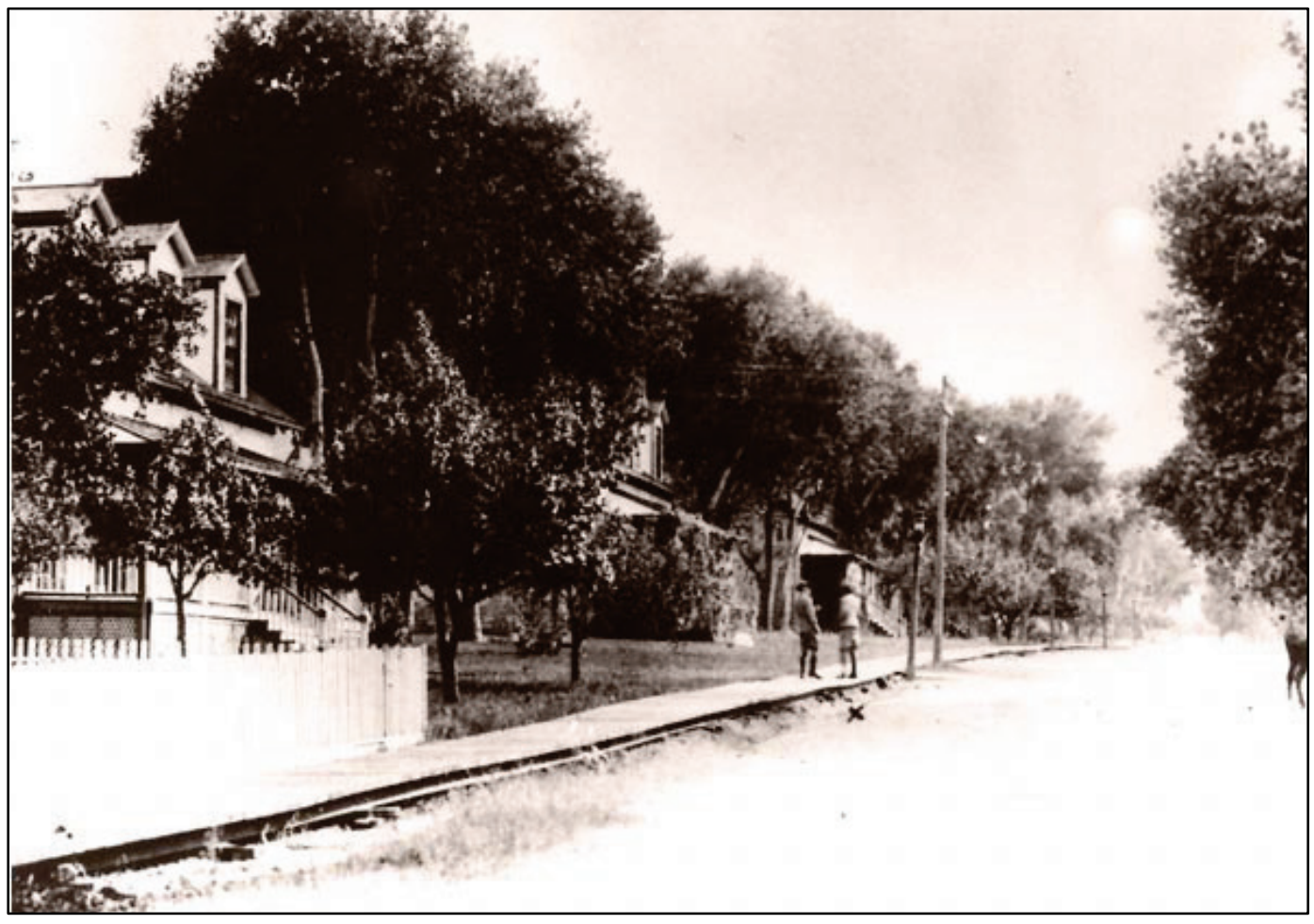

Figure 278. WAAC members arrive by train, 1942 (Fort Huachuca Historical Museum).

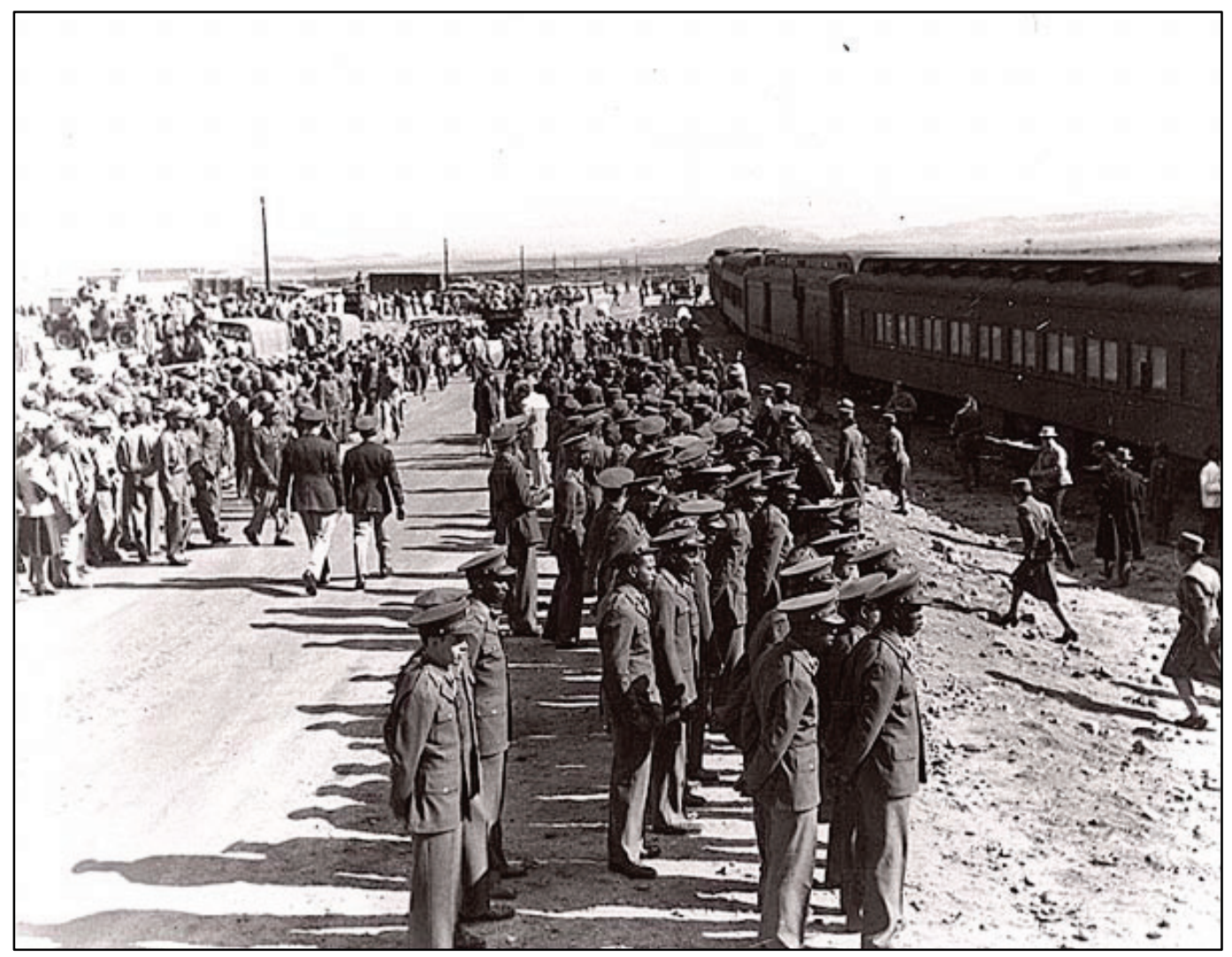


Figure 279. Former Southern Pacific railroad station at Fort Huachuca (located northeast of Old Post), 1943 (Fort Huachuca Historical Museum).

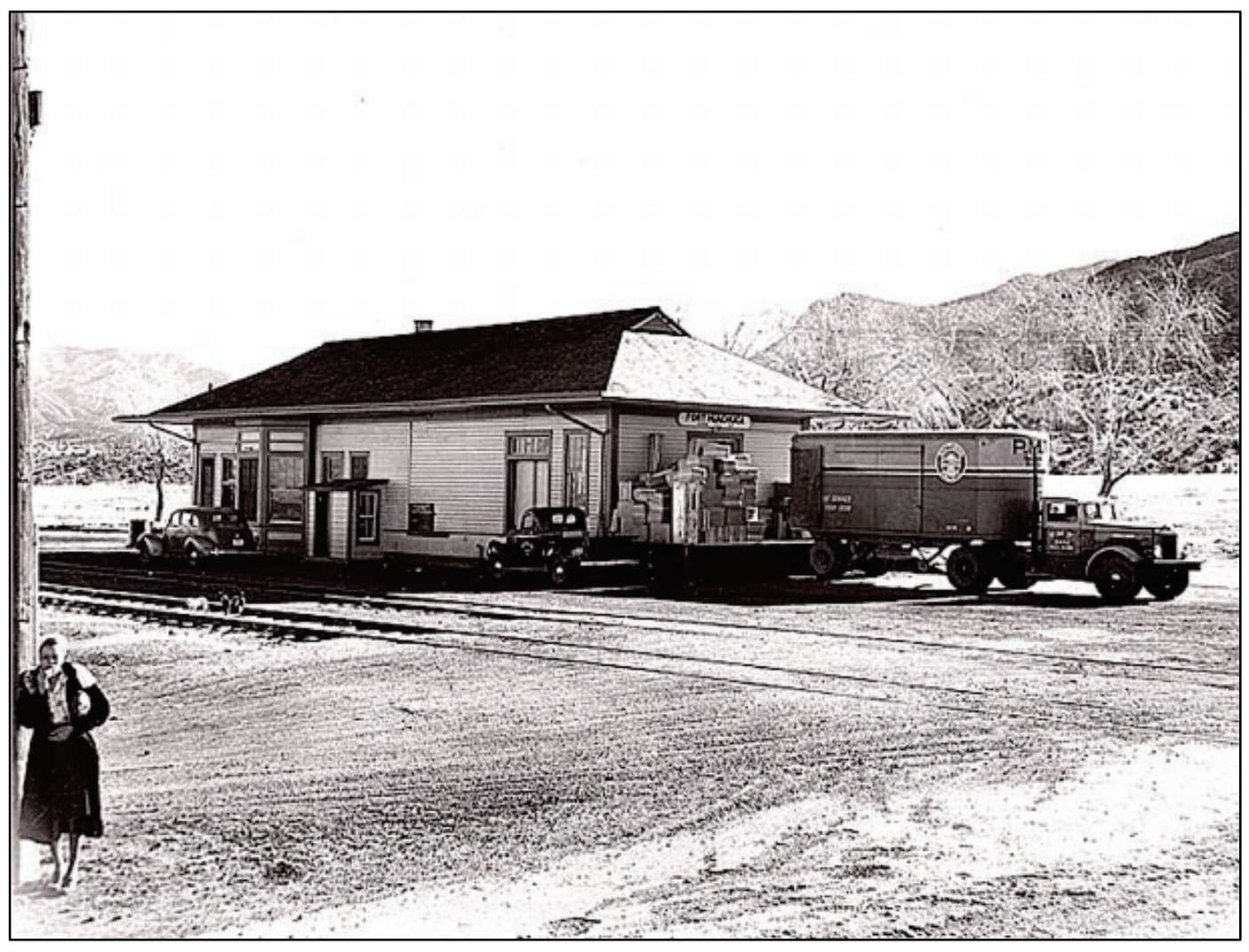


Figure 280. Map showing rail line (green), rail station (magenta), the railroad trestle (green), and railroad worker housing (adjacent to railroad station), 1945 (Fort Huachuca).

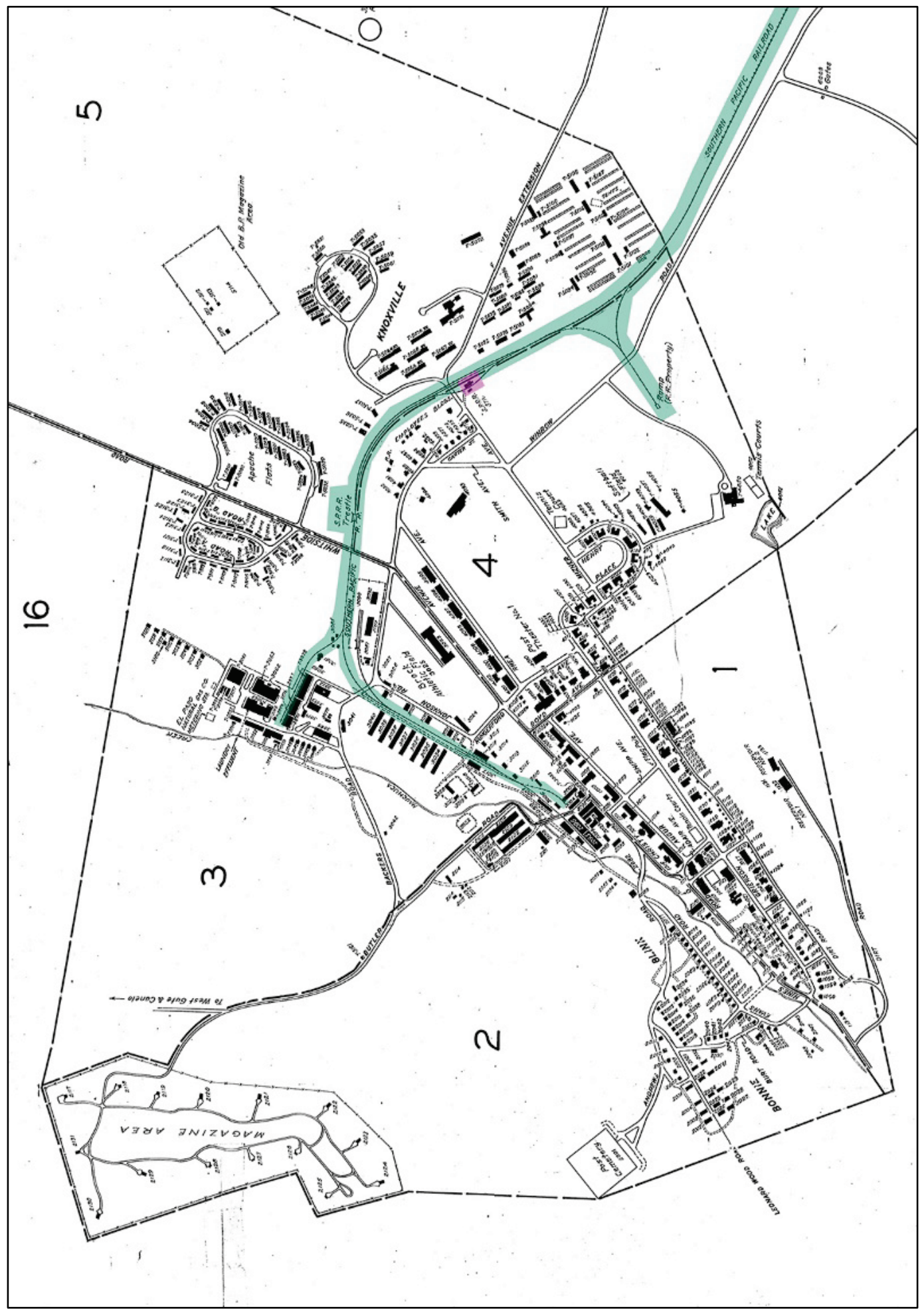


Figure 281. Looking north at remnants of railroad bed just east of stables (ERDC-CERL 2016).

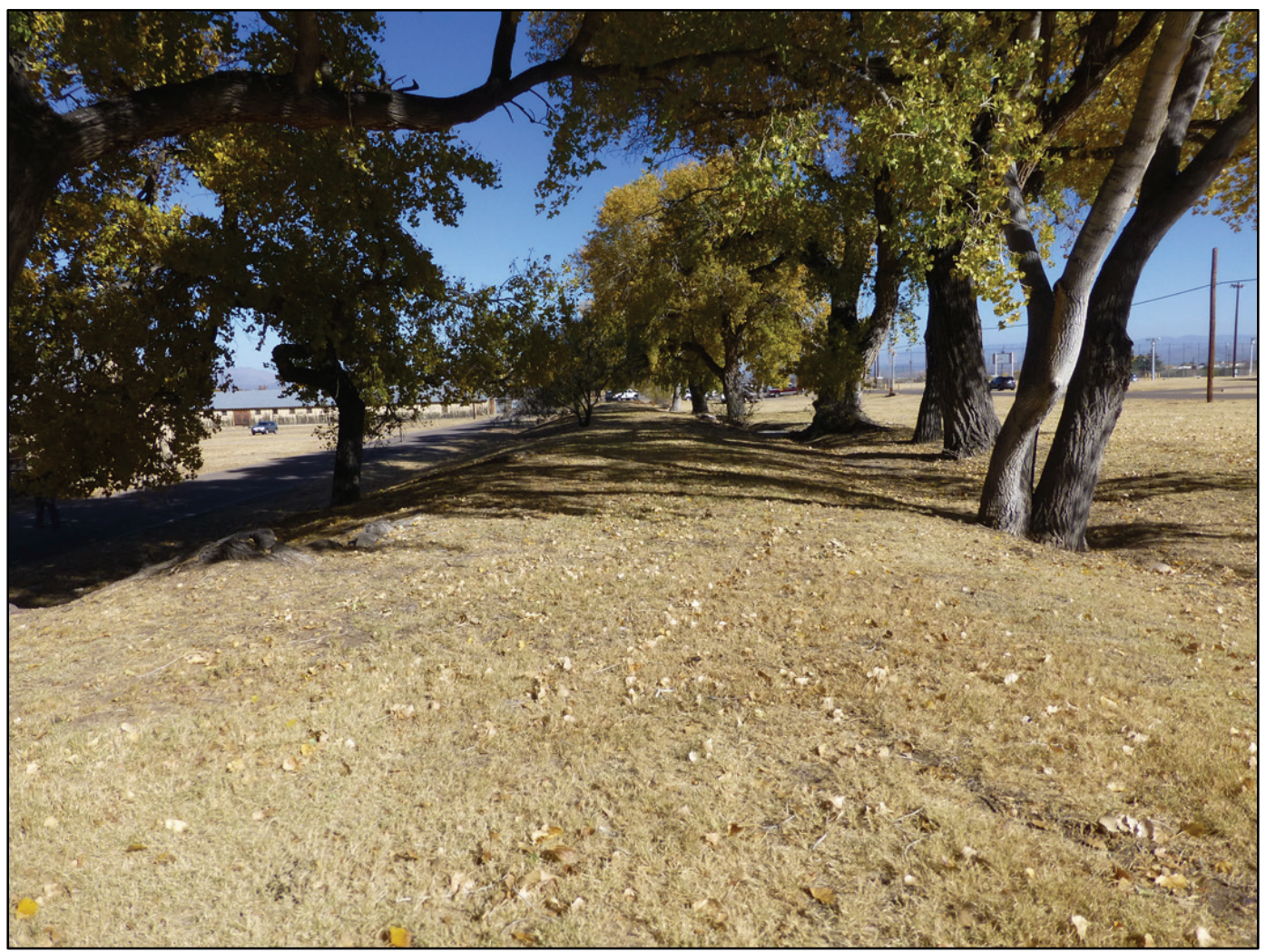

\subsection{Military culture}

Military cultural traditions are reflected on military installations through both spatial organization and design aesthetics. The military is a unique culture that values hierarchy, discipline, utility, and patriotism. These ideologies are physically reinforced in the landscape, giving military installations a distinct appearance and sense of place that makes their design easily recognizable. $4^{1}$

Hierarchy and rank are visible in the layout of the officers' quarters along the eastern edge of the parade field with the commanding officer's quarters in a prominent location with the flagpole in front. The highest-ranking quarters, made of adobe, are prominently located along and facing the parade ground with the duplex quarters along Henry Circle to the north. In addition, the lower ranking officers occupied the frame buildings.

41 Loechl et al. 2009, p. 73. 


\subsection{Buildings and structures}

Clusters of buildings and structures are often similar in style and function as a cohesive unit. Clusters are usually designed to create a symbiotic relationship with the buildings' exteriors and interiors relating to one another through similar scales, mass, styles, or functions. $4^{2}$ The footprints of buildings, their masses, the spaces in between the buildings, and the circulation between buildings are integral to defining the historic landscape.

How the buildings architecturally relate to one another is also important. Because adobe and wood were the predominant construction materials of the buildings at Fort Huachuca, there is an architectural compatibility throughout the original cantonment. There are also consistencies in the massing and architectural detailing of these buildings and open spaces because similarly functioning buildings are grouped together.

The 49 contributing buildings within the Fort Huachuca Historic District NHL represent collectively the plan and function of a late 19th and early 2oth century frontier cavalry post. The post is dominated, visually though not numerically, by structures built during the Apache Wars of the 1880 . These are joined by numerous buildings from the 1910s, when the post was expanded in response to border skirmishes with Mexico. The POS for the NHL historic district extends to 1920, which is the construction date of the newest contributing building. The vast majority of post-1920 buildings are WPA-era small garages and servants' quarters, located at the eastern periphery of the historic district along Grierson Service Road. They do not impact the feeling and character of the historic district, which is clearly that of the 1880 s and 1910s. Note, several servants' quarters (22008, 22106 and 22136) date to 1884 but are still listed as non-contributing to the district. In addition, one former stable (22007) exists from 1880 os, but it was converted to a garage in the 1920 s and is also non-contributing.

The character of the historic district may be appreciated by reference to the period of construction, function, and structural materials. These three characteristics are often closely linked, as different functional building types were built at different times, often using distinctive building methods. 


\subsubsection{Old Post Officers' Quarters}

The Old Post Officers' Quarters were made of adobe brick and prominently located along the parade field. The 14 officers' quarters at Fort Huachuca were built during the 1880 s. Of these, 10 are essentially identical, varying only according to post-1880 modifications. Of the four unique adobe residences, one (Building 22108) was built as a temporary hospital, another as a residence for the post veterinarian (not always an officer; 22102), and a third was built as a duplex for married officers (22104). The fourth unique building is the historic and current residence of the commanding general (22126). It is very similar to the 10 standardized adobe officers' quarters, distinguished by having a larger kitchen and an added ballroom. The plan was a standardized Quartermaster Corps design, commonly built in brick in the East and Midwest.

A number of buildings were constructed in the 1930s to support the households that occupy the adobe quarters along Grierson Avenue. These fall into two basic groups: servants' quarters and garages. The vast majority of these are located behind (east of) the officers' quarters that face Grierson Avenue; the support buildings are generally accessed through Grierson Service Road, at the eastern edge of the historic district. Because these are very small buildings, their construction and maintenance were not recorded with the care given to larger buildings on the post. In addition, coal bins were constructed to serve these households. More research is being done on these structures as they were not included in earlier reports.

\subsubsection{Old Post Barracks}

The Old Post Barracks (Buildings 22208, 22214, 22216, and 22320) were built as part of the original Fort Huachuca post, housing all cavalry troops. As such, they represent the functional core of the district, in addition to their large physical presence. Three of the four barracks (Buildings 22214, 22216, and 22320) were designed to house a 65-man company and associated non-commissioned officers and service personnel. Building 22208 was built as a double-company barracks for 130 men. All four are currently used as office space for various administrative functions. Latrines were added west of these barracks between 1903 and 1916 (Buildings 22210, 22214, 22218, and 22322). 


\subsubsection{Duplex Officers' Quarters}

The Fort Huachuca Historic District includes 14 frame officers' quarters, built during the second decade of the 2oth century. The quarters are located along Grierson Avenue, beginning north of the Morrow House, the most northerly of the 188 os adobe officers' quarters, and extending north along Grierson to Henry Circle. At Henry Circle, the buildings are arranged around an ellipse formed by Henry Circle, with a horseshoe-shaped park at the front. The 13 duplexes built for married officers and their families are practically identical. Each is a two-story frame building with a side gable roof and twin cross gable extensions to the rear. The living quarters - the two sides of the duplex -- are mirror images. The most dominant element of the facade of each building is a two-story porch. The porches were designed to be opened but were enclosed almost as soon as the buildings were occupied. The buildings were constructed in 1914-17, and most, if not all, porches were enclosed by 1918 . The fourteenth building is quarters for bachelor officers. It is nearly identical to the 13 duplexes in its facade elevation but is, of course, very different in plan. Coal bins were added to the properties in 1920. Garages were built behind the quarters in 1936. These are outside the NHL historic district boundary (except for 22021, 22022 and 22023), and some coal bins were attached to the garages.

\subsubsection{Barracks}

During the period 1914-17, the facilities at Fort Huachuca were expanded dramatically to accommodate an enhanced border patrol mission for the cavalry in the politically unstable period following the Mexican Revolution in 1913. The officers' duplexes along Henry Circle reflect that expansion but not as dramatically as the seven barracks along Rhea Avenue. These large 76-man company barracks tripled the troop capacity of the post and indicated forcefully that the post had been revitalized with major responsibilities for maintaining law and order along the international border. The seven barracks were built in a line on Rhea Avenue, which continues the plane of the western side of the parade ground. The 1914-16 Barracks were clearly patterned after the older barracks but were not identical to them. The 1914-16 Barracks were identified as Quartermaster Plan No. 299, while the older barracks were identified as "local plans."

\subsubsection{Old Post Administration and Recreation buildings}

The original administration buildings were built along the north end of the parade field in both adobe and wood. The recreation buildings were built 
along the south end of Brown Field. A theater (Building 41305) was added to the southeast corner of the North Parade Field in 1934. It was built using standardized plans. These buildings are key aspects of the Fort Huachuca Historic District as they represent different time periods and styles of construction, but their common architectural materials contribute to the overall integrity of the Old Post Cantonment.

\subsection{Vegetation}

Vegetation is a characteristic of the landscape that has a relationship to land use patterns. 43 Differences in vegetation patterns can delineate boundaries, land use areas, and natural areas such as streams or ravines. In the military context, how vegetation is used can connote ceremonial, residential, training, or utilitarian areas. For example, residential neighborhoods are often the most heavily planted areas on military installations while open spaces allow for gatherings or training. Additionally, prominent support buildings, such as headquarters, chapels, hospitals, and officers' clubs, tend to have more decorative landscaping than utilitarian buildings, such as motor pools, warehouses, and stable areas.

\subsubsection{Old Post Officers' Quarters}

After the essential buildings were constructed, the permanent military landscape of Fort Huachuca took shape. The line of officers' quarters became more attractive as many trees were planted, lawns were established, and quarters occupants gave an individual touch to foundation plantings, flower beds and gardens to the rear. A white picket fence ran along the length of the front of these quarters for several years around the turn of the century but was removed prior to 1936 according to old property cards. Some fences remain at the rear of the quarters today (Figure 282).

Today the foundation plantings consist mostly of ornamental trees accenting the doors and corners and evergreen shrubs. The evergreen shrubs offer year-round green color but require maintenance to maintain manicured shapes. A few quarters have very little foundation plantings. Cottonwood trees are located behind the quarters (Figures 283-286).

43 Loechl et al., 2009, p. 83. 
Figure 282. View to the east of officers' quarters with vegetation and white picket fence, 1899 (NARA College Park, RG1111-SC).

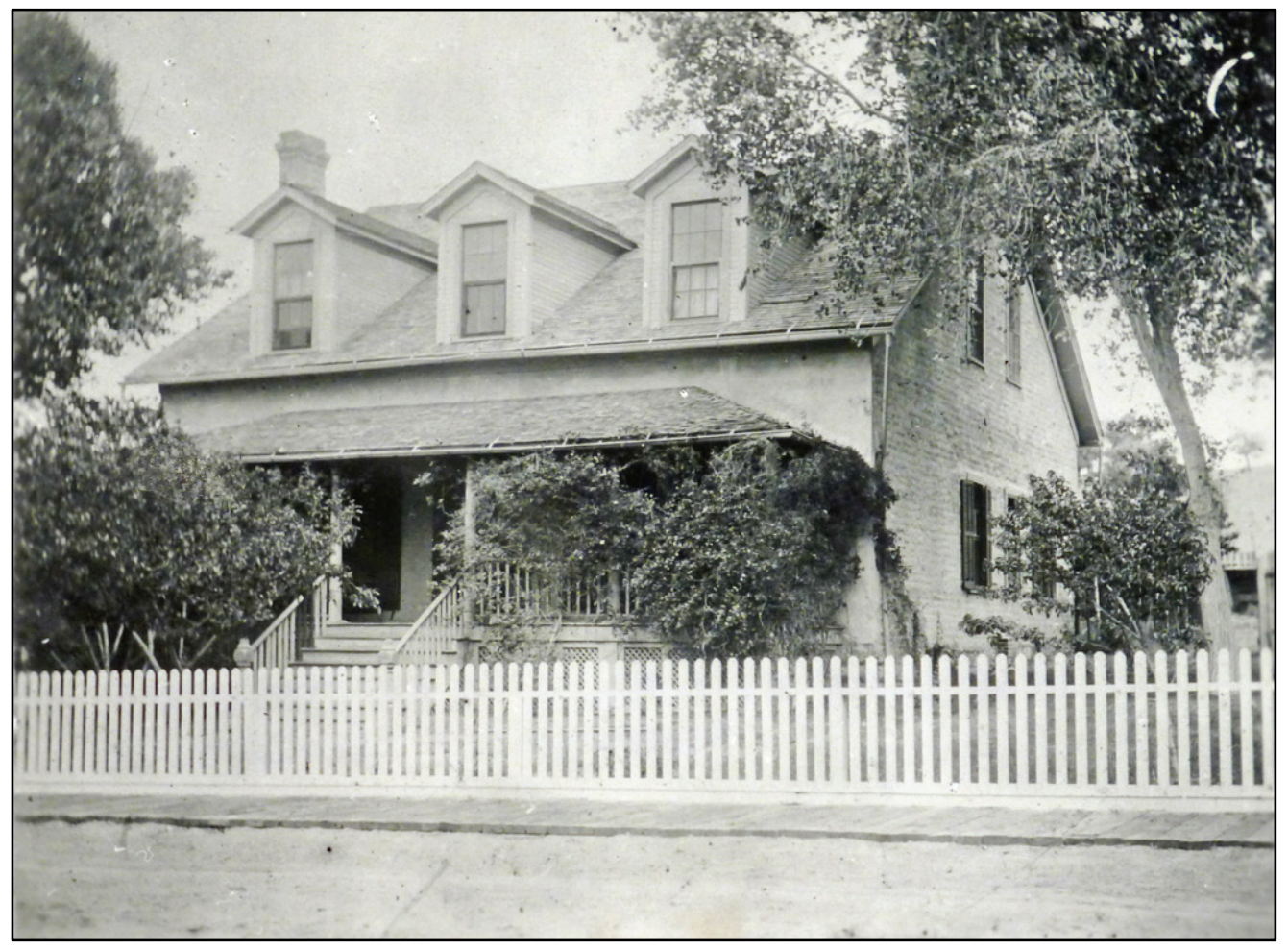

Figure 283. View to the southeast of foundation plantings at 22114 (ERDC-CERL 2016).

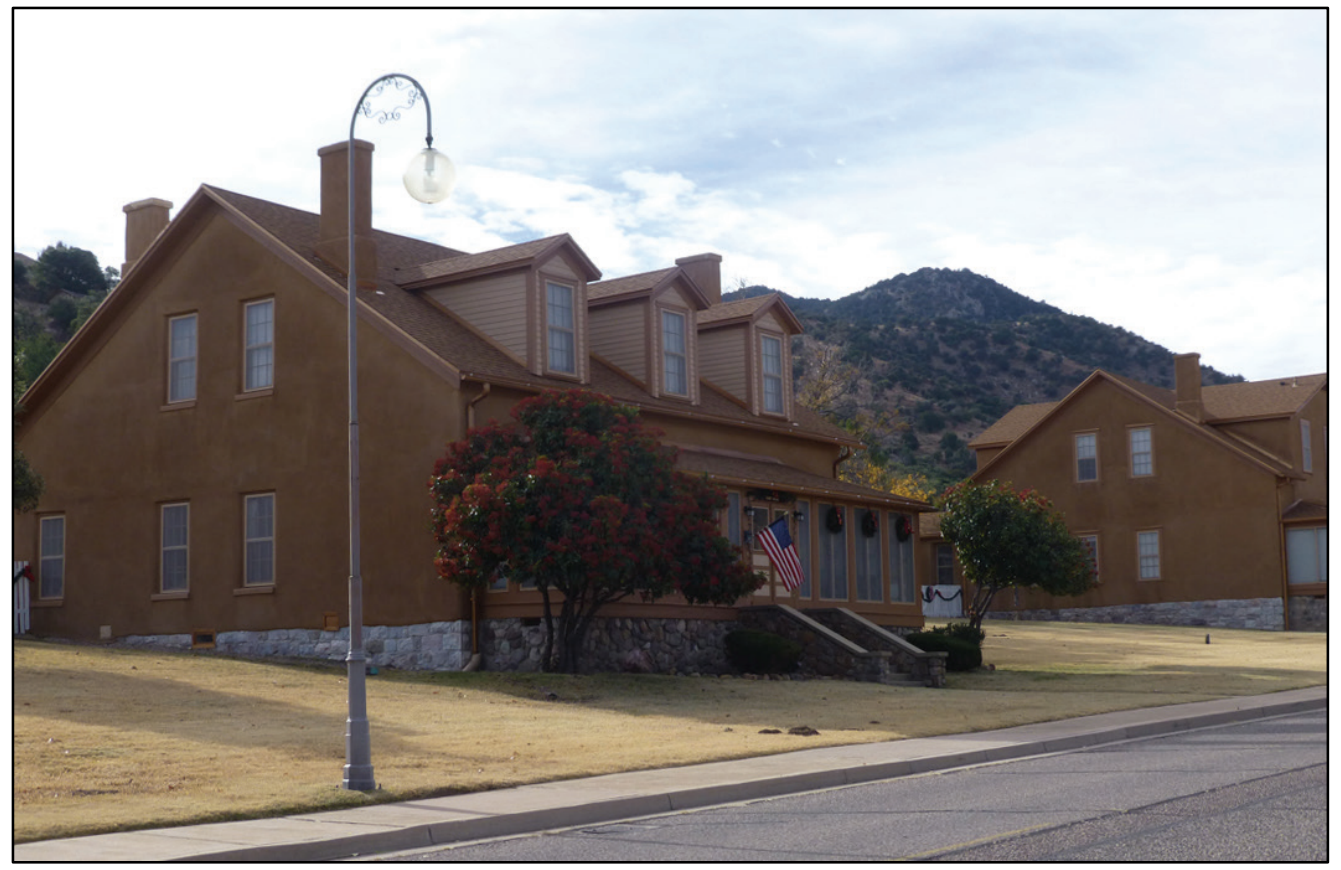


Figure 284. View to the northeast of foundation plantings at 22120 (ERDC-CERL 2016).

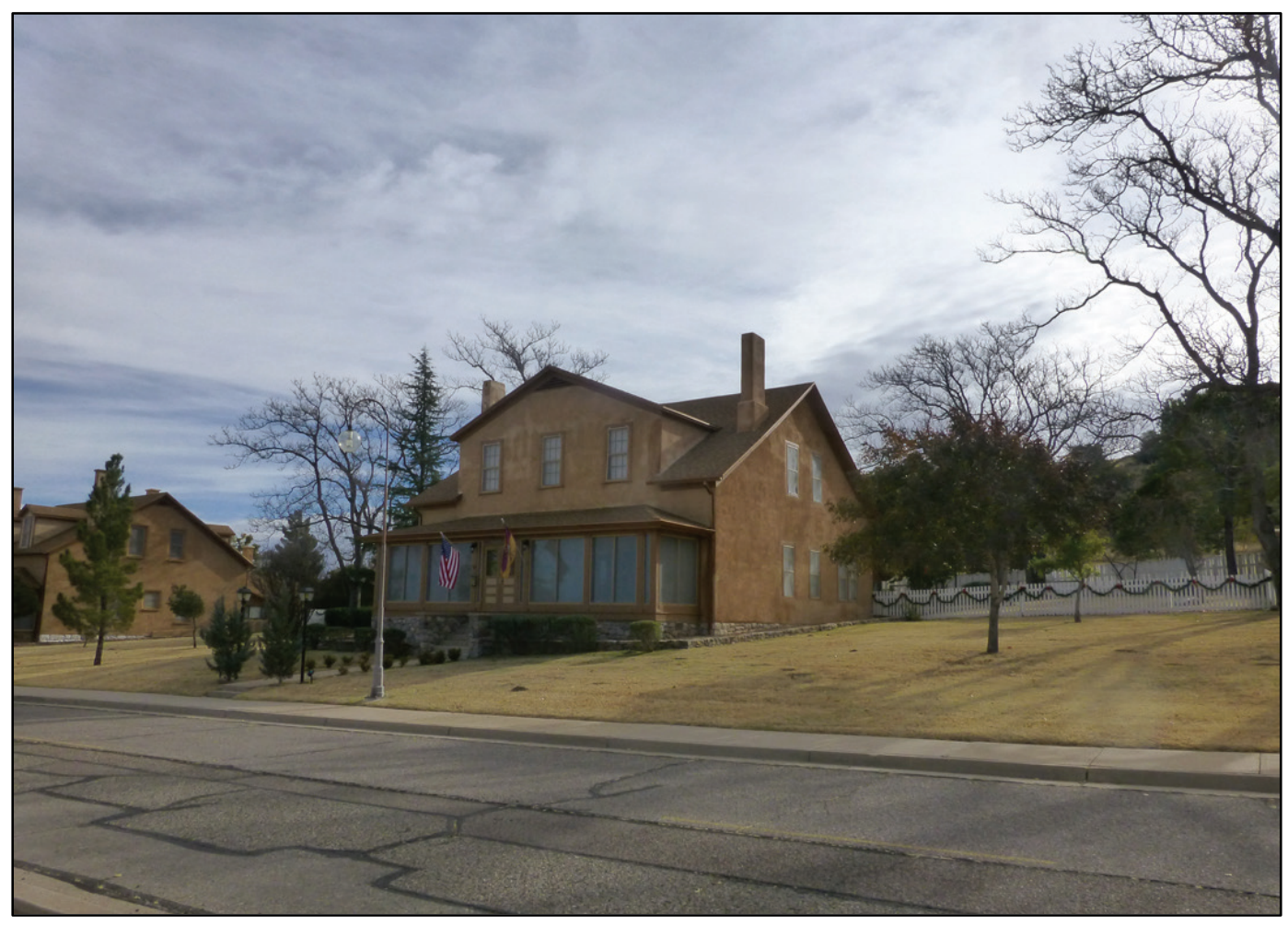

Figure 285. View to the northeast of plantings at 22126 (ERDC-CERL 2016).

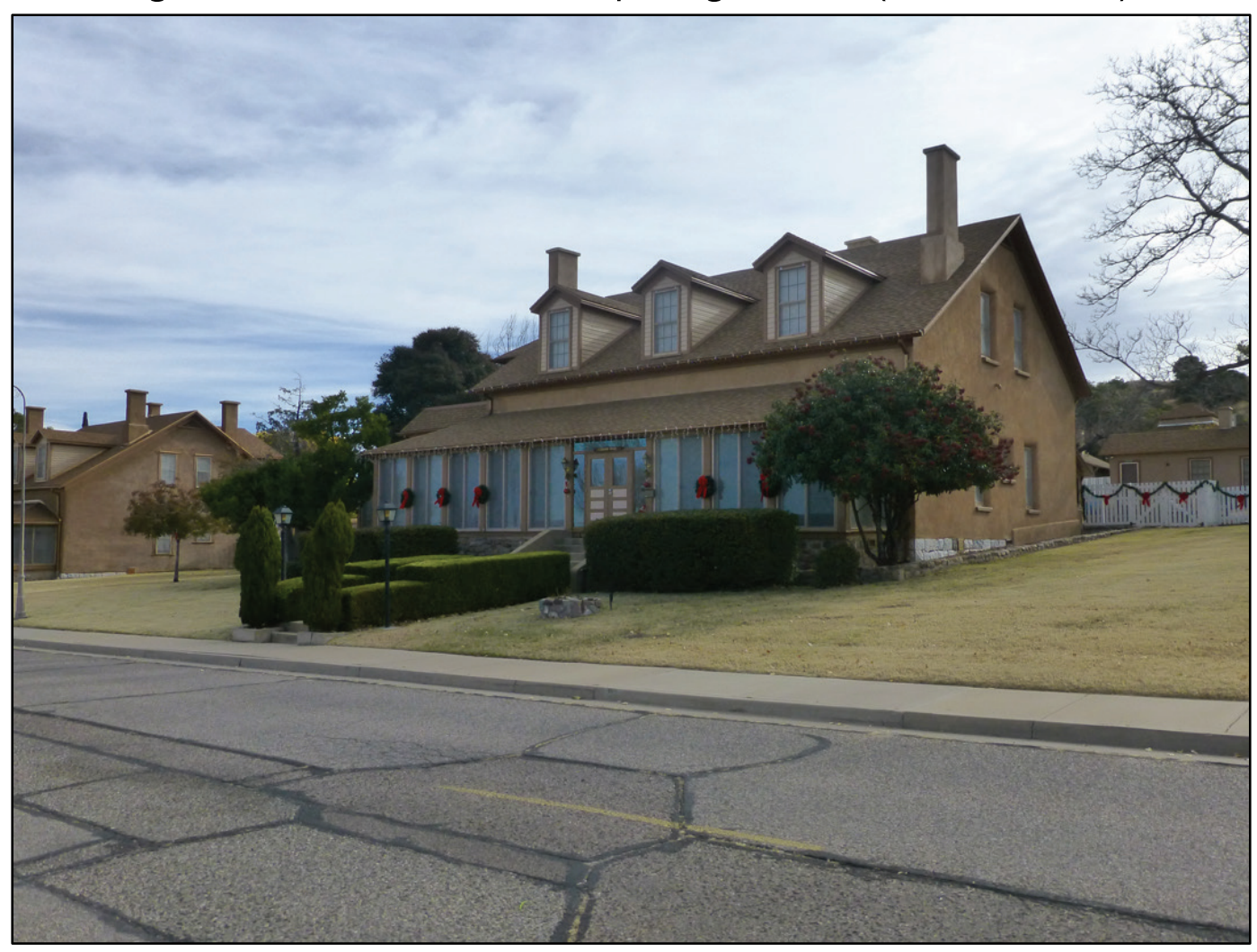




\subsubsection{Old Post Barracks}

The line of barracks across the field garnered less attention, with some shade trees planted in between the buildings and scattered low plantings along the facades. Today, many of the plantings along the foundation have died and not been replaced. Other plantings have overgrown the allotted space as parking is now allowed along the roadways in front of the former barracks (Figures 286 and 287).

Figure 286. Landscaping in front of 22215 (ERDC-CERL, 2016).

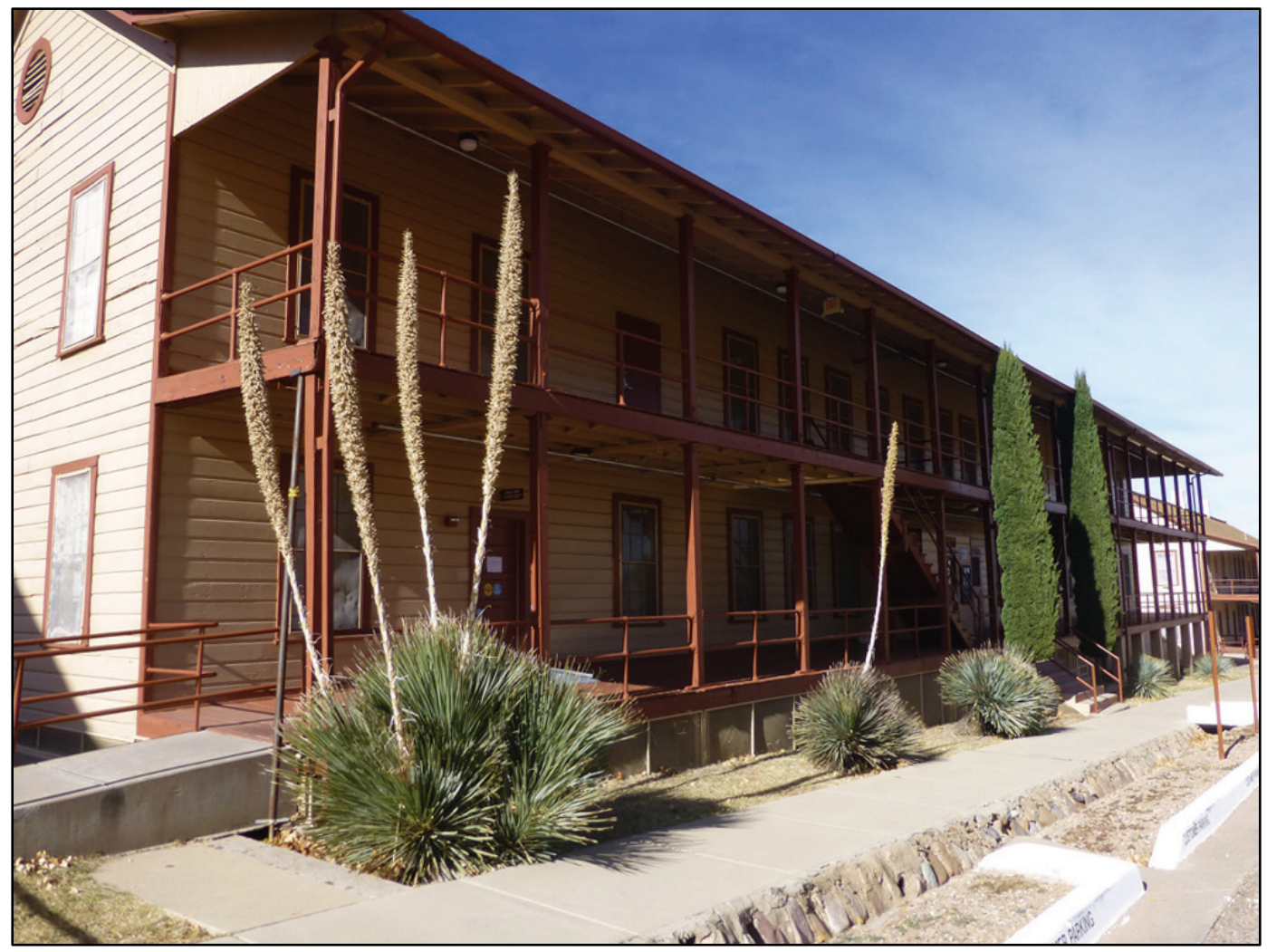


Figure 287. Old Post area barracks (22208) with a lack of foundation plantings (ERDC-CERL, 2016).

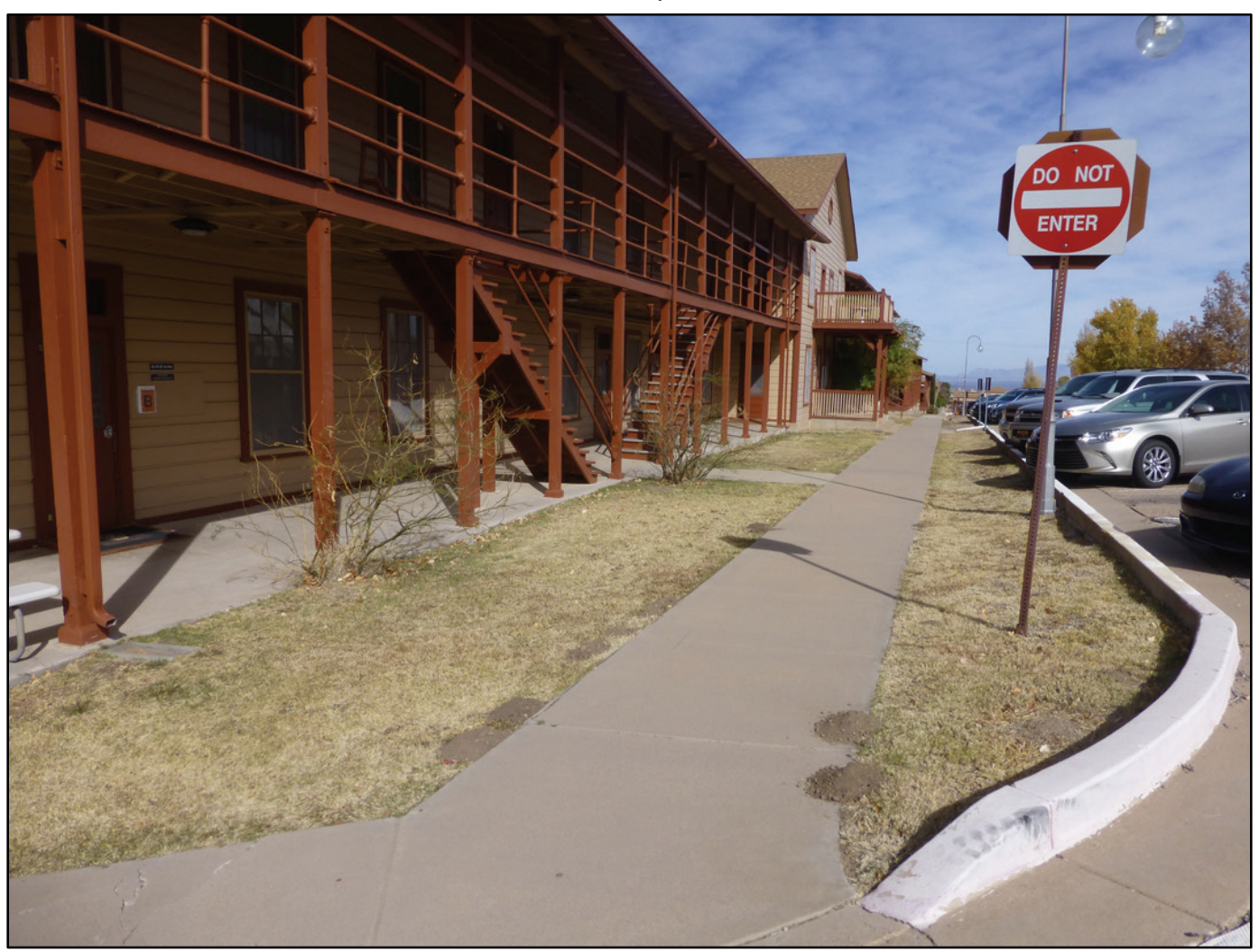

\subsubsection{Brown Field}

The parade field was sowed with grass seed in the early years, which ultimately helped reduce blowing dust during dry periods and the mud that appeared after intense rainstorms. Tall shade trees were planted in tight, formal rows along the two long sides of the parade field, while those in the middle of the field were removed. A small grouping of trees remained at the upper end of the parade field, establishing a pattern that has remained to the current day. The lower end was left more open for views, until additional buildings were constructed, partially obscuring the view of the valley (Figure 288).

These landscape improvements gradually enhanced the appearance of the fort as well as the quality of life of post personnel and residents. As the original configuration of the post was expanded to include Henry Circle and Rhea Avenue, similar landscape improvements were implemented. The Historic District landscape, as it exists today, retains a remarkable level of integrity and character. Today, there are fewer trees planted along the parade field (Figure 289). 
Figure 288. View to the northwest of foundation plantings in front of Old Post Barracks $(22208,22214,22216), 1946$. [Note also row of shade trees along edge of Brown Field] (Fort Huachuca Museum).

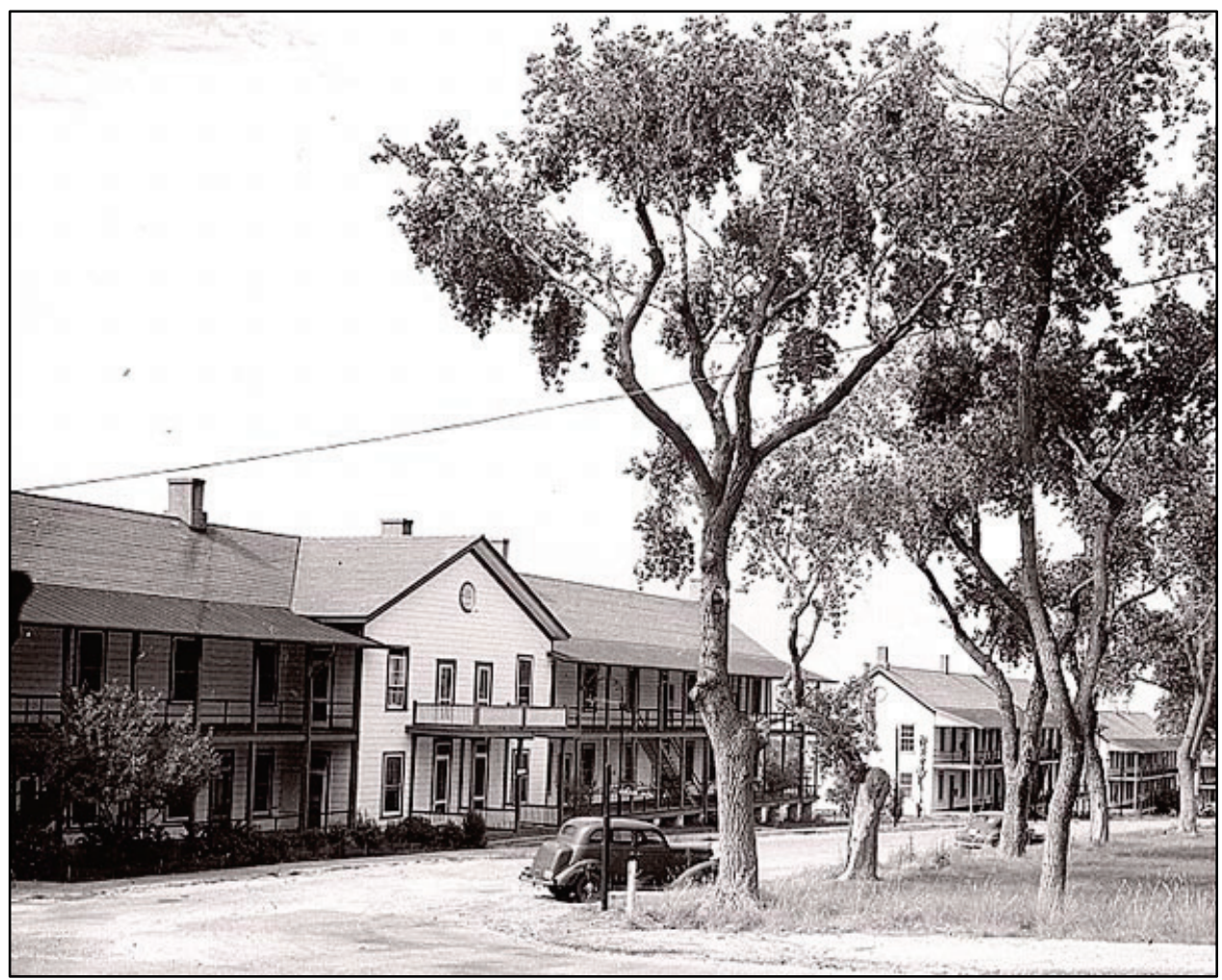

Figure 289. Same view in 2016 showing that few trees remain along edge of Brown Field (ERDC-CERL 2016).

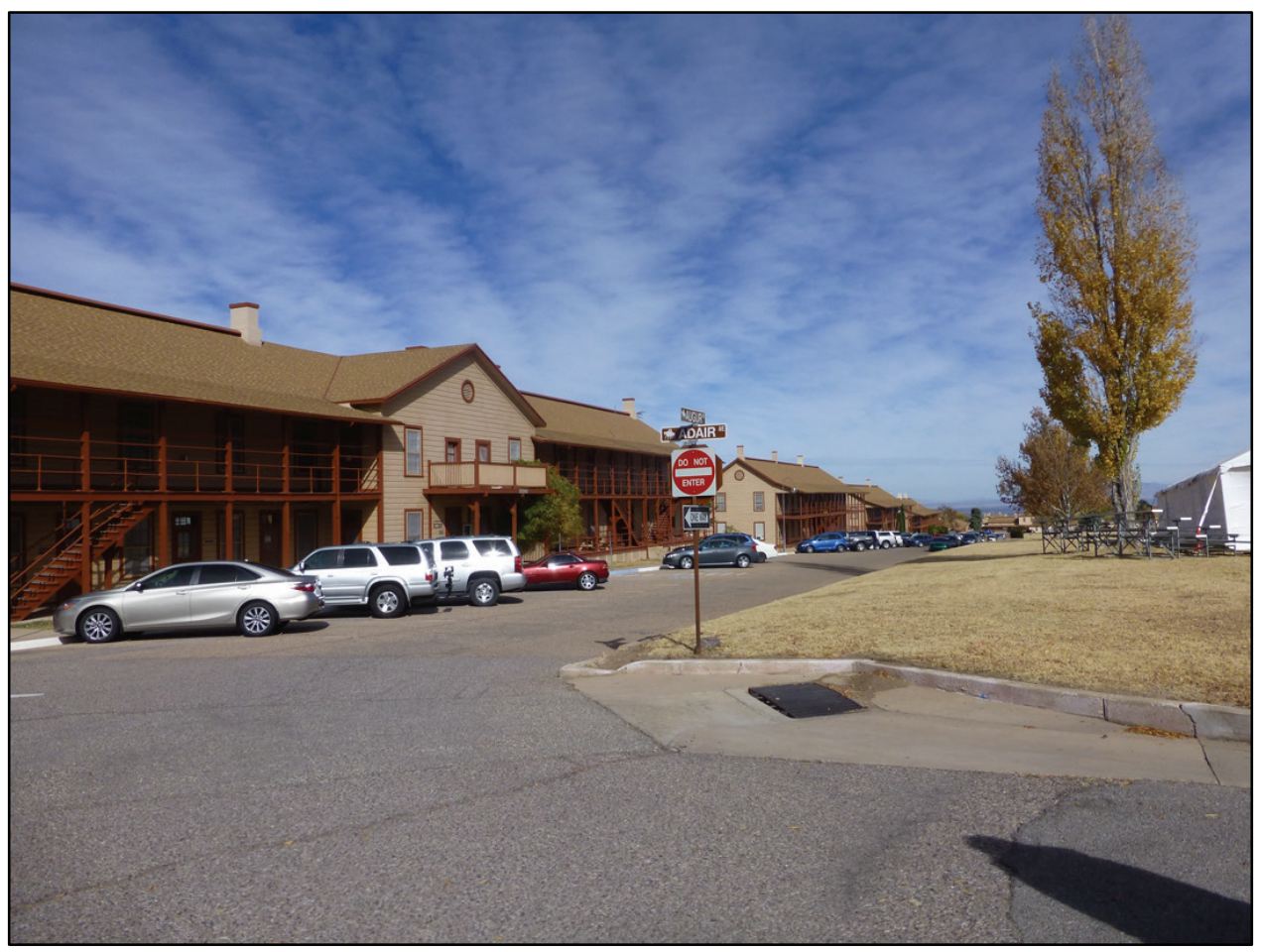




\subsubsection{Officers' Quarters}

The plantings in front of and around the Officers' duplexes varied. By the 1940 , ornamental trees are seen in the front yards, and vines and some small shrubs were planted along the foundations (Figures 290-292). Today, few foundation plantings remain, but some overgrown evergreens are located in the front yards of the duplexes (Figures 293-295).

According to a 1929 aerial photograph, an orchard was once planted in Henry Circle with a row of street trees along Mizner Avenue (Figure 296). Today, no vegetation remains in the center of the circle, but two rows of trees have recently been planted along the Mizner Avenue at end of the circle to try and screen the new housing area across the street (Figure 297 and 298).

Figure 290. Officers' duplex (42011), 1941 (NARA College Park, RG111-SCA).

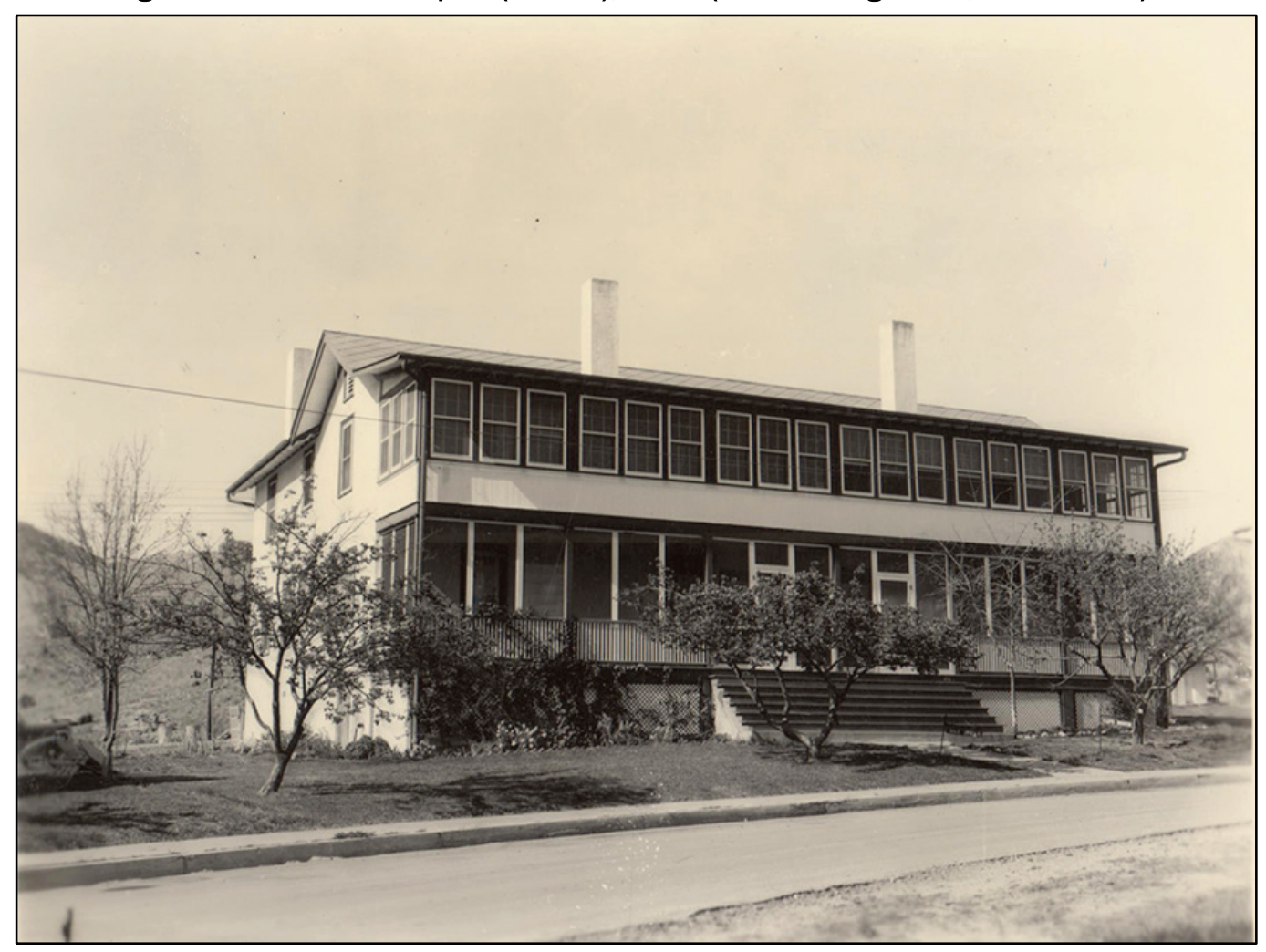


Figure 291. Officers' duplex (former Quarters 116), 1941 (NARA College Park, RG111-SCA).

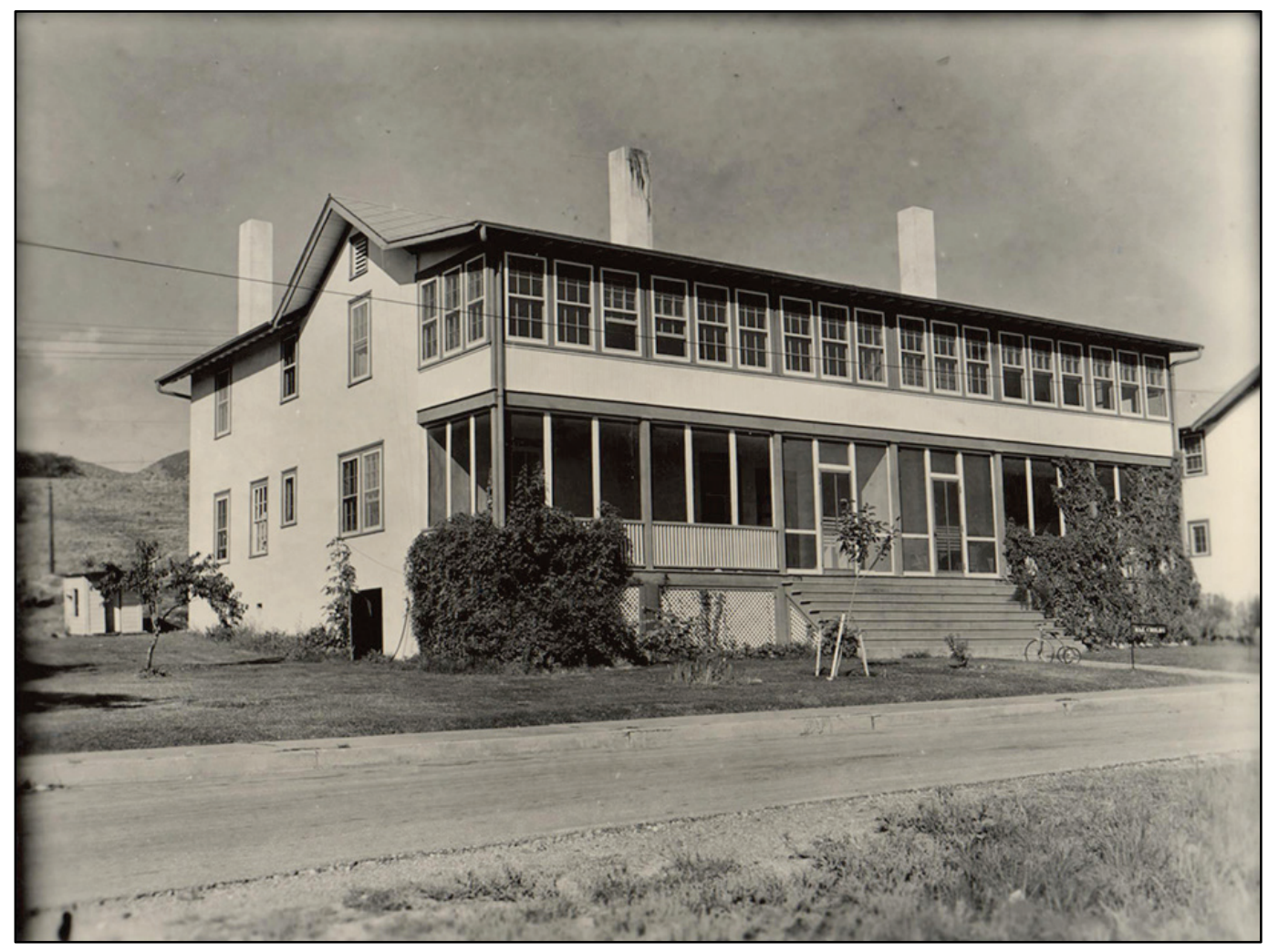

Figure 292. Officers' duplex (former Quarters 120), 1941 (NARA College Park, RG111-SCA).

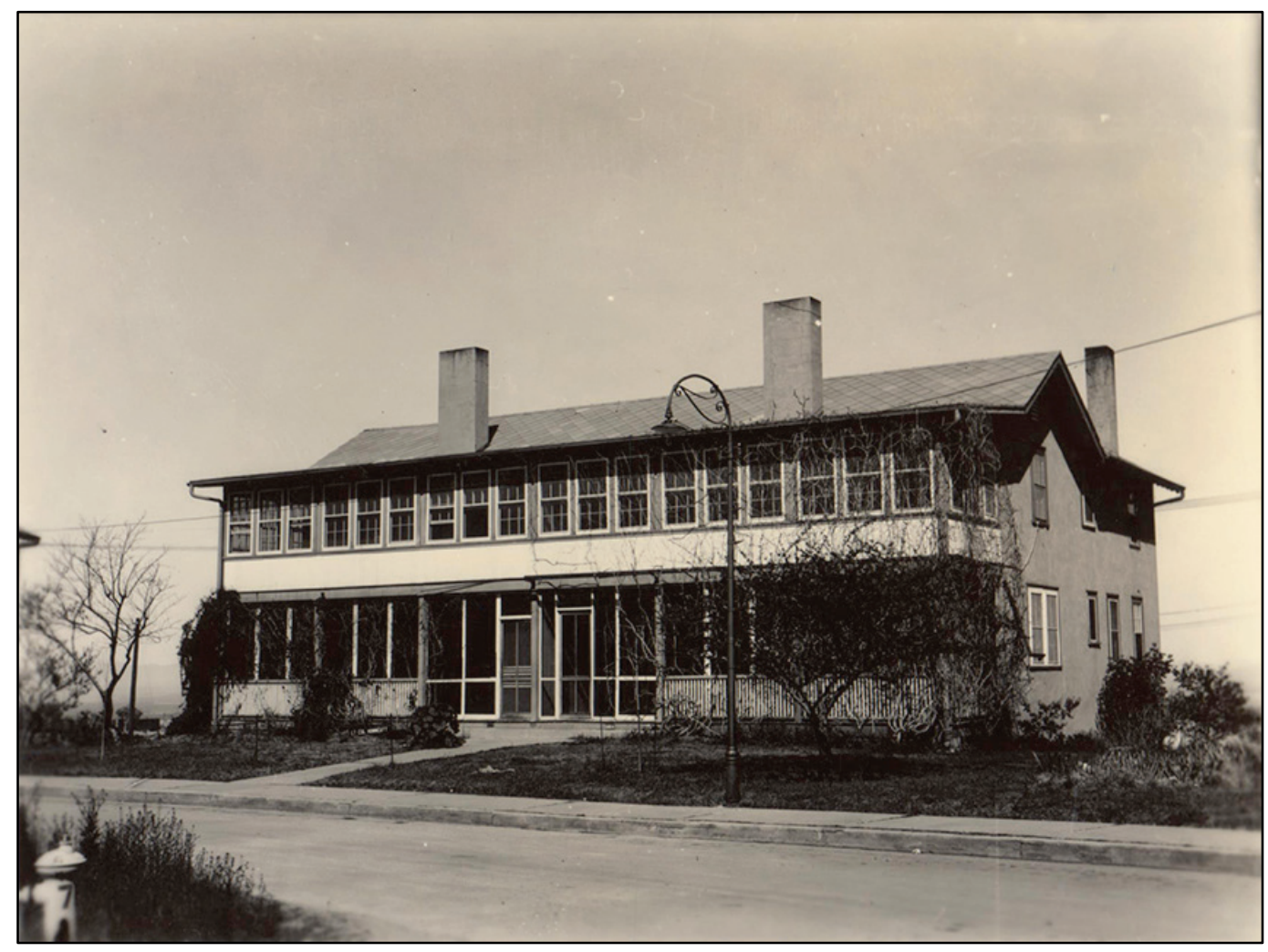


Figure 293. Plantings in front of 42017, Henry Circle (ERDC-CERL 2016).

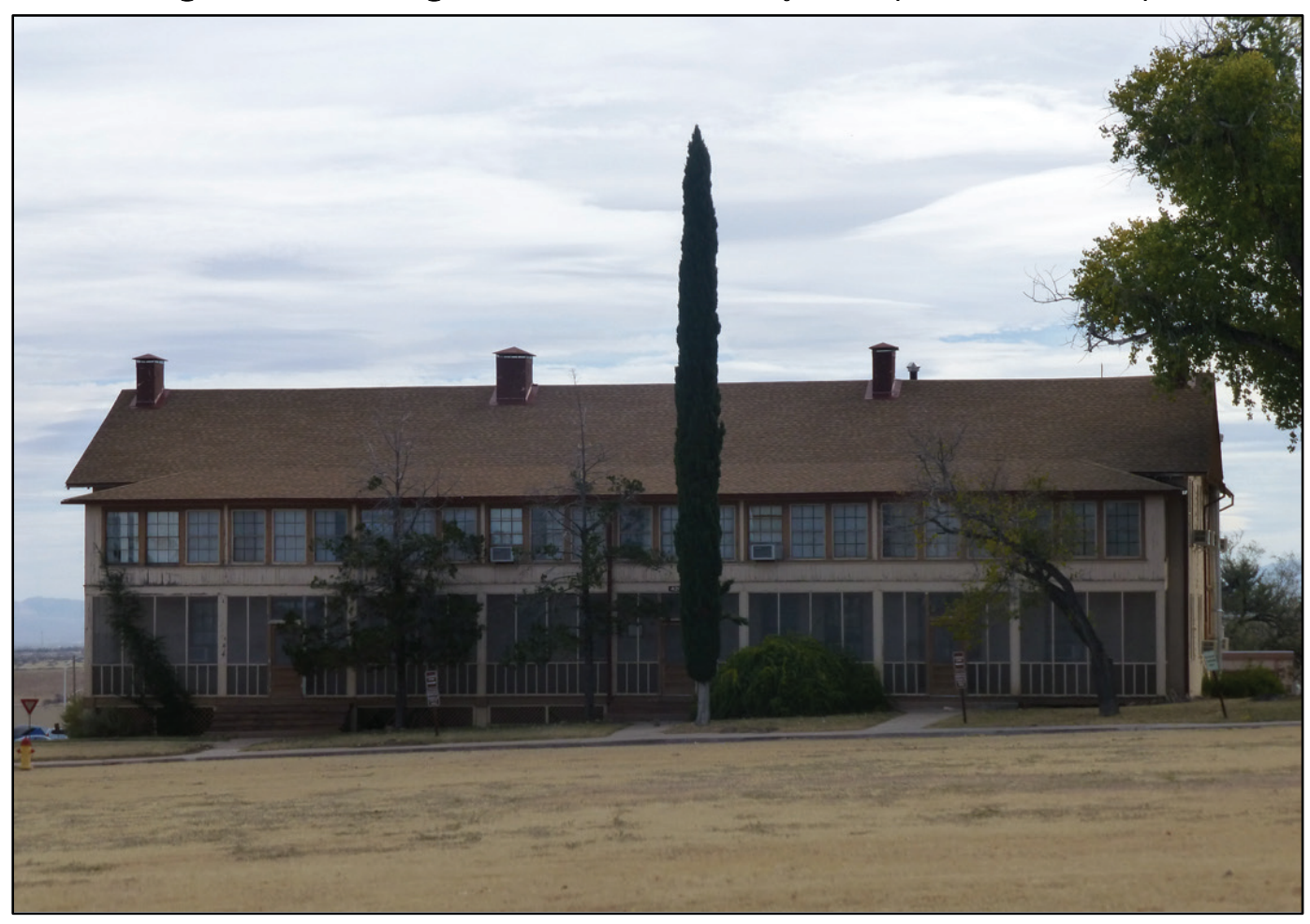

Figure 294. Officers' duplex (42018), Henry Circle (ERDC-CERL 2016).

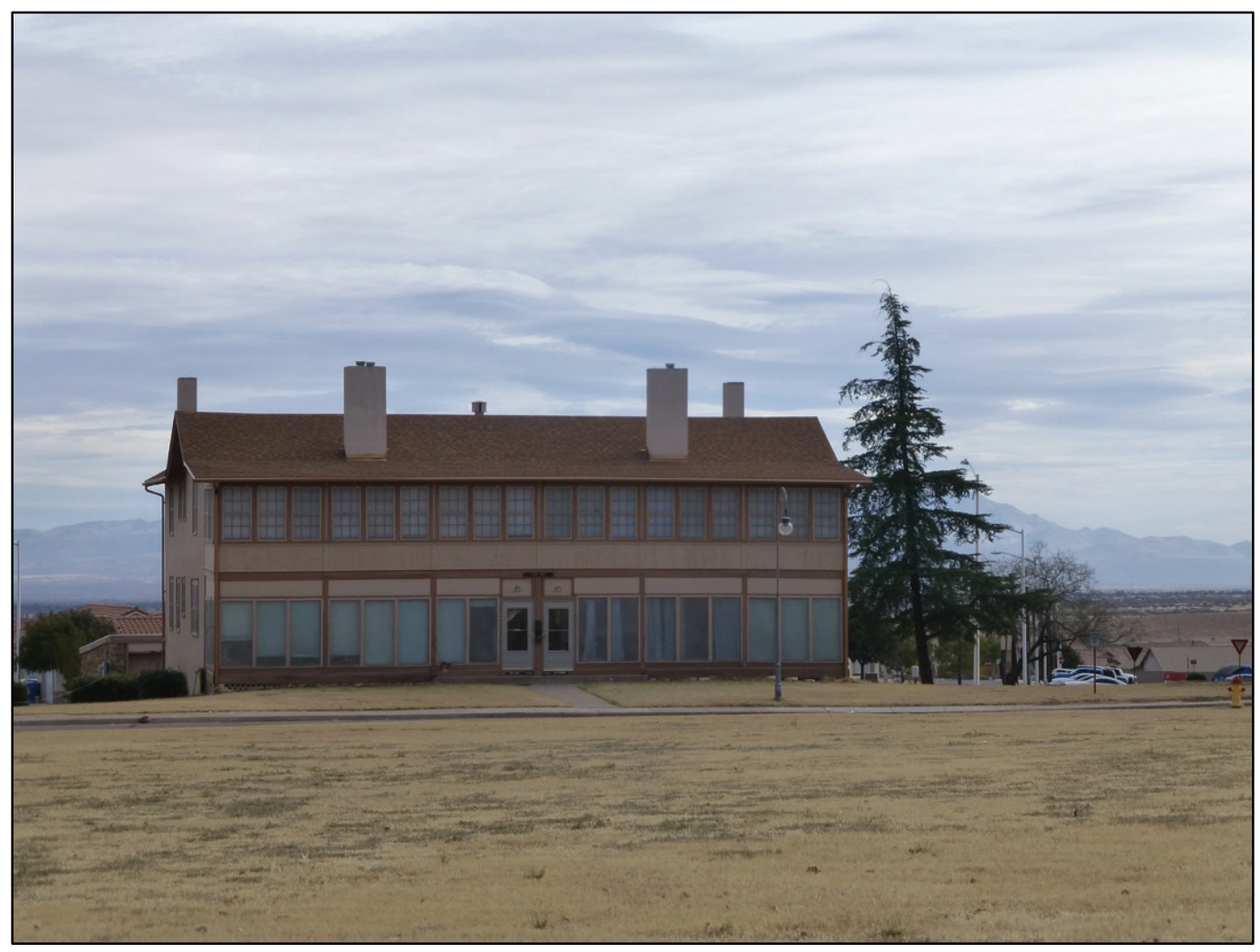


Figure 295. Officers' duplex (41021), Henry Circle (ERDC-CERL 2016).

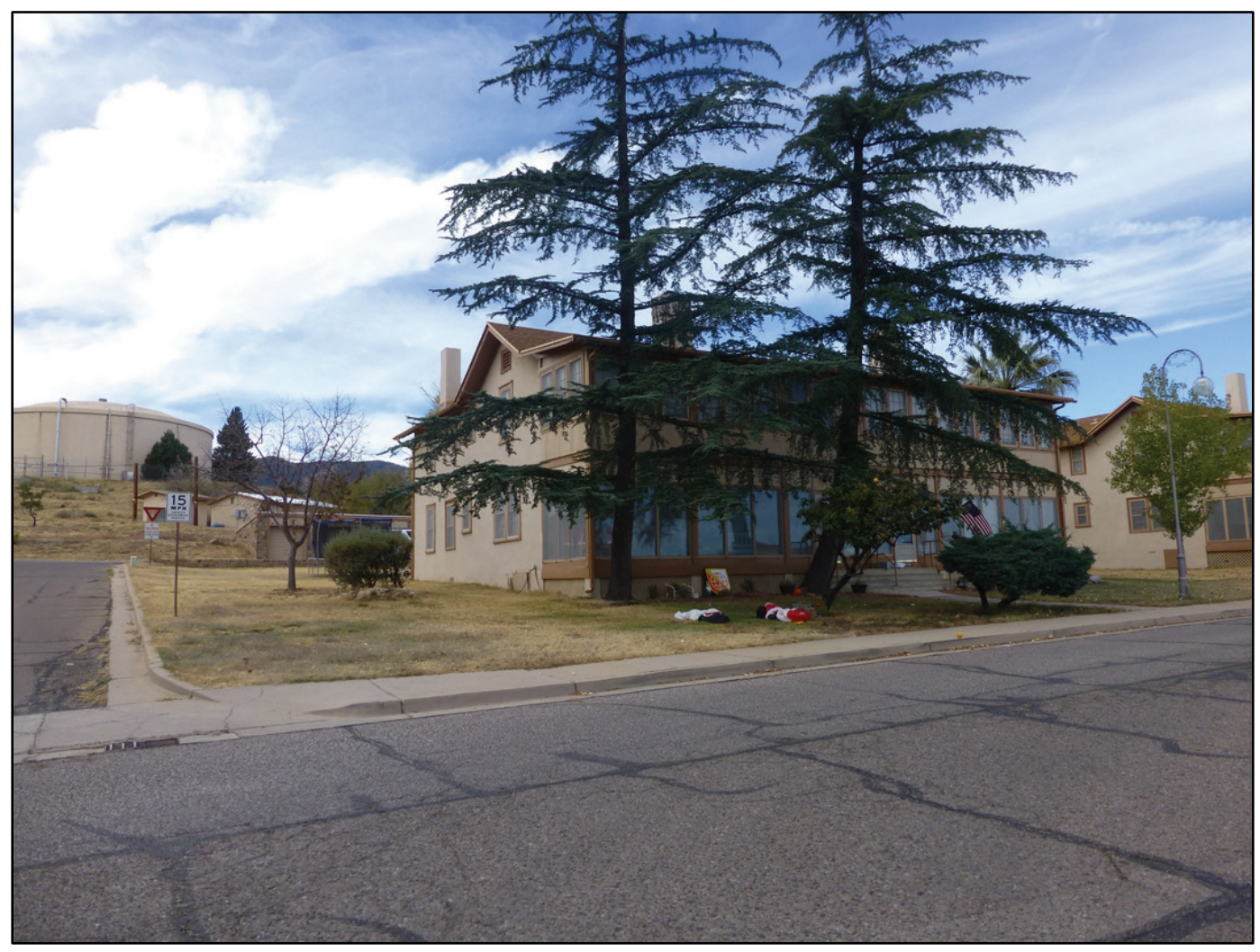

Figure 296. Aerial of Henry Circle showing orchard, 1929 (NARA College Park, RG165-FF).

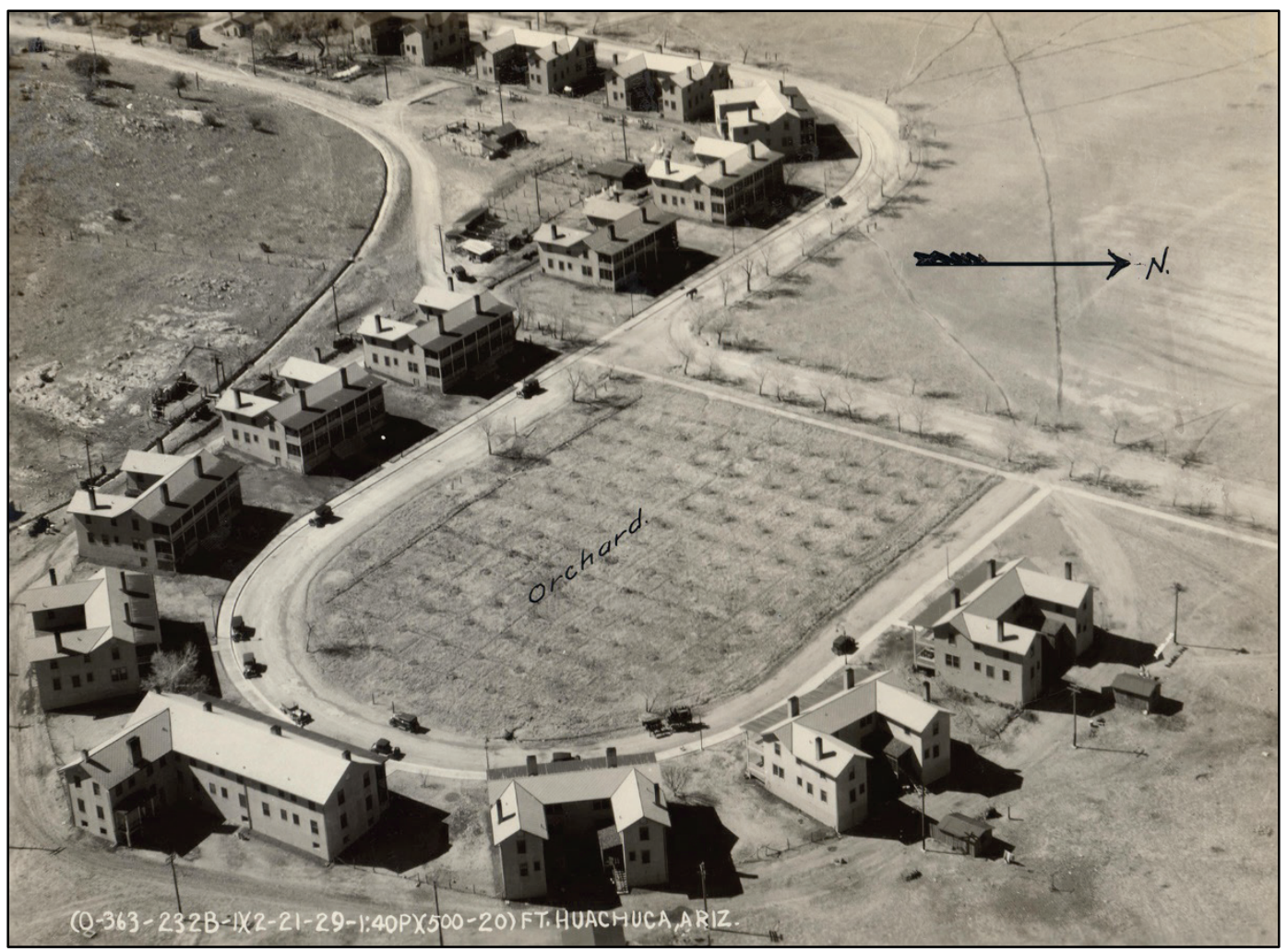


Figure 297. View looking southeast at mature trees at corner of park, Henry Circle (ERDCCERL 2016).

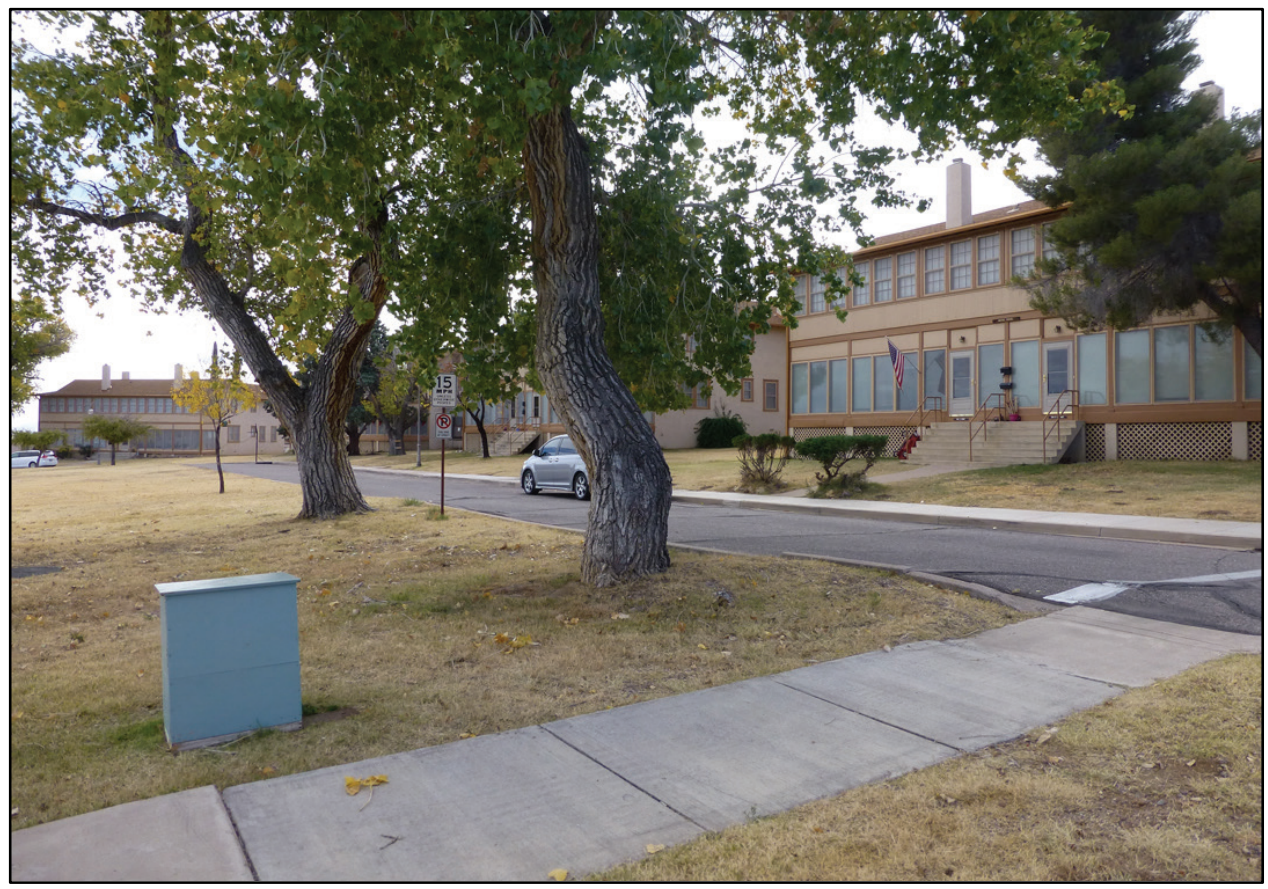

Figure 298. Newly planted trees in Henry Circle along Mizner Avenue to screen modern neighborhood (ERDC-CERL 2016).

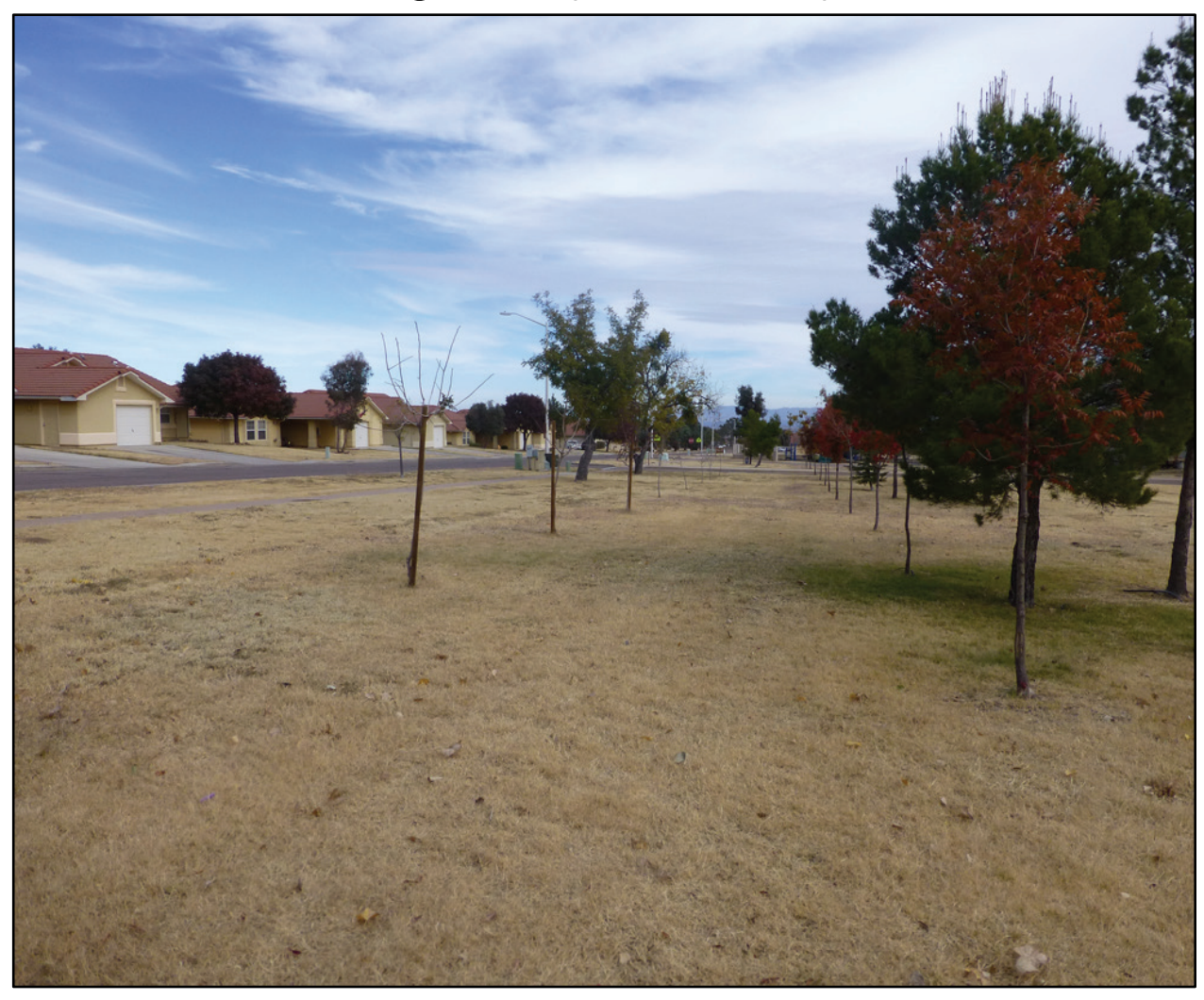




\subsubsection{Barracks}

Historically, the 1914 Barracks had few if any foundation plantings, although early photographs show shade trees planted along the edge of North Parade Field in front of the barracks (Figure 299). These trees were removed prior to WWII (Figures 300 and 301). Today, all but one of the barracks have any foundation plantings (Figures 302 and 303). Very few trees remain in this area today, as it is mostly parking lots and a new trail with interpretive signage (Figure 304).

Figure 299. $10^{\text {th }}$ Cavalry review, 1921 [Based on topography, it is likely this is the North Parade Field. Note the heavily planted trees along the edge of the field in front of barracks.]

(Fort Huachuca Historical Museum).

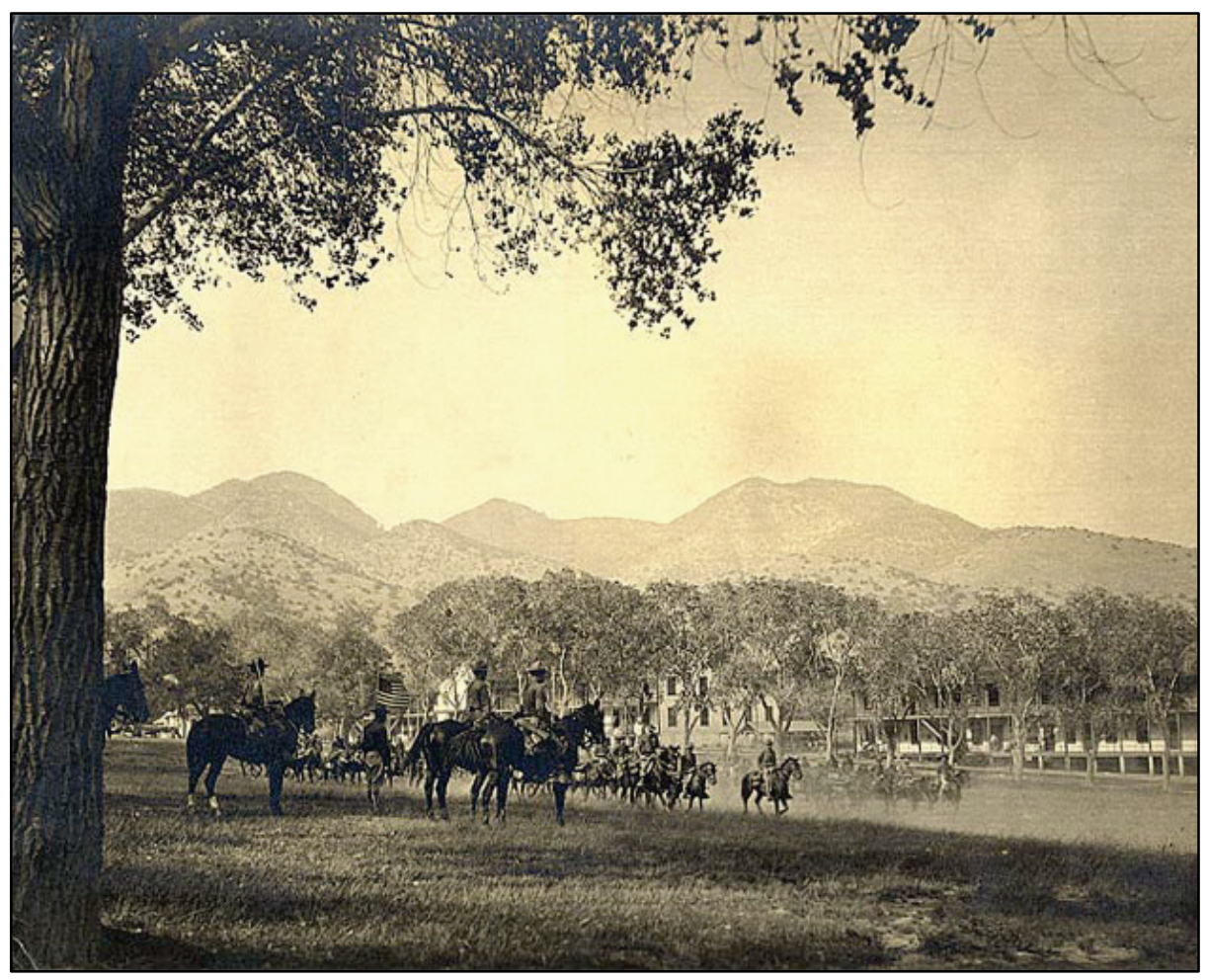


Figure 300. View looking west at barracks (41414), no date [Note lack of plantings.] (NARA College Park, RG77 Entry 393 Box 95).

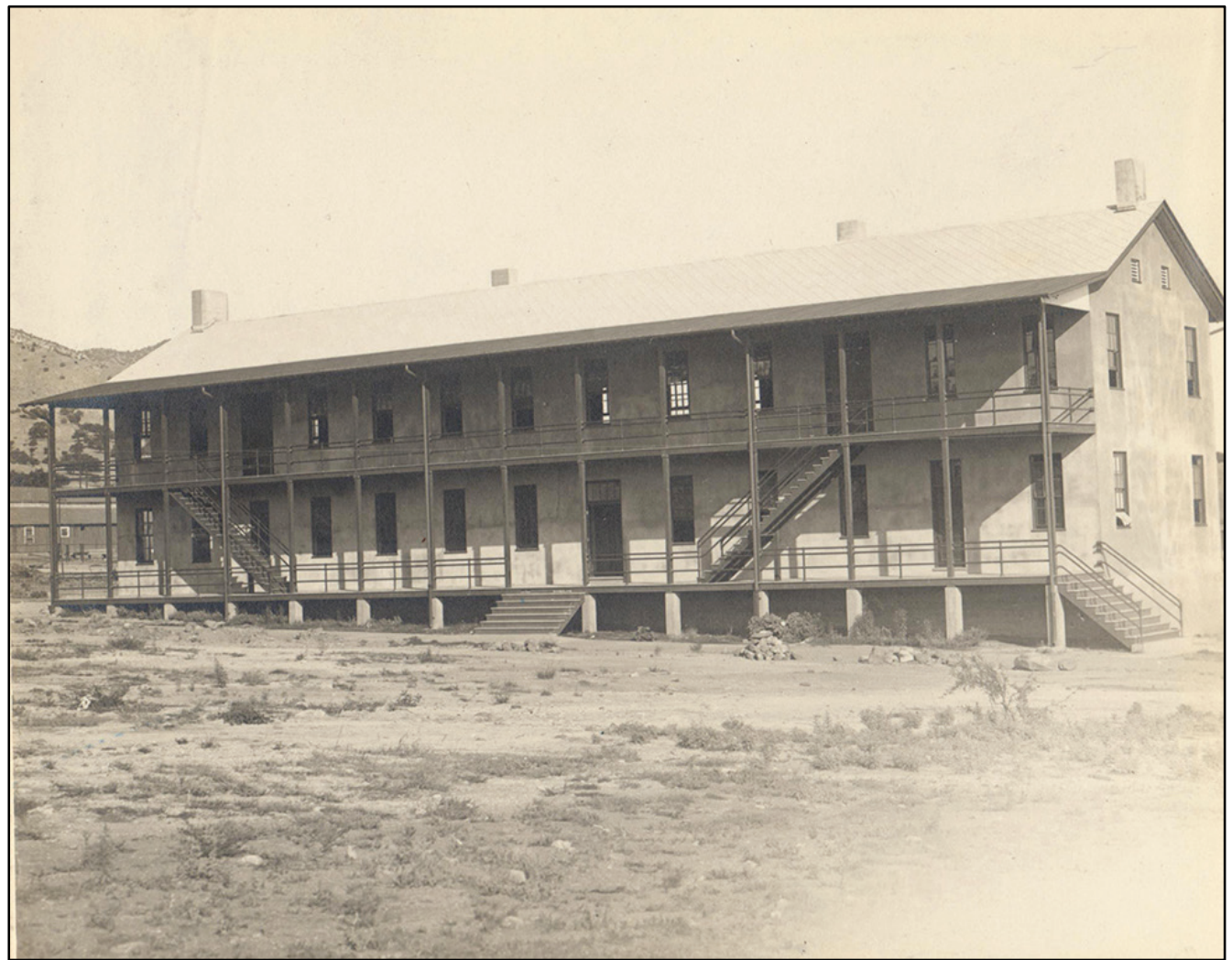

Figure 301. View looking west at barracks (41415), 1941 (NARA College Park, RG77 Entry 393 Box 95).

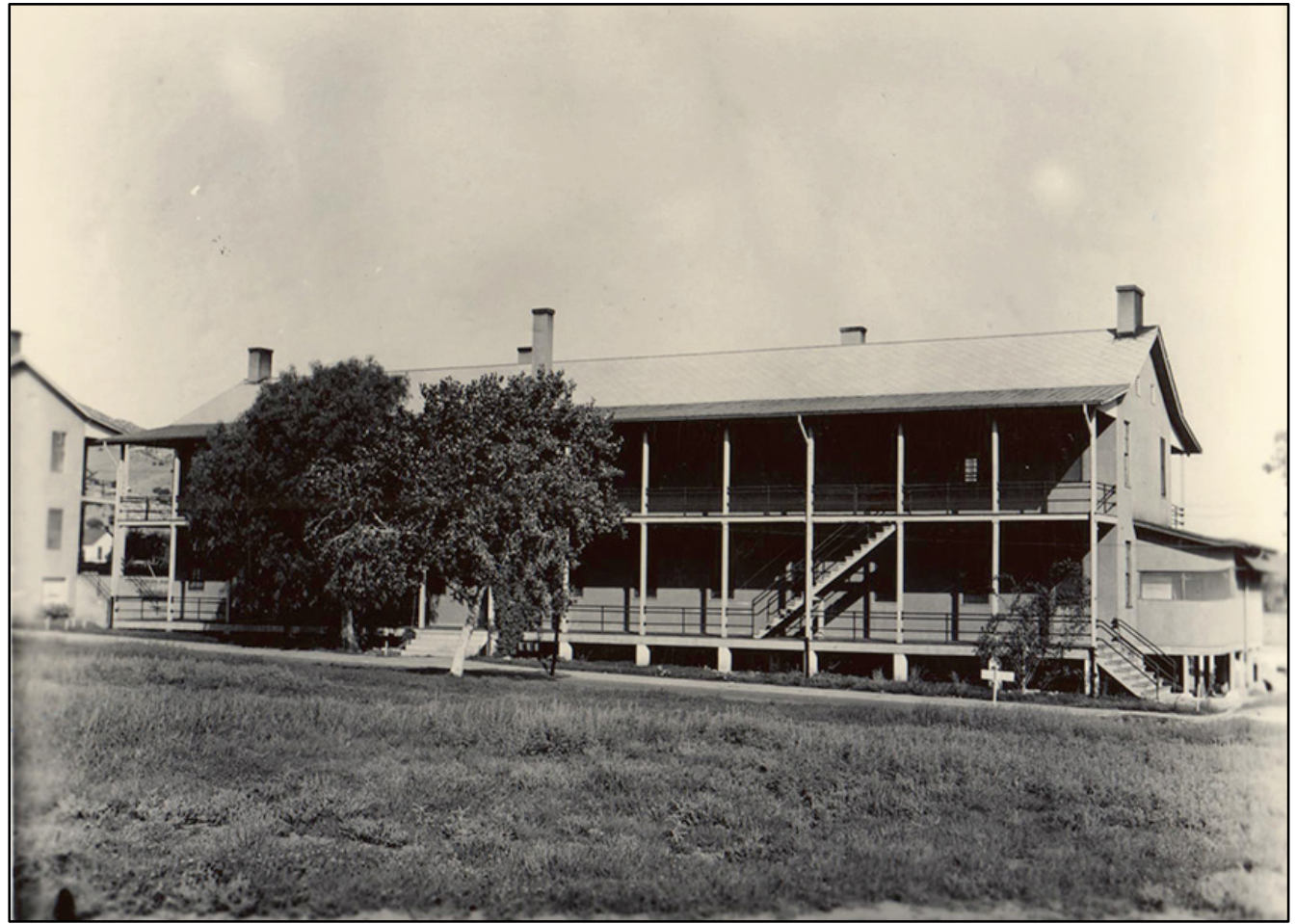


Figure 302. View looking west at barracks (41415) with some foundation plantings (ERDCCERL 2016).

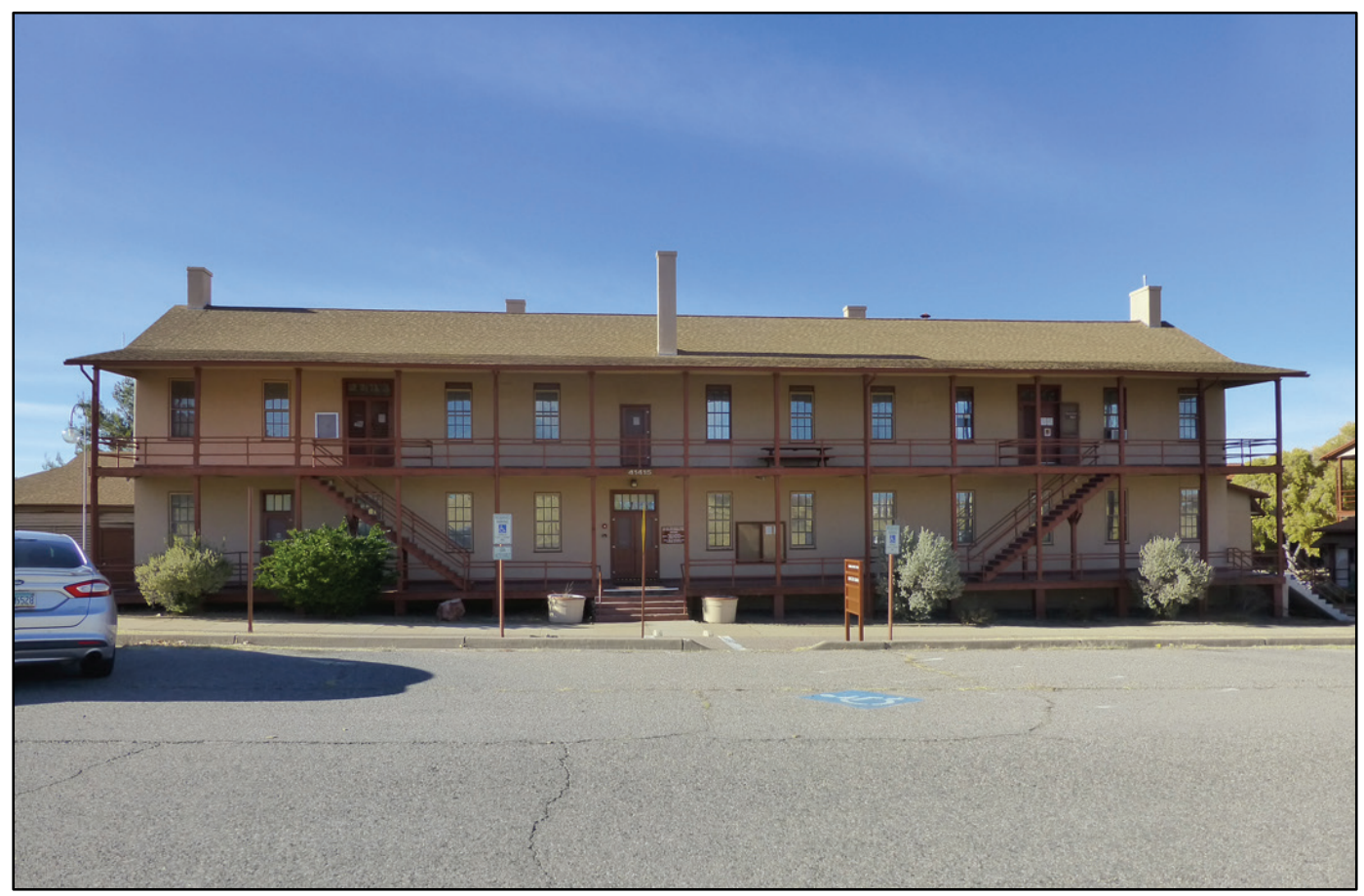

Figure 303. View looking northwest at barracks (Building 41412) with no foundation plantings remaining (ERDC-CERL 2016).

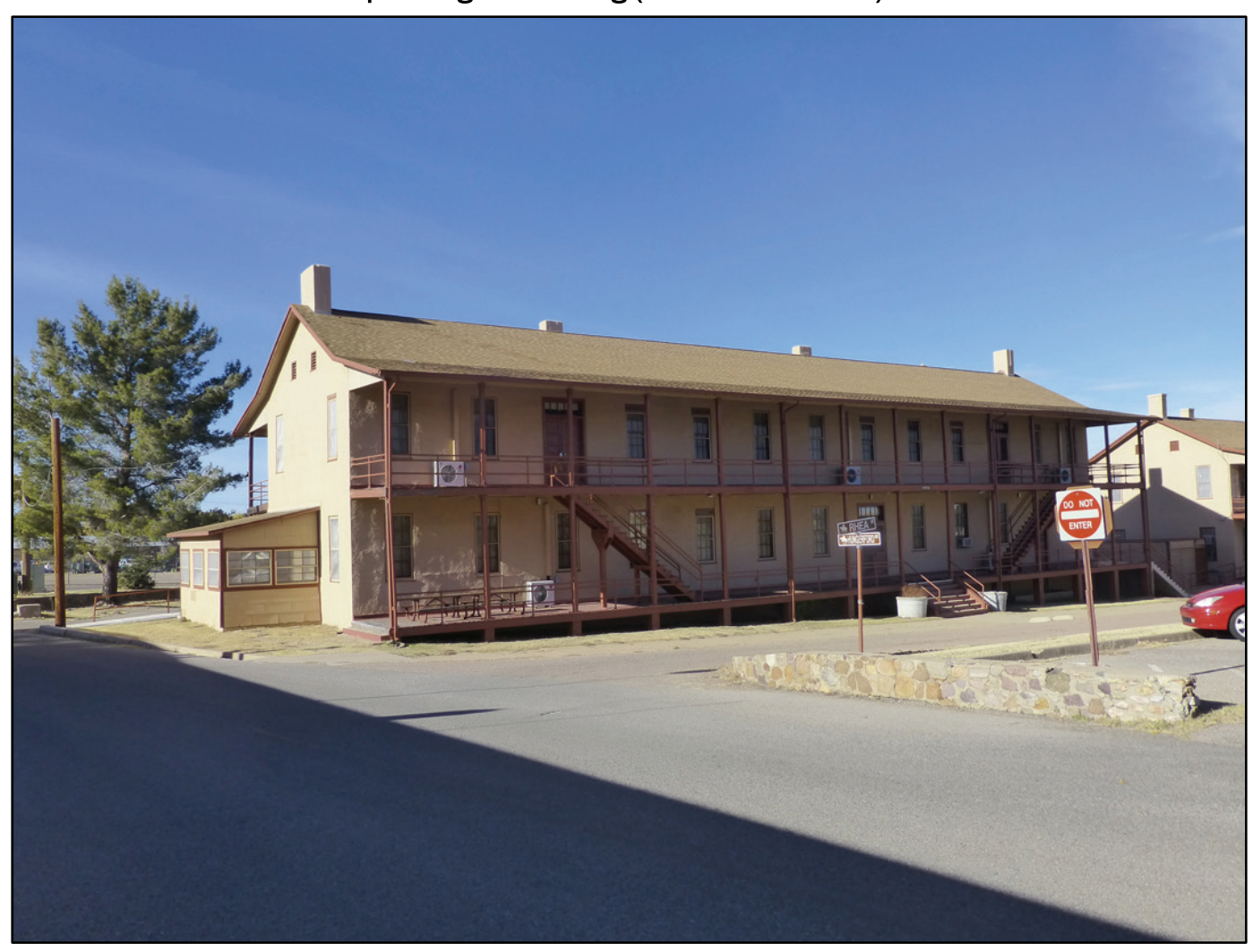


Figure 304. View looking east of North Parade Field showing open space with no trees (ERDC-CERL 2016).

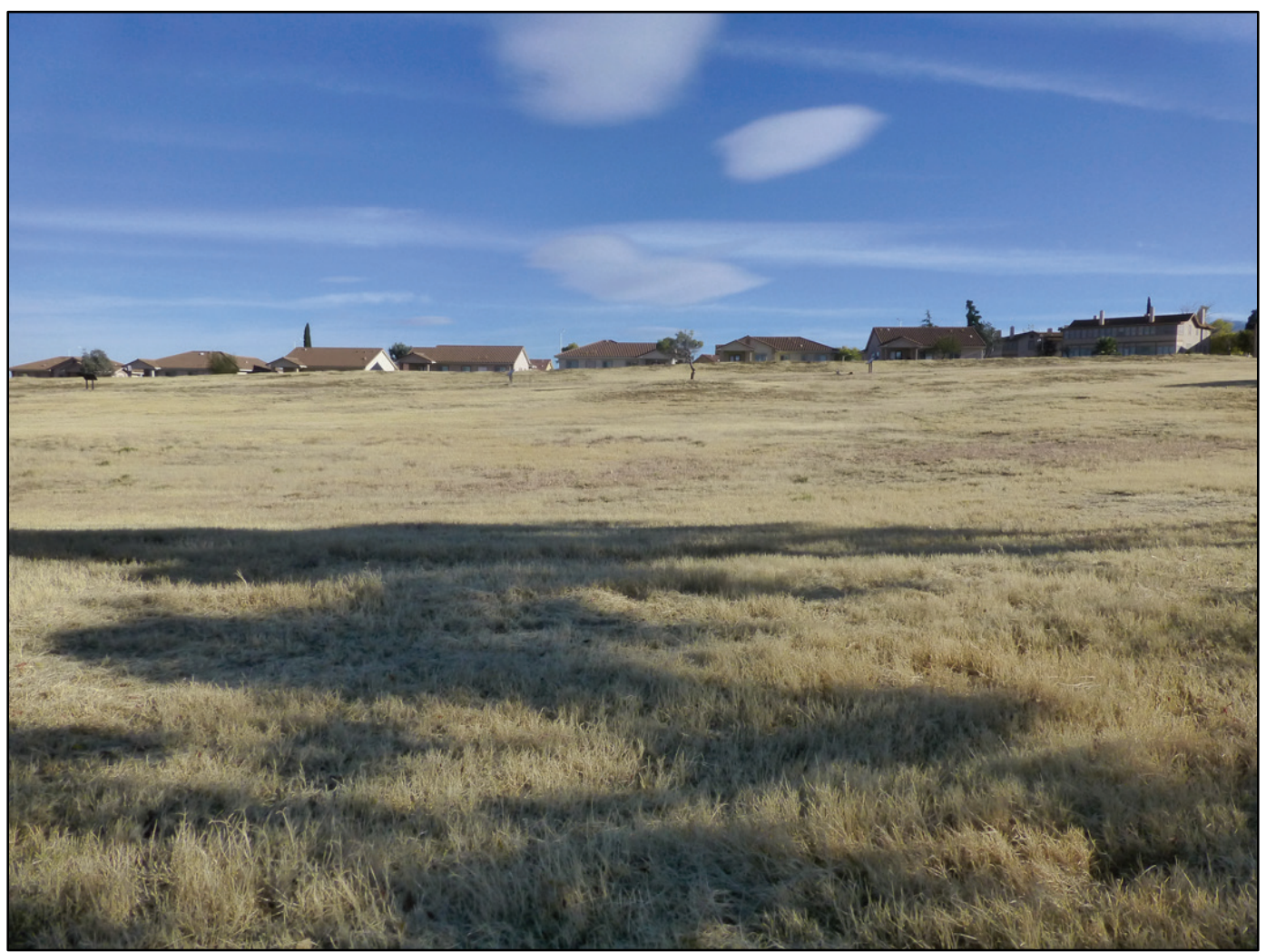

\subsubsection{Old Post Administration and Recreation}

The administration buildings and recreation buildings, now used for administration, historically had foundation plantings due to their prominent locations within the Old Post and their historic uses (Figure 305). Today, many of these foundation plantings are missing, and other southwestern plantings have been placed in non-historic beds, such as those in front of the Headquarters Building (41402) and theater (41305) (Figures 306-309). 
Figure 305. View to the north of former Post Headquarters, now Museum, 1943 [Note the evergreen foundation plantings.] (Fort Huachuca Historical Museum).

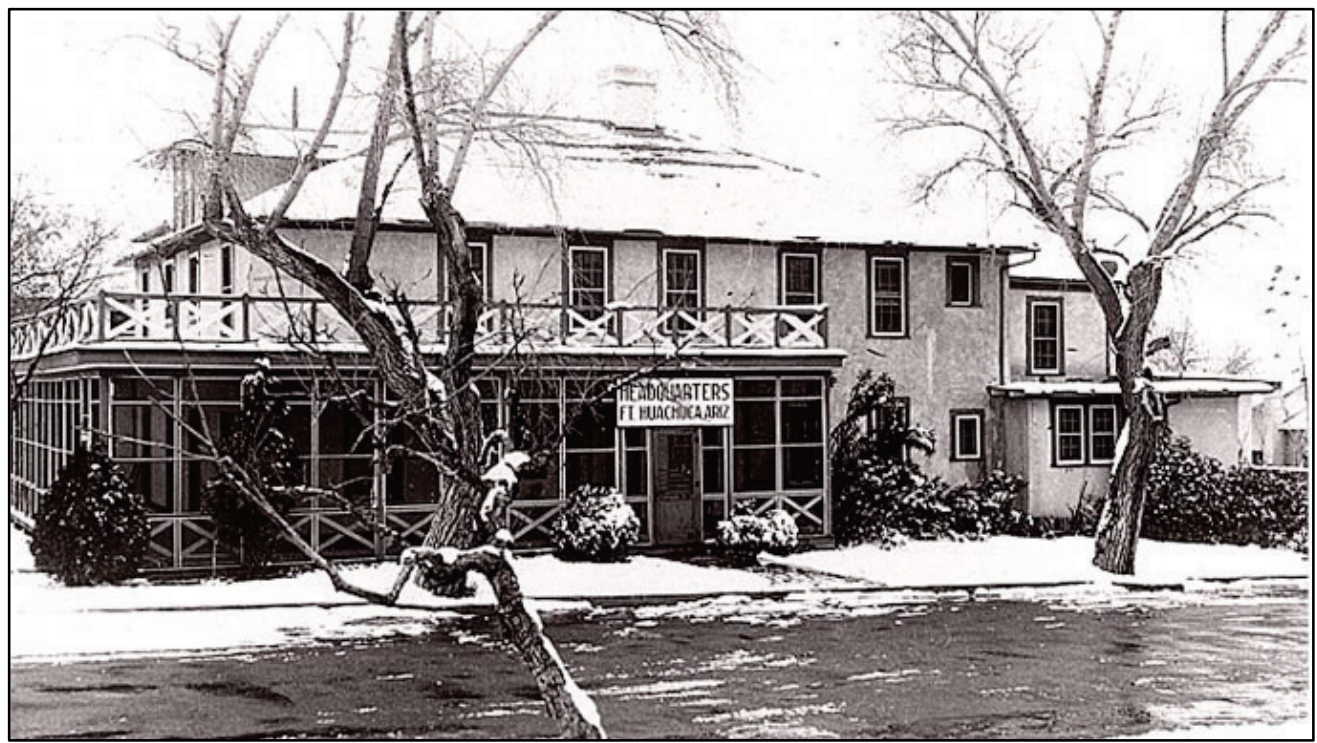

Figure 306. View to the north of the Museum, which no longer has foundation plantings, but several trees remain (ERDC-CERL 2016).

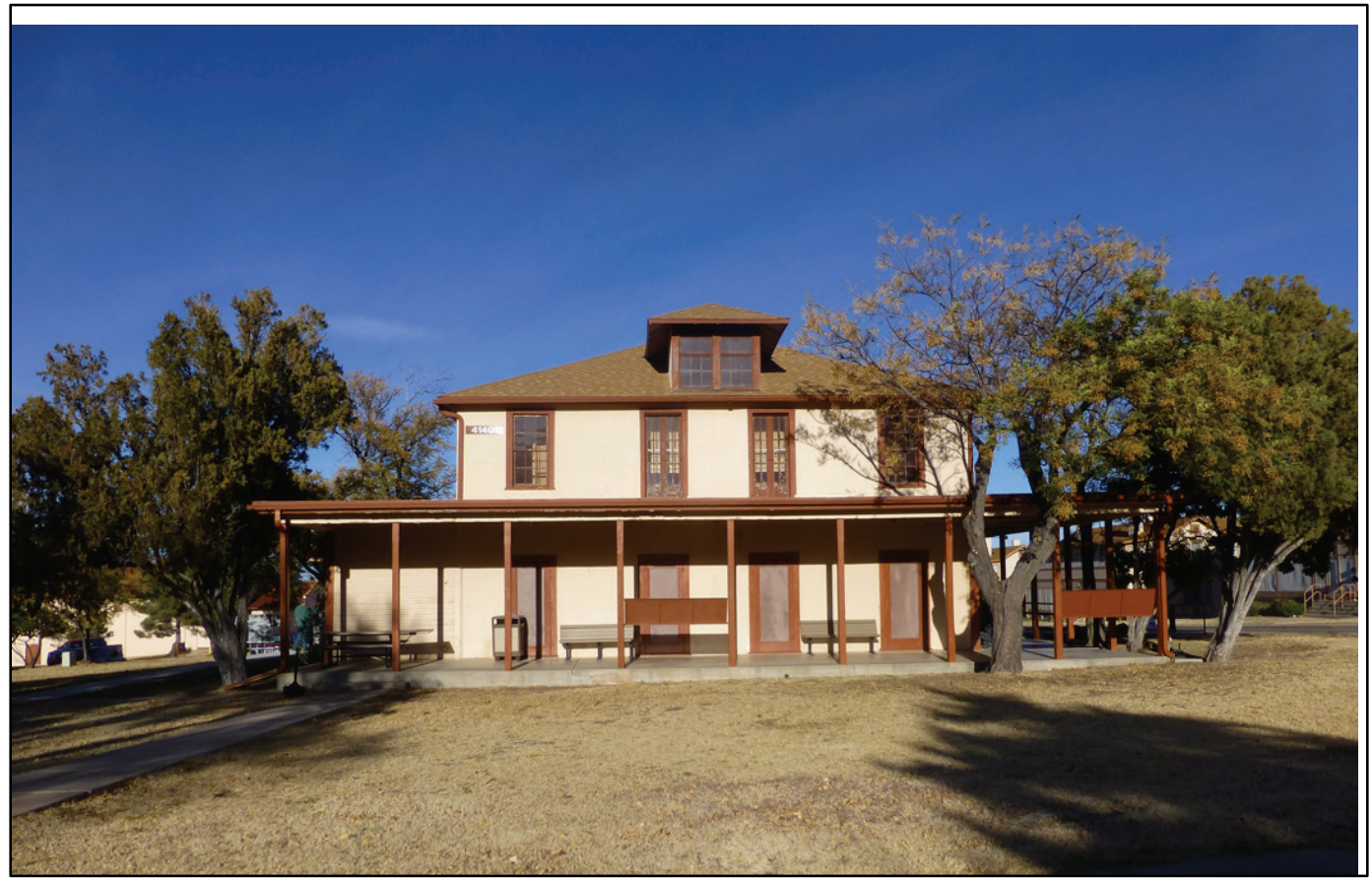


Figure 307. View to the west of plantings in front of former theater, 1936 (Fort Huachuca Historical Museum).

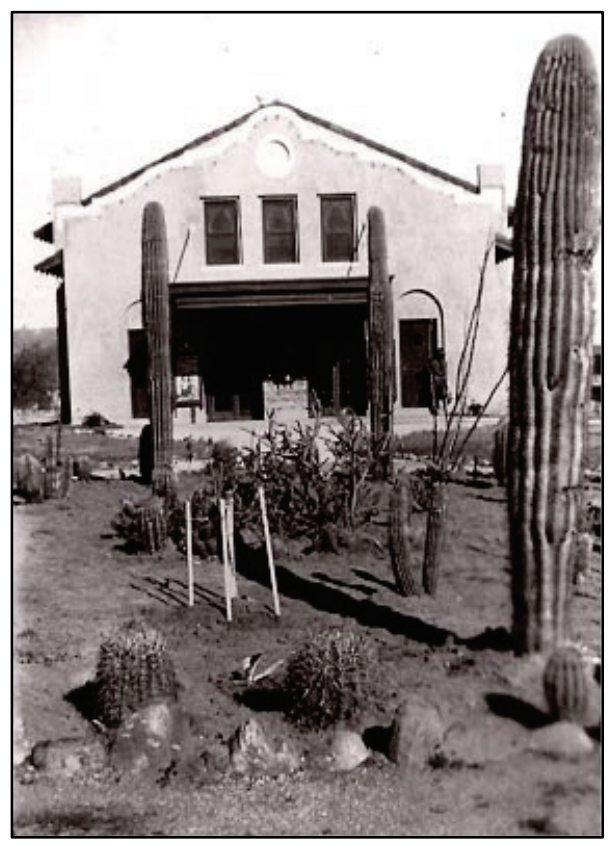

Figure 308. View to the west of the front of former theater (now the Museum Annex) with no landscaping (ERDC-CERL 2016).

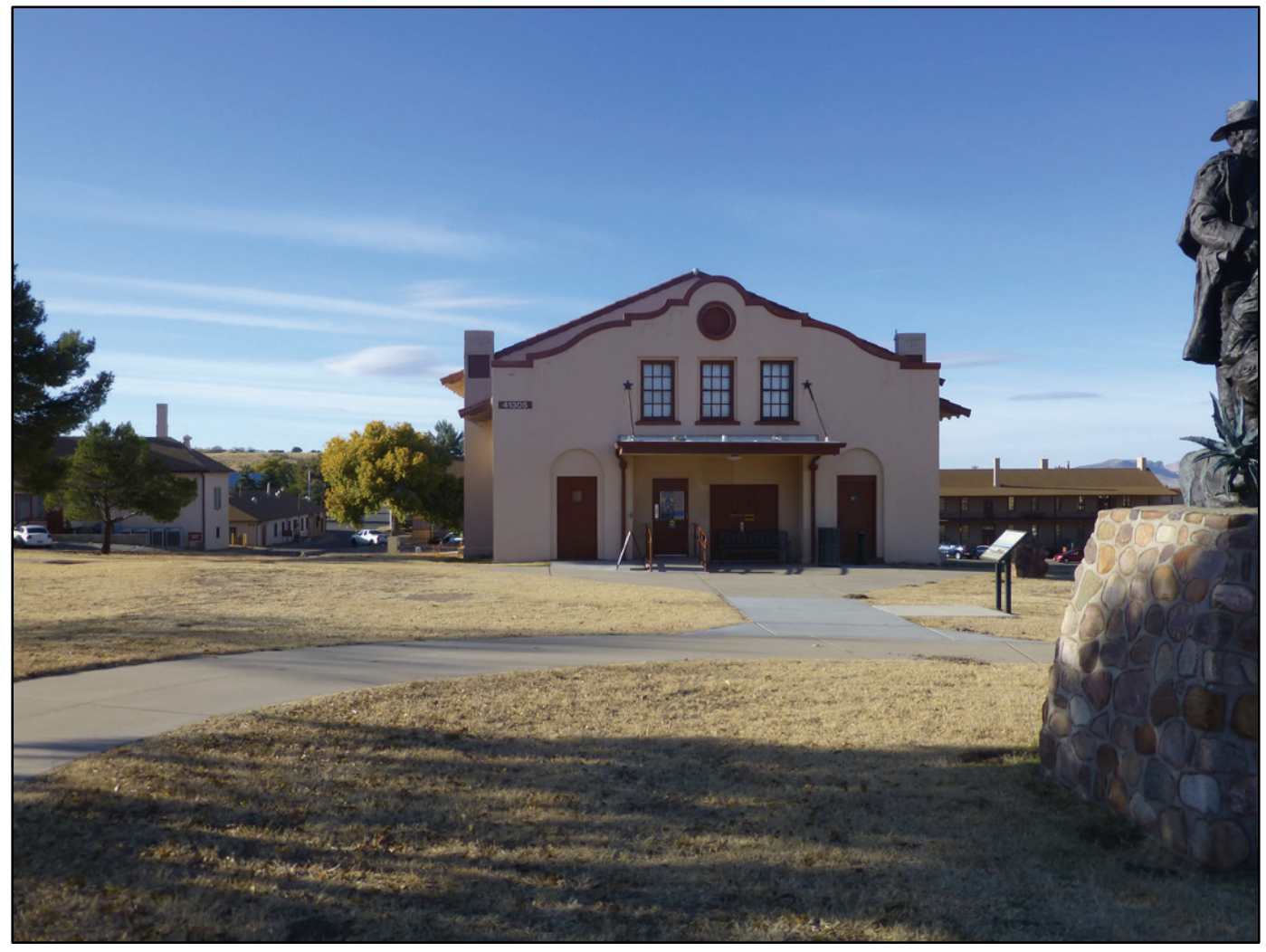


Figure 309. Planting in front of former PX (Building 21115) (ERDC-CERL, 2016).

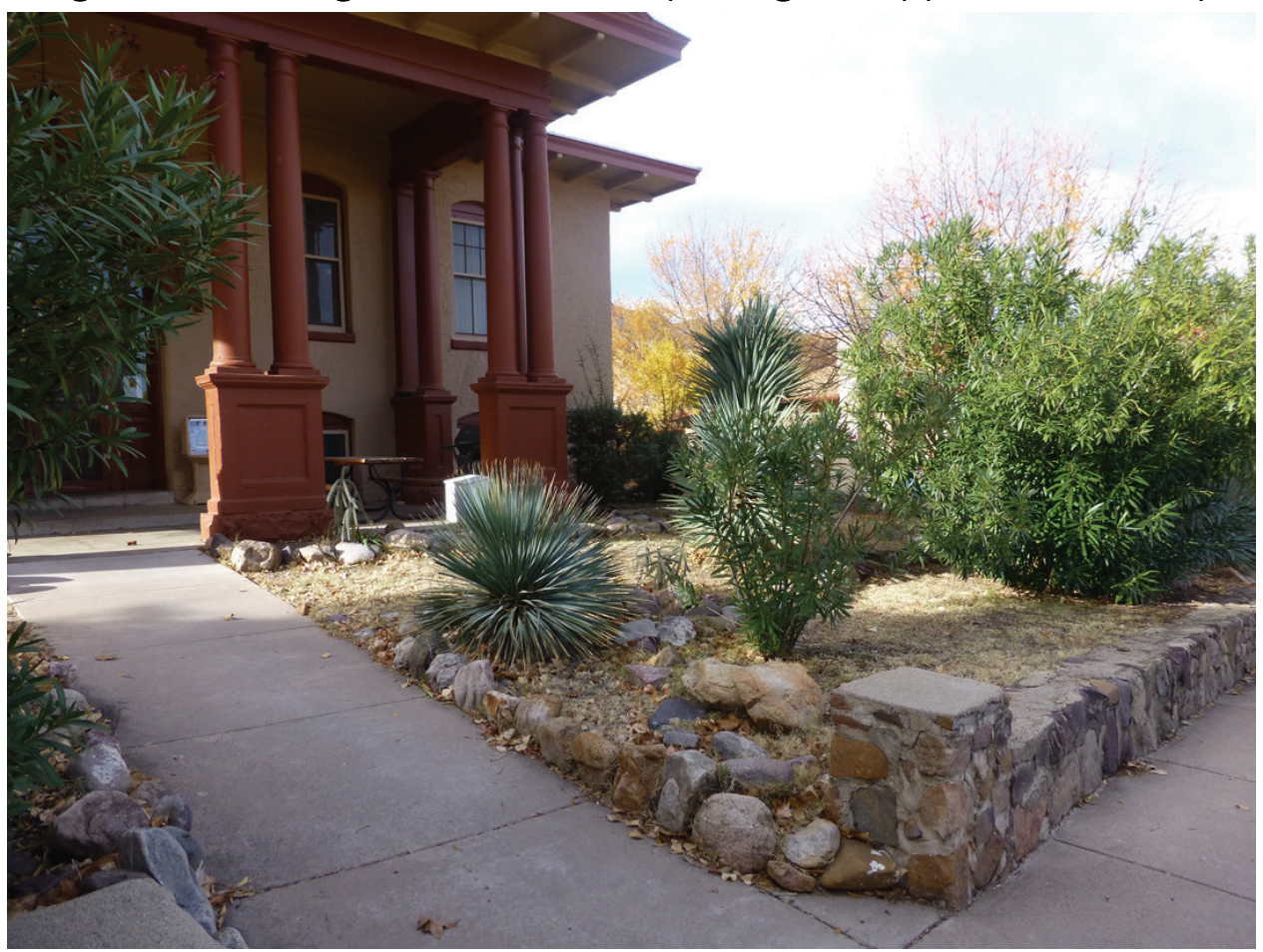

\subsubsection{Surrounding vegetation}

The surrounding vegetation is also contributing to the views and viewsheds of the NHL historic district. Mature cottonwood trees surround the district along with oaks, while the hills have grassland and desert scrub (Figure 310). 
Figure 310. View looking south of vegetation along Huachuca Creek along Hines Road (ERDC-CERL 2016).

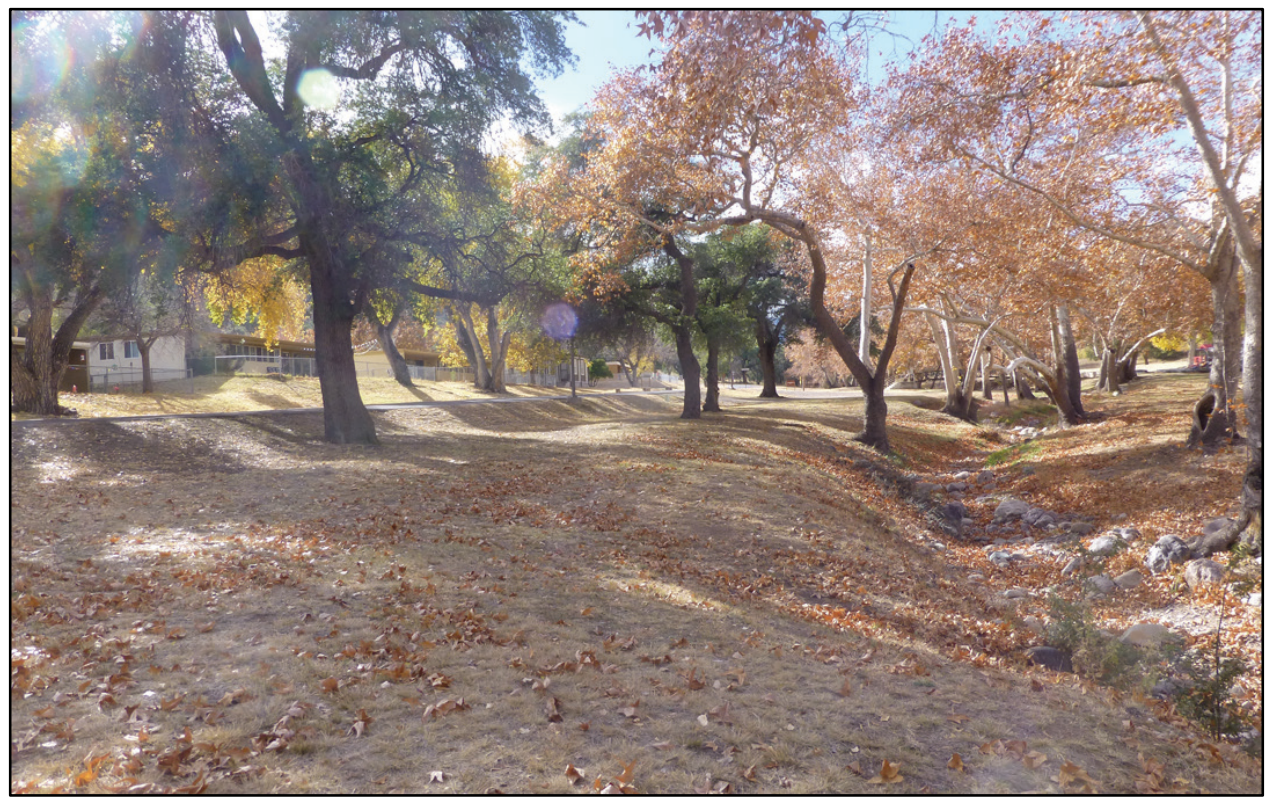

\subsubsection{Plant list}

No historic planting plans, designs or lists were located for the Old Post. One plant list was found in the WWII completion report for the WWII area located elsewhere on the installation (Table 15). It noted in the report that the following trees and shrubs were "well adapted to the region and would grow with a minimum amount of water". However, this planting list is typical of other WWII installations in other regions of the United States, so may not be as well suited to the desert climate at Fort Huachuca. Many of these species are planted in the NHL district as well as the Italian Cypress, junipers, crepe myrtle and sycamores. The Installation Design Guide (IDG) for Fort Huachuca does have a plant list (2008). The plant list is separated into plants for the historic areas and Bonnie Blink Housing Area, plants for the other housing areas, and plants for the community and industrial areas. This list and more discussion on plant material is provided in the appendix.

Table 15. List of trees and shrubs for Fort Huachuca from WWII completion report (NARA College Park, RG77 Completion Report).

\begin{tabular}{|l|l|}
\hline Type & Plant \\
\hline Shrubs & Euonymus japonica and radicans \\
\cline { 2 - 2 } & Cotoneaster parneyi \\
\cline { 2 - 2 } & Cotoneaster pannosa \\
\cline { 2 - 2 } & Chinese photina \\
\hline
\end{tabular}




\begin{tabular}{|c|c|}
\hline Type & Plant \\
\hline & Jasmine, trailing \\
\hline & Myrtle Roman or common or dwarf \\
\hline & Nandina domestica \\
\hline & Oregon grape (Mahonia aquifolium) \\
\hline & Pittosporum tobira \\
\hline & Privit, Japanase of Nepal \\
\hline & Pyracantha 'Lalandei' and P. yunnanensis \\
\hline & Viburnum suspensum and tinus \\
\hline & Oleander Red \\
\hline & Euonymus japonica and radicans \\
\hline \multirow[t]{8}{*}{ Coniferous evergreen } & Cypress, Arizona \\
\hline & Pine, Aleppo \\
\hline & Juniper, Irish, prostrate, pfitzer, sabin \\
\hline & Spruce, Colorado, blue \\
\hline & Silver Spruce \\
\hline & Manzanita \\
\hline & Arbor vitae, Golden and Bonita \\
\hline & Scrub Oak \\
\hline \multirow[t]{4}{*}{ Deciduous flowering shrubs } & Crepe Myrtle \\
\hline & Pomegranate-flowering \\
\hline & Rose of Sharon \\
\hline & Wild Grape \\
\hline \multirow[t]{7}{*}{ Deciduous trees } & Mexican Walnut \\
\hline & Black Walnut \\
\hline & Mesquite \\
\hline & Male Mulberry \\
\hline & Poplar, Common and Lombardy \\
\hline & Sycamore \\
\hline & Fruit - Apple, Pear, Plum, Peach, Almond etc. \\
\hline
\end{tabular}

\subsection{Small-scale features}

Small-scale features can range in size and be stationary or moveable objects that often contribute to the historic character of the installation. 44 These features may include monuments, light poles, benches, flagpoles, fencing, or signs and can be functional or purely decorative. The pragmatic small-scale features are arranged through the site according to their use; benches, signs, and trashcans are placed where people need them while fences, lighting, and material choices subtly inform the larger landscape.

44 Loechl et al., 2009, p. 90. 
Small-scale landscape elements are scattered throughout the historic district. These structures and features, great and small, generally carry structure numbers in the maintenance schedule for Fort Huachuca but are not regarded as buildings, structures, or objects in this nomination, except as noted.

The most numerous landscape elements comprise 16 coal bins, scattered throughout the residential areas of the historic district. All but one were built in 1920; the 16th was built in 1934. Pursuant to NPS guidelines, these small units (each is a $40 \mathrm{sq}$. $\mathrm{ft}$. open-topped concrete bin) were counted as neither contributing nor non-contributing for purposes of this historic district. If they had been counted, all but one would be considered contributing.

\subsubsection{Post Flagpole}

Early historic photographs show the flagpole on Brown Field, although it is hard to tell the exact location (the flagpole is normally in front of the Commander's residence). The flagpole is first noted on a plan dated 1912, and on the plan, it appears to be in the same location north of a path through Brown Field (which is no longer present) (Figure 311). In the $1993 \mathrm{Na}$ tional Register nomination, the flagpole (22301) is listed as non-contributing to the NHL district because it was built in 1951. Over the years, a retaining wall, several monuments and trees have appeared around the flagpole detracting from the pole and the facade of Pershing House (Figures 312 and 313). 
Figure 311. View to the southeast of the flagpole and officers' quarters, 1898 (Fort Huachuca Historical Museum).

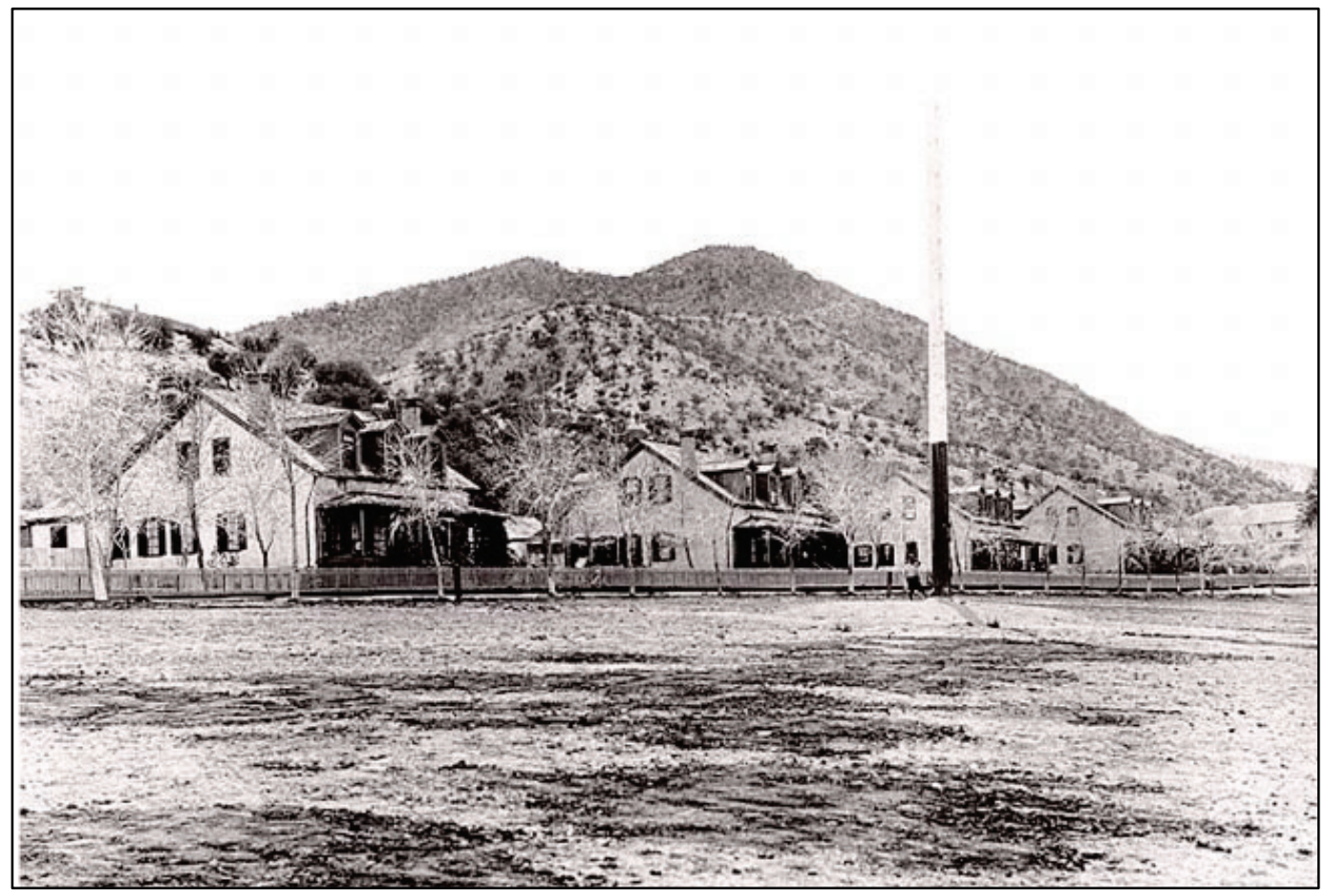

Figure 312. View to the northeast of the flagpole and Quarters 22126, the Commanding General's residence from Star Hill (ERDC-CERL, 2016).

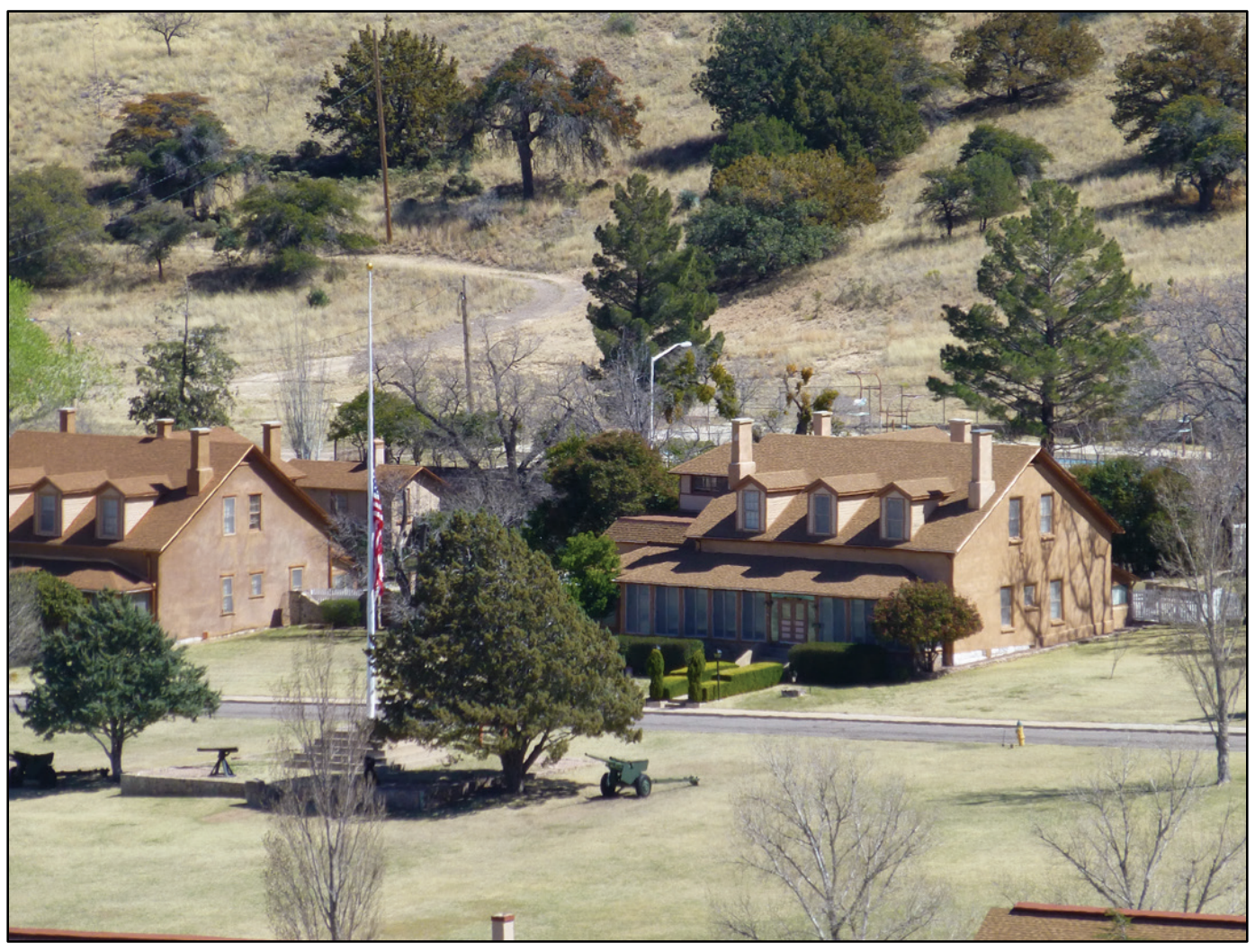


Figure 313. View to the south of the flagpole and surrounding vegetation and features (ERDC-CERL, 2016).

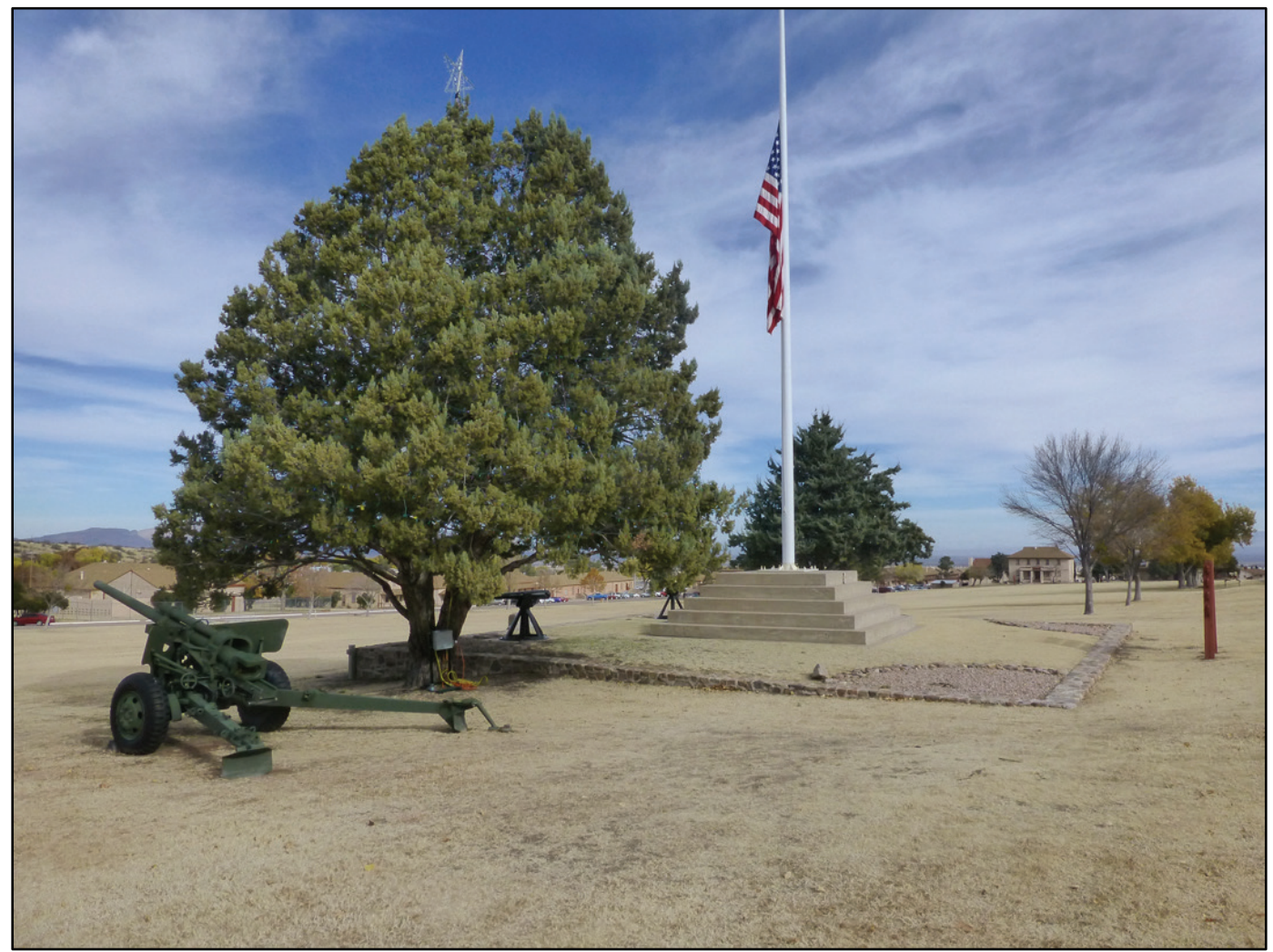

\subsubsection{Fencing}

The picket fence that ran along the entire length of the row of quarters existed for a short time between the late 1890 s and early 1900 (Figures 314 and 315). White picket fences were gone by 190245 . Today, many quarters have white picket fences around the back yards (Figure 316). There is a change from allowing the use of chain link (Figure 317). 
Figure 314. View to the south of picket fencing between Old Post Barracks, 1918 (Fort Huachuca Historical Museum).

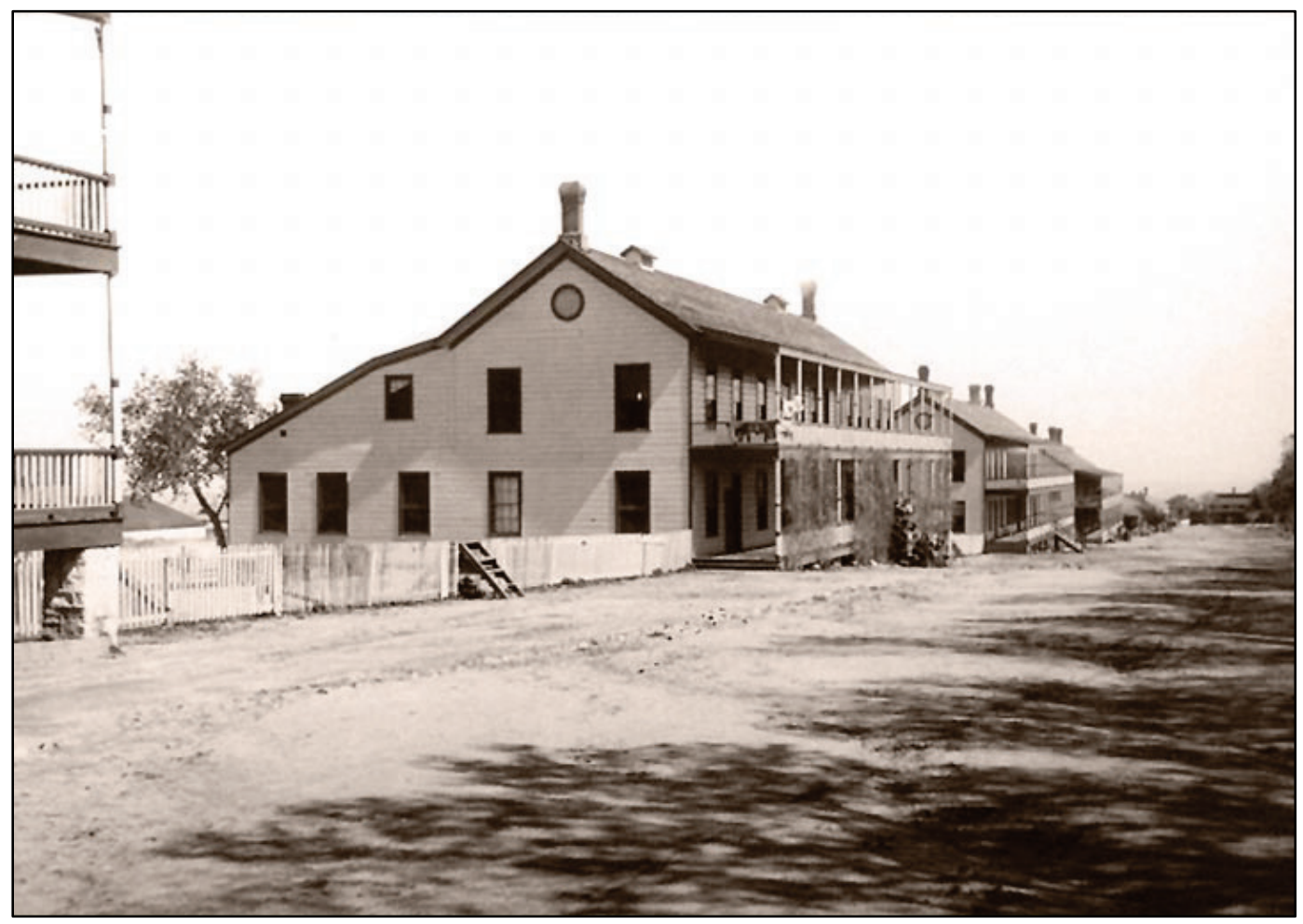

Figure 315. View to the south showing only some of the officers' quarters have fencing by 1900 (Fort Huachuca Historical Museum).

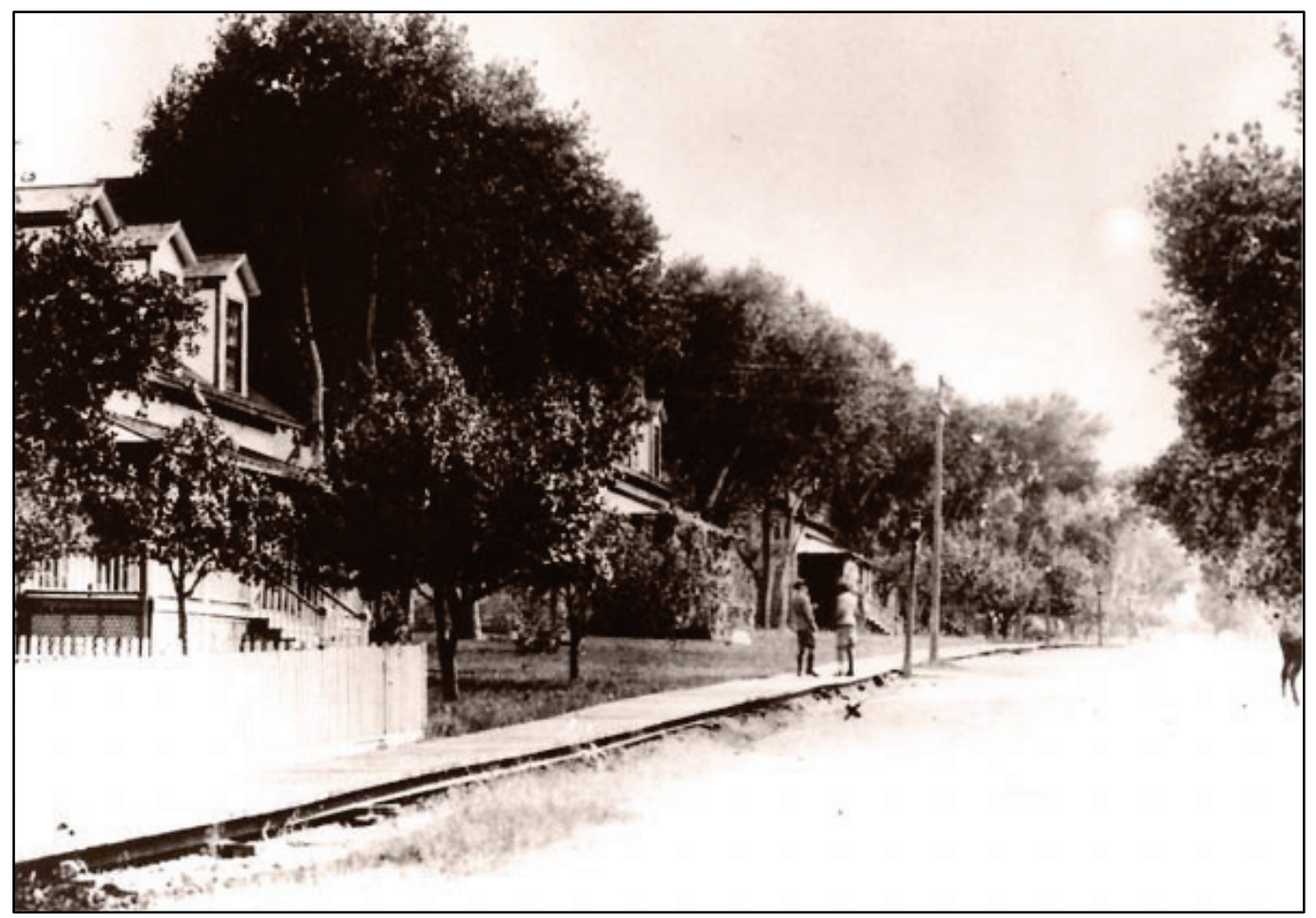


Figure 316. View to the east showing fencing used today to separate the front from the rear yards of the officers' housing (ERDC-CERL 2016).

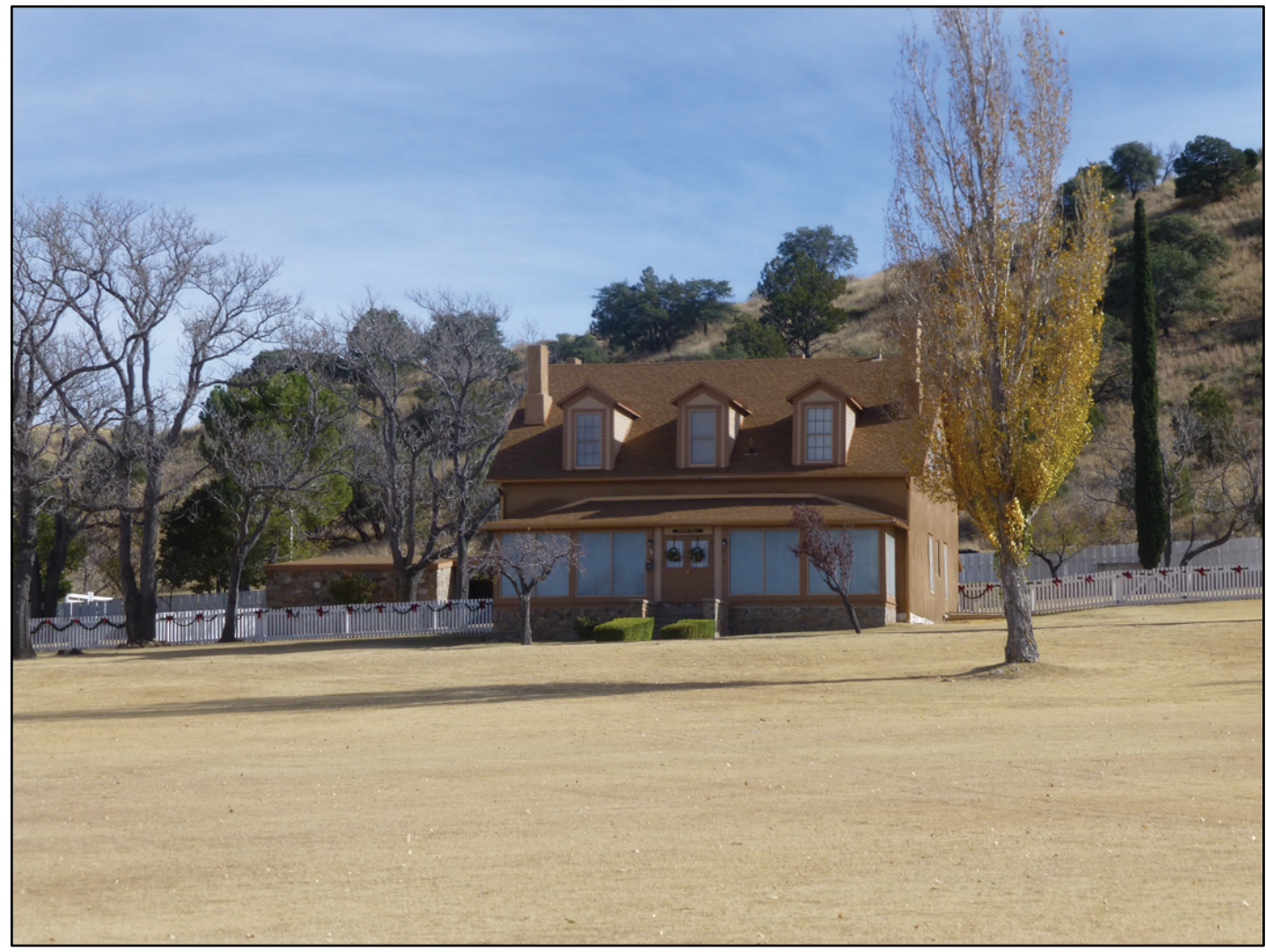

Figure 317. White vinyl fencing used to screen backflow preventor by former hospital (ERDCCERL 2016).

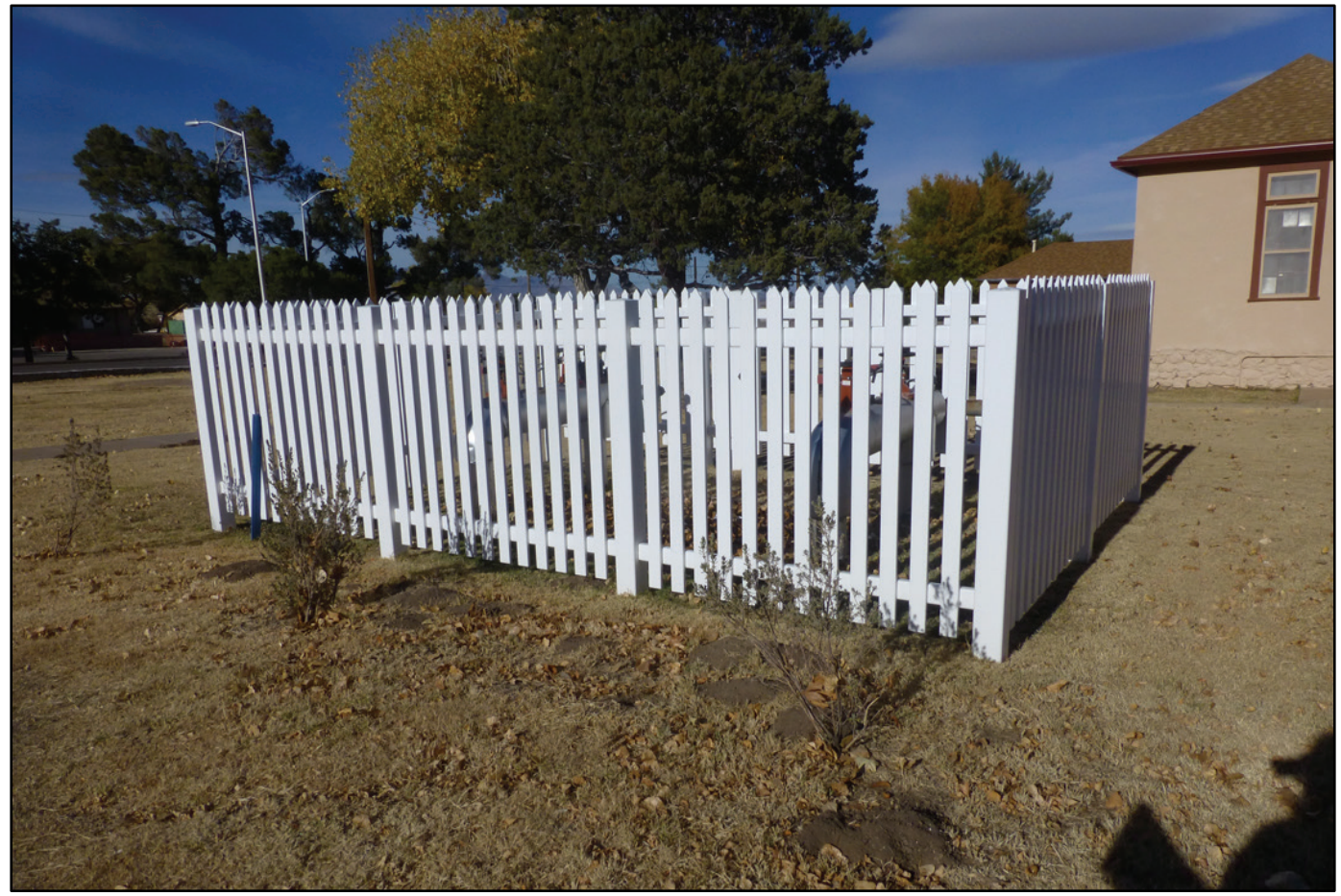




\subsubsection{WPA stonework}

The historic district is laced with stone masonry curbs, drainage canals and retaining walls. These linear structures were built during the mid1930 s by the WPA (Figures 318 and 319). Many have been evaluated and determined eligible for their association with the WPA. While the stonework is noticeable and located throughout the district, the same stone has been used on more recent landscape elements, dating to the 1980 s, making it difficult to discern the difference (Figures 320 and 321).

Figure 318. Looking east at stone wall and gate to yard behind Pershing House (22126)

(ERDC-CERL 2016).

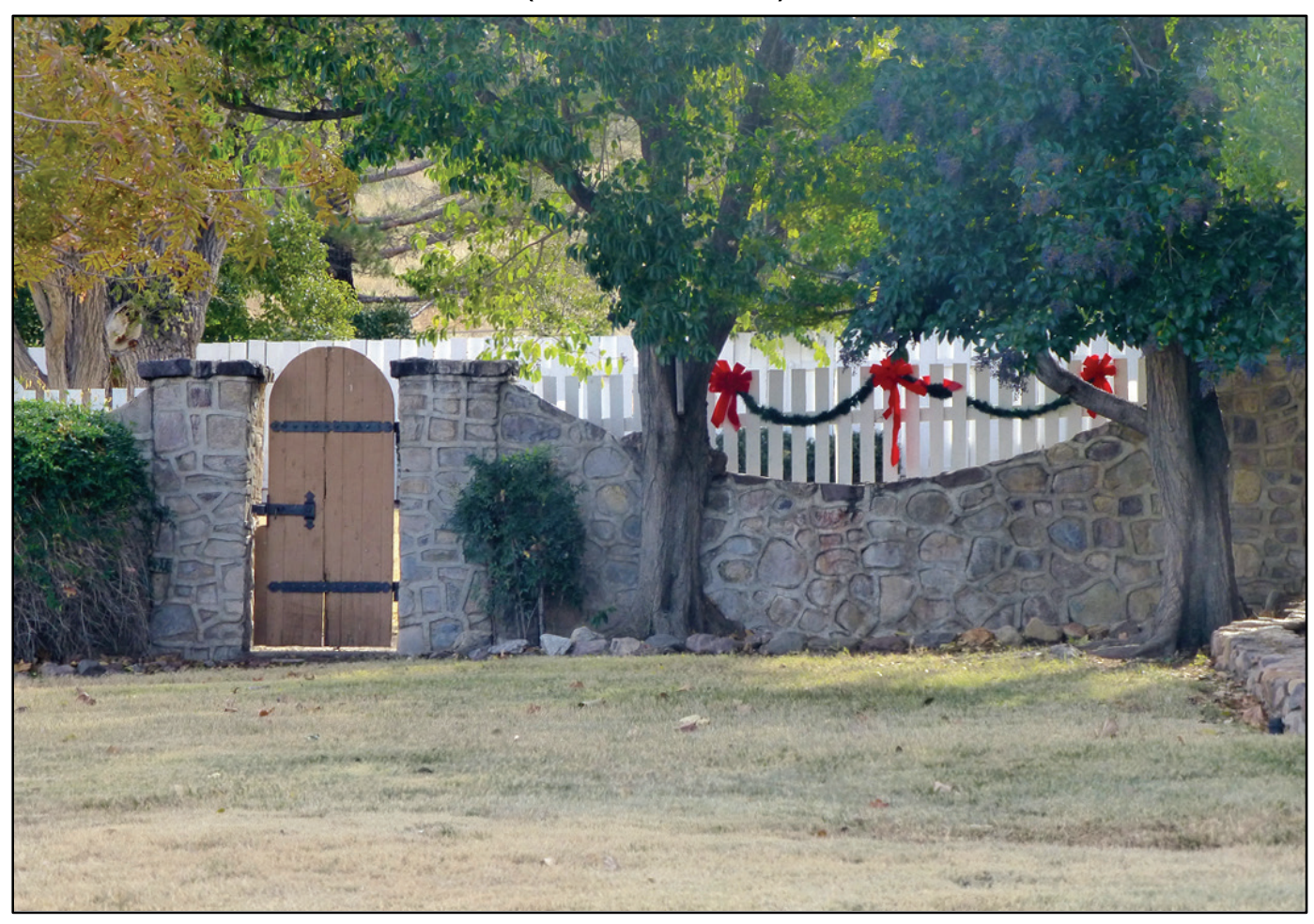


Figure 319. Looking north at WPA stone culvert adjacent to Building 41421 along Rhea Avenue (ERDC-CERL 2016).

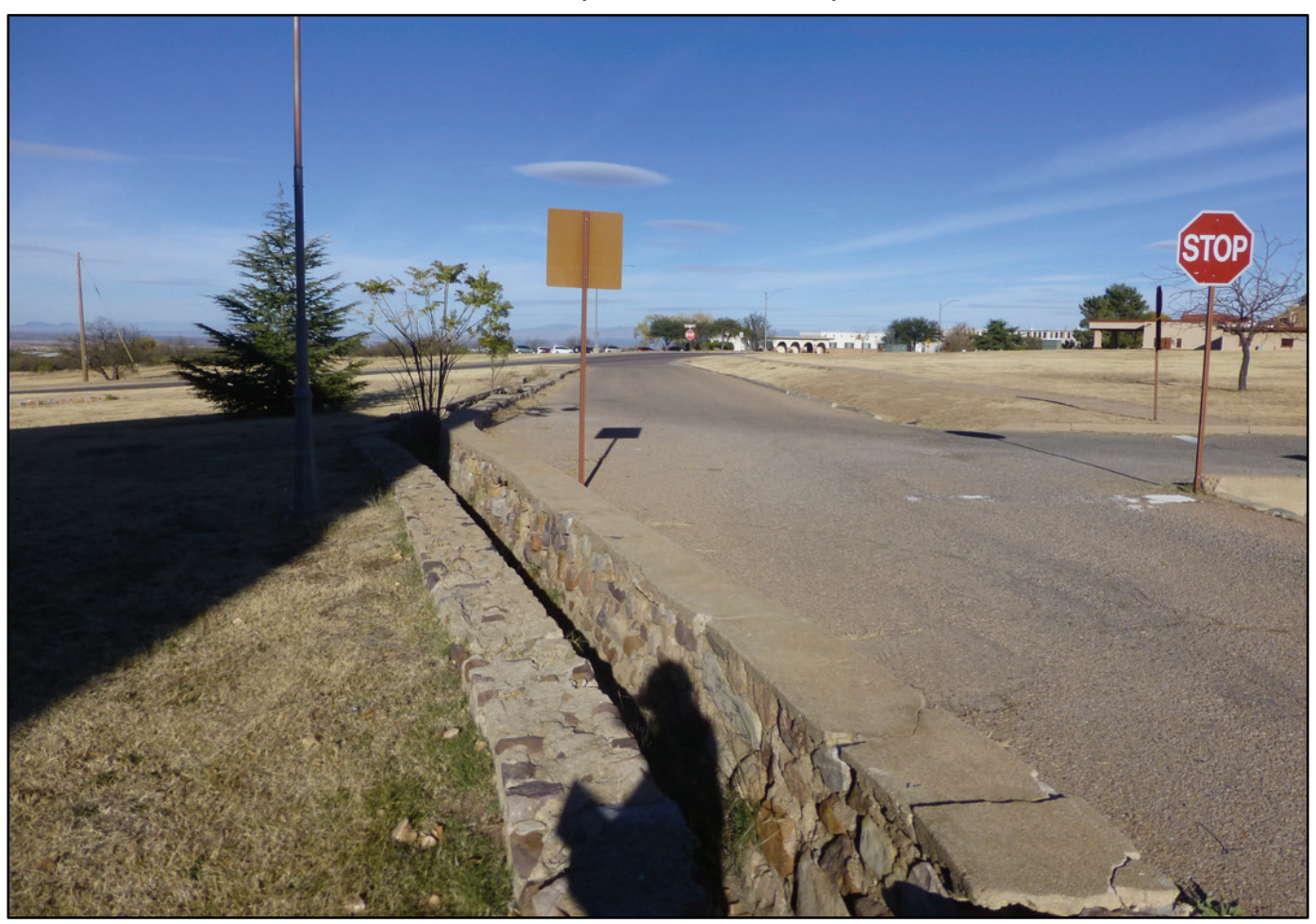

Figure 320. Recent stonework concealing utilities on Brown Field (ERDC-CERL 2016).

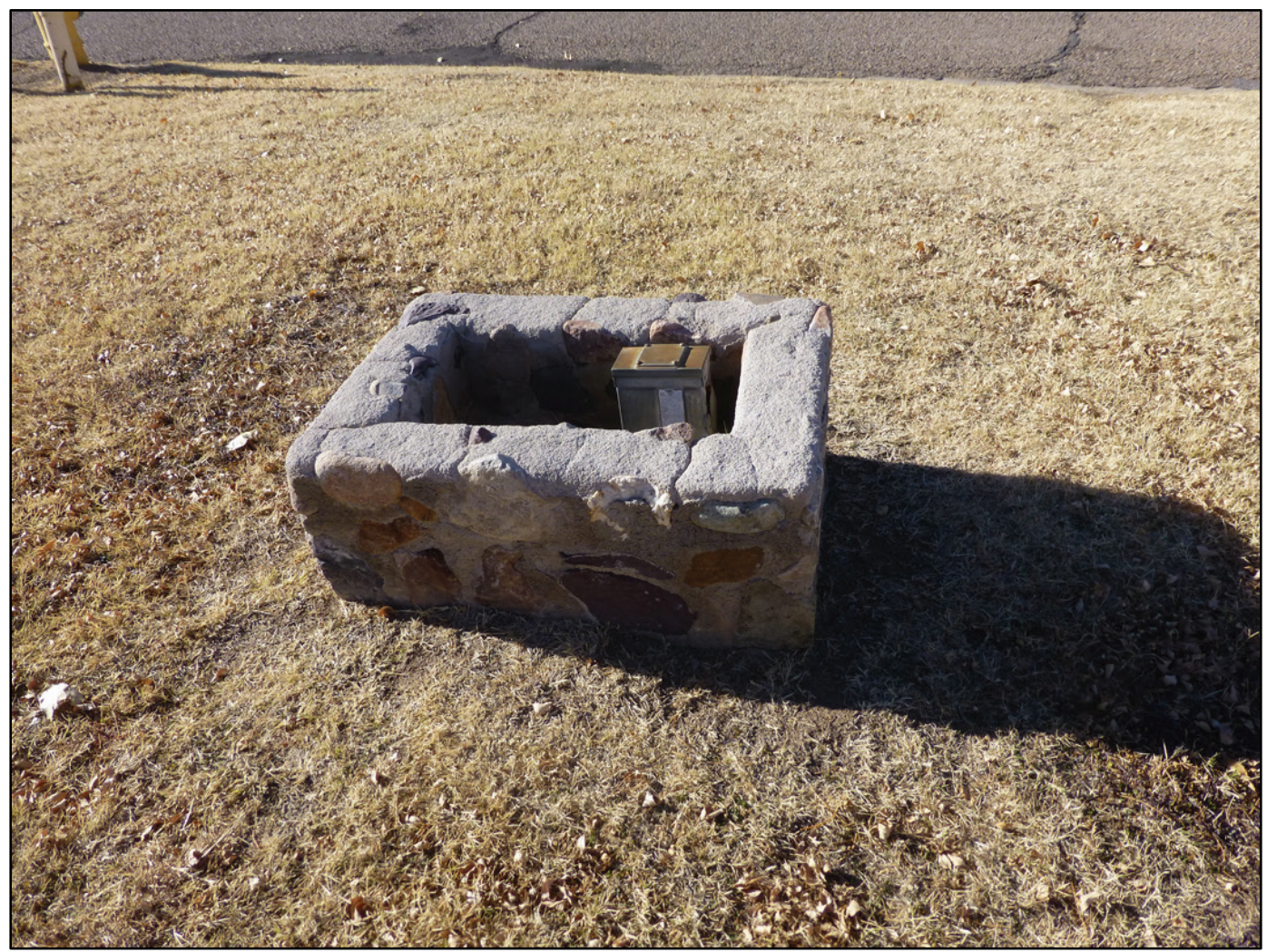


Figure 321. Modern stone retaining wall along Boyd Avenue and stone planter at base of 6th Cavalry Memorial sign just south of the Fort Huachuca Museum (ERDC-CERL 2016).

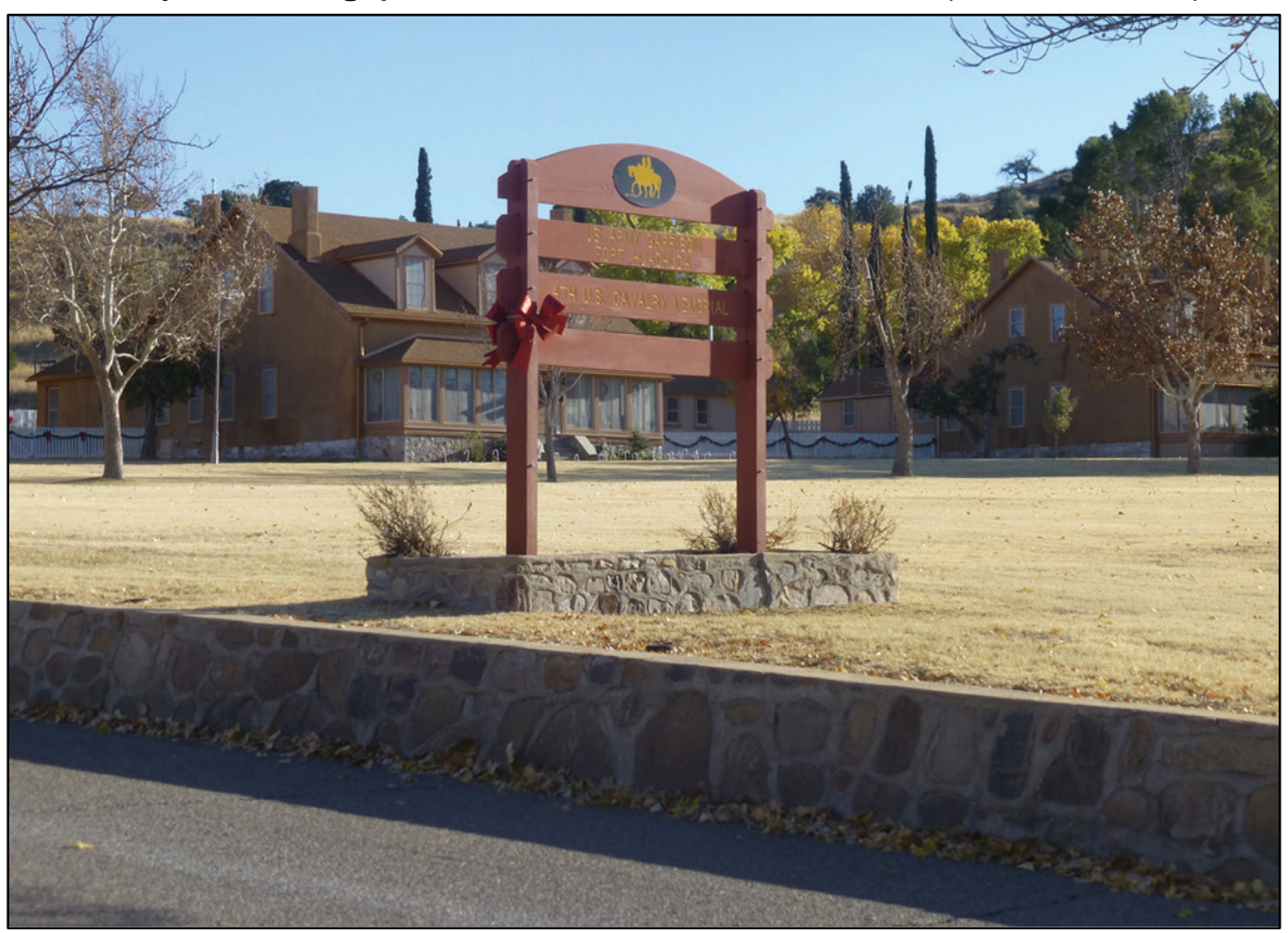

\subsubsection{Street lamps}

Street lights are located within the historic district, but they are not assigned building numbers nor counted as contributing or non-contributing. Several generations of lights are located there (Figures 322 and 323). The most recently-installed are patterned after the original electric light standards installed at the post and are located only in the historic district (Figures 324-327). 
Figure 322. Example of street lamp on Brown Field, c.1900 (NARA College Park).

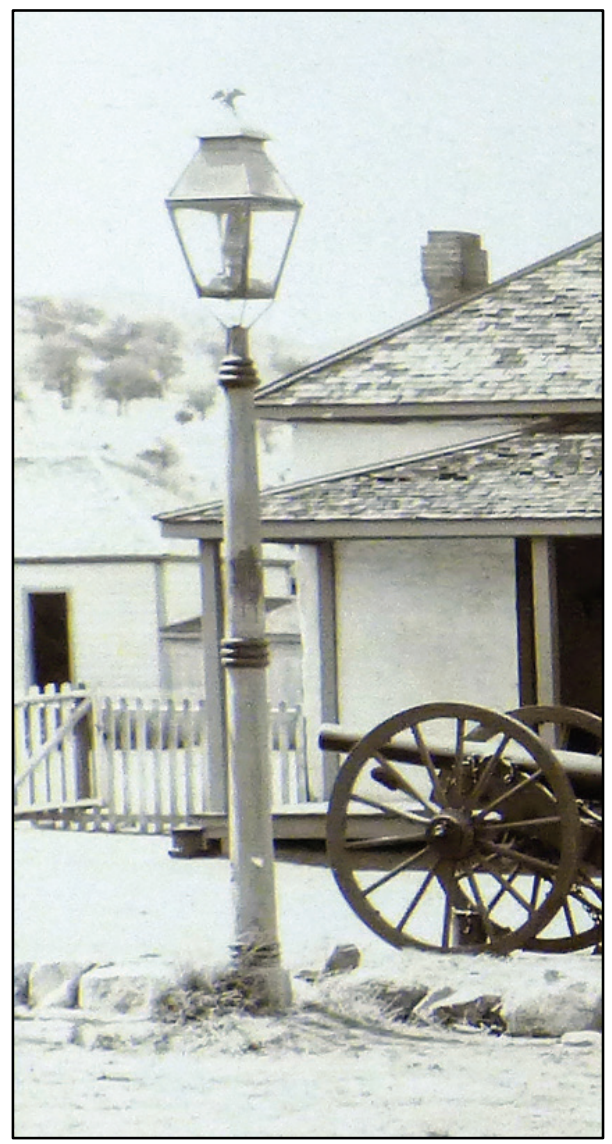

Figure 323. Street lamp style from Henry Circle, 1941 (NARA College Park).

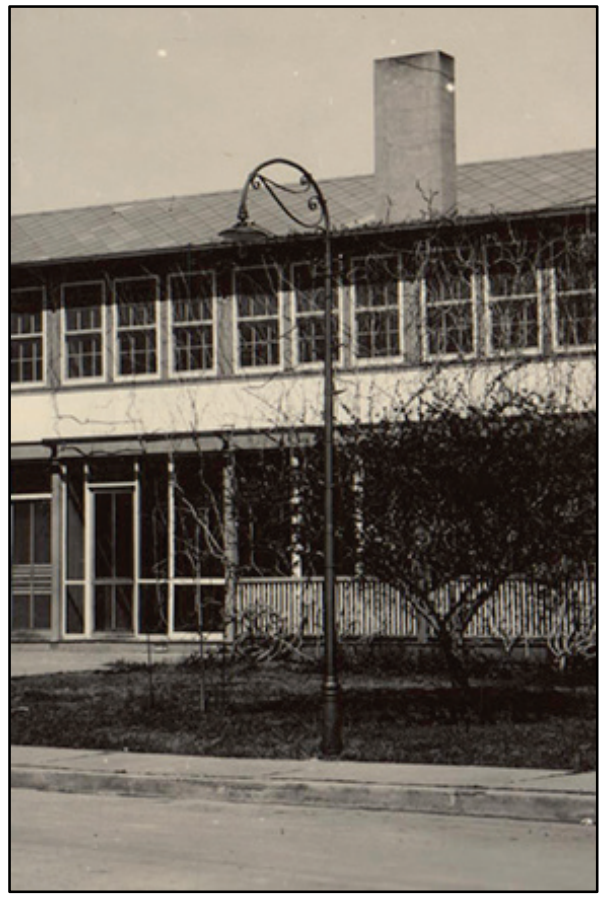


Figure 324. Replica metal street lamp near 21114 (ERDC-CERL, 2016).

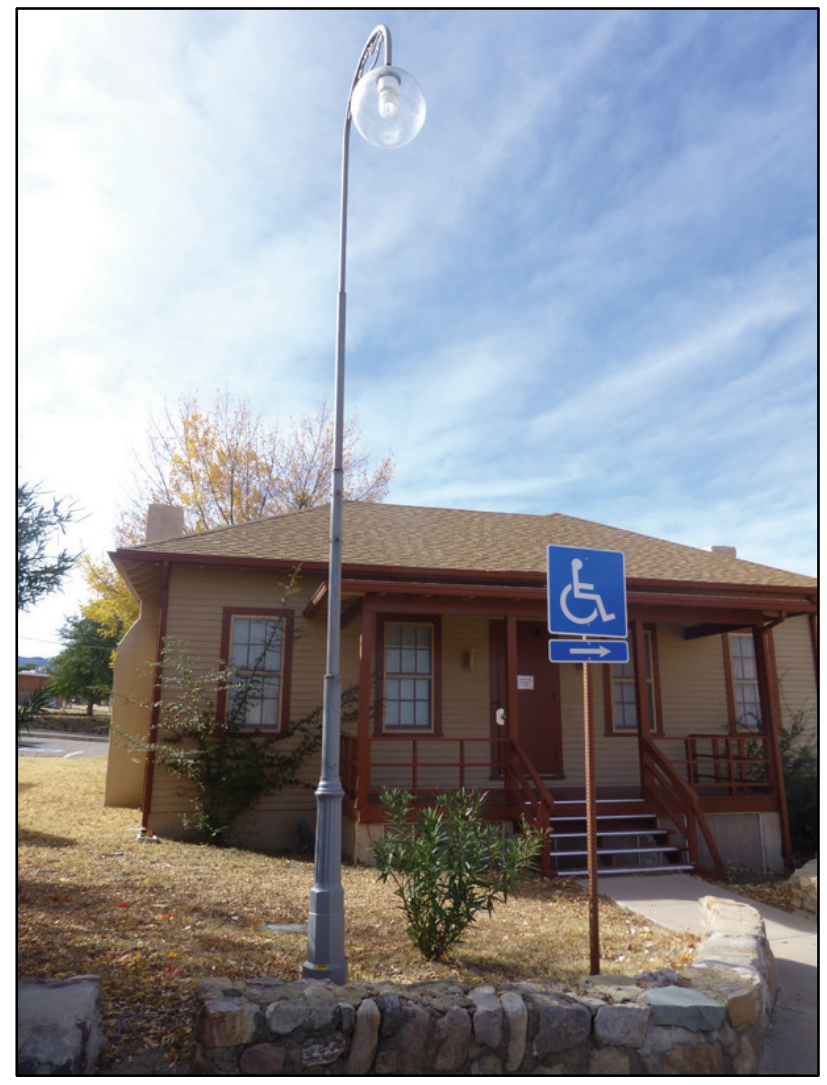

Figure 325. Typical lamp post in Fort Huachuca Historic District with Museum Annex (41305) in background (ERDC-CERL, 2016).

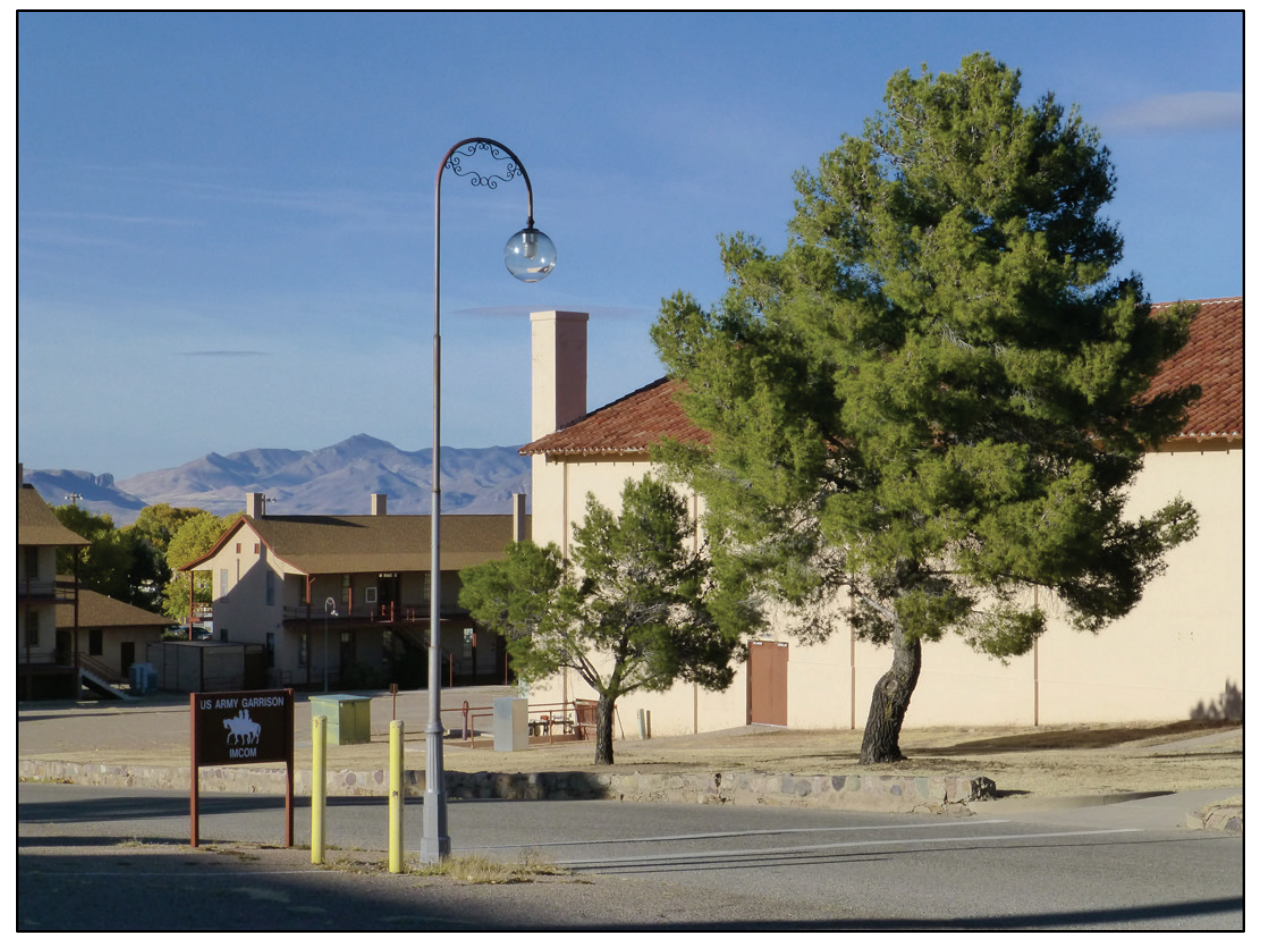


Figure 326. Manufacturer of replica street lamps (ERDC-CERL, 2016).

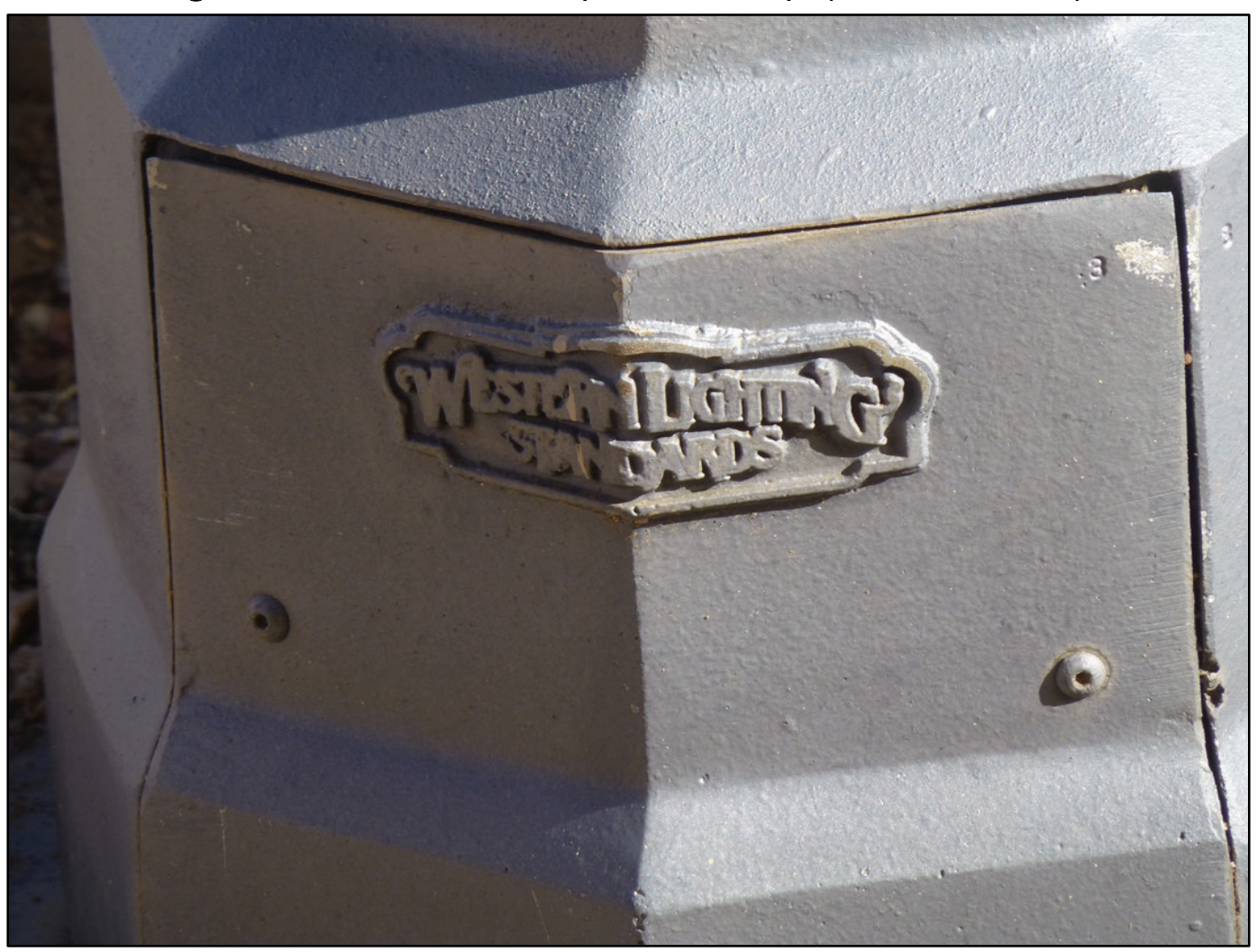

Figure 327. Street lamp located near Henry Circle (ERDC-CERL 2016).

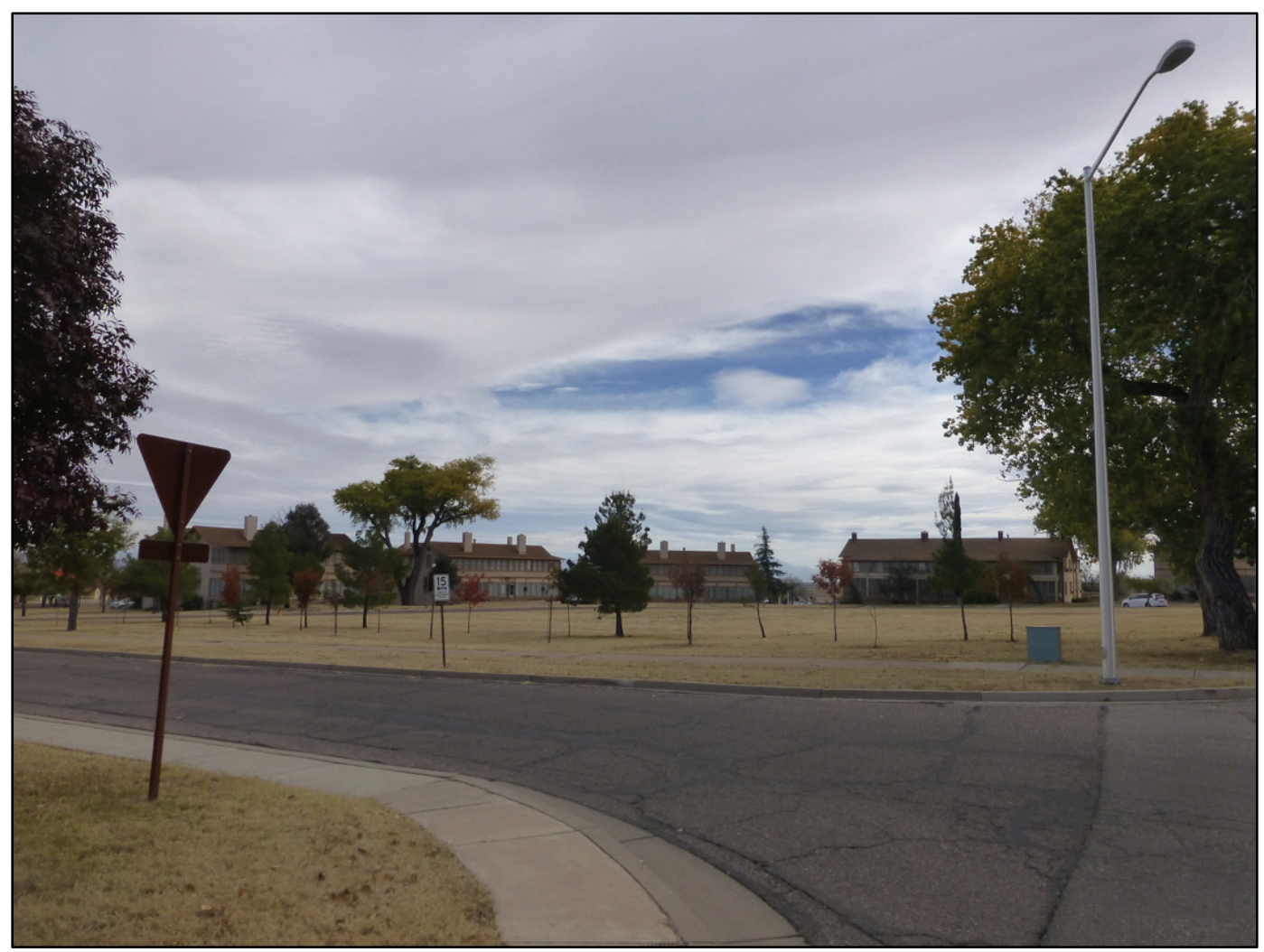




\subsubsection{Monuments and memorials}

Monuments and memorials are located throughout the Old Post Historic District. Many are located on Brown Field in front of Pershing House surrounding the flagpole (Figures 328 and 329). Modern statues are placed in front of the former theater (now the Museum Annex) and by the Credit Union (Figures 330 and 331).

Figure 328. Looking east at historical marker for NHL near flagpole on Brown Field (ERDCCERL 2016).

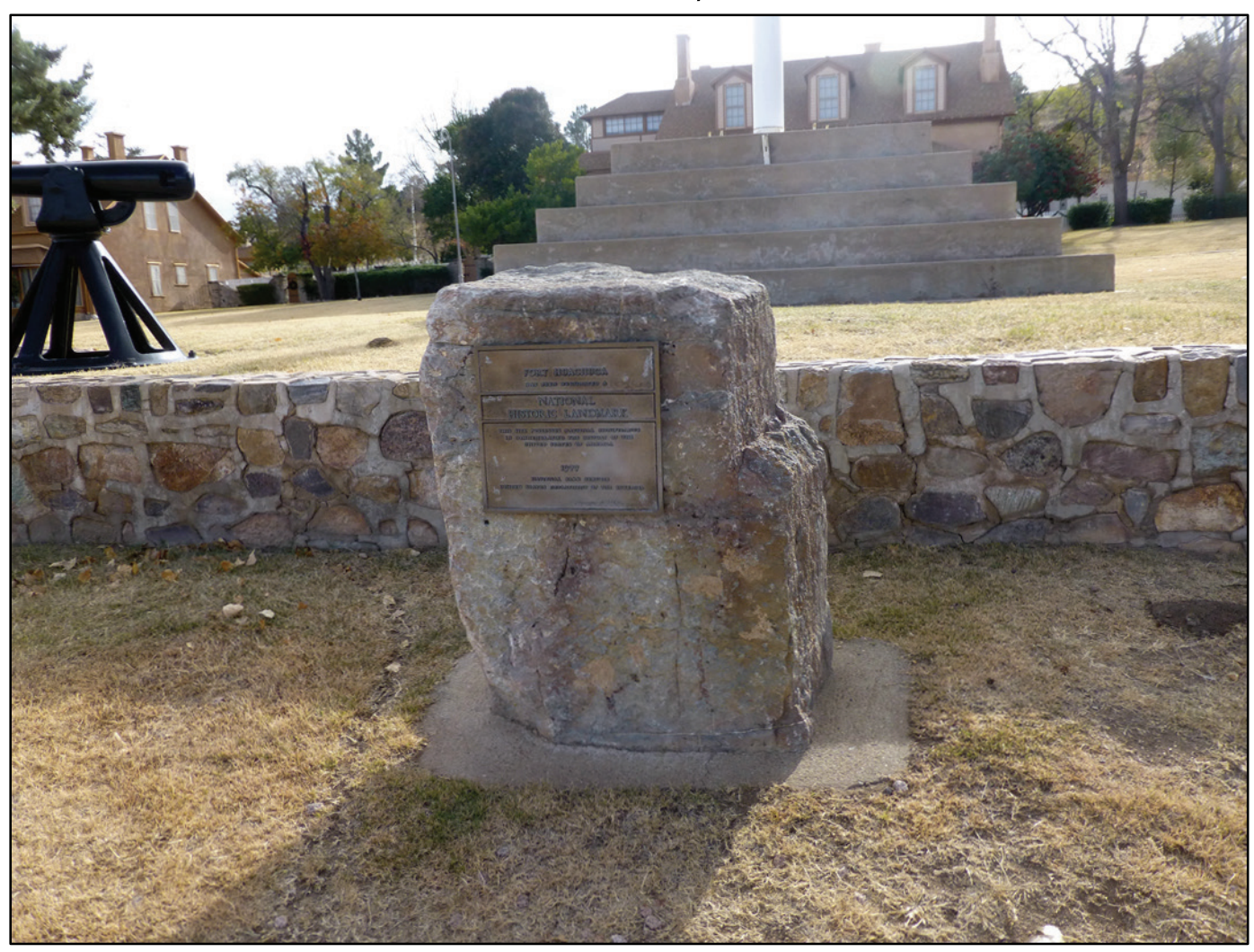


Figure 329. Looking northeast at monuments near flagpole on Brown Field (ERDC-CERL 2016).

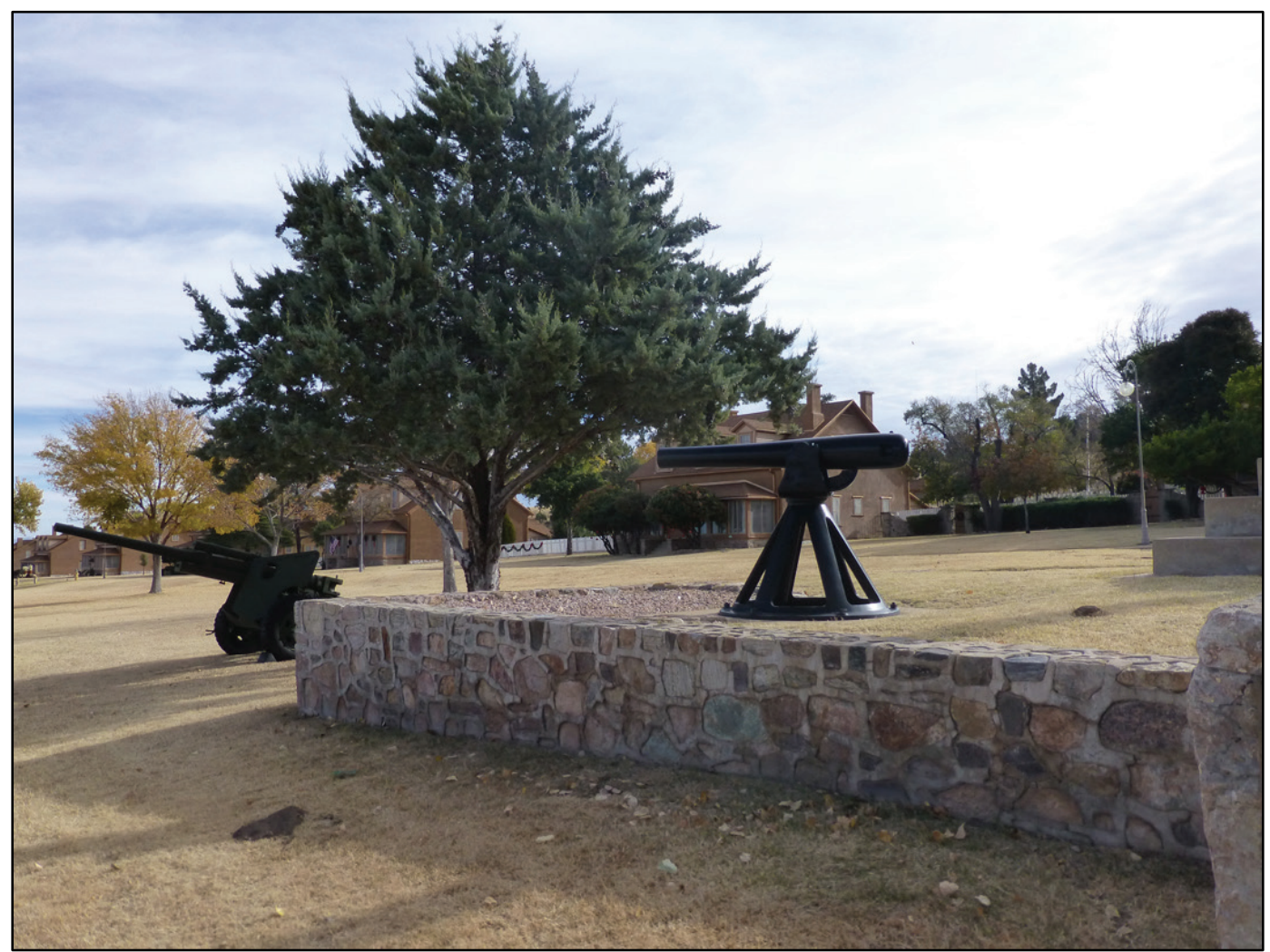

Figure 330. Looking west at sculpture and monument of an Apache Scout in front of Museum Annex (ERDC-CERL 2016).

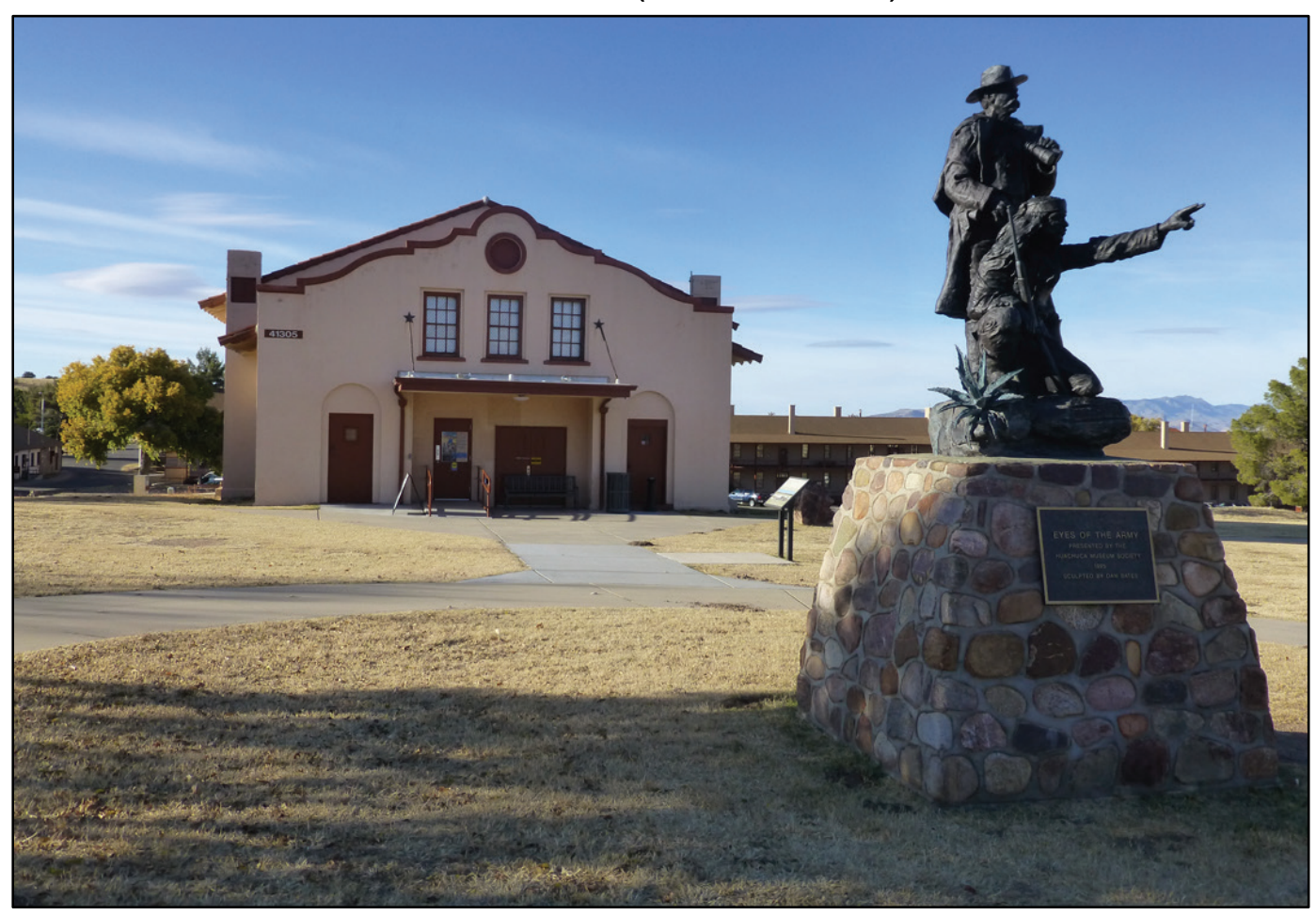


Figure 331. Looking north at Buffalo Soldiers Memorial located near the Credit Union (ERDCCERL 2016).

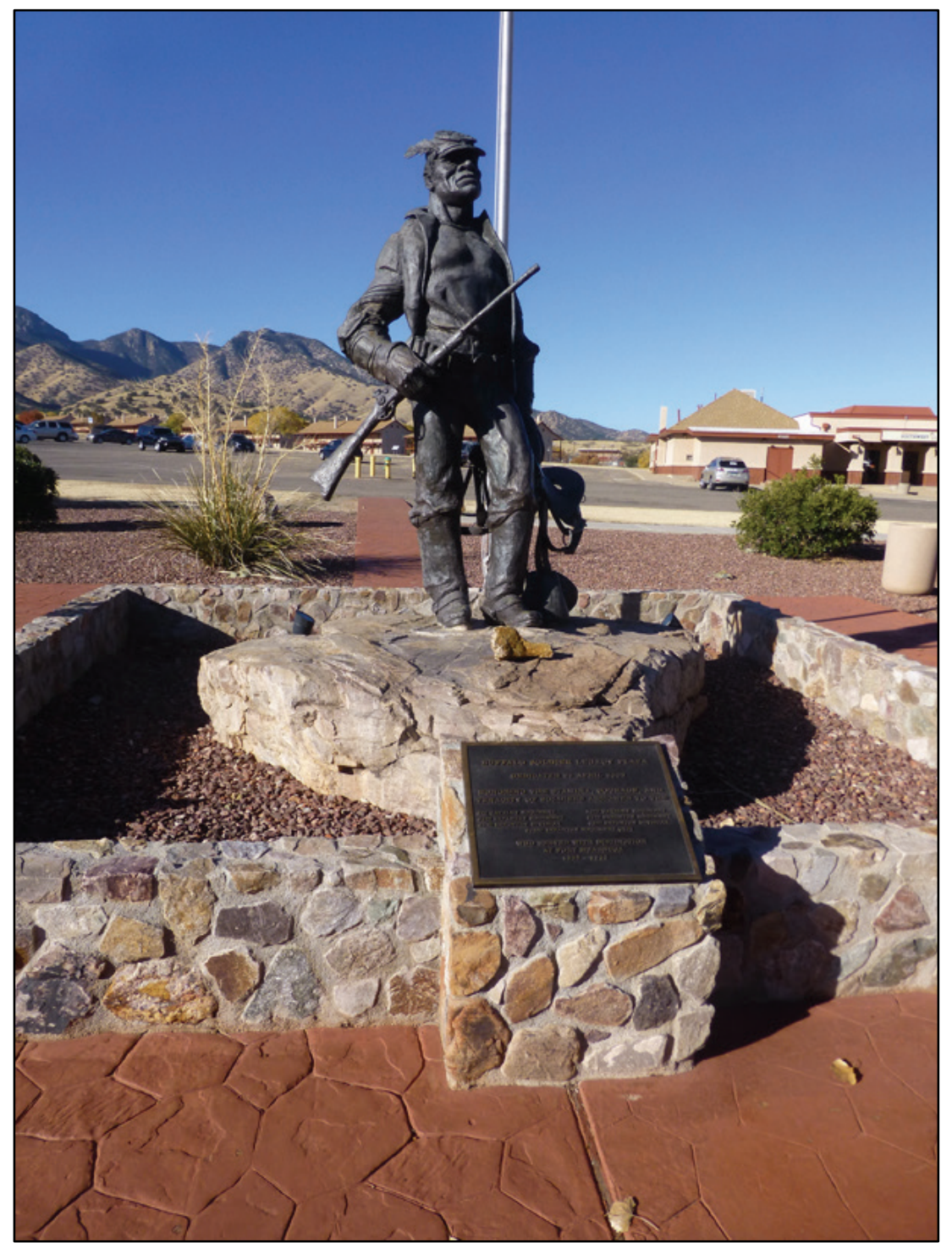

\subsubsection{Signage}

Other common landscape elements are locational signs scattered throughout the historic district, especially at the edge of the parade ground. These signs do not have building numbers and are considered neither contributing nor non-contributing; all are of recent construction (Figures 332 and 333). 
Figure 332. Signage on Brown Field in front of Fort Huachuca Museum (ERDC-CERL 2016).

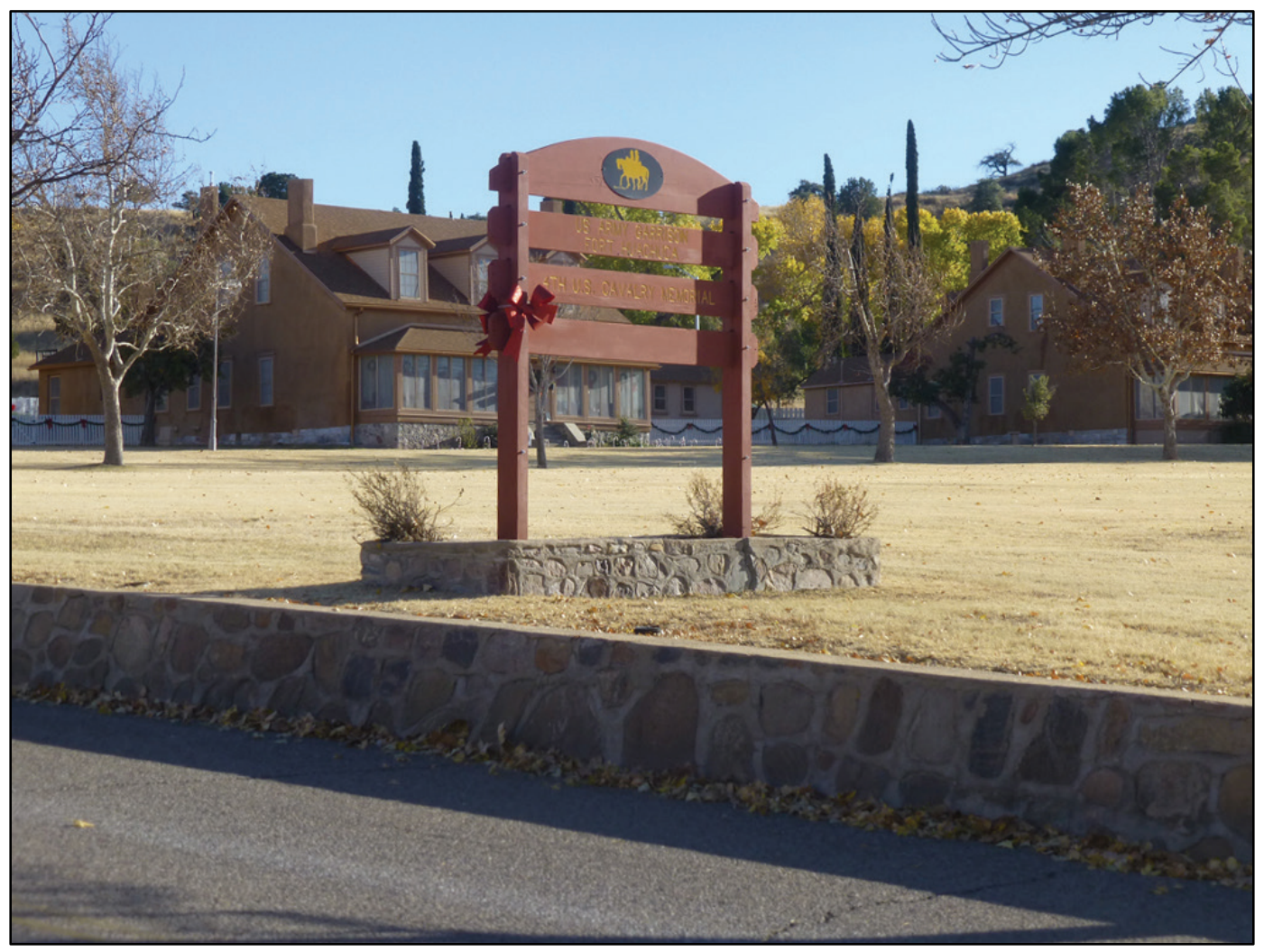

Figure 333. Signage at the Museum (ERDC-CERL 2016).

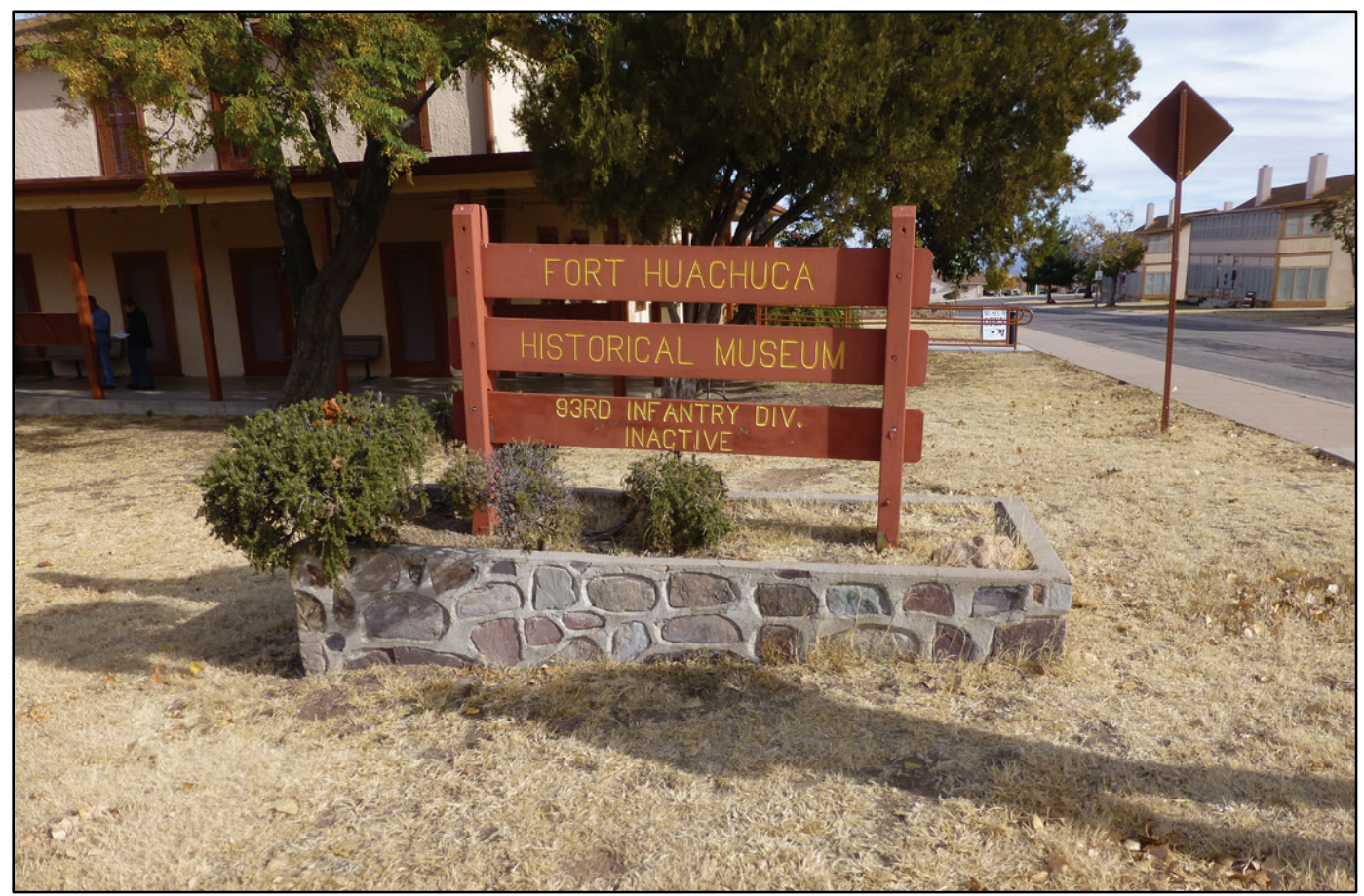




\subsubsection{Views and viewsheds}

Views played a vital role in the site selection, programmatic organization, and character of Fort Huachuca. Cultural landscapes are a relatively new field of inquiry, and as a consequence, the idea of documenting and preserving historically planned views and viewsheds is also a new idea in landscape studies. Views and viewsheds are intentionally designed features in a landscape. Although intangible, physical encroachment on them significantly alters the aesthetics of the design.

Views and viewsheds are created by landscape-scale physical elements. In the process of identifying and evaluating historic views and viewsheds, the historic physical elements are compared with the contemporary site context (Figure 334).

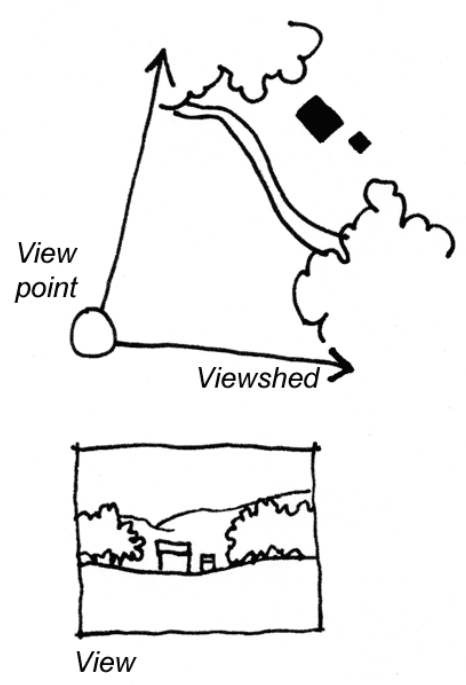

Figure 334. View and viewshed examples (ERDC-CERL).
Viewshed: Viewshed refers to all visible elements that can be seen from a certain viewpoint. Viewsheds are both external and internal. External viewsheds can have views from viewpoints outside of the historic district, while internal viewsheds are viewpoints from within the historic district.

Viewpoint: The exact point a person is standing when looking at a view.

View: A scene or vista that can be seen when looking in one direction standing at a certain viewpoint. The views in this report are illustrated through photographs.

There are many views and viewsheds at Fort Huachuca that are integral to the original design of the installation. The location of the Cantonment nestled at the mouth of Huachuca Canyon allowed for significant views from both Star Hill and from Reservoir Hill. The linear layout of the Cantonment and the vast open space of Brown Field allows for views up and down Augur Avenue and Grierson Avenue. 
Significant Views:

1. The view from Star Hill

2. The view from Reservoir Hill

3. View southwest over Fort Huachuca

4. Aerial of historic Cantonment looking south

5. View of Pershing House (22126) and flagpole

6. Views along Grierson Avenue

7. Views along Augur Avenue

8. View from Museum and Headquarters toward Brown Field

9. View across Brown Field looking north

10. Views of 1914 Barracks

11. Views across Henry Circle.

\subsubsection{The view from Star Hill}

The view from Star Hill, historically referred to as Observation Point or Cemetery Hill, is a significant one that has been well documented in historic photographs since the start of the Post (Figure 335 and 336). It is most recently called Star Hill because in the winter there is an illuminated star placed on the top of the hill. It has a high degree of integrity since there are few new structures and consistent vegetation (Figure 337). 
Figure 335. Looking east over Fort Huachuca from Star Hill, 1890 (NARA College Park, RG165-FF).

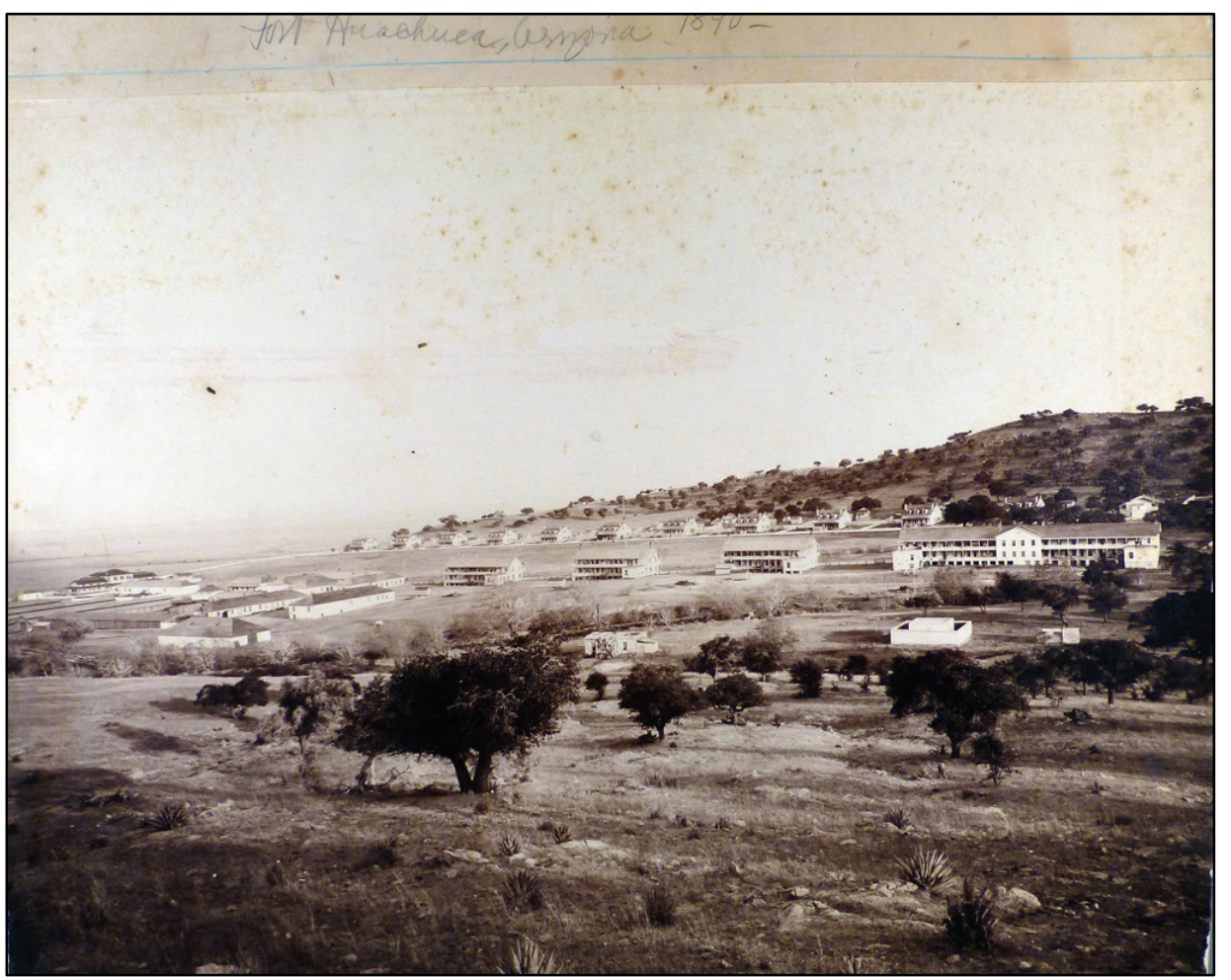

Figure 336. Post card of close-up view from Star Hill, date unknown (ERDC-CERL Collection).

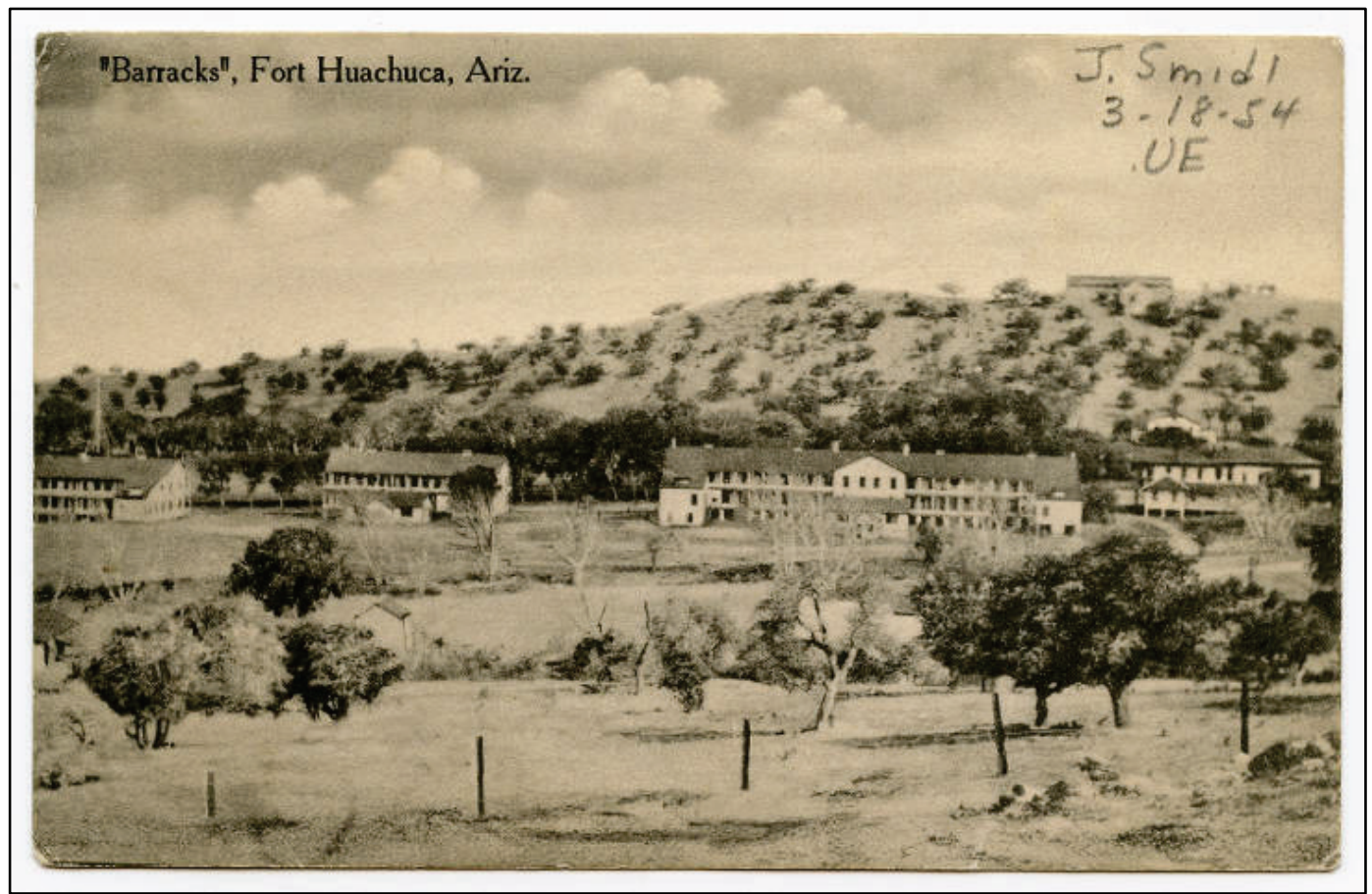


Figure 337. View south over Fort Huachuca from Star Hill (ERDC-CERL, 2016).

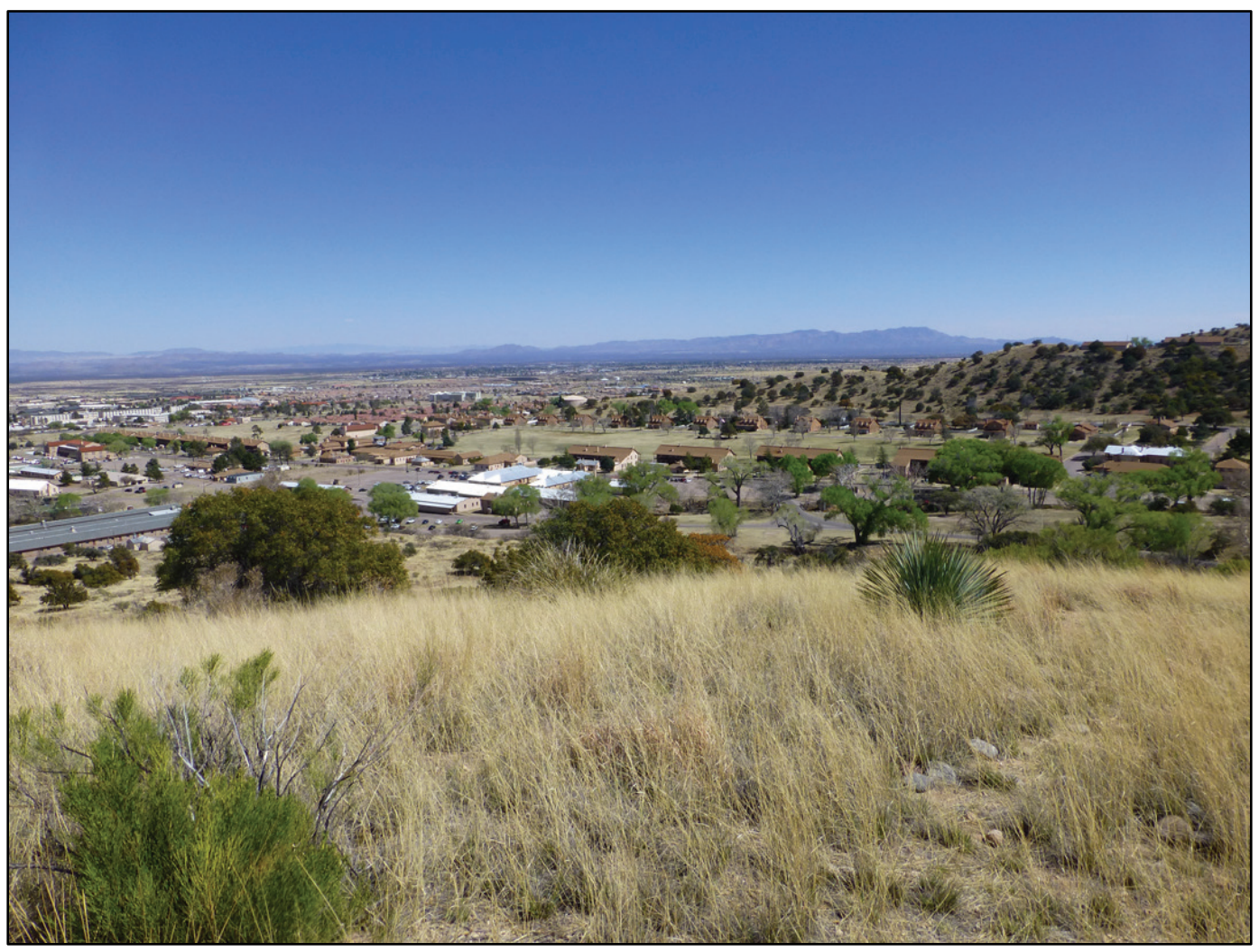

5.8.7.2 The view from Reservoir Hill

The view from Reservoir Hill is a significant one that has been well documented in historic photographs and post cards since the 1880 s (Figure 338-341). It has a high degree of integrity since there are few new structures and consistent vegetation (Figure 342). 
Figure 338. Looking west over Fort Huachuca from west of the reservoir, c.1900 (NARA College Park, RG165-FF).

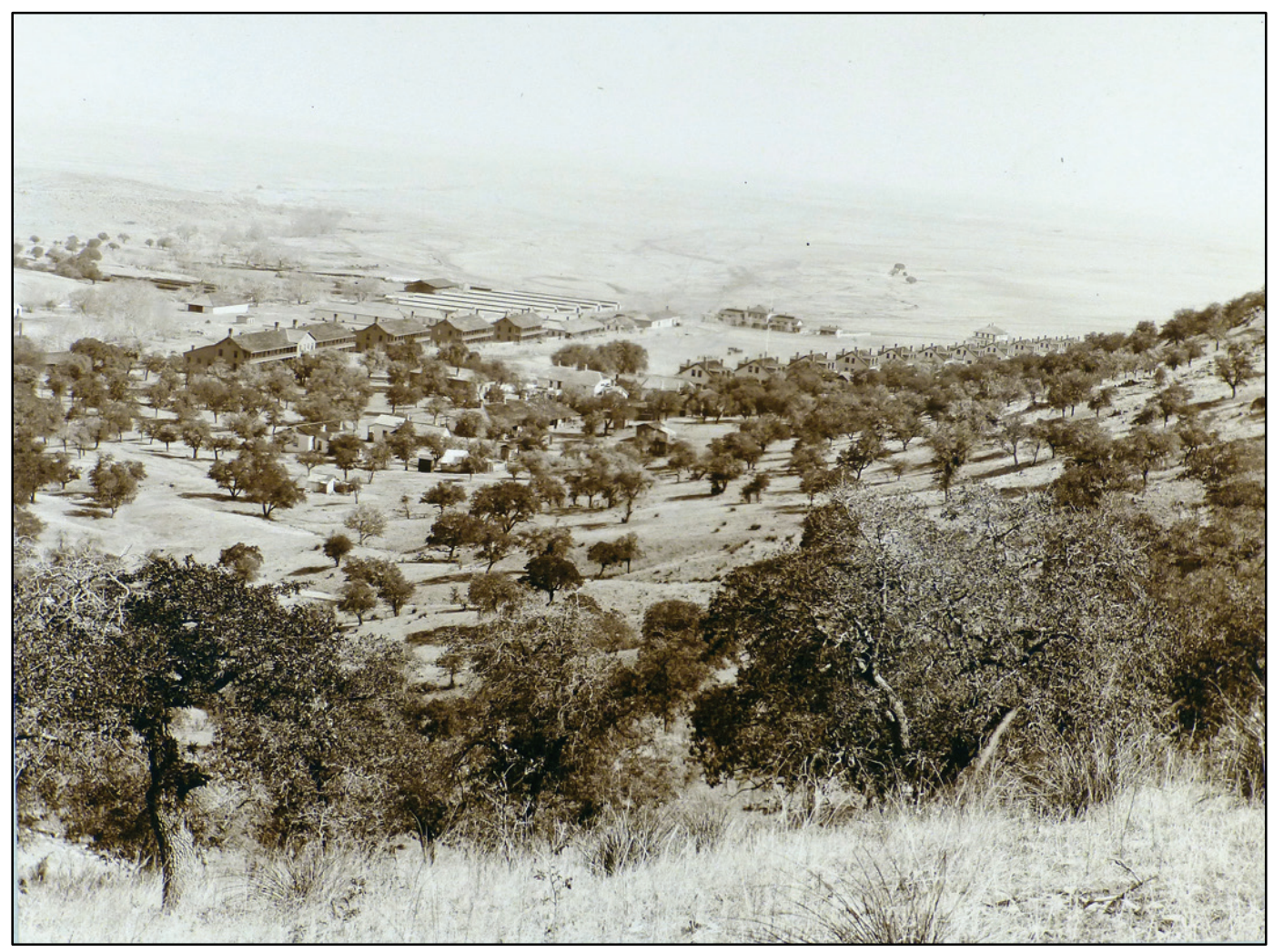


Figure 339. View north over Fort Huachuca from Reservoir Hill, 1954 (NARA College Park, RG111-SC).

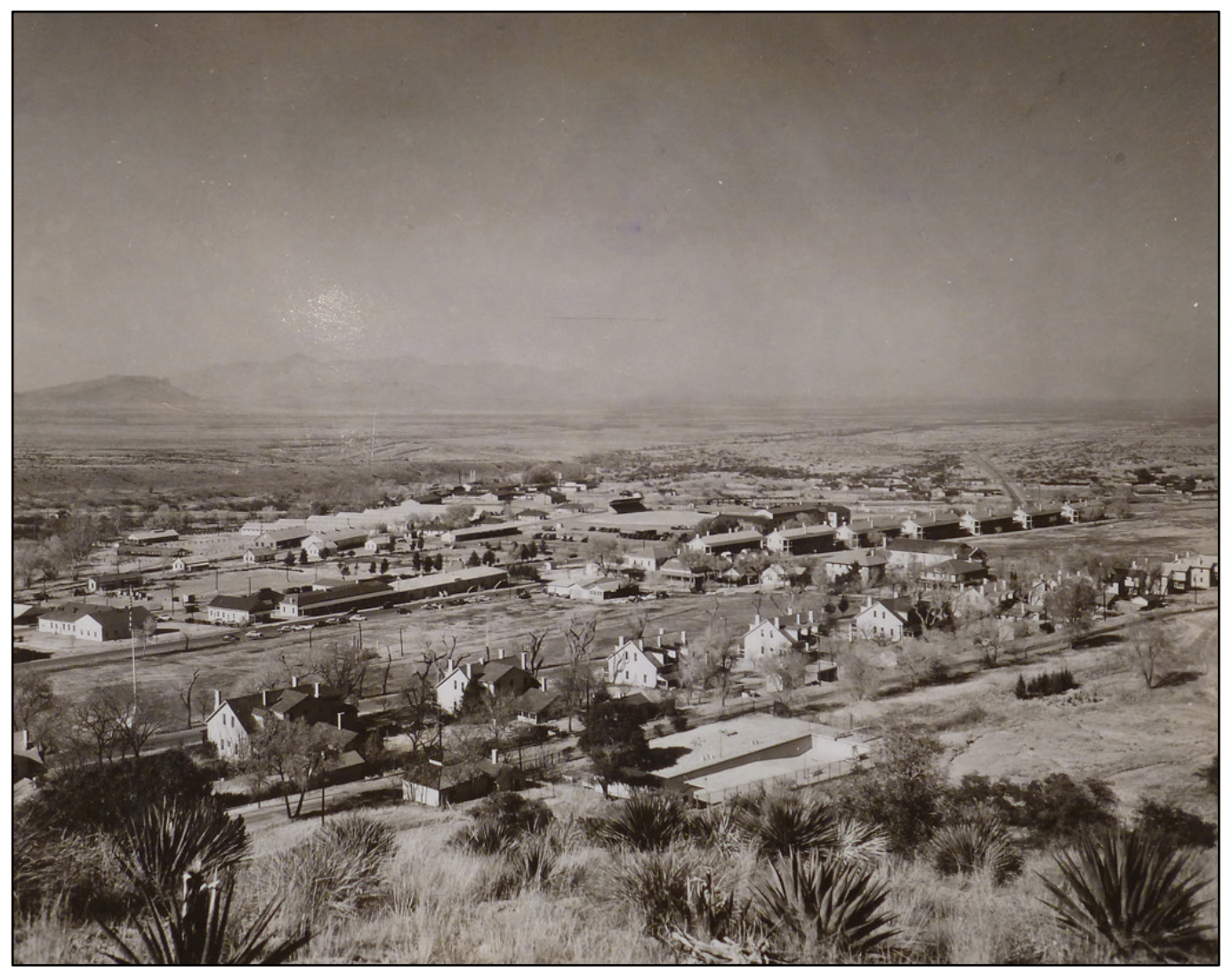

Figure 340. Historic postcard of view from Reservoir Hill, date unknown (ERDC-CERL Collection).

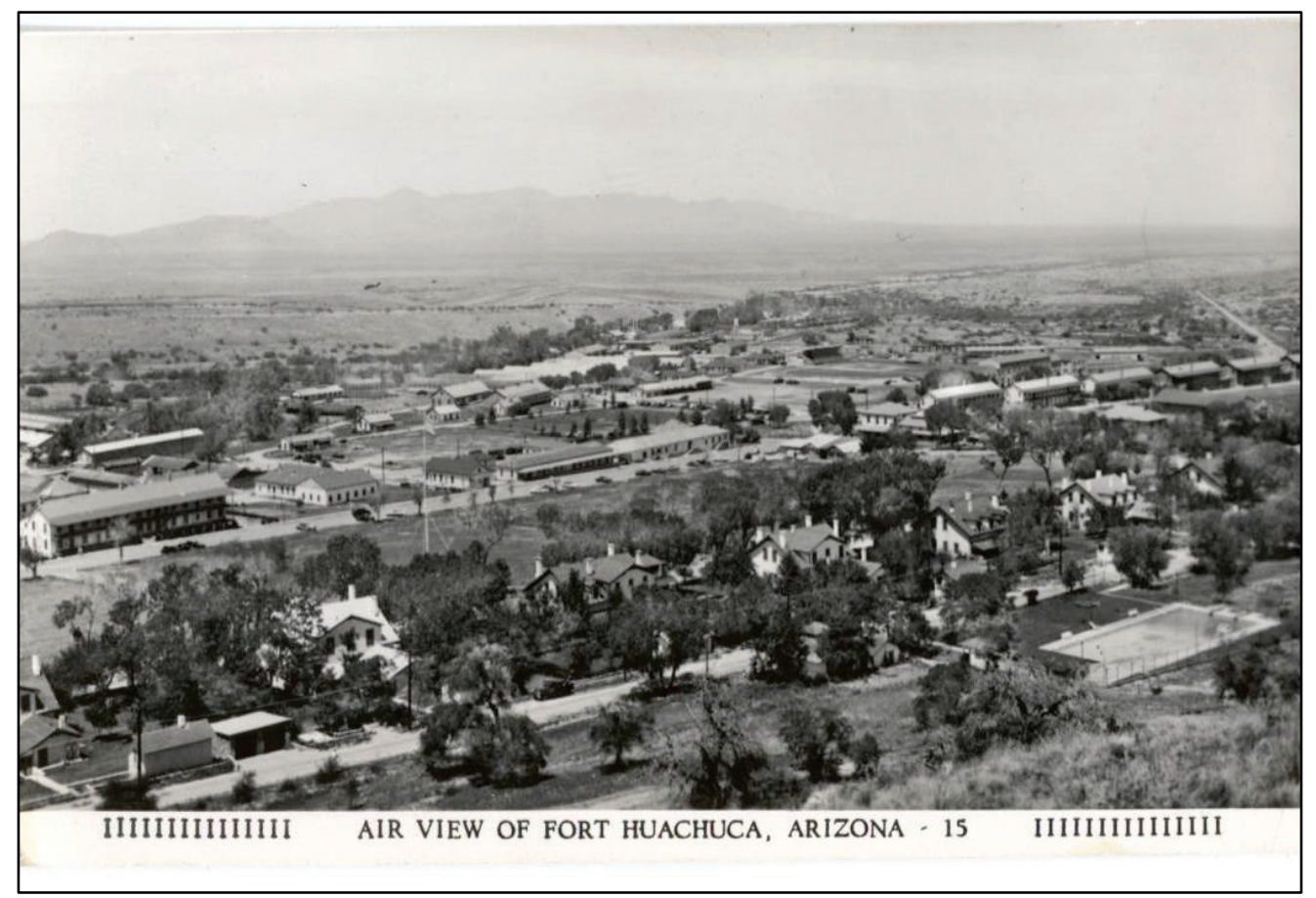


Figure 341. Postcard of view from Reservoir Hill, c.1956 (ERDC-CERL Collection).

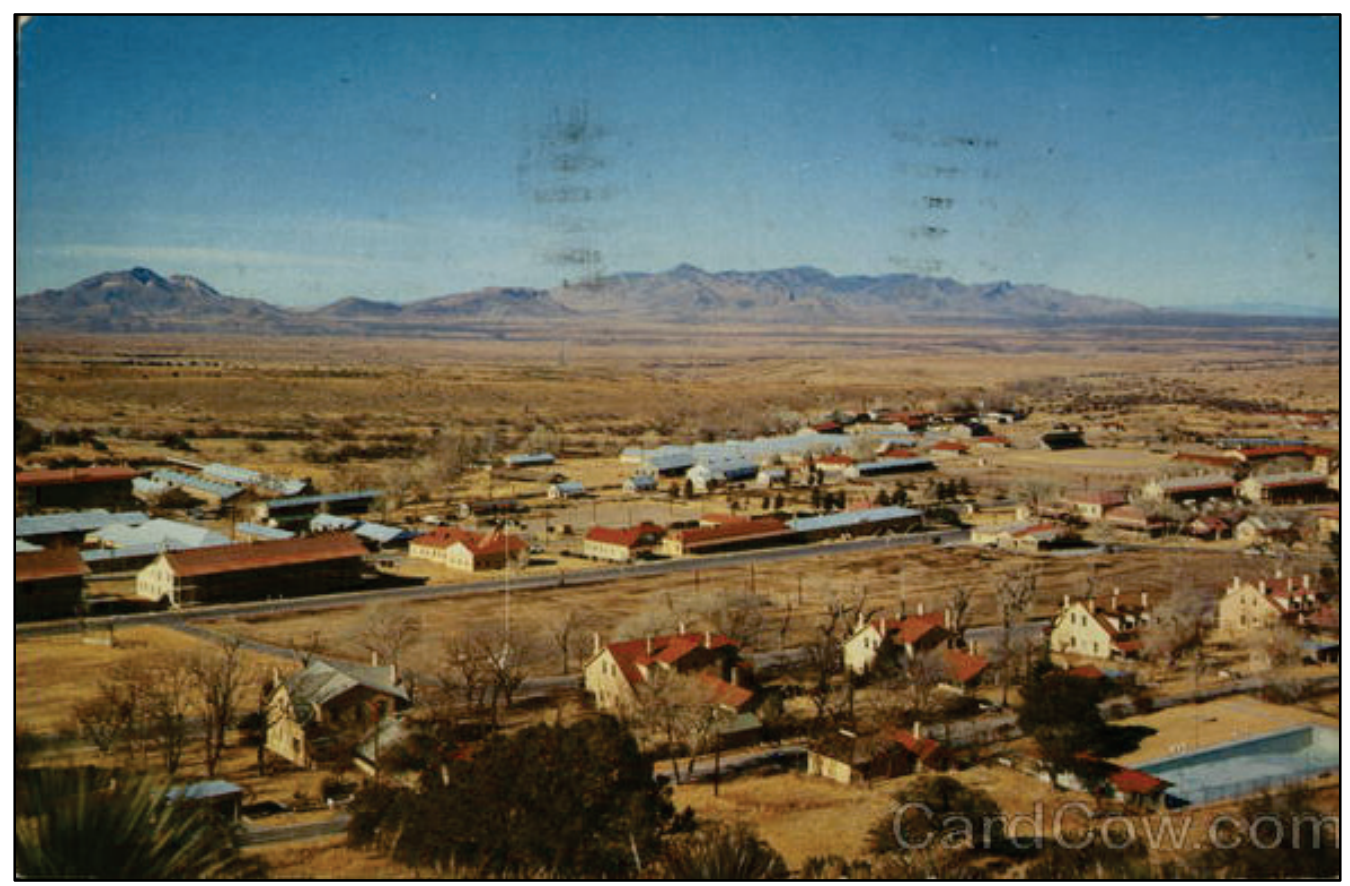

Figure 342. View north over Fort Huachuca from Reservoir Hill (ERDC-CERL, 2016).

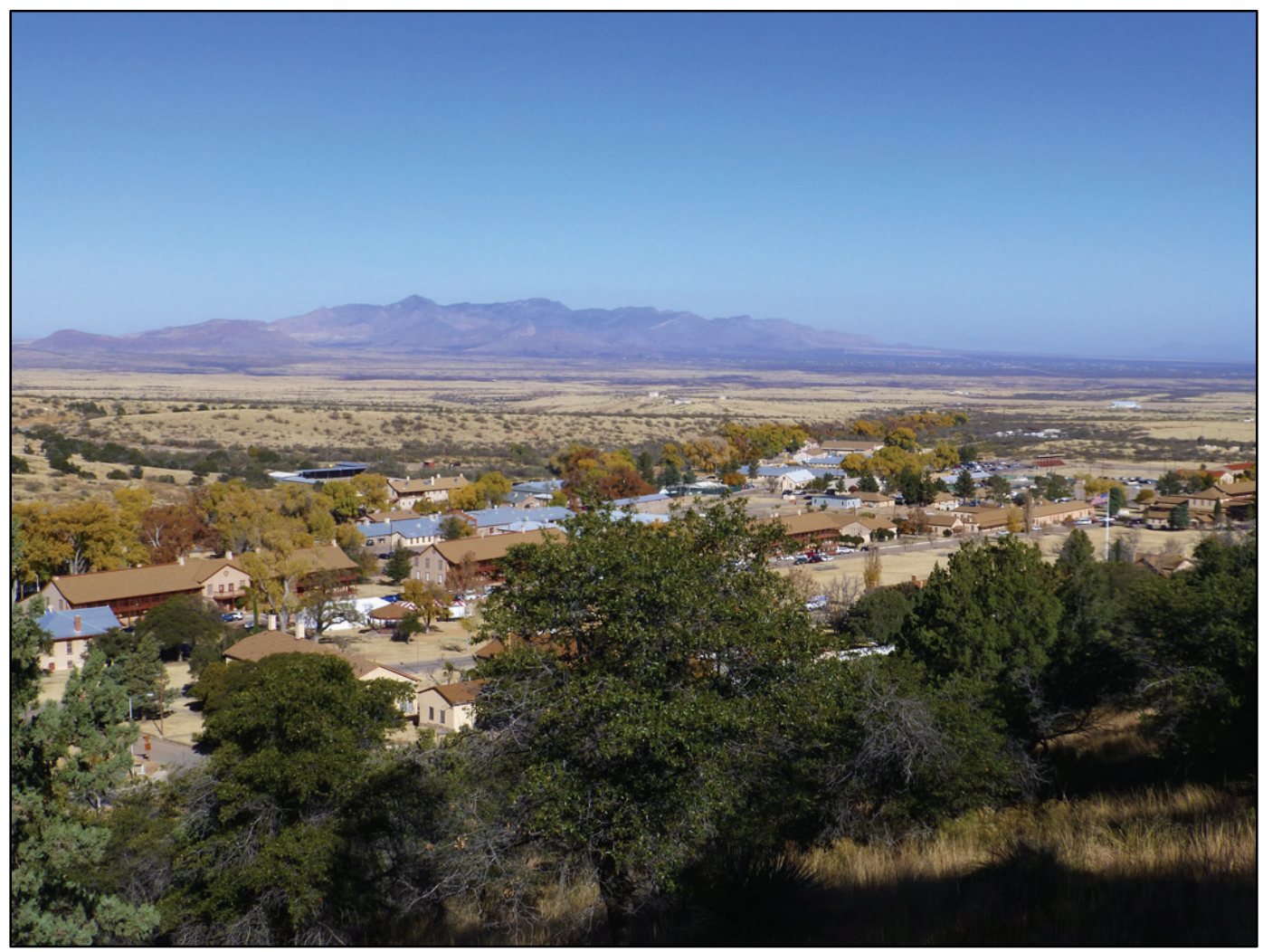




\subsubsection{View southwest over Fort Huachuca}

This view from behind the Old Post Officers' Quarters looking out over the parade field toward the barracks and Cemetery Hill was present in historic photographs (Figures 343 and 344). Today the garages, servants' quarters, coal bins, fencing, and Grierson Service Road are visible in the view. While contributing resources to the historic district, the view is not as open as it was historically due to fencing, garages, and parking (Figure 345). The view still has integrity.

Figure 343. View southwest over Fort Huachuca, c.1883 (NARA College Park, RG165-FF).

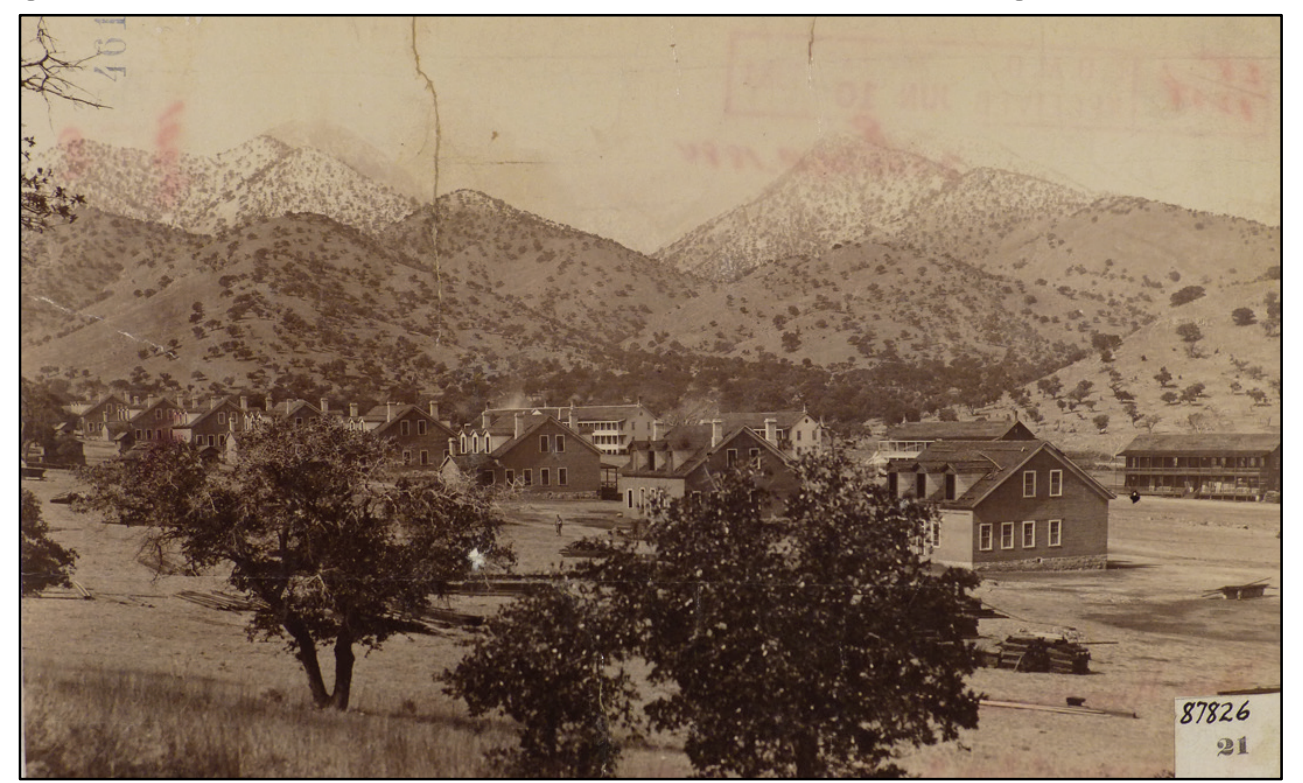

Figure 344. View southwest over Fort Huachuca, 1893 (Fort Huachuca Museum).

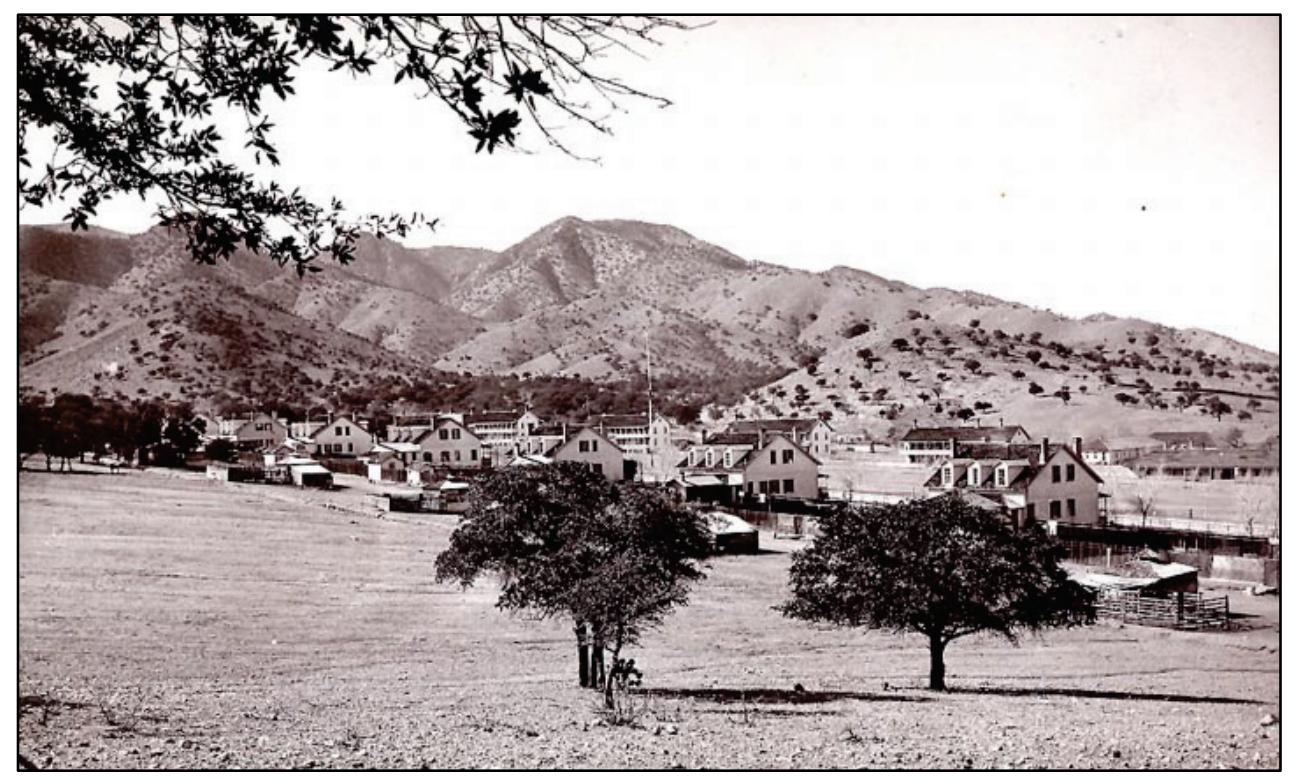


Figure 345. View south from behind officers' quarters down Grierson Service Road (ERDCCERL 2016).

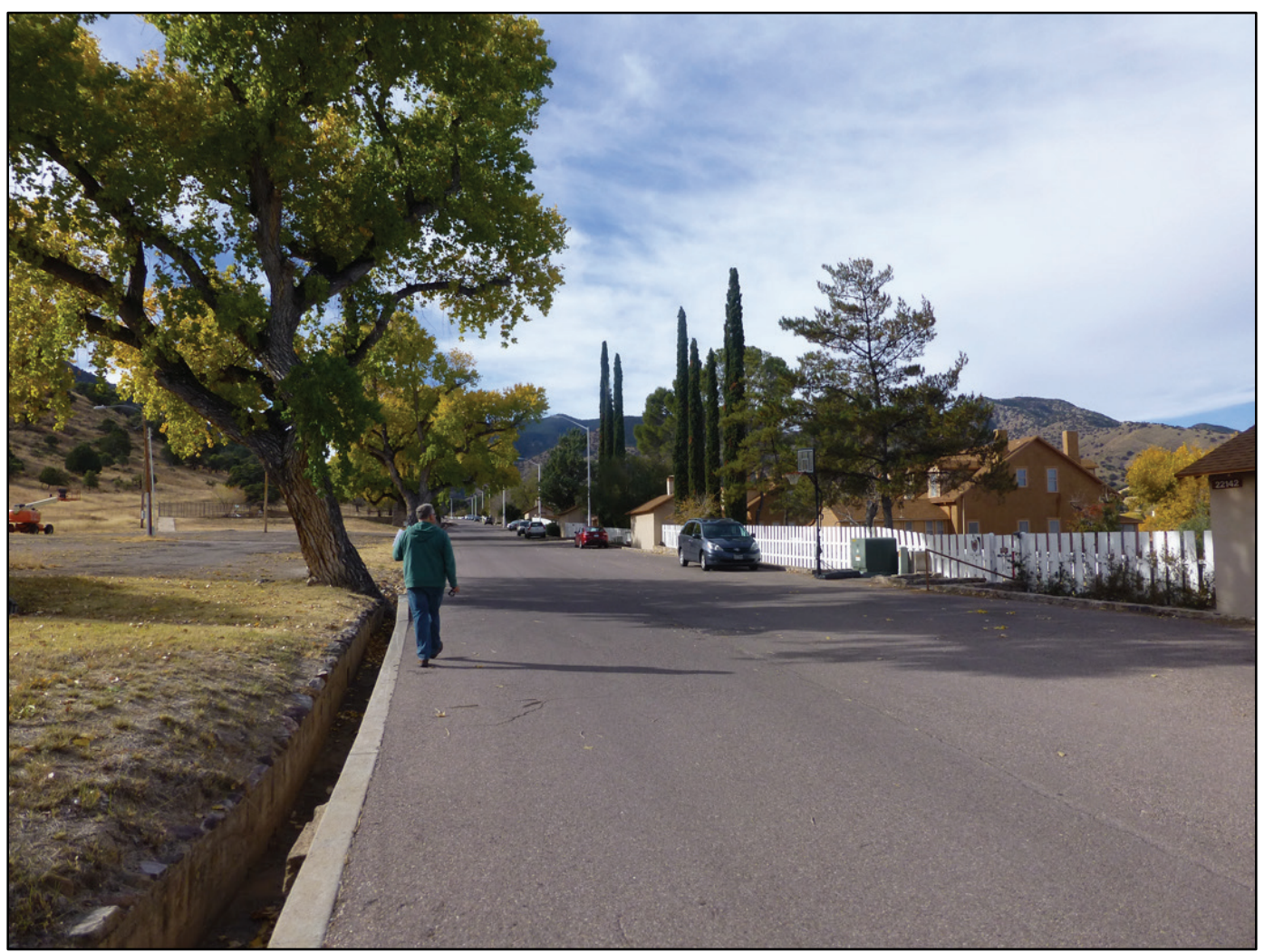

\subsubsection{Aerial of historic Cantonment looking south}

The view looking south over the historic Cantonment is a very significant view of the historic district. It is possible early aerial photographs were originally taken from the radio tower. This view clearly shows the Old Post and the 1910s additions to the landscape (Figure 346). It has high integrity today (Figure 347). 
Figure 346. Aerial view of historic Cantonment, 1929 (NARA College Park, RG165-FF).

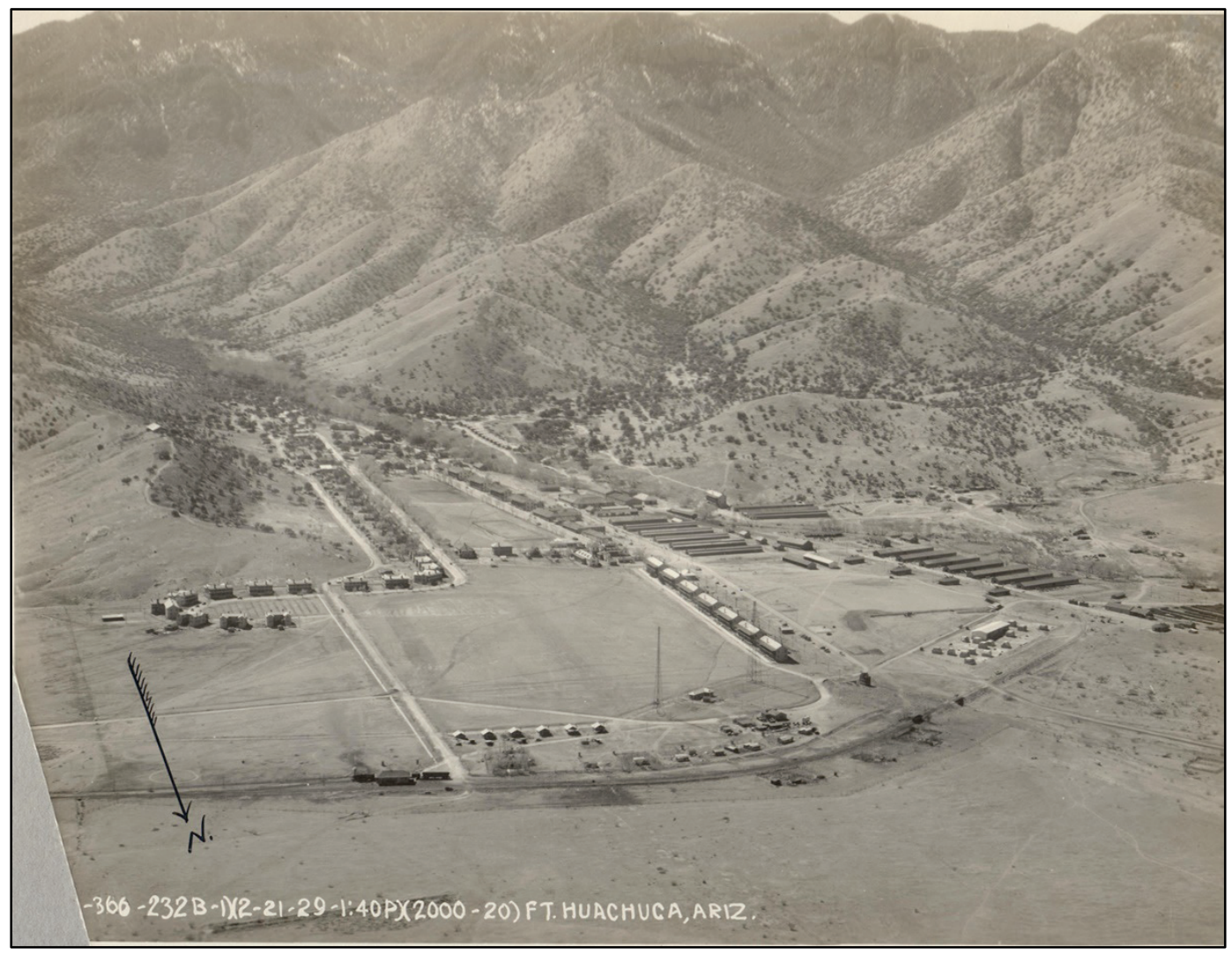

Figure 347. Aerial view of historic Cantonment, c.1980 (Fort Huachuca).

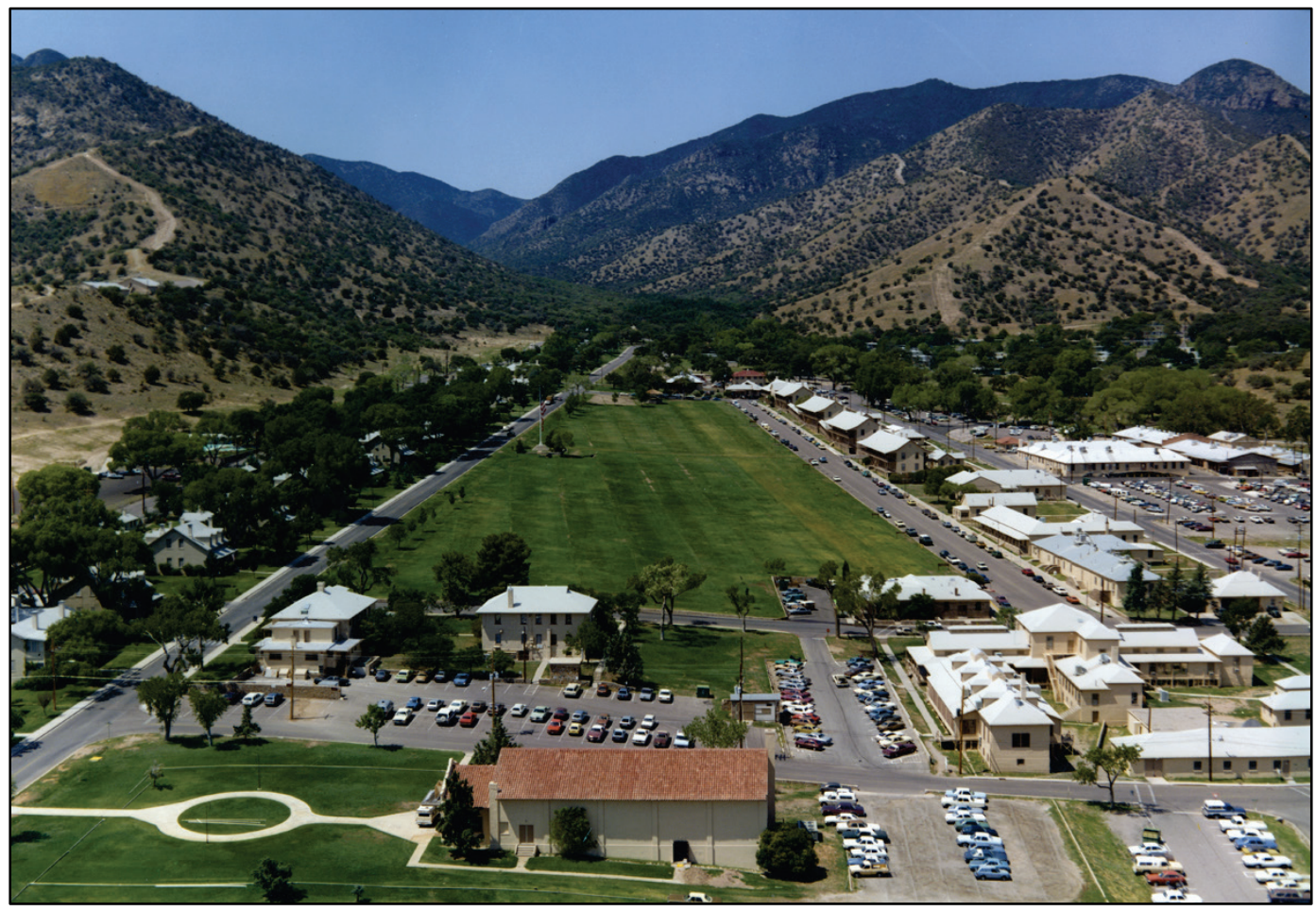


5.8.7.5 View of Pershing House (22126) and Flagpole

At many installations, the flagpole is located in front of the Headquarters building or on or near the parade field. At Fort Huachuca, the flagpole is located on the parade field in a prominent location in front of the Commanding General's quarters, Pershing House (22126). Views to the flagpole from across Brown Field are common (Figure 348). A new retaining wall, evergreen trees and shrubs, and artillery pieces are located around the flagpole. In addition, many shade trees along the edge of the parade field are missing. This view has moderate integrity (Figure 349).

Figure 348. View southeast of Pershing House and flagpole, 1898 (NARA College Park, RG165-FF).

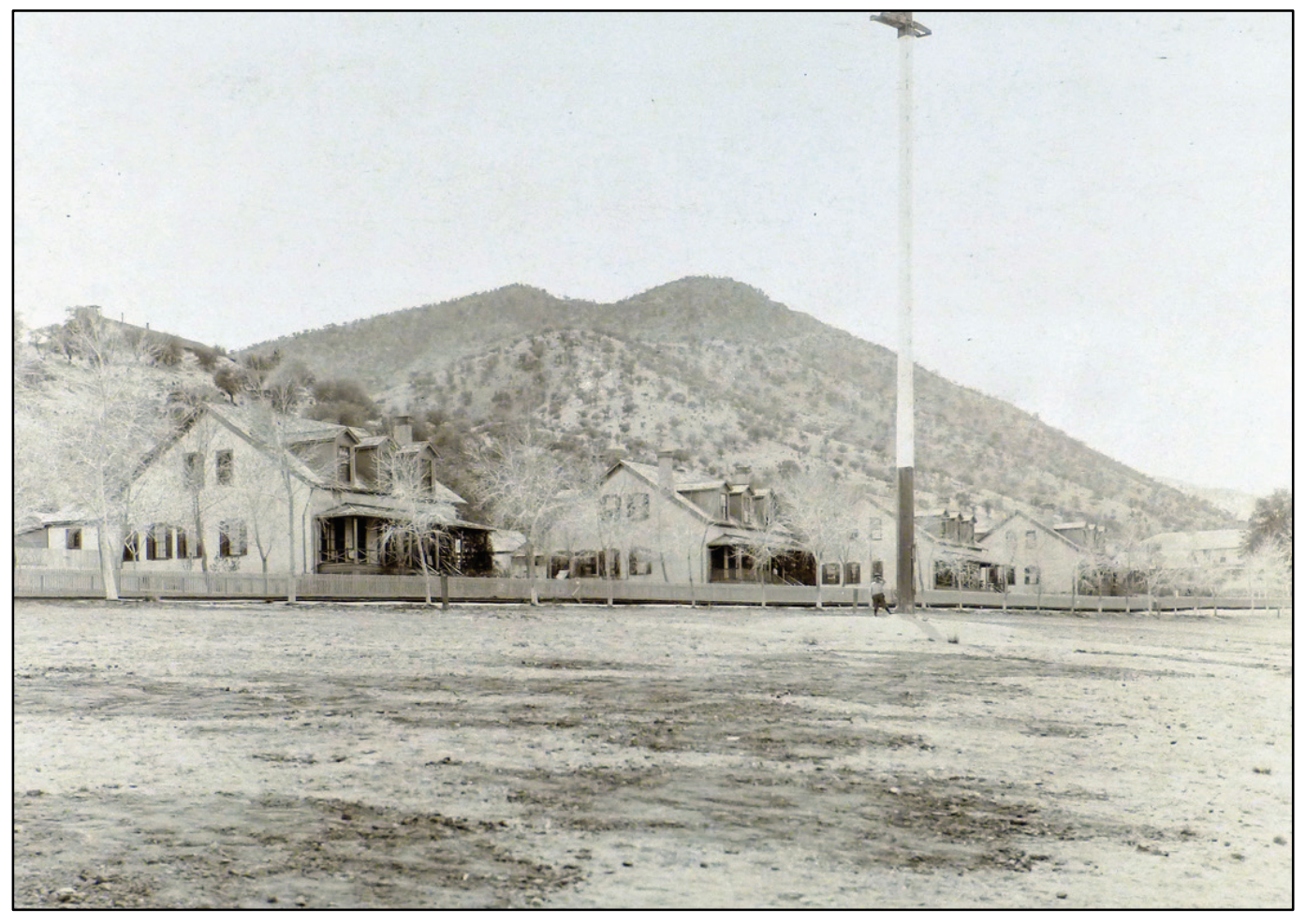


Figure 349. View east of the flagpole and Pershing House (ERDC-CERL 2016).

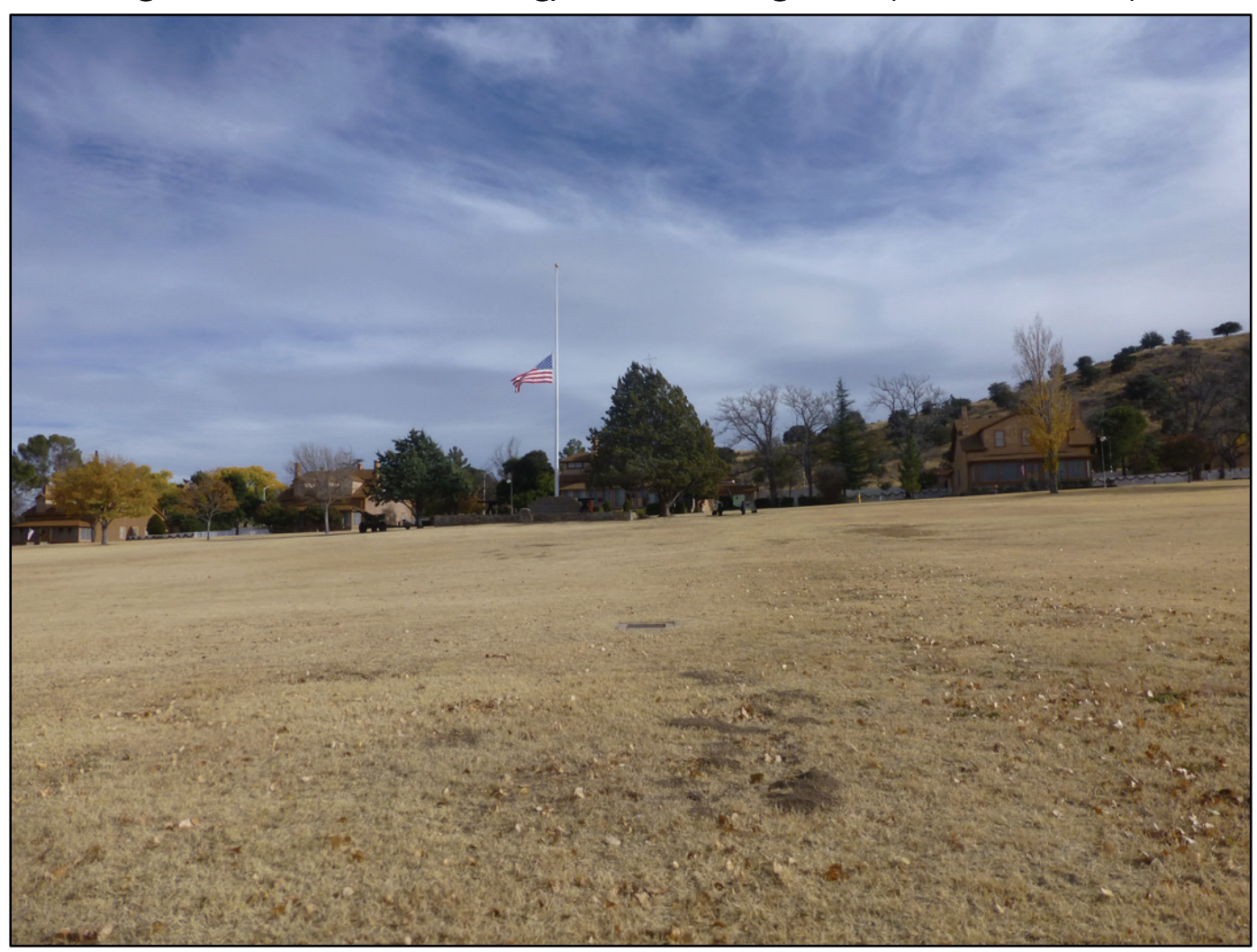

5.8.7.6 Views along Grierson Avenue

There are many historic views of the Old Post Officers' Quarters up and down Grierson Avenue (Figure 350). While 1890s photographs included the white picket fencing and the wooden sidewalks, the quarters have a high degree of integrity and contribute greatly to the integrity of these views. There are fewer street trees on the edge of the parade field and by the quarters (Figures 351 and 352). 
Figure 350. View south of quarters along Grierson Avenue, c.1900 (Fort Huachuca Museum).

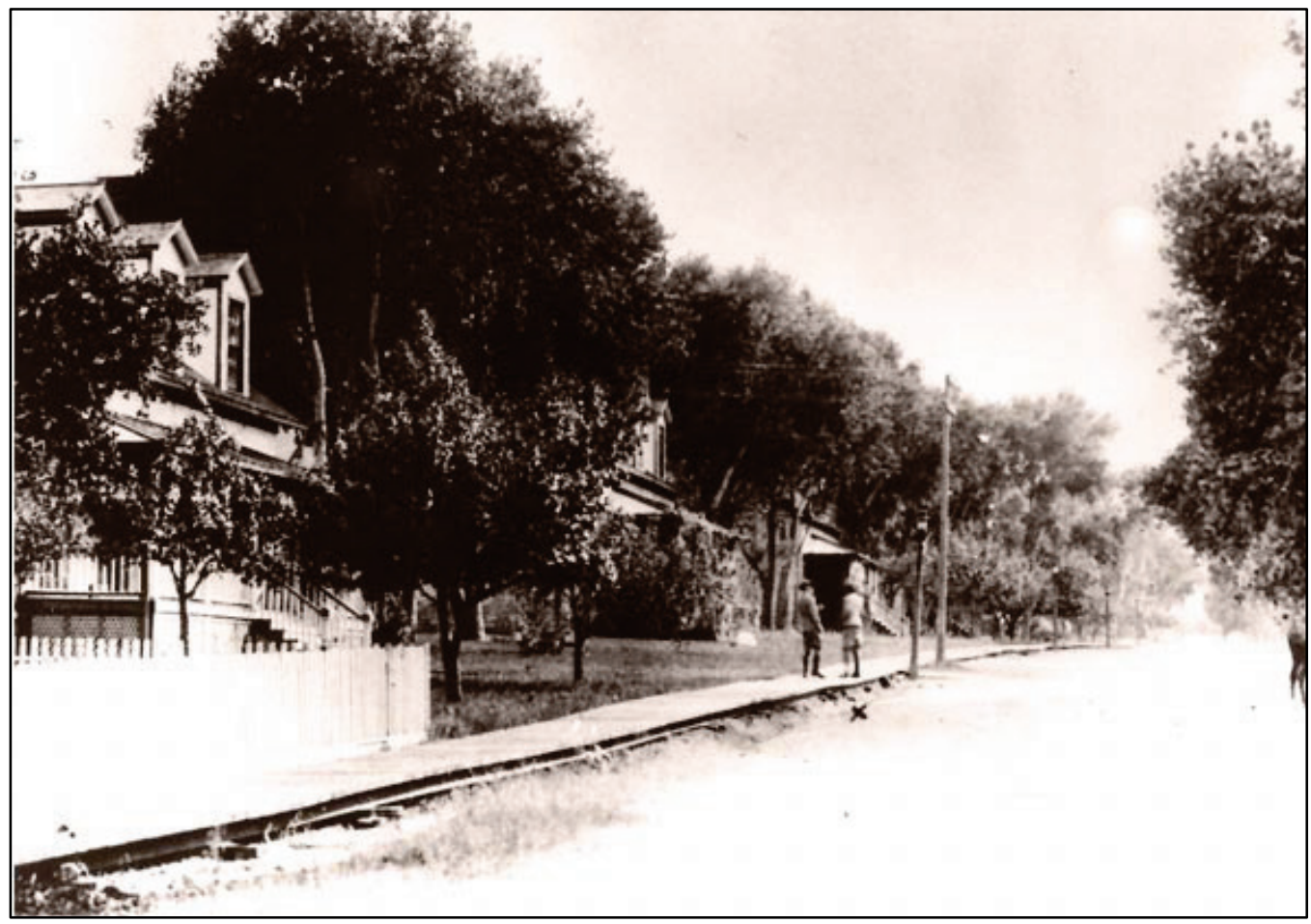

Figure 351. View north looking north along Grierson Avenue (ERDC-CERL 2016).

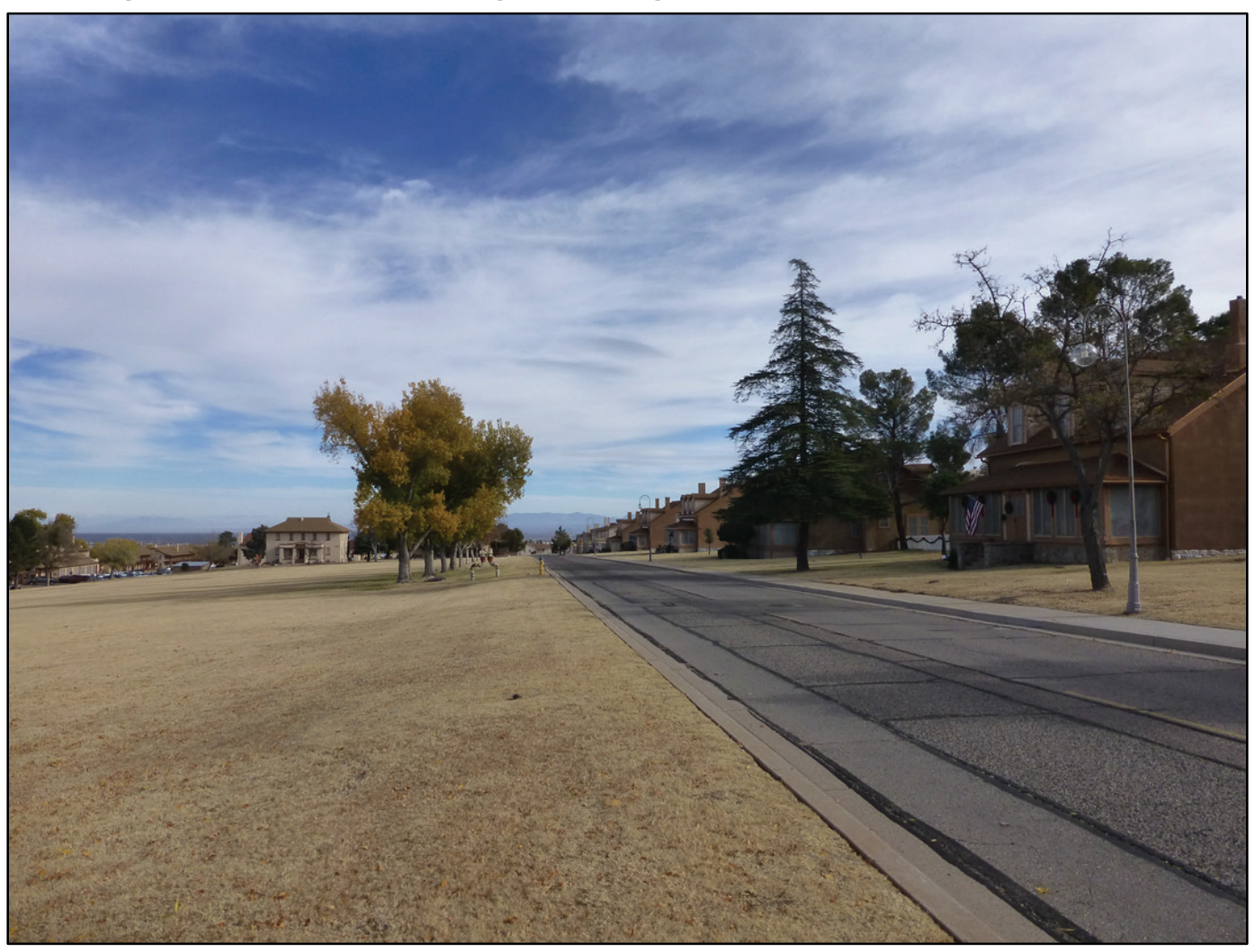


Figure 352. View south looking south along Grierson Avenue (ERD-CERL 2016).

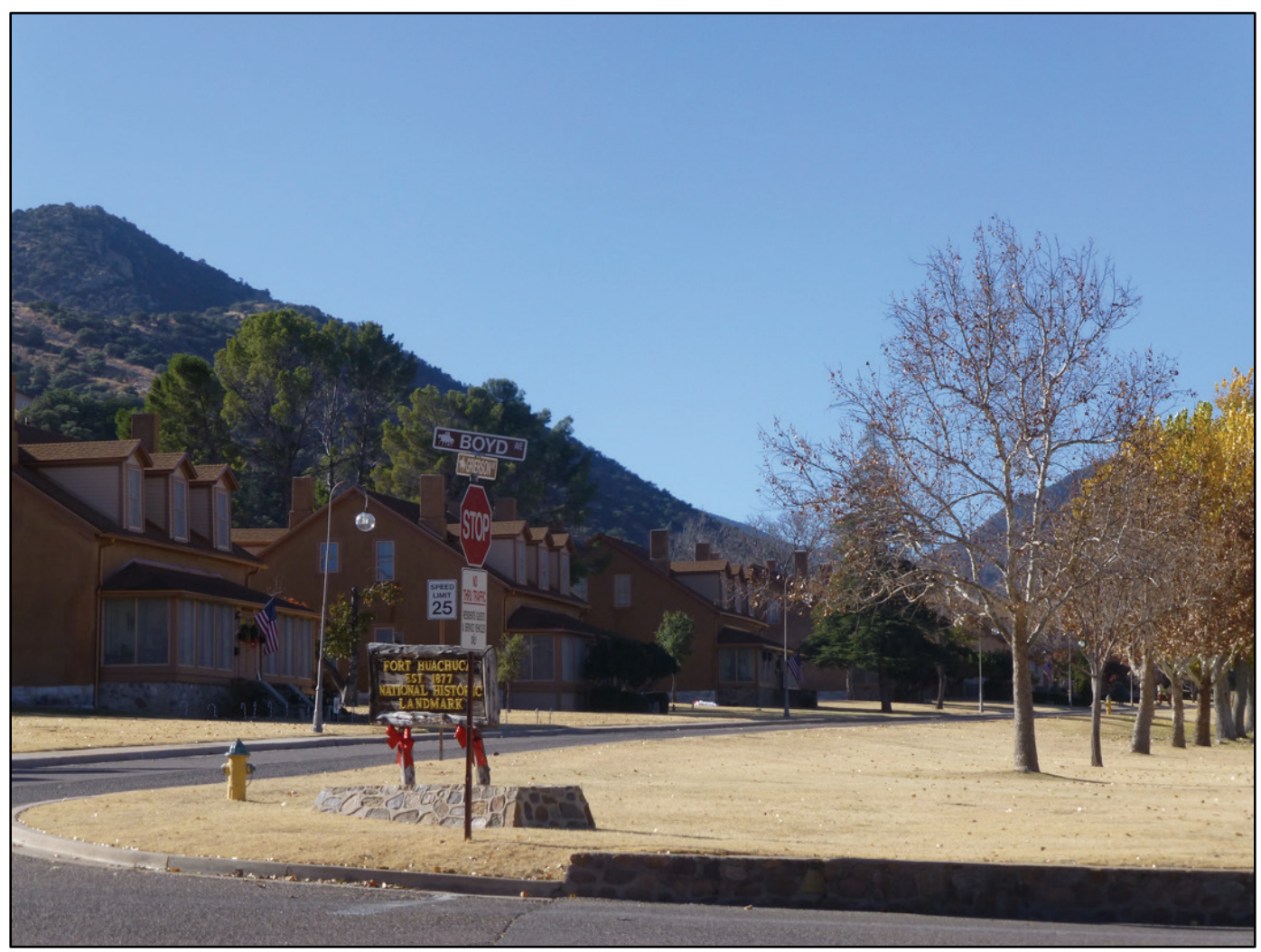

5.8.7.7 Views along Augur Avenue

The views along Augur Avenue of the Old Post Barracks is a significant view in the historic district (Figure 353). The loss of some of the vegetation, foundation plantings, and street trees, plus the addition of parking in front of the barracks, has affected this historic view some (Figure 354). It retains moderate integrity. 
Figure 353. View north of barracks (22214, 22216, and 22320) along Augur Avenue, 1918 (Fort Huachuca Museum).

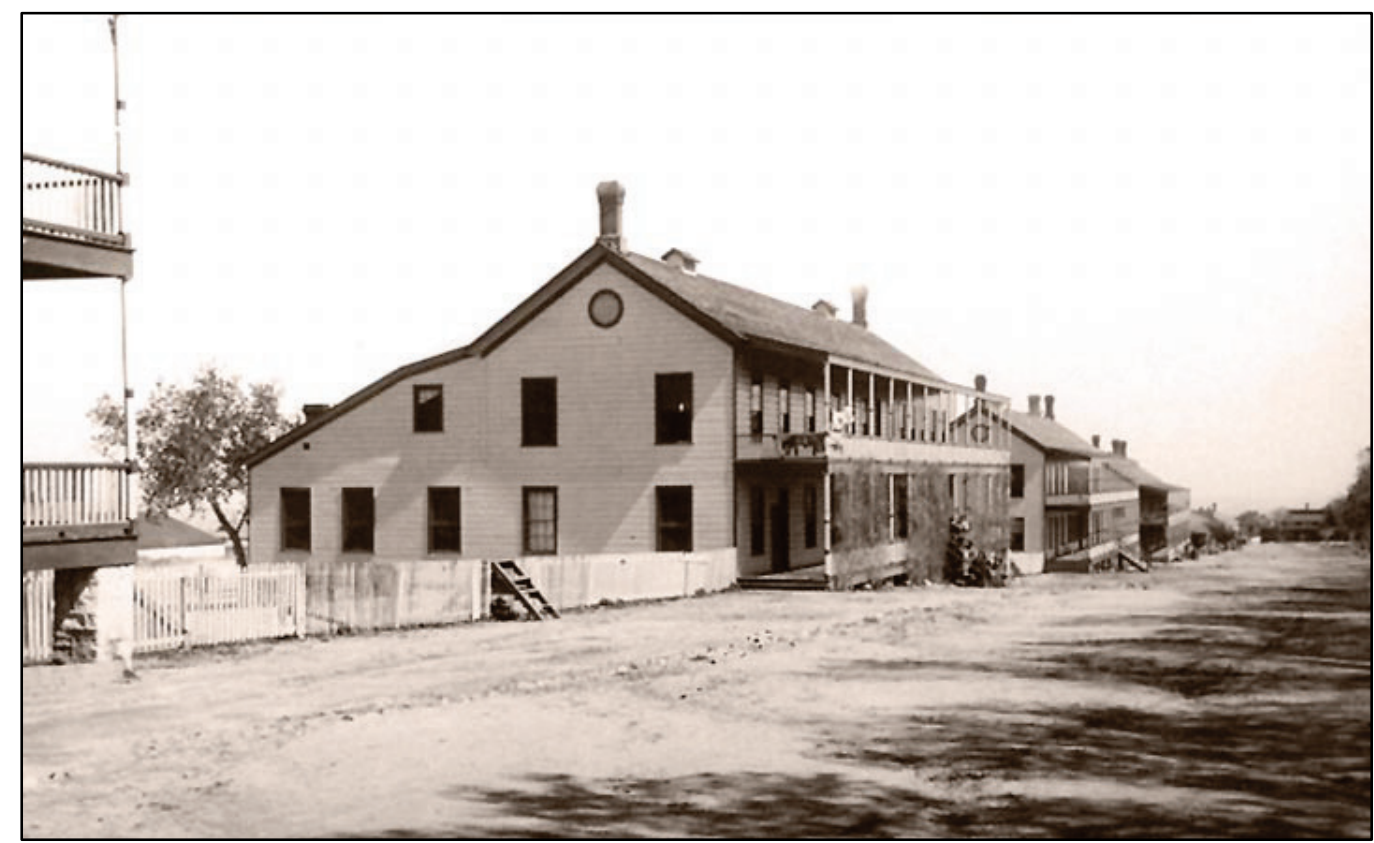

Figure 354. View southwest of 1880s Barracks looking southwest across Brown Field (ERDCCERL 2016).

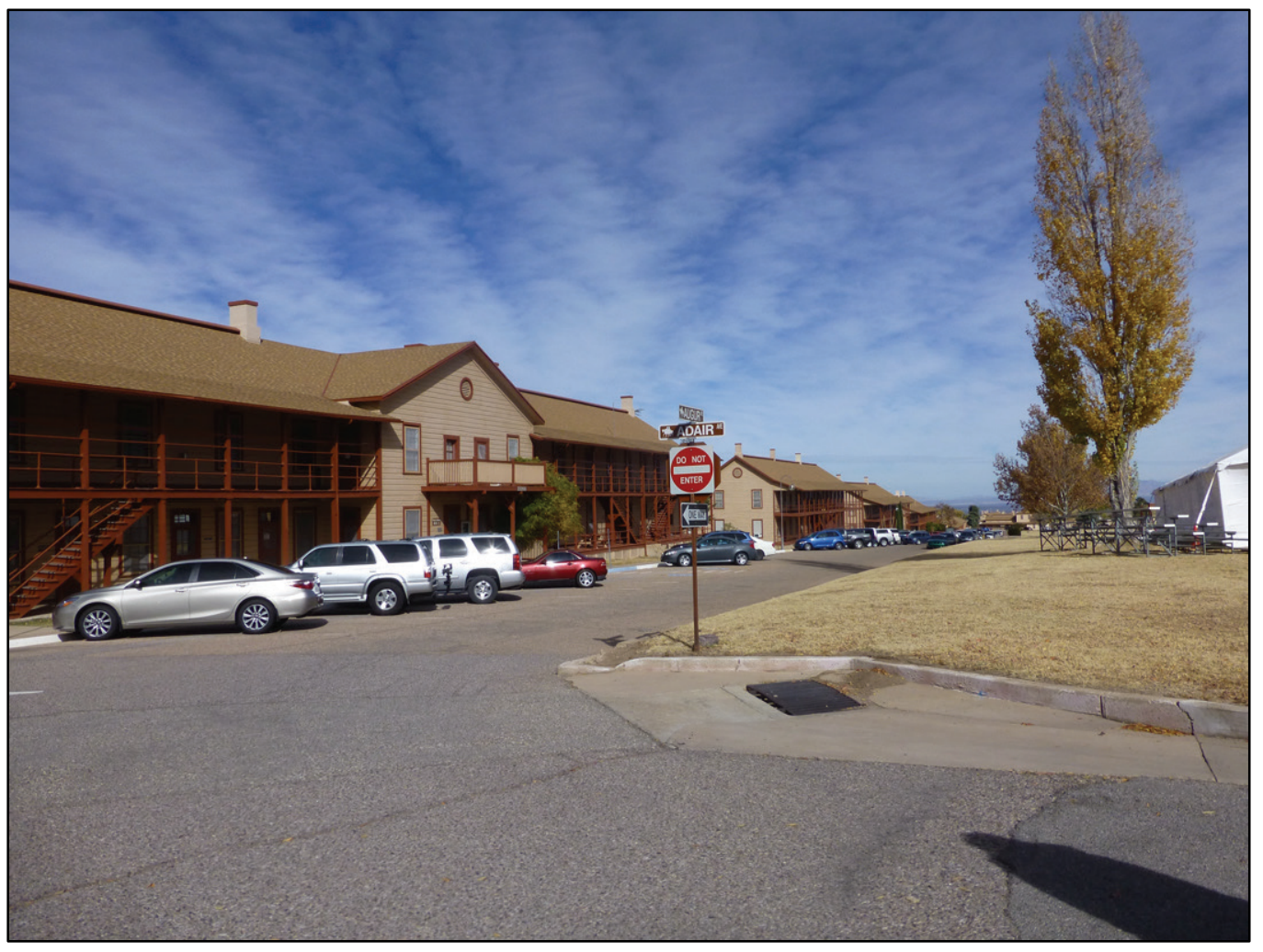


5.8.7.8 View from hospital and Headquarters toward Brown Field

This view dates from the design of the post when the administration buildings first occupied the northern edge of the parade field (Figure 355). This viewpoint has been occupied by the Post Headquarters (first in the $\mathrm{Mu}-$ seum, then in its current building) (Figure 356).

Figure 355. View south across Brown Field from hospital/Headquarters/Officers' Club, 1899 (NARA College Park, RG111-SC).

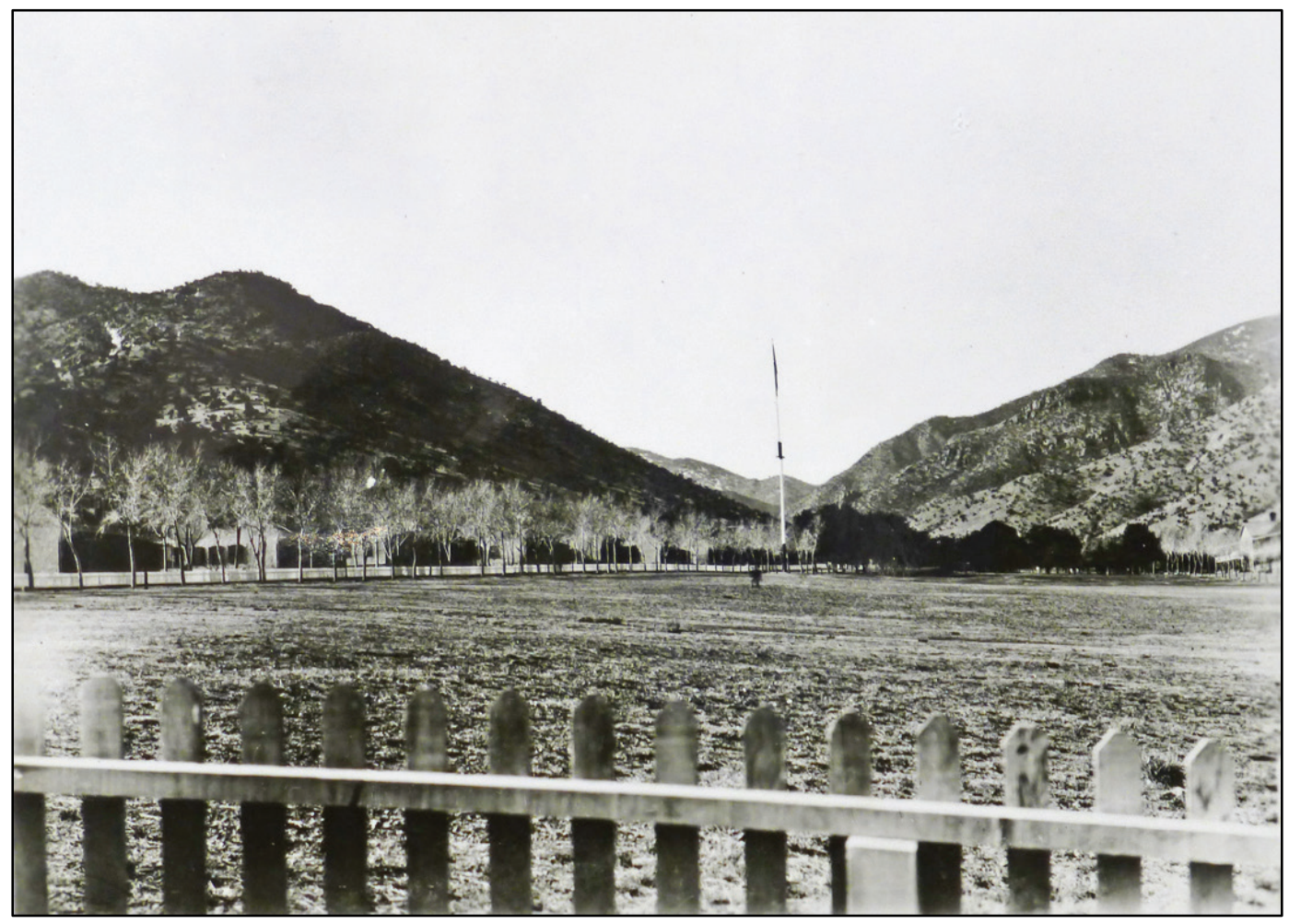


Figure 356. View south across Brown Field from hospital and Garrison Headquarters (ERDCCERL 2016).

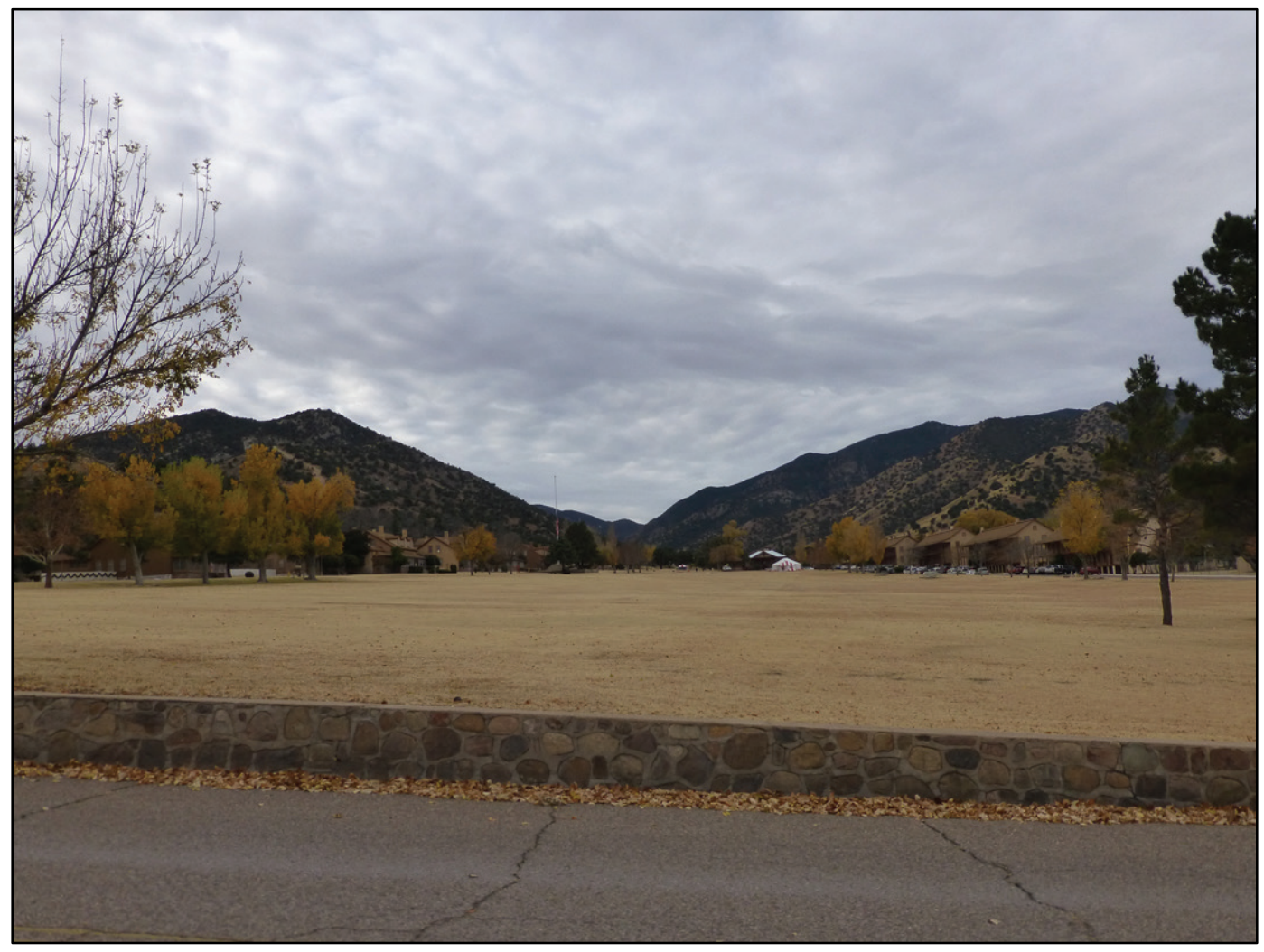

5.8.7.9 View across Brown Field to north

Brown Field is the heart of the Old Post design and spatial arrangement and, as a result, is highly significant. Views across Brown Field to the historic buildings have high integrity (Figures 357 and 358). 
Figure 357. View north across Brown Field, 1900 (NARA College Park, RG165-FF).

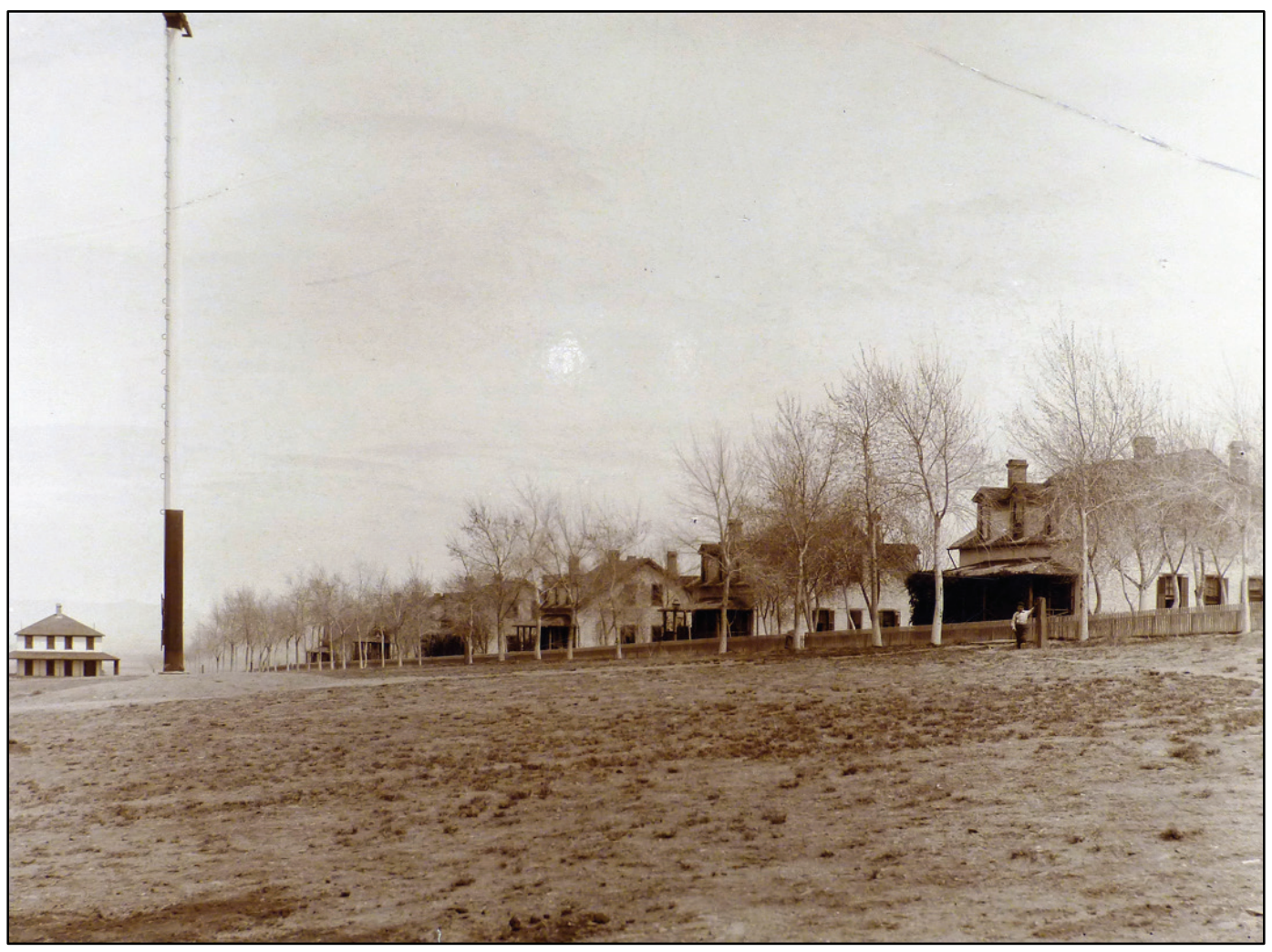

Figure 358. View north across Brown Field (ERDC-CERL 2016).

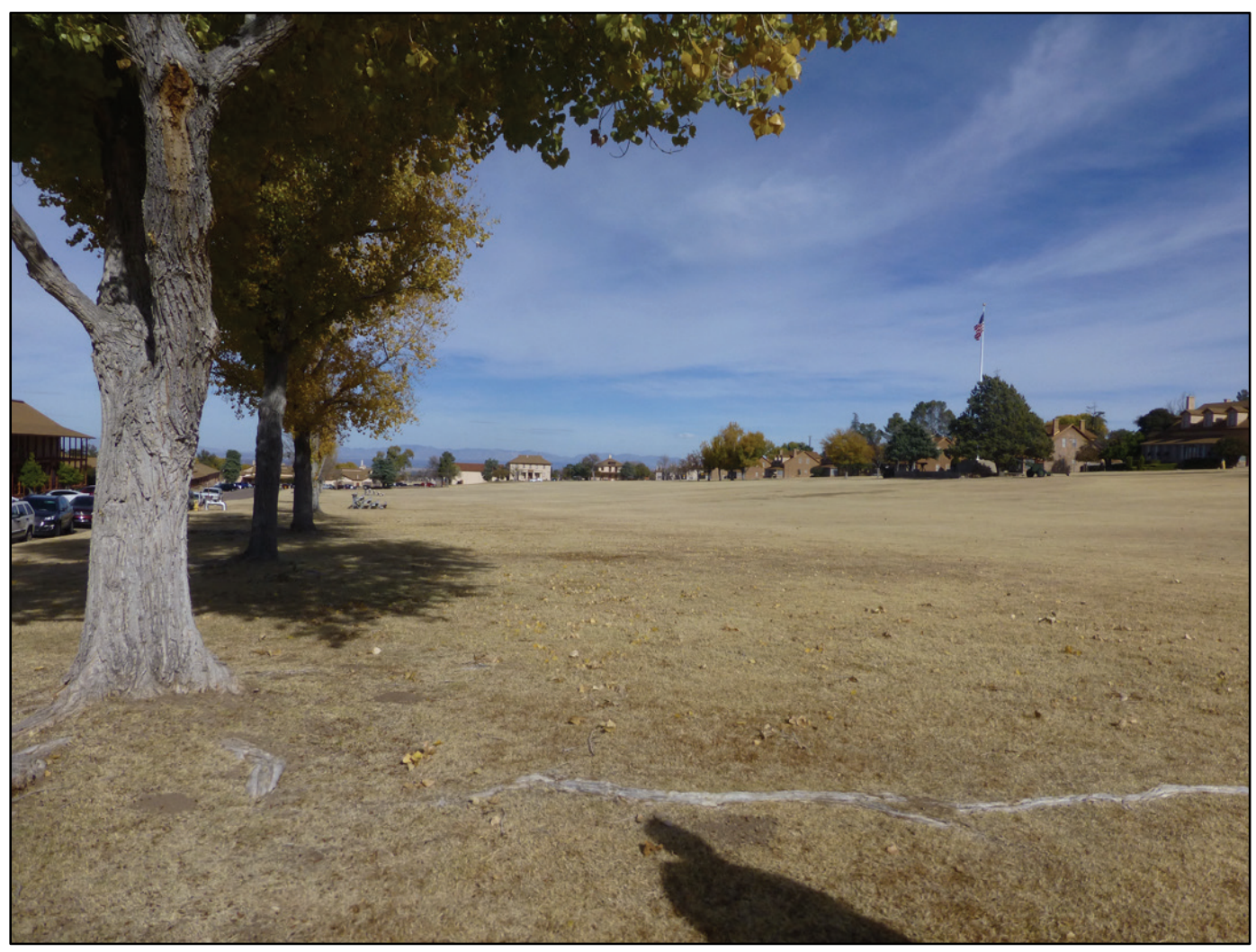




\subsubsection{Views of 1914 Barracks}

Views toward the 1914 Barracks along Rhea Avenue are highly significant (Figure 359). Today, the row of street trees is missing, there is parking in front of the barracks on what used to be the parade field. This view has moderate integrity due to these changes (Figure 360).

Figure 359. View south of 1914 Barracks looking up Rhea Avenue, 1918 (Fort Huachuca Historical Museum).

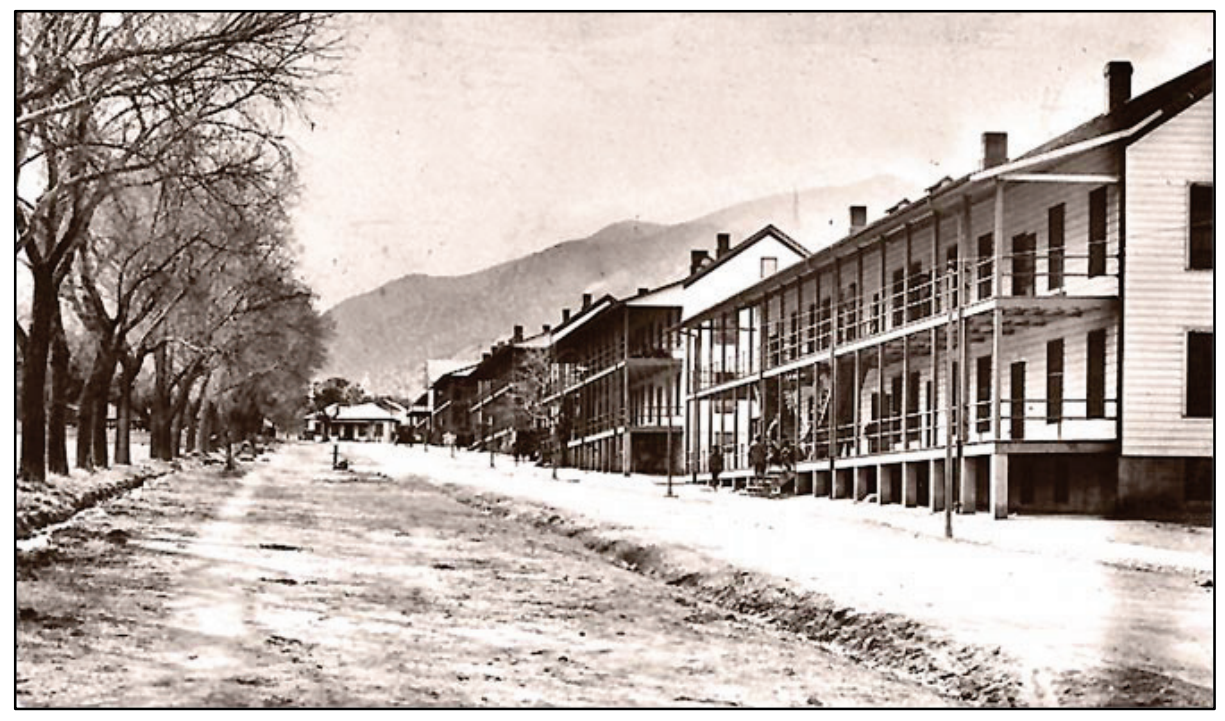

Figure 360. View south of 1914 Barracks looking up Rhea Avenue (ERDC-CERL 2016).

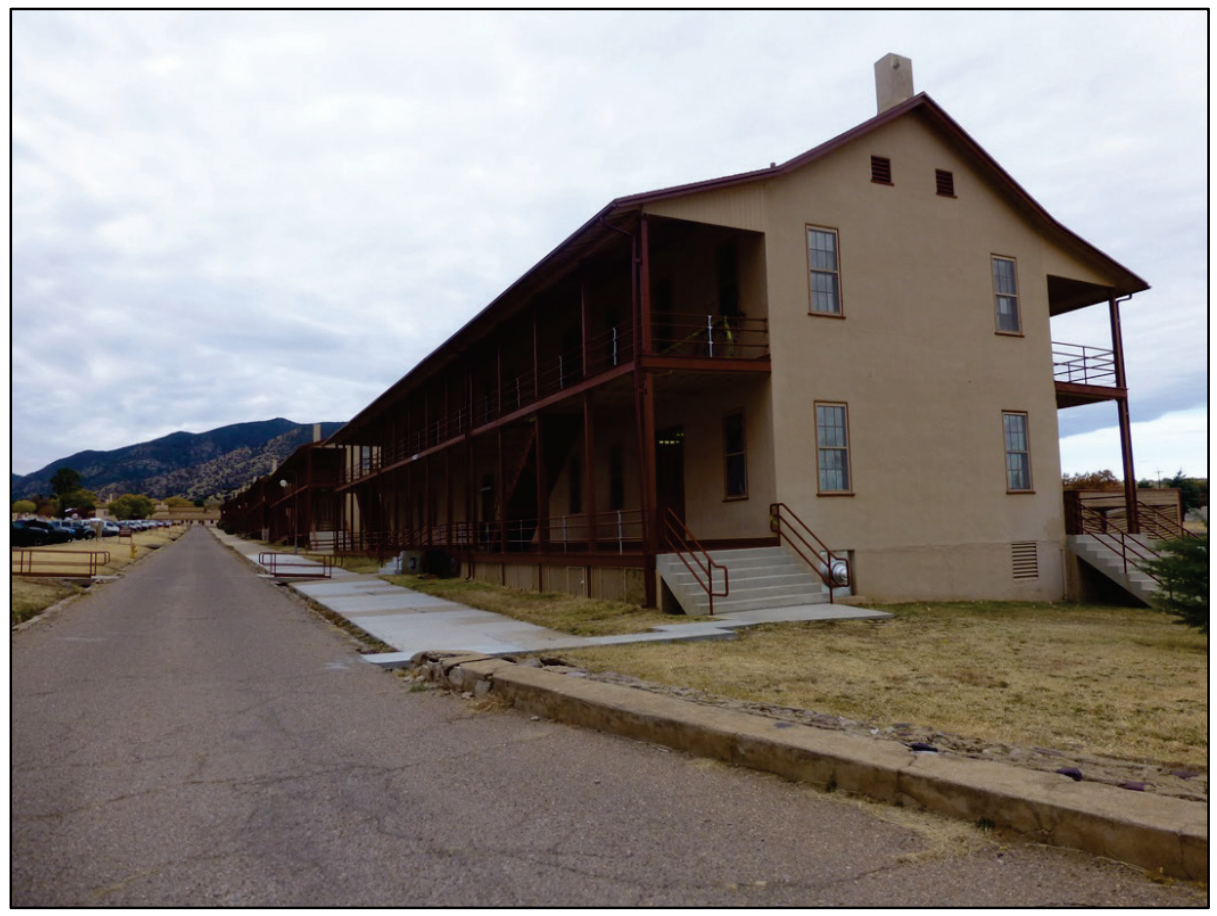




\subsubsection{Views around Henry Circle}

Both the semicircular layout of the street and the central open space or park are a noticeable change from the linear layout of the Old Post Quarters and Barracks at Fort Huachuca. Views toward the quarters over the park are significant and have integrity, although the vegetation had changed over the years (Figure 361).

Figure 361. View east toward Henry Circle, the park and the quarters (ERDC-CERL 2016).

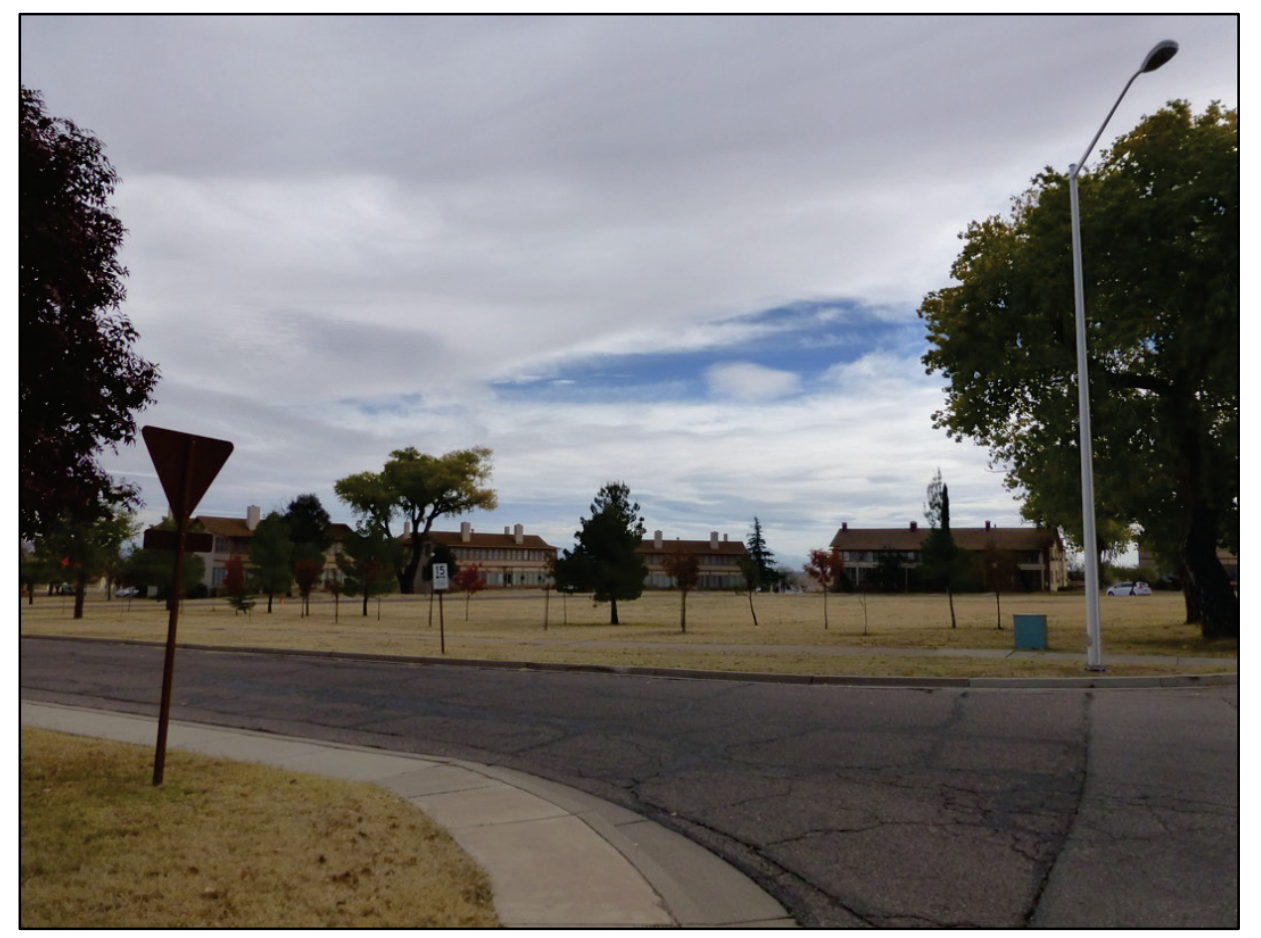

\subsubsection{Summary of character-defining features}

The character-defining features of the NHL historic district are summarized in the table below (Table 16).

Table 16. Character-defining features of the component landscapes in the NHL Historic District.

\begin{tabular}{|l|l|l|l|l|}
\hline $\begin{array}{l}\text { Component } \\
\text { Landscapes }\end{array}$ & \multicolumn{2}{|c|}{$\begin{array}{l}\text { Character-Defining } \\
\text { Historical Significance }\end{array}$} & \multicolumn{2}{|c|}{$\begin{array}{c}\text { NRHP } \\
\text { Eligibility }\end{array}$} \\
\hline $\begin{array}{l}\text { Overall layout } \\
\text { and design }\end{array}$ & $\begin{array}{l}\text { Designed as an early } \\
\text { frontier post with a } \\
\text { rectangular layout around a a } \\
\text { central parade field. }\end{array}$ & $\begin{array}{l}\text { Central parade field } \\
\text { - } \begin{array}{l}\text { Linear layout of } \\
\text { buildings } \\
\text { Buildings in clusters } \\
\text { of similar use. }\end{array}\end{array}$ & $\begin{array}{l}\text { High integrity, little new construction } \\
\text { and almost all buildings remain. }\end{array}$ & Yes \\
\hline
\end{tabular}




\begin{tabular}{|c|c|c|c|c|}
\hline $\begin{array}{l}\text { Component } \\
\text { Landscapes }\end{array}$ & Historical Significance & $\begin{array}{l}\text { Character-Defining } \\
\text { Features }\end{array}$ & Significance/Integrity & $\begin{array}{l}\text { NRHP } \\
\text { Eligibility }\end{array}$ \\
\hline $\begin{array}{l}\text { Topography and } \\
\text { Natural } \\
\text { Features }\end{array}$ & $\begin{array}{l}\text { The site was chosen due to } \\
\text { the surrounding hills, the } \\
\text { canyon, and the creek. }\end{array}$ & $\begin{array}{l}\text { - Huachuca Mountains } \\
\text { - Huachuca Canyon } \\
\text { - Huachuca Creek } \\
\text { - } \quad \text { Views from Reservoir } \\
\text { Hill and Cemetery Hill }\end{array}$ & $\begin{array}{l}\text { High integrity, natural features still } \\
\text { intact }\end{array}$ & Yes \\
\hline Land use & $\begin{array}{l}\text { Original design of the post } \\
\text { clustered buildings by use. }\end{array}$ & $\begin{array}{l}\text { - Central parade field } \\
\text { lined with barracks } \\
\text { and quarters with } \\
\text { recreation and } \\
\text { administration on } \\
\text { end }\end{array}$ & $\begin{array}{l}\text { Moderate integrity, many of the } \\
\text { buildings have changed from their } \\
\text { initial use to administration. }\end{array}$ & Yes \\
\hline $\begin{array}{l}\text { Transportation } \\
\text { Networks }\end{array}$ & $\begin{array}{l}\text { The road system, planned } \\
\text { in the } 1880 \text { s, and in the } \\
1910 \text { s, provides } \\
\text { organization to the } \\
\text { cantonment. }\end{array}$ & $\begin{array}{ll}\text { - } & \text { Railroad lines still } \\
\text { visible in landscape. } \\
\text { - } & \text { Roads still in same } \\
\text { locations as } 1880 \text { s } \\
\text { - } & \text { Addition of Henry } \\
& \text { Circle in } 1910 \text { s } \\
\end{array}$ & $\begin{array}{l}\text { High integrity, road system still intact } \\
\text { although rail lines are gone. }\end{array}$ & Yes \\
\hline $\begin{array}{l}\text { Old Post } \\
\text { Officers' } \\
\text { Quarters }\end{array}$ & $\begin{array}{l}\text { Part of the original } 1880 \text { s } \\
\text { frontier post }\end{array}$ & $\begin{array}{l}\text { - Layout and location } \\
\text { along the southeast } \\
\text { side of Brown Field } \\
\text { - Associated garages } \\
\text { and servants' } \\
\text { quarters } \\
\text { - Associated coal bins } \\
\text { - Specimen trees and } \\
\text { foundation plantings } \\
\text { where remain } \\
\text { - WPA-era ditches, } \\
\text { culverts and retaining } \\
\text { walls } \\
\text { - Consistent } \\
\text { architecture, } \\
\text { setbacks } \\
\text { - Views along Grierson } \\
\text { Ave }\end{array}$ & $\begin{array}{l}\text { High level of integrity; porches } \\
\text { screened in and some quarters } \\
\text { missing foundation plantings. }\end{array}$ & Yes \\
\hline $\begin{array}{l}\text { Old Post } \\
\text { Barracks }\end{array}$ & $\begin{array}{l}\text { Part of the original } 1880 \text { s } \\
\text { frontier post; located along } \\
\text { west side of parade field. }\end{array}$ & $\begin{array}{l}\text { - Layout and location } \\
\text { along the southwest } \\
\text { side of Brown Field } \\
\text { - Consistent } \\
\text { architecture and } \\
\text { setbacks } \\
\text { - Associated latrines } \\
\text { - Specimen trees and } \\
\text { foundation plantings } \\
\text { where remain } \\
\text { - WPA-era ditches, } \\
\text { culverts and retaining } \\
\text { walls } \\
\text { - Views along Augur } \\
\text { Ave }\end{array}$ & $\begin{array}{l}\text { High level of integrity; although } \\
\text { missing some vegetation, and } \\
\text { addition of parking between } \\
\text { barracks and Brown Field. }\end{array}$ & Yes \\
\hline $\begin{array}{l}\text { Old Post } \\
\text { Administration } \\
\text { Buildings }\end{array}$ & $\begin{array}{l}\text { Part of the original } 1880 \text { s } \\
\text { frontier post; located along } \\
\text { northern edge of parade } \\
\text { field. }\end{array}$ & $\begin{array}{l}\text { - Unique but } \\
\text { compatible } \\
\text { architecture } \\
\text { - Prominent location at } \\
\text { north end of parade } \\
\text { field } \\
\text { - Consistent land use } \\
\text { as administration } \\
\text { - Views to and from } \\
\text { parade field }\end{array}$ & $\begin{array}{l}\text { High level of integrity; although much } \\
\text { of historic vegetation seen in } \\
\text { photographs missing, with the } \\
\text { exception of Headquarters building. }\end{array}$ & Yes \\
\hline
\end{tabular}




\begin{tabular}{|c|c|c|c|c|}
\hline $\begin{array}{l}\text { Component } \\
\text { Landscapes }\end{array}$ & Historical Significance & $\begin{array}{c}\text { Character-Defining } \\
\text { Features }\end{array}$ & Significance/Integrity & $\begin{array}{l}\text { NRHP } \\
\text { Eligibility }\end{array}$ \\
\hline Brown Field & $\begin{array}{l}\text { Part of the original 1880s } \\
\text { frontier post; provided } \\
\text { layout and spatial } \\
\text { organization of the post. }\end{array}$ & $\begin{array}{l}\text { - } \quad \text { Central focus of Old } \\
\text { Post area } \\
\text { - Open space for drills } \\
\text { and ceremonial use } \\
\text { - Lined with Old Post- } \\
\text { era buildings }\end{array}$ & $\begin{array}{l}\text { High level of integrity; missing street } \\
\text { trees along edge. }\end{array}$ & Yes \\
\hline $\begin{array}{l}\text { Old Post } \\
\text { Recreation }\end{array}$ & $\begin{array}{l}\text { Part of the original } 1880 \text { s } \\
\text { frontier post; located along } \\
\text { southern end of parade } \\
\text { field. }\end{array}$ & $\begin{array}{l}\text { - Unique but } \\
\text { compatible } \\
\text { architecture } \\
\text { - Prominent location at } \\
\text { south end of parade } \\
\text { field } \\
\text { - Views to and from } \\
\text { parade field }\end{array}$ & $\begin{array}{l}\text { High level of integrity; vegetation } \\
\text { around buildings. }\end{array}$ & Yes \\
\hline $\begin{array}{l}1914 \text { Officers' } \\
\text { Quarters }\end{array}$ & $\begin{array}{l}\text { Part of } 1910 \text { s expansion of } \\
\text { Fort Huachuca to } \\
\text { accommodate arrival of } \\
10^{\text {th }} \text { Cavalry. }\end{array}$ & $\begin{array}{l}\text { - Semicircular layout } \\
\text { around Henry Circle } \\
\text { and central park } \\
\text { - Consistent } \\
\text { architecture and } \\
\text { setbacks } \\
\text { - Associated WPA } \\
\text { garages } \\
\text { - Specimen trees and } \\
\text { foundation plantings } \\
\text { where remain } \\
\text { - WPA-era ditches, } \\
\text { culverts and retaining } \\
\text { walls } \\
\text { - Views along Henry } \\
\text { Circle }\end{array}$ & $\begin{array}{l}\text { High level of integrity; foundation } \\
\text { plantings are varied and little } \\
\text { vegetation remains in central park } \\
\text { area. }\end{array}$ & Yes \\
\hline 1914 Barracks & $\begin{array}{l}\text { Part of } 1910 \text { s expansion of } \\
\text { Fort Huachuca to } \\
\text { accommodate arrival of } \\
10^{\text {th }} \text { Cavalry. }\end{array}$ & $\begin{array}{ll}\text { - } & \text { Long rectangular } \\
\text { barracks fronting a } \\
\text { large open drill field } \\
\text { - } & \text { Consistent } \\
\text { architecture and } \\
\text { setbacks as Old Post } \\
\text { Barracks }\end{array}$ & $\begin{array}{l}\text { Moderate integrity due to addition of } \\
\text { parking lot and construction of } \\
\text { housing and nature train on historic } \\
\text { drill field. Little vegetation remains. }\end{array}$ & Yes \\
\hline $\begin{array}{l}\text { Stables and } \\
\text { Quartermaster } \\
\text { Area }\end{array}$ & $\begin{array}{l}\text { Part of } 1910 \text { s expansion of } \\
\text { Fort Huachuca to } \\
\text { accommodate arrival of } \\
10^{\text {th }} \text { Cavalry. }\end{array}$ & $\begin{array}{l}\text { - } \text { Association with } \\
\text { 1914 Barracks } \\
\text { - } \quad \text { Rail line }\end{array}$ & $\begin{array}{l}\text { Moderate integrity; three stables } \\
\text { have been demolished and one clad } \\
\text { in stone. Some used for storage and } \\
\text { administration. }\end{array}$ & Yes \\
\hline Cemetery & $\begin{array}{l}\text { Part of the original } 1880 \mathrm{~s} \\
\text { frontier post }\end{array}$ & 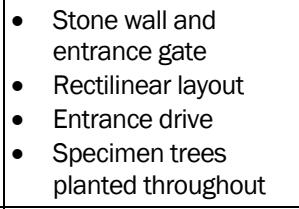 & $\begin{array}{l}\text { Moderate integrity; while consistent } \\
\text { use since } 1880 \text { s, wall built later, } \\
\text { modern front gate. }\end{array}$ & Yes \\
\hline Vegetation & & 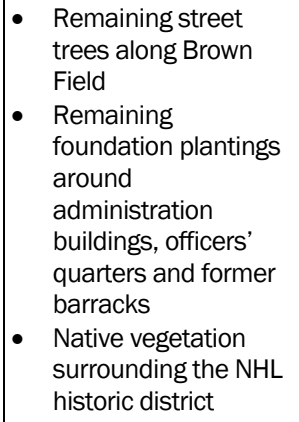 & $\begin{array}{l}\text { Moderate integrity; historically, the } \\
\text { Old Post area was more heavily } \\
\text { vegetated; street trees lined Brown } \\
\text { Field and quarters had foundation } \\
\text { plantings and shade trees in side } \\
\text { yards. }\end{array}$ & Yes \\
\hline
\end{tabular}




\begin{tabular}{|c|c|c|c|c|}
\hline $\begin{array}{l}\text { Component } \\
\text { Landscapes }\end{array}$ & Historical Significance & $\begin{array}{c}\text { Character-Defining } \\
\text { Features }\end{array}$ & Significance/Integrity & $\begin{array}{l}\text { NRHP } \\
\text { Eligibility }\end{array}$ \\
\hline $\begin{array}{l}\text { Small-scale } \\
\text { features }\end{array}$ & $\begin{array}{l}\text { Significant landscape } \\
\text { features have been around } \\
\text { since the POS. }\end{array}$ & $\begin{array}{l}\text { - } \quad \text { Location of flagpole } \\
\text { - } \quad \text { Original fencing } \\
\text { - } 1920 \text { s Coal bins }\end{array}$ & $\begin{array}{l}\text { Moderate integrity; coal bins, and } \\
\text { compatible fencing, }\end{array}$ & Yes \\
\hline WPA Stonework & $\begin{array}{l}\text { WPA stonework contributing } \\
\text { to WPA }\end{array}$ & $\begin{array}{l}\text { - } \text { Culverts } \\
\text { - } \text { Ditches } \\
\text { - Retaining walls }\end{array}$ & $\begin{array}{l}\text { Most culverts and retaining walls } \\
\text { retain integrity. }\end{array}$ & Yes \\
\hline $\begin{array}{l}\text { Views and } \\
\text { Viewsheds }\end{array}$ & $\begin{array}{l}\text { Views around NHL were } \\
\text { constructed and } \\
\text { emphasized by the natural } \\
\text { topography, the rectangular } \\
\text { layout of the post, and the } \\
\text { linear layout of the buildings } \\
\text { along a central open space. }\end{array}$ & $\begin{array}{l}\text { - Views across parade } \\
\text { field } \\
\text { - Towards quarters } \\
\text { and barracks, admin } \\
\text { and rec buildings }\end{array}$ & $\begin{array}{l}\text { The original views constructed as } \\
\text { part of NHL retain a high degree of } \\
\text { integrity. }\end{array}$ & Yes \\
\hline
\end{tabular}




\section{Management Recommendations}

This chapter provides a detailed list of landscape design recommendations that will provide a guide for maintaining and preserving the historic characteristics of the Fort Huachuca landscape. To determine appropriate guidance, the historic fort plans, planting plans, and photographs were analyzed to determine the scope of change within the landscape. The planting designs shown in historic photographs were compared with the current landscaping conditions of these areas to determine a planting and/or landscaping strategy that will reflect the historic precedent of the installation, as well as landscaping requirements for low-maintenance vegetation and water conservation. Illustrations of historically compatible landscaping for the major buildings at Fort Huachuca are also included as suggestions for possible planting strategies for the component landscapes.

\subsection{Landscape treatment}

The Secretary of the Interior is responsible for establishing professional standards and providing advice on the stewardship of cultural resources listed in or as eligible for the NRHP. The Secretary's standards describe four basic approaches to treatment of historic landscapes. 46

\subsubsection{Restoration approach}

Restoration is the act or process of accurately depicting the form, features, and character of a property as it appeared at a particular period in time. This process includes reconstruction of missing features from the restoration period and removal of features from all other periods. The approach can be considered only when the property's significance during a particular period of time outweighs the loss of extant elements from other historical periods, when there is substantial physical and documentary evidence for the work, and when contemporary alterations and additions are not planned. 47

\footnotetext{
46 National Park Service, 1996. The Secretary of the Interior's Standards for the Treatment of Historic Properties with Guidelines for the Treatment of Cultural Landscapes, Charles A. Birnbaum and Christine Capella Peters (eds.). Washington, DC: U.S. Department of the Interior, National Park Service, p. 3. 47 NPS, 1996, The Secretary of the Interior's Standards, pp. 89-90.
} 
Restoration is not an appropriate approach for Fort Huachuca since the changes to the historic landscape have occurred over an extended period of time in response to changes in the military mission.

\subsubsection{Reconstruction approach}

Reconstruction is the act or process of using new construction to depict a non-surviving site, landscape, building, structure, or object as it appeared at a specific period of time and in its historic location. The approach is appropriate only when the property's significance during a particular period of time outweighs the potential loss of extant features that characterize other historical periods. In addition, there must be substantial physical and documentary evidence for the work, and the work must be clearly identified as a contemporary re-creation. 48

Reconstruction is a viable path for maintaining the historic character of Fort Huachuca since this report contains sufficient documentary evidence to reconstruct elements of the landscape, such as street tree plantings and foundation plantings, which changed or have been removed from the site over the years.

\subsubsection{Preservation approach}

Preservation involves applying measures to sustain the existing form, integrity, and materials of a historic property. This approach focuses on stabilizing and protecting extant historic resources, rather than replacing missing elements. It is appropriate when a historic property is essentially intact and does not require extensive repair or replacement; depiction at one particular period of time is not appropriate; and when continuing or new use does not require additions or alterations. 49

Preservation is a potential management treatment for the Fort Huachuca NHL due to the many intact resources within the historic district boundary. Currently, landscape preservation efforts include the removal of nonnative trees and shrubs, as well as the preservation of large mature native trees, such as cottonwoods, since they contribute to the district.

48 NPS, 1996. The Secretary of the Interior's Standards, pp. 127-129.

49 NPS, 1996. The Secretary of the Interior's Standards, pp. 17-18. 


\subsubsection{Rehabilitation approach}

Rehabilitation allows repairs, alterations, and additions necessary to enable a compatible use for a property as long as the portions or features, which convey the historical, cultural, or architectural values, are preserved. This approach is appropriate when depiction at one particular period of time is not appropriate, repair or replacement of deteriorated features is necessary, and alterations or additions are needed for a new use. $5^{\circ}$

Rehabilitation is a potential management treatment for the Fort Huachuca NHL, due to the many intact resources within the historic district boundary. Rehabilitation would allow for the removal of non-contributing or non-compatible elements and the use of more historically appropriate replacements.

\subsection{Overall management issues and recommendations}

The landscape of the historic district generally retains a high degree of integrity and still retains the same layout and design as it did in 1932. The views, major open spaces (parade grounds, etc.), and circulation patterns retain the same feel as they did in 1931. Brown Field is still intact from the 1880s. The quarters and barracks still line the parade field contributing to the overall integrity and feel.

Overall landscape recommendations include:

- Preserve historic views from quarters to barracks and back, as well as views north towards the hospital and Headquarters and south to Buildings 21114 and 21115.

- Preserve natural landscape and open space in surrounding hills.

- Replant street trees in character with historic landscape.

- Replant foundation plantings with an eye for the historic character using sustainable native or desert plants.

- The use of cacti plants and gravel mulch is not allowed to discourage javelina.

- Preserve the original layout and design of the Old Post with the buildings bordering the parade field based on land use.

50 NPS, 1996, The Secretary of the Interior's Standards, pp. 47-48. 
- For visual continuity throughout the district, establish one or two natural mulch types and a uniform garden edging type from which to choose.

- The physical layout of the roads should not be altered by changing the width of the streets, blocking the through streets, or removing any streets or adding parking areas.

- Small-scale landscape features should be similar in their design, type, and color scheme. Examples of small-scale features include street lighting, benches, and signage. Using a consistent array of these elements will give the district a unified appearance.

Overall landscape is lacking integrity based on the following:

- Historically, there were street tree plantings or plantings along the parade fields. These trees have died and have not been replaced. Many of the remaining trees are in poor shape.

- Historically the barracks and quarters had foundation plantings. Many have little or no plantings today.

- Non-contributing plantings have been added around the flagpole at the center of Brown Field.

- Parking areas added in front of Old Post Barracks and on North Field.

Per DoD directives, installations are recommended to develop and maintain a sustainable landscape plan which may encompass the following elements: site selection and planning, soils, water, vegetation, materials selection, human health, and well-being, existing and/or historic facilities and cultural landscapes, construction, operations, and management.

- Increase use of regionally appropriate vegetation to conserve water and reduce maintenance. See plant lists in Appendix A.

- Implement the management plan in phases. While there will be initial costs to establish the program, the total life-cycle costs and maintenance will be significantly reduced.

- Application of the management plan provides Fort Huachuca with the opportunity to be a model installation, sensitive to both its historic character and its environment.

\subsubsection{Old Post Officers' Quarters}

Historically, the officers' quarters were surrounded by picket fences until the early 1900s. The Army mission is not to recreate the historic features 
that have not been there for 100 years; however, if fencing is needed today, it should follow the historic precedents of wood picket fences (following the Secretary of Interior Standards). When placing new wood fencing, look to old fence locations when placing new fencing.

- Position tall shade trees between and behind the quarters to preserve unobstructed views of the historic architecture and for cooling during hottest months; integrate smaller ornamental trees in side yards and closer to corners of the residences to frame facades (Figure 362).

- Keep front lawns free of inappropriate additions (i.e., lawn ornaments or inappropriate plants).

- Implement a variety of foundation plantings that frame and enhance the architecture without obscuring the facades (Figures 363 and 364).

- If fencing is needed at quarters in the future, the historic precedent is white picket fencing. Any other choice would be inappropriate as this style fencing still exists between quarters to separate side and rear yards.

Figure 362. Planting plan for officers' quarters with shade and flowering trees behind and to sides of quarters (ERDC-CERL).

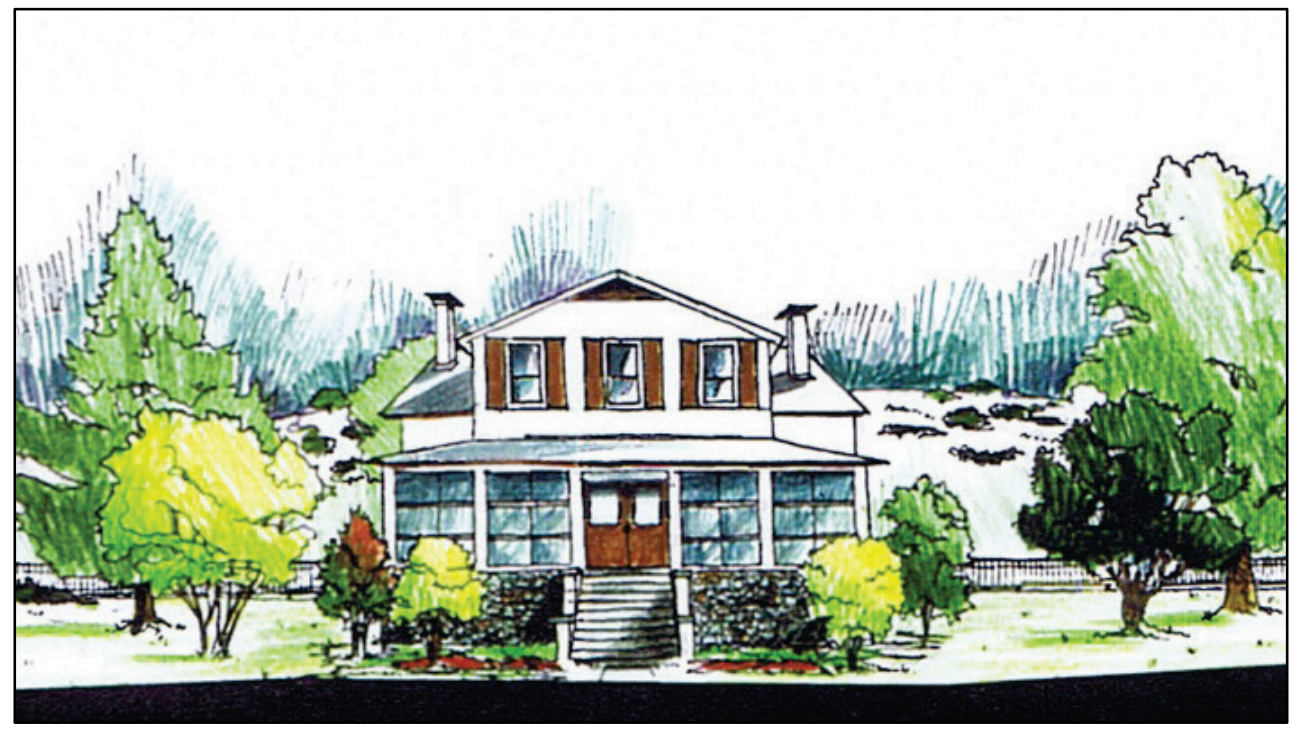


Figure 363. Planting plan for officers' quarters showing a variety of foundation plantings (ERDC-CERL).

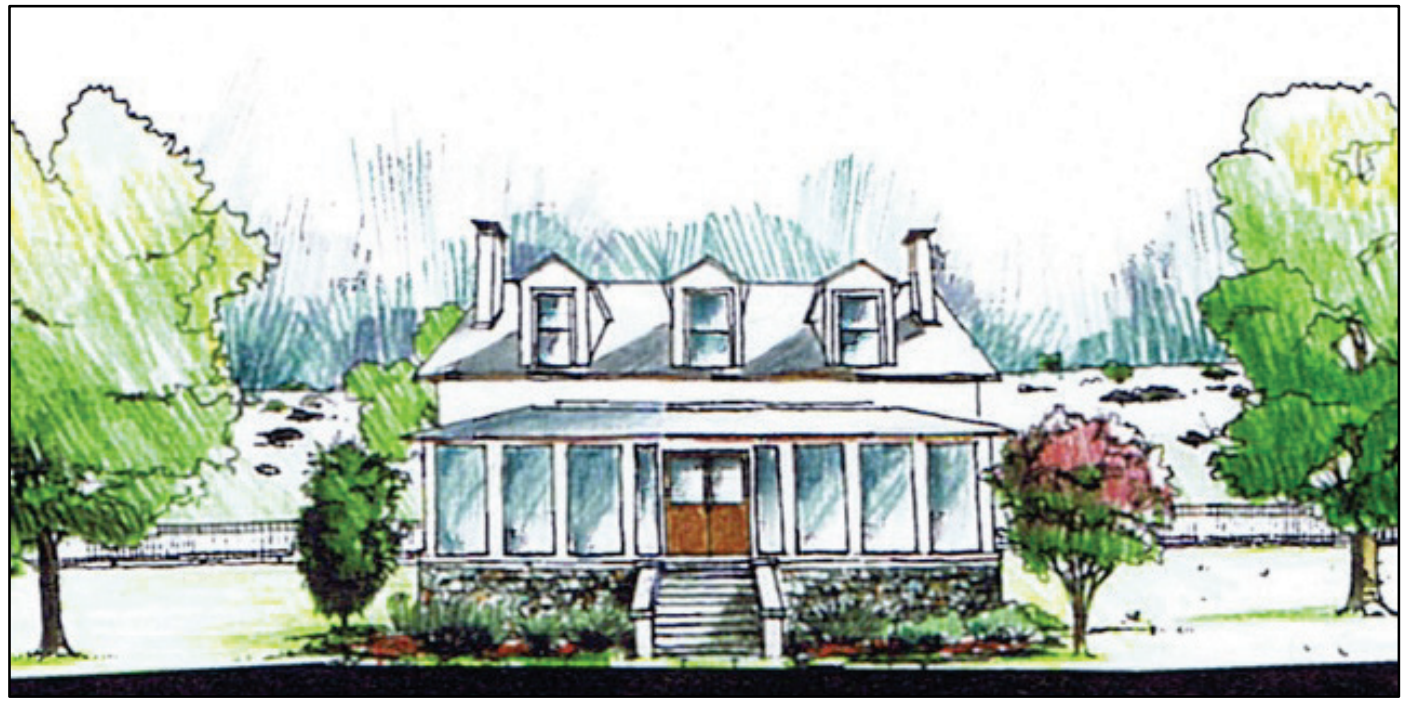

Figure 364. Planting plan for officers' quarters using plants from proposed list in Appendix A (ERDC-CERL).

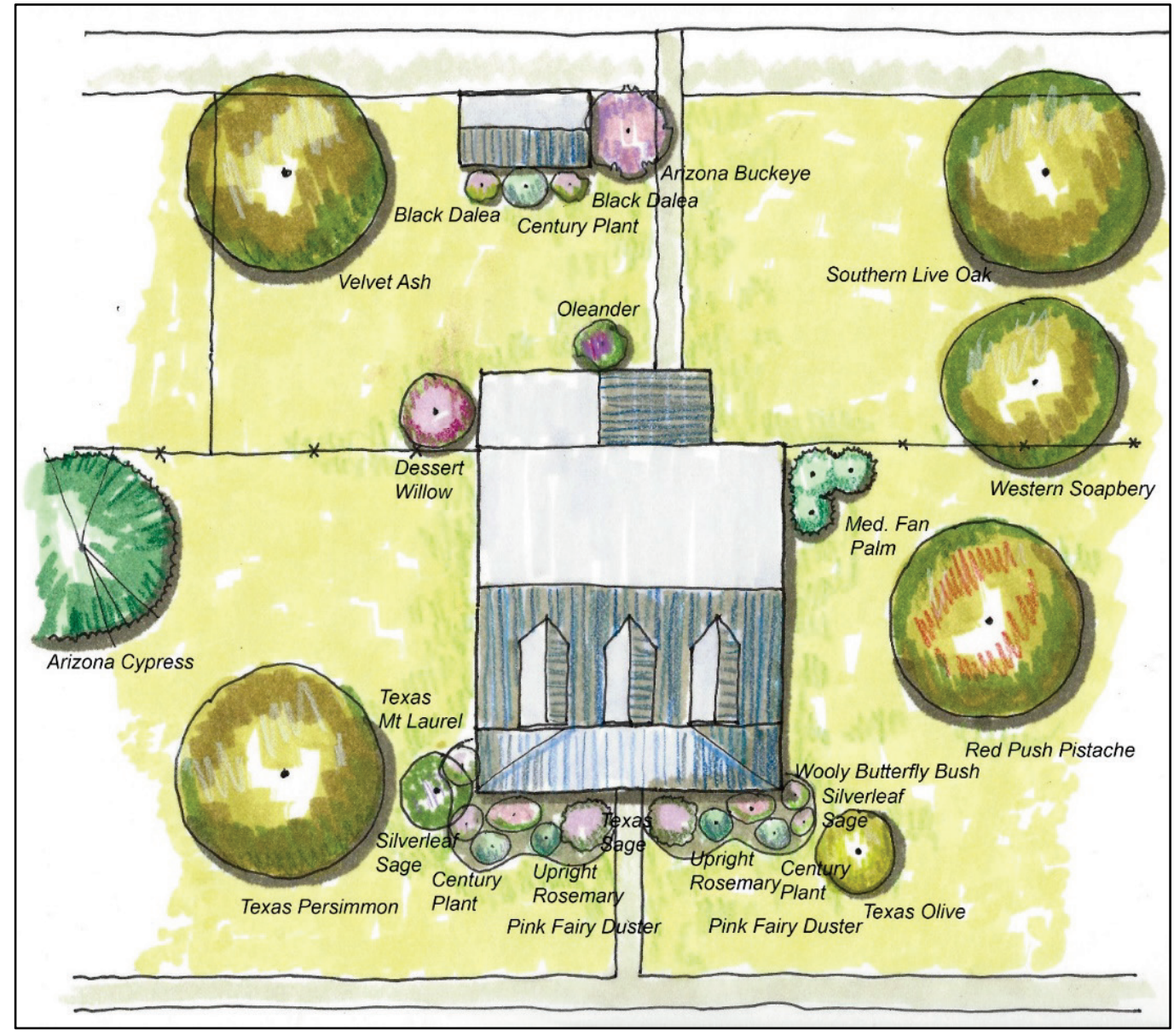




\subsubsection{Old Post Barracks}

Historically the Old Post Barracks were sparsely planted with vegetation since there is little room between building and sidewalk. Parking in front of barracks have made area more crowded.

- Lack of plantings along barracks has led to erosion.

- Rogue trees have grown up too close to building.

- Low shrubs should be planted in front of historic barracks (Figure 365).

Figure 365. View of proposed low plantings in from of barracks (ERDC-CERL).

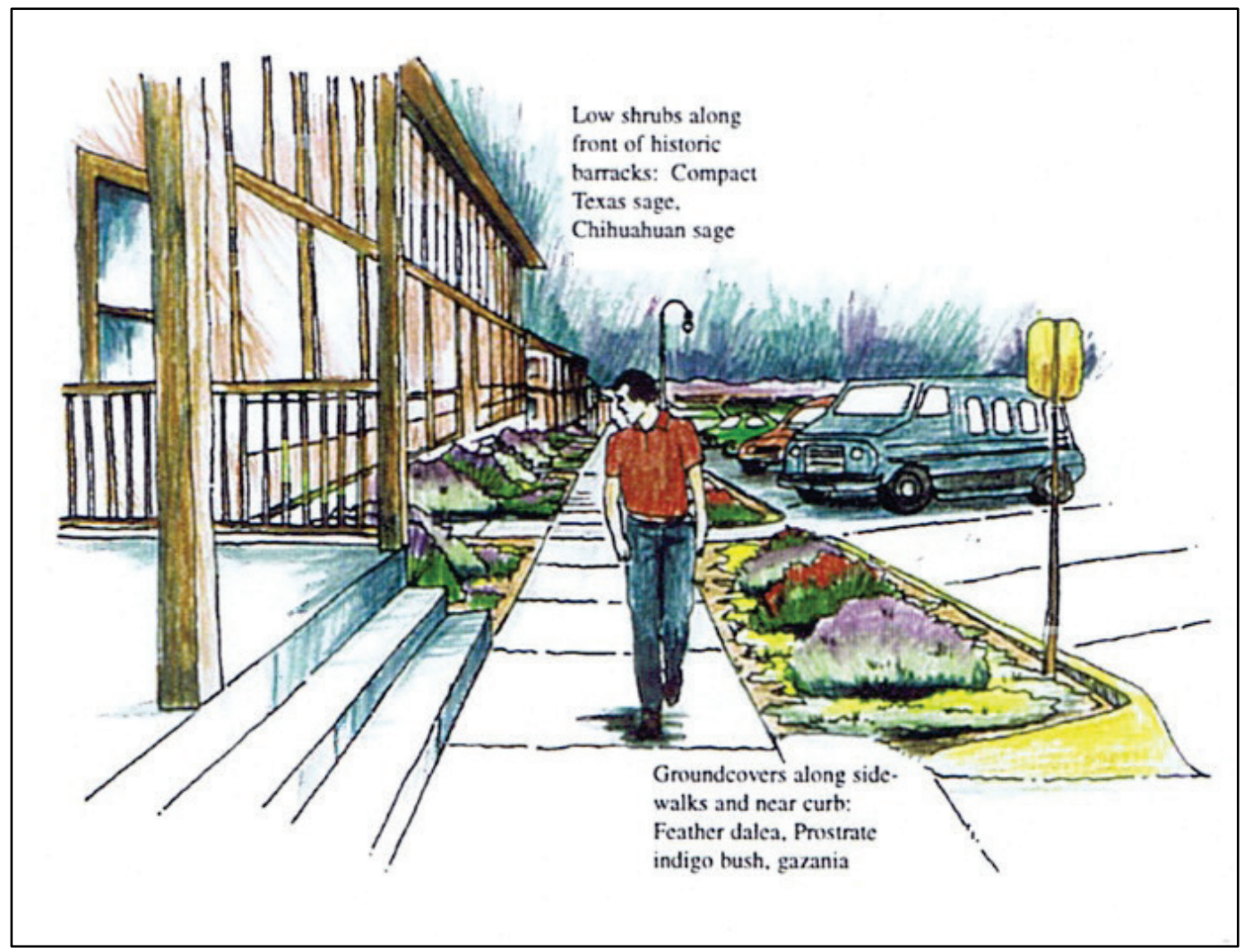

\subsubsection{Brown Field}

- Proposed realignment and replacement of trees around the perimeter of the parade field based on historic precedence. It is recommended that a single row of tall shade trees should be planted along the sides of the field, but smaller trees or no trees are planted along the northern end to reserve the views to the valley.

- Future planting of trees along the perimeter of the parade field should follow the appropriate historic layout, which is formal, repetitive, and 
consistent. In addition, the selection of varieties should follow this plan (Figure 366).

- Planting around the base of the flagpole should be limited in size and selection. Only small shrubs and ground covers should be used as the base should not be obscured (Figure 367).

- View should remain open as it was historically as well as the view out over the valley. Views are contributing features of the historic district.

- Preserve the open spatial character of the parade field and keep it free of any intrusive features, such as buildings, structures, or paved areas.

- Retain current features including the flagpole and grouping of mature shade trees at the southwestern corner.

Figure 366. Planting suggestions for trees along the perimeter of Brown Field (ERDC-CERL).

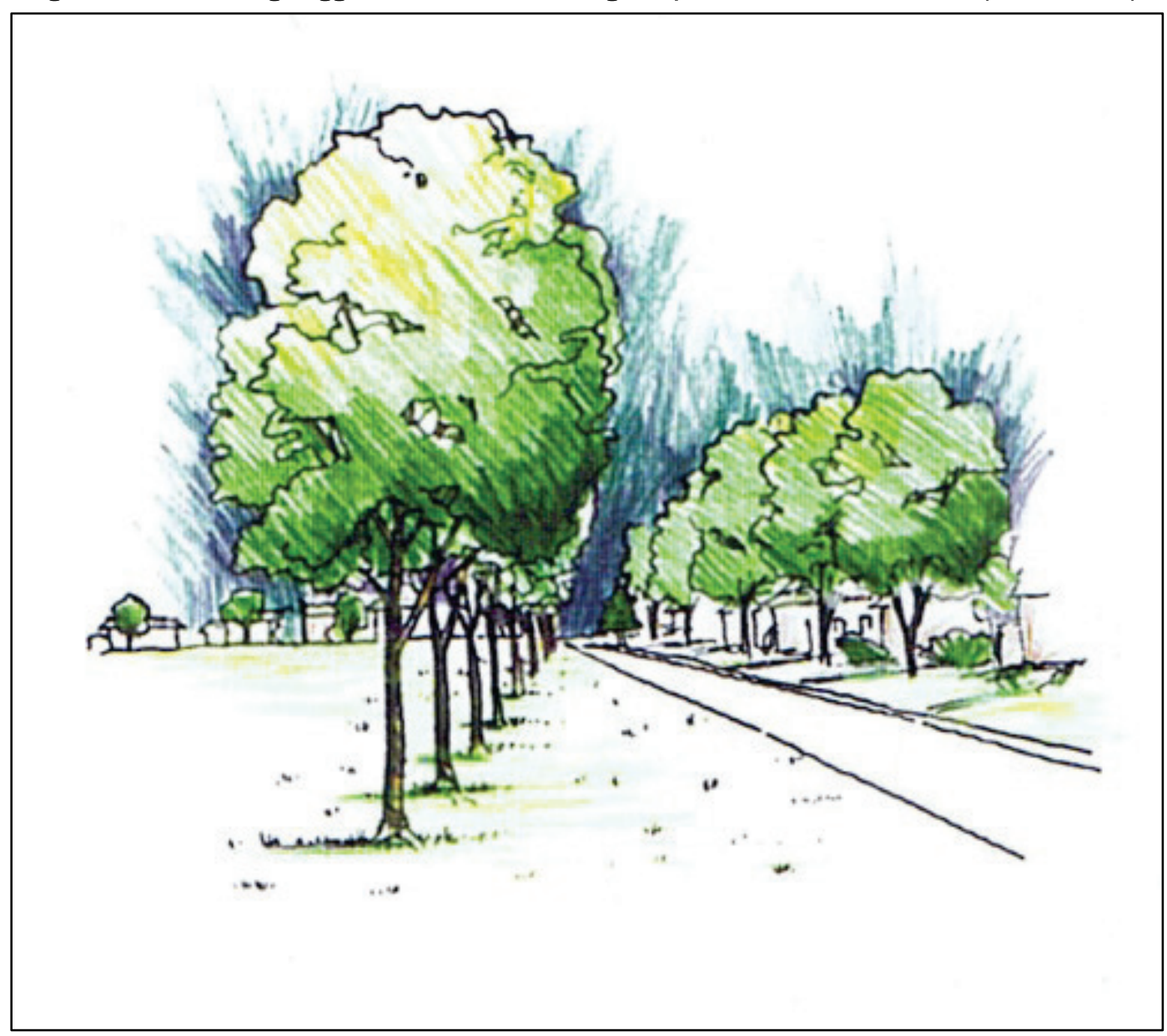


Figure 367. Planting suggestions for base of flagpole on Brown Field (ERDC-CERL).

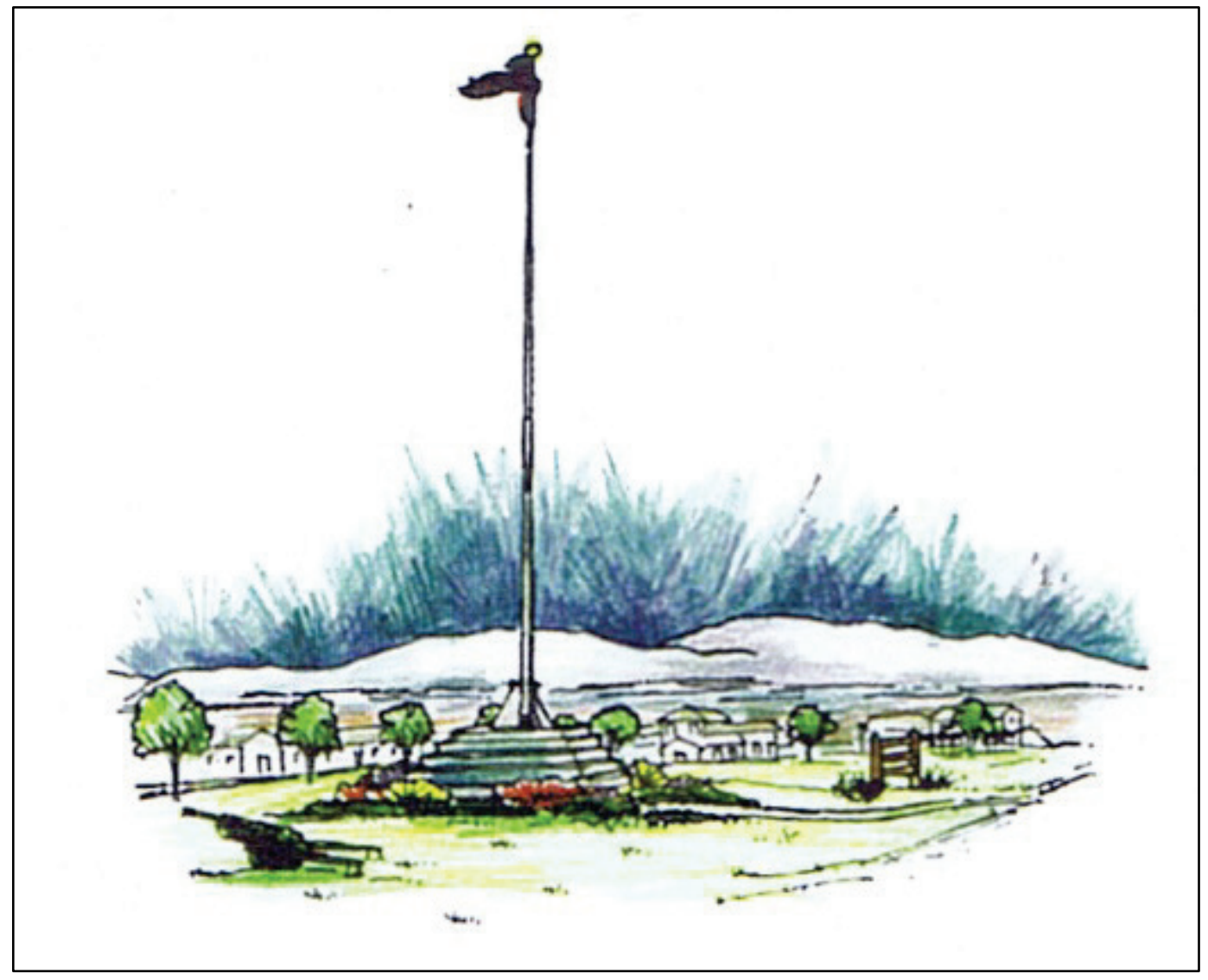

\subsubsection{Old Post Administration}

- Historically, administration buildings, like the Headquarters, were more heavily landscaped to show hierarchy of the military (Figure 368).

- Keep facades of historic architecture free of visual intrusions (Figure 369).

- Retain medium-sized shade trees in between buildings as per historic setting.

- Plant low-growing groundcovers and shrubs in front of historic buildings to add color and texture and reduce erosion of ground. 
Figure 368. Planting plan for Headquarters using plants from proposed list in Appendix A (ERDC-CERL).

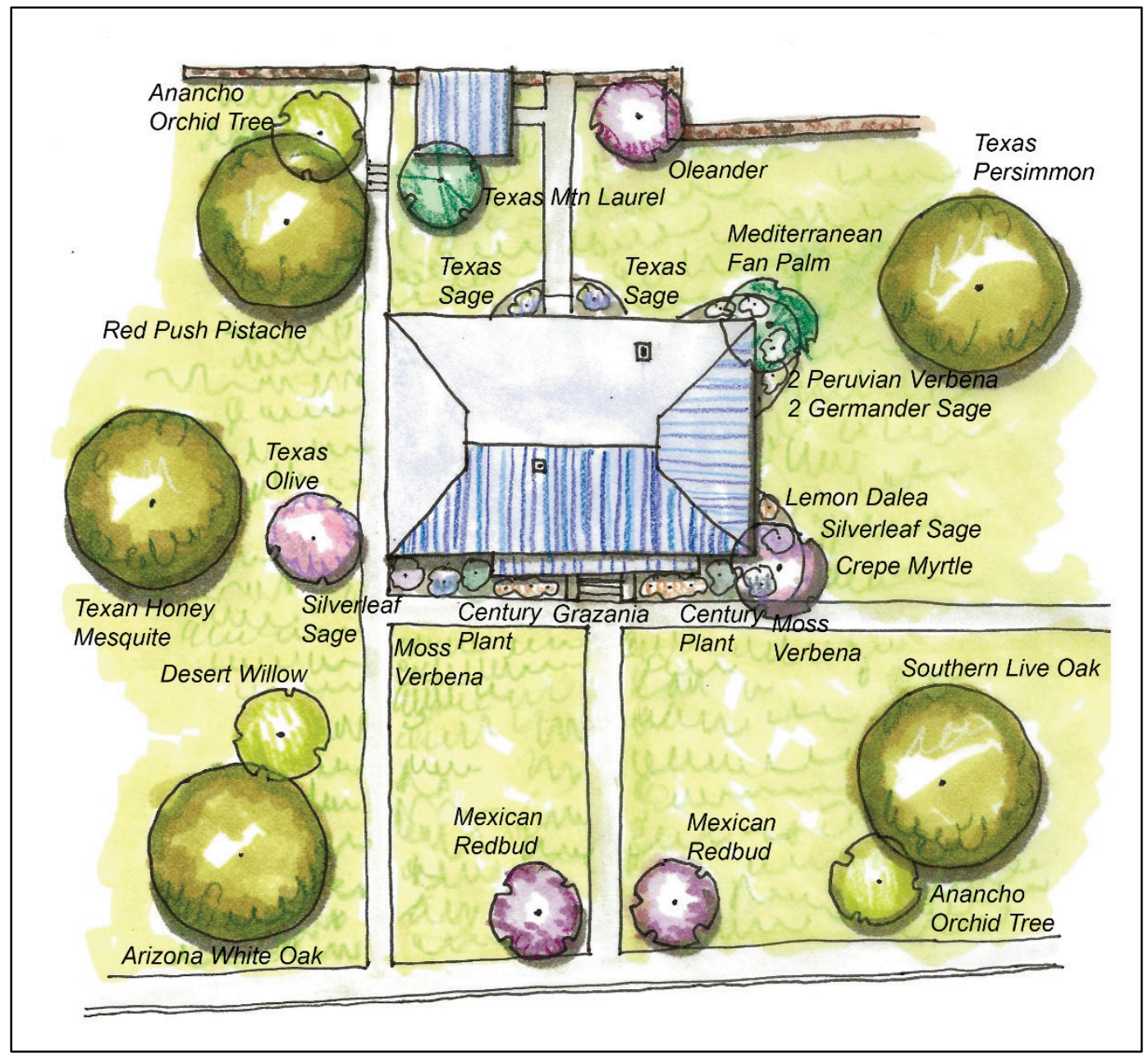


Figure 369. Planting plan for Museum using plants from proposed list in Appendix A (ERDCCERL).

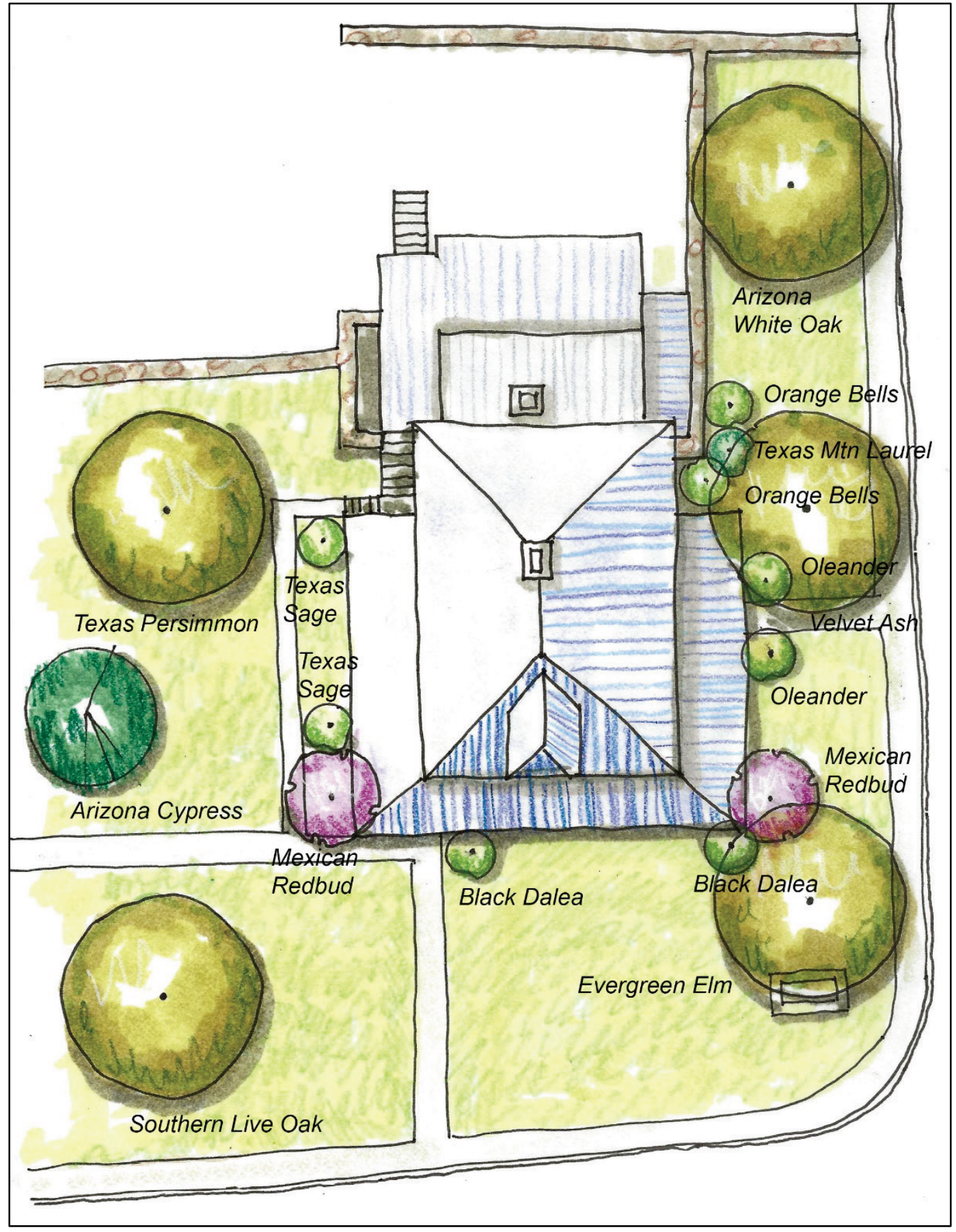




\subsubsection{Recreation}

- Historically, the recreation buildings, like Brayton Hall (21115), were more heavily landscaped to show hierarchy of the military.

- The planting design for the recreation buildings should be compatible with the vegetation of the former hospital, Headquarters, and current Museum. To have compatible landscaping does not mean the PX building design has to feature an elaborate use of plants, but the vegetation used should feature a variety of species and be well maintained.

- Keep facades of historic architecture free of visual intrusions.

- Retain medium-sized shade trees in between buildings as per historic setting.

- Plant low-growing groundcovers and shrubs in front of historic buildings to add color and texture and reduce erosion of ground (Figure 370 ). 
Figure 370. Planting plan for Bowling Alley (21114) using plants from proposed list in Appendix A (ERDC-CERL).

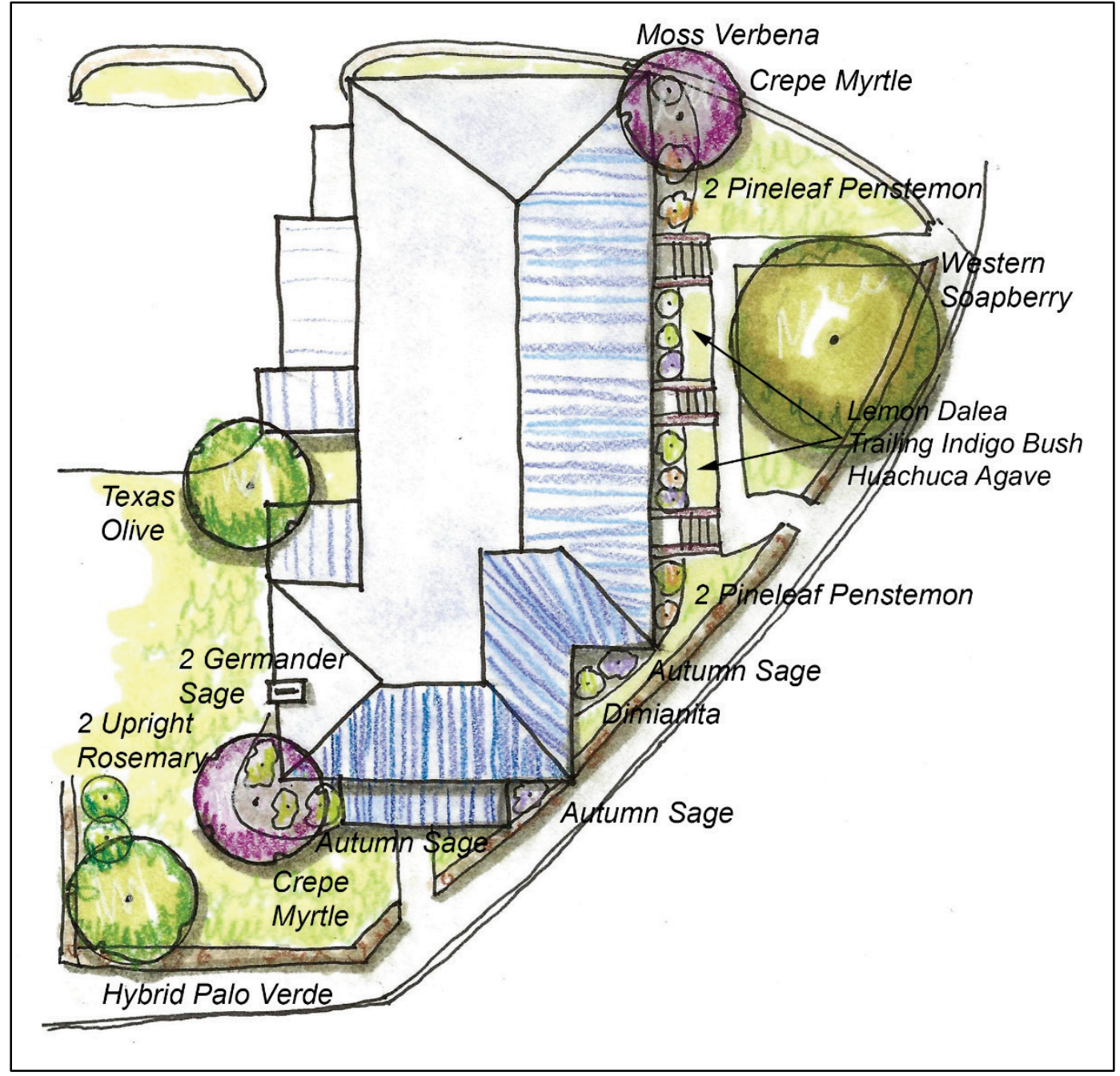




\subsubsection{Officers Duplexes}

Historically the officers' duplexes were surrounded by a variety of shrubs and flowering trees.

- While the common open space at Henry Circle was once an orchard, it is recommended that the use of small trees around the periphery be restored. The interior of the open space should remain open for play and to allow views of the historic architecture.

- Position tall shade trees between and behind the quarters to preserve unobstructed views of the historic architecture and for cooling during hottest months; integrate smaller ornamental trees inside yards and closer to corners of the residences to frame facades (Figure 371).

- Keep front lawns free of inappropriate additions (i.e., lawn ornaments or inappropriate plants).

- Implement a variety of foundation plantings that frame and enhance the architecture without obscuring the facades (Figure 372).

- If fencing is needed at quarters in the future, the historic precedent is white picket fencing. Any other choice would be inappropriate, as this style fencing still exists between quarters to separate side and rear yards.

Figure 371. Planting plan for officers' duplexes showing shade trees in rear and flowering trees inside yards (ERDC-CERL).

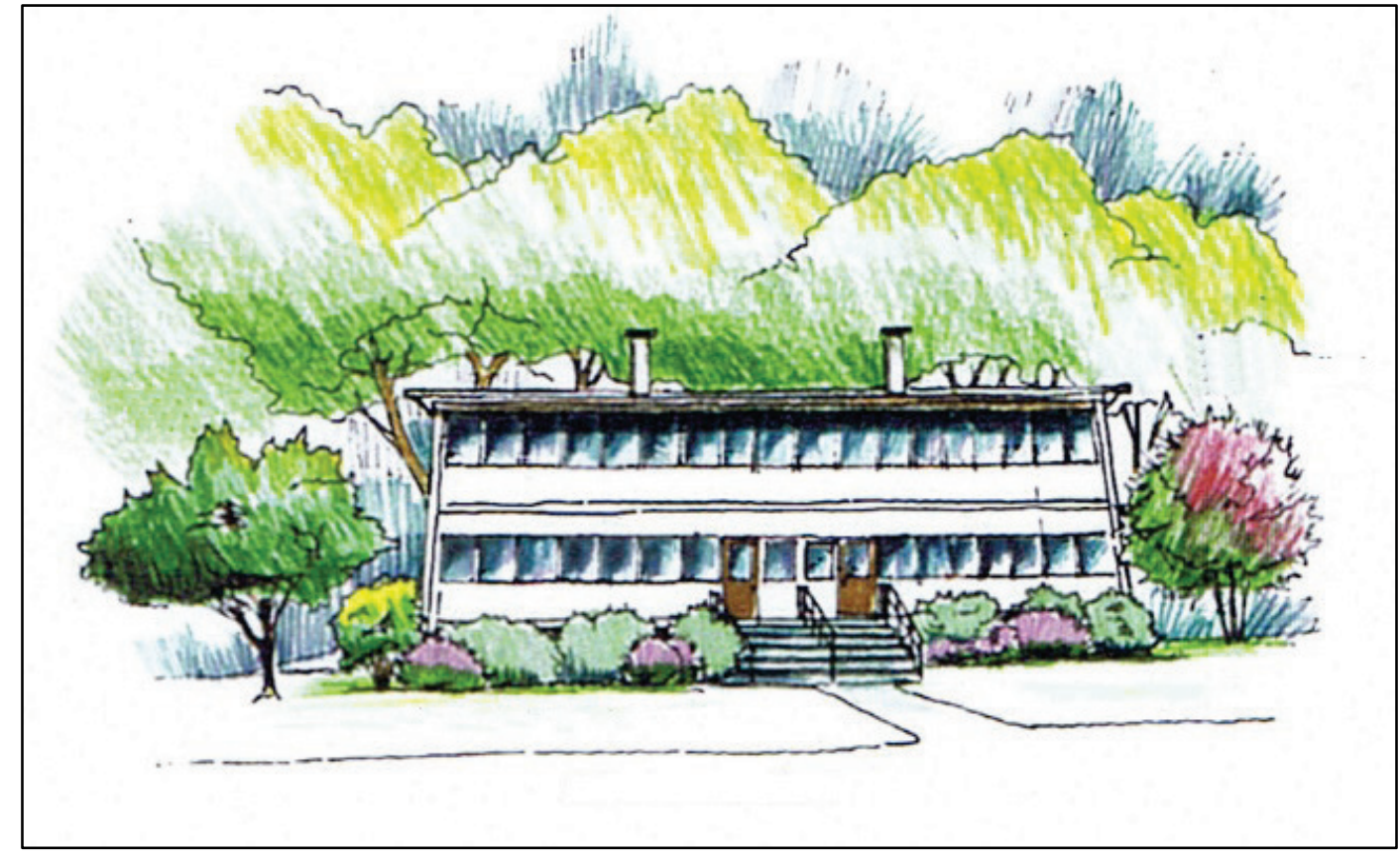


Figure 372. Planting plan for officers' duplexes using plant list in Appendix A (ERDC-CERL).

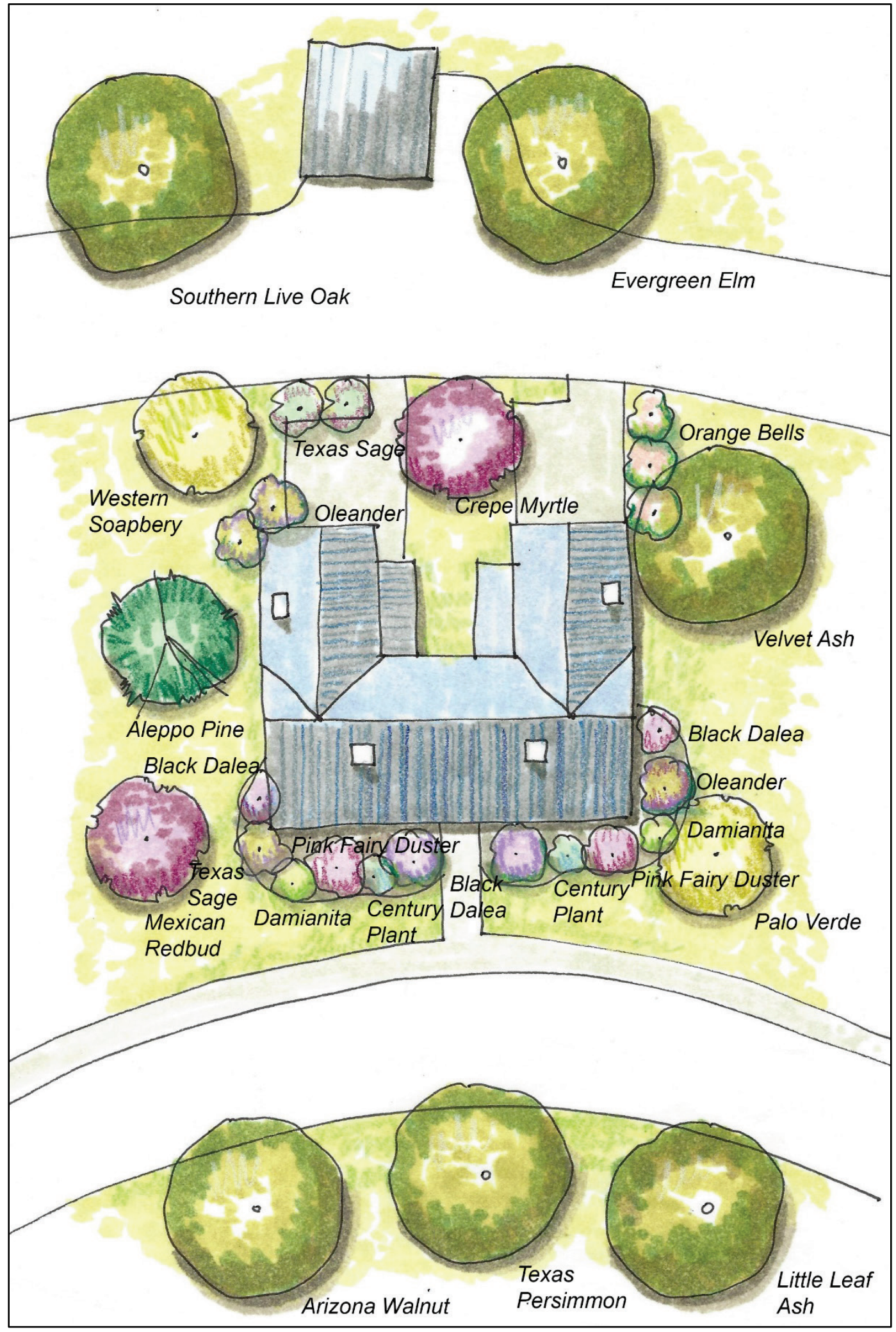




\subsubsection{Barracks}

Historically the 1914 Barracks were sparsely planted with vegetation since there is little room between building and sidewalk.

- Lack of plantings along barracks has led to erosion.

- Rogue trees have grown up too close to building.

- Low shrubs should be planted in front of historic barracks (see Figure 365).

- Shade trees should be planted in rear and inside yards where possible. 


\section{Supplemental Landscape Areas}

During the course of this project, several areas adjacent to the NHL district were found to have associations with the Old Post and were found to deserve mention in the final chapter of this report. These supplemental landscape areas date to the POS for the NHL district and will be discussed in this chapter (Figure 373).

Figure 373. Supplemental landscape areas as identified by ERDC-CERL (2020).

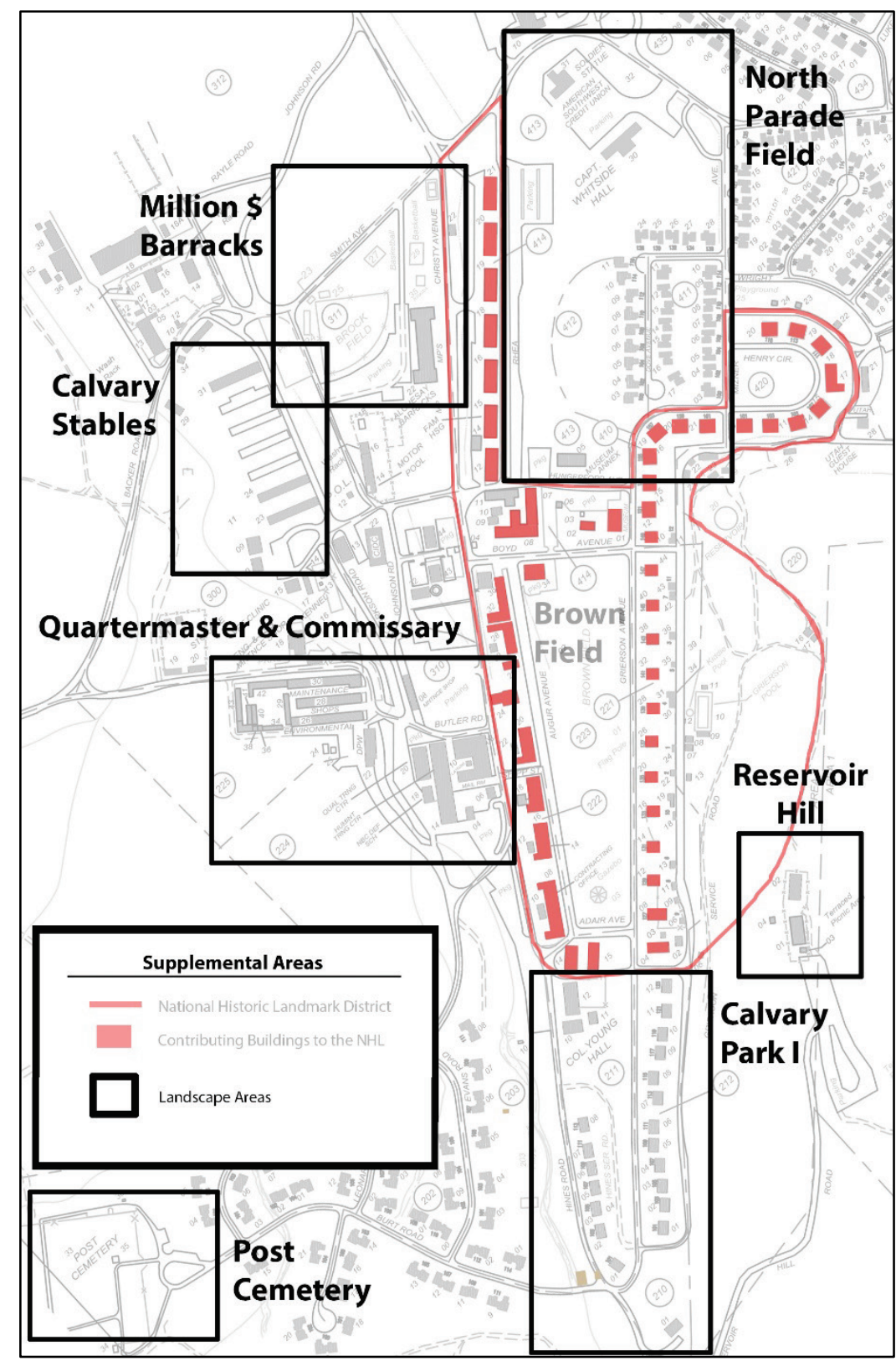




\subsection{North Parade Field}

The North Parade Field is located between Hungerford Avenue, Rhea Avenue, Smith Avenue to the north and the Cavalry Park V Housing Area to the southeast (Figure 374). The buildings located in this landscape area include the Museum Annex (41305), Whiteside Hall (41330), the credit union (41331), and the Buffalo Soldiers Memorial Plaza (Table 17).

Figure 374. Map of North Parade Field landscape area (ERDC-CERL).

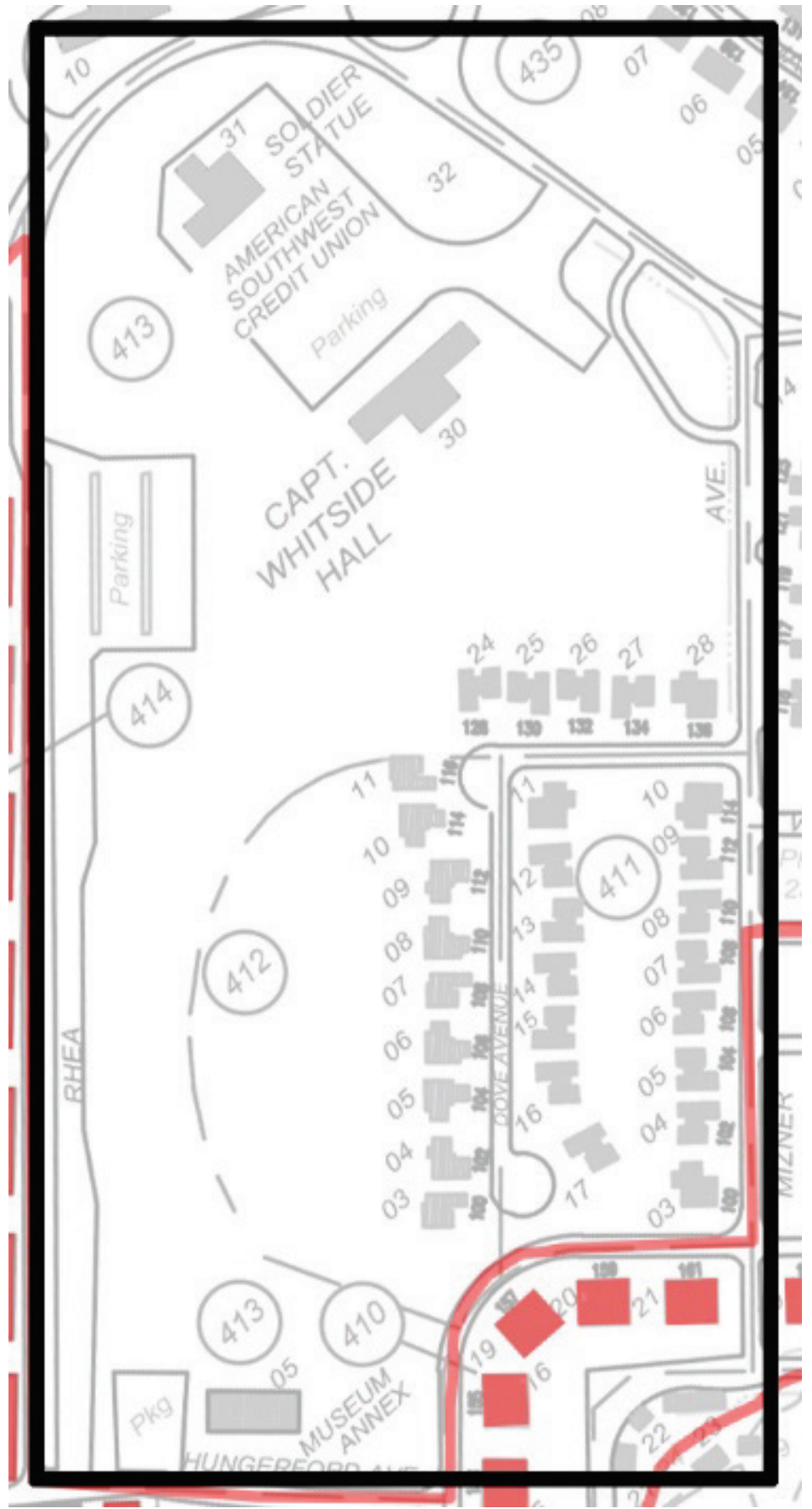


Table 17. Buildings associated with North Parade Field landscape area.

\begin{tabular}{|c|c|l|l|c|}
\hline Building Number & Year Built & Original Use & Current Use & Historic Status \\
\hline & 1914 & North Parade Field & Heritage walk, parking lot & NEV \\
\hline 41305 & 1936 & Theater & Museum Annex & NEV \\
\hline 41330 & 1942 & School & Administration & NEV \\
\hline 41331 & 1917 & Radio Station & Bank & NEV \\
\hline NA & 1977 & Buffalo Soldiers Memorial & Buffalo Soldiers Memorial & NEV \\
\hline NA & NA & Apache Scout Statue & Apache Scout Statue & NEV \\
\hline
\end{tabular}

North Parade Field was developed in the early $20^{\text {th }}$ century when the 1914 Barracks were built. ${ }^{11}$ This field was used for drills, especially for cavalry drills which required more space than provided at Brown Field. In 1936, a theater was constructed at the south end of the parade field. (See Figures 375-388.)

At the north end of the parade field was a radio tower and telegraph building. A school was constructed in 1942, now Whiteside Hall. The former radio station has been added onto and is a credit union. Along Smith Avenue is the recently added Buffalo Soldier Memorial. Near this area was the old Southern Pacific Railroad station, located between the current traffic circle and Burger King. ${ }^{2}$

Family housing was constructed on the parade field in the late 1950s. In the 2000s, the housing was replaced with the new housing seen on the field today called the Cavalry 5 Housing Area. A heritage walk with interpretive signs separates the housing area from what is left of the drill area and the parking lot in front of the 1914 Barracks. While the housing area and trail affect the integrity of this area, further evaluation is needed due to the area's association with the $10^{\text {th }}$ Cavalry.

\footnotetext{
51 North Parade Field, also referred to as Lower Parade Field is the name designated in all the heritage signage on site. See Figure 382.

52 While 41330 was determined eligible for the WPA-era Historic District by Valenzuela (2011), it was not on the list provided by Tomes and Thomas, 2014. In a previous report Tomes and Thomas, 2013, determined 41331 not eligible.
} 
Figure 375. Aerial of North Parade Field with radio station at bottom center, 1923 (Fort Huachuca Historical Museum).

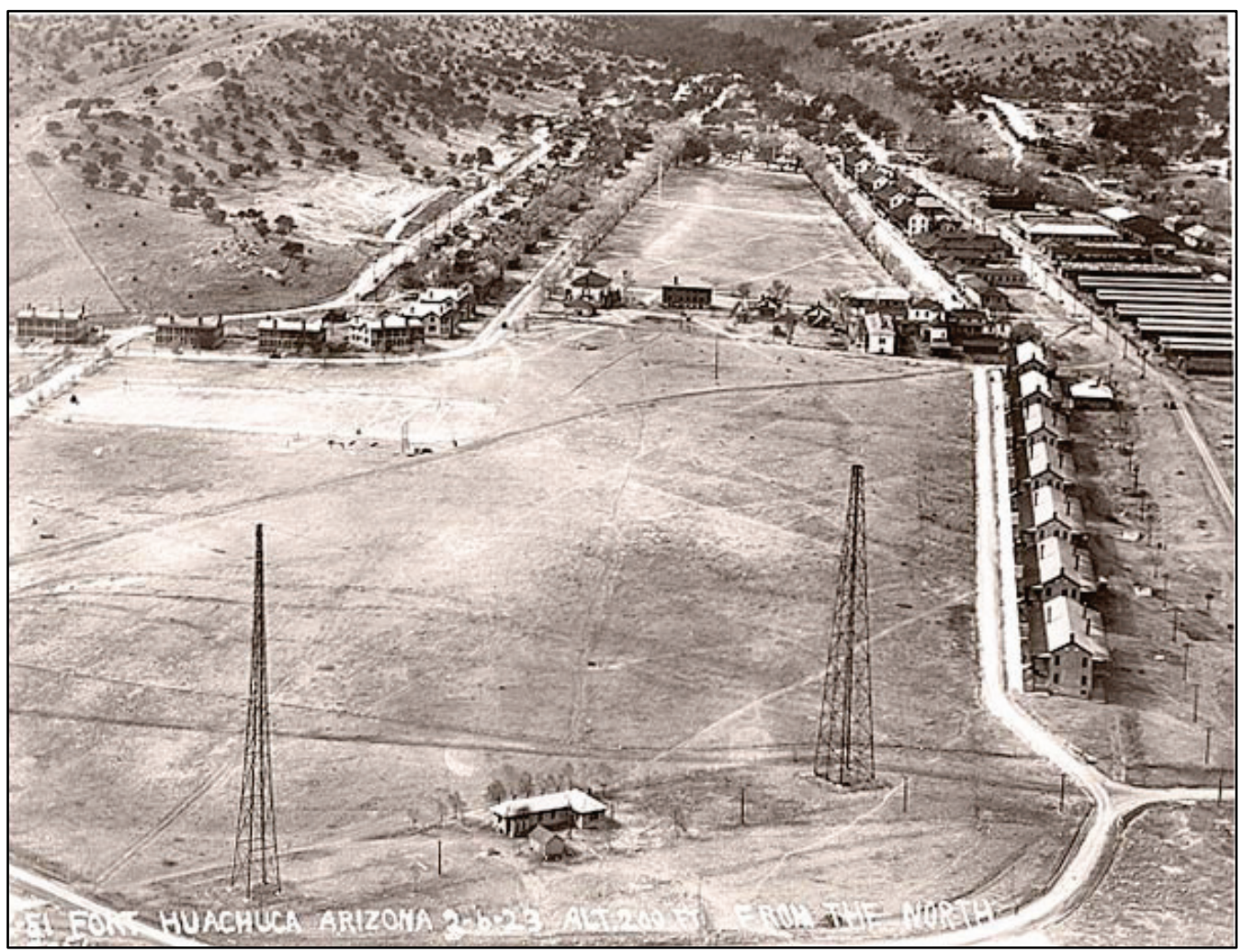

Figure 376. Looking northwest at the 25th Infantry Band on North Parade Field, 1933 (Fort Huachuca Museum).

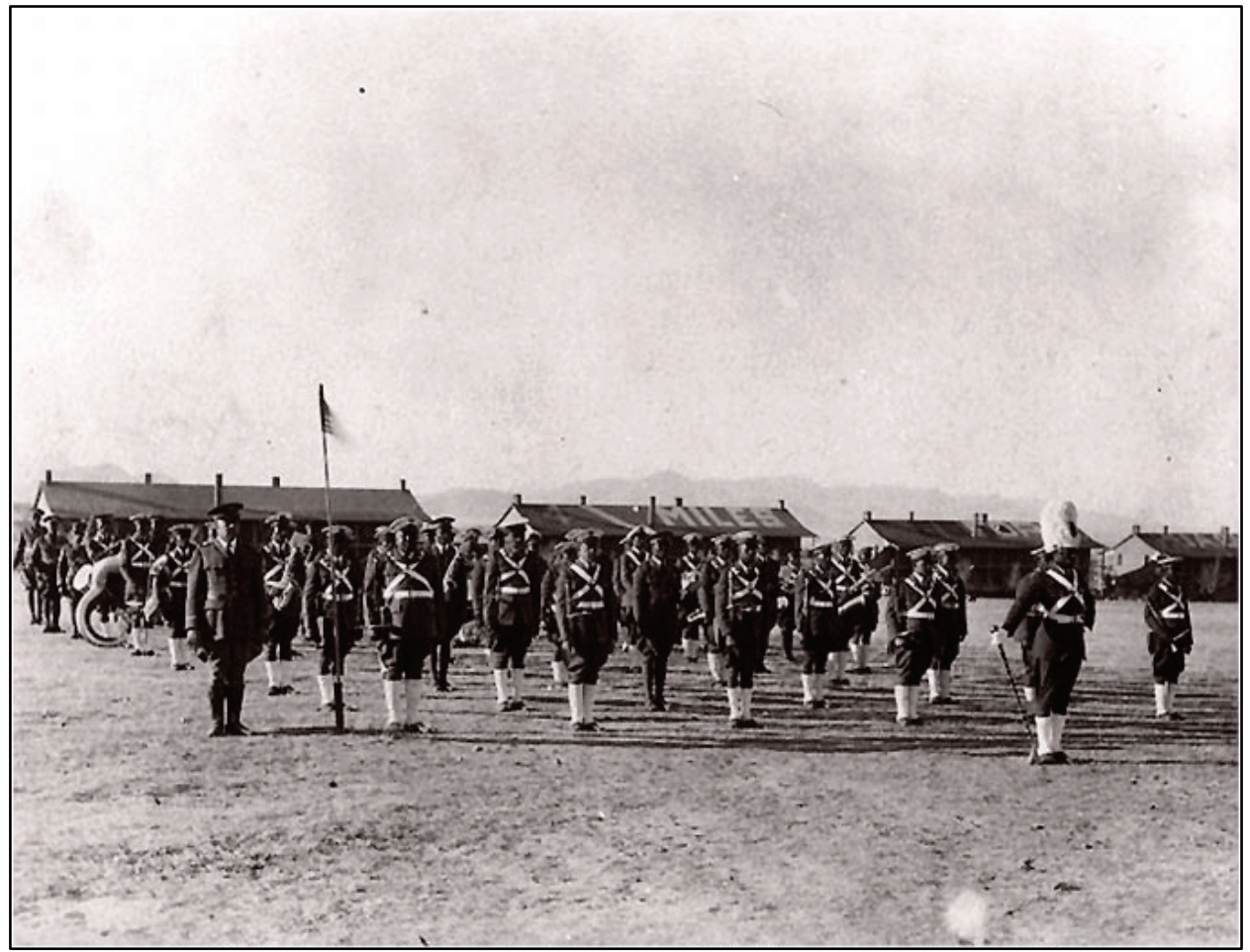


Figure 377. Aerial of North Parade Field prior to construction of housing area, 1954 (Fort Huachuca Historical Museum).

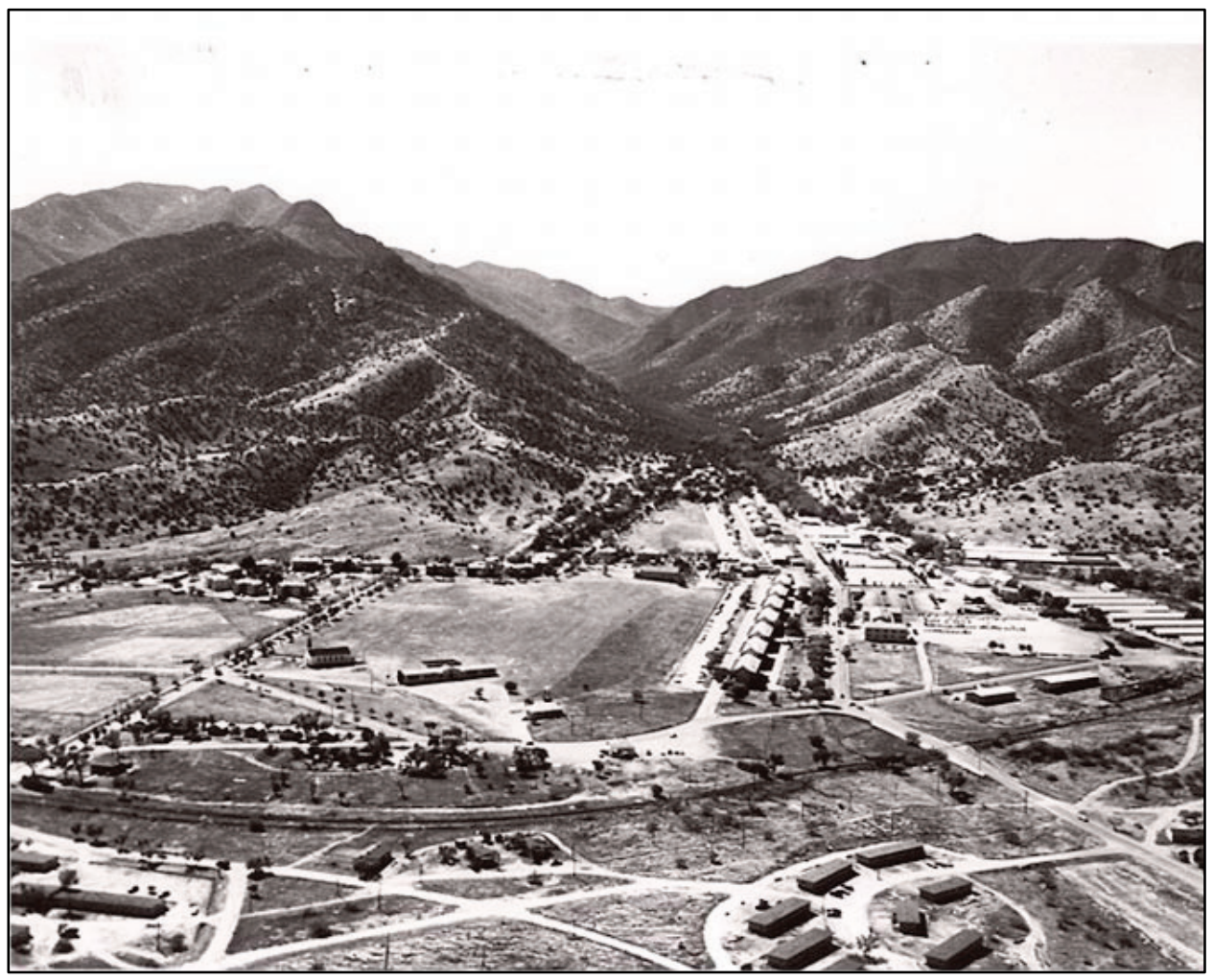

Figure 378. Aerial showing the new housing area on the North Parade Field, 1961 (Fort Huachuca Historical Museum).

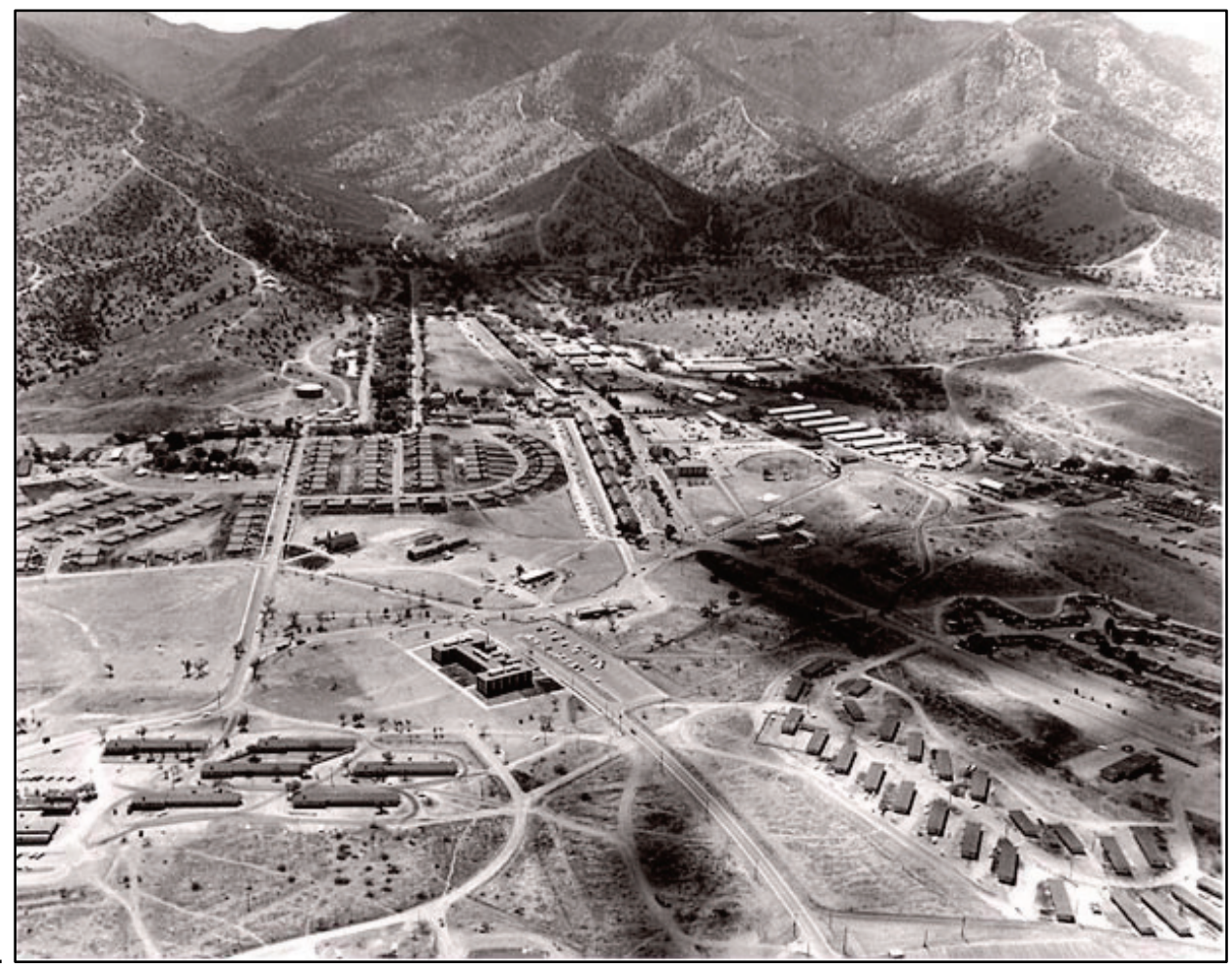


Figure 379. Looking east at the former theater (Building 41305) now the Museum Annex, with Apache Scout statue in foreground (ERDC-CERL 2016).

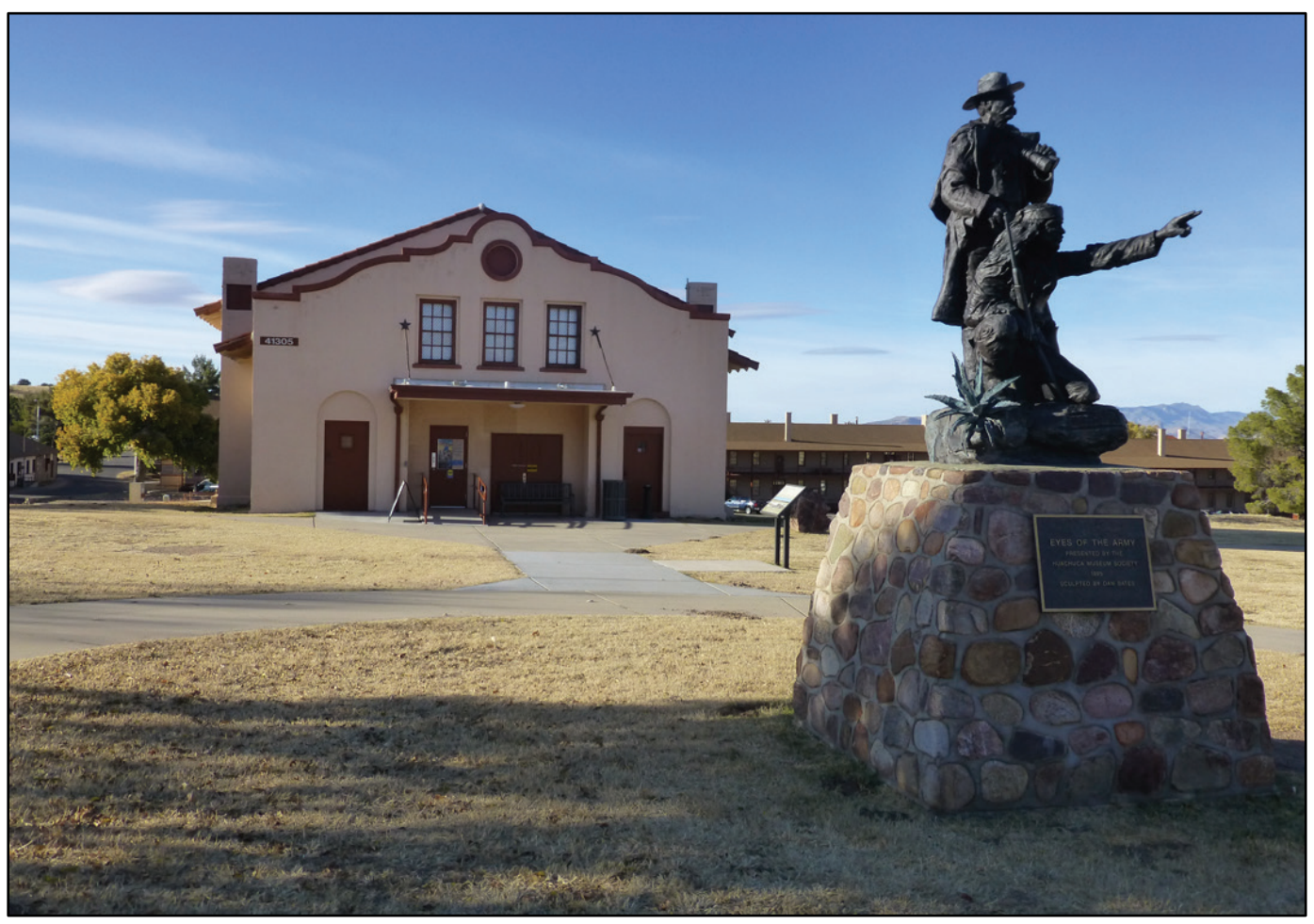

Figure 380. View south of heritage trail on the 1914 Parade Field (ERDC-CERL, 2016).

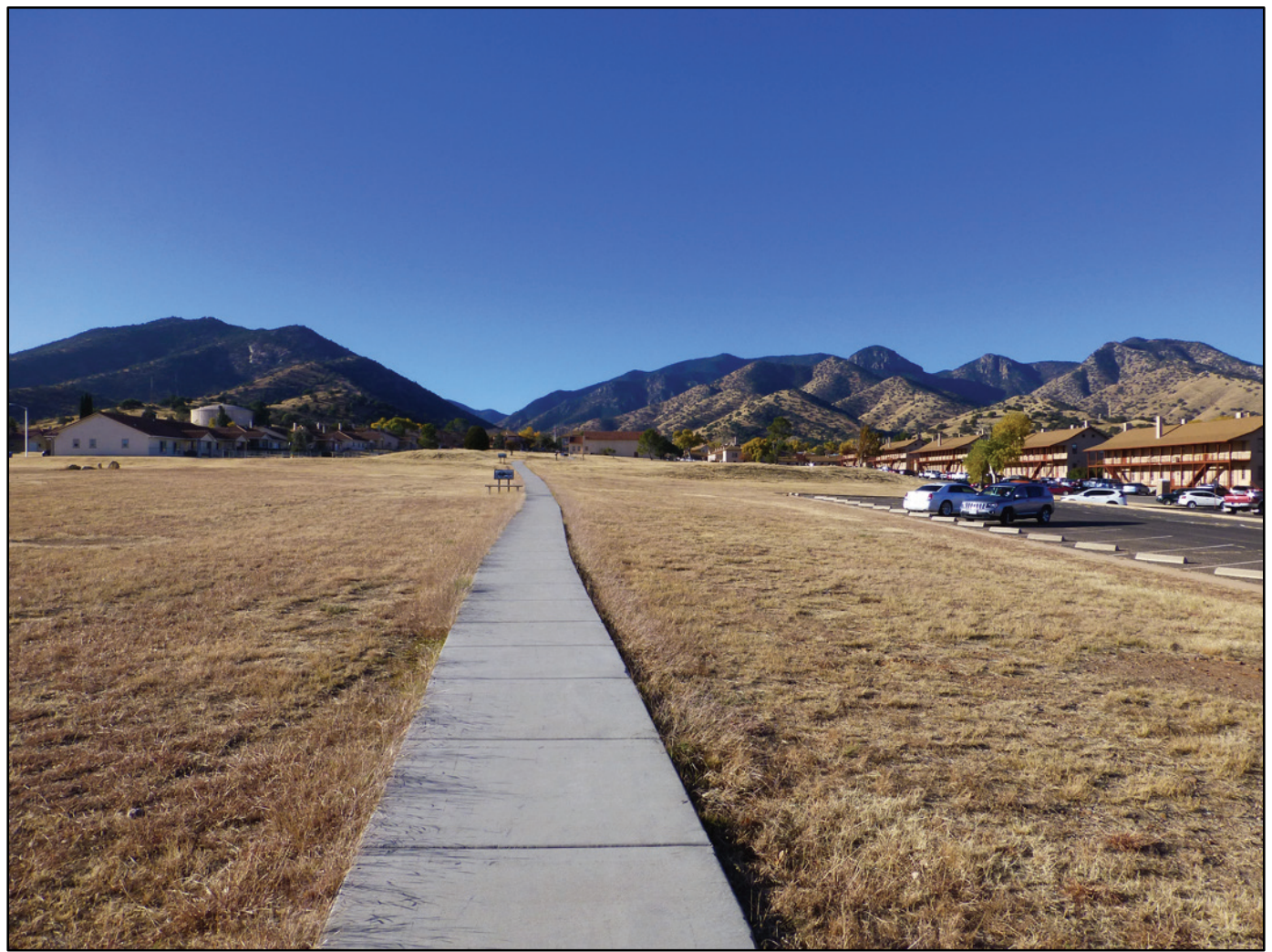


Figure 381. View west on the 1914 Parade Field with heritage trail sidewalk and historical interpretive sign (ERDC-CERL, 2016).

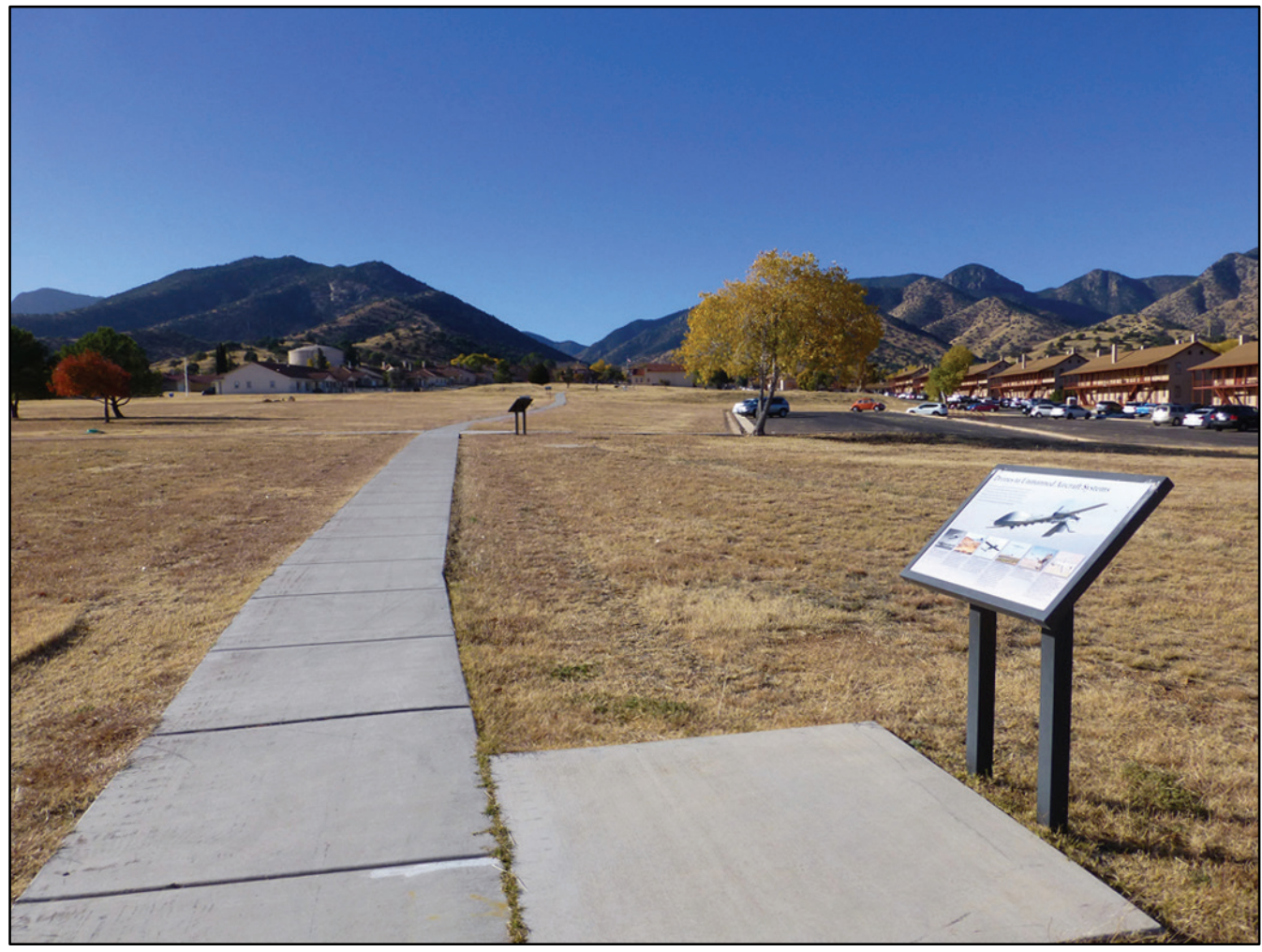

Figure 382. Example of historical interpretive signage along heritage trail sidewalk (ERDCCERL, 2016).

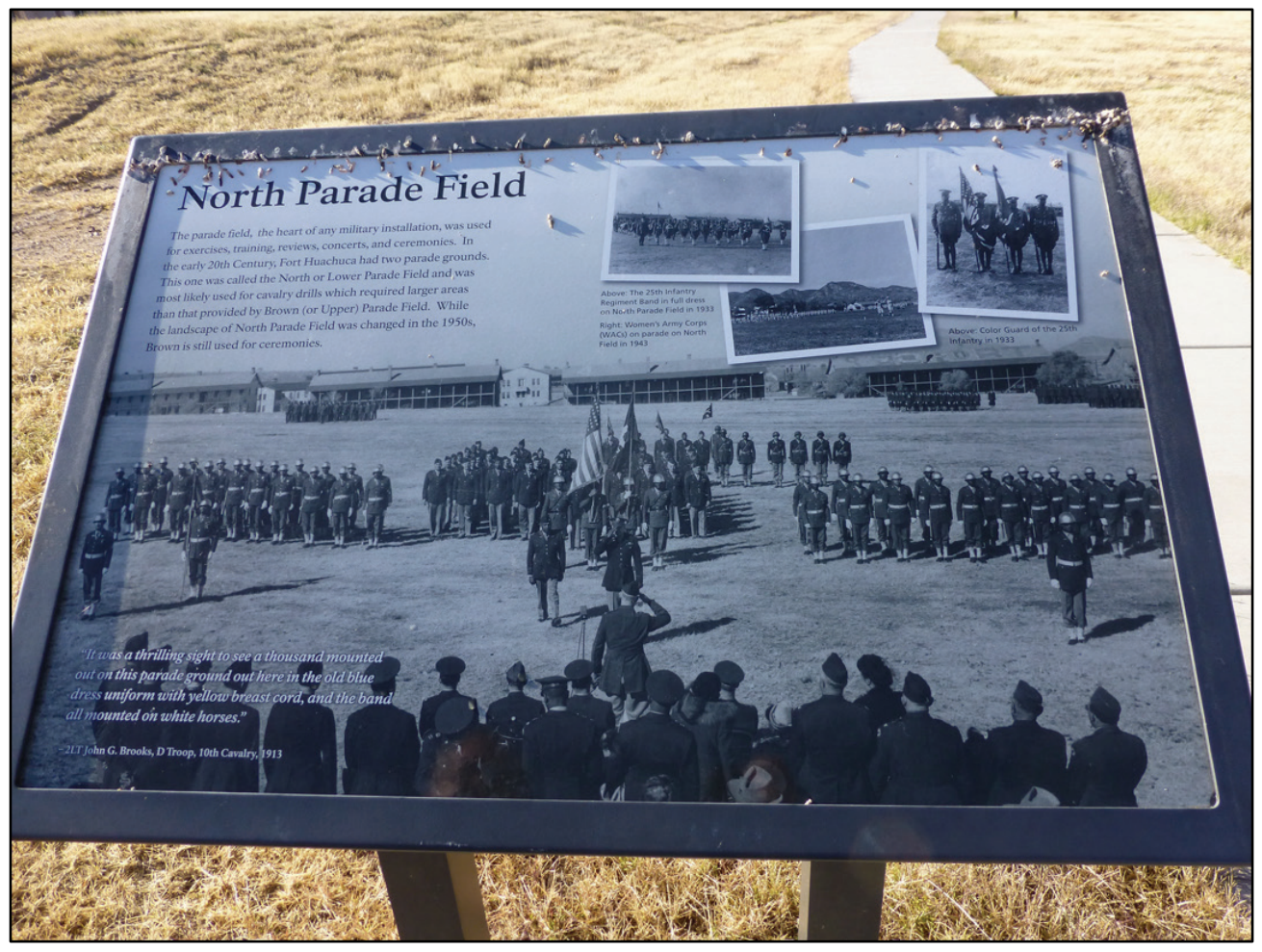


Figure 383. View east on the 1914 Parade Field with heritage trail sidewalk and historical interpretive signs (ERDC-CERL, 2016).

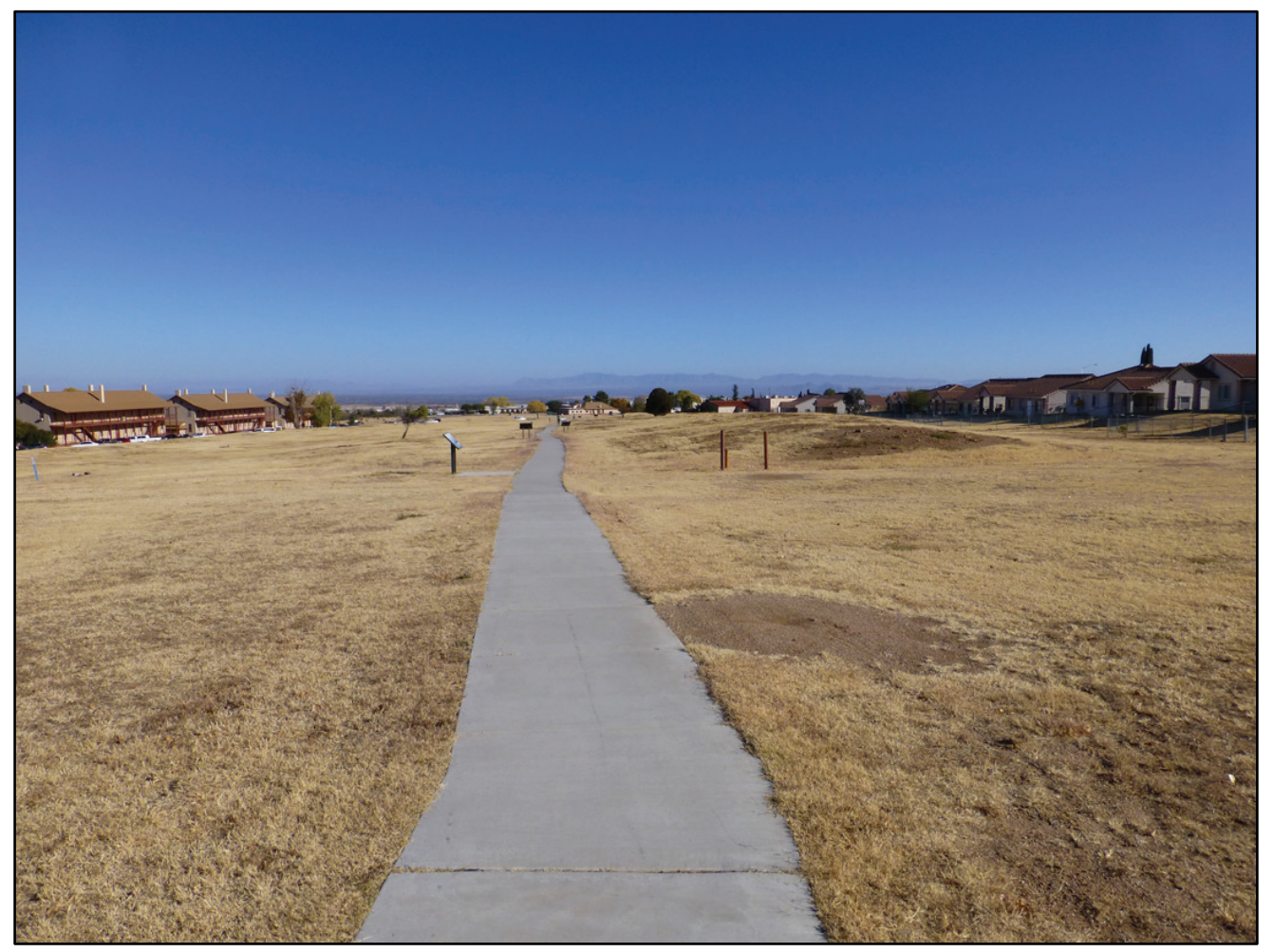

Figure 384. View of the parking lot at the eastern end of the 1914 Parade Field with 41331 credit union in center and Buffalo Soldier Statue Plaza at right (ERDC-CERL, 2016).

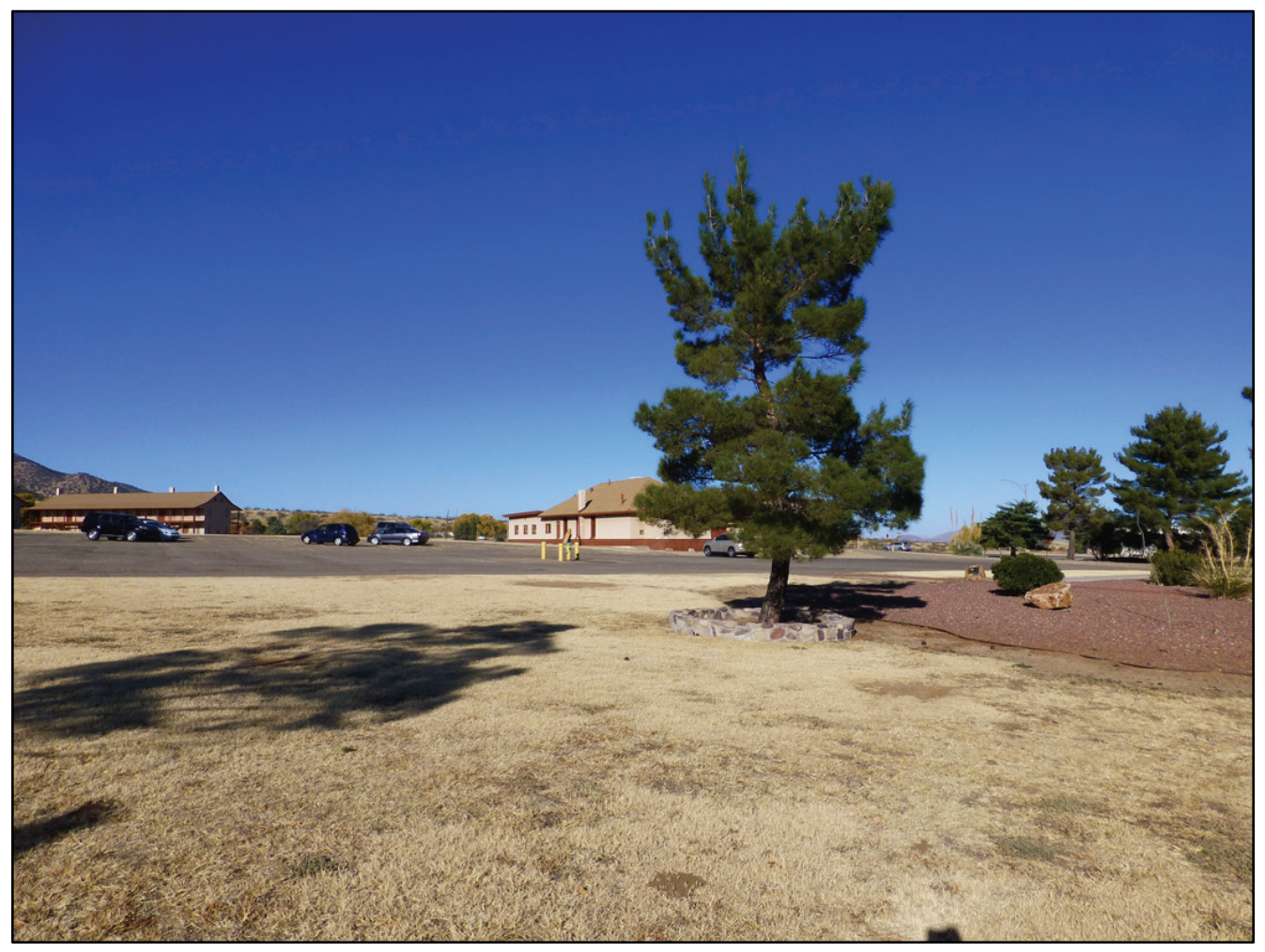


Figure 385. View towards 41330 at the north end of the North Field (ERDC-CERL, 2016).

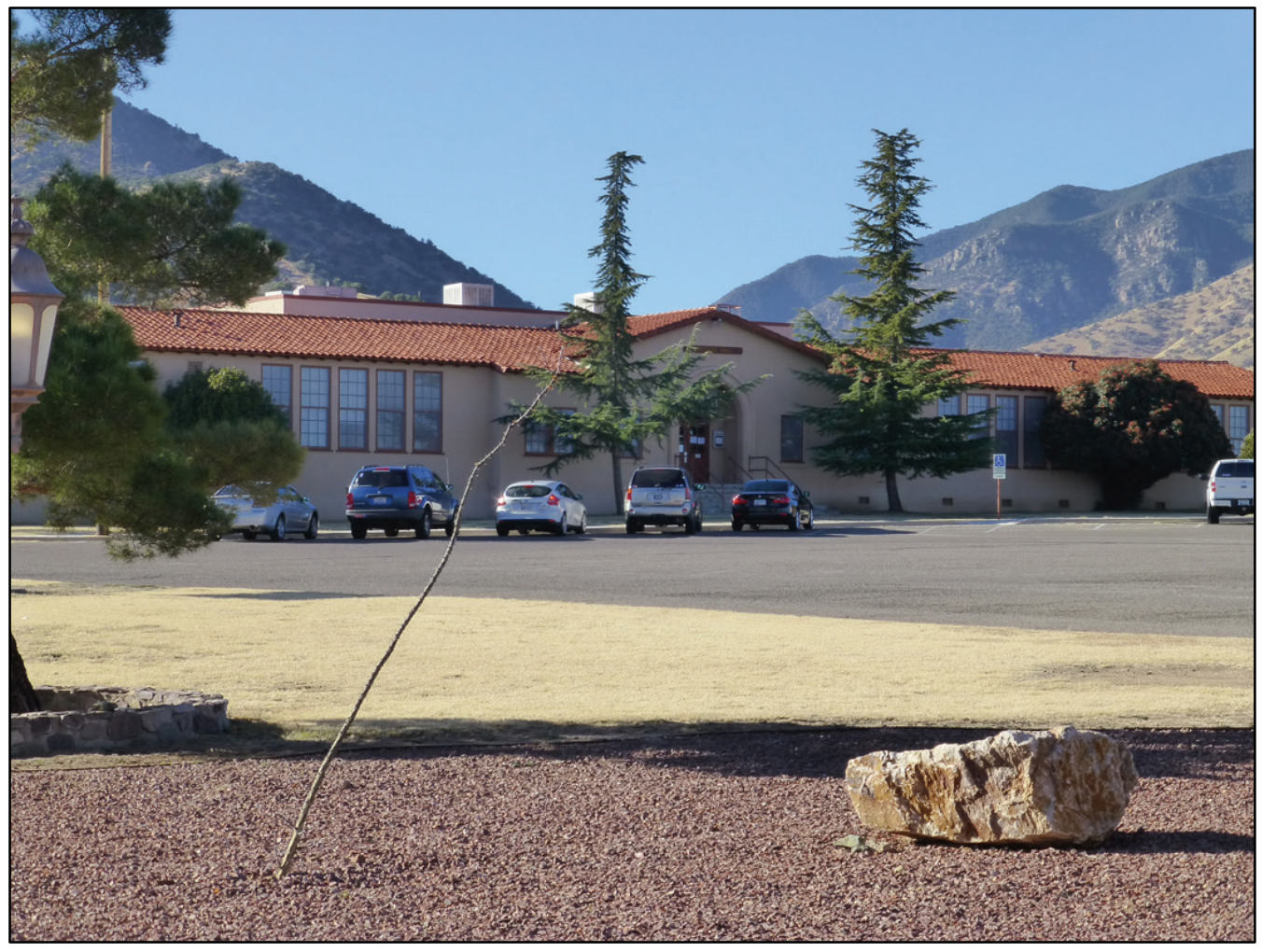

Figure 386. View towards 41331 credit union on the north end of the North Parade Field (ERDC-CERL, 2016).

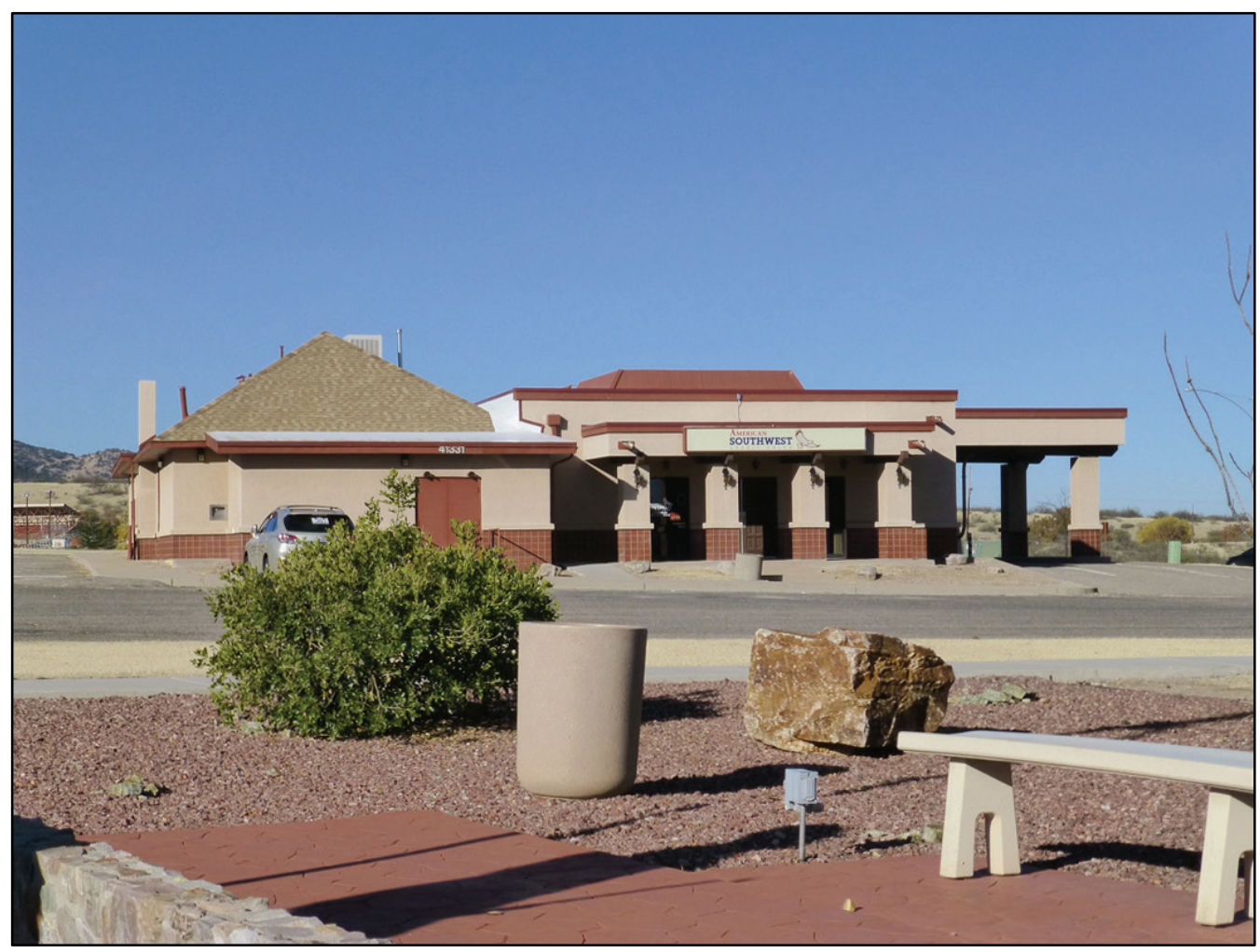


Figure 387. View west of the Buffalo Solder Legacy Plaza at the northeastern end of the 1914 Parade Field, with 41330 in the left background (ERDC-CERL, 2016).

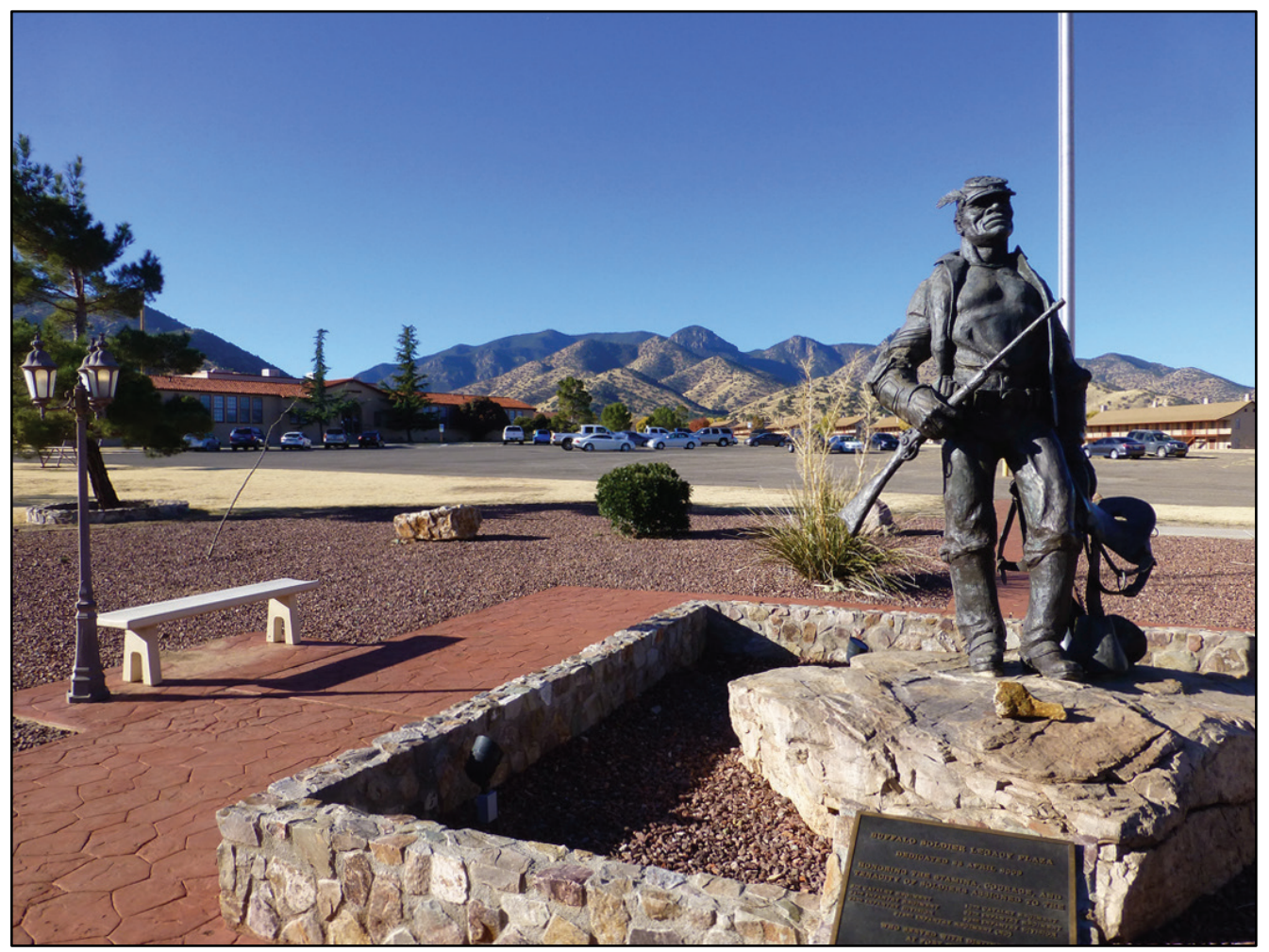

Figure 388. View south toward the 1914 Officers' Quarters from the North Parade Field with 2003 housing in front (ERDC-CERL, 2016).

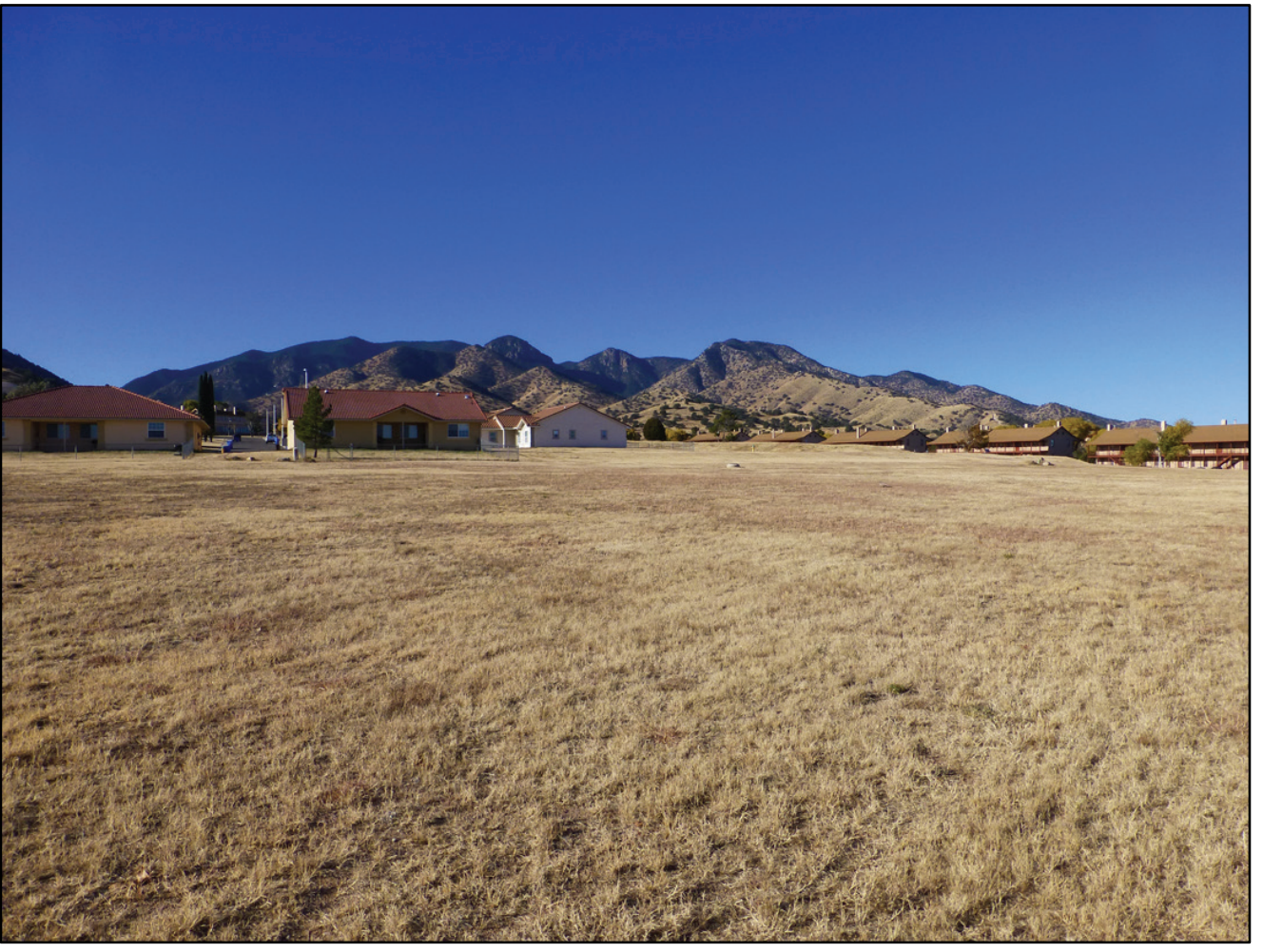




\subsection{Million Dollar Barracks}

The Million Dollar Barracks area is located between Johnson Avenue and Christy Avenue with Smith Avenue to the north (Figure 389). The buildings located in this landscape area include the Alchesay Barracks (31122) and associated recreational resources, including the baseball field, Brock Field, and basketball courts (Table 18).

Figure 389. Map of Million Dollar Barracks landscape area (ERDC-CERL).

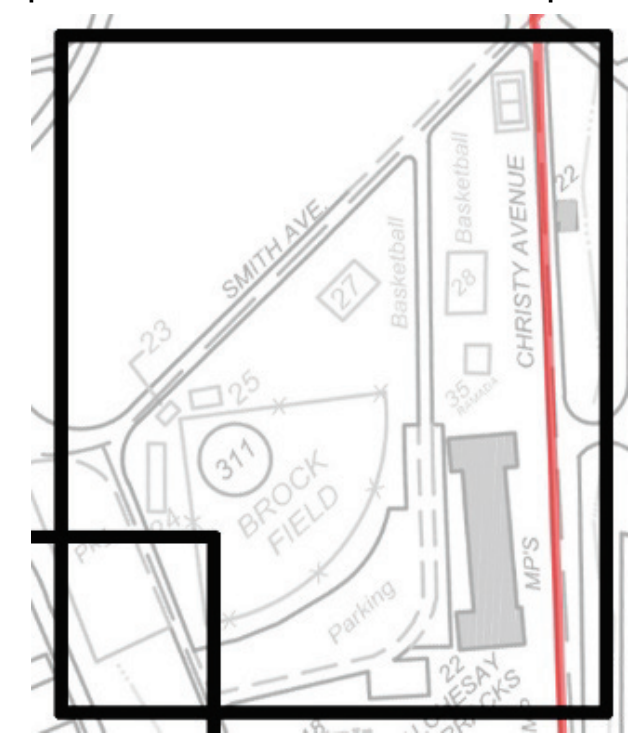

Table 18. Buildings associated with Million Dollar Barracks landscape area.

\begin{tabular}{|c|c|l|l|c|}
\hline Building Number & Year Built & Original Use & Current Use & Historic Status \\
\hline 31122 & 1939 & Barracks & Barracks & NREC \\
\hline 31123 & 1951 & Baseball field & Baseball field & NEV \\
\hline 31124 & 1937 & Enlisted Men's Grandstand & Recreation & NREC \\
\hline 31125 & 1937 & Officers' Grandstand & Recreation & NREC \\
\hline 31127 & 1953 & Basketball Court & Basketball Court & NEV \\
\hline 31128 & 1953 & Basketball Court & Basketball Court & NEV \\
\hline 31135 & 1996 & Recreation Shelter & Recreation & NEV \\
\hline
\end{tabular}

In 1939, the WPA constructed the "Million Dollar Barracks" (31122) for the

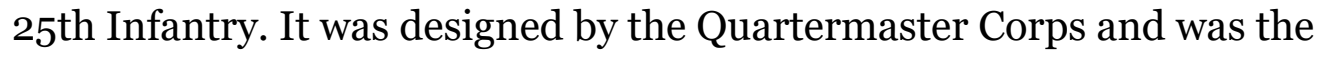
largest construction project by the WPA on Fort Huachuca (Figure 390). The Spanish Colonial Revival motif building is unlike any other building near the NHL District. A NRHP nomination, determining it individually 
eligible, was written for the barracks but was never submitted to the Arizona SHPO.53 It is considered a contributing building to the WPA-era Historic District (Figure 391).

Other WPA projects at Fort Huachuca were to construct grandstands at Brock Field located at the rear of the Million Dollar Barracks. The Enlisted Men's Grandstand along the first base line included a dugout, canopy, wood bleachers and storage rooms along the rear facade (Figure 392 and Figure 393). The Officers' Grandstand located behind the home plate backstop (Figure 394). The Officers' Grandstand originally had a canopy and folding stadium chairs. Both are considered contributing to the WPAera Historic District (Figure 395).54

Added to the area in the 1950 os were two basketball courts to the north of the barracks (31127 and 31128). Adjacent to the basketball courts are two sand volleyball courts (not on Real Property). A recreation shelter (31135) was added in 1996.

\footnotetext{
53 Rand F. Herbert and Stephen D. 1993. Mikesell, National Register Nomination for Million Dollar Barracks, Fort Huachuca.

54 While earlier reports determined the Officers' Grandstand was not eligible due to integrity, Tomes and Thomas (2014) determined the similar materials and workmanship made it contributing to the district.
} 
Figure 390. View looking north of Million Dollar Barracks (now Alchesay Barracks), 1941 (NARA College Park, RG 77, 393 Box 94).

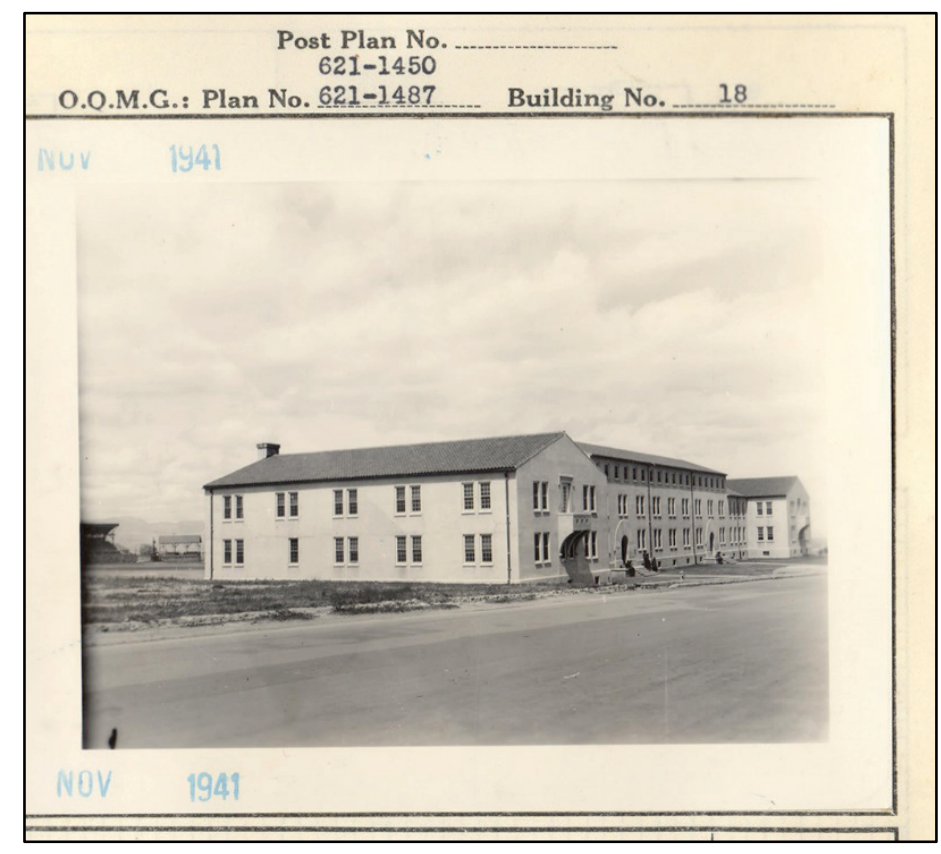

Figure 391. View east of Alchesay Barracks (31122) and parking lot (ERDC-CERL 2016).

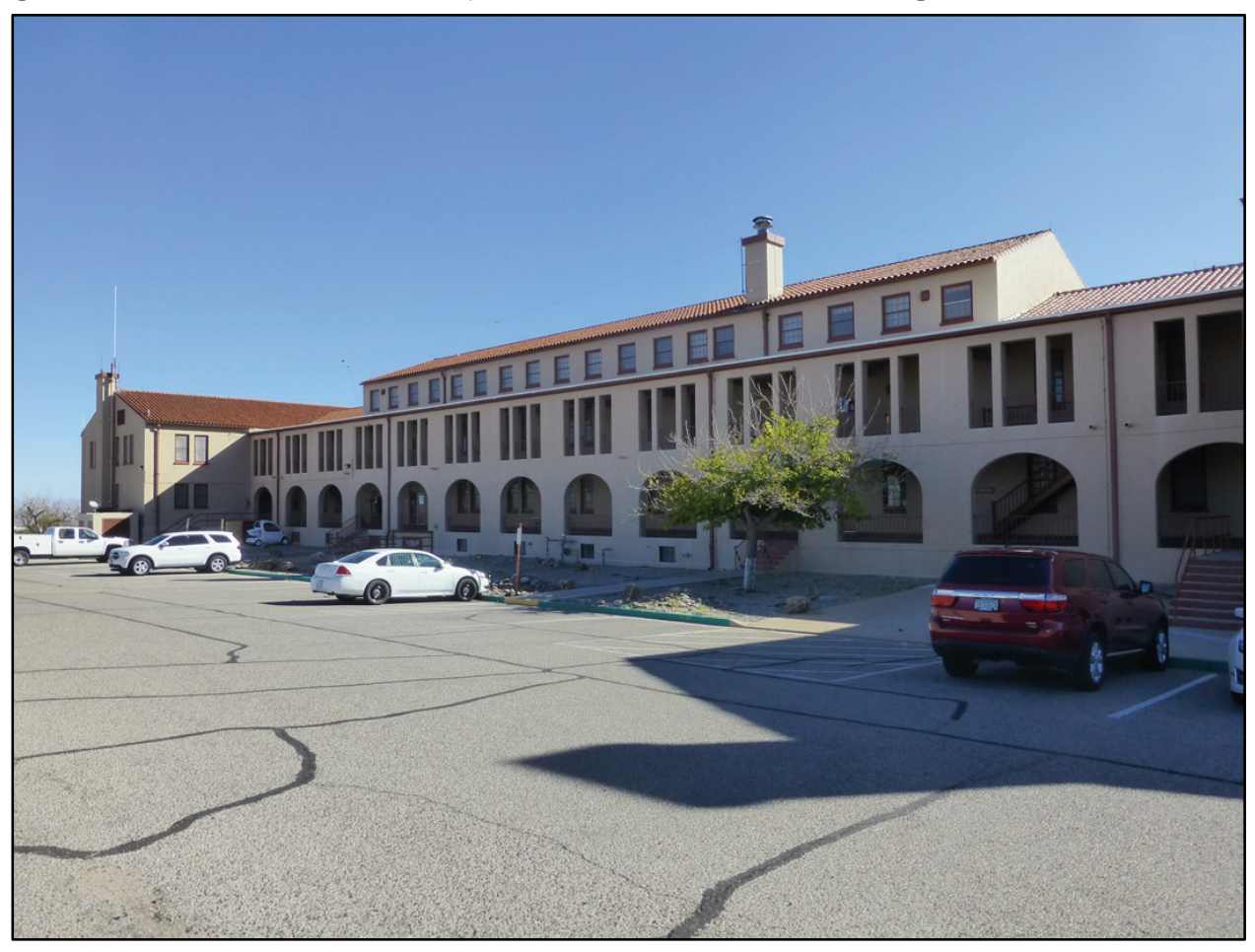


Figure 392. View looking north of Enlisted Men's Grandstand, originally Building 109 (31124), 1941 (NARA College Park).

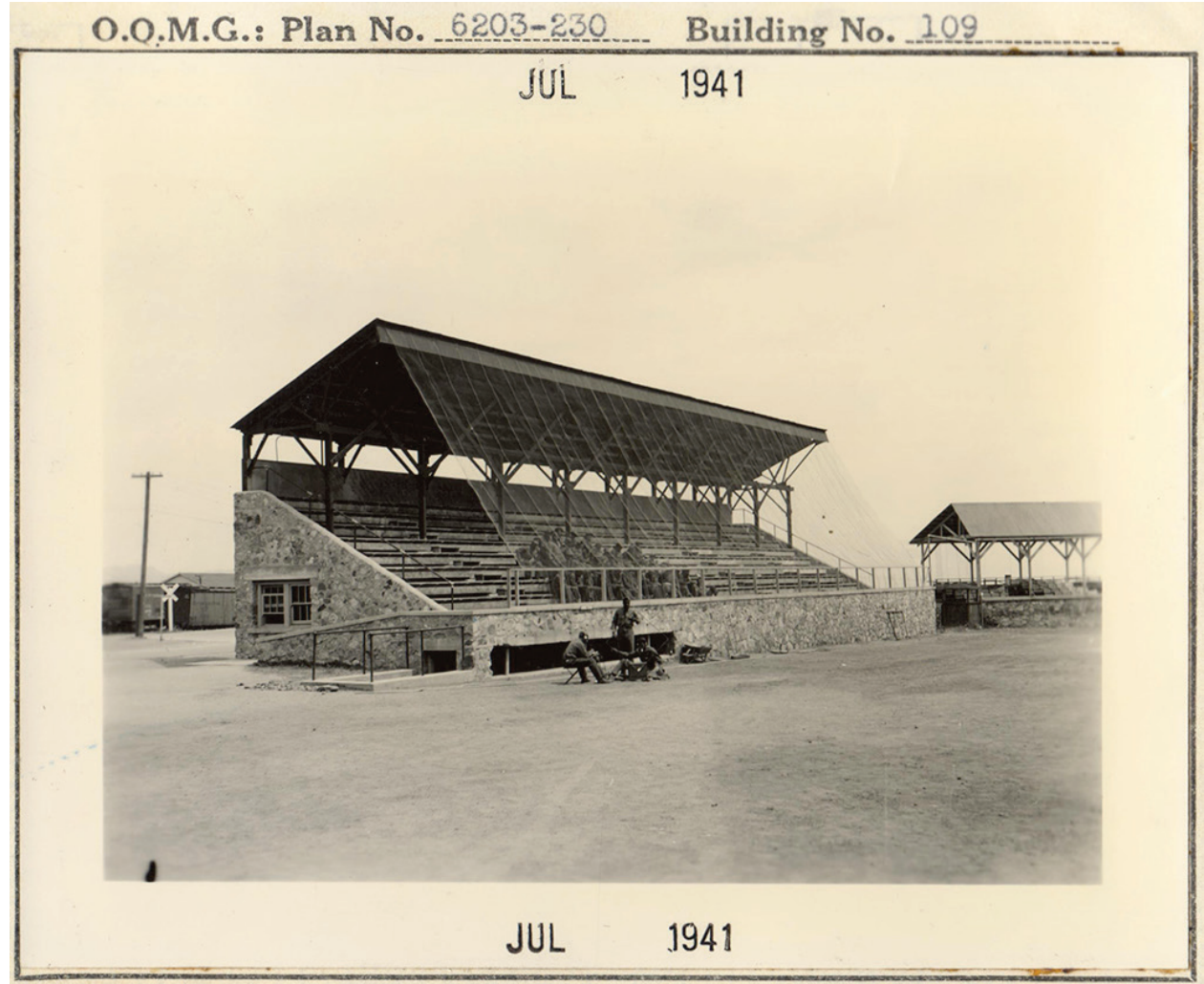

Figure 393. View looking north of Enlisted Men's Grandstand (31124) (ERDC-CERL 2016).

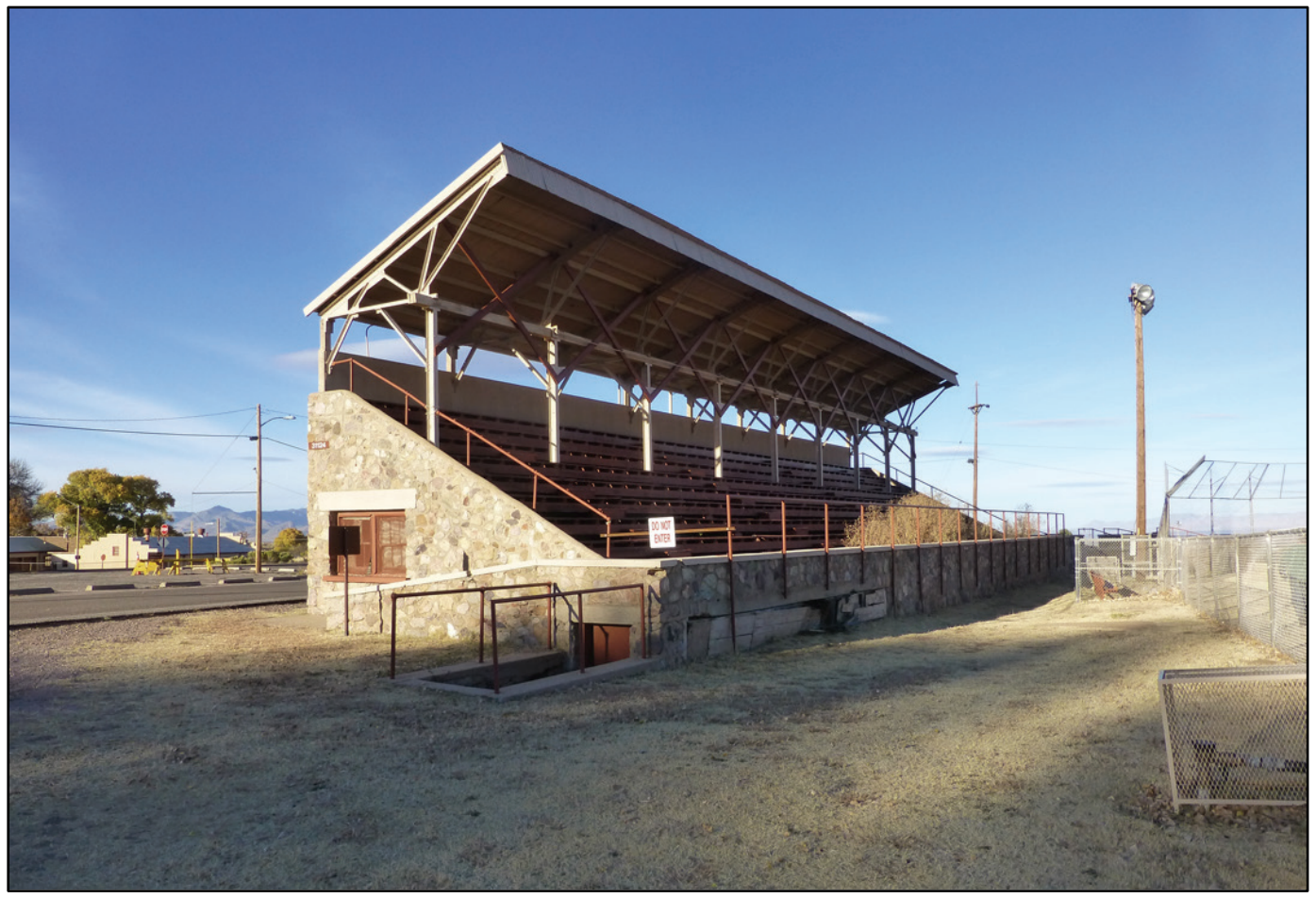


Figure 394. View looking north of Officers' Grandstand (31123) (ERDC-CERL 2016).

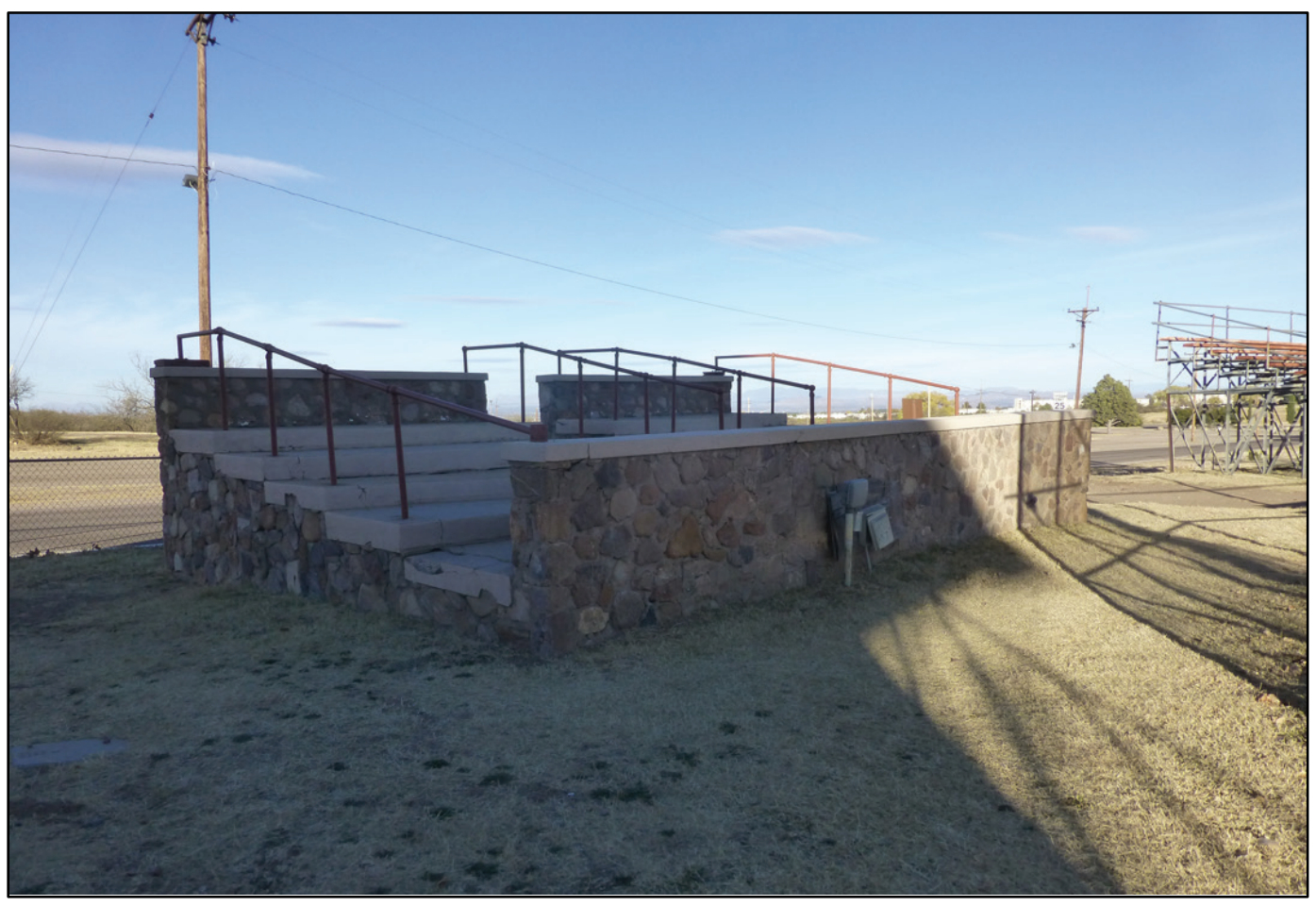

Figure 395. View east from Enlisted Men's Grandstand (31124) to Alchesay Barracks (31122) across baseball field (ERDC-CERL 2016).

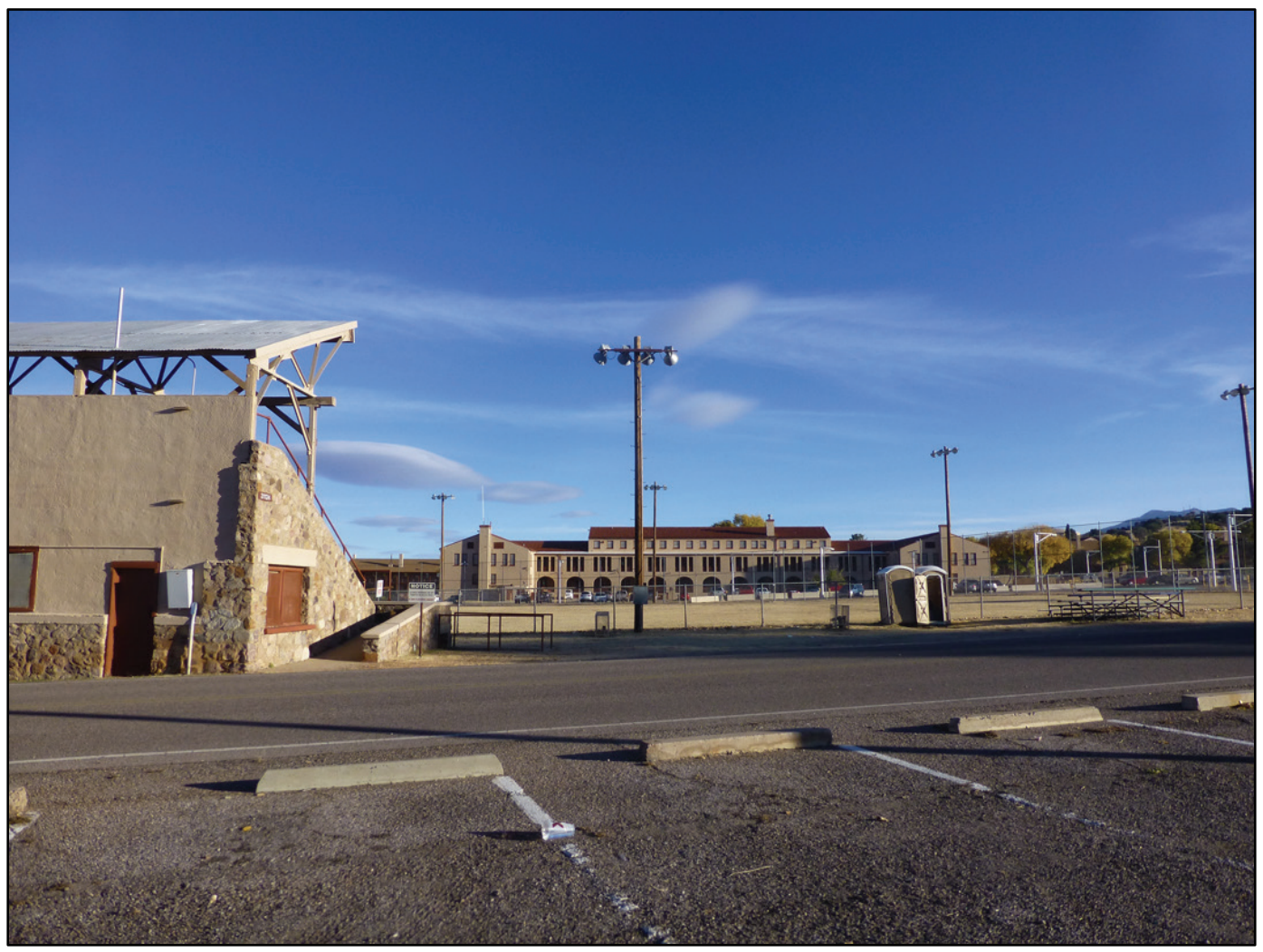




\subsection{Cavalry stables}

The cavalry stables are located along Clarkson Street west of Brock Field (31123) and Alchesay Barracks (31122) (Figure 396). The remaining stables are 30023, 30024, 30028 and 30031 (Table 19).

Figure 396. Map of cavalry stables landscape area (ERDC-CERL).

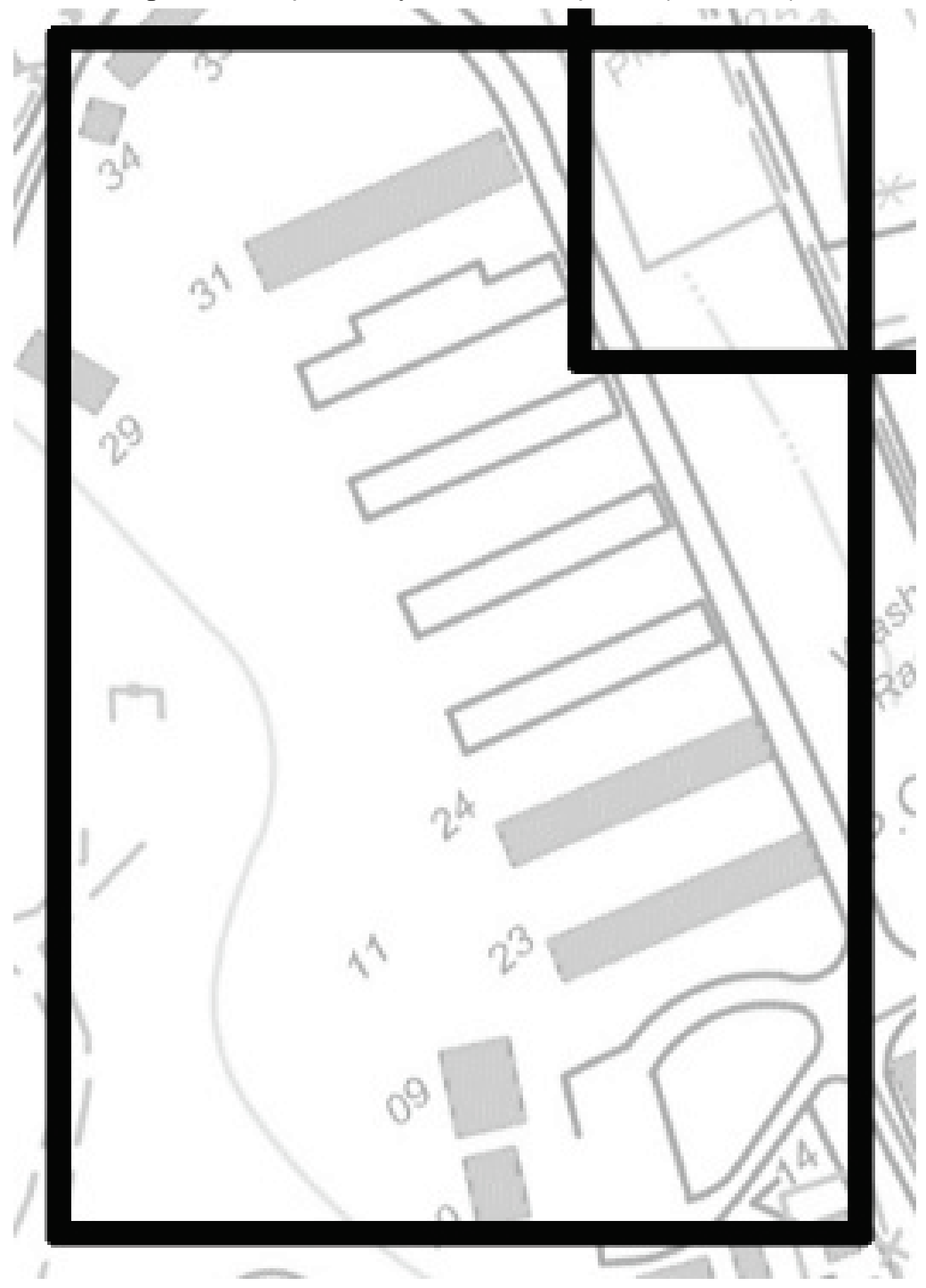


Table 19. List of buildings in the Cavalry landscape area.

\begin{tabular}{|c|c|l|l|c|c|}
\hline Building Number & Year Built & Original Use & Current Use & Category Name & Historic Status \\
\hline 30023 & 1916 & Cavalry Stables & Working Animal Building & & NREC \\
\hline 30024 & 1916 & Cavalry Stables & Warehouse & & NREC \\
\hline 30028 & 1916 & Cavalry Stables & Warehouse & & NREC \\
\hline 30031 & 1916 & Cavalry Stables & Warehouse & & NREC \\
\hline
\end{tabular}

The first troop stables were built for the Old Post in the late 1880 os and located directly west of the Old Post Barracks. In 1912, when troops were increased at Fort Huachuca, temporary stables were constructed north of the current complex. As barracks and officers' quarters were constructed in 1914 for the arrival of the $10^{\text {th }}$ Cavalry, seven permanent stables were built along with this effort (Buildings 30023, 30024, 30025, 30026, 30027, 30028, 30031). These stables were located west of the 1914 Barracks and just west of the railroad tracks to the quartermaster area. Stables were completed in 1916 utilizing standardized Quartermaster Corps plan no. 291.

A 1923 map shows four stable guardhouses for handlers and shops east of the stables and two hay buildings to the south; these are no longer present (Figures 397-402). The stables continued to function in that capacity until 1941. Building 30031 was altered by the WPA shortly after that time. Its exterior frame walls were replaced with stone masonry walls and piers. The stone masonry matches WPA work elsewhere at Fort Huachuca. Apparently between 1951 and 1955, at least five of the buildings' interiors were modified to become warehouses. These buildings included Buildings 30024-30028. Building 30031 was further modified in 1954 and converted to an ordnance inspection station. The interior of Building 30026 was modified and partitioned into offices in 1982. Building 30023 was converted into a veterinary care facility in 1984.55

55 HABS. 2005., Fort Huachuca Cavalry Stables (HABS No. AZ-210). Washington, DC: Historic American Buildings Survey, National Park Service, pp. 26-27. 
Figure 397. Former stable buildings located west of Old Post Barracks, 1898 (Fort Huachuca Museum).

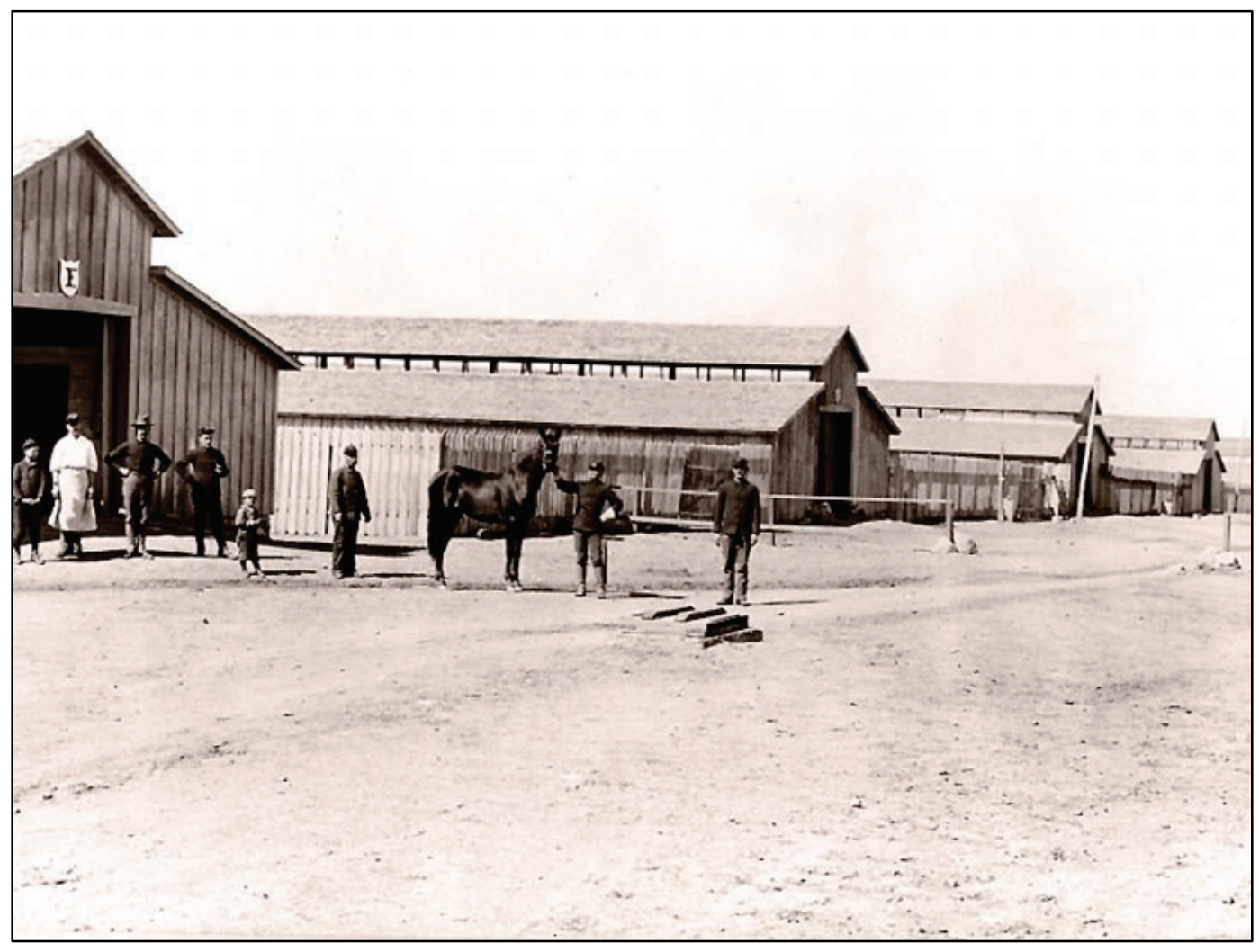

Figure 398. Photograph looking south of stables and stable guard and shops buildings to the east, 1918 (Library of Congress, Historic American Buildings Survey [HABS] AZ-210-11).

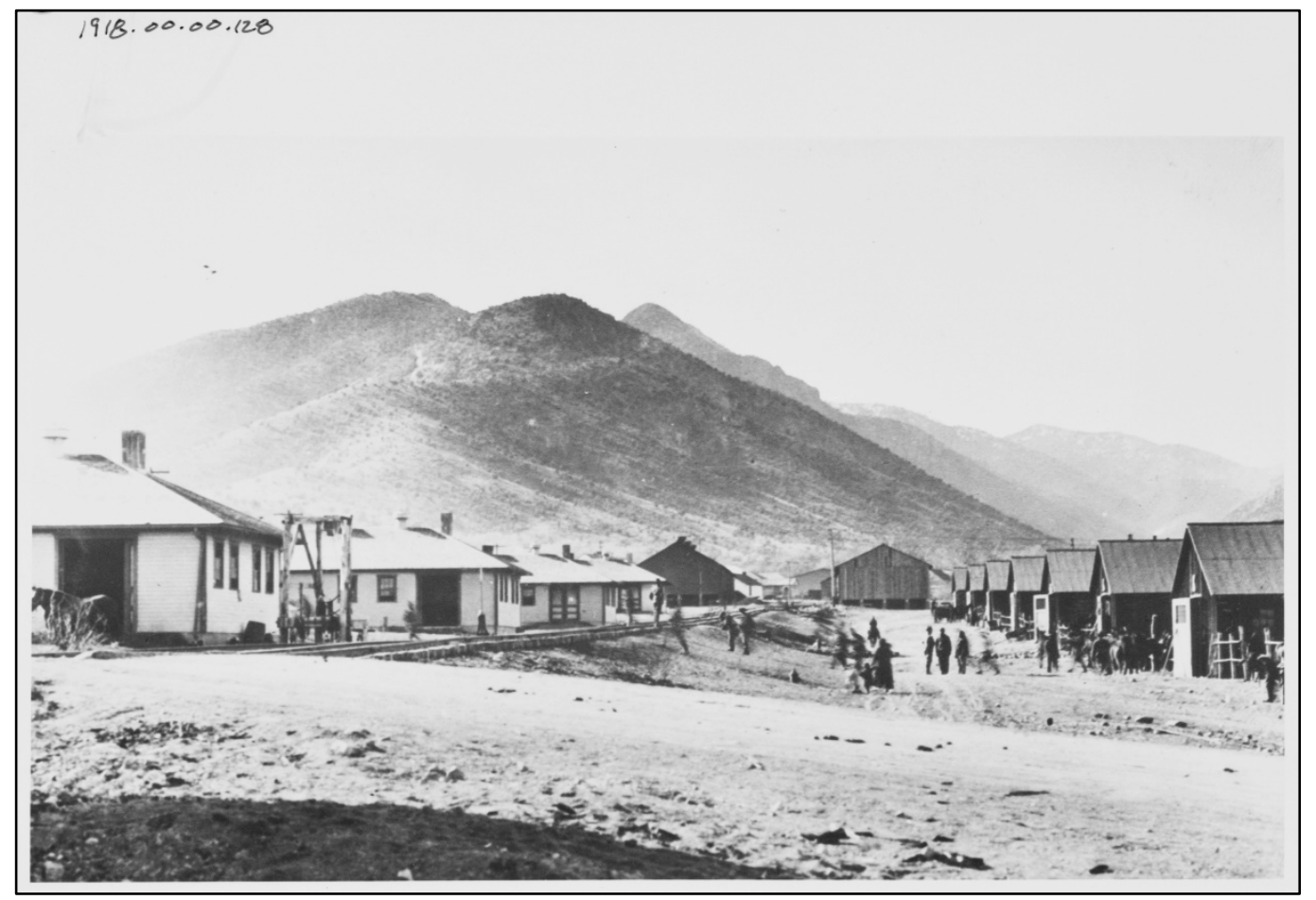


Figure 399. Map showing cavalry stables and associated buildings, 1923 (NARA College Park, RG 393, AZ-1).

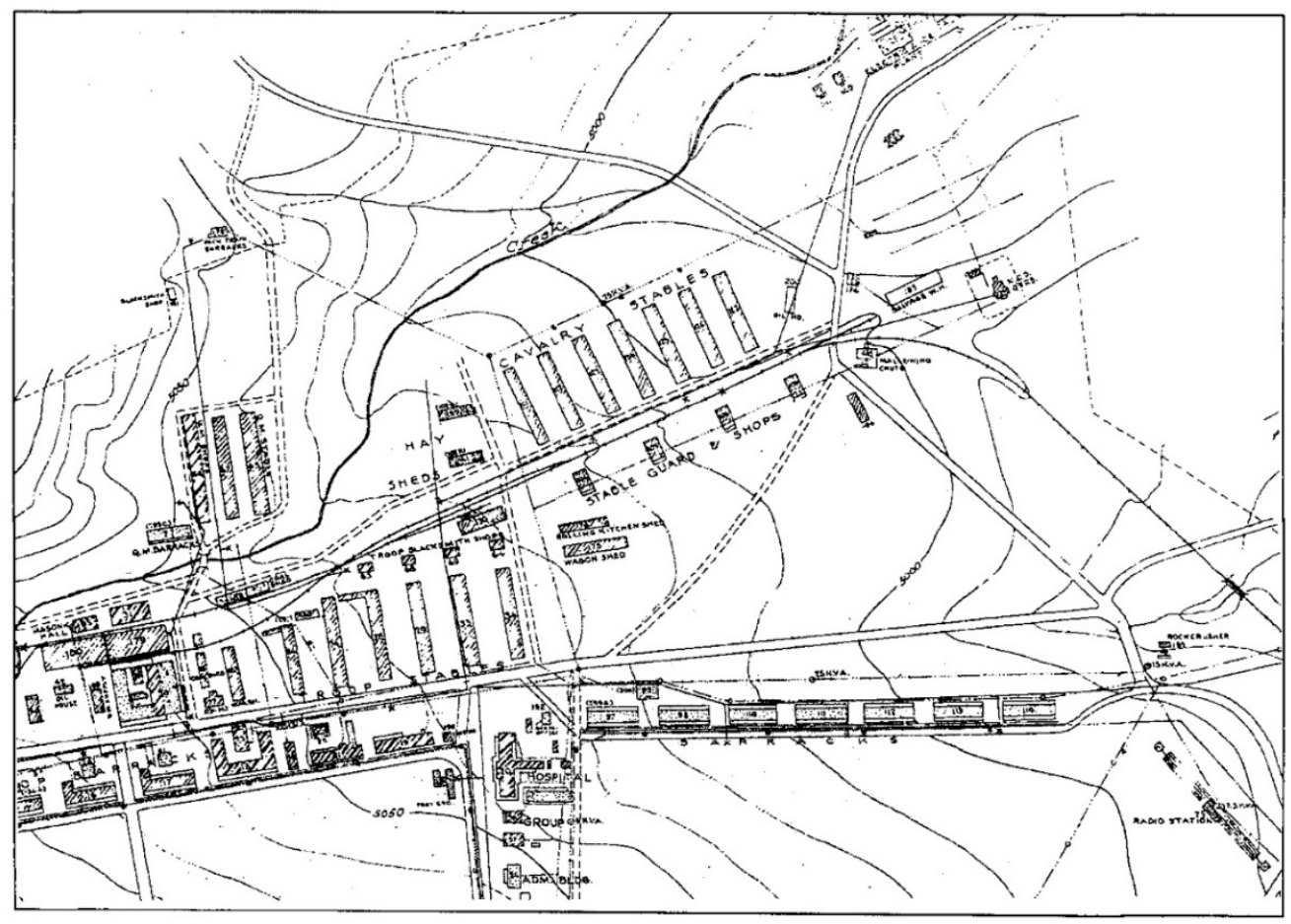

Figure 400. Aerial looking south of Fort Huachuca, showing the original stables in the center and the current stables to the right, 1924 (NARA College Park, RG165-FF).

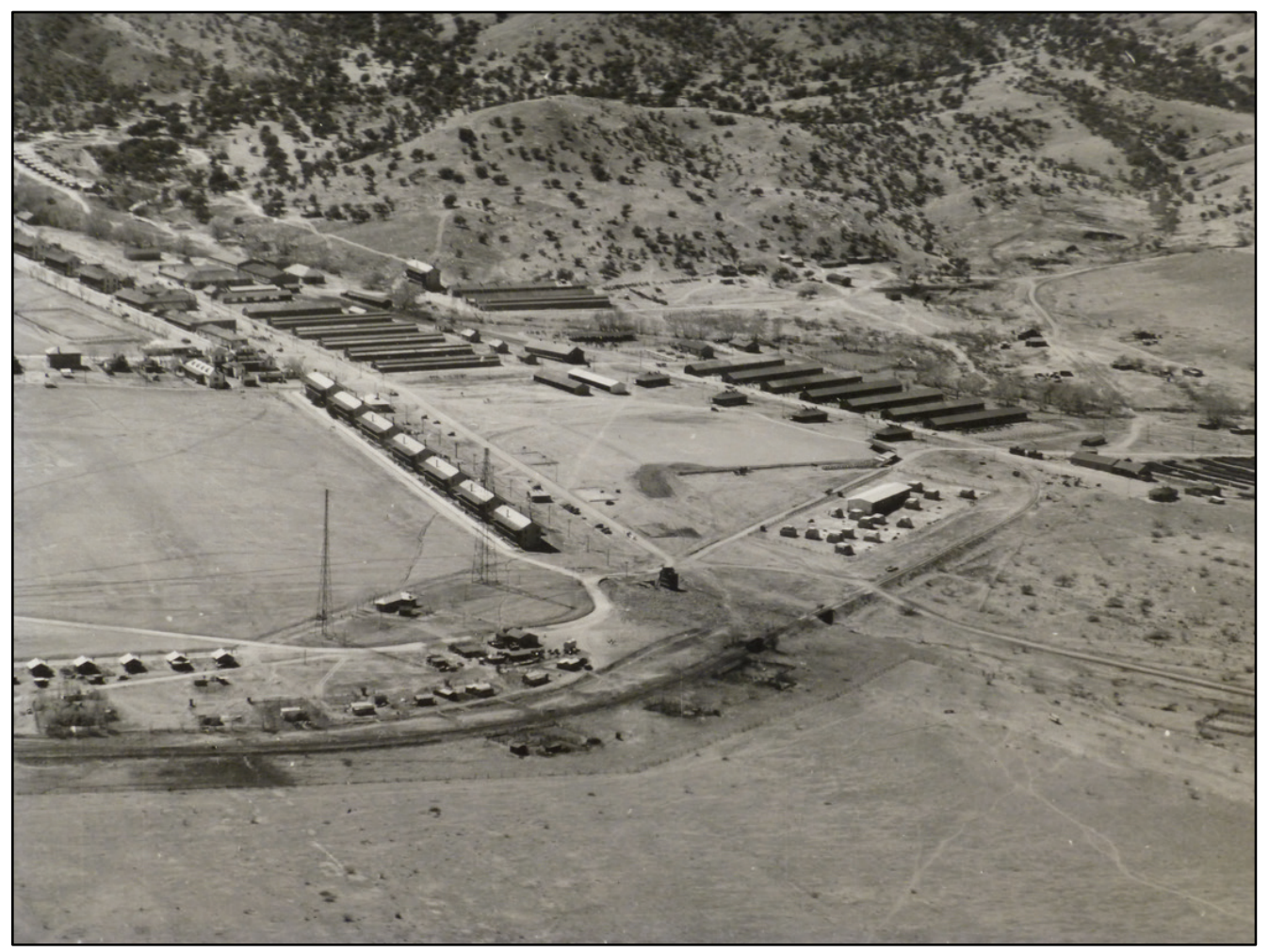


Figure 401. View looking west at stable building (30023), 1941 (NARA College Park, RG 77, 393 Box 95).

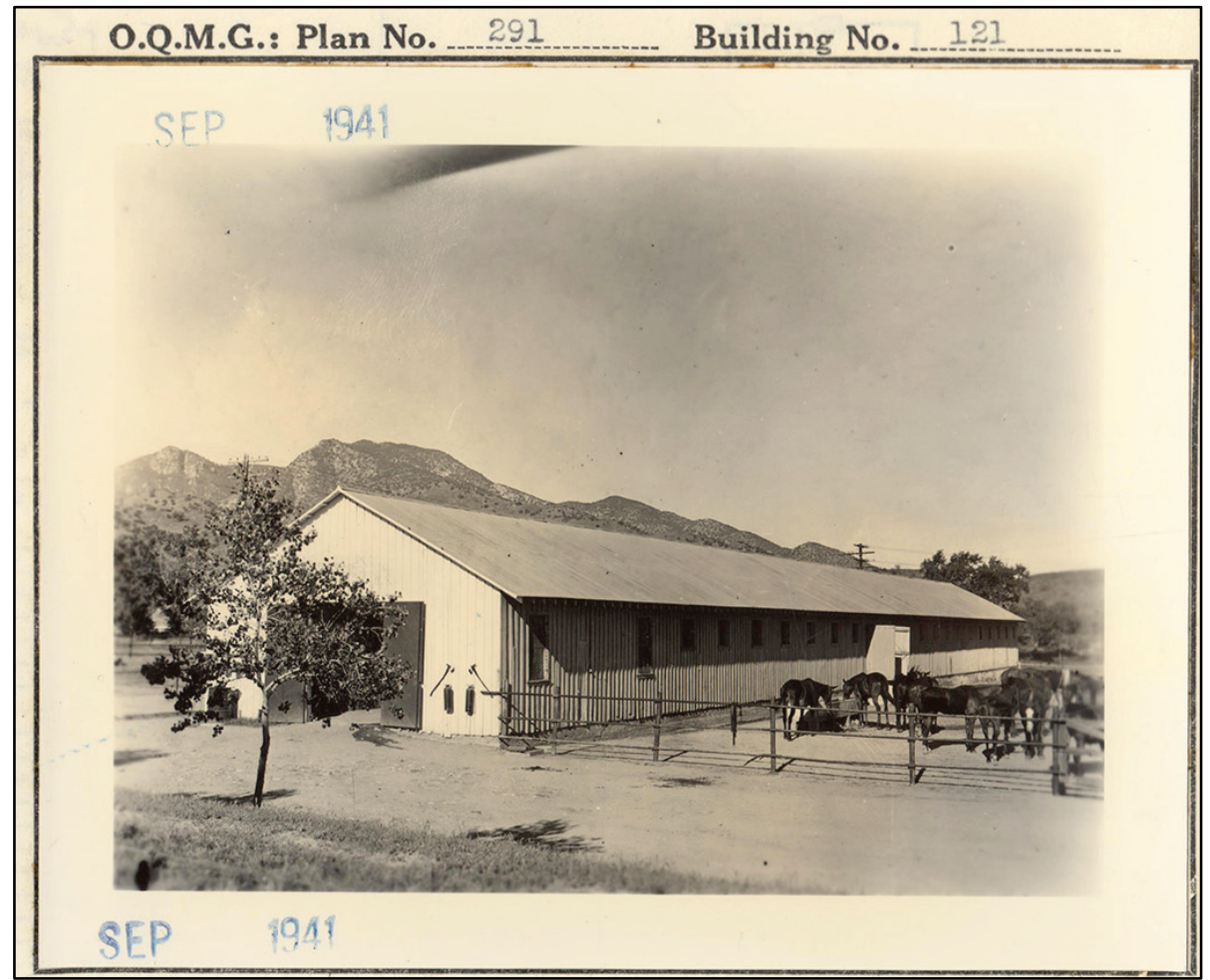

Figure 402. View looking west at stable building (30025), demolished, 1941 (NARA College Park, RG 77, 393 Box 95).

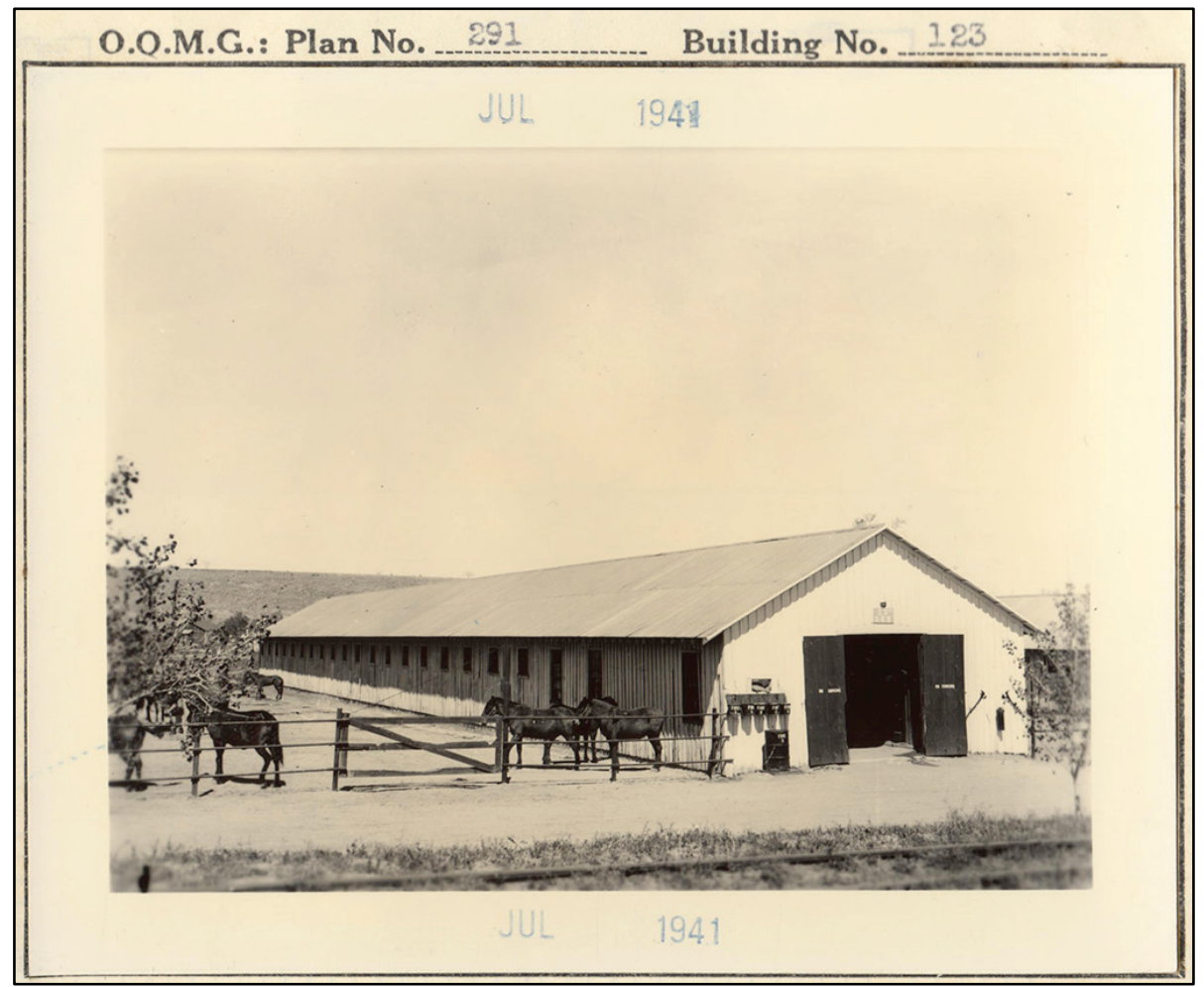


In 2003, three of the original seven stables (30025-27) were demolished to make room for a corral as part of a project to move B Troop, Fort Huachuca's memorial cavalry unit, to this area. Building 30023 was planned to be used as a working stable for up to 30 military horses while the other buildings were administration. This project did not happen, and B Troop built a new facility at Buffalo Corral instead.

In 2005 a HABS report was completed on the seven cavalry stables at Fort Huachuca in mitigation for the demolition of some of the stables. ${ }^{6}$ The HABS report determined the structures eligible for listing on the NRHP, due to their association with the 1oth Cavalry and the Punitive Expedition into Mexico in 1916-1917 (Criterion A) and because they represent the only known examples of stables constructed using the Quartermaster Corps Plan no. 291 (Criterion C).

Today four stables remain (Figures 403 and 404). Stone stairs still remain across Clarkson Street from the stables along the former rail line, but they were found not eligible to the WPA-era Historic District (Figures 405408). 57

\footnotetext{
56 Janet H. Parkhurst and J. Homer Thiel, 2005. A Historic American Buildings Survey of the Fort Huachuca Cavalry Stables, Cochise County, Arizona. HABS, National Park Service, HABS AZ-210.

57 Angel Tomes and Scott Thomas, 2014. Inventory, Documentation, and Evaluation of 30 Buildings and Structures, 192 Works Progress Administration (WPA) Features, and Identification of a Potential WPA Historic District at Fort Huachuca, Arizona. Fort Huachuca Cultural Resources Report FH-12-21. Statistical Research, Tucson.
} 
Figure 403. View northeast of stables on left, with Building 30023 in foreground and railroad bed with trees on right (ERDC-CERL, 2016).

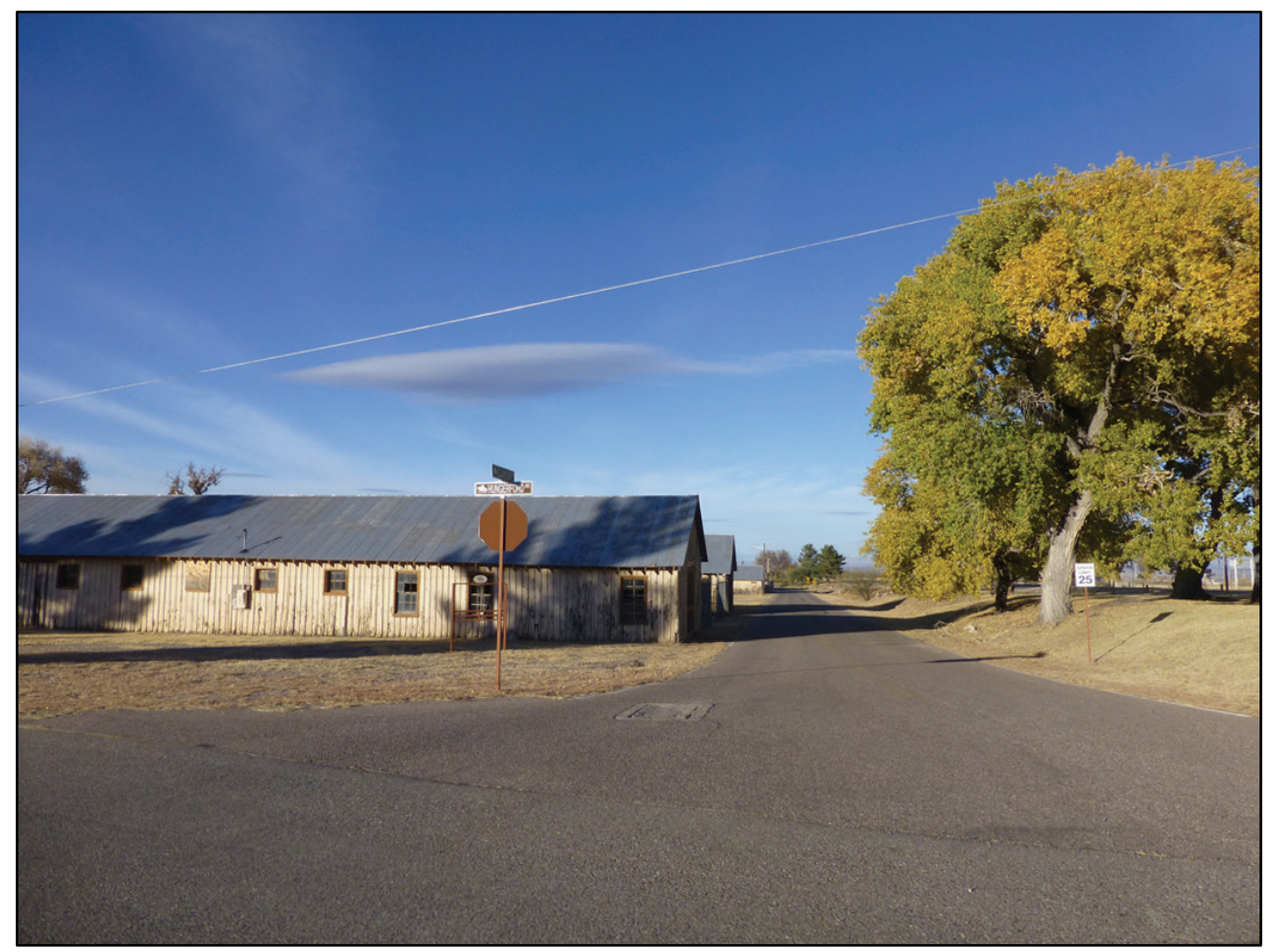

Figure 404. View looking northeast at the stables 30023 and 30024 (ERDC-CERL, 2016).

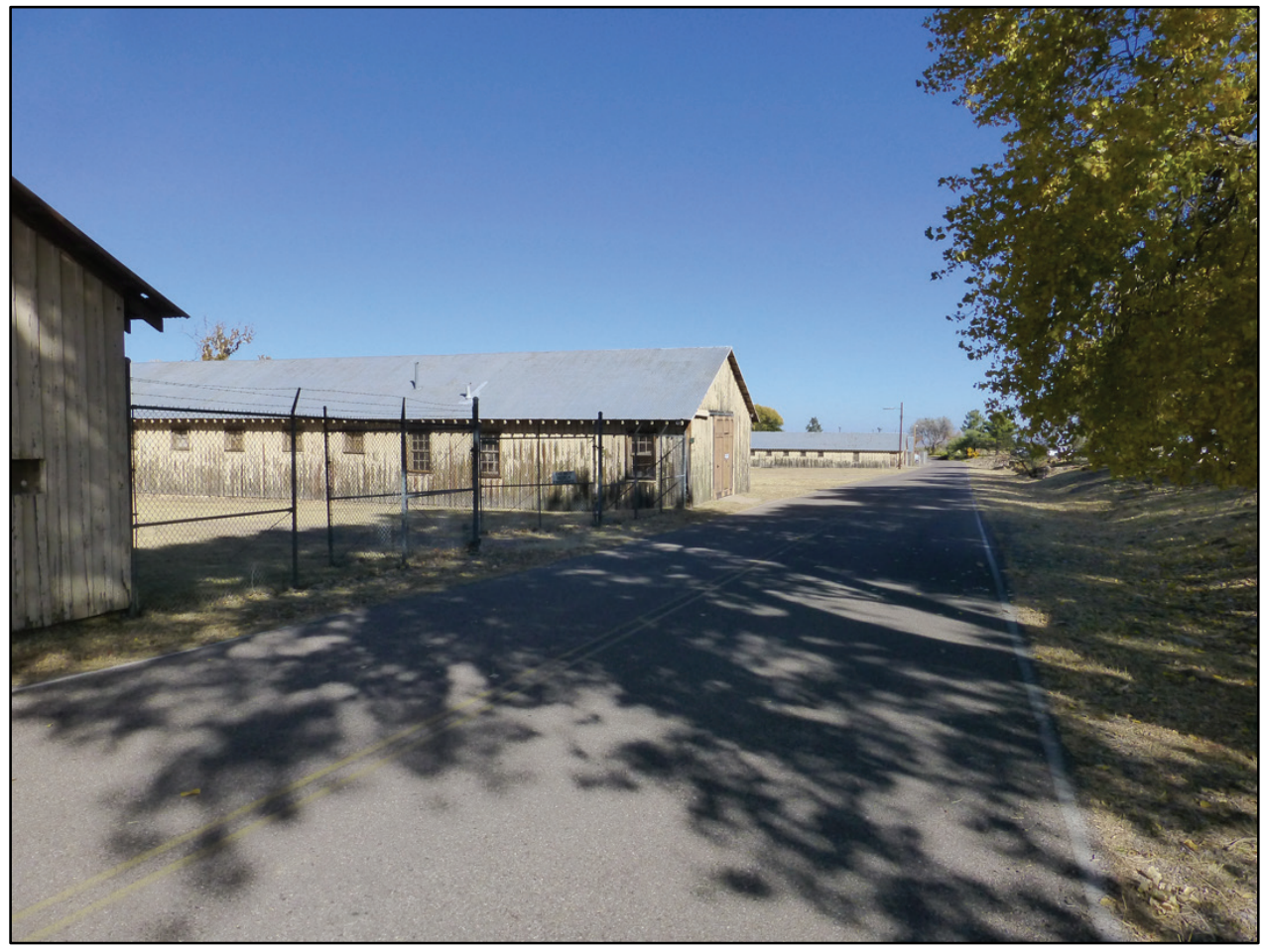


Figure 405. View south of stone steps going up railroad bed to stable guardhouse location, looking towards 41420 (ERDC-CERL, 2016).

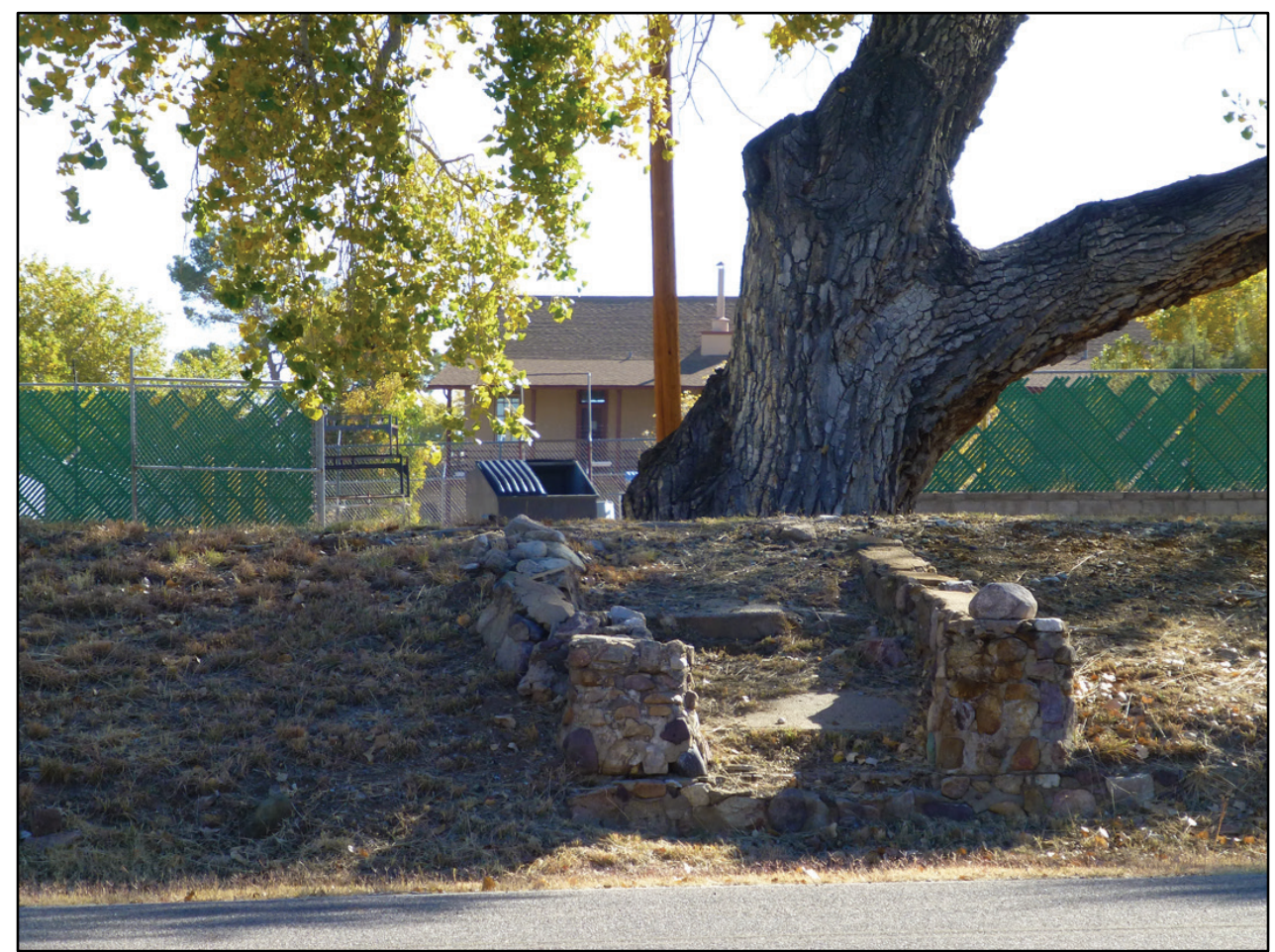

Figure 406. View south of stone steps from 30031 to parking lot (ERDC-CERL, 2016).

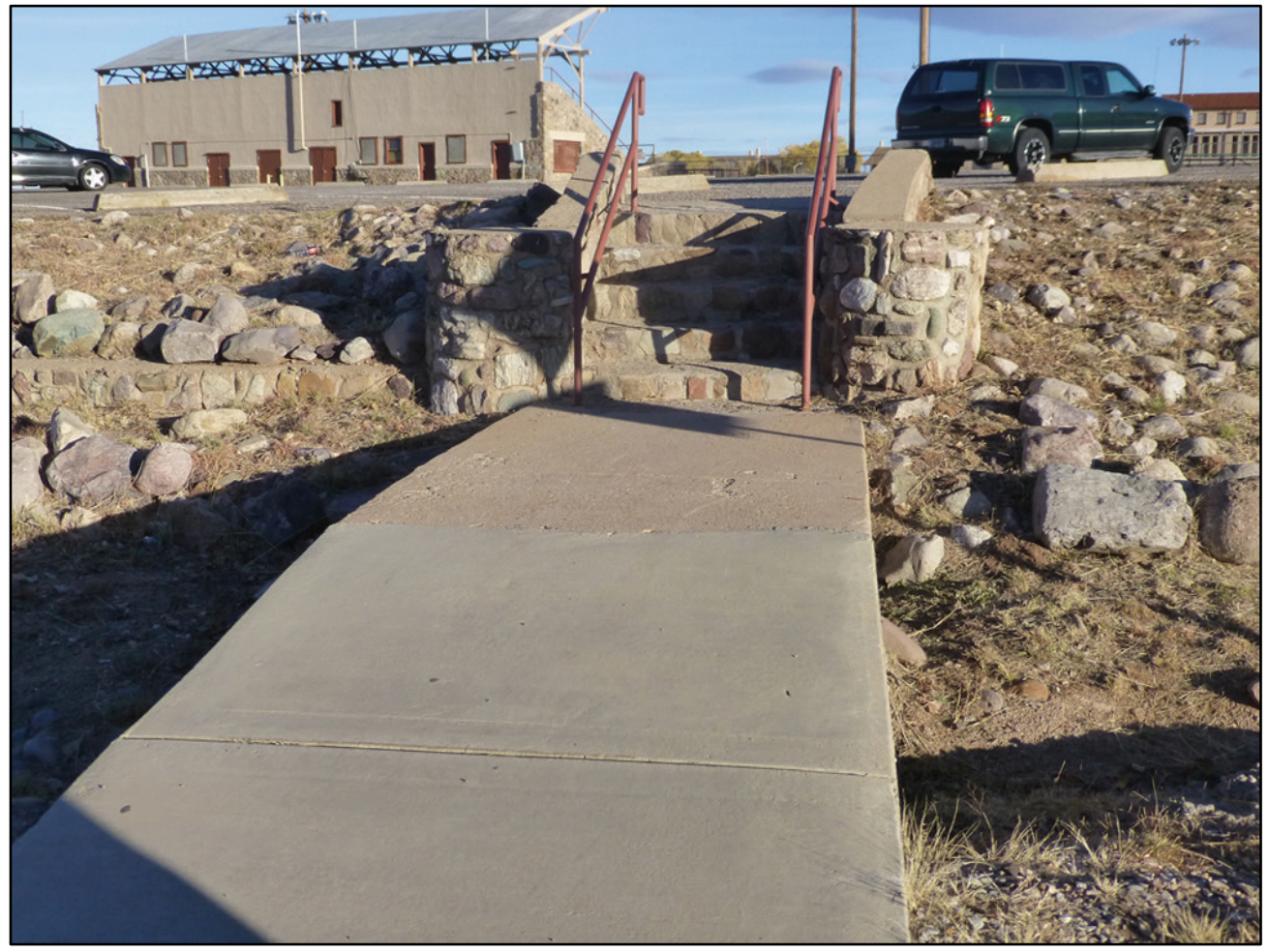


Figure 407. Looking southwest on railroad bed with stables on the right (ERDC-CERL, 2016).

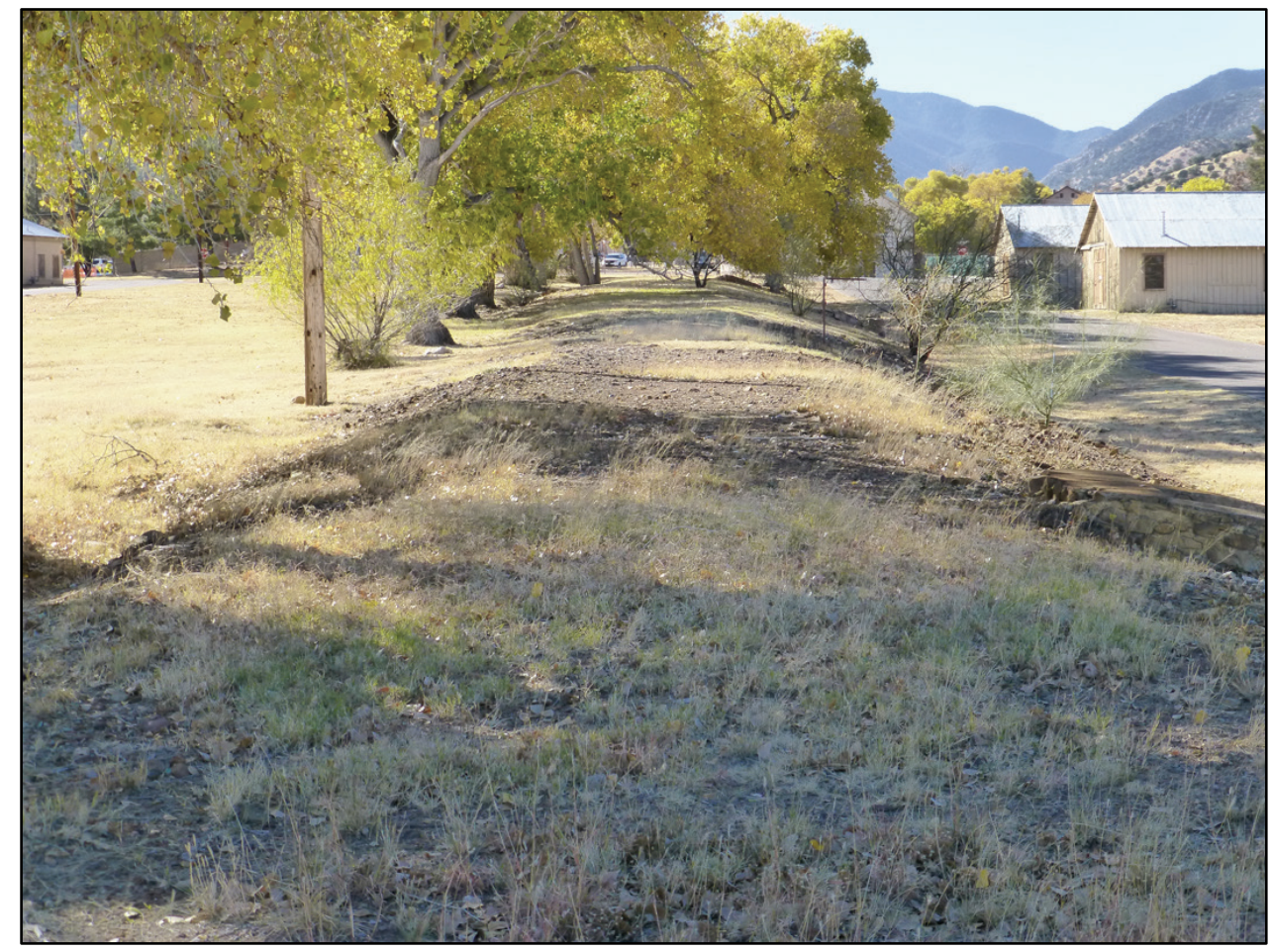

Figure 408. Looking at remnants of stone steps on right and railroad culvert on left (ERDCCERL, 2016).

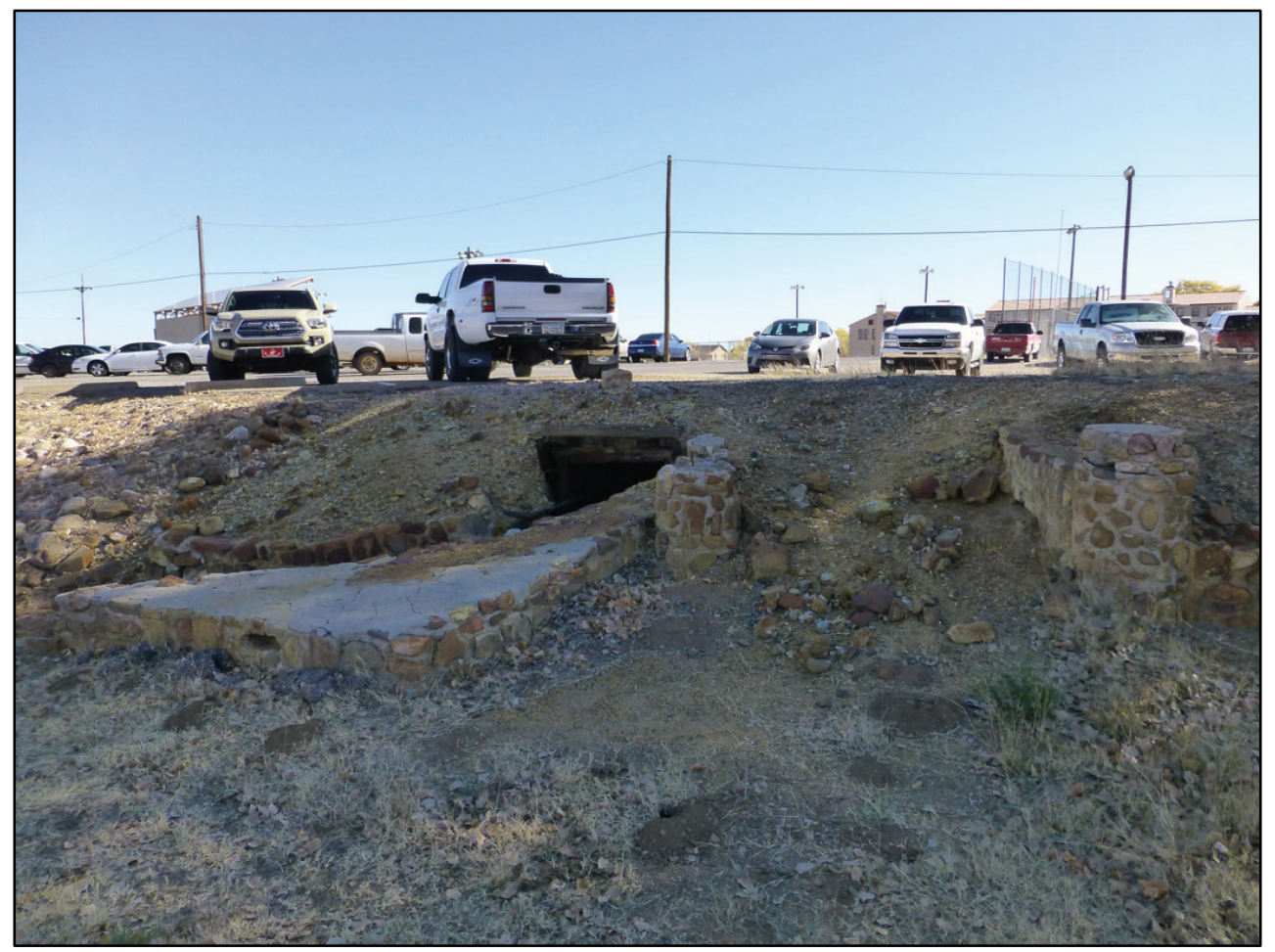




\subsection{Quartermaster and commissary area}

The quartermaster and commissary buildings are located west of Hines Road and south of Butler Road and Shipp Avenue (Figures 409 and 410). Many quartermaster, commissary, and warehouse buildings are in this landscape area (Table 20).

Figure 409. Map of quartermaster and commissary area (ERDC-CERL).

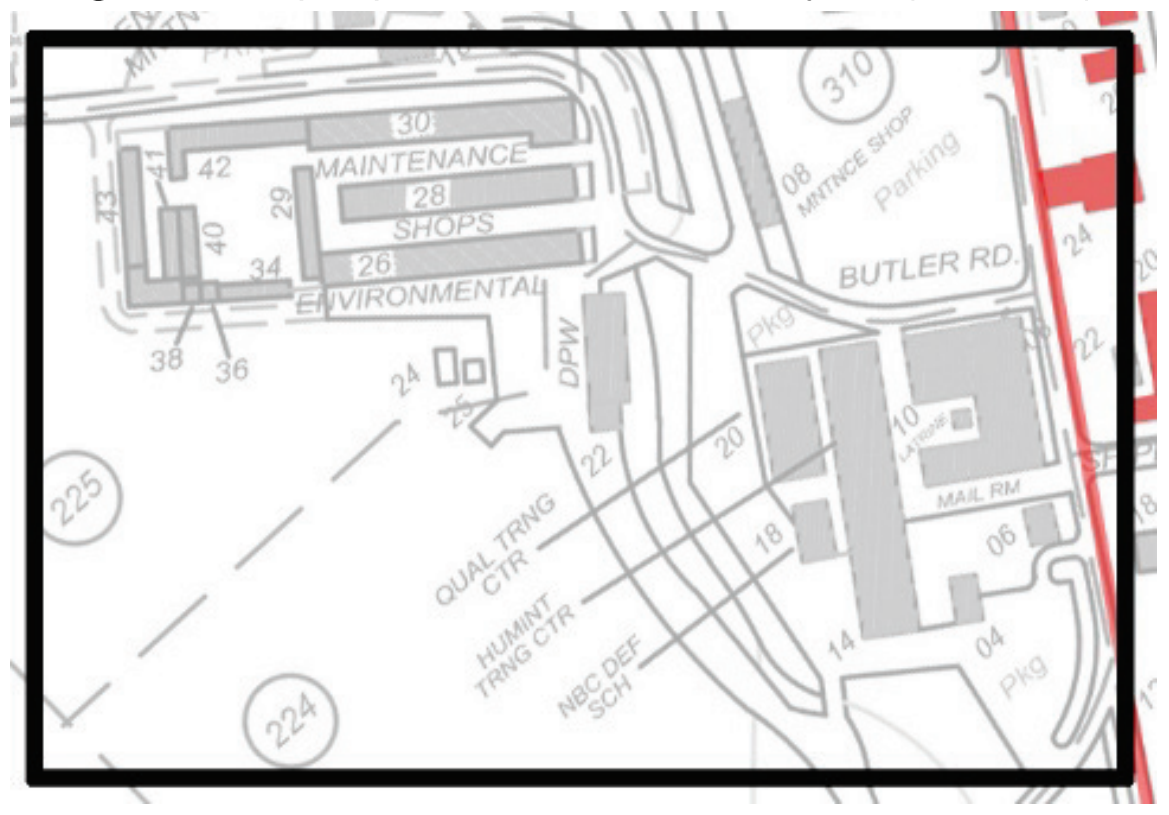

Table 20. Buildings in the quartermaster and commissary area.

\begin{tabular}{|c|c|l|l|l|c|}
\hline $\begin{array}{c}\text { Building } \\
\text { Number }\end{array}$ & $\begin{array}{l}\text { Year } \\
\text { Built }\end{array}$ & \multicolumn{1}{|c|}{ Original Use } & \multicolumn{1}{|c|}{ Current Use } & \multicolumn{1}{|c|}{ Category Name } & $\begin{array}{c}\text { Historic } \\
\text { Status }\end{array}$ \\
\hline 22401 & 1890 & Office & Office & $\begin{array}{l}\text { Company Headquarters } \\
\text { Building }\end{array}$ & NREI \\
\hline 22406 & 1941 & Bank & Troop Supply & CIDC Field Operations & DNE \\
\hline 22408 & 1887 & & $\begin{array}{l}\text { Storehouse, } \\
\text { Quartermaster Office }\end{array}$ & Administration & NREI \\
\hline 22410 & 1915 & Latrine & Lavatory & Separated Toilet/ Shower & NREI \\
\hline 22414 & 1920 & $\begin{array}{l}\text { Quartermaster } \\
\text { Warehouse }\end{array}$ & Commissary & $\begin{array}{l}\text { General Installation } \\
\text { Building }\end{array}$ & NREC \\
\hline 22418 & 1916 & Masonic Lodge & Administration & $\begin{array}{l}\text { General Installation } \\
\text { Building }\end{array}$ & DNE \\
\hline 22420 & 1934 & Commissary, Warehouse & Bakery & $\begin{array}{l}\text { General Installation } \\
\text { Building }\end{array}$ & NREI \\
\hline 22422 & 1917 & Post Engineer & Post Engineer & Administration & NREC \\
\hline 22524 & 1958 & Paint Spray & Paint Spray & $\begin{array}{l}\text { Engineering/ Housing } \\
\text { Maintenance }\end{array}$ & DNE \\
\hline 22525 & 1959 & $\begin{array}{l}\text { Engineering / Housing } \\
\text { Maintenance }\end{array}$ & $\begin{array}{l}\text { Engineering / Housing } \\
\text { Maintenance }\end{array}$ & $\begin{array}{l}\text { Engineering/ Housing } \\
\text { Maintenance }\end{array}$ & DNE \\
\hline 22526 & 1903 & Quartermaster & PE Shop & Administration & NREC \\
\hline
\end{tabular}




\begin{tabular}{|c|c|l|l|l|c|}
\hline $\begin{array}{c}\text { Building } \\
\text { Number }\end{array}$ & $\begin{array}{l}\text { Year } \\
\text { Built }\end{array}$ & \multicolumn{1}{|c|}{ Original Use } & \multicolumn{1}{c|}{ Current Use } & \multicolumn{1}{|c|}{ Category Name } & $\begin{array}{c}\text { Historic } \\
\text { Status }\end{array}$ \\
\hline 22528 & 1940 & Storage & Storage & Storage General Purpose & NREC \\
\hline 22529 & 1982 & Storage & Storage & Storage General Purpose & DNE \\
\hline 22530 & 1903 & Quartermaster & PR Shop & $\begin{array}{l}\text { Administration } \\
\text { General } \\
\text { Purpose }\end{array}$ & NREC \\
\hline 22534 & 1953 & Storage & Storage & Storage General Purpose & DNE \\
\hline 22536 & 1939 & Storage & Storage & Storage General Purpose & DNE \\
\hline 22538 & 1940 & Warehouse & Warehouse & Storage General Purpose & NREC \\
\hline 22542 & 1940 & Warehouse & Warehouse & Storage General Purpose & DNE \\
\hline 31008 & 1942 & Warehouse & Warehouse & Storage General Purpose & NREC \\
\hline
\end{tabular}

Figure 410. Photograph looking south of area, 1918 (Library of Congress, HABS AZ-210-12).

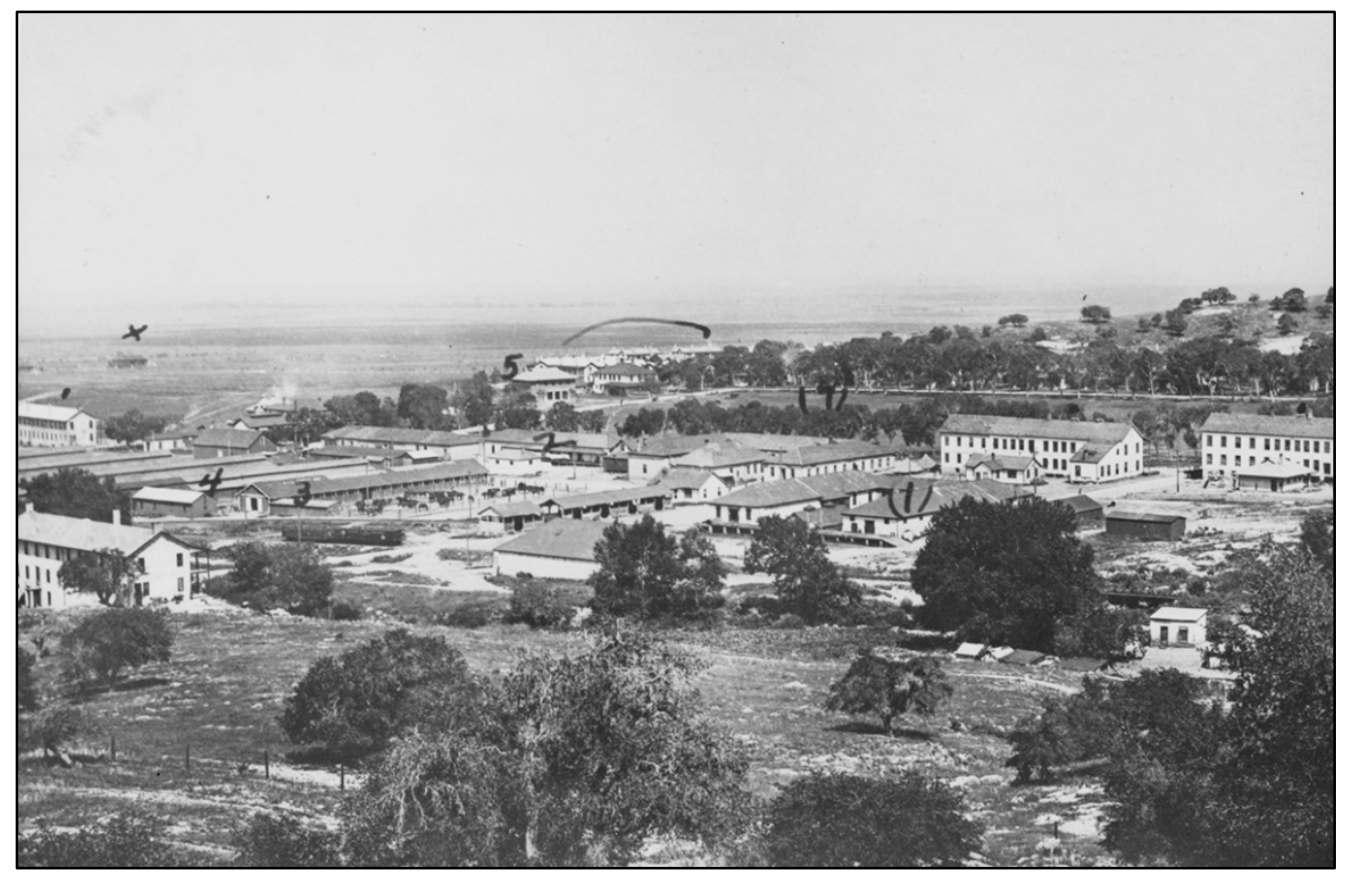

In the original layout and design of the Old Post, the utilitarian buildings were located at the northwest corner of the post adjacent to the administration buildings. Most of these buildings were storehouses operated by the Quartermaster Corps and were located at the end of the rail line after the passenger station. The first troop stables (no longer extant) and then the quartermaster stables (22526, 22528, and 22530) were built in this area, as well as the Quartermaster Barracks (22422) (Figures 411-417).

In 1988, Janus Associates looked as expanding the NHL boundaries to include five of the quartermaster buildings, but subsequent work discouraged the boundary increase. When Wee and Mikesell prepared the 1993 
nomination (never submitted), they included only two of the quartermaster buildings in the area, a quartermaster storehouse (22408) and its associated lavatory (22410). In 2014, the following buildings were found contributing under the WPA-era Historic District: 22414, 22422, 22526, 22528, 22530, 22538, and 31008. $5^{8}$ The Butler Road Bridge over Huachuca Creek was also constructed by the WPA (later expanded to two lanes, but materials and workmanship still evident) and is also contributing to the historic district (Figure 418).

Figure 411. Looking northwest at Building 22526, former quartermaster stable (ERDC-CERL).

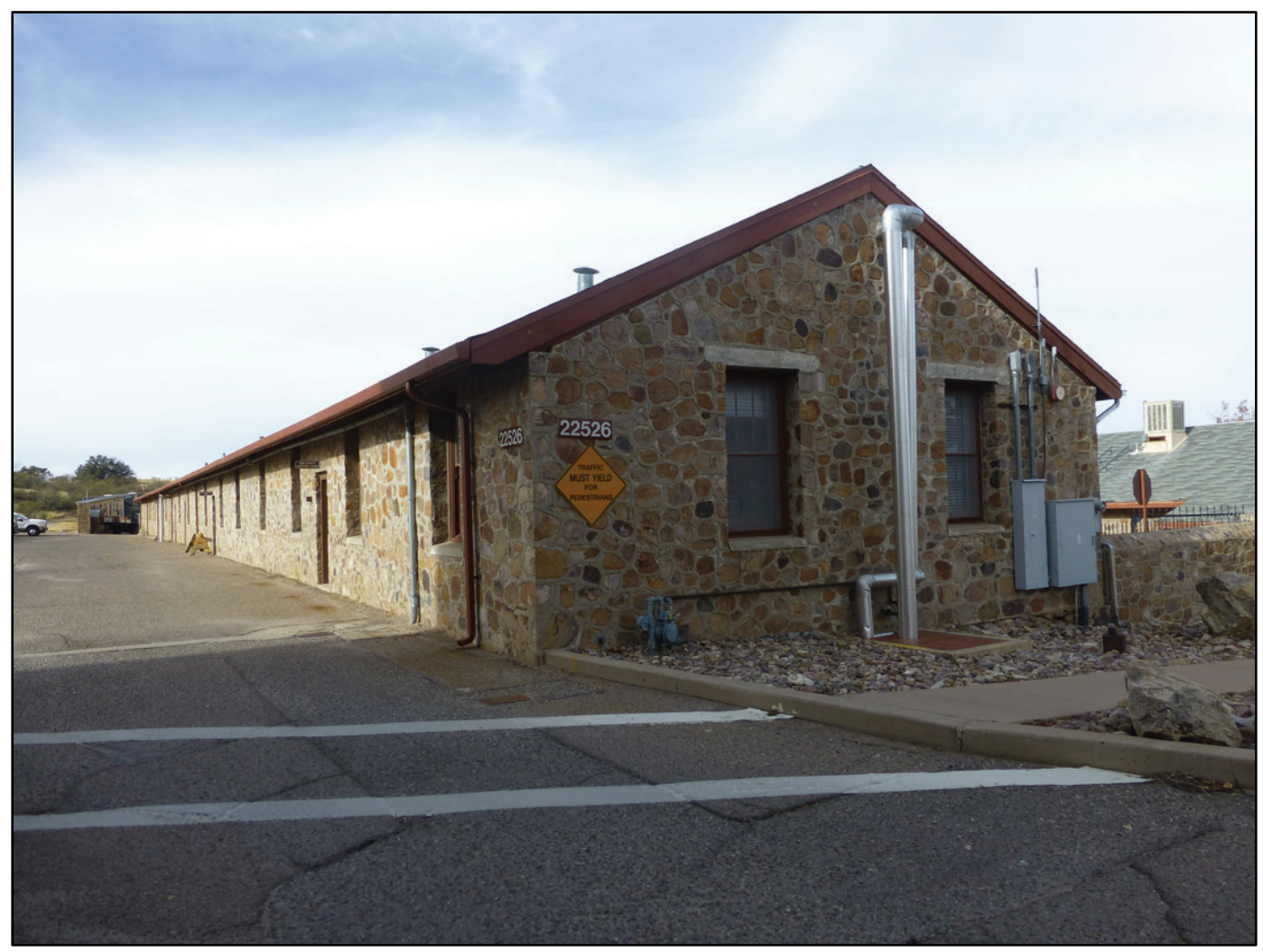

58 Angel Tomes and Scott Thomas, 2014. Inventory, Documentation, and Evaluation of 30 Buildings and Structures, 192 Works Progress Administration (WPA) Features, and Identification of a Potential WPA Historic District at Fort Huachuca, Arizona. Fort Huachuca Cultural Resources Report FH-12-21. Statistical Research, Tucson. 
Figure 412. Looking west at former Quartermaster Barracks, Building 22422, and eligible WPA retaining wall (ERDC-CERL 2016).

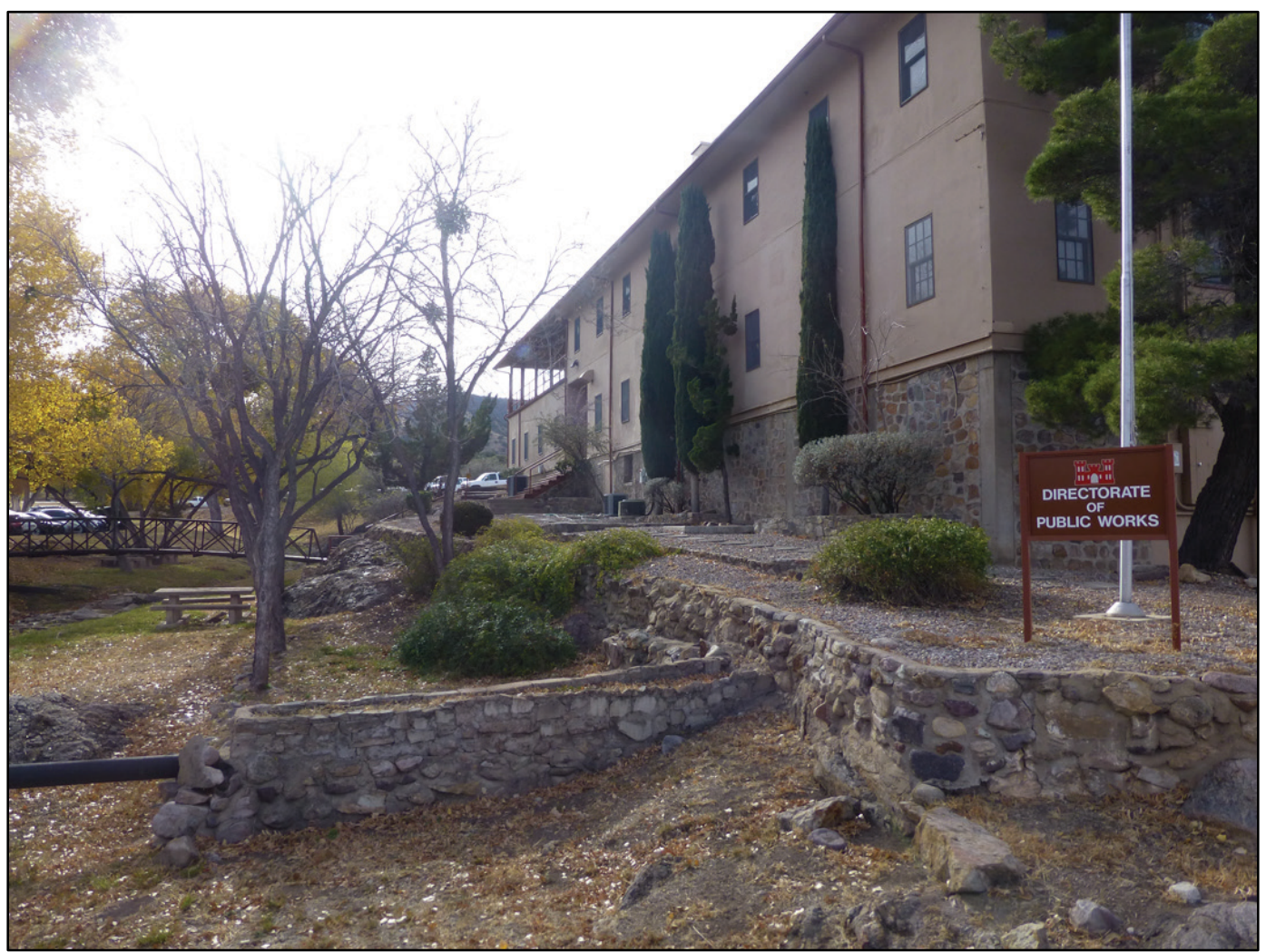

Figure 413. Looking southwest at Building 22530 (ERDC-CERL 2016).

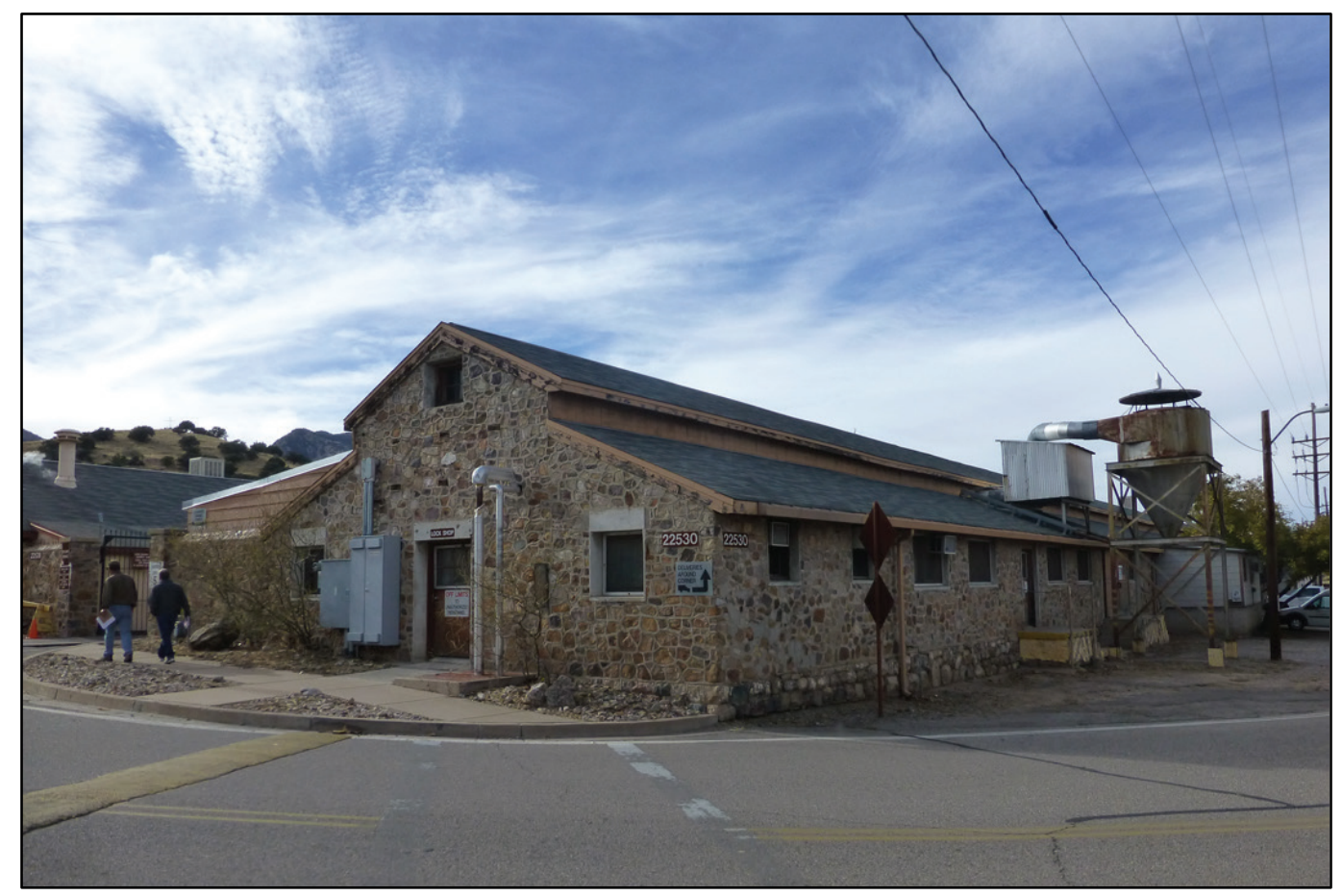


Figure 414. Looking north at warehouse building (31008) (ERDC-CERL 2016).

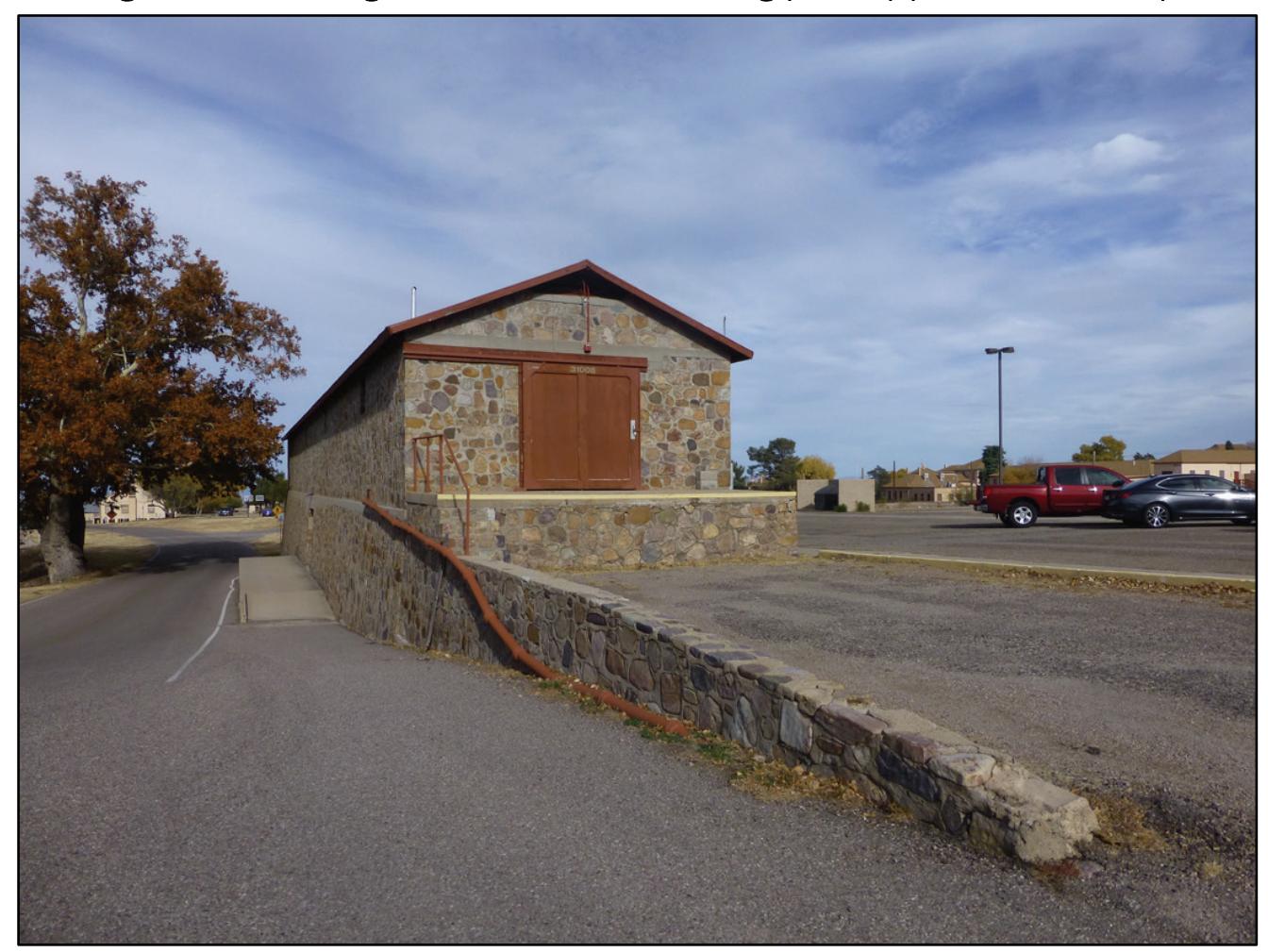

Figure 415. View looking south of Building 22408, a quartermaster storehouse built in 1887 (ERDC-CERL 2016).

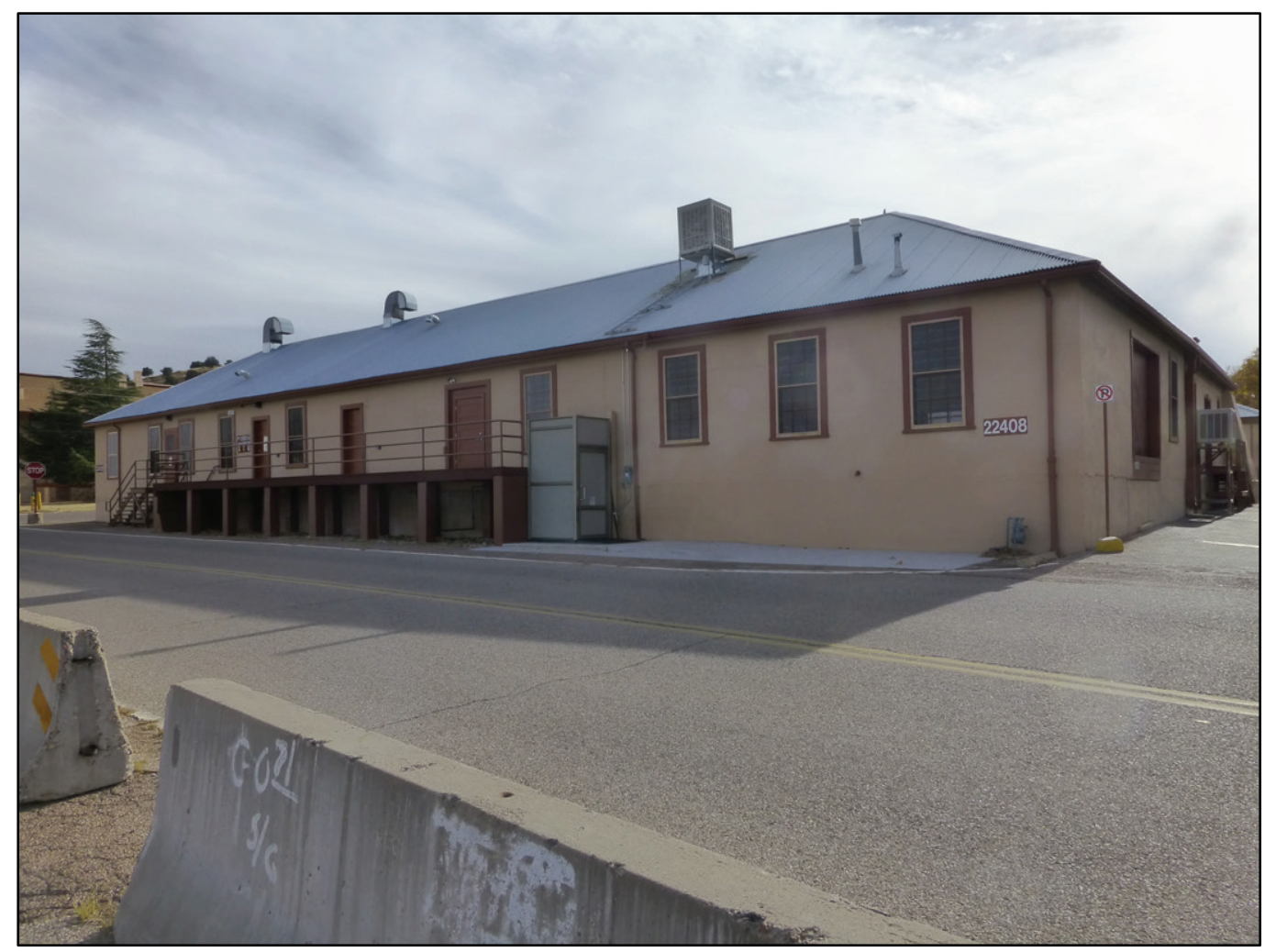


Figure 416. View looking south at Building 22414, quartermaster warehouse built in 1920 (ERDC-CERL 2016).

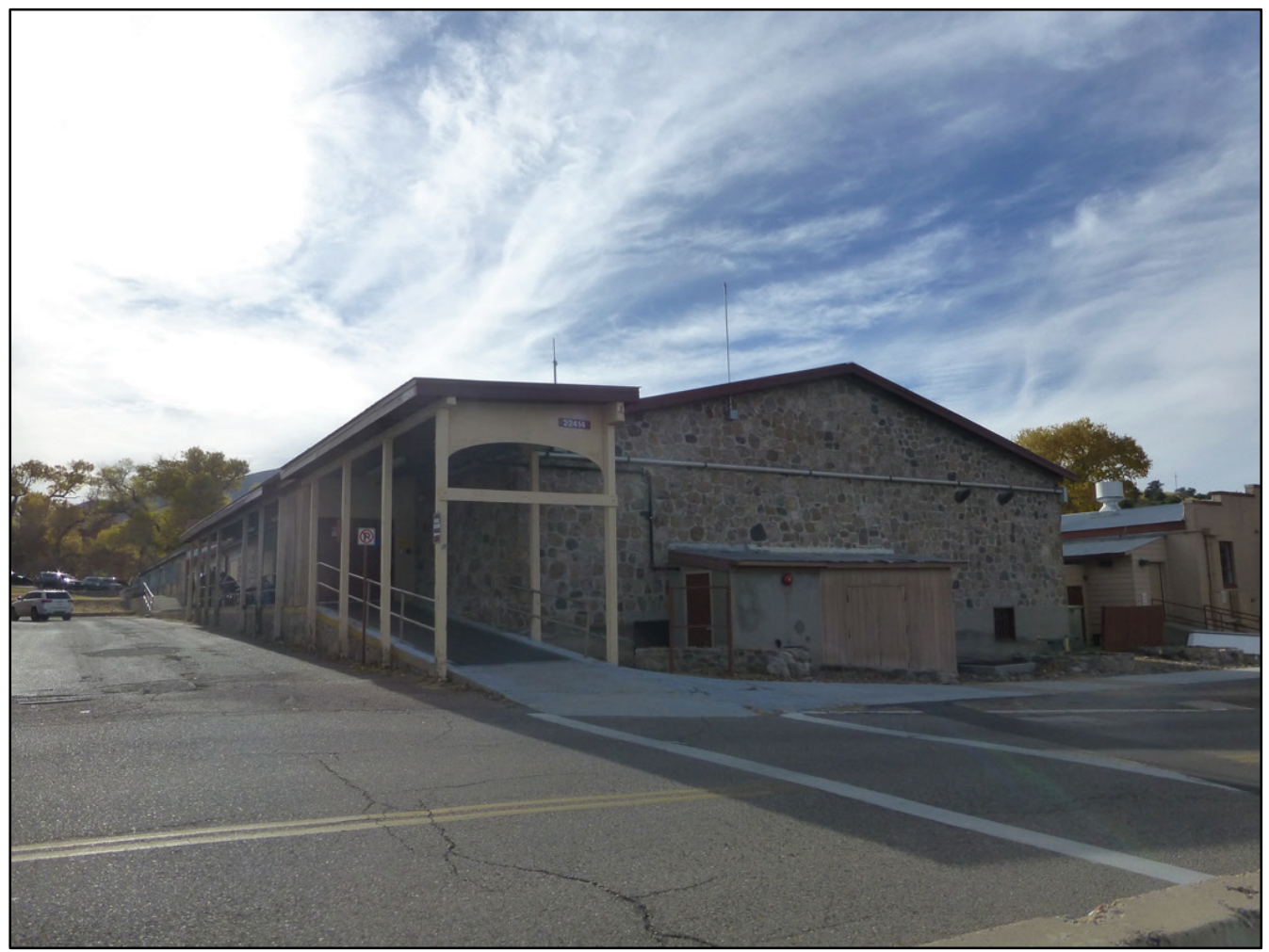

Figure 417. View looking south at commissary storehouse and bakery (22420) (ERDC-CERL 2016).

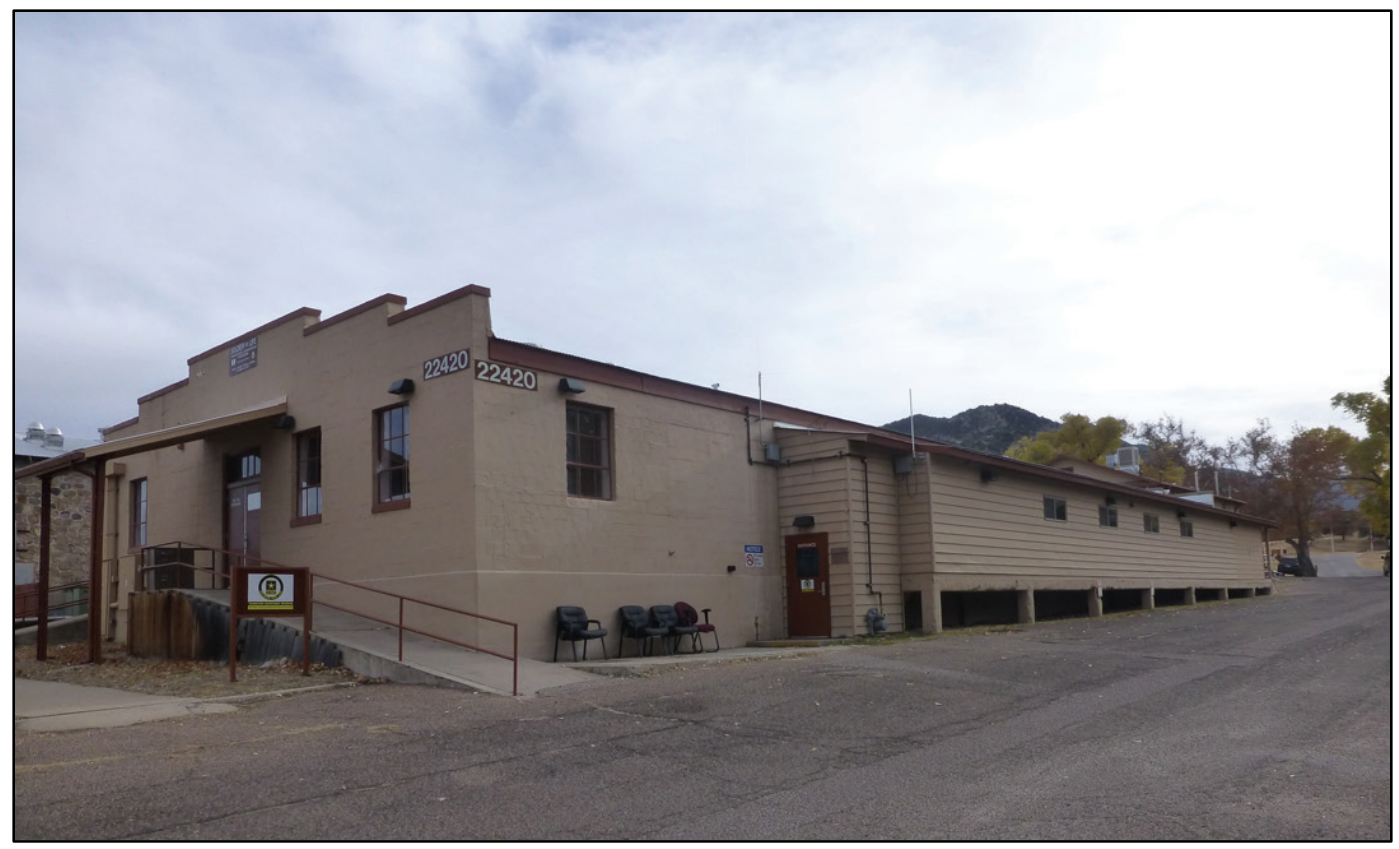


Figure 418. View north from pedestrian bridge, adjacent to 22422, toward Butler Road Bridge over Huachuca Creek (ERDC-CERL 2016).

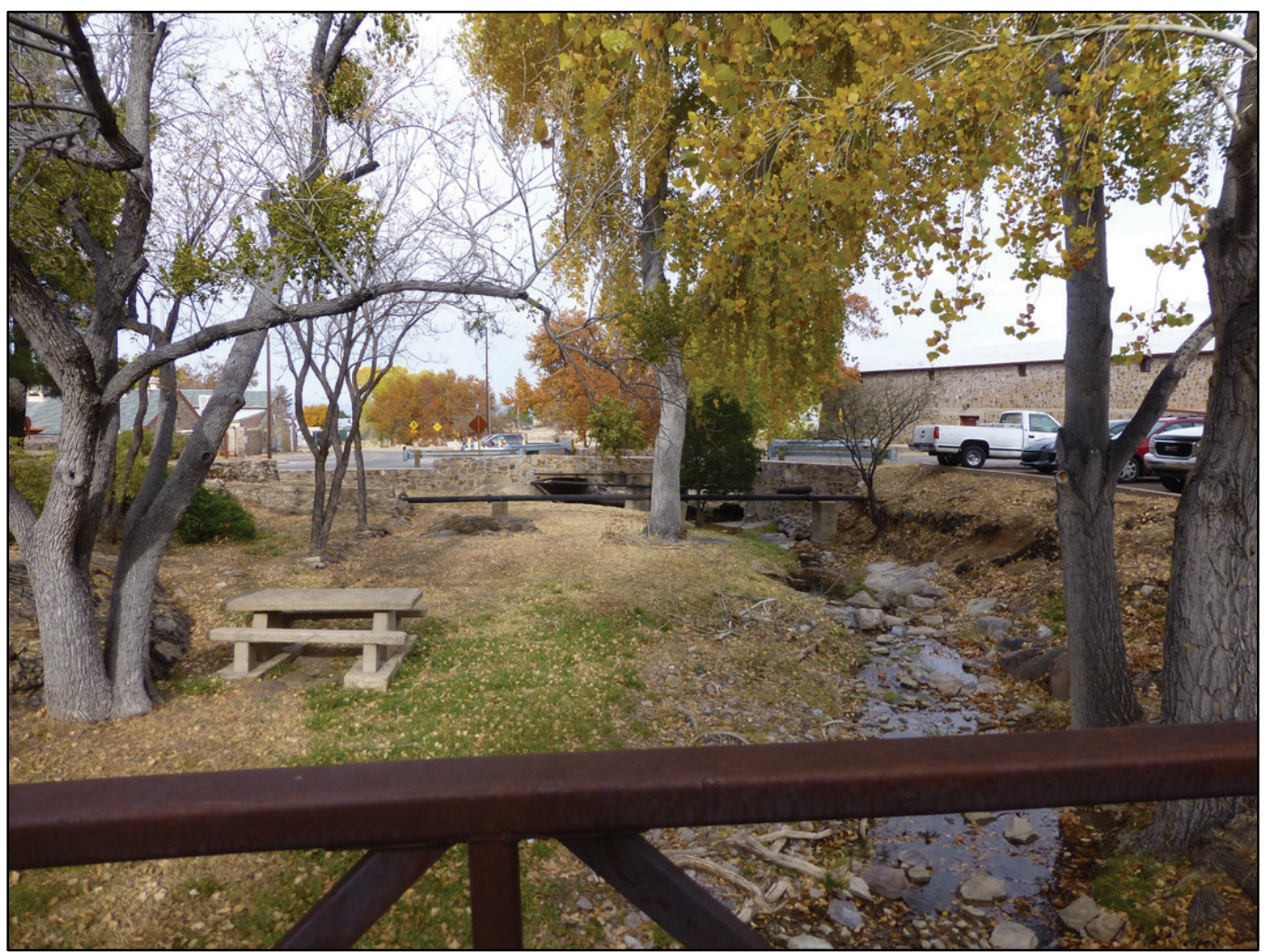

\subsection{Cemetery}

The cemetery is located southwest of the Old Post Cantonment on the west side of the Bonnie Blink Housing Area at the end of Burt Road (Figure 419). Buildings associated with the cemetery (20033) are the information kiosk (20032), two maintenance sheds (20034), cemetery pavilion (20035), and a restroom (20036) (Table 21). 
Figure 419. Map of the Fort Huachuca Post Cemetery (ERDC-CERL).

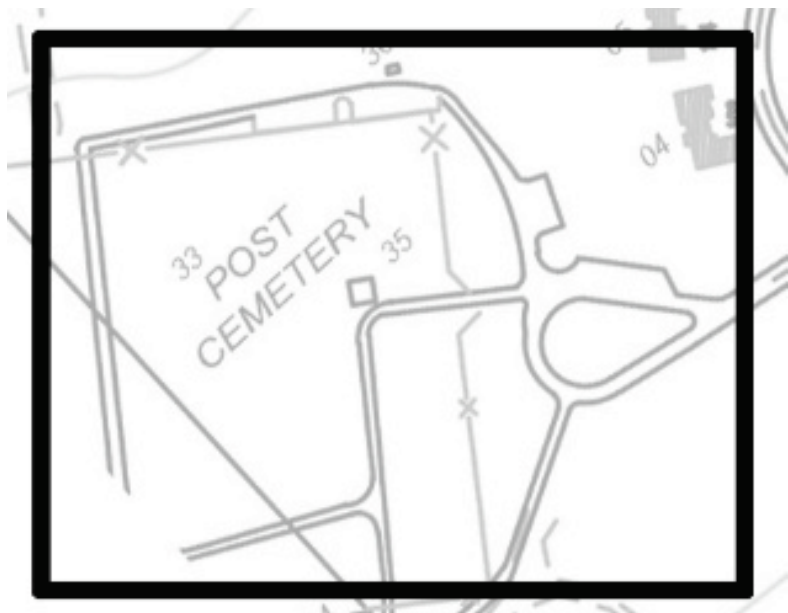

Table 21. Buildings associated with the Cemetery landscape area.

\begin{tabular}{|c|c|l|l|l|c|}
\hline Building Number & Year Built & \multicolumn{1}{|c|}{ Original Use } & Current Use & \multicolumn{1}{|c|}{ Category Name } & Historic Status \\
\hline 20032 & 2005 & Information Kiosk & & Information Kiosk & NEV \\
\hline 20033 & 1881 & Post Cemetery & Post Cemetery & Post Cemetery & NEV \\
\hline 20034 & 1975 & Storage General Purpose & & Storage General Purpose & DNE \\
\hline 20035 & 1977 & Cemetery Pavilion & & Cemetery Pavilion & NEV \\
\hline 20036 & 2005 & Separate Toilet/ Shower & & Separate Toilet/ Shower & NEV \\
\hline
\end{tabular}

The present cemetery is the second location on the post. The first cemetery was located in the vicinity of the southwest corner of Grierson and Mizner Avenues. The first burial there was Private Thomas P. Kelly of Company B, 6th Cavalry, in 1878. The cemetery, and its 16 burials, were moved to the current location on 18 May 1883.59 An Inspection Report dated 21 September 1883 noted, "Cemetery neatly enclosed by a picket fence-painted. Condition: very good." 60 The layout of the cemetery is seen in the 1893 map (Figure 420).

59 Fort Huachuca, Cemetery Booklet, 20 September 2016.

60 Inspection reports (NARA College Park). 
Figure 420. Layout of Post Cemetery from 1893 map (Fort Huachuca Museum).

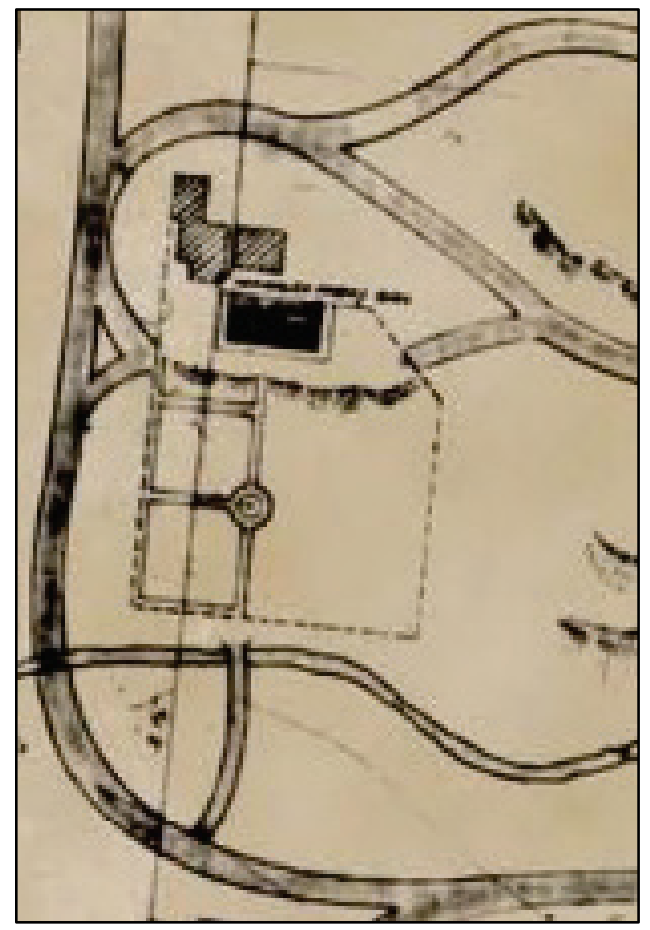

Today the entrance to the cemetery is marked with stone laid gateposts and stone wall (Figure 421). The wall and gateposts were built by the WPA with wall segments extending north and south from gateposts or columns flanking the cemetery gate. This wall contains two distinct stone-and-mortar construction styles (Figure 422). The columns and part of the wall were constructed of small cobbles and are different from the WPA stonework on the rest of the installation. The rest of the wall on either side are similar to other stonework on post. Further research is clearly warranted to verify construction dates. ${ }^{6}$

Other sides of the cemetery are marked with a modern iron fence (Figure 423). The cemetery is mown grass with mature specimen trees (Figure 424). The maintenance sheds (20034) are located to the south and the restrooms (20036) to the north adjacent to a parking area (Figures 425 and 426). The information kiosk (20032) is located inside the main gates, adjacent to the cemetery pavilion (20035) for services (Figures 427 and 428). Burt Road terminated in a loop in front of the cemetery (Figure 429). Several former post commanders are buried here, along with infantrymen,

61 Angel Tomes and Scott Thomas, 2014. Inventory, Documentation, and Evaluation of 30 Buildings and Structures, 192 Works Progress Administration (WPA) Features, and Identification of a Potential WPA Historic District at Fort Huachuca, Arizona. Fort Huachuca Cultural Resources Report FH-12-21. Statistical Research, Tucson. 
cavalrymen, one known seaman, Apache scouts and the children of renowned military families. Records show that 4,171 known and 98 unknown dead have been interred here since 1883 .

Figure 421. View looking west at entrance to Fort Huachuca Cemetery (ERDC-CERL 2016).

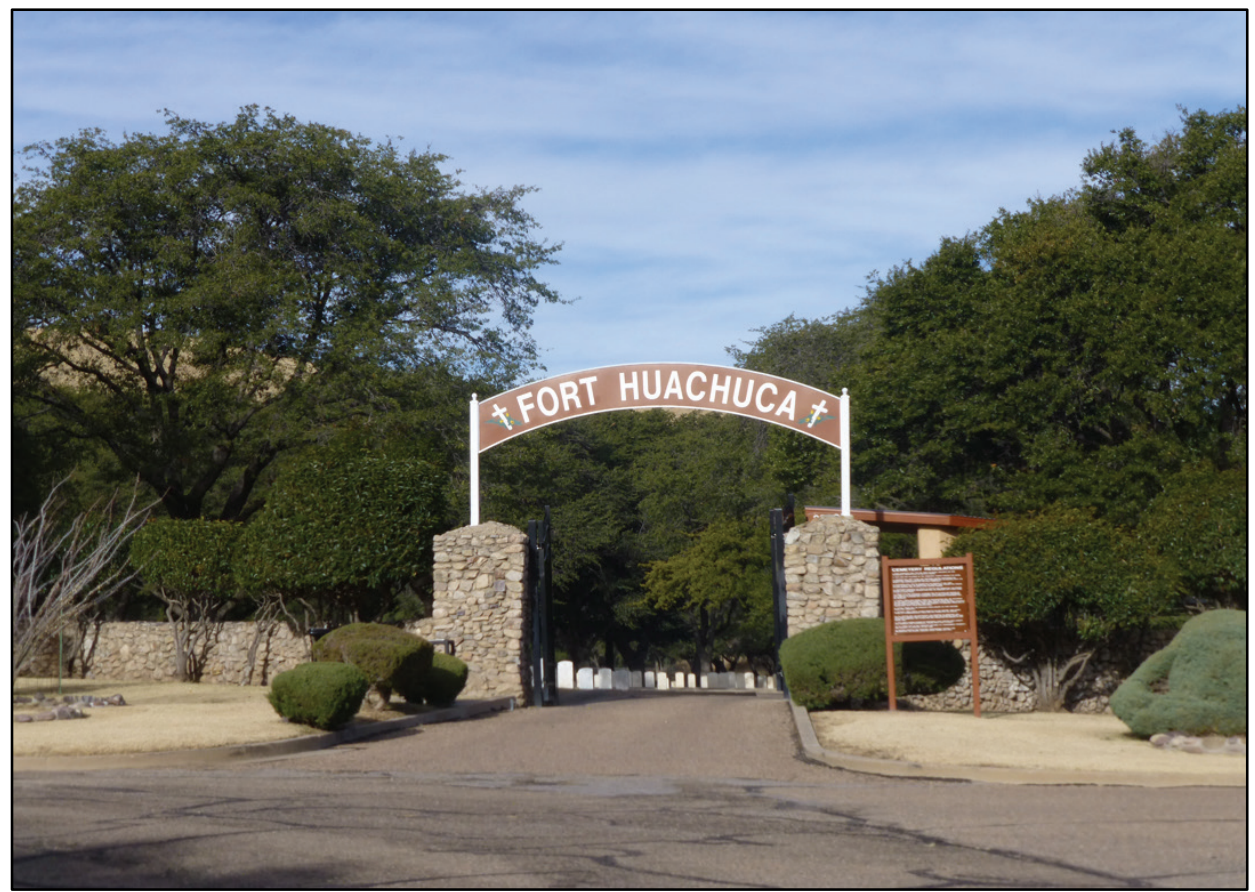

Figure 422. View looking north at different stone wall types (ERDC-CERL 2016).

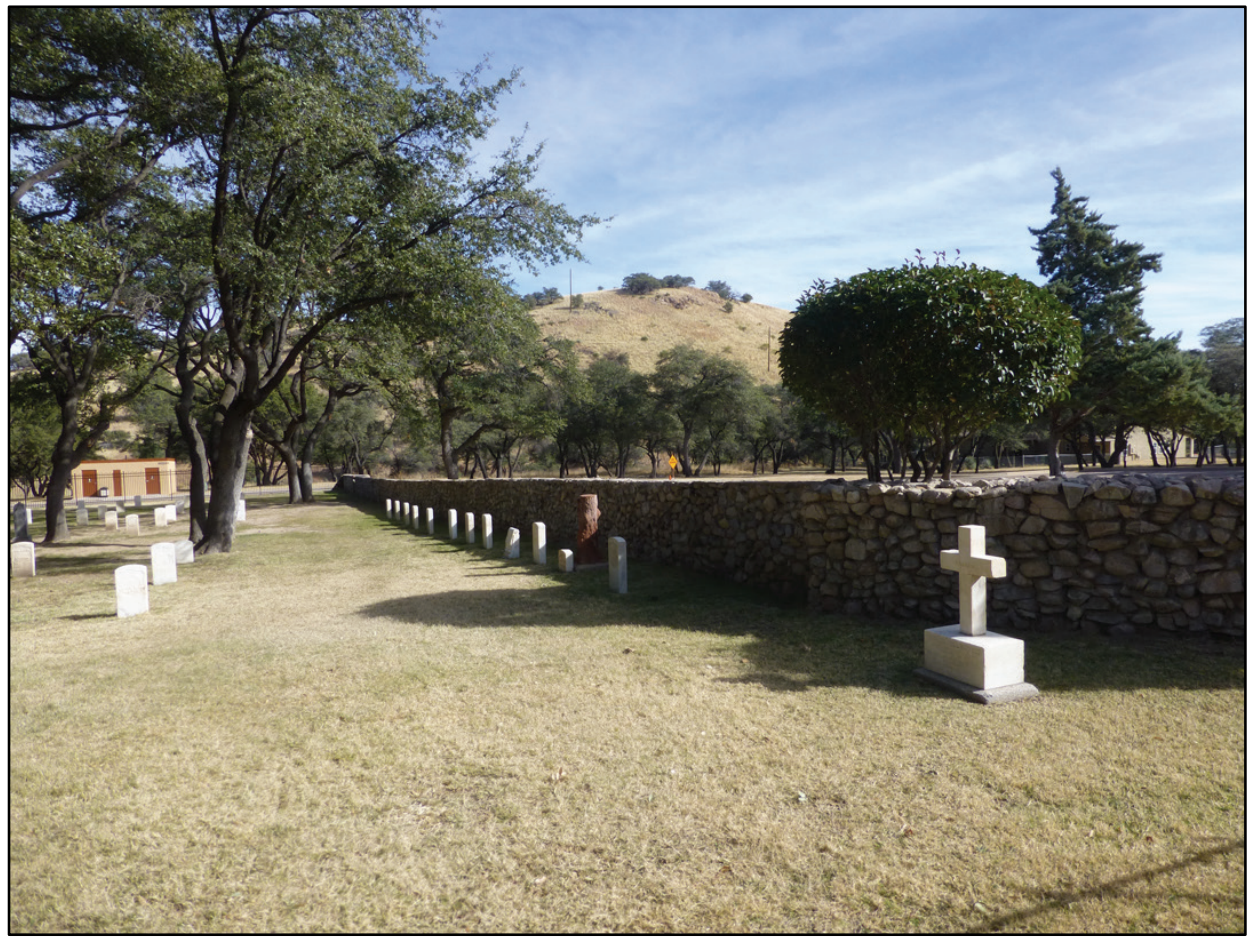


Figure 423. View looking west of cemetery markers in the modern cremation section and iron fence along rear of cemetery (ERDC-CERL 2016).

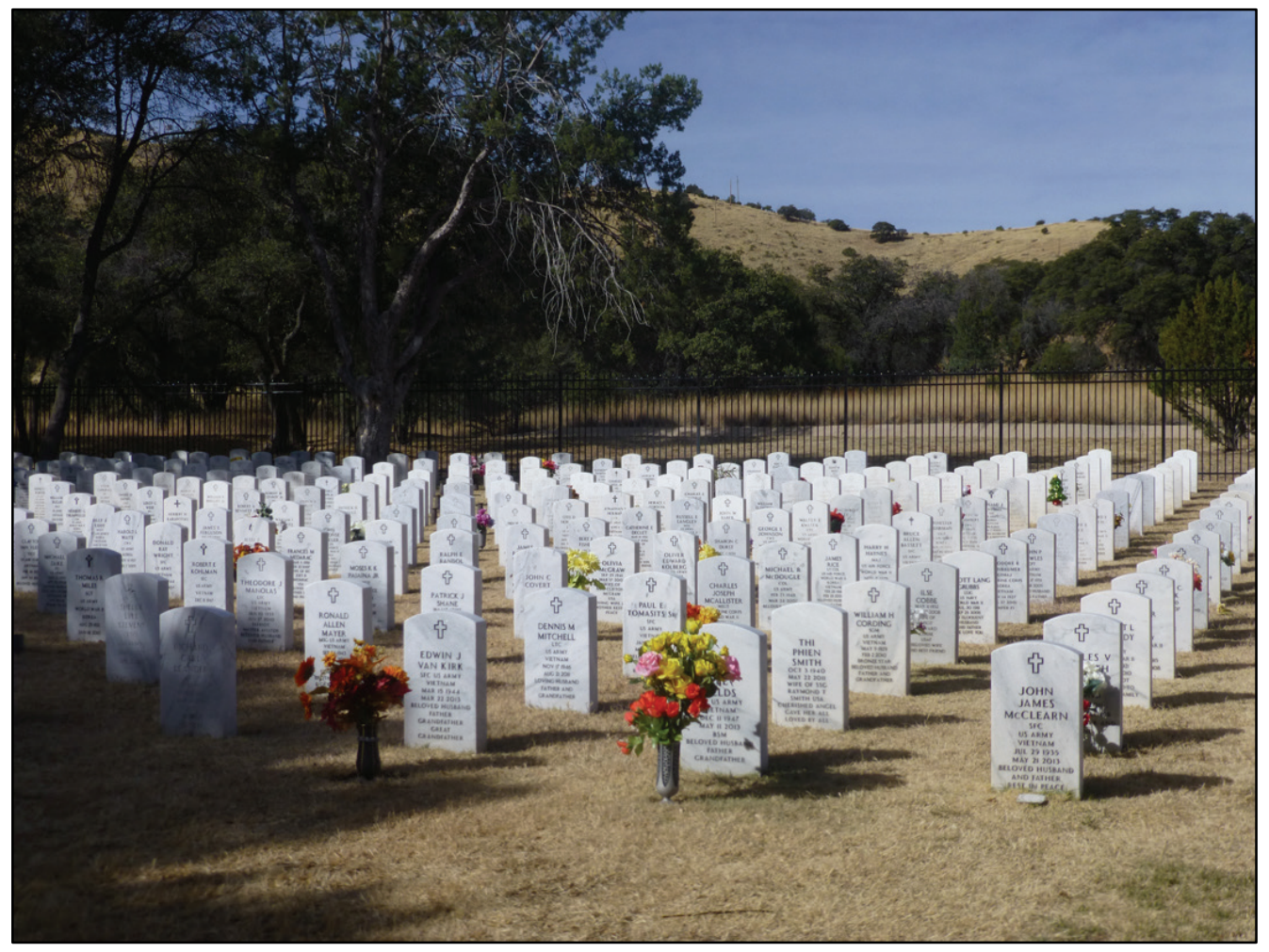

Figure 424. View looking north of mature shade trees scattered throughout cemetery (ERDCCERL 2016).

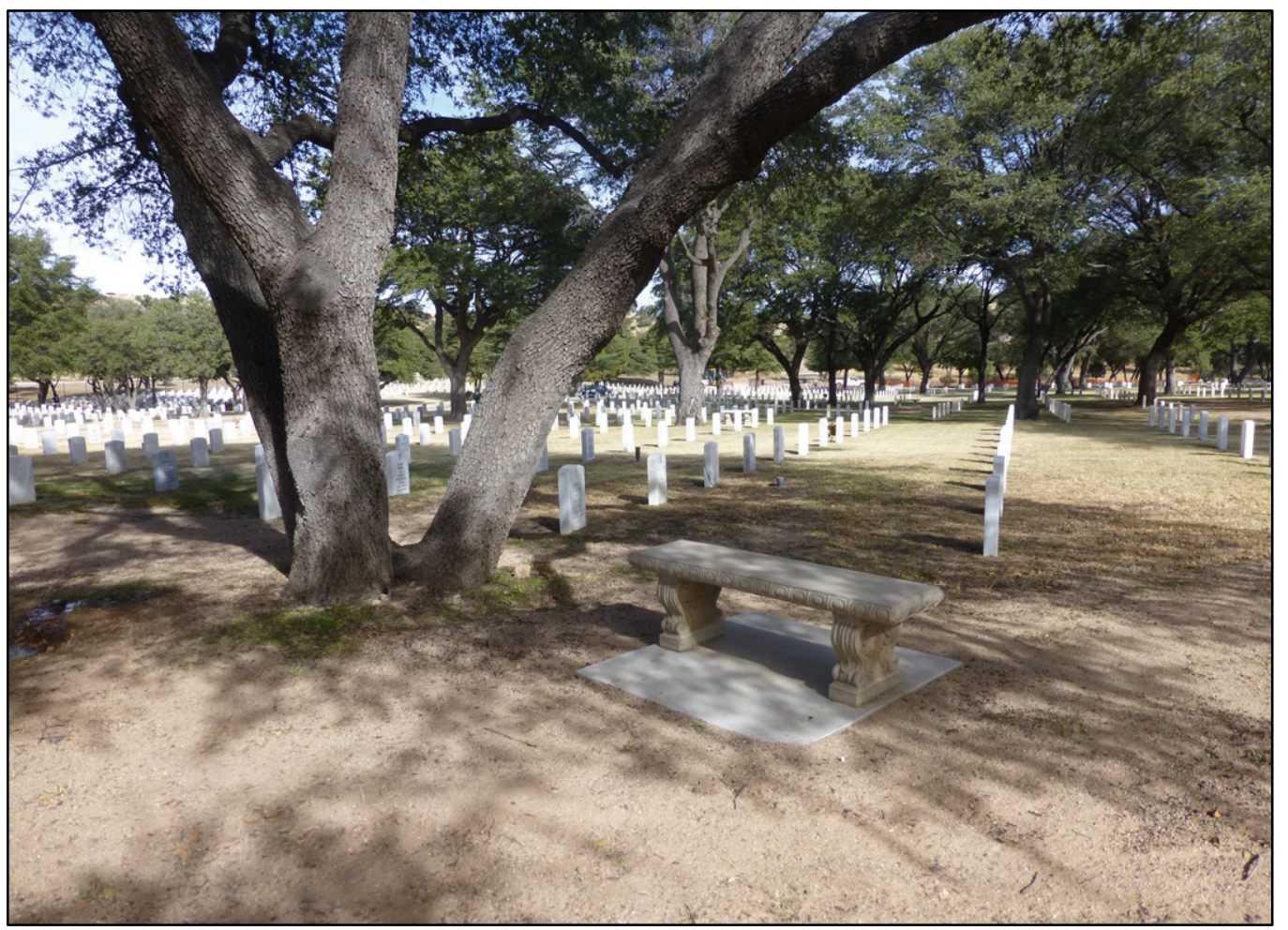


Figure 425. View looking north at maintenance sheds (20034) (ERDC-CERL 2016).

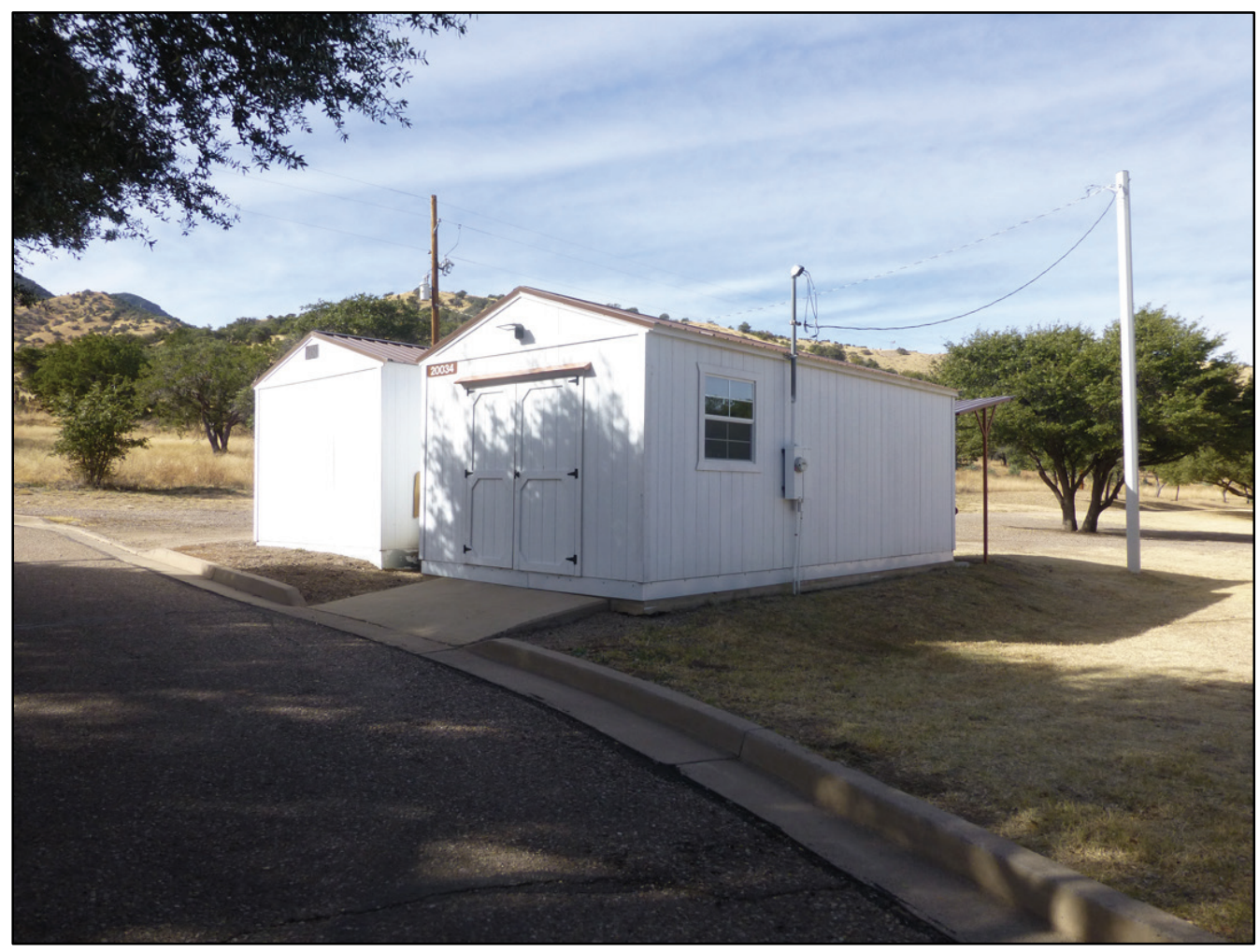

Figure 426. View looking north at restrooms (20036) (ERDC-CERL 2016).

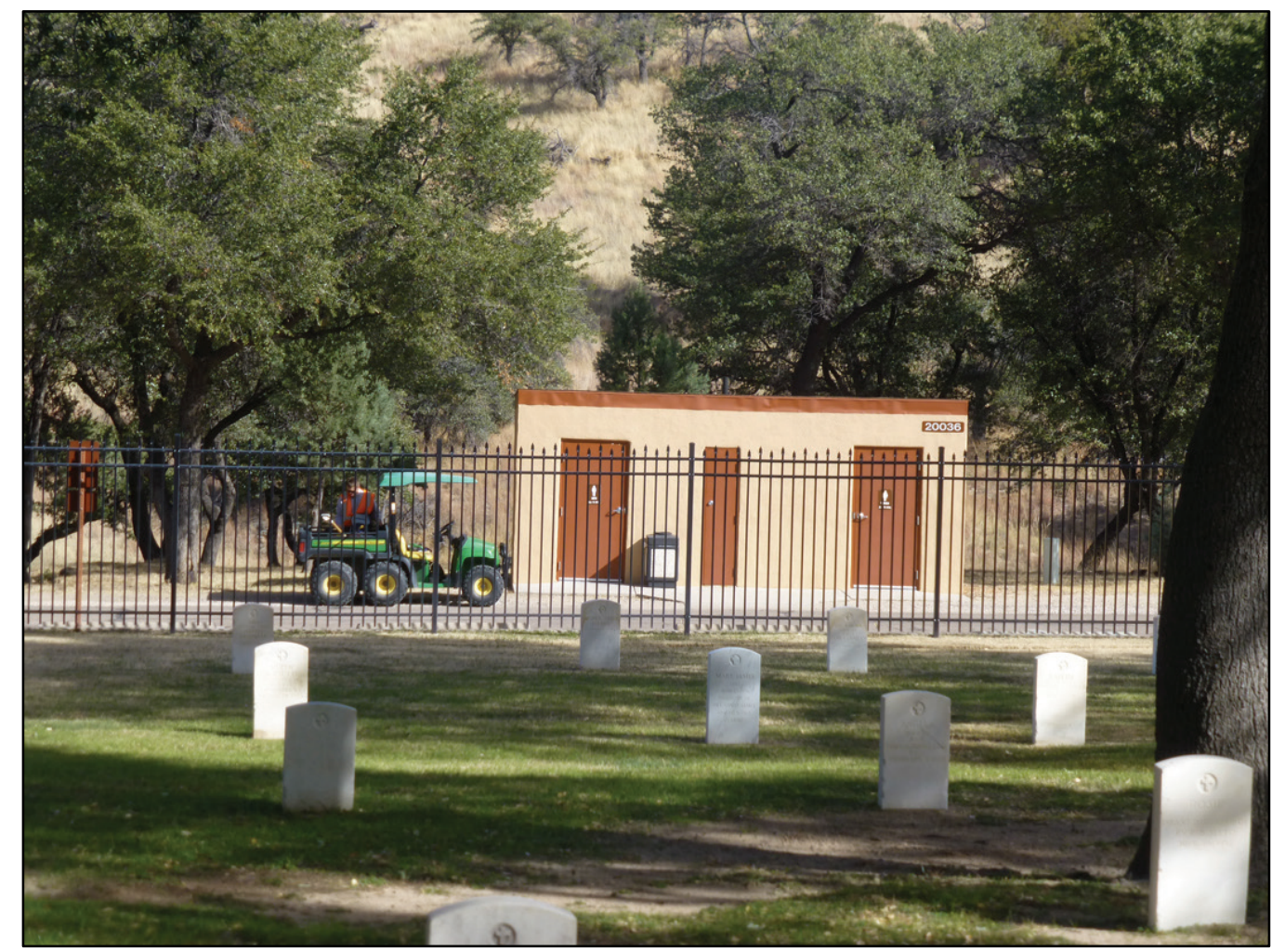


Figure 427. View looking north at information kiosk (20032) and stonework (ERDC-CERL 2016).

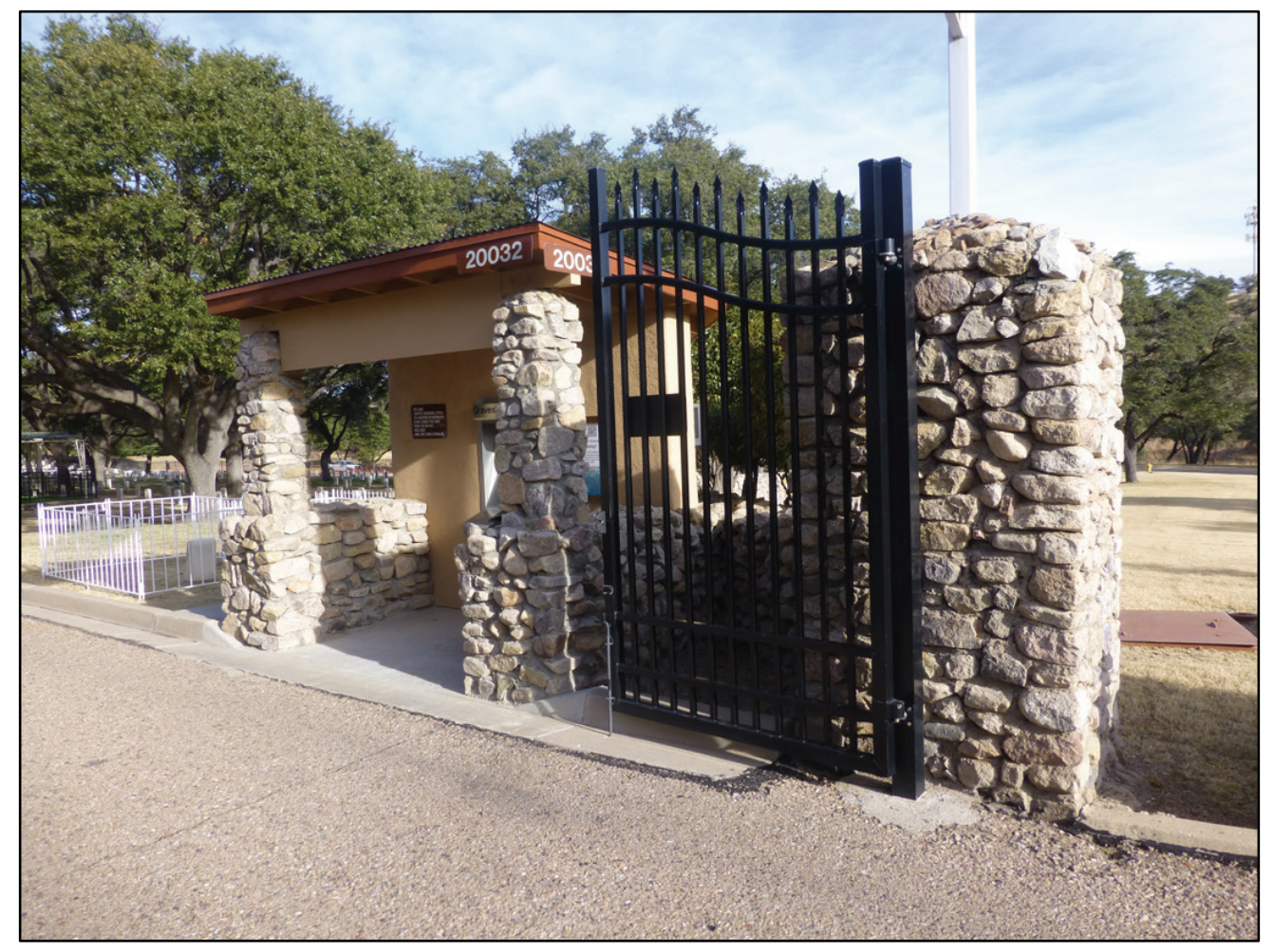

Figure 428. View looking north at cemetery pavilion (20035) and seating (20035).

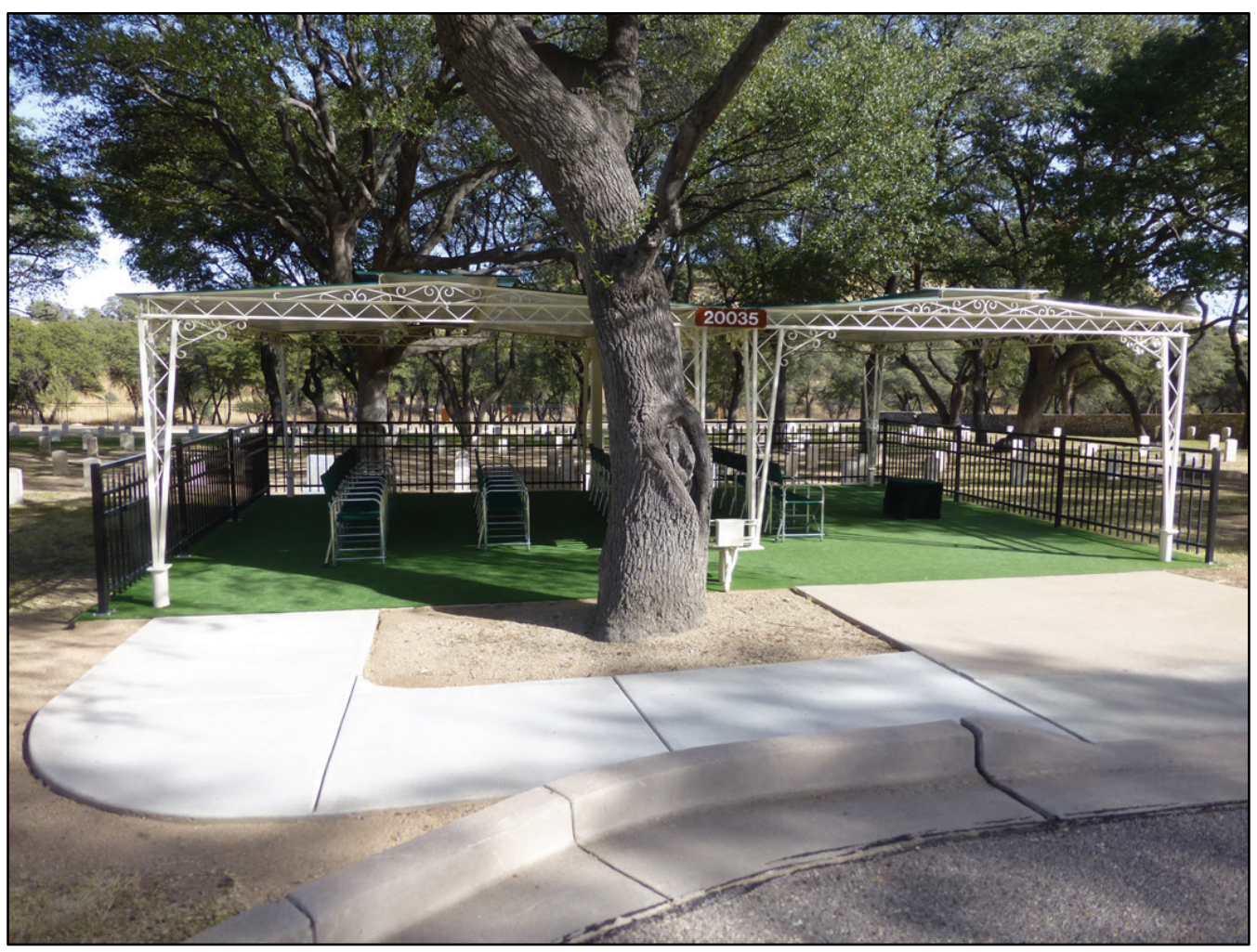


Figure 429. View looking west at entrance loop to Post Cemetery (ERDC-CERL 2016).

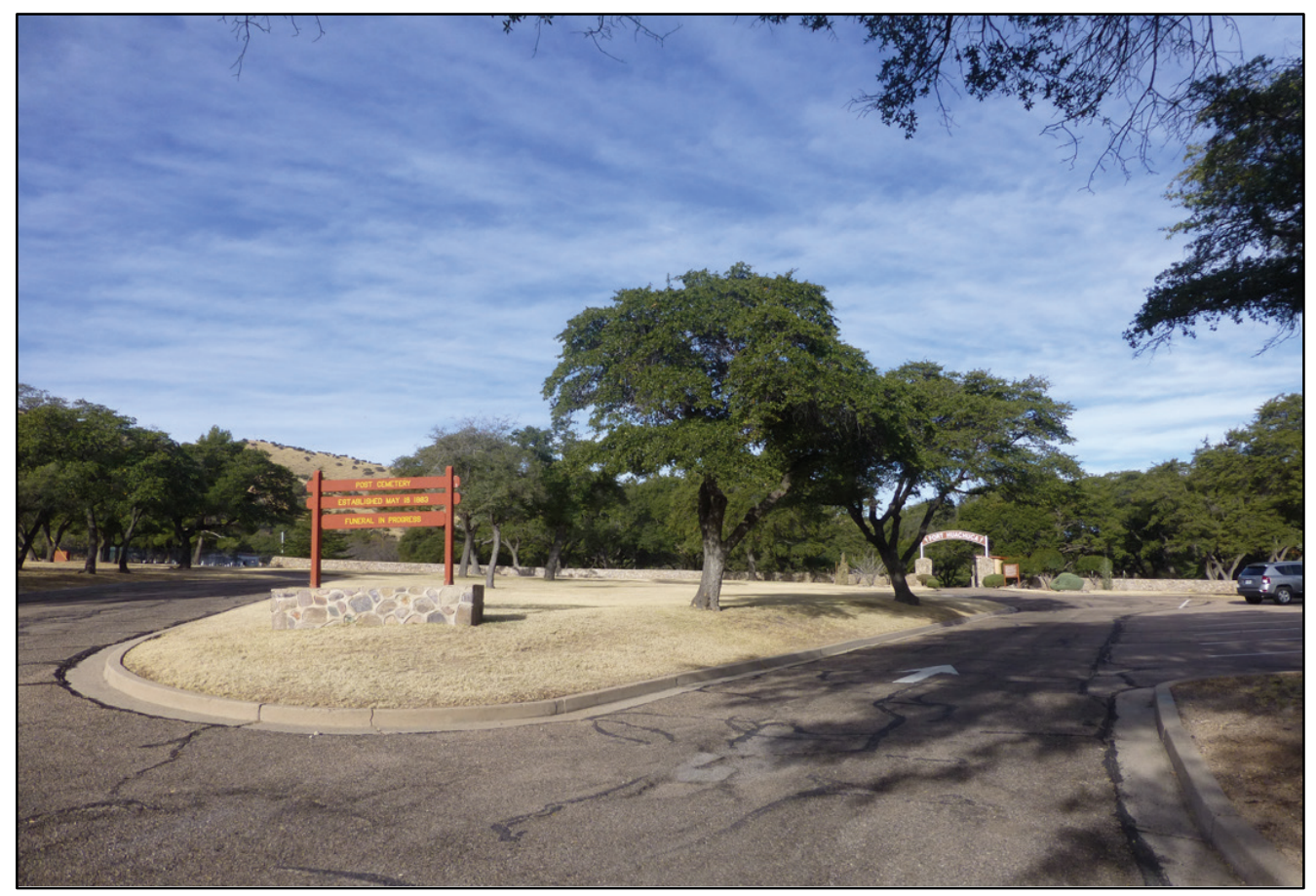

\subsection{Reservoir Hill}

Reservoir Hill is located on the ridge above the Old Post Officers' Quarters at the end of Reservoir Hill Road (Figure 430). The water supply buildings in the area include Reservoir No. 1 (22001), Reservoir No. 2 (22002), a chlorinator building (22004) and a water treatment building (22003) (Table 22).

Figure 430. Map of Reservoir Hill landscape area (ERDC-CERL).

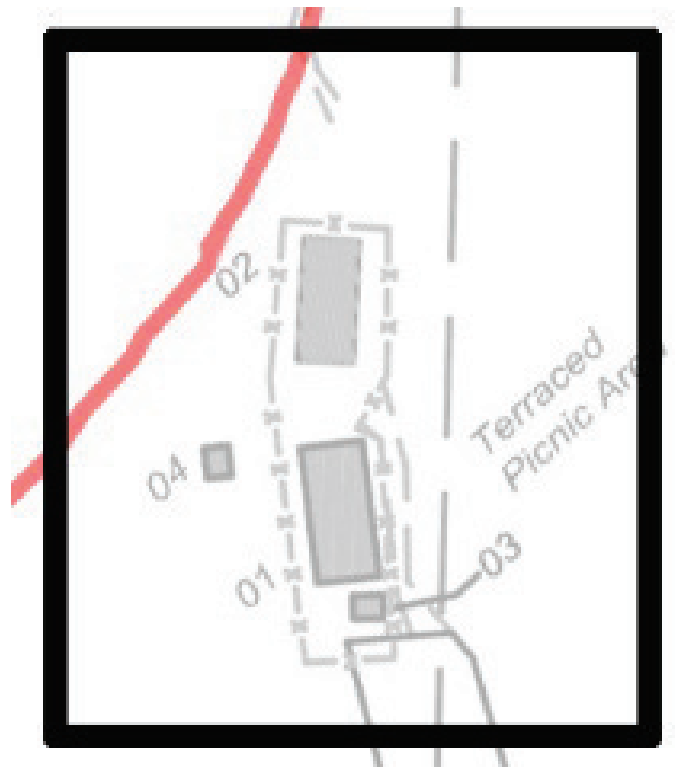


Table 22. Buildings on Reservoir Hill.

\begin{tabular}{|c|c|l|l|l|c|}
\hline $\begin{array}{c}\text { Building } \\
\text { Number }\end{array}$ & $\begin{array}{l}\text { Year } \\
\text { Built }\end{array}$ & Original Use & Current Use & Category Name & $\begin{array}{c}\text { Historic } \\
\text { Status }\end{array}$ \\
\hline 22001 & 1884 & Old Post Reservoir & Reservoir No. 1 & Reservoir & DNE \\
\hline 22002 & 1939 & Reservoir & Reservoir No. 2 & Reservoir & NREC \\
\hline 22003 & 1970 & $\begin{array}{l}\text { Water Support Treatment } \\
\text { Building }\end{array}$ & $\begin{array}{l}\text { Water Support Treatment } \\
\text { Building }\end{array}$ & NEV \\
\hline 22004 & 1938 & Water treatment & Water treatment & Water treatment & NREC \\
\hline
\end{tabular}

The Old Post Reservoir (22001) was constructed in 1884 at the top of a ridge overlooking the Old Post Area. While built during the POS for the NHL District, it is located outside of the boundary and, therefore, is not eligible to the NRHP. ${ }^{62}$ Adjacent to 22001 are two buildings constructed by the WPA to establish a regular source and storage of water for the post. These buildings include Reservoir No. 2 (22002) and the Chlorinator Building (22004). Also constructed by the WPA are stone walls around the reservoirs and stairs and retaining walls to the Chlorinator Building on the side of the ridge (Figure 431). The WPA also constructed an archway which once stood at the entrance to the reservoir (no longer extant). These two buildings and the associated landscape features are contributing to the WPA-era Historic District. A water treatment building was constructed adjacent to Building 22001 in 1970 (Figure 432). A recently constructed terraced picnic area is located east of the water buildings. A parking lot is south of the reservoir buildings (Figure 433).

62 A 2014 report by Tomes and Thomas (FH-12-21), incorrectly lists 22001 as contributing to the NHL district. 
Figure 431. View looking south of chlorinator building (22004) and stairs and retaining walls, 1941 (NARA College Park).

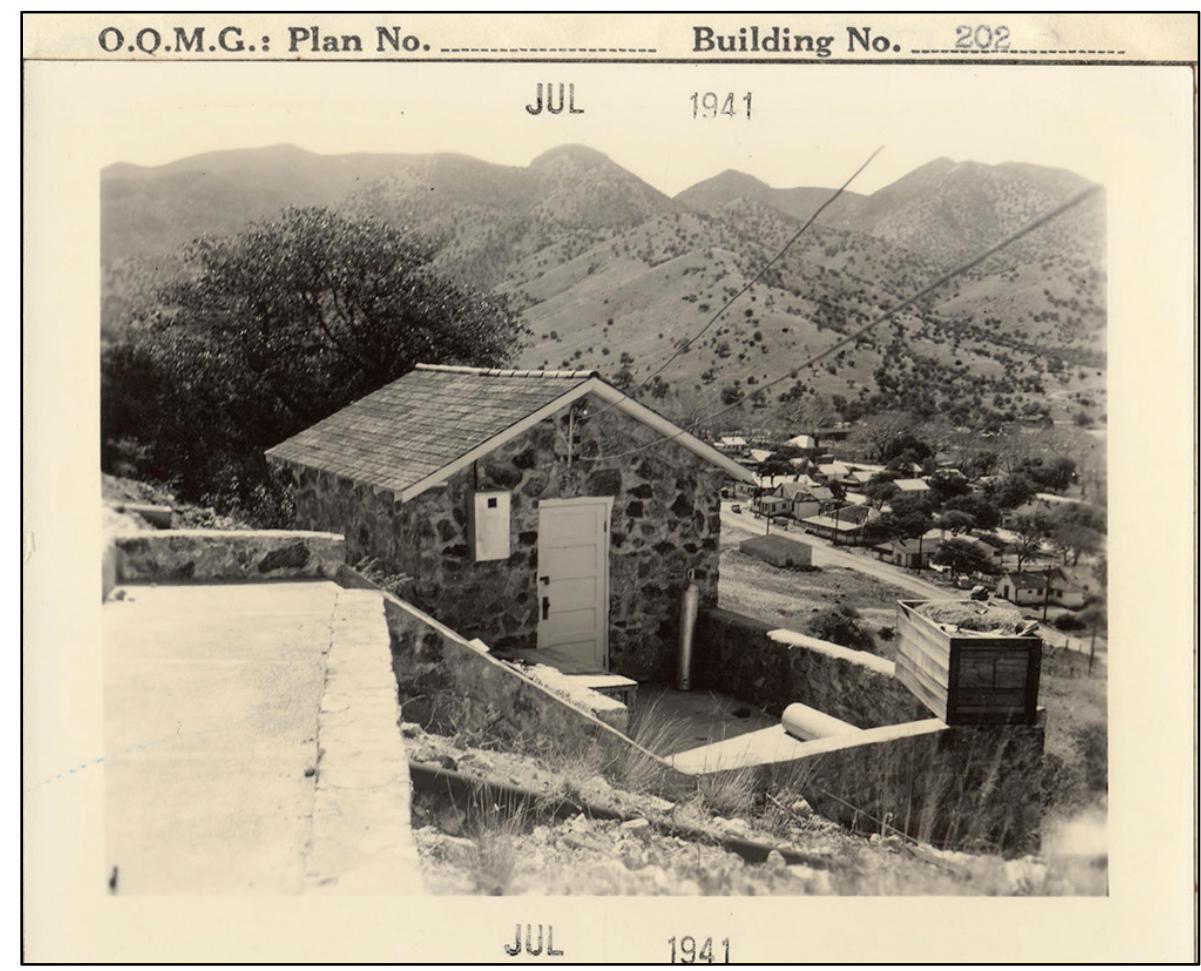

Figure 432. View on Reservoir Hill looking north at WPA wall, Building 22003 in front, 22001 in center, and 22002 at rear on Reservoir Hill (ERDC-CERL 2016).

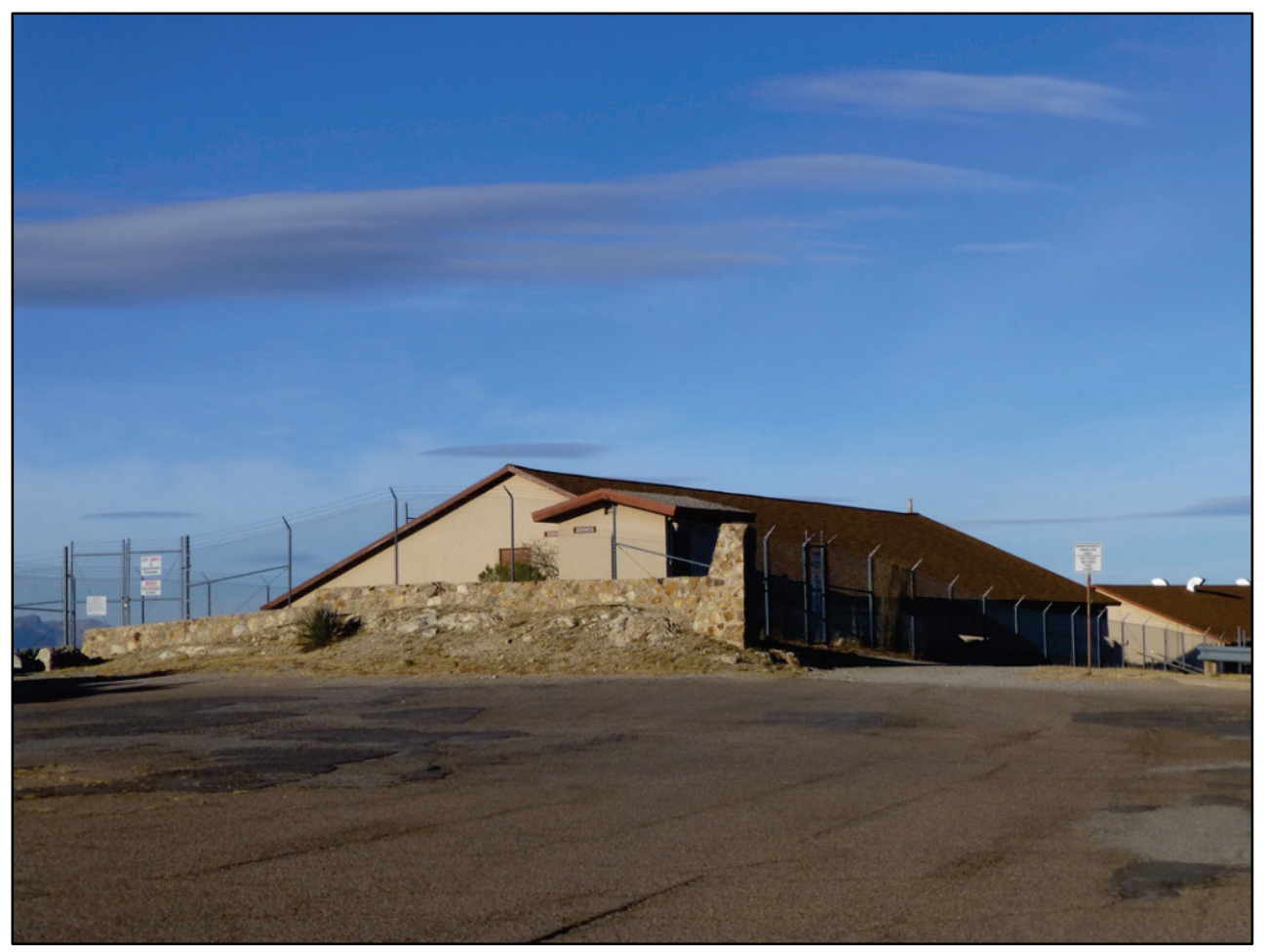


Figure 433. View south toward parking area along Reservoir Hill Road (ERDC-CERL 2016).

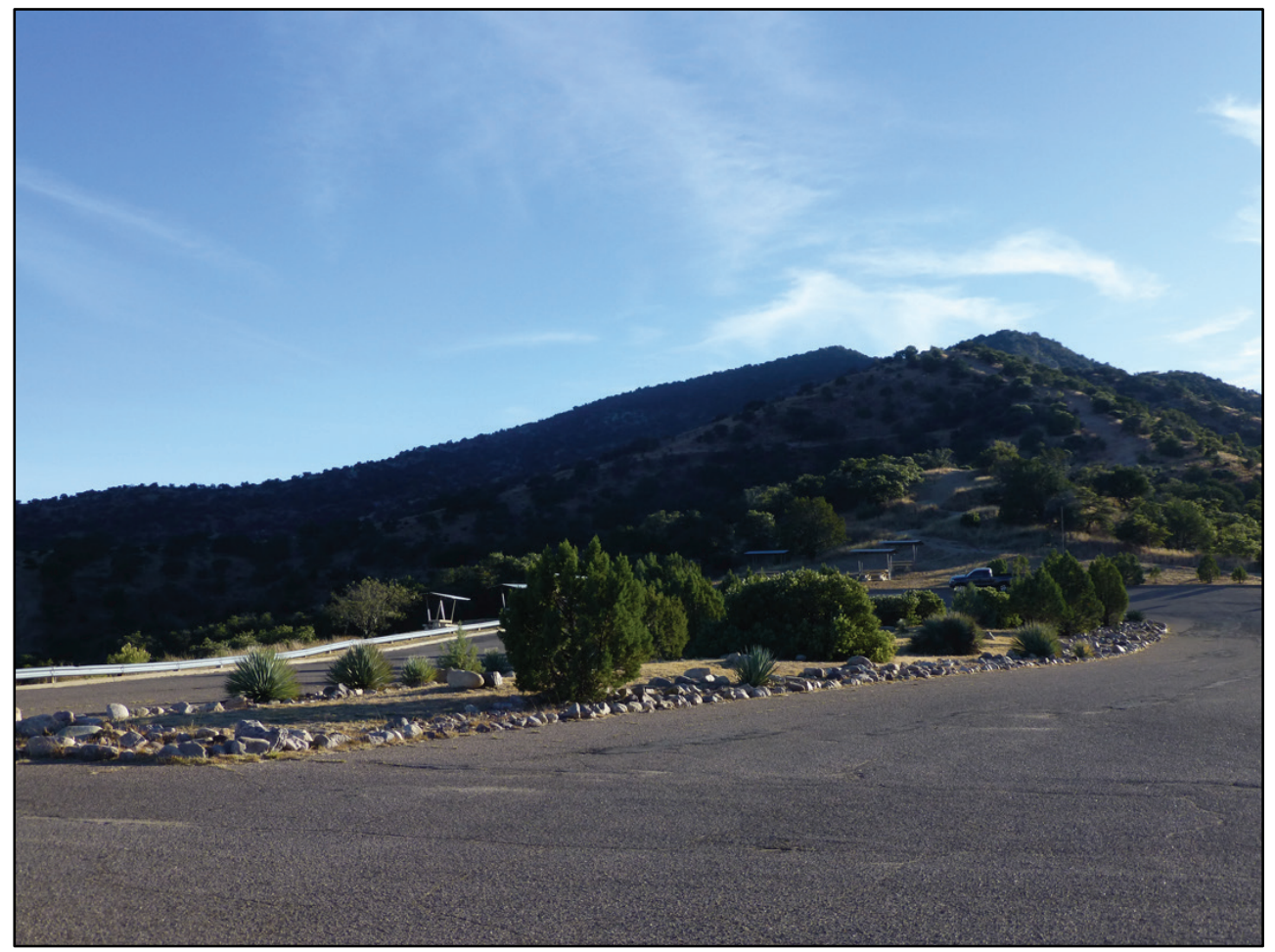

\subsection{Cavalry Park 1 Housing Area}

The Cavalry Park 1 Housing Area, single-family housing, is located south of the NHL historic district on the southwest end of Grierson and Hines Roads and set in the canyon landscape (Figure 434). The Capehart building numbers are: 21001, 21101, 21102, 21105-21108, and 21201-21212 (Table 23). Nestled in with these Capehart Quarters, but not constructed at the same time, are the Stone Warrant Officer's Quarters (21103) and garage (21104). At the northwest corner of this area, at the corner of Hines Road and Carnahan Street, is the cluster of three buildings originally known as the Colonel Young School (21110, 21111, and 21112). 
Figure 434. Current map of Cavalry Park 1 Housing Area (ERDC-CERL).

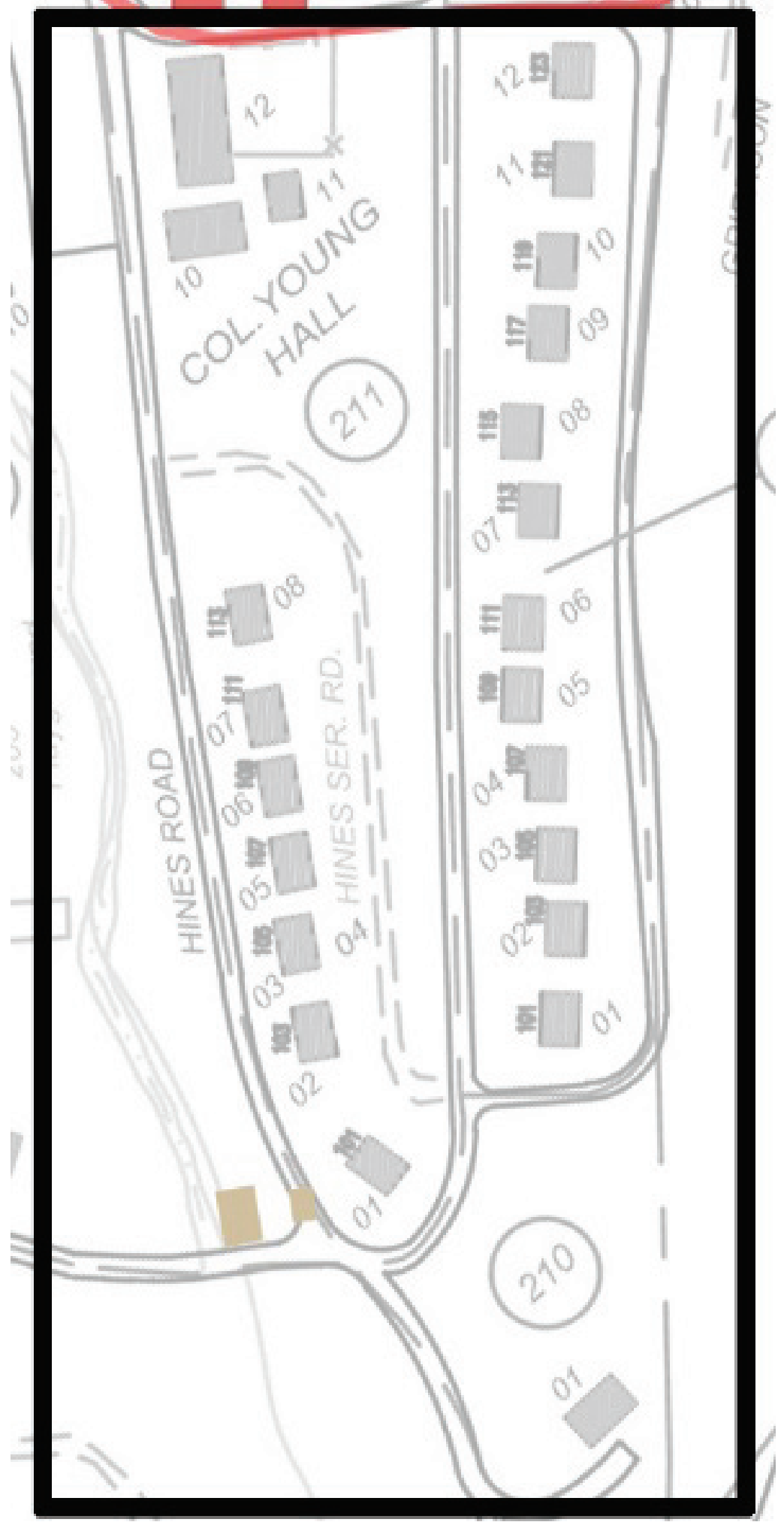


Table 23. Table of buildings in Cavalry Park 1 landscape area.

\begin{tabular}{|c|c|c|c|c|c|}
\hline Building Number & Year Built & Original Use & Current Use & Category Name & Historic Status \\
\hline 20310 & 1936 & Garage & Garage & Storage & NREC \\
\hline 21001 & 1958 & Housing & Family Quarters & Housing & NREC \\
\hline 21101 & 1958 & Housing & Family Quarters & Housing & NREC \\
\hline 21102 & 1958 & Housing & Family Quarters & Housing & NREC \\
\hline 21103 & 1939 & Housing & Family Quarters & Stone Quarters & NREC \\
\hline 21104 & 1939 & Garage & Garage & Stone Quarters garage & NREC \\
\hline 21105 & 1958 & Housing & Family Quarters & Housing & NREC \\
\hline 21106 & 1958 & Housing & Family Quarters & Housing & NREC \\
\hline 21107 & 1958 & Housing & Family Quarters & Housing & NREC \\
\hline 21108 & 1958 & Housing & Family Quarters & Housing & NREC \\
\hline 21110 & NA & School & Col. Young School & ACCOMD Offices & NEV \\
\hline 21111 & NA & School & Col. Young School & Administration & NEV \\
\hline 21112 & 1939 & School & Col. Young School & ACES Facility & DNE \\
\hline 21201 & 1958 & Housing & Family Quarters & Housing & NREC \\
\hline 21202 & 1958 & Housing & Family Quarters & Housing & NREC \\
\hline 21203 & 1958 & Housing & Family Quarters & Housing & NREC \\
\hline 21204 & 1958 & Housing & Family Quarters & Housing & NREC \\
\hline 21205 & 1958 & Housing & Family Quarters & Housing & NREC \\
\hline 21206 & 1958 & Housing & Family Quarters & Housing & NREC \\
\hline 21207 & 1958 & Housing & Family Quarters & Housing & NREC \\
\hline 21208 & 1958 & Housing & Family Quarters & Housing & NREC \\
\hline 21209 & 1958 & Housing & Family Quarters & Housing & NREC \\
\hline 21210 & 1958 & Housing & Family Quarters & Housing & NREC \\
\hline 21211 & 1958 & Housing & Family Quarters & Housing & NREC \\
\hline 21212 & 1958 & Housing & Family Quarters & Housing & NREC \\
\hline
\end{tabular}

The Stone Warrant Officers' Quarters (21103) and its associated garage (21104) were built by the WPA in 1938-1939 using federal relief funding and WPA and PWA crews (Figure 435 and Figure 436). Located to the southwest of the parade ground, the stone duplex was built to house two warrant officers and their families. At the time, the quarters and garage were originally surrounded by frame officers' quarters.

The Stone House and its associated garage have changed little since their original construction; however, the surrounding neighborhood has changed. By 1958, the frame NCO Quarters to the north, south, and east had all been replaced with modern, International Style Capehart units. A lone WPA-era garage (20310) is located across Hines Road across from 
Building 21110 (Figure 437). These three buildings were found eligible for their contributions to the WPA Historic district. ${ }^{63}$

Between 1942 and 1962, the Army Housing Program built many family housing units under the Wherry Act and later the Capehart Act. Under the Capehart Act, the Army contracted with private-sector architects and contractors to design and build the neighborhoods that were turned over the military after completion. In 1958, Blanton \& Cole Architects of Tucson, AZ designed the Cavalry Park 1 Housing Area at Fort Huachuca (Figure 438 - Figure 443). It was one of six areas built at Fort Huachuca. ${ }^{64}$ One of the other neighborhoods was built west of Cavalry Park 1 across the Huachuca Creek (Bonnie Blink Housing Area). These units were demolished in 2001 and replaced with two-story, gable-roofed duplexes. The 19 remaining Capehart International Style units in the Cavalry Park I Housing area were evaluated and found eligible for the NRHP as a Capehart historic district. 65

Also in this landscape area, but not in the Capehart Historic District boundary, is the former Colonel Young School (Building 21112) (Figure 444 and Figure 445). The building, now administration for ACES, was evaluated in 2013 and found not eligible for listing on the NRHP. ${ }^{66}$ There are two associated school buildings (21110 and 21111), but the dates of construction were incorrect in the real property list.

\footnotetext{
63 Daniel Hart and Chad Blackwell, 2009. CCC-WPA Resources Legacy Grant Case Study: Fort Huachuca, Arizona. Appendix D in Nationwide Context, Inventory, and Heritage Assessment of Works Progress Administration and Civilian Conservation Corps Resources on Department of Defense Installations. Legacy Project No. 07-357. Engineering-Environmental Management, Denver, Colorado (FH-08-8).

64 Center of Expertise for Preservation of Historic Structures and Buildings, 1999. Seattle District Corps of Engineers, Capehart Housing at Fort Huachuca, Arizona: Determination of Eligibility for the National Register Due to Association with Richard Neutra, Architect. Prepared for Directorate of Installation Support, U.S. Army Intelligence Center and Fort Huachuca, Fort Huachuca, AZ 85613. Seattle, WA: Seattle District Corps of Engineers.

65 CP\&Y, Inc., 2009. National Register of Historic Places Evaluation of Cavalry 1 Housing Area. Fort Huachuca, Arizona. CPY Project \#MMH09023.00. CP\&Y Inc., Austin, Texas. (FH-09-6).

66 Angel Tomes, 2013. Architectural Survey, Documentation, and Evaluation of 110 Buildings and Structures at Fort Huachuca, Arizona. Fort Huachuca Cultural Resources Report FH-12-6. Statistical Research, Tucson.
} 
Figure 435. View looking east at the front of the Stone Warrant Officers Quarters (21103) (ERDC-CERL 2016).

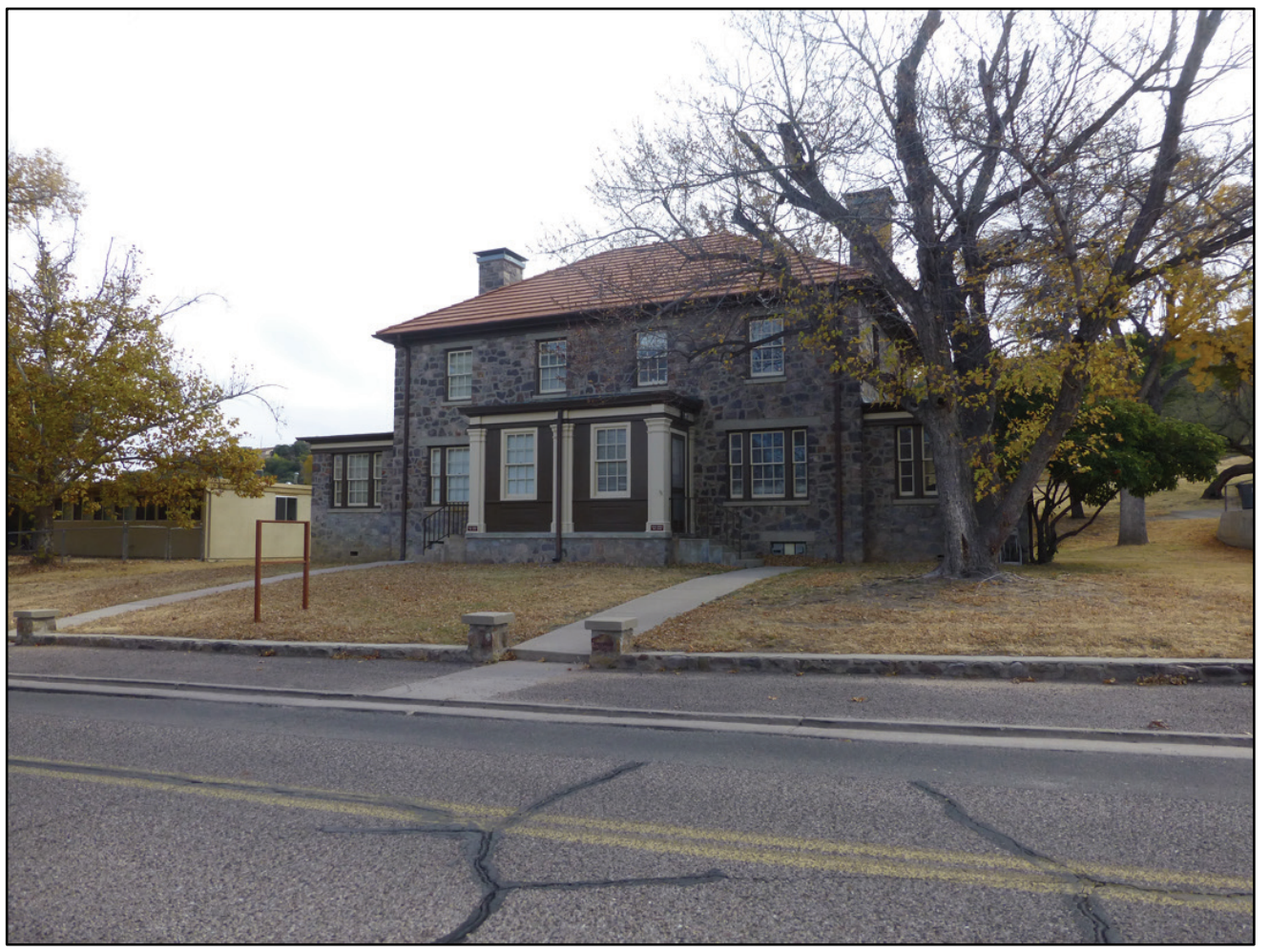

Figure 436. View looking north at the rear of the Stone Warrant Officers Quarters (21103) and associated garage (21104) (ERDC-CERL 2016).

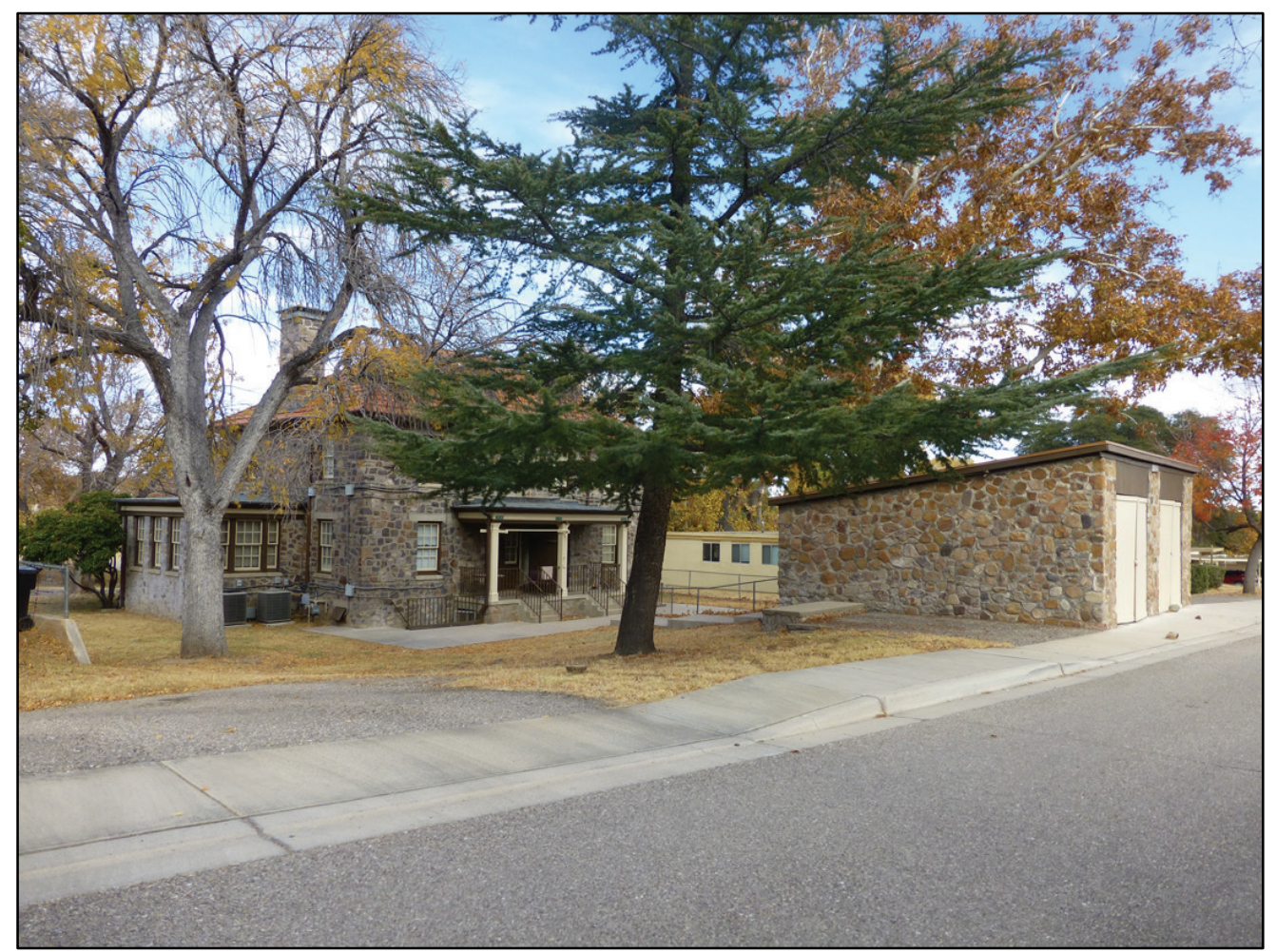


Figure 437. View looking west of lone garage (20310) west of Hines Road (ERDC-CERL 2016).

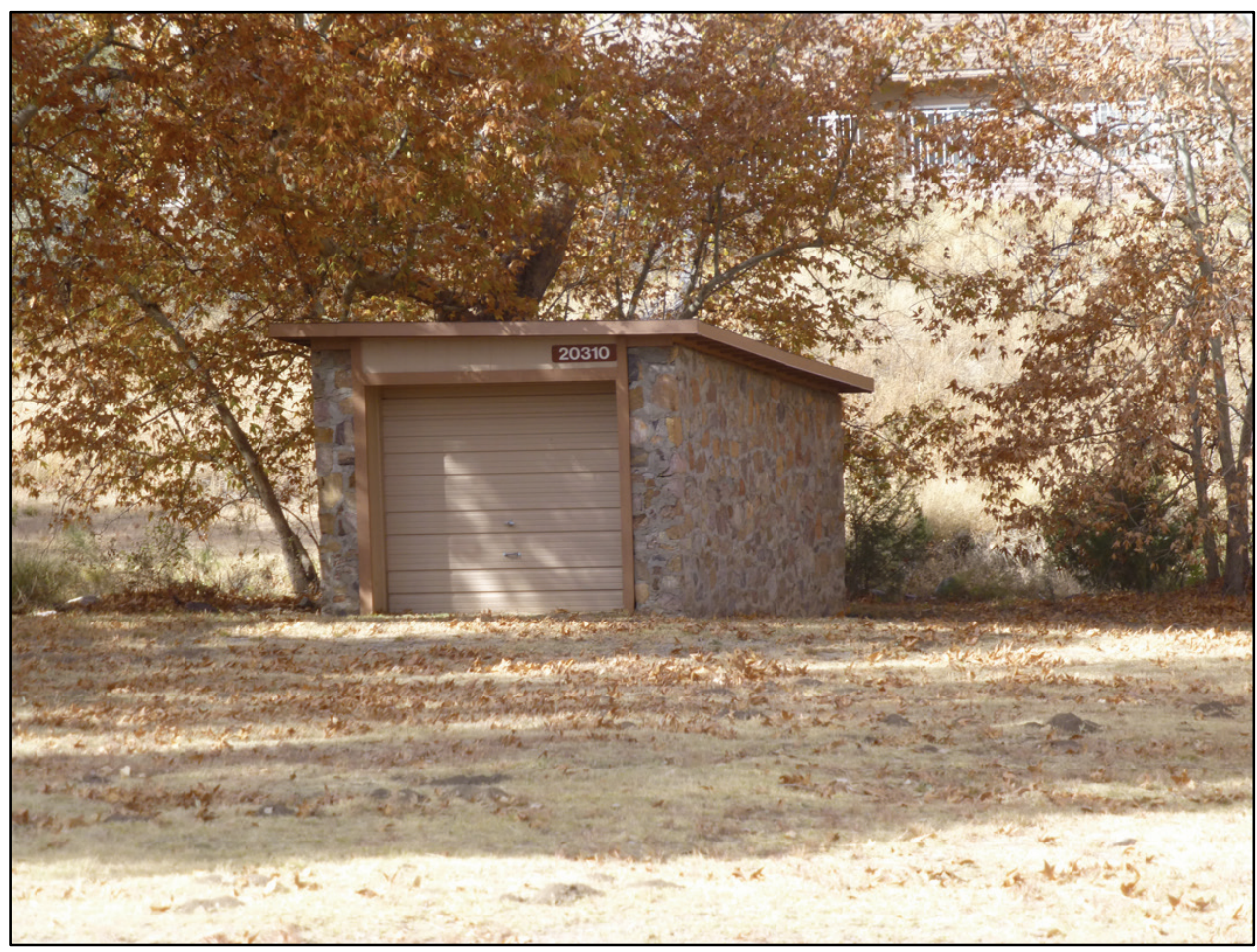

Figure 438. View south of Capehart housing along Grierson Service Road (ERDC-CERL 2016).

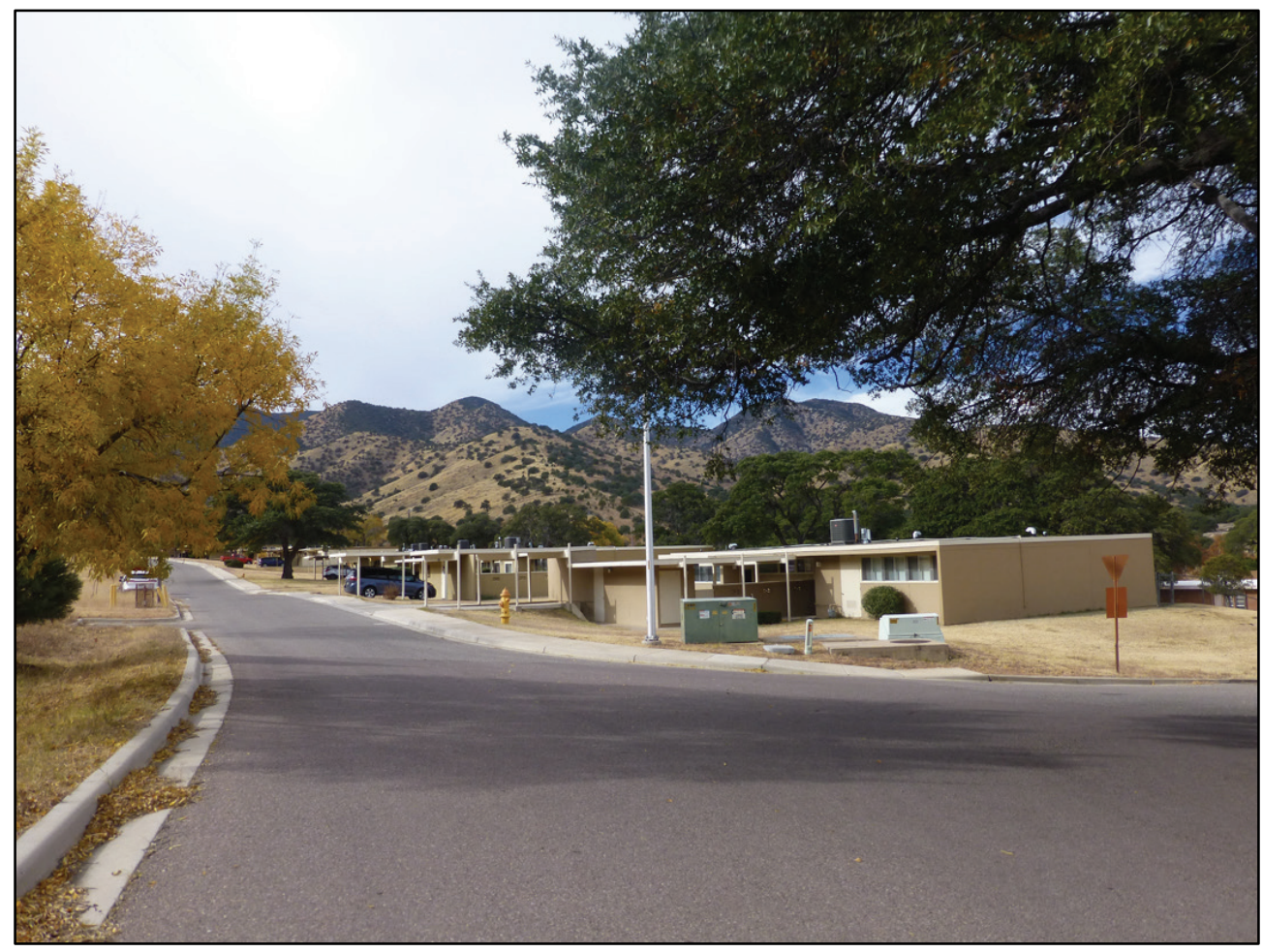


Figure 439. View west of vegetation in front of 21206 in Cavalry Park 1 Housing Area (ERDCCERL 2016).

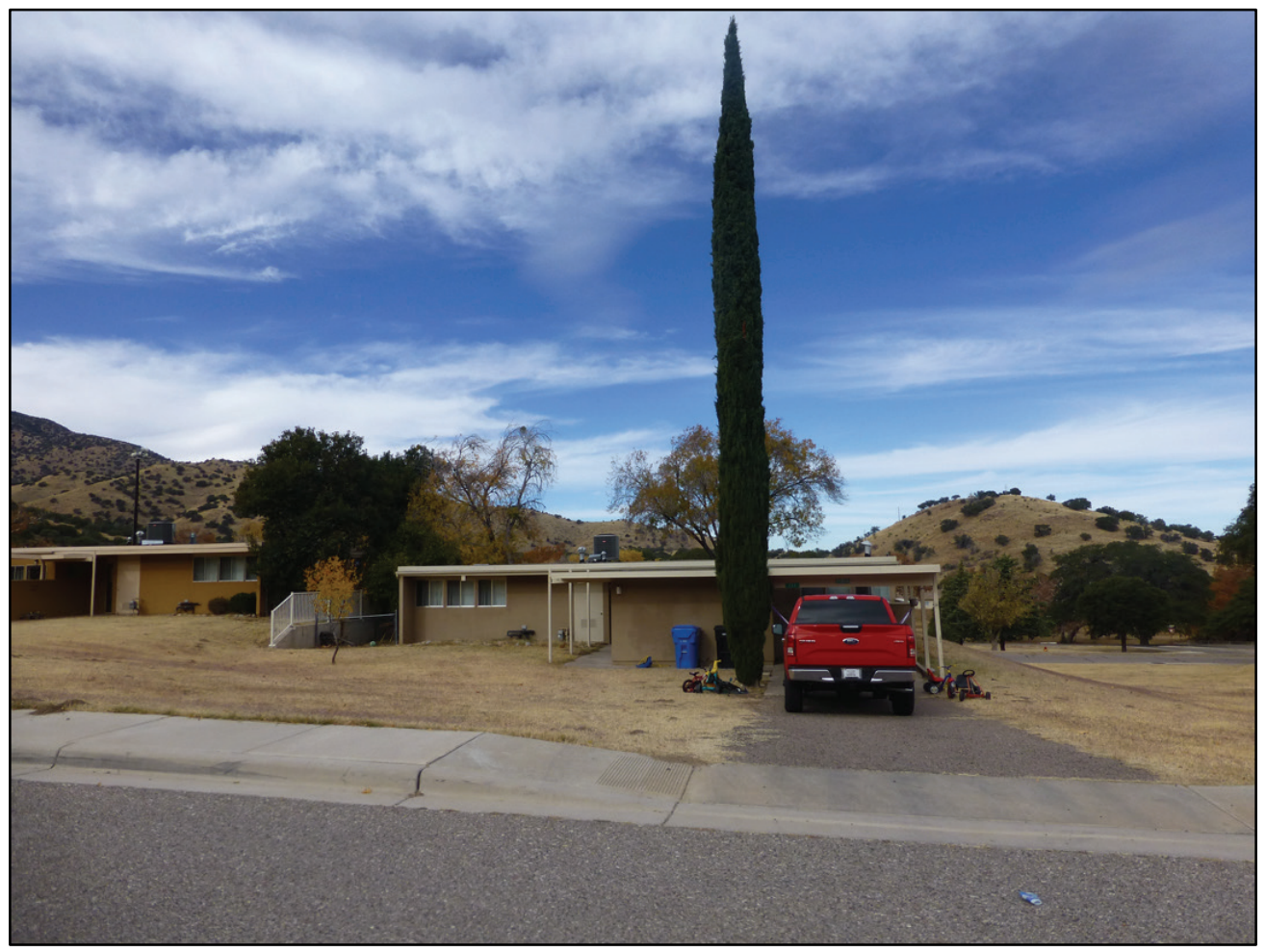

Figure 440. View west of vegetation in front of 21204 in Cavalry Park 1 Housing Area (ERDCCERL 2016).

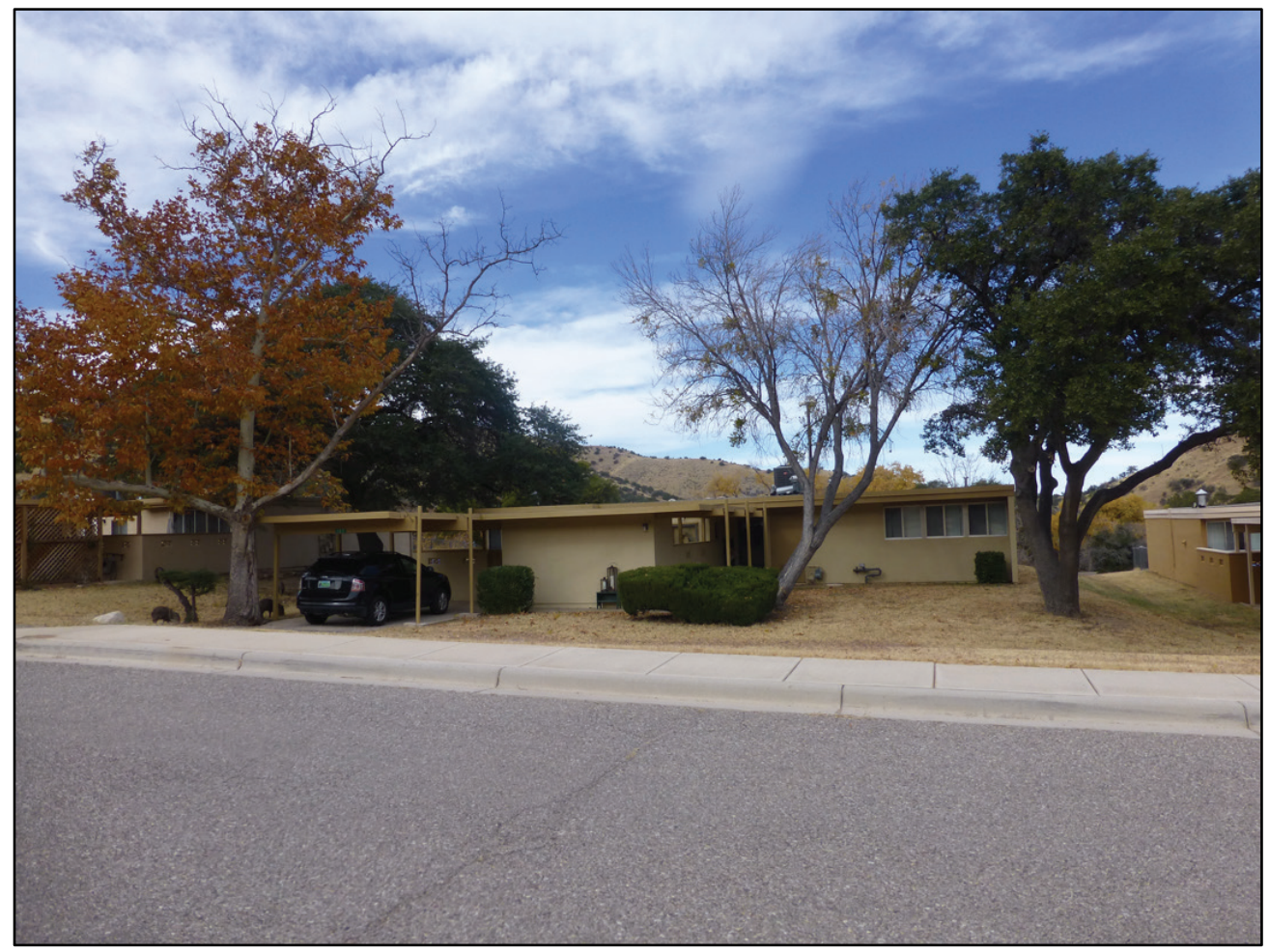


Figure 441. View west of vegetation in front of 21102 in Cavalry Park 1 Housing Area (ERDCCERL 2016).

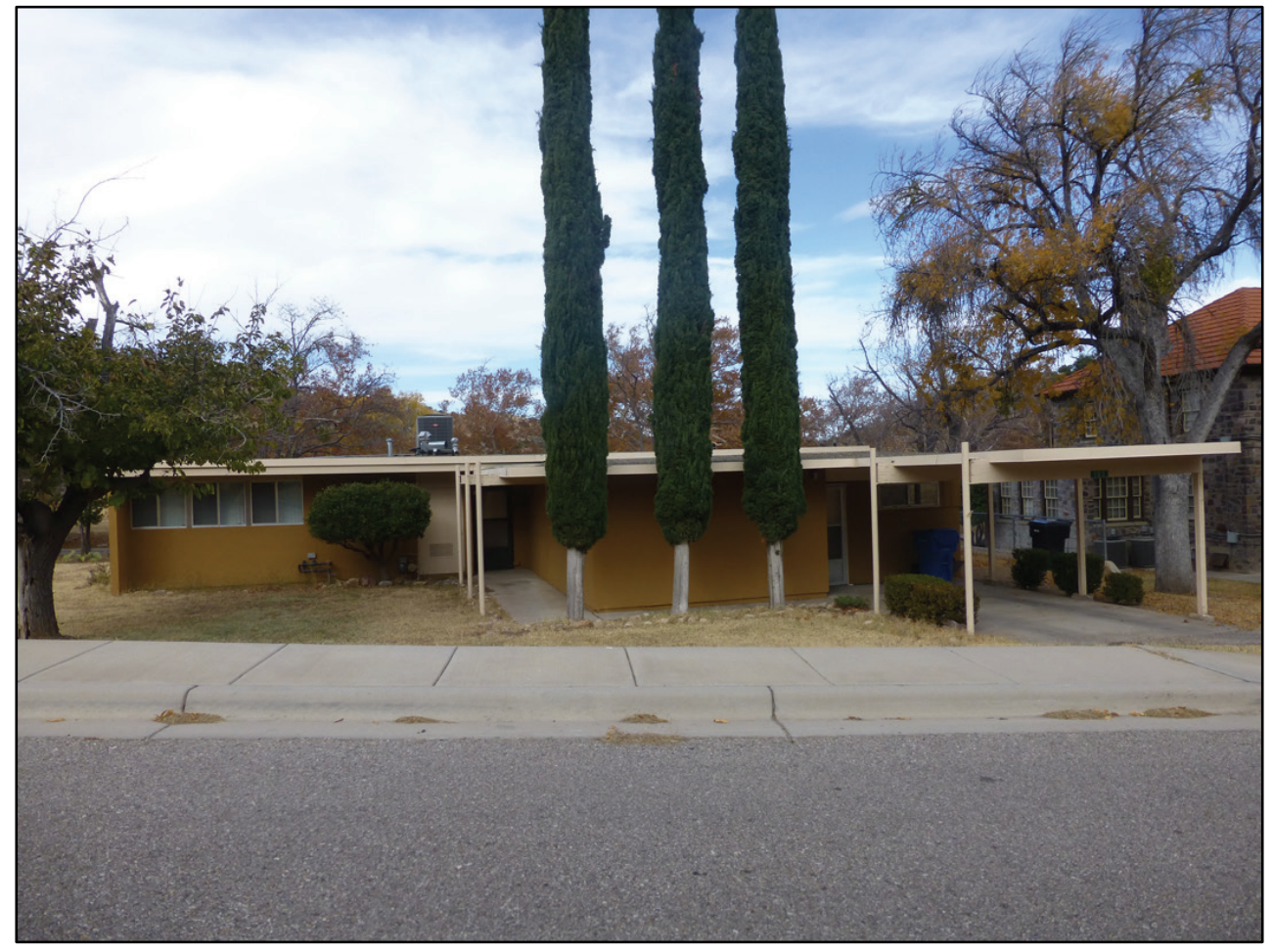

Figure 442. View south of 21101 in Cavalry Park 1 Housing Area and surrounding hills (ERDC-CERL 2016).

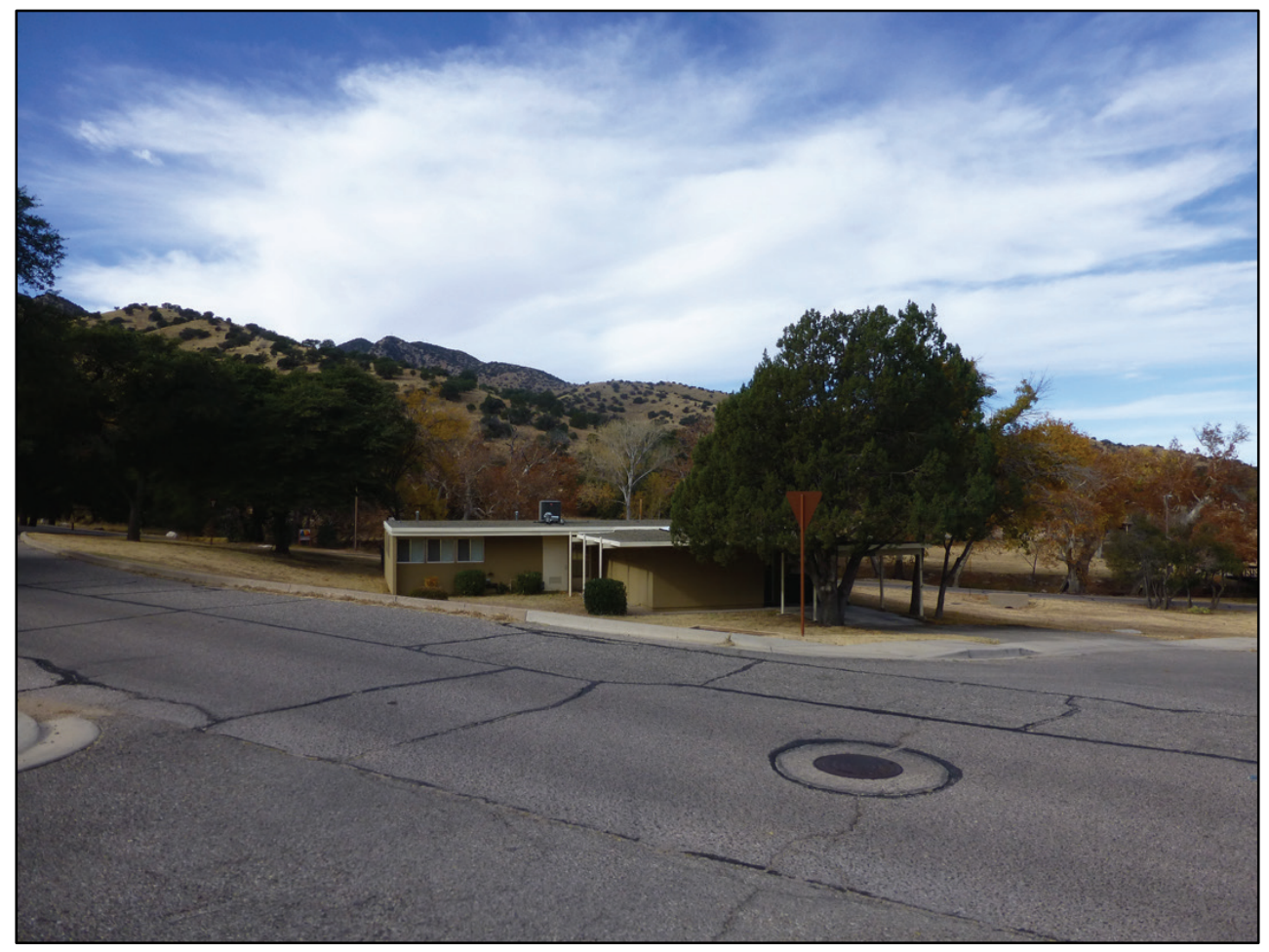


Figure 443. View looking west of Cavalry Park 1 housing area from Reservoir Hill (ERDC-CERL 2016).

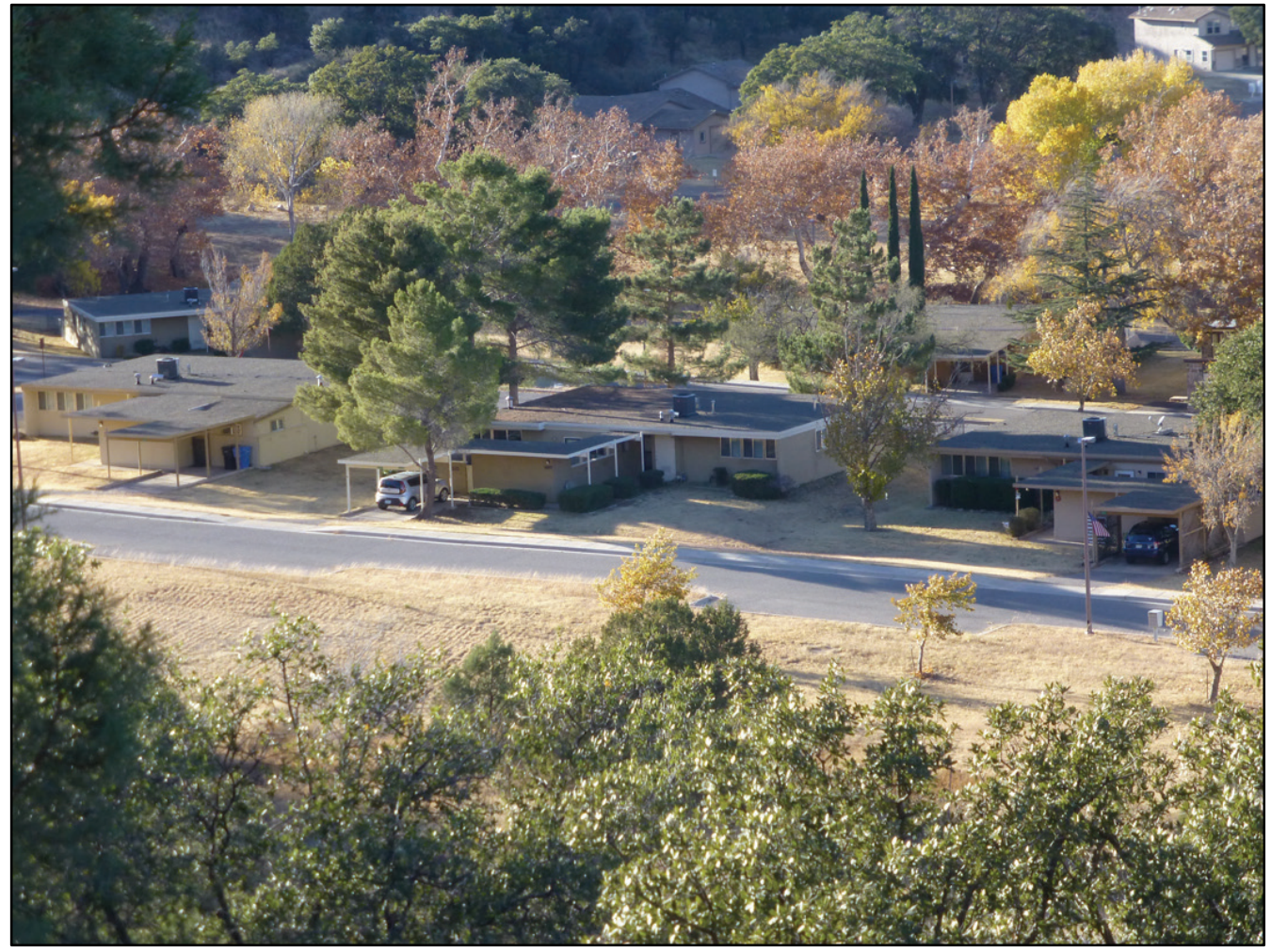

Figure 444. View looking south at front of former school (21112), now ACES administration (ERDC-CERL 2016).

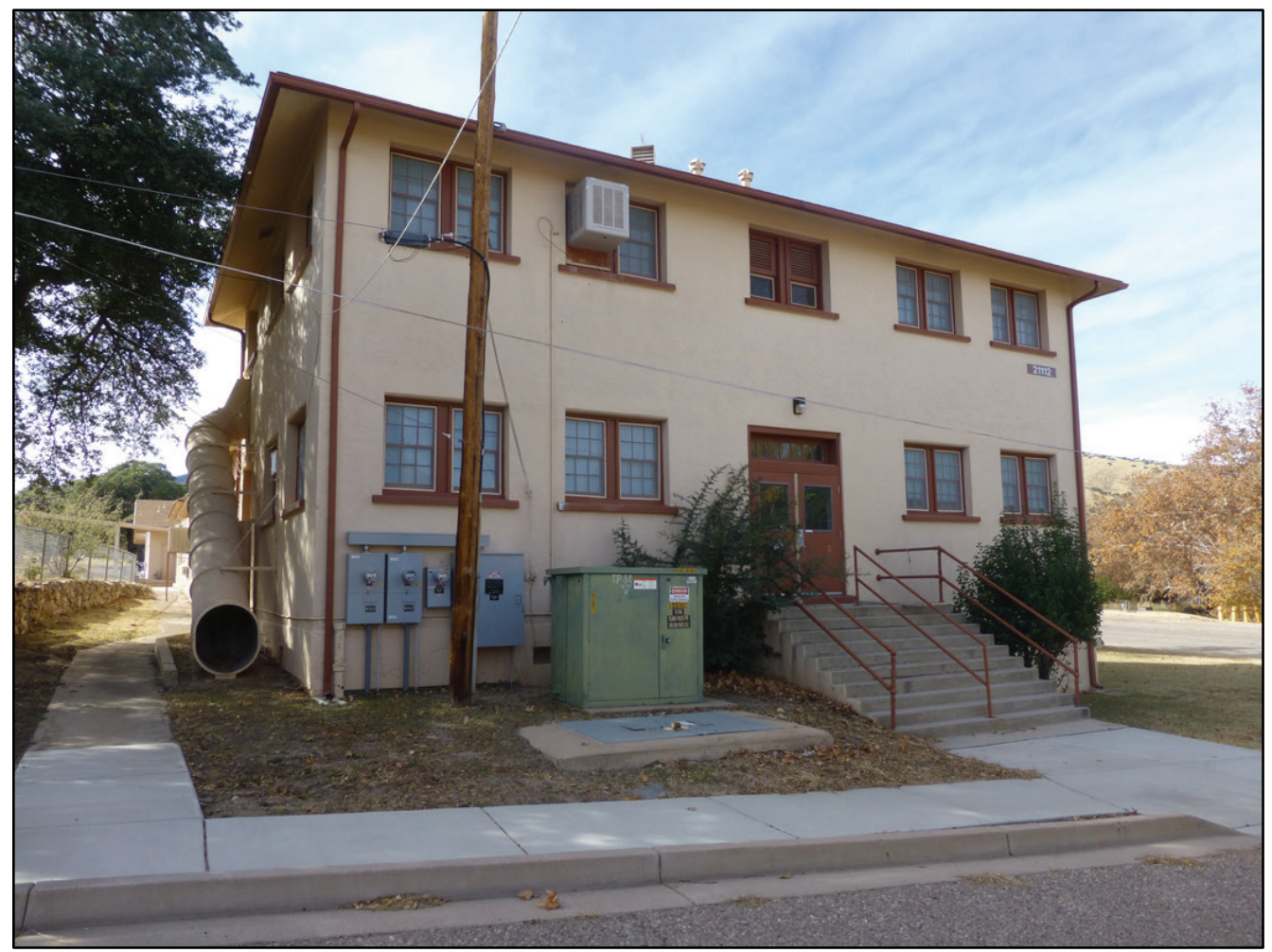


Figure 445. View looking east at school (21112) and annex building (21110) (ERDC-CERL 2016).

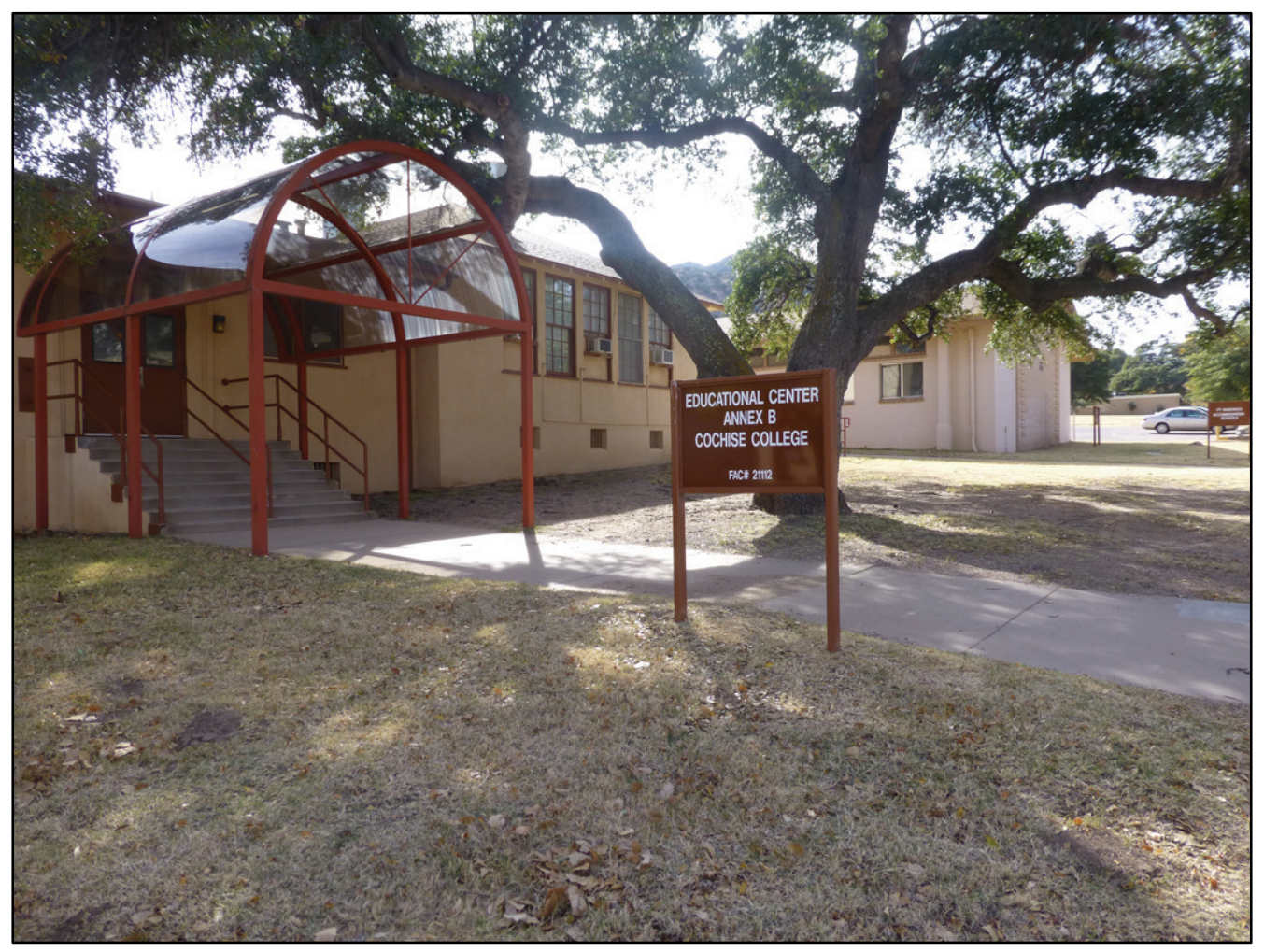




\section{Conclusion}

The Fort Huachuca Historic District NHL landscape retains many character-defining features and much of its integrity. The district retains the setting, location, feeling and workmanship of the 1880 s frontier cavalry post. While many of the buildings date to the 1910 s when the post was expanded, these buildings were built similar in character. The POS for this historic district extends to 1920 . The vast majority of post-1931 buildings in the district are small garages and servants' quarters, located adjacent to and associated with the officers' quarters that line the Brown Field and Henry Circle. These same associated buildings have been determined significant for the WPA construction efforts at Fort Huachuca. An argument could be made to extend the POS to include these associated buildings.

In addition to re-examining the POS, a further look should be made at the multiple historic districts at Fort Huachuca and their boundaries to examine whether one all-inclusive historic district, to include all development until WWII, is a better management tool rather than continuing to have separate district boundaries and individually eligible buildings and landscape features. It is possible this might be better covered in a design guideline format or a historic resource management plan. Since it is difficult to change an NHL (it must go to the NHL committee at the NPS), it is recommended the original 1974 Historic District nomination be increased.

Additional architectural evaluation is needed of the areas left out of the NHL historic district boundary, specifically, the cavalry stables, Reservoir Hill, North Parade Field, and the remaining Quartermaster and Commissary warehouse areas since there is integrity in the landscape surrounding the buildings and their relationship to the rail line, as well as to the Alchesay Barracks. Previously, it was determined buildings within these areas lack individual integrity, and the areas collectively lack integrity. These were excluded from the boundary because their inclusion would have brought the total ratio of contributing to non-contributing buildings to an unacceptably low level. If the POS or the historic district boundaries is changed, these buildings should be re-examined as part of this process.

The cemetery needs to be evaluated for eligibility since the area dates back to the development of Fort Huachuca. It is possible it should be part of the NHL district, or it may be better managed as a cemetery landscape the same as other Army cemeteries, such as Arlington National Cemetery and 
Marietta National Cemetery. Due to the National Register of Eligibility of National Cemeteries Clarification of Policy (9/8/2011), which states that the POS is the period of time beginning with the date of the earliest burials and extending to the present, this may be difficult as the POS would differ from the rest of the NHL.

Further research should go into examining the built environment and the Buffalo Soldiers experience. Sadly, the construction of the Cavalry 5 Housing Area and the associated heritage trail, as well as the parking lot, have compromised the North Parade Field, the $10^{\text {th }}$ Cavalry drill area. Did the construction of the Million Dollar Barracks also break a landscape connection between the 1914 Barracks and the stables? What was the open space and landscape used for? The work for this report noted stone stairways from the stables over the train tracks to the stable guardhouses. Was there a connection then from the guardhouses to the barracks? Many questions still remain. 


\section{Bibliography}

[NOTE: Fort Huachuca report numbers in brackets after a reference indicate the number was provided after 2010 when the numbering system was established.] Adams, George R. Fort Huachuca National Register of Historic Places Inventory National Historic Landmark Nomination Form. Washington, DC: U.S. Department of the Interior, National Park Service, January 1976.

Birnbaum, Charles A. National Park Service Preservation Brief \#36; "Protecting Cultural Landscapes Planning, Treatment and Management of Historic Landscapes." Washington, DC: National Park Service, 1994.

Center for Expertise for Preservation of Historic Structures and Buildings. Capehart Housing at Fort Huachuca; Determination of Eligibility for the National Register Due to Association with Richard Neutra, Architect. Seattle, WA: Seattle District Corps of Engineers: 1999.

CP\&Y, Inc., National Register of Historic Places Evaluation of Cavalry 1 Housing Area. Fort Huachuca, Arizona. CPY Project \#MMHo9023.00. CP\&Y Inc., Austin, Texas, 2009. [FH-09-6].

CP\&Y, Inc. National Register of Historic Places Evaluation of WPA Resources within the Residential Communities Initiative Footprint. Austin, TX: CP\&Y, Inc.: 2009. [FH-09-5]

GADA, Viewshed Study, Fort Huachuca National Historic Landmark, Fort Huachuca, Arizona. Prepared for Environmental and Natural Resources Division, U.S. Army Garrison, Fort Huachuca, AZ. Phoenix, AZ: GADA, 2002. [FH-02-68].

Goodfellow, Dr. Susan, Marjorie Norwick, Chad Blackwell, Dan Hart and Kathryn Plimpton. Nationwide Context, Inventory, and Heritage Assessment of Works Progress Administration and Civilian Conservation Corps Resources on Department of Defense Installations. Legacy Report No. 07-357. Crystal City, VA: Department of Defense, Office of the Deputy Under Secretary of Defense for Installations \& Environment, Legacy Resource Management Program, 2009.

Hart, Daniel and Chad Blackwell. CCC-WPA Resources Legacy Grant Case Study: Fort Huachuca, Arizona. Appendix D in Nationwide Context, Inventory, and Heritage Assessment of Works Progress Administration and Civilian Conservation Corps Resources on Department of Defense Installations. Legacy Project No. 07-357. Engineering-Environmental Management, Denver, Colorado, 2009. [FH-08-8]

Herbert, Rand F. and Stephen D. Mikesell. Fort Huachuca: An Evaluation of Architectural/Historical Resources. Davis, California: JRP Historical Consulting Services, 1989. [FH-89-6].

Herbert, Rand F. and Stephen D. Mikesell. National Register Nomination for Million Dollar Barracks, Fort Huachuca. Davis, CA: JRP Historical Consulting Services, 1993. 
Herbert, Rand F. and Stephen D. Mikesell. National Register Nomination for Stone Quarters and Garage/Warrant Officers' Quarters, Fort Huachuca. Davis, CA: JRP Historical Consulting Services, 1993.

Herbert, Rand F., W. Turrentine Jackson, and Stephen R. Wee. Fort Huachuca, Arizona; A Century of Development and Changing Missions 1877-1977. Davis, CA: JRP Historical Consulting Services, 1990.

Janus Associates, Inc. Draft Technical Synthesis Report: Fort Huachuca Architectural/Historical Resources Survey. Phoenix, Arizona: Janus Associates, Inc., 1988. [FH-88-2]

Loechl, Suzanne Keith, Susan I. Enscore, Megan W. Tooker, and Samuel A. Batzli. Guidelines for Identifying and Evaluating Historic military Landscapes. Champaign, IL: U.S. Army Construction Engineering Research Laboratory, 2009.

Mikesell Stephen D. and Stephen R. Wee. National Register of Historic Places Registration Form for Fort Huachuca Historic District. (Davis, CA: JRP Historical Consulting Service). 1993.

National Park Service. Guide to Cultural Landscape Reports: Contents, Process, and Techniques. Credited authors: Robert R. Page, Cathy Al. Gilbert, Susan A. Dolan. Washington, DC: U.S. Department of the Interior, 1998.

National Park Service. National Register Bulletin \#15, How To Apply the National Register Criteria for Evaluation. Washington, DC: U.S. Department of the Interior, National Park Service, 1991.

National Park Service. National Register Bulletin \#16A: How to Complete the National Register Registration Form. Washington, DC: U.S. Department of the Interior, National Park Service, 1997 (rev).

National Park Service. National Register Bulletin \#18: How to Evaluate and Nominate Designed Historic Landscapes. Prepared by J. Timothy Keller and Genevieve P. Keller. Washington, DC: U.S. Department of the Interior, National Park Service, n.d..

National Park Service. National Register Bulletin \#30, Guidelines for Evaluating and Documenting Rural Historic Landscapes. Washington, DC: U.S. Department of the Interior, National Park Service, 1992a.

National Park Service. The Secretary of the Interior's Standards for the Treatment of Historic Properties with Guidelines for the Treatment of Cultural Landscapes. Credited editors: Charles A. Birnbaum and Christine Capella Peters. Washington, DC: U.S. Department of the Interior, 1996.

Parkhurst, Janet H., Ralph Comey, J. Homer Thiel and Susan D. Hall. Fort Huachuca Cavalry Stables (HABS No. AZ-21O). Washington, DC: Historic American Buildings Survey, National Park Service: 2005. [FH-05-6]

Puzzi, Herman V. Old Post Area, Old Fort Huachuca: National Register of Historic Places Inventory-Nomination Form. Washington, DC: U.S. Department of the Interior, National Park Service, May 1973. Entered National Register, 20 November 1974. 
Schneider, Anna E. Historic District Coal Bins: Cultural Resources Evaluation, Fort Huachuca, Arizona, [Draft]. Cultural Resources Report FH-17-17, Fort Huachuca, AZ, 2017.

Tomes, Angel. Architectural Survey of 110 Buildings Documentation, and Evaluation of 110 Buildings and Structures at Fort Huachuca, Arizona. Tucson, AZ: Fort Huachuca Cultural Resources Report FH-12-6, Tucson, AZ: Statistical Research, Inc. (Technical Report 12-21), 2013.

Tomes, Angel and Scott Thomas. Inventory, Documentation, and Evaluation of 30 Buildings and Structures, 192 Works Progress Administration (WPA) Features, and Identification of a Potential WPA Historic District at Fort Huachuca, Arizona. Fort Huachuca Cultural Resources Report FH-12-21. Tucson, AZ: Statistical Research, Inc. (Technical Report 12-31), 2014.

Valenzuela, S. Elizabeth. FY 12 SRM Facilities and Demolition Projects: Documentation and National Register Evaluation of 29 Buildings on Fort Huachuca, Arizona. Fort Huachuca Cultural Resources Report FH-11-8. Austin, TX: Valenzuela Preservation Studios, 2011.

Wee, Stephen R. Wee and Stephen D. Mikesell. National Register of Historic Places Registration Form for Fort Huachuca Historic District, National Register. Unpublished document, U.S. Department of the Interior, National Park Service, 1993. [FH-93-9] 


\section{Appendix A: Plant List}

This appendix provides lists of plants that are adapted to regional conditions and climate, and ultimately require fewer resources and less maintenance. The use of native and appropriate non-native plants can enhance biodiversity, reduce pesticide use, conserve water, and reduce energy costs. In addition, native and appropriate non-native plants also support important pollinator species that are necessary for plant reproduction. A healthy vegetation cover will also inhibit the establishment of invasive plants. Invasive species compete with and harm plant and animal communities.

\section{A.1 IDG plant list}

Fort Huachuca and its RCI, Mountain Vista Communities, provides residents with an approved plant list from the Fort Huachuca Installation Design Guide (IDG) (Table A-1). While the plant list is for all Fort Huachuca residents, only those plants with a planting location of $\mathrm{F}$ are approved for historical areas and the NHL District. 
Table A-1. Fort Huachuca Approved Plant List (IDG, 2008).

Installation Design Guide

Ft. Huachuca Plant List

Jan 1, 2008

Botanical Name

\section{Trees:}

Brahea armata

Cedrus deodara

Ceris occidentalis

Chilopsis linearis

Cupressus arizonica

Cupressus sempervirens

Fraxinus velutina 'Modesto'

Fraxinus velutina 'Rio Grande'

Gleditsia triacanthos inermis

Juglans major

Olea europaea 'Swanhill'

Pinus eldarica

Pistacia atlantica

Pistacia chinensis

Platanus wrightii

Prosopis glandulosa

Quercus arizonica

Quercus emoryi

Quercus gambelli

Quercus hypoleucoides

Quercus ilex

Quercus suber

Trachycarpus fortunei

Vitex agnus-castus

Washingtonia filifera

Washingtonia robusta
Common Name

Blue hesper palm

Deodar cedar

Western redbud

Desert willow

Arizona cypress

Italian cypress

Modesto ash

Fan-tex ash

Honey locust (thornless)

Arizona walnut

Fruitless european olive

Afghan pine

Mt. Atlas pistache

Chinese pistache

Arizona sycamore

Honey mesquite

Arizona white oak

Emory oak

Gambel oak

Silverleaf oak

Holly oak

Cork oak

Windmill palm

Chaste tree

California fan palm

Mexican fan palm
Planting Location

$\mathrm{F}, \mathrm{G}, \mathrm{H}$

$\mathrm{F}, \mathrm{H}$

$\mathrm{G}, \mathrm{H}$

G,H

F,G,H

$\mathrm{F}, \mathrm{H}$

$\mathrm{G}, \mathrm{H}$

$\mathrm{G}, \mathrm{H}$

$\mathrm{H}$

$\mathrm{F}$

$\mathrm{F}, \mathrm{G}, \mathrm{H}$

$\mathrm{F}, \mathrm{G}, \mathrm{H}$

$\mathrm{G}, \mathrm{H}$

$\mathrm{G}, \mathrm{H}$

$\mathrm{F}$

$\mathrm{H}$

$\mathrm{F}, \mathrm{G}, \mathrm{H}$

$\mathrm{F}, \mathrm{G}, \mathrm{H}$

$\mathrm{F}, \mathrm{G}, \mathrm{H}$

$\mathrm{F}, \mathrm{G}, \mathrm{H}$

$\mathrm{G}, \mathrm{H}$

$\mathrm{G}, \mathrm{H}$

F,G,H

$\mathrm{G}, \mathrm{H}$

F,G,H

$\mathrm{F}, \mathrm{G}, \mathrm{H}$ 
Jan 1, 2008

Botanical Name Common Name

Planting Location

\section{Shrubs:}

Anisacanthus species

Atriplex canescens

Berberis species

Caesalpinia gilliesii

Calliandra eriophylla

Cercocarpus species

Chamaerops humilis

Cowania mexicana

Dalea pulchra

Dasylirion wheeleri

Fallugia paradoxa

Fouquieria splendens

Hesperaloe pariflora

Juniperus species

Larrea tridentata

Lecucophyllum species

Nerium species

Nolina microcarpa

Nandina domestica

Flame anisacanthus
Fourwing saltbush
Barberry
Yellow bird of paradise
Fairy duster
Mountain mahogany
Mediterranean fan palm
Cliffrose
Bush dalea
Desert spoon
Apache plume
Ocotillo
Red yucca
Junipers
Cresote bush
Texas ranger/sages
Oleanders
Beargrass
Heavenly bamboo
Purple fountain grass
Pomegranate
Pyracantha
Rosemary
Littleleaf sumac
Sugar sumac
Mojave sage
Texas mountain laurel
Arizona rosewood
Soap tree
Yucca

$\mathrm{G}, \mathrm{H}$

$\mathrm{G}, \mathrm{H}$

$\mathrm{G}, \mathrm{H}$

$\mathrm{F}, \mathrm{G}, \mathrm{H}$

$\mathrm{G}, \mathrm{H}$

$\mathrm{F}, \mathrm{G}, \mathrm{H}$

$\mathrm{F}, \mathrm{G}, \mathrm{H}$

$\mathrm{G}, \mathrm{H}$

$\mathrm{F}, \mathrm{G}, \mathrm{H}$

$\mathrm{H}$

$\mathrm{G}, \mathrm{H}$

$\mathrm{H}$

$\mathrm{H}$

F, G,H

$\mathrm{H}$

$\mathrm{F}, \mathrm{G}, \mathrm{H}$

$\mathrm{F}, \mathrm{H}$

$\mathrm{F}, \mathrm{G}, \mathrm{H}$

$\mathrm{F}, \mathrm{G}, \mathrm{H}$

Pennisetum setaceum 'Cupreum'

$\mathrm{H}$

Punica granatum

Pyracantha species

Rosmarinus officinalis

Rhus microphylla

Rhus ovata

Salvia mohavensis

Sophora secundiflora

Vauquelinia californica

Yucca elata

Yucca species

F,G,H

F,H

F, G,H

$\mathrm{F}, \mathrm{G}, \mathrm{H}$

$\mathrm{F}, \mathrm{G}, \mathrm{H}$

$\mathrm{F}, \mathrm{G}, \mathrm{H}$

$\mathrm{F}, \mathrm{G}, \mathrm{H}$

$\mathrm{F}, \mathrm{G}, \mathrm{H}$

$\mathrm{H}$

$\mathrm{H}$

\section{Groundcover:}

Atriplex semibacata

Baccharis pilularis 'Twin Peaks'

Australian saltbush

$\mathrm{H}$

Dalea greggii

Coyote bush

$\mathrm{H}$

Trailing indigo bush

$\mathrm{H}$

Juniperus horizontalis

Creeping juniper

Planting Location

$\mathrm{F}=$ Historical Areas and Bonnie Blink Housing

$\mathrm{G}=$ All Other Housing

$\mathrm{H}=$ Community, Industrial, Mission, All Other 


\section{A.2 ERDC-CERL plant list}

As part of the project, ERDC-CERL created a plant list based on the historic character of Fort Huachuca. Recommended plants were selected based on their appropriateness to historic context, adaptability to the desert region, and commercially availability (Table A-2-Table A-4). While no plant is completely disease, pest or maintenance free, these plants were found to be relatively easy to grow and maintain and had limited problems. The list is intentionally limited as a technique to aid in the development of a consistent historic character. The list offers enough variety to allow for unique planting schemes for all areas of a historic district as well as individuality for each building, but still have repetition of plant materials that will promote a uniform image for the historic district overall and for similar historic areas of the installation.

It is important to not use any one plant, especially street trees or groundcovers, exclusively in all situations. Select a plant suitable to a site's specific conditions and use a variety throughout the installation to minimize disease and pest problems. This list presents suggestions; plants can be substituted when an installation's horticultural expert identifies a species or cultivar that is more suitable for the historic district. Substitutions should remain faithful to the historic character and to the design concepts in terms of plant type, habit, and ornamental features.

\section{A.2.1 Trees}

Table A-2. Suggested trees that may be suitable for the historic district.

\begin{tabular}{|l|l|l|}
\hline Common Name & Scientific Name & Characteristics \\
\hline Afghan Pine & Pinus eldarica & 80-ft x 20-ft; evergreen \\
\hline Aleppo Pine & Pinus halepensis & 20-50-ft height x 20-50-ft wide, evergreen \\
\hline Alligator Juniper & Juniperus deppeana & 20-ft x 16-ft; evergreen \\
\hline Anancho Orchid Tree & Bauhinia lunarioides & 12-ft, semi-deciduous, flowering tree \\
\hline Arizona Cypress & Cupressus arizonica (glabra) & 40-ft, evergreen, seedless varieties, 'Blue Ice' \\
\hline Arizona Walnut & Juglans major & 20-50-ft height x 20-50-ft wide, shade tree \\
\hline Arizona White Oak & Quercus arizonica & 20-50-ft height x 20-50-ft wide, evergreen \\
\hline Crepe Myrtle & Lagerstroemia indica & 10-30-ft height, 5-25-ft wide, ornamental flowers \\
\hline Desert Willow & Chilopsis linearis & 25-ft, deciduous, small tree, flowering \\
\hline Evergreen Elm & Ulmus parvifolia & 35-ft height; umbrella shaped; semi-evergreen \\
\hline Feather Bush & Lysiloma watsonii & 20-ft, semi-evergreen, white flowers \\
\hline Hybrid Palo Verde & $\begin{array}{l}\text { Cercidium hybrid } \\
\text { (Recently reclassified as } \\
\text { Parkinsonia hybrid) }\end{array}$ & $\begin{array}{l}\text { 25-ft x 25-ft; vase-shaped; yellow flowers, spring to summer, } \\
\text { see 'Desert Museum' }\end{array}$ \\
\hline
\end{tabular}




\begin{tabular}{|l|l|l|}
\hline Common Name & Scientific Name & Characteristics \\
\hline $\begin{array}{l}\text { Little Leaf Ash (Gregg } \\
\text { Ash) }\end{array}$ & Fraxinus greggii & 15-25-ft height x 10-18-ft wide, \\
\hline Mexican Blue Palm & Brahea armata & 25-ft, palm tree, fan fronds \\
\hline Mexican Redbud & Cercis canadensis 'mexicana' & 20-ft x 12-ft, purple flowers \\
\hline Red Push Pistache & Pistacia x & 30-40-ft height x 20-40-ft wide, beautiful fall color, deciduous \\
\hline Southern Live Oak & Quercus virginia & 20-50-ft height x 20-50-ft wide, shade tree \\
\hline Sweet Acacia & Acacia farnesiana & 20-ft height, vase-shaped, yellow flowers late winter to spring \\
\hline Texas Honey Mesquite & Prosopis glandulosa v. glandulosa & 30-ft height x 30-ftwide, pale yellow spring flowers, thorns \\
\hline Texas Mountain Laurel & Sophora secundiflora & $\begin{array}{l}\text { 15-ft, evergreen, multi-trunked, purple flowering tree, sweet- } \\
\text { smelling, toxic }\end{array}$ \\
\hline Texas Persimmon & Diospyros texana & 40-ft height x 10-ft wide, fragrant flowers, pretty bark \\
\hline $\begin{array}{l}\text { Thornless Chilean } \\
\text { Mesquite }\end{array}$ & Prosopis chilensis & 30-ft height x 30-ft wide, thornless but drops pods \\
\hline Velvet Ash & Fraxinus velutina & 40-ft height, flowers for butterflies and bees \\
\hline Velvet Mesquite & Prosopis velutina & 20-50-ft height, 20-50-ft wide \\
\hline Western Soapberry & Sapindus sapanaria & 30-ft height; white flowers, berries, deciduous \\
\hline
\end{tabular}

\section{A.2.2 Shrubs}

Table A-3. Suggested shrubs that may be suitable for the historic district.

\begin{tabular}{|l|l|l|}
\hline Common Name & Scientific Name & Characteristics \\
\hline Autumn Sage & Salvia greggii & 2-3-ft, pink-red flowers \\
\hline Black Dalea & Dalea frutescens & 3-4-ft, rose-purple flowers \\
\hline Century Plant & Agave americana & 6-ft x 10-ft, yellow flowers, spring \\
\hline Damianita & Chrysactinia mexicana & 2-ft x 2-ft, yellow flowers, spring-fall \\
\hline Flame Anisacanthus & Anisacanthus quadrifidus & 4-5-ft height, orange-red flowers, late summer-fall \\
\hline Huachuca (Artichoke) Agave & Agave parryi huachucensis & 1-2-ft x 2-3-ft, \\
\hline Hollywood Juniper & Juniperus chinensis 'Torulosa' & 8-10-ft height, evergreen \\
\hline Mediterranean Fan Palm & Chamaerops humilis & 10-ft x 10-ft; evergreen \\
\hline Mexican Buckeye & Ungnadia speciosa & 10-ft x 10-ft, rose pink spring \\
\hline Oleander & Nerium oleander & 6-ft x 4-ft, white, pink or red flowers, spring to fall \\
\hline Orange Bells & Tecoma hybrid & 8-ft x 5-ft; orange flowers year-round \\
\hline Pink Fairy Duster & Calliandra eriophylla & 1-3-ft x 3-4-ft, pink flowers, spring \\
\hline Red Bird of Paradise & Caesalpinia pulcherrima & 6-ft x 6-ft, orange and yellow flowers \\
\hline Silverleaf Sage & Leucophyllum zygophyllum & 3-ft x 3-ft, violet flowers \\
\hline Sonoran Scrub Oak & Quercus turbinella & 3-18-ft height and width, acorns \\
\hline Texas Mountain Laurel & Sophora secundiflora & 8-ft x 6-ft; upright, evergreen; purple cluster flowers, spring \\
\hline Texas Olive & Cordia boissieri & 10-ft x 10-ft; white showy flowers spring to fall \\
\hline Texas Sage & Leucophyllum frutescens & 6-ft x 6-ft white pink or purple flowers, summer to fall \\
\hline Upright Rosemary & Rosmarinus officinalis & 4-ft height, evergreen, blue flowers \\
\hline Violet Silverleaf & Leucophyllum candidum & 3-ft x 3-ft violet flowers summer to fall \\
\hline Woolly Butterfly Bush & Buddelia marrubifolia & 6-ft height, tiny orange flowers \\
\hline
\end{tabular}




\section{A.2.3 Perennials and ground covers}

Table A-4. Suggested perennials and ground covers that may be suitable for the historic district.

\begin{tabular}{|l|l|l|}
\hline Common Name & Scientific Name & Characteristics \\
\hline Angelita Daisy & Hymenoxys acaulis & 1-ft height, grey foliage, yellow flowers \\
\hline Germander Sage & Salvia chamaedryoides & 1-3-ft height, dark blue flowers, summer - fall \\
\hline Grazania & Gazania rigens & 12-in. x 12-in., yellow to orange flowers, spring \\
\hline Hartweg's Sundrops & Calylophus hartwegii & 1-ft height, yellow flowers, spring - summer \\
\hline Lemon Dalea & Dalea capitata & 1-ft height, yellow flowers, fall \\
\hline Mexican Evening Primrose & Oenothera speciosa & 1-ft height, rose pink flowers, spring \\
\hline Moss Verbena & Glandularia tenera & 9-in. height, purple flowers, spring - fall \\
\hline Peruvian verbena & Verbena peruviana & 9-in. height, pink to white flowers, spring to fall \\
\hline Pineleaf Penstemon & Penstemon pinifolius & 1-2-ft height, reddish orange flowers, summer \\
\hline Southwest Mock Vervain & Glandularia gooddingii & 1-ft height, purple to pink flowers, spring - fall \\
\hline Trailing Indigo Bush & Dalea greggii & 18-in. height, lavender flowers spring \\
\hline
\end{tabular}

\section{A.2.4 Invasive species}

Invasive plants are introduced species that thrive and spread aggressively throughout an area outside of their natural range. Invasive species take advantage of the ecological mechanisms that keep growth in check. Invasive species should not be planted at Fort Huachuca.

The following list outlines several of the common invasive species for the Southwest region (Table A-5). The list is not comprehensive and consultation with a horticulturist is necessary to develop an effective strategy for invasive species management.

Table A-5. Common invasive species for the Southwest region.

\begin{tabular}{|l|l|l|}
\hline Common Name & Scientific Name & Characteristics \\
\hline African Rue & Peganum harmala & $\begin{array}{l}\text { Young seedlings are capable of growing during periods of extreme water } \\
\text { deficits. }\end{array}$ \\
\hline Buffelgrass & Pennisetum ciliare & $\begin{array}{l}\text { Buffelgrass produces large numbers of wind-dispersed seeds, which } \\
\text { establish easily on roadsides, vacant lots, and remote parts of the desert. }\end{array}$ \\
\hline Dalmatian Toadflax & Linaria dalmatica & $\begin{array}{l}\text { Toadflax can grow in harsh dry sites and produce seeds in those } \\
\text { conditions. }\end{array}$ \\
\hline Hoary Cress & $\begin{array}{l}\text { Lepidium draba (also } \\
\text { Cardaria draba) }\end{array}$ & Reproduces by root segments and seeds. Very aggressive. \\
\hline $\begin{array}{l}\text { Fountain Grass } \\
\text { Loosestrife }\end{array}$ & Pennisetum setaceum & $\begin{array}{l}\text { Fountain grass is found along roadways and is invading rangelands } \\
\text { competing with natives. }\end{array}$ \\
\hline Red Bromegrass & Bromus rubens & $\begin{array}{l}\text { Suppresses resident plant } \\
\text { communities altering wetlands structure and function. }\end{array}$ \\
\hline
\end{tabular}




\begin{tabular}{|l|l|l|}
\hline Common Name & Scientific Name & Characteristics \\
\hline $\begin{array}{l}\text { Russian } \\
\text { Knapweed }\end{array}$ & Rhaponticum repens & Crowds out native species and desirable forage. \\
\hline Yellow Starthistle & Centaurea solstitialis & Creates monotypic stands in disturbed soils. \\
\hline
\end{tabular}




\section{Acronyms and Abbreviations}

\begin{tabular}{|c|c|}
\hline Abbreviation & Term \\
\hline ACES & Army Continuing Education System \\
\hline ACHP & Advisory Council on Historic Preservation \\
\hline ADA & Americans with Disabilities Act \\
\hline BOQ & Bachelor Officer Quarters \\
\hline $\operatorname{CCC}$ & Civilian Conservation Corps \\
\hline CWA & Civil Works Administration \\
\hline DoD & Department of Defense \\
\hline DPW & Directorate of Public Works \\
\hline EPG & U.S. Army Electronic Proving Ground \\
\hline ERDC- CERL & $\begin{array}{l}\text { Engineer Research and Development Center, Construction } \\
\text { Engineering Research Laboratory }\end{array}$ \\
\hline HABS & Historic American Buildings Survey \\
\hline IDG & Installation Design Guide \\
\hline$J A G$ & Judge Advocate General \\
\hline JRP & Joint Requirements Planning \\
\hline NARA & National Archives and Records Administration \\
\hline NCO & Non-Commissioned Officer \\
\hline NETCOM & Network Energy Technology Command \\
\hline $\mathrm{NHL}$ & National Historic Landmark \\
\hline NHPA & National Historic Preservation Act of 1966 \\
\hline NPS & National Park Service \\
\hline NRHP & National Register of Historic Places \\
\hline PA & Programmatic Agreement \\
\hline POS & Period of Significance \\
\hline PWA & Public Works Administration \\
\hline PX & Post Exchange \\
\hline QMC & Quartermaster Center \\
\hline $\mathrm{RCl}$ & Residential Communities Initiative \\
\hline SHPO & State Historic Preservation Office \\
\hline SPRR & Southern Pacific Railroad \\
\hline STRATCOM & Strategic Communications \\
\hline TRADOC & U.S. Army Training and Doctrine Command \\
\hline USACE & U.S. Army Corps of Engineers \\
\hline USAICS & U.S. Army Intelligence Center and School \\
\hline WAACS & Women's Army Auxiliary Corps \\
\hline WPA & Works Progress Administration \\
\hline
\end{tabular}




\section{Unit Conversion Factors}

\begin{tabular}{|c|c|c|}
\hline Multiply & By & To Obtain \\
\hline acres & $4,046.873$ & square meters \\
\hline cubic feet & 0.02831685 & cubic meters \\
\hline cubic inches & 1.6387064 E-05 & cubic meters \\
\hline cubic yards & 0.7645549 & cubic meters \\
\hline degrees (angle) & 0.01745329 & radians \\
\hline degrees Fahrenheit & $(\mathrm{F}-32) / 1.8$ & degrees Celsius \\
\hline feet & 0.3048 & meters \\
\hline gallons (U.S. liquid) & 3.785412 E-03 & cubic meters \\
\hline hectares & $1.0 \mathrm{E}+04$ & square meters \\
\hline inches & 0.0254 & meters \\
\hline miles (U.S. statute) & $1,609.347$ & meters \\
\hline square feet & 0.09290304 & square meters \\
\hline square inches & $6.4516 \mathrm{E}-04$ & square meters \\
\hline square miles & $2.589998 E+06$ & square meters \\
\hline square yards & 0.8361274 & square meters \\
\hline yards & 0.9144 & meters \\
\hline
\end{tabular}





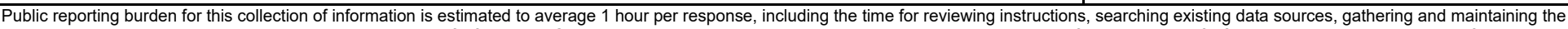

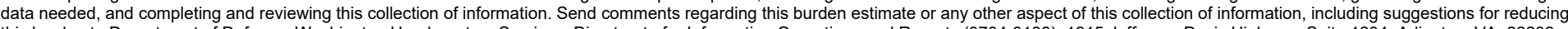

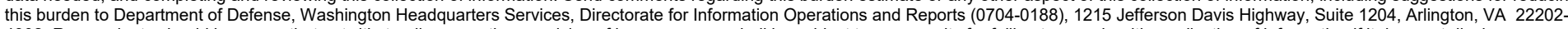

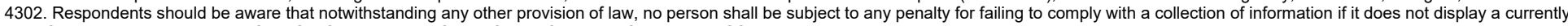
valid OMB control number. PLEASE DO NOT RETURN YOUR FORM TO THE ABOVE ADDRESS.
1. REPORT DATE (DD-MM-YYYY)
June 2021
2. REPORT TYPE
Technical Report
3. DATES COVERED (From - To)

\section{TITLE AND SUBTITLE}

Technical Report

Historic Landscape Management Plan for the Fort Huachuca Historic District National Historic Landmark and Supplemental Areas

5a. CONTRACT NUMBER

5b. GRANT NUMBER

5c. PROGRAM ELEMENT

6. AUTHOR(S)

Megan W. Tooker and Adam D. Smith

5d. PROJECT NUMBER

5e. TASK NUMBER

5f. WORK UNIT NUMBER

7. PERFORMING ORGANIZATION NAME(S) AND ADDRESS(ES)

U.S. Army Engineer Research and Development Center (ERDC)

Construction Engineering Research Laboratory (CERL)

PO Box 9005,

Champaign, IL 61826-9005

8. PERFORMING ORGANIZATION REPORT NUMBER

ERDC/CERL TR-21-15

\section{SPONSORING / MONITORING AGENCY NAME(S) AND ADDRESS(ES)}

Environmental and Natural Resources Division

Directorate of Public Works

U.S. Army Garrison

3040 Butler Road, Building 22526

Fort Huachuca, AZ 85613
10. SPONSOR/MONITOR'S ACRONYM(S)

11. SPONSOR/MONITOR'S REPORT NUMBER(S)

\section{DISTRIBUTION / AVAILABILITY STATEMENT}

Approved for public release; distribution is unlimited.

\section{SUPPLEMENTARY NOTES}

Funding provided by MIPR7ACE5355.

\section{ABSTRACT}

The U.S. Congress codified the National Historic Preservation Act of 1966 (NHPA) to provide guidelines and requirements for preserving tangible elements of our nation's past. This preservation was done primarily through creation of the National Register of Historic Places (NRHP), which contains requirements for federal agencies to address, inventory, and evaluate their cultural resources, and to determine the effect of federal undertakings on properties deemed eligible or potentially eligible for the NRHP.

This work inventoried and evaluated the historic landscapes within the National Landmark District at Fort Huachuca, Arizona. A historic landscape context was developed; an inventory of all landscapes and landscape features within the historic district was completed; and these landscapes and features were evaluated using methods established in the Guidelines for Identifying and Evaluating Historic Military Landscapes (ERDC-CERL 2008) and their significance and integrity were determined. Photographic and historic documentation was completed for significant landscapes. Lastly, general management recommendations were provided to help preserve and/or protect these resources in the future.

\section{SUBJECT TERMS}

Fort Huachuca (Ariz.)

Historic preservation
Historic districts

Landscape protection
Cultural landscape

Military landscape

\begin{tabular}{|c|c|c|c|c|c|}
\hline \multicolumn{3}{|c|}{ 16. SECURITY CLASSIFICATION OF: } & \multirow{2}{*}{$\begin{array}{l}\text { 17. LIMITATION } \\
\text { OF ABSTRACT } \\
\text { SAR }\end{array}$} & \multirow{2}{*}{$\begin{array}{l}\text { 18. NUMBER } \\
\text { OF PAGES } \\
380\end{array}$} & 19a. NAME OF RESPONSIBLE PERSON \\
\hline $\begin{array}{l}\text { a. REPORT } \\
\text { Unclassified }\end{array}$ & $\begin{array}{l}\text { b. ABSTRACT } \\
\text { Unclassified }\end{array}$ & $\begin{array}{l}\text { c. THIS PAGE } \\
\text { Unclassified }\end{array}$ & & & $\begin{array}{l}\text { 19b. TELEPHONE NUMBER } \\
\text { (include area code) }\end{array}$ \\
\hline $7540-01-280-5500$ & & & & & $\begin{array}{l}\text { Standard Form } 298 \text { (Rev. 8-98) } \\
\text { Prescribed by ANSI Std. 239.1 }\end{array}$ \\
\hline
\end{tabular}

